\title{
Turismo, planificación y bienestar en Lanzarote
}

ASENET SOSA ESPINOSA 



\section{ESCUELA TÉCNICA SUPERIOR DE INGENIEROS DE CAMINOS, CANALES Y PUERTOS}

\section{DEPARTAMENTO DE URBANISMO}

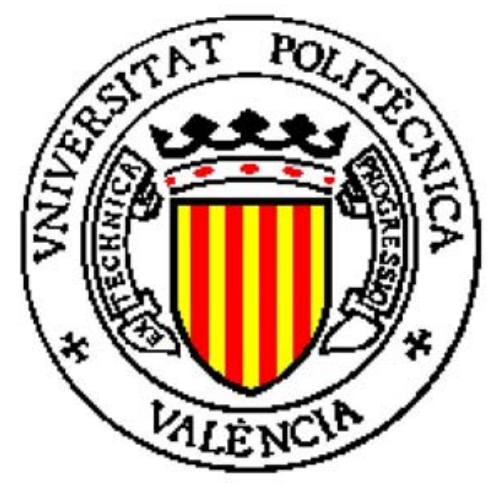

\section{TURI SMO, PLANI FI CACI ÓN Y BI ENESTAR EN LANZAROTE}

\section{TESIS DOCTORAL}

DOCTORANDO: ASENET SOSA ESPINOSA DIRECTOR: ANTONIO SERRANO RODRÍGUEZ TUTOR: JOSÉ VICENTE FERRANDO CORELL 


\section{Colección Tesis Doctorales}

\section{(c) Asenet Sosa Espinosa}

(C) 2014, de la presente edición: Editorial Universitat Politècnica de València Telf.: 963877012 / www.lalibreria.upv.es

ISBN: 978-84-9048-192-9 (versión CD)

Queda prohibida la reproducción, distribución, comercialización, transformación, y en general, cualquier otra forma de explotación, por cualquier procedimiento, de todo o parte de los contenidos de esta obra sin autorización expresa y por escrito de sus autores. 


\section{Resumen}

La presente tesis doctoral se centra en el estudio y análisis de los efectos de la actividad turística sobre el bienestar social de las sociedades de acogida. Su finalidad es demostrar como ciertas formas de turismo derivan hacia pérdidas del bienestar para los residentes en ese territorio, en la medida en que el constante crecimiento de la actividad, alcanzando la forma de turismo masificado o de masas, desborda su capacidad de adaptación y de acogida del medio. Llegados a ese punto, los beneficios, en términos socioeconómicos, que inicialmente presenta la actividad en una sociedad rural o de bajo nivel de desarrollo, quedan en entredicho, pues se detectan dinámicas de transformación territorial, económica y social poco compatibles con el mismo, sin reflejo positivo sobre el bienestar de los ciudadanos.

Alumbrados por el pensamiento enmarcado dentro de la Sociología del cambio y el conflicto, se consideran los enfoques provenientes de la Sociología humanista y de la neomarxista, enunciándose tres grandes hipótesis. La primera presume que el cambio en la actividad socioeconómica y territorial derivado de la implantación de la actividad turística modifica las formas de vida subyacente; produciendo, como segunda hipótesis, un primer periodo de mejoras en el bienestar de la sociedad de acogida, que se estancará y descenderá por el fuerte crecimiento de la actividad turística y se observará en su madurez (con desequilibrios demográficos, escasez en los niveles de instrucción, precariedad en el empleo e insuficiente capacidad de adaptación de las infraestructuras básicas). Por último, la tercera hipótesis afirma que es la calidad y no la cantidad la que debe presidir las políticas de desarrollo turístico.

Para verificar las hipótesis citadas se ha tomado el caso de una isla: Lanzarote, partiendo desde los comienzos de la implantación de la actividad, 1970, hasta el estado alcanzado en su madurez turística, en el siglo presente, describiendo la dinámica que se ha producido en tres etapas de su desarrollo como economía turística. Etapas que se han relacionado directamente con los procesos de ordenación del territorio y de transformación socioeconómica real que se han producido en cada momento.

Para la contrastación de las hipótesis se ha trabajado sobre una selección de áreas concretas del bienestar, consideradas las más significativas para los objetivos perseguidos, cuya evolución se analiza a partir y en relación a los crecimientos de la oferta y la demanda turística. Se constata que ésta produce incrementos notables de la población en breves periodos de tiempo, por lo que la evolución provocada en la estructura demográfica es el primer punto tratado. Y para evaluar las consecuencias sobre la población autóctona (nacida en la isla) y la alóctona (nacida fuera de la isla) se considera la evolución de los niveles de cualificación y equipamiento educativo, dotaciones de salud, estructura laboral, renta, 
energía, ciclo del agua y comunicaciones por carretera, transporte privado y público, y la incidencia diferencial de estos elementos sobre la población autóctona y el conjunto de residentes, así como sobre la población total equivalente (que incluye el número de turistas diarios).

Finalmente, a partir de la información y recopilación de los indicadores medidos a lo largo de su evolución, se realiza una reflexión de forma interrelacionada e integradora de dichos indicadores con el fin de extraer la verdadera dimensión del cambio insular y su deriva hacia efectos no positivos sobre el bienestar social en Lanzarote.

Las conclusiones principales evidencian que la implantación de la actividad turística en territorios insulares inicia un primer periodo de incremento del bienestar en la sociedad de acogida, en términos socioeconómicos, infraestructurales y dotaciones de los que se beneficia la población autóctona y residente, pero tras la consolidación del territorio como turístico y la implantación de un modelo en forma de turismo masificado o de masas, se ve negativamente compensado por dinámicas de transformación territorial, económica y social poco compatibles con estos beneficios y sin reflejo positivo sobre el bienestar de los ciudadanos: desequilibrios demográficos, niveles de instrucción básicos generalizados, crecimiento de la oferta y la demanda turística sin reflejo proporcional sobre el volumen de empleos y precariedad del mismo, colapso en las dotaciones sanitarias y dificultades infraestructurales para la producción y el acceso a la energía y al agua, e invasión de la escena por el vehículo privado, es la situación alcanzada. Todo ello confirma una conclusión tradicional de este tipo de estudios cual es que la calidad, y no la cantidad, debe presidir las políticas de desarrollo turístico, siendo la contención de la oferta y la demanda turística la vía para la mejora del bienestar social. Lo que demuestra las hipótesis de partida asumidas en la realización de esta tesis.

\section{Resum}

Aquesta tesi doctoral se centra en l'estudi i l'anàlisi dels efectes de l'activitat turística sobre el benestar social de les societats d'acollida. La finalitat de la qual és demostrar que certes formes de turisme deriven cap a la pèrdua del benestar dels residents en aqueix territori, en la mesura que el creixement constant de l'activitat, assolint la forma de turisme massificat o de masses, desborda la seua capacitat d'adaptació i d'acollida del medi. Arribats a aquest punt, els beneficis, en termes socioeconòmics, que inicialment presenta l'activitat en una societat rural o de baix nivell de desenvolupament, es posen en dubte, perquè es detecten dinàmiques de transformació territorial, econòmica i social poc compatibles, sense reflex positiu sobre el benestar dels ciutadans.

Enllumenat pel pensament emmarcat en la sociologia del canvi i el conflicte, es consideren els enfocaments provinents de la sociologia humanista i de la neomarxista, s'enunciaran tres 
grans hipòtesis. La primera presumeix que el canvi en l'activitat socioeconòmica i territorial derivat de la implantació de l'activitat turística modifica les formes de vida subjacent; produieix, com a segona hipòtesi, un primer període de millores en el benestar de la societat d'acollida, que s'estancarà i descendirà pel fort creixement de l'activitat turística i s'observarà en la seua maduresa (amb desequilibris demogràfics, escassetat en els nivells d'instrucció, precarietat en l'ocupació i insuficient capacitat d'adaptació de les infraestructures bàsiques). Finalment, la tercera hipòtesi afirma que és la qualitat, i no la quantitat, que ha de presidir les polítiques de desenvolupament turístic.

Per a verificar la hipòtesi esmentada s'ha pres el cas d'una illa: Lanzarote, partint des dels començaments de la implantació de l'activitat, en l'any 1970, fins a l'estat aconseguit en la seua maduresa turística, en el present segle, es descriu la dinàmica que s'ha produït en tres etapes del seu desenvolupament com a economia turística. Etapes que s'han relacionat directament amb els processos d'ordenació del territori i de la transformació socioeconòmica real que s'han produiit a cada moment.

Per a la contrastació de les hipòtesis s'ha treballat sobre una selecció d'àrees concretes del benestar, considerades les més significatives per als objectius perseguits, l'evolució de les quals s'analitza a partir i en relació als creixements de l'oferta i la demanda turística. Es constata que aquesta produeix increments notables de la població en breus períodes de temps, motiu pel qual l'evolució provocada en l'estructura demogràfica és el primer punt tractat. I per tal d'avaluar les conseqüències sobre la població autòctona (nascuda a l'illa) i l'al·lòctona (nascuda fora de l'illa) es considera l'evolució dels nivells de qualificació i equipament educatiu, dotacions de salut, estructura laboral, renda, energia, cicle de l'aigua i comunicacions per carretera, transport privat i públic, i la incidència diferencial d'aquests elements sobre la població autòctona i el conjunt de residents, així com sobre la població total equivalent (que inclou el nombre de turistes diaris).

Finalment, a partir de la informació i recopilació dels indicadors mesurats al llarg de la seua evolució, es realitza una reflexió de forma interrelacionada i integradora dels susdits indicadors a fi d'extraure la veritable dimensió del canvi insular i la seua deriva cap a efectes no positius sobre el benestar social a Lanzarote.

Les conclusions principals evidencien que la implantació de l'activitat turística en territoris insulars inicia un primer període d'increment del benestar en la societat d'acollida, en termes socioeconòmics, infraestructurals i dotacionals de què es beneficia la població autòctona i resident, però després de la consolidació del territori com turístic i la implantació d'un model en forma de turisme massificat o de masses, es veu negativament compensat per dinàmiques de transformació territorial, econòmica i social poc compatibles amb aquests beneficis i sense reflex positiu sobre el benestar dels ciutadans: desequilibris demogràfics, nivells d'instrucció bàsics generalitzats, creixement de l'oferta i la demanda turística sense 
reflex proporcional sobre el volum d'ocupació i precarietat del mateix, col·lapse en les dotacions sanitàries i dificultats infraestructurals per a la producció i l'accés a l'energia i a l'aigua, i invasió de l'escena pel vehicle privat, és la situació aconseguida. Tot això confirma una conclusió tradicional d'aquest tipus d'estudis la qual és que la qualitat, i no la quantitat, ha de presidir les polítiques de desenvolupament turístic, sent la contenció de l'oferta i la demanda turística la via per a la millora del benestar social. El que demostren les hipòtesis de partida assumides en la realització d'aquesta tesi.

\section{The thesis's summary}

The present doctoral thesis centres on the study and analysis of the effects of the tourist activity on the social welfare of the societies of reception. Its finality is to demonstrate how certain forms of tourism derive towards the welfare losses for the residents in this territory, as the constant growth of the activity, reaching the form of tourism of masses; it exceeds its capacity of adaptation and of reception.

Come to this point, the benefits, in socioeconomic terms, which initially the activity presents in a rural society or of low development level, stay in doubt, since it was detected dynamics of territorial, economic and social transformation hardly compatible with the same one, without positive reflex on the well-being of the citizens.

Lighting by thinking framed within the sociology of change and conflict, from approaches to Sociology considered as humanist and neo-Marxist., stating three major hypotheses.

The first one presumes that the change in the socioeconomic activity and territorial derivative of the implantation of the tourist activity modifies the underlying forms of life.

Producing, as a second hypothesis, a first period of improvements in the well-being of the society of reception that will stagnate and decline by the strong growth of tourist activity and it will be noted in its maturity (With demographic imbalances, shortages in the levels of introduction, job insecurity and insufficient capacity of adaptation of the basic infrastructure).

Finally, the third hypothesis affirms that it is the quality and not the quantity the one that must preside at the development policy.

Taken to verify the hypothesis mentioned the case of an island: Lanzarote, starting from the beginning of the implementation of the activity, 1970, until the status achieved in its tourist maturity, in the present century, describing the dynamic that has occurred in three stage of their development as tourist economy. Stages that have been directly linked with the processes of land use and real socio-economic transformation that have occurred in every moment. 
For the verification of the hypotheses one has worked on a selection of specific areas of wellbeing, considered the most significant to the objectives pursued whose development is analyzed on the basis of and in relation to the growth of the supply and demand in tourism. Note that this produces notable increases in population in short periods of time, so evolution caused in the demographic structure is the first treaty point.

And to evaluate the consequences on the population born in the island and the born one out of the island it is considered to be the evolution of the levels of qualification and educational equipment, endowments of health, labour structure, revenue, energy, hydrologic system and communications by highway, transport private and public, and the differential impact of these elements on the indigenous population and the set of residents, as well as the equivalent total population (which includes the number of daily tourists).

Finally, from information and compilation of indicators measured throughout their evolution, is a reflection interrelated way and inclusive of those indicators in order to extract the true dimension of the island change and its drift toward no positive effects on social welfare in Lanzarote.

The main conclusions demonstrate that the introduction of the tourist activity in insular territories initiates the first period of increase of the well-being in the reception society, in socioeconomic terms, infrastructural and allocations from that the indigenous and resident population benefits, but after the consolidation of the territory like tourist and the introduction of a model in the shape of tourism from masses It turns out to be negatively compensated by dynamics of territorial, economic and social transformation compatible with these benefits and without positive reflex on the well-being of the citizens: demographic imbalances, basic levels of training widespread, growth of the offer and the tourist demand without proportional reflex on the volume of work places and instability of the same one, collapse in sanitary provisions and infrastructural difficulties for production and access to energy and water, and invasion of the scene for the private way, it is the reached situation.

All this confirms a traditional conclusion of this type of studies: that the quality, and not the quantity, must preside over tourism development policies. Beings the containment of the offer and the tourist demand the route for the progress of the social welfare. Which prove the hypothesis assumed in the completion of this thesis. 



\section{Reconocimientos}

Durante el tiempo transcurrido en la realización de una tesis se acumulan apoyos y enormes deudas de gratitud, por lo que estas primeras líneas están dedicas a todas las personas que de una forma $u$ otra me han aportado su ayuda para que esta tesis pueda ser una realidad.

En primer lugar a mi director de tesis, Antonio Serrado Rodríguez, pues apoyó mis primeras ideas e intuiciones sobre las que construir una tesis y me animó en los momentos bajos a no abandonar esta línea de investigación. Por su incansable y constante trabajo en las correcciones de los contenidos y sus innumerables aportaciones como especialista de la ordenación del territorio y profundo conocedor de las dinámicas territoriales de las Islas Canarias y en especial de Lanzarote. Sin su contribución este trabajo no hubiese llegado a su fin.

Mi tutor, José V. Ferrando Corell, que tan amablemente se ha encargado de trámites administrativos necesarios para la defensa de la tesis, y ha sido fuente de ánimo y consejo en estos años.

Al Centro de Datos del Cabildo Insular de Lanzarote, y especialmente a su director, Martín Rosa, M.A., pues la inconmensurable labor que lleva realizando desde hace más de una década permite, en la actualidad, el fácil acceso a la documentación e información que existe sobre el pasado y el presente insular, ayudando y apoyando la labor de los investigadores. La conservación y recopilación de documentos históricos que realiza esta área ha sido fundamental para esta tesis.

Así, también al Instituto de Estadística de Canarias (ISTAC), que amablemente, a lo largo de estos últimos once años, ha ido respondiendo a mis peticiones y en el año 2010, durante el mes de agosto, me facilitó un despacho en sus dependencias y a sus técnicos para bucear, con mayor profundidad, en la documentación que conservan realizada por el antiguo Centro de Documentación de Canarias, del que son herederos.

A mis compañeros del Departamento de Urbanismo por su apoyo y ayuda. Principalmente a Eric Gielen por la elaboración de los mapas. Especial mención merece Elisabeth Delios por compartir en múltiples ocasiones mis reflexiones y dudas en estos años, constituyendo una fuente de luz en los lugares oscuros, y por su ayuda en la maquetación del documento final.

Debo dar las gracias a dos personas, externas al mundo académico y de la investigación científica, con intensos conocimiento del marco en el que se mueve su vida profesional. En primer lugar a Juan Sosa Núñez, que tras medio siglo de trabajo en el Hospital Insular de Lanzarote, actualmente jubilado, es una enorme fuente de conocimiento en relación a cómo se encontraban los servicios y el equipamiento sanitario en la Isla en la década de los años sesenta y setenta. Conocimiento este que me trasladó con suma claridad y sin el cuál no se 
podía recoger el estado del que partía la isla en este campo, pues no existen estudios a este detalle. En segundo lugar, al actual Jefe de Servicio de Redes de INALSA, Miguel Ángel Figueras Alfonso, que posee un conocimiento enciclopédico sobre la infraestructura y los procesos que han acontecido en la isla en relación a la producción de agua desalada.

Finalmente quisiera dejar constancia de mi agradecimiento a mi familia, por su estímulo constante, y especialmente a Ramón, por acompañarme, asistir y apoyarme a lo largo de este extenso camino. 


\section{Índice}

CAPÍTULO 1.-OBJETIVOS GENERALES E HIPÓTESIS DE PARTIDA ............................................1

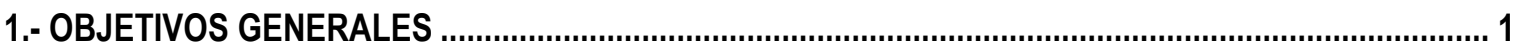

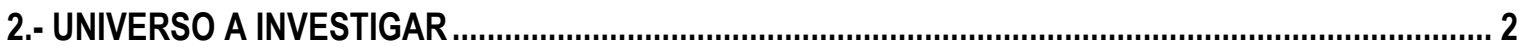

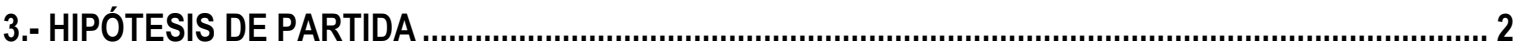

CAPÍTULO 2.-ESTADO DE LA CUESTIÓN. PRINCIPALES APORTACIONES A LA MATERIA..........7

1.- CONCEPTOS BÁSICOS

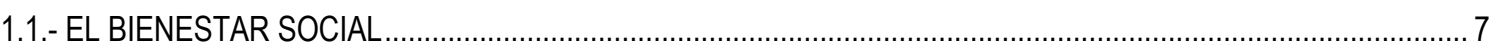

1.1.1.- ESTADO DE BIENESTAR Y SOCIEDAD DE BIENESTAR .............................................................. 11

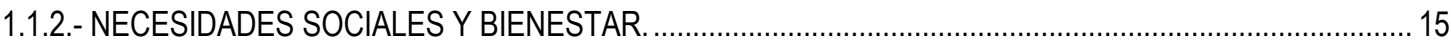

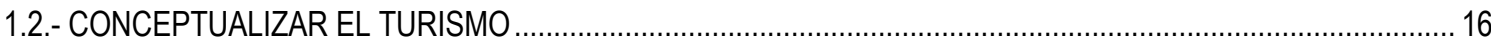

1.2.1.- LA MASIFICACIÓN DEL TURISMO

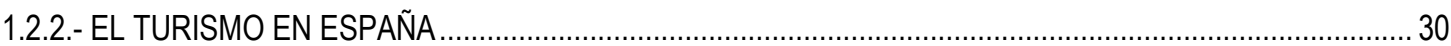

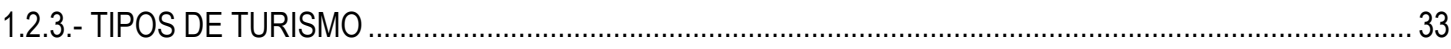

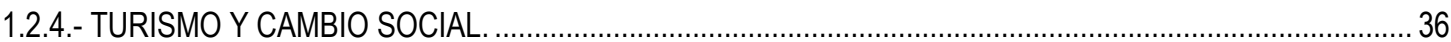

1.2.5.- TURISMO Y DESARROLLO ECONÓMICO …………….......................................................... 40

2.- BIENESTAR SOCIAL Y TURISMO

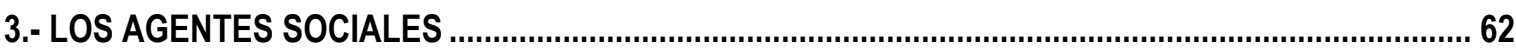

3.1.- LOS ORGANISMOS INTERNACIONALES

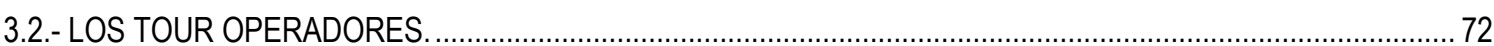

3.3.- LA INTERVENCIÓN DEL SECTOR PÚBLICO EN EL TURISMO ……...................................................... 74

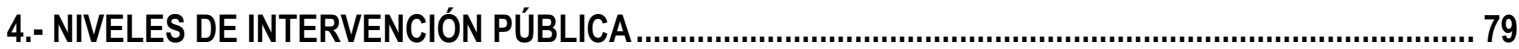

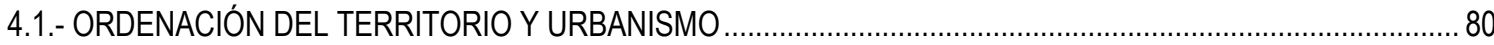

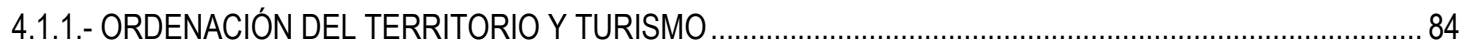

4.2.- LA ADMINISTRACIÓN GENERAL DEL ESTADO. POLÍTICA Y LEGISLACIÓN ……..................................... 86

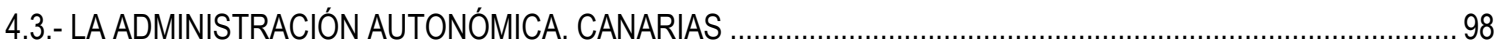

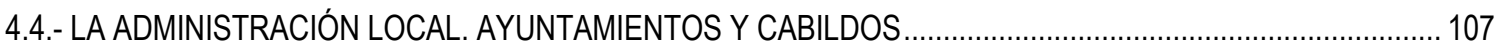

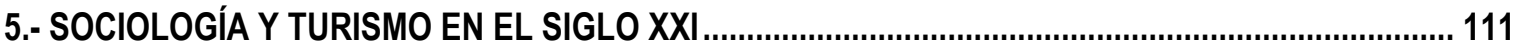

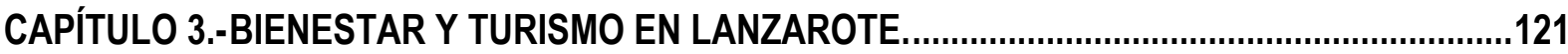


1.- CARACTERÍSTICAS POLÍTICO-GEOGRÁFICAS DE LANZAROTE 121

2.- RELEVANCIA PARA EL CONOCIMIENTO DEL CASO DE LANZAROTE 123

3.- POLÍTICA, LEGISLACIÓN URBANÍSTICA Y TURISMO EN LANZAROTE 124

4.- METODOLOGÍA 127

\section{5.- ETAPAS DEL DESARROLLO TURÍSTICO INSULAR Y SUS EFECTOS SOBRE EL} BIENESTAR 136

5.1.- PRIMERA ETAPA. DESPEGUE Y CONSOLIDACIÓN. 1970-1986 ............................................................ 138

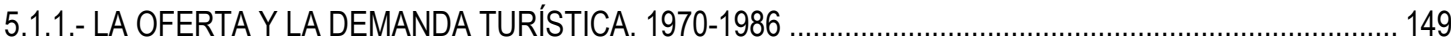

5.1.1.1.- Evolución de las plazas de alojamiento turístico........................................................................... 149

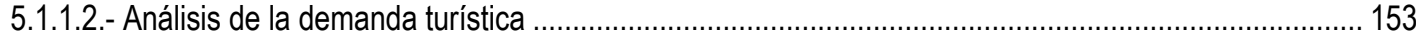

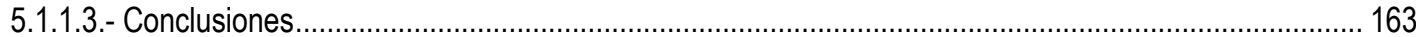

5.1.2.- EFECTOS SOBRE LA ESTRUCTURA DEMOGRÁFICA BÁSICA. 1970-1986 ....................................... 164

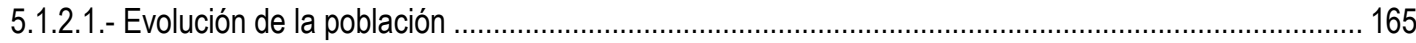

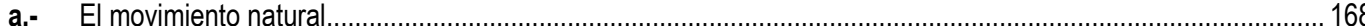

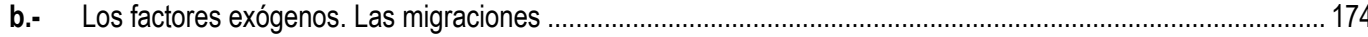

c.- $\quad$ La población autóctona ............... 177

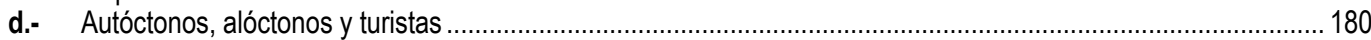

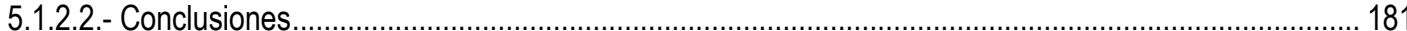

5.1.3.- EFECTOS SOBRE LA CUALIFICACIÓN Y EL EQUIPAMIENTO EDUCATIVO. 1970-1986 .................... 182

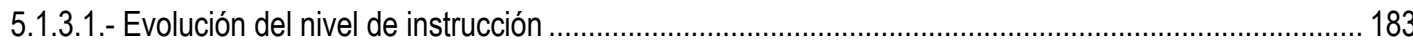

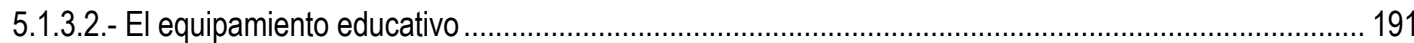

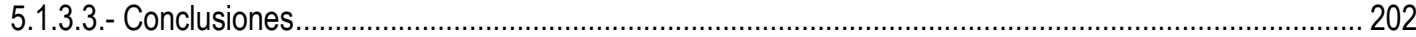

5.1.4.- EFECTOS SOBRE LA DOTACIÓN DE SERVICIOS DE SALUD. 1970-1986 ....................................... 204

5.1.4.1.- Dotación hospitalaria y extrahospitalaria. .................................................................................. 205

a.- El personal facultativo.

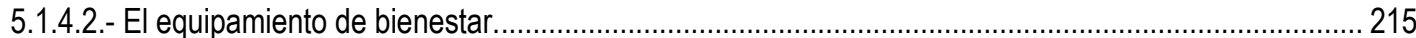

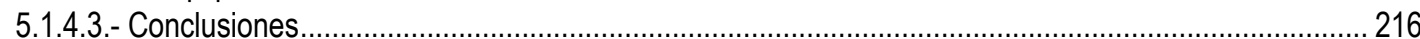

5.1.5.- EFECTOS SOBRE LA ACTIVIDAD ECONÓMICA Y EL EMPLEO. 1970-1986 ...................................... 218

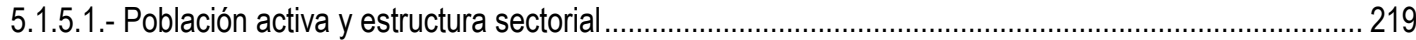

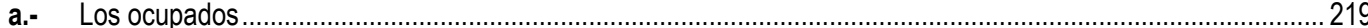

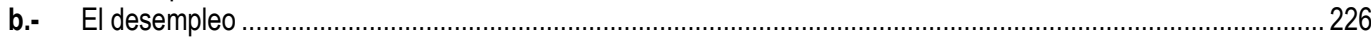

5.1.5.2.- Población, oferta y demanda turística, empleo y paro ..................................................................... 230

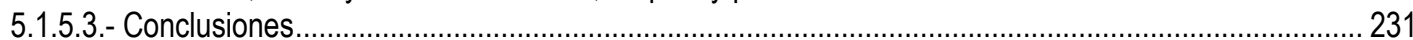

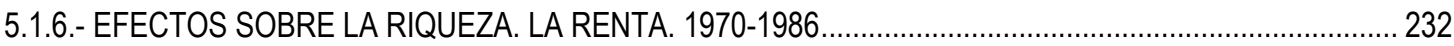

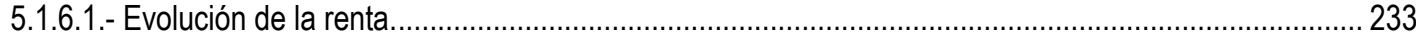

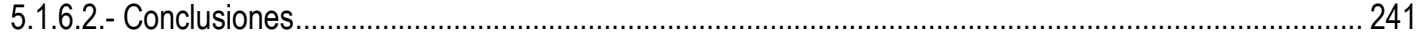

5.1.7.- EFECTOS SOBRE LA CAPACIDAD ENERGÉTICA. 1970-1986 ...................................................... 241

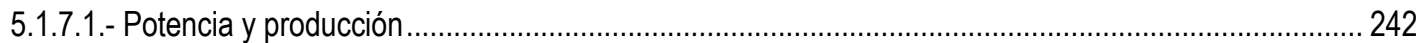

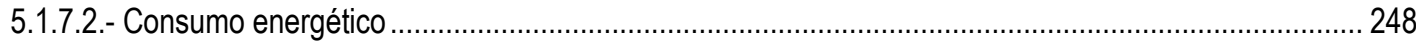

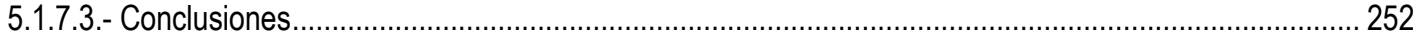

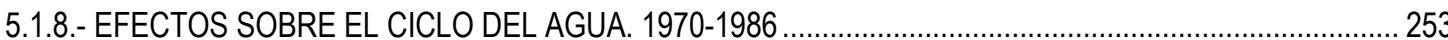


5.1.8.1.- La disponibilidad de agua. Oferta

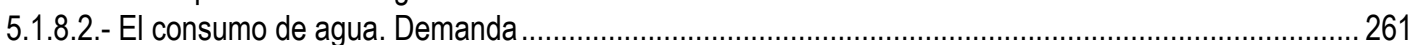

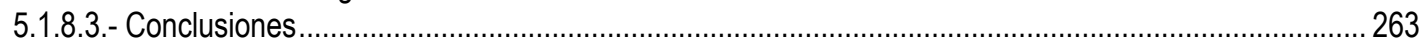

5.1.9.- EFECTOS SOBRE LAS VÍAS DE COMUNICACIÓN. CARRETERAS. 1970-1986 ................................... 264

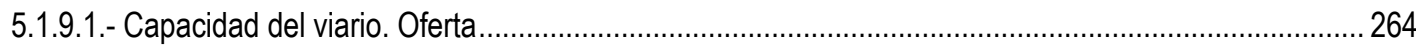

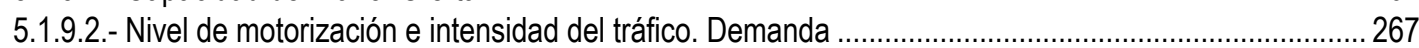

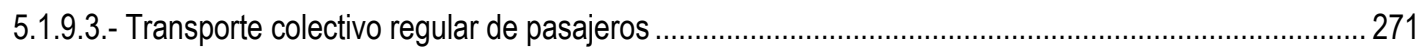

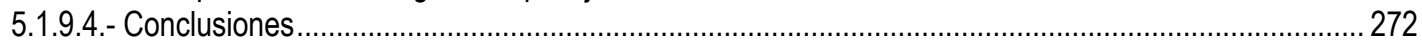

5.1.10.- CONCLUSIONES A LA PRIMERA ETAPA. DESPEGUE Y CONSOLIDACIÓN. 1970-1986 ................... 273

5.2.- SEGUNDA ETAPA. BOOM TURÍSTICO Y NUEVO PIOT. 1986-1996 …….................................................... 283

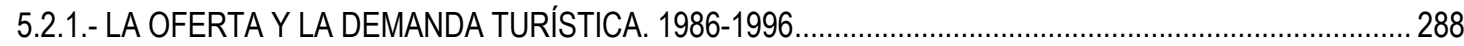

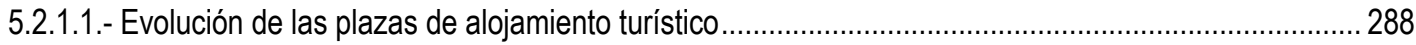

5.2.1.2.- Análisis de la demanda turística....................................................................................................... 293

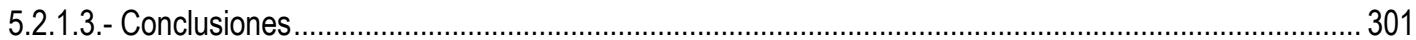

5.2.2.- EFECTOS SOBRE LA ESTRUCTURA DEMOGRÁFICA BÁSICA. 1986-1996 ........................................ 302

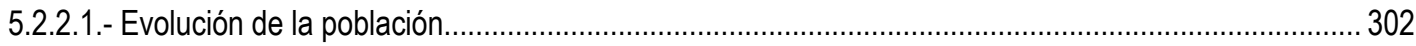

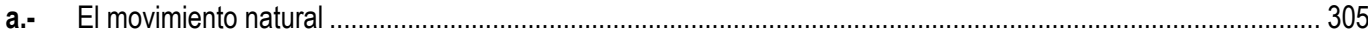

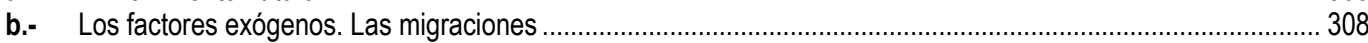

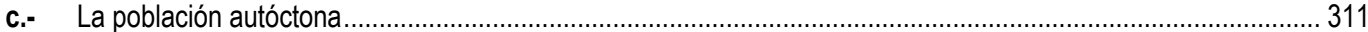

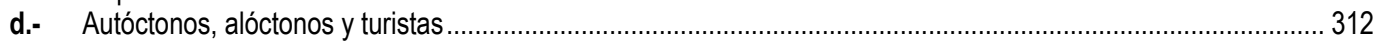

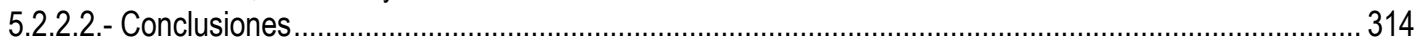

5.2.3.- EFECTOS SOBRE LA CUALIFICACIÓN Y EL EQUIPAMIENTO EDUCATIVO. 1986-1996 ...................... 315

5.2.3.1.- Evolución del nivel de instrucción .............................................................................................. 315

a.- $\quad$ Nivel de instrucción de los inmigrantes .................................................................................................. 320

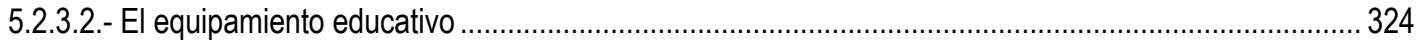

5.2.3.3.- Conclusiones

5.2.4.- EFECTOS SOBRE LA DOTACIÓN DE SERVICIOS DE SALUD. 1986-1996 ........................................ 334

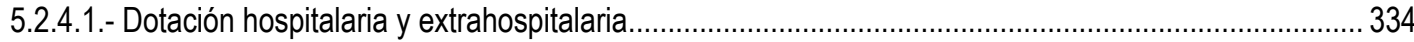

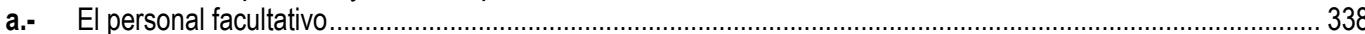

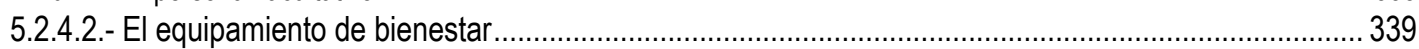

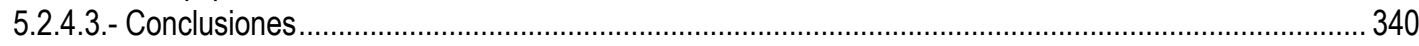

5.2.5.- EFECTOS SOBRE LA ACTIVIDAD ECONÓMICA Y EL EMPLEO. 1986-1996 …………….................... 343

5.2.5.1.- Población activa y estructura sectorial ........................................................................................ 343

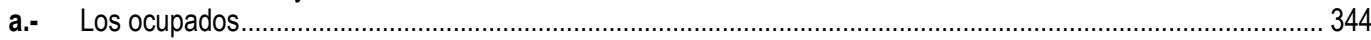

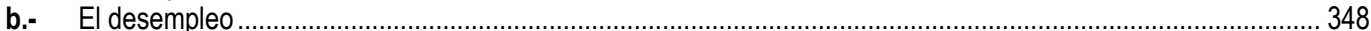

5.2.5.2.- Población, oferta y demanda turística, empleo y paro ……............................................................. 352

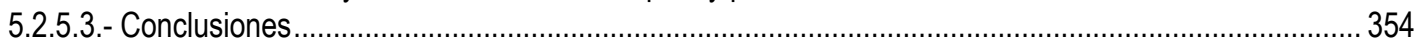

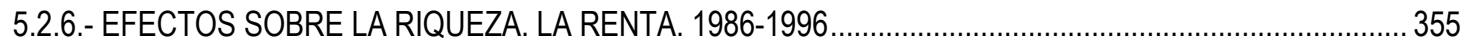

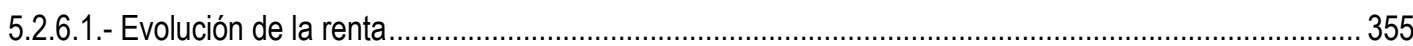

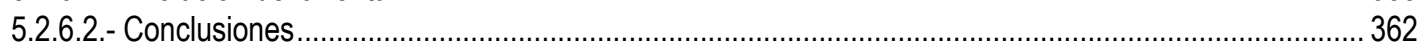

5.2.7.- EFECTOS SOBRE LA CAPACIDAD ENERGÉTICA. 1986-1996 ............................................................. 363

5.2.7.1.- Potencia y producción ............................................................................................................... 363

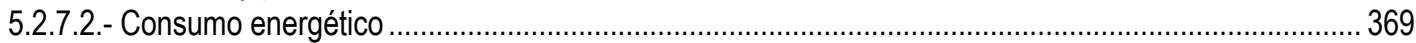

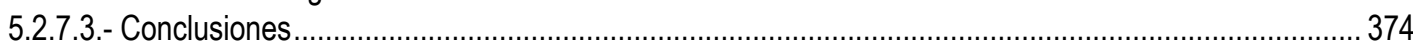




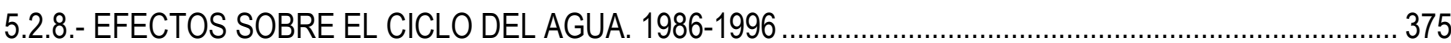

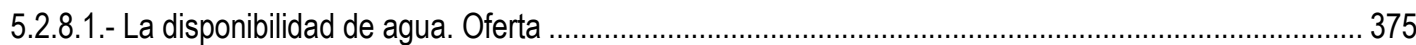

5.2.8.2.- El consumo de agua. Demanda .......................................................................................... 381

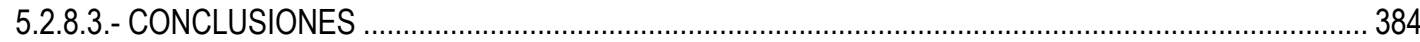

5.2.9.- EFECTOS SOBRE LAS VÍAS DE COMUNICACIÓN. CARRETERAS. 1986-1996 ................................. 385

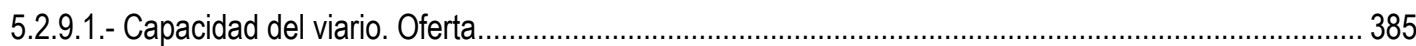

5.2.9.2.- Nivel de motorización e intensidad del tráfico ............................................................................. 387

5.2.9.3.- Transporte colectivo regular de pasajeros ................................................................................ 391

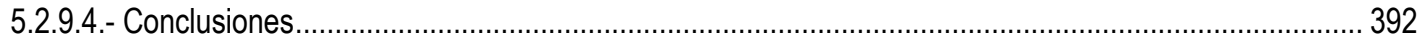

5.2.10.- CONCLUSIONES A LA SEGUNDA ETAPA. BOOM TURÍSTICO Y PIOT. 1986-1996 ........................... 393

5.3.- TERCERA ETAPA. MADUREZ TURÍSTICA Y MORATORIA. 1996-2006..................................................... 405

5.3.1.- LA OFERTA Y LA DEMANDA TURÍSTICA. 1996-2006 ................................................................ 410

5.3.1.1.- Evolución de las plazas de alojamiento turístico........................................................................... 410

5.3.1.2.- Análisis de la demanda turística .................................................................................... 415

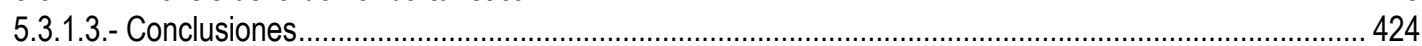

5.3.2.- EFECTOS SOBRE LA ESTRUCTURA DEMOGRÁFICA BÁSICA. 1996-2006..................................... 426

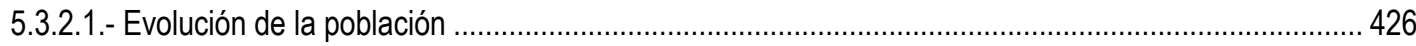

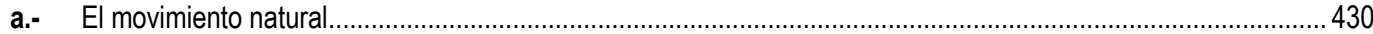

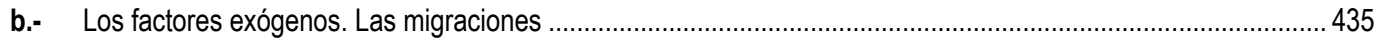

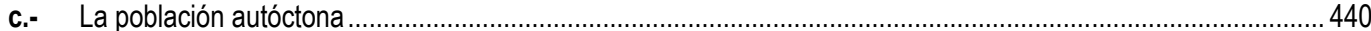

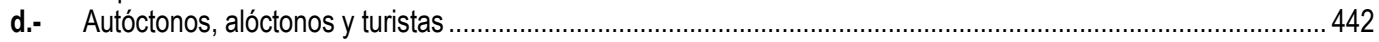

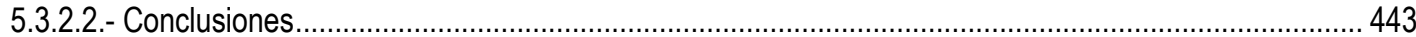

5.3.3.- EFECTOS SOBRE LA CUALIFICACIÓN Y EL EQUIPAMIENTO EDUCATIVO. 1996-2006 .................... 445

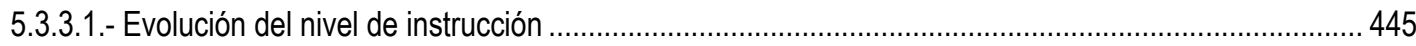

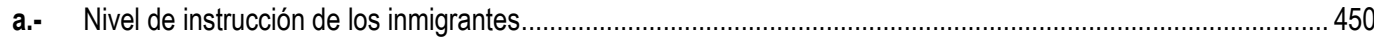

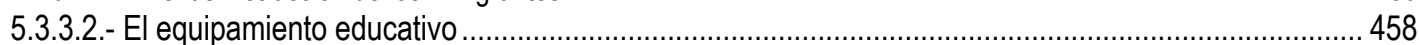

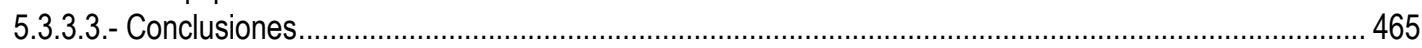

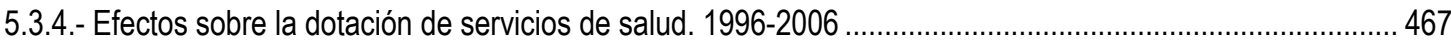

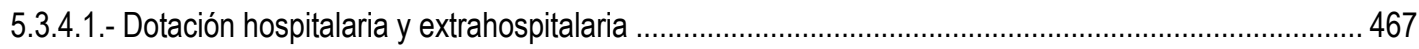

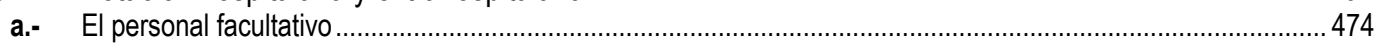

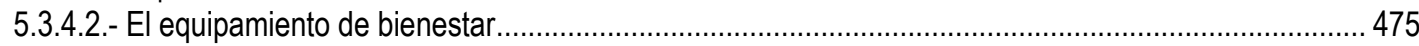

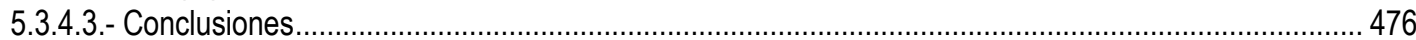

5.3.5.- EFECTOS SOBRE LA ACTIVIDAD ECONÓMICA Y EL EMPLEO. 1996-2006 ..................................... 478

5.3.5.1.- Población activa y estructura sectorial del empleo ..................................................................... 478

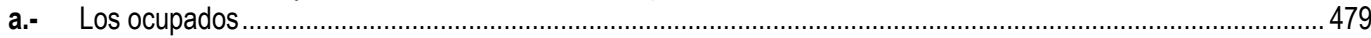

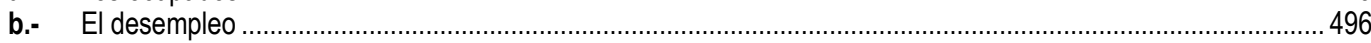

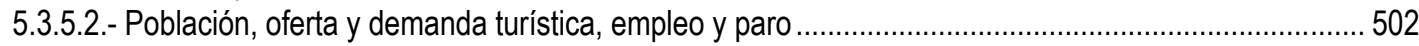

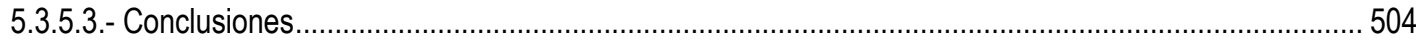

5.3.6.- EFECTOS SOBRE LA RIQUEZA. LA RENTA. 1996-2006............................................................ 506

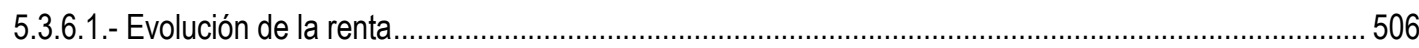

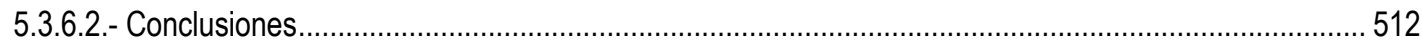

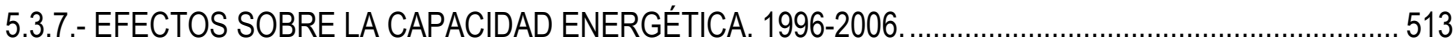

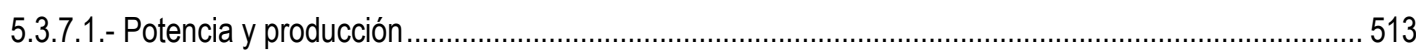




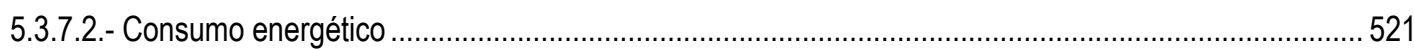

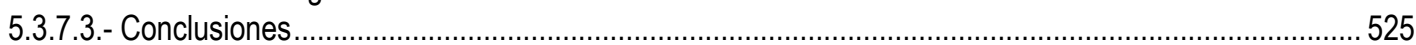

5.3.8.- EFECTOS SOBRE EL CICLO DEL AGUA. 1996-2006 ……........................................................526

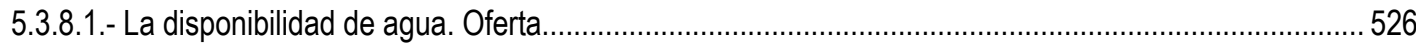

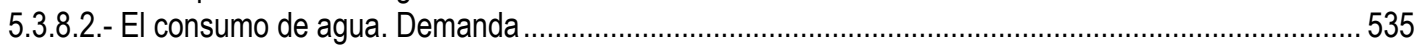

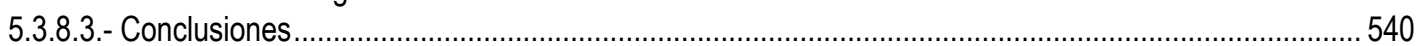

5.3.9.- EFECTOS SOBRE LAS VÍAS DE COMUNICACIÓN. CARRETERAS. 1996-2006 ..................................541

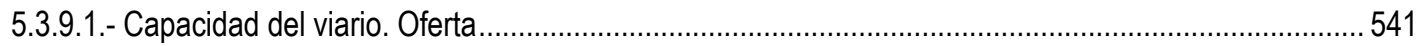

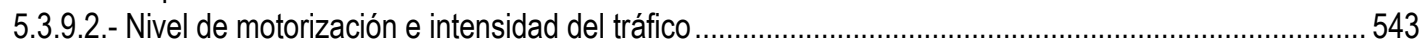

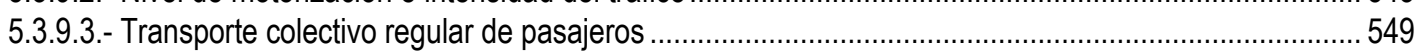

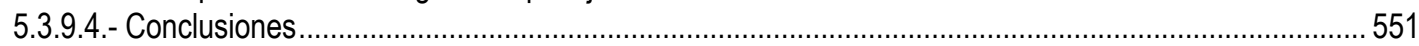

5.3.10.- CONCLUSIONES A LA TERCERA ETAPA. 1996-2006. CRISIS TURÍSTICA Y MORATORIA...............552

\section{CAPÍTULO 4.-DIMENSIONES DEL CAMBIO INSULAR. ANÁLISIS INTEGRADO Y APORTACIONES}

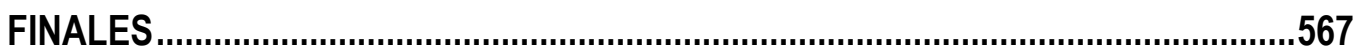

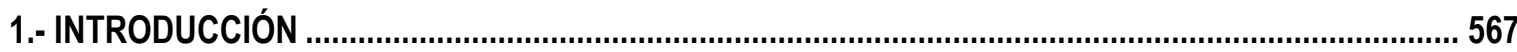

2.- HOMOGENEIZACIÓN DE LAS SERIES Y EVOLUCIÓN DE LA RENTA PER CÁPITA A

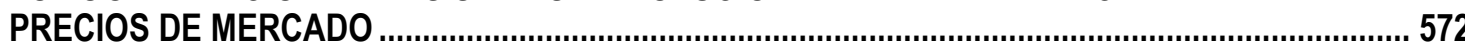

3.- FACTORES INCIDENTES EN LA EVOLUCIÓN DE LAS VARIABLES............................................. 577

3.1.- SU RELACIÓN CON LA OFERTA Y DEMANDA TURÍSTICA. LOS INICIOS DEL CRECIMIENTO

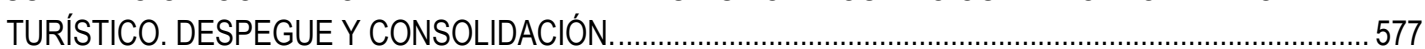

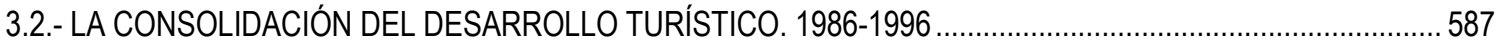

3.2.1.- MADUREZ TURISTICA Y NEGATIVA DEPENDENCIA DEL MONOCULTIVO DE LA CONSTRUCCIÓN Y

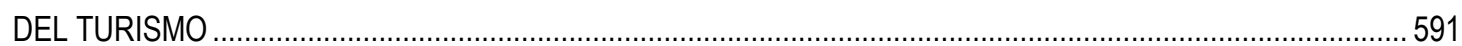

4.- UN BALANCE MEJORABLE

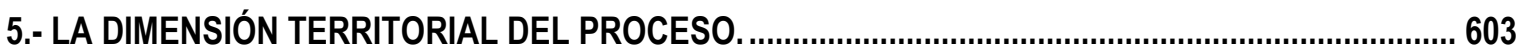

6.- ELEMENTOS COMPLEMENTARIOS PARA LA COMPRENSIÓN DE LAS TRANSFORMACIONES PRODUCIDAS

CAPÍTULO 5.-SÍNTESIS Y CONCLUSIONES...........................................................................627

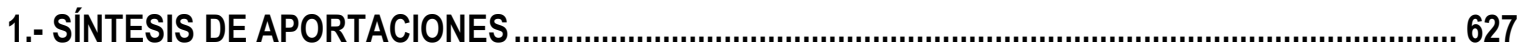

2.- CONCLUSIONES

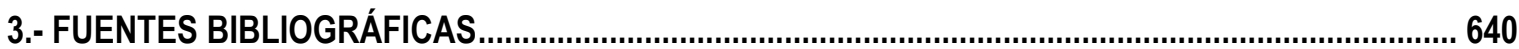

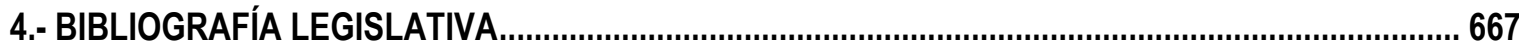




\section{Índice de tablas}

Tabla 1. Impactos del turismo sobre los recursos naturales en destinos de sol y playa ..................................................... 61

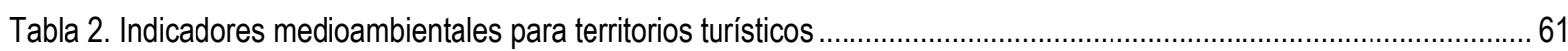

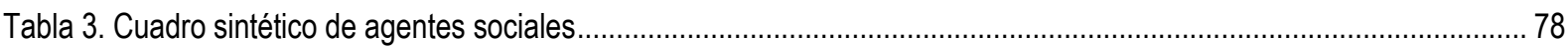

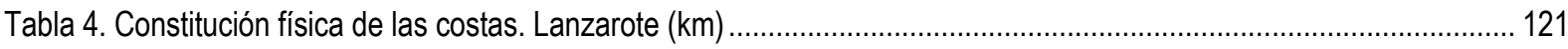

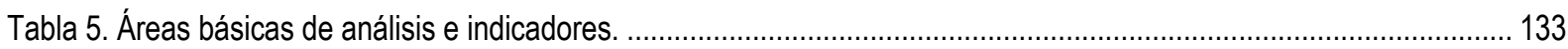

Tabla 6. Presidentes del Cabildo Insular de Lanzarote (1960-1991) ......................................................................... 145

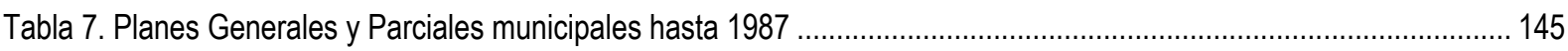

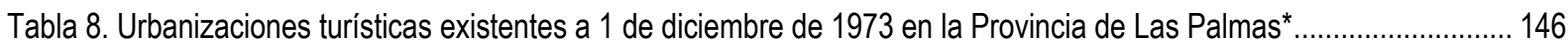

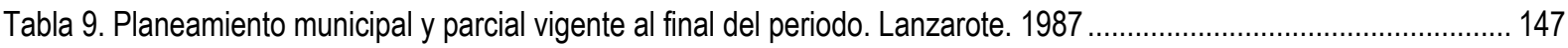

Tabla 10. Oferta de plazas de alojamiento turístico, según tipo. España, Canarias y Lanzarote 1970-1986 ....................... 149

Tabla 11. Turistas entrados e incremento quinquenal. España, Canarias y Lanzarote. 1970-1986 ..................................... 154

Tabla 12. Estancia media en establecimientos hoteleros. España, Canarias y Lanzarote. 2001-2006................................ 156

Tabla 13. Número de viajeros-turistas equivalentes al día. España. 1970-1986 .............................................................. 157

Tabla 14. Número de viajeros-turistas equivalentes al día. Canarias. 1970-1986 .......................................................... 157

Tabla 15. Número de viajeros-turistas equivalentes al día. Lanzarote. 1970-1986 ...................................................... 158

Tabla 16. Turistas entrados y relación turistas/residentes (trr). España, Canarias y Lanzarote. 1970-1986 .......................... 159

Tabla 17. Ratio turistas/plazas. España, Canarias y Lanzarote. 1970-1986 ................................................................... 162

Tabla 18. Población total. España, Canarias y Lanzarote 1970-1986 (\%) .................................................................... 165

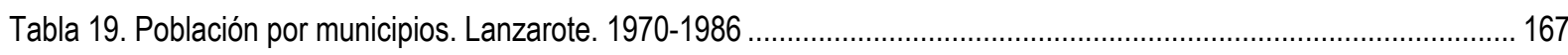

Tabla 20. Evolución de las tasas quinquenales de mortalidad. España, Canarias y Lanzarote. 1966-1985 (\%) .................. 169

Tabla 21. Evolución de las tasas quinquenales de natalidad. España, Canarias y Lanzarote .1966-1985 (\%o) .................... 170

Tabla 22. Evolución de las tasas quinquenales de crecimiento vegetativo de Lanzarote. 1966-1985 (\%) .......................... 171

Tabla 23. Población de hecho y derecho. España, Canarias y Lanzarote. 1960-1991 ......................................................... 173

Tabla 24. Porcentaje de incremento de la población de hecho con respecto a la de derecho. España, Canarias

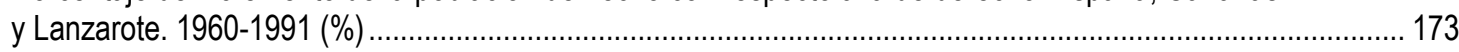

Tabla 25. Población residente según lugar de nacimiento. Inmigrantes netos. Lanzarote. 1970-1986 .................................. 175

Tabla 26. Población inmigrante y población autóctona. Absolutos y relativos. Lanzarote. 1970-1986 .................................. 178

Tabla 27. Relación entre autóctonos, alóctonos y turistas. Lanzarote. 1970-1986 ....................................................... 180

Tabla 28. Evolución del analfabetismo. España, Canarias y Lanzarote 1900-1975 (\%) ................................................... 184

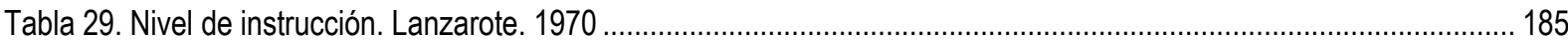

Tabla 30. Evolución del nivel de instrucción. España, Canarias y Lanzarote. 1981-1986. Absolutos y relativos .................. 186

Tabla 31. Inmigrantes por nivel de instrucción y lugar de procedencia. Lanzarote. 1981 (\%) ............................................ 190

Tabla 32. Inmigrantes por nivel de instrucción. España. 1981 (\%) ........................................................................ 191

Tabla 33. Relación alumnos/maestros/as en primera enseñanza*. Lanzarote. Curso 1967-1968 ...................................... 193

Tabla 34. Capacidad docente. E.G.B. Lanzarote. Curso 1968-1969 .................................................................... 194

Tabla 35. Capacidad docente. Cursos 1976-1977 y 1980-1981. Lanzarote …………………………............................. 195

Tabla 36. Alumnos por nivel de instrucción. Cursos 1976-1977 y 1980-1981. Lanzarote ................................................ 195 
Tabla 37. Oferta y demanda docente. Infantil, E.G.B. y Medias. Lanzarote. Curso 1985-1986........................................ 198

Tabla 38. Capacidad de los Institutos de Bachillerato. Lanzarote. Curso 1985-1986 ........................................................ 199

Tabla 39. Oferta y demanda docente. Enseñanza especial y de adultos. Lanzarote. Curso 1985-1986 ...........................202

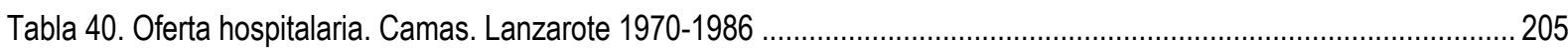

Tabla 41. Equipamientos y servicios. Hospital nuestra señora de los volcanes (Insalud). Lanzarote. 1975 .......................208

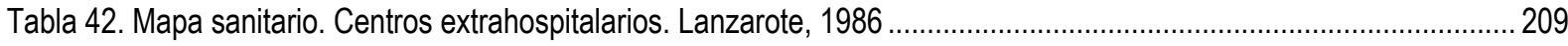

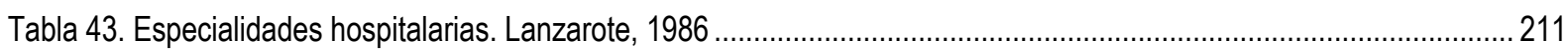

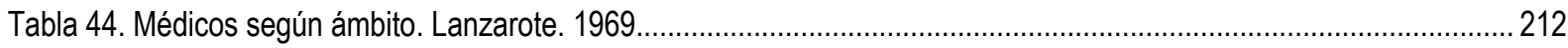

Tabla 45. Habitantes por médico. Europa, España y Lanzarote. 1965-1969 .............................................................. 212

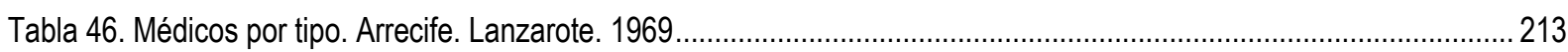

Tabla 47. Número de facultativos por tipo y ratio habitantes/médicos. España, Canarias y Lanzarote. 1970-1986 ............. 214

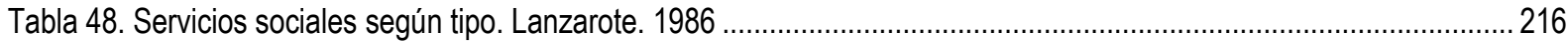

Tabla 49. Población activa insular, según municipios y tipos de ocupación. Lanzarote. 1965 .......................................... 219

Tabla 50. Ocupación por sectores. Lanzarote, Canarias y España. 1965 (\%) ..................................................................... 220

Tabla 51. Población activa estimada, según municipios y niveles ocupacionales. Lanzarote. 1970 ................................. 222

Tabla 52. Evolución de la población activa 1965 y 1970. Lanzarote. (\%) ……................................................................ 222

Tabla 53. Estructura sectorial del empleo. Ocupados. Lanzarote, Canarias y España. 1981-1986 .................................... 224

Tabla 54. Incremento quinquenal de la población ocupada por sector económico. Lanzarote, Canarias y

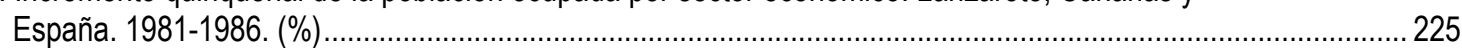

Tabla 55. Evolución de la población activa por sectores económicos. Lanzarote. 1965-1986 (\%).................................... 225

Tabla 56. Tasa de actividad y paro por sexo. Lanzarote, Canarias y España. 1981-1986 (\%) ....................................... 227

Tabla 57. Estructura sectorial del paro. Lanzarote, Canarias y España. 1981-1986 (\%).................................................. 229

Tabla 58. Incremento de la población potencialmente activa, la oferta y demanda turística, el empleo y el paro. Lanzarote, Canarias y España entre 1970 y 1986 (\%)

Tabla 59. Rentas monetarias per cápita y por hogar, por municipio. Lanzarote, Provincia de Las Palmas y Canarias. 1970 (ptas/mes).....

Tabla 60. Distribución de ingresos monetarios familiares por municipios / mes. Lanzarote. 1970. (\%) ............................. 234

Tabla 61. Distribución de los ingresos monetarios familiares por mes. Provincia de Las Palmas y Comunidad Autónoma. 1970. (\%)

Tabla 62. Nivel de renta por habitante de los municipios de Lanzarote, Canarias y España. 1981 ...................................237

Tabla 63. Nivel de renta por habitante de los municipios de Lanzarote, Canarias y España. 1986 ....................................2238

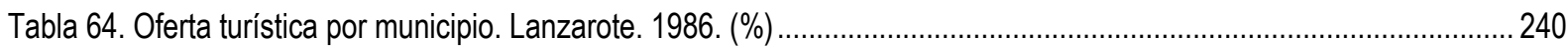

Tabla 65. Potencia instalada. Lanzarote, Canarias y España. 1970-1986 (kw) .........................................................243

Tabla 66. Producción de energía eléctrica disponible. Lanzarote, Canarias y España. 1970-1986 (mwh) ......................... 247

Tabla 67. Consumo eléctrico e intensidad energética. Lanzarote. 1970-1986 (mwh) ......................................................249

Tabla 68. Consumo eléctrico e intensidad energética. Canarias. 1970-1986 (mwh) ....................................................249

Tabla 69. Consumo eléctrico e intensidad energética. España. 1970-1986 (mwh) ........................................................249

Tabla 70. Resumen. Variación de la oferta y demanda de energía eléctrica por habitante (kwh). España,

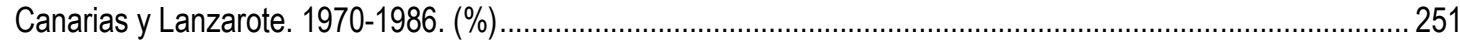

Tabla 71. Fuentes de captación y producción de agua potable. Oferta. Lanzarote. 1970-1986 (hm³/año)......................... 256 
Tabla 72. Incremento interperiodo de la producción de agua. Oferta. Lanzarote. 1970-1986 (\%) .................................... 257

Tabla 73. Producción media diaria de agua y población a abastecer. Lanzarote. 1970-1986 (m³/día) .............................. 258

Tabla 74. Producción media diaria de agua, privada y pública, y población que abastece. Lanzarote. 1975-1986 ............. 259

Tabla 75. Viviendas con agua corriente por municipio. Lanzarote 1970-1981 (\%) ............................................................ 260

Tabla 76. Consumo medio diario de agua y producción. Lanzarote. 1970-1981 (I/habitantes*día).................................. 261

Tabla 77. Consumo medio diario de agua, producción y población a abastecer. Lanzarote. 1986 (m³/año) ....................... 262

Tabla 78. Ancho de calzada y kilómetros de carreteras. Lanzarote. 1970-1986. .............................................................. 265

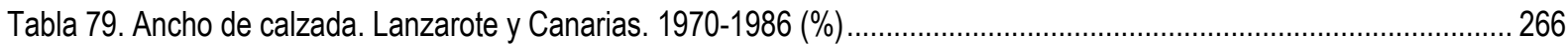

Tabla 80. Número de vehículos (turismos) e Índice de motorización. Lanzarote, Canarias y España. 1970-1986 ............... 267

Tabla 81. Evolución de la intensidad media diaria de vehículos, por tramos. Lanzarote. 1975-1985 (\%) ........................... 269

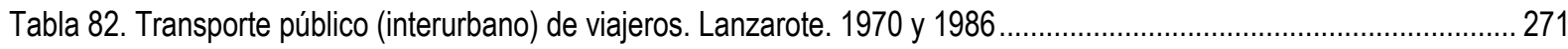

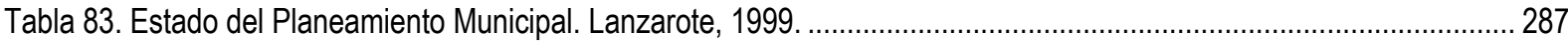

Tabla 84. Oferta de plazas de alojamiento turístico, según tipo. España, Canarias y Lanzarote 1986-1996.......................289

Tabla 85. Turistas entrados e incremento interperiodo. España, Canarias y Lanzarote. 1986-1996 .................................. 293

Tabla 86. Estancia media en establecimientos hoteleros. España, Canarias y Lanzarote. 2001-2006............................. 296

Tabla 87. Número de viajeros-turistas equivalentes al día. España. 1986-1996 ............................................................296

Tabla 88. Número de viajeros-turistas equivalentes al día. Canarias. 1986-1996 .......................................................... 297

Tabla 89. Número de viajeros-turistas equivalentes al día. Lanzarote. 1986-1996 ......................................................... 297

Tabla 90. Turistas entrados y relación turistas/residentes (t/r). España, Canarias y Lanzarote. 1986-1996........................ 298

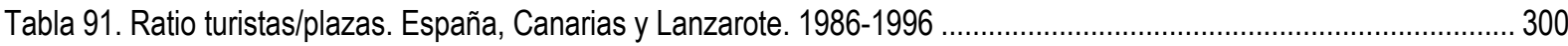

Tabla 92. Población total. España, Canarias y Lanzarote 1986-1996 (\%)................................................................... 303

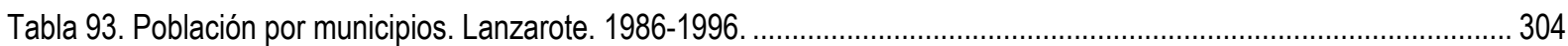

Tabla 94. Evolución de las tasas quinquenales de mortalidad. España, Canarias y Lanzarote. 1986-1995 (\%o) ................. 305

Tabla 95. Evolución de las tasas quinquenales de natalidad. España, Canarias y Lanzarote .1986-1995 (\%) .................. 306

Tabla 96. Evolución de las tasas quinquenales de crecimiento vegetativo de Lanzarote. 1986-1995 (\%o) .........................307

Tabla 97. Población residente según lugar de nacimiento. Inmigrantes netos. Lanzarote. 1986-1996 ............................... 309

Tabla 98. Población inmigrante y población autóctona. Absolutos y relativos. Lanzarote. 1986-1996................................ 311

Tabla 99. Relación entre autóctonos, alóctonos y turistas. Lanzarote. 1986-1996 ........................................................ 313

Tabla 100. Evolución del nivel de instrucción. España, Canarias y Lanzarote. Absolutos y relativos.1986-1996................ 316

Tabla 101. Inmigrantes por nivel de instrucción y lugar de procedencia entre 1981 y 1991. Lanzarote. (\%)...................... 321

Tabla 102. Inmigrantes por nivel de instrucción y lugar de procedencia. Lanzarote. Absolutos y relativos. 1996 ................ 322

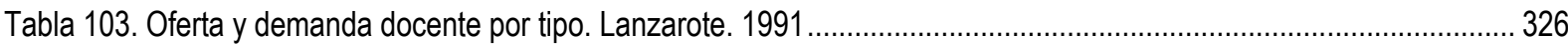

Tabla 104. Capacidad docente. Bachillerato y Formación profesional. Lanzarote. 1991 ................................................... 327

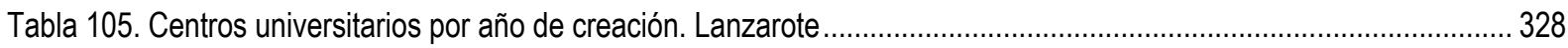

Tabla 106. Oferta y demanda docente. Infantil, E.G.B y Medias. Lanzarote. 1996 ....................................................... 329

Tabla 107. Evolución de la capacidad docente en preescolar. Lanzarote. 1986-1996 .....................................................3 329

Tabla 108. Evolución de la capacidad en la enseñanza obligatoria. Lanzarote. 1986-1996 ............................................ 330

Tabla 109. Capacidad docente. Resto de oferta no universitaria. Lanzarote. 1996 ........................................................ 330

Tabla 110. Evolución de la capacidad en la Enseñanza de Adultos. Lanzarote. 1986-1996............................................ 331 
Tabla 111. Evolución de la capacidad en la Enseñaza. Especial. Lanzarote. 1986-1996 _...............................................331

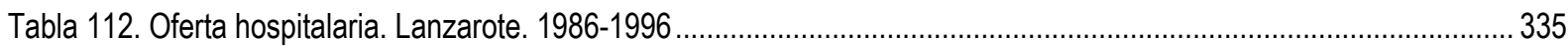

Tabla 113. Número de facultativos por tipo y ratio habitantes/médicos. España, Canarias y Lanzarote. 1986-1996 .......... 338

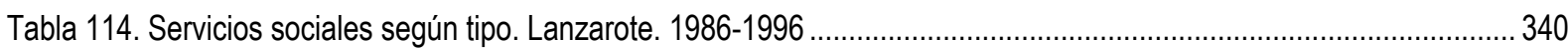

Tabla 115. Tasa de actividad. Lanzarote, Canarias y España. 1986-1996 (\%) ........................................................... 343

Tabla 116. Población activa municipal por sectores económicos. Lanzarote. 1965 y 1991 (\%)....................................... 344

Tabla 117. Estructura sectorial del empleo. Ocupados. Lanzarote, Canarias y España. 1986-1996................................. 345

Tabla 118. Incremento interperiodo de la población ocupada por sector económico. Lanzarote, Canarias

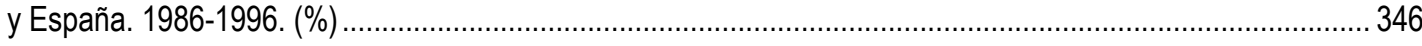

Tabla 119. Ocupados por sexo y profesión. Resultados insulares. 1991-1996 (\%).........................................................348

Tabla 120. Tasa de actividad y paro por sexo. Lanzarote, Canarias y España. 1986-1996 (\%) ........................................ 349

Tabla 121. Estructura sectorial del paro. Lanzarote, Canarias y España. 1986-1996 (\%).............................................. 350

Tabla 122. Incremento de la población potencialmente activa, la oferta y demanda turística, el empleo y paro. Lanzarote, Canarias y España. Entre 1986 y 1996(\%) ................................................................................. 352

Tabla 123. Incremento interperiodo. Población, oferta y demanda turística, empleo y paro. Lanzarote 1986-1996 (\%)....... 353

Tabla 124. Nivel de renta media por habitante de los municipios y de Lanzarote, Canarias y España. 1986...................... 355

Tabla 125. Nivel de renta media por habitante de los municipios y de Lanzarote, Canarias y España. 1991...................... 356

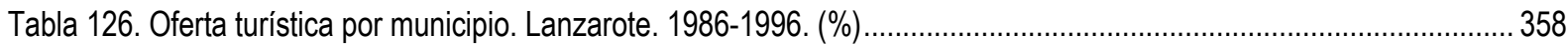

Tabla 127. Nivel de renta disponible por habitante de los municipios y de Lanzarote, Canarias y España. 1996. .............. 360

Tabla 128. Potencia instalada. Lanzarote, Canarias y España. 1986-1996 (kw) .............................................................364

Tabla 129. Producción de energía eléctrica disponible. Lanzarote, Canarias y España. 1986-1996 (mwh) ....................... 368

Tabla 130. Consumo eléctrico e intensidad energética eléctrica. Lanzarote, Canarias y España. 1986-1996 (mwh)........... 370

Tabla 131. Resumen. Variación de la oferta y demanda de energía eléctrica por habitante equivalente (kwh/P. Total).

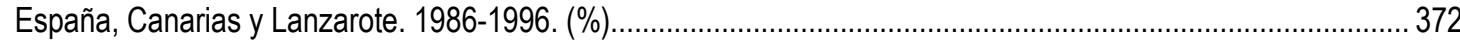

Tabla 132. Producción pública de agua potable. Oferta. Lanzarote. 1986-1996 (hm³/año). ............................................377

Tabla 133. Incremento interperiodo de la producción pública de agua. Oferta. Lanzarote. 1986-1996 (hm/año) (\%) ......... 378

Tabla 134. Producción media diaria de agua pública y población residente. Lanzarote. 1986-1996 (mª́a) .....................378

Tabla 135. Disponibilidad de agua desalada pública, en destino final, para consumo de la población diaria estimada. Lanzarote. 1991-1996 (I/residente*día).......................................................................... 380

Tabla 136. Consumo medio diario de agua, producción y población a abastecer. Lanzarote. 1986-1996 (m³/año) ............. 381

Tabla 137. Consumo unitario por residente y turista. Lanzarote. 1986 y 1996 (I/habitantes*día).................................... 383

Tabla 138. Crecimiento del consumo, la producción, los residentes y turistas. Lanzarote. 1986-1996................................ 383

Tabla 139. Ancho de calzada y kilómetros de carretera. Lanzarote y Canarias. 1986 ................................................... 386

Tabla 140. Número de vehículos (turismos) e índice de motorización. Lanzarote, Canarias y España. 1986-1996 ............. 388

Tabla 141. Evolución de los coches de alquiler. Lanzarote, 1991-1996 …..................................................................... 389

Tabla 142. Evolución de la intensidad media diaria de vehículos, por tramos. Lanzarote. 1987-1995.............................. 390

Tabla 143. Transporte público (interurbano) de viajeros. Lanzarote. 1986-1996............................................................. 391

Tabla 144. Planeamiento urbanístico municipal vigente, según tipo, año de aprobación y gobierno.

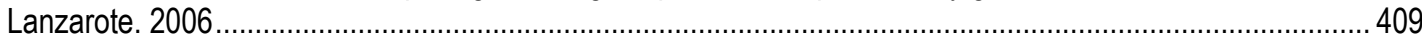

Tabla 145. Oferta de plazas de alojamiento turístico, según tipo. España, Canarias y Lanzarote. 1996-2006...................4 411 
Tabla 146. Turistas entrados e incremento interperiodo. España, Canarias y Lanzarote. 1996-2006 416

Tabla 147. Estancia media en establecimientos hoteleros. España, Canarias y Lanzarote. 2001-2006 420

Tabla 148. Número de viajeros-turistas equivalentes al día. España. 1986-1996......................................................420

Tabla 149. Número de viajeros-turistas equivalentes al día. Canarias. 1986-1996 .........................................................421

Tabla 150. Número de viajeros-turistas equivalentes al día. Lanzarote. 1986-1996. .....................................................421

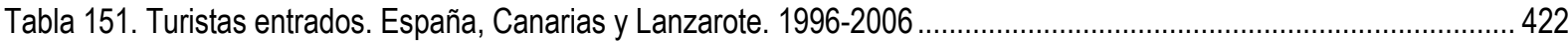

Tabla 152. Ratio turistas/plazas. España, Canarias y Lanzarote. 1986-1996 ................................................................. 423

Tabla 153. Población total registrada. España, Canarias y Lanzarote 1996-2006 (\%)....................................................427

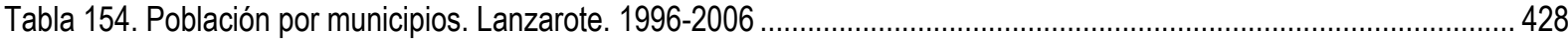

Tabla 155. Evolución de las tasas quinquenales de mortalidad. España, Canarias y Lanzarote. 1996-2005 (\%o) ............... 430

Tabla 156. Evolución del índice de juventud. España, Canarias y Lanzarote. 1996-2005 (\%)......................................... 431

Tabla 157. Estructura de la población por edad. Grandes grupos. España, Canarias y Lanzarote. 1996-2005 (\%)............ 432

Tabla 158. Evolución de las tasas quinquenales de natalidad. España, Canarias y Lanzarote. 1996-1985 (\%o) ..................433

Tabla 159. Población entre 20 y 39 años de edad. España, Canarias y Lanzarote. 1996-2005 (\%).................................. 434

Tabla 160. Evolución de las tasas quinquenales de crecimiento vegetativo. España, Canarias y Lanzarote.

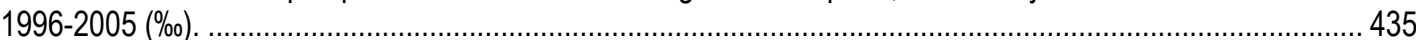

Tabla 161. Población residente según lugar de nacimiento. Inmigrantes netos. Lanzarote. 1996-2006.............................436

Tabla 162. Población según lugar de nacimiento. Inmigración externa neta. Lanzarote. 1996-2006................................ 438

Tabla 163. Población inmigrante y población autóctona. Absolutos y relativos. Lanzarote. 1986-1996 ............................... 440

Tabla 164. Relación entre autóctonos, alóctonos y turistas. Lanzarote. 1996-2006...........................................................442

Tabla 165. Evolución del nivel de instrucción. Absolutos y relativos. España, Canarias y Lanzarote. 1996-2007 ............... 446

Tabla 166. Inmigrantes por nivel de instrucción. Absolutos y relativos. Lanzarote. 1996-2001 .......................................... 451

Tabla 167. Inmigrantes por nivel de instrucción y lugar de procedencia. Lanzarote. 1996-2001 (\%)............................... 452

Tabla 168. Inmigrantes por nivel de instrucción y lugar de procedencia. Valores relativos e incremento quinquenal.

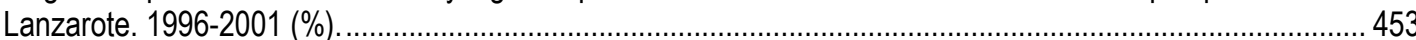

Tabla 169. Inmigrantes por lugar de procedencia y nivel de instrucción. Valores absolutos y relativos.

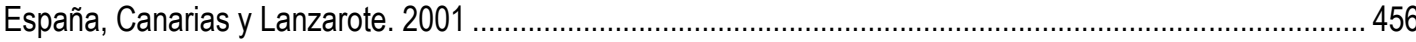

Tabla 170. Extranjeros por continente de origen y nivel de instrucción. Lanzarote. 2001 (\%) ..........................................457

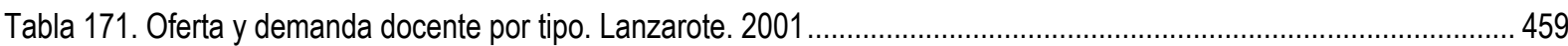

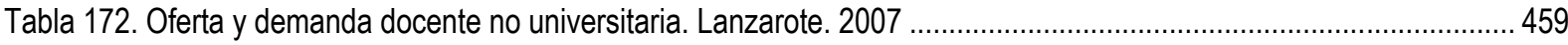

Tabla 173. Evolución del número de alumnos por nivel. Lanzarote. 1996-2006 ............................................................ 459

Tabla 174. Ratio alumno/unidad escolar. Lanzarote. 1996-2001 .............................................................................. 460

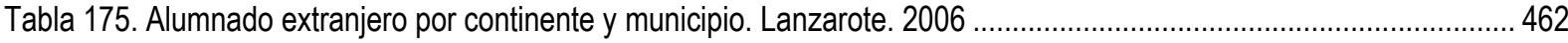

Tabla 176. Características equipamentales de la enseñanza de adultos. Lanzarote. 1996-2001 ......................................464

Tabla 177. Evolución del programa de garantía social. Lanzarote. 2001-2006 ............................................................... 464

Tabla 178. Evolución del ratio profesor/alumno en la Educación Especial y en la E. O. de Idiomas.

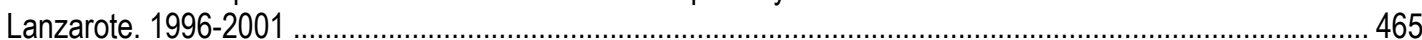

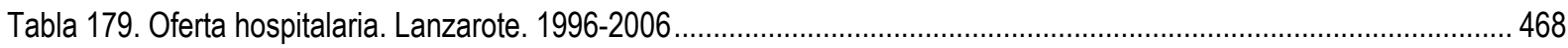

Tabla 180. Evolución de las camas hospitalarias. Lanzarote. 1996-2006 .................................................................. 469 
Tabla 181. Evolución de la zona básica de salud. Centros extrahospitalarios públicos, en funcionamiento. Lanzarote. 1986-1996-2006 471

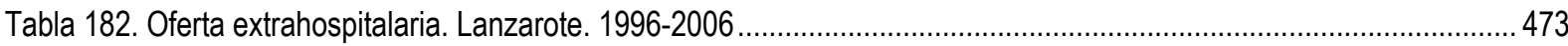

Tabla 183. Número de facultativos por tipo y ratio habitantes/médicos. Lanzarote. 1996-2006 ........................................474

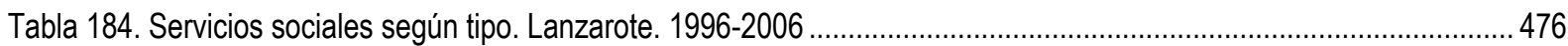

Tabla 185. Tasa de actividad. Lanzarote, Canarias y España. 1996-2006 (\%) ..............................................................479

Tabla 186. Estructura sectorial del empleo. Ocupados. Lanzarote, Canarias y España. 1996-2006 .................................. 480

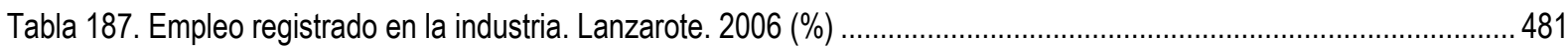

Tabla 188. Oferta y demanda turística en relación al límite alojativo turístico hasta el 2010 (moratoria). Lanzarote. 1996-2006.

Tabla 189. Incremento interperiodo de la población ocupada por sector económico. Lanzarote, Canarias y España. 1996-2006. (\%).......

Tabla 190. Empleo registrado por actividades económicas principales. Lanzarote. 2006 (\%) .........................................484

Tabla 191. Contratos temporales según ramas de actividad principales. Lanzarote. 2001-2006 ...................................... 484

Tabla 192. Contratos temporales por municipios. Lanzarote. 2001-2006 .................................................................... 485

Tabla 193. Contratos temporales según sectores y municipios. Lanzarote. 2001-2006................................................. 486

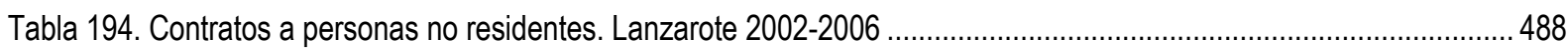

Tabla 195. Contratos a extranjeros en municipios que superan la media de Canarias. 2006 (\%)..................................... 490

Tabla 196. Contratos a extranjeros por tipo y sectores económicos principales. Lanzarote. 2006 .................................... 491

Tabla 197. Contratos a extranjeros por origen. Lanzarote y Canarias. 2006 (\%) .......................................................... 492

Tabla 198. Contratos a extranjeros según país de origen, sector económico y temporalidad. Lanzarote. 2006.................. 492

Tabla 199. Tasa de actividad y paro por sexo. Lanzarote, Canarias y España. 1996-2006 (\%) ......................................... 497

Tabla 200. Estructura sectorial del paro. Lanzarote, Canarias y España. 1996-2006 (\%)................................................500

Tabla 201. Población potencialmente activa según lugar de nacimiento. Lanzarote 1996-2006.......................................502

Tabla 202. Incremento quinquenal de la población, la oferta y la demanda turística, el empleo y el paro.

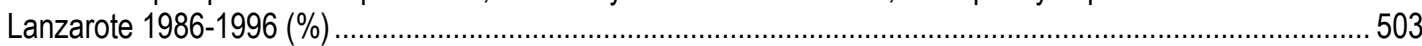

Tabla 203. Nivel de renta disponible por habitante de los municipios y de Lanzarote, Canarias y España. 1996 (ptas)

Tabla 204. Nivel de renta disponible por habitante de los municipios y de Lanzarote, Canarias y España. 2001 (euros)

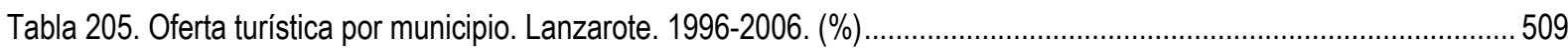

Tabla 206. Nivel de renta disponible por habitante de los municipios y de Lanzarote, Canarias y España. 2003 (euros). 510

Tabla 207. Potencia instalada. Lanzarote, Canarias y España. 1996-2006 (kw) ........................................................5 514

Tabla 208. Potencia instalada por tipo de infraestructura eléctrica. Lanzarote. 2006.....................................................5 516

Tabla 209. Producción de energía eléctrica disponible. Lanzarote, Canarias y España. 1996-2006 (Mwh) .......................519

Tabla 210. Consumo eléctrico e intensidad energética. Lanzarote, Canarias y España. 1996-2006 (Mwh) ........................521

Tabla 211. Resumen. Variación de la oferta y demanda de energía eléctrica por habitante equivalente (kwh/P.total).

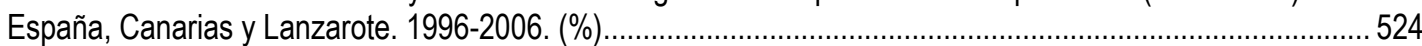

Tabla 212. Fuentes de captación y producción de agua potable. Oferta. Lanzarote. 1996-2006 (hm³/año)......................527

Tabla 213. Incremento interperiodo de la producción pública de agua potable. Oferta. Lanzarote. 1996-2006 (Hm³/año) (\%). 
Tabla 214. Producción media diaria y población a abastecer. Lanzarote. 1996-2006 (mª́a)...... 529

Tabla 215. Producción y disponibilidad de agua desalada en destino final. Lanzarote. 1996-2006. 530

Tabla 216. Producción media diaria y población a abastecer. Canarias y España. 1996-2006 (m³/año) 531

Tabla 217. Historial de plantas desaladoras de Lanzarote. 1975-1999. 532

Tabla 218. Energía eléctrica consumida en la producción de agua desalada pública. Lanzarote. 1996-2006 $\left(\mathrm{kwh} / \mathrm{m}^{3 *} \mathrm{dí} a\right)$

Tabla 219. Energía eléctrica producida y consumo en la producción de agua desalada pública. Lanzarote. 1986-2006.

Tabla 220. Evolución de las tarifas de consumo de agua potable. Lanzarote. 1996-2007 (€) ........................................534

Tabla 221.Consumo de agua. Lanzarote, Canarias y España. 1996-2001 (m³/año).......................................................535

Tabla 222. Consumo medio diario y población a abastecer. Lanzarote. 1996-2006 (l/habitante*día) .................................555

Tabla 223. Consumo medio diario y población a abastecer. Canarias y España. 1996-2006 (I/habitantes*día).................. 537

Tabla 224. Consumo unitario por residente y turista. Lanzarote. 1996-2006 (I/habitante día) .........................................558

Tabla 225. Estimación de la evolución del consumo de agua de los residentes y los turistas. Lanzarote. 1996-2006 (m³/año)

Tabla 226. Incrementos interperiodo estimados de consumo de agua. 1996-2006(\%) ..................................................539

Tabla 227. Ancho de calzada y kilómetros de carreteras. Lanzarote y Canarias. 1996-2006 (\%) ..................................... 542

Tabla 228. Número de vehículos (turismos). Lanzarote, Canarias y España. 1996-2006...............................................544

Tabla 229. Índice de motorización. Lanzarote, Canarias y España. 1996-2006 ............................................................554

Tabla 230. Evolución de los coches de alquiler. Lanzarote, 1996-2006 ....................................................................5 546

Tabla 231. Evolución de la intensidad media diaria de vehículos, por tramos. Lanzarote. 1995-2006 _.............................547

Tabla 232. Transporte público (interurbano) de viajeros. Lanzarote. 1996-2006 ...........................................................5 549

Tabla 233. Evolución del PIB per cápita a precios corrientes de mercado. Las Palmas, Canarias y España. 1970-2006 (€)

Tabla 234. Evolución del PIB per cápita de Las Palmas y Canarias respecto al de España. 1970-2006 (\%) .....................574

Tabla 235. Evolución del PIB per cápita. Lanzarote y sus municipios, Las Palmas, Canarias y España. 1970-2003 (€).....576

Tabla 236. Evolución del PIB per cápita de Lanzarote respecto a Las Palmas, Canarias y España. 1970-2003 (\%).......... 578

Tabla 237. Incremento de la oferta turística en cada periodo. España, Canarias y Lanzarote (\%) ...................................5 579

Tabla 238. Incremento de la demanda turística en cada periodo. España, Canarias y Lanzarote (\%) ...............................579

Tabla 239. Incremento de la población residente en cada periodo. España, Canarias y Lanzarote (\%).............................582

Tabla 240. Evolución de las camas de hospital y comparación con la OMS. España. Canarias y

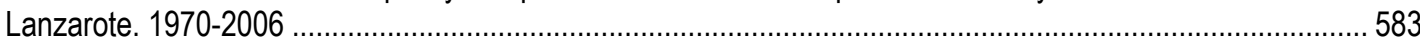

Tabla 241. Incremento de la potencia instalada en cada periodo. España, Canarias y Lanzarote (\%)..............................585

Tabla 242. Evolución del índice de motorización. Lanzarote, Canarias y España (\%) ....................................................586

Tabla 243. Evolución de la población alóctona, autóctona y foránea (alóctonos y turistas diarios) de Lanzarote. 1970-2006 (\%)

Tabla 244. Evolución del precio de la vivienda libre. Las Palmas y Canarias. 1996-2006 594

Tabla 245. Evolución de la producción y consumo de energía eléctrica, en relación a la oferta y demanda turística y la población residente. Lanzarote. 1970-2006 $(1970=100)$.

Tabla 246. Evolución del consumo y la disponibilidad de agua después de pérdidas en red (I/hab*día), en relación a demanda y oferta turística y a la población residente. Lanzarote. 1970-2006 (1970=100). 
Tabla 247. Evolución del número de habitantes por médico. España, Canarias y Lanzarote. 1970-2006 599

Tabla 248. PIB per cápita a precios corrientes de mercado de los municipios de la isla (Lanzarote=100) 603

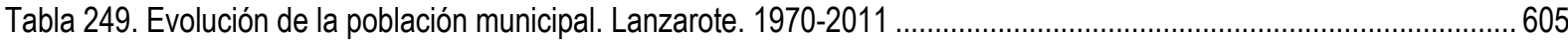

Tabla 250. Índice de evolución de la población municipal e insular. Lanzarote.1970-2006 (1970=100) ............................606

Tabla 251. Distribución municipal de la oferta turística. Lanzarote. 1986-2006 (\%) .....................................................608

Tabla 252. Número de viviendas familiares censadas, por municipio. Lanzarote. 1970-2001 .........................................609

Tabla 253. Viviendas principales censadas, por municipio e isla. Lanzarote. 1970-2001 ................................................610

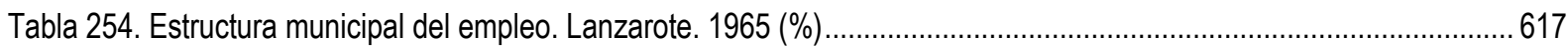

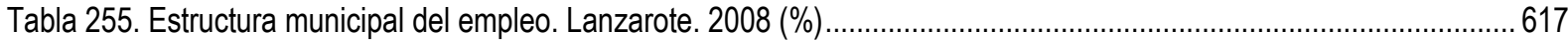

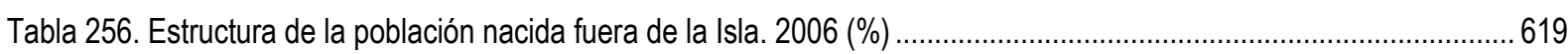

Tabla 257. Estructura de la población por lugar de nacimiento y edad. Lanzarote. 2006. (\%) .........................................620

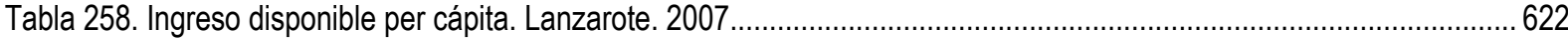

\section{Índice de gráficos}

Gráfico 1. Incremento de plazas de alojamiento turístico por tipo. Lanzarote. 1970-1986 (\%) 151

Gráfico 2. Incremento interperiodo de la oferta de alojamiento turístico. España, Canarias y Lanzarote. 1970-1986 (\%).... 152

Gráfico 3. Oferta de alojamiento turístico por tipo. España, Canarias y Lanzarote. 1970-1986 (\%)................................. 153

Gráfico 4. Incremento de la demanda turística. España, Canarias y Lanzarote. 1970-1986 (\%) ...................................... 155

Gráfico 5. Evolución de la relación turistas/residentes (t/r). Lanzarote. 1970-1986 (\%) ................................................. 160

Gráfico 6. Evolución de la relación turistas/residentes (t/r). España, Canarias y Lanzarote. 1970-1986 (\%o)....................... 161

Gráfico 7. Evolución de la relación Turistas/Plazas (t/p). España, Canarias y Lanzarote, 1970-1986.............................. 162

Gráfico 8. Incremento de la oferta y la demanda turística. Lanzarote. 1970-1986 (\%) ................................................... 163

Gráfico 9. Evolución de la oferta y la demanda turística. Lanzarote. 1970-1986 ............................................................164

Gráfico 10. Incremento de la población de derecho. España, Canarias y Lanzarote. 1970-1986 (\%)................................ 166

Gráfico 11. Evolución de la población municipal sobre el total insular. Lanzarote 1970-1986 (\%) .................................... 167

Gráfico 12. Evolución de la tasa de mortalidad media. España, Canarias y Lanzarote. 1966-1985.................................. 169

Gráfico 13. Evolución de la tasa de natalidad media. España, Canarias y Lanzarote. 1966-1985................................... 171

Gráfico 14. Evolución del crecimiento vegetativo. España, Canarias y Lanzarote. 1966-1985.........................................172

Gráfico 15. Incremento de la población de hecho sobre la de derecho. España, Canarias y Lanzarote. 1960-1981 (\%) ..... 174

Gráfico 16. Evolución de la inmigración. Lanzarote. 1970-1986 .................................................................................. 176

Gráfico 17. Evolución de la inmigración según origen. Lanzarote. 1970-1986 (\%)......................................................177

Gráfico 18. Inmigración externa a Canarias. Lanzarote. 1970-1986 (\%) ........................................................................ 177

Gráfico 19. Evolución de la población autóctona y alóctona. Lanzarote. 1970-1986 (\%) ................................................. 179

Gráfico 20. Incremento quinquenal de la población autóctona y alóctona. Lanzarote. 1970-1986 (\%) .............................. 179

Gráfico 21. Evolución de los ratios alóctonos/autóctonos (al/at) y foráneos/autóctonos (fr/at). Lanzarote. 1970-1986......... 180

Gráfico 22. Evolución de la población foránea y autóctona. Lanzarote. 1970-1986 ........................................................ 181

Gráfico 23. Evolución del nivel de instrucción. Lanzarote. 1970-1986 (\%) .................................................................. 187

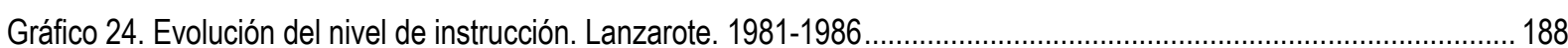


Gráfico 25. Evolución del nivel de instrucción. España, Canarias y Lanzarote. 1981-1986 189

Gráfico 26. Inmigrantes por nivel de instrucción y procedencia. Lanzarote. 1981 (\%) 191

Gráfico 27. Relación alumnos por unidad y profesores y nivel de cobertura (\%), por tipo de enseñanza. Lanzarote. Curso 1985-1986....

Gráfico 28. Comparación de los ratios camas hospitalarias por cada mil habitantes de derecho y sobre la población total estimada. Lanzarote. 1970-1986

Gráfico 29. Comparación del ratio camas hospitalarias por cada mil habitantes. España, Canarias y Lanzarote. 1970-1986.

Gráfico 30. Comparación de los ratios población de derecho y población total estimada por médico. Lanzarote. 1970-1986

Gráfico 31. Comparación de los ratios población de derecho y población total estimada por médico. España, Canarias y Lanzarote. 1970-1986

Gráfico 32. Camas hospitalarias por mil habitantes y comparación con el estándar de la O.M.S. España, Canarias y Lanzarote. 1986.

Gráfico 33. Evolución del número de habitantes por médico en relación a la población de derecho y a la población total estimada. Lanzarote. 1970-1986.

Gráfico 34. Población ocupada por sectores de actividad. Lanzarote, Canarias y España. 1965 (\%)

Gráfico 35. Evolución de la población activa por sector. Lanzarote. 1965-1970 (\%)

Gráfico 36. Evolución de la población ocupada por sectores. España, Canarias y Lanzarote. 1981-1986 (\%) .................... 224

Gráfico 37. Evolución de la población activa por sectores económicos. Lanzarote. 1965-1986 ....................................... 226

Gráfico 38. Evolución de la tasa de paro. Lanzarote, Canarias y España. 1981-1986

Gráfico 39. Evolución de la tasa de paro por sexo. Lanzarote, Canarias y España. 1981-1986 ....................................... 228

Gráfico 40. Evolución del paro por sectores económicos. Lanzarote. 1981-1986 (\%) ................................................... 229

Gráfico 41. Estructura sectorial del paro. Lanzarote, Canarias y España. 1981-1986 (\%) ............................................. 230

Gráfico 42. Distribución del ingreso monetario familiar por mes. Lanzarote. 1970 (\%) ................................................. 235

Gráfico 43. Distribución del ingreso monetario familiar por mes. Canarias, provincia Las Palmas y Lanzarote. $1970(\%)$

Gráfico 44. Plazas de alojamiento turístico por municipio. Lanzarote. 1986 (\%).............................................................. 240

Gráfico 45. Evolución de la potencia instalada por habitante. España, Canarias y Lanzarote. 1970-1986 (Kw/P.Total) ...... 245

Gráfico 46. Incremento interperiodo de la potencia instalada en relación a la población total estimada. España, Canarias y Lanzarote. 1970-1986 (Kw/P.Total)

Gráfico 47. Evolución de la producción de energía eléctrica por habitante. Lanzarote, Canarias y España. 1970-1986 (Kwh/PTotal)

Gráfico 48. Incremento interperiodo del consumo eléctrico en relación a la población total estimada. España, Canarias y Lanzarote. 1970-1986 (\%)

Gráfico 49. Evolución del consumo de energía eléctrica por habitante. España, Canarias y Lanzarote. 1970-1986 (Kwh/PTotal)

Gráfico 50. Variación de la oferta y la demanda de energía eléctrica por habitante. España, Canarias y Lanzarote. 1970-1986 (\%).

Gráfico 51. Evolución de la producción de agua potable por tipo. Lanzarote. 1970-1986 (Hm³/año y l/habitante*día)......... 257

Gráfico 52. Incremento de la producción de agua potable por tipo. Lanzarote. 1970-1986 (\%).

Gráfico 53. Producción privada y pública de agua por población que abastece. Lanzarote. 1975-1986 (I/habitante*día) .... 259 
Gráfico 54. Consumo, producción y disponibilidad de agua después de pérdidas en red. Lanzarote. 1970-1986 (I/habitante*día)

Gráfico 55. Índice de motorización (turismos) sobre la población residente y la población total estimada. España, Canarias y Lanzarote. 1986

Gráfico 56. Intensidad media diaria de vehículos por tramos. Lanzarote. 1975-1985

Gráfico 57. Evolución de la oferta y la demanda turística. Lanzarote. 1970-1986 .........................................................2 275

Gráfico 58. Plazas de alojamiento turístico por tipo. Porcentaje sobre el total. Lanzarote. 1970-1986 (\%)........................275

Gráfico 59. Evolución de la población foránea y autóctona. Lanzarote. 1970-1986 ........................................................2 276

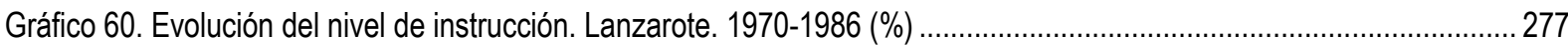

Gráfico 61. Incremento de la oferta y demanda turística. Los ocupados y los parados. Lanzarote. 1970-1986 (\%) ............ 277

Gráfico 62. Municipios según nivel de renta media por habitante. Lanzarote. 1986 .........................................................2 278

Gráfico 63. Producción de energía eléctrica disponible y consumo, en relación a la población residente y a la población total estimada. Lanzarote. 1970-1986 (kwh).

Gráfico 64. Evolución de la producción de agua potable por tipo (Hm3/año). Disponibilidad (I/habitante*día) y consumo (I/habitante*día). Lanzarote. 1970-1986

Gráfico 65. Evolución de las camas hospitalarias por mil residentes y sobre la demanda potencial. Comparación con el estándar de la O.M.S. Lanzarote. 1970-1986

Gráfico 66. Evolución del número de habitantes por médico en relación a la población de derecho y a la población total estimada. Lanzarote. 1970-1986.

Gráfico 67. Relación alumno por unidades y profesores, y nivel de cobertura (\%), por tipo de enseñanza. Lanzarote. Curso 1985-1986.

Gráfico 68. Evolución del índice de motorización de la población residente en relación a la población total estimada. Lanzarote. 1970-1986

Gráfico 69. Incremento de la oferta de alojamiento turístico. Lanzarote. 1981-1996 (\%)

Gráfico 70. Incremento de la oferta de alojamiento turístico por tipo, sobre el total. Lanzarote. 1986-1996 (\%)..................291

Gráfico 71. Incremento de plazas de alojamiento turístico por tipo. Lanzarote. 1986-1996 (\%)....................................... 291

Gráfico 72. Incremento de plazas de alojamiento turístico. España, Canarias y Lanzarote. 1986-1996 (\%)...................... 292

Gráfico 73. Oferta de alojamiento turístico por tipo. España, Canarias y Lanzarote. 1986-1996 (\%)................................ 293

Gráfico 74. Incremento de la demanda turística. España, Canarias y Lanzarote. 1986-1996 (\%). ...................................295

Gráfico 75. Evolución de la relación turistas/residentes. España, Canarias y Lanzarote. 1986-1996 ................................ 299

Gráfico 76. Evolución de la relación turistas/plazas. España, Canarias y Lanzarote. 1986-1996..................................... 300

Gráfico 77. Evolución de la oferta y la demanda turística. Lanzarote. 1986-1996 ..........................................................302

Gráfico 78. Incremento interperiodo de la población de derecho. España, Canarias y Lanzarote. 1986-1996 (\%).............. 303

Gráfico 79. Evolución de la población municipal sobre el total insular. Lanzarote. 1986-1996 (\%) .....................................304

Gráfico 80. Evolución de la tasa de mortalidad media. España, Canarias y Lanzarote. 1986-1995 ...................................306

Gráfico 81. Evolución de la tasa de natalidad media. España, Canarias y Lanzarote. 1986-1995......................................307

Gráfico 82. Evolución del crecimiento vegetativo. España, Canarias y Lanzarote. 1986-1995...................................... 308

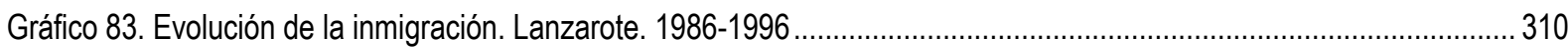

Gráfico 84. Evolución de la inmigración según origen. Lanzarote. 1986-1996 (\%).........................................................310

Gráfico 85. Evolución de la población autóctona y alóctona. Lanzarote. 1986-1996 (\%) ................................................312

Gráfico 86. Incremento interperiodo de la población autóctona y alóctona. Lanzarote. 1986-1996 (\%) .............................. 312 
Gráfico 87. Evolución de los ratios alóctonos/autóctonos (al/at) y foráneos/autóctonos (fr/at). Lanzarote. 1986-1996....... 313

Gráfico 88. Evolución de la población foránea y autóctona. Lanzarote. 1986-1996 ...........................................................314

Gráfico 89. Evolución del nivel de instrucción. Lanzarote. 1986-1996 (\%) .................................................................317

Gráfico 90. Evolución del analfabetismo y la educación superior. Extremos. Lanzarote. 1986-1996 (\%) .......................... 318

Gráfico 91. Evolución de la población sin estudios, la educación básica y media. Lanzarote. 1986-1996 (\%)................... 319

Gráfico 92. Evolución del nivel de instrucción. España, Canarias y Lanzarote. 1986-1996 (\%)....................................... 320

Gráfico 93. Inmigrantes por nivel de instrucción entre 1981-1991. Lanzarote (\%) .......................................................... 321

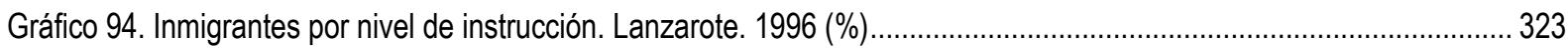

Gráfico 95. Inmigrantes por nivel de instrucción y procedencia. Lanzarote. 1996 (\%) .................................................... 324

Gráfico 96. Relación alumnos por unidad y profesor, y estándar, por tipo de enseñanza. Lanzarote. 1991-1996 ...............333

Gráfico 97. Comparación de los ratios camas hospitalarias por mil habitantes de derecho y sobre la población total estimada. Lanzarote. 1986-1996

Gráfico 98. Comparación del ratio camas hospitalarias por mil habitantes. España, Canarias y Lanzarote. 1986-1996

Gráfico 99. Comparación de los ratios población de derecho y población total estimada por médico.

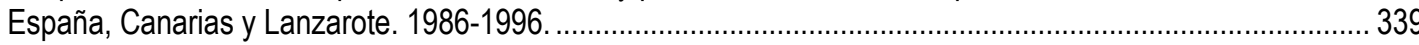

Gráfico 100. Camas hospitalarias por mil habitantes y comparación con e estándar de la O.M.S. España, Canarias y Lanzarote. 1996

Gráfico 101. Evolución del número de habitantes por médico en relación a la población de derecho y la población total estimada. Lanzarote. 1986-1996

Gráfico 102. Número de habitantes por médico en relación a la población de derecho y la población total estimada. España, Canarias y Lanzarote. 1986-1996

Gráfico 103. Estructura sectorial del empleo. Ocupados. España, Canarias y Lanzarote. 1986-1996 (\%) ..........................346

Gráfico 104. Evolución de la tasa de paro. Lanzarote, Canarias y España. 1986-1996 (\%) ............................................349

Gráfico 105. Evolución de la tasa de paro por sexo. Lanzarote, Canarias y España. 1986-1996 ..................................... 350

Gráfico 106. Evolución del paro por sectores económicos. Lanzarote. 1986-1996 (\%). ..................................................351

Gráfico 107. Evolución del paro por sectores económicos. Lanzarote, Canarias y España. 1986-1996 (\%) ....................... 352

Gráfico 108. Evolución de las plazas de alojamiento turístico por municipio. Lanzarote. 1986-1996 (\%).......................... 358

Gráfico 109. Renta media familiar disponible por habitante. Lanzarote, sus municipios, la provincia y Canarias. 1991 ....... 359

Gráfico 110. Renta media familiar disponible por habitante. Lanzarote, sus municipios y provincia, Canarias y España. 1996

Gráfico 111. Incremento interperiodo de la potencia instalada en relación a la población total estimada. Lanzarote, Canarias y España. 1986-1996 (\%)

Gráfico 112. Evolución de la potencia instalada en relación a la población total estimada. Lanzarote, Canarias y España. 1-86-1996 (kw/P.Total)

Gráfico 113. Evolución de la producción de energía eléctrica por habitante. Lanzarote, Canarias y España. 1986-1996 (Kwh/Ptotal)

Gráfico 114. Incremento interperiodo del consumo de energía eléctrica en relación a la población total estimada. Lanzarote, Canarias y España. 1986-1996 (\%).

Gráfico 115. Evolución del consumo de energía eléctrica por habitante. Lanzarote, Canarias y España. 1986-1996 (\%)... 372

Gráfico 116. Variación de la oferta y demanda de energía eléctrica por habitante equivalente (kwh/P. Total).

España, Canarias y Lanzarote. 1986-1996 (\%) 373

Gráfico 117. Evolución de la producción pública de agua potable. Lanzarote. 1986-1996 (Hm³/año) ...... 377 
Gráfico 118. Evolución de la producción de agua pública por residente. Lanzarote. 1986-1996 (1/residentes*día). 379

Gráfico 119. Producción de agua en relación a la población estimada y disponibilidad final. 1986-1996 (I/habitante*día). 380

Gráfico 120. Consumo y producción media diaria de agua en relación a la población total diaria estimada. Lanzarote. 1986-1996 (I/habitante*día). 382

Gráfico 121. Consumo y disponibilidad de agua después de pérdidas en red. Lanzarote. 1986-1996 (I/habitante*día)....... 382

Gráfico 122. Índice de motorización (turismos) en relación a la población residente y la población total estimada. España, Canarias y Lanzarote. 1986-1996 389

Gráfico 123. Intensidad media diaria de vehículo por tramos. Lanzarote. 1987-1995 390

Gráfico 124. Evolución de la oferta y la demanda turística. Lanzarote. 1986-1996 ..........................................................394

Gráfico 125. Plazas de alojamiento turístico por tipo. Porcentaje sobre el total. Lanzarote. 1986-1996 ..............................395

Gráfico 126. Incremento de la oferta y la demanda turística. Lanzarote. 1989-1996 (\%) ................................................395

Gráfico 127. Evolución de la población foránea y autóctona. Lanzarote. 1986-1996 .........................................................396

Gráfico 128. Inmigrantes por nivel de instrucción y procedencia. Lanzarote. 1996 (\%) ..... 397

Gráfico 129. Incremento interperiodo de la población potencialmente activa, la oferta y demanda turística, los ocupados y los parados. Lanzarote. 1989-1996 (\%).

Gráfico 130. Nivel de renta media por habitante. España, Canarias, Las Palmas y municipios de Lanzarote. 1996

Gráfico 131. Producción de energía eléctrica disponible y consumo, en relación a la población residente y a la población total estimada. Lanzarote. 1986-1996 (kwh)

Gráfico 132. Consumo y producción media diaria de agua en relación a la población a abastecer estimada. Lanzarote. 1986-1996 (I/hab/día).

Gráfico 133. Evolución de las camas hospitalarias por mil residentes y sobre la demanda potencial. Comparación con el estándar de la O.M.S. Lanzarote. 1986-1996.

Gráfico 134. Evolución de la población residente y la población total estimada por médico. Lanzarote. 1986-1996 ............ 402

Gráfico 135. Relación alumnos por unidad y profesor. Estándar, por tipo de enseñanza. Lanzarote. 1986-1996 ................403

Gráfico 136. Evolución de la relación alumnos por profesor en enseñanza de adultos y especial. Lanzarote. 1986-1996.

Gráfico 137. Evolución del índice de motorización de la población residente en relación a la población total estimada. Lanzarote. 1986-1996.

Gráfico 138. Incremento de la oferta de alojamiento turístico. Lanzarote. 1996-2006 (\%)

Gráfico 139. Evolución de la oferta de alojamiento por tipo, sobre el total. Lanzarote. 1996-2006 (\%)............................ 412

Gráfico 140. Incremento de las plazas de alojamiento turístico por tipo. Lanzarote. 1996-2006 (\%)

Gráfico 141. Incremento interperiodo de plazas de alojamiento turístico. España, Canarias y Lanzarote. 1996-2006 (\%) .. 413

Gráfico 142. Oferta de alojamiento turístico por tipo. España, Canarias y Lanzarote. 1996-2006 (\%) .............................. 415

Gráfica 143. Incremento de la demanda turística. Lanzarote. 1996-2006 (\%) ............................................................. 417

Gráfico 144. Incremento de la demanda turística. España, Canarias y Lanzarote. 1996-2006 (\%). ..................................418

Gráfico 145. Evolución de la relación turistas/ residentes. España, Canarias y Lanzarote. 1996-2006 (t/r)........................423

Gráfico 146. Evolución de la relación turistas/plazas. España, Canarias y Lanzarote. 1996-2006 (t/p) ..............................424

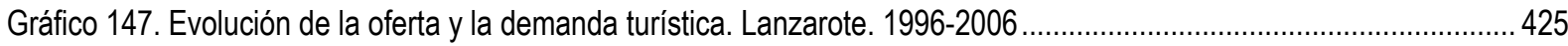

Gráfico 148. Incremento interperiodo de la población de derecho. España, Canarias y Lanzarote. 1996-2006 (\%)............ 428

Gráfico 149. Evolución de la población municipal sobre el total insular. Lanzarote. 1996-2006 (\%) 429 
Gráfico 150. Evolución de la tasa de mortalidad media. España, Canarias y Lanzarote. 1996-2005 431

Gráfico 151. Estructura de la población por edad. Grandes grupos. Lanzarote. 1996-2005 (\%) ... 432

Gráfico 152. Estructura de la población por edad. Grandes grupos. España, Canarias y Lanzarote. 1996-2005 (\%) .......... 433

Gráfico 153. Evolución de la tasa de natalidad media. España, Canarias y Lanzarote. 1996-2005..................................434

Gráfico 154. Evolución del crecimiento vegetativo. España, Canarias y Lanzarote. 1996-2005 .......................................435

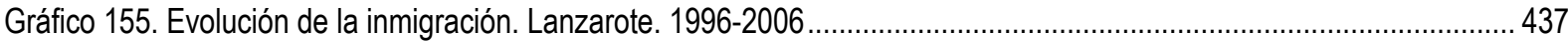

Gráfico 156. Evolución de la inmigración según origen. Lanzarote. 1996-2006 (\%) ....................................................... 437

Gráfico 157. Evolución de la población residente según lugar de nacimiento. Extranjeros. Lanzarote. 1996-2006 (\%) ....... 439

Gráfico 158. Evolución de la población autóctona y alóctona. Lanzarote. 1996-2006 (\%) .............................................. 441

Gráfico 159. Incremento interperiodo de la población autóctona y alóctona. Lanzarote. 1996-2006 (\%) ............................441

Gráfico 160. Evolución de los ratios alóctonos/autóctonos y foráneos/autóctonos. Lanzarote. 1996-2006 ......................... 442

Gráfico 161. Evolución de la población foránea y autóctona. Lanzarote. 1996-2006 ..................................................... 443

Gráfico 162. Evolución del analfabetismo y la educación superior. Extremos. Lanzarote. 1996-2007 (\%) ......................... 448

Gráfico 163. Evolución del nivel de instrucción. Lanzarote. 1996-2007 (\%) .......................................................................449

Gráfico 164. Evolución del nivel de instrucción. España, Canarias y Lanzarote. 2001-2007 (\%)..................................... 450

Gráfico 165. Evolución del nivel de estudios de la población inmigrante. Lanzarote. 1996-2001 (\%) ................................. 452

Gráfico 166. Evolución del nivel formativo primaria y secundaria de la población inmigrante nacional.

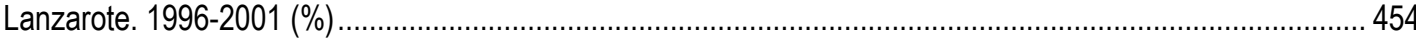

Gráfico 167. Nivel de instrucción de los inmigrantes extranjeros. Lanzarote. 1996-2001 (\%)..........................................454

Gráfico 168. Nivel de instrucción de la población inmigrante por procedencia. Lanzarote. 1996-2001 (\%) ......................... 455

Gráfico 169. Inmigrantes por lugar de procedencia y nivel de instrucción. España, Canarias y Lanzarote (\%) ................... 457

Gráfico 170. Alumno por unidad y profesor y estándar, por tipo de enseñanza. Lanzarote. 1996-2001 ............................. 466

Gráfico 171. Comparación de los ratios camas hospitalarias por mil habitantes de derecho y sobre la población total estimada. Lanzarote. 1996-2006

Gráfico 172. Comparación del ratio camas hospitalarias por mil habitantes. España, Canarias y Lanzarote. 1996-2006

Gráfico 173. Evolución del ratio habitantes/médicos de atención primaria. Lanzarote. 1996-2006.

Gráfico 174. Comparación de los ratios población de derecho y población total estimada por médico. España, Canarias y Lanzarote. 1996-2006

Gráfico 175. Camas hospitalarias por mil habitantes y comparación con el estándar de la O.M.S.

España, Canarias y Lanzarote. 2006.

Gráfico 176. Estructura sectorial del empleo. Ocupados. España, Canarias y Lanzarote. 1996-2006 (\%).

Gráfico 177. Evolución de los contratos a personas según origen. Foráneos. Lanzarote. 2002-2006

Gráfico 178. Contrato a extranjeros según sector económico y país de origen. Lanzarote. 2006 (\%). 496

Gráfico 179. Evolución de la tasa de paro. Lanzarote. Canarias y España. 1996-2006 (\%).............................................497

Gráfico 180. Paro registrado y afluencia turística, por meses. Lanzarote. 2001 ...............................................................498

Gráfico 181. Paro registrado y afluencia turística, por meses. Lanzarote. 2006 ................................................................ 499

Gráfico 182. Evolución de la tasa de paro por sexo. Lanzarote, Canarias y España. 1996-2006 ......................................500

Gráfico 183. Evolución de paro registrado por sectores económicos. Lanzarote. 1996-2006 (\%)...................................501

Gráfico 184. Evolución el paro registrado por sectores económicos. Lanzarote, Canarias y España. 1996-2006 (\%).........501 
Gráfico 185. Evolución de las plazas de alojamiento turístico por municipio. Lanzarote 1996-2006 (\%). 509

Gráfico 186. Nivel de renta disponible por habitante. Lanzarote, sus municipios y Provincia, Canarias y España. 2003 .....512

Gráfico 187. Evolución de la potencia instalada por habitante. Lanzarote. 1996-2006 (kw/hab).....................................518

Gráfico 188. Evolución de la capacidad de producción de energía eléctrica por habitante. Lanzarote, Canarias y España. 1996-2006 (kw/hab)

Gráfico 189. Evolución de la producción de energía eléctrica por habitante. Lanzarote, Canarias y España. 1996-2006 (kw/PTotal).

Gráfico 190. Incremento interperiodo del consumo de energía eléctrica en relación a la población total estimada. Lanzarote, Canarias y España. 1996-2006 (kwh/Ptotal) .....

Gráfico 191. Evolución del consumo de energía eléctrica por habitante. Lanzarote, Canarias y España. 1996-2006 (kwh/Ptotal).

Gráfico 192. Variación de la oferta y la demanda de energía eléctrica por habitante equivalente (kwh/Ptotal). Lanzarote, Canarias y España. 1996-2006 (\%).

Gráfico 193. Evolución de la producción de agua potable por habitante y día. Lanzarote. 1996-2006 529

Gráfico 194. Evolución de la producción media diaria de agua por habitante. Lanzarote, Canarias y España. 1996-2006 (I/habitantes*día)

Gráfico 195. Consumo y disponibilidad media de agua después de pérdidas en red. Lanzarote. 1996-2006 (l/habitantes*día)

Gráfico 196. Consumo medio diario de agua por habitante. Lanzarote, Canarias y España. 1996-2006 (l/hab*día)............537

Gráfico 197. Evolución del consumo de agua estimado de residentes y turistas. Lanzarote. 1996-2006 (m³/año). 539

Gráfico 198. Incremento interperiodo del número de vehículos (turismos). Lanzarote, Canarias y España. 1991-2006 (\%)

Gráfico 199. Índice de motorización (turismos) en relación a la población residente y a la población total estimada. España, Canarias y Lanzarote. 1996-2006

Gráfico 200. Evolución de la intensidad media diaria de vehículo por tramos. Lanzarote. 1995-2006 547

Gráfico 201. Evolución de la oferta y la demanda turística. Lanzarote. 1996-2006 .........................................................553

Gráfico 202. Plazas de alojamiento turístico por tipo. Porcentaje sobre el total. Lanzarote. 1996-2006 .............................553

Gráfico 203. Incremento de la oferta y la demanda turística. Lanzarote. 1996-2006 (\%) ................................................554

Gráfico 204. Evolución de la población autóctona y alóctona. Lanzarote. 1996-2006 (\%) .............................................. 555

Gráfico 205. Evolución de la población foránea y autóctona. Lanzarote. 1996-2006 ........................................................55

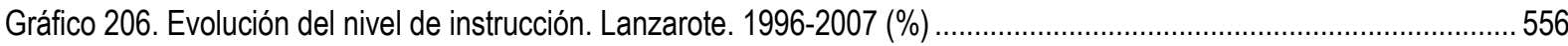

Gráfico 207. Nivel de instrucción de la población inmigrante por procedencia. Lanzarote. 1996-2001 (\%) .........................556

Gráfico 208. Paro registrado y afluencia turística, por meses. Lanzarote. 2006 .............................................................5 557

Gráfico 209. Nivel de renta disponible por habitante. Lanzarote, sus municipios y provincia, Canarias y España, 2003.

Gráfico 210. Evolución de la producción y el consumo de energía eléctrica por habitante. Lanzarote (kwh/Ptotal) ............559

Gráfico 211. Consumo y disponibilidad de agua después de pérdidas en red. 1996-2006 (I/hab*día)..............................560

Gráfico 212. Evolución de las camas hospitalarias por mil residentes y sobre la demanda potencial. Comparación con el estándar de la O.M.S. Lanzarote. 1996-2006.

Gráfico 213. Evolución del ratio habitantes/médico, en relación a la población residente y la población total estimada. Lanzarote. 1996-2006

Gráfico 214. Alumnos por unidad y profesor y estándar, por tipo de enseñanza. Lanzarote. 1996-2001 562 
Gráfico 215. Evolución del número de vehículos e índice de motorización (turismos) de la población residente y del total de población estimada. Lanzarote. 1996-2006

Gráfico 216. Evolución del índice de motorización (turismos) sobre la población total estimada. España, Canarias y Lanzarote. 1996-2006 563

Gráfico 217. Evolución de la oferta y la demanda turística. Lanzarote. 1970-2006 571

Gráfico 218. Evolución del PIB per cápita a precios corrientes de mercado. Las Palmas, Canarias y España. 1970-2006 (€)

Gráfico 219. Evolución del PIB per cápita de Las Palmas y Canarias respecto al de España. 1970-2006 (\%) 575

Gráfico 220. Evolución del PIB per cápita. Lanzarote y sus municipios, Las Palmas, Canarias y España. 1970-2006 (€) 577

Gráfico 221. Evolución del PIB per cápita de Lanzarote respecto a Las Palmas, Canarias y España. 1970-2003 (\%) ........578

Gráfico 222. Incremento de la oferta turística en cada periodo. España, Canarias y Lanzarote (\%) .................................5 579

Gráfico 223. Incremento de la demanda turística en cada periodo. España, Canarias y Lanzarote (\%)..............................580

Gráfico 224. Incremento de la población residente en cada periodo. España, Canarias y Lanzarote (\%) ...........................582

Gráfico 225. Evolución de las camas de hospital y comparación con la OMS. España. Canarias y Lanzarote. 1970-2006 584

Gráfico 226. Incremento de la potencia instalada en cada periodo. España, Canarias y Lanzarote (\%)............................585

Gráfico 227. Evolución del índice de motorización. Lanzarote, Canarias y España (\%) ..................................................587

Gráfico 228. Evolución de la población alóctona, autóctona y foránea de Lanzarote. 1970-2006 (\%) ................................589

Gráfico 229. Censos de vivienda familiar. Lanzarote. 1970-2001.....

Gráfico 230. Evolución de la producción y consumo de energía eléctrica, en relación a la oferta y demanda turística y la población residente. Lanzarote. 1970-2006 (1970=100)

Gráfico 231. Evolución del consumo y la disponibilidad de agua después de pérdidas en red (l/hab*día), en relación a demanda y oferta turística y a la población residente. Lanzarote. 1970-2006 $(1970=100)$.............. 598

Gráfico 232. Evolución del número de habitantes por médico. España, Canarias y Lanzarote. 1970-2006 ........................600

Gráfico 233. PIB per cápita a precios corrientes de mercado de los municipios de la isla (Lanzarote=100)......................604

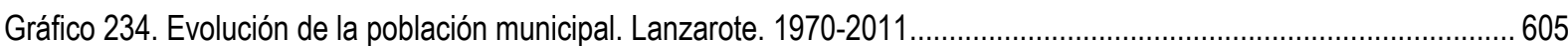

Gráfico 235. Índice de evolución de la población municipal e insular. Lanzarote.1970-2006 (1970=100).........................606

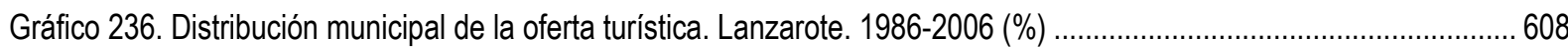

Gráfico 237. Viviendas familiares censadas, por municipio. Lanzarote. 1970-2001 ......................................................610

Gráfico 238. Viviendas principales censadas, por municipio e isla. Lanzarote. 1970-2001.........................................611

\section{Índice de mapas}

Mapa 1. Zonas de uso turístico previsto, 1973

Mapa 2. Ordenación estructural. Lanzarote, 1973.

Mapa 3. Evolución demográfica municipal. Lanzarote. 1970-1986 (base=1970) …......................................................... 168

Mapa 4. Centros docentes de educación no obligatoria. Lanzarote. 1973 ....................................................................... 196

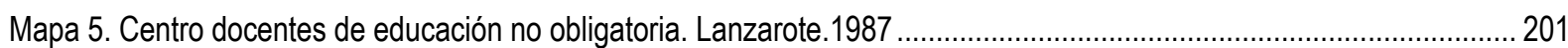

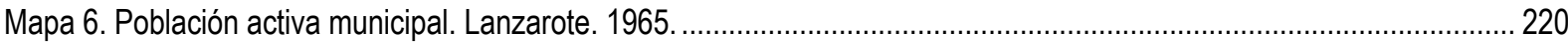

Mapa 7. Nivel de renta disponible por habitante de los municipios de Lanzarote. 1970.............................................236 
Mapa 8. Nivel de renta disponible por habitante de los municipios de Lanzarote. 1981 ...............................................2238

Mapa 9. Nivel de renta por habitante de los municipios de Lanzarote. 1986 .................................................................... 239

Mapa 10. Redes eléctricas y sistema energético de Lanzarote. 1973 ....................................................................243

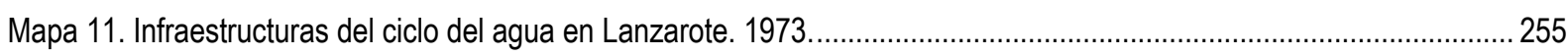

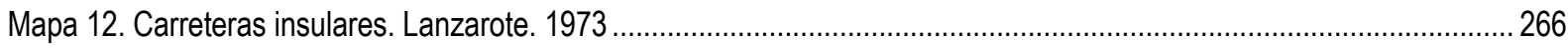

Mapa 13. Intensidad media diaria de tráfico. Carreteras insulares. Lanzarote. 1975 ......................................................269

Mapa 14. Intensidad media diaria de tráfico. Carreteras insulares. Lanzarote. 1985 ....................................................... 270

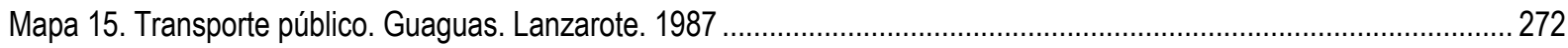

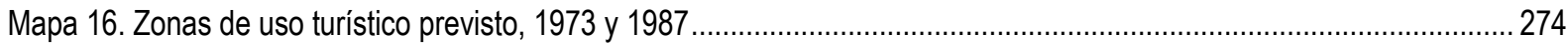

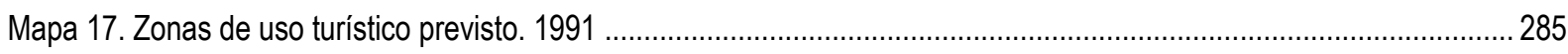

Mapa 18. Ordenación de núcleos de población turísticos y no turísticos. Lanzarote. 1987..............................................288

Mapa 19. Evolución demográfica municipal. Lanzarote. 1986-1996 (base=1970) ...................................................... 305

Mapa 20. Nivel de renta disponible por habitante de los municipios de Lanzarote. 1991.............................................. 357

Mapa 21. Nivel de renta disponible por habitante de los municipios de Lanzarote. 1996............................................. 361

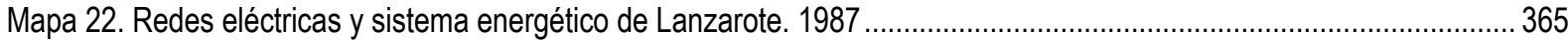

Mapa 23. Infraestructuras del ciclo del agua. Lanzarote. 1987 ............................................................................... 376

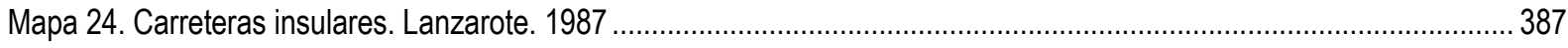

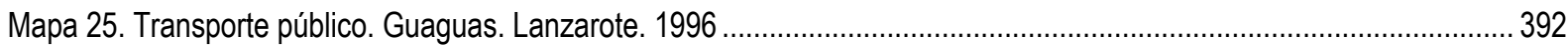

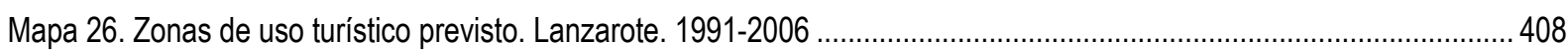

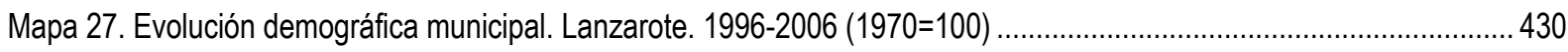

Mapa 28. Centros docentes de educación no obligatoria. Lanzarote. 1970-2002 ….................................................... 461

Mapa 29. Evolución de las dotaciones en atención primaria (sanidad). Lanzarote. 1986, 1996, 2006 .............................. 472

Mapa 30. Nivel de renta media por habitante de los municipios de Lanzarote. 2001 ....................................................508

Mapa 31. Nivel de renta media por habitante de los municipios de Lanzarote. 2003.....................................................511

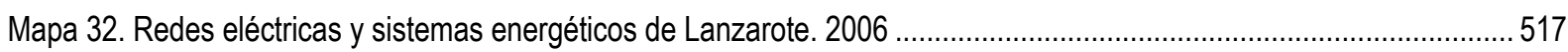

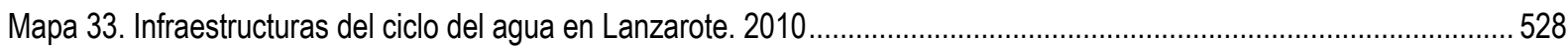

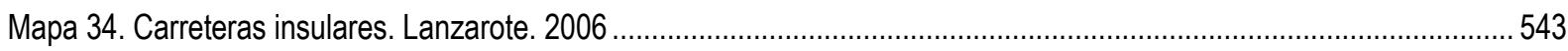

Mapa 35. Intensidad media diaria de tráfico. Carreteras insulares. Lanzarote. 2006 .......................................................5 548

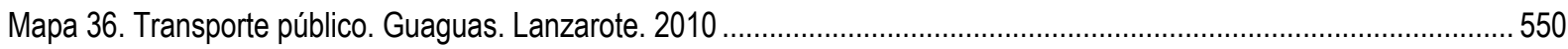

Mapa 37. Evolución demográfica municipal. Lanzarote. 1970-2006 $(1970=100)$...........................................................607

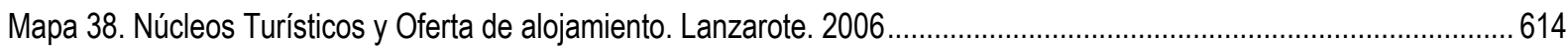

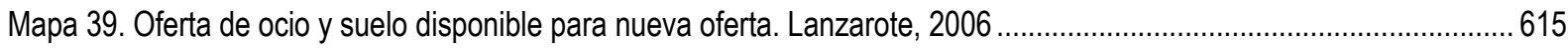





\section{INTRODUCCIÓN}

El turismo en cuanto fenómeno socioeconómico, engendra múltiples manifestaciones de interacción social entre visitantes y anfitriones, originando numerosos cambios, en la estructura social de acogida, que se instalan de forma permanente y que tienen efectos de diferente signo sobre aspectos básicos de bienestar.

La importancia que este sector ha alcanzado en las últimas cuatro décadas en España, y especialmente en los territorios insulares, inducen a una evaluación del proceso de crecimiento alcanzado en su repercusión sobre el estado del bienestar de las sociedades locales que nutren su posibilidad de desarrollo a través de ésta vía, y llegan a limitar sus opciones de vida a su curso y desarrollo.

Cuanto mayor es su importancia en una economía, mayor es el grado de intervención pública, es por ello que el turismo es político y la política turística se hace necesaria en todo momento para dirigir y regular la actividad a medio y largo plazo manteniendo una visión del conjunto socio-territorial afectado. Dicha política se imprime en la ordenación territorial de estos espacios-sociedades siendo la que marca el modelo de crecimiento y desarrollo turístico, el modelo territorial, y las repercusiones sobre la totalidad de los ámbitos de bienestar de los anfitriones y cómo éste se distribuye, en cuanto a que su distribución puede significar el cubrir más o menos estándares mínimos en materias de educación, salud, agua, energía, vivienda, etc.; es decir la cobertura suficiente de las necesidades básicas, recogidas como derechos, que deberán ser satisfechas a lo largo de la evolución de una sociedad.

La política turística ha estado marcada por unas primeras fases donde la preocupación se centraba en incrementar la oferta y la demanda sin observar repercusiones locales de dicha dinámica y en ensalzar las bondades de la actividad. No será hasta el primer gobierno democrático español cuando se empiecen a abordar las contradicciones del turismo, en cuanto a los problemas que genera, y no únicamente en cuando a los problemas que sufre. Dicha nueva orientación será fundamental desde finales de la década de los años ochenta donde ya se van recogiendo efectos positivos y negativos en las sociedades de acogida, que, en algunos casos, ha ocasionado un comportamiento del mercado depredador de los recursos que sustentan la propia actividad.

Es por ello que, el análisis que emprendemos en esta tesis no se focaliza sobre el turista, sus necesidades y circunstancias, sino, por el contrario, centra la atención sobre la situación de los residentes, en términos de necesidades sociales, a partir de que irrumpe la actividad turística y absorbe las posibilidades socioeconómicas. Se concentra en el efecto del crecimiento de la oferta y la demanda turística sobre el bienestar de los anfitriones. 
En este caso será la isla de Lanzarote, en el Archipiélago Canario, la que se toma como caso de estudio, ya que se presenta como un espacio idóneo por sus características físicas y socioeconómicas afectadas en su totalidad por la dinámica turística.

Previamente, y antes de abordar el estudio de caso, se hace necesario la conceptualización de los términos bajo los que se plantea esta tesis, que se convierten en las ideas "fuerza" sobre las que pivotan los análisis que se realizan y las conclusiones derivadas. Éstos se concretan en los siguientes: Turismo, Cambio Social, Ordenación del Territorio y Bienestar. Dichas sentencias estarán alumbradas por marcos de pensamiento cuyo origen se encuentra en la disciplina sociológica, que en el primer cuarto del siglo XX, en Europa, dirige su mirada hacia el movimiento de forasteros, al fenómeno de los viajes y a sus efectos económicos-políticos. A mitad de siglo ya se habrá configurado una rama específica de la misma: la Sociología del Ocio y de Turismo, que será referente epistemológico, junto con otras disciplinas como la antropología, la geografía y la economía.

Posteriormente se recogen aquellos agentes o sujetos sociales que han participado y participan en el impulso y crecimiento de la actividad turística de masas, es decir, los que tienen capacidad para intervenir, modificar o influir en el curso del sector y en los destinos que acogen economías fundamentadas en el mismo.

Otro de los bloques contempla, de forma evolutiva, la orientación política, en cuanto actividad pública cuya finalidad es reguladora, que se ha impreso en el sector desde los diferentes Gobiernos de España (inicialmente no democráticos) y las diferentes administraciones territoriales (nacional, autonómica e insular), junto con la legislación derivada con incidencia en la ordenación del territorio y el urbanismo.

El siguiente bloque de esta tesis corresponde al estudio de caso en el que la isla de Lanzarote será analizada de forma diacrónica desde temas o áreas que absorben, de diferente forma, los efectos de la actividad turística modificando el sistema insular. Concretamente se analizan nueve áreas (estructura demográfica, cualificación, equipamiento educativo, dotaciones de salud, estructura laboral, renta, energía, ciclo del agua, carreteras y transporte), que se recorren y describen desde los primeros desarrollos turísticos, hasta la mitad de la primera década del siglo XXI, como punto de inflexión de una evolución con resultados no óptimos. Subdivididos en tres grandes etapas, definidas a través de los diferentes Planes de Ordenación Insulares, se pretende dar una visión integrada del cambio social experimentado en la isla, analizando la transformación derivada del proceso productivo turístico inicialmente "turismo selectivo" que rápidamente evoluciona bajo la forma de "turismo de masas".

De esta manera, se aborda, finalmente, si la forma o modelo turístico que acoge y alimenta Lanzarote, que originalmente es beneficiosa, ha podido verse negativamente contrarrestada por dinámicas socio-territoriales que revierten estos beneficios afectando al bienestar de sus residentes. 


\section{Capítulo 1}

\section{OBJETIVOS GENERALES E HIPÓTESIS DE PARTIDA}





\section{CAPÍTULO 1.- OBJETIVOS GENERALES E HIPÓTESIS DE PARTIDA}

\section{1.- OBJETIVOS GENERALES}

El objetivo principal de esta tesis es demostrar que ciertas formas de turismo pueden significar pérdida de bienestar para los habitantes de territorios que ven desbordada su capacidad de carga asociada, a consecuencia de la implantación y crecimiento de una actividad turística en forma de "turismo masificado o de masas". De esta forma, el beneficio que originalmente presenta el turismo desde la perspectiva del crecimiento económico y la transformación social, se puede ver negativamente compensado por dinámicas de transformación territorial, económica y social que revierten estos beneficios y terminan afectando al bienestar de los ciudadanos residentes en el territorio.

Se pone aquí en relación la actividad turística, el tipo de implantación de la misma, la política territorial y las áreas básicas de bienestar para llegar a tal demostración. Se evidencia, por tanto, la estrecha relación de dependencia causal entre estas variables, de forma que el tipo o modelo turístico, "de masas", es responsable del efecto producido: "un menor bienestar para la población autóctona y residente".

La demostración, sustentada en un análisis transversal, de las interrelaciones e interdependencias que posee la actividad con ámbitos ligados al bienestar local seleccionados (evolución de la estructura demográfica, de la instrucción, del mercado laboral y la renta, junto con las dotaciones de educación y salud, e infraestructuras básicas como carreteras, energía y agua), permite no sólo evaluar el proceso en los términos descritos - la afección sobre éstas variables —, sino también reflexionar acerca del marco político-territorial en el que se sustentan estos procesos, traducido a la ordenación del territorio.

La intensión y finalidad es ver cómo, a medida que el turismo se masifica y se va imponiendo éste monocultivo, sus intereses van depredando y condicionando el resto de las actividades y relaciones en el marco del bienestar objetivable, referido al acceso a requisitos primordiales de condiciones de vida.

La tesis se centra en el caso de la isla de Lanzarote, y se adentra en el periodo histórico en el que sufre los principales procesos de transformación territorial como consecuencia de una dinámica turística que afecta radicalmente a ésta a través de: cambios demográficos en la población autóctona, movimientos de población foránea, cambios económicos, evolución del equipamiento turístico y social, etc.; que en esta tesis se tratan de caracterizar y valorar desde la perspectiva de sus consecuencias sobre la población residente en la isla. 


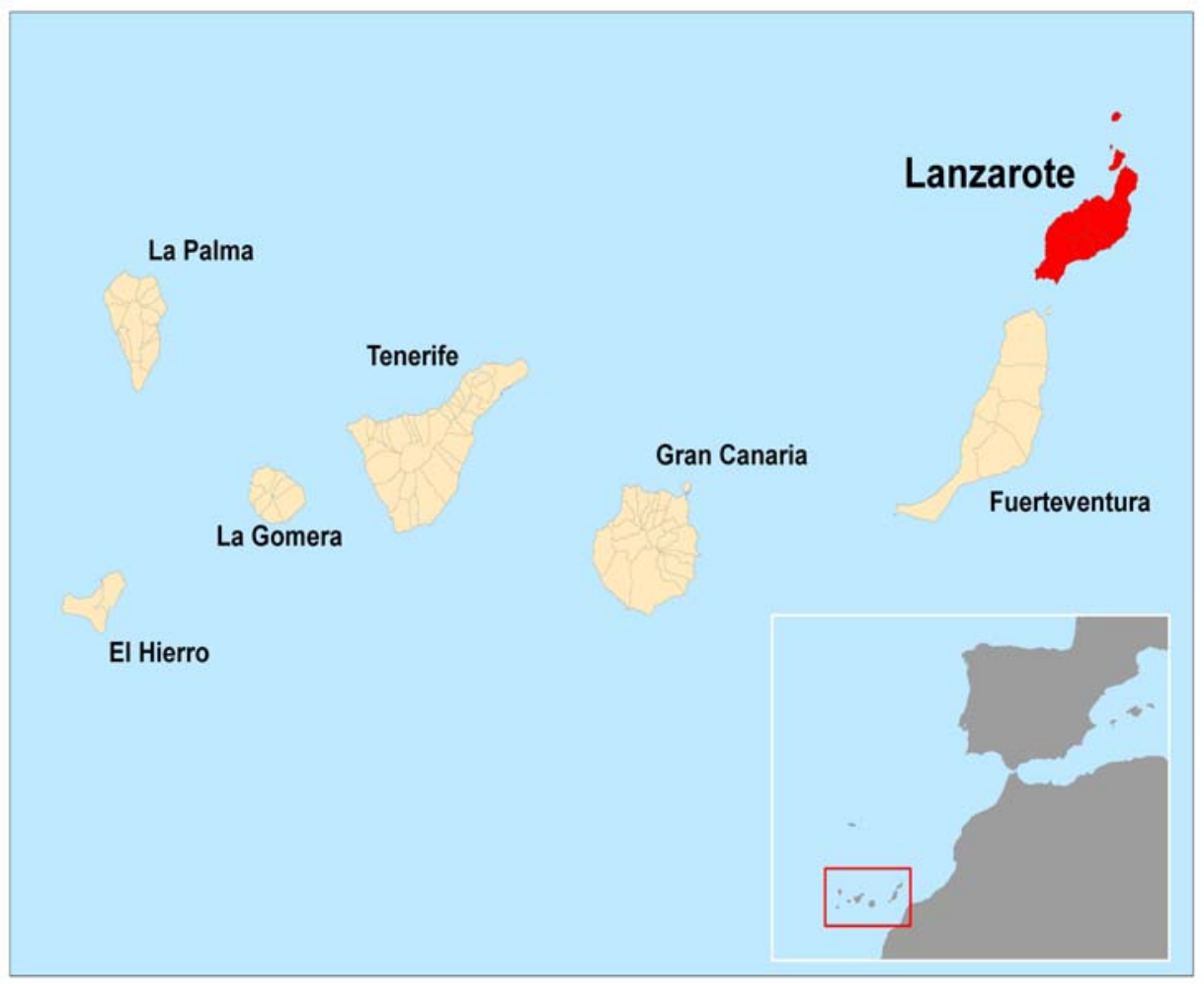

\section{2.- UNIVERSO A INVESTIGAR}

Una isla reúne, por sus propias circunstancias físicas, ambientales y socioeconómicas, un espacio idóneo para la investigación de fenómenos complejos. Por ello, el universo a investigar está referido a la isla de Lanzarote.

\section{3.- HIPÓTESIS DE PARTIDA}

En relación a los objetivos descritos se enuncian, en las siguientes líneas, las hipótesis generales de las que se parte en esta tesis, a partir de la cuales se abren hipótesis menores que, tomadas en conjunto, y tras su posterior verificación, nos permitirán demostrar cómo la actividad turística de masas merma el bienestar de las sociedades de acogida y el papel que en ello juega la política territorial.

1. Se ha producido un cambio en la actividad socioeconómica y territorial en Lanzarote entre 1970 y 2006 como consecuencia del crecimiento de la actividad turística en la isla que ha transformado radicalmente ésta así como la forma de vida de su población autóctona.

2. La incorporación de la actividad turística produce un primer periodo de incremento del bienestar en la sociedad de acogida, pero tras la consolidación del territorio como 
turístico y la implantación de un modelo de turismo de masas, comienza el descenso y estancamiento en aspectos importantes del bienestar de la población residente:

2.1 Se producen rápidos crecimientos del volumen de la población residente exógena, atraída por la generación de puestos de trabajo en el sector turístico y de servicios al mismo, y por el número de turistas que, a diario, acoge la Isla. La actividad turística de masas demanda un elevado número de trabajadores que han de ser incorporados a través de fuertes procesos inmigratorios, lo que deriva en desequilibrios demográficos que afectan negativamente a la situación relativa de la población autóctona.

2.2 Inicialmente, la incorporación de actividades del terciario turístico impulsa mejoras en el nivel de instrucción de la población residente (autóctona e inmigrante), pero la línea de ascenso está condicionada por el mercado de trabajo que no demanda elevada capacitación, pues queda sujeto a actividades con fuerte vinculación turística, dentro de las ramas de la construcción, la hostelería y el comercio, manteniendo bajos niveles de instrucción en su madurez como destino de turismo de masas.

2.3 La actividad turística de masas produce precariedad en el empleo por temporalidad del mismo y queda sujeto a las crisis de crecimiento de la oferta y la demanda turística. La decadencia, por abandono, del sector agrario e industrial hace que no existan posibilidades de empleo alternativas durante las crisis de demanda turística.

2.4 El incremento constante de las plazas de alojamiento turístico no es directamente proporcional al incremento del empleo, ni al incremento de la ocupación y mejora territorial. Genera efectos socio-económicos y sobre el bienestar cuyo balance no puede considerarse positivo.

2.5 La presión sobre equipamientos (de salud y educación), infraestructuras y servicios (agua, energía eléctrica y comunicaciones por carretera) en Lanzarote, que deterioran las condiciones de acceso a los mismos de la población residente, se explica por factores demográficos exógenos (inmigrantes y turistas).

3. El análisis de los procesos efectuados confirma una conclusión tradicional de este tipo de estudios cual es que la calidad, y no la cantidad, debe presidir las políticas de desarrollo turístico. La contención, en niveles adecuados a la capacidad de carga y sostenibilidad de las características territoriales, de la oferta y la demanda turística es la vía para la mejora del bienestar social. 



\section{Capítulo 2}

\section{ESTADO DE LA CUESTIÓN. PRINCIPALES APORTACIONES A LA MATERIA}





\section{CAPÍTULO 2.- ESTADO DE LA CUESTIÓN. PRINCIPALES APORTACIONES A LA MATERIA}

\section{1.- CONCEPTOS BÁSICOS}

Al tener este trabajo como objeto principal la observación de la transformación del estado de ciertas áreas del Bienestar social en relación con la evolución de la actividad turística, se hace necesario esclarecer conceptos básicos que aquí manejamos como son, principalmente, los de Bienestar social y Turismo. Es por ello que las próximas páginas se destinan a recoger la evolución de dichos conceptos, permitiéndonos así llegar a establecer la definición de los mismos, que nos guiará a lo largo de la investigación.

\section{1.- EL BIENESTAR SOCIAL}

Los beneficios y efectos materiales e inmateriales del desarrollo turístico, derivados de la implantación y consolidación de la actividad en un territorio insular, es nuestro objeto de estudio. Hablamos, por tanto, de su repercusión sobre el bienestar en el territorio que acoge la actividad, pero ¿qué entender por bienestar y bienestar social?

En un sentido denotativo básico, bienestar significa "conjunto de las cosas necesarias para vivir bien" (RAE, 2001, 22ª edición). En un sentido estricto, el vocablo bienestar o welfare significa sólo aquel bienestar objetivado (consistente en hechos objetivos, no en estados subjetivos de conciencia), externo (apreciable por los demás) y mínimo (indispensable) (Moix, $M^{1}$., 1986, pp. 23). Así, los juicios sobre el bienestar pueden ser entendidos desde la esfera objetiva del conocimiento, de ahí que pueda ser mensurable desde indicadores sociales. Por otro lado, su carácter mínimo hace referencia al bienestar, pero no en su totalidad global, sino en sus requisitos primordiales, apuntando hacia la idea de un determinado mínimo en el nivel de estos requisitos, consecuentemente los fallos en alcanzar dicho nivel se consideran deficiencias en el alcance del bienestar.

Pero el bienestar no empieza y acaba en una dimensión individual, sino que tiene una importante dimensión social, unificado por valores comunes, hablando por tanto de Bienestar Social. Nos referimos a la responsabilidad colectiva asumida por la comunidad para hacer frente a la cobertura de las necesidades de la población, desde un punto de vista

\footnotetext{
1 Moix Martínez, Manuel es Catedrático de Política Social, Trabajo Social y Bienestar, de la Universidad Complutense y Doctor en CC.PP., Económicas y Comerciales, Doctor en Derecho y en Filosofía.
} 
del desarrollo ${ }^{2}$ o institucional, como actividad organizada, poniendo el acento en la planificación del cambio social y en la provisión de los recursos esenciales para mantener y mejorar el funcionamiento de la sociedad (social planning, social utilities). Es relevante, por ello, mencionar la concepción de Naciones Unidas (1959) donde se une una mirada asistencial e institucional: "el Bienestar Social es una actividad organizada que se propone ayudar a una mutua adaptación de los individuos y de su entorno social. Este objetivo es alcanzado mediante el uso de técnicas y métodos que están ideados para capacitar a los individuos, grupos y comunidades para hacer frente a sus necesidades y resolver sus problemas de adaptación a un modelo cambiante de sociedad, y mediante la acción cooperadora para mejorar las condiciones económicas y sociales"3.

En términos generales, bienestar social puede referirse al "orden social como instrumento para promover la satisfacción de las necesidades de bienestar individual, que son comunes, compartidas o experimentadas conjuntamente por diversos miembros de la sociedad" (Moix, M., 1986, pp. 27) y por tanto desde la construcción social de las necesidades, que son sentidas y que varían en espacio y tiempo. De forma particular, se referirá al orden social como promotor de aquellos sectores en que se dan empresas compartidas y situaciones de interacción social, que van desde la creación de recursos públicos disfrutados en común (infraestructuras y equipamientos, principalmente), hasta aspectos de recursos humanos (por ejemplo el nivel educativo o de instrucción de la población). Para Moix, M. (1986) es en todo caso, "la referencia a un orden social compartido que impulse, fomente y potencie el logro por parte de los ciudadanos de su propio bienestar personal lo que constituye, en definitiva, lo característico y definitorio del bienestar social'.

Dentro del pensamiento sobre el bienestar y su medición aparecen dos grupos de alternativas: a) las utilitaristas que hacen hincapié en la felicidad y placer de los individuos o, alternativamente, en el grado de satisfacción objetiva de sus deseos y preferencias; b) las valorativas que tratan de definir una relación mínima de las situaciones objetivas que permiten a los individuos desarrollar una vida de calidad. Entre estas últimas juega un papel fundamental el nivel de igualdad que tienen los individuos en el acceso a bienes básicos (J. Rawls), en el uso de recursos (G. Dworkin), en las capacidades de funcionamiento (A. Sen) o en las oportunidades de realización (G.A. Cohen). La idea subyacente es que el bienestar social será menor cuanto mayor sea la desigualdad social en el control que los individuos tienen de los recursos que les permiten dirigir conscientemente sus condiciones de vida.

\footnotetext{
2 Se parte de la base de que en una sociedad industrial, todos los ciudadanos pueden requerir muy diversos servicios sociales para poder desenvolver su capacidad productiva (Moix, M., 1986, pp. 62).

${ }^{3}$ Naciones Unidas. "The development of National Social Welfare Programmes". New York, 1959 (pp. 3).
} 
Desde este último punto de vista, Nathan E. Cohen (1958) $)^{4}$ carga el acento en el papel positivo que el Gobierno tiene que asumir para hacer frente a los problemas sociales y económicos.

El alcance del welfare al discurso de las necesidades básicas colectivas, sobre todo a su multidimensionalidad, queda reflejado en la siguiente observación de Tortosa, J. M. (1992, pp. 15): "Un mundo sano es aquel que permite satisfacer las necesidades básicas (todas) de todos sus habitantes, comenzando por los más necesitados.(...) La curación de una enfermedad no debería hacerse creando otra. Es preciso, entonces conocer las relaciones entre las distintas partes (enfoque holístico, psicosomático, etc.), los efectos secundarios que puede producir un determinado tratamiento, las contraindicaciones y demás acercamientos a la complejidad del asunto. Pasando del sistema temporal al sistema social (...).

A pesar de lo dicho, debemos tener en cuenta que no existe una concepción unánime en la definición de bienestar social, pero sí hay unanimidad en cuanto a que se le considera un concepto que pertenece al mundo de lo ideológico y que es complejo, puesto que la vida humana en sí misma y en sociedad posee múltiples facetas. Así, no tiene sentido preguntarse si una definición conceptual es acertada o no, simplemente resulta más o menos útil para reflexionar $\mathrm{y}$, a partir de la cual poder acuñar un concepto válido para el análisis que aquí abordamos. Después de estas reflexiones previas, las características del bienestar social que han de resaltarse son: su carácter multidimensional (compuesto por partes o áreas diversas que se afectan mutuamente) y su carácter dinámico, puesto que los elementos que lo integran no sólo se modifican internamente a lo largo del tiempo, sino que también va incorporando otros nuevos por el proceso de evolución de la sociedad y por tanto de las necesidades colectivas, que se construyen socialmente en cada momento y espacio. El bienestar social debe ajustarse al cambio social constantemente, aunque también debe ser agente de cambio social, acelerándolo y sobre todo encausándolo en armonía con las finalidades político-sociales. Existe una tercera característica que parte de los múltiples sectores o dimensiones que componen el bienestar, que se encuentran relacionados y afectados los unos con los otros, haciendo que no pueda explicarse por un único elemento, por tanto, hablamos del bienestar como sistema ${ }^{5}$.

Entendemos aquí, por tanto, el bienestar como un concepto complejo, multidisciplinar, multidimensional, objetivo y objetivable, mensurable a través de indicadores sociales

\footnotetext{
${ }^{4}$ Nathan E. Cohen. (1958) "Social Work in the American Tradition". Dryden Press, New York, 1958 (pp. 6-8).

5 Crampton, H. y Keiser, K. (1970) lo entienden como "un sistema que entraña una aproximación polifacética a los problemas sociales y económicos, reflejando valores sociales y usando la pericia de disciplinas conexas para el bien colectivo".
} 
objetivos, referido al acceso a servicios primordiales, recogidos como derechos, que tiene reflejo en el nivel de vida y en el estado de la "igualdad de oportunidades". Por tanto habrá correspondencia entre bienestar, nivel de satisfacción de las necesidades y desarrollo. No debemos olvidar que cada uno de los elementos que componen el bienestar se relaciona, afecta y es afectado por los otros componentes.

Diferenciamos así el bienestar del concepto que aparece en la década del setenta, la calidad de vida, también complejo y sobre el que no existe, tampoco, acuerdo denotativo. Entendemos la calidad de vida en cuando percepción de la población de su vida, de cómo percibe el estado de la satisfacción de sus necesidades y deseos, desde un punto de vista subjetivo (estado de conciencia), de lo que denomina Díez Nicolás (1993, pp. 191-192) estándar de vida (nivel de vida modélico o ideal al que aspira $)^{6}$, o en términos weberianos "opciones de vida" 7 .

Las formas en las que el desarrollo turístico, en cuanto posibilidad de crecimiento económico, afecta al bienestar por un lado y por otro a las opciones de vida de la población que lo acoge, están relacionadas no sólo con los efectos sobre los equipamientos o los ingresos, sino también con su distribución, que es lo que finalmente afecta al bienestar, en cuanto a que su distribución puede significar el cubrir o no un estándar mínimo en materias de educación, salud, seguridad social, vivienda, etc. Desde la Teoría del Bienestar económico, Pigou, A.C. señaló como "condiciones del bienestar económico: la producción medida en dinero, más alta posible, una distribución de la renta igualitaria y la modificación de las actividades, por muy rentables y muy productivas que sean, cuando resulten perjuicios para los ciudadanos". La extensión de la economía del bienestar a la idea de un conjunto creciente de servicios sociales (preconizada en Inglaterra por Beveridge en 1942) generaría el Welfare State o Estado Benefactor o de Bienestar ${ }^{8}$. Estas ideas, nos ponen ante la necesaria definición de crecimiento económico y de desarrollo.

El crecimiento en economía supone el aumento de una variable y especialmente del Producto Interior Bruto (PIB), cuyo ritmo puede dar una idea de la expansión de una

\footnotetext{
${ }^{6}$ A diferencia de lo aquí establecido, existen conceptualizaciones de la calidad de vida que aúnan lo objetivo y subjetivo, lo material e inmaterial, como es el caso de $M^{a}$ Luisa Setién (1993, pp. 56-69) que entiende la calidad de vida como "el grado en que una sociedad posibilita la satisfacción de las necesidades (materiales y no materiales) de los miembros que la componen. Tal capacidad se manifiesta a través de las condiciones objetivas en que se desenvuelve la vida societal y en el sentimiento subjetivo que de la satisfacción de sus deseos, socialmente influidos, y de su existencia poseen los individuos".

${ }^{7}$ El término "opciones de vida", usado por primera vez por el sociólogo alemán Max Weber hace más de un siglo, se refiere a la probabilidad que tienen los individuos de alcanzar durante su vida un conjunto de metas (buena salud, un empleo deseable, reconocimientos social, vivienda, seguridad social, educación, etc..). Los diferentes patrones de opciones de vida, tomados por diferentes grupos nos hablará de clases sociales, de diferenciación y desigualdad.

${ }^{8}$ Ramón Tamames y Santiago Gallego.- "Diccionario de Economía y Finanzas" 13ª Edición.- Alianza Editorial, Madrid, 2006.
} 
economía determinada, o sea, guarda relación con el ritmo de variación e incremento de las macromagnitudes económicas fundamentales, pero no da idea de su calidad y sus consecuencias para el Bienestar, que sí es objeto, en cambio, de aquellos que se preocupan del desarrollo. Por el contrario, hay que entender el desarrollo como un proceso de cambio estructural en el ámbito económico, social y político, cuyos objetivos son la consecución de una real igualdad de oportunidades y la participación efectiva de todos los grupos sociales en la definición de objetivos, fines e instrumentos a utilizar en la puesta a punto del proceso ${ }^{9}$. Implica considerar los niveles de bienestar de la población: potencial de acceso a servicios públicos e igualdad de oportunidades.

De cómo el crecimiento de la actividad turística puede afectar al bienestar social de la sociedad insular, en cuanto bienestar objetivo, hablaremos en próximos capítulos.

\subsection{1.- ESTADO DE BIENESTAR Y SOCIEDAD DE BIENESTAR}

El Estado de Bienestar es un tema insoslayable en el debate de la Ciencias Sociales y a la hora de valorar el bienestar de las sociedades en las que ha irrumpido con fuerza un determinado sector económico, como aquí es el turismo.

La real Academia de la Lengua Española establece el significado de Estado de Bienestar de la siguiente forma "Sistema social de organización en el que se procura compensar las deficiencias e injusticias de la economía de mercado con redistribuciones de renta y prestaciones sociales otorgadas a los menos favorecidos" (2001, 22ª edición).

Lo definimos aquí como aquel "conjunto de instituciones estatales que garantizan una serie de derechos sociales ejercitables por la inmensa mayoría de los ciudadanos, desarrollados a través de políticas y programas de carácter redistributivo en base a la solidaridad intergeneracional y apoyados en la idea básica de ciudadano trabajador que es sujeto de derechos sociales y residualmente como ciudadano necesitado" (Rodríguez Cabrero, 2002, pp. 19). Significa, por tanto, la garantía de un estándar mínimo en materias de educación, salud, seguridad social, vivienda, etc. (Álvarez Rico, M. 1998, pp.123), como exigencia para el bienestar de la población y que forman parte de la denominada "renta social", necesaria para asegurar la igualdad de oportunidades ${ }^{10}$. La intervención pública aparece como una exigencia porque los beneficios externos de estos sectores no pueden ser internalizados por

\footnotetext{
9 Lázaro Araujo, Laureano (1977).- "Materiales para una Teoría del Desarrollo Regional". Revista Información Comercial Española, 1977 JUN-JUL; (526-527), páginas 15-44.

10 Se mueve bajo el principio "marshalliano" de la inclusión: incorpora la población global a las prestaciones de los distintos sistemas funcionales de la sociedad. Marshall T. H. (1964). "Class Citizenship and Social Development". Garden City. New York.
} 
el mercado, como ya señalaría Pigou (1920) desde sus estudios de economía de bienestar ${ }^{11}$ con el fin de poner de manifiesto el que la ganancia privada no redundaría en bienestar para la sociedad (estableciendo la diferencia entre producto social marginal neto o el producto privado marginal neto), apoyando una mayor difusión de la renta y abogando por la intervención del Estado mediante subsidios e impuestos para corregir los fallos del mercado e internalizar las externalidades (positivas y negativas). En él, no existen esferas de funciones socialmente exclusivas (Beriain, J. 1990, pp. 94).

Este Estado se alimenta de la contribución de todos, ya sean personas físicas, empresas o sectores económicos. Desde este punto de vista, los ingresos por turismo, uno de los puntales fuertes de la economía española, debe ser una garantía, para las diferentes comunidades que la constituyen, del mantenimiento y mejora de esos estándares.

Así, en palabras de Álvarez, M. ${ }^{12}$, el Estado de Bienestar se articula como una doctrina compleja fundada en la aceptación del Estado de Derecho, legitimado a través del sufragio universal, basado en el imperio de la Ley y en el principio de división de poderes. Todo ello, nos dice Álvarez, ha constituido una cultura inseparable de la conciencia colectiva, de lo que el pueblo considera sus derechos políticos y de cómo percibe su existencia; la frecuencia en el uso de una determinada idea llega a convertirse en un determinante de la existencia, termina conformando la conciencia individual y el imaginario colectivo, marcándose en la visión del mundo (cosmovisión). Por tanto, "el pueblo" no es capaz de percibir el Estado sin considerarlo proveedor de unos estándares mínimos en materia de servicios.

Desde este hábito en la conformación de las ideas, la Ética de la Sociedad Civil, reflejada en la Declaración Universal de los Derechos Humanos de la ONU (1948) y firmada por España, en su artículo 22 señala: "Toda persona, como miembro de una sociedad tiene derecho a la seguridad social, y a obtener, mediante el esfuerzo nacional y la cooperación internacional, habida cuenta de la organización y los recursos de cada Estado, la satisfacción de los derechos económicos, sociales y culturales, indispensables a su dignidad y al libre desarrollo de su personalidad". Si esto lo unimos a lo que proclama nuestra Constitución (por ejemplo en los artículos 35.1, 40.1., 41., 43.1. y 2., 44.1.), decimos que desde la Ética interesa que el sistema social asegure a todo individuo el situarse en un nivel de vida que no se distancie mucho del nivel medio de vida del país. Por tanto, la lógica del Estado de

11 Pigou, A. C. (1920) "The Economics of Welfare", publicada por primera vez en 1912, con el título "Wealth and Welfare". (Versión española por Sánchez Ramos F., Gráficas Nebrija, S.A., Madrid, 1946). Abrió un amplio campo de oportunidades para la política pública, constituyendo un primer intento de desarrollar una teoría razonada de dicha política. Su teoría tiene su imagen en el Estado de Bienestar Social, que proporciona seguridad social y da oportunidades para un consumo casi uniforme en sectores como la educación, la vivienda y la sanidad.

12 Álvarez, M. 1998, pp. 123-124. 
Bienestar sólo puede ser comprendida bajo el principio de compensación (Luhmann, N. 1993, pp. 32) ${ }^{13}$. A esta afirmación, desde el punto de vista del derecho, le corresponderá otra desde el punto de vista del deber. Ese deber se reconoce, aquí, reflejado en Artículos de la Constitución Española -como, por ejemplo, los anteriormente citados-, en las palabras siguientes: "los poderes públicos promoverán las condiciones favorables para el progreso social y económico y para la redistribución de la renta (...) más equitativa, (...)" (Art. 40.1.); "Ios poderes públicos mantendrán un régimen público de Seguridad Social para todos (...)" (Art. 41); "compete a los poderes públicos organizar y tutelar la salud pública (...)" (Art. 43.1.). El Gobierno es el que tiene la obligación estricta de satisfacer el derecho al bienestar y para ello genera una Política de bienestar fundamentada en cuatro grandes apartados de gastos: educación, sanidad, vivienda, pensiones y seguros de desempleo (Muñoz de Bustillo, 1993, pp. 25) y en el s. XXI se añade un apartado más, el de la dependencia. Supone un código moral bajo el cual se asientan las ideologías que definen el Estado de Bienestar. Por tanto, el debate sobre las necesidades sociales no se aleja de la moral, sino que es ésta la que establece derechos $\mathrm{y}$, en consecuencia, obligaciones morales, generándose derechos sociales y civiles que adoptan y se reafirman en las políticas sociales, las cuales son las que varían de cultura a cultura, así como el modo de dar satisfacción a las necesidades. Plant y Lesser (1980, pp. 51), señalan que sea cuál fuese la posición moral, cualquier moralidad lógicamente autoconsciente, debe admitir que ciertas cosas sean necesidades humanas. Por tanto, el cubrir estas necesidades debe ser realizado por el Sector Público, en la medida en que se corresponden con bienes preferentes (Musgrave, R. A. 1959, pp. 20).

Si bien es cierto que España estructura un sector clásico de economía del bienestar en un periodo en el que, en otros países, se discutía sobre su futuro y en ocasiones se recurría a su modificación o reducción parcial. La polémica, acerca de la sostenibilidad de las instituciones básicas del Estado de Bienestar, mantiene su vigor en la actualidad y no ha dejado de estar presente en el debate de los políticos, académicos, instituciones sociales y ciudadanos, desarrollándose en diversas dimensiones: ideológica, ética, cultural, jurídica, económica, etc. (Vidal Fernández, F. 2003, pp. 9). A finales del s. XX, el Estado social de corte europeo, se ve sometido a un proceso de transformación como resultado, entre otros factores, de un nuevo modelo de desarrollo económico, social y cultural propiciado por la revolución tecnológica (de la información y la comunicación, las TIC) y el proceso de

13 "Se trata de la compensación de aquellas desventajas que recaen sobre cada cual como consecuencia de un determinado sistema de vida". Luhmann, 1993, pp. 32. 
globalización $^{14}$ (que genera una nueva economía), así como las nuevas necesidades sociales que aparecen fruto del aumento de la esperanza de vida, la incorporación progresiva de la mujer a la actividad laboral, la reducción de la natalidad, la mayor precariedad del mercado de trabajo y el flujo creciente de inmigrantes, la irrupción de nuevas sociedades en los mercados de consumo, etc. El marco de la globalización se corresponde con un proceso de mutación de las fuerzas productivas a nivel mundial que ha modificado el modelo anterior en dos sentidos: congelando la oferta de consumos públicos y segmentando los consumos privados en base a mayores dispersiones en la distribución de la renta, en la que el Estado juega un papel más pasivo (Rodríguez Cabrero, 2002, pp. 18).

La década de los años ochenta viene acompañada de cambios en el discurso acerca del Estado de Bienestar. Ahora se mira hacia la Sociedad de Bienestar, en la que todos los elementos integrantes de la misma deben o deberían servir al bienestar social internacional, no sólo el Estado y las instituciones. Es una sociedad de servicios. Llega lo que se ha denominado el post-welfarismo, en él, el principal tema ya no será por más tiempo la satisfacción de las necesidades básicas, la consecución de niveles mínimos (una vida adecuada), sino más bien la creación de condiciones conducentes a un más elevado y más favorable estándar de vida para toda la sociedad, forjar las circunstancias que alienten y sostengan a los individuos en sus esfuerzos por progresar al máximo por sí mismos y alcanzar un vida más satisfactoria (Moix, M. 1986, pp. 337). El welfarismo y el Estado de Bienestar se caracterizaban por ser esencialmente protectores, mientras que el postwelfarismo se caracteriza por preocuparse del enriquecimiento de la vida, de la plena realización de la persona. El post-welfarismo, que se asienta y avanza en países desarrollados del Norte de Europa ${ }^{15}$, supone una sociedad orientada hacia los servicios y la diversificación, junto con la decadencia de los modelos de masas. Aunque los países en vías de desarrollo del Sur de Europa, como España, sigan consolidándose como destinos turísticos de masas.

En esta tesitura se sigue desarrollando la actividad turística de masas en el territorio insular canario, durante el periodo que aquí nos ocupa. Ésta actividad, seguirá repercutiendo, directa e indirectamente, tanto sobre actividades económicas y empresariales, como sobre los elementos tradicionales del bienestar, entre los que se encuentran las dotaciones en servicios públicos en general (sanidad, seguridad ciudadana, sistema educativo, cultura, etc.), tanto en épocas de bonanza económica como de crisis.

\footnotetext{
14 Una forma neoliberal, que sitúa en difíciles condiciones de competitividad internacional a las empresas que pagan elevados impuestos, necesarios para mantener un Estado de Bienestar, junto con la existencia de paraísos fiscales y mecanismos de ingeniería puntera para pagar menos IRPF.

15 Como Gran Bretaña y los Países Escandinavos.
} 


\subsection{2.- NECESIDADES SOCIALES Y BIENESTAR.}

El Bienestar se justifica a través de la noción de necesidad, vendrá definido en términos de necesidades, preferencias y recursos (Díez Collado, 1994, pp. 34), por ello, el objeto de la política de bienestar es satisfacer las necesidades humanas (Taylor-Gooby, P. 1991, pp. 187), entendiendo que su cobertura es básica y fundamental para cualquier labor humana.

Las necesidades humanas las entendemos aquí como un conjunto de precondiciones de la existencia humana, como requisitos previos para la vida autónoma dentro de las sociedades, que tienen como objetivos generales la creación de modos de vida libres y emancipatorios $^{16}$ (Rodríguez, G. 1994, pp. 14). Son históricas, construidas y jerarquizadas socialmente (Doyal y Gough 1994, pp. 67), varían en espacio y tiempo y son universales. Esta universalidad introduce un sentido de redistribución de los recursos y de organización de modos de satisfacción de necesidades que no supongan la explotación irracional de la naturaleza y de los recursos (Rodríguez, G., 1994, pp. 15).

La dimensión de la necesidad básica es múltiple, no sólo se puede centrar en lo material, sino también en el ámbito subjetivo, afectivo y de personalidad, aspectos estos que no se abordan desde la idea de bienestar que aquí se utiliza, sino puramente lo objetivo y material. Las necesidades básicas no cubiertas cimentan una primera pretensión sobre los recursos disponibles (Harris, D. 1990, pp. 303), no pueden eludirse a la hora de administrar los recursos $^{17}$. En consecuencia, las necesidades definen la prioridad de las demandas, hacen referencia a una categoría específica de objetivos que se creen universales. Así, las convertimos en un principio de distribución, que acerca a las sociedades hacia la igualdad de oportunidades y al bienestar.

Serán aquellas necesidades básicas, recogidas como derechos las que deberán ser satisfechas a lo largo de la evolución de una sociedad para que no suponga la pérdida de bienestar. Teniendo en cuenta que el crecimiento económico, tal como hemos señalado anteriormente, y la opulencia, no significan mayor igualdad de oportunidad, mayor satisfacción de las necesidades y mayor bienestar.

\footnotetext{
16 "La supervivencia física y la autonomía personal son las necesidades básicas de todo individuo en cualquier cultura y tienen que ser satisfechas para poder participar en el logro de otros objetivos individuales y sociales" Rodríguez, G. 1994, pp. 14.

17 "Una sociedad moralmente aceptable es aquella que garantiza la satisfacción de las necesidades de sus miembros como su obligación primaria" Harris, D. 1990, pp. 304.
} 


\section{2.- CONCEPTUALIZAR EL TURISMO}

A pesar de los múltiples trabajos realizados desde la sociología sobre el ocio y el turismo, no se encuentra una definición concreta y consensuada del turismo desde el punto de vista sociológico. Sí podremos encontrar diferentes definiciones del mismo desde distintas disciplinas y ámbitos institucionales, debido a su enorme complejidad y multidimensionalidad, lo que nos lleva a que sólo sea abordable desde el conocimiento interdisciplinar.

Hemos seleccionado aquí alguna de las aportaciones semánticas consideradas significativas dentro de la tradición sociológica e institucional para llegar a desentramar y enunciar finalmente la idea de turismo con la que aquí trabajaremos. Teniendo en cuenta que hay que diferenciar turismo de oferta turística, actividad turística y sector turístico.

El turismo es un fenómeno contemporáneo y de naturaleza compleja. Aunque históricamente el ser humano se ha desplazado por el territorio e interactuado con otros entornos socioculturales diferentes al suyo por motivos de ocio, el turismo como materia de investigación comienza a importar en el periodo "entreguerras", es decir entre la I y la II Guerra Mundial (Fernández Fuster, 1988, pp. 23).

En la primera veintena del s. XX destaca en Alemania la Escuela Berlinesa, que debe su nombre a radicar en Berlín. Dicha Escuela desarrolla la "Ciencia del movimiento de forasteros" como una disciplina próxima a la economía de empresa y a la economía política. Se inclinan al estudio del impacto económico que producían los viajeros, pero a la hora de definir el turismo quedaron circunscritos al estudio del sujeto agente, el turista.

Es en este momento cuando comienza la Sociología del Turismo, muy centrada en la investigación en torno al carácter social del turista, pero sin incidir en la interacción con la población autóctona, aunque puede ser revelador en cuanto a desentramar el "ser" del turista que afectará a los servicios que se desarrollan en los lugares que visita, para generar mayor afluencia de divisas. Es por ello que aquí nos limitamos a enunciarla brevemente, por su importancia dentro del arranque de la Sociología del Turismo.

En esta época las definiciones de Turismo que aparecen están derivadas del concepto de tráfico, se centran en la superación de las barreras espaciales. Antes de la aparición del turismo de masas, éste aparece como un ser animado de movimiento. Tal es el caso de definiciones como la que presenta Morgenroth (1929): "Tráfico de personas que se alejan temporalmente de su lugar fijo de residencia para detenerse en otro sitio con objeto de satisfacer sus necesidades vitales y de cultura o para llevar a cabo deseos de diversa 
índole, únicamente como consumidores de bienes económicos y culturales" ${ }^{18}$ (Fernández Fuster, L. 1988, pp. 24). Y en la misma línea, Bormann (1930). A ello hay que añadir el componente de clase, se califica de "consumo de lujo" (Roscher y Stradner, 1929), propio de las posiciones sociales altas para diferenciarse de las otras clases sociales, puesto que la primera mitad del siglo XX es aristocrática en cuanto al turismo.

Estas conceptualizaciones poco después serán superadas, apareciendo lo que se ha calificado, en palabras de Fernández Fuster, L. (1988, pp. 24) como la mejor definición de turismo antes de la II Guerra Mundial, que viene de la mano de uno de los pensadores más relevantes dentro de la Escuela Berlinesa, Glücksmann (1935) ${ }^{19}$ : "Turismo es la suma de las relaciones existentes entre personas que se encuentran pasajeramente en un lugar de estancia y los naturales de ese lugar". Además, advierte acerca del error de tomarlo únicamente como desplazamiento de viajeros: "Quien interpreta el turismo como un problema de transporte lo confunde con el tráfico de turistas. El Turismo empieza allá donde el tráfico termina, en el puerto del Turismo, en el lugar de hospedaje"."El tráfico de viajeros conduce al Turismo. Sin embargo, no es el Turismo propiamente dicho, ni siquiera en parte". Opinión ésta que en la actualidad no cubriría alguna de las múltiples formas en las que se está dando el turismo, del todo comprensible puesto que está enunciada bajo un modelo de sociedad en la que aún no había arrancado el turismo de masas.

En lo que a esta investigación concierne se considera importante el legado de Glücksmann, en la medida en que ya lo percibe como un fenómeno sociológico, puesto que señala la relación que se establece entre el forastero y el habitante del lugar al que llega. Aunque Leopoldo von Wiese $(1930)^{20}$, heredero de Simmel, G. y perteneciente a la Escuela Sociológica Formal alemana, años antes, ya lo había tomado como un aspecto a estudiar dentro de las relaciones interpersonales (Knebel, 1973, pp. 3).

Knebel, en 1973, recoge las ideas de Wiese comentando que en su definición parte de la idea de que, en los estadios culturales primitivos, extranjero significaba originalmente algo hostil, desarrollándose con posterioridad un culto al forastero en los lugares donde, por causa de los encuentros con extranjeros, se había obtenido provechos económicos o donde, gracias a la curiosidad, se constituía poco a poco un ansia de conocimientos (Knebel, 1973, pp. 3). Este planteamiento de Wiese abre las puertas a una nueva mirada hacia el extranjero, y hacia el turismo, siendo, quizás, un visionario en la medida en que esa imagen del turista y del turismo es la que va a impulsar el turismo de masas que acogerán las

\footnotetext{
18 Artículo titulado "Fremdenverkehr" en el Handwörterbuch der Staatswissenschaften, vol. IV, Jena, 1929.

19 Glücksmann, R. (1935). "Fremdenverkehrskunde”. Berna, 1935, pp. 3.

20 Leopoldo von Wiese (1930). "Fremdenverkehr als zwischenmenschliche Beziehungen". Archiv für den Fremdenverkehr, abril, 1930.
} 
sociedades de la Segunda mitad del s. XX. Y apoya la idea contraria a la que expresó Vierkandt (1928, pp. 96 y 172) ${ }^{21}$ con anterioridad, que aseguraba lo siguiente: "El forastero por sus especiales características no tiene participación alguna en el comportamiento de la sociedad: no es concebido como una persona, sino que permanece distanciado como si fuera un simple objeto, al que escasas o ningunas relaciones útiles podemos asociar". La ruptura con esta idea ampliará los horizontes de la Sociología del Turismo que empieza a gestarse, aunque no será hasta el último tercio del siglo $X X$, cuando se abre el interés por los efectos positivos y negativos que genera la actividad turística en los territorios de acogida.

La ciencia del movimiento de forasteros pasa posteriormente por nuevas y más amplias definiciones de dicho movimiento, y quizás más completas y aceptadas puesto que se acercan a concepciones actuales de Turismo, como la elaborada por Hunziker y Krapf (1942), recogida por Knebel (1973, pp. 4): “El tránsito de forasteros es el conjunto de las interacciones y de los fenómenos que se producen como consecuencia de los viajes y de las estancias de forasteros, siempre que de ellas no surja un asentamiento duradero ni estén unidas a actividad productiva alguna" 22 . Todos los posibles fenómenos derivados de la interacción que surge de las estancias breves en otros lugares, sin finalidad económica, es turismo. Sentido y significación en la que se inscribe los estudios posteriores, como los realizados por Fernández Fuster, L. (1988, pp. 25).

En la segunda mitad del siglo XX, el profesor Arrillaga, J. L. (1962, pp. 19) enuncia la siguiente definición de turismo: "todo desplazamiento voluntario y temporal determinado por causas ajenas al lucro, el conjunto de bienes y servicios y organización que en cada nación determinan y hacen posibles esos desplazamientos $y$ las relaciones $y$ hechos que entre estos y los viajeros tienen lugar". En ella incluye al propio turista, las causas de su viaje, al espacio turístico (bienes, servicios que consume y las relaciones que se producen en su destino) y al viaje. Entendemos que esta definición es más próxima al concepto de sector turístico que a una definición de turismo ya que incluye en el mismo la oferta turística que es de enorme complejidad.

El historiador social norteamericano Boorstin (1972), en su libro "The imagen" (La imagen) diferencia entre viajar -travelling-, noción que está conectada etimológicamente con la noción de trabajo (travail), en inglés y en castellano viene del latín "viaticum": camino, vía y tiene el sentido de hacer el camino participando activamente en el viaje. Sin embargo, turismo, procede del inglés "tourist", que sería "el que da vueltas", término que deriva del

21 Vierkandt, A. (1928). "Gesellschaftslehre", $3^{\text {a }}$ ed. Stuttgart.

22 Hunziker y Krapf. (1942). "Grundriss der allgemeine Fremdenverkehrslehre". Zurich. 
griego "tornos": torno, vuelta, e implica cierta pasividad, en el sentido de que gira impulsado por una fuerza que recibe en la que sólo participa de ella como mero receptor ${ }^{23}$. Lo que Boorstin nos quiere decir es que "el turista es un visitante pasivo; el turismo es una experiencia organizada en la que el contacto con el autóctono no tiene por qué darse". Dicha idea es también afirmada por Crick (1989, pp. 342) ${ }^{24}$ cuando nos dice que "el turismo gira en torno a un mundo descubierto, o incluso creado por los empresarios (...)".

Martínez Quintana, V. (2003, pp. 99) recoge definiciones de turismo basadas en la connotación del viaje, señalando a Burkart y Medlik (1981) - establecen una definición de turismo donde hacen alusión a desplazamientos cortos y temporales que efectúa la población hacia destinos que están fuera de su lugar de residencia y de trabajo, y todas aquellas actividades realizadas durante la estancia en el destino turístico - y a Mathieson y Wall (1982) - turismo es el movimiento temporal de la gente, por periodos inferiores a un año, a destinos fuera del lugar de residencia y trabajo, las actividades emprendidas durante la estancia, y las facilidades creadas para satisfacer la necesidades de los turistas -, aportaciones éstas que tendrán cierta influencia en la definición que adopta la Organización Mundial del Turismo (OMT) en 1993, y que en palabras de Martínez Quintana (2003, pp. 99) "supone una conceptualización que acota temporalmente la actividad turística en la que se ha aproximado bastante a la terminología esencial que encierra el fenómeno, trabajando nuevos factores, "periodo inferior a un año», "facilidades creadas» y la "satisfacción de las necesidades de los turistas», que concretan más los elementos que ahí intervienen".

Aunque las primeras acciones tendentes a establecer definiciones internacionales sobre el turismo las emprende el Consejo de la Sociedad de Naciones, en 1937, recomendando la siguiente definición: "la actividad de cualquier persona que viaje durante veinticuatro horas o más por cualquier otro país que el de su residencia habitual", sólo es interesante en cuanto a establecer un criterio que guíe y haga comparables las estadísticas turísticas internacionales.

No será hasta la década de los noventa cuando la OMT acote la definición, a partir de la celebración de la Conferencia Internacional sobre estadística de viajes y turismo en Ottawa (1991), de la que surge la Comisión de Estadísticas de la Naciones Unidas, que en 1993, recoge varias definiciones y clasificaciones, enunciando el concepto de turismo de la forma que sigue: "las actividades de las personas que se desplazan a un lugar distinto al de su entorno habitual, por menos de un determinado tiempo y por un motivo principal distinto al

23 Boorstin, D. (1972). "The Image. A Guide to Pseudoevents in America". New York: Atheneum.

24 Crick, M. (1989). "Representaciones del turismo internacional en las Ciencias Sociales: sol, sexo, paisajes y servilismos". Publicado en el Annual Review Anthropology, Vol. 18: pp. 307-344. Aquí ha sido utilizada la traducción al castellano, publicada en el libro "Los mitos del turismo" en 1992. 
de ejercer una actividad que se remunere en el lugar visitado y donde: a) la noción de «entorno habitual» excluye como turísticos los desplazamientos dentro del lugar de residencia habitual y los que tienen carácter rutinario; b) la noción de «duración» por menos de un determinado tiempo implica que se excluyen las migraciones a largo plazo; c) la noción de "motivo principal distinto al de ejercer una actividad que se remunere en el lugar visitado» implica que se excluyan los movimientos migratorios de carácter laboral ${ }^{25}$; y añade que «el turismo comprende las actividades que realizan las personas durante sus viajes y estancias en lugares distintos al de su entorno habitual, por un periodo de tiempo consecutivo inferior a un año con fines de ocio, por negocios y otros» (OMT, 1998, pp. 44).

En las dos últimas décadas del s. XX y principios del s. XXI seguiremos encontrando multitud de definiciones, aunque internacionalmente, será la de la OMT la que prevalezca. Así, en lo que respecta a esta tesis, y en cuanto que incluye como parte de la idea de turismo los efectos de su expansión en los núcleos receptores, se recoge la definición de Turismo publicada por Fernández Fuster, L., en 1988 (pp. 26-27), en línea con los pensadores alemanes Krapf, K. y Hunziker, W. (1942), de los que también se nutrió la OMT, que señala lo siguiente: "es el conjunto de fenómenos originados por los viajes", indicando que dentro de lo que es el turismo se encuentra todo el equipo receptor y organizador para atender a esta corriente (hoteles, agencias de viajes, guías-intérpretes, etc.). Entran dentro también todas aquellas organizaciones públicas y privadas que surgen ante la necesidad de expansión del núcleo, del fomento de infraestructuras, etc.; se crean Oficinas de Información, Escuelas de Turismo, campañas de propaganda, etc. Pero, bajo esta idea, se puede considerar también como turismo los efectos negativos y positivos que se producen en las poblaciones receptoras (económicos, sociales, culturales, etc.) y el que se produce por interacción de éstas con sus poblaciones próximas. Como paradoja, según Fernández, L., también es turismo el efecto que se produce en un núcleo receptor cuando se corta la afluencia turística, o sea, el darse efectos negativos derivados de la no-existencia de turistas. Con respecto a esta última idea, en este trabajo entendemos que el concepto de turismo debe diferenciarse de sector turístico, actividad turística, demanda y oferta turística y los efectos de esta actividad.

En el contexto actual y citando a Barreto, M. (2000, pp. 17) "basta con decir simplemente que el turismo es un fenómeno social que abarca el mundo entero desde el punto de vista geográfico y todos los extractos y grupos sociales" (...). "Abarca todos los extractos y grupos sociales no porque todos puedan ser algún día turistas, como da a entender muchas publicaciones, sino porque el fenómeno turístico alcanza, de alguna manera también a los que no lo practican".

${ }^{25}$ Recogido por Agüí López, J.L., 1994 (pp. 20). 
Así, de todo lo visto hasta ahora obtenemos las siguientes características que posee el turismo:

- Conlleva el movimiento físico del sujeto agente fuera de su lugar de residencia, el viaje. Por tanto, el desarrollo de infraestructuras que lo permitan y faciliten.

- Es motivado por diferentes fines, no responde a una sola causa: ocio, negocios, placer, diferenciación social y otros.

- La estancia en el destino no puede ser permanente.

- Comprende las actividades a realizar durante la estancia.

- Abarca los servicios, productos y equipamientos para satisfacer las necesidades del sujeto agente o turista.

- Conlleva interacción directa o indirecta con la sociedad de acogida.

- Tiene efectos sobre las naciones que lo originan y sobre las que lo reciben.

Consideramos por tanto aquí el turismo como un fenómeno social y como tal produce afecciones de diverso tipo sobre las sociedades, interesándonos las afecciones sobre las sociedades receptoras a lo largo de la aparición y consolidación de la actividad en la zona.

Estas características generales extraídas a través de las definiciones citadas, se mezclan con conceptos paralelos al turismo pero que no son turismo en sí mismo y que por tanto deben ser especificados, entre los que se encuentran: ocio, oferta y demanda turística y sector turístico.

La historia del pensamiento sociológico sobre el ocio es amplia y abundante. Su concepto, al igual que el de turismo, puede ser enfrentado desde diferentes disciplinas. La Sociología del ocio aparece en los países industrializados occidentales en los años 50, aunque hay antecedentes en Norteamérica en los años 20 y 30 del siglo XX. Son muchos los que han tratado sociológicamente el ocio desde la Segunda Guerra Mundial, pero aquí nos vamos a limitar a aportar un concepto de ocio que nos permita diferenciarlo del turismo, teniendo en cuenta que el ocio, como toda actividad humana y social, se redefine continuamente según épocas y culturas. Por tanto deberá ser un concepto ajustado a la realidad de la sociedad europea del último tercio del siglo $\mathrm{XX}$, en la que el ocio es un fenómeno central, que no depende de la iniciativa individual, sino que es una actividad de competencia y de responsabilidad colectiva al convertirse en un derecho civil y un hecho político (Giner, S. y Lamo de Espinosa, E., 1998, pp. 687)

El ocio - loisir, leisure, freizeit, de los franceses, ingleses y alemanes, respectivamente -, en palabras de Callizo, J. (1991, pp. 17) "es una medida de tiempo que se usa 
habitualmente para significar el tiempo sobrante después del trabajo, el sueño y los quehaceres personales y domésticos". El tiempo libre, por antonomasia, debe ser el tiempo de la libre elección o tiempo liberado. Éste sólo existe como antítesis del tiempo de trabajo, o sea, es el tiempo no sujeto a necesidades, de una parte, ni a obligaciones de otra ${ }^{26}$.

Pero el ocio no es sinónimo de tiempo libre. El tiempo es únicamente una condición necesaria, pero no suficiente. El sentido de ambos términos no es equivalente. Se crea una situación de ocio, cuando la persona, durante su tiempo libre, decide y gestiona libremente sus actividades, obtiene placer y satisface necesidades personales, tales como descansar, divertirse o desarrollarse. Engloba amplias y diversas actividades. Así, el turismo es un elemento más del ocio, que no puede estar separado de la concepción social del ocio y su función social y económica.

Desde la perspectiva económica, en cuanto a la demanda turística, tomando a Martínez Quintana, V. (2002, pp. 100), entendemos que "en ella entran en juego la totalidad de consumidores de los bienes y servicios que ofrece el turismo", aunque no vamos aquí a diferenciar los tipos de consumidores que pueden entrar en la demanda turística, siendo conscientes que el tipo de demanda puede condicionar y condiciona la oferta turística. Trataremos aquí la demanda como volumen de visitantes que van a ejercer influencia y presión sobre la oferta y la sociedad de acogida.

En cuanto a oferta turística, ésta se define como el "conjunto de procesos turísticos y servicios puestos a disposición del usuario turístico en un destino determinado, para su disfrute y consumo" (Martínez, V. 2002, pp. 100). Es, por tanto, un todo formado por los servicios, los productos, la imagen, el hábitat, etc., que constituyen los bienes y servicios turísticos consumidos por los turistas". La oferta está configurada, en parte, por la práctica urbanística. Así aparece el urbanismo del ocio como la práctica planificadora y de intervención-gestión que configura una determinada oferta, en este caso turística.

$\mathrm{Y}$, finalmente, el sector turístico es el conjunto de unidades productivas que elaboran planes o programas de viajes de ida y vuelta para otros con o sin concurso de mecanismos de mercado. El análisis de este sector equivale al análisis del mercado turístico.

26 "(...) El tiempo liberado, pequeña parcela del tiempo libre en la que finalmente el sujeto se encuentra "liberado" de cualquier tipo de actividad en la que teóricamente está en disposición de optar libremente por hacer aquello que desee; es decir, ni obligado, ni necesitado, no, supongamos, en principio, condicionado. El sujeto está en situación de "ocioso", es decir, dispuesto a realizar actividades de ocio o, sencillamente, al dolce far niente". Francesc Pedró, 1984 (pp.17). 


\subsection{1.- LA MASIFICACIÓN DEL TURISMO.}

Después de los años 50 del siglo $\mathrm{XX}$, el turismo deja de ser privativo de las clases burguesas y de la aristocracia, se extiende a las clases obrera y media. Pasa a tomar otra naturaleza, es algo distinto, es crecimiento y cambio, se convierte en el símbolo del desarrollismo. Surge una nueva cultura del ocio en el mundo occidental impulsada por la recuperación de la economía tras la II Guerra Mundial, acompañada de estabilidad social y política, necesaria para su recuperación. Será el periodo comprendido "entre 1950-1975 donde se concentra el mayor boom turístico, ya que en estos años el turismo internacional experimenta un rápido crecimiento" (Martínez Quintana, V., 2002, pp. 79). Estamos ante la etapa del turismo industrializado.

Las causas de su aparición son múltiples y complejas y para explicarlo debemos evitar caer en el monocausalismo, aunque la mayoría de los motivos se centran en aspectos técnicos y socioeconómicos. Mazón, T. (2001, pp. 99-104) tipifica estos aspectos en trece puntos, que pueden servirnos de guía en cuanto a la exposición de motivos que conducen al asentamiento de la industria del turismo para las masas y por tanto a la popularización de la actividad. Estos aspectos han sido agrupados y ampliados aquí en cinco grandes factores, que se exponen a continuación:

- Factores de tipo político y relaciones internacionales. El nuevo orden internacional que surge una vez acaba la II Guerra Mundial fue imprescindible para poder generar la estabilidad política, económica y social que necesitan los desplazamientos de este tipo. Solo bajo estos estados, de no conflicto interno e internacional, tanto en los países emisores como receptores, se puede motivar y garantizar un flujo constante de viajes por turismo, regulando, por primera vez, el transporte aéreo internacional. Todo ello apoyado e impulsado por la aparición de Organismos Internacionales, que intervinieron en la regulación de la aviación civil (O.A.C.I.) ${ }^{27}$, en la facilitación de viajes y en la promoción de actividades turísticas (U.I.O.O.T., actualmente O.M.T.) ${ }^{28}$, entre otros.

- Por otro lado, la simplificación de los trámites aduaneros impulsará el movimiento de personas por turismo. La Conferencia de Roma de la ONU, 1963, recoge a modo de normas o pautas, una serie de principios generales para la promoción y el desarrollo del turismo interior e internacional, recomendando, en su Informe Final, la simplificación de las formalidades oficiales para los viajes internacionales (II), relativas a pasaportes, visados y otros trámites administrativos y controles. Su incorporación por los diferentes

${ }^{27}$ Organización Internacional de Aviación Civil.

28 Unión Internacional de Organismos Oficiales de Turismo. Actualmente Organización Mundial de Turismo. 
países facilitará el tránsito de viajeros y su estancia temporal. A la vez, recoge el concepto de visitante temporal (turista).

- Factores de tipo económico. La política económica integracionista llevada a cabo por la Europa occidental a partir de 1945, se traduce en recuperación económica en los años cincuenta y en la prosperidad en los sesenta. Prosperidad, estabilidad económica e incremento del nivel de vida serán necesarios para el impulso de esta industria.

El incremento de los niveles de las rentas familiares y con ello la capacidad de consumo, hizo posible elevar el poder adquisitivo ${ }^{29}$ y la calidad de vida, "posibilitando el que una gran parte de la población de clase media y obrera pueda pasar sus vacaciones fuera de su país de origen, así como la proliferación de un número indeterminado de destinos turísticos que se concentran, en sus primeros estadios, en las costas del mar Mediterráneo" (Mazón, T. 2001, pp. 99). Y es que la nueva economía permite liberar recursos para dedicarlos a hacer turismo, puesto que los cambios en el sistema productivo y en la organización del trabajo propiciaron la reducción del tiempo de trabajo quedando "tiempo libre", elemento del que no disponían los trabajadores antes de estas modificaciones.

\section{- Factores socioculturales.}

1. Cambios en la estratificación social. La extensión de la clase media. El gran cambio que aparece en las sociedades industriales de la Europa desarrollada de mitad del siglo XX es la expansión del estrato medio de la sociedad, que aunque existía anteriormente es ahora cuando empezará a crecer ocupando la mayor parte de la pirámide de estratificación social, fruto de las nuevas necesidades que aparecen con la extensión del aparato burocrático del Estado de Bienestar y de la reducción de las desigualdades en el acceso a bienes y servicios de una parte significativa de la población. La dinámica que se abre es de nivelación ${ }^{30}$ en cuanto a la disposición y acceso a determinados bienes de consumo básicos, lo que permite llegar a otros

29 "El turismo depende estructuralmente de la capacidad de ingresos y gastos de las familias; el dibujo de un mundo globalizado y, en cierto modo, excluyente discrimina la posibilidad de hacer turismo relativamente entre menos gente en el mundo, aunque éstos tengan mayor capacidad de repetir y fragmentar el tiempo de ocio y turismo". Vera Rebollo, J.F. 1995 (pp. 17).

30 En las comunidades civilizadas modernas, las líneas de demarcación entre las clases sociales se han hecho vagas e inexistentes, y dondequiera que esto ocurre la norma que gradúa la reputación, impuesta por la clase superior, extiende su influencia coactiva a lo largo de la estructura social hasta los estratos más bajos, sin tener que salvar para ello sino obstáculos muy ligeros. El resultado es que los miembros de cada estrato aceptan como ideal de decoro el esquema general de la vida que está en boga en el estrato superior más próximo y dedican sus energías a vivir con arreglo a ese ideal". Veblen, Th. (1974). "Teoría de la clase ociosa". Fondo de cultura económica, México, (pp. 90-91) 
productos de consumo, entre ellos el turismo. Será este estrado de población el que ocupará en masa la demanda turística.

2. Diferentes autores ponen en el acento en el malestar de la vida urbana. En palabras de Mazón, T. (2001, pp. 100), el ritmo de crecimiento económico, la intensidad de los cambios en el sistema productivo y en la estructura social, produce una profunda alteración en las ciudades grandes y medias europeas, que no dejan de crecer. Semejante desarrollo urbano, hace que las ciudades dejen de ser lugares atractivos para los ciudadanos que perciben el deterioro de la calidad de vida. La gran ciudad provoca y obliga a una vida deshumanizada, con lo que la integración en ese modo de vivir muchas veces no se produce y sobreviene la necesidad de evadirse, de encontrar aire libre, ser turista es, por tanto, salirse de la realidad social ordinaria, apartarse de las obligaciones sociales cotidianas de adulto (Crompton, J. 1979, pp. 417), en lugar de deberes y horarios estructurados se tiene libertad y diversión despreocupada. "La aglomeración en los países avanzados engendra deseos de dispersión que se plasman en los viajes turísticos" (Perdomo, M. A., 1987, pp. 434). Esta necesidad no aparece en el hombre del campo, en el hombre rural, el que la naturaleza ejerce una acción reguladora sobre su organismo, con lo que no sentirá de la misma forma la necesidad del viaje (Fernández, L. 1991), al menos de manera perentoria, es por eso que se llega a afirmar que el turismo es un fenómeno urbano. La necesidad de escapar de la aglomeración urbana, por tanto, favorece el turismo.

3. Sociedad y cultura de consumo. A partir del los años cincuenta del s. XX comienza a instalarse en Europa el Estado de Bienestar, se impone la Teoría Keynesiana en el modelo de Estado y en el enfoque económico. El enfoque keynesiano, entre otras cosas, se "basa en la propensión a consumir, demostrando que es posible garantizar un nivel de empleo elevado a condición de que el volumen total de los gastos de la inversión pública y privada, así como de consumo privado y público sea lo suficientemente grande como para adquirir todos los bienes que la sociedad puede producir, teniendo ocupados todos los puestos de trabajo existentes. Este concepto implica mover la maquinaria industrial a base de ofrecer bienes de consumo a sectores muy amplios, incitar su consumo al hacerlos pasar por bienes necesarios y proporcionar los medios económicos y crediticios para lograrlos, es decir, una filosofía del consumo" (Mazón, T., 2001, pp. 101), cuyas bases se van poniendo en la primera mitad del s. XX en Estados Unidos y en la Europa Occidental, siendo en la segunda mitad del s. XX cuando se consolida como un nuevo sistema social. Unido a ello, este modelo de Estado modifica el sistema de prestaciones sociales, generando sentimientos de seguridad entre los ciudadanos, necesario para impulsar el 
consumo ${ }^{31}$.

Lo que queremos significar en estas líneas es que el consumo se constituye por esta época en un fenómeno cultural inserto en un nuevo sistema social relacionado con el modo de producción ${ }^{32}$. "El nacimiento de la sociedad de consumo de masas sólo puede entenderse previa revolución del sistema productivo, que permite la producción y distribución en masa" (Rubio, A. 2003, pp. 29). El turismo de masas, por tanto, nace de los nuevos grupos de consumidores que surgen en el periodo de la producción en masa, del fordismo y del consumo de masas.

Veblen, T. será pionero en el análisis del comportamiento de las clases sociales en relación al consumo y al estilo de vida, en su obra, ya clásica, "Teoría de la clase ociosa. 1899"33, en palabras de Rubio, A. (2003, pp. 28), "Veblen pone de relieve no sólo la importancia económica del acto de consumir, sino también, y sobre todo, la importancia social del consumo por lo que supone de símbolo de prestigio y estatus social, y de diferenciación social. El turismo, como manifestación de nuestros hábitos de consumo, es uno de los mayores exponentes de la importancia social, que comentamos, del consumo", puesto que el consumir se muestra ahora como un deber social y como un comportamiento determinante de la posición social de cada individuo, conduciendo a la diferenciación e individualización. En este nuevo entorno sociocultural, donde los deseos se convierten en necesidades, el turismo se transforma en un deseo y necesidad en la amplia clase intermedia o media, no sólo por posibilidad económica (tratada anteriormente), sino también por la exigencia de una imagen social, por el deseo de parecerse a las gentes conocidas (mimetismo), a las antiguas clases ociosas y mostrar al mundo que se es como ellos (Knebel, 1973, pp. 151). El objeto de consumo se hace apto para el consumo cuando se ha convertido en signo, cuando tiene significación social (Baudrillard, 1970). El turismo se fue transformando en un producto de consumo básico, convirtiéndose en símbolo de socialización, en fuente de prestigio social, en un valor, a lo que en buena parte contribuyó, entre otros factores, el marketing llevado a cabo por diferentes organismos impulsores y organizadores de esta actividad. Se perfila, así, la llamada

31 "Los ciudadanos pueden beneficiarse de la bonanza económica, de la mejora del nivel de vida y de todo tipo de prestaciones sociales, lo que ayuda a cambiar la actitud de las gentes con respecto al futuro. Se sienten respaldados por los Estados en sus necesidades del mañana" (Mazón, T., 2001, pp. 101).

32 El turismo, desde el punto de vista de la demanda, se explicaría "a partir del cambio básicamente cualitativo que logra el consumidor como agente del proceso productivo con objeto de satisfacer sus funciones de descanso y recreación" Hernández Díaz, E. A. (1991, pp. 11).

33 Veblen, T. (1899). "Teoría de la clase ociosa". $1^{0}$ Edición en castellano en 1944. Fondo de Cultura Económica, México. 1944. 
"Civilización de los loisirs"34, donde hacer turismo recibe una sanción social y cultural positiva.

4. Nueva mentalidad. La política social del Estado de Bienestar, con la universalización de la seguridad social y mejoras en las condiciones laborales, entre otros factores, permite cierta despreocupación por el ahorro preventivo. Además la nueva economía que se instala, dirigida hacia una sociedad de consumo, debe impulsar el gasto. "El llamado ahorro a largo plazo pierde vitalidad y sentido por la idea postmodernista de vivir el presente y por la no rentabilidad del dinero en cuentas corrientes que son las que permiten liquidez. En definitiva, se produce una disonancia entre la carga ideológica y moral heredada que representaba el ahorro y la tendencia social de permanente obligación de estar gastando" (Mazón, T. 2001, pp. 103). Naturalmente, para que este nuevo modelo de sociedad funcionase era necesario el cambio de mentalidad, destacando ahora "la pérdida de la mística cuasi-religiosa del trabajo, valorándose cada vez más el ocio como elemento esencial de la cultura occidental y como hecho social generalizado" (Perdomo, M. A., 1987, pp. 434).

5. Emancipación de la mujer. Empezó a lograrse en la década de los años sesenta del siglo XX, mediante la conquista del trabajo fuera del hogar. Esta conquista daría fondos económicos, seguridad social y tiempo libre a las mujeres, de los que había carecido hasta entonces. Pero también el que, en muchos hogares, de dispusiera de un sueldo más, incrementándose la renta familiar, lo que permitía aumentar el consumo e incorporarse a viajes turísticos. Esta emancipación estuvo apoyada por otros factores como fue el control de la natalidad y la reducción del número de hijos.

6. Tendencias hacia actitudes y modas. Para Baudrillard, lo que caracteriza a la sociedad de consumo moderna es la generación de deseos individuales a través de una industria cultural que gestiona el valor simbólico de lo consumido. El turismo, como objeto de consumo, está afectado y manejado por esa industria cultural, y por tanto por la moda, que es lanzada por los medios de comunicación de masas y que afecta psíquica e intelectualmente a los individuos, les proporciona refuerzos psíquicos positivos frente a su imagen social. En términos marxistas se convierte en alienante, además de subyugar las experiencias turísticas a un estándar. La moda es el motor de la producción y el consumo de masas, se crea para las capas sociales, no la crean las capas sociales. Para Knebel la "técnica de organización es el elemento

34 En la que el turismo "es comparable con funciones básicas tales como la alimentación, la salud, la vivienda y el transporte" y así como "el hombre busca mejorar la calidad y cantidad de su alimentación, transporte y vivienda, así también mantiene constante su esfuerzo por progresar en las condiciones y satisfacciones propias de las funciones de reposo y, sobre todo, la del esparcimiento" (Hernández Días, E. A. 1991, pp. 11). 
estructural del aparato turístico", su función es ser una técnica de adaptación, es decir, debe conducir al turista «pasado de moda» hacia la moda prescrita y "modernizar mediante atracciones de actualidad aquellos lugares típicos de la clásica industria de alojamientos". "La técnica coacciona la mecánica organizadora y coordinadora, suponiendo la desintegración del aparato institucional de la industria turística" sujeto a la moda turística que es una cuestión nacional en palabras de Knebel (1973, pp. 156-158), o sea que el turismo al extranjero está estructurado a partir de preferencias y prejuicios nacionales. Aspecto este que se ha ido modificando en la medida en que el desarrollo de las tecnologías de la información y la comunicación han impulsado no sólo la globalización de la economía sino también la de modelos culturales. Por tanto, la moda, afecta a la movilización psíquico-intelectual de la persona, y se crea para la masa, convirtiéndose en el motor de la producción y el consumo. La elección de los lugares de turismo viene condicionada por la presión social de los medios de comunicación de masas, que crean lugares nuevos donde es preciso ir para estar a la moda. Así, "la presión social de la moda como parte de la opinión pública se intensifica” (Knebel, 1973, pp. 156), aunque a través de su continuo cambio, abre el abanico de posibilidades de elección y disminuye su poder coercitivo. Consideramos que puede convertirse en una dictadura que desvía los flujos turísticos hacia unos destinos $u$ otros y que en muchos momentos se comporta de forma ajena a los países receptores que verán afectada su demanda turística por la misma y con ello su economía y sus posibilidades de bienestar social.

\section{- Factores dotacionales.}

1. Infraestructuras de transporte y comunicaciones. Después de la Segunda Guerra Mundial, la aviación comercial incorpora el jet, que alcanza grandes velocidades supone reducción de las distancias y del tiempo de desplazamiento -, permite el transporte masivo de pasajeros, con reducción del coste del viaje, principalmente "con la aparición de los vuelos charter que permite un abaratamiento de los precios gracias a sus coeficientes de carga" (Vogeler y Hernández, 1997, recogido por Mazón T. 2001, pp. 100). Se perfeccionan también, aumentado su confort, el transporte terrestre y marítimo (autobuses para viajes colectivos en líneas regulares, con itinerarios fijos y tarifas económicas). "A partir de los años cincuenta también se produce la expansión del automóvil", se produce en serie, se hacen modelos más asequibles, se pueden adquirir a crédito, etc., los que hace que se amplíen los sectores de la población que pueden acceder a ellos y que pueden utilizarlos para sus desplazamientos turísticos. 
Sin el desarrollo de la tecnología en el ámbito de las comunicaciones ${ }^{35}$, nunca se hubiese desarrollado el turismo de masas, puesto que para ello es necesario tener capacidad para transportar a miles de personas a la vez, a gran velocidad, con reducción del tiempo y de los costes del viaje. Por otro lado, los Estados, tanto emisores como receptores de turismo pondrán en marcha inversiones públicas en infraestructuras básicas - puertos marítimos, aeropuertos, autovías, autopistas, suministro energético y de agua potable, etc.- hacia centros de desarrollo turísticos y en los centros de este desarrollo, para favorecer los servicios a los viajeros e incrementar el número de visitas.

2. Oferta de alojamiento turístico. Aunque la oferta turística no podemos reducirla únicamente a factores de alojamiento, ni que decir tiene que para el despegue y consolidación de la industria turística la inversión, tanto pública como privada, en la construcción, modernización y diversificación de establecimientos de alojamiento turístico, "con diferentes niveles de precio" y condiciones, facilitan y estimulan los viajes turísticos a lugares distintos al de residencia.

- Factores organizativos. Ante la necesidad de organizar la industria turística para la masa se constituyen los denominados tour operadores y agencias de viaje, apareciendo como "grupos intermedios", o sea, agentes sociales que intervienen en el proceso de expansión del turismo, puesto que van a "introducir nuevas técnicas comerciales y de marketing turístico". Los tour operadores van a "canalizar la ascendente demanda de viajes por turismo" y a "estandarizar el producto" (Mazón T., 2001, pp. 101). A partir de su aparición e intervención, desaparece el pasado del turismo, marcado por su elitismo, y aparece el turismo industrializado o masificado. Apoyándose en el desarrollo del transporte y el abaratamiento de costes en los traslados, van a captar a la clase media y obrera de la Europa desarrollada, ofreciendo ofertas de vacaciones en las playas del sur de Europa. Tour operadores y agencias de viaje "se convierten en la parte más dinámica de la organización turística, con amplias o variadas ofertas, pagaderas al contado o a crédito, con sistemas de reserva para transporte, hoteles, espectáculos, etc.”, (...), "promueven y dan difusión a los distintos destinos turísticos que trabajan con ellos".

Una vez el turismo ha consolidado su naturaleza de movimiento de masas, de negocio de masa, su rasgo más representativo es su ritmo acelerado de crecimiento, prácticamente hasta finales de la década del ochenta. Entre las regiones donde se

\footnotetext{
35“El turismo surge cuando las personas se sirven de los medios disponibles de transporte para sus actividades de tiempo libre". Smith, 1992, pp. 74.
} 
localiza, nos interesa aquí Europa, en la que el movimiento turístico caminará de norte a sur $^{36}$, convirtiéndose España en uno de los principales países receptores.

Hasta ahora hemos esbozado los aspectos que llevan a la aparición del turismo de masas y a su consolidación. Este periodo se cierra en la década de los años setenta con una crisis energética y su consecuente repercusión en las economías de los países emisores y receptores turísticos. Consecuentemente, las saturaciones producidas durante este periodo se enfrenten ahora a una etapa diferente, debiendo establecerse pautas nuevas. Se abre una etapa marcada por una perspectiva que enfoca las diferentes cuestiones hacia su dimensión internacional, por lo que la década de los años ochenta "supone, en general, una fase de transición del turismo de masas al turismo de nueva era (...)" (Martínez Quintana, V., 2002, pp. 84). Se constituye una nueva fase que algunos han denominado turismo post-industrial, caracterizada por una fuerte recesión, que obliga a cuestionarse el modelo tradicional de turismo de sol y playa. Aparecen nuevas necesidades, el turismo "se hace más exigente y con preocupaciones que aglutinan distintos aspectos: culturales, medioambientales, de calidad de los productos y del servicio ofrecido, etc., y que buscan, asimismo, mayores y mejores ofertas complementarias" Se abre una nueva demanda, "marcada por nuevas modas y preferencias" (...) "se incrementa el interés por la especialización en una actividad, viajar por un motivo, como puede ser la cultura, el deporte, la salud, el aprendizaje o en busca de satisfacer aficiones" (Mazón, T. 2001, pp. 111). La década del noventa deberá incorporar nuevas formas de turismo, entrando al s. XXI con corrientes y actividades innovadoras.

\subsection{2.- EL TURISMO EN ESPAÑA}

Aunque en la década del cincuenta España ya recibía turistas, esta es una década en la que se está rompiendo con el cerco al que el país quedó sometido tras la guerra mundial, pues a partir de su ingreso en la ONU, en 1955, se adhiere a la Organización Europea de Cooperación Económica (O.E.C.E) y al Fondo Monetario Internacional (FMI). Avanza ahora hacia la apertura al exterior. Se abre un periodo de liberalización de la economía junto con medidas de estabilización. Se inicia así, en la década de los sesenta, lo que se ha denominado la Etapa desarrollista, hasta 1975, último periodo de la dictadura franquista. La entrada de inversiones extranjeras y la liberalización de los movimientos de pasajeros por fronteras coinciden con el auge de la demanda turística que había crecido enormemente en la Europa industrializada del norte. Si hasta ahora, esa demanda estaba polarizada hacia

36 "Ningún otro fenómeno social aventajará al turismo en su espectacular tasa de crecimiento anual, llegando a superar algunos años el 16\%" (Jurdao, F. 1990, pp. 125). 
Italia y Francia, a partir de los sesenta, España se convierte en un polo de atracción de la demanda masiva. "En esta época surgen agencias de viaje y mayoristas para canalizar la amplia demanda de servicios requeridos por los turistas" (Martínez Quintana, V. 2003, pp. 352).

La década de los setenta seguirá explotando el turismo de sol y playa, y al final de la misma ya se considera a España un destino consolidado, aunque afectado por problemas estructurales de deterioro ambiental y límites de demanda planificada, unido a la escasa rentabilidad, deterioro del entorno, necesidad de inversiones en carreteras, depuración de aguas, etc., y, por otro lado, unido a la excesiva concentración (Díaz, J.A., 2003, pp. 352). Mario Gaviria (1974, pp. 296-297), al referirse al turismo residencial establece varias etapas en las que se ha desarrollado el proceso de inversión en suelo español por parte de extranjeros señalando la mitad de esta década como la etapa en la que "los alemanes se convierten en promotores de terrenos, cambian de suelo rústico a urbano, y promotores de apartamentos y chalets, no queda a los españoles sino la función de albañiles".

Los años ochenta se plantean como la década del turismo social, que impulsa una modalidad para jubilados como forma de mejorar la vida de las personas mayores y a su vez mantener el empleo en el sector turístico, que en el Mediterráneo español posee una fuerte estacionalidad a diferencia de Canarias que recibe turismo prácticamente todo el año. En esta década, además, se observa el incremento que ha venido teniendo el consumo turístico entre los españoles, aumentando las segundas residencias en las zonas turísticas. Bayón, F. y Hernández, C. $\left(1999\right.$, pp. 145) ${ }^{37}$ señala que este programa no solo creó empleo, sino que contribuyó a desestacionalizar el sector turismo, sin coste adicional para la Administración. Muy rentable desde el punto de vista social y económico.

La década de los años noventa marca la madurez del sector. España entra en ella con una "caída del 3,7\% en la entrada de visitantes (1990), que sin embargo no perjudicó a los ingresos, que aumentaron", pero la mala coyuntura internacional de la época, (propiciada por la Guerra del Golfo), hace que se desplomen los ingresos por turismo en 1993. El sector inicia una tímida recuperación a finales de 1995 y no será hasta 1997, cuando comience el auge sostenido del mercado emisor español, que se prolongará hasta 1999 (De Quesada, E. 1999, pp. 154-155) $)^{38}$.

${ }^{37}$ En Bayón Mariné, F. (1999), Capítulo 6. "Desarrollo y transformación" de "50 años de turismo español. Un análisis histórico y estructural" Editorial Centro de Estudios Ramón Areces, Madrid, 1999.

38 De Quesada, E (1999), en Bayón Mariné, F. (1999), Capítulo 7. "Los 90. Hacia un nuevo milenio"; de "50 años de turismo español. Un análisis histórico y estructural” Editorial Centro de Estudios Ramón Areces, Madrid, 1999. 
Es a finales de ésta cuando empieza a escucharse un nuevo concepto: sostenibilidad. Se entiende ahora que el crecimiento continuado en los destinos turísticos no existe. El acontecimiento decisivo lo marcarán las Islas Baleares, en 1998, cuya administración decide impulsar una moratoria que tiene como principal objetivo fijar un tope de crecimiento a la infraestructura de alojamiento e impedir el aumento excesivo de la oferta hotelera. Política a la que, posteriormente, también se acogerá las Islas Canarias y en especial Lanzarote. "En consecuencia, el concepto de sostenibilidad para un destino maduro de sol y playa pasaría por la mejora en la calidad de la oferta existente, al tiempo de frenar su crecimiento" (De Quesada, E. 1999, pp. 158) ${ }^{39}$. Se cuestiona ahora, por tanto, el modelo tradicional de desarrollo turístico, basado en la masificación y competencia en precios. Sostenibilidad, calidad y excelencia serán los objetivos, en cuanto necesidad y garantía de futuro "pues se trata de un estrategia necesaria, que persigue insertar el turismo en un marco de compatibilidad con el medio ambiente, con la sociedad, con el patrimonio cultural y con la economía" (Troitiño, M.A. 1998, p. 212)

Así, para lograr que el sistema turístico español sea el más competitivo y sostenible, debemos aquí señalar, el Plan elaborado por el Ministerio de Industria, Turismo y Comercio y aprobado en el año 2007, denominado "Plan Turismo Español Horizonte 2020", con el fin de responder a los retos que plantea esta actividad en el nuevo siglo y ante la crisis de demanda a la que España se enfrenta a principios de siglo, y que señala seis debilidades del modelo español (2007, pp. 21-22):

- Elevada concentración y estacionalidad de la actividad, que implica la saturación de los destinos en temporada alta y que afecta a los niveles de satisfacción de la demanda.

- Desconocimiento sobre el patrimonio cultural español en el extranjero.

- Falta de identidad en las propuestas turísticas de los destinos tradicionales.

- Inadecuación de los sistemas de planificación territorial de los destinos turísticos.

- Excesiva concentración geográfica de la oferta de alojamiento turístico y residencial.

- Deterioro medioambiental de un elevado número de destinos, como consecuencia de un excesivo y desordenado urbanismo.

En próximos epígrafes se ampliará la orientación política, el marco legislativo e institucional que cruzará la segunda mitad del siglo XX y principios del siglo XXI en España.

39 Idem, pp. 158. 


\subsection{3.- TIPOS DE TURISMO}

Son muchos los tipos de turismo señalados a lo largo de toda la producción científica sobre el tema. A este respecto se considera que no existe una definición y tipificación del turismo correcta o incorrecta, ya que todas las conceptualizaciones aportan desde sus perspectivas unas interpretaciones que sirven para dilucidar los principales elementos. Recogeremos aquí aquellas aportaciones que puedan servir adecuadamente a nuestros propósitos, «tipos» que podamos integrar en las diferentes etapas por las que pasa el objeto de estudio de este trabajo.

La situación que hace referencia al tipo de turismo que aquí nos interesa es la que describe Kadt, E. (1991, pp. 35) citando a Noronha, R. (1979), "el centro turístico que consiste mayoritariamente en turistas que buscan sol y arena, residen en hoteles relativamente grandes $y$, con frecuencia, (pero no siempre), viajan en grupo organizado que incluye transporte, habitación y pensión completa dentro de un paquete. Este tipo de turismo ha sido especialmente importante en países en vías de desarrollo que, en los últimos años, se han asegurado un crecimiento rápido y a gran escala del número de turistas procedentes de Europa y Norteamérica. Algunos de los motivos de esta situación estaba total o en gran medida fuera del control del país de destino (...)".

De la Torre, O. $(1980)^{40}$ establece una tipología sobre el tema, influida de la progresión del fenómeno en el tiempo, hablando entonces de: 1) "turismo incipiente" o elitista y restringido a las capas sociales con mayores recursos; 2) "turismo de transición", que coincide con la etapa de popularización precursora del turismo generalizado y que corresponde a la primera mitad del siglo XX; 3) "turismo en desarrollo" o masivo, categoría que comienza a adquirir cuerpo a finales de la década de los cincuenta del s. XX (hay que buscar su origen en las condiciones de productividad superior, propias de las sociedades industriales) y en la cual los mayoristas van haciéndose cargo del mercado de un modo creciente. Nos interesa aquí el último tipo, que se caracteriza por percibirse como un objeto de consumo básico, que se configura después de una etapa de transición, generado por la sociedad industrial e indicador de bienestar social y de calidad de vida, cuyos flujos se conforman desde los puntos emisores (países postindustriales desarrollados del norte) a los puntos receptores (países en vías de desarrollo del sur de Europa ${ }^{41}$.

${ }^{40}$ Citado por E. Mira (1992, pp. 33).

${ }^{41}$ Smith, V. (1992, pp. 72) nos señala que "el turismo no es enteramente exclusivo de la sociedad industrial o moderna", pero a su vez deja claro que "sólo en una sociedad de este tipo acaba convirtiéndose en un fenómeno social omnipresente". 
Las características señaladas y etapas de evolución, tanto en Kadt como en De la Torre reflejan el modelo y tipo que desarrolla y presenta Lanzarote, siendo esta isla fiel reflejo de los objetivos que, en palabras de Crick, M. (1989, pp. 343), son los que se han definido, en cuanto representaciones colectivas del turismo internacional y de masas, como las "Cuatro $S^{\prime \prime}$ : sun (sol), sex (sexo), sea (mar) y sand (arena). Estos cuatro elementos serán los criterios de selección del destino elegido por el turismo de masas y que marcarán el desarrollo de los mismos en España, y por supuesto en el Archipiélago Canario, durante toda la segunda mitad del s. XX, determinando su tipo de oferta turística.

En esta línea aparecerán las aportaciones tipológicas de Smith, V. (1992, pp.32-37) ${ }^{42}$, de fuerte influencia principalmente en la antropología del turismo de finales del s. XX por su sencillez de planteamiento, denominando al turismo de sol y playa como "recreativo", y que recoge muchos de los aspectos ya citados, por lo que no abundaremos en sus ideas.

Al final de la década de los años ochenta, principios de los noventa, con la incorporación de la idea de sostenibilidad a las políticas de desarrollo y crecimiento económico, que marcará toda la década del noventa, la Conferencia de Naciones Unidas sobre Medio Ambiente y Desarrollo de 1992, aplica este concepto a la actividad turística y se sientan las bases de un nuevo tipo de turismo, el turismo sostenible, asociado al turismo posfordista y a los turismos alternativos, de los que hablaremos más adelante. La definición aportada por la ONU es acuñada en términos de desarrollo sostenible, por lo que más que un tipo de turismo, entendemos que lo que refleja es el principio "sostenibilidad": "El desarrollo turístico sostenible satisface las necesidades de los turistas en el presente, y de las zonas que los acogen, al tiempo que protege e incrementa las oportunidades para el futuro. Se define como un proyecto que gestionará todos los recursos, de modo que respete las necesidades económicas, sociales y estéticas, y a un tiempo conserve la integridad cultural, el proceso ecológico esencial, la biodiversidad y los sistemas que permiten la vida".

Por último, desde la mirada de la geografía, Vera Rebollo (1997, pp. 54), nos presenta binomios que reflejan realidades turísticas que constituyen categorías a partir de condiciones del hecho turístico: turismo de masas-turismo minoritario; turismo nacionalinternacional; turismo itinerante-residencial; turismo de litoral-de montaña; turismo rural-

42 Smith, V. (1992, pp. 36), El turismo masivo constituye una afluencia continua, como la que inunda Hawai durante la mayor parte del año y también en determinadas estaciones del año como ocurre en los centros vacacionales de Europa, México y el Caribe. Son turistas que llegan en vuelos chárter y por tanto llegan en masa. Este turismo de masas depende de los ingresos y de los valores de la clase media, tiene un elevado impacto debido a la enormidad de los números que bajara. Tienen gustos y presupuestos diversos y se mueven bajo la filosofía de que cada uno recibe en función de lo que paga, llegan a hoteles y apartahoteles de todas las categorías, incluidas pensiones y hostales. Esperan para ser transportados a los hoteles previstos y tienen su correspondiente chapa de identificación y una vez en el hotel apalabran excursiones, itinerarios y otros servicios, pero siempre sin salirse del grupo. Exigen que se les atienda con solicitud todos sus deseos y necesidades. El hotelero, para ahorrarse quejas, estandariza el servicio al gusto europeo. 
urbano; turismo colectivo-individual; turismo organizado-independiente; turismo pasivoactivo; y turismo masivo o fordista frente a turismo sostenible o posfordista. Por el carácter estructural que señala para algunos de estos turismos, abunda en tres de los que propone, partiendo de entender que "los tipos de turismo son determinantes en la configuración de los espacios turísticos, en razón a las prácticas turísticas que generan en cada caso". Apuntamos aquí algunas sus reflexiones (1997, pp. 55):

a.- Turismo masivo-turismo alternativo. El turismo masivo se asocia al turismo pasivo desde punto de vista de actitud, motivación y participación. Turismo alternativo, se asocia, por tanto a lo contrario, englobando la forma de turismo no asimilables al de masa (masividad en las actividades), comprendiendo al turismo cultural, rural o verde, urbano, deportivo, de aventura, fluvial, el de cruceros, de balneario, y de negocios. Por su carácter activo, se le asocia al turismo posfordista y al sostenible.

b.- Turismo nacional-turismo internacional. El nacional referido al interno, desarrollado en el propio país de origen, fuera de su residencia habitual. El turismo internacional es el configurado, en contraposición, por el flujo de turistas desde su país de residencia habitual hacia otro destino.

c.- Turismo itinerante-turismo residencial. El primero de ellos se refiere a corrientes de turistas que visitan recursos turísticos en rutas diseñadas por empresas o individualmente, y consumen productos turísticos en dichas rutas, más o menos configuradas objetivamente por la demanda. El residencial, va a conceptualizar la estancia en un lugar determinado por motivos turísticos y de recreación, caracterizado, muchas veces, por una frecuentación discontinua en diversos períodos del año. Ambos, "tienen unas implantaciones espaciales y unos impactos económicos diferenciados, hasta el punto que el predominio de uno u otro determina una cierta especialización turística en cada zona. De hecho, el fenómeno de la residencia secundaria y de la urbanización turística se engloba dentro del denominado turismo residencial". Representan dos formas o modelos distintos en cuanto al sistema de organización del espacio turístico, su dinámica y transcendencia socioeconómica. El primero "se relaciona con el alojamiento en hoteles, hostales, campamentos de turismo", y apartahoteles, siendo más fácil medir su afluencia a través de las estadísticas sobre pernoctaciones. "Se organiza en torno a un gran núcleo turístico "ociourbe», con fuerte aparato comercial, relacionado con estancias cortas y gran concentración de servicios adicionales, y segmentos de demanda cuyo poder adquisitivo condiciona la variedad y calidad de dichos servicios". El turismo residencial, "en su vertiente espacial, se asocia con la venta del suelo, la construcción y la promoción inmobiliaria y, en menor medida, con el aparato de prestación de servicios" (Vera Rebollo, 1997, pp. 56). 
En relación a esta tipología, Lanzarote presenta un turismo masivo, principalmente internacional en sus primeros desarrollos, acogiendo posteriormente y con fuerza también el nacional, e itinerante en cuanto a la especialización de la oferta turística insular. A ello se une el turismo a tiempo compartido o time sharing o turismo de multipropiedad, modalidad que se desarrolla en la década de los años noventa, que también acogerá la isla, y que puede incluirse dentro del turismo itinerante, puesto que la especialización de la oferta no va a variar para poder incorporarlo.

Debemos tener en cuenta que el objetivo de este trabajo no es analizar la sostenibilidad de turismo, por lo que sólo ha sido contemplado como "tipo", al igual que tampoco está orientada a determinar qué tipo de turismo es el que genera bienestar sostenible.

\subsection{4.- TURISMO Y CAMBIO SOCIAL.}

El cambio social puede definirse como "toda transformación observable en el tiempo, que afecta, de una manera no efímera ni profesional, a la estructura o al funcionamiento de la organización de una colectividad dada y modifica el curso de su historia" (Rocher, G.1973, pp. 415). En las sociedades modernas, el turismo se convierte en un agente de cambio social de primer orden, puesto que incide de pleno en diferentes factores, al entrar en contacto personas con bagajes culturales, sociales y económicos totalmente diferentes, incluso en ocasiones antagónicos. Este encuentro ocasiona una serie de influencias capaces de modificar no solamente el nivel de vida, que sería lo más evidente, sino también la personalidad social e individual de la población receptora. Los cambios sociales que han sido más estudiados por los sociólogos se centran, principalmente, en dos tipos de factores: a) los vinculados con el proceso productivo: demografía, economía y tecnología y b) los vinculados a la cultura de las sociedades: los valores, las normas, las ideologías y las creencias (Rocher, G. 1973, pp. 425). Ámbitos estos, modificados por la actividad turística, que a su vez también puede propiciar, en muchos casos, conflictos sociales que protagonizan grupos profesionales, grupos étnicos, sindicales o movimientos sociales como el ecologista. Así, en diferentes estudios sobre los impactos sociales que genera el turismo, se ha podido ir constatando su afección sobre múltiples variables: las formas de vida, el sistema de valores, el comportamiento individual, las relaciones familiares, los estilos de vida colectivos, los niveles de seguridad, la conducta moral y política, la religión, las expresiones creativas, la cultura tradicional, el urbanismo, la estructura demografía, la inmigración, la movilidad en la escala social, el trabajo y las formas de producción tradicionales, el aumento del nivel de vida, las modificaciones en el comportamiento del consumo, las variaciones en las necesidades cotidianas, y un largo etc. (Mazón, T. 2001, pp. 114). 
Todas estas variables que son afectadas por el turismo, y que éste puede modificar, establecen una lectura, sobre el estado del bienestar del país o región receptora.

Como factor de cambio, encontraremos dentro de la Teoría Sociología discursos que se mueven sobre la disyuntiva de si el turismo es un factor de desarrollo de las sociedades receptoras, o por el contrario, un reflejo del subdesarrollo y la dependencia (es alienante en términos marxistas).

Las corrientes sociológicas humanistas interpretan el turismo desde una perspectiva compensatoria: no sólo propicia una actividad productiva, sino que también es una oportunidad para que cada cual exprese lo mejor de sí. Además destacan las ventajas que obtienen los países en vías de desarrollo para los que el turismo es una oportunidad de incorporación a las culturas y estructuras productivas de los países desarrollados. Producirá una aculturación en las sociedades de contacto, favorable para la comprensión y acercamiento de los pueblos, muy adecuada para evitar conflagraciones internacionales (Rubio, A., 2003, pp. 270). Ideas sostenidas por autores como Toffler, A. (1971) y Owen, $W^{43} \cdot(1964)$.

En el lado opuesto se sitúan las teorías críticas y de izquierda freudomarxista y las teorías de la alienación. Lefebvre, en su obra El ocio, dirá que el turismo es una forma de consumo propia, que persigue al igual que otras formas de éste, como el deporte, la asimilación de modelos culturales propios de la clase burguesa dirigente. Es decir un rasgo típico de la alienación de las necesidades, propia del neocapitalismo (Rubio, A. 2003, pp. 271). Dentro de esta línea se encuentra la Escuela de Frankfurt (Adorno, Horkheimer, el pensamiento de Marcuse o Habermas) que enfrenta el análisis del ocio como instrumento de poder, junto con Benjamín y posteriormente Louis Turner y John Ash que ejercieron una notable influencia en la sociología del turismo posterior, con su obra The Golden Hordes (1975); para ellos, el turismo de masas manipula y explota y además traslada a los destinos todo lo malo de las sociedades industrializadas, impide el desarrollo y el progreso humano, pues adopta un modelo de integración en el sistema económico capitalista con un bagaje negativo, con lo que la visión filantrópica (propia de la Sociología humanista) no se cumple (Turner y Ash, 1975, p. 292) ${ }^{44}$. Así, Mantecón A. (2008, pp. 50) afirma que "el turismo no escapa a la dialéctica entre liberación y control que ha configurado el devenir de las formas de ocio".

\footnotetext{
43 Owen, Wilfred. Inmobility: Barrier to development. En Rev Transportation Journal. Vol, 4; $n^{\circ}$ 2. Pennsylvania: Penn State University Press, 1964, p. 20-26.

44 Recogido por Rubio, A. Turismo, sociedad y desarrollo. En Sociología del Turismo. Capítulo 10. Barcelona: Ariel, 2003 (p. 271).
} 
Desde este punto de vista, se añade a la aportación analítica en relación a los cambios que se producen en las culturas receptoras, la idea de folklorización de la cultura, falsificación o mercantilización de la misma, a través de autores como Moore (1963), Aerin (1972), MacCannel (1973), Thurot (1975), McLean (1976), Kadt (1976) y Greenwood (1992) ${ }^{45}$, entre otros.

Por otro lado, las teorías del conflicto se centrarán más en la dimensión de los intereses que en los impactos del turismo. El antagonismo entre poblaciones receptoras y los visitantes refleja el conflicto entre sociedades industrializadas y las que no lo están durante la primera fase de implantación de la actividad, no así en destinos de masa maduros. "Todo ello conlleva un proceso instrumental de negociación, que no siempre tendrá que ser negativo, pero sí fuente de otra serie de conflictos de intereses que perfilan un nuevo tipo de colonialismo económico, político y cultural" (Rubio, A. 2003, pp. 272). La idea del turismo como imperialismo (muy comentada desde la antropología) en cuanto expansión en el extranjero de los intereses de una sociedad determinada, desarrolladas anteriormente, señala que esos intereses -que pueden ir desde lo económico, político, militar, hasta religioso - son impuestos y adoptados por una sociedad extranjera, y crean transacciones intersociales cambiantes que se distinguen por las fluctuaciones del poder (Smith, V. 1992, pp. 70). Pero, para que este imperialismo del turismo se produzca, es necesario que las sociedades indígenas acepten voluntariamente y participen de las transacciones que produzcan esos beneficios externos, aunque en un primer momento no sean conscientes de esa utilidad exterior, sino de la posibilidad de beneficios, principalmente económicos, que les va a suponer asumir voluntariamente esas transacciones, por lo que reproducen y alimenta las nuevas estructuras a través del espacio y del tiempo. El poder que somete a las regiones menos desarrolladas viene de los grandes centros metropolitanos de los países y regiones desarrolladas, que gozan de diversos grados de control sobre la naturaleza y crecimiento del turismo en las sociedades anfitrionas. Este poder sobre el desarrollo turístico, que ejercen en el extranjero, es lo que hace que esos centros metropolitanos puedan ser considerados como imperialistas, y el turismo como una forma de imperialismo. Y si como afirma Young, R. (1977, pp. 157) la forma estructural de cualquier desarrollo turístico va en paralelo a la preexistente estructura socioeconómica de un país, no es de extrañar que, para algunos, este tipo de turismo se presente como una reproducción de la estructura de un enclave dominado por extranjeros, que reacciona según los intereses metropolitanos y se haya completamente desconectado de la realidad de la economía local. El imperialismo y colonización del turismo se reflejará en el manejo de la economía turística nacional por

45 Greenwood, acuña el término "color local" para designar la promoción mercantilizada de la cultura local en tanto parte del ensueño turístico local, señalando la constante de esta práctica (1992, pp. 258). 
extranjeros. Esos dos procesos van acompañados de un tercero, aculturación ${ }^{46}$ (Nash, 1970 y 1987; Maluga, 1973; Gaviria, 1974; Jean Pierre Prod'Homme ${ }^{47}$, 1985; Smith, V., 1992; entre otros). El poder económico cambia de manos, pero también se reflejará en la asimilación, por parte de la población receptora, de nuevos modelos culturales (Manning, F. 1978; Wood R. 1980; Britton, S. 1982; Biddlecomb, 1981; entre otros), que según esta visión supondrá la pérdida de la identidad local.

Así, la pregunta a la que nos enfrentamos es: ¿Cuál es la dirección que toma el cambio que produce la actividad y cuál es su repercusión sobre el bienestar local? La capacidad de influencia del turismo sobre una sociedad varía en relación a diferentes aspectos o variables endógenas de la sociedad receptora ${ }^{48}$, es decir, en qué estado de evolución y desarrollo se encuentra en el momento en que incorpora la actividad turística a su sociedad y economía. Es por ello que, la pregunta formulada, no tiene una respuesta unívoca puesto que la dirección que toma el cambio derivado está en relación, en primer lugar, con la estructura social que lo acoge. Así como con el tipo de turismo que recibe e impulsa -individual, en grupo, itinerante, etc.- (ya que cada uno de ellos marca una impronta diferente), con el motivo del viaje -cultural, de sol y playa, rural, de aventura, etc.-, con la capacidad de acogida o carga en cuanto territorio más o menos limitado, sin olvidar la planificación y gestión que se haga del crecimiento de la actividad, entre otros aspectos. Siendo, en consecuencia, sólo posible contestar a dicha pregunta desde un estudio micro, sobre un caso $^{49}$.

46 La sociedad anfitriona entra en un proceso de aculturación de modelos importados: hábitos alimenticios (horarios, comidas rápidas, etc.), vestimentarios, diversión, expresiones, adaptaciones al idioma foráneo (y no a la inversa), etc. Estos nuevos modelos vendrán revestidos de valores como progreso, desarrollo, modernidad y libertad, entre otros,

47 Jean Pierre Prod'Homme (1985) afirma que el resultado de estos procesos es la desintegración de la coherencia cultural de las antiguas sociedades, debido al mimetismo o imitación de los nuevos modelos, haya o no intercambio directo entre los turistas y autóctonos. "Progresivamente, por los modelos que vehicula y por las normas de comportamiento que induce, tiene una función de unificación cultural para las poblaciones turísticas, y de colonización (...) hacia los territorios y poblaciones autóctonas en la medida en impone de hecho sus propios modelos técnicos y culturales" (1985, pp. 26).

48 En poblaciones, cuyo nivel de evolución es muy avanzado, apenas se dejará notar en las formas de vida la llegada masiva del turismo; pero en aquellos otros, en cierto modo marginados de las tendencias modernas, el comportamiento un tanto extraño y anormal que les supone la conducta de los visitantes, va a significar una alteración sustancial de la manera de desenvolverse". Figuerola Palomo, M. (1976). "Turismo de masas y sociología: el caso español, en Travel Research.

49 "No debemos recurrir a generalizaciones en cuanto a la evolución de los sistemas turísticos. Es necesario siempre concretar aquellos parámetros que tienen mayor importancia en los cambios socioculturales: ¿cuáles son las necesidades del centro/s metropolitano/s al que vamos a satisfacer su demanda?, la evolución de las necesidades de dichos centros se verá reflejada en la evolución del sistema turístico; ¿cuál es la distribución del poder en el sistema? La modernización de la zona turística después de su primer desarrollo, seguirá siendo un reflejo de las demandas subsiguientes que lleguen del centro metropolitano, este reflejo se verá afectado por quién esté en el centro del poder dentro del sistema turístico, o sea, si aquellos que ostentan el poder poseen objetivos distintos a las necesidades metropolitanas, el desarrollo del sistema no reflejará fielmente estas necesidades 0 , si por el contrario, el poder está enteramente en manos de agentes (continuación) 


\subsection{5.- TURISMO Y DESARROLLO ECONÓMICO}

La economía ha tenido un peso importante en la teoría turística, concibiéndose el fenómeno en términos de desarrollo económico.

El desarrollo (en cuanto fenómeno social) aparece en la teoría sociológica desde la perspectiva del cambio, "designará las transformaciones de las estructuras económicas y sociales que permiten la diversificación de las economías tradicionales, y no tan sólo el incremento cuantitativo de las variables económicas" (Rubio, A. 2003, pp. 268).

Es en las décadas de los años cincuenta y sesenta del $s$. XX cuando se interpreta la potenciación del sector servicios basado en el turismo como vía de desarrollo económico. La idea que se tiene de dicho sector es muy positiva desde este punto de vista ${ }^{50}$, proclamándose internacionalmente. Así, como ya dijera Hirsch (1985, pp. 15), el crecimiento económico actúa como la significación social legitimadora básica. Debemos tener en cuenta que por esta década existía un número importante de países dentro del Tercer Mundo, que sufrían grandes dificultades puesto que sus principales productos de exportación estaban sufriendo una pérdida de valor a largo plazo (Crick, M. 1989, pp. 353). La oportunidad que se les abría para salvar sus dificultades económicas con éxito era abrir sus puertas a visitantes que buscan placer y ocio. El turismo se les presenta como la «gallina de los huevos de oro», la panacea; los hábitos de la población postindustrial de los países ricos iban abrir las puertas al desarrollo económico y al bienestar social de los habitantes de los países pobres.

Por otro lado, el objetivo que con este impulso del turismo se planteaba en 1960, era el conseguir la diversificación de las exportaciones, reduciendo la dependencia de productos primarios (Crick, M. 1989, pp. 360), se buscaba un desarrollo autosuficiente, que apreciara las necesidades locales.

Organizaciones internacionales importantes, de la talla de la OCDE (Organización para la Cooperación y el Desarrollo económico), la $\mathrm{OMT}^{51}$ (Organización Mundial del Turismo), el Banco Mundial o las Naciones Unidos, se lanzaron a impulsar la promoción del turismo entre los más pobres, proclamando que con ello se contribuía a un nuevo orden económico internacional e insistiendo en que así se ayudaría a eliminar las crecientes diferencias

metropolitanos, el sistema se desarrollará únicamente de acuerdo con las necesidades que les vienen impuestas desde el exterior". Nash, D. (1992, pp. 89-91).

50 Conviene, ahora citar a Hernández Díaz, E. A. (1991, pp. 9) cuanto afirma que "el turismo es principalmente una actividad económica y, por lo tanto, responde a esa naturaleza con la misma intensidad con la cual responde cualquier elemento a su determinante fundamental".

51 En 1980, durante la Declaración de Manila, la OMT, presenta el turismo como un auténtico derecho humano fundamental. 
económicas entre países desarrollados y subdesarrollados y contribuiría sustancialmente al desarrollo social y al progreso en general de los países en vías de desarrollo (Crick, M. 1989, pp. 362). Representándose por esta época, como el único sentido del turismo, la búsqueda de la autenticidad cultural, de la paz y el entendimiento mundiales, como algo ennoblecedor y ensanchador de horizontes mentales -recogido en la Conferencia de 1963 de las Naciones Unidas sobre el Viaje Internacional y el turismo-. En palabras de Britton, R. (1978, pp. 155) "el internacionalismo que defiende la industria turística es coherente con sus propios intereses, puesto que un mundo sin fronteras favorece mucho mejor la circulación sin trabas del capital, de la mano de obra y de la tecnología". Por otro lado, la política local también buscaba su importante impacto económico, especialmente si se trataba de un país en vías de desarrollo. Por ello, lo normal es hallar en las políticas de todos los países actitudes positivas hacia el turismo aún hoy, que ya se tienen datos sobre sus efectos positivos y negativos.

Esta imaginería -como así la califica Crick, M. (1989, pp. 377) ${ }^{52}$ - acerca del turismo internacional, ha generado diferentes realidad socioeconómicas. Para pensadores como Crick supuso una manipulación de intereses comerciales de los países hegemónicos occidentales, cuya prioridad era el beneficio a corto plazo. Una gallina de huevos de oro, inagotable, que sólo dependía de los recursos naturales que ya existían en la zona (sol, playa, arena, paisajes exóticos y salvajes, con gente acogedora ${ }^{53}$ y pintoresca...). Además, como señala Kadt, E. (1991, pp. 36) "Ios recursos humanos y financieros requeridos para construir y poner en funcionamiento las instalaciones turísticas podían asegurarse tanto de fuentes nacionales como internacionales si no estaban disponibles localmente". Y sabemos que "la mayoría de los países pobres que esperan obtener beneficios desarrollistas a través del turismo, no tienen ni un sector privado fuerte ni una clase empresarial vigorosa, ni siquiera mucha capacidad gestora disponible en el sector público" (Kadt, E. 1991, pp. 64).

Cierto es, como dice Jafari (1982, pp. 137), que hoy en día, "cualquier comunidad o nación, grande o pequeña, desarrollada o subdesarrollada, se halla influida en diversos grados por el turismo". Pero lo que aquí nos trae son las comunidades que han elegido la actividad turística de masas como medio o estrategia para alcanzar desarrollo, salir de la pobreza y entrar en el concierto internacional de países y zonas del Primer Mundo, principalmente la importancia en las islas, que poseen un territorio y recursos limitados, como es el caso de Baleares y Canarias en el contexto nacional.

52 "Se trata sólo de mitos y fantasías, y en este sentido puede dañar los esfuerzos de un país por desarrollarse, porque su propio sistema de construcción de imágenes crea un cuadro falso del Tercer Mundo". Crick, M. 1989, pp. 377.

${ }^{53}$ Aunque luego se constatará que los turistas "no viajan al Tercer Mundo porque la gente sea acogedora, sino que van porque las vacaciones allí resultan baratas". Crick, M. 1989, pp. 360. 
Debemos tener en cuenta, que "el turismo no es un sector de desarrollo económico acotado, sino la suma insumo o producto intersectorial de variadas ramas de actividad, administraciones públicas, infraestructuras y servicios complementarios específicos y generales. Por tanto, es desde aquí donde hay que analizar su aportación estructural y productiva al desarrollo, y no exclusivamente desde el aporte de ingresos externos" (Vera Rebollo, J. F., y Marchena Gómez, M., 1990. pp.62). Por ello, se crea la Cuenta Satélite del Turismo en España (CSTE), elaborada por el Instituto Nacional de Estadística (teniendo en cuenta las indicaciones de la Organización Mundial del Turismo (OMT), desde 1995, cuya finalidad, entre otras, será observar la interrelación entre la oferta y la demanda turística, que permita obtener mediciones integradas de la aportación del turismo a la economía a través de variables marco, como el Producto Interior Bruto, la producción o el empleo y establecer su relevancia económica ${ }^{54}$.

En la aportación al desarrollo de la actividad se diferencian varias etapas. En la primera fase, de impulso del sector turístico para alcanzar desarrollo y mejora de las condiciones de vida y del bienestar social, se consiguen una serie de inversiones que sí van a tener un reflejo positivo en cuanto a rentabilidad social y bienestar de la población, puesto que, desde el momento que se implanta, tiene que ir paulatinamente equipándose en transporte y hostelería, o sea, en actividades que empiezan a conocer el valor económico de los viajeros (Fernández, L. 1988, pp. 26). Es un momento de inversiones, y solamente un desarrollo rápido y a gran escala proporcionará una tasa de retorno razonable a la inversión infraestructural (Kadt, E. 1991, pp. 63), a la vez que, si pretende tener con rapidez una adecuada infraestructura turística tendrá que buscar financiación extranjera. En esta etapa se desea el "Boom", caracterizado por cifras de llegadas de millones de personas: "vale más muchos pocos que pocos muchos". Empiezan a depender de los operadores extranjeros para hacer los paquetes de viajes, comercializarlos (Kadt, E. 1991, pp. 65) y, así, alcanzar el lleno. Pero, poco a poco, para el caso de países o comunidades que necesiten importar capital extranjero para construir su infraestructura turística -puesto que en un principio las infraestructuras, los equipamientos y servicios no están preparados para la recepción-, sobre todo hoteles, los continuos pagos de intereses promoverán su dependencia en lugar del efecto contrario (Crick, M. 1989, pp. 356). Cuando esto ocurre ¿podemos afirmar que invertir en turismo es invertir en dependencia? como afirma Heiberg, T. (1980, pp. 71); ¿es lo opuesto al desarrollo autosuficiente y sostenible? El monocultivo sí.

Lo cierto es que la aportación del turismo ha resultado trascendental para el desarrollo económico de España, que ha podido renovar su capacidad industrial y modernizar la estructura productiva por la aportación de los ingresos por turismo. "El aportar sobre dos

${ }^{54}$ Instituto Nacional de Estadística (INE). "Cuenta Satélite del Turismo. Metodología". INE. Madrid, 2004 
billones de pesetas en divisas, cerca del $10 \%$ del PIB y, un punto más, en cuanto a generación de empleo directo, con su consiguiente multiplicador de empleo indirecto (difícil de evaluar, pero temporalmente muy acentuado por el volumen de demanda que soporta España), indica la necesidad de un reconocimiento del turismo como entidad funcional específica y de gran importancia" (Vera Rebollo, J. F., y Marchena Gómez, M., 1990. pp.60).

Será cuando la ocupación empieza a alcanzar, años después, límites insospechados, cuando empiece el cuestionamiento en relación a la capacidad del sector turístico para generar un desarrollo económico continuado. A partir de ahí, diferentes autores van a tratar dicho aspecto desde una óptica negativa hacia el Bienestar social de las poblaciones que acogen la actividad, afirmándose, en la producción intelectual de la década del ochenta, la quiebra social de la población de acogida desde diferentes puntos de vista: a) pérdida, en la mayoría de los casos, de la identidad cultural original fruto del contacto masivo con el foráneo que viene de las áreas metropolitanas desarrolladas y que es portador de modelos culturales diferentes al de los lugares que visita ${ }^{55}$; b) comienza a ser muy marcado el déficit de infraestructuras y servicios (colegios, salud, seguridad...) que no llegan a cubrir las necesidades reales de la población que de hecho se encuentra residiendo dentro del sistema turístico masificado. Esto nos hace recordar un comentario significativo, hecho en 1985 por Hirsch, F.: "Luego el crecimiento generalizado aumenta el apiñamiento de la gente (pp. 26), y sabemos que si todo el mundo se pone de puntillas, nadie verá mejor (pp. 22)"; c) cae el mercado laboral, se abarata, por el exceso de mano de obra que sigue llegando atraída por la demanda, sin cualificar, que generaron los primeros desarrollos, con lo que las perspectivas de empleo pueden no mejorar en las localidades más inmediatas si se trae mano de obra del exterior (Crick, M. 1989, pp. 357); d) A la vez se produce una falta de diversificación sectorial, no dándose los efectos multiplicadores que se esperan en un sistema desarrollado, genera enclaves localizados de actividad que no afectan a las restantes actividades que se desarrollan a su alrededor, limitando o reduciendo la economía local al sector turístico, lo que significa que pasan de la dependencia del sector primario a la dependencia de ingresos por turismo -como bien afirma Rodríguez, W., pasan al monocultivo del turismo- $y$ el turista viene del exterior.

Liew, J. (1980, pp. 16-17), considera que no estimula la producción agrícola local sino que incrementa el valor de la tierra, provocando el éxodo de la mano de obra agrícola, el abandono de la tierra de cultivo y la necesaria importación de alimentos para el abastecimiento local. El paso siguiente será acabar con lo que quede de las estructuras de comercialización de los productos agrícolas que ya no se producen, porque ahora se pasa a un nuevo monocultivo, el turismo. "El turismo ha solido ser exclusivo y excluyente de otras

${ }^{55}$ Nash, 1977; Crick, 1989; Smith, V., 1992; entre otros. 
actividades en esas zonas, por más que ejerciese un efecto multiplicador y de arrastre sobre un amplio espectro de actividades económicas. Ha supuesto el fin, la transformación radical o la minimización extrema de actividades previas a las cuales ya no hay retorno, a la vez que las nuevas actividades se organizan en función suya". (Mira, E. 1992, pp. 109-110).

Para Britton, R. (1978, pp. 207) estamos, en consecuencia, ante una reestructuración del poder local, cayendo éste en manos extranjeras, es la antítesis al desarrollo autosuficiente; y puede también afectar a la estructura de clases sociales haciéndose más marcadas las diferencias entre clases, que aumentan, incrementándose las desigualdades de riqueza (Forster, J. 1964, pp. 225). En palabras de Crick, M. (1989, pp. 357-367) "sus beneficios van a las élites -aquellos que ya son ricos y aquellos con influencia política-", esto no refleja apreciaciones o necesidades locales, aunque hayan intervenido élites indígenas colaboradoras $^{56}$; está vinculado a empresas multinacionales que dirigen a las élites y las hegemonías políticas (O Grady, R. 1980) ${ }^{57}$. "Son raros los casos en los que la gente de la comunidad local tiene una auténtica oportunidad de influir en el curso de los acontecimientos, ya sea a través de las estructuras existentes de gobierno local, ya mediante organizaciones especialmente creadas para el caso -a pesar de que estos acontecimientos afectarán profundamente a sus vidas-" (Kadt, E, 1991, pp. 40). Por tanto, la periferia está estructuralmente atada a las necesidades de la metrópolis; las élites locales y extranjeras obtienen beneficios mientras que las privaciones siguen siendo lo que corresponde a las masas (Schoesmith, D. 1980, pp. 50). "El turismo ha borrado, pues, actividades, ecosistemas y estructuras sociales preexistentes, a la vez que anulaba otras opciones" (Mira, E. 1992, pp. 112). En relación a ello, Crick (1989, pp. 361) propone el repensar el turismo fuera de su normal marco materialista de modo que sus beneficios puedan ser repartidos de forma más equitativa.

El optimismo de muchos países ante la posibilidad de crecimiento económico que se mostraba a través de la actividad, provocó, en palabras de Rubio, A. (2003), el que se "embarcaran en la promoción del turismo sin estudios adecuados de viabilidad, planificación $y$ análisis de los verdaderos costes”, pero ¿qué nivel de cultura urbanística existía en estos países en el momento de la incorporación de la actividad? No será hasta algún tiempo

56 "Las élites locales pueden identificarse muy bien con el estilo de vida consumista de los turistas internacionales más que con las aspiraciones de su propio pueblo, puestos que ellos mismos pueden ser parte de la jet set internacional. Cuando (...) ellos incentivan el turismo (...) puede que hasta obtengan sustanciosos beneficios" Crick, M. 1989, pp. 368.

${ }^{57}$ Esta idea fue expuesta en 1980 durante la Conferencia Cristiana de Asia, por O`Grady, perteneciente a uno de los grupos eclesiásticos que se presentaron. Añadía que a estas élites no les importa en absoluto las auténticas necesidades espirituales, político-económicas y socioculturales. (O 'Grady, R. (1980). "Third World Tourism”. Singapore. Christian Conf. Asia). 
después de su implantación para la masa cuando algunos de estos destinos se den cuenta del factor negativo de la misma, que Rubio (2003, pp. 274) sintetiza en cinco puntos:

- Los beneficios económicos no eran tan importantes como se pensaba, por la inversión en capital constante que exige la actividad y por las inversiones y repatriación del capital extranjero.

- El turismo posee limitaciones estructurales de gran envergadura: su naturaleza estacional, la fluctuación de los flujos de visitantes, la dependencia de los precios del petróleo, el carácter antojadizo de la afluencia, etc.

- La gran integración vertical de la industria turística - que señala Britton, citado anteriormente - que integra servicios de los grandes tour operadores extranjeros y que retrae el gasto en los países de destino.

- La necesaria promoción de los destinos exige grandes inversiones en publicidad en los países emisores, que tendrán que acometer los países pobres, a favor de los ricos, en detrimento de otros posibles proyectos e inversiones propios (O`Gray, 1982).

- Es un producto, el turismo, adquirido en un sitio (países emisores) y consumido en otro (países receptores), dejando a estos últimos en una situación de desventaja y dependencia con relación a los primeros (Crick, 1989; Kadt, 1991; Mira, 1992; entre otros).

En relación a estos aspectos no positivos de la actividad, Asher (1985) afirmará, "son los tour operadores los que manejan la industria turística y cuanto mayor sea el grado de subdesarrollo de un país, menor será el beneficio global del turismo" ${ }^{28}$. En palabras de Rubio, A. (2003), en este entorno un concepto de crecimiento económico que no tiene en cuenta la distribución de la riqueza y toda una multitud de cuestiones políticas y sociales no tiene ningún valor, aspecto este que como ya habían puntualizado Britton y Crick, para los que definir el desarrollo simplemente en términos de índice tales como el Producto Nacional Bruto creciente o cantidad de divisas importadas, resulta problemático allí donde los indicadores sociales (niveles y equipamientos educativos y sanitarios, etc.) permanecen estáticos o se ha modificado muy poco.

58 Estos efectos producidos por los tour-operadores son recogidos en multitud de artículos sobre el tema, así, más recientemente autores como Troitiño, M.A. (1998, p. 216) señalan lo siguiente: "los beneficios que el turismo proporciona no siempre redundan en favor de la comunidad local, dado que frecuentemente las empresas más poderosas de la industria turística, los tour-operadores, tienen su sede en el lugar en el que se genera el turismo". 
Hasta bien entrados los años ochenta políticos y economistas no concebían otro desarrollo que no pasase por la industrialización y la terciarización. A finales de los años ochenta y durante los noventa, las nuevas tecnologías y las tecnologías de la información, "viran la estrategia de desarrollo económico hacia el ámbito local, alejándose de los teoremas industrialización-urbanización-concentración. Habrá ahora una mayor preocupación por conciliar los aspectos económicos, culturales y territoriales-medioambientales" (Rubio, A. 2003, pp. 280). En España se acaba con la idea de que el modelo de desarrollo turístico debe estar basado exclusivamente en la intensiva explotación de los recursos costeros medioambientales y, de la consiguiente venta continua y depredadora del territorio. De la gestión de esta idea llevada a un nuevo modelo de desarrollo turístico dependerá el sostén del bienestar alcanzado en la primera etapa de demanda turística masiva o fordista.

Se entiende, por tanto, el desarrollo local como "un complejo proceso de concertación entre agentes que interactúan dentro de los límites de un territorio determinado con el propósito de impulsar un proyecto común que combine la generación de crecimiento económico, equidad y cambio territorial, con el fin de elevar la calidad de vida y el bienestar de cada familia y ciudadano que viven en ese territorio". Encontrándose el turismo como "un sector privilegiado en el marco del desarrollo local, al constituirse en un agente potenciador de aspectos relacionados con el desarrollo desde una vertiente territorial, así como la conservación del patrimonio cultural y medioambiental, que caracteriza la sostenibilidad". En esta etapa que se abre a partir del final de la década del ochenta y bajo la idea del desarrollo local, se "perseguirá eliminar las políticas turísticas de carácter "extractivo» que, como ocurrió con el "boom» de los años sesenta, condujo a la práctica destrucción de extensas zonas del litoral español, y que no tenían en cuenta consideraciones de impacto ambiental, urbanístico, paisajístico, etc., como tampoco sobre la calidad de los servicios y el empleo a ellos dedicados" (Rubio, A. 2003, pp. 281-282).

Así, desde diferentes pensadores en el ámbito no sólo de la sociología, sino de la política y de la economía, podemos entrar a cuestionar y reflexionar la relevancia del turismo en la consecución de bienestar social en el territorio nacional y principalmente en el insular.

\section{2.- BIENESTAR SOCIAL Y TURISMO}

Las formas en las que se produce el desarrollo turístico y cómo afecta al bienestar de la sociedad anfitriona y a sus condiciones de vida objetivas, son el motivo de esta tesis. La discusión, por tanto, se centra en la naturaleza de los efectos que sobre el Bienestar se producen en las sociedades que acogen una demanda turística de masas, puesto que, como ya señalara Kadt, E. (1991, pp. 75) "puede tener repercusiones sobre el bienestar de la gente que no se halla implicada directamente en el sector turístico. Los turistas también consumen algunos de los mismos bienes y servicios que usan los residentes. Si el turismo 
tiende a incrementar la disponibilidad de bienes deseados, esto beneficiará a la gente local, pero si los turistas compiten con los residentes por un abastecimiento limitado, entonces el resultado tenderá a ser negativo para la población local como consumidora, si bien no como productora". Esta afirmación está sujeta a matices, puesto que la presión sobre los bienes y servicios puede ser ocasionada directamente por los turistas, o indirectamente por la actividad turística, que produce un efecto multiplicador sobre el territorio, dando lugar a dinámicas socioeconómicas y demográficas nuevas a las que hay que responder.

Aunque son muchos los efectos asociados al proceso de implantación y crecimiento de la actividad turística, que han sido tratados desde diferentes disciplinas, a continuación se presenta una sistematización en relación a los factores, elementos o grandes áreas del bienestar social sobre los que repercute y pueden ser objetivables y por tanto medibles a través de indicadores sociales objetivos. Ya que lo que pretendemos estudiar no es la magnitud del bienestar, sino de qué forma se ve afectada esta magnitud por el desarrollo turístico, en las áreas que de forma clásica se establecen como propias del Bienestar.

Estas grandes áreas generales del bienestar se pueden organizar atendiendo a la política social, como es el caso del enfoque de la OCDE (1973) estableciendo ocho grupos ${ }^{59}$, pero para el caso del turismo en su afección sobre el bienestar de la sociedad insular receptora, hay ámbitos afectados no incluidos en esa relación. Así, de una manera general, y considerando las distintas fuentes citadas en esta tesis, es posible articular los efectos del turismo sobre el bienestar atendiendo a los siguientes aspectos sobre los que la incidencia es más significativa:

A. Efectos sobre la estructura demográfica básica. Una de las repercusiones que genera la actividad turística de forma inmediata se produce sobre la estructura demográfica de los territorios que acogen la actividad, generando cambios sustanciales en ellas. Estos cambios, cuando son significativos por volumen respecto a la población local, influyen muy sustancialmente sobre el funcionamiento del territorio y afectan a todas las variables asociadas al bienestar de la población autóctona. Son, por lo tanto, unas de las variables fundamentales para comprender las trasformaciones que se producen. Los efectos principales son:

59 Salud (probabilidad de disfrutar de buena salud y efectos de los atentados a la salud, etc.); Educación y adquisición de conocimientos (utilización de las posibilidades y medios disponibles, etc.); Empleo y condiciones laborales (posibilidad de acceso y calidad de vida laboral, remuneraciones, etc.); Empleo del tiempo y esparcimiento (posibilidad de elegir, flexibilidad en fijar el tiempo de trabajo, etc.); Bienes y servicios disponibles (posibilidad de disponer, igualdad de acceso, accesibilidad, número de marginados, etc.); Medio Ambiente (condiciones de vida, exposición a materias nocivas, polución, etc.); Seguridad física y jurídica (equidad en la aplicación de leyes, formas de violencia abierta o encubierta, etc.); Participación en la vida colectiva (grado de desigualdades sociales, participación en toma de decisiones, etc.). Publicado en castellano por el INE (1981). "Medida del bienestar social. Programa de la OCDE de elaboración de los indicadores sociales". España, 1981, Anexo I. (pp. 251-258). 
3. Fuerte ritmo de crecimiento de los valores absolutos de la población, convirtiendo el área de afección en regiones dinámicas. Es generado principalmente por movimientos de población que se desplaza bajo el reclamo que representan los empleos ofrecidos por la industria turística. Esta movilidad geográfica, por tanto, va unida a la movilidad ocupacional y social. Se concreta en dos tipos de movimientos:

- Migraciones internas, principalmente caracterizadas por el éxodo de la población rural local y de la población de otras zonas del país con menor actividad económica, que produce una reorganización interna de la población al trasladarse ésta a los lugares que focalizan la actividad y nueva demanda de empleo.

- Migraciones externas, que en algunos casos pueden constituir el elemento que da explicación al fuerte incremento poblacional, constituida por contingentes de población venidos de otros países.

Estos contingentes de población inmigrada se caracterizan, en la mayoría de los destinos, por pertenecer al grupo de población de edad potencialmente activa, o sea, en edad de trabajar. Aunque, en algunas zonas del territorio se observa el asentamiento de personas en edad muy madura, jubilados (turismo residencial), cuya presión sobre elementos del bienestar es distinta a la de los primeros.

El volumen de las inmigraciones puede abrir un nuevo frente de conflicto social en las sociedades receptoras de turismo, ya que pueden llegar a superar en número a las poblaciones autóctonas y dar lugar a transformaciones sociales. "Los emigrantes, al trasladarse de un lugar a otro, cargan consigo sus características culturales, pero estas características se modifican a su vez por la influencia del nuevo medio" (Alomar, 1961) ${ }^{60}$.

- Relanzamiento de la natalidad por la llegada de población en edad de procrear. Fecundidad y natalidad se verían modificadas.

- El volumen de visitantes (turistas), afecta a la población que a diario soporta un territorio, con la consiguiente carga ambiental y demanda de bienes y servicios.

Consecuentemente, el fenómeno turístico tiene capacidad para modificar, en su ámbito territorial de influencia, la estructura de la población, cuya mayor o menor intensidad será detectada a través de indicadores demográficos, que, fundamentalmente, deben ser los siguientes: dinámica de los incrementos de

60 Recogido por Mazón, T. 2001, pp. 160. 
población; tasa de natalidad y mortalidad; migraciones y saldo migratorio (volumen y origen); proporción de alóctonos (inmigrantes) sobre autóctonos; y población autóctona frente a la foránea (alóctonos más turistas).

Los cambios demográficos repercuten sobre las dotaciones de servicios, equipamientos e infraestructuras, sobre el mercado laboral y sobre el medioambiente, entre otros. Lo que repercute directamente sobre el bienestar de la población autóctona y residente.

\section{B. Efectos sobre la dotación de servicios y equipamientos básicos: educación y salud.}

1. EDUCACIÓN. En cuanto elemento básico del bienestar afectado por la actividad turística supone varios enfoques: a) La implantación de una economía terciaria basada en turismo incide en la modificación del nivel de instrucción de la población en cuanto que genera una demanda de mano de obra más cualificada, lo que convierte a la educación en centro neurálgico en el proceso de transformación, ayudando a romper el círculo de la pobreza, tanto por su función motora (de cambio social) como por su función económica, de creación de capital humano y formación profesional de la mano de obra que la actividad turística requiere, para comenzar y tener continuidad. Su efecto se mide a través de los cambios en el peso relativo del analfabetismo y de los diferentes niveles formativos de la población residente y de los inmigrantes; b) El crecimiento de la población en edad de trabajar y procrear que trae consigo la implantación de la actividad turística presiona sobre el nivel de equipamiento educativo (cantidad, oferta) que existe. Dicha presión puede tener un resultado positivo o negativo sobre el bienestar, en la medida en que la sociedad y la economía sean capaces de responder a dicha demanda. Se mide a través del nivel de equipamiento (oferta) en relación al volumen de la población (demanda).

2. SALUD. En relación a los aspectos de salud, interesa conocer y medir, en qué grado la actividad turística presiona a través de los efectos demográficos que genera dicha actividad sobre los equipamientos de salud, puesto que la modificación de la demanda que supone puede dar lugar a fuertes estrangulamientos en el oferta de dicho equipamiento, ya que es uno de los servicios que comparte la población residente y la turista, así como los inmigrantes asociados a esta actividad. Se mide en cuanto a nivel de equipamiento (oferta hospitalaria, extrahospitalaria, y número de médicos) puesto en relación con el volumen de población (demanda potencial). Otro indicador es el número de servicios sociales existentes, según tipo de servicio asistencial. 
C. Efectos sobre la Estructura Laboral. Empleo y desempleo. Entre los efectos socioeconómicos del turismo se encuentra la creación de empleo. Desde la Sociología, Greenwood (1992) lo ha señalado como el impacto más importante del turismo sobre la población local, como consecuencia de que el turismo incorpora actividades intensivas en el empleo de mano de obra. El turismo como industria no hubiese sido posible sin la importante aportación del empleo directo (destinado a producir servicios de índole turística, o sea, creado en los establecimientos propiamente turísticos), indirecto (destinado a la producción indirecta, obtención de materias primas utilizadas en la producción de los bienes y servicios consumidos por turistas) e inducido (derivado del aumento de demanda que crean las rentas e inversiones realizadas por la población ocupada en las empresas turísticas y sus suministradoras). Así, el empleo en una sociedad de actividad económica turística está directamente relacionado con el consumo de bienes y servicios proporcionados por el sector, facilitando la configuración de amplios mercados de trabajo. Se le atribuye el ser un importante yacimiento de empleo, "no sólo porque sus servicios ofrecen mayores limitaciones para la sustitución de mano de obra por nuevas tecnologías, sino porque además, son actividades en alza desde el punto de vista del consumo, producto de la mayor disponibilidad de tiempo libre y las preferencias sociales" (Rubio, A., 2003, pp. 279). Y toca de lleno uno de los importantes componentes del bienestar de las sociedades de acogida, hasta el punto en que, en ocasiones, se contempla su desarrollo como la única alternativa a dinámicas recesivas en otros sectores, hasta el punto de que se afirma, como es el caso de Marchena y Santos (1997) "que las actividades turísticas obtienen mejores resultados en términos de empleo, tanto en tiempos de recesión como en los de recuperación, situación que demuestra que el turismo es un sector de sostenimiento de empleo en momentos de crisis y de dinamización en situaciones favorables" (Vera, F. 1997, pp. 254).

Pero todos los efectos sobre el empleo que se le achacan no son positivos: en relación a la cantidad y calidad (eventualidad, estacionalidad, etc.) sus efectos pueden ser menos positivos por atraer mano de obra no cualificada, por no promover la diversificación ocupacional y por atribuírsele, para su desarrollo, la necesidad de una mano de obra barata, o sea, que ha de tener un nivel de retribución notoriamente inferior al existente en los países de origen de los turistas, además de acusársele de no generar una estructura de empleo favorable para las poblaciones autóctonas de las regiones de destino. Así, pensadores como Mazón T. (2001, pp. 141) hacen afirmaciones como la siguiente: "es un hecho comprobado, que en las primeras fases del desarrollo turístico, los nacionales o locales que se emplean en la industria turística, ocupan, por regla general, todos aquellos trabajos que no precisan de una cualificación específica, es decir, como personal para desarrollar las funciones menos comprometidas $y$, por supuesto, con las más bajas remuneraciones"; esta situación, puede ir suavizándose a lo largo del tiempo, en la medida en que la población local adquiere experiencia, 
conocimientos y aprenden otras lenguas. Aunque también puede suceder que la porción de población con mayor formación emigre hacia mercados laborales más diversificados.

Dicho esto, hay que destacar el hecho de que, en todo caso, su incidencia sobre el empleo hace que el turismo influya directamente en la estructura social de la sociedad anfitriona, puesto que puede ampliar las posibilidades de movilidad social, tanto vertical como horizontal e intergeneracional ascendente, aunque en los destinos turísticos de masas consolidados existe la posibilidad de que este hecho se invierta y la movilidad sea descendente. En todo caso, la afección sobre la estructura social es un hecho.

Por otro lado, los efectos positivos o negativos sobre el empleo están muy relaciones con el tipo o modelo turístico que se implante. Así, una de las cuestiones espinosas en un destino de masas derivaría de la cuantificación del número de empleos que genera el turismo, aspecto este harto difícil, puesto que debe contemplar el empleo directo, el indirecto y el inducido sobre el empleo total. Atendiendo a todos estos aspectos, lo que interesa medir se puede concretar en los siguientes indicadores: población activa por sectores económicos o de actividad, desagregada en ocupados y parados, junto con las correspondientes tasas (de actividad y de paro), observando como varían esas tasas en relación al sexo; las variaciones en la población potencialmente activa, en los ocupados y en los parados deberá ponerse en relación con las variaciones que experimenta la oferta y la demanda (afluencia) turística, para estimar la incidencia de éstas en esos cambios.

D. Efectos sobre la generación de renta. Uno de los efectos importantes, que se le atribuye a la incorporación de actividades turísticas en un territorio, se focaliza en relación al crecimiento económico (aumento en la producción real per cápita de un país) que va a experimentar dicha zona, pues el turismo es un acto que supone desplazamiento con gastos de renta para llegar al destino y para comprar en él bienes y servicios. Por lo que genera repercusiones sobre los diversos factores productivos (tierra, trabajo y capital) que se suponen que son positivos tanto en términos de valor (precio del suelo y de las viviendas, salarios y capital productivo acumulado) como de flujos de renta asociados a los mismos.

Se espera que la actividad turística derive incrementos positivos, en general, sobre la renta disponible personal y familiar de su población anfitriona, siendo ésta un indicador básico en la repercusión económica de la actividad turística sobre el bienestar, pues mejora el acceso de la población a bienes y servicios de consumo.

E. Efectos sobre los servicios y dotaciones asociados a las infraestructuras básicas. Sería impensable el desarrollo de un turismo de masas de un territorio sin servicios y dotaciones adecuadas en aspectos de energía, ciclo del agua, carreteras y transporte 
terrestre, que cuentan con un notable peso en la configuración de la ordenación del territorio, y suponen un importante condicionante para la penetración de capitales turísticos.

El crecimiento y mejora de las dotaciones de infraestructuras básicas necesarios para el desarrollo del turismo sirve también para dotar de los mismos servicios a la población autóctona favoreciendo su bienestar. Así se constata que, en un primer momento, la implantación turística empuja la mejora y adecuación de los servicios correspondientes a la nueva realidad económica, aunque a medida que la actividad se masifica puede llegar a generar excesiva presión, derivada del volumen de turistas y del crecimiento de la población asociada que reside en la zona, especialmente sobre las infraestructuras y servicios citados (de transporte, hidráulicos y energéticos). Se llega en muchos casos a la paradoja de la existencia de miles de hectáreas turísticas, o urbanizables, con agua, luz, alcantarillado y pavimentación, mientras que parte de la periferia de las ciudades y zonas rurales donde reside la población autóctona, se encuentran sin esos servicios, generando desequilibrios territoriales y sociales. A continuación se consideran los efectos sobre cada una de estos servicios, dotaciones e infraestructuras.

1. CICLO DEL AGUA. Los recursos hídricos son, al tiempo, un factor natural de atracción para el turismo (paisajes litorales y rurales ligados a la presencia del agua, el agua como adorno y elementos para unos asentamientos turísticos más amenos) y un recurso natural básico (abastecimiento) fundamental para la subsistencia y la salud, tanto para la población residente como para la turística, y también, por lo tanto, en los procesos de puesta en valor turístico de cualquier territorio. Es este último papel (recurso) el que genera mayor complejidad, tanto en las fases iniciales de desarrollo y diseño de las intervenciones, como en la de funcionamiento del destino. Constituye, por tanto, un factor esencial a considerar en la planificación del desarrollo turístico, sobre todo en ámbitos de escasez de agua y especialmente en espacios insulares, donde el problema central será la insuficiencia de la disponibilidad de recursos para satisfacer demanda de estos.

La escasez de recursos hídricos, la mala calidad del agua, el continuo incremento de las demandas de agua potable y los conflictos por su uso entre actividades, ha llevado a destinos eminentemente turísticos como las Islas Canarias, y en particular Lanzarote, donde la disponibilidad de agua potable, ligada al ciclo natural del agua es insuficiente para satisfacer la demanda, a apostar por sistemas de desalinización para compensar dichas insuficiencias. "El problema es hacer frente al coste de las infraestructuras, sobre todo su amortización y al elevado precio del agua producida, lo cual limita su utilización a actividades y ámbitos productivos capaces de afrontar altos costes del recurso" (Vera, F., 1997, pp. 273). Porque la producción de agua potable a través de la desalinización requiere importantes consumos energéticos, 
normalmente ligados a derivados del petróleo en las Islas Canarias, y lleva a un precio final del agua desalada que puede conducir a que actividades como la agricultura agonice frente al turismo, puesto que la constante apertura de nuevas plazas turísticas supone más exigencia en la producción de agua y por tanto ampliaciones en las dotaciones de infraestructuras de potabilización destinadas principalmente al abastecimiento turístico.

Por otro lado, se combinan otras soluciones a la escasez y búsqueda de la eficiencia en la aplicación y gestión de los recursos hídricos a través de la depuración terciaria de aguas residuales, que se destinan a usos en los que no es necesaria la calidad del agua potable, principalmente para la agricultura, jardinería y lavado de calles, con lo que contribuye al incremento de recursos disponibles, a la vez que a la disminución de la contaminación por vertidos.

Los indicadores que se utilizan para medir el efecto del turismo sobre este recurso son las variaciones que se producen al variar la demanda turística en la: producción total de agua potable $\left(\mathrm{Hm}^{3} / a n ̃ o\right)$, en la producción media diaria de agua $\left(\mathrm{m}^{3} / \mathrm{día}\right)$ por habitante residente (litros/residente*día) y en relación a población total que acoge a diario la isla (es decir residentes y turistas en litros/habitantes*día) y por tipo de producción (privada y pública). También se utilizan como indicadores las variaciones en el número de viviendas con agua corriente y en el consumo medio de agua por habitante (residentes y turistas) y día (litros/habitantes*día).

2. ENERGÍA. La implantación de actividades turísticas exige el incremento de la producción eléctrica y la ampliación de su red por los territorios de potenciales nuevos desarrollos turísticos y residenciales. Ello exige incrementar la producción energética, sobre todo en sociedades con economía inicial de base agraria, como la de Lanzarote, cuya oferta es insuficiente para responder a las necesidades que conlleva la incorporación de actividades turísticas. Será por tanto necesario medir los cambios en los siguientes indicadores energéticos: capacidad de producción o potencia instalada $(\mathrm{kw})$, producción de energía eléctrica disponible (kwh) y consumo eléctrico (kwh). Todos ellos en relación a la población residente, y al total de habitantes que, a diario, absorbe la isla (residentes y turistas).

El análisis ha de completarse observando la evolución de la intensidad o eficiencia energética (consumo energía en relación al PIB) derivado de las distintas fases de evolución turística, ya que un aspecto muy importante del consumo energético, como es el consumo de energías fósiles, y en particular del petróleo y sus derivados, son otros factores que afectan a sociedades receptoras, como las de Lanzarote, desde varios puntos de vista. Así, el incremento de la demanda de transporte (aéreo, marítimo y por carretera) generada por el turismo hace que se incrementen los 
consumos de petróleo y de sus derivados, aspecto que ligado a la casi total dependencia externa de las importaciones y precios de los mercados exteriores del petróleo, de España y Lanzarote, hacen que se incrementen los costes de transporte para el consumidor, lo que afecta tanto a la población turística, como a los autóctonos.

Si el territorio con desarrollo turístico no es productor de energía suficiente, está abocado a la absoluta dependencia de la oferta exterior y de sus fluctuaciones en los precios, lo que condiciona tanto la disponibilidad y precios para los residentes, afectando a su bienestar.

3. CARRETERAS Y TRANSPORTE. EI desarrollo del turismo ha estado íntimamente vinculado a los progresos en la tecnología del transporte y, en particular, al transporte aéreo y por carretera para el turismo de masas. La evolución de dicha tecnología, junto con la mejora y construcción de nuevas infraestructuras, ha llevado al abaratamiento de los precios de los viajes, lo que ha favorecido el incremento de las áreas emisoras y del número de desplazamientos por turismo, contribuyendo a la ampliación de los mercados de demanda y, consecuentemente, también a una mayor presión sobre la oferta de alojamiento y servicios turísticos y, en general, sobre todos los bienes y servicios de la sociedad anfitriona que deberán ser adaptados al nuevo volumen y tipo de demanda.

El desarrollo turístico de los territorios insulares depende, en primer lugar, de la disponibilidad de aquellas infraestructuras que permiten acceso, por aire y por mar. Por ello, estas infraestructuras y servicios de transporte asociados han sido de vital importancia para el crecimiento turístico. La utilización de las islas como espacios turísticos "es históricamente posterior a la funcionalidad de las costas continentales, y se ha producido, en buena medida gracias a las intensificaciones y mejora de las conexiones marítimas y aéreas que enlazan las tierras a un lado y a otro del mar" (Artigues, A., 2001, pp. 104). La aparición de líneas aéreas regulares de larga distancia, junto con la de líneas regulares de medio y corto recorrido y líneas chárter, que operan redes que trasladan a viajeros alrededor del mundo, han dominado el tráfico aéreo europeo de corto alcance por motivos vacacionales y turísticos. A través de ellas se han consolidado los destinos insulares como turísticos de masas y han impulsado la creación y ampliación de aeropuertos que puedan dar cobertura a su enorme tráfico, lo que puede derivar en la ampliación y mejora de las posibilidades de comunicación y de oportunidad de acceso a servicios de la población local.

Con respecto al transporte marítimo, la fuerte demanda de productos (cruceros, navegación deportiva, mercancías de consumo, etc.) que provoca la actividad 
turística, impulsa la ampliación de puertos como vía de entrada, no sólo de turistas, sino de recursos a los que la sociedad de acogida, por si sola, no puede responder, enriqueciendo y facilitando también el acceso a bienes de consumo de la población local, cuya importación sólo para ella implicaría costes mucho menos asequibles.

Las consecuencias en ambos casos del incremento turístico es el incremento de la capacidad de transporte en puertos y aeropuertos, y el incremento de los servicios asociados, utilizables también por parte de la población residente en las islas, que se aprovecha de los precios más reducidos que se derivan de las economías de escala producidas por la demanda turística.

No obstante, el factor esencial para viabilizar la explotación turística de las islas es la disponibilidad de una red de transportes terrestres (fundamentalmente carreteras y servicios de transporte público y privado) que provean de accesibilidad a los distintos puntos de la isla, tanto para el acceso a los recursos turísticos como para el acceso a los equipamientos, dotaciones, y ámbitos de ocio, por parte del turista; y de acceso a los puntos de trabajo y de residencia de los empleados ligados, directa o indirectamente, a estas actividades.

Por ello, las comunicaciones por carretera tienen una importancia fundamental en el estudio de los efectos del turismo sobre el territorio, pues no sólo las carreteras lo configuran, sino que establecen las posibilidades de movilidad y grado de accesibilidad de la población a los distintos puntos del mismo. Las necesidades ligadas al desplazamiento de los autobuses de uso turístico y al alquiler de vehículos privados han sido aspectos del servicio al turista que han impulsado la ampliación y mejora de las conexiones por carretera, afectando a la cantidad, calidad y capacidad de las vías. $Y$ el incremento de la movilidad por el crecimiento de la actividad turística tiene efectos de diferente signo sobre las posibilidades de acceso (que se mejoran) y condiciones de la movilidad de los residentes (que en muchas ocasiones se ven deterioradas) y, consecuentemente, estas variaciones afectan a su bienestar.

En lo que se refiere al transporte público por carretera, el crecimiento del turismo y de la población inmigrante asociada a esta actividad, tienen efectos sobre la oferta del transporte colectivo regular de pasajeros, ejerciendo presión para la ampliación y mejora de dicho servicio público de la que se beneficia también la población autóctona. Sin embargo la relación oferta/demanda final puede implicar empeoramiento de las condiciones de transporte y encarecimiento en sus precios. Aspectos ambos que afectan al bienestar de la población residente. 
En lo que se refiere a las condiciones de circulación del transporte privado por carretera, éste se incrementa tanto por el crecimiento de la población residente derivada de la inmigración generada por la actividad turística, como por los viajes generados directa o indirectamente por ésta y, en particular, por el tráfico asociado al alquiler de vehículos. Alquiler de vehículos que repercute directamente también sobre el índice de motorización, sobre todo en pequeños territorios turísticos como son las islas.

El conjunto de aspectos anteriores muestra que hay unos claros efectos del turismo sobre el sistema de transportes local, que tienen derivaciones sobre el bienestar de los residentes por su incidencia sobre aspectos como la dotación de carreteras y consecuentes niveles de accesibilidad; la variación en el parque automovilístico e índices de motorización; los niveles de servicio asociados a cambios en la intensidad media diaria de circulación; número de líneas de autobús; y, en síntesis, oferta de transporte público en relación a los residentes y a los viajeros potenciales (residentes y turistas).

F. Efectos sobre el alojamiento residencial. Los espacios destinados a acoger el equipamiento turístico y al turista, así como a la población inmigrante trabajadora que se pueda generar, constituyen centros que dinamizan el tejido local desde el punto de vista económico y social, ya que su urbanización, construcción y funcionamiento moviliza nuevas inversiones y recursos, generando las rentas correspondientes. Se convierten en zonas que concentren servicios, normalmente de calidad mejor que los preexistentes, y en ámbitos de atractivo residencial, tanto para la población local como para la inmigración nacional, europea y de terceros países, situación esta que será aprovechada por la industria inmobiliaria. Poco a poco pasan de ser zonas donde la concentración de población viene derivada del volumen de turistas a convertirse en polos de atracción para la localización de la vivienda habitual o de segunda residencia. Es por ello que la actividad turística, allá donde se asienta, tiene consecuencias en la valoración del suelo y en el precio de la vivienda, por tanto en la mayor o menor posibilidad de acceso a la misma (ya sea vivienda habitual o segunda residencia), tanto en alquiler como en propiedad para la población residente, así como en el incremento de la demanda de alojamiento residencial. $Y$ debemos tener en cuenta que el acceso a la vivienda constituye unos de los aspectos claves del bienestar, aunque el mismo viene asociado a la relación entre precio de la vivienda y la renta disponible de los demandantes. Es por ello que los efectos se evalúan a través de indicadores como la evolución de la oferta y demanda de vivienda residencial, el tipo de tenencia (alquiler y propiedad) o los índices de acceso (el cociente entre salario y precio medio de las viviendas).

G. Efectos sobre las Tecnologías de la Información y de la Comunicación (TIC). Los cambios que se producen como consecuencia de la actividad turística vienen también 
asociados a las demandas que la misma requiere para considerar atractivo un determinado destino. Por ello, tras la generalización del uso de las TIC a partir de inicios de la década de los noventa, estos servicios han pasado a ser elementos progresivamente incorporados a la oferta turística convencional, lo que también ha repercutido en el acceso a los mismos por parte de la población residencial, que se ha visto así indirectamente favorecida por la cantidad y calidad de los servicios ofrecidos al turista, mejorando su condiciones potenciales de bienestar. La incorporación de nuevos servicios asociados a las TIC no sólo se convierte en un indicador de desarrollo territorial, sino que también beneficia a la población local que puede acceder a estos servicios por la influencia de la actividad turística, antes que territorios semejantes que no cuentan con dicho tipo de actividad, beneficiándose de las aportaciones al bienestar que proporciona unos buenos servicios e infraestructuras de telecomunicaciones. En concreto, una de las dimensiones asociadas al cambio tecnológico y al bienestar objetivo es la penetración de Internet en la sociedad, puesto que es el representante más destacado de la nueva generación de tecnología que aparece a finales del siglo XX (OSE ${ }^{61}, 2005$, pp. 187). Para medir este efecto se utilizan indicadores como el número de hogares que poseen conexión a la red y la penetración de Internet en las empresas.

H. Efectos sobre los precios. Al turismo también se le atribuyen efectos sobre los precios y la calidad de los productos de los servicios disponibles para el consumo en las zonas receptoras, ya que la demanda turística y de la población inmigrante asociada a esta actividad, compiten con la demanda local autóctona, disminuyendo el abastecimiento disponible de bienes para la población autóctona e incrementa sus precios, afectando al acceso a los mismos (Kadt, E., 1991, pp. 87) ${ }^{62}$. Paradójicamente, las mejoras en el bienestar producidas por el incremento de puestos de trabajo, tiene como contrapunto las pérdidas derivadas de la elevación de los precios de los alimentos y de la vida en general, debido, por un lado, al abandono de las producciones agrícolas locales (cuya mano de obra se localizará en trabajos mejor pagados dentro del sector turístico y que requieren menor esfuerzo) convirtiéndose en zonas importadoras de productos básicos; y por otro debido al incremento de la demanda derivada de la presión demográfica

61 Observatorio de la Sostenibilidad en España.

62“El flujo de mano de obra que sale de la agricultura hacia los puestos de trabajo mejor pagados en la construcción y el turismo en el caso de las Seychelles puede haber tenido cierta influencia en la elevación de los precios de los alimentos en aquella zona durante la rápida expansión del turismo (...), en parte como resultado del declive de la actividad agraria a medida que los agricultores se pasaron a los empleos mejor pagados en el sector del turismo y fueron sustituidos por emigrantes menos cualificados. Presumiblemente (...), las mejoras del bienestar producidas por la abundancia de puestos de trabajo contrarrestó las pérdidas debidas a la elevación de los precios de los alimentos, aunque los efectos sobre los grupos más pobres de la población bien podrían haber sido negativos. Además, las fluctuaciones estacionales del turismo podrían provocar ciclos estacionales en los precios de la alimentación”. Kadt, E., 1991, pp. 87. 
(Mazón, T., 2001, pp. 122-123) que asume la zona y que establece el nuevo orden basado en la actividad turística.

Así pues, el turismo normalmente es, por un lado, un factor de incremento de la inflación (Mathieson, A. y Wall, G., 1990, pp. 73 y 115) en la economía de sociedades anfitrionas, por incremento de la demanda de consumo y por depender del abastecimiento de mercancías importadas ${ }^{63}$, pues, en palabras de Sadler y Archer (1974, pp. 5) "las economías de los países en vías de desarrollo están frecuentemente incapacitadas para abastecer la cantidad y calidad de mercancías y servicios requeridos que satisfagan las demandas creadas por el turismo internaciona ${ }^{p 4}$, como puede ser el caso de las Islas Canarias. Y, por otro, de la elevación del valor de la tierra, puesto que el turismo incrementa la competencia por la tierra, al elevar los precios de ésta y alentar las ventas para las infraestructuras, urbanizaciones y servicios necesarios, con lo cual contribuye a fragmentar la posesión de tierras. "La tierra se vende en unidades más pequeñas y a precios más altos, lo que contribuye a la inflación. Las víctimas de esta inflación son los jóvenes residentes que tratan de comprar terrenos o casas" (Mathieson, A. y Wall, G., 1990, pp. 112 y 116).

Los municipios turísticos son más caros en la oferta inmobiliaria, en los impuestos municipales, en los servicios que ofrecen, etc.

Otro factor que tiende a elevar la inflación, sobre todo en las islas pequeñas, es el establecimiento de monopolios, que reducen la diversidad del abasto local, en alimentación, materiales de construcción, etc., lo que origina la falta de competitividad e incremento de los precios.

La inflación eleva el coste de la vida para la población residente y reduce la proporción de ingresos disponibles para otro tipo de adquisiciones que no sean básicas (vivienda, alimentación, energía, etc.). Consecuentemente genera efectos de malestar social, y "no se ha registrado el grado en que el incremento del precio inflacionario se compensa por medio de beneficios económicos, como la expansión de empleo e ingreso" (Mathieson, A. y Wall, G., 1990, pp. 116).

\footnotetext{
${ }^{63}$ Lundberg (1972, pp. 137), citó a Hawai como ejemplo e indicó que los diferentes tipos de establecimiento tienen distintas tendencias a importar. La tendencia total de importación para Hawai es del 45\%. (recogido por Mathieson, A. y Wall, G., 1990, pp. 82)

${ }^{64}$ Recogido en Mathieson, A. y Wall, G., 1990, pp. 83.
} 
Las variaciones en el IPC nos permitirán saber la evolución de los precios de los bienes y servicios que generalmente adquieren los consumidores, reflejando cómo se ha encarecido la vida y se ha reducido la capacidad adquisitiva real de la población.

I. Efectos sobre la seguridad. El turismo de masas tiene repercusiones sobre la percepción social de la seguridad que tiene la población anfitriona, debido a los efectos del volumen de visitantes con culturas diferentes, como del incremento de población residente, principalmente por inmigración de mano de obra. El resultado es, con frecuencia, un aumento considerable de conflictividad y de la delincuencia, y con ello de una merma del bienestar local. Sin lugar a dudas, los cambios en la estructura social que genera esta actividad masiva supone un crecimiento de la pauperización social y con ello de la delincuencia, pudiendo encontrarse, en parte, explicaciones de la inseguridad y del incremento de los delitos en el incremento de los grupos de población asociados a condiciones de pobreza.

Lo cierto es que ciertos territorios, principalmente en el caso de isla, pasan de ser rurales a adquirir las características urbanas de forma rápida, tras la implantación masiva de la actividad turística, lo que conlleva, al menos, modificaciones en las tipologías delictivas, apareciendo nuevos tipos de delitos que no estaban registrados anteriormente, puesto que no son propios de sociedades rurales.

El crecimiento positivo o negativo de la inseguridad se estima a partir de indicadores como el número de delitos por cada cien habitantes, y el estado de la pobreza (hogares por debajo del umbral de la pobreza).

J. Efectos sobre el medioambiente natural. Los componentes ambientales son aquellas condiciones o atributos que cuantitativa y cualitativamente conforman el espacio geográfico, lo diferencian y lo diversifican. Muchos de estos componentes naturales que constituyen a priori recursos turísticos potenciales, que se unen a algunos de los culturales específicos de un territorio que también son objeto de valoración como recurso turístico (gastronomía, fiestas, patrimonio arquitectónico, etc.) y que intervienen en los procesos de producción y consumo para la actividad turística. Ambos adquieren el rango de recurso económico cuando se les adjudica un valor social y turístico, actuando como factor que conduce a diferentes formas de explotación (Vera Rebollo, F., 1997, pp. 64). En el caso de la transformación turística de espacios como las Canarias o Lanzarote, los elementos fundamentales significativos en la rápida dinámica de transformación territorial han sido básicamente los ambientales (sol y playa), viéndose afectados por el mismo, sin embargo, un mucho más amplio conjunto de recursos naturales que el turismo transforma, afectando al entorno y bienestar de la población residente. Esta 
transformación tiene aspectos positivos y negativos sobre el medioambiente que la acoge. En términos generales se pueden señalar los siguientes:

a) positivos: el turismo proporciona un incentivo para restaurar elementos del patrimonio territorial (naturales y culturales) como son los monumentos antiguos, los tesoros arqueológicos, la conservación de recursos naturales como los integrados en la Red Natura 2000, o el paisaje natural y construido (principalmente del medio rural). Ello implica destinar medios económicos con sus correspondientes consecuencias no sólo ambientales y territoriales, sino también socioeconómicas en términos de empleo, renta, etc.

b) negativos: el turismo de masas significa congestión (por el elevado volumen de personas, que visitan y que son atraídas por la demanda de mano de obra), ruido, basura, ruptura con el ciclo de vida animal, pérdidas de endemismos vegetales y animales, incremento de los vertidos contaminantes al mar, destrucción de playas, etc.

Bosch, R y otros (2001, pp. 43) establece tres categorías básicas de recursos que utiliza el turismo y que por añadidura serán afectados por él:

1) Territorio y paisaje (para situar equipamientos e infraestructuras necesarias).

2) Vectores ambientales (que suponen el soporte de numerosos procesos y que pueden resultar contaminados, por ejemplo el agua).

3) Comunidades naturales (como consecuencia de acciones directas (destrucción) o indirecta por alteración de las condiciones ambientales).

Estos autores señalan los principales impactos que sobre los recursos naturales pueden acontecer en un destino turístico de sol y playa, entre los que se encuentran los siguientes en líneas generales (pp. 44-45): 
Tabla 1. Impactos del turismo sobre los recursos naturales en destinos de sol y playa

\begin{tabular}{||l||l||}
\hline \hline RECURSO & IMPACTO \\
\hline \multirow{3}{*}{$\begin{array}{l}\text { Suelo y } \\
\text { Territorio }\end{array}$} & $\begin{array}{l}\text { Cambios de uso del suelo; pérdida de diversidad, destrucción y alteración de la vegetación, } \\
\text { flora y fauna (interior y de litoral), e introducción de especies extrañas; Modificación, } \\
\text { alteración y banalización del paisaje; consumo de agua, reducción de carga de acuíferos; } \\
\text { cambio de la dinámica del litoral, regresión de playas; destrucción de duna; generación de } \\
\text { residuos y contaminación, etc. }\end{array}$ \\
\hline \multirow{2}{*}{ Aguas litorales } & $\begin{array}{l}\text { Contaminación química, microbiológica, por hidrocarburos; destrucción de vegetación y } \\
\text { fauna marina, etc. }\end{array}$ \\
\hline Atmósfera & $\begin{array}{l}\text { Incremento de la contaminación atmosférica; contaminación acústica; emisión de gases y } \\
\text { olores. }\end{array}$ \\
\hline Comunidades naturales & $\begin{array}{l}\text { Pérdida de valor ecológico: pérdida de biodiversidad, reducción de especies locales, } \\
\text { erosión, incendios, etc. }\end{array}$ \\
\hline \hline
\end{tabular}

Fuente: Elaboración propia a partir de Bosch, R., 2001.

La medición de los efectos medioambientales es actualmente importante para el bienestar, pero también entraña gran complejidad, en la medida en que es necesario conocer los límites del territorio que se analiza - capacidad de carga de un determinado nivel de uso a partir del cual se inicia un proceso de degradación y pérdida que puede ser irreversible para poder evaluar la gravedad de su estado.

Para el diagnóstico medioambiental de las sociedades de economía turística, podemos señalar, a modo de ejemplo, los indicadores siguientes, orientados y seleccionados a partir de los indicadores que presenta el Observatorio de la Sostenibilidad en España (OSE):

Tabla 2. Indicadores medioambientales para territorios turísticos

\begin{tabular}{|c|c|}
\hline AIRE & $\begin{array}{l}\text { Emisiones de gases de efecto invernadero, por sectores y total: } \mathrm{CO}_{2}, \mathrm{~N}_{2} \mathrm{O}, \mathrm{CH}_{4}, \mathrm{HFC}, \mathrm{PFC} \text {, } \\
\mathrm{SF}_{6} \text {. }\end{array}$ \\
\hline SUELO & $\begin{array}{l}\text { Superficie urbanizada }\left(\mathrm{km}^{2}\right) \text {, superficie urbanizada en el litoral }\left(\mathrm{km}^{2} \text {, franje de } 1 \mathrm{~km} \text { desde la }\right. \\
\text { línea de costa). }\end{array}$ \\
\hline RESIDUOS & $\begin{array}{l}\text { Generación de residuos urbanos y peligrosos por sectores de actividad y total (t); Kilos de } \\
\text { basura por habitante y día; ratio kilos de basura al año/total de residentes y total de turistas. } \\
\text { Vertidos de aguas residuales al mar ( } \mathrm{hm}^{3} / \text { año), cantidad de residuos, urbanos entrados a } \\
\text { vertedero/sin tratamiento previo (\%) y controlados (\%), vertidos incontrolados, incineración (con } \\
\text { y sin recuperaron de energía), residuos que van a plantas de triaje y compostaje, reciclados } \\
(\%) \text {. }\end{array}$ \\
\hline $\begin{array}{l}\text { AGUA Y } \\
\text { BIODIVERSIDAD }\end{array}$ & $\begin{array}{l}\text { Calidad de aguas continentales y marinas; superficie protegida }\left(\mathrm{km}^{2}\right) \text {. especies protegidas, } \\
\text { especies amenazadas; Índice de estado de la biodiversidad; }\end{array}$ \\
\hline
\end{tabular}

Fuente: Elaboración propia a partir de OSE, 2005. 
Para el caso de Lanzarote, es pertinente referirse a los trabajos realizados para la declaración de Reserva de Biosfera para la Isla, y el seguimiento de indicadores mantenido para la misma como una aproximación a la evaluación y seguimiento de estos efectos.

\section{3.- LOS AGENTES SOCIALES}

Zapata, $M^{a}$. J., (2003, pp. 213$)^{65}$ nos dice que todo agente social turístico puede ser descrito genéricamente, como la persona, grupo o institución con poder para generar un efecto sobre la actividad turística, es decir, con capacidad para intervenir, modificar o influir en el curso del sector y, por ello, con enorme relevancia, en aquellos destinos donde la principal y casi única fuente de ingresos económicos sea el sector turístico. Son, por tanto, sujetos con capacidad de influencia en la toma de decisiones que afectan a la colectividad social, con «poder» de presión y de actuación.

Organismos internacionales, Patronatos de promoción turística, Comunidades Autónomas, Cabildos, Ayuntamientos, asociaciones de empresarios turísticos, sindicatos, tour operadores, comerciantes, turistas y residentes, etc., son algunos de los componentes del sistema turístico, que constituyen agentes sociales, estableciéndose entre ellos complejas relaciones e intercambios que suponen su fuerza motriz. Trataremos aquí algunos, tanto públicos como privados, que han sido muy significativos en la incorporación, extensión y consolidación de la actividad turística en el territorio nacional e insular.

\section{1.- LOS ORGANISMOS INTERNACIONALES}

A escala internacional, y una vez acabada la Segunda Guerra Mundial, fue preciso aunar los esfuerzos para suprimir las múltiples barreras que el conflicto había levantado, sin los protagonistas que llevaron a cabo estos esfuerzos no hubiese podido arrancar el turismo.

Las organizaciones y asociaciones internacionales relacionadas con su despegue y desarrollo son de diverso tipo, tanto por su carácter público como privado, así como por su ámbito geográfico. En el marco mundial y europeo podemos citar las siguientes: la Alianza Internacional de Turismo (AIT), la Organización de Cooperación y Desarrollo Económico (OCDE), la Unión Europea (UE), la Comisión Europea de Turismo (ETC), la Organización Internacional del Trabajo (OIT), la Organización de Naciones Unidas (ONU) y la Organización Mundial de Turismo (OMT), la Organización de Aviación Civil Internacional

65 Zapata, Ma . J. (2003). "Los agentes turísticos: una aproximación desde la sociología y la ciencia política". Capítulo 8. En Rubio A., (coord.), (2003). "Sociología del Turismo". Editorial Ariel, Barcelona. 2003. 
$(\mathrm{OACl})$, la Organización Marítima Internacional (OMI), la Asociación Mundial de Agencias de Viajes (WATA) y la Asociación Internacional de Hostelería (AIH), entre otros.

En las próximas líneas trataremos brevemente algunas de ellas, incidiendo en la aportación de la ONU y la OMT, y en varias de las conferencias y cumbres a través de las cuales estos organismos van a alabar las cualidades de la actividad turística y presionar a los Estados para que la permitan y la regulen internamente:

1. Alianza Internacional de Turismo (AIT). Es uno de los organismos más antiguos, fue fundada en la última década del siglo XIX y reestructurada en 1919. Tiene sede en Ginebra. Sus funciones son las de estudiar las cuestiones relativas al turismo internacional y sugerir reformas, alentar el desarrollo del turismo y todas las materias relativas al transporte, seguridad, protección del consumidor y defensa de los intereses de las asociaciones turísticas.

2. Organización de Aviación Civil Internacional (OACI). Creada en 1945, con sede en Montreal (Canadá), con el propósito de promover la aviación civil a escala mundial y establecer normas internacionales en este campo. Es una agencia especializada de Naciones Unidades y consta de 161 miembros, todos ellos gubernamentales. Tiene establecido, entre otras cosas, los derechos de tráfico y los principios de libertad aérea. Es por ello que tuvo un importante papel en la conformación del turismo de masas, donde la libertad aérea y la mediación y reducción de posibles conflictos entre países era necesaria para garantizar la seguridad e incentivar así los viajes.

3. Asociación Internacional de Transporte Aéreo (IATA), creada en 1945, es de carácter privado, a diferencia de la anterior. Tiene sus sedes en Ginebra (Suiza) y Montreal (Canadá). Puede ser miembro de ella cualquier compañía aérea encargada por un Gobierno de explotar un espacio aéreo de forma regular. Dentro de sus funciones está: a) establecer la cooperación entre compañías en cuanto a servicios, liquidación de billetes, tarifas, etc.; b) intervenir y regular los servicios de tráfico de pasajeros, equipajes, carga, etc.; c) homogeneizar las informaciones de los servicios aéreos en cuanto a horarios y tarifas, y actuar en el campo de la seguridad aérea; d) servir de marco en las negociaciones de acuerdos intergubernamentales, etc.; Todas estas funciones han sido de gran importancia en el despegue del turismo de masas, desde de la Segunda Guerra Mundial, ante el factor de seguridad que necesita el viajero-turista, la regulación de tarifas y su reducción para motivar el viaje en masa.

4. Asociación Mundial de Agencias de Viajes (WATA), creada en 1945, con sede en Ginebra, tiene como objetivo el fomento del turismo y de los viajes organizados: 
recopilar y difundir información del sector; asesorar a organizaciones e instituciones nacionales de turismo de todo el mundo; favorecer intereses económicos de sus miembros, así como el intercambio de servicios entre ellos.

5. Asociación Internacional de Hostelería (AIH), nace en 1946, con sede en París, tiene como objetivo el estudio y progreso de la hostelería, la mejora de la calidad de los servicios, la formación y perfeccionamiento del factor humano en el sector, y el intercambio de estudiantes.

6. Organización de Cooperación y Desarrollo Económico (OCDE), fundada en 1960, en París, por una convención intergubernamental de 18 países europeos, incorporándose posteriormente países de otros continentes. Sus objetivos son, básicamente, fomentar el desarrollo económico y social de los países miembros y realizar estudios periódicos sobre la situación económica de los mismos y del resto del mundo, a través de una serie de indicadores. Intenta diagnosticar los problemas económicos y sociales y formular previsiones futuras. Los países que la forman son los principales países turísticos del mundo, tanto por la importancia de los ingresos como de los gastos del turismo internacional.

7. Organización de Naciones Unidades (ONU). Fundada en 1945, por 51 países, al finalizar la Segunda Guerra Mundial, con la firma de la Carta de Naciones Unidas, es la mayor organización internacional existente, se define como una "Asociación de Gobiernos Global" que facilita la cooperación en asuntos como Derecho Internacional, la Paz y seguridad internacional, el desarrollo económico y social, los asuntos humanitarios y los derechos humanos. Su contribución al crecimiento de la actividad turística en cuanto vía al desarrollo aparece principalmente en 1963, cuando se celebra, en Roma, la Conferencia de Naciones Unidades sobre viajes internacionales, en ella: a) se reconoce el importante papel que juega el turismo en el plan nacional e internacional por el hecho de las ventajas económicas que proporciona a los países que de él se benefician, aumentando sus entradas de divisas y estimulando el comercio internacional; b) contribuye al afianzamiento de la economía de los países en vías de desarrollo, impulsando la diversidad de actividades económicas, la creación de nuevas posibilidades de empleo, y alentando la creación de industrias autóctonas; c) aporta al desarrollo del entendimiento y comprensión internacionales; d) recomienda que los Gobiernos alienten la creación de agencias de viajes y les reconozcan un estatuto profesional; e) que se reconozca y apoye, por la ONU, a la Unión Internacional de los Organismo Oficiales de Turismo (U.I.O.O.T) como su instrumento principal para la promoción del turismo (actualmente Organización Mundial del Turismo-OMT); f) pide la conservación de patrimonio natural, histórico y cultural de los países por su valor 
turístico; g) considera la importancia de la disminución de los precios internacionales en todos los medios de transporte y solita tarifas más bajas, indispensables para el desarrollo continuo del turismo; h) para lograr el éxito de los programas de desarrollo turístico ve necesario que los Gobiernos alienten el apoyo de la actividad en la opinión pública.

Entre las acciones que lleva a cabo la ONU, que hayan constituido un hito en la historia de la política turística internacional, encaminada a despertar la conciencia turística, es la declaración del Año Internacional del Turismo, en 1967, cuyo lema será «Turismo, pasaporte para la Paz», a partir del cual, su Asamblea General acuerda lo siguiente:

- Las comisiones regionales emprenderán programas duraderos de cooperación en el campo de la promoción.

- Cada país ha de consolidar las medidas que ha introducido tanto en el campo de la facilitación como en el de promoción.

- Cada país ha de continuar la acción, ante sus administraciones competentes, dirigida a aligerar las formalidades oficiales de los viajes.

- Cada organismo nacional de turismo ha de reforzar los lazos de cooperación del sector.

- Que el emblema del Año Internacional del Turismo continúe siendo utilizado tanto por los organismos nacionales de turismo como por los operadores privados y que llegue a ser el signo distintivo de todas las actividades turísticas.

A través de diferentes conferencias y cumbres internacionales desde la segunda mitad del s. XX hasta nuestros días, y en cooperación con la Organización Mundial del Turismo, aportará apoyo y propuestas de gestión a los territorios turísticos.

8. Unión Internacional de los Organismo Oficiales de Turismo (UIOOT) es un organismo intergubernamental que se crea en 1945, pasando a ser la Organización Mundial de Turismo (OMT) en 1974. Quedará vinculado a Naciones Unidas en 1976, transformándose en agencia ejecutiva del Programa de Naciones Unidas para el desarrollo (PNDU). Caminará hacia convertirse en un órgano especializado de Naciones Unidades en el s. XXI, ingresando dentro de la misma en el año 2003. A lo largo de estas décadas ha tenido como objetivo la promoción del turismo aunque sus políticas han ido cambiando en relación a las perspectivas que de la actividad se iban abriendo. En la década del setenta, y parte de la siguiente, promueve el derecho a las vacaciones, los derechos laborales de los profesionales del sector y la profesionalización; en los noventa fomentaron el turismo como fuente de creación 
de empleo, defendiendo la importancia de incluir al sector privado en las políticas de turismo; entra en el nuevo milenio con el objetivo de evitar los efectos negativos del desarrollo turístico, como la sobreexplotación de recursos, fomentar el turismo sostenible y las nuevas tecnologías. El acceso universal al turismo ha estado siempre entre sus objetivos, junto a la atención del desarrollo de los países a través de esta actividad, del desarrollo de un código ético turístico entre los países miembros y observando los efectos económicos, sociales y culturales que la actividad produce, para dirigir sus propuestas a que éstos sean positivos y minimizar sus efectos negativos. Su importancia e influencia en las perspectivas europeas e internacionales sobre el turismo ha ido crecimiento en estas décadas, contando en la actualidad con 160 países miembros y más de 350 afiliados representantes del sector privado.

9. Comisión Europea de Turismo (ETC). Creada en 1948, con sede en París y formada por las organizaciones turísticas nacionales de 33 países europeos. Es una asociación voluntaria que agrupa a las Oficinas Nacionales de Turismo. Desde su creación se orientó hacia la toma de conciencia por parte de los Gobiernos de la importancia del turismo para sus economías nacionales paralizadas por la Segunda Guerra Mundial como principal prioridad. Así, ha contribuido al desarrollo de una actitud de cooperación internacional, de acción colectiva y de solidaridad europea. Tiene por tanto, como objetivos principales aumentar los flujos turísticos hacia Europa, que provienen de otros continentes, a través de la estrategia de mercado, y constituir un forum que permita a sus miembros intercambiar ideas y experiencias, dentro de los intereses de cada uno y en el del conjunto. Opera sobre los mercados transoceánicos, que proveen la mayor parte de la clientela, a través de los "grupos de operaciones" constituidos por los representantes en el extranjero de los Organismos Nacionales de Turismo.

10. Unión Europea (UE). Aunque el turismo se cita en el tratado fundacional (Tratado de Roma, 1957), no se le dio gran importancia y por tanto prioridad como subsector económico del sector terciario. No será hasta la década del noventa cuando la Unión se embarque en revisiones sobre este subsector económico, aunque las reflexiones sobre el mismo comenzarán a principios de los ochenta. En 1982, la Comisión de Turismo presenta al Consejo de Ministros de la Unión orientaciones para una política comunitaria del turismo (Diario Oficial del UE, $N^{\circ} \mathrm{C} 115 / 2$ de abril de 1984), con el objetivo de aumentar la eficacia de las políticas nacionales con una acción concertada. Se trata de escalonar la temporada turística, salvaguardar el patrimonio arquitectónico, desarrollar actividades turísticas en las regiones desfavorecidas y promover el turismo social, cultural y rural. Estos temas seguirán preocupando en los años siguientes, hasta la declaración en 1990 del "Año Europeo del Turismo", cuyo principal objetivo fue motivar a los ciudadanos europeos a hacer 
turismo en todas las estaciones del año, basándose en el turismo cultural, social y rural. La década del noventa estará llena de acciones, entre la que destaca la elaboración del Libro Verde del Turismo (1995). A partir de aquí, el Consejos de Ministros de la Unión adopta una serie de recomendaciones y directivas en relación a (Montaner, J., 1998, 54-55): a) información estandariza de los hoteles; b) seguridad de los hoteles contra riesgos de incendio; c) mejor reparto estacional y geográfico del turismo; d) viajes, vacaciones y circuitos combinados; y e) la multipropiedad o "time sharing". Posteriormente a esto, la UE también va a tomar otras medidas, muchas de ámbito normativo, que afectan a los países que conforman la Unión, destacamos las siguientes: política de libre circulación y protección de turistas, derecho al establecimiento y libre prestación de servicios en el mercado único (empresas turísticas), libre circulación de trabajadores, política de transporte en relación a la liberalización del mismo (aéreo, ferroviario y marítimo), política regional y desarrollo del turismo en zonas desfavorecidas, armonización fiscal en especial sobre el Impuesto del Valor Añadido en agencias de viajes y establecimientos hoteleros y política de protección a los consumidores turistas.

Por otro lado, el impulso del turismo hacia el turismo de masas se ve reflejado en una serie de Declaraciones y Cartas elaboradas entre la década del sesenta y el ochenta. En las próximas líneas se citan algunas de las principales, brevemente, puesto que constituyen discursos internacionales que influyen en las políticas nacionales de desarrollo económico a través de la actividad turística.

1. Declaración Universal de los Derechos del Humanos (1948), reconoce, en su punto quinto, el derecho al cambio de residencia y de trabajo, al desplazamiento y a los viajes. Es la llamada «quinta libertad» del mundo moderno, que incorpora la libre decisión humana de viajar. El turismo va a entrar así en la Carta de Naciones Unidas como uno de los inalienables poderes de la humanidad.

2. Declaración de Río de Janeiro (1972). Es la primera reunión del Congreso Interamericano de turismo. Considera el turismo como una fuerza cultural, económica y social cuyo impacto en todos los sectores de la sociedad es reconocido universalmente, además de contemplar objetivos de paz y cooperación. Por ello, los programas de turismo deben integrarse en el proceso de desarrollo económico y social, racionalizando las inversiones en el sector e impulsando la creación de nuevas zonas turísticas, potenciando la comercialización de este producto en todo el mundo, estimulando la iniciativa pública y privada. Además, esta Declaración llama la atención sobre la necesidad de poner en ejecución programas multinacionales que estén destinados a contrarrestar los problemas derivados del turismo masivo, tales como la contaminación del medio ambiente, y contribuir a la conservación y valorización del patrimonio histórico, artístico, arqueológico y paisajístico, 
procurando integrar dichos programas en los planes de desarrollo de los Estados Americanos.

3. Declaración de Puerto Plata (1973). Celebrada en la República Dominicana, contiene una serie de fórmulas que pueden ser aplicables a cualquier país que espere lograr con el turismo la salida al subdesarrollo. Entre ellas están las siguientes: a) el turismo debe entrar en la política de desarrollo del país como un sector prioritario; b) las divisas que proporciona son recursos de propiedad exclusiva de la nación y es necesaria su captación integral; c) debe crearse un Plan Nacional de Turismo, específico para este desarrollo, dentro del Plan Nacional de Desarrollo Económico y Social; d) dicho Plan determinará las acciones de promoción y de organización legal y administrativa y las prioridades; e) habrá un organismo encargado del sector, el Organismo Nacional de Turismo, al que se les asignarán recursos suficiente y se le dotará de autoridad, de la capacidad para promover la legislación necesaria y hacer observancia de su cumplimiento. (Fernández Fuster, L. 1991, pp. 947)

4. Año Europeo del Patrimonio Cultural (1975), promovido por el Consejo de Europa, cuyo fin fue hacer campaña para suscitar el orgullo e interés de los pueblos europeos con vistas a su patrimonio arquitectural y exigir la toma de medidas para la conservación de ese patrimonio (leyes, reglamentos, adaptación de presupuestos, etc.).

5. Conferencia de Helsinki (1975). Participan treinta y cinco Estados y contiene principios generales y específicos para las dos políticas representadas por el bloque occidental americano y el soviético. En lo que aquí respecta, incluyó una declaración sobre turismo. Reconoce la contribución del turismo internacional en el desarrollo de la mutua comprensión entre los pueblos y para el progreso económico, social y cultural, así como las múltiples interrelaciones que se dan entre desarrollo turístico y las medidas para otras áreas de la actividad económica. Expresan la intensión de favorecer el crecimiento de la actividad a través de múltiples acciones: desarrollo de infraestructura turística, proyectos turísticos conjuntos, intercambio de información (desde legislación hasta estudios, estadísticas y documentación turística), facilitar la actividad de agencias de viajes extranjeras y compañías de transporte de pasajeros y promover conferencias y simposios sobre planificación y desarrollo del turismo. En palabras de Fernández Fuster, L. (1991, pp. 949), el acuerdo al que se llega en esta conferencia, en materia de turismo, "quedaría como un documento de intenciones entre las que destaca una cierta insistencia sobre la labor cooperativa entre los países que los firman en el campo de la investigación y facilitación del viaje".

6. Declaración de Manila (1980). Nace de la Conferencia Mundial de Turismo, celebrada en Filipinas en la fecha señalada. Es convocada por OMT, con la 
participación de 107 países y tendrá como objetivo esclarecer, por un lado, la naturaleza auténtica del turismo en todos sus aspectos y, por otro lado, la función que éste está llamado a desempeñar en un mundo dinámico y profundamente cambiante, además de examinar las responsabilidades de los Estados en el desarrollo y la expansión del turismo en las sociedades modernas. Conscientes de que el turismo mundial sólo puede florecer si está basado en la equidad, la igualdad soberana, la no interferencia en asuntos internos y la cooperación entre los Estados, cuyo objetivo último es mejorar la calidad de vida de todos los pueblos, las declaraciones que recoge girarán en este orden de ideas, incidiendo en su capacidad para crear empleo, en la necesidad de mejorar las prestaciones laborales de los trabajadores del sector, la profesionalización del mismo, el respeto a la personalidad de los pueblos, evitar el que se convierta en una amenaza para los intereses sociales, económicos, medioambientales, para el patrimonio cultural e histórico. Por otro lado, los recursos turísticos se consideran patrimonio de la humanidad y por tanto las comunidades nacionales y la comunidad internacional entera deben desplegar los esfuerzos necesarios para su preservación y el necesario control de los mismos.

7. Reunión Mundial de Turismo (1982). Dos años después de la Declaración de Manila, la OMT, convoca en México una reunión internacional en la que participarán 79 países y 57 delegados observadores, su finalidad es aplicar progresivamente los objetivos fijados en la Declaración de Manila.

8. Declaración de la Haya sobre Turismo (1989), establece un decálogo de principios sobre el turismo. Sintetizando las ideas principales que recoge, señalamos lo siguiente: a) el turismo como fenómeno cotidiano y esencial en la vida de los hombres, junto con el derecho al descanso y el disfrute del tiempo libre y la misión de los Gobiernos para garantizar la paz y seguridad nacional imprescindible para el desarrollo turístico y facilitar los viajes (I, V, VI, VII); b) el turismo como un instrumento de crecimiento socioeconómico y de economía autosuficiente para los países que lo acogen. Recomendando: construir una infraestructura sólida, incluir el turismo en un Plan de desarrollo integral y conseguir que los planes rectores regionales den lugar a un crecimiento equilibrado e integrado, que beneficie a toda la comunidad local, teniendo presente la capacidad general de absorción turística territorial y sociocultural (II); c) la gestión racional del turismo puede contribuir considerablemente a la protección y mejora del entorno físico y del patrimonio cultural, así como el aumento de la calidad de vida. La planificación integrada y el desarrollo sostenible son esenciales para alcanzarlo (III); d) La calidad del servicio es fundamental, para ello se hace necesario, entre otras cosas, educar a la población en general y formar profesionales. 
Esta declaración incide enormemente en aspectos relativos a la seguridad del turista, a la calidad de los servicios que se le prestan y en general a su bienestar, por tanto las medidas a tomar por los Gobiernos, irían principalmente hacia el factor turista.

9. En 1992 las Naciones Unidas (ONU) celebró una Cumbre de la Tierra ${ }^{66}$ en Río de Janeiro, Brasil. Los documentos que surgieron de la Cumbre fueron la Declaración de Río, la Las recomendaciones enunciadas en el Programa 21 están destinadas a los gobiernos y las empresas. Entre las medidas que el Programa pide tomar a la industria de viajes estás las siguientes: aumentar el reciclaje, la reutilización de residuos y su reducción, la gestión y protección de las aguas, aumentar la conciencia ambiental, y establecer políticas en todo el mundo. La Declaración y el Programa son los documentos en los que la mayoría de las políticas relacionadas con el medio ambiente y el Eco-Turismo, desarrollados después de 1992, se basan.

10. Carta del turismo sostenible (1995). Conferencia mundial de turismo sostenible. Celebrada en 1995, en España. Reconoce no sólo las grandes ventajas del turismo en el ámbito socioeconómico y cultural sino también su contribución a la degradación medioambiental (puesto que los recursos en los que se basa son frágiles), y a la pérdida de la identidad local, por lo que deberá ser abordado de una forma global. Por ello instan a los Gobiernos, profesionales, asociaciones de todo tipo relacionadas con el turismo, y a los propios turistas, sobre la base de la necesidad de desarrollar un turismo que satisfaga las expectativas económicas, las exigencias ambientales y el respeto a las poblaciones locales en este final de siglo, a adoptar una serie de principios que resumimos brevemente: 1) el desarrollo turístico a de hacerse sobre criterios de sostenibilidad y debe contribuir a ese desarrollo integrándose en el entrono físico y sociocultural, respetando el frágil equilibrio de muchos destinos, en particular islas y áreas ambientalmente sensibles. Por ello, la actividad turística debe tener una evolución aceptable respecto a su incidencia sobre los recursos naturales, la biodiversidad y la capacidad de asimilación de los impactos y residuos producidos; 2) La actividad turística ha de considerar los efectos inducidos sobre el patrimonio cultural y los elementos, actividades y dinámicas tradicionales de las comunidades locales, y su formulación debe contemplar el apoyo a la identidad, la cultura y los intereses locales, especialmente en países en vías de desarrollo; 3) Para ello será necesaria la colaboración y participación de todos los actores implicados en el proceso, públicos y privados, a todos los niveles: local, nacional, regional e internacional. Lo que exige

66 http://www.tuspain.com/env/env2.htm (consultada 20-02-09) 
innovación cultural, tecnológica y profesional, además de crear y desarrollar instrumentos de planificación y de gestión integrados; 4) Participar en el desarrollo sostenible supone la plena integración del turismo y su contribución positiva al desarrollo económico local, debiendo contribuir de forma efectiva en la mejora de la calidad de vida de la población e incidir en el enriquecimiento sociocultural de cada destino. Así, los gobiernos y autoridades competentes, junto con organizaciones no gubernamentales, deben actuar orientándose hacia la planificación integrada del turismo para contribuir al desarrollo sostenible.

11. Conferencia Mundial (2005). Celebrada en Iguazú y organizada por la Naciones Unidades a través de su órgano especializado en turismo, la OMT. Con representación de más de 80 países. Se centra en el estudio del turismo no sólo como demanda, sino como actividad productiva, que genera valor añadido, empleo, ingresos para el Tesoro público y otros beneficios, directa o indirectamente, lo que lleva a elaborar y aprobar el marco conceptual de la cuenta satélite de turismo (CST) ${ }^{67}$ (comprender el turismo y diseñar estrategias) por la Comisión de Estadística de las Naciones Unidades en el año 2000. La CST es un instrumento estadístico, un "satélite" que gira alrededor de los conceptos, las definiciones y los agregados del Sistema de Cuentas Nacionales y que hace posible realizar comparaciones válidas con otros sectores, así como entre países o grupos de países. Esta Conferencia mundial estudiará a fondo posibles formas de sacar el máximo partido a la CST: su interés para los responsables políticos, las consecuencias para las políticas comerciales, su contribución a los estudios de mercado y a la preparación de previsiones, las mejoras de la CST para que refleje convenientemente la importancia del turismo de reuniones, incentivo, congresos y ferias o la creación de empleo y su desarrollo a escala subnacional.

En líneas generales, a través del seguimiento de las distintas conferencias internacionales sobre turismo que bañan el final del siglo XX, se determina la línea de apoyo que, hacia la actividad turística, han definido los organismos internacionales, principalmente ONU y OMT, siempre basada en un mirada positiva hacia la actividad: como generadora de conocimiento, información y entendimiento entre los pueblos, de desarrollo económico y social, como vía de conservación del medio natural y del patrimonio sociocultural, principalmente. Incidiendo a partir de finales de la década del ochenta en la importancia de la gestión y planificación adecuada de los territorios que reciben dicha demanda como vía para alcanzar sostenibilidad, en la que deben intervenir en cooperación los sectores

67 OMT.-CCST/2005/ Nota Técnica, Agosto 2005.

http://www.world-tourism.org/TSAconf2005/spanish/visit.htm (consultada 20-02-2009) 
públicos y privados, puesto que es ahora cuando van a reconocer no sólo beneficios, sino también los costos de la actividad.

\section{2.- LOS TOUR OPERADORES.}

Aunque dentro de la estructura del mercado turístico, podemos señalar, en otros, dos tipos de empresas mercantiles, los tour operadores y las agencias de viajes, ambos pertenecientes a los agentes sociales dentro del sector privado. Las próximas líneas las dedicaremos exclusivamente a los tour operadores puesto que sus formas de operar en el mercado turístico han supuesto beneficios y costes en términos socioeconómicos, para las sociedades receptoras.

Los tour operadores desde el punto de vista económico pueden definirse como "empresas turísticas que se dedican a producir planes de desplazamiento de idea y de vuelta, para ser ofrecidos en el mercado con especificación de calidades, precios y formas de pago" (Muñoz, F. 1990 pp. 8), son las grandes empresas intermediarias, del turismo, son multinacionales que elaboran el producto turístico y tienen instalaciones de servicios en más de un país. Organizan paquetes turísticos -viajes todo incluido- en grandes cantidades (tienen grandes paquetes de clientes, ahí es donde radica su poder) y a precios más reducidos, pudiendo prestar ellos mismos todos o partes de los servicios al poseer, en un régimen de integración empresarial de carácter horizontal, es decir con otras agencias (por ejemplo minoristas), o vertical con compañías aéreas, cadenas hoteleras, empresas de restauración, etc. Hacen pues reservas masivas de plazas de transporte y de hostelería, fletan trenes, autocares, aviones en servicio "chárter", que durante temporadas más o menos largas, con idénticos itinerarios, horarios y frecuencias, llegan a ser, en realidad, como líneas regulares. Pueden por tanto abaratar los costes del viaje turístico.

Estos grupos empresariales están constituidos, en principio, por capitales y personas pertenecientes a las metrópolis, es decir, a los grandes focos emisores de turistas del centro y del norte de Europa. Su creación se remonta a los primeros momentos del desarrollo del turismo moderno, por tanto la actividad de los tour operadores ha sido la piedra angular alrededor de la cual ha girado el nacimiento del turismo moderno, al conseguir que éste se encuentre al alcance de todas las economías de los ciudadanos de los países desarrollados, convirtiéndose en el vehículo principal de acceso a los diferentes productos turísticos por parte del consumidor, es el creador del producto turístico manufacturado, estandarizado para el turismo de masas (Mazón, T., 2001, pp. 166). Básicamente, en la práctica, sus características son similares a las de las agencias de viajes mayoristas. Se trata, pues, de empresas que transforman el producto básico en otro producto totalmente distinto, crea su envoltorio y lo comercializa bajo su marca, amparado por la fuerza y por la garantía de su propia marca (González Soria, 1999). 
Una de las formas de extenderse que utilizan es la inversión en proyectos nuevos y no suelen tener más opción que la inversión en instalaciones en el extranjero, una inversión directa, además de su comercialización. Por tanto participan en el establecimiento de la oferta turística, y en muchos casos han sido invitados por los países receptores para que los apoyen en el desarrollo turístico, bien porque no existan empresas locales en ese país, o porque éstas no posean los recursos económicos adecuados y una amplia cartera de clientes que les permita derivar, hacia esos destinos, un contingente considerable de turistas, como es el caso de las Islas Canarias en el periodo de despegue de la actividad.

El mayor beneficio para las economías anfitrionas es la introducción de nueva inversión, adicional a la que la propia economía genera. La inversión dará lugar a un aumento de la renta y al crecimiento de la economía, con beneficios asociados en términos de empleo y ganancia de divisas. Por otro lado, puede suceder que el empleo de mano de obra cualificada y tecnología avanzada introducido en la zona por la multinacional, se transfiera a la economía local por el efecto de demostración, lo que lleva a la modernización.

En cuanto a los problemas que puede generar estas inversiones, Tribe, J. (2000, pp. 415) señala que "generará en una economía fugas, puesto que la multinacional remite los beneficios a la empresa matriz, suelen contratar extranjeros y a veces usan una mayor cantidad de input importado". Si alcanzan una posición monopolista en un país receptor, tendrán una gran capacidad para ejercer todo tipo de presiones sobre los gobiernos y poder así adaptar el futuro del turismo a sus inversiones en infraestructuras, pudiendo negociar precios bajos con los ofertantes y reduciendo el impacto del gasto extranjero en el ámbito local. El control de las riendas del turismo por los tour operadores puede llegar a ser total y negativo para la economía local.

Adicionalmente, se les acusa de: a) instalarse en el extranjero para poder evitar costes extras derivados de cumplir la ley en su país madre, de modo que las externalidades las exportan, principalmente a países en vías de desarrollo, que suelen estar dispuestos a aceptar dichas externalidades para poder retener su competitividad internacional; b) los bajos costes, la alta tecnología y la alta calidad de los bienes y servicios que disponen, puede dificultar y muchas veces impedir, el ingreso en la industria de empresas locales nuevas, puesto que deberán enfrentarse a costes medios más elevados y por tanto tendrán dificultadas para competir; c) los tour operadores buscan maximizar sus beneficios, por lo que no dejan de estudiar el entorno para explotar los cambios en los costes internacionales o en los patrones de demanda. Por esta razón no tienen ninguna lealtad especial con zona alguna y pueden retirarse, en cualquier momento, llevándose consigo el gasto extranjero (Tribe, J. 2000, pp. 417), puesto que también controlan la comercialización, llevando a los clientes hacia aquellos lugares donde les interesa por obtener mayores beneficios empresariales, por tanto, tienen capacidad para desviar los flujos turísticos e impulsar un territorio receptor o deprimirlo; d) puede resultar que el complejo creado por la 
multinacional, se convierta en un enclave, o sea, en un complejo exclusivamente para extranjeros, controlando e impidiendo el acceso de los nativos, por ejemplo, a la zona de playa; e) pueden comprar grandes extensiones de tierra a precios baratos, perdiéndose este recurso para la explotación local, que quizás sea necesario en una fase futura de desarrollo del país.

Todas estas razones han hecho que para muchos pensadores el turismo no sea más que una forma nueva de colonización, económica y sociocultural, ejercida por las metrópolis sobre los países en vías de desarrollo cuando estos pretenden desarrollarse económicamente. Bajo esta forma de control del turismo, las sociedades receptores se ven obligadas a invertir ingentes cantidades de dinero para construir aeropuertos turísticos, red de carreteras, infraestructura energética y conducciones de agua en las zonas de influencia turística, etc., surgiendo contradicción entre el súper desarrollo de la costa y el subdesarrollo interior con estructuras arcaicas. Autores como Gaviria, M., en 1969, señala todos estos peligros al observar la dinámica que se está desarrollando, alrededor de la actividad turística, en Lanzarote y Fuerteventura.

Todas estas circunstancias han supuesto, para los países receptores, en líneas generales, que la estructura del turismo se encuentre controlada casi por completo por decisiones que se toman fuera de su territorio y que por tanto convierte sus economías en dependientes del exterior y no autosuficientes. Los tours operadores siguen constituyendo, en la actualidad, el principal intermediario para las empresas turísticas que operan en un destino. Los viajes combinados o paquetes organizados siguen siendo la fórmulas más empleadas por los europeos para sus viajes turísticos (Parra, E, y otros, 2003, pp. 221).

\section{3.- LA INTERVENCIÓN DEL SECTOR PÚBLICO EN EL TURISMO}

Cuanto mayor es la importancia del sector turístico para una economía, mayor es el grado de intervenciones públicas y más numerosas las Administraciones involucradas, principalmente debido a que es una actividad que engloba diversos sectores. Es por ello que el turismo es político y la política turística es necesaria en todo momento, siendo la Administración Pública la que tiene y debe dirigir y regular la actividad, pues sólo ella puede tener la posición y la capacidad para resolver problemas multisectoriales, manteniendo una visión a medio y largo plazo del conjunto socio-territorial afectado, puesto que entre los componentes del producto turístico se encuentran bienes públicos.

Así pues, y bajo las premisas en las que se fundamenta el Estado de Bienestar, la intervención pública en la económica viene justificada por la existencia de fallos en el mercado. A estos fallos también se enfrenta la actividad turística, puesto que este sector no puede corregir o crear por sí mismo unas condiciones que normalmente son parte y lugar del conjunto de políticas sociales y económicas nacionales (Kadt, E. 1991, pp. 39). La 
Organización Mundial del Turismo (1998), enumera una serie de fallos a los que hay que hacer referencia para entender el papel del Estado en el mercado turístico:

1. La competencia imperfecta de los mercados, con presencia de oligopolios y monopolios que lo controlan, afectando al consumidor. El papel del Estado será, por tanto, garantizar condiciones de competencia para una óptima asignación de recursos, evitando situaciones de control de la oferta y la demanda y aumentando la transparencia y la flexibilidad del mercado.

2. La actividad turística está estrechamente relacionada, o sea, emplea bienes públicos, de distinta naturaleza: las infraestructuras, la seguridad del visitante, las playas, los monumentos, etc., dependen del Estado. Estos bienes, de los que se pueden beneficiar todos los ciudadanos y donde no se puede dar la exclusión en su consumo, no se pueden dejar en manos del sector privado. Por ello, el papel del Estado en esta área se mueve hacia la provisión correcta de este tipo de bienes. "El conjunto de relaciones que despliega el turismo precisan de actuaciones políticas transversales que necesitan un alto nivel de coordinación entre los diversos actores implicados y que exigen, inevitablemente, decisiones públicas" (Velasco, Mª. 2004, pp. 32).

3. Las actividades económicas (del tipo que sean) producen efectos externos, que pueden ser beneficios (economías externas) o costes (deseconomías externas) para otros individuos o actividades. Las empresas privadas fijan sus cantidades óptimas de producción según sus costes privados, sin considerar los impactos que su actividad, por vía ajena al mercado, puede producir en la zona y en los demás sectores económicos, afectando a la población (costes sociales), y sin que ésta pueda decidir sobre la producción de dichas empresas, ni sobre su intensidad. Con estos efectos externos, el mercado no asigna correctamente los recursos disponibles. La solución la tiene, por tanto, la intervención pública a través de los instrumentos que tenga a su alcance: impuestos (sobre actividades), subvenciones (para la mejora de espacios), regulación de usos (uso del suelo) y actividades (establecimiento de cuotas) y asumiendo la propiedad pública de los bienes con la finalidad de evitar un uso no adecuado de la iniciativa privada. En palabras de Kadt, E. (1991, pp. 39) "sin una planificación y seguimiento, la proporción de beneficios del desarrollo turístico que corresponde a los pobres será más pequeña que la que va a parar a los grupos acomodados, a las empresas multinacionales y a los ejecutivos, o incluso a los propios turistas"

Sobre la base de las externalidades anteriormente citadas, la defensa de los intereses de la comunidad exige la formulación de los mismos y luego su defensa mediante los instrumentos ejecutivos adecuados (Kadt, E. 1991, pp. 57), por tanto, el fin de toda Política Turística debe ser el garantizar la obtención de un beneficio sostenido a largo plazo, de un reparto equitativo de éste entre las diferentes clases sociales, compatibilizando el principio 
de libertad de mercado y de empresa con la preservación de las ventajas estructurales que aseguren la continuidad de la actividad en unas condiciones adecuadas. Por tanto, "la posición lógica para que un país comience el desarrollo del sector turístico es determinar cómo encaja dentro del Plan Nacional de Desarrollo (...) y qué prioridad ha de recibir" (Kadt, E. 1991, pp. 38).

En el ámbito nacional es el Estado el que debe formular una Política Turística general, especificando el peso que se le va a dar al sector en la economía nacional, cuáles son los objetivos fundamentales perseguidos, qué medios van a emplearse para alcanzar dichos objetivos (O.M.T. 1998), qué tipo de turismo quiere potenciar, etc. La mayoría de los Gobiernos de países en vías de desarrollo buscan en el turismo la obtención de divisas, el incremento de los ingresos nacionales y el empleo, así como poder alcanzar desarrollo para sus regiones más atrasadas.

La primera etapa o función por la que pasan las políticas turísticas de los países en vías de desarrollo después de la II Guerra Mundial, y que también implementará España, es la de asumir la promoción del país en el extranjero, a través de campañas y la apertura de oficinas de información en el exterior, es la etapa que la OCDE (1989) denomina como "Estado promotor". Esta etapa se caracteriza por la búsqueda desesperada de divisas, el objetivo es económico, equilibrar la balanza de pagos, aunque, como en el caso de España, se ampliará hacia la creación de un tejido empresarial cuya única actividad sea el turismo".

La segunda etapa denominada "el Estado como estímulo"68 (OCDE, 1989) se caracterizará por la asunción por parte del Estado, de la construcción de la infraestructura pública suficiente como para permitir la llegada de turistas de forma masiva. A partir de este momento, los decisores políticos de los países receptores "observan que la creación de infraestructuras se convierte en el instrumento básico del diseño de los flujos turísticos en su país, así aparece la función de "Estado como planificador" turístico", que canalizará los flujos turísticos hacia sus territorios con escasa posibilidad de desarrollar otro tipo de industria (Velasco, $\mathrm{M}^{a}$. 2004, pp. 79 y 82). Así será posible el desarrollo de la actividad turística en las Islas Canarias.

Velasco, $M^{a}$. (2004, pp. 79-83) recoge, después de la anterior etapa señalada, tres funciones o políticas más, que nos llevan hasta la actualidad de la política turística nacional: el Estado como garante, cuyo objetivo es controlar y garantizar el orden dentro del sistema turístico, evitando abusos, haciendo cumplir derechos y obligaciones a las empresas y

${ }^{68}$ En este momento los objetivos del Estado Español también son políticos, puesto que la recepción de turistas europeos posibilita cambiar la imagen de la Dictadura de Franco en el exterior, a través de la propaganda que éstos hagan en sus países de origen (Velasco, Ma. 2004, pp. 82). 
protegiendo al turista; el estado como coordinador y el Estado como armonizador, modelos o funciones que aparecerán en la última década del s. XX hasta la actualidad, puesto que las condiciones del entorno van cambiando y ahora ya no se trata de alcanzar objetivos de crecimiento de la actividad, sino de su adaptación y mejora.

Por otro lado, el despliegue progresivo de visitantes, que van saliendo de los centros turísticos hacia núcleos más alejados, dificulta la gestión y el control centralizado de la actividad turística, por tanto entra en juego activamente, en el territorio nacional, las Comunidades Autónomas. Este nivel administrativo en la intervención pública turística tiene la ventaja en la cercanía y mejor conocimiento de los problemas que afectan a su región así como de los agentes implicados en el mercado turístico de la misma ${ }^{69}$. Actualmente disfrutan de plenas competencias para la gestión, planificación y promoción del sector turístico. A ello se añade, que la creciente afluencia de visitantes obligó a una planificación del desarrollo turístico, por lo que no debemos olvidar que es la Administración Local, los municipios y los cabildos (en el caso de las islas), los que tienen el instrumento político básico que contiene el conjunto de acciones para intervenir en su territorio y en la actividad turística. Por ello, este nivel administrativo parece ser el más adecuado para responder a las necesidades específicas de los residentes de la zona y de los visitantes, ya que permite un seguimiento "in situ" y un mejor conocimiento de las necesidades y problemas del destino turístico, puesto que es a este nivel administrativo donde se entra en competencia la población turística con la residente en los períodos de máxima ocupación turística del municipio. Es ahí donde se producen los estrangulamientos.

Todas las fases o funciones recogidas en las líneas anteriores, se irán expresando en la legislación española estatal y autonómica, aunque para nuestro marco temporal de análisis, nos interesa la que se crea a partir de la década de los años sesenta hasta la actualidad, que se detalla en próximas líneas.

69 "Las competencias de las autoridades públicas en el ámbito regional permiten frenar políticas negativas para el desarrollo de la región, adoptadas tan sólo sobre la base de consideraciones económicas generales del país" (O.M.T. 1998). 
Tabla 3. Cuadro sintético de agentes sociales

\begin{tabular}{|c|c|}
\hline ORGANISMOS & 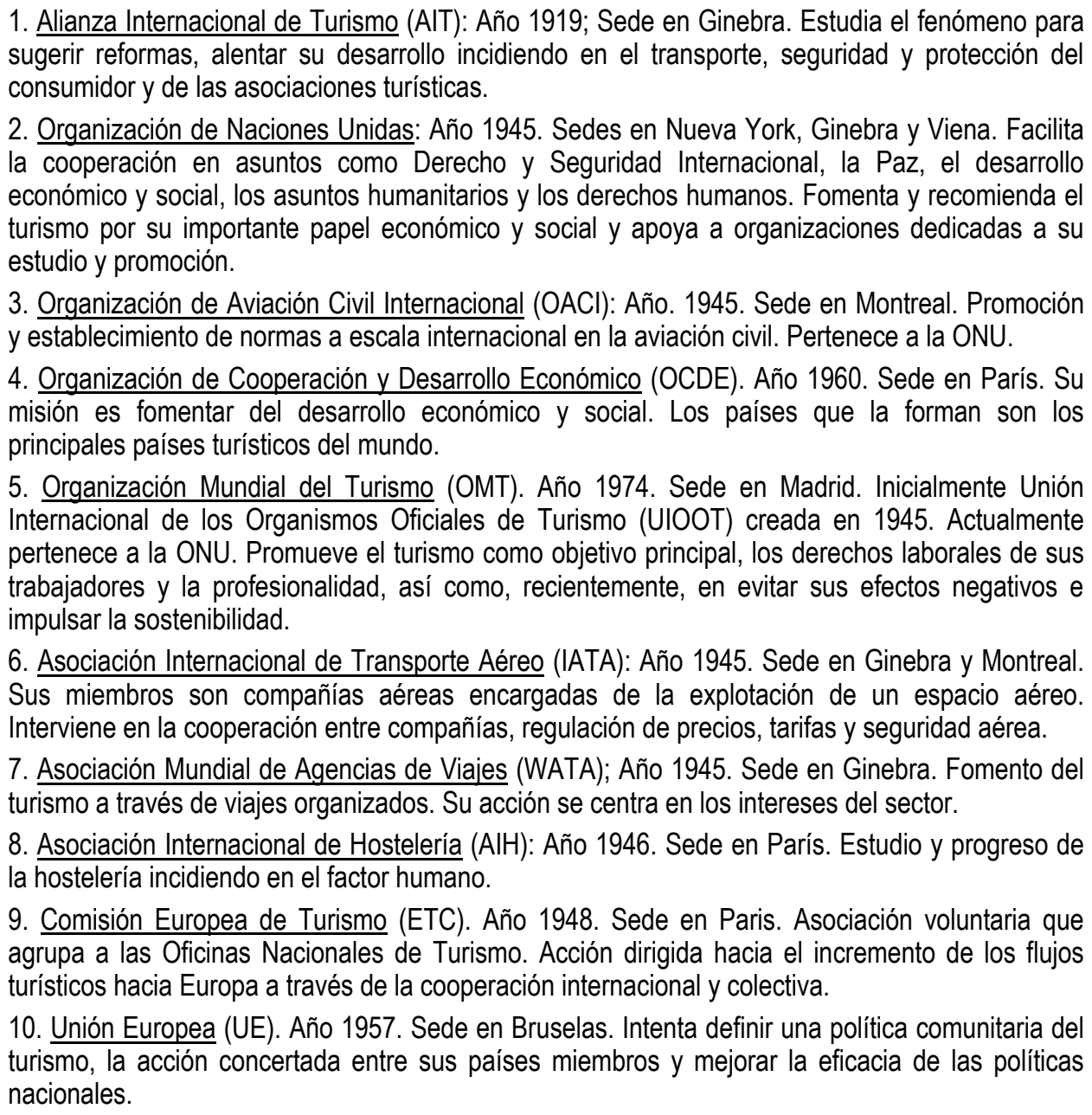 \\
\hline
\end{tabular}




\begin{tabular}{|c|c|}
\hline & $\begin{array}{l}\text { 1. Declaración Universal de Derechos Humanos (1948). Reconoce el derecho al desplazamiento y } \\
\text { a los viajes (quinta libertad). } \\
\text { 2. Declaración de Río de Janeiro (1972). Entiende el turismo como una fuerza que impacta en } \\
\text { todos los sectores de la sociedad. Señala la necesidad de ejecutar programas multinacionales } \\
\text { que contrarresten los efectos del turismo masivo. } \\
\text { 3. Declaración de Puerto Plata (1973). Celebrada en la República Dominicana. Establece } \\
\text { fórmulas para salir del subdesarrollo a través del turismo. } \\
\text { 4. Año Europeo del Patrimonio Cultural (1975). Exige la toma de medidas para la conservación } \\
\text { del patrimonio en Europa. } \\
\text { 5. Conferencia de Helsinki (1975). Reconoce la contribución del turismo a la comprensión entre } \\
\text { los pueblos y para el progreso económico y socio-cultural. } \\
\text { 6. Declaración de Manila (1980). Convoca la OMT. Fundamenta el importante papel que el } \\
\text { turismo representa en el dinamismo mundial, de una base ética (equidad, igualdad), de su papel } \\
\text { en el impulso de la calidad de vida respetando la personalidad de los pueblos y sus intereses en } \\
\text { todos los sectores. } \\
\text { 7. Declaración de la Haya sobre turismo (1989). Elabora un decálogo de principios sobre el } \\
\text { turismo. } \\
\text { 8. Cumbre de la Tierra (1992). Organizada por la ONU. Surgen tres importantes documentos: } \\
\text { Declaración de Río, la Agenda } 21 \text { y la Declaración sobre principios forestales, destinados a los } \\
\text { Gobiernos y las empresas. } \\
\text { 9. Carta del Turismo Sostenible (1995). Reconoce los efectos positivos (socio-económicos) y } \\
\text { negativos (medioambientales y en la identidad de los pueblos) del turismo. Debe abordarse de } \\
\text { forma global y orientarse hacia la sostenibilidad. } \\
\text { 10. Conferencia Mundial (2005). Organiza la OMT. Centrada en el estudio del turismo como } \\
\text { actividad productiva, define el marco conceptual para la elaboración de la Cuenta Satélite del } \\
\text { Turismo (CST), como instrumento estadístico, a elaborar por los estados, para observar su } \\
\text { aportación a la riqueza. }\end{array}$ \\
\hline $\begin{array}{l}\text { EMPRESAS } \\
\text { MERCANTILES }\end{array}$ & $\begin{array}{l}\text { Tour operadores: empresas intermediarias del turismo (multinacionales). Elaboran el producto } \\
\text { (estandarizan) y tiene instalaciones en los países receptores. Controlan la oferta y la demanda, } \\
\text { afectando positiva o negativamente a las economías de las sociedades anfitrionas. }\end{array}$ \\
\hline SECTOR PÚBLICO & $\begin{array}{l}\text { Diferentes organismos: Estados, Gobiernos Locales, etc. Elabora la política en las sociedades de } \\
\text { acogida, por el empleo de bienes públicos de la actividad, y por su afección económica, social y } \\
\text { cultural sobre los ámbitos nacionales y regionales. Papel de promoción, coordinación, } \\
\text { planificación, control, regulación, gestión y garante de orden en su sistema turístico. }\end{array}$ \\
\hline
\end{tabular}

Fuente: Elaboración propia.

\section{4.- NIVELES DE INTERVENCIÓN PÚBLICA}

Entre las competencias del sector público, repartida entre los diferentes niveles de la administración, se encuentra la normativa con incidencia en la ordenación del territorio y en el urbanismo. Esta competencia está destinada, en buena medida a regular la ocupación del territorio que pueden realizar los agentes privados.

Será en el primer cuarto del s. XX cuando se plantee la necesidad de una visión más integradora de los problemas urbanos y su resolución a escala supramunicipal y pasar así desde una perspectiva urbana a una perspectiva regional, desde la ciudad al territorio. Esta visión es la que se encuentra en el nacimiento de la ordenación del territorio. 


\section{1.- ORDENACIÓN DEL TERRITORIO Y URBANISMO}

Existen múltiples definiciones de ordenación del territorio. Entre los conceptos ampliamente difundidos, y que han tendido a ser aceptados, nos hacemos eco aquí del que recoge la Carta Europea de Ordenación de Territorio, suscrita por los países representados en la Conferencia Europea de Ministros Responsables de Ordenación del territorio (CEMAT), en 1983. En ella se define como "la expresión espacial de las políticas económicas, sociales, culturales y ecológicas de toda la sociedad. Es a la vez una disciplina científica, una técnica administrativa y una práctica política, concebida como un enfoque interdisciplinario y global, cuyo objetivo es un desarrollo equilibrado de las regiones y la organización física del espacio según un concepto rector". Señala que una política territorial ha de ser: a) democrática, garantizando la participación de la población afectada; b) coordinadora de sus distintas políticas sectoriales, asegurando su conjunción en un enfoque integrado; c) funcional, respectando los valores, la cultura y los intereses de las diversas regiones o comarcas; d) prospectiva, considerando las tendencias actuales y el desarrollo a largo plazo de los procesos económicos, sociales, culturales, ecológicos y medioambientales. Es por ello que, los objetivos que establece para la ordenación del territorio son los siguientes:

- El desarrollo socioeconómico equilibrado, con tendencia a la reducción de las diferencias en el nivel de vida.

- La mejora de la calidad de vida, facilitando a la población accesibilidad a los equipamientos sanitarios, docentes, administrativos, comerciales y de todo tipo.

- La gestión responsable de los recursos naturales y la protección del medio ambiente, respetando las peculiaridades comarcales en cuanto a sus formas de vida.

- La utilización racional del territorio, definiendo usos aceptables o a potenciar para cada tipo de suelo, creando redes infraestructurales adecuadas e incluso fomentando actuaciones que mejor se adapten al fortalecimiento del espíritu comunitario.

El desarrollo socioeconómico equilibrado, la mejora de la calidad de vida, la gestión responsable de los recursos y la utilización racional del territorio serán, por tanto, sus frentes.

Desde esta perspectiva, Serrano, A. (1986, pp. 11) considera que "la ordenación del territorio presenta una doble expresión formal, científica y conceptual, en cuanto que integra dos niveles diferenciados: el Análisis Territorial o disciplina científica básica (exige una aproximación interdisciplinaria y global, permitiendo la definición y comprensión del modelo de desarrollo territorial, que es reflejo de una determinada sociedad en un tiempo y espacio concreto) y la Planificación Territorial o disciplina científica aplicada (consecución de los 
objetivos que se definan para cada territorio aplicando los recursos disponibles a la transformación de la realidad territorial y así acercarla a la deseada)".

Pujadas, R y Font, J (1998, pp. 12) establecen tres grandes interrogantes de la ordenación territorial: ¿qué se ha de ordenar? Los múltiples usos del suelo que coexisten en un determinado territorio; ¿para qué se ha de ordenar? La respuesta a esta pregunta se encuentra en los fines y objetivos de la ordenación territorial (que no son únicos y dependen en primer lugar de quién ordene, estableciéndose de antemano), que se encuentran recogidos en las legislaciones y de forma general en lo establecido en la Carta Europea citada anteriormente, o en la Estrategia Territorial Europea (1999) que recoge tres grandes grupos dentro de los conceptos de desarrollo (sostenible), equilibrio y conservación. Por otro lado, en el sector privado también es frecuente la realización de planes de ordenación de territorio, con el objetivo de promover grandes actuaciones urbanísticas (turísticas, complejos industriales, etc.), es por ello que sus objetivos y formas de plantear el proceso de O.T. difieren sensiblemente de los señalados en la Carta Europea (Serrano, A., 1986, pp. 12); ¿cómo se ha de ordenar? La pregunta hace referencia a los criterios de ordenación que conformarán su resultado. De forma general se señala uno de los criterios básicos: el carácter limitado del territorio puesto que este es un bien escaso, de ahí la necesidad de utilización racional del mismo.

Consecuentemente, nos encontramos con una serie de requisitos básicos que se plantean en toda ordenación: elegir entre diferentes usos alternativos posibles del suelo, que enfrentará los distintos intereses presenten en la sociedad. Esta elección es siempre multicriterio (criterios ambientales, económicos, territoriales, técnicos, culturales, etc.), puesto que la vida social es multicomponente, lo que "implica llegar a definir un modelo territorial futuro al que se quiere llegar mediante el proceso de ordenación" (Pujadas y Font, 1998, pp. 13). Y por último poder político para impulsar la alternativa escogida, lo que conlleva el diseño de políticas territoriales y de instrumentos de planificación para llevar a la práctica las decisiones tomadas. Por todo ello, la ordenación del territorio se concreta en tres etapas: legislar, planificar y ejecutar los planes aprobados.

No debemos olvidar aquí que sobre la ordenación del territorio están incidiendo una serie de elementos externos que afectan de lleno al modelo territorial que plantee: por un lado, la ideología, que nutre y transforma el cuerpo doctrinal de esta disciplina, sobre todo a la hora de identificar los problemas territoriales a resolver y en la priorización de actuaciones. $Y$ en segundo lugar su estrecha vinculación a otras disciplinas científicas con implicaciones territoriales, que la nutren de cuerpo doctrinal y que proceden tanto de las ciencias sociales, como físicas y medioambientales, aportando criterios e instrumentos científicos en el trabajo territorial. Cuando estas disciplinas avanzan en su parcela de conocimiento avanza también la ordenación del territorio. 
Desde algunas aproximaciones, la urbanística o planeamiento urbanístico, es una "disciplina que aporta las técnicas para la formulación y el desarrollo del proyecto de ciudad" (Esteban, J. 2003, pp. 19). El planeamiento urbanístico es una de las partes del urbanismo, vinculado más al análisis previo de la formación de la ciudad, al proceso de urbanización de la sociedad y, en cuanto que planificación, a su transformación. Puede ser definido como "el conjunto de conocimientos relativos a la planificación, desarrollo, reforma y ampliación de los edificios y espacios de las ciudades" (RAE). El urbanismo es "reflexión, proyección y construcción de las ciudades o partes de ellas, generalmente de acuerdo con un plan previamente realizado" ( ADUAR, 2000, pp. $360^{70}$ ) y tal como señala Le Corbusier (1989, pp. 119 y 145) "es la ordenación de los lugares y de los locales diversos que deben abrigar el desarrollo de la vida material sentimental y espiritual en todas sus manifestaciones, individuales y colectivas, cuyas claves se contienen en tres funciones: habitar, trabajar, recrearse y circular".

El objeto del urbanismo son los hechos urbanos; su escala es urbana y municipal, se ocupa tanto del espacio urbano y natural como de las actividades que acoge, del cambio urbano y la propia acción urbanística. Es una disciplina compleja y multidimensional en la que confluyen tres tradiciones que nos llevan a tres aproximaciones epistemológicas del hecho urbano (Sánchez, I. 1999, pp. 9-16: a) la estética y artística cuya praxis es el diseño urbano; b) la proveniente de las ciencias sociales y la técnica ${ }^{71}$, basada en la aplicación de la racionalidad científico-técnica; c) la proveniente de la filosofía política, que considera al urbanismo como un medio de reforma social a través de la acción social en el ámbito público como parte del Estado de Bienestar ${ }^{72}$, con la necesaria institucionalización de los sistemas de planificación urbana, la actual apertura hacia la participación pública (que se ha ido institucionalizando en igual medida) y la negociación.

Se acude a él para lograr solucionar los conflictos urbanos, armonizando las actuaciones individuales o aisladas y prevenir las implicaciones que cada una de ellas pueda tener en el conjunto urbano, así como hacer posible las intervenciones colectivas que sean necesarias (Trapero, J. 1994, pp. 19). Así, en el ámbito del planeamiento urbano los temas centrales son los siguientes: a) la ordenación de la totalidad del término municipal, integrando la ciudad en el territorio en su conexión con otros núcleos urbanos con los que mantenga interrelaciones y articulada con su entorno de características no urbanas; b) delimitar el

70 Grupo ADUAR (2000) "Diccionario de Geografía Urbana, Urbanismo y Ordenación del Territorio". Editorial Ariel, S.A. Barcelona, 2000.

${ }^{71}$ Que engarza los inicios del urbanismo científico como el funcionalismo, la planificación de sistemas, la cibernética y la relativización actual del papel del cientifismo.

72 Todo el urbanismo moderno, ya desde Cerdá, es reformista. 
espacio público y el privado; c) definir el patrón de crecimiento urbano; d) definir y delimitar la red de espacios públicos y los usos del suelo.

Tanto el urbanismo como la ordenación del territorio tienen el plan como proceso de racionalización del territorio. El plan regula el estatuto jurídico de la propiedad del suelo, sujetándolo al cumplimiento de una función social. Así, se contempla como todo conjunto de actuaciones políticas o disposiciones que permiten acercar la realidad observada a la realidad deseada (Serrano, A. 2003, pp. 12).

En cuanto a la participación de la Administración en la Ordenación del Territorio, la implantación del Estado de las Autonomías con la Constitución (CE) de 1978 implicó modificaciones en la estructura y el funcionamiento de las instituciones públicas de España. Así, las Comunidades Autónomas (CC.AA) pasan a tener competencias plenas en materia de ordenación del territorio, urbanismo y vivienda (CE, Art. 148.1.3ª), careciendo el Estado de competencias sobre estas materias, aunque se le atribuyen títulos que inciden de manera relevante en tales ámbitos (recogidos en el Art. 149.1 de la CE) y posee todas aquellas competencias que no hayan sido atribuidas a las Comunidades Autónomas (CE, Art. 149.3) y a las entidades locales. Además, la CE, en su artículo 150, establece la posibilidad de que el Estado transfiera o delegue en las CC.AA. facultades correspondientes a materias de titularidad estatal a través de leyes orgánicas de transferencia, de leyes de delegación legislativa o leyes de armonización. Por tanto, compete a las Comunidades Autónomas generar normas que afecten a la ordenación territorial y urbanística, sin perjuicio de que tal competencia haya de integrarse con aquellas otras estatales que pueden incidir puntualmente en la materia. Poseen, además, otras vías de intervención como la planificación sectorial en los ámbitos de su competencia, reservándose la aprobación definitiva de los planes urbanísticos, el establecimiento de la política regional y de desarrollo económico así como medidas reequilibradoras y de desarrollo de áreas atrasadas, políticas ambientales, sobre recursos y patrimonio natural, etc.

En cuanto a las entidades locales, municipios y provincias, la CE en sus Art. 137, 140 y 141 les garantiza autonomía para la gestión de sus intereses y señala como administración propia de las islas los Cabildos o Consejos (Art. 141.4). Es en la Ley 7/1985 Reguladora de las Bases de Régimen local (LRBRL) ${ }^{73}$ donde se concreta los diferentes servicios que han de prestar. En el caso de los municipios, estos no se contemplan con competencias en ordenación del territorio, aunque sí en varios aspectos que inciden sobre ella: la

73 Inicialmente aprobada por la Ley 7/1985, de 2 de abril, y modificada por las Leyes 57/2003, 24/2001, 14/2000, 55/1999, 11/1999, 50/1998, 34/1998, 7/1997, 4/1996, 13/1995, 39/1994, 10/1993, 9/1991, 31/1991, 39/1988, por las Leyes Orgánicas 14/2003 y 1/2003, los Reales Decretos Legislativos 2/2000 y 2/1994 y el Real Decreto-Ley 7/1996. 
Ordenación, gestión, ejecución y disciplina urbanística (Art. 25.2.d), el patrimonio histórico artístico (Art. 25.2.e) y la promoción del medio ambiente (Art. 25.2.f.), entre otros.

Las normas contenidas en los capítulos II y III del título X, de la LRBRL, serán también de aplicación a los Cabildos Insulares Canarios de Islas cuya población sea superior a 175.000 habitantes, y a los restantes Cabildos Insulares de Islas cuya población sea superior a 75.000 habitantes, siempre que así lo decida mediante Ley el Parlamento Canario a iniciativa de los Plenos de los respectivos Cabildos. Así, los Cabildos Insulares Canarios, como órganos de gobierno, administración y representación de cada isla (Art. 41 de LRBRL), les compete en materia de urbanismo y ordenación, al Presidente del Cabildo y al Consejo de Gobierno Insular "la aprobación inicial del planeamiento general y la aprobación que ponga fin a la tramitación municipal de los planes y demás instrumentos de ordenación previstos en la legislación urbanística" (Art. 123.1.i), "la aprobación de los proyectos de instrumentos de ordenación urbanística cuya aprobación definitiva o provisional corresponda al Pleno ${ }^{74 " ~(A r t . ~ 127.1 . c), ~ " l a s ~ a p r o b a c i o n e s ~ d e ~ l o s ~ i n s t r u m e n t o s ~ d e ~}$ planeamiento de desarrollo del planeamiento general no atribuidas expresamente al Pleno, así como los de los instrumentos de gestión urbanística y de los proyectos de urbanización" (Art. 127.1.d) y "la concesión de cualquier tipo de licencia, salvo que la legislación sectorial la atribuya a otro órgano" (Art. 127.1.e). Por otro lado, la LRBRL en materia de urbanismo también le atribuye competencias al Consejo Social Insular ${ }^{75}$, al que le corresponderá, además de las funciones que le asigne el Pleno mediante normas orgánicas, la emisión de informes, estudios y propuestas en materia de desarrollo económico local, planificación estratégica de la ciudad y grandes proyectos urbanos (Art. 131.2.)

\subsection{1.- ORDENACIÓN DEL TERRITORIO Y TURISMO}

En cuanto que la explotación de los recursos turísticos de un territorio convierte a dicho territorio y medio ambiente físico y social en un producto de atracción en sí mismo para los flujos turísticos, se hace necesario la regulación y planificación de dicha actividad sobre el territorio que la acoge, dado que, la presión de los agentes económicos para maximizar el beneficio en el menor tiempo posible, pueden poner en peligro el propio capital fijo del turismo, que no es otro que el atractivo social y medioambiental del destino.

\footnotetext{
74 En el Reglamento Orgánico del Cabildo de Lanzarote (BOP, № 138, 24/10/2007), en el Art. 62.2.j) Se le atribuye al Pleno la siguiente competencia: "La aprobación inicial y provisional del Plan Insular de Ordenación y sus modificaciones, así como de los Planes Territoriales en desarrollo del mismo".

75 Integrado por representantes de las organizaciones económicas, sociales, profesionales y de vecinos más representativas.
} 
Desde el encuadre epistemológico que aquí venimos utilizando, para afrontar el estudio del turismo en su impacto en el sistema de bienestar, es importante fijarnos en los modelos de desarrollo o modelo territorial que se implementan desde la ordenación del territorio y la urbanística. En todo proceso de planificación se siguen tres grandes pasos: 1) establecimiento de objetivos, 2) elaboración de un diagnóstico (establecer capacidades, limitaciones, potencialidades y riesgo para alcanzar los objetivos y capacidades de intervención (viabilidad)) y 3) establecimiento del Plan. Vera, J.F. (1997, pp. 352) establece, para una adecuada ordenación territorial y urbanística de las actividades turísticas, las siguientes cuestiones operativas; a) identificar los condicionamientos que el desarrollo de actividades turísticas y recreativas impone a los procesos de planificación territorial; b) estudiar los instrumentos y las estrategias de planificación a implementar para la creación de productos y organización del espacio turístico y c) analizar las características de los procesos económicos resultantes poniendo de manifiesto sus principales logros y limitaciones.

El modelo turístico ha ido variando en Europa desde la segunda mitad del S. XX, cuando empieza a despegar como actividad masiva. En esos momentos se observa un modelo espontáneo, principalmente surgido como respuesta a la demanda, donde los asentamientos de población originarios o tradicionales conviven con la nueva actividad (típico en todo el litoral peninsular e insular), y dónde la demanda se producía como respuesta a distintas motivaciones: el atractivo cultural de los pueblos de nuestras costas, naturaleza y playas vírgenes, los bajos precios, etc. Así, en los años sesenta, los Planes de desarrollo de España generan crecimiento económico a costa del turismo.

No será hasta finales de siglo cuando se pretenda que la puesta en valor turístico del territorio acoja otra concepción, que se localice en las regiones europeas más desarrolladas: "un modelo abierto en el cual el territorio se ordena y se pone en valor de manera integrada (urbanización y naturaleza, espacios llenos y vacío), una apuesta por la baja-media densidad y una oferta diversificada del producto, tanto en tipologías (apartamentos, hoteles, villas...), como actividades complementarias (deporte, cultura, naturaleza...) y segmentación social de la demanda (jóvenes, tercera edad...)"; constituye un "modelo definitorio de un intencionado espacio turístico" en busca de la sostenibilidad del modelo (Roger, G. 2002, pp. 51), que debe implantarse en relación a la capacidad de acogida del territorio. Así, Roger, G. (2002, pp. 53) habla de "capacidad turística" como garantía de alcanzar un turismo sostenible, lo entiende como "aquella intensidad de uso aplicable a un área concreta a partir de la cual se generaría la satisfacción de los usuarios o se sustituirán o alterarán sustancialmente las características identitarias de la cultura de la zona y que son la causa de su atracción originaria". Es por ello que este modelo exige la disposición de instrumentos jurídico-urbanísticos para poder regular y ordenar el desarrollo espacial del mismo. La ordenación racional del territorio y el urbanismo han sido y son los 
instrumentos que permiten garantizar la redirección de las sociedades que acogen los espacios turísticos consolidados, y la dirección de los nuevos, hacia la sostenibilidad, el bienestar y la calidad de vida como cualidad.

Dentro del territorio nacional, Baleares y Canarias son las Comunidades Autónomas que han desarrollado un modelo de planificación turística coordinado con la planificación territorial, puesto que el turismo es muy importante en términos estratégicos. En el resto de las Comunidades Autónomas no se ha alcanzado tal nivel de coordinación.

\section{2.- LA ADMINISTRACIÓN GENERAL DEL ESTADO. POLÍTICA Y LEGISLACIÓN}

La primera disposición, que marca el inicio de la política turística en España, data del 6 de octubre de 1905, y se concreta en un Real Decreto que crea una Comisión Nacional, integrada en el Ministerio de Fomento, con la misión de desarrollar la práctica del turismo en el interior de nuestras fronteras y la de atraer extranjeros que contribuyeran con sus divisas al saneamiento de nuestra economía.

Seis años más tarde, se crea una Comisaría Regia (1911), que va a absorber las funciones de la Comisión anterior, alcanzando un rango superior, al depender de la Presidencia y al integrar funciones de los Ministerios de Estado, Fomento, Gobernación e Instrucción Pública.

En la época de la Dictadura de Primo de Rivera, se creó el Patronato Nacional de Turismo (Real Decreto de 25 de abril de 1928), que disponía de una Delegación de Propaganda y otra de Viajes y realizó la primera zonificación turística del territorio (se puede considerar como un intento de realización de un Plan Territorial). Su mayor aportación, en palabras de Díaz Álvarez (1993), es la ejecución de un Plan de albergues y paradores de turismo.

Posteriormente, y con el inicio de la Dictadura del general Franco, este Patronato se transformará en el Servicio Nacional de Turismo, que poco después tomará el nombre de Dirección General de Turismo, dependiente del Ministerio de Gobernación. En esta época no se planifica. "La Dirección General ejerce un papel tutelar sobre los restos de la anterior industria turística, vigilando los precios y manteniendo lo que quedaba de la red de albergues del período republicano". (Díaz Álvarez, 1993 pp. 111).

Con la creación, en 1951, del Ministerio de Información y Turismo se inicia en España una planificación turística que pretende ser estricta. Se desarrollan varios planes de turismo (uno en 1953 y el otro en 1959), que no consiguen llegar a ser planes directrices de la actividad del sector, sino que se quedan en un conjunto de normativas para regular la actividad existente (Díaz Álvarez, 1993). 
El cambio de gobierno de 1962 significaría una revolución en la concepción del turismo (Fernández, L. 1991, pp. 830). El año anterior, el sector había supuesto para España un ingreso de 384,6 millones de dólares en la Hacienda Pública, lo que despierta la atención del Gobierno. Se crea la Subsecretaría de Turismo que cuenta con dos Direcciones Generales, la de Promoción del Turismo y la de Empresas y Actividades Turísticas y que coordinará y centralizará las políticas que ambas Direcciones lleven a cabo. Dicha subsecretaría tenía entre sus objetivos el ordenamiento territorial de las zonas turísticas, pero analistas políticos posteriores van a afirmar que en esta área su actuación no fue efectiva: "El ordenamiento territorial resultó complejo y cuestionable, pues en él intervinieron múltiples intereses privados y el ejercicio de influencias en favor de la especulación vació de contenido muchas de las normativas dirigidas a preservar las riquezas naturales y los patrimonios paisajísticos de muchos parajes". (Díaz Álvarez, J.R. 1989). Ahora, la estructura es triangular. En palabras de León Herrera (1999, pp. 72) "así comenzaba, coincidiendo con la creciente llegada de turistas y de ingresos, una etapa importante que con el telón de fondo de una sostenida recuperación de las economías occidentales, sería decisiva para la consolidación de España como uno de los destinos turísticos más deseados de Europa y del mundo".

Fue la evolución vertiginosa del fenómeno turístico la que contribuyó a la creación de un marco legislativo e institucional, que hace que en el año 1963, aparezca una nueva Ley relativa a las Competencias en materia de Turismo (Ley 48/1963 de 8 de Julio), que asignaba tales competencias al Ministerio de Información y Turismo, cuyo principal papel será la ordenación y vigilancia de toda clase de actividades turísticas, a través de la aprobación del Estatuto Ordenador de las Empresas y Actividades Turísticas privadas (Decreto 231/1965, de 14 de enero) —el Estatuto dedicaba un Capítulo a las Empresas, otro a las Actividades y otro como los anteriores, muy pormenorizado, al Procedimiento Sancionador-, estableciendo una primera y simple definición de las empresas de Hostelería y otros alojamientos turísticos.

A partir de este momento, se generaliza un concepto propagandístico del turismo, en la medida en que los hechos que se sucedían hacen que corresponda a la administración la acción para que la corriente turística no sea limitada, sino que se vea alentada con medidas de promoción y estímulo, implementado políticas directas de asistencia al turista —en 1964 es editado por el Servicio de Publicaciones de la Subsecretaría de Turismo, un librito de 71 páginas que pretendía ser una guía del turista, con todo aquello que les podía interesar. Su información estaba distribuída en tres bloques: LLEGAR, VER Y VENCER-, políticas de estímulo a la industria turística, políticas de control sobre instalaciones, servicios y trato a la clientela y estableciendo enseñanzas a este nivel (León Herrera, 1999, pp. 72 y 93-99).

La actividad del Ministerio de Información y Turismo desde 1962 hasta 1969 que se produce con el cambio ministerial, cuyo Ministro es Fraga Iribarne, M., se basó en tres 
campos de intervención (Fernández, L. 1991. Pp. 832) que se desarrollan dentro del I Plan de Desarrollo Económico (1963-1967):

1. Medidas de ordenación de sector: se estructura la composición y funciones de las Juntas Centrales, Provinciales y Locales de Información, Turismo y Educación Popular, como órganos periféricos, además de las bases de trabajo en las Delegaciones Provinciales. En este tiempo el Ministerio elabora una serie de disposiciones de diverso rango, que resumiendo, señalamos las siguientes: Ley de 8 de julio (1964) de Competencias en Materia de Turismo; en el mismo año se aprueba el Reglamento, del 31 de Enero de 1964, del Ejercicio de Actividades Turístico-Informativas Privadas, el Registro de Empresas y Actividades Turísticas, y el Registro de Denominaciones Geo-turísticas. En 1965 se aprueba, por Decreto, el Estatuto Ordenador de las Empresas y Actividades Turísticas Privadas, la Ordenación Turística de Restaurantes y Cafeterías, la imposición de multas por infracción de normas y las formas legales de actuación, en España, de las agencias de viajes. En 1966, la Comisión Mixta de Vigilancia para Agencias de Viajes.

El 10 de junio de 1967 aparece una Orden para la regulación del Estatuto de los Directores de Empresas Turística y, para terminar el período, en 1968 nuevas normas sobre clasificación de establecimientos hoteleros (19 de julio) y la ordenación turística de las ciudades de vacaciones (28 de octubre).

2. Medidas de promoción. Es el período de la creación de premios, de concesión anual, para incentivar a los organismos, empresas y particulares del sector. Se resalta la importancia del crédito hotelero y del Banco de Crédito Local para Ayuntamientos, abriéndose vías para la construcción y venta de edificaciones con destino a la venta a extranjeros (14 de abril de 1964), a partir de las posibilidades que abrió la Ley de Centros y Zonas de Interés Nacional, promulgada por Decreto el 28 de diciembre de 1963 (Ley 197/1963, de 28 de diciembre, y su Reglamento: Decreto 4.297/1964, de 23 de diciembre). Se abrió un sistema de subvenciones a fondo perdido para promover la mejora de casas de labranza para el turismo social $^{76}$, o ayudas para equipamientos de campos de golf, estaciones de invierno o puertos deportivos. El Decreto 1.124, de 9 de mayo de 1963 (por la Subsecretaría de Turismo) crea la Exposición Nacional de Recursos Turísticos (EXPOTUR) y contempla la Matrícula Turística para automóviles; en 1964 se convoca la I Asamblea Nacional de Turismo precedida de Asambleas Provinciales.

76 Un turismo impulsado por el Estado con el objeto de que también los colectivos de rentas más bajas puedan disfrutar de la actividad. Se encuentra dentro el denominado turismo interior. 
La obsesión por la propaganda y la información en el exterior del país llevó a impresionantes tiradas de carteles y folletos en diferentes idiomas, la edición de un Noticiario turístico (5.000 ejemplares cada tres meses), Suplementos, Calendarios, Guías Hoteleras, de Camping y Apartamentos, etc.

3. Creación de organismos y equipos complementarios. Elaboración de un Plan de Ampliación de la Red de Paradores Nacionales y Albergues de Carretera, junto con la creación del Instituto de Estudios Turísticos (Decreto 227, de 5 de septiembre de 1962) y la Escuela Oficial de Turismo, ambos en Madrid. León Herrera y Esteban (1999, pp. 77), apunta que "la actividad de carácter normativo desarrollada en este campo, por el Ministerio de Información y Turismo - 1962-1973 - fue muy intensa tanto en la promoción como en la ordenación del sector".

La década de los sesenta termina con la supresión de la Subsecretaría de Turismo (Decreto de 27 de Noviembre de 1967) ante el miedo a una crisis económica y la consecuente reducción del gasto público que trajo consigo. Se crean dos Direcciones Generales: de promoción del Turismo y de Empresas y Actividades Turísticas, que quedan sin coordinación alguna e ignorándose mutuamente en sus proyectos.

Por esta época, España abre el II Plan de Desarrollo Económico (1968-1971) cuyos objetivos generales son los siguientes: aumentar la cifra de turismo interior y extranjero, mantener la cifra de turismo español hacia el extranjero en menos de 5.5 millones de personas, diversificar la oferta turística (nuevos productos, como el turismo de nieve), y diversificar la estructura de la demanda. En palabras de Velasco, $\mathrm{M}^{\mathrm{a}}$. (2004, pp. 153) este Plan supondrá un "esfuerzo por ampliar el concepto de oferta turística".

En ambos planes de desarrollo, no se dejó de contemplar la necesidad de mejorar los sistemas y medios de transporte y de infraestructura urbanística como complemento indispensable de la oferta.

En la década del setenta y principios de la década del ochenta, España continuará con su política de promoción y su actividad ministerial y legislativa. Las fuertes políticas de promoción generan oleadas de turistas que provocan déficit infraestructural en el/los municipio/s de acogida. Se corría el riesgo de causar la propia estrangulación de dicho desarrollo. Dicha presión debía estar contenida y tenida en cuenta en el reparto de los presupuestos públicos. Se toma cartas en el asunto y se emite el Decreto № 3787/70 de 19 de diciembre, que instrumenta una serie de obligaciones mínimas sobre infraestructura en los alojamientos turísticos, estableciéndose como zonas de aplicación la Costa mediterránea, el Golfo de Cádiz, las islas Baleares y las Islas Canarias, ampliándose a las costas Cantábrica y Gallega dos años más tarde (Velasco, Mª. 2004, pp. 175-176). En palabras de Fernández (1991, pp. 860), esto dio lugar a una sensible mejora en el equipo 
receptor en materia de infraestructura. Todo ello se vio formalizado con la creación de una Subdirección General de Infraestructura en la Dirección General de Empresas y Actividades Turísticas.

Se abre el III Plan de Desarrollo Económico (1972-1975) que sigue en la línea de los dos anteriores. Este periodo viene marcado por la crisis política y económica internacional que genera la guerra del Yon Kippur, y que fue la detonante de la decisión de la OPEP (1973) de subir los precios del petróleo. Este periodo se alargará hasta la década de los años ochenta pues le seguirá la segunda crisis del petróleo (1979). Ambas afectaron inevitablemente al turismo, conformándose un periodo de crisis que va desde 1972 a 1982, caracterizado por Vasallo, I. (1999, pp. 105-106) de la siguiente forma:

- Inestabilidad gubernamental: nueve ministros responsables de Turismo.

- Política aérea liberal: consolidación de España como primer destino mundial de tráfico charter.

- Escasa inversión pública en infraestructura relacionada con el turismo.

- Quiebras en el sector turístico, en España y entre los tour operadores europeos.

- Crecimiento acelerado del alojamiento turístico extrahotelero y moderado del hotelero.

- Dependencia de la economía española del sector terciario, con gran incidencia del turismo.

- Graves accidentes relacionados con el sector turístico.

- Dificultades económicas de las compañías aéreas mundiales

Dentro del III Plan de desarrollo mencionado, en 1972 se divide el territorio español por zonas y se nombran Comisarios de Zona, bajo la Ley de Centros y Zonas de Interés Turístico (Ley 197/1963), se crean los Centros de Iniciativa Turística (Decreto 2.481/1974, de 9 de agosto) y el Decreto de Ordenación de la Oferta Turística 2.482/1974, como instrumentos jurídicos, entre otros. Todo ello da lugar a una legislación específica que generó el concepto de Territorios de Preferente Uso Turístico (Decreto de Declaración de Territorios de Preferente Uso Turístico, de 28 de marzo de 1977).

Con el nuevo Gobierno del 74, el nuevo ministro de Información y Turismo, Cabanillas, P., ante la crisis económica de 1973, que afectó seriamente al sector turístico, y el problema de la descoordinación que existía entre las dos Direcciones Generales de Turismo, la de Ordenación y la de Empresas, etc., crea dos Comisarías: un Comisario Nacional de Turismo que lleva la Dirección General de Ordenación y un Comisario Adjunto, Director General de Empresas, ambos duraron poco, lo único que consiguieron fue convocar la II Asamblea Nacional de Turismo, a esto le siguió un nuevo cambio ministerial el 29 de octubre de 1974, toma el cargo León Herrera, que suprime ambos cargos y crea la 
Subsecretaría como órgano coordinador (Decreto de 22 de octubre de 1974). En este tránsito se redactan los documentos del IV Plan de Desarrollo Económico (1976-1979), que nunca sería aprobado.

Aunque, como ya hemos señalado, España entra en la década de los setenta enfrentándose a una crisis del turismo propiciada por la crisis del petróleo, que genera inestabilidad política en el país. La crisis que sufre el sector en el Mediterráneo peninsular no se traslada a Canarias, por lo menos no a todas las islas, y en todo caso no afecta a Lanzarote que es lo que nos trae aquí. En palabras de Fernández Fuster (1991) esto puede deberse a que los territorios de soberanía alejados del territorio metropolitano, y por tanto de los verdaderos focos de crisis, no suelen ser identificados con el Estado.

Una vez dentro del modelo democrático, el Gobierno de la UCD, cuyo ministro con competencias en turismo será García Díez, J.A., dentro del Ministerio de Comercio y Turismo $^{77}$ se crea la Secretaría de Estado de Turismo en 1977, que a su vez crea una tercera Dirección General de Servicios, paralela a la de Promoción y de Empresas y Actividades Turísticas. Ello ocurre en un momento en el que ya se habla de transferir competencias a los entes Autonómicos en que se estructurarían las regiones españolas. (Fernández, L. 1991, pp. 987) y se da comienzo a dicho traspaso. Analistas como Vasallo I. (1999) señala las virtudes del Ministro García Díez, en la medida en que será la primera vez que se aborden las contradicciones del turismo, en cuanto a los problemas que genera, y no únicamente en cuando a los problemas que sufre (Velasco, $M^{a}$. 2004, pp. 217), así señala "se muestra favorable a la implantación de precios más elevados para el sector, saca a la luz los problemas de un exceso de Turismo: rentabilidad escasa del turismo marginal, negativas consecuencias sobre el medio, excesiva concentración y necesidad de altas inversiones en infraestructuras, especialmente en carreteras y depuración de aguas" (Vasallo, I. 1999, pp. 118).

Con la Constitución de 1978 y la política territorial que contempla, se favorece el traspaso de competencias a las Comunidades Autónomas. Se acerca la planificación turística a la política autonómica y local, mediante la aprobación de la mayor parte de las Leyes Orgánicas de Autonomía, quedando "en general el Turismo como competencia autonómica, excepto las actividades de promoción turística en ó para países extranjeros, que serían competencia exclusiva de la Secretaría de Estado de Turismo" (Vasallo, I. 1999, pp. 109).

77 Una vez suprimido el Ministerio de Información y Turismo heredado del periodo franquista. 
Posteriormente, se reestructurará el Ministerio denominándose Ministerio de Transportes, Turismo y Comunicaciones (Real Decreto 22/1982, de 7 de diciembre, sobre medidas urgentes de reforma administrativa).

En la década de los años ochenta, con el gobierno del PSOE, el núcleo de la política turística dependerá de una única Dirección General de Política Turística, creándose junto a ella el Instituto Nacional de Promoción del Turismo (Real Decreto 1209/1985, de 19 de Junio) con el fin de mejorar la operatividad y eficacia de los servicios, que posteriormente será Turespaña (1988), encomendándosele las funciones de promoción del turismo en el exterior (Velasco, Ma . 2004, pp. 248). Entre 1983 y 1984, se completará el proceso de transferencias en materia de turismo a las Comunidades Autónomas.

La promoción del país hacia el exterior y el turismo interior son acciones que siguen muy marcadas a lo largo de toda la década de los años ochenta, aunque en la primera mitad de esta década, el Ministerio, cuya cabeza era Barón, E. (1982-1985), se plantea el objetivo de desarrollar una planificación adecuada, que garantice diversificación, especialización y conservación de los valores paisajísticos, monumentales y culturas (Velasco, $\mathrm{M}^{\mathrm{a}}$. 2004, pp. 252-253): como acción principal, se abre un programa de creación de Núcleos de Turismo Rural, que busca como vía de desarrollo económico, en los núcleos rurales, la explotación de sus recursos endógenos por el turismo. A ello se añade varios instrumentos normativos con la intención de ordenar y clasificar la diversidad de alojamiento en todo el territorio nacional y estableciendo menciones de calidad.

Al final de la década de los años ochenta (1988) se reforma, de nuevo, la estructura orgánica del Estado. El Real Decreto 124/1988 de 12 de febrero, por el que se reorganiza la Secretaría General de Turismo y el Instituto Nacional de Promoción del Turismo, tiene como finalidad que exista la información necesaria y fácilmente disponible para la formulación de los planes de promoción turística en el exterior. $Y$ conseguir un mejor nivel en la coordinación con las Comunidades Autónomas que será la principal misión de la Dirección General de Política Turística.

Será en la segunda mitad de la década de los años ochenta cuando se acometan, según varios autores, verdaderas acciones en turismo social (que ya aparecía como uno de los objetivos en el Plan Nacional del año 1952), a través de la puesta en marcha del Programa de Vacaciones para la Tercera edad, que se pone en marcha junto con el IMSERSO y, que en palabras de Velasco (2004, pp. 260), "persigue dos objetivos: mejorar la calidad de vida de la personas mayores y mantener las instalaciones hoteleras en funcionamiento durante la temporada baja", reduciendo el impacto de la fuerte estacionalidad del turismo como actividad económica en todo el país. En los años siguientes se irá aumentado la oferta para este colectivo, sobre todo basada en programas de circuitos culturales por el país. 
Esta década acaba y comienza la siguiente con una fuerte crisis en el sector turístico, lo que hace que en 1990 el Congreso de los diputados constituya una Ponencia Parlamentaria sobre el Sector Turístico que analice el estado del mismo y proponga medidas para salir de la crisis y generar su desarrollo. Para ello, el Estado reúne a una pluralidad de agentes sociales del sector ${ }^{78}$ nacional y organiza reuniones con los principales tour operadores que operan en el país. De dicha ponencia se emitirá un informe (1991) de cuyas conclusiones señalamos algunas significativas: la necesidad de reorientar el sector según criterios de calidad y competitividad, elaborar estudios de impacto ambiental, social y cultural para nuevas implantaciones, la necesidad de mantener un diálogo continuado con las administraciones locales y que éstas realicen una planificación adecuada de los servicios públicos que se prestan en sus zonas turísticas, la necesaria diversificación de los productos de ocio nacionales, ampliación de la seguridad en zonas turísticas, diálogo con las asociaciones de consumidores y elaborar un Plan Integral de Infraestructuras que afectan al sector, entre otros (Velasco, $M^{a}$. 2004, pp. 264-265). El informe configura el nuevo papel del sector público donde queda recogida la preocupación entorno al bienestar de las sociedades de acogida de dicha actividad.

A la vez se realiza una reorganización de la Administración Turística Española, bajo la Ley 4/1990 de 29 de junio (Art. 81), donde se establece que las competencias en materia turística pasan a ser ejercidas por un Organismo Autónomo, el Instituto de Promoción del Turismo de España (TURESPAÑA), con lo que el papel ministerial queda reducido a la aprobación anual de plan de objetivos presentado por dicho organismo y a velar por su cumplimiento (Velasco, Ma . 2004, pp. 266). Por otro lado, se elabora el Libro Blanco sobre Turismo Español (1990), que presenta un nuevo análisis de la problemática del sector, bajo las que se señalan propuestas de acción, muchas de las cuales tienen repercusión indirecta y otras directamente sobre el bienestar de las sociedades locales anfitrionas: mejora de la accesibilidad a través de obras de infraestructura, rehabilitación de núcleos históricos, formación de capital humano, elaboración de Planes de Ordenación del Territorio de zonas turísticas, mejorar la seguridad ciudadana en los destinos, reducir la polución estética, acústica y la suciedad, etc. Debemos señalar que planes de formación profesional para el sector, se han contemplando en todas las acciones gubernamentales tanto en el período no democrático como en la España de la Democracia Constitucional hasta la actualidad. En opinión de Velasco, $\mathrm{M}^{\mathrm{a}}$ (2004, pp. 277), el Libro Blanco contiene el concepto de turismo desde una perspectiva sistémica. "El sistema de recursos conformado básicamente por el territorio y el conjunto de servicios, actividades y prestaciones ordenadamente ligadas a éste, componen el patrimonio turístico de un país (...) Estos

${ }^{78}$ Para ampliar información consultar a Velasco, Mª 2004 (pp. 263). 
recursos ligados al sistema de infraestructura, equipamiento y servicios, deben ser la base de la oferta turística de España (Libro Blanco, 1990, pp. 32).

La década de los años noventa empieza con el traslado de la Secretaría General de Turismo al nuevo Ministerio de Industria, Comercio y Turismo, en 1991, (Ley 31/1991. de 30 de diciembre de Presupuestos Generales del Estado para 1992, y con la derogación de la Ley 197/63, sobre Centros y Zonas de Interés Turístico nacional (Ley 28/91 de 5 de diciembre), que chocaba con las nuevas competencias autonómicas. Posteriormente, en la primera mitad de esta década será reorganizado dicho Ministerio separando las competencias en industria y tomando el nombre de Ministerio de Comercio y Turismo.

Para la primera mitad de la década se presenta el Plan marco de competitividad del Turismo Español (Plan FUTURES, 1992-1995), puesto en marcha por el Estado junto con las Comunidades Autónomas, con él se emprendieron planes globales en destinos turísticos basados en el principio de corresponsabilidad de todos los agentes sociales y económicos, con la intensión de modificar el estado en el que se encontraban algunos destinos del Mediterráneo y de los Archipiélagos, por desordenes urbanísticos, explotación medioambiental, masificación e infraestructuras obsoletas. "El desafío del turismo sostenible sólo podrá se afrontado con éxito si todos los participantes, cada uno según su nivel de acción y de competencia, ponen en marcha las acciones necesarias en el marco de un proceso continuo" (Troitiño, M.A. 1998, p. 212). Este Plan se renovó para los años 19961999 y fue sustituido por el Plan Integral de Calidad del Turismo Español (PICTE) en 2000. A la vez vuelve a ponerse en funcionamiento el Instituto de Estudios Turísticos (1993), consolidándose como órgano encargado del análisis, de las estadísticas y de la difusión de la información turística ${ }^{79}$, la Comisión Interministerial de Turismo (suprimida en 1985, y puesta de nuevo en marcha en 1994) y se institucionaliza la Conferencia Sectorial del Turismo, como foro de las administraciones Públicas de carácter territorial que reúne a los responsables en la materia de todas las Comunidades Autónomas (1994).

EI Plan FUTURES presenta objetivos, en torno a competitividad, en tres fines: política social, económica y medioambiental. En lo que a este trabajo se refiere señalamos lo siguiente: a) los fines sociales que presenta pretenden mejorar la calidad turística para incrementar el bienestar en las sociedades receptoras, junto con potenciar la formación cualificación en turismo, y mejoras en la coordinación interadministrativa y en el entorno

\footnotetext{
79 "Los años 1995-1996 se pueden considerar como los años de consolidación del Instituto de estudios Turísticos, por varios motivos: se define y aprueba un plan de investigación a corto y medio plazo, se renuevan las dos operaciones estadísticas sobre la demanda turística: FRONTUR Y FAMILITUR; se inicia una política sistemática de cooperación institucional con las Comunidades Autónomas, con las Administraciones Públicas y con los Organismo Internacionales y se estructura el organigrama y se comienza, tras una cuidadosa planificación, el proceso de informatización de instituto". Rodríguez, N. 1997, pp. 207
} 
informativo de los trabajadores, las empresas y las administraciones públicas; b) en los aspectos económicos señalamos el objetivo de "mejora de las infraestructuras como factor generador de economías externas y componente de determinados productos turísticos"; c) en cuanto a los fines medioambientales: apoyo a proyectos de mejora del entorno, desarrollo de normativa de medio ambiente, natural y urbano. Resumiendo, apoyo a iniciativas dirigidas a la conservación del medio por su importancia para la actividad turística; En su renovación para el periodo (1996-1999) sus principios rectores serán "sostenibilidad, corresponsabilidad de todos los agentes, concentración de las acciones e integración de la iniciativas empresariales en proyectos comunes con las distintas administraciones" (Velasco, $\mathrm{M}^{\mathrm{a}}$. 2004, pp. 300). Se cambia, en este período, el modelo de relación entre Estado y Comunidades Autónomas, entendiendo que los fondos para subvenciones previstos en el Plan Futures II, debían ser gestionados por las Comunidades Autónomas (Velasco, Mª. 2004, pp. 318).

Es en la década de los años noventa cuando España tratará el turismo como un sector industrial. "El Plan Futures resulta revolucionario en el mundo del turismo pero en realidad se limita a aplicar las teorías de planificación económica e industrial de finales de la década de los ochenta al sector turístico (...). Los nuevos entorno cambiantes y turbulentos, exigían cambiar el punto de vista y planificar previniendo las capacidades que la indeterminación exigiría desarrollar. Era necesario incorporar los aspectos sociales, económicos y medioambientales del entorno: había que situarse en el entorno para analizar las organizaciones"(Velasco, Mª. 2004, pp. 313), como aconsejaba las conclusiones de la Conferencia de Manila (1980), que había reconocido a esta industria como multifacética y cuyo desarrollo provocaba impactos sociales, económicos y medioambientales no siempre positivos.

En el año 2011 se abrirá la tercera edición del Plan Futures, que dará continuidad al compromiso del Gobierno de mejorar la calidad de las infraestructuras turísticas nacionales desde la óptica de la sostenibilidad ${ }^{80}$.

El último quinquenio de la década de los años noventa se enmarca dentro de un cambio en el Gobierno de España que cubrirá el periodo 1996-2004. Durante este tiempo, el turismo dependerá primero del Ministerio de Economía y Hacienda y después del Ministerio de Economía. Es durante este periodo cuando se aprueba el Plan Integral de Calidad del Turismo Español (PICTE), 2000-2006, cuyo concepto básico será la calidad. Renueva los

80 Ministerio de Industria, turismo y comercio. "Plan FuturE 2011". (http://www.mityc.es/turismo/esES/Paginas/FuturE2011.aspx. Fecha de consulta: 20-05-2011). 
esfuerzos de la última década del sector privado y de la Administración para la creación de una nueva oferta y la inversión en infraestructuras.

Los objetivos del PICTE a destacar, en lo que a este trabajo se refiere, serán los siguientes: 1) sostenibilidad sociocultural y medioambiental de la actividad; 2) aumento de la calidad del empleo y la formación del sector. Supone la activación de dos líneas de acción principales: a) la implantación de sistemas de calidad en los distintos subsectores y b) planes de calidad en destino, comprendiendo programas de Turismo Sostenible, Planes de Excelencia y Dinamización y el Modelo de Gestión Integral de la Calidad en Destino (Matas y Martín, 2001, pp. 57). Se continúa con los Planes de Excelencia, pensados para los destinos maduros, caracterizados por haberse especializado en el segmento de sol y playa y se añaden los Planes Dinamizadores orientados a destinos en fase de desarrollo turístico.

Destacar que, bajo este Plan Integral del Calidad, comienza el Programa de Turismo Sostenible, amparado por el $\mathrm{V}$ Programa Marco de la Unión Europea que considera al turismo como uno de los cinco sectores clave sobre los que hay que actuar para la protección del medio ambiente, especificando diversos aspectos problemáticos (usos del suelo, construcciones ilegales, automóviles, ruido, aguas, emisiones a la atmósfera, riesgo de zonas sensibles, etc.). Adoptando estos objetivos, la Administración Turística del Estado implanta el Sistema de Gestión Medioambiental en los municipios turísticos y da también comienzo el Sistema de Calidad Turística en Espacios Naturales Protegidos (Velasco, $\mathrm{M}^{\mathrm{a}}$. 2004, pp. 340-341).

Por otro lado, también se establece el Sistema Integral de la Calidad Turística Española (S.I.C.T.E.D.), cuya idea se centra en trabajar en el destino teniendo en cuenta que la calidad percibida en el mismo es la suma de factores turísticos junto con otros que no lo son, o sea, comprende la naturaleza transversal de la calidad en un destino turístico, en la que intervienen tanto los subsectores ya desarrollados (hoteles, restaurantes, agencias de viajes, etc.), como los nuevos subsectores no desarrollados previamente (alquiler de coches, pequeño comercio, etc.), y tanto los servicios públicos municipales no turísticos (transporte Público, gestión del Patrimonio, limpieza, seguridad ciudadana, etc.) como los servicios turísticos municipales (oficinas de Turismo, Convention Bureaux, Palacios de Congresos, etc.), y por tanto "plantea un nuevo objetivo: alcanzar un nivel de calidad homogéneo dentro de un mismo destino, esto es, que incluso en el caso de que exista un nivel de calidad aceptable en un destino determinado, no se aprecien deficiencias de calidad sustanciales entre los diferentes elementos o agentes que componen la oferta en el destino que puedan condicionar la percepción y satisfacción del turista". Así, pretende facilitar la participación y colaboración de todos los sectores económicos y servicios públicos en cualquier actividad vinculada con la calidad turística, para poder desarrollar un plan estratégico propio de ese destino, midiendo la calidad y haciendo seguimiento de la misma en los sectores mencionados. La implantación piloto del Modelo se realiza en 24 
destinos de diferente tipología rural/montaña, sol y playa y ciudad/cultural, entre los que se va a encontrar Lanzarote. A partir de diciembre de 2003, se amplía hasta 46 destinos en total (Ministerio de Industria, Turismo y Comercio. Subdirección General de Calidad e Innovación Turística, 2003) ${ }^{81}$.

En la actualidad la política turística del Estado español está contemplada en el Plan Turismo Español Horizonte 2020, citado en epígrafes anteriores, aprobado a finales del año 2007, por Ministerio de Industria, Turismo y Comercio, a través de la Secretaría de Estado de Turismo. Plan que es fruto del consenso entre el sector público y privado, cuyo objetivo es que "el desarrollo turístico de España en el futuro se asiente sobre las bases de la competitividad y la sostenibilidad medioambiental, social y económica". Este gran objetivo se desglosa en siete específicos que pasamos a resumir: 1) alcanzar la sostenibilidad del sistema turístico español, mejorar su calidad, eficacia y eficiencia teniendo en cuenta la capacidad de carga ambiental; 2) mejorar el modelo de gestión de las personas en el sector, profesionalidad y talento para ser más competitivos; 3) aumentar la competitividad a través de una promoción y comercialización diferencial, especializada y rentable; 4) generar y difundir conocimiento útil para la toma de decisiones por parte de los agentes del turismo español; 5) mejorar el rendimiento económico del turismo aumentando el valor de los productos ofertados, adaptados a cada cliente y con personalidad propia; 6) Crear las mejores condiciones para el desarrollo de la actividad turística, las infraestructuras, el marco económico, legislativo, y fiscal , así como los instrumentos de gestión y relación de los agentes públicos y privados; 7) incorporar la innovación como elemento diferencial de los negocios, los productos y los destinos turísticos, que caracterice la oferta turística española en el mundo (Ministerio de Industria, Turismo y Comercio, 2008) ${ }^{82}$

Estos objetivos, cuyo alcance impulsa, se fundamentan en las debilidades del modelo que diagnostica que, entre otras, citamos las siguientes: el sobreuso y deterioro ambiental del litoral, la elevada estacionalidad, el deterioro del binomio precios-productividad y la baja rentabilidad socioeconómica del "turismo residencial". Todas ellas aportan a la desviación hacia el camino de la sostenibilidad del sector a largo plazo y constituyen dificultades para evitar o minimizar los efectos de las crisis cíclicas que sufre el sector y, por tanto, de la mejora del bienestar de las sociedades que acogen dicha actividad como principal fuente de riqueza.

El reconocimiento de qué cosas han funcionado mal ya se detecta en este Plan, apareciendo con más detalle en posteriores declaraciones de compromiso que pretender

81 http://www.sgt.tourspain.es (16-09-2009).

82 http://www.turismo2020.es (16-09-2009) 
reorientar la política impresa a este sector, en los destinos maduros nacionales, con un horizonte a más largo plazo (2020-2050). Así surge la "Declaración de compromiso a favor de un nuevo modelo de turismo del litoral español y de adhesión al Plan Turismo Litoral Siglo XXI", aprobada en el Consejo Español de Turismo a 31 de marzo de 2011, que no sólo reconoce las dificultades del sector a causas del modelo que presenta en su madurez, tanto en el litoral mediterráneo como en ambos archipiélagos, sino que además insta a la instituciones nacionales, autonómicas y locales, a la necesidad de impulsar una "estrategia país" y procurar una política turística integral y global que apueste por la diferenciación frente a la estandarización propia de los destinos de masa nacionales, como una de las vías para su modernización y mayor competitividad internacional, lo que conlleva la introducción de nuevos modelos de gestión de la oferta y la demanda turística del litoral y la necesaria revalorización de sus espacios/productos turísticos.

Para concluir, en relación el objetivo de esta tesis señalamos que la preocupación y la intervención política por los efectos que tiene la actividad turística sobre aspectos concretos del bienestar de la población anfitriona, pasa por diferentes fases a lo largo del período de análisis que contempla este trabajo y que establecemos de la siguiente forma:

- Fase 0. La atención e intervención política se basa en la ampliación de la oferta y la promoción externa del país. Esta política cubre todo el período dictatorial y la Transición.

- Fase 1 o fase de reconocimiento. A partir de 1977, con el primer gobierno democrático, la UCD, será la primera vez que se van a abordar las contradicciones del turismo, en cuanto a los problemas que genera en los entornos territoriales donde se instala (consecuencias negativas para el medio ambiento, altas inversiones en infraestructura de comunicaciones e hídricas principalmente), y no únicamente en cuando a los problemas del turista. Este Gobierno tendrá gran actividad en planificación turística, realizándose Planes de Ordenación de la Oferta Turística de ámbito provincial, para las provincias de Las Palmas de Gran Canaria y Tenerife (1978), entre otros.

- Fase 2 o fase de planificación. El período democrático estará salpicado de Planes y Programas Turísticos que contemplan objetivos, actuaciones y medidas para la mejora del bienestar de los entornos sociales que acogen la actividad, su equilibrio social, económico y medioambiental hasta la actualidad (Plan FUTURES, PICTE y Plan Turismo 2020).

\section{3.- LA ADMINISTRACIÓN AUTONÓMICA. CANARIAS}

Como se ha referido anteriormente, la Constitución de 1978 establece la nueva organización territorial de Estado que se formaliza con los correspondientes Estatutos de Autonomía entre 1979 y 1983, y los Decretos de Transferencias de Medios y Funciones del 
Estado a las Comunidades Autónoma, debiendo considerarse a partir de entonces un nuevo marco urbanístico y territorial. Las nuevas capacidades de las Comunidades les van a permitir legislar y en todo caso ejercer las competencias urbanísticas junto a las Administraciones Locales (Art. $148 \mathrm{CE}$ ). En este campo se va a producir el paquete de normas más amplio y variado (Candela, C. 1994, pp. 63-64).

Así, la ordenación territorial y urbanística del desarrollo turístico ha ido articulándose, específicamente, sobre la base de las regulaciones de ámbito regional. Las diferentes Comunidades Autónomas españolas han definido su política turística y han ido legislando en materia de ordenación territorial del turismo, destacando aquellas comunidades donde el turismo es importante, no sólo en términos cuantificables sino también estratégicos, como es el caso de Canarias, estableciendo así instrumentos o figuras normativas específicas a aplicar a distinta escala (regional y local) y sobre los diversos entornos territoriales (litoral, rural, natural o urbano).

El territorio de la Comunidad Autónoma de Canarias que, como recurso natural, viene definido por las características de escasez, singularidad, no renovabilidad e insularidad, constituye la base del desarrollo económico y social del Archipiélago. Principio este reconocido en los textos legislativos promulgados por la Comunidad Autónoma en materia de ordenación territorial, a fin de poder hacer frente a la problemática más acuciante derivada de las peculiares características de su territorio ${ }^{83}$. En este orden, el proceso es iniciado con la Ley 3/1985, de 29 de julio, de Medidas Urgentes en Materia de Urbanismo y Protección de la Naturaleza, que será desarrollada por la Ley 1/1987 de 13 de marzo Reguladora de los Planes Insulares de Ordenación.

Dicha Ley aparece con el objetivo de llenar el vacío que existía en cuanto a figuras de planeamiento que fueran operativas a escala insular, puesto que dentro del esquema organizativo del Archipiélago se ha mantenido históricamente la isla como unidad de Gobierno Local. Contempla, por tanto, como único instrumento para establecer el modelo territorial, los Planes Insulares de Ordenación (PIOT), situándolos, en todo caso, con posición jerárquicamente superior al planeamiento municipal (aspecto éste que se mantiene hasta la actualidad), o sea, como marco referencial de la ordenación urbanística, incluida la ordenación de los recursos naturales y, la ordenación de estrategias territoriales. Identifica al Cabildo como órgano político encargado de la formulación del Plan, establece garantías para la participación municipal en dicha formulación y, en cuando instrumentos de gobierno, permiten que el ejecutivo Regional se beneficie de la visión global de isla que presenten dichos planes y disponer de mayor capacidad para evaluar la repercusión de las

${ }^{83}$ Exposición de motivos. Ley 9/1999 de 13 de mayo, Ordenación del Territorio de Canarias 
inversiones sectoriales del Gobierno. Presenta determinaciones de ordenación y directrices de compatibilidad y de coordinación sectorial sobre el marco físico, justificadas en relación a las exigencias del desarrollo regional, a la articulación racional de las distintas políticas y actuaciones con incidencias sobre el territorio, a la mejor distribución global de los usos o actividades e implantación coordinada de las infraestructuras básicas, y a la necesaria protección del medio ambiente, de los recursos naturales y de los bienes culturales, teniendo en cuenta las características socio-económicas de su territorio y población en relación con las posibilidades y los programas de actuación del sector público y las posibles actuaciones del privado (Art. 2.1, 2.2 y 2.3). Así, toda actividad estará sometida al PIOT, incluido la turística. La Ley lo que hace es establecer objetivos generales que cada PIOT concreto, pudiendo encontrarse muchas diferencias en los objetivos de unos u otros Planes Insulares.

El marco legislativo autonómico en este orden seguirá desarrollándose con la Ley 5/1987, de 7 de abril, sobre Ordenación Urbanística del Suelo Rústico de la Comunidad Autónoma de Canarias, la Ley 6/1987, de 7 de abril, sobre el Sistema de Actuación de Urbanización Diferida o la Ley 12/1987, de 19 de junio, de Declaración de Espacios Naturales de Canarias. Todas ellas afrontan aspectos como la insularidad, la positiva ordenación del suelo rústico, la regulación de los desarrollos urbanos no ortodoxos o la protección de los espacios naturales, también abordado por la posterior actividad legislativa desarrollada en la ley $7 / 1990$, de 14 de mayo, de Disciplina Urbanística y Territorial y la Ley 12/1994, de 19 de diciembre, de Espacios Naturales de Canarias.

Pero, la política y legislación en torno a la ordenación del territorio de Canarias necesariamente abordará también el marco en el que el turismo, principal actividad económica del archipiélago, deba desarrollarse. Así, aparece la Ley 7/1995, de 6 de abril de Ordenación del Turismo de Canarias que presenta una regulación general del sector y además contiene determinaciones con incidencia territorial. En dicha ley, se admite el turismo como elemento económico estratégico del archipiélago, y se concibe Canarias como una unidad de destino turístico (Art. 3) y como bien colectivo (Art. 30), de ahí su necesaria ordenación y promoción, junto con el fomento (Art. 52 al 56) del sector turístico empresarial, en todos los sentidos (en cuanto actividad y establecimientos (Art. 2), cuyas tipologías se amplían). Insiste en el medio ambiente, el paisaje y la cultura autóctonos como recursos turísticos, como un bien de capital, de los que hay que hacer un uso racional y entiende al turista como "usuario turístico" estableciendo garantías de protección de su estatus jurídico. Incide, pues, sobre la oferta, apoyando su diversificación y en la calidad a través de la ordenación general de dicha oferta: regulación del alojamiento y zonas a rehabilitar (Art. 31 al 46), regulación de la sobrecontratación (Art. 76.12) como infracción grave (amplía la Ley de Disciplina en materia turística (Ley 3/1986, de 8 de abril) en los artículos 72 al 84), del alojamiento a tiempo compartido (Art. 46) o "time-sharing", de las 
actividades de restauración (Art. 49 al 51), de los requisitos exigibles para las empresas, la profesionalidad (Art. 45) a través de la formación del personal (Art. 68 al 71) haciendo mandato al Gobierno de Canarias para la creación de una Comisión para la formación profesional turística, de carácter interdepartamental, y de las condiciones que preserven el medio ambiente y la cultura, principalmente. Y creó el Registro General de Empresas, Actividades y Establecimientos Turísticos, como instrumento público de conocimiento y seguimiento de la oferta turística, regulándolo en sus artículos 22 y 23.

Por otro lado, regula las infraestructuras y los servicios públicos (Art. 57 al 67) y destaca al Plan Insular de Ordenación del Territorio (PIOT) como instrumento de ordenación urbanístico-turística y de los recursos naturales del Archipiélago, obligando a que la vigente Ley reguladora de los P.I.O.T, se adecuara a ella (Disposición Adicional Primera) y a la que también debía adaptarse todo el planeamiento urbanístico municipal. Por ello, ante la necesaria coordinación entre Planificación Insular y Municipal establece la posibilidad de suspender el planeamiento urbanístico y la concesión de licencias, en zonas a rehabilitar o insuficientemente dotadas mientras se produce la adaptación del planeamiento municipal al P.I.O.T. (Preámbulo 3.k); a lo que se añade el mandato al Gobierno de Canarias para confeccionar el Estatuto de los municipios turísticos. Por otro lado, reparte competencias entre Administraciones públicas (Art. 5 y 7 ) y las bases e instrumentos para que se relacionen.

Ese mismo año, se reestructura la Administración Pública creándose la Consejería de Turismo y Transporte (Decreto 187/1995, de 20 de julio) reunificando las atribuciones de las competencias en materia de turismo y transporte. A ella se adscribe el Consejo Regional de Turismo (Decreto 281/1995, de 11 de septiembre) como órgano colegiado, de asesoramiento y consulta del Gobierno de Canarias en materia turística, que al año siguiente tomará el nombre de Consejo Canario de Turismo. En su composición estarán representados los agentes económicos y sociales de la Región, junto a las Administraciones públicas competentes (representantes de los Cabildos, de los municipios, de las organizaciones empresariales, representantes de los trabajadores del sector, etc.). Entre sus funciones se encuentran: a) Evacuar los informes y consultas que, en materia turística, le sean solicitados por cualesquiera de las Administraciones públicas de Canarias; b) Ser oído en el trámite de audiencia en los planes sectoriales de interés general; c) Hacer sugerencias a las Administraciones públicas de Canarias en cuanto a la adecuación del sector turístico; d) Elaborar un informe anual sobre la situación turística de Canarias, principalmente. Bajo esta Consejería se modifica la ley vigente de Ordenación del Turismo de Canarias y la ley de Ordenación del territorio.

Dentro del ámbito competencial de esta Consejería, y bajo la Ley 7/1995 de Ordenación del Turismo en Canarias, se elabora el Plan de Excelencia y liderazgo del sector turístico de Canarias (ELITUR). Como plan estratégico los principios bajo los que se elabora 
constituyen una modificación en la orientación política turística de la comunidad autónoma hacia el crecimiento de las plazas de alojamiento turístico en las islas. Señalamos aquí los siguientes principios: a) fundamentar el crecimiento turístico de Canarias en el incremento del gasto turístico y en el impacto que debe tener en el tejido empresarial local, en vez de centrarse en el incremento del número de turistas recibidos; b) mejora de la calidad, competitividad, y fomento del desarrollo turístico sostenible; c) diversificación del producto turístico, potenciando el desarrollo de una oferta de ocio complementaria al sol y la playa, y el desarrollo de otras formas de turismo; d) utilización de las nuevas tecnología en actividades de comercialización y gestión de destinos y empresas turísticas; e) la internacionalización del sector turístico canario y sus empresas, impulsando la presencia de Canarias en los principales organismos y grupos empresariales europeos del sector; f) coordinación de las actividades de los distintos agentes sociales del sector, así como el consenso sobre temas de interés general.

En el año 1999 se aprueba la nueva ley de Ordenación del Turismo (Ley 5/1999 de 15 de marzo, de Modificación de la Ley 7/1995, de 6 de abril, de Ordenación del Turismo de Canarias), que añade flexibilidad a la práctica del comercio turístico sin que sea un obstáculo en la creación de un sistema que asegure el destino turístico de las unidades de alojamiento de los establecimientos y complejos ya autorizados y en funcionamiento, por razones de interés público basadas en el "principio de unidad de explotación" en el que se fundamenta esta reforma (sometimiento a una única empresa de la actividad de explotación turística alojativa en cada uno de los establecimiento (...) cuyas unidades deberán de destinarse en su totalidad a la actividad turística a la que quedan vinculadas. Art. 38.2)

Por otro lado, se aprueba, ese mismo año, la Ley 9/1999, de 13 de mayo, Ordenación del Territorio de Canarias, que pretende, mediante la ordenación integral, asumir la legislación autonómica de incidencia territorial, para terminar con la dispersión de normas urbanísticas y medioambientales sectoriales, a fin de formar un cuerpo legal en el que de forma sistemática y coherente se relacionen entre sí, propiciando la simplificación de los procedimientos administrativos. Así, busca ampliar la perspectiva para vincular dentro de ella el contenido medioambiental y la ordenación de los recursos naturales, referidos no sólo a aquellas partes del territorio objeto de protección sino también al ámbito urbano y rural, a fin de garantizar como objetivo último la consecución de la calidad de vida de los ciudadanos y la armonía con su entorno. La filosofía y los objetivos de este texto legal es incorporar los criterios propuestos en el Real Decreto-Ley 5/1996 de 7 de junio y la Ley 7/1997, de 14 de abril, o sea, incorporar la política de liberalización del mercado del suelo del Estado, y asumir la concepción de la Ley 6/1998, de 13 de abril, sobre Régimen del Suelo y Valoraciones, de los principios de flexibilidad, agilidad y capacidad de adaptación a la necesidades cambiantes del mercado, con el objetivo de abaratar los costes del suelo y de la vivienda. 
El fin de la década de los años noventa viene marcado por la participación de la Comunidad Autónoma en el Plan Futures, diseñado por el Gobierno de España, estableciéndose bajo él regímenes de ayuda a la competitividad del turismo canario, actuando sobre la formación de los recursos humanos, la innovación tecnológica y el desarrollo de nuevos productos turísticos ${ }^{84}$.

El ejercicio de las competencias territoriales atribuidas a la Comunidad Autónoma Canaria ${ }^{85}$ encuentra en las Directrices de Ordenación la herramienta más adecuada, en tanto que instrumento de planeamiento del Gobierno, que integra la ordenación de los recursos naturales y del territorio para la consecución de su primer objetivo básico: la articulación de las actuaciones tendentes a garantizar el desarrollo sostenible, como establece el Texto refundido de las leyes de Ordenación del Territorio de Canarias y de Espacios naturales de Canarias $^{86}$ (Decreto legislativo 1/2000, de 8 de mayo, Art. 15), que pretende armonizar la regulación y los preceptos de ambas leyes. Así, para lograr un modelo de desarrollo más sostenible y duradero para la islas, pero también socialmente más equilibrado y justo, se acuerda la formulación conjunta de las Directrices de Ordenación General y las Directrices de Ordenación del Turismo de Canarias, al entender que la definición de un marco territorial y de los recursos naturales para el archipiélago, no podía ser eficaz, dada su evidente interacción, si simultáneamente no se diseñaba el marco para la principal actividad económica. En palabras de Ramón Fernández, R. (2002, pp. 41), constituyó un factor de confusión puesto que "aunque texto ambicioso" resulta de él "en total: diecinueve tipos de instrumentos de ordenación".

Por otra parte, era (y es) el ritmo de crecimiento de esta actividad, y sus efectos sociales, ambientales y económicos, el factor que más urgentemente demandaba una ordenación general y sectorial desde una perspectiva de sostenibilidad ${ }^{87}$. Se empieza aprobando el Decreto 4/2001, de 12 de enero, por el que se acuerda la formulación de las Directrices de Ordenación General y del Turismo de Canarias. Queremos señalar aquí una de las variaciones que establece sobre la Ley 7/1995; nos referimos al apartado sexto por el que deja en suspenso por el plazo de un año, ampliable hasta un máximo de dos años, la

${ }^{84}$ Real Decreto 2.346/1996, de 8 de noviembre, por el que se establece el régimen de ayudas y se regula su sistema de gestión en aplicación del II Plan Marco de Competitividad del Turismo Español (1996-1999).

85 Ley Orgánica 10/1982 de 10 de agosto, de Estatuto de Autonomía de Canarias. Art. 30.15, 30.16 y 32.12 (competencias en ordenación del territorio, litoral, urbanismo y vivienda, espacios naturales protegidos, conservación del medio ambiente y vertidos. Reformada por la Ley Orgánica 4/1996, de 30 de diciembre. Actualmente, se esta tramitando una nueva reforma, que ha sido rechazada por el Congreso de los Diputados, volviendo a Canarias para ser debatida.

${ }^{86}$ Elaboración de un Texto Refundido de las disposiciones de la Ley 9/1999, de 13 de mayo, de Ordenación del Territorio de Canarias y de las Leyes 12/1994, de 19 de diciembre, de Espacios Naturales de Canarias y 13/1994, de 22 de diciembre, de Modificación del Anexo de la Ley anterior.

87 Ley 19/2003. Exposición de motivos. I. 
tramitación y aprobación de los Planes Territoriales Parciales (6.1), tramitación y aprobación de las modificaciones y revisiones parciales de los instrumentos de planeamiento general (6.2.), que incidan en la ordenación de cualquier tipo de uso turístico, la tramitación y aprobación de los instrumentos de planeamiento general (Planes Generales y Normas Subsidiarias), y de los planes y normas de Espacios Naturales Protegidos, así como de sus revisiones, cuando permitan el desarrollo de uso "alojativo" turístico, de los planes parciales de ordenación, así como de sus modificaciones puntuales o revisiones, de los proyectos de urbanización relativos a sectores de suelo en los que planeamiento admita cualquier uso turístico, así como el otorgamiento de toda licencia de edificación de obra nueva de establecimientos turísticos o de ampliación de los existentes, sin excepción. "El stop es general e indiscriminado porque no distingue (...) por islas, ni por municipios, ni tiene en cuenta la muy diversa situación en que aquéllas y éstos se encuentran, tanto por lo que hace a cantidad, como por lo por lo que respecta a la calidad. Tampoco se hace distinción en atención a la diversa situación en la que se encuentran los diversos planes (...) o sobre las tipología edificatorias que presentan" (Ramón, T., 2002, pp. 45). La intención fue generar una moratoria, que en la historia reciente de Canarias no han sido bien recibidas por los inversores, lógicamente. Además, no sólo afectó, en algunas islas, al uso turístico, sino también al residencial.

Todo ello culmina en la Ley 19/2003, de 14 de abril, por la que se aprueban las Directrices de Ordenación General y la Directrices de Ordenación del Turismo de Canarias. Esta ley habilita la figura excepcional de los Planes Territoriales Especiales de Ordenación Turística Insular (Disposición Adicional I), bajo la idea de que un sector tan vital y dinámico como el turístico no puede quedar condicionado a un lento y encadenado proceso de adaptaciones sucesivas. Así que, para la adaptación de la ordenación turística a los límites y ritmos de crecimiento que fije trienalmente el Parlamento de Canarias, de forma ágil, los Cabildos deberán formular estos Planes Especiales de ámbito insular (que establecen previsiones específicas de desarrollo territorial y turístico), cuyas determinaciones se han de entender como alteración de las que presente el Plan Insular de Ordenación de Territorio. Por otro lado también modifica el artículo 23.5 del Texto Refundido de las Leyes de Ordenación del Territorio de Canarias y de Espacios Naturales de Canarias (Disposición Adicional II) para dar capacidad vinculante a los Planes de Territoriales Especiales que desarrollen determinaciones de las Directrices de Ordenación. Además de modificar los artículos 32.2.A.8) y 71.1.a) en pro de mejorar la política de vivienda social, potenciando las reservas de suelo con destino a viviendas protegidas y estableciendo la obligatoriedad de una reserva mínima a nivel municipal.

La estructura de la Administración Pública de Canarias volverá a ser modificada en el año 2003 (Decreto 241/2003, de 11 de julio), bajo la cual se crea un único órgano en materia específica turística, la Consejería de Turismo, que asume las competencias que legal y 
reglamentariamente tenía encomendadas la anterior Consejería de Turismo y Transportes, excepto la de transportes que pasa a la Consejería de Infraestructuras, Transportes y Vivienda. Dichas competencias se concretan en lo siguiente (Decreto 84/2004, de 29 de junio): de estudio, propuesta, impulso y ejecución de la política del Gobierno de Canarias en las materias de ordenación, promoción e infraestructura turísticas, así como de costas (antes asignadas a la extinguida Consejería de Obras Públicas, Vivienda y Aguas). Por tanto, su misión será orientar la política turística canaria hacia la consecución del modelo de desarrollo sostenible promovido por las Directrices de Ordenación del Turismo, aprobadas por la Ley 19/2003, anteriormente tratada. Estas directrices también prevén la creación de un sistema de información turística compartido por las tres Administraciones Públicas canarias y vinculado al Registro General de Empresas, Actividades y Establecimientos Turísticos, como instrumento para acometer adecuadamente la planificación, ordenación y regulación del sector (directriz $\mathrm{N}^{\circ} 28$ de su texto normativo), alcanzable a través del uso de las nuevas tecnologías de la información (impulsado ya por el artículo 45 de la Ley 30/1992, de 26 de noviembre, de Régimen Jurídico de las Administraciones Públicas y del Procedimiento Administrativo Común y posteriormente por ELITUR). ELITUR sentó las bases para el desarrollo e implantación de un sistema informático turístico que posibilite la disponibilidad y tratamiento eficaz de la información y, por otro lado, mejore la calidad de la gestión y servicios prestados por la Administración Turística, sirviendo, en todo momento, de soporte a una Sistema de Información Turística, cuyo sistema informático será TURIDATA (DECRETO 75/2005, de 17 de mayo, por el que se regula el Registro General de Empresas, Actividades y Establecimientos Turísticos, así como el sistema de información turística y se aprueba el sistema informático que les da soporte).

Al final de la primera década del s. XXI, Canarias se encuentra ante un nuevo marco, caracterizado por la desaceleración económica y la pérdida de los niveles de empleo. Ante esta situación es necesario hacer una nueva y profunda reflexión acerca de una economía prácticamente basada en la actividad turística en su totalidad.

El Gobierno de Canarias aconsejará hacer determinados ajuntes en orden a facilitar los procesos de adaptación del planeamiento, a la vez de precisar la regulación a los elementos sustantivos de los objetivos de sostenibilidad, liberalizando con criterios simplificadores aquellas actividades de menor trascendencia territorial, con especial incentivación al desarrollo rural, a la producción de energías limpias endógenas, y al equilibrio sectorial, especialmente a través de la promoción industrial, a través de la Ley 6/2009, de 6 de mayo, de medidas urgentes en materia de ordenación territorial para la dinamización sectorial y la ordenación del turismo, abordando el marco en el que el turismo, como principal actividad económica del archipiélago, deba desarrollarse en los próximos años, garantizando la sostenibilidad de su ocupación territorial (objetivo sobre el que la normativa viene trabajando desde hace una década) y la fortaleza de su competitividad, 
actualmente puesta en duda. A estos efectos, la Ley 19/2003, de 14 de abril, por la que se aprueban las Directrices de Ordenación General y las Directrices de Ordenación del Turismo de Canarias en materia turística, establece la necesidad de limitar el crecimiento y aumentar la cualificación de la oferta alojativa, mediante la rehabilitación de las áreas turísticas degradadas y la renovación de los establecimientos, adaptando sus estándares a las exigencias actuales de los usuarios. En el tiempo transcurrido desde la aprobación de estas Directrices, se ha producido un aumento de la oferta turística en las islas de Tenerife, Gran Canaria, Lanzarote y Fuerteventura, por lo que se va a afirmar en la Ley 6/2009 (exposición de motivos) que "no hay razones que justifiquen el incremento de la superficie que los instrumentos de ordenación destinen a uso turístico en esas islas" y que el proceso de renovación de la planta alojativa, que se ha presentado como eje fundamental para la calidad de la oferta de alojamiento turístico junto con la adaptación del equipamiento complementario ambiental territorialmente sostenible, ha tenido poco impulso, constituyendo un "grave problema estructural que debe afrontarse con medidas estables de contención de la ocupación del territorio". Por tanto, el reto político que se plantea Canarias en este momento y que se recoge en esta ley, es la consecución de la renovación y mejora de las infraestructuras y establecimientos turísticos, mediante rehabilitación o sustitución de las camas turísticas y bajo la acción concertada entre el sector privado y la Administración.

Ante este estado de la cuestión, el Gobierno de España junto con el Gobierno Autonómico de Canarias elabora el Plan Canarias (2009-2020), que sigue haciendo una fuerte apuesta por el turismo del archipiélago, pero aboga por doblar el peso del sector industrial canario para diversificar la economía del territorio insular.

A modo de síntesis, señalamos los siguientes aspectos que marcan la política canaria en materia de turismo desde la década de los años ochenta:

\section{Fase de definición.}

- Se define como instrumento clave y único para establecer el modelo territorial, los Planes Insulares de Ordenación del Territorio, por encima del planeamiento municipal.

- El turismo como elemento económico estratégico del archipiélago y Canarias como una unidad de destino turístico, como un producto turístico y como un recurso turístico en sí misma. Fomento, promoción y ordenación son las palabras claves del periodo.

\section{Fase de desarrollo.}

- Está marcada por una profunda vinculación entre turismo, ordenación del territorio y el medio ambiente, dando lugar a refundir las leyes enunciadas en estos ámbitos, con el objeto de armonizar los sectores y simplificar la legislación. 
- Se añade una política de diversificación del producto turístico.

\section{Fase de renovación.}

- El inicio del s. XXI está marcado por una política de limitación del crecimiento de la planta de alojamiento turístico, sin éxito.

- Los retos en la definición del modelo territorial futuro (horizonte 2020) se centran en las siguientes ideas: rehabilitación frente a nueva planta y diversificación de la economía canaria.

\section{4.- LA ADMINISTRACIÓN LOCAL. AYUNTAMIENTOS Y CABILDOS}

En el ámbito local, las autoridades están investidas con poderes legales para regular los efectos del turismo mediante controles de planificación y responsabilidad de los servicios municipales. Pero, como establece el Art. 148 de la Constitución Española, en su punto 1.18, la competencia exclusiva sobre la ordenación del turismo corresponde a cada una de las Comunidades Autónomas dentro de sus respectivos ámbitos territoriales: son ellas, pues, las encargadas de legislar y gestionar.

La acción municipal en el desarrollo de empresas turísticas ha sido de vital importancia. El comportamiento de dichas administraciones estuvo impulsado por la ferviente convicción de entender la inversión turística como un fecundo recurso de vitalización de sus comunidades, impulsado por la propia Ley de Régimen Local (Zaragoza, P. 1999, pp. 125).

Serían los Planes Generales de cada municipio los que verdaderamente van a obligar a cumplir unas normas determinadas para cada zona y es que, el producto turístico tiene un gran componente municipal por cuanto los servicios, la escena urbana, la comunicación de la imagen de marca y otros aspectos de fuerte incidencia en la competitividad y comercialización del sector, dependen en gran manera del grado de eficacia y compromiso asumidos por los Ayuntamientos. El problema radica en que éstos planes se realizan por iniciativa municipal y existían a finales de los sesenta municipios que ya habían incorporado plenamente el desarrollo turístico y no se decidían a confeccionar dichos Planes (como es el caso de múltiples municipios Canarios aún a principios del s. XXI), con lo cual su territorio quedaba libre de previsión, planificación y normas o no se han adaptado a la nueva normativa y su concepción del territorio. A ello se añade las dificultades o incapacidad de coordinación, puesto que en muchos casos de lo que se trata es de actuar conjuntamente sobre el mismo territorio, que se encuentra dividido administrativamente.

Deficiencias administrativas de este orden encontraremos en la historia del desarrollo turístico en muchos municipios españoles, puesto que la capacidad local para controlar dicho desarrollo parece ser generalmente débil, en especial donde el crecimiento es rápido y masivo; esto se debe en parte a la falta de personal cualificado -carecen de los recursos 
humanos para conocer a fondo las cuestiones implicadas- y de una organización efectiva a nivel local, pero sobre todo a la penetrante fuerza de los intereses foráneos, que hace que su capacidad para hacer cumplir las leyes y las regulaciones que les competen se vea disminuida cuando esto supone entorpecer las actividades de importantes grupos de interés de fuera de la comunidad (Kadt, E, 1991, pp. 38 y 57). En palabras de Morris y Dickinson (1987, pp. 19), la planificación del uso del suelo urbano, durante el franquismo, fue un privilegio municipal y, por consiguiente, el desarrollo turístico fue inseparable de la actitud de las comunidades locales o de sus gobernantes, "quienes lo condujeron en diferentes direcciones, de acuerdo con los intereses locales dominantes (los mayores terratenientes o, más frecuentemente, los altos funcionarios municipales, propietarios también del suelo y, en algunos casos, relacionados con empresas constructoras); el gobierno local controló el hilo, y el nivel y la dirección de la corrupción"

Todo ello unido se convierte en "una bomba de relojería", que puede llevar al territorio hacia la excesiva concentración, al desorden urbanístico y la mala gestión por la falta de coordinación entre las entidades municipales. "Con frecuencia esto puede provocar, y de hecho provoca, el resentimiento de la población local contra el turismo" (Kadt, E, 1991, pp. 40).

Por tanto, el papel municipal ha sido y es de vital importancia en el desarrollo territorial y urbanístico derivado del turismo, afectado por la capacidad de comprensión del fenómeno turístico y de su porvenir, "así como de una preparación técnica-turística para hallar las mejores soluciones a una problemática compleja de urbanismo, infraestructura, abastecimiento y servicios, etc." (Fernández, L. 1991, pp. 53). El anclaje de los ediles en unos conceptos tradicionales, educados en el centralismo, a veces rígido y autoritario, ha sido determinante en el proceso y la forma en que se ha asentado la actividad turística en nuestro territorio peninsular e insular ${ }^{88}$.

Para los Ayuntamientos, en el caso de Canarias, Rodríguez, W. (1992, pp. 162) señala: "el territorio no es más que un solar que hemos de ocupar con cemento y asfalto a la mayor brevedad, puesto que con ello se pretende resolver el problema de las arcas municipales ahora, y mantener el poder económico y político de los ediles sin tener que realizar mucho esfuerzo". El enriquecimiento rápido a costa del bien público ha sido el leit motiv de la euforia irresponsable que vino con el turismo de masas como importante fuente de

88 "(...) Los pueblos del ocio muestran bien a las claras la incompetencia, la cortedad, la rapacidad o la indiferencia de los ediles. Buscaron el enriquecimiento personal a través del turismo, valiéndose de su puesto, como lo buscaban antes en alcaldadas caciquiles sobre las tradicionales fuentes de riqueza de su término municipal". Fernández Fuster, L. (1991). "Historia General del turismo de masas". Alianza Editorial. Madrid. 
ingresos ${ }^{89}$. Se debe reconocer que la mayor parte de las comunidades dedicadas en uno $u$ otro modo al turismo deben, desde un punto de vista estrictamente económico, obtener el máximo rendimiento de la explotación de la clientela turística, el interrogante ético será: el quién y el cómo se pueda beneficiar de dicha explotación (Núñez, T. 1992, pp. 399).

De todo ello se concluye que un municipio tendrá solvencia económica en tanto en cuanto pueda urbanizar más, "las rentas se adquieren en la plusvalía del cemento para el aparato político administrativo del Ayuntamiento que funciona como agencia inmobiliaria". (Rodríguez, W. 1992, pp. 163). Así aparece el problema del Ayuntamiento con un gran peso agrario, pero que tiene problemas para mantener el aparato administrativo local dada su escasa recaudación. Consecuentemente, se ha generado una lucha entre municipios por entrar en el mercado turístico o por poder continuar en expansión para los que ya han entrado. Se ha ido fomentando una "carrera desenfrenada para captar contribuyentes ofreciendo, como contrapartida, la urbanización del territorio, para extranjeros y para los del país (...). En numerosas ocasiones se urbaniza el mejor suelo agrícola especulando los que lo venden y participando como socios directos los Ayuntamientos en la nueva "productividad" del mismo. (...).Los ciudadanos de los Ayuntamientos no turísticos van quedando marginados en servicios e instalaciones, quedando como reserva. " (Rodríguez, W. 1992, pp. 172-173).

Esta situación es denunciada, en reiteradas ocasiones, para Canarias, donde las políticas de desarrollo han hecho del turismo su principal eje, lo que se concreta en la elaboración de planes, programas y proyectos para el impulso de la actividad, al igual que ha venido produciéndose en múltiples municipios de la Costa Mediterránea española.

En la ordenación territorial del turismo, en el archipiélago, tienen un papel relevante los Cabildos, puesto que como administración propia de las islas (CE, Art. 141.4) y órgano político (recogido anteriormente), es el que define los objetivos de desarrollo marcados para la isla y los objetivos de sus Planes Insulares de Ordenación del territorio (Ley 1/1987), de los cuáles ostentan la responsabilidad, así como la potestad de observancia y control de su cumplimiento por parte de los municipios, puesto que el Plan es una necesidad supramunicipal, nacida del hecho de que en la isla cualquier fenómeno urbanístico tiene una repercusión indirecta sobre todo el territorio, por eso su control debe ser global y tal efecto nadie mejor que el Cabildo para llevarlo acabo, pues allí se encuentran representados todos los intereses municipales (Avance PIOT, Lanzarote, 1987, Tomo 6, pp. 32), y donde deben examinarse los procesos urbanísticos, teniendo la última palabra para la creación de nuevas plazas turísticas, pues se le ha de informar de cualquier actuación

${ }^{89}$ En opinión de Fernández L. (1991, pp. 54) "halló su práctica más escandalosa alrededor del año 68". 
urbanística y deberá ejercer sus legítimas acciones impugnatorias contra los que incumplan la legalidad. De la misma forma tendrá que vigilar el que los Planes Generales de Ordenación Urbana (PGOU) municipales se adecuen al Plan Insular, así como Planes Parciales y Especiales: "es en el momento de la aprobación definitiva y de los informes que se emitan después de las aprobaciones inicial y provisional por el Municipio cuando la Administración urbanística competente -el Cabildo Insular tendrá siempre alguna intervención en esa fase - debe apreciar si el planeamiento general propuesto se ajusta a las determinaciones del Plan Insular, con objeto de aprobar, denegar o señalar las rectificaciones que procedan" (Avance PIOT, Lanzarote, 1987, Tomo 6, pp. 91). Y tendrán potestad para revisar o modificar el Plan.

En síntesis, los Cabildos establecen dónde, cuándo y cuánto debe crecerse turísticamente y los ayuntamientos aplican dicha planificación.

Así mismo, los Cabildos podrán crear, internamente, órganos de control cuya función será meramente de gestión y de estudio y propuesta, a favor de los órganos que tengan encomendadas funciones de intervención (a título de informe). En base a esto los distintos Cabildos del archipiélago han ido creando Oficinas del Plan Insular.

Pero la misión del Cabildo no se agota en la formulación del Plan, sino que a lo largo de estos años, la Comunidad Autónoma de Canarias ha ido transfiriendo competencias a los mismos como propias ${ }^{90}$, generales y sectoriales (Acosta, A.D. 2003, pp. 15-22). Así, en la Disposición Adicional Primera de la Ley 14/1990 de Régimen Jurídico de las Administraciones Públicas de Canarias ya se transfieren competencias administrativas (genéricamente ${ }^{91}$ ) sobre un amplio conjunto de materias, modificadas en la Ley 8/2001, de 3 de diciembre (Art. 1), quedando de la siguiente forma las que se refieren a materias que afectan directa e indirectamente a la actividad turística, de ocio y al bienestar, según tipo de competencia y por orden de aparición en la Ley: generales: 6) protección del medio ambiente, 7) gestión y conservación de espacios naturales protegidos, 8) caza, 10) subrogación en las competencias municipales sobre planeamiento urbanístico, de conformidad a lo establecido en la legislación sectorial vigente, 11) carreteras, su

90Ley 14/1990 de Régimen Jurídico de las Administraciones Públicas de Canarias. Art. 12.1. "La Comunidad Autónoma de Canarias, al regular los diversos sectores de la acción pública, que sean de su competencia legislativa, transferirá a los Cabildos Insulares la titularidad y el ejercicio de las funciones administrativas autonómicas que respondan preponderantemente a un interés insular. Las competencias transferidas se integrarán entre las propias de la Autonomía local de los Cabildos Insulares".

${ }^{91}$ En la Disposición Transitoria Tercera de la Ley 14/1990, se señalan las fases a seguir para detallar las funciones concretas que comporte la competencia transferida, las que sigan correspondiendo a la Administración Pública de la Comunidad, las que se deban compartir entre Cabildo y Comunidad, el método para el cálculo y determinación de los servicios, medios personales y materiales y recursos que deban ser traspasados a los Cabildos Insulares para el ejercicio de las funciones transferidas. 
explotación uso, defensa y régimen sancionador (excepto las que se declaren de interés regional), 12) gestión de puertos de refugio y deportivo (salvo los declarados de interés regional, 13) obras hidráulicas (que no sean de interés regional o general) conservación de obras hidráulicas y administración insular de aguas terrestres (en los términos de la legislación sectorial autonómica), 14) transportes por carretera o por cable, 15) ferias y mercados insulares, 16) policía de espectáculos, 17) promoción y policía de turismo insular, 18) actividades molestas, insalubres, nocivas y peligrosas, 20) conservación y administración del parque público de viviendas, 22) fomento de la cultura, deportes, ocupación, ocio y esparcimiento en el ámbito insular, 23) conservación y administración del patrimonio histórico-artístico insular, 24) museos, bibliotecas y archivos que se reserve para sí la CCAA., 25) fomento de la artesanías, 26) asistencia social y servicios sociales, 27) defensa del consumidor, etc.; y sectoriales: servicios sociales (Ley 9/1987, de 28 de abril), aguas (Ley 12/1990, de 26 de julio), protección de animales (Ley 8/1991, de 30 de abril), carreteras (Ley 9/1991, de 8 de mayo), ordenación sanitaria (Ley 11/1994), ordenación del turismo (Ley 7/1995, de 6 de abril y posteriores), canaria del deporte (Ley 8/1997, de 9 de julio), espectáculos públicos y actividades clasificadas (Ley 1/1998, de 8 de enero), caza (Ley 7/1998, de 6 de julio), residuos ( Ley 1/1999, de 29 de enero), patrimonio histórico (Ley 4/1999, de 15 de marzo), juegos y apuestas (Ley 6/1999 de 26 de marzo), ordenación del territorio y espacios naturales de canarias (D.L. $1 / 2000$, de 8 de mayo y posteriores).

En efecto, como hemos visto, los Cabildos Insulares juegan un importantísimo papel en cuanto Administración reguladora y con posibilidades de efectiva intervención sobre el control de la actividad urbanística (oferta turística) en la isla y de los aspectos del bienestar, pues tiene la competencia para establecer la estrategia territorial en la misma, como órgano que elabora el Plan Insular de Ordenación del Territorio (PIOT), que posee la potestad de observación y control de su cumplimiento y de la legalidad, lo que incluye la vigilancia en la adecuación de los Planes Generales municipales a dicha estrategia insular.

\section{5.- SOCIOLOGÍA Y TURISMO EN EL SIGLO XXI}

El turismo es esencialmente un campo de conocimiento transversal y en la actualidad no posee una malla disciplinar definida en el sentido tradicional del término. En líneas generales, se puede afirmar que los estudios en el campo del turismo presentaban como características que la investigación y los conocimientos se limitaban a describir cuantitativamente variables (origen de los turistas, gastos, niveles de ocupación en los diferentes destinos entre otros) y no tenían marcos metodológicos y conceptuales de referencia.

A partir de la década de los 90 , las ciencias sociales se encuentran en una nueva etapa a la que varios autores han llamado en términos generales de "reconstrucción epistemológica" 
(Carrizo et al., 2004: 9-18). Jafari, J. (2005, pp. 43) ${ }^{92}$, referente internacional en los estudios turísticos dentro de la Sociología ${ }^{93}$ y que viene reivindicado la necesidad de construir un cuerpo epistemológico y metodológico propio de la Sociología del Turismo, señala que, al final del siglo XX, emerge una Plataforma que denomina Científico-Céntrica, que trata, hasta la actualidad, de "dotarse de una fundamentación científica, estudiando sistemáticamente la propia estructura del turismo; lo coloca en continuidad con diversos campos de investigación o disciplinas; define su lugar en el contexto multidisciplinar; examina sus funciones a escala personal, grupal, empresarial, gubernamental y sistémica, e identifica los factores que influyen y son influidos por el turismo". Su contribución se centra en dar un tratamiento totalizador del turismo, no sólo de sus impactos y formas.

Supone, por tanto un tránsito desde el pensamiento simple y lineal al pensamiento complejo. Una nueva etapa que tiene como eje central una reconstrucción en el plano epistemológico transdisciplinar, pues el turismo como campo científico implica ser tratado por expertos en distintas áreas de conocimiento "lo cuales pueden tener una enorme competencia teórica y práctica en su disciplina, pero con ausencias significativas de ejes conceptuales en el marco del tiempo libre y el turismo (Conde, 2010, pp. 42) ${ }^{94}$.

Consecuentemente se va a enfatizar en esta convergencia de los distintos órdenes de pensamiento que pueda permitir profundizar en la interacción entre objeto y sujeto turístico, pasando del pensamiento simple al pensamiento complejo (Campodónico, R. y Chalar, L. 2011, pp. 1309).

A pesar de todo ello, dentro del campo de la Sociología se sigue lamentando el que a día de hoy "no se ha conformado unas bases teóricas que permitan analizar adecuadamente el fenómeno del turismo y que orienten las cada vez más numerosas investigaciones que lo tiene como objeto de estudio" (López Rey, J.A. 2012, pp. 155) ${ }^{95}$. El esfuerzo para remediar estas carencias se viene realizando dentro del cuerpo académico e instituciones de investigación relevantes, por lo que las próximas líneas están destinadas a presentar, brevemente, algunos de los trabajos que se vienen haciendo y las orientaciones desde las teorías sociológicas que presentan.

\footnotetext{
92 Jafari, J. El turismo como disciplina científica. En Revista Política y Sociedad, Vol. 42, nº 1. 2005, pp. 39-56.

93 Universidad de Wisconsin-Stout. Departamento de Hospitalidad y Turismo.

94 Conde, N. (2010) "Hacia una epistemología del discurso turístico". En: Castillo, M. \& Panosso Netto, A. Epistemología del Turismo. Estudios Críticos. Trillas, México DF, pp. 41-52.

95 López Rey, J.A. Reseña bibliográfica Teoría sociológica y turismo. En Revista Investigaciones Turísticas, nº 4. 2012 (pp. 155-159).
} 
Desde los paradigmas del pensamiento complejo, la lógica dialéctica y la transdisciplina como herramientas válidas para la construcción de un marco conceptual, Campodónico, R. y Chalar, L. (2011) ${ }^{96}$ diseñan como nueva herramienta un campo de análisis denominado T.E.M.A. que posibilita realizar abordajes partiendo de cuatro ejes que lo componen: Tiempo (se aprecia a distintos niveles: desde el objeto - historia, grado de desarrollo, región, país, etc. - o desde el sujeto - turista, residente, comunidad, políticos, empresarios, etc.-), Espacio (lugares de origen, espacio de tránsito y espacio de destino, donde se podrán en valor todas las manifestaciones de las actividades turísticas), Motivaciones (razones que genera el desplazamiento, la elección de destino y actividades que estarán en relación a origen, capital cultural y condiciones socioeconómicas) y Actividades (acciones interrelacionadas llevadas a cabo por los turistas en sus estancias y las producidas por empresas, instituciones y la población residente). Señala así, "que la utilización de este esquema permitirá indagar los distintos procesos mediante un enfoque integral del fenómeno turístico, articulando de manera balanceada los componentes objetivos así como los subjetivos que se presentan en las distintas etapas permitiendo una investigación multidimensional" (Campodónico, R. 2011, pp. 1321).

Desde una perspectiva sistémica integral, sobresalen los trabajos de Álvarez Sousa, A., en los que propone un nuevo paradigma que denomina sistémico reconstructivo-integrador para analizar las posibilidades de desarrollo de un territorio a través del turismo y las estrategias a seguir $\left(2005^{97}, 2009^{98}\right)$. Así como innumerables artículos que giran en relación a funciones, gestión, desarrollo integral, empresa e innovación turística y, en sus trabajos más recientes, las líneas de investigación que proporciona al estudio del turismo el nuevo paradigma ecológico (2012). Tomando a la sociedad en cuanto sistema compuesto por distintos subsistemas o campos, las posibilidades de desarrollo estarán en relación con el capital que tengan dichos campos o capitales (social, humano-cultural, económicofinanciero, simbólico, patrimonial, ecológico e infraestructural).

El fenómeno del turismo también está siendo abordado partiendo del constructivismo estructuralista de Bourdieu (1990), aplicando sus conceptos de "habitus" y "campo" (tomado por Álvarez, A. en sus análisis). El concepto de "campo" referido a las áreas de la vida social en las que se presentan las luchas relacionadas con bienes o recursos valiosos, capitales, que están en juego. Así, el turismo puede ser visto como un campo en el que se

96 Campodónico, R. y Chalar, L. Hacia la construcción del conocimiento en turismo. Rev. Estudios y Perspectivas en Turismo. Vol. 20, nº 6, 2011 (pp. 1307-1323).

${ }^{97 A ́ l v a r e z ~ S o u s a, ~ A . ~ L a ~ c o n t r i b u c i o ́ n ~ d e l ~ t u r i s m o ~ a l ~ d e s a r r o l l o ~ i n t e g r a l ~ d e ~ l a s ~ s o c i e d a d e s ~ r e c e p t o r a s . ~ A s p e c t o s ~ t e o ́ r i c o s-~}$ metodológicos. En Rev. Política y Sociedad. Vol. 42, n² 1, 2005, pp. 57-84.

98 Álvarez Sousa, A. y Gomis Rodríguez, A. El turismo y desarrollo. En Sociología del ocio y del turismo: tipos, planificación y desarrollo. Universidad de Granada, 2009, pp. 25-55. 
lucha por recursos valiosos, económicos, simbólicos, culturales y sociales, en el que la lucha se presenta entre los diversos participantes en él (González Damián, A., 2010, pp. 134). Destacando en esta línea los trabajos de Anaya, J. (2005) $)^{99}$ en los que invita a reflexionar sobre la posibilidad de que el turismo no sea un campo, sino un conjunto de campos vinculados, en los cuales se darían múltiples luchas; Pavón (1999) que analiza la práctica turística en la Ciudad de Oaxaca, México, haciendo patente que la lucha por un capital cultural se pone en evidencia en la elección misma del destino turístico; La idea de que el gusto por cierta clase de actividad en el turismo depende del "habitus" (esquema generador de disposiciones adquiridas que varía según la clase social), está representada por los estudios de Flores, A. (2005) $)^{100}$ entre otros.

Dentro de la Sociología Económica destacan los trabajos realizados por Santana Turégano, M.A., en cuanto a su aportación al análisis del turismo y el desarrollo, en España y en especial sobre el análisis de las dinámicas turísticas de las Islas Canarias. En esta línea de trabajo, parte de señalar como cuestión clave que muchos problemas, que por definición se han contemplado como pertenecientes al campo de la economía, se pueden analizar mejor si se tienen en cuenta consideraciones sociológicas. Pretende un enfoque más social de la economía. Utilizando un enfoque inductivo, toma tres principios claves: 1) la actividad económica es una forma de acción social, 2) la actividad económica está socialmente insertada y 3) las instituciones son construcciones sociales. Partiendo de los análisis Swedberg, R, siguiendo las aportaciones de Weber, M., afirma que la ordenación del territorio y las justificaciones que se usan para legitimar o no determinadas actuaciones urbanísticas, que constituyen la base del desarrollo turístico, no son en sí fenómenos económicos pero sí fenómenos económicos relevantes (es decir, influencia los fenómenos económicos, la actividad económica del turismo) y fenómenos económicamente condicionados (explicados parcialmente por la influencia de factores económicos) ${ }^{101}$, imponiéndose una determinada visión de política económica. Influenciado por la Teoría de Bourdieu sobre los "campos-capital", afirma que "La planificación urbanística es un terreno para la "competencia económica. (...) El resultado de la misma está determinado por las posiciones de los agentes (capacidad para intervenir en la definición del juego), los tipos de capital que poseen (no sólo dinero, sino también capital social, cultural o simbólico) y las tasas de conversión entre cada uno de estos (Santana, 2007, pp.62-63). Así, sostiene que

\footnotetext{
99 Anaya Ortiz, J. S. El estudio del turismo a partir de la teoría de los campos de Pierre Bourdieu. En Palafox Muñoz, A. "Turismo. Teoría y Praxis". México: Plaza y Valdés Ediciones, 2005, pp. 29-38.

100 Flores Gutiérrez, A. La industria restaurantera de la ciudad de Toluca: una visión desde el estudio de la estructura social. En Palafox Muñoz, A. "Turismo. Teoría y Praxis". México: Plaza y Valdés Ediciones, 2005, pp. 21-28.

101 Santana Turégano, M.A. Turismo, economía y planificación urbana: una relación compleja. En Pasos. Revista de Turismo y Patrimonio cultural. Vol. 5, nº 1.2007, pp. 53-67.
} 
las distintas definiciones de "lo económico" están en relación a los actores sociales que entran en juego, favoreciendo a unos frente a otros. Interacción entre actores, posiciones de poder, redes sociales, etc.

Desde la Universidad de Alicante, Mantecón, A., viene realizando estudios en relación a la percepción social del turismo por parte de las poblaciones receptores $(2008)^{102}$. Su principal línea de trabajo se basa en el estudio de las relaciones que se establecen en el sur de España entre la movilidad residencial orientada por el ocio (el turismo que se aloja en viviendas privadas y las migraciones no laborales de europeos) y los procesos de urbanización asociados. Su mirada sobre este objeto se centra en el análisis de la legitimación social de la expansión turístico-inmobiliaria y en el estudio de la formación de espacios duales vinculados a los asentamientos de ciudadanos noreuropeos (página personal de la UA; http://www.dsoc1.ua.es/). Entre sus trabajos más recientes, en lo que aquí respecta, destaca la adaptación de la Teoría de la Estructuración de Giddens a la realidad del turismo, para explicar, a partir de ella, las formas de movilidad y sus dimensiones económicas, ecológicas, demográficas, culturales y urbanísticas, tanto en los planos macro como microsociológicos (López, J.A., 2012, pp.158).

Con lo hasta aquí expuesto y para el caso que nos ocupa, la isla de Lanzarote, la década de los noventa, a partir de su segunda mitad, abre un periodo donde se van a multiplicar lo estudios acerca del fenómeno turístico en la isla y sus efectos. Los trabajos que abordan la complejidad de este sistema insular tienen origen, mayoritariamente, en entidades públicas o por encargo de éstas. Así, el Cabildo Insular de Lanzarote se convierte en la entidad pública y de Gobierno que impulsa y recoge estudios que abordan dicha complejidad y los efectos derivados de los procesos de rápido crecimiento de la actividad turística en la Isla.

Desde la transdisciplina, el pensamiento complejo y la integración sistémica, se han de señalar aquí lo trabajos realizados, a final del siglo XX (1998), para la Estrategia Lanzarote en la Biosfera (E.L.+B) bajo el Programa Life de la Unión Europea, dirigido a analizar la situación en la que se encontraba la isla en esos momentos y establecer el escenario tendencial o de riesgo al que se encaminaba, fruto de los efectos no siempre positivos que estaba dejando el fuerte ritmo de crecimiento de la actividad. Diagnosticar con una mirada integradora para intervenir, planificar y reconducir, con objetivos finalistas dirigidos al bienestar social y la sostenibilidad.

En el área disciplinar de la Sociología, destacan los trabajos de Marrero, J.R., junto con su equipo de investigación TURILAB, en la Universidad de la Laguna. Citando algunas de sus

\footnotetext{
102 Mantecón Terán, A. La experiencia del turismo. Un estudio sociológico sobre el proceso turístico-residencial. Barcelona: Icaria Editorial, 2008.
} 
líneas de trabajo, inscrita dentro de la Sociología del trabajo y económica, resalta el informe realizado para el Cabildo de Lanzarote, en el que se analiza la situación del empleo en el sector turístico insular, principalmente en la rama de hostelería (2007). Esta investigación enfoca al cliente-turista como agente que ejerce control sobre la producción-consumo y por tanto sobre el tipo de trabajador que se requiere para la actividad, ya que en el servicio turístico entre en juego el valor de la experiencia ${ }^{103}$ y la emoción para el cliente, su expectativa, es decir elementos intangibles de la demanda que tiene su base en el "habitus" del cliente, pues "sus elecciones no son independientes de la existencia de grupos de pertenencia y de referencia" (Marrero, 2007, pp.6), así como en su valor simbólico, como signo de diferenciación social y de clase desde la visión del interaccionismo simbólico. Afectando así al tipo de trabajador que se demanda, interrelacionando capital cultural, capital humano y capital económico. Concluyen que, dado que la Isla se ha orientado hacia un turismo de calidad no ha conseguido que la calidad del empleo turístico sea mejor que en otras islas del archipiélago, no se ha traducido en la gestión de personal. En la misma línea, junto a Santana Turégano, M., publica un artículo en el que analiza y compara el nivel de competitividad de las cuatro islas turísticas canarias más importantes $(2008)^{104}$, entre las que se encuentra Lanzarote, concluyendo que, en cuanto destino de calidad, esto no se traduce en una mayor competividad para su sector turístico, frente a otras isla más masificadas, como Gran Canaria y Tenerife, en parte explicado por el papel que juegan los tour operadores como agentes configuradores del mercado.

En la línea de la Sociología Agraria, Rural y Urbana aparecen los trabajos realizados por Sosa, A., donde señala el deterioro del sector agrícola y del mundo rural fruto del monocultivo del turismo en la isla de Lanzarote y el papel que juega el Plan Insular de Ordenación del Territorio $(1999)^{105}$. Así como artículos donde, por una lado, será protagonista la ordenación del territorio, como instrumento que acoge la visión sistémica del territorio insular, y como principio ordenador del desarrollo turístico para la consecución de los principios del Estado de Bienestar $(2002)^{106} \mathrm{y}$, por otro, el protagonismo será el de la

\footnotetext{
103 Urry, J. The tourist gaze. Safe Publications. London, 1990.

104 Marrero Rodríguez, J.R. y Santana Turégano, M. A. Competitividad y calidad en los destinos turísticos de sol y playa. El caso de las Islas Canarias. En Cuadernos de Turismo, n²22, 2008, pp. 123-143.

105 Sosa Espinosa, A. Agricultura, paisaje rural y turismo. El caso de Lanzarote. En Cuadernos de Ordenación del Territorio, Vol, 6. Tercera Época, 1999, pp. 18-22.

106 Sosa Espinosa, A. Los planes de ordenación del territorio como principio ordenador del desarrollo turístico. En Cuadernos de Ordenación del Territorio, Vol, 3. Cuarta Época. 2002, pp. 23-33
} 
sociedad anfitriona y su proceso de adaptación al modelo turístico de masas en Lanzarote $(2004)^{107}$

Con lo aquí expuesto se ha pretendido realizar un breve acercamiento a algunas de las líneas de trabajo abiertas en la actualidad, encaminadas a delimitar un campo epistemológico propio de la Sociología del turismo, siendo conscientes de la multiplicidad de líneas de trabajo que acoge esta área de la disciplina. Así, como citar, brevemente, algunos trabajos recientes al respecto que tienen como marco disciplinar la Sociología y marco de análisis la isla de Lanzarote.

107 Sosa Espinosa, A. La adaptación social al turismo de masas y sus efectos. Una mirada desde la sociedad anfitriona. En $X$ Jornadas de estudios sobre Lanzarote y Fuerteventura. Tomo I. Arrecife: Cabildo Insular de Lanzarote y Fuerteventura. 2004 (p. 437-450) 



\section{Capítulo 3}

\section{BIENESTAR Y TURISMO EN LANZAROTE}





\section{CAPÍTULO 3.- BIENESTAR Y TURISMO EN LANZAROTE.}

\section{1.- CARACTERÍSTICAS POLÍTICO-GEOGRÁFICAS DE LANZAROTE}

El ámbito territorial tomado como referencia en esta tesis es la isla de Lanzarote. Isla que se encuentra en el Océano Atlántico, aproximadamente a $1.000 \mathrm{Km}$. al suroeste de la Península Ibérica y a $100 \mathrm{Km}$. al oeste de Marruecos, entre los $13^{\circ} 25^{\prime}$ y $13^{\circ} 52^{\prime}$ de longitud oeste y los $29^{\circ} 14^{\prime}$ y los $28^{\circ} 50^{\prime}$ de latitud Norte.

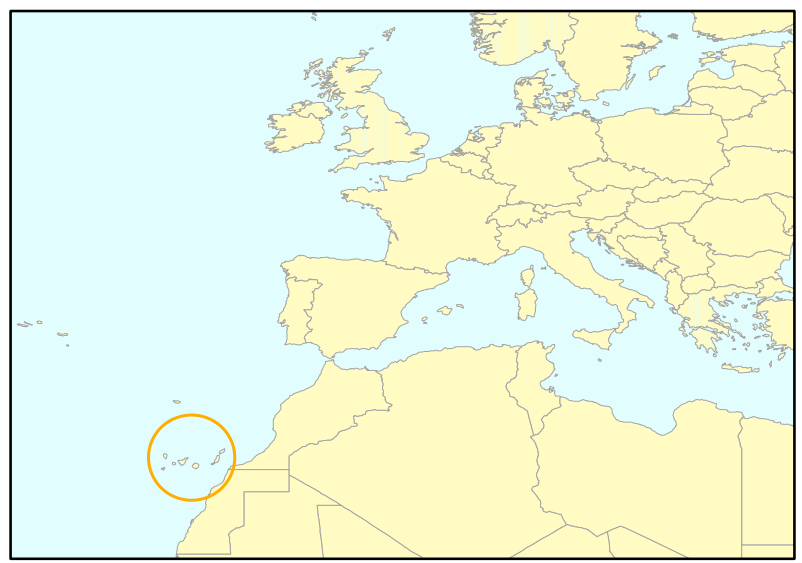

Ocupa una posición Nororiental en el Archipiélago Canario, siendo a su vez la isla más Septentrional. A pesar de ser la más oriental, no es la más próxima al continente africano.

Posee una superficie total de $845,94 \mathrm{~km}^{2}$, situándose la altura máxima en $671 \mathrm{~m}$. Su longitud total de costa se sitúa en $213,26 \mathrm{Km}$., de los cuales casi el $15,6 \%$ pertenece a playas $(33,22 \mathrm{Km}$.).

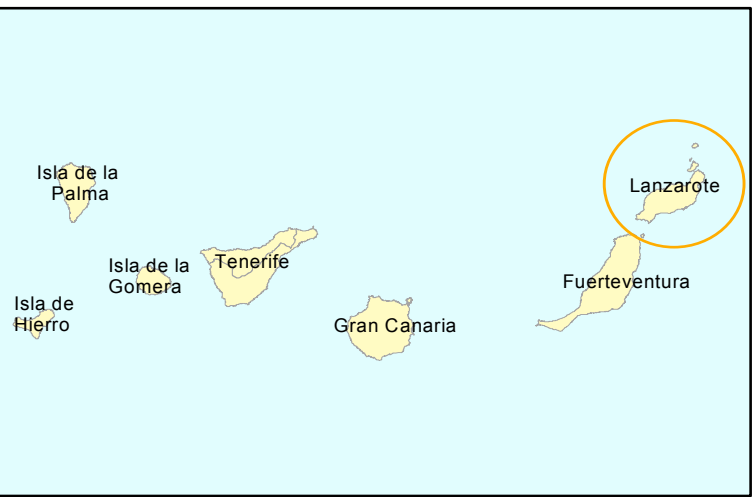

Tabla 4. Constitución física de las costas. Lanzarote (km)

\begin{tabular}{|l|l|l|l|l|l|l|l||}
\hline $\begin{array}{l}\text { Acantilado Alto } \\
\text { con rasa al pie }\end{array}$ & $\begin{array}{l}\text { Acantilado de } \\
\text { 2a } 20 \mathrm{~m} .\end{array}$ & $\begin{array}{l}\text { Costa } \\
\text { Baja }\end{array}$ & $\begin{array}{l}\text { Playa de } \\
\text { cantos } \\
\text { rodados }\end{array}$ & $\begin{array}{l}\text { Playa de } \\
\text { cantos y } \\
\text { arena }\end{array}$ & $\begin{array}{l}\text { Playas de } \\
\text { arena fina y } \\
\text { gruesa }\end{array}$ & $\begin{array}{l}\text { Obras } \\
\text { artificiales }\end{array}$ & TOTAL \\
\hline 110,59 & 47,79 & 2,2 & 6,64 & 16,94 & 9,64 & 19,46 & 213,26 \\
\hline
\end{tabular}

FUENTE: CONSEJERÍA DE MEDIO AMBIENTE Y ORDENACIÓN DEL TERRITORIO: "Plan Especial de Protección de Espacios Naturales. 1986".

Sus características climáticas están condicionadas por su posición en el cinturón de presiones subtropicales, por la influencia del océano Atlántico, por la falta de una potente alineación montañosa a los largo de la isla, sus bajas cotas $(670 \mathrm{~m}$.) y por la vecindad de la 
costa Sahariana $(100 \mathrm{Km}$.), de donde proceden las peores situaciones climáticas que padece cíclicamente la isla. El tiempo del sudeste le da a Lanzarote un acento más cálido y tenso y condicionan la existencia de un clima subtropical seco, con temperaturas estables durante el año (medias de $16^{\circ}$ en enero y febrero y de $24^{\circ} \mathrm{C}$ en los meses de verano). $\mathrm{Y}$ además, en ocasiones, se ve afectada por los vientos de levante caracterizados por bajos índices de humedad y por transportar polvo en suspensión procedente del desierto africano (calimas). A esto añadimos sus condiciones de humedad, que oscilan desde $73,2 \%$ de máxima humedad relativa medida en el mes de Noviembre y la mínima en Marzo con un valor del 66,94\%; junto con unas precipitaciones anuales de $38,5 \mathrm{~mm}$., siendo la media mensual de 11,5 mm, el mes más lluvioso es Diciembre con precipitaciones medias de 40,7 $\mathrm{mm}$ y los meses más secos con precipitaciones inapreciables, que son Julio y Agosto.

La isla de Lanzarote es de origen volcánico, se configura geomorfológicamente como consecuencia de dos ciclos volcánicos con actividad subaérea. El primero de ellos durante el Mioceno, entre 15,5 y 4 millones de años y el segundo hace unos 1,5 millones de años.

En el vulcanismo histórico de las Islas Canarias, Lanzarote tomará protagonismo a partir de 1730, y durante seis años, puesto que sufrirá erupciones volcánicas continuadas a lo largo de este periodo que afectarán a la tercera parte de la superficie de la isla (más de treinta mil hectáreas de terrenos agrícolas y pueblos enteros cubiertos de coladas lávicas, piroclastos y cenizas). La última erupción que se registra será en 1824, pero de menor importancia que la anterior. Se configura así el paisaje volcánico actual de la isla.

Administrativamente, está dividida en siete municipios: Arrecife (capital), Haría, San Bartolomé, Teguise, Tías, Tinajo, y Yaiza.

Al norte de la isla y dependiendo administrativamente de la misma se encuentran un conjunto de islas menores, islotes y roques, conocidos como Archipiélago Chinijo (formado por La Graciosa, Alegranza y Montaña Clara, junto con los Roques del Este y del Oeste), que en la actualidad es parte del Parque Natural que lleva su mismo nombre. Sólo en uno de ellos, La Graciosa, reside una población permanente de 656 habitantes ${ }^{108}$ actualmente, dedicados a la pesca y al turismo.

Aunque el Archipiélago Chinijo se encuentre gestionado por la isla de Lanzarote, recordamos que el universo de investigación de este trabajo es únicamente dicha Isla, como se ha señalado anteriormente.

108 Padrón Municipal de Habitantes, 2011. "Entidades y núcleos o diseminados. Municipio de Teguise. INE [Consulta realizada a través del Instituto Canario de Estadística (ISTAC). Ref. 15/02/2012. [http://www.gobiernodecanarias.org/istac/estadisticas.html] 


\section{2.- RELEVANCIA PARA EL CONOCIMIENTO DEL CASO DE LANZAROTE}

En la década de los sesenta Lanzarote "poseía unas características paracoloniales, desérticas y rurales, con muy baja densidad de población, y en muchos lugares sin agua, sin electricidad y sin infraestructuras suficientes" (Gaviria, 1974, pp. 298). Su vida económica giraba en torno a actividades agrarias, por lo que su población activa se concentraba en la pesca y en la agricultura. Una agricultura de secano y artesanal, que abastecía el mercado interior, con una exportación reducida a tomates y cebollas, dirigida al mercado peninsular y europeo (Acosta, E., 1990, pp. 1). A ello se sumaba la inexistencia de un poder económico local que pudiera acometer grandes iniciativas y una Administración insular pobre, que sólo podía promover pequeñas inversiones. En definitiva, era un entorno absolutamente rural y marinero, que alberga a una comunidad preindustrial y precapitalista.

Pero Lanzarote tenía unas características físicas, ambientales y paisajísticas que la hacían idónea para la práctica turística, basada principalmente en sol y playa. Cumplía con lo que Gaviria (1974, pp. 62) llamó los "atractivos del paraíso español" para las nuevas masas consumidoras de vacaciones: "sol abundante, buenas temperaturas, buenas playas, paisaje natural bello, ambientes no contaminados, precios bajos, alcohol barato, (...), gente amable y hospitalaria, poca distancia a las capitales europeas, etc. Y, para los Gobiernos e inversionistas privados: ausencia de legislación o legislación favorable a las inversiones extranjeras incontroladas, nulo control fiscal y urbanístico, suelo edificable abundante y a precios bajos, mano de obra barata y obediente, y suficiente nivel técnico como para permitir el despegue rápido en la construcción y hostelería". Es por ello por lo que, en la década de los sesenta, empiezan a llegar los capitales europeos destinados a una inversión de base que permitiese la explotación turística de la isla (Acosta, E. 1990, pp. 1). Así, pasó súbitamente, sin transición, de una agricultura de supervivencia a los servicios; un sector servicios basado en hostelería y turismo y muy poco diversificado (aún en la actualidad). La llegada masiva del turismo trastocó una situación socioeconómica tradicional, sin implementar mecanismos de defensa e integración ante un cambio tan brusco; esto llegará mucho después. La actividad turística, en la década de los años ochenta, ya no es marginal o paralela, como lo fue en la década anterior, sino que ahora es general y estructural, asumiendo una producción turística de masas, que absorbe todas las posibilidades socioeconómicas.

La rápida introducción de la actividad turística, en a penas quince años, modificó totalmente la vida social y cultural que se vio obligada a plegarse ante la dependencia de intereses, capitales y decisiones foráneas y del monocultivo turístico, que imponían nuevas formas de relación socio-cultural y económica para poder dar respuesta a las necesidades del incipiente turismo que recibe, apareciendo nuevos centros y funciones territoriales derivadas de los procesos de explotación turística y especulación inmobiliaria que vive la 
Isla. A lo que hay que añadir la transformación físico-ambiental derivada de la enorme "artificialización" del territorio, y antropización frutos de la urbanización asociada al ocio turístico.

La afección sobre el bienestar de la población autóctona y residente será notable desde todos los puntos de vista, pues sus intereses quedan relegados a un nivel absolutamente secundario. $Y$ ello pese a que, ésta isla, fue declarada Reserva de la Biosfera, por la UNESCO, en el año 1993.

Es por ello que Lanzarote es un espacio idóneo para la investigación de fenómenos complejos como es el estudio de la evolución de los componentes básicos del bienestar, en sociedades de economía turística de masas que constituyen destinos turísticos maduros en la actualidad.

\section{3.- POLÍTICA, LEGISLACIÓN URBANÍSTICA Y TURISMO EN LANZAROTE}

El punto de partida o antecedente urbanístico de Lanzarote hay que fijarlo en la resolución de 30 de Julio de 1970, dictada por el entonces Ministerio de Vivienda, en la que se aprobaron unas Normas Complementarias y Subsidiarias de Planeamiento para la Isla, al amparo de la Ley de suelo del 56. Dichas Normas van a posibilitar los crecimientos urbanoturísticos en los municipios costeros.

Posteriormente, este mismo Ministerio, aprueba mediante Orden de 29 de Noviembre de 1973, el Ilamado Plan Insular de Lanzarote ${ }^{109}$, en realidad, un Plan Provincial —bajo la vigencia de la Ley de Ordenación y Uso del Suelo de 12 de mayo de 1956- con doble carácter, por un lado de Normas Complementarias y Subsidiarias de Planeamiento y por otro de Plan Territorial Intermedio, "aunque con habilitación para legitimar planeamiento de desarrollo y la urbanización subsiguiente" (Revisión del PIOT, Lanzarote, 1999, pp. 5). Así, se clasifica el suelo en urbano, de reserva urbana y rústico, "clasifican concretamente el territorio en los distintos tipos de suelo, según su utilización urbanística, (...), cumplen una función similar a la zonificación de los Planes Generales Municipales" (Avance PIOT, Lanzarote, Tomo 6, 1987, pp. 44), previéndose el desarrollo mediante Planes Parciales y Planes Especiales, lo que lleva a que, por esta época, se disparasen las clasificaciones de suelo, "abarcando más de 8.000 hectáreas, con capacidad para 450.000 plazas turísticas, aproximadamente" (Revisión del PIOT, Lanzarote, 1999, pp. 6). A su vez, este Plan, a) delimitó el suelo urbano en aquellos municipios que carecían de Planeamiento General y en

109 Ministerio de Vivienda. Dirección General de Urbanismo. 1973 
algunos núcleos turísticos importantes y b) formuló Planes Parciales de Iniciativa Particular directamente desde el Plan Insular, integrando unidades urbanizadas anteriores, consolidándolas, y creando, ampliando y proyectando nuevos desarrollos. Junto con la misión de hacer $\mathrm{c}$ ) la valoración jurídica del planeamiento que se realice al amparo de la Ley de Zonas y Centros de Interés Turístico, de 28 de diciembre de 1963 (aunque sólo actuó en un caso aislado).

La entrada en vigor de la Ley de 2 de mayo de 1975 de Reforma de la Ley del Suelo y del posterior Texto Refundido de 9 de Abril de 1976, al contrario de lo que se podía suponer, "no supuso la abrogación de todos los instrumentos de Planeamiento anteriormente existentes. Por el contrario, la ley dispuso la conservación de la ordenación urbanística anterior" (Avance PIOT, Lanzarote, Tomo 6. 1987, pp. 48), aunque sí obligó a la Administración a adaptar a la nueva Ley el contenido de los Planes anteriormente existentes; pero si la adaptación no se llevaba a cabo en los períodos exigidos, tampoco se consideraba caducada la vigencia del Planeamiento Urbanístico anterior. Paradójicamente, si las "posteriores mediadas introducidas por el Real decreto Ley de 16 de Octubre de 1981, tendentes a facilitar la adaptación, tampoco se hubieran llevado a cabo, tampoco podría entenderse sin más caducada la vigencia del planeamiento anterior" (García de Enterría, E. Avance del Plan Insular, Tomo 6. 1987, pp. 48).

En 1991, se formula el Plan Insular de Ordenación del Territorio (PIOT), al amparo de la Ley 1/1987, de 13 de marzo, reguladora de los Planes Insulares, aprobado por el Gobierno de Canarias mediante el Decreto 63/1991, 9 de abril, (BOC números 80, 81, y 82 de 17, 19 y 21 de Junio de 1991; y BOER No 75, de 27 de marzo de 1992). Bajo esta Ley, se prevé la obligación de revisar los Planes Generales para acomodarlos a sus determinaciones y racionalizar y delimitar el desarrollo turístico de la Isla. "Pero la Ley tampoco determinó la pérdida de vigencia de la ordenación hasta el momento existente" (García de Enterría, E. Avance del Plan Insular, Tomo 6. 1987, pp. 51).

Este PIOT, pionero entre los instrumentos de planeamiento de su clase, delimitó el suelo máximo para los núcleos de población turística en base a las clasificaciones y reclasificaciones del Suelo Rústico ${ }^{110}$ Insular y fijó unos límites cuantitativos máximos de plazas de alojamiento turísticas y residenciales, o sea, establece una programación de ritmos de implantación de usos. (Revisión PIOT, Lanzarote, 1999, pp. 8-9). Aunque establece la necesidad de adaptar a él los PGOU municipales existentes y que los municipios que no los poseían los hiciesen, no es hasta su revisión, denominada

\footnotetext{
110 Proyecto de Ley de la Comunidad Autónoma de Canarias sobre suelo rústico. Boletín Oficial del Parlamento de Canarias de 22 de octubre de 1986.
} 
"Moratoria" - aprobada en Pleno extraordinario del Cabildo Insular el 21 de mayo de 1998 y con aprobación definitiva por Decreto en el año $2000^{111}$ — cuando el Planificador Público - el Cabildo Insular de Lanzarote - va a intentar obligar a los municipios a llevar a cabo dichas actualizaciones. Esto ocurrirá, también bajo la necesidad de adaptar la planificación a la nueva Ley de Ordenación del Turismo de Canarias, la Ley $7 / 1995$, que regula la materia específica de la que trata y tiene determinaciones con clara incidencia territorial, y debido, principalmente, a "el desajuste entre sus previsiones y los procesos de adaptación del planeamiento general y de desarrollo de los municipios lanzaroteños; (...); la Estrategia de Lanzarote en la Biosfera impulsada por el programa LIFE de la Unión Europea y avalada por el Comité español "MAN + BIOSPHERE" de la UNESCO; la evolución de la población y la rápida irrupción del turismo, que han propiciado en poco más de un decenio, que el suelo insular ocupado aumente el 5\% y la densidad territorial se haya incrementado más de un $60 \%$, aconsejan revisar el documento, si quiera sea parcialmente, para atajar la degradación ecológica y paisajística en la isla, adoptando las medidas de contención y de programación del crecimiento que se han considerado más oportunas" (Decreto 95/2000. Exposición de motivos). Así, esta revisión parcial del PIOT tendrá como principales objetivos: la reducción del ritmo de crecimiento turístico y residencial y la cualificación de la oferta de alojamiento turístico, que afecta a los Títulos Segundo y Cuarto de las Normas del Plan Insular, referido a los núcleos turísticos y Arrecife, en lo que hace mención a la nueva previsión de distribución de la población por municipios y a la programación de las nuevas plazas alojativas, en sus distintos usos para el período 2000-2010, sin establecer o modificar clasificaciones de suelo.

En el periodo de revisión y adaptación del PIOT de 1991, a la nueva legislación, Lanzarote, "en ejercicio de la facultad que la Ley 7/1995 concede, suspende, respecto a los planeamientos municipales, el otorgamiento de licencias de obras que supongan la creación de nueva "oferta alojativa", para evitar que la aplicación de los planeamientos municipales desvirtúen la finalidad pretendida con la adaptación del Plan Insular a la Ley" (Decreto 108/1999, de 25 de mayo, por el que se suspende el otorgamiento de licencias de obras que supongan la creación de nueva oferta turística alojativa en Lanzarote). Pero también este cese se justifica, en relación a los motivos que recoge el Decreto, que son los siguientes: a) en ocho años de vigencia del Plan no se han adecuado a éste los planeamientos generales de la isla (los municipios de Teguise, Haría y Tinajo carecen de planeamiento general; el de Yaiza data de 1973 y el de Arrecife no se ha adaptado igualmente ni al Plan Insular de Ordenación ni a la Ley 7/1995, de 6 de abril, encontrándose

111 Decreto 95/2000 de 22 de mayo, de aprobación definitiva de la Revisión Parcial del Plan Insular de Ordenación de Lanzarote. BOC, 29 de mayo de 2000. 
en la misma situación las Normas Subsidiarias de los municipios de Tías y San Bartolomé) y b) el constante crecimiento de la población flotante y el del número de plazas "alojativas" autorizadas. Todo lo mencionado condiciona e influye de forma determinante sobre la identidad cultural y el patrimonio, la vertebración social, el sistema urbanístico y medioambiental y sobre todo, de forma trascendente, en la ordenación y planificación turística, que siendo el motor de la economía insular se sustenta sobre escasos recursos disponibles y dotaciones desequilibradas con respecto al crecimiento turístico.

Lo que va a suponer la Revisión del PIOT es una especie de "moratoria turística", en la medida en que algunas previsiones de desarrollo turístico incorporadas al Plan Insular han sido demoradas hasta el 2010 (Suay, J. 2002, pp. 327), no eliminadas, con el fin de estudiar e intentar reconducir la situación. Pero también contempla modificaciones en la medida en que transforma usos turísticos en residenciales. Por otro lado, asume la necesidad de rehabilitación y remodelación de las instalaciones turísticas obsoletas y contempla la determinación de que la nueva oferta alojativa turística sea exclusivamente hotelera (Decreto 95/2000. Art. 3.3.2.4., 1.A $)^{112}$, así como la remodelación y reconversión de apartamentos en hoteles de tres o de cuatro estrellas. El tipo de oferta de alojamiento turístico queda muy regulado.

Ante el incremento que la oferta turística de Lanzarote ha experimentado en los últimos años, la Ley 6/2009, de 6 de mayo, de medidas urgentes en materia de ordenación territorial para la dinamización sectorial y la ordenación del turismo, mencionada en páginas anteriores, señala la isla como un entorno sobre el cual no se justifica, en la actualidad, el incremento de la superficie destinada a uso turístico. Dicha Ley, por tanto, supone una contención del crecimiento del alojamiento turístico insular, a excepción del alojamiento de turismo rural (limitado por legislación específica o el planeamiento insular) y de hoteles de cinco estrellas y de mayor categoría, siempre y cuando sean hoteles escuela, o suscriban convenios de formación y empleo con la Administración (obligando a que el $60 \%$ de su plantilla quede reservado para personal formado). Ordenación territorial del turismo y política de empleo van a ir de la mano al final del primer decenio del siglo XXI, momento éste que queda fuera del marco temporal que cubre esta tesis.

\section{4.- METODOLOGÍA}

La investigación se formula como una investigación "no experimental", que se elabora de forma sistemática, donde se combina, según el análisis de los resultados, un modelo

\footnotetext{
112 Boletín Oficial de Canarias. № 66. Lunes 29 de mayo de 2000. Decreto 95/2000 de Aprobación de la revisión parcial del PIOT de Lanzarote (pp. 7003).
} 
descriptivo -que nos da una representación de la evolución de la situación socioeconómica y del tipo o modelo de crecimiento turístico- a través del cual descomponemos las variables y damos cuenta de ellas, detallando el instrumento de medida y estableciendo relaciones entre los datos obtenidos, con un modelo explicativo, a través del cual contrastamos la hipótesis.

Según el tiempo en el que ocurren los hechos es una investigación de tipo retrospectivo, ya que se estudia un suceso ocurrido en el pasado y es observado por el investigador desde el presente. Además, dicho hecho se investiga en su evolución en el tiempo, por tanto, la observación del estado de las variables es dinámica (diacrónica), se realiza en el período histórico comprendiendo entre el año 1970 hasta el 2006 en la isla de Lanzarote, correspondiéndose con el periodo de inicio de la actividad turística, de modo significativo, y hasta que la misma se consolida como un turismo de masas. El diseño responde a un "estudio de caso".

Concluimos, por tanto, que la investigación es no experimental, descriptiva-explicativa, retrospectiva y de estudio de caso.

El análisis se va a circunscribir al estudio de los cambios que produce la dinámica turística sobre áreas concretas del bienestar social en la isla de Lanzarote. Lo que supone una elección parcial, prestando atención a los efectos sobre algunos subsistemas específicos, considerados básicos y fundamentales, del sistema de bienestar.

Así, el enfoque metodológico está basado en indicadores que se han considerado relevantes a estos efectos, seleccionados en relación a los mejores indicadores "disponibles" y/o los mejores indicadores "necesarios" de los considerados en el capítulo 2 de la primera parte de esta tesis.

Los criterios de selección de los mismos han sido: solidez analítica, representatividad, disponibilidad de datos comparables en el tiempo, fácil comunicabilidad, relevancia política y coherencia con el sistema insular.

Para establecer y medir la causalidad señalada, es necesario partir, en primer lugar, del estudio de la oferta (plazas de alojamiento) y de la demanda turística (afluencia) en su evolución temporal. Junto con las relaciones que se establecen entre esta demanda (número de turistas) y el volumen de plazas de alojamiento turístico y entre el número de turistas equivalentes diarios estimados y la población residente, que nos permitirán extraer unas primeras conclusiones sobre el equilibrio poblacional insular.

Una vez abordado este aspecto, el estudio de los efectos del turismo sobre el bienestar se enfrenta a través del análisis de aquellas áreas consideradas en el Capítulo 2, epígrafe 2 de la primera parte de la tesis, que hemos tipificado como básicas o fundamentales. Estos 
elementos del bienestar pueden presentar estrangulamientos por la mayor presión de la demanda social frente a una actuación desfasada de la oferta pública y discriminatoria de la privada sobre la población local; y, por tanto, afectar directamente al bienestar de la población residente, como se aprecia en los correspondientes capítulos de la tesis.

Del conjunto de los efectos señalados en el epígrafe 2, del segundo capítulo de la tesis, se han priorizado los elementos y efectos que se detallan a continuación, integrando los restantes a través de la síntesis de las conclusiones de distintos trabajos e investigaciones disponibles sobre Lanzarote, cuya consideración se realiza de manera más marginal. Todos ellos son efectos que se centran sobre las áreas que definen el estado básico de la población, sujeto y objeto del bienestar y de la actividad económica, así como sobre las infraestructuras, servicios y dotaciones básicas asociadas con ambas, ya que son éstos los considerados fundamentales para analizar el efecto del turismo sobre la sociedad anfitriona: evolución demográfica; dotación de servicios y equipamientos de salud y educación; mercados laborales, sectores de actividad productiva y de renta; y servicios y dotaciones básicas infraestructurales (carreteras, energía y agua). Esto no quiere decir que en los capítulos que siguen no se haga referencia al resto de efectos citados en el epígrafe 2, ligados también de forma complementaria al bienestar de la población, tanto en cuanto a dotaciones y servicios como en su aportación al desarrollo de actividades productivas en el territorio o a la transformación de éste, sino que se consideran complementarios a efectos de los objetivos directos de esta tesis.

Los efectos sobre el bienestar se estudian a lo largo de tres etapas, definidas atendiendo, en primer lugar, a los cambios de política territorial y turística que ha sufrido la Isla, expresada en base a los instrumentos de ordenación del territorio que se van sucediendo desde la década de los años setenta hasta la primera mitad de la década del siglo presente, en la medida en que establecen el modelo de desarrollo deseado, lo que incluye las tendencias urbanísticas y el rol del turismo en dicho desarrollo, generando efectos que son objeto de estudio en esta tesis; y, en segundo lugar, a periodos quinquenales (lustros), que nos permiten observar la intensidad de lo cambios en breves periodos de tiempo disponiendo de información demográfica más fiable.

Como conclusión, en el Capítulo 2.2, de esta tesis se ha hecho referencia al conjunto de efectos más significativos que normalmente se consideran a la hora de evaluar las consecuencias del turismo sobre el territorio. A todos ellos nos referimos en las páginas siguientes, de una manera más o menos directa, si bien los efectos básicos que van a ser objeto específico de análisis detallado en esta tesis y su descripción y tratamiento metodológico para el análisis de los efectos de la evolución turística sobre Lanzarote, son los siguientes, con el esquema metodológico que a continuación se señala y los indicadores a analizar, cuya evolución se calcula en relación a los años que coinciden con la existencia 
de datos censales, padronales y estadísticos sobre empleo y el resto de variables consideradas (dentro de cada etapa):

1. Estructura demográfica básica. Se analiza la dinámica de población y se relaciona con los efectos sobre la misma de la actividad turística a través de los siguientes indicadores: evolución del volumen de población (dinámica de crecimiento): población de hecho y de derecho, tasa de natalidad, de mortalidad y de crecimiento vegetativo, volumen y evolución de la inmigración y origen, estimación de la población autóctona y alóctona, proporción de alóctonos sobre autóctonos y de población foránea (alóctonos y turistas equivalentes al día) sobre autóctonos (nacidos en la Isla). Se contrasta la producción esperada de los efectos recogidos en el epígrafe 2, del segundo capítulo, de la primera parte de esta tesis: crecimiento demográfico asociado a la actividad turística por fuertes flujos migratorios; y cambios culturales y sociales asociados a la progresiva reducción de la población autóctona sobre la emigrante.

2. Cualificación y equipamiento educativo. La cualificación de la población como factor de cambio social que debe asumir las modificaciones socioeconómicas, se abordará a través de la medición del peso relativo del analfabetismo, y de los diferentes niveles formativos de la población residente y de los inmigrantes. En segundo lugar, se consideran las presiones derivadas sobre esta dotación como consecuencia de la demanda asociada a la población inmigrante, que serán medidas a través del nivel de equipamiento (oferta) en relación al volumen de la población (demanda): número de alumnos, unidades y maestros por tipo de enseñanza, y relación alumnos/unidades/maestros por tipo de enseñanza. Se contrasta que, en una primera etapa, el cambio de una población empleada fundamentalmente en el sector primario al desarrollo del sector servicios tiene una influencia positiva innegable en la mejora de la cualificación de la población (menor analfabetismo y mayor nivel de instrucción y formación) para, al generalizarse el turismo de masas y sobrepasar los flujos inmigratorios a la población a la población local, constituirse en un problema tanto de equipamiento (caída de los niveles de servicio medidos por la relación demanda/oferta) como por los problemas sociales asociados a una desculturización progresiva local.

3. Dotaciones de salud. La interrelación entre la oferta y la demanda en este epígrafe, y los posibles estrangulamientos que puede generar el volumen de población derivado de la actividad turística, se establecen a través del nivel de equipamiento (oferta hospitalaria, extrahospitalaria y números de médicos) en relación al volumen de población residente y a la población total compuesta por residentes y turistas diarios (demanda potencial). Adicionalmente, se contabilizará el número de servicios sociales según tipo de asistencia prestada. Como en el caso de la educación, se contrasta el hecho de que el cambio que implica el desarrollo del turismo lleva a una rápida mejora del equipamiento sanitario de la que se beneficia toda la población, incluida la local. En 
fases posteriores el turismo de masas implica fuertes flujos inmigratorios que presionan sobre el equipamiento y generan ofertas diferenciadas sanitarias asociadas a servicios privados, que tienen efectos negativos sobre la accesibilidad de la población local a la sanidad.

4. Estructura laboral. El turismo comprende básicamente actividades del sector servicios, las cuales son intensivas en el empleo de mano de obra aunque muchas de ellas generadoras de reducido valor añadido. No obstante, éste es mayor que el asociado a otras actividades tradicionales (agricultura, pesca, etc.) y requieren un esfuerzo más reducido, por lo que su nivel de implantación va asociado a la modificación, en mayor o menor medida, de la participación de otras actividades en la economía. La medición de estos efectos se concreta en los siguientes indicadores: población activa por sectores económicos o de actividad, desagregada en ocupados y parados, junto con las correspondientes tasas (de actividad y de paro), observando como varían esas tasas en relación al sexo. Las variaciones en la población potencialmente activa, en los ocupados y en los parados se pone en relación con las variaciones que experimenta la oferta (camas) y la demanda (afluencia) turística. Se contrasta un importante cambio de efectos desde las primeras etapas de actividad, donde hay un importante trasvase del sector primario a la construcción y actividad turística y se reduce el paro existente, con mejora de las condiciones económicas de la población local, a las asociadas al desarrollo del turismo de masas, con el que una inmigración intensa lleva al fuerte incremento en las tasas de paro, a la temporalidad y al empeoramiento de las condiciones de trabajo, sobre todo en las crisis de afluencia turística que se van produciendo en paralelo a las crisis socioeconómicas de los lugares de origen y al incremento de la oferta de destinos competitivos.

5. Renta. Las actividades turísticas generan crecimiento económico (aumento en la producción real per cápita de un país), por lo que originan repercusiones sobre los diversos factores productivos (tierra, trabajo y capital) que se suponen que son positivas tanto en términos de valor (precio del suelo y de las viviendas, salarios y capital productivo acumulado) como de flujos de renta asociados a los mismos. Se derivan incrementos positivos sobre la renta disponible personal y familiar de su población anfitriona, siendo ésta un indicador básico en la repercusión económica de la actividad turística sobre el bienestar, pues mejora el acceso de la población a bienes y servicios de consumo. Para el caso insular, el indicador que se mide será la renta familiar disponible desagregada para los municipios de la isla, derivando a partir de ella conclusiones sobre la dinámica insular y el papel del crecimiento turístico en la misma.

6. Energía. La variación en el consumo de energía eléctrica en la isla, que supone la asunción de actividades turísticas de masas y la presión que esta ejerce, junto con dinámicas socioeconómicas derivadas (construcción, incremento de la población, etc.) 
sobre la capacidad de producción, genera estrangulamientos coyunturales o estructurales, sobre todo en una Isla en la que la dependencia energética es muy elevada y asociada a la importancia de combustibles fósiles. Es por ello que se consideran los siguientes indicadores energéticos en la medición de los efectos: capacidad de producción o potencia instalada $(\mathrm{kw})$, producción de energía eléctrica disponible (kwh) y consumo eléctrico (kwh). Todos ellos en relación a la población residente, $\mathrm{y}$ al total de habitantes que, a diario, absorbe la isla (residentes y turistas). El análisis se completa analizando la evolución de la intensidad o eficiencia energética eléctrica (consumo de energía eléctrica en relación al PIB). Se contrasta la hipótesis del fuerte cambio negativo que implica el desarrollo de la actividad turística, tanto en cuanto al incremento de los consumos energéticos, como en relación a la creciente dependencia exterior que significa el no haber promovido sistemas de producción renovable de energías en la Isla.

7. El ciclo del agua. Otro de los recursos naturales fundamentales para el desarrollo de la actividad turística es la disponibilidad de agua. Por la escasez de precipitaciones y de acuíferos naturales, la disponibilidad de agua siempre ha sido un problema para el desarrollo en la Isla, con lo que la localización de actividades turísticas se ha sostenido sobre la desalinización de agua del mar consumidora de energía. Es por ello que el crecimiento turístico y demográfico asociado ha incidido en estrangulamientos, racionamientos del acceso a este recurso y alzas en su precio. Los indicadores que se utilizan para medir estos efectos son: producción total de agua potable ( $\left.\mathrm{Hm}^{3} / a n ̃ o\right)$, producción media diaria de agua $\left(\mathrm{m}^{3} /\right.$ día) por habitante residente ( $/ /$ resd $^{*}$ día) y para el total de población (residentes y turistas) que acoge diariamente la Isla (I/hab*día) y por tipo de producción (privada y pública); consumo medio de agua por habitante (residentes y turistas) y día (I/hab*día); número de viviendas con agua corriente y, cuando la información oficial lo permite, el consumo de agua diario por turista (I/turista*día). Se contrastan procesos similares a los señalados para la energía ya que la dinámica es paralela. 
8. Carreteras y transporte terrestre. Aunque se ha señalado que las mejoras en las dotaciones y servicios aeroportuarios y marítimos que se producen como consecuencia del desarrollo turístico mejoran indiscutiblemente el acceso de la población local a los mismos, facilitando su accesibilidad al resto de territorios canarios y exteriores al archipiélago, el principal efecto sobre el bienestar de toda la población se produce en los cambios generados en la accesibilidad interna a la propia Isla, por la mejora en sus dotaciones de carreteras y servicios de transportes públicos terrestres, aspectos a contrastar con el análisis de la evolución de las correspondientes dotaciones. Por otra parte, los efectos sobre la movilidad que las actividades turísticas de masas van a ejercer sobre el territorio de acogida, junto con la elevación del tránsito de personas y vehículos, afectan directamente, en primer lugar, a la capacidad de las carreteras para absorber dicha movilidad y dar un servicio adecuado, pues ordenan y limitan las posibilidades de movimiento y accesibilidad de la población residente, que la comparte con los turistas. En segundo lugar, el vehículo privado (turismos) puede irrumpir fuertemente en la escena (en propiedad o en alquiler) y producir no sólo la congestión señala antes, sino también la ocupación de espacios de los que expulsa al peatón e incide sobre el paisaje y el ambiente. Los niveles de motorización permiten una aproximación a esta incidencia. Y en tercer lugar, la ampliación de los movimientos por variaciones en el volumen de población que a diario se localiza en la isla, generará presión sobre el transporte colectivo de pasajeros, que puede quedar estrangulado. Se proponen, por tanto, los siguientes indicadores para abordar y medir los efectos: capacidad del viario (ancho de calzada y kilómetros de carreteras); parque automovilístico (turismos) en propiedad y alquiler (número de vehículos), índice de motorización e intensidad media diaria de vehículos por tramos relevantes; número de líneas de autobús, número de buses en relación a los residentes y a los viajeros potenciales (residentes y turistas).

Tabla 5. Áreas básicas de análisis e indicadores.

\section{TURISMO}

- Oferta: Plazas de alojamiento, total y por tipo (hotelera y extrahotelera); Y evolución (interperiodo): Incremento (\%).

- Demanda: Turistas entrados y equivalentes diarios; Evolución (interperiodo): Incremento (\%); Relación turistas residentes (t/r) .y turistas plazas (t/p)

- Relación demanda/oferta: Ratio turistas/plazas. 


\section{ÁREAS DE AFECCIÓN BÁSICA SOBRE EL BIENESTAR.}

\section{ESTRUCTURA DEMOGRÁFICA}

- Volumen: número de habitantes (hecho y derecho); Evolución (interperiodo): Incremento (\%).

- Movimiento Natural: Tasas (interperiodo) de Natalidad, Mortalidad y Crecimiento Vegetativo (\%o).

- Población Autóctona (nacidos en la isla): Volumen y Evolución (interperiodo): Incremento (\%).

- Factores Exógenos:

- Inmigrantes-alóctonos (residente nacidos fuera de la isla): volumen y evolución (interperiodo): Incremento (\%)

- Foráneos (alóctonos y turistas equivalentes diarios): volumen y evolución (interperiodo): Incremento (\%).

- Equilibrio Demográfico: Relación alóctonos/autóctonos (al/at); Relación foráneos/autóctonos (fr/at).-

\section{CUALIFICACIÓN Y EQUIPAMIENTO EDUCATIVO}

- Cualificación: Nivel de instrucción general y la población inmigrante por lugar de procedencia (absolutos y relativos).

- Equipamiento:

- Oferta: número de unidades y de maestros por tipo de enseñanza.

- Demanda: Número de alumnos, relación Alumnos/Unidad y Alumnos/maestros y por tipo de enseñanza.

\section{DOTACIONES DE SALUD}

- Oferta: número de camas por mil habitantes (de derecho y población total diaria estimada); número de centros extrahospitalarios y capacidad; número de médicos. Y número de servicios sociales por tipo.

- Demanda: Índice de ocupación hospitalaria; nivel de cobertura extrahospitalaria; habitantes por médicos (en relación a la población de derecho y a la total diaria estimada).

\section{ESTRUCTURA LABORAL}

- Tasa de Actividad general y por sexo.

- Ocupados: por sector económico (absolutos y relativos) y por sexo y profesión (\%); Incremento (interperiodo) por sector (\%).

- Parados: número de parados; por sector económico (\%). Tasa de paro general y por sexo

- Relación entre oferta y demanda turística, población potencialmente activa, empleo y paro por crecimiento interperiodo (\%).

\section{RENTA}

- Renta Familiar Disponible a pesetas corrientes de cada año por municipio.

\section{ENERGÍA}

- Capacidad: potencia instalada $(\mathrm{kw})$, en relación a la población residente $(\mathrm{kw} / \mathrm{resd})$ y a la total diaria estimada (kw/P.Total). Y evolución (interperiodo): incremento (\%).

- Oferta: producción de energía eléctrica disponible (kwh) en relación a la población residente (kwh/resd) y a la total diaria estimada (kwh/P.Total). Y evolución (interperiodo): incremento (\%).

- Demanda: consumo eléctrico (kwh), en relación a la población residente (kwh/resd) y a la total diaria estimada (kwh/P.Total). Y evolución (interperiodo): incremento (\%).

- Eficiencia energética eléctrica (consumo de energía eléctrica en relación al PIB).

\section{CICLO DEL AGUA}

- Oferta: Producción total de agua potable ( $\left.\mathrm{Hm}^{3} / a n ̃ o\right)$, producción media diaria de agua ( $\mathrm{m}^{3} / \mathrm{dí}$ ) por tipo de producción, privada y pública $\left(\mathrm{Hm}^{3} / \mathrm{año}\right.$ ) y por habitante residente (I/resddía) y para el total de población (I/habdía). Y evolución (interperiodo): incremento (\%).

- Demanda: Consumo total ( $\left.m^{3} / a n ̃ o\right)$, consumo medio diario de agua por residente (l/resd*día), por población total a abastecer (I/hab*día) y por turista (I/turista*día). Y evolución (interperiodo): incremento (\%). 


\section{CARRETERAS Y TRANSPORTE TERRESTRE}

- Carreteras. Oferta: Capacidad del viario: ancho de calzada (m) y Km. de carreteras.

- Transporte. Demanda: Parque automovilístico (turismos) en propiedad y alquiler (número de vehículos).

- Índice de motorización (turismos), en relación a la población residente y a la total.

- Intensidad media diaria de vehículos por tramos relevantes. Y evolución (interperiodo): incremento (\%).

- Número de líneas de autobús y buses en relación a los residentes y a los viajeros potenciales (residentes y turistas).

Fuente: Elaboración propia.

Los indicadores, por áreas, señalados, se podrán en relación con la dinámica de la Comunidad Autónoma de Canarias y del país, España.

Todo ello se reduce al siguiente esquema metodológico:

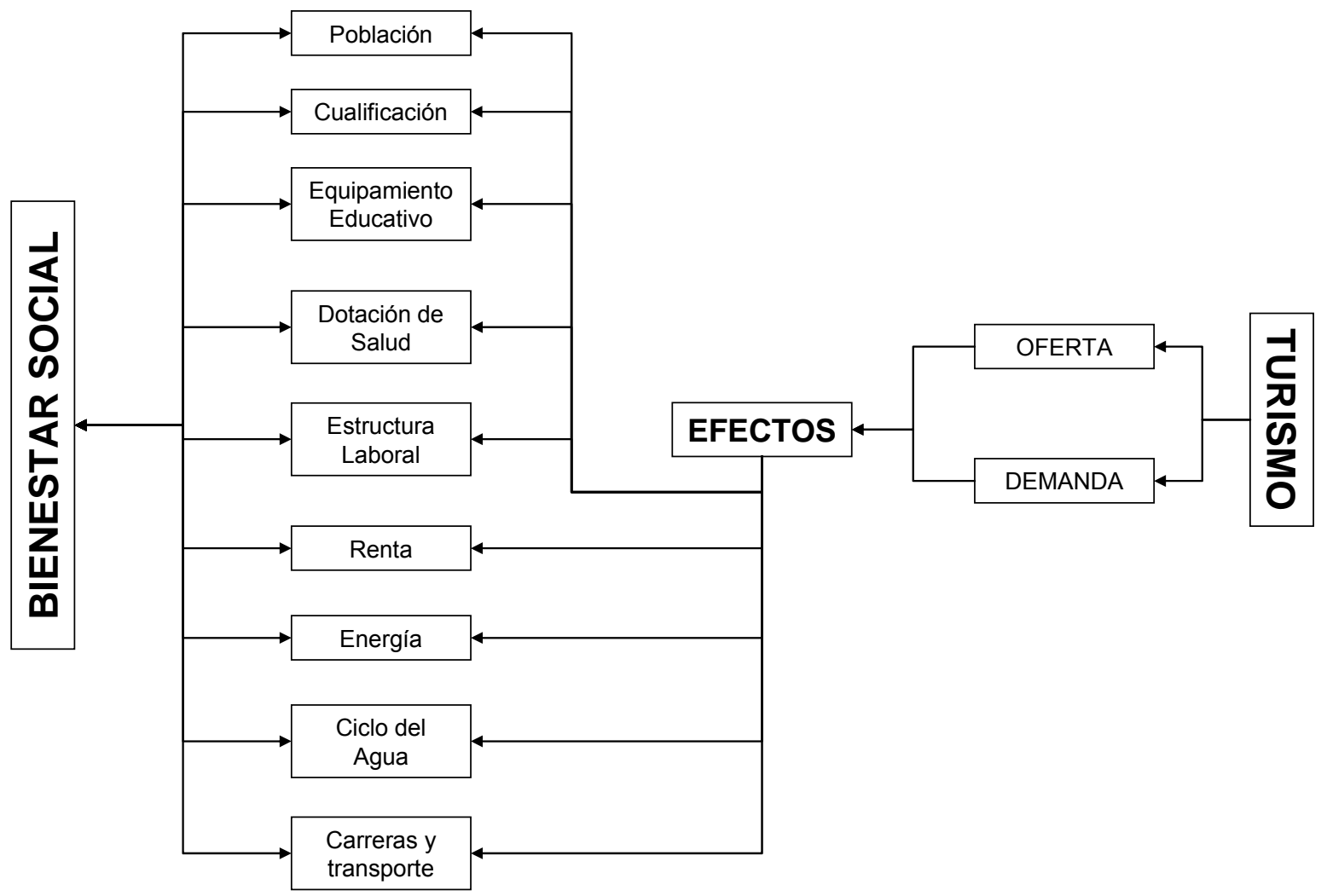

Al circunscribirse, el análisis, alrededor de los cambios que imprime el sistema turístico sobre el bienestar, éste se encuentra afectado, en su globalidad, por la demanda y la oferta turística. Es por ello que ha de estimarse la demanda o turistas diarios que soporta el territorio, pues su estado y variación afecta directamente a la mayor o menor presión sobre el bienestar.

La dificultad encontrada para el cálculo de los turistas diarios radica en el valor de la estancia media, ya que ésta observa variaciones en relación al tipo de alojamiento donde se produce, ya sea hotelero o extrahotelero. Pero el análisis se ve dificultado porque los 
datos estadísticos existentes se refieren a pernoctaciones y estancias medias en establecimientos hoteleros, no ofreciendo, las fuentes oficiales, estimación para el que se produce en establecimientos extrahoteleros hasta el año 2001, lo que obliga a hipótesis de adaptación que se comentan en cada caso, basadas en el hecho de que los registros tomados del Instituto Nacional de Estadística, a partir del año 2001, en la estancia media entre los dos tipos de alojamiento (hotelero y extrahotelero), muestran variaciones porcentuales diferentes para España, Canarias y Lanzarote. Estas variaciones en las estancias medias por tipo de alojamiento conocidas, para el año 2001 y 2006, se han aplicado para estimar la estancia media en aquellos años en los que no se dispone de información extrahotelera (1970-1996), con el fin de minimizar el efecto del tipo de alojamiento sobre dicho valor medio y conseguir una estimación del número de turistas diarios más próxima a la realidad del territorio que se analiza, Lanzarote, y sobre el que se pone en comparación, Canarias y España.

\section{5.- ETAPAS DEL DESARROLLO TURÍSTICO INSULAR Y SUS EFECTOS SOBRE EL BIENESTAR}

La llegada del turismo supuso una revolución. Aunque para algunos fue paulatina y para otros fue realmente breve, algunos pueblos y sus alcaldes han asistido a su completa transformación en períodos que pueden ir desde ocho a quince años. Desde esta circunstancia sí podemos hablar de revolución, de la "década revolucionaria del turismo" (Fernández, L. 1991).

Algunos autores establecen o definen etapas de desarrollo turístico como principio ordenador. Puesto que, en palabras de Kadt, E (1991, pp. 34) intentar caracterizar un destino particular dentro de su propia historia natural de desarrollo turístico, puede ayudar al planificador a identificar alternativas factibles y a valorar sus posibles resultados. Tal es el caso de Noronha, R. (1979) que las resumió en tres: $1^{a}$ ) unos pocos turistas descubren el destino; $2^{\mathrm{a}}$ ) en respuesta a ellos los empresarios locales proporcionan instalaciones para alojar al creciente número de visitantes; $3^{a}$ ) a continuación le sigue la institucionalización del turismo de masas, cuando caen bajo el control de las agencias arraigadas fuera de la comunidad local y, con frecuencia, fuera del país.

Para el caso que aquí nos trae, el principio ordenador ${ }^{113}$, que nos va a guiar para establecer las etapas de desarrollo turístico por las que pasa la isla, son los distintos Planes de

113 Véase Sosa, A. "Los planes de ordenación del territorio como principio ordenador del desarrollo turístico". En Cuadernos de Ordenación del Territorio, № 3. Cuarta Época. Madrid: Asociación Interprofesional de Ordenación del Territorio (FUNDICOT), 2002 (pp. 23-33). 
Ordenación del Territorio que se fueron sucediendo desde la década del setenta hasta el año 2001, ya que la ordenación del territorio es considerada como la expresión espacial de las políticas económicas, sociales, culturales y ecológicas de toda la sociedad, posee objetivos definidos desde los responsables de la gestión territorial insular, nutridos de ideología y sometidos a la influencia de los distintos actores o poderes en pugna que constituyen las diferentes fuerzas sociales que presionan sobre el territorio.

A partir y a través de estos Planes se expresa la política dominante en ordenación territorial, urbanismo y medio ambiente, estableciéndose el modelo de desarrollo deseado y el papel de los distintos sectores económicos en el mismo. Así, los distintos Planes, por los que pasa la Isla, han aparecido ante necesidades de desarrollo socioeconómico, han marcado éste y se constituyen en el principio ordenador del desarrollo turístico y social insular, por lo que tienen sentido como puntos de inflexión en el análisis del estado del bienestar en la isla de Lanzarote. A ello hay que añadir que, dentro del territorio nacional, Baleares y Canarias son las Comunidades Autónomas que han desarrollado un modelo de planificación turística, al menos teóricamente, coordinado con la planificación territorial.

Obviamente, existen otras posibilidades de establecer distintas etapas de desarrollo turístico de la Isla ${ }^{114}$, algunas de ellas con referencia a los hitos geográficos de transformación espacial (desarrollo de determinadas áreas del territorio) que, aunque se suponen derivados de la planificación territorial y urbana, a veces no guardan paralelo con la misma, o etapas asociadas a las personas, grupos o partidos en el poder, con manifiesta diferencia en intereses y consecuencias sobre el territorio, por citar sólo dos de la amplia gama de alternativas de periodificación válidas para el análisis que cabría hacer en la isla. En todo caso, y por los motivos señalados, en la tesis se ha optado por la periodificación asociada a los instrumentos de ordenación del territorio, con consideración específica de las transformaciones en períodos de cinco años, periodos para los que es posible disponer de información más fiable y detallada. En síntesis, se incorporan tres períodos en la tesis:

1. El primero comprende las décadas del setenta y del ochenta, hasta 1986. Periodo de despegue y consolidación de la actividad.

2. El segundo (1986-1996) Ilega con un "boom" turístico que acontece a finales de los ochenta y la elaboración del Plan Insular de Ordenación del Territorio (PIOT) que entrará en vigencia en 1991 y pasa a ser cuestionado en 1996.

\footnotetext{
114 Véase, a modo de ejemplo, González Morales, A. Urbanismo y crecimiento turístico en Lanzarote durante la segunda mitad del siglo XX. En Papeles de Geografía, nº. 044, año 2006 (pp. 39-57).
} 
3. El último período, hasta el que llega este trabajo, se establece desde 1996 hasta el año 2006, donde Lanzarote se presenta como un destino maduro. Cubre una nueva crisis turística, la revisión del PIOT y aprobación de una Moratoria (2001) y su derogación a finales del año 2006 por no ajustarse a derecho.

Será el sector de la construcción el elemento clave para que se pueda dar una recepción turística en masa, puesto que es a través de este sector como se puede dotar al sistema económico turístico de las infraestructuras técnicas y sociales adecuadas para su avance, lo que hará que, finalmente, se erija como sector central del desarrollo turístico. Este punto es de referencia obligada cuando tratemos las diferentes etapas por las que ha pasado el desarrollo turístico en Lanzarote. Analizaremos, por tanto, la evolución de las plazas de alojamiento en el periodo comprendido entre 1960 y 2007, para lo que se utilizarán los datos recogidos por diferentes organismos públicos, así como Normas Subsidiarias de Planeamiento, los Planes de Ordenación, etc., teniendo en cuenta que los datos, referidos a la industria turística en sí misma, cobran relevancia fundamental en la medida en que se relacionan con la realidad social y territorial de cada isla (Díaz Feria, L. y otros, 2001, pp. 28), cosa que iremos haciendo a lo largo de los capítulos.

\section{1.- PRIMERA ETAPA. DESPEGUE Y CONSOLIDACIÓN. 1970-1986}

A finales de los sesenta, las condiciones mínimas requeridas para la iniciación del negocio turístico eran casi inexistentes. "Piénsese en la situación de las comunicaciones exteriores, en la carencia tradicional de agua y energía y en las grandes dificultades de los transportes dentro de la isla (red viaria, parque móvil, etc.)" (C.I.E.S., 1971, pp. 114). La década del setenta, principalmente, será el período en el que se ubican los primeros procesos de desarrollo, a lo que posteriormente va a ser una economía basada en el terciario turístico.

A comienzos de esta década "Lanzarote tenía unas características paracoloniales, desérticas y rurales, con muy baja densidad de población, y en muchos lugares sin agua, sin electricidad y sin infraestructuras suficientes. Por lo que los precios del suelo eran muy baratos" (Gaviria, 1974, pp. 298), fundamentalmente en sus zonas costeras. Aunque ya a finales de los sesenta comienzan a realizarse algunas obras de infraestructuras -construcción de una potabilizadora dual que comienza a funcionar en 1965, reforma y acondicionamiento de la red de caminos vecinales en 1969, el aeropuerto es abierto a vuelos "charter" internacionales en 1970 (C.I.E.S., 1971, pp. 114)- que irán cambiando el panorama y posibilitando el asentamiento del sector turístico, no será hasta la década de los setenta cuando empiece su lanzamiento turístico real, puesto que las infraestructuras técnicas y sociales son las condiciones necesarias (reformas exigidas también por las empresas explotadoras). 
El paso previo consistió en el acondicionamiento de zonas naturales para su visita. Ya en 1964 se genera el primer Parque Insular de Turismo ${ }^{115}$ y posteriormente, el Cabildo Insular empieza a estudiar nuevas posibilidades para otras zonas de la isla. Así, con la entrada de la nueva década ya se habían dado los primeros pasos desde la "inversión institucional" para implantar la actividad, apoyados en la demanda que estaba surgiendo. Se optó por el turismo como forma de sacar a la isla de su atraso ${ }^{116}$. Desde 1960 hasta 1974, la isla estuvo gobernada por Ramírez Cerdá, J., al que se le atribuye el arranque de la actividad turística y el sentar las bases de la planificación del futuro de la isla ${ }^{117}$.

Por tanto, el espacio natural pasa por una primera fase que se puede llamar de producción del espacio turístico. Así se creará, en tiempos más modernos, la red de Centros Turísticos, cuya finalidad de creación fue apostar por el impulso de valores paisajísticos, ecológicos, estéticos y culturales, promovidos a través de estas pequeñas inversiones institucionales. "No sólo son meros centros de visita. Son Arte y Cultura en la Naturaleza" (Cabildo de Lanzarote, Moratoria, 1999). Esto permitió el comienzo de una red de calidad e imagen difícilmente asumible por la iniciativa privada. Se concibe Lanzarote, por los propios, como una zona industrial-turística a explotar "El paisaje pasa a ser activo económico y el éxito conseguido es fruto de una forma de proceder" (Cabildo de Lanzarote, Moratoria, 1999). Paralelamente a esto comienza la urbanización del territorio y construcción de hoteles y apartamentos, es "la fiebre de la construcción", surgiendo una dialéctica entre producción del espacio turístico de calidad y consumo de dicho espacio (Gaviria, 1974, pp. 276). Es el inicio de lo que luego será un proceso de masificación.

Las dificultades infraestructurales con las que Lanzarote entra en la década de los setenta, que dificultan las grandes inversiones, "obligan a los pequeños y medianos inversionistas a plantearse la oferta turística a una escala muy reducida y esperando que la serie de elementos que ellos no pueden aportar vayan surgiendo espontáneamente del propio mercado turístico" (C.I.E.S., 1971, pp. 115) ${ }^{118}$. Aunque a finales de los años sesenta irrumpen de forma generalizada Sociedades Anónimas y de capital exterior ante la práctica inexistencia de medidas de control sobre usos de suelo y medidas fiscales. Principalmente estos capitales son de procedencia alemana y vienen amparados por la Ley Strauss (1968)

\footnotetext{
115 En 1962, el Excmo. Cabildo Insular llega a un concierto con el Ayuntamiento de Haría por el que se traspasa una extensión de 250 has., que engloba los actuales "Jameos del Agua" y la "Cueva de los verdes", que en el año 1964, se convertirá en Parque Insular de Turismo. CIES, 1971 (pp. 116).

$116 \mathrm{http}: / /$ www.cabildo.com/moratoria/ini.htm 16-12-99.

117 Encomienda de número al Mérito Civil. Gran Caballero de la Orden de Cisneros. Medalla de bronce del Mérito Turístico

118 "Los recursos humanos y financieros requeridos para construir y poner en funcionamiento las instalaciones turísticas podían asegurarse tanto de fuentes nacionales como internacionales si no estaban disponibles localmente" (Kadt, E. 1991, pp. 36).
} 
que eximía de impuestos durante doce años a las compras de terrenos efectuadas por los alemanes en las Islas Canarias, subsumiendo dichas operaciones en el concepto de "ayuda al tercer mundo" (Pera Soro. 1986, pp. 206), "que pone en contacto al capitalismo internacional con el capitalismo canario" (Perdomo, M. A., 1987, pp. 439). A partir de ahora, la oferta turística será instrumentada por la iniciativa privada ${ }^{119}$.

Las oleadas especulativas toman posesión y buscan la expansión siguiendo una serie de fases (C.I.E.S., 1971, pp. 117):

1. Cambio de titularidad de la propiedad inmobiliaria, para dejar pasar el tiempo y revender a un precio más elevado, sin realizar labores de transformación ${ }^{120}$.

2. Urbanizar: delimitar sobre plano amplias extensiones y venderlas -incluso en forma de saldo. C.I.E.S, 1971- por parcelas.

3. Invertir de verdad para luego vender o arrendar.

Así, la isla entra en una situación tremendamente dinámica y cambiante ${ }^{121}$. Esta especulación primaria abre paso a una situación más compleja, que traerá consigo fuertes actividades inversoras.

El modelo de implantación, ahora (década de los años setenta), se caracteriza por un proceso de urbanización acelerado, que desemboca en la especialización turística del espacio litoral, como consecuencia de la demanda creciente de suelo para construir alojamiento. "El primer síntoma que se produjo fue superestructural y se canalizó por la vía de la contratación jurídica, básicamente de compraventa de terrenos y también por actos de deslinde de propiedades, expedientes de dominio, etc." (C.I.E.S., 1971, pp. 117). Al igual que ocurrió, años antes, en toda la ribera del Mediterráneo, la producción del espacio urbano-turístico es una actividad más importante que la del uso de ese espacio (Pera Soro. 1986, pp. 205).

119 "La mayoría de los países pobres que esperan obtener beneficios desarrollistas a través del turismo, no tienen ni un sector privado fuerte ni una clase empresarial vigorosa, ni siquiera mucha capacidad gestora disponible en el sector público" (Kadt, E. 1991, pp. 64). Lanzarote no era la excepción.

120 En Lanzarote esta fase supuso el paso de grandes extensiones, especialmente costeras, a manos de súbditos extranjeros, peninsulares y en mucha menos parte, a individuos o sociedades pertenecientes a la región. C.I.E.S. 1971 (pp 117).

121 No podemos olvidar el papel que jugaron la instalación de infraestructuras, como es el caso de una planta potabilizadora, que comienza a funcionar a partir de 1965, y que "produjo un cierto grado de expansión en la actividad económica insular y una mejora de la flota por parte de los armadores con importantes alzas del producto y los salarios". C.I.E.S., 1971 (pp. 117). 
El fuerte crecimiento turístico inmobiliario no estará enmarcado en una planificación turístico-territorial de carácter insular, capaz de interrelacionar dicho desarrollo con los parámetros básicos de la isla. En 1970 se aprueban unas Normas Insulares excesivamente sencillas, aprobándose otras en 1973. En el marco de este PIOT (1973) ${ }^{122}$ se permitía edificar y urbanizar directamente una gran parte de suelo de la isla-"Al amparo de este Plan Insular se dispararon unas clasificaciones de suelo que abarca a más de 8.000 hectáreas, con capacidad para 450.000 plazas turísticas, aproximadamente" ${ }^{123}$ —, sin más requisito que la redacción de un Plan Parcial, debido a la forma en que quedaron aprobadas: supeditadas al planeamiento municipal (Avance PIOT. Tomo 1.A., 1987, pp. 20) y sin enmarcarse en un ámbito planificado municipal o insular (Avance PIOT, Tomo 6, 1987, pp.3) ${ }^{124}$. En muchos casos era el promotor quien decidía libremente sobre la actuación, con Plan Parcial o sin él, por la vía de los hechos. Este PIOT lo único que hizo fue regularizar una situación ya existente, puesto que al final de la década de los sesenta ya entraban capitales extranjeros a comprar terreno rústico en zonas de suelo barato o simplemente llegaban y reclamaban terrenos, de forma que si en el periodo abierto por el Ayuntamiento no aparecía su dueño, pasaba automáticamente a sus manos. Después elaboraban un Plan Parcial o Especial de Ordenación Turística. Los criterios urbanísticos, territoriales, paisajísticos o ecológicos no fueron los determinantes de la localización y el ámbito de actuación. Esa "cultura" llegaría más tarde a la Administración Insular. Primó criterios de expansión turística.

La ordenación que resultó de esto era la suma de Planes inconexos. El Planeamiento Parcial aprobado en esta época no cuenta con sus correspondientes Proyectos de Urbanización, con lo cual no se dio en ningún momento un proceso urbanizador, sino que solamente supuso una forma de "tomar posiciones", o sea, de clasificar grandes cantidades de suelo turístico y acumular así un gran fondo inmobiliario (Avance PIOT, Tomo 6, 1987, pp. 3-6). El surgimiento, por esta época de un potente, complejo y especulativo mercado inmobiliario, es descrito por C.I.E.S. (1971, pp. 117) como "ebullición social".

Como consecuencia de esta dinámica comienza el desarrollo urbano de determinado núcleos costeros. En el caso de Lanzarote centrado, primero en la costa del municipio de Tías (Pueblo de la Tiñosa, hoy Puerto del Carmen ${ }^{125}$ ) y después en la del municipio de

122 El llamado Plan Insular de 1973, aprobado por el Ministerio de Vivienda (Dirección General de Urbanismo).

${ }^{123}$ Excmo. Cabildo Insular de Lanzarote (1999). "Revisión del Plan Insular de Ordenación Territorial de Lanzarote. Documento de Aprobación Provisional". Lanzarote. (pp. 6).

${ }^{124}$ Excmo. Cabildo Insular de Lanzarote (1987). "Avance del Plan Insular". Tomo 6. Dictamen sobre el planeamiento urbanístico existente y futuro. Área Jurídica. AUIA. 1987.

125 "Era un pueblo marinero dedicado casi exclusivamente a la pesca artesanal y a su alrededor existía la "materia prima" necesaria para la atracción y asentamiento de las organizaciones de viajes y una ínfima parte del mismo explotado (continuación) 
Teguise (Costa de Teguise) y de Yaiza (Pueblo de Playa Blanca). Es decir, los núcleos turísticos están en las franjas costeras y las cabeceras municipales están situadas en el interior (donde están los suelos más aptos para la explotación agrícola). Municipios estos que concentraron y concentran la dinámica del desarrollo y los mayores ingresos por turismo, cuya oferta de alojamiento "estuvo apoyada en la existencia de playas y en grandes operaciones especulativas" (Avance del Plan Insular, Tomo 5. 1987, pp. 46). El Centro de Investigación Económica y Social (C.I.E.S ${ }^{126}$. 1970, pp. 118) estima, para la época, un $10 \%$ de las costas de la isla fuera del fuerte movimiento especulativo ${ }^{127}$. Todo ello dio lugar a una modificación en la jerarquía de los núcleos o municipios preexistentes. "Es decir, el trasfondo del milagro turístico es la construcción de ciudades nuevas, la producción, revalorización y destrucción de los espacios antiguamente rurales y costeros". (Mario Gaviria, 1976, pp. 314).

Las décadas de los años setenta y ochenta, que hemos establecido como la primera etapa de nuestro análisis, se caracterizan por un crecimiento incontrolado, puesto que la demanda aumenta, se produce congestión y esto obliga a buscar nuevo espacio rápidamente (al igual que sucedió en la Costa del Sol o en la Costa Banca), con una marcada falta de control e inexistencia de planeamiento; este proceso estuvo propiciado, en primer lugar, por el Plan Insular de Ordenación del Territorio de 1973 aprobado por Resolución de Ministerio de Vivienda, que asume el carácter de Norma Subsidiaria de Planeamiento con la correspondiente clasificación del suelo y normativa de edificación y convierte la mayor parte de las superficies utilizables de la isla en suelo de reserva urbana a desarrollar por Planes Parciales ${ }^{128}$ y en segundo lugar, por el Plan Insular de la Ordenación Turística de la Isla de Lanzarote, aprobado en 1982, que no se realiza con criterios operativos y no tiene ninguna competencia de intervención ${ }^{129}$ (Avance PIOT, 1987, Tomo 1.A., pp. 20).

productivamente (...)" Perdomo, M. A., 1987 (pp. 439). Era una zona desértica muy parcelada y muy barata, con buen clima, playas y cercana al aeropuerto de la isla.

${ }^{126}$ Perteneciente a la Caja Insular de Ahorros. Las Palmas de Gran Canaria.

127 "El crecimiento turístico originó una fuerte proliferación inmobiliaria, que a través de una urbanización abusiva transformó las colinas litorales en un mero soporte para el alojamiento". Callizo J., 1991, pp. 104.

${ }^{128}$ Avance del Plan Insular (1987). "Dictamen sobre el Planeamiento urbanístico existente y futuro". Tomo 6. Área Jurídica. AUIA. (pp. 3).

129 "El objetivo final que se pretende es la elaboración de un Plan de Ordenación del territorio de las de Lanzarote que sin ser necesariamente vinculante para los municipios de ésta isla canaria sea sin embargo asumible por ellos y susceptible de ser incorporado en los Planes Generales de ordenación o cualquier otra figura de Planeamiento que actualmente esté en vigor o se realice, para dichos términos municipales con posterioridad". Plan Insular de Ordenación de la Oferta Urbanística de la isla de Lanzarote. Tomo I, 1982 (pp. 15). 
Mapa 1. Zonas de uso turístico previsto, 1973

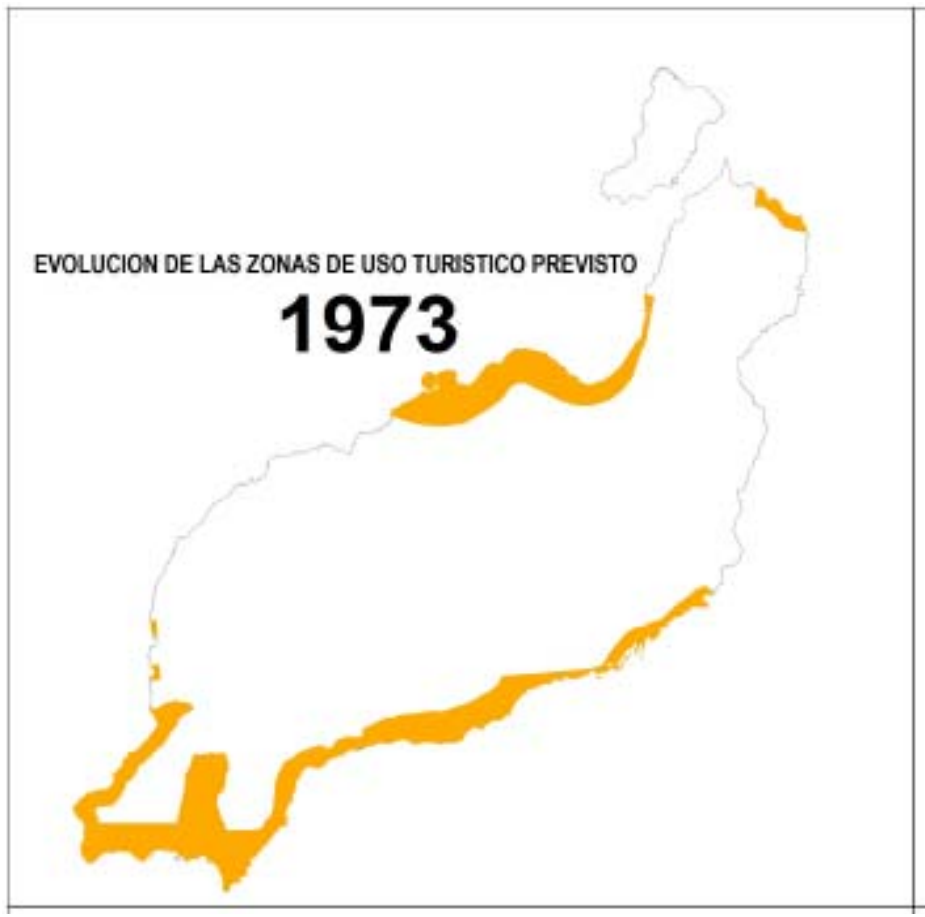

Fuente: Cabildo Insular de Lanzarote. Resumen del Plan Territorial Especial de Ordenación Turística Insular de Lanzarote, 2006. (Elaborado por AUIA). [En línea] Lanzarote: Cabildo de Lanzarote, 2006. (p. 7) [Ref. de 17 de junio de 2011] Disponible en Web: http://www.datosdelanzarote.com/itemDetalles.asp?idFamilia=24\&idltem=3023

Por tanto, y según lo dicho hasta ahora, el modelo de planificación que se va a dar en Lanzarote en esta primera etapa, basado en la tipología elaborada por Callizo Soneiro, J. (1991, pp. 103-108) sobre formas de extensión de las actividades turísticas en el litoral, y que aquí adoptamos para el caso de Lanzarote, sería del tipo intensivo espontáneo, en el que la puesta en valor turística del territorio responde a modelos de desarrollo intensivos (proliferación inmobiliaria) surgidos de forma espontánea, donde los impulsos de demanda han ido condicionando y han precedido la creación de la oferta. Así, se aseguraban un crecimiento rápido y a gran escala del número de turistas procedentes de Europa (Kadt, E, 1991, pp. 35). Los turistas, en el momento en que son una fuerza (demanda), se imponen a la oferta, siendo instrumentos en manos de la agencia extranjera que domina (Tour Operators), quedando el proceso expansionista en manos de extranjeros que compran el territorio, básicamente porque, como ya hemos dichos anteriormente, no existían en la isla agentes económicos con fuerza para llevar a cabo esas inversiones ${ }^{130}$; por tanto, la demanda estuvo controlada desde el exterior. Es decir, primó la lógica de la maximización del beneficio económico, que aunque con cierto beneficio para los municipios pioneros,

130 "Optar por el turismo como estrategia de crecimiento es como pedir estar sometido continuamente a control de fuerzas externas". Crick, M. 1989. 
principalmente resulta en un beneficio privado que volvió a los países emisores del turismo (Jurdao, F. 1992, pp. 20). Esto provocó elevados costes para el conjunto de la oferta turística, costes que no fueron asumidos por la empresa privada. La no internalización de estos costes por la empresa privada ha hecho que la suma de actuaciones basadas en el criterio de maximización individual no conduzca a una maximización colectiva. Era por tanto un modelo dependiente del exterior y depredador en cuanto a su gran capacidad de extensión urbana y de consumo del territorio.

Este hecho no es exclusivo de la Isla, sino que es producto de la política que venía imponiéndose desde principios de siglo. En esta época, en la política urbanística prevalece la concepción de un crecimiento maximizador y fundamentalmente cuantitativo ${ }^{131}$ y para conseguirlo se legisla, únicamente, para promover el territorio español turísticamente en el exterior y no para controlar la especulación y el desorden urbanístico. La cultura urbanística llegará más tarde al territorio insular.

Estos desarrollos presentan una serie diversa de problemas, que tal y como se analizan en los documentos de elaboración previa del PIOT de Lanzarote, aprobado en 1991, se concretan en los siguientes para la isla:

1. Falta de control y regulación en la ocupación del espacio. Tras el Plan de 1973, la clasificación del suelo y normas de ordenación quedan con carácter provisional hasta la redacción del Planeamiento Municipal, que se puede redactar sin tener que asumir referencias a nivel insular. Al ser su carácter de Norma Subsidiaria, en el suelo de "reserva urbana" o "apto para urbanizar", el desarrollo se realiza mediante Planes Parciales. Los análisis elaborados sobre ésta época, realizados para la elaboración del siguiente PIOT (1987), concluyen que el Plan de 1973 "era inadecuado o no estaba pensado para el fuerte desarrollo de la actividad. La ordenación resultante fue la suma de Planes inconexos" (Avance PIOT. Tomo 6. 1987, pp. 3). En este marco, en el ámbito de la planificación y el planeamiento se elabora lo siguiente, a la largo de estas dos décadas analizadas. Señalamos adicionalmente, quién ocupaba, en la época, la Presidencia del Cabildo de Lanzarote y la Alcaldía de los Ayuntamientos:

131'La actuación política existe en España desde el momento en que el Estado percibe las bondades económicas que podrían derivarse del uso turístico de los espacios nacionales (...)". Díaz Álvarez J.R. "Geografía del Turismo. Editorial Síntesis. Madrid, 1989, pp. 109. 
Tabla 6. Presidentes del Cabildo Insular de Lanzarote (1960-1991)

\begin{tabular}{||l|l|l|l||}
\hline & \multicolumn{1}{|c|}{ INICIO } & \multicolumn{1}{|c|}{ FIN } & \multicolumn{1}{|c|}{ PARTIDO } \\
\hline Ramírez Cerdá, J. & $08-02-1960$ & $20-09-1974$ & ---- \\
\hline Gómez Ruiz, F. & $20-09-1974$ & $23-04-1977$ & ---- \\
\hline Acosta Cruz, A. & $23-04-1977$ & $10-10-1978$ & ---- \\
\hline De Páiz Pereyra, N. & $10-10-1978$ & $19-04-1979$ & ---- \\
\hline Lorenzo Martín, A. & $19-04-1979$ & $23-05-1983$ & UCD \\
\hline Pérez Parrilla, E. & $23-05-1983$ & $30-06-1987$ & PSOE \\
\hline De Páiz Pereyra, N. & $30-06-1987$ & $21-06-1991$ & CDS \\
\hline
\end{tabular}

Fuente: Archivo histórico. Elaboración propia

Tabla 7. Planes Generales y Parciales municipales hasta 1987

\begin{tabular}{|c|c|c|c|}
\hline MUNICIPIO & $\begin{array}{l}\text { PLANES GENERALES } \\
\text { (año) }\end{array}$ & DELIMITACIÓN DE SUELO URBANO (año) & $\begin{array}{l}\text { PLANES } \\
\text { PARCIALES }\end{array}$ \\
\hline \multirow{2}{*}{ ARRECIFE } & 1968 & \multirow{2}{*}{---} & \multirow{2}{*}{6} \\
\hline & Alcalde: De la Hoz Gil, G. & & \\
\hline HARÍA & --- & 1974; Alcalde: Santana de León, J. J. & --- \\
\hline SAN BARTOLOMÉ & --- & 1974; Alcalde: Bermúdez Bermúdez, M. & 1 \\
\hline TEGUISE & -- & 1975 & 12 \\
\hline TÍAS & --- & $\begin{array}{l}\text { 1974: Alcalde Perdomo Perdomo, Juan Ma } \\
\text { 1984; } 1986 \text { (PSOE) }\end{array}$ & 9 \\
\hline TINAJO & --- & 1975 & 1 \\
\hline \multirow{2}{*}{ YAIZA } & 1973 & \multirow{2}{*}{---} & \multirow{2}{*}{4} \\
\hline & Alcalde: Padrón Mesa, A. & & \\
\hline
\end{tabular}

Fuente: Cabildo de Lanzarote. Avance del PIOT. "Dictamen sobre el Planeamiento urbanístico existente y futuro". Tomo 6 . Área Jurídica. (Elaborado por AUIA, 1987, pp. 3-4) y Archivos históricos municipales. Elaboración Propia.

La Planificación dirigida a la expansión turística, así como la desconexión y el insuficiente control urbanístico y arquitectónico, ha permitido que, en la producción del espacio urbanoturístico, cualquier nacional o extranjero hiciese lo que quisiese. Lo que lleva a una profunda confusión del espacio (Gaviria, M. 1976, pp., 313). "La especulación del suelo se convierte en práctica habitual dando lugar a cambios en la titularidad de la propiedad inmobiliaria (...)" (Perdomo, M. 1987, pp. 440).

2. El condicionamiento respecto de las circunstancias del mercado, implica el que no exista control en el ritmo de creación de nuevas plazas turísticas. La oferta surge como respuesta a la demanda de suelo, sin previsión y sin objetivos de ámbito planificado insular. 
Tabla 8. Urbanizaciones turísticas existentes a 1 de diciembre de 1973 en la Provincia de Las Palmas*

\begin{tabular}{|l|l|l|l|l|l|l|l|}
\hline \multicolumn{2}{|l|}{ LANZAROTE (Has) } \\
\hline LANZAROTE & ARRECIFE & S. BARTOLOMÉ & TEGUISE & TÍAS & TINAJO & YAIZA & Desconocido \\
\hline $2.267,99$ & 159,46 & 24 & 801,74 & 123,71 & 127,75 & 266,73 & 764,6 \\
\hline
\end{tabular}

\begin{tabular}{|l|l|l|l|}
\hline \multicolumn{2}{|l|}{ RESTO DE LA PROVINCIA (Has) } \\
\hline FUERTEVENTURA & $11.939,80$ & GRAN CANARIA & $6.129,21$ \\
\hline $\mathrm{N}^{0}$ de Urbanizaciones $=73$ & $\mathrm{~N}^{0}$ de Urbanizaciones $=86$ \\
\hline
\end{tabular}

\begin{tabular}{|l|l|}
\hline \multicolumn{2}{|l|}{ TOTAL PROVINCIAL } \\
\hline TOTAL SUP. PROVINCIAL (Has) & 20.337 \\
\hline TOTAL N' URBANIZACIONES & 189 \\
\hline
\end{tabular}

*Nota: Estos datos elaborados por Gaviria de refieren a terrenos y urbanización de los que ya existe algún documento en tramitación legal a través de los municipios o del Ministerio de Vivienda. Fuente: Gaviria, M. (1974). "España a Go-Go. Turismo charter y neocolonialismo del espacio". Ediciones Turner. Madrid. Elaboración Propia.

Mapa 2. Ordenación estructural. Lanzarote, 1973.

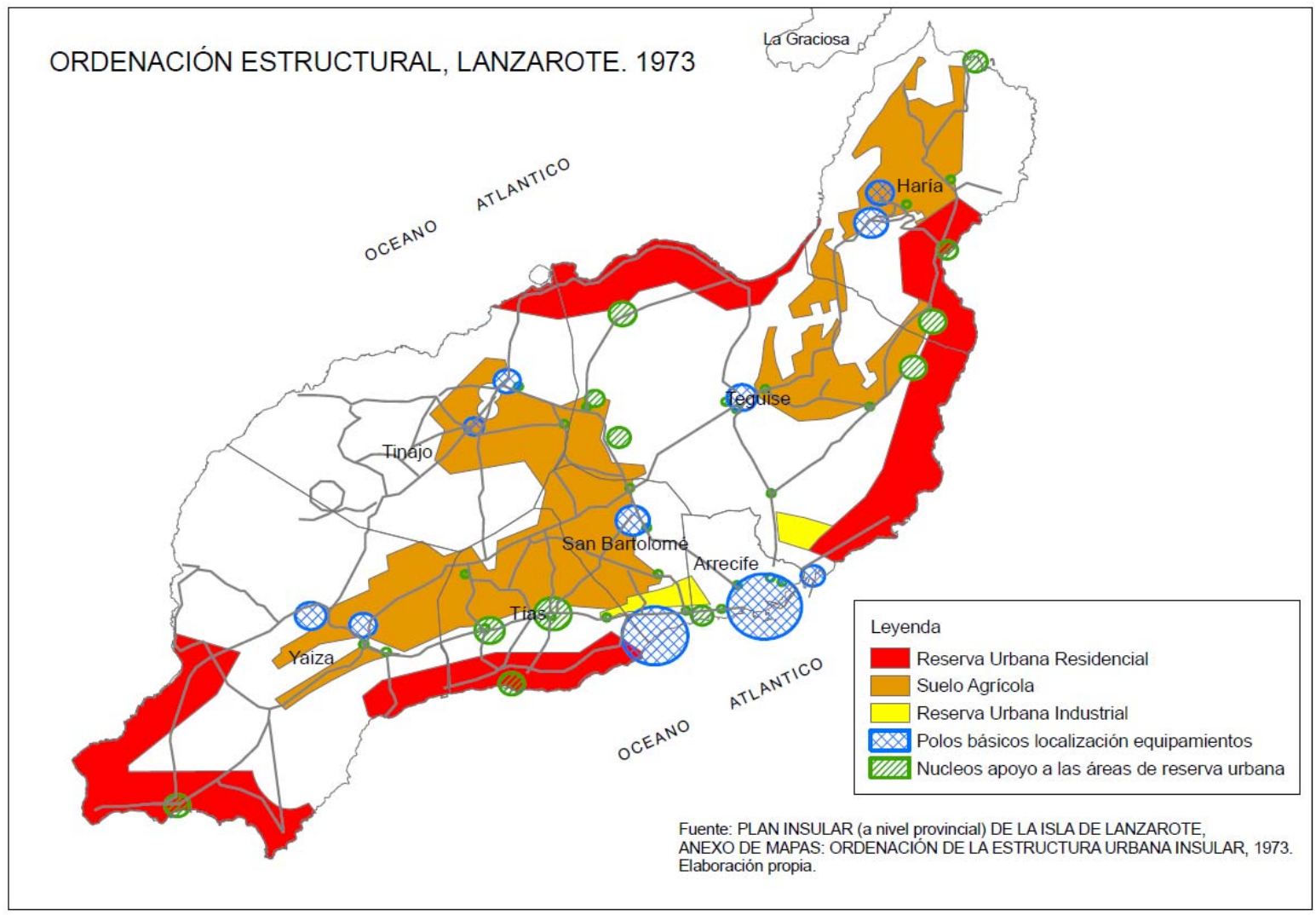


Lanzarote hasta el año 1973 era la isla que contaba con menos urbanizaciones, con un tamaño medio de urbanización aproximado al de Gran Canaria (Gaviria, 1971, pp. 302), pero estaba en una situación de peligro importante que ya por esta época se sospechaba.

Tabla 9. Planeamiento municipal y parcial vigente al final del periodo. Lanzarote. 1987

\begin{tabular}{|l|r|r|r|r|r|r|}
\hline \multirow{2}{*}{ MUNICIPIO } & \multirow{2}{*}{$\begin{array}{l}\text { HAS. CON } \\
\text { PLANEAMIENTO }\end{array}$} & \multirow{2}{*}{$\begin{array}{l}\text { CAPACIDAD } \\
\text { CAMAS }\end{array}$} & \multicolumn{4}{|l|}{ ESTIMACIÓN PROVISIONAL \%. GRADO DE URBANIZACIÓN } \\
\cline { 5 - 8 } & & CONSOLIDADO & URBANIZADO & $\begin{array}{l}\text { PARCIALMENTE } \\
\text { URBANIZADO }\end{array}$ & $\begin{array}{l}\text { SIN } \\
\text { URBANIZAR }\end{array}$ \\
\hline ARRECIFE & 912 & 41.692 & 79 & 1 & 10 & 10 \\
\hline HARÍA & 50 & 5.000 & 20 & --- & --- & 80 \\
\hline $\begin{array}{l}\text { SAN } \\
\text { BARTOLOMÉ }\end{array}$ & 128 & 12.650 & 40 & --- & 18 & 42 \\
\hline TEGUISE & 1.498 & 126.870 & 11 & 5 & 8 & 76 \\
\hline TÍAS & 414 & 48.996 & 61 & 5 & 26 & 8 \\
\hline TINAJO & 288 & 28.000 & 9 & --- & 78 & 15 \\
\hline YAIZA & $5.204(\mathrm{PG})$ & $140.000(\mathrm{PG})$ & 4 & 2 & 2 & 92 \\
\hline LANZAROTE & 8.494 & $453.208^{*}$ & 21 & 3 & 12 & 64 \\
\hline
\end{tabular}

* Aproximadamente 250.000 camas son de carácter turístico.

Fuente: Cabildo Insular de Lanzarote. Avance del Plan Insular de Ordenación del Territorio de Lanzarote. Tomo 6. "Dictamen sobre el Planeamiento Urbanístico existente y futuro. (Elaborado por AUIA). Lanzarote: Cabildo Insular de Lanzarote, 1987 (p. 4).

3. Se produce un gran crecimiento del espacio urbanizado y de la población (Joan Cals, 1986). La planificación que se lleva a cabo, dirigida hacia la expansión turística, trae consigo el que las infraestructuras, los equipamientos y servicios necesarios se hagan a posteriori de los procesos de crecimiento de los alojamientos ${ }^{132}$, es decir, cuando ya se ha sufrido fuertes procesos de estrangulamiento (Avance del Plan Insular. Tomo 6. 1987, pp. 282), que se hacen más patentes en determinadas épocas del año a causa de la sobrecarga de población. Se urbaniza pero no se hace ciudad. "Ello ha repercutido en la degradación, principalmente, y en la congestión, después, de los núcleos tradicionales, de los recursos naturales y de la calidad de vida". Situación que se hace visible y es recogida por la clase política a finales de los años ochenta.

132 "Se produce un gran crecimiento del espacio urbanizado y de la población sin que se cree la red viaria, los nuevos espacios públicos y el equipamiento que han de acompañar el alojamiento para definir el modo de vida propio de la ciudad". Joan Cals (1986). "Turismo y Territorio: los términos de una dialéctica" (pp. 159). Cursos internacionales Benidorm. "Ecología, economía y turismo en el Mediterráneo". Ayto. de Benidorm. Universidad de Alicante. Alicante. (Pp. 153-152). 
4. Los procesos de reorganización espacial del territorio, donde se generan nuevas pautas de asentamiento, traen consigo conflictos entre las nuevas actividades turísticas y las que originariamente estaban implantadas en dicho territorio. Se da una nueva reorganización jerárquica de los núcleos, trayendo como consecuencia el desplazamiento de la sociedad local por la nueva población turística y residente. Se mezclan usos urbanos y turísticos y se integra la nueva actividad en el medio social. El poder económico y la influencia sobre la actividad política cambia de manos.

La ausencia de control fruto de la política establecida propició, en este período, la entrada de los inversores extranjeros_-"Grandes franjas de terreno situadas en primera línea de playa (<sobre la playa>) pasan a manos peninsulares y/o extranjeras", (Perdomo, M. 1987, pp. 440)—, de manera que una parte sustancial del proceso de producción de espacio turístico se encontraba ya, a finales de los setenta, bajo su control (Pera Soro. 1986, pp. $206)^{133}$. Durante 1972, el 40\% del capital existente en Canarias era extranjero. Lanzarote quedó, después de esta época, en manos del capital alemán, todo gracias a la Ley Strauss -citada anteriormente-. Se asienta en la isla lo que Gaviria (1976, pp. 334) va a denominar el neocolonialismo de uso del espacio ${ }^{134}$, o sea, la colonización del espacio por los usos turísticos como prioridad principal, en detrimento de otros sectores económicos que existían en la isla (el proceso supuso un trasvase de mano de obra desde la agricultura, la pesca y la industria hacia actividades de servicios). Al final de este período, el monocultivo del turismo es ya un hecho al que se ha llegado desde una economía de subsistencia y sin transición; Lanzarote es una zona industrial-turística en completa explotación, que ha perdido su carácter tradicional.

¿Cuáles son los requisitos para convertirse en un gran centro de atracción turística? Estos requisitos los enumera Gaviria (1974, pp. 20) y adaptados a las condiciones de la isla pueden ser los siguientes: sol y clima cálido y seco, playas, precios baratos del suelo y de alimentación, salarios bajos de la mano de obra de la construcción y de la hostelería, mínimos controles burocráticos estatales y presión fiscal hacia los Tour Operadores y agencias de viaje, poco control real de la importación y exportación de divisas y capitales, existencia de equilibrio ecológico (agua, aire, paisaje), elevada seguridad física del turista, ausencia de grandes complejos industriales, ausencia inmediata de redes importantes de

133 "El caso de Canarias, en que unas 20.000 ha. de las mejores playas están en manos de extranjeros, y en las que los españoles sólo hacen labores de arquitectura y albañilería, es un fenómeno fehaciente de la amplitud y extensión de este fenómeno". (Pera Soro. 1986, pp. 206).

134 "(...) Gran parte de lo que se consideran ingresos por turismo son en realidad ingresos por la venta del territorio español”. (M. Gaviria, 1974, pp.334). 
transporte: puertos industriales y autopistas, existencia de una infraestructura mínima: acceso, agua potable, luz eléctrica y posibilidad de inmediatez de los hoteles a la Playa.

\subsection{1.- LA OFERTA Y LA DEMANDA TURÍSTICA. 1970-1986}

\subsubsection{1.- EVOLUCIÓN DE LAS PLAZAS DE ALOJAMIENTO TURÍSTICO.}

Diferentes informes llegan a la conclusión de la dificultad de llegar a determinar con precisión el volumen total de plazas turísticas en la provincia de Las Palmas (Secretaría de Estado de Territorio. Plan de ordenación de la Oficina Turística de la Provincia de Las Palmas. 1978, pp. 209.) y en la de Tenerife. Señalan que la principal problemática radica en la cuantificación de las plazas extrahoteleras y entre las principales causas destacan las siguientes:

1. Gran abundancia de plazas extra-hoteleras no declaradas como alojamiento turístico.

2. Dificultad de determinar qué parte de las plazas no declaradas son turísticas, de uso privado, o mixtas.

3. Desconocimiento, por parte de los Ayuntamientos del volumen de plazas turísticas existentes en su término municipal.

4. Enormes disparidades de estimación entre las diferentes fuentes (...).

De ahí que, dentro de los periodos de análisis elegidos nos podamos encontrar con inexistencia de datos acerca de la oferta extrahotelera en Canarias. En las siguientes tablas se recogen las estimaciones existentes.

Tabla 10. Oferta de plazas de alojamiento turístico, según tipo. España, Canarias y Lanzarote 1970-1986

\begin{tabular}{|c|c|c|c|c|c|c|c|c|c|}
\hline \multicolumn{10}{|c|}{ ESPAÑA } \\
\hline & HOTELERA & $\begin{array}{c}\% \\
\text { sobre } \\
\text { el } \\
\text { Total }\end{array}$ & $\begin{array}{c}\text { Incremento } \\
\text { quinquenal } \\
\%\end{array}$ & $\begin{array}{l}\text { EXTRA- } \\
\text { HOTELERA }^{* *}\end{array}$ & $\begin{array}{l}\% \text { sobre } \\
\text { el Total }\end{array}$ & $\begin{array}{c}\text { Incremento } \\
\text { quinquenal } \\
\%\end{array}$ & TOTAL & $\begin{array}{c}\text { Incremento } \\
\text { quinquenal } \\
\%\end{array}$ & $\begin{array}{l}\text { Índice } \\
\text { base } 100 \\
=1970\end{array}$ \\
\hline 1970 & 465.386 & 61,89 & 100 & 286.570 & 38,11 & 100 & 751.956 & 100 & 100 \\
\hline $1975^{*}$ & 808.015 & 69,83 & 73,62 & Sin datos & sin datos & Sin datos. & 808.015 & 7,46 & 107,46 \\
\hline 1981 & 811700 & 69,93 & 0,46 & 349.057 & 30,07 & 0,00 & 1.160 .757 & 43,66 & 154,37 \\
\hline 1986 & 864.834 & 55,39 & 6,55 & 696.461 & 44,61 & 99,53 & 1.561 .295 & 34,51 & 207,63 \\
\hline
\end{tabular}

* Para 1975 no existen datos de ámbito nacional acerca del número de plazas en apartamentos turísticos (extrahotelera).

** La oferta extrahotelera está compuesta de número de plazas en camping y apartamentos turísticos.

Fuente: De 1969 a 1986: "Establecimientos hoteleros. Número de Plazas". Datos históricos; "Apartamentos y Camping". Estadísticas de Turismo, 1969-1991. Ministerio de Transporte, Turismo y Comunicaciones. IET, 1991. Elaboración propia 


\begin{tabular}{|c|c|c|c|c|c|c|c|c|c|}
\hline \multicolumn{10}{|c|}{ CANARIAS } \\
\hline AÑO & HOTELERA & $\begin{array}{c}\% \\
\text { sobre } \\
\text { el } \\
\text { Total }\end{array}$ & $\begin{array}{c}\text { Incremento } \\
\text { quinquenal } \\
\%\end{array}$ & $\begin{array}{c}\text { EXTRA- } \\
\text { HOTELERA }\end{array}$ & $\begin{array}{l}\% \text { sobre } \\
\text { el Total }\end{array}$ & $\begin{array}{c}\text { Incremento } \\
\text { quinquenal } \\
\%\end{array}$ & TOTAL & $\begin{array}{l}\text { Incremento } \\
\text { quinquenal } \\
\%\end{array}$ & $\begin{array}{l}\text { Índice } \\
\text { base } 100 \\
=1970\end{array}$ \\
\hline 1970 & 33.346 & --- & 100 & Sin datos & Sin datos & 100 & 33.346 & 100 & 100 \\
\hline 1975 & 62.328 & 43,02 & 86,82 & 82.522 & 56,98 & Sin datos & 144.820 & 334,29 & 434,29 \\
\hline 1981 & 74.184 & 34,85 & 19,08 & 138.682 & 65,15 & 68,05 & 212.866 & 46,99 & 638,36 \\
\hline 1986 & 96.126 & 37,67 & 29,58 & 159.041 & 62,33 & 14,68 & 255.167 & 19,87 & 765,21 \\
\hline
\end{tabular}

Fuente: Para 1970: "Capacidad hotelera de la Región, por islas y categoría de los establecimientos". Economía Canaria, 1969 y 1970. C.I.E.S; Para 1975: Se han tomado datos de 1976, recogidos en Cáceres Morales, E. "Génesis y desarrollo del espacio turísticos en canarias", 2002 (Pp. 35 y 40) La oferta hotelera es el computo de Gran Canaria, Tenerife, Fuerteventura y Lanzarote, y para la extrahotelera se han agregado los mismos datos territoriales sin Fuerteventura (no constan); Para 1981: Rodríguez Martín, J.R.- "El turismo en la Economía Canaria" IV Jornadas de Estudios Económicos Canarios 1985 (pp. 248); Para 1986: "Plazas Hoteleras y Extrahoteleras. 1987". Bases de datos insular y municipal. ISTAC. Elaboración propia.

Nota: Los datos sobre plazas extrahoteleras en Canarias para 1970, "son contradictorios o no existen" (C.I.E.S, 1971, pp. 37)

\begin{tabular}{|c|c|c|c|c|c|c|c|c|c|}
\hline \multicolumn{10}{|c|}{ LANZAROTE } \\
\hline AÑO & HOTELERA & $\begin{array}{c}\% \\
\text { sobre } \\
\text { el } \\
\text { Total }\end{array}$ & $\begin{array}{c}\text { Incremento } \\
\text { quinquenal } \\
\%\end{array}$ & $\begin{array}{c}\text { EXTRA- } \\
\text { HOTELERA }\end{array}$ & $\begin{array}{l}\% \text { sobre } \\
\text { el Total }\end{array}$ & $\begin{array}{c}\text { Incremento } \\
\text { quinquenal } \\
\%\end{array}$ & TOTAL & $\begin{array}{l}\text { Incremento } \\
\text { quinquenal } \\
\%\end{array}$ & $\begin{array}{l}\text { Índice } \\
\text { base } 100 \\
=1970\end{array}$ \\
\hline 1970 & 858 & 48,81 & 100 & 900 & 51,19 & 100 & 1.758 & 100 & 100 \\
\hline 1975 & 2.937 & 36,25 & 242,31 & 5.164 & 63,75 & 473,78 & 8.101 & 360,81 & 460,81 \\
\hline 1981 & 4.164 & 32,41 & 41,78 & 8.683 & 67,59 & 68,14 & 12.847 & 58,59 & 730,77 \\
\hline 1986 & 3.646 & 9,47 & $-12,44$ & 34.852 & 90,53 & 301,38 & 38.498 & 199,67 & $2.189,87$ \\
\hline
\end{tabular}

Fuente: Para 1970: "Capacidad hotelera de la Región, por islas y categoría de los establecimientos". Economía Canaria, 1969 y 1970. C.I.E.S y "Número de plazas extrahoteleras, 1970". Plan Insular de la Isla de Lanzarote, 1973. Doc. VI. Ordenación Económica y Social. Anexo 1. Síntesis información. Cuadro, № 2 (pp. 128); Para 1975: "Plazas Hoteleras. Lanzarote, 1975". Plan de Ordenación de la Oferta turística de la Isla de Lanzarote, Tomo III (pp. 390); Para 1981: "Plaza Hoteleras. Lanzarote, 1981". Plan de Ordenación de la Oferta Turística de Lanzarote, 1982. Tomo III (pp. 390), y para plaza Extrahoteleras Rodríguez Martín, J.R.- "El turismo en la Economía Canaria" IV Jornadas de Estudios Económicos Canarios". Colección Viera y Clavijo. Gobierno de Canarias. 1985 (pp. 248$) ;$ Para 1986: "Oferta de Alojamiento. Enero de 1987". Avance del Plan Insular. Tomo 5. Análisis y diagnóstico de la situación actual. Capítulo IV. "Consideraciones sobre las características y niveles de la oferta turística Lanzaroteña. Elaboración propia.

La dinámica general que presenta la isla en esta primera etapa es de rápido crecimiento en cortos periodos de tiempo. De la explotación de los datos existentes, se definen dos fases con fuerte incremento del número de plazas de alojamiento:

a.- Los periodos iniciales de explotación turística del territorio (1970-1975), que arroja cifras de crecimiento muy elevadas, del 361\%, es parte de la primera fase de "producción del espacio turístico", acompañada de una fiebre de la construcción. La explosión es considerablemente mayor en el alojamiento extrahotelero, que pasa a suponer el $64 \%$ del total de la oferta. 
El quinquenio siguiente (1975-1981) se caracteriza por una ralentización de los incrementos porcentuales de crecimiento del alojamiento con respecto al comienzo de la década.

b.- Periodo previo al comienzo de la elaboración del PIOT (aprobado en 1991), 1981-1986, "el Boom de los ochenta". Caracterizado por el crecimiento de la oferta de alojamiento en un $200 \%$ con respecto al quinquenio anterior. En este periodo se asienta definitivamente el modelo de economía turística insular. Esta explosión refleja el primer modelo de planificación señalado, de "tipo intensivo", proliferación inmobiliaria, donde los impulsos de demanda condicionan y preceden a la oferta.

Al igual que al comienzo de la década de los años setenta, esta década también definirá la oferta de alojamiento de la isla como extrahotelera sobre la hotelera cuyo peso es significativamente bajo sobre la oferta general al final de la etapa $(9,5 \%)$.

Gráfico 1. Incremento de plazas de alojamiento turístico por tipo. Lanzarote. 1970-1986 (\%)

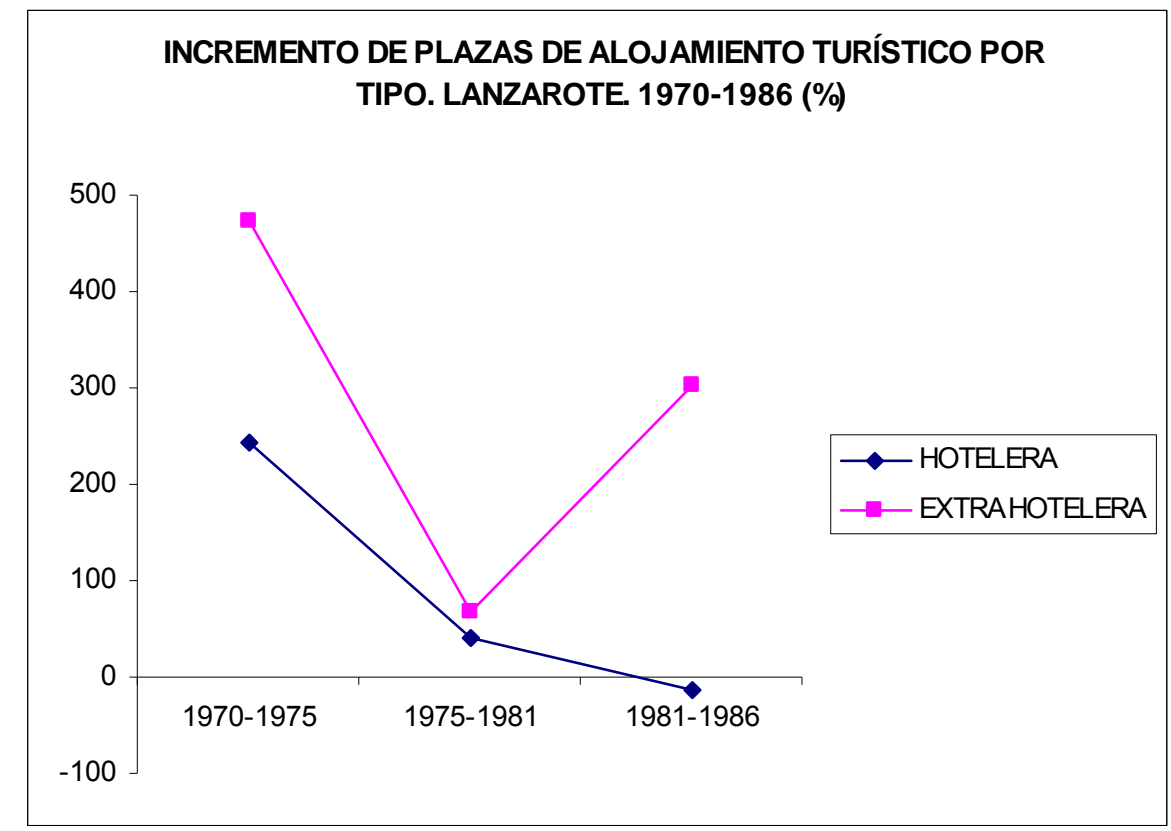

Fuente: Elaboración propia a partir de la información recogida en la Tabla 10.

Estas dos etapas señaladas para Lanzarote, distan mucho de la dinámica de la nación, cuyo incremento de las plazas de alojamiento turístico se sitúa entre el 54\% (1970-1975) y $35 \%$ (1981-1986) respectivamente, nada que ver con el vertiginoso crecimiento de la isla, que también supera el cómputo de la Comunidad Autónoma, que aunque enorme entre 1970 y 1975 (334 \%) y se reduce considerablemente entre 1981 y 1986, situándose en un 
crecimiento del $20 \%$, debido a una crisis de receptividad que sufren las islas mayores entre 1980 y 1983 y que frena el crecimiento ${ }^{135}$.

Gráfico 2. Incremento interperiodo de la oferta de alojamiento turístico. España, Canarias y Lanzarote. 1970-1986 (\%)

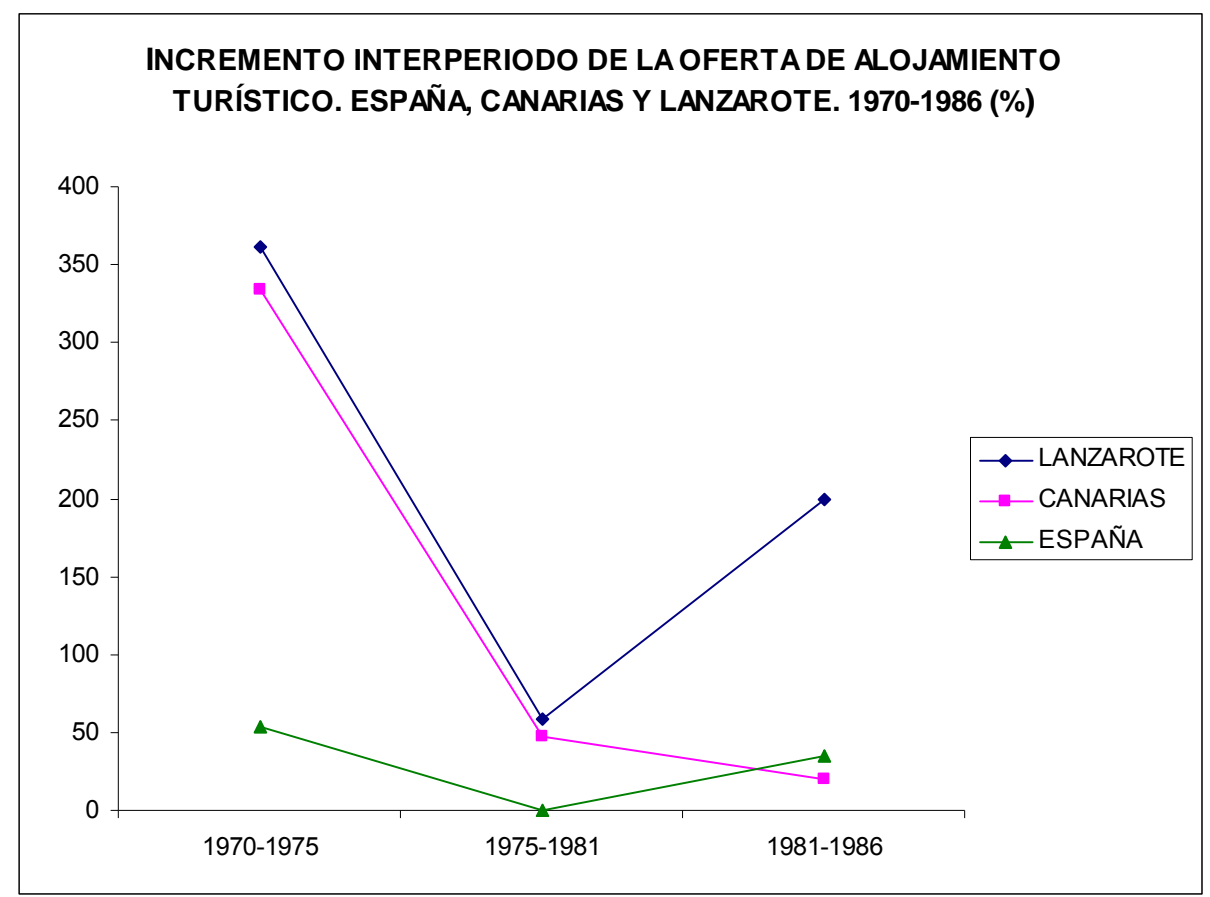

Fuente: Fuente: Elaboración propia a partir de la información recogida en la Tabla 10.

En cuanto a la dinámica en relación al tipo de establecimiento, Lanzarote sigue la misma que el resto de Canarias, donde predomina el equipamiento extrahotelero sobre el hotelero, en toda la etapa de análisis. El cómputo nacional refleja el camino opuesto, el alojamiento hotelero sobresale frente al extrahotelero, pesando el primero entre el $55 \%$ y el $70 \%$ de la oferta nacional total entre 1970 y 1986.

135 Véase Cáceres Morales, E. (2002). "Génesis y desarrollo del espacio turísticos en canarias". Gobierno de Canarias y ULPGC (pp. 38). 
Gráfico 3. Oferta de alojamiento turístico por tipo. España, Canarias y Lanzarote. 1970-1986 (\%).

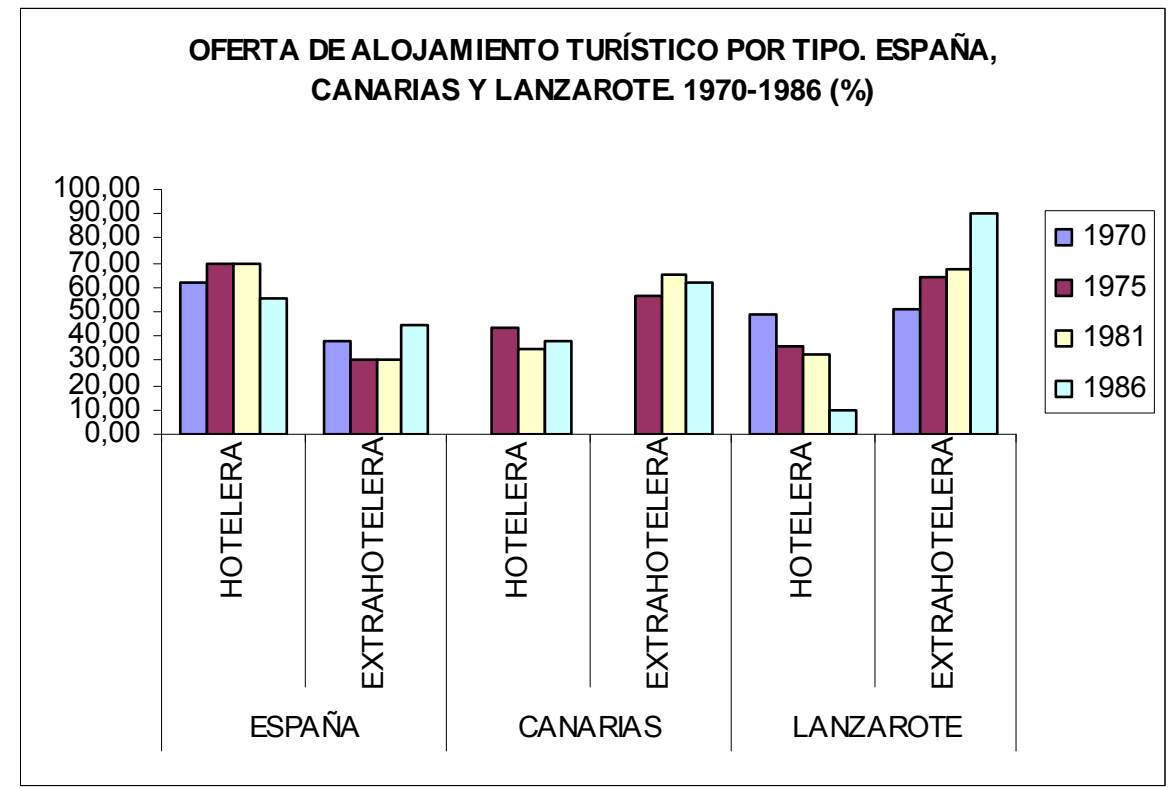

Fuente: Elaboración propia a partir de la información recogida en la Tabla 10.

La intervención en la racionalización y delimitación del desarrollo de la actividad no ocurrirá hasta la década de los años noventa, con la entra en vigor de la Ordenación del Territorio Insular (PIOT) aprobada en 1991, que marca el punto de inflexión en el crecimiento de la oferta de alojamiento y que se analiza en la segunda etapa.

\subsubsection{2.- ANÁLISIS DE LA DEMANDA TURISTICA}

Lanzarote ha desarrollado su economía turística bajo un modelo de masas, pero la afluencia de población tanto turística como residente fue desbordando las previsiones, hasta hablar de no sostenibilidad del territorio debido al fuerte crecimiento de la población (Revisión PIOT. Documento de aprobación provisional, 1999, pp. 14). Como indicador de la relación entre la población residente insular y la presión turística se ha calculado el volumen de turistas equivalentes diarios que corresponde al conjunto de pernoctaciones turísticas, tanto hoteleras como extrahoteleras. 
Tabla 11. Turistas entrados e incremento quinquenal. España, Canarias y Lanzarote. 1970-1986

\begin{tabular}{|c|c|c|c||}
\hline Año & ESPAÑA & $\begin{array}{c}\text { Incremento } \\
\text { quinquenal } \%\end{array}$ & $\begin{array}{c}\text { Índice en } \\
\text { base } \\
100=1970\end{array}$ \\
\hline \hline 1970 & 24.105 .312 & & 100 \\
\hline 1975 & 30.122 .478 & 24,96 & 124,96 \\
\hline 1981 & 40.129 .323 & 33,22 & 166,48 \\
\hline 1986 & 47.388 .793 & 18,09 & 196,59 \\
\hline
\end{tabular}

Fuente: "Viajeros procedentes del extranjero que han entrado en España" Tabla II. I. Datos históricos. Anuario Estadístico, 1993. IET; "Viajeros que pernoctaron y pernoctaciones causadas en establecimientos hoteleros, 1970, 1975, 1981, 1986". Anuario estadístico de España, 1971, 1976, 1982, 1987. INE; Elaboración propia.

\begin{tabular}{||c|c|c|c||}
\hline Año & CANARIAS & $\begin{array}{c}\text { Incremento } \\
\text { quinquenal } \%\end{array}$ & $\begin{array}{c}\text { Índice en } \\
\text { base } \\
100=1970\end{array}$ \\
\hline \hline 1970 & 792.548 & & 100 \\
\hline 1975 & 2.011 .024 & 153,74 & 253,74 \\
\hline 1981 & 2.779 .382 & 38,21 & 350,69 \\
\hline 1986 & 5.068 .242 & 85,35 & 639,49 \\
\hline
\end{tabular}

Fuente: Para 1970-1975: "Número de turistas entrados en Canarias, 1970 y 1975", en Rodríguez Martín J.R. "El turismo en la economía Canarias". IV Jornadas de Estudios Económicos Canarios, 1985 (pp. 247); Para 1981: "Número de viajeros y pernoctaciones en establecimientos hoteleros de Canarias, según nacionalidad por provincias, 1982". En Estadísticas Básicas de Canarias 1980-1985. CEDOC Para 1986: "Número de turistas entrados en Canarias, 1987. Estadísticas Básicas de Canarias, 1987-1992. ISTAC; "Viajeros entrados y pernoctaciones en establecimientos de Canarias según la categoría del establecimiento y meses, Total Canarias. 1986". Anuario Estadístico de Canarias, 1986. CEDOC; Elaboración propia.

\begin{tabular}{|c|c|c|c||}
\hline Año & LANZAROTE & $\begin{array}{c}\text { Incremento } \\
\text { quinquenal } \%\end{array}$ & $\begin{array}{c}\text { Índice en } \\
\text { base } \\
100=1970\end{array}$ \\
\hline \hline 1970 & 26.812 & & 100 \\
\hline 1975 & 85.152 & 217,59 & 317,59 \\
\hline 1981 & 187.661 & 120,38 & 699,91 \\
\hline 1986 & 468.331 & 149,56 & 1746,72 \\
\hline
\end{tabular}

Fuente: Para 1970: "Número de turistas entrados, Lanzarote, 1970. Cabildo Insular de Lanzarote. Avance del PIOT, 1987. Análisis y Diagnóstico de la situación actual. Tomo 4. Área Económica. Informe Área Socioeconómica, Documento 1. Cuadro 2.1. (pp. 17); Para 1975: "Número de turistas entrados, Lanzarote, 1975. Cabildo Insular de Lanzarote. Avance del PIOT, 1987. Análisis y Diagnóstico de la situación actual. Tomo 4. Área Económica. Informe Área Socioeconómica, Documento 1. Cuadro 2.1. (pp. 17); Para 1981: "Número de turistas entrados, Lanzarote, 1981. Cabildo Insular de Lanzarote Avance del PIOT, 1987. Análisis y Diagnóstico de la situación actual. Tomo 4. Área Económica. Informe Área Socioeconómica, Documento 1. Cuadro 2.1. (pp. 17); Para 1986: "Número de turistas entrados, Lanzarote, 1981. Cabildo Insular de Lanzarote. Avance del PIOT, 1987. Análisis y Diagnóstico de la situación actual. Tomo 4. Área Económica. Informe Área Socioeconómica, Documento 1. Cuadro 2.1. (pp. 17); Elaboración propia a partir de la tabla anterior.

Las décadas setenta y ochenta son de fuerte demanda turística, se produce una explosión de visitantes que no dejará de crecer. Este incremento de la población turista se ralentiza entre 1975-1981 derivado de la crisis energética de 1974, a partir de la cual la isla ya se ha 
consagrado como destino de masas. Así, los crecimientos se mantienen muy por encima del $120 \%$ durante todo este período (1970-1986), dinámica ésta que dista mucho de la observada en el país y en la comunidad autónoma. Canarias, aunque presenta incrementos elevados de la afluencia turística en la década del setenta, el resto del periodo su tendencia es bajista (por debajo del $40 \%$ de crecimiento) ${ }^{136}$. Esta tendencia de la Comunidad Autónoma es similar a la de la Nación. España no sobrepasa el 33\% de crecimiento de la demanda turística a lo largo del periodo.

Gráfico 4. Incremento de la demanda turística. España, Canarias y Lanzarote. 1970-1986 (\%)

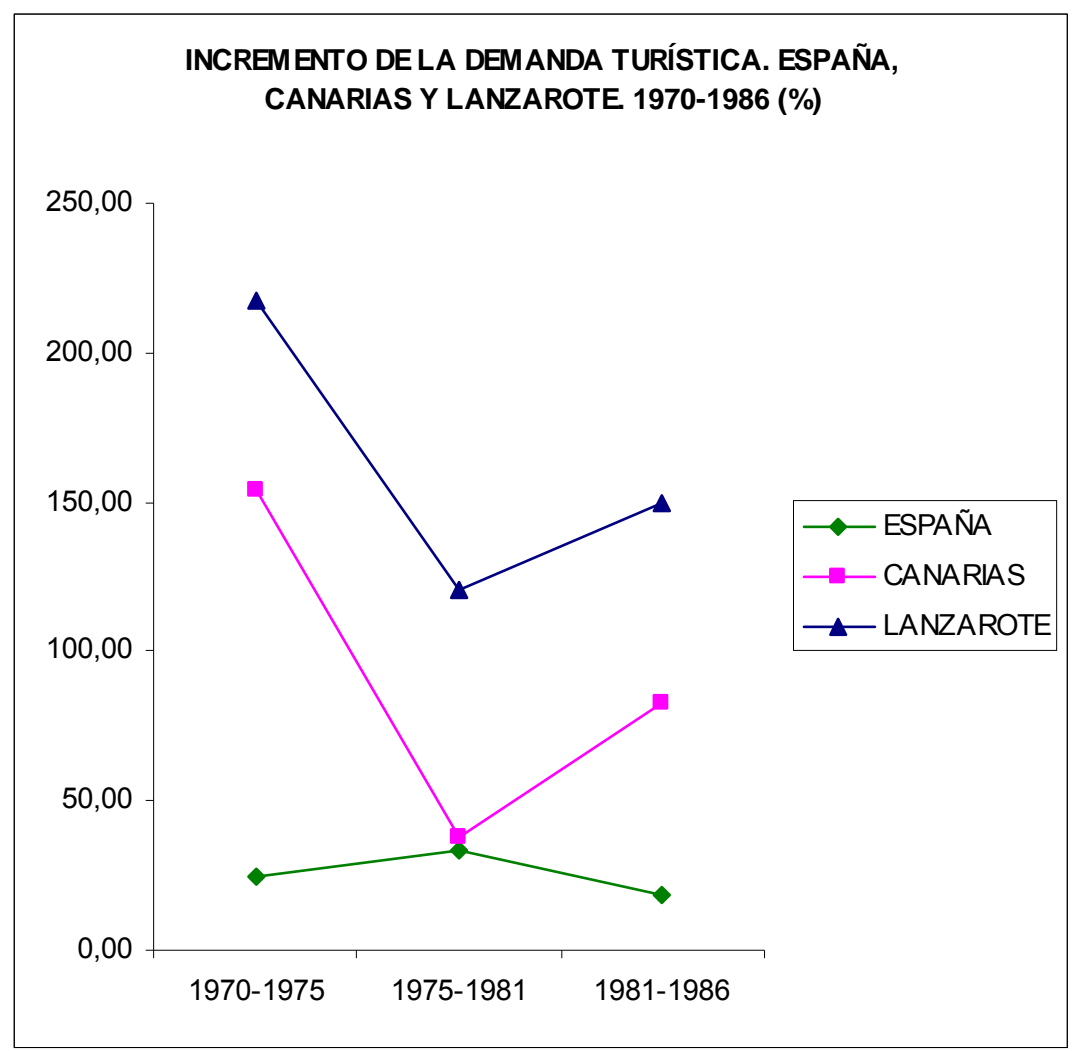

Fuente: Avance PIOT, 1987, ISTAC, IET e INE. Elaboración propia.

La caída en el crecimiento porcentual de la afluencia turística a Lanzarote llegará justo después, aunque ya se observa un decremento del crecimiento a final de los años ochenta, el cambio se advierte al comienzo de la siguiente década.

Estas variaciones de la afluencia inciden en dos, ratios, por un lado en el ratio turistas/residentes (t/r) y por otro lado en el ratio turistas/plazas (t/p).

\footnotetext{
136 Derivado de una crisis de receptividad que sufre Canarias entre 1980 y 1983 (Cáceres Morales, E., 2002, pp. 37), que no toca en igual medida a Lanzarote.
} 
Para el cálculo del primer indicador $(\mathrm{t} / \mathrm{r})$, es necesario estimar el volumen de turistas equivalentes diarios que corresponde al conjunto de pernoctaciones turísticas, tanto hoteleras como extrahoteleras.

Los datos existentes para este periodo (1970-1986) se refieren a estancias medias en establecimientos hoteleros, no ofreciendo estimaciones para el extrahotelero. Ésta última no existe hasta el año 2001 (INE).

Para estimar las pernoctaciones del periodo indicado, dado que no existen datos directos, se ha calculado la relación en la estancia media entre el turista alojado en el establecimiento hotelero y el alojado en el establecimiento extrahotelero, tal y como se aprecia en el Cuadro siguiente para 2001 y 2006 (INE), apreciándose que la diferencia en las cifras proporcionadas es constante: $150 \%$ a nivel de España, $20 \%$ a nivel de Canarias y $32 \%$ a nivel insular para Lanzarote. Estas diferencias son las que aplicaremos a nuestros cálculos de la estancia media extrahotelera en el periodo (1970-1986).

Tabla 12. Estancia media en establecimientos hoteleros. España, Canarias y Lanzarote. 20012006

\begin{tabular}{|c|c|c|c|c|c|c|c|c|c|}
\hline & \multicolumn{3}{|l|}{ ESPAÑA } & \multicolumn{3}{|l|}{ CANARIAS } & \multicolumn{3}{|c|}{ LANZAROTE } \\
\hline Año & Tipo & Días & $\begin{array}{c}\text { Variación } \\
(\%)\end{array}$ & Tipo & Días & $\begin{array}{c}\text { Variación } \\
(\%)\end{array}$ & Tipo & Días & $\begin{array}{c}\text { Variación } \\
(\%)\end{array}$ \\
\hline \multirow{2}{*}{2001} & Hotelera & 3,8 & \multirow{2}{*}{150} & Hotelera & 7,8 & \multirow{2}{*}{20} & Hotelera & 7,3 & \multirow{2}{*}{---} \\
\hline & Extrahotelera & 9,5 & & Extrahotelera & 9,4 & & Extrahotelera & --- & \\
\hline \multirow{2}{*}{2006} & Hotelera & 3,3 & \multirow{2}{*}{150} & Hotelera & 6,9 & \multirow{2}{*}{20} & Hotelera & 6,6 & \multirow{2}{*}{32} \\
\hline & Extrahotelera & 8,1 & & Extrahotelera & 8,3 & & Extrahotelera & 8,7 & \\
\hline
\end{tabular}

Fuente: "Estancia media de los viajeros por zonas, Comunidades Autónomas y total Nacional, 2001" y "Estancia media de los viajeros por Comunidades Autónomas y total Nacional, 2006". Encuesta de ocupación hotelera, 2001 y 2006 . INE; "Estancia media de los viajeros en apartamentos, por Comunidades Autónomas y total Nacional. 2001" y "Estancia media de los viajeros en apartamentos, por zonas, Comunidades Autónomas y total Nacional. 2006". Encuesta de ocupación de apartamentos turísticos, 2001 y 2006. INE; Elaboración propia. 
Tabla 13. Número de viajeros-turistas equivalentes al día. España. 1970-1986

\begin{tabular}{|c|c|c|c|c|c|c|c|c|c||}
\hline $\mathbf{A n ̃ o}$ & Viajeros & $\begin{array}{c}\text { Viajeros que } \\
\text { Pernoctan en } \\
\text { Hoteles }\end{array}$ & $\begin{array}{c}\text { Viajeros que No } \\
\text { Pernoctan en } \\
\left.\text { Hoteles }{ }^{*}\right)\end{array}$ & $\begin{array}{c}\text { Pernoctación } \\
\text { Hotelera }\end{array}$ & $\begin{array}{c}\text { Estancia } \\
\text { media } \\
\text { Hotelera } \\
(1)\end{array}$ & $\begin{array}{c}\text { Estancia } \\
\text { media } \\
\text { ExtraHotelera } \\
(2)\end{array}$ & $\begin{array}{c}\text { Pernoctación } \\
\text { ExtraHotel } \\
(3)\end{array}$ & $\begin{array}{c}\text { Pernoctaciones } \\
\text { Totales }(H+E x h)\end{array}$ & $\begin{array}{c}\text { Turistas } \\
\text { equivalentes al } \\
\text { día }\end{array}$ \\
\hline \hline $\mathbf{1 9 7 0}$ & $\mathbf{2 4 . 1 0 5 . 3 1 2}$ & 15.472 .483 & 8.632 .829 & 69.503 .842 & 4,5 & 11,3 & 97.550 .968 & 167.054 .810 & $\mathbf{4 5 7 . 6 8 4}$ \\
\hline $\mathbf{1 9 7 5}$ & $\mathbf{3 0 . 1 2 2 . 4 7 8}$ & 25.738 .665 & 4.383 .813 & 103.171 .036 & 4,0 & 10,0 & 43.930 .263 & 147.101 .299 & $\mathbf{4 0 3 . 0 1 7}$ \\
\hline $\mathbf{1 9 8 1}$ & $\mathbf{4 0 . 1 2 9 . 3 2 3}$ & 25.593 .135 & 14.536 .188 & 111.637 .758 & 7,7 & 19,2 & 279.094 .395 & 390.732 .153 & $\mathbf{1 . 0 7 0 . 4 9 9}$ \\
\hline $\mathbf{1 9 8 6}$ & $\mathbf{4 7 . 3 8 8 . 7 9 3}$ & 29.911 .551 & 17.477 .242 & 129.514 .100 & 7,4 & 18,5 & 323.785 .250 & 453.299 .350 & $\mathbf{1 . 2 4 1 . 9 1 6}$ \\
\hline
\end{tabular}

$\left({ }^{*}\right)$ Viajeros que no pernoctan en hoteles: diferencia entre los Viajeros totales y los viajeros que pernoctan en hoteles.

(1) Estancia media hotelera: cociente entre el número de pernoctaciones causadas en hoteles y viajeros que pernoctan en hoteles.

(2) Estancia media extrahotelera: estancia media hotelera incrementada un 150\%, según las estimaciones de 2001 del INE.

(3) Pernoctaciones extrahoteleras: producto de la estancia media extrahotelera por los viajeros que no pernoctan en hoteles

Fuente: De 1970 a 1986: "Viajeros procedentes del extranjero que han entrado en España" Tabla II.I. Datos históricos. Anuario Estadístico, 1993. IET; "Viajeros que pernoctaron y pernoctaciones causadas en establecimientos hoteleros, 1970, 1975, 1981, 1986". Anuario estadístico de España, 1971, 1976, 1982, 1987. INE;

Tabla 14. Número de viajeros-turistas equivalentes al día. Canarias. 1970-1986

\begin{tabular}{|c|c|c|c|c|c|c|c|c|c||}
\hline Año & Viajeros & $\begin{array}{c}\text { Viajeros que } \\
\text { Pernoctan en } \\
\text { Hoteles }\end{array}$ & $\begin{array}{c}\text { Viajeros que No } \\
\text { Pernoctan en } \\
\text { Hoteles }\end{array}$ & $\begin{array}{c}\text { Pernoctación } \\
\text { Hotelera }\end{array}$ & $\begin{array}{c}\text { Estancia } \\
\text { media } \\
\text { Hotelera (1) }\end{array}$ & $\begin{array}{c}\text { Estancia media } \\
\text { ExtraHotelera } \\
(2)\end{array}$ & $\begin{array}{c}\text { Pernoctación } \\
\text { ExtraHotel } \\
(3)\end{array}$ & $\begin{array}{c}\text { Pernoctaciones } \\
\text { Totales (H+Exh) }\end{array}$ & $\begin{array}{c}\text { Turistas } \\
\text { equivalentes al } \\
\text { día }\end{array}$ \\
\hline $\mathbf{1 9 7 0}$ & $\mathbf{7 9 2 . 5 4 8}$ & --- & --- & -- & 5,1 & 6,1 & -- & 7.195 .910 & $\mathbf{1 9 . 7 1 5}$ \\
\hline $\mathbf{1 9 7 5}$ & 2.011 .024 & -- & --- & -- & -- & -- & -- & -- & -- \\
\hline $\mathbf{1 9 8 1}$ & $\mathbf{2 . 7 7 9 . 3 8 2}$ & 1.801 .784 & 977.598 & 15.587 .375 & 8,7 & 10,4 & 10.148 .733 & 25.736 .108 & $\mathbf{7 0 . 5 1 0}$ \\
\hline $\mathbf{1 9 8 6}$ & 5.068 .242 & 180.038 & 4.888 .204 & 1.689 .247 & 9,4 & 11,3 & 55.037 .607 & 56.726 .854 & $\mathbf{1 5 5 . 4 1 6}$ \\
\hline
\end{tabular}

(1) Estancia media hotelera de 1981 a 1996: cociente entre el número de pernoctaciones causadas en hoteles y viajeros que pernoctan en hoteles.

(2) Estancia media extrahotelera: estancia media hotelera incrementada un 150\%, según las estimaciones de 2001 del INE.

(3) Pernoctaciones extrahoteleras: producto de la estancia media extrahotelera por los viajeros que no pernoctan en hoteles.

Fuente: Para 1970-1975: "Número de turistas entrados en Canarias, 1970 y 1975", en Rodríguez Martín J.R. "El turismo en la economía Canarias". IV Jornadas de Estudios Económicos Canarios, 1985 (pp. 247); "Viajeros que pernoctaron y pernoctaciones causadas, por provincias. Las Palmas y Santa Cruz de Tenerife, 1970". Anuario estadístico de España, 1971, INE; No existen otros registros para 1975. Para 1981: "Número de viajeros y pernoctaciones en establecimientos hoteleros de Canarias, según nacionalidad por provincias, 1982" (Estancia media=pernoctaciones/viajeros). En Estadísticas Básicas de Canarias 1980-1985. CEDOC Para 1986: "Número de turistas entrados en Canarias, 1987. Estadísticas Básicas de Canarias, 1987-1992. ISTAC; "Viajeros entrados y pernoctaciones en establecimientos de Canarias según la categoría del establecimiento y meses, Total Canarias. 1986". Anuario Estadístico de Canarias, 1986. CEDOC; 
Tabla 15. Número de viajeros-turistas equivalentes al día. Lanzarote. 1970-1986

\begin{tabular}{|c|c|c|c|c|c|c|c|c|c||}
\hline Año & Viajeros & $\begin{array}{c}\text { Viajeros que } \\
\text { Pernoctan } \\
\text { en Hoteles }\end{array}$ & $\begin{array}{c}\text { Viajeros que } \\
\text { No Pernoctan } \\
\text { en Hoteles }\end{array}$ & $\begin{array}{c}\text { Pernoctación } \\
\text { Hotelera }\end{array}$ & $\begin{array}{c}\text { Estancia media } \\
\text { Hotelera (1) }\end{array}$ & $\begin{array}{c}\text { Estancia Media } \\
\text { ExtraHotelera (2) }\end{array}$ & $\begin{array}{c}\text { Pernoctación. } \\
\text { ExtraHotel } \\
(3)\end{array}$ & $\begin{array}{c}\text { Pernoctaciones. } \\
\text { Totales (H+Exh) }\end{array}$ & $\begin{array}{c}\text { Turistas } \\
\text { equivalentes } \\
\text { al día }\end{array}$ \\
\hline $\mathbf{1 9 7 0}$ & 26.812 & 13.151 & 13.661 & 67.071 & 5,1 & 6,7 & 91.965 & 159.036 & $\mathbf{4 3 6}$ \\
\hline $\mathbf{1 9 7 5}$ & 85.152 & --- & --- & --- & 5,1 & 6,7 & --- & -- & -- \\
\hline $\mathbf{1 9 8 1}$ & 187.661 & 25.282 & 162.379 & 202.253 & 8,0 & 10,6 & 1.714 .726 & 1.916 .979 & $\mathbf{5 . 2 5 2}$ \\
\hline $\mathbf{1 9 8 6}$ \\
$\mathbf{( * )}$
\end{tabular}

(1) Al no existir datos sobre viajeros que pernoctan en 1970 y 1981, se ha tomado las pernoctaciones hoteleras y no hoteleras, y se ha calculado a partir de esos datos (viajeros en hoteles= pernoctaciones hoteleras en relación a la estancia media hotelera).

(2) Estancia media extrahotelera: estancia media hotelera incrementada un 32\%, según las estimaciones de 2006 del INE.

(3) Pernoctaciones extrahotelera: producto de la estancia media extrahotelera por los viajeros que no pernoctan en hoteles.

(*) Para 1986 no se registran datos sobre el número de pernoctaciones, por que se han calculado a partir del porcentaje de pernoctaciones en 1985 por tipo de establecimiento, recogido en Cabildo Insular de Lanzarote, Avance PIOT, 1987, Tomo 5. Cap. IV. "3.1. La oferta turística en Lanzarote", pp. 21 (Pernoctaciones Hoteleras= 8,6\% y Pernoctaciones Extrahoteleras = 91,4\%). Aplicándose el siguiente cálculo: Viajeros= [ (\%pernoctaciones en Hotel / Estancia Media Hot $)+(\%$ Pernoctaciones Extrahoteleras / Estancia Media ExtraHotelera)] ${ }^{*}$ pernoctaciones.

Fuente: Para 1970: "Número de turistas entrados, Lanzarote, 1970. Cabildo Insular de Lanzarote, Avance del PIOT, 1987. Análisis y Diagnóstico de la situación actual. Tomo 4. Área Económica. Informe Área Socioeconómica, Documento 1. Cuadro 2.1. (pp. 17); "Número de pernoctaciones o estancias, 1969". Plan Insular de Ordenación de la isla de Lanzarote, 1973. Documento IV Ordenación económica y social (pp. 187); Para 1975: "Número de turistas entrados, Lanzarote, 1975. Cabildo Insular de Lanzarote, Avance del PIOT, 1987. Análisis y Diagnóstico de la situación actual. Tomo 4. Área Económica. Informe Área Socioeconómica, Documento 1. Cuadro 2.1. (pp. 17); No existen otros datos para ese año.

Para 1981: "Número de turistas entrados, Lanzarote, 1981. Cabildo Insular de Lanzarote, Avance del PIOT, 1987. Análisis y Diagnóstico de la situación actual. Tomo 4. Área Económica. Informe Área Socioeconómica, Documento 1. Cuadro 2.1. (pp. 17); "Pernoctaciones en establecimientos hoteleros, 1981". Secretaria de Estado de Turismo. Plan Insular de Ordenación de la Oferta Turística de la isla de Lanzarote, 1982. Tomo III. Información y análisis. 6.4 Demanda turística. (pp. 426-427).

Para 1986: "Número de turistas entrados, Lanzarote, 1981. Cabildo Insular de Lanzarote, Avance del PIOT, 1987. Análisis y Diagnóstico de la situación actual. Tomo 4. Área Económica. Informe Área Socioeconómica, Documento 1. Cuadro 2.1. (pp. 17); "Estancia media en establecimientos hoteleros de Lanzarote, 1986". Cabildo Insular de Lanzarote, Avance PIOT, Documento 4: Economía. "Área socioeconómica. Documento №1: El turismo. Punto 5. Conclusiones" (pp. 52);

Una vez estimados los turistas equivalentes al día, se ha podido elaborar el indicador que pone en relación el volumen de población residente con la estimación del volumen de turistas equivalentes diarios, y observar su evolución, que se refleja en la siguiente tabla y que comentaremos en las próximas líneas: 
Tabla 16. Turistas entrados y relación turistas/residentes (t/r). España, Canarias y Lanzarote. 1970-1986

\begin{tabular}{||c|r|r|r|r|r||}
\hline \hline Año & \multicolumn{1}{|c|}{ ESPAÑA } & $\begin{array}{c}\text { Incremento } \\
\text { quinquenal (\%) }\end{array}$ & $\begin{array}{c}\text { Índice en base } \\
100=1970\end{array}$ & $\begin{array}{c}\text { Turistas } \\
\text { equivalentes al día }\end{array}$ & Ratio (t/r) \\
\hline \hline 1970 & 24.105 .312 & & 100 & 457.684 & 13,44 \\
\hline 1975 & 30.122 .478 & 24,96 & 124,96 & 403.017 & 11,29 \\
\hline 1981 & 40.129 .323 & 33,22 & 166,48 & 1.070 .499 & 28,41 \\
\hline 1986 & 47.388 .793 & 18,09 & 196,59 & 1.241 .916 & 32,28 \\
\hline
\end{tabular}

\begin{tabular}{||r|r|r|r|r|r||}
\hline \hline Año & CANARIAS & $\begin{array}{c}\text { Incremento } \\
\text { quinquenal (\%) }\end{array}$ & $\begin{array}{c}\text { Índice en base } \\
100=1970\end{array}$ & $\begin{array}{c}\text { Turistas } \\
\text { equivalentes al día }\end{array}$ & Ratio (t/r) \\
\hline \hline 1970 & 792.548 & & 100 & 19.715 & 17,52 \\
\hline 1975 & 2.011 .024 & 153,74 & 253,74 & --- & --- \\
\hline 1981 & 2.779 .382 & 38,21 & 350,69 & 70.510 & 51,55 \\
\hline 1986 & 5.068 .242 & 85,35 & 639,49 & 155.416 & 106,74 \\
\hline
\end{tabular}

\begin{tabular}{||c|r|r|r|r|r||}
\hline \hline Año & LANZAROTE & $\begin{array}{c}\text { Incremento } \\
\text { quinquenal (\%) }\end{array}$ & $\begin{array}{c}\text { Índice en base } \\
100=1970\end{array}$ & $\begin{array}{c}\text { Turistas } \\
\text { equivalentes al día }\end{array}$ & Ratio (t/r) \\
\hline \hline 1970 & 26.812 & & 100 & 436 & 10,60 \\
\hline 1975 & 85.152 & 217,59 & 317,59 & --- & -- \\
\hline 1981 & 187.661 & 120,38 & 699,91 & 5.252 & 103,55 \\
\hline 1986 & 468.331 & 149,56 & $1.746,72$ & 16.493 & 295,76 \\
\hline
\end{tabular}

Fuente: Ratio (t/r) aparece de la relación entre el número de turistas equivalentes diarios y la población de derecho (residentes) en tantos por mil. Elaboración propia a partir de la tabla anterior.

Los documentos elaborados a finales de la década del noventa, acusan el crecimiento poblacional impulsado por el turismo como un elemento de no sostenibilidad insular, presentando un ratio que pone en relación los turistas presentas en la isla a diario con la población residente, denominado equilibrio poblacional. Se ha calculado la evolución de dicho ratio siguiendo el modelo del planificador, lo que arroja una curva de fuerte pendiente puesto que el peso del turista sobre la población residente no deja de crecer vertiginosamente entre 1970 y 1986, lógico en esta etapa de despegue y consolidación de la actividad. Supuso, por tanto, pasar de una relación de casi 11 turistas por mil residentes $(10,6)$ en 1970, a, aproximadamente, unos 300 turistas $(295,76)$ en 1986. 
Gráfico 5. Evolución de la relación turistas/residentes (t/r). Lanzarote. 1970-1986 (\%)

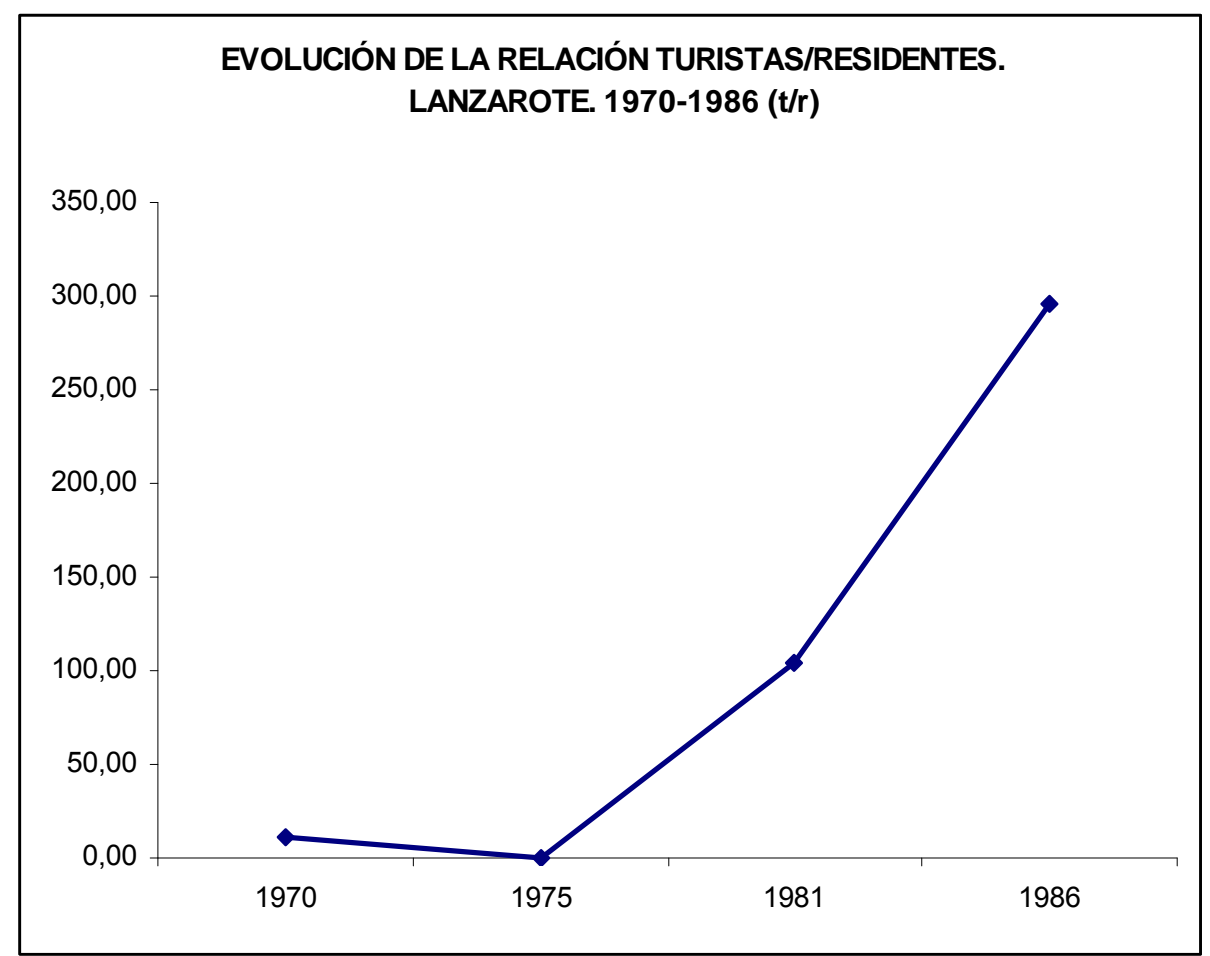

Fuente. Elaboración propia a partir de la infamación recogida en la Tabla 16.

Sin embargo, no se estima cuál sería el ratio que se acerque a un estado de sostenibilidad insular, ¿cuánta población puede soportar este territorio diariamente?, así como, tampoco, se contemplan propuestas de intervención encaminadas a su regulación. Cálculos estos que sobrepasan los objetivos de este estudio.

En relación a la dinámica que presenta este ratio ( $t / r)$ en Canarias, es muy inferior a la de Lanzarote, puesto que, mientras la Comunidad Autónoma entra en la década de los años ochenta con una relación de casi 56 turistas equivalente al día por mil residentes (1981), Lanzarote se sitúa en casi 104 , lo que supone una diferencia del $85,7 \%$, enorme, con respecto a Canarias. En el cómputo nacional este indicador se encuentra muy por debajo del de la isla, pues sólo se contabilizan 32 turistas equivalente al día por mil residentes en 1981. 
Gráfico 6. Evolución de la relación turistas/residentes (t/r). España, Canarias y Lanzarote. 1970-1986 (\%)

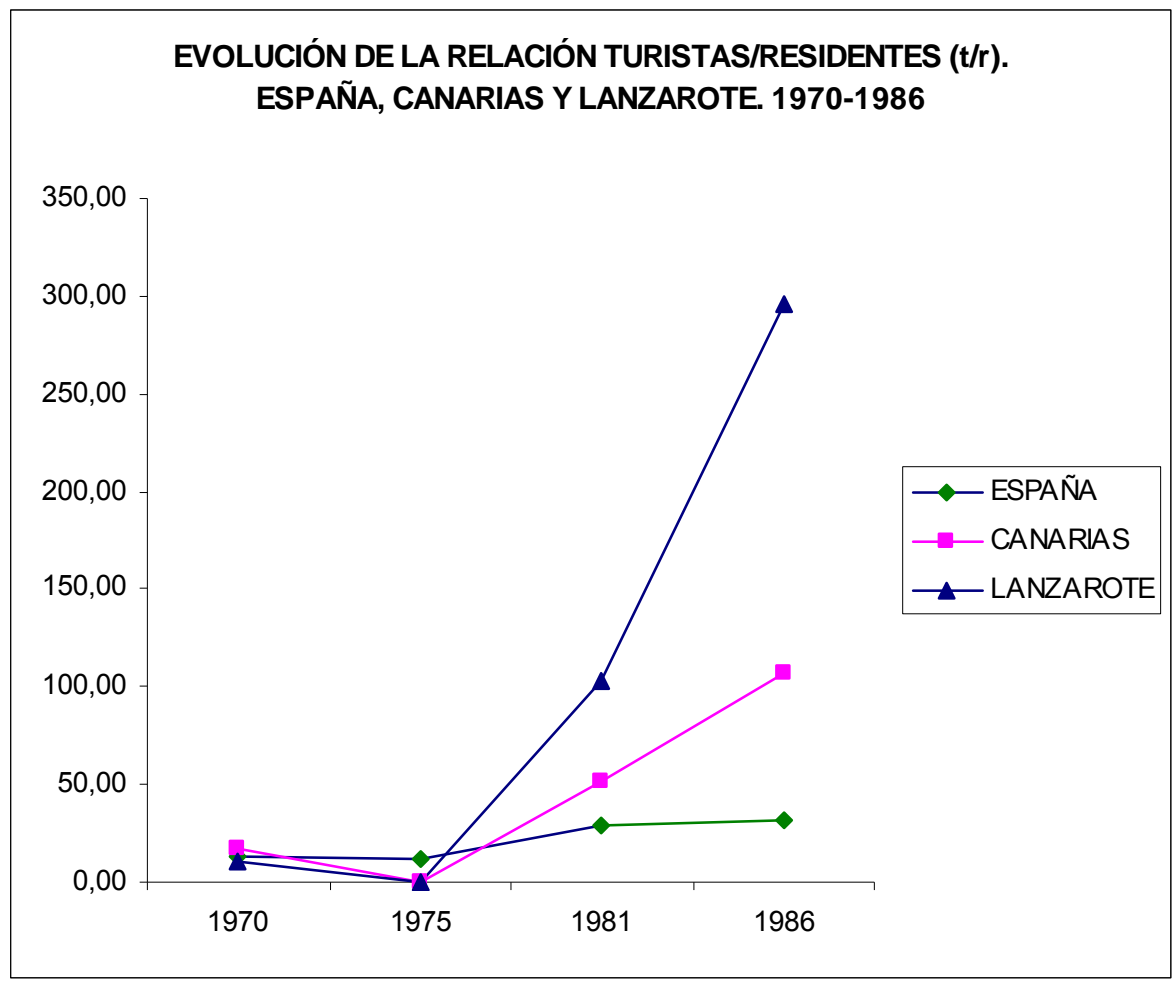

Fuente. Elaboración propia a partir de la infamación recogida en la Tabla 16.

Por otro lado, la relación entre turistas que entran en la isla y las plazas que se ofertan (ratio $t / p$ ), es muy elevada en la década de los años setenta con respecto al resto de la etapa (15 turistas por plaza), en la que se observa ciertas fluctuaciones a lo largo del tiempo pero en continuo descenso. De modo que acaba el periodo situándose en 12 turistas por plaza para 1986. Llama la atención, la caída que experimente en 1975, que se explica por el enorme incremento de plazas de alojamiento (360\%) que se ponen en oferta. Estas variaciones descendentes, durante toda la etapa, tienen razón de ser en el elevado y constante incremento de la oferta de alojamiento turístico (epígrafe 5.1.1.1.), que deriva, al final de los años ochenta, en una crisis de sobreproducción ${ }^{137}$, que afecta en el siguiente periodo de análisis.

Entre 1970 y 1986 la oferta es muy elevada en relación a la demanda.

137 Oficina del Plan Insular. Dossier de prensa (1992). "La crisis turística y el Plan Insular". Cabildo Insular de Lanzarote. (pp. 10). 
Tabla 17. Ratio turistas/plazas. España, Canarias y Lanzarote. 1970-1986

\begin{tabular}{|c|c|c|c|c|c|c|c|c|c|}
\hline & \multicolumn{3}{|c|}{ ESPAÑA } & \multicolumn{3}{|c|}{ CANARIAS } & \multicolumn{3}{|c|}{ LANZAROTE } \\
\hline Años & № Plazas & Turistas & $\begin{array}{l}\text { Ratio } \\
(t / p)\end{array}$ & $\begin{array}{l}\mathrm{N}^{0} \\
\text { Plazas }\end{array}$ & Turistas & $\begin{array}{l}\text { Ratio } \\
(t / p)\end{array}$ & $\begin{array}{l}\text { No } \\
\text { Plazas }\end{array}$ & Turistas & $\begin{array}{l}\text { Ratio } \\
\text { (t/p) }\end{array}$ \\
\hline 1970 & 751.956 & 24.105.312 & 32,1 & 33.346 & 792.548 & 23,8 & 1.758 & 26.812 & 15,3 \\
\hline 1975 & 1.157.072 & 30.122 .478 & 26,0 & 144.820 & 2.011 .024 & 13,9 & 8.101 & 85.152 & 10,5 \\
\hline 1981 & 1.160 .757 & 40.129 .323 & 34,6 & 212.866 & 2.779.382 & 13,1 & 12.847 & 187.661 & 14,6 \\
\hline 1986 & 1.561 .295 & 47.388 .793 & 30,3 & 255.167 & 5.068 .242 & 19,9 & 38.498 & 468.331 & 12,3 \\
\hline
\end{tabular}

Fuente: Elaboración propia a partir de los datos de viajeros entrados y plazas de alojamiento. Cabildo de Lanzarote, CEDOC, ISTAC, IET, INE.

En relación a los valores que arroja el ratio (t/p) autonómico y nacional, Lanzarote se mantiene por debajo de la relación turista/plazas de Canarias prácticamente durante todo el periodo, alrededor de cuatro puntos de media.

Ambas dinámicas distan mucho de España que se mantendrá muy por encima, con fluctuaciones derivadas de caídas de recepción turística en la década de los setenta, variando entre 26 y 35 turistas por plaza durante toda la etapa.

Gráfico 7. Evolución de la relación Turistas/Plazas (t/p). España, Canarias y Lanzarote, 1970-1986.

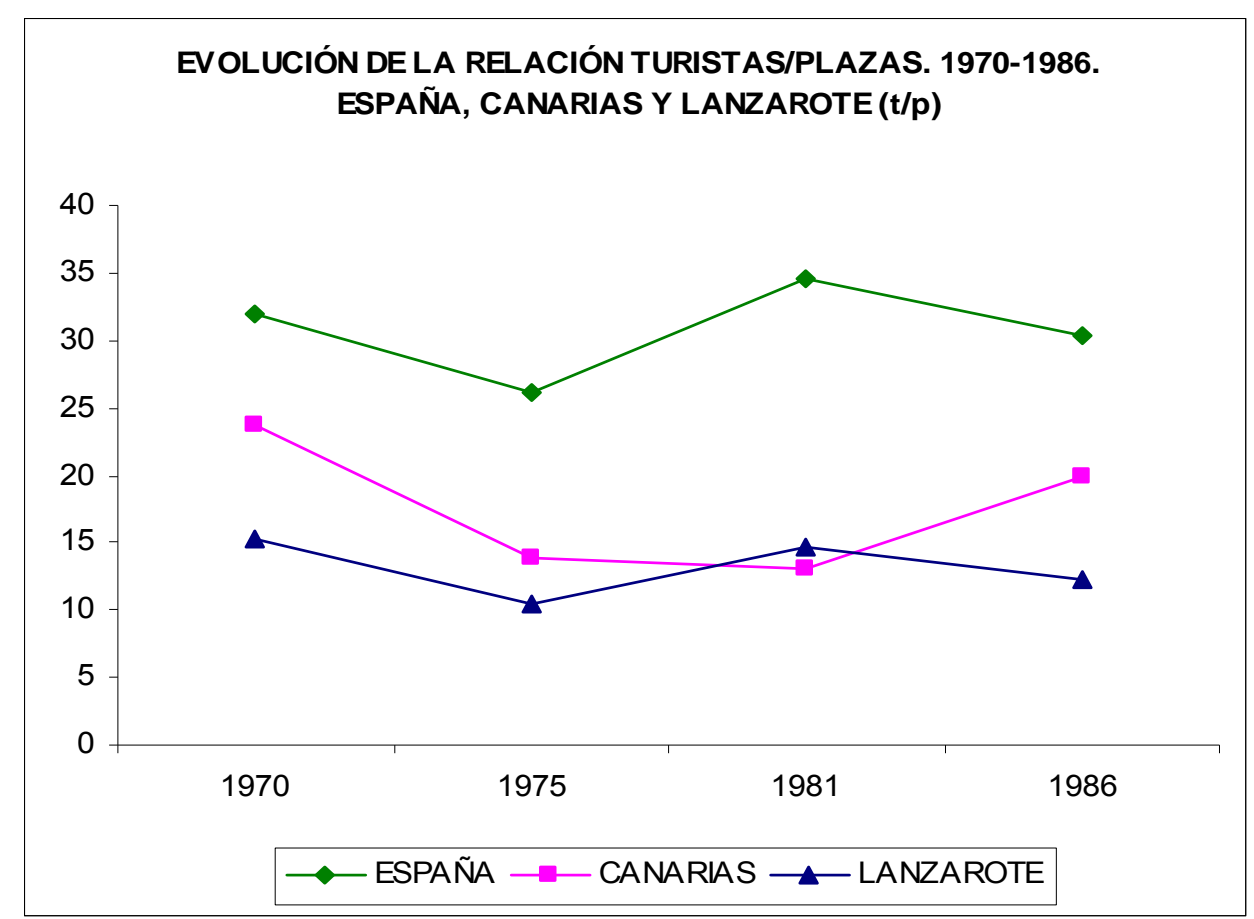

Fuente: Elaboración propia a partir de los datos de viajeros entrados y plazas de alojamiento. Cabildo de Lanzarote, CEDOC, ISTAC, IET, INE. 


\subsubsection{3.- CONCLUSIONES}

La fase de despegue y consolidación se caracteriza por rápidos y elevados crecimientos de la oferta y demanda turística de la isla en cortos periodos de tiempo, acompañado de la extensión del espacio urbano, derivado de una planificación dirigida exclusivamente a la expansión turística, sin referencias a nivel insular, que es fruto de políticas nacionales que presentan el mismo signo. Así, a modo de conclusión, señalamos lo siguiente:

1. Explosión del crecimiento de la oferta turística, a lo largo de toda la etapa, con pequeñas fluctuaciones, muy por encima de la dinámica de Canarias y España, que reducirán mucho antes sus incrementos de oferta que la isla.

Esta oferta se perfila marcada por inversión extrahotelera que irá en crescendo durante todo el periodo, frente a la hotelera que se reduce enormemente.

Gráfico 8. Incremento de la oferta y la demanda turística. Lanzarote. 1970-1986 (\%)

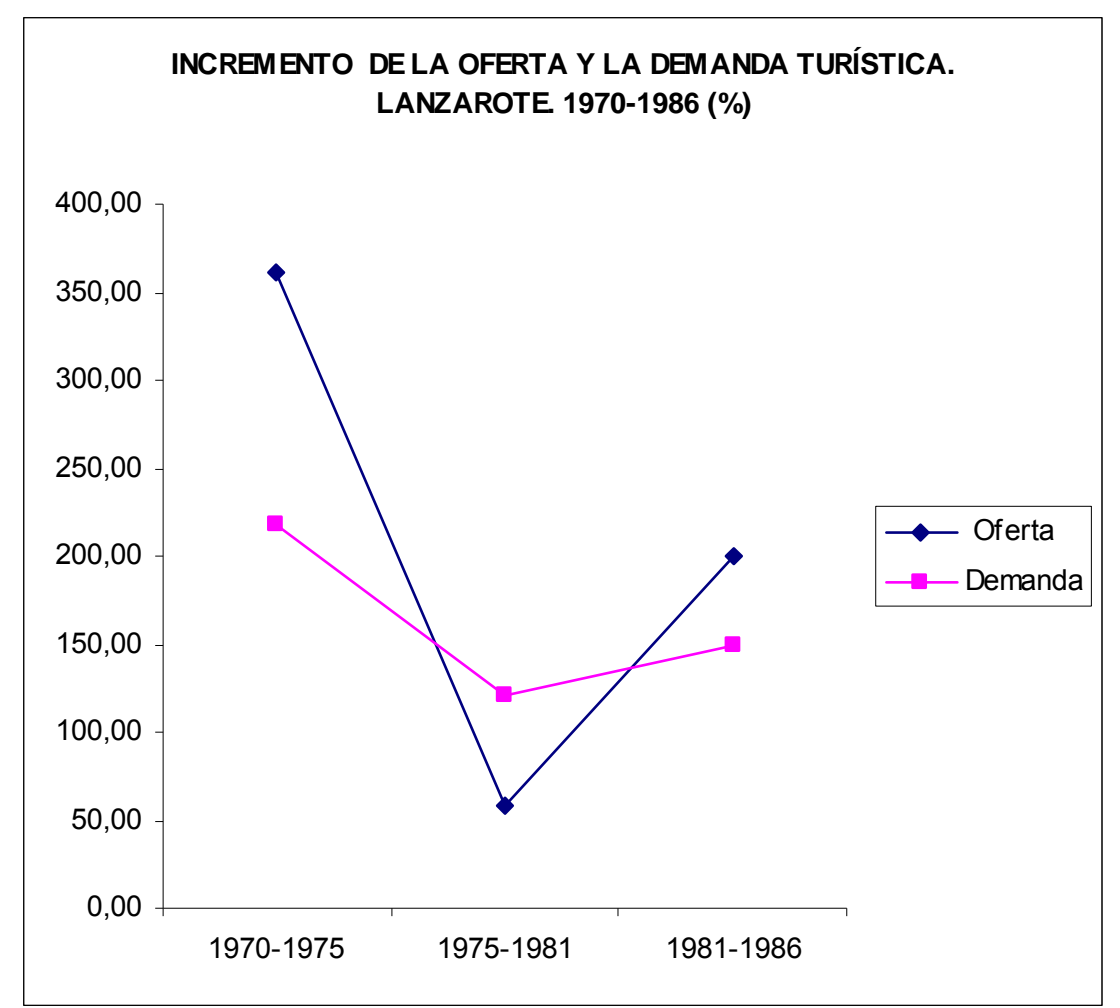

Fuente: Elaboración propia a partir de la información recogida en las Tablas 10 y 15.

2. Irrupción de una fuerte demanda turística, fluctuando su incremento en el resto del periodo, que hará que en la mitad de la etapa la demanda crezca más que la oferta. Derivando, al final de este periodo, hacia una crisis de producción a consecuencia del efecto contrario, demasiada oferta frente al volumen de la demanda de visitantes turistas. 
Gráfico 9. Evolución de la oferta y la demanda turística. Lanzarote. 1970-1986

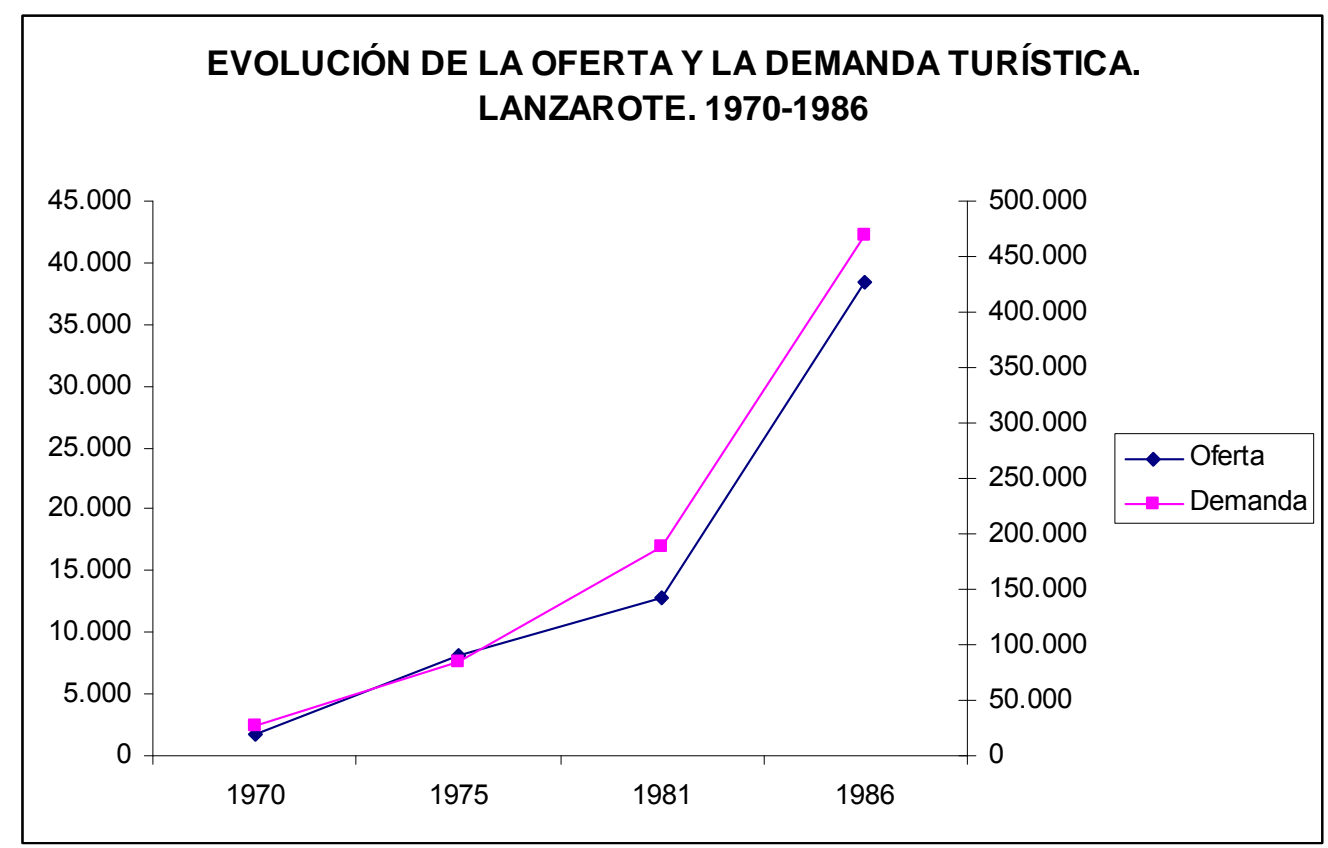

Fuente: Elaboración propia a partir de la información recogida en las Tablas 10 y 15.

3. El equilibrio poblacional en relación al volumen de turistas sobre el volumen de residentes, crece de forma muy elevada y acelerada durante toda la etapa. Casi el $30 \%$ de la población que soporta a diario la isla, en 1986, es turista. Muy por encima de Canarias.

4. El ritmo de crecimiento de la oferta es muy superior al de la demanda, por lo que la relación entre turistas que entran en la isla y las plazas de alojamiento que se ofertan, desciende a lo largo del periodo, manteniéndose por debajo de Canarias y de España.

\subsection{2.- EFECTOS SOBRE LA ESTRUCTURA DEMOGRÁFICA BÁSICA. 1970-1986}

Un primer aspecto a considerar, es la relación que existe y ha existido entre la evolución de la población de la isla y sus características básicas y la evolución de la actividad turística. En qué grado esta evolución ha venido condicionada por el turismo, se puede estudiar teniendo en cuenta la evolución comparada de España en su conjunto, sin olvidar que también en España el turismo ha sido uno de los elementos responsables de la fuerte transformación que se ha producido en el país en el periodo de estudio, y de cada uno de los municipios en los que el fenómeno turístico se produce, en distintos momentos del tiempo. 
En lo que respecta a esta investigación, también interesa llegar a conclusiones sobre cómo ha evolucionado la población autóctona (nacidos en la isla), en volumen y características básicas, frente al crecimiento demográfico total de la isla y las características básicas de la población alóctona residente, en las diferentes etapas abordadas. Para ello comenzaremos analizando de forma general la evolución demográfica de la isla y cómo ésta es afectada por la actividad turística, para luego centrarnos en el estado de la población autóctona.

Trabajaremos con los datos recogidos por las distintas estadísticas nacionales e insulares. En dicho análisis, tendremos en cuenta las modificaciones sobre los tipos de población registrada que presentan los Censos de Población y Viviendas y los Padrones Municipales.

\subsubsection{1.- EVOLUCIÓN DE LA POBLACIÓN}

El turismo hoy, se puede considerar como el fenómeno que representa el mayor número de movimiento de poblaciones humanas fuera de los períodos de guerra (Crick, M. 1989, pp. 345). A ello se debe agregar, en el crecimiento del núcleo receptor, la absorción temporal o constante, de una corriente inmigratoria de trabajadores de todas clases -construcción y hostelería principalmente- que se intercalan entre las dos masas anteriores (Fernández, L. 1988, pp. 63).

La evolución demográfica del archipiélago es asombrosa en cuanto a su ritmo de crecimiento, altamente progresivo a lo largo del s. XX, propio de regiones dinámicas e industrializadas y focalizadas -como es el ejemplo de Madrid-, por tanto, de regiones con migraciones internas (PIOT, Tomo 5, pp. 2).

Tabla 18. Población total. España, Canarias y Lanzarote 1970-1986 (\%)

\begin{tabular}{||l|l|c||c|c||c|c||}
\hline Años & ESPAÑA & $\begin{array}{l}\text { Incremento } \\
\text { quinquenal (\%) }\end{array}$ & CANARIAS & $\begin{array}{l}\text { Incremento } \\
\text { quinquenal (\%) }\end{array}$ & LANZAROTE & $\begin{array}{l}\text { Incremento } \\
\text { quinquenal (\%) }\end{array}$ \\
\hline \hline 1970 & 34.117 .623 & & 1.125 .442 & & 41.146 & \\
\hline 1975 & 36.012 .702 & 5,6 & 1.303 .997 & 15,9 & 44.337 & 7,8 \\
\hline 1981 & 37.682 .355 & 4,6 & 1.367 .669 & 4,9 & 50.721 & 14,4 \\
\hline 1986 & 38.473 .418 & 2,1 & 1.456 .000 & 6,5 & 55.764 & 9,9 \\
\hline
\end{tabular}

Fuente: Censos de Población y viviendas 1970, 1981 (Población de Derecho). INE; Censo de Población y Viviendas de Canarias, 1991 (Población de derecho). ISTAC (http// www.istac.rcanaria.es; Fecha de consulta 15-10-2001); "Estadísticas Insulares y Municipales". Base de datos ISTAC; Padrón Municipal de habitantes "Población de derecho. Resultados Nacionales y provinciales". 1975, 1986. INE. Elaboración propia.

La isla, experimenta un crecimiento demográfico progresivo a lo largo de todo el siglo. Crecimiento éste que comienza a ser más marcado a partir de la década de los setenta, experimentando el mayor aumento de esta etapa en la segunda mitad de la década de los años ochenta, entre 1975 y 1981 (14\%), coincidiendo con el crecimiento de la oferta 
turística y con el boom inmobiliario que recorrerá toda la década. Es en los años ochenta cuando va a superar los niveles de crecimiento que presenta Canarias, en más del 9\% entre 1975 y 1981, diferencia que se reduce en la primera mitad de la década (1981-1986) a casi un tercio $(3,4 \%)$. Con respecto a la dinámica nacional, el crecimiento es vertiginoso en toda la etapa.

Gráfico 10. Incremento de la población de derecho. España, Canarias y Lanzarote. 1970-1986 (\%)

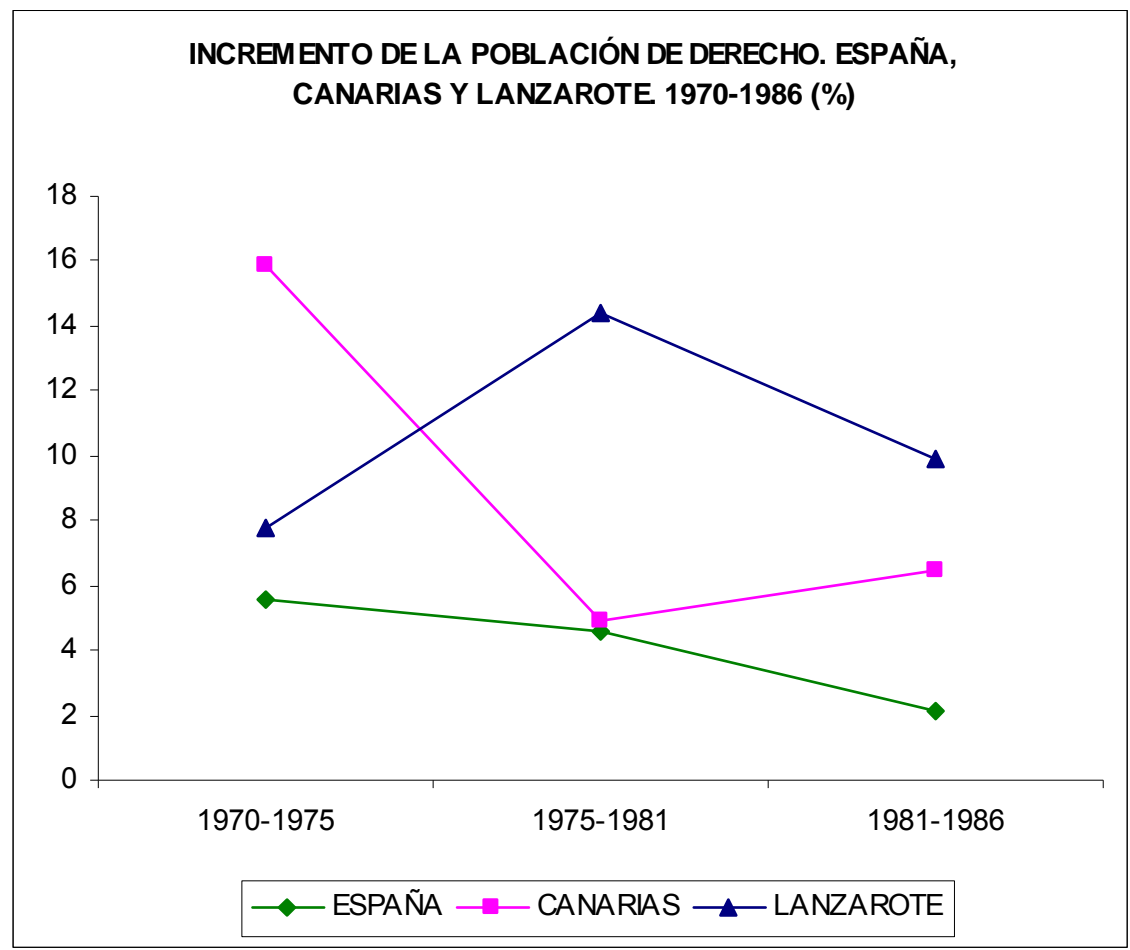

Fuente: Elaboración propia a partir de ISTAC e INE.

A pesar de que el ámbito de análisis es insular, las dinámicas municipales de la isla presentan variaciones, que, de forma breve, se caracterizan por ser el municipio capitalino, Arrecife, el que concentra el mayor número de habitantes registrados, por su calidad de centro administrativo y comercial de la isla

El mayor crecimiento experimentado, entre el inicio de este periodo de análisis y el final (1970-1986), será el del municipio de Tías (78,4\%), pues es en él donde se concentra la mayor parte de la actividad turística (oferta y demanda) y la construcción en esta etapa. Le seguirá, en nivel de crecimiento, San Bartolomé, que explica su dinámica demográfica $(47,3 \%)$ por la proximidad a la capital insular, Arrecife, que entre 1970 y 1986 aumenta su población en un $45 \%$. 
Tabla 19. Población por municipios. Lanzarote. 1970-1986

\begin{tabular}{|c|c|c|c|c|c|c|c|c|c|c|c|c|c|c|c|}
\hline Año & Arrecife & $\%$ & Haría & $\%$ & $\begin{array}{l}\text { San } \\
\text { Bartolomé }\end{array}$ & $\%$ & Teguise & $\%$ & Tías & $\%$ & Tinajo & $\%$ & Yaiza* & $\%$ & TOTAL \\
\hline 1970 & 21.135 & 51,4 & 2.986 & 7,3 & 3.550 & 8,6 & 5.977 & 14,5 & 3.018 & 7,3 & 2.822 & 6,9 & 1.658 & 4,0 & 41.146 \\
\hline 1975 & 23.294 & 52,5 & 2.878 & 6,5 & 3.866 & 8,7 & 6.211 & 14,0 & 3.241 & 7,3 & 2.975 & 6,7 & 1.872 & 4,2 & 44.337 \\
\hline 1981 & 28.864 & 56,9 & 2.624 & 5,2 & 4.650 & 9,2 & 6.096 & 12,0 & 3.484 & 6,9 & 3.071 & 6,1 & 1.932 & 3,8 & 50.721 \\
\hline 1986 & 30.694 & 55,0 & 2.790 & 5,0 & 5.229 & 9,4 & 6.475 & 11,6 & 5.383 & 9,7 & 3.229 & 5,8 & 1.994 & 3,6 & 55.764 \\
\hline $\begin{array}{l}\text { Incremento } \\
1970-1986 \\
(\%)\end{array}$ & \multicolumn{2}{|c|}{45,2} & \multicolumn{2}{|c|}{$-7,6$} & \multicolumn{2}{|l|}{47,3} & \multicolumn{2}{|c|}{8,3} & \multicolumn{2}{|c|}{78,4} & \multicolumn{2}{|c|}{14,4} & \multicolumn{2}{|c|}{20,3} & 35,5 \\
\hline
\end{tabular}

Fuente. "Población de derecho". Censo de Población y Viviendas de Canarias, 1991 ISTAC (http// www.istac.rcanaria.es; Fecha de consulta 15-10-2001); "Población de derecho por municipios, 1981, 1986". Estadísticas Insulares y Municipales. Base de Datos. ISTAC. ISTAC (http://gobiernodecanarias.org/istac/estadisticas/esta_insulares/1_.html; Fecha de consulta 15-09-04). Elaboración propia.

Gráfico 11. Evolución de la población municipal sobre el total insular. Lanzarote 1970-1986 (\%)

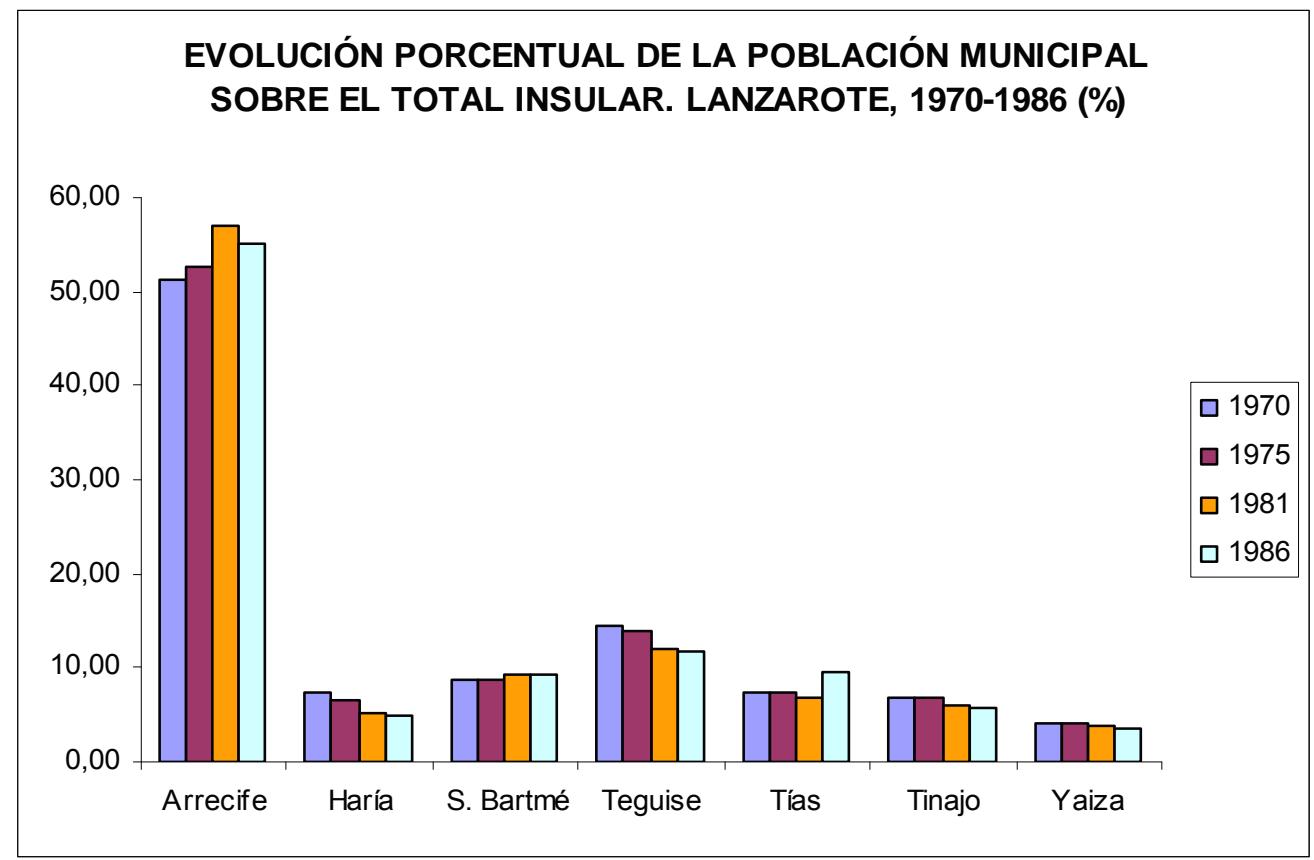

Fuente: Elaboración propia a partir de la Tabla 19 (anterior)

Por otro lado, los municipios que no incorporan la nueva actividad, el turismo, entran en una dinámica emigratoria, como es el caso de Haría (situado en el extremo Norte de la isla) que pierde población a lo largo de la etapa $(7,6 \%)$. 
Mapa 3. Evolución demográfica municipal. Lanzarote. 1970-1986 (base=1970)

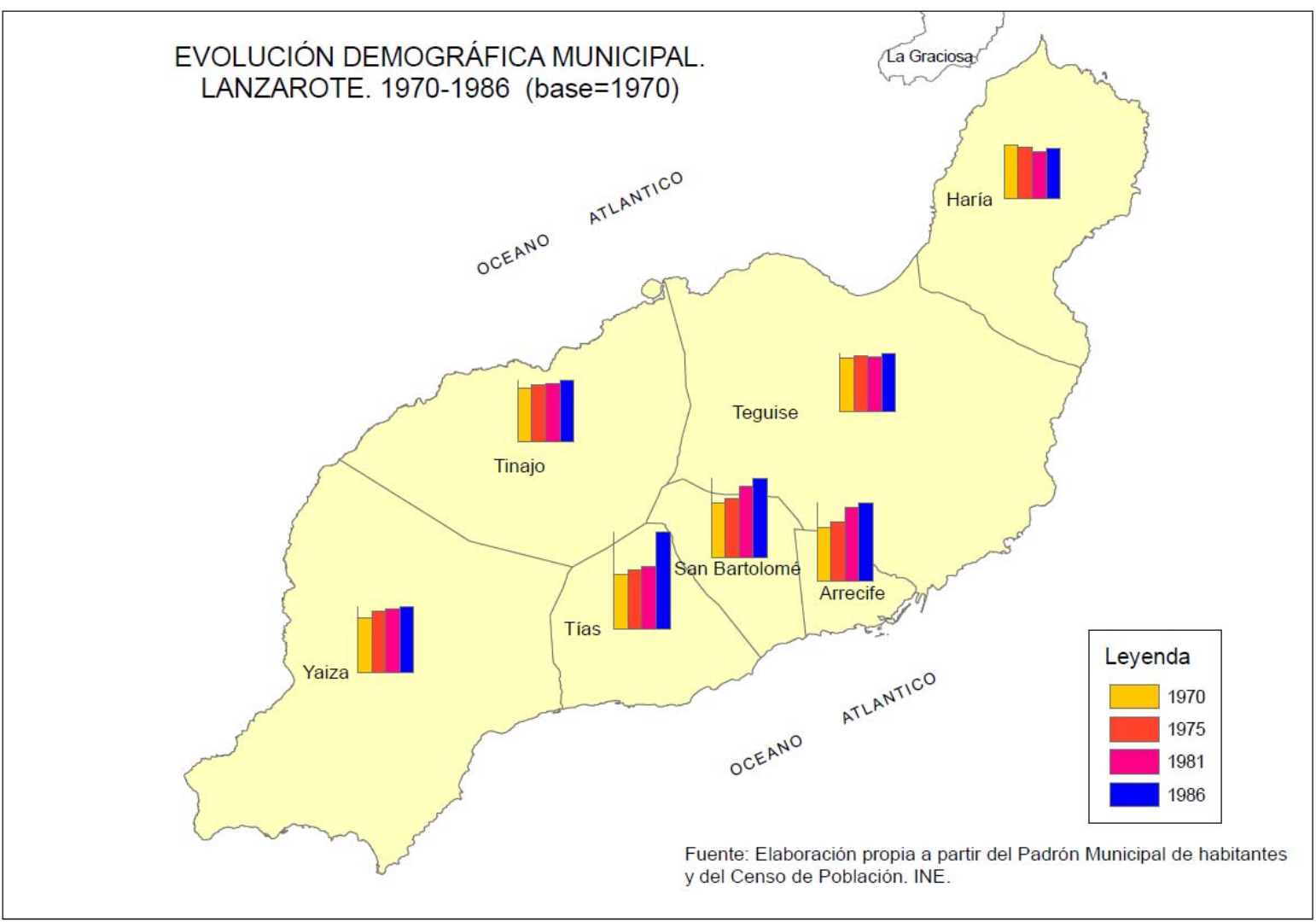

El crecimiento de la población insular va a venir explicado por la dinámica migratoria y no por la dinámica vegetativa insular, y así lo señalan autores como González A. y Betancor, A., denominando al mismo como "carácter endógeno" (1995, pp. 324), tal y como se aprecia a continuación.

\section{a.- El movimiento natural}

Desde finales de los sesenta, es notable el descenso de la mortalidad, apareciendo como un factor de influencia clave. La creación de la Seguridad Social, en 1963, aunque en Canarias se instaura cuatro años después (González Morales, A., 1993, pp.468), contribuirá a la reducción de la tasa de mortalidad, que se sitúa desde finales de los años sesenta y toda la década de los años setenta en un $6 \%$. 
Tabla 20. Evolución de las tasas quinquenales de mortalidad. España, Canarias y Lanzarote. 1966-1985 (\%)

\begin{tabular}{|l||c|c|c||}
\cline { 2 - 4 } \multicolumn{1}{c|}{} & ESPAÑA & CANARIAS & LANZAROTE \\
\hline \hline $1966-1970$ & 8,7 & 6,7 & 6,4 \\
\hline $1971-1975$ & 8,6 & 6,6 & 6,2 \\
\hline $1976-1980$ & 7,9 & 6,4 & 6,3 \\
\hline $1981-1985$ & 7,8 & 6,4 & 5,8 \\
\hline
\end{tabular}

Fuente: Lanzarote: de 1966 a 1985: Registro Civil. González, A. 1993, pp. 470 y "Defunciones". Base de datos Insular y Municipal. ISTAC; España y Canarias: Anuario Estadístico de España 1966-1986 y Movimiento Natural de la Población. Total Nacional y Comunidades Autónomas, 1966-1985. INE. Elaboración propia.

En las décadas sucesivas irá descendiendo, fenómeno este propio de un régimen demográfico moderno, encontrándose siempre, a lo largo del periodo analizado, hasta dos puntos por debajo de los valores nacionales. La dinámica de la isla sigue la línea de la Comunidad Autónoma hasta la década de los años ochenta en la que se sitúa casi un punto por debajo.

Gráfico 12. Evolución de la tasa de mortalidad media. España, Canarias y Lanzarote. 1966-1985

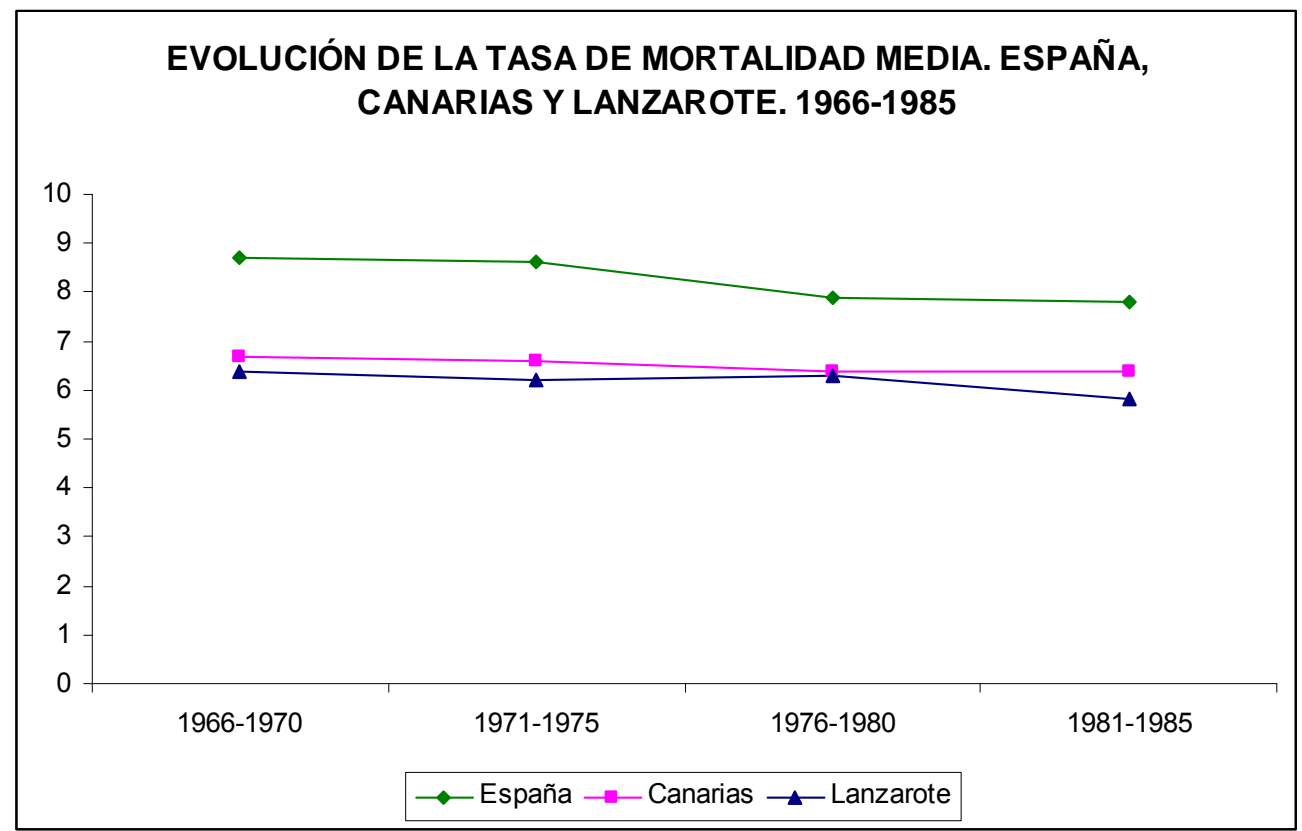

Fuente: Elaboración propia a partir de la Tabla 20 (anterior).

En cuanto a las Tasas de Natalidad, vemos como es elevada en la década del sesenta y así se mantendrán durante toda la etapa. Estos valores son normales para una sociedad poco desarrollada, con características rurales, una escasa división del trabajo, y donde prevalecían actividades agrarias, y un bajo nivel de sus fuerzas productivas. 
Tabla 21. Evolución de las tasas quinquenales de natalidad. España, Canarias y Lanzarote $.1966-1985(\%)$

\begin{tabular}{||c|c|c|c||}
\cline { 2 - 4 } \multicolumn{1}{c|}{} & ESPAÑ A & CANARIAS & LANZAROTE \\
\hline $\mathbf{1 9 6 6 - 1 9 7 0}$ & 20,3 & 25,9 & 31,3 \\
\hline $\mathbf{1 9 7 1 - 1 9 7 5}$ & 19,3 & 23,8 & 26,4 \\
\hline $\mathbf{1 9 7 6 - 1 9 8 0}$ & 17,1 & 19,4 & 21,4 \\
\hline $1981-1985$ & 12,9 & 15,6 & 17,1 \\
\hline
\end{tabular}

Fuente: Lanzarote: de 1966 a 1985: Registro Civil. González, A. 1993, pp. 470 y "Nacimientos”. Base de datos Insular y Municipal. ISTAC; España y Canarias: Anuario Estadístico de España 1966-1986 y Movimiento Natural de la Población. Total Nacional y Comunidades Autónomas, 1966-1985. INE. Elaboración propia

El descenso en las Tasas de Natalidad, sucederá ya entrada la década de los ochenta, cuando se produce un claro proceso de desagrarización en pro de una fuerte terciarización de la economía insular, que trae consigo cambios en la mentalidad, fruto de cambios en el modelo de vida debido - como sucedió en las islas mayores (Gran Canaria y Tenerife) y en el resto de España con anterioridad - a una imperiosa necesidad económica, que lleva a la introducción en el territorio de actividades relacionadas con el turismo y los servicios, y con ello a la incorporación de la mujer al mercado laboral. Esto, unido a la mejora de las condiciones sanitarias, conduce al aumento de la esperanza de vida de los niños al nacer, con lo cual la prole pasa a tener mayor probabilidad de superar con éxito los primeros años de vida, lo que va a sentar la bases del cambio demográfico insular, incorporando, la isla, lentamente, las características natalicias de un régimen demográfico moderno. Dicho proceso de transformación estará apoyado en el cambio de mentalidad que impulsa la nueva actividad que irrumpe: el turismo procedente de las grandes áreas metropolitanas europeas.

A pesar de todos estos cambios, la isla sigue presentando una tasa de natalidad elevada con respecto a los valores nacionales durante toda esta etapa, aunque con respecto a la tasa de la Comunidad Autónoma, se acerca mucho antes a un régimen demográfico moderno. 
Gráfico 13. Evolución de la tasa de natalidad media. España, Canarias y Lanzarote. 1966-1985

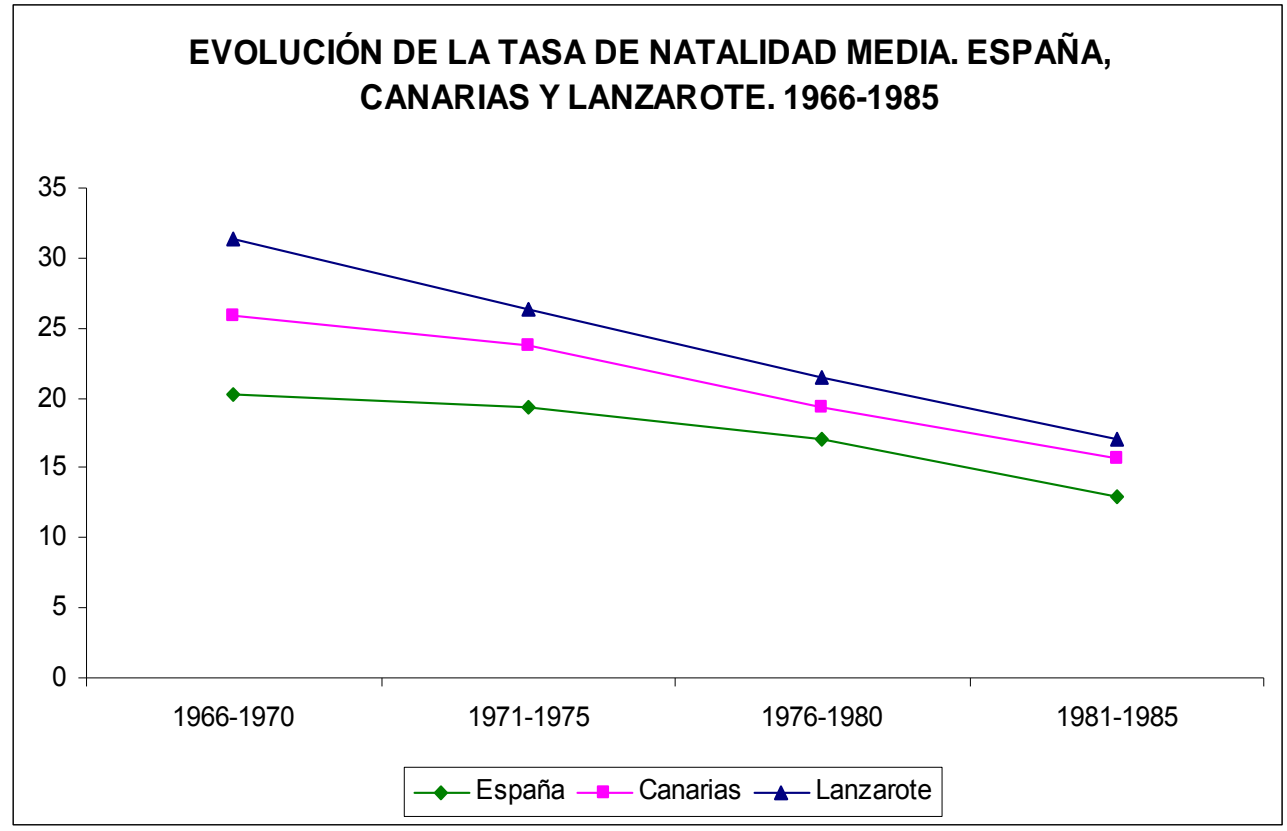

Fuente: Elaboración propia a partir de la información recogida en la Tabla 21.

Así, distintos autores concluyen que, los mayores crecimientos se deben a procesos inmigratorios, ya que las tasas de natalidad y mortalidad se han reducido de forma significativa con respecto al pasado, y con ello también el crecimiento vegetativo de manera considerable, puesto que el ciclo comienza con un crecimiento natural de la población de 25\%o (1966-1970) y se reduce a menos de la mitad, 11,3\%o al final del mismo (1981-1985).

Tabla 22. Evolución de las tasas quinquenales de crecimiento vegetativo de Lanzarote. 19661985 (\%)

\begin{tabular}{|l|c|c|c||}
\cline { 2 - 4 } \multicolumn{1}{c|}{} & ESPAÑ A & CAN ARIAS & LANZAROTE \\
\hline $\mathbf{1 9 6 6 - 1 9 7 0}$ & 11,6 & 19,2 & 24,9 \\
\hline $\mathbf{1 9 7 1 - 1 9 7 5}$ & 10,7 & 17,2 & 20,2 \\
\hline $\mathbf{1 9 7 6 - 1 9 8 0}$ & 9,2 & 13,0 & 15,1 \\
\hline $\mathbf{1 9 8 1 - 1 9 8 5}$ & 5,1 & 9,2 & 11,3 \\
\hline
\end{tabular}

Nota: Tasa de crecimiento vegetativo: diferencia entre la Tasa de Natalidad y la de Mortalidad.

Fuente: Elaboración propia a partir de las tasas de natalidad y mortalidad para los diferentes quinquenios analizados. 
Gráfico 14. Evolución del crecimiento vegetativo. España, Canarias y Lanzarote. 1966-1985.

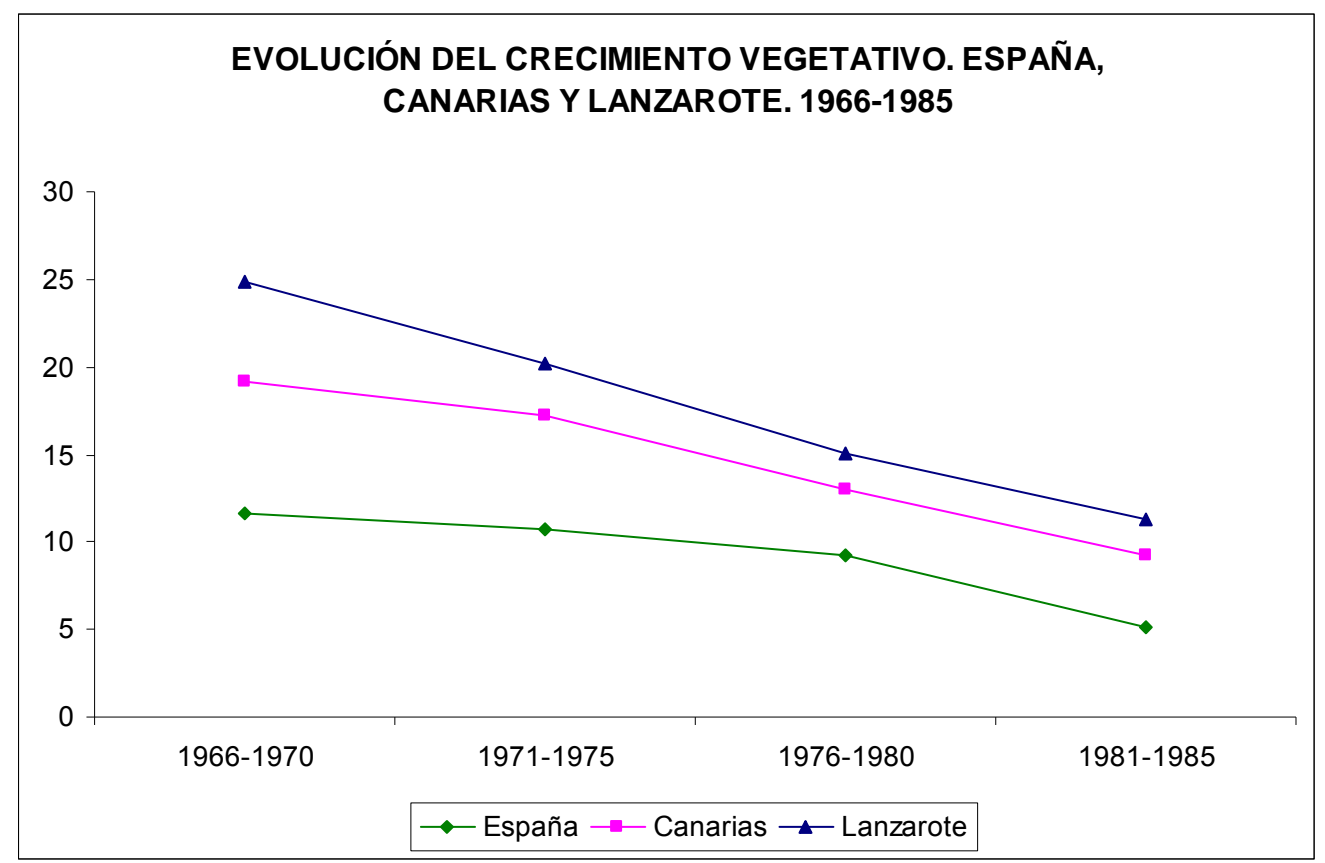

Fuente: Elaboración propia a partir de la información recogida en la Tabla 22.

Pero si comparamos la tasa de crecimiento vegetativo insular con respecto a la nacional a lo largo del periodo de análisis, Lanzarote se ha mantenido con niveles de crecimiento muy superiores al del territorio nacional, no sólo antes de la transición demográfica tardía con respecto a España, si no incluso en la década de los años ochenta, donde sobresale con un saldo de seis puntos por encima de la nación (11,3\% y $5,1 \%$ respectivamente entre 19811985). Esta diferencia se explica básicamente a través de la natalidad, que se ha reducido en menor cuantía en la isla, a la vez que, la entrada de contingentes de población en edad de trabajar, con menor tasa de mortalidad y mayor de fecundidad que la media isleña, ha suavizado dicho descenso.

De todo ello se desprende la necesidad de explicar la dinámica de crecimiento de la población insular a través de la influencia de factores externos. Éstos son los siguientes:

- Irrupción brusca de una nueva actividad económica: la hostelería y el turismo, que acoge al turista en masa y que supone una fuerte demanda de mano de obra.

- Rápido crecimiento del sector de la construcción y de la promoción inmobiliaria fruto de la fuerte demanda de ocupación exterior, que supone la construcción constante de camas para satisfacer dicha demanda, lo que requiere una gran contratación de mano de obra que no se puede cubrir con la población local. 
Debido a estos factores, sobreviene una serie de cambios estructurales, que Martín Ruiz (1981, pp. 6) califica de "desequilibrios económicos y espaciales" que son "generados por la aplicación de una política económica tecnocrática y desestabilizadora", y que junto al "fuerte desarrollo del modo de producción capitalista (dominante) en la Formación Social Canaria Oriental", trae como consecuencia "transferencias de fuerza de trabajo de unas áreas desfavorecidas por el modelo económico dominante, a otras en alza por el desarrollo turístico".

Dichos factores explicarían los cambios que se observan en el peso de la población de hecho insular con respecto a la de derecho.

Tabla 23. Población de hecho y derecho. España, Canarias y Lanzarote. 1960-1991

\begin{tabular}{|c|c|c|c|c|c|c|}
\hline & \multicolumn{2}{|l|}{ ESPAÑ A } & \multicolumn{2}{|c|}{ CANARIAS } & \multicolumn{2}{|c|}{ LANZAROTE } \\
\hline AÑO & Hecho & Derecho & Hecho & Derecho & Hecho & Derecho \\
\hline 1960 & 30.582 .936 & 30.776 .935 & 944.448 & 966.177 & 34.818 & 36.519 \\
\hline 1970 & 33.956.047 & 34.041 .531 & 1.170 .224 & 1.125 .442 & 41.912 & 41.146 \\
\hline 1981 & 37.742 .561 & 37.677 .044 & 1.444 .626 & 1.367 .669 & 53.452 & 50.721 \\
\hline 1991 & 39.433 .942 & 38.872 .268 & 1.637 .641 & 1.493 .784 & 88.475 & 64.911 \\
\hline
\end{tabular}

Fuente: Población de Hecho y de Derecho. Censo de Población y Vivienda. 1960-1991. INE.

Tabla 24. Porcentaje de incremento de la población de hecho con respecto a la de derecho. España, Canarias y Lanzarote. 1960-1991 (\%)

\begin{tabular}{|l||c|c|c|}
\hline Año & España & Canarias & Lanzarote \\
\hline \hline $\mathbf{1 9 6 0}$ & $-0,63$ & $-2,25$ & $-4,66$ \\
\hline $\mathbf{1 9 7 0}$ & $-0,25$ & 3,98 & 1,86 \\
\hline $\mathbf{1 9 8 1}$ & $\mathbf{0 , 1 7}$ & 5,63 & 5,38 \\
\hline $\mathbf{1 9 9 1}$ & 1,44 & 9,63 & 36,30 \\
\hline
\end{tabular}

Fuente: Elaboración propia a partir de la tabla anterior.

Los datos censales reflejan pequeñas variaciones decenales de la población de hecho sobre la de derecho en esta primera etapa de despegue y consolidación de la actividad. La distancia entre ambos tipos se hace mayor en cada década de análisis, explotando en 1991, que registra un incremento de la población de hecho sobre la de derecho del $36 \%$. Estos datos censales de 1991, tienen su explicación en los procesos socioeconómicos insulares de la década de los años ochenta ya señalados: la isla se consolida como destino turístico de masas, con un excesivo crecimiento de la construcción y de la oferta de hotelera, para lo cual es necesario la entrada de trabajadores foráneos, puesto que la isla no posee suficiente capital humano para abordar la fuerte demanda de mano de obra. 
La dinámica insular es similar a la de la comunidad autónoma hasta 1981, año a partir del cual se aleja de forma brusca, de modo que la relación población hecho/derecho de Lanzarote queda a una distancia del $27 \%$ con respecto a la de Canarias y siempre enormemente alejada de la de España.

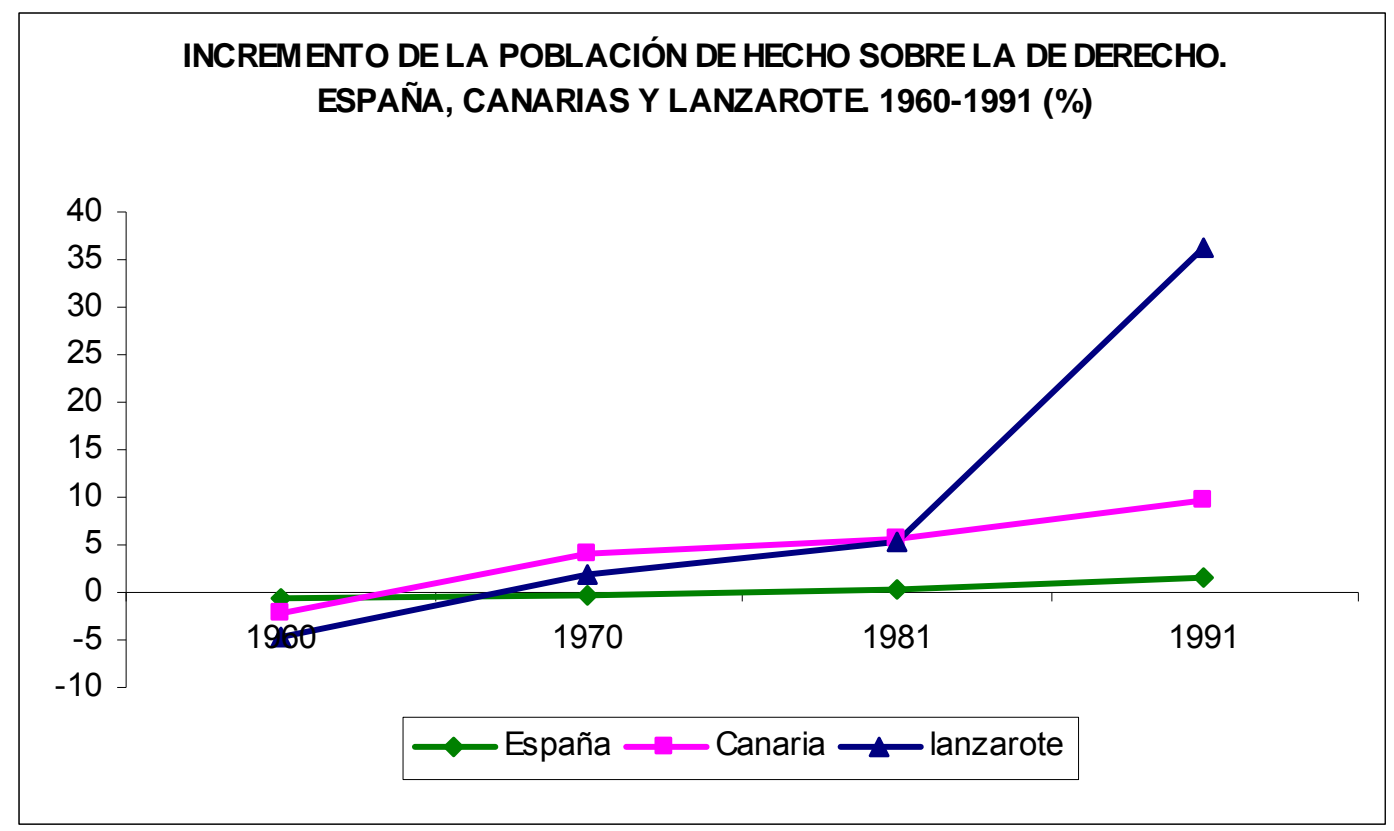

Fuente: Elaboración propia a partir de la información recogida en la Tabla 24.

\section{b.- Los factores exógenos. Las migraciones}

El crecimiento de la población insular será en esta etapa impulsado, como también señalan diversos autores, por agentes externos (migraciones), atraídos por la fuerte demanda de mano de obra que traen consigo las nuevas actividades económicas derivadas de la recepción de turistas, que convierten a la isla en un foco económico, puesto que supone "para una masa heterogénea de personas (...), facilidad y oportunidad para conseguir empleo y emprender negocios" (ISTAC, 1996, pp. 26).

En la década de los ochenta, será Canarias la Comunidad Autónoma española de mayor inmigración, definiéndose, en el marco del modelo migratorio de España y en palabras del Instituto Canario de Estadística (1996, pp. 31), como un modelo de carácter universal, donde participan todas las regiones españolas, desde las más pobres a la más ricas. Este modelo migratorio que observa el archipiélago, incluye emigraciones internas (dentro de la isla y entre islas) y emigraciones procedentes del exterior. El fenómeno de la inmigración -legal o ilegal, o de trabajadores no registrados- hacia toda Canarias es sobresaliente; ésta, "de modo continuo ha sido y es impactada por la entrada, salida y retorno de pobladores" (Avance PIOT, 1987. Tomo 5, pp. 92). 
Es por ello, que se puede hablar de un avance continuo en el crecimiento de la población en Lanzarote, que tiene su explicación en la desaparición de las corrientes de emigración de su población a otras islas y fuera del archipiélago (en períodos anteriores a la década del setenta) y la aparición de corrientes contrarias, es decir, de un proceso de inmigración o de entrada de población a Lanzarote (desde las otras islas, otras regiones españolas o desde el extranjero). Así, una buena parte del incremento del efectivo poblacional, a partir de 1970, tanto en población de hecho como de derecho, se va a deber a los inmigrantes que entran en la isla respondiendo a la demanda de mano de obra, que genera la actividad turística (directa e indirectamente), y por la continua llegada de turistas a la misma.

Lo primero que ocurre, a partir de la década de los sesenta, es un cambio en el asentamiento de la población. El éxodo rural hacia zonas de la isla con desarrollo turístico ya existe. Esto, unido a la "tradicional emigración a la capital" da "lugar a un enorme vacío demográfico en determinados municipios de la isla” (Barrera, C., 1994, pp. 249-250) ${ }^{138}$.

Tabla 25. Población residente según lugar de nacimiento. Inmigrantes netos. Lanzarote. 19701986

\begin{tabular}{|c|c|c|c|c|c|c|c|c|c|c|c|}
\hline \multirow[b]{2}{*}{ AÑO } & \multicolumn{2}{|c|}{ EN OTRA ISLA } & \multicolumn{2}{|c|}{ EN OTRA CCAA } & \multicolumn{2}{|c|}{ EN OTRO PAÍS } & \multicolumn{3}{|c|}{ INMIGRANTES NETOS } & \multirow[b]{2}{*}{$\begin{array}{l}\text { POBLACIÓN } \\
\text { AUTÓCTONA }\end{array}$} & \multirow[b]{2}{*}{$\begin{array}{l}\text { POBLACIÓN } \\
\text { DERECHO }\end{array}$} \\
\hline & Total & $\%$ & Total & $\%$ & Total & $\%$ & TOTAL & $\%$ & $\begin{array}{l}\text { Incremento } \\
\text { quinquenal } \\
(\%)\end{array}$ & & \\
\hline 1970 & 1.004 & 61,6 & 525 & 32,2 & 100 & 6,1 & 1.629 & 3,9 & & 39.517 & 41.146 \\
\hline 1975 & 1.475 & 56,3 & 934 & 35,7 & 210 & 8,0 & 2.619 & 5,9 & 60,8 & 41.738 & 44.357 \\
\hline 1981 & 2.255 & 53,2 & 1.595 & 37,7 & 386 & 9,1 & 4.236 & 8,3 & 61,8 & 46.485 & 50.721 \\
\hline 1986 & 4.447 & 43,0 & 4.735 & 45,8 & 1.148 & 11,1 & 10.330 & 18,5 & 143,9 & 45.434 & 55.764 \\
\hline
\end{tabular}

Nota: los porcentajes están calculados sobre el total de la población insular en el año indicado.

Fuente: Para 1970 y 1975: "Población según la relación entre el lugar de nacimiento y el de residencia. Lanzarote". Censo y Padrón. INE; Para 1981: "Población con 10 o mas años según lugar de residencia a 1-3-81, por municipio. Provincia de las Palmas". Censo de Población y Viviendas de 1991, INE.; Para 1986: "Migrantes. Población que no ha residido siempre en el mismo municipio, según año de llegada y lugar de procedencia" y "Población de derecho según edad y lugar de nacimiento". Padrón Municipal de 1986 ISTAC;

Esta etapa (1970-1986) se caracteriza por la continua entrada de fuerza de trabajo, por lo que asistimos al constante incremento relativo de la inmigración. El periodo comienza con un $4 \%$ de inmigrantes en la isla, para elevarse hasta el $18,5 \%$ al final del mismo (1986). La

138 Como Haría, Tinajo y Yaiza, cuyo incremento de la población en este período es escaso en relación al resto de municipios. Es por ello, que los municipios turísticos (Teguise y Tías principalmente) y la capital han crecido de forma considerable; en palabras de González, A. y Betancort, A. (1995, pp. 325), "pasan de una situación de potenciales áreas de emigrantes a convertirse en espacios receptores de fuerza de trabajo" 
mayor variación se observa en la década de los años ochenta, cuando la actividad turística se va consolidando, y el incremento de la inmigración alcanza el 144\% entre 1981 y 1986.

Gráfico 16. Evolución de la inmigración. Lanzarote. 1970-1986

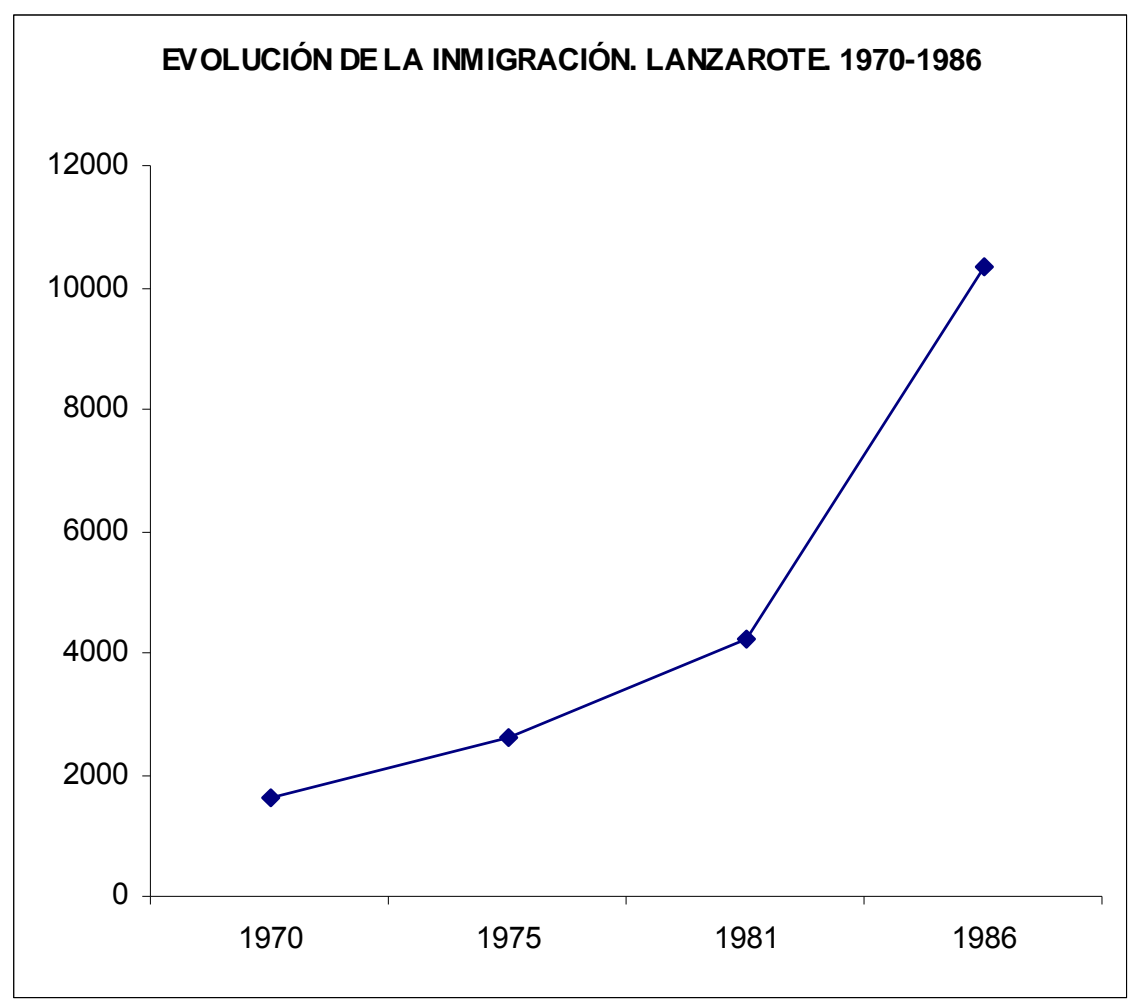

Fuente: Censos y Padrones municipales. ISTAC e INE. Elaboración propia a partir de la Tabla 25.

En cuanto al origen de la población que emigra hacia Lanzarote, la década de los setenta está marcada por una inmigración proveniente de las otras islas del archipiélago, suponiendo un $61,6 \%$ del total de inmigrantes que recibe. Esta inmigración sólo será protagonista hasta 1981, pues su peso relativo se va reduciendo, de modo que, al final de esta etapa (1986), el protagonismo lo toma la entrada de población que tiene como origen otras Comunidades Autónomas españolas, aunque la diferencia sólo es del 3\% (46\% y 43\% respectivamente) ${ }^{139}$.

\footnotetext{
${ }^{139} \mathrm{Al}$ igual sucede con Fuerteventura. Cifra que cambia para otras islas menores como La Gomera y el Hierro que cuentan con cifras relativas más altas de inmigrantes del extranjero. En términos absolutos, serán las islas mayores, Tenerife y Gran Canaria, las que cuentan con un mayor número de migrantes del extranjero y de otras Comunidades Autónomas (ISTAC, 1999, pp. 6).
} 
Gráfico 17. Evolución de la inmigración según origen. Lanzarote. 1970-1986 (\%)

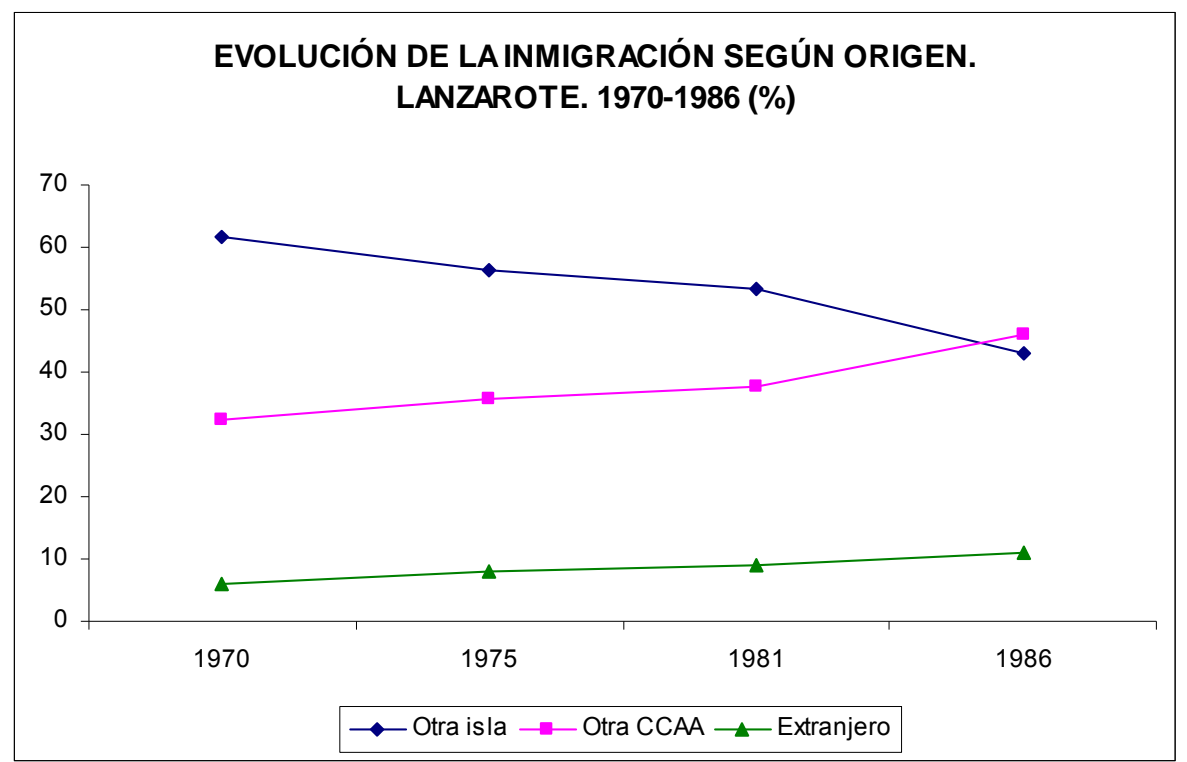

Fuente: Censos y Padrones municipales. ISTAC e INE. Elaboración propia.

En 1986, la población entrada a Lanzarote externa a Canarias va a suponer, por primera vez, más de la mitad de inmigración, alrededor del $57 \%$, con tendencia al alza.

Gráfico 18. Inmigración externa a Canarias. Lanzarote. 1970-1986 (\%)

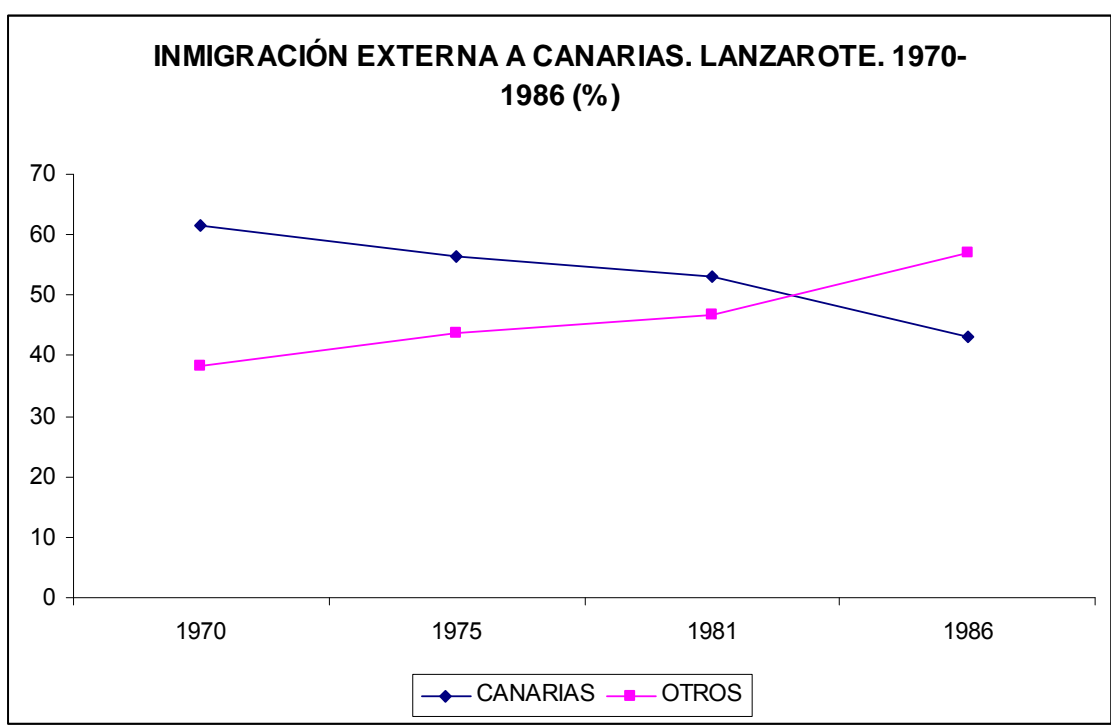

Fuente: Censos y Padrones municipales. ISTAC e INE. Elaboración propia.

\section{c.- La población autóctona}

En 1970 cuando aún Lanzarote presentaba una economía basada principalmente en el sector primario, la población autóctona alcanzaba un peso relativo del $96 \%$, pero este peso 
observa una tendencia decreciente a lo largo de toda la etapa, derivada de la entrada de población externa que va en crescendo durante todo el periodo, al igual que la participación de la actividad turística en la economía.

Tabla 26. Población inmigrante y población autóctona. Absolutos y relativos. Lanzarote. 19701986

\begin{tabular}{|l||r|r|r||r|r|r||}
\hline \multirow{2}{*}{ AÑO } & \multirow{2}{*}{$\begin{array}{l}\text { POBLACIÓN } \\
\text { DERECHO }\end{array}$} & \multicolumn{2}{|l|}{ INMIGRACIÓN TOTAL } & \multicolumn{3}{|c|}{ POBLACIÓN AUTÓCTONA } \\
\cline { 5 - 8 } & & Absolutos & \multicolumn{1}{l|}{$\%$} & Absolutos & $\%$ & $\begin{array}{r}\text { Incremento } \\
\text { quinquenal } \\
(\%)\end{array}$ \\
\hline \hline 1970 & 41.146 & 1.629 & 3.9 & 39.517 & 96,0 & \\
\hline 1975 & 44.357 & 2.619 & 5.9 & 41.738 & 94,1 & 5,6 \\
\hline 1981 & 50.721 & 4.236 & 8.3 & 46.485 & 91,6 & 11,4 \\
\hline 1986 & 55.764 & 10.330 & 18.5 & 45.434 & 81,5 & $-2,3$ \\
\hline
\end{tabular}

Nota: Población autóctona: diferencia entre inmigrantes (no nacidos en la isla) y población total residente.

Fuente: Elaboración propia a partir de la población por lugar de nacimiento. INE e ISTAC.

Cuando la isla alcanza su consolidación como destino turístico de masas, la población nacida en Lanzarote se ha reducido hasta el 81,5\% (1986). Entre 1981 y 1986 su crecimiento es negativo, alrededor del $2 \%$, o lo que es lo mismo, la población autóctona frente a la residente decrece.

Del comienzo de la etapa hasta su fin (1970-1986) el incremento de la población autóctona ha supuesto un $15 \%$, frente a la población alóctona ${ }^{140}$ (inmigrante) que crece del orden del $534 \%$ (base 1970=100).

140 Se consideran alóctonos los residentes no nacidos en la isla. 
Gráfico 19. Evolución de la población autóctona y alóctona. Lanzarote. 1970-1986 (\%)

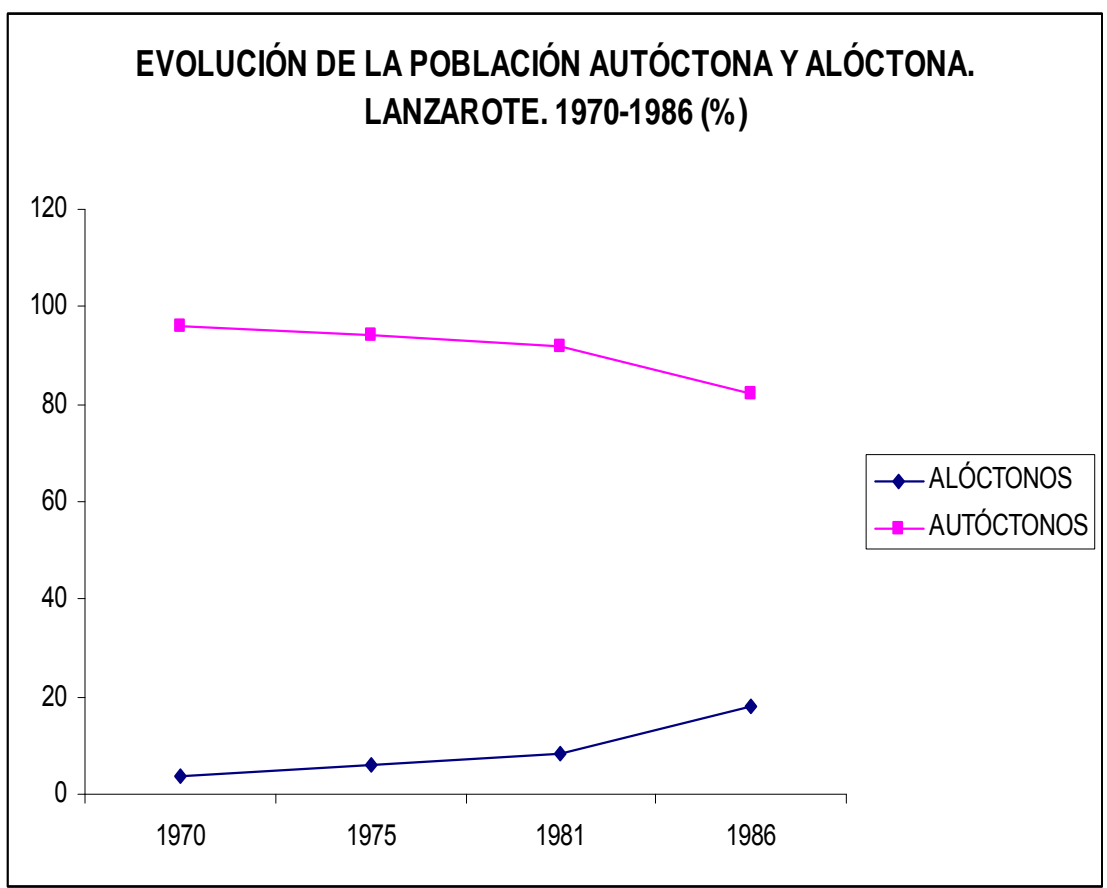

Fuente: Elaboración propia a partir de la población por lugar de nacimiento. Censos y Padrones. ISTAC e INE.

Gráfico 20. Incremento quinquenal de la población autóctona y alóctona. Lanzarote. 1970-1986 (\%)

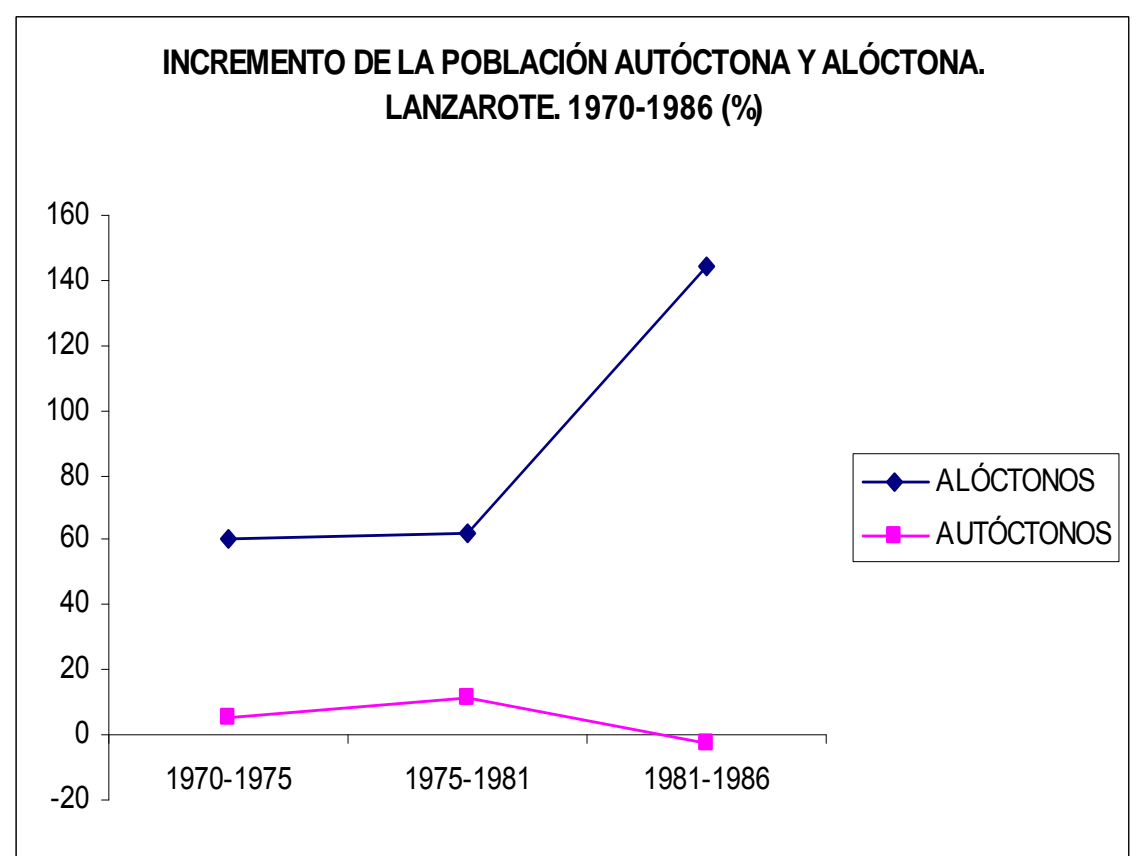

Fuente: Elaboración propia a partir de la población por lugar de nacimiento. Censos y Padrones. ISTAC e INE 


\section{d.- Autóctonos, alóctonos y turistas}

En las próximas líneas se construyen dos ratios: el primero encaminado a establecer la relación entre alóctonos y autóctonos (al/at) y el segundo destinado a observar la proporción de la población autóctona frente a la población foránea (alóctonos y turistas equivalentes residiendo) que asume la isla cada día, que nos permitirá detallar el equilibrio de autoctonía (frlat), una mirada nueva sobre la población insular.

Tabla 27. Relación entre autóctonos, alóctonos y turistas. Lanzarote. 1970-1986

\begin{tabular}{|r||c|r|r|r|r|r|r||}
\hline AÑO & Residentes & Autóctonos & Alóctonos & $\begin{array}{c}\text { Turistas } \\
\text { equivalentes al día }\end{array}$ & Hab/día & al/at & fr/at \\
\hline \hline 1970 & 41.146 & 39.517 & 1.629 & 436 & 41.582 & 41,22 & 50,69 \\
\hline 1975 & 44.357 & 41.738 & 2.619 & -- & 44.357 & 62,75 & 146,58 \\
\hline 1981 & 50.721 & 46.485 & 4.236 & 5.252 & 55.973 & 91,13 & 200,00 \\
\hline 1986 & 55.764 & 45.434 & 10.330 & 16.493 & 72.257 & 227,36 & 590,00 \\
\hline
\end{tabular}

* Calculado por cada mil autóctonos.

Fuente: Residentes. Población registrada (Censos y Padrones); Habitantes al día: suma de autóctonos (at), alóctonos (al) y turistas; (fr): alóctonos más turistas equivalentes al día=población foránea. Elaboración propia.

Gráfico 21. Evolución de los ratios alóctonos/autóctonos (al/at) y foráneos/autóctonos (fr/at). Lanzarote. 1970-1986

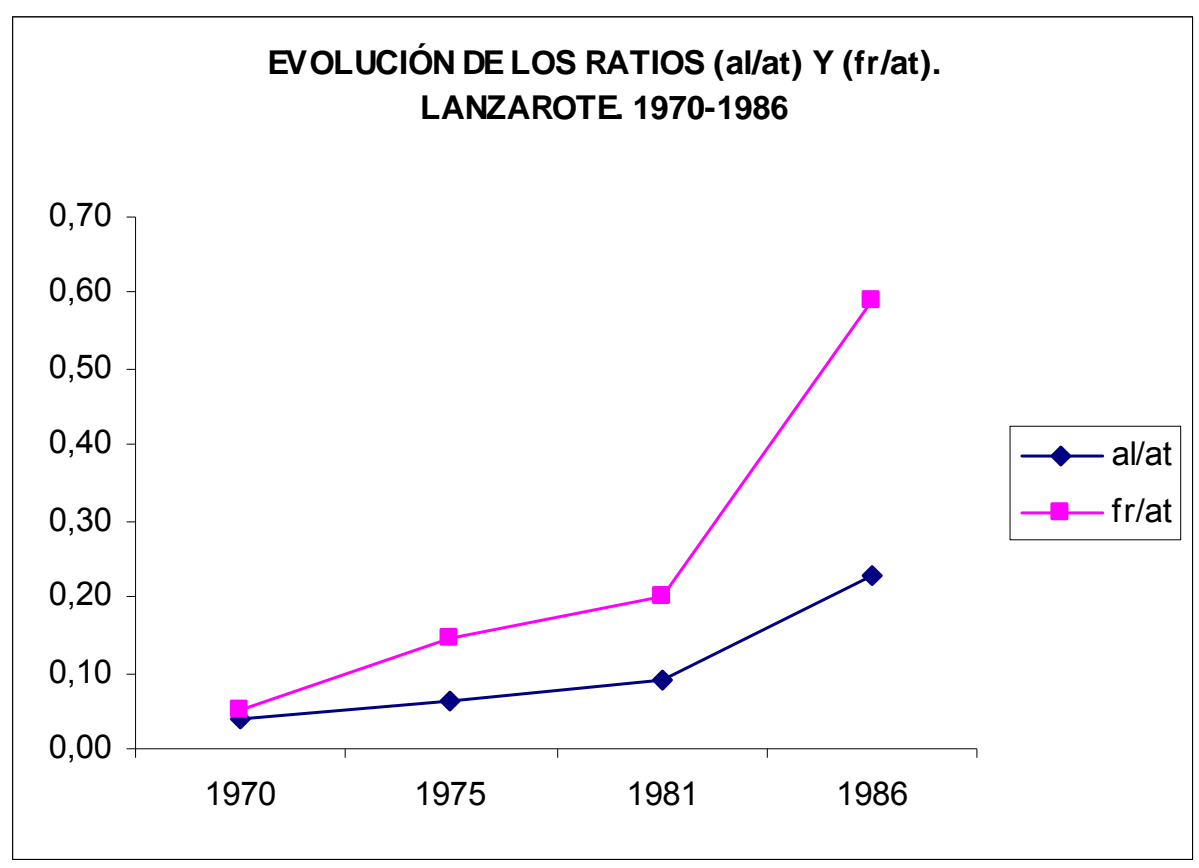

Fuente: Elaboración propia a partir del cálculo de ratios recogidos en la Tabla 27.

La explosión urbanística que vive Lanzarote en esta etapa modifica la relación entre alóctonos y autóctonos, de modo que el periodo empieza con 41 inmigrantes por mil autóctonos (1970) y termina con una relación de 227 por mil, lo que quiere decir que el $25 \%$ 
de la población no ha nacido en la isla a finales de la década de los años ochenta. Porcentaje éste que se agrava si se incluyen los turistas equivalente diarios, que hace que la población autóctona sea menos de la mitad de la población que acoge la isla a diario, del orden del $40 \%$, lo que quiere decir que el índice frlat se establece en una 590 personas foráneas (turistas equivalentes al día e inmigrantes) por mil autóctonos, un fuerte ascenso de la población foránea.

Gráfico 22. Evolución de la población foránea y autóctona. Lanzarote. 1970-1986

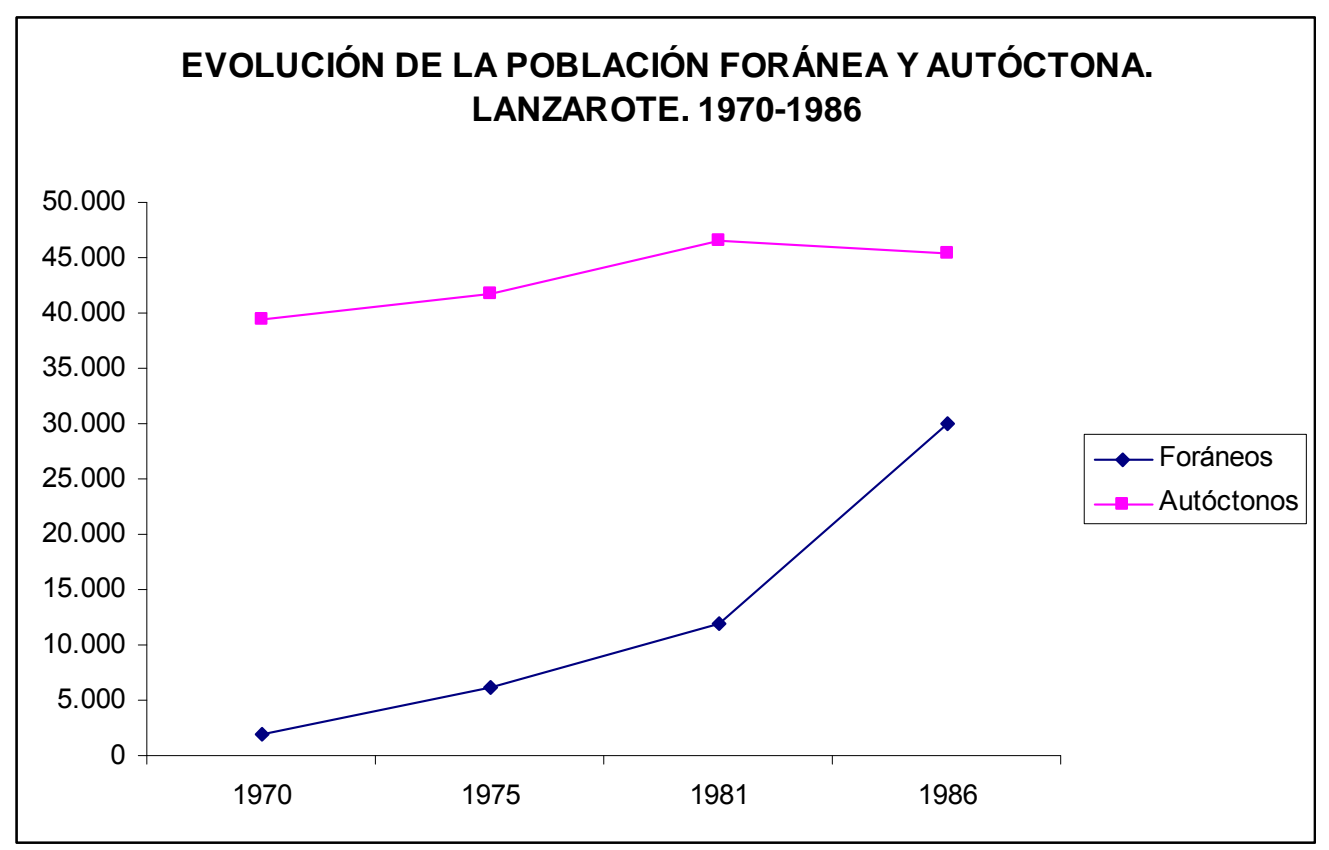

Fuente: Elaboración propia a partir de la información recogida a través de Censos y Padrones. ISTAC e INE.

\subsubsection{2.- CONCLUSIONES}

La isla sufre un ritmo de crecimiento poblacional rápido y elevado en comparación con la dinámica de la comunidad autónoma y del país. Este crecimiento tiene su explicación en la entrada constante y cada vez más numerosa de trabajadores externos, de orígenes diversos (insulares, nacionales y de otros países), cuyo incremento porcentual en los quince años que cubren este análisis es de más del 500\%. El origen de este desplazamiento es, fundamentalmente, de mano de obra hacia Lanzarote, y se encuentra en la explosión de la construcción de plazas de alojamiento turístico, y en la demanda de trabajadores en los servicios derivados de la entrada de turistas. La actividad turística genera la explosión demográfica.

Estos crecimientos poblacionales señalados afectan al peso relativo de la población autóctona, de la siguiente forma en esta etapa: 
1. Reducción progresiva de su participación en el cómputo total de población residente en el periodo. El índice de evolución de la población autóctona es al final de esta etapa muy inferior al de la población alóctona. Se ha pasado de un 96\% de población autóctona (nacida en la isla) en 1970 (aproximadamente 39.500 personas) al 81\% en quince años de evolución (aproximadamente 45.400 personas, en 1986).

2. El volumen de población que acoge la isla a diario (residentes y turistas) trae consigo el que la población autóctona sea aproximadamente el $40 \%$ del total de población diaria estimada.

El desequilibrio demográfico comienza a ser un hecho. La presión sobre equipamientos, infraestructuras y servicios en Lanzarote se explica, cada vez más y de forma acelerada, por factores demográficos exógenos (inmigrantes y turistas) a la población autóctona.

\subsection{3.- EFECTOS SOBRE LA CUALIFICACIÓN Y EL EQUIPAMIENTO EDUCATIVO. 1970- 1986}

Entender la educación como centro neurálgico en el proceso de desarrollo, como vía para la eclosión del cambio socio-económico y de la sociedad en su conjunto, será el camino que emprenda España para romper el círculo de la pobreza en el que estaba sumida y más aún cuando se encuentra ante la posibilidad de implantar una economía terciaria, con un fuerte peso de las actividades turísticas.

Es así como la implantación y la necesidad de desarrollo de una nueva actividad económica, el turismo, puede generar el impulso necesario para modificar el estado del nivel de instrucción de la población, en tanto recurso fundamental para el despegue de la nueva economía. Idea que recorre la política nacional, ya de forma importante en la década de los años sesenta hasta la actualidad, con la creación de Escuelas Oficiales de Turismo, Libros Blancos sobre turismo, y siempre presente en los diferentes Planes de desarrollo (FUTURES, PICTE y TURISMO 2020).

Por ello, el análisis que se enfrenta en las próximas líneas tiene la finalidad de describir el curso que ha llevado, en la isla, dos aspectos del sistema educativo que se concretan, a su vez, en dos ámbitos de análisis, dentro del periodo abordado (1970-2007): a) la evolución de la cualificación de la población (participación en la enseñanza formalizada de la población insular, en sus diferentes niveles), en cuanto vía de análisis del capital humano con el que la sociedad lanzaroteña aborda su posibilidad de desarrollo económico-turístico; y b) la evolución oferta-demanda del equipamiento educativo en dicho periodo. 


\subsubsection{1.- EVOLUCIÓN DEL NIVEL DE INSTRUCCIÓN}

El analfabetismo ${ }^{141}$ en Canarias "ha sido una auténtica lacra social"142, que, según autores, ha acarreado un sentimiento de infravaloración a la población.

El predominio de las actividades económicas del sector primario hasta la primera mitad de los ochenta, implicó que no fuera necesario cualificar a la mano de obra. Pero, "En la medida que las actividades terciarias, en general las actividades urbanas, han ido reemplazando a la agricultura y la pesca, se ha ido imponiendo la necesidad de aumentar el nivel educativo de los autóctonos, al tiempo que se importaba (...), fuerza de trabajo

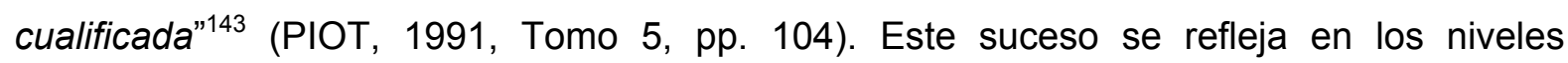
educativos que va alcanzando Canarias según va caminando la década de los ochenta y las sucesivas, cuando la actividad económica principal se centra en el sector terciario, basado en el Turismo como principal fuente de ingresos para las islas.

Así, Lanzarote comienza el siglo XX con unos niveles importantes de analfabetismo, cuatro de cada cinco conejeros no sabían leer ni escribir. Sólo 1 de cada 5 había cursado algún tipo de estudio. Álvarez, M. (1980, pp. 129) señala que sobre la sociedad canaria actúa "un proceso analfabetizante" alimentado por mecanismos como los siguientes, entre otros: a) nivel cultural de los padres, procedentes de familias obreras campesinas y no campesinas, teniendo en cuenta que entre 1930 y 1950 la tasa de no escolarizados osciló del 70 al $52 \%$; b) elevadas tasas de desescolarización; c) trabajo a corta edad de los hijos de campesinos y de los no campesinos.

\footnotetext{
141 Entendido éste como la carencia del aprendizaje básico

142 "Mientras, en la cima de la pirámide de niveles educativos (los estudios superiores y aún los estudios de grado medio) sólo encontramos a reducidas élites" (PIOT, 1991, Tomo 5, pp. 104).

${ }^{143} \mathrm{~A}$ mediados de la década de los años noventa esto ya no es necesario.
} 
Tabla 28. Evolución del analfabetismo. España, Canarias y Lanzarote 1900-1975 (\%)

\begin{tabular}{||l||r|r|r|r|r|r||}
\hline \multicolumn{1}{c|}{} & \multicolumn{1}{c|}{1900} & \multicolumn{1}{c|}{1920} & \multicolumn{1}{c|}{1940} & \multicolumn{1}{c|}{1960} & \multicolumn{1}{c|}{1970} & \multicolumn{1}{c|}{1975} \\
\hline LANZAROTE & 80,1 & 78,3 & 58,3 & --- & 21,2 & 13,7 \\
\hline CANARIAS & 75,3 & 77,6 & 51,1 & 31,9 & 22,6 & --- \\
\hline ESPAÑ A & 63,8 & 52,0 & 28,7 & 24,3 & 8,8 & 5,8 \\
\hline
\end{tabular}

Nota: 1960 no se ha contemplado porque para la isla sólo existe información de los municipios de más de 10.000 habitantes, por lo que el único municipio que se recoge es el capitalino, Arrecife, (con 18,6) que no es representativo del total insular; En los datos nacionales para 1975, no se contempla la población que no sabe leer ni escribir menor de 10 años y en los datos insulares no se contempla la menor a 6 años de edad.

Fuente: Datos insulares: Marcelo Álvarez en Estructura Social de Canarias. Cuaderno no 5 del CIES (1980). Recogido en el PIOT, 1991, Tomo 5; Datos nacionales: Censo de Población de 1900 y 1920 "Clasificación de la población de hecho. Instrucción elemental por sexo. Total nacional y Canarias". INE; Censo de Población de 1940 "Población de hecho. Alfabetos por provincias". INE; Censo de Población de 1960: "Instrucción elemental y estudios en curso, por provincias". INE; Censo de 1970, "Población según el sexo, la edad y la clase de enseñanza más elevada recibida". INE. Padrón Municipal de habitantes de 1975, INE.

Será a partir de la década de los sesenta, con las nuevas condiciones de producción desarrolladas en Canarias, que implicaron: la intensificación de las actividades productivas terciarias, el rechazo del sistema de vida rural e imbricación progresiva en la dinámica de un sistema capitalista urbano (Álvarez, M. 1980, pp. 131) y de consumo, cuando el tema educativo cobre especial importancia debido a que:

1. La enorme juventud de la población hace que sea el momento de capacitar, a través de la preparación educativa, a dicha población para enfrentar los cambios. Esta juventud hace el proceso socialmente rentable.

2. Los cambios que trae el turismo hace que se desmoronen los viejos esquemas y puntos de referencia que la población ha tenido para enfrentar el día a día, encontrándose en un momento de cambio que deja indefinido el futuro. Por tanto, la "educación se convierte en esa pieza clave para esta labor de clarificación de perspectivas posibles y deseables para comenzar a andar con coherencia por los derroteros acordados". (C.I.E.S. 1971, pp. 176).

Así, 1970 se presenta con una reducción importante en el analfabetismo insular, que se sitúan por debajo de los niveles de Canarias.

Ya entrados en el desarrollo turístico (1975), la proporción de analfabetos, se ha reducido considerablemente, "prácticamente se han invertido en comparación con el comienzo del siglo; más de cuatro de cada cinco lanzaroteños han seguido algún tipo de estudio, menos de 1 de cada cinco no sabe leer ni escribir" (PIOT, Tomo 5, pp. 105-106), el menor analfabetismo corresponde a los municipios más urbanos, con mayor actividad comercial y administrativa y de inmigración interior, como es Arrecife y San Bartolomé. 
El analfabetismo ya no es generalizado, el desarrollo económico y social, no sólo de Canarias sino también de España, ha corregido progresivamente esta situación, la isla pasa a una situación de analfabetismo restringido y registrado principalmente en los municipios de mayor ruralización. Aunque, siempre, sensiblemente superior a la media del Estado.

El comienzo de esta etapa de análisis (1970) presenta una estructura de población en relación a niveles de instrucción, marcada, por tanto, por la reducción del analfabetismo y más de dos tercios de la población $(67 \%)$ con cualificación básica (primaria). En cuanto al resto de los niveles formativos, aunque los valores son marginales, sí sobresalen los estudios técnicos medios (5,5\%), seguidos de los universitarios (4\%). El peso relativo de este extremo superior, puede ser erróneo, derivado de un hecho sociológico: "la tendencia de los titulados medios a autoclasificarse entre los titulados superiores" (Cabildo Insular de Lanzarote. Avance PIOT, 1987. Tomo 5. Cap. 1.5, pp. 109). El nivel de instrucción de la población es bajo.

Tabla 29. Nivel de instrucción. Lanzarote. 1970

\begin{tabular}{||l||r||}
\hline \hline INSTRUCCIÓN & $\%$ \\
\hline \hline Analfabetos & 21,23 \\
\hline Primaria & 67,12 \\
\hline Secundaria & 2,05 \\
\hline Título Medio & 5,48 \\
\hline Título Universitario & 4,11 \\
\hline
\end{tabular}

Fuente: Encuesta CIES. Realizada en Lanzarote para el Plan Insular de 1973. Tomo IV, pp. 279 (los datos son recogidos a finales de 1969).

Para la década de los años ochenta se tienen datos más exhaustivos, aunque los institutos de estadística se limitan a recoger datos de la población a partir de los diez años, contabilizando así grupos infantiles con estudios en curso y con años de vida académica pendiente. Esto supone introducir un elemento distorsionador de los resultados, que sesga el análisis detallado del peso relativo que tiene la formación profesional o media en la estructura demográfica insular. A pesar de ello si que podemos señalar la dinámica de evolución que en relación a la instrucción está teniendo la isla.

Con respecto a la década anterior, el fenómeno significativo es la reducción del analfabetismo de forma rápida y muy significativa, pues en 1981 se ha reducido a la mitad y al final de esta etapa (1986) parece tener un peso relativo del $5 \%$.

En el otro extremo la población con formación superior en la isla registra un movimiento descendente, además de no suponer más del 3,5\% al final de la etapa. Esta escasez caracteriza tanto al conjunto del archipiélago como a España (4\% y el 5\% respectivamente). 
Tabla 30. Evolución del nivel de instrucción. España, Canarias y Lanzarote. 1981-1986. Absolutos y relativos

\begin{tabular}{||l||l|c||c|c||c|l|l|l||}
\hline \multicolumn{1}{|c||}{} & \multicolumn{4}{c|}{ ESPAÑ A } & \multicolumn{4}{c|}{ CANARIAS } \\
\hline \hline INSTRUCCIÓN144 & 1981 & $\%$ & 1986 & $\%$ & 1981 & $\%$ & 1986 & $\%$ \\
\hline Analfabetos & 1.991 .581 & 9,17 & 1.290 .318 & 3,89 & 90.756 & 13,37 & 70.873 & 5,76 \\
\hline Sin Estudios & 6.102 .950 & 28,11 & 12.985 .870 & 39,19 & 217.490 & 32,03 & 451.156 & 36,70 \\
\hline Primer Grado & 7.676 .917 & 35,35 & 8.228 .298 & 24,83 & 187.629 & 27,63 & 301.088 & 24,49 \\
\hline $2^{\circ}$ Grado 10 Ciclo & 3.300 .610 & 15,20 & 4.733 .205 & 14,28 & 103.300 & 15,21 & 188.959 & 15,37 \\
\hline $2^{\circ}$ Grado 20 Ciclo & 1.141 .804 & 5,26 & 3.791 .193 & 11,44 & 30.034 & 4,42 & 128.018 & 10,41 \\
\hline $\begin{array}{l}\text { E. Universitaria y } \\
\text { Equivalente }\end{array}$ & 814.441 & 3,75 & 901.550 & 2,72 & 30.024 & 4,42 & 35.722 & 2,91 \\
\hline $\begin{array}{l}\text { Facultades, E.T.S. y 30 } \\
\text { Ciclo }\end{array}$ & 640.347 & 2,96 & 846.864 & 2,56 & 19.047 & 2,80 & 25.097 & 2,04 \\
\hline $\begin{array}{l}\text { No Clasificados o No } \\
\text { Especificados. }\end{array}$ & 44.057 & 0,20 & 360.161 & 1,09 & 759 & 0,11 & 28.464 & 2,32 \\
\hline TOTAL & 21.714 .707 & & 33.137 .459 & & 679.039 & & 1.229 .377 & \\
\hline
\end{tabular}

\begin{tabular}{|l|r|r||r|r||}
\hline \multicolumn{5}{|c|}{ LANZAROTE } \\
\hline INSTRUCCIÓN & 1981 & \multicolumn{1}{c|}{$\%$} & 1986 & $\%$ \\
\hline Analfabetos & 3.440 & 11,18 & 2.355 & 5,02 \\
\hline Sin Estudios & 1.735 & 5,64 & 15.867 & 33,84 \\
\hline Primer Grado & 18.002 & 58,49 & 17.208 & 36,70 \\
\hline $2^{\circ}$ Grado $1^{\circ}$ Ciclo & 4.699 & 15,27 & 4.928 & 10,51 \\
\hline $2^{\circ}$ Grado 2 ${ }^{\circ}$ Ciclo & 1.364 & 4,43 & 4.787 & 10,21 \\
\hline E. Universitaria y Equivalente & 1.041 & 3,38 & 1.131 & 2,41 \\
\hline Facultades, E.T.S. y 30 Ciclo & 463 & 1,50 & 546 & 1,20 \\
\hline No Clasificados o No Especificados & 32 & 0,10 & 43 & 0,09 \\
\hline TOTAL & $\mathbf{3 0 . 7 7 6}$ & & 46.882 & \\
\hline \hline
\end{tabular}

Fuente: Para 1981: "Población de 10 y más años que no cursa estudios según los estudios realizados. Por islas". INE, Censo de población de España. Explotación del CEDOC; "Población de 10 y más años de Canarias según el nivel de instrucción (completado), 1981". Estadísticas básicas de Canarias. 1980-1985. ISTAC; "Población de 10 y más años que no cursa estudios por Ámbito Territorial y estudios realizados. Total Nacional".Censo de Población de 1981. INE.

Para 1986: "Población de 10 y más años según título académico". Resultados Autonómicos, Provinciales e Islas. Padrón Municipal de habitantes de 1986. Explotación del ISTAC y del INE para el total nacional. Elaboración propia.

144 La clasificación establecida considera lo siguiente: Primer grado (EGB $1^{\circ}$ etapa, educación especial, primaria, preaprendizaje industrial y alfabetización de adultos); Segundo grado: $1^{\circ}$ Ciclo (EGB $2^{\circ}$ etapa o ESO, Grado Elemental Conservatorio de música, Artes y Oficios, Bachiller elemental, otros medios elementales), $2^{\circ}$ Ciclo (BUP y COU, FPI y II, Grado Medio Conservatorio, Oficialía Industrial, etc.); Tercer grado (Escuelas Universitarias y equivalentes) y Nivel Universitario (Facultades, Escuelas técnicas superiores y postgraduados y doctores). 
Gráfico 23. Evolución del nivel de instrucción. Lanzarote. 1970-1986 (\%)

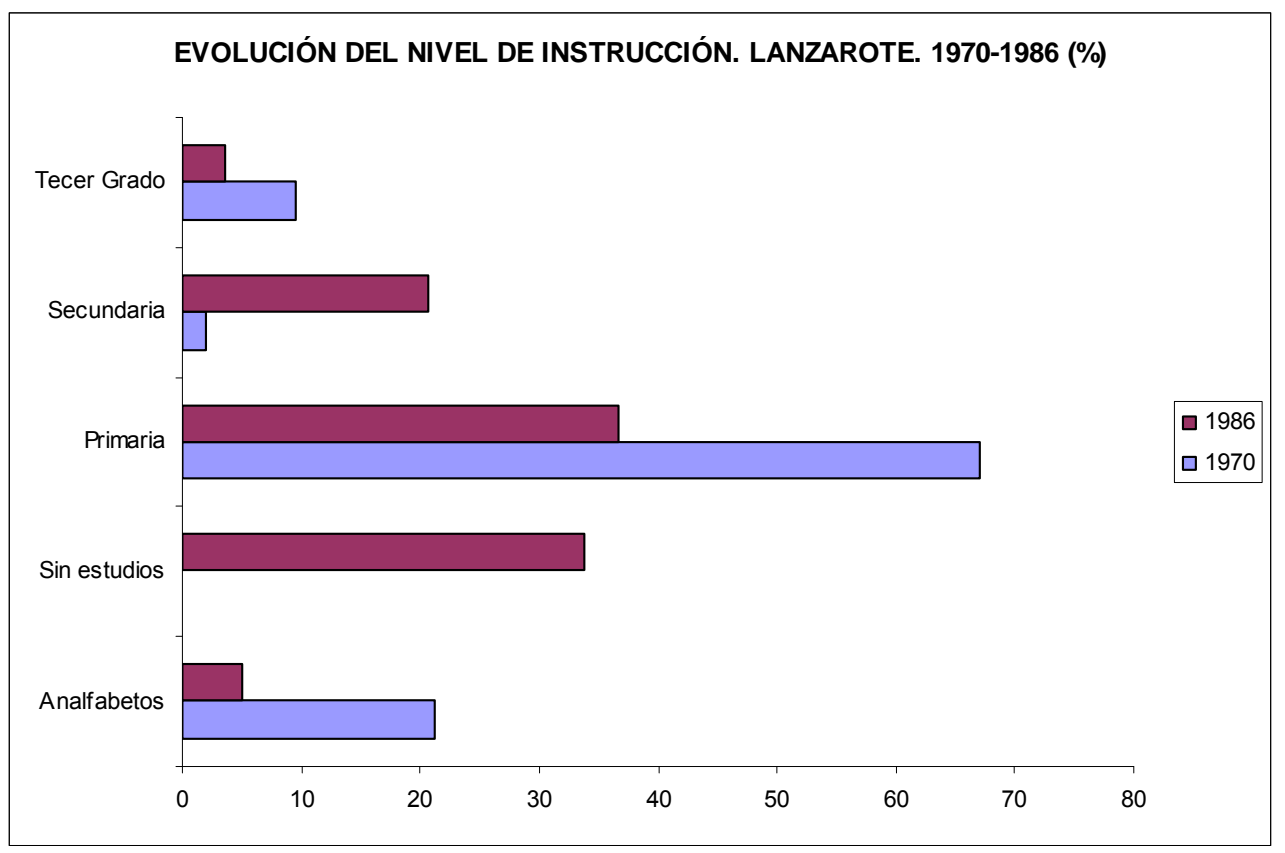

Fuente: Estadísticas básicas de Canarias, Censo de Población y Padrón Municipal. CEDOC, ISTAC e INE. Elaboración propia.

La información recogida en las tablas anteriores, nos muestran una población insular dominada por la escasa instrucción escolar formalizada, que entendida como instrumento de formación del recurso humano, nos da idea de una estructura demográfica de baja capacitación y con tendencia a concentrarse en niveles que indican no finalizar la educación general básica. Este fenómeno, y su crecimiento, puede ser explicado por diferentes aspectos: en primer lugar la distorsión que genera trabajar con datos de población a partir de diez años (en esta época la enseñanza obligatoria es hasta los catorce) pues no nos permite acercarnos a su peso relativo con mayor fiabilidad, además la isla se caracteriza por un perfil demográfico joven, al igual que el conjunto del archipiélago), pues el $29 \%$ de la población tiene menos de quince años de edad ${ }^{145}$. El dato más lógico y por tanto más próximo a lo que puede ser la realidad insular lo encontramos en el análisis que realiza el Avance del PIOT en el año 1987 (Tomo 5. Cap. I. Tabla 5.1, pp. 109), a partir de la población mayor de 14 años de edad, para el 1981, concluyendo que el $45 \%$ de la misma se localiza al nivel de estudios primarios incompletos; y en segundo lugar, el boom inmobiliario que vive la isla en el año 1986, con incrementos de la oferta turística entre 1981 y 1986 del orden del $200 \%$ atrae población externa hacia la construcción y el sector

145 La población entre cero y catorce años tiene un peso relativo del 29\% en Lanzarote, y en Canarias del 27\%. Fuente: "Estructura de población de Canarias por edad y sexo, por isla. 1986". Anuario estadístico de Canarias, 1986. Tomo I. CEDOC. 
servicios no avanzado dirigido al turista, ámbitos económicos que no exigen formación y en el que se pueden localizar recursos humanos que sólo han alcanzado lo niveles primarios de instrucción.

La dinámica de evolución autonómica y nacional parece ser similar.

Por tanto, en las etapas posteriores ha de observarse cómo evoluciona el peso de la población sin estudios, cuyo crecimiento parece marcar toda la década de los años ochenta, pues las ofertas laborales insulares no se caracterizan por precisar de capital humano con elevada capacitación.

Gráfico 24. Evolución del nivel de instrucción. Lanzarote. 1981-1986

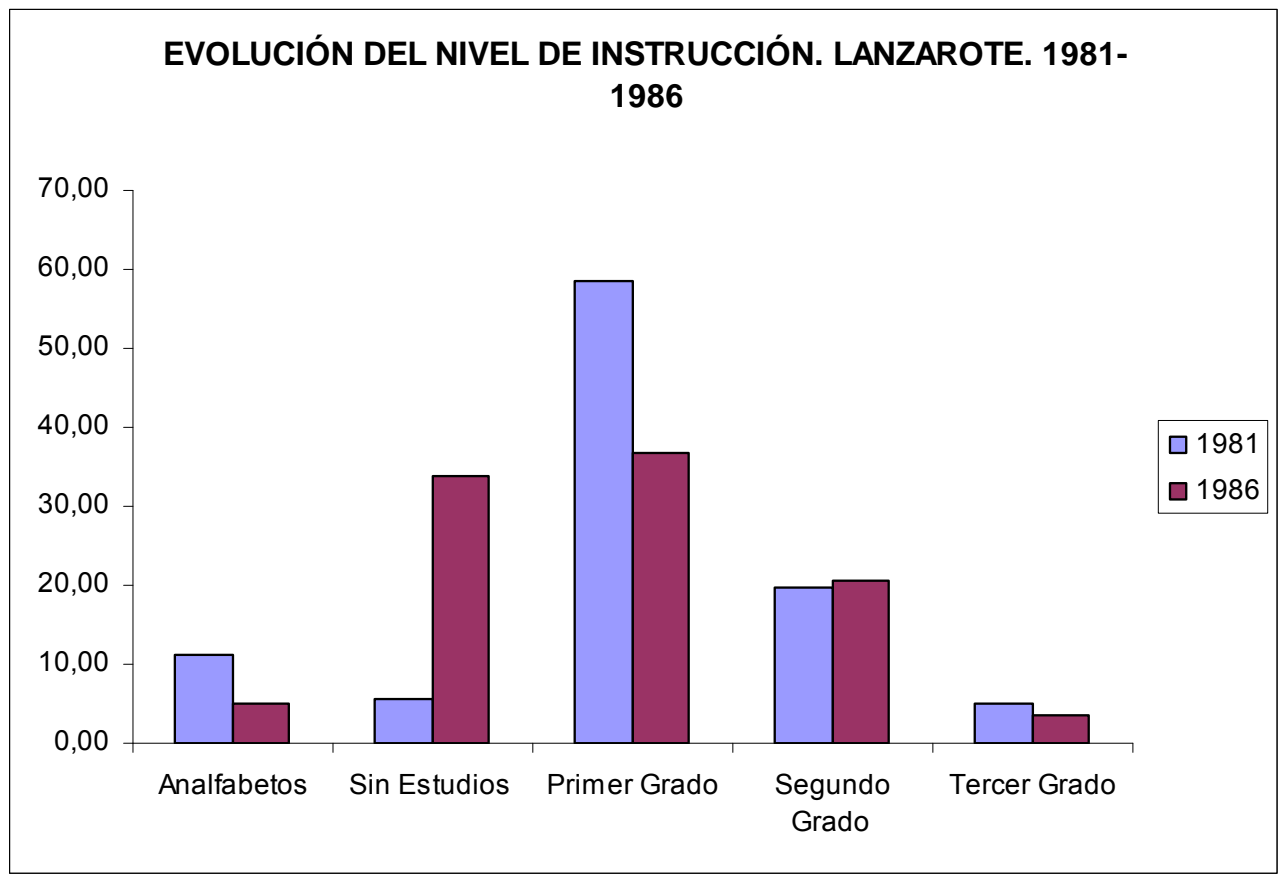

Fuente: Estadísticas básicas de Canarias, Censo de Población y Padrón Municipal. CEDOC, ISTAC e INE. Elaboración propia.

A pesar de ello, la estructura educativa de Lanzarote va incorporando, progresivamente, más población con formación profesional (segundo ciclo de grado medio). Que en la población de 10 y más años de edad supone una variación importante en su peso relativo en Lanzarote, pasando del $2 \%$ en 1970 a casi el $20 \%$ en una década (1981), aunque su crecimiento posterior hasta 1986, será escaso. En este sentido la evolución está siendo positiva. Aunque por debajo del cómputo autonómico y nacional en aproximadamente un $5 \%$. Será necesario observar el papel que está teniendo la incorporación de población externa en esta evolución.

En términos generales los españoles, y en particular los canarios, tienen escasa formación. 
Gráfico 25. Evolución del nivel de instrucción. España, Canarias y Lanzarote. 1981-1986

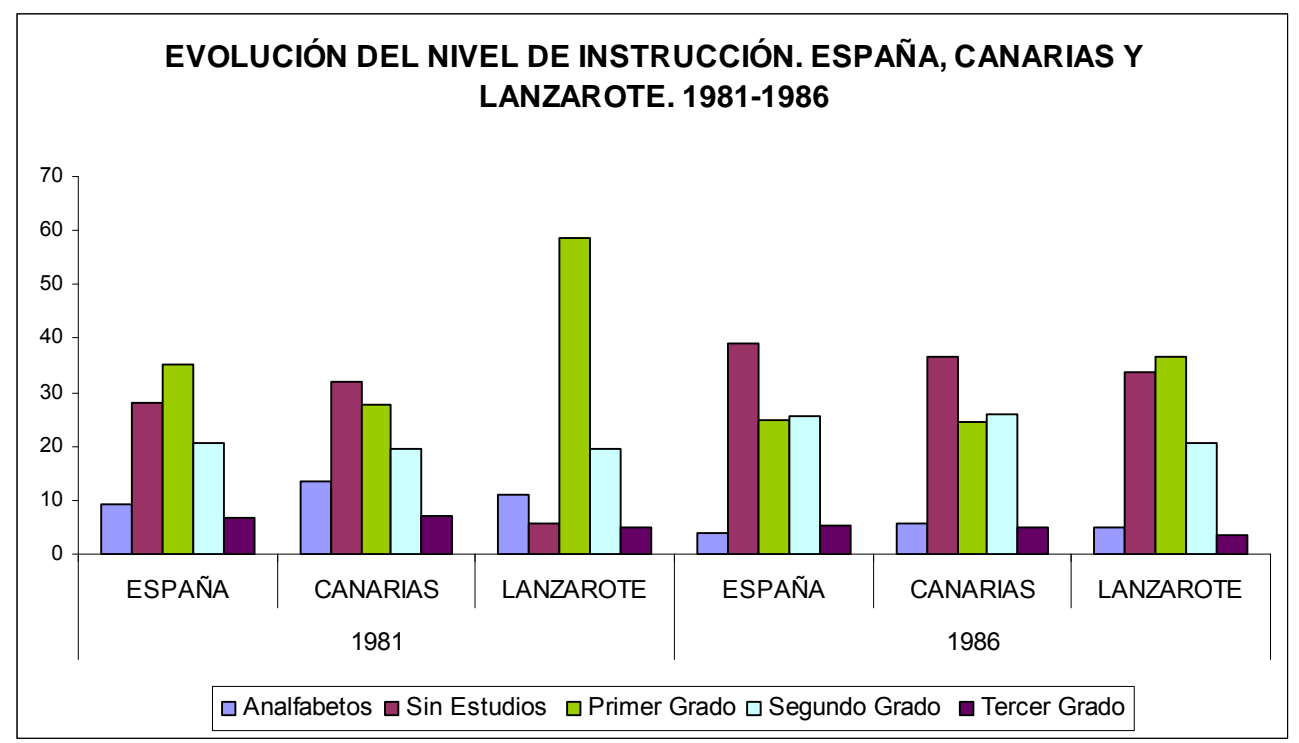

Fuente: Estadísticas básicas de Canarias, Censo de Población y Padrón Municipal. CEDOC, ISTAC e INE. Elaboración propia.

En cuanto al nivel formativo de los inmigrantes resulta difícil establecer su evolución como consecuencia de la falta de explotaciones censales y padronales con tal desagregación, tanto para el cómputo insular como para el nacional. Esta realidad no nos permite elaborar evidencias empíricas evolutivas. Aún así, en las próximas líneas se intenta dar idea del estado en el que se encuentra este colectivo dentro del ámbito formativo, puesto que la isla en el período de análisis, aquí establecido, se asienta como territorio receptor de población, tanto nacional como extranjera y se constata que lo que se eleva entre 1981 y 1986 es la población con formación básica y sin estudios.

La población inmigrante en la isla de Lanzarote que va a tener efectos sobre la estructura educativa insular, en el año 1981, será la proveniente de otras islas del archipiélago $(53,2 \%$ del total de inmigrantes internos) junto con la que procede de otras Comunidades Autónomas $\left(37,7 \%\right.$ del total de inmigrantes internos) ${ }^{146}$. La inmigración exterior (otros países) sólo supondrá en este momento el 6\% (PIOT, 1991. Tomo 5, Capítulo I, pp. 100), por lo que no se ha considerado significativa en la estructura formativa insular, sí lo será en el futuro tanto en niveles formativos como en el mercado laboral.

\footnotetext{
146 Véase AUIA. Avance PIOT, 1987. Tomo 5. Cap. I. Epígrafe 5.1.2. Efectos del turismo sobre la estructura demográfica básica. Apartado 5.1.2.1.2.
} 
Tabla 31. Inmigrantes por nivel de instrucción y lugar de procedencia. Lanzarote. 1981 (\%)

\begin{tabular}{||l||c|c||}
\hline \multicolumn{1}{|c||}{} & \multicolumn{2}{c|}{ PROCEDENCIA } \\
\hline \hline INSTRUCCION & Provincia & Resto de España \\
\hline \hline No sabe leer ni escribir & 33,6 & 15,6 \\
\hline Primaria incompleta & 38,6 & 29,3 \\
\hline Primaria o $1^{\text {a }}$ Ciclo EGB & 17,6 & 21,4 \\
\hline Bachiller Elemental o ${ }^{\circ}$ Ciclo EGB. & 5,1 & 10,7 \\
\hline F. P. y Oficialía & 0,6 & 2,0 \\
\hline Bachiller Superior y COU & 2,0 & 7,7 \\
\hline Títulos medios & 1,0 & 5,3 \\
\hline Titulados superiores & 1,5 & 8,0 \\
\hline \hline
\end{tabular}

Nota: A partir de los datos municipales se ha calculado la media insular.

Fuente: Avance PIOT. Análisis y diagnóstico de la situación actual. Área de Sociedad y turismo. Anexo al epígrafe 4, Tabla 4.8. "Los inmigrantes por el nivel de instrucción según tipo de procedencia, por municipios, 1981 (\%)". Tomo 5, 1987. Cabildo Insular de Lanzarote. Elaboración propia.

Los inmigrantes asentados en la isla, en este momento, se caracterizan por concentrarse en niveles formativos muy bajos, o son analfabetos o no completaron la primaria, tanto en el caso de los provenientes de la provincia $(71,2 \%)$, como los que vienen del resto de España (45\%). EI PIOT (1991, Tomo 5, Capítulo I, pp. 100) explica dicha diferencia, en relación a la "forma de calcular las proporciones: en ambos casos sobre la población inmigrante total respectiva. Dado que el peso de los niños es muy superior entre los inmigrantes internos que entre los externos". Si ello es así, los porcentajes señalados no arrojan datos fiables sobre la formación de la inmigración, al menos en los primeros niveles, aunque lo que sí están evidenciando dichos datos es que los inmigrantes externos a las islas destacan en los niveles formativos más altos, haciendo la mayor aportación a la formación profesional (secundaria en todos sus niveles) y universitaria ( $23 \%$ frente al $5 \%$ de los provenientes de la provincia). 
Gráfico 26. Inmigrantes por nivel de instrucción y procedencia. Lanzarote. 1981 (\%)

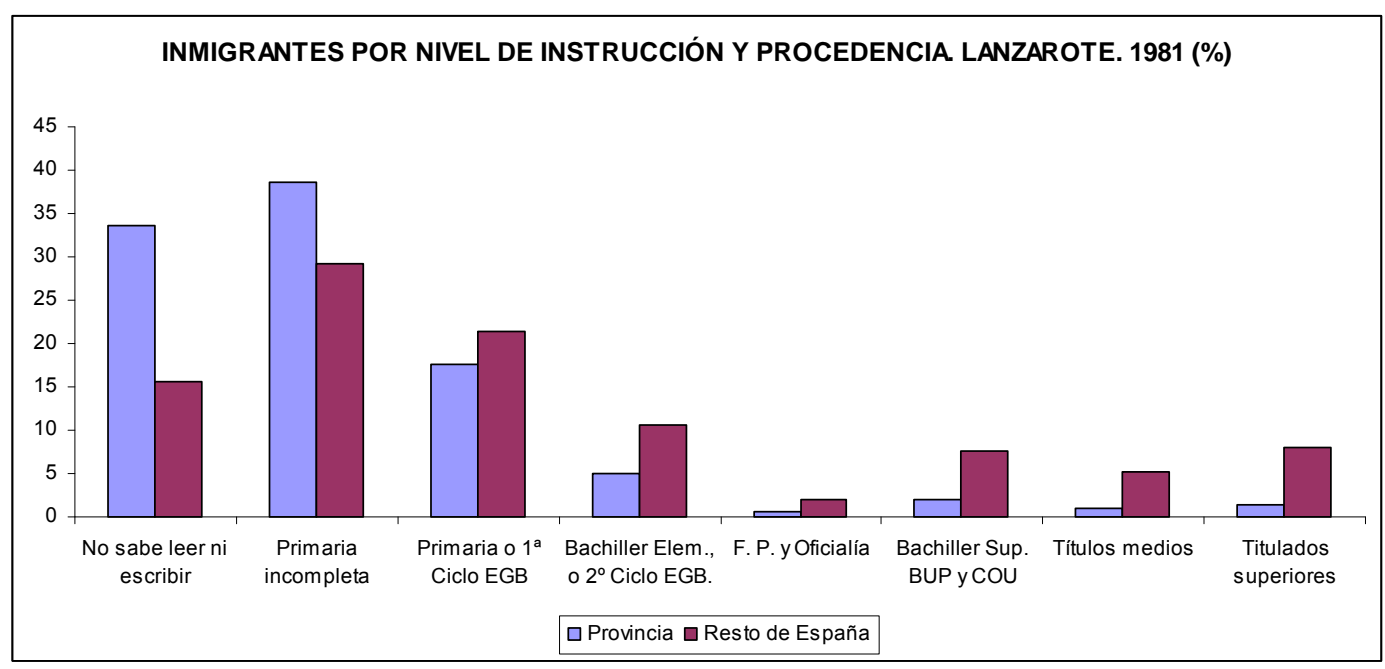

Fuente: Elaboración propia a partir de AUIA, Avance PIOT de Lanzarote, Tomo 5, 1987.

Ante esta situación descrita para Lanzarote, el estado de la nación, al respecto, varía cualitativamente, puesto que la población inmigrante exterior, en España, se sitúa, para 1981 , en el nivel formativo básico (33\%) y medio (37\%) mayoritariamente.

Tabla 32. Inmigrantes por nivel de instrucción. España. 1981 (\%).

\begin{tabular}{|l|r|}
\hline INSTRUCCIÓN & $\%$ \\
\hline \hline Analfabetos & 2,08 \\
\hline Sin estudios y No Clasificados & 16,78 \\
\hline Primer Grado & 32,57 \\
\hline Segundo Grado & 37,41 \\
\hline Enseñanzas Universitarias & 11,15 \\
\hline
\end{tabular}

Fuente: "Población de 11 y más años por sexo, relación municipio 1970-1981 (del extranjero) y nivel de instrucción. Censo de Población y Viviendas, 1981. INE.

\subsubsection{2.- EL EQUIPAMIENTO EDUCATIVO}

El crecimiento turístico puede entrañar importantes consecuencias disfuncionales, puesto que el proceso entra en conflicto con la capacidad de los propios recursos de la isla. En este caso, la presión que el crecimiento de la población, derivado de la inmigración laboral, ejerce sobre el equipamiento educativo, puede llevar a estrangulamientos o déficits dotacionales en el mismo.

A lo largo de este epígrafe se hará una descripción cuantitativa de la evolución de la oferta y demanda de los servicios educativos en la isla, a fin de estimar los posibles déficits funcionales de la dotación. 
Los análisis se realizarán en relación a la Ley de educación vigente y de los estándares que presenta. Esta etapa de despegue y consolidación de la isla como destino turístico de masas, se enmarca dentro de la Ley 14/1970 de 4 de agosto, General de Educación y Financiamiento de la Reforma, bajo una política cuya principal aspiración en este momento es democratizar la enseñanza. Es por ello que en este análisis, además de las capacidades de los centros educativos, han de tenerse en cuenta dos indicadores: la población en edad escolar y la población escolarizada, para dar idea del estado de dicha democratización y de su evolución, en cuanto aspecto relevante en el bienestar de las sociedades.

Todos los centros de enseñanza pueden tener una titularidad tanto pública como privada, o privada-concertada. Para medir la cantidad de equipamiento tomaremos el conjunto de centros por nivel educativo, independientemente de su titularidad, puesto que lo que importa es contabilizar el total de la oferta. Por otro lado, se parte de entender que hay varios niveles dentro del sistema educativo esenciales en el bienestar en las sociedades actuales desarrolladas, y que en ámbito insular pueden presentar una escasa oferta, éstos pertenecen a la educación no obligatoria: educación infantil, educación especial y permanente de adultos.

El equipamiento social en la década de los sesenta y comienzo de los setenta se caracteriza por su "insuficiencia y concentración en determinados puntos de relevancia administrativa", principalmente el municipio capitalino, Arrecife (que absorbe casi todo el equipamiento insular), y las cabezas municipales. Por tanto, uno de los objetivos de la Planificación de 1973 será "modificar las áreas de influencia de modo que cubran todo el territorio habitable”. (Plan Insular, 1973. Documento $\mathrm{VI}^{147}$, pp. 224-225).

Los centros de enseñanza primaria serán fundamentales, puesto que son el centro neurálgico en el proceso de desarrollo, la punta de lanza para desarticular el círculo vicioso de la pobreza y adaptar el capital humano insular a las actividades económicas turísticas que han despuntado en la isla.

Los centros escolares previstos en la Ley de educación para la E.G.B., son de tres categorías que corresponden con su capacidad, estableciendo 40 alumnos por unidad.

Arrancamos la etapa presentando brevemente la información que nos facilita el Plan Insular de 1973, que está principalmente referida a los cursos 1967-1968 y 1968-1969.

147 Documento VI. Ordenación Económica y Social, 1973. 
Tabla 33. Relación alumnos/maestros/as en primera enseñanza*. Lanzarote. Curso 1967-1968

\begin{tabular}{|l|c|c|c||}
\hline Nivel & Maestros & Alumnos $^{* *}$ & Alumnos/Maestro \\
\hline \hline $1^{0}$ Ciclo E.G.B & 151 & 5.021 & 33 \\
\hline Enseñanza Especial & No consta & No consta & --- \\
\hline TOTAL & 151 & 5.021 & 33 \\
\hline
\end{tabular}

(*) $1^{\circ}$ Ciclo de E.G.B.

$\left({ }^{*}\right)$ Población escolarizada.

Fuente. Centros (escuelas) y unidades totales en la isla recogidas en el Plan Insular de 1973, Documento VI. Ordenación Económica y Social: VI.7. Equipamiento Social, Anexo 8, pp. 326; Para profesores y alumnos consta los recogidos para el curso 1967-1968 en el nivel de enseñanza primaria ( $1^{\circ}$ ciclo de E.G.B.) por el Plan Insular 1973, Documento VI. Ordenación Económica y Social: VI.7. Equipamiento Social, Anexo 8, pp. 327. Elaboración propia.

En cuando al $1^{\circ}$ ciclo de la Educación General Básica, la relación alumno/maestro se establece en 33 alumnos (entre 6 y 11 años) por profesor. Si consideramos que a cada unidad le corresponde un profesor, no se observan déficit de plazas, antes de que finalice la década de los años sesenta, puesto que no llega a completarse el estándar de la Ley (40 alumnos por unidad), aunque tenemos que tener en cuenta que los datos que se aportan son en relación a los alumnos escolarizados y no sobre el total de población de la cohorte de edad que corresponde a la enseñanza de primer ciclo.

El curso 1968-1969 es el que realmente nos facilita datos en relación al posible déficits de plazas escolares de educación básica en la isla. Con 147 unidades escolares estimadas en la isla no se puede cubrir el estándar que marca la Ley de educación, puesto que hay casi 46 niños por unidad, eso teniendo sólo en cuenta la población escolarizada, pero si lo que tenemos en cuenta es la población potencial que puede ser escolarizada (entre 6 y 14 años), el déficits es aún mayor ya que para cubrir la demanda demográfica en ese año escolar harían falta aproximadamente 197 unidades, casi 50 más de las existentes. El déficits real de plazas, por tanto, es de 1.978 , el $25 \%$ de la necesarias. 
Tabla 34. Capacidad docente. E.G.B. Lanzarote. Curso 1968-1969

\begin{tabular}{||l|c|}
\hline Centros & 40 \\
\hline Unidades & 147 \\
\hline Población de 6 a 14 años & 7.858 \\
\hline Población Escolarizada & 6.685 \\
\hline Población No escolarizada & 1.173 \\
\hline Alumnos/Unidades* & 45,5 \\
\hline Población Potencial/ unidades (de 6 a 14 años) & 53,5 \\
\hline Unidades Necesarias & 196,5 \\
\hline Unidades que faltan & 49,5 \\
\hline Plazas que faltan & 1.978 \\
\hline
\end{tabular}

$\left(^{\star}\right)$ Relación entre alumnos escolarizados y unidades escolares.

Fuente. Centros (escuelas) y unidades totales en la isla, 1969, recogidas en el Plan Insular de 1973, Documento VI. Ordenación Económica y Social: VI.7. Equipamiento Social, Anexo 8, pp. 326; La población total entre 6-14 años y el Total escolarizados está recogido de el Plan Insular de 1973, Documento VI. Ordenación Económica y Social: VI.7. Equipamiento Social, Anexo 8, pp. 332. Elaboración propia.

Entrada la década de los años setenta, el Plan Insular de Ordenación del Territorio (1973) estima el déficits de plazas escolares para E.G.B. en 1.450 plazas (Documento VI. 7, Anexo 8, pp. 231), que aquí tomamos como dato de arranque de la etapa (1970-1986), aunque es de señalar que no indica cómo se llega a dicha estimación. Para 1970, la única referencia gira alrededor de la población escolar que es subdividida en dos categorías referidas a edades y ciclos (Plan Insular de 1973. Documento VI. 7, Anexo 8, pp. 229):

a) De 5 a 15 años de edad, que abarca a la población comprendida dentro del ámbito de la Educación General Básica (E.G.B.) y que se sitúa en 9.665 alumnos.

b) De 15 a 20 años, que abarca a la población que puede realizar estudios superiores o incorporarse al mercado productivo, por tanto son alumnos potenciales. Se contabilizan en 3.855.

Bajo la intensión de medir la evolución de este déficits, a lo largo de la década de los años setenta, los datos existentes sobre centros, unidades y puestos escolares han sido recogidos del Plan de Ordenación de la Oferta Turística de la isla de 1982, sobre el que se detectan deficiencias pues se limita a analizar el equipamiento escolar sin referencias en relación al tipo de enseñanza que imparten los centros, unidades y puestos escolares. Es por ello que los datos existentes entre 1976 y el año 1981, son pobres y confusos para el ámbito insular, por lo que la relación oferta y demanda que señalen no será comparable con 1970. Así, no será hasta 1986 cuando la información que recogen los organismos oficiales está mejor desagregada y es más factible. 
No obstante, reproducimos, en la siguiente tabla, la información existente al respecto para los cursos 1976-1977 y 1980-1981, que pueda tener cierta coherencia en relación a los datos de comienzo de la década. Teniendo en cuenta que el número de centros no se va a señalar puesto que la cuantificación que realiza el Plan de 1982, anteriormente citado, es incoherente con respecto a los datos de 1970 de los que se dispone, en el PIOT de 1973, en la medida en que supone una reducción de centros escolares en la isla de más del $50 \%{ }^{148}$.

Tabla 35. Capacidad docente. Cursos 1976-1977 y 1980-1981. Lanzarote

\begin{tabular}{||l|c|c|c|}
\hline Curso & Unidades & \multicolumn{1}{|l|}{ Puestos } & Alumnos/unidad \\
\hline \hline $\mathbf{7 6 - 7 7}$ & 294 & 10.712 & 36,4 \\
\hline $\mathbf{8 0 - 8 1}$ & 404 & 12.995 & 32,2 \\
\hline
\end{tabular}

Fuente: Secretaría de Estado de Turismo. "Plan de Ordenación de la Oferta turística de la isla de Lanzarote. Tomo III". 1982 (pp. 298). Elaboración propia.

En cuanto a la capacidad docente, señalada en la anterior tabla, ésta ha ido aumentando a lo largo de la década de los años setenta, de modo que el número de plazas docentes se incrementa, posicionándose por debajo del estándar legal que se sitúa en esta época en 40 alumnos por unidad. Es por ello que estos datos insinúan reducción del déficits, aunque no será hasta entrada la década de los ochenta cuando la fiabilidad de los mismos nos acerque a la realidad académica insular.

Tabla 36. Alumnos por nivel de instrucción. Cursos 1976-1977 y 1980-1981. Lanzarote

\begin{tabular}{||l|r|r||}
\hline \hline Nivel & Curso 76-77 & Curso 80-81 \\
\hline \hline Preescolar & 324 & 1.139 \\
\hline E.G.B. & 9.800 & 10.626 \\
\hline Formación Profesional $^{*}$ & 836 & \\
\hline Educación Especial $^{*}$ & 21 & -- \\
\hline Educación de adultos $^{*}$ & 84 & 60 \\
\hline
\end{tabular}

Fuente: Secretaría de Estado de Turismo. "Plan de Ordenación de la Oferta turística de la isla de Lanzarote. Tomo III". 1982 (pp. 311 316). ( $\left(^{*}\right)$ En la década de los años setenta es tipo de enseñanza era itinerante, por lo que los diferentes tipos de cursos se trasladan de municipio en municipio. Para el curso 1980-1981 no consta. Elaboración propia.

Hasta la década de los años ochenta la educación preescolar es muy reducida en la isla. Tanto en el caso de la educación especial (sólo se imparte hasta el curso 78-79) como en la

148 Curso 1976-1977: 12 centros escolares; Curso 1980-1981: 43 centros escolares. Secretaría de Estado de Turismo. "Plan de Ordenación de la Oferta turística de la isla de Lanzarote. Tomo III". 1982 (pp. 298). 
de adultos, habrá cursos en los que se imparta y otros en los que no, es intermitente. A ello se une la formación profesional, que es volante, itinerante, "ya que según cursos, el mismo tipo va de un municipio a otro con objeto de facilitar el acceso de la población a esta modalidad" (Plan de Ordenación Turística, Tomo III, 1982 (pp. 311-316). Por tanto, el único nivel formativo estable es el de la Educación General Básica. El resto de los servicios están sujetos a oferta institucional, y son aún pobres en la isla.

Centros de formación universitaria no existen en esta etapa de desarrollo, están centralizados en las capitales de provincia y la única Universidad existente está en Tenerife. Ello dificulta el acceso de la población a dichos niveles educativos, puesto que conlleva desplazamiento y eleva el coste para las familias. Aunque en 1973 ya hay sede de la UNED. El planificador alega sobre la necesidad de descentralizar este tipo de formación y localizar en la isla titulaciones de primer ciclo, pero esto no será una realidad hasta la década de los años noventa.

La siguiente figura señala los centros docentes de enseñanza no obligatoria que existen en Lanzarote en 1973, donde resalta la centralización, en la capital Arrecife, de dicho equipamiento.

Mapa 4. Centros docentes de educación no obligatoria. Lanzarote. 1973

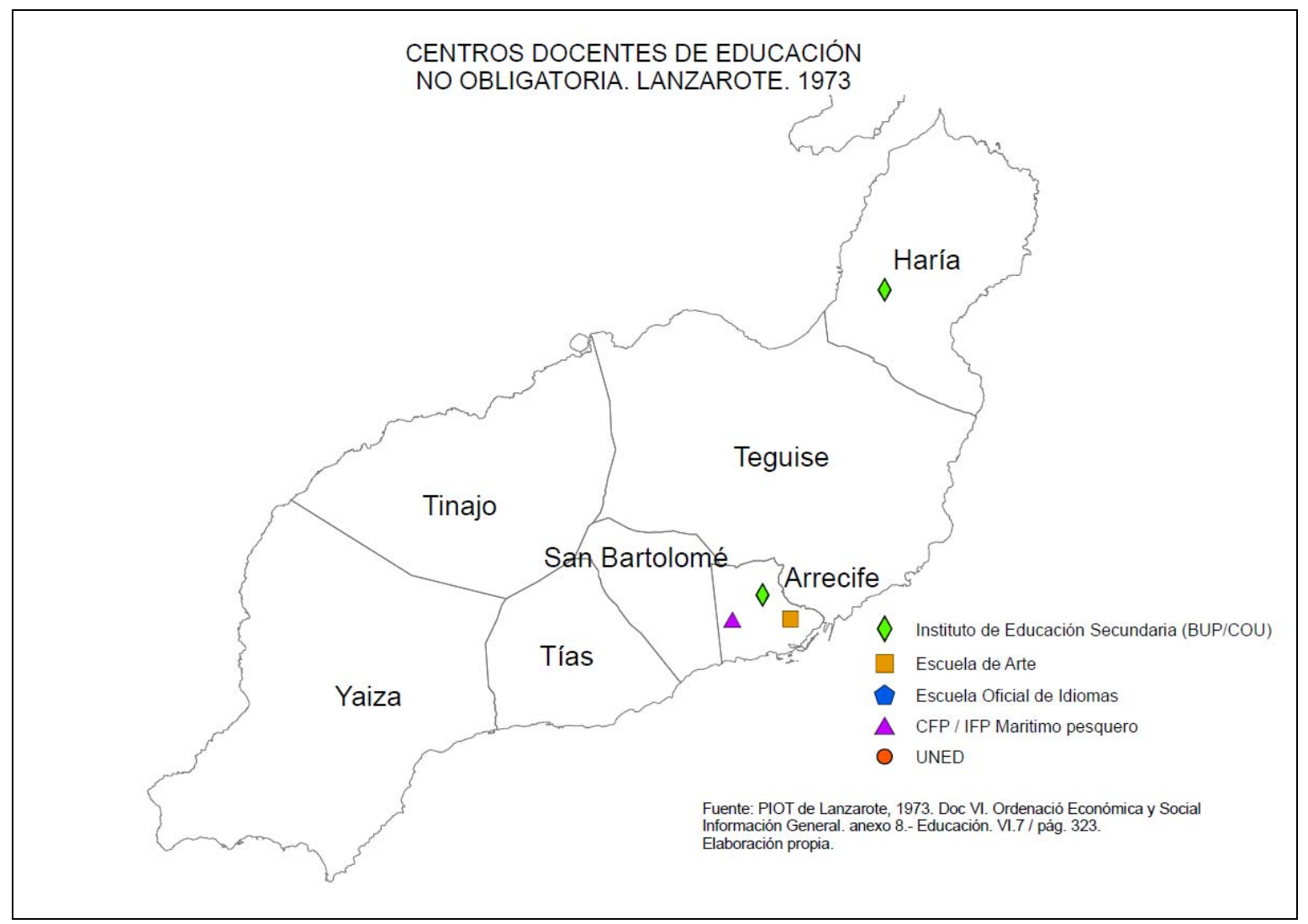


El proceso de incremento del equipamiento que viene aconteciendo, hace que, en los años ochenta, los déficits en el área educativa empiezan a ser puntuales, o sea, insuficiencia sólo en el caso de algunos niveles de formación. No será, por tanto, hasta finales de la década de los años ochenta, cuando la isla, mejore su equipamiento educativo.

Para los próximos datos que se van a analizar y dónde se establece la demanda potencial en los diferentes niveles educativos, se ha de tener en cuenta que se ha calculado sobre la base de la población residente o de derecho (registrada en el Padrón Municipal de 1986), sin considerar la posible existencia de demandas extracensales; ello puede llevar a una "subvaloración de la cuantificación total, por no tener en cuenta la demanda proveniente de familias de inmigrantes no censados" (Avance PIOT, 1987, Tomo 5. Cap. II, pp. 18), cuyo origen, en su mayoría, estará en otras islas del archipiélago y el resto de comunidades autónomas del país, como se ha señalado en epígrafes anteriores. Cabe, por tanto, la posibilidad que la demanda real sea mayor de la manejada. $\mathrm{Ni}$ que decir tiene que en sociedades de economía turísticas y fuerte crecimiento inmobiliario, como es en este momento Lanzarote, la demanda real en las dotaciones de bienestar estará sujeta a las variaciones de los ritmos constructivos que se desarrollen en la isla, que atraen más o menos mano de obra y con ella a sus familias.

El análisis de la segunda mitad de la década de los años ochenta se enmarca dentro de la Ley Orgánica 8/1985, de 3 de julio, reguladora del Derecho a la Educación. Aunque no será hasta 1991 cuando exista un reglamento, derivado de la misma, donde se regulen los estándares de calidad (Real Decreto 1004/1991, de 14 de junio) para enseñanzas de régimen general no universitarias (requisitos mínimos: relación alumno/profesor, alumno/unidad, etc.).

El curso 1986-1987 se presenta con mayor optimismo con respecto a cursos anteriores. En primer lugar por el superávit que presenta la isla en una dotación como es la enseñanza de "preescolar" (con una cobertura del 100,1\%), que mejora mucho el mapa de bienestar insular, puesto que no es obligatoria la escolarización a estas edades (4-5 años) y no existe estándar de calidad en la legislación en este momento, aun así, el ratio alumno/aula (unidad), se sitúa alredor de 21 alumnos, lo que se considera bastante satisfactorio. Es necesario señalar que, para este nivel, los déficits son municipales, aunque aquí no serán analizados puesto que este trabajo tiene como ámbito la isla y su dinámica ${ }^{149}$. Adicionalmente, la demanda real teniendo en cuenta la inmigración no censada, es

149 Para ampliar la información y análisis al ámbito municipal consultar el Avance del PIOT, 1987, Tomo 5. Capítulo II.2. (pp. 11-66). 
estimada por el PIOT (Avance, 1987, Tomo 5. Cap. II, pp. 19) entre el $5 \%$ y el $8 \%$ de incremento sobre la demanda global manejada.

Tabla 37. Oferta y demanda docente. Infantil, E.G.B. y Medias. Lanzarote. Curso 1985-1986

\begin{tabular}{|c|c|c|c|c|}
\hline & Nivel & $\underset{\left({ }^{* \star *}\right)}{\text { Infantil-Preescolar }}$ & $\begin{array}{l}\text { Primaria y Secundaria } \\
\text { Obligatoria (EGB). }\end{array}$ & $\begin{array}{c}\text { Secundaria no } \\
\text { obligatoria (BUP, COU, } \\
\text { F.P.) }\end{array}$ \\
\hline Centros & & 46 & 46 & 7 \\
\hline Unidades & & 79 & 402 & 215 \\
\hline Puestos (oferta) & & 1.920 & 13.288 & 3.120 \\
\hline Profesores* & & 41 & 356 & No consta \\
\hline Alumnos $* *$ & & 1.642 & 10.700 & 2.583 \\
\hline $\begin{array}{l}\text { Población de Derec } \\
\text { (demanda) }\end{array}$ & & 1.918 & 9.174 & 4.700 \\
\hline Nivel de Cobertura. & ferta (\%) & 100,1 & 124,2 & 66,4 \\
\hline Superávit o déficit & Absolutos & 2 & 2.588 & 537 \\
\hline & $\%$ & 2 & 19,5 & 17,2 \\
\hline Alumnos/Unidad & & 20,6 & 28,5 & 12,0 \\
\hline
\end{tabular}

$\left({ }^{*}\right)$ Sólo constan los profesores de centro públicos. $\left({ }^{* *}\right)$ Se contabilizan los matriculados. $\left.{ }^{* * *}\right)$ Los centros de educación infantil y E.G.B. que se contemplan, están dentro de Centros que también imparten primaria y medias. El dato se refiere a párvulos, entre 4 y 5 años de edad.

Nota: dentro de la Formación profesional se incluye la Escuela Marítimo Pesquera y la de Artes y Oficios.

Fuente: Centros, unidades y plazas, preescolar, E.G.B., Curso 1986-1987, en Avance PIOT, 1987, Tomo 5, Cap. II, cuadro 2.1, 2.2, 2.5, (pp. 16, 18, 27); "Alumnos matriculados en EGB y Educación Especial. Curso 1985-1986. Lanzarote. Anuario Estadísticas de Canarias, 1986. ISTAC; "Unidades y alumnos matriculados, por nivel. Lanzarote. Curso 1985-1986". Anuario estadístico de Canarias. Tomo I, Tablas 13.A, B, C (pp. 352-353), 1986. CEDOC; "Número de profesores de centros públicos de educación primaria Curso 1984-1985. Lanzarote". Estadísticas insulares y municipales de Canarias, 1986. ISTAC. Elaboración propia.

Para el análisis cuantitativo de las dotaciones en Educación General Básica, no nos sirve tomar la demanda potencial de alumnos (población derecho entre 6 y 13 años), puesto que la matriculación registrada supera esta cifra (cuya explicación se encuentra en los alumnos que repiten curso y la población en edad escolar no registrada en el padrón), por lo que la matriculación es la que va a marcar en este caso la cobertura de la oferta y la relación alumnos/unidad. Así, el nivel de oferta o porcentaje de cobertura posible, estimado, es bastante satisfactorio, puesto que supone el $124 \%$ sobre la demanda potencial, lo que permite abordar crecimientos de demanda a corto plazo. La escolarización ya es plena ${ }^{150}$. La oferta de puestos supera a la demanda, el superávits se estima en $24 \%$. Esta sobretasa permite un ratio alumno/aula muy satisfactorio, al estar por debajo de 30 alumnos/aula.

Es por ello que no cabe hablar de déficits dotacional insular en el nivel de E.G.B.; no obstante desde una perspectiva de resultados del servicio ofertado la situación cambia si se analiza el fracaso escolar. Para el curso 1984-1985 la tasa de obtención del graduado

150 El Avance del Plan Insular (1987) de 1991 la estima en 99,1\% (Tomo 5. Capítulo II. Cuadro 2.8. (pp. 35). 
escolar se estima en $67 \%$, frente al $57 \%$ de Canarias. Los resultados son negativos no sólo para la isla, sino también para toda la comunidad autónoma (Avance PIOT, 1987. Tomo 5. Cap. II, pp. 40-42).

En cuanto a la enseñanza secundaria no obligatoria, el estándar técnico con el que se trabaja en la época, establece la tasa de escolarización aceptable para adolescentes entre 14 y 17 años, en un 80\% (Avance PIOT, 1987, Tomo 5. Cap. II, pp. 43), sin embargo, la tasa de cobertura real de la oferta de la isla es ligeramente superior al $66 \%$, lo que supone un notable déficits con respecto al estándar mencionado. Este hecho tiene su explicación en la abundante oferta laboral que existe en la isla, frutos de los desarrollos turísticos, que disuade a los adolescentes de seguir las enseñanzas medias. Así, para el curso 1985-1986, el Avance del PIOT estimó un 35,6\% de la población entre 14 y 17 años inserta en el mercado de trabajo (Tomo 5. Cap. II, pp. 45). Esta realidad empobrece el nivel cultural de la población, que es vía para mejorar el bienestar.

Sin embargo, la capacidad dotacional de la isla, al respecto, presenta un superávit del $17 \%$, debido a la escasa escolarización que presenta este nivel. Porcentaje este que permite abordar nueva demanda a corto plazo. No obstante, aunque en términos generales no figure desbordamiento, este hecho necesita mayor detalle de análisis, puesto que, si analizamos los centros de B.U.P. y F.P. de la isla, por separado es cuando podemos observar los estrangulamientos.

Son tres los Institutos de bachillerato existentes en la isla, los dos principales situados en Arrecife, uno de los cuales presenta un desbordamiento de más del $30 \%$ y el otro cubre casi el $100 \%$ de sus puestos escolares. El tercer instituto está situado en uno de los municipios del norte (Haría) y sólo cubre el $28 \%$ de su capacidad (destinado a la población de la isla de La Graciosa y con capacidad para alojamiento durante el curso). El desequilibrio territorial es enorme. Hay que descentralizar o ampliar las dotaciones.

Tabla 38. Capacidad de los Institutos de Bachillerato. Lanzarote. Curso 1985-1986

\begin{tabular}{||c|c|c||}
\hline I. Bachillerato & Alumnos & $\begin{array}{c}\text { Ocupación de } \\
\text { Puestos (\%) }\end{array}$ \\
\hline \hline Blas Cabrera & 1.322 & 132,0 \\
\hline Agustín Espinosa & 477 & 95,4 \\
\hline Extensión Haría & 113 & 28,2 \\
\hline TOTAL ISLA & 1.912 & 101 \\
\hline
\end{tabular}

Fuente. Avance PIOT, 1987. Tomo 5. Cap. II., pp. 49. 
En cuanto a la formación profesional, un estudio realizado por el Centro de Investigación Económica y Social de Canarias (CIES) ${ }^{151}$, en 1983, la califica de "escandalosa" por los siguientes aspectos: a) se trata de un sistema educativo de espaldas a la realidad económica y social canaria; b) es generador de paro y frustraciones; c) es irracional en su estructura y no se vislumbra cambio; d) con consecuencias negativas en la economía canaria y la situación de paro de la juventud.

Estas disfunciones señaladas por CIES se concretan en: a) el peso predominante, en F.P.1, de la rama administrativo comercial (tanto en F.P.1, 42\%, y 2 (63\%), seguida de la sanitaria (F.P.1. 22\%) y la marítimo pesquera (F.P.2., 17\%); b) no existe oferta formativa en construcción y obras (sólo electricidad y electrónica), ni en hostelería y turismo. Las dos ramas laborales más demandas en la isla en este momento (Avance PIOT, 1987, Tomo 5. Cap. II, pp. 58, 60-61). Esta oferta formativa no se corresponde con las políticas nacionales que han contemplado planes de formación profesional para el sector tanto en el periodo no democrático como dentro de la España Constitucional (a través de los diferentes Planes de Desarrollo).

La intención de crear una Escuela de Hostelería, necesaria ante la oferta de trabajo en esta rama que tiene la isla y que se va ampliando derivada del crecimiento constante de la actividad y el equipamiento turístico, persigue todo este periodo. Aunque no verá la luz hasta finales de la década de los años ochenta.

Sin embargo, las titulaciones impartidas a través de la Escuela de Artes y Oficios (principalmente delineación y decoración), creada en 1913, han tenido gran aceptación en el mercado de trabajo (CIES, 1983).

151 CIES. Las enseñanzas profesionales en Las Palmas. 1983. 


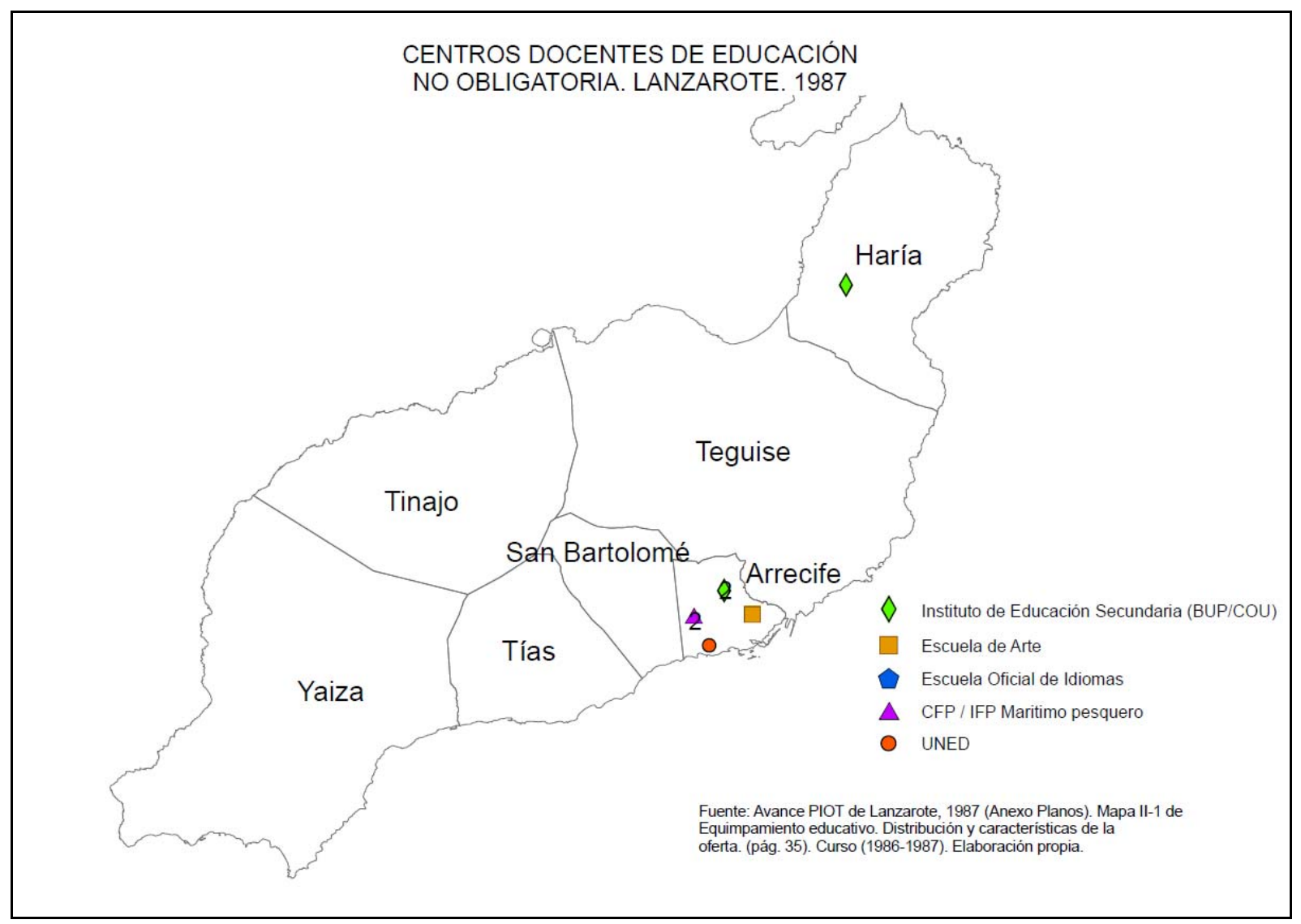

En relación a la educación especial, se observan serios estrangulamientos, puesto que la oferta de puestos que se contempla es menor del número de alumnos que aparecen matriculados, situándose el déficits en $45,5 \%$. Esto hace que la relación alumno/unidad sea elevada para este tipo de educación (algo más de 14 alumnos por aula). A ello se une la escasez de profesorado especializado, pues cada uno tiene que atender a unos 42 alumnos. Esta situación produce no sólo el que la atención a las discapacidades sea de baja calidad, sino que al contemplarse, este tipo de oferta educativa, como uno de los elementos que afectan al bienestar social, en el caso de Lanzarote no se contribuye a su mejora.

Y por último, la educación permanente de adultos, que a mitad de la década de los años setenta era escasa (84), los datos reflejan su evolución positiva, de modo que el curso 1985-1986 presenta una matriculación de 452 personas. Los datos en cuanto al equipamiento existente para este tipo de demanda son escasos y contradictorios, por lo que no podemos evaluarlos con rigor. 
Tabla 39. Oferta y demanda docente. Enseñanza especial y de adultos. Lanzarote. Curso 19851986

\begin{tabular}{|c|c|c|c|}
\hline \multicolumn{2}{|l|}{ Tipo } & Educación Especial & Educación de Adultos \\
\hline \multicolumn{2}{|l|}{ Centros } & 5 & No consta \\
\hline \multicolumn{2}{|l|}{ Unidades } & 15 & No consta \\
\hline \multicolumn{2}{|l|}{ Puestos (oferta) } & 115 & No consta \\
\hline \multicolumn{2}{|l|}{ Profesores } & 5 & 4 \\
\hline \multicolumn{2}{|l|}{ Alumnos } & 211 & 452 \\
\hline \multicolumn{2}{|l|}{ Alumnos/Unidad } & 14,1 & --- \\
\hline \multicolumn{2}{|c|}{ Alumnos/profesor } & 42,2 & 113 \\
\hline \multicolumn{2}{|c|}{ Nivel de Cobertura. Oferta (\%) } & 54,5 & --- \\
\hline \multirow{2}{*}{ Superávit o déficit } & Absolutos & -96 & --- \\
\hline & $\%$ & $-45,5$ & --- \\
\hline
\end{tabular}

Nota: Estándar técnico de plazas de E. Especial por cada 1.000 habitantes: 1,5-2. Tomado del Avance PIOT, 1987, Tomo 5. Cap. II. (pp. 64)

Fuente: "Número de centros con aulas de E. Especial específicas", en Características de la oferta en Educación Especial, Curso 85-86. Lanzarote. Avance PIOT, 1987, Tomo 5, Cap. II. Cuadro 2.21 (pp. 63); "Unidades y alumnos matriculados, por nivel. Lanzarote. Curso 1985-1986". Anuario estadístico de Canarias. Tomo I, Tabla 13.A. (pp. 352), 1986. CEDOC; Alumnos en E. P. de Adultos, Curso 19851986, en Avance PIOT, 1987, Tomo 5, Cap. II. Cuadro 2.21 (pp. 64).

El acceso a centros de educación universitaria no existe en la isla, en este momento. La única posibilidad es la existencia de una delegación del UNED en la capital, puesto que estos servicios están centralizados en las islas capitalinas (Gran Canaria y Tenerife).

\subsubsection{3.- CONCLUSIONES}

La participación en la enseñanza formalizada de la población, en cuanto vía de análisis del capital humano con que la sociedad aborda su posibilidad de desarrollo económicoturístico, junto con la evolución de la oferta-demanda del equipamiento educativo, a lo largo de esta primera etapa (1970-1986) de consolidación de la nueva actividad, se caracteriza, en términos generales, por lo siguiente:

En relación a la cualificación:

1. Constante elevación del nivel formativo de su población. Marcado por: a) notable reducción del nivel de analfabetismo que arranca de los de los años setenta (situándose por debajo de los niveles de Canarias), como primera vía para salir de la pobreza, que marca los años ochenta; b) en el otro extremo el peso relativo de la formación superior desciende en la primera mitad de los años ochenta; c) la escolarización a nivel de educación obligatoria, al final de la etapa, es casi plena.

A pesar del éxito de la alfabetización, los residentes presentan un perfil concentrado en niveles que indican no haber completa la educación general obligatoria, es por ello que la categoría "sin estudios" es muy significativa. Característica que puede explicarse por 
la fuerte irrupción de la actividad en la construcción y los servicios hacia el turismo que no requieren formación.

2. La dinámica inmigratoria es de escaso nivel formativo, fruto del modelo económico que se instala y domina su mercado: turismo de masas y fuerte desarrollo de la construcción, que no exige elevada formación. Así, los incrementos de población dentro de los niveles formativos inferiores se corresponden con incrementos de la oferta turística y de la construcción. La incorporación de población externa, en su mayoría, no aporta a la elevación del nivel de instrucción y cultural de la isla, salvo pequeñas contribuciones principalmente en formación profesional y entre los que proceden de otras Comunidades Autónomas.

3. Es en la segunda mitad de la década de los años ochenta cuando se observa el camino que va a seguir la formación insular, caracterizada por el incremento continuado de la población con formación profesional, principalmente de primer ciclo.

En cuanto al equipamiento educativo, la etapa está marcada por:

1. Estrangulamientos dotacionales en la enseñanza obligatoria en 1970. Al final de la etapa (1986) se rompe la dinámica deficitaria, presentando un notable superávit del equipamiento educativo a dos niveles: preescolar (no obligatorio) y educación general básica (obligatoria).

Gráfico 27. Relación alumnos por unidad y profesores y nivel de cobertura (\%), por tipo de enseñanza. Lanzarote. Curso 19851986.

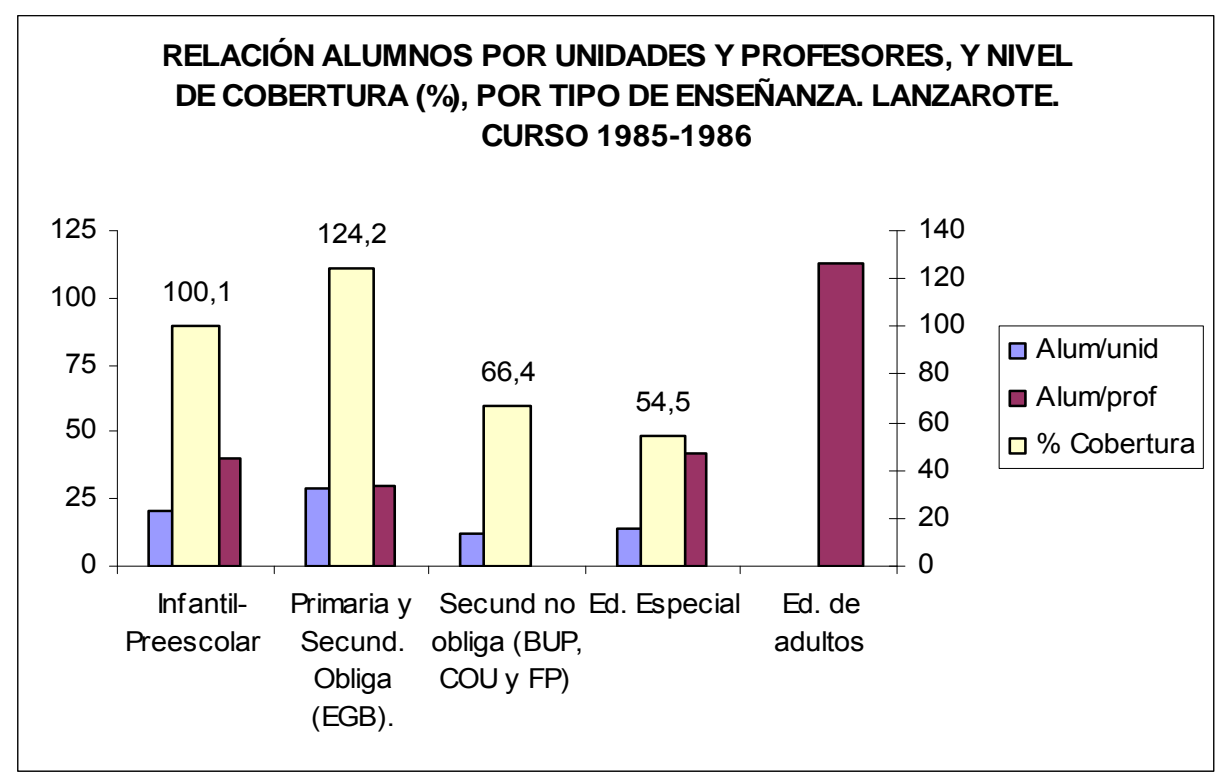

Fuente: AUIA, Avance PIOT de Lanzarote, 1987 y Estadísticas insulares y municipales de Canarias. CEDOC e ISTAC. Elaboración propia. 
2. Déficits en el equipamiento educativo destinado a la enseñanza especial en dos aspectos: a) el número de puestos es inferior a la matriculación existente. Para poder cubrir la demanda se eleva el número de alumnos por aula; b) el profesorado es escaso y está desbordado; Por lo que la atención a las discapacidades es de baja calidad.

3. Avance hasta alcanzar, al final de la etapa, superávit en las dotaciones destinadas a la enseñaza de "preescolar", que no es obligatoria, pero supone la asunción, por parte de la administración, de cambios sociales de género derivados de la incorporación de la mujer al mercado laboral. Dando respuesta a una demanda concreta.

4. Las dotaciones en enseñanza media (no obligatoria) presentan niveles insulares satisfactorios, debido principalmente a la escasa escolarización que presenta (baja demanda) explicada por la abundante oferta laboral existente. Los problemas principales se encuentran en los siguiente aspectos: a) la distribución de centros (que hace que el déficits esté localizado por centros de Bachillerato) por centralización, generando un fuerte desequilibrio territorial; b) en el tipo de formación profesional, no adecuada a la demanda del mercado laboral, principalmente por no contemplar estudios en hostelería y turismo (que sólo se pueden realizar en la capital de la provincia, Las Palmas, dentro de centros privados, en este momento).

5. No existe oferta de enseñanza universitaria presencial en la isla. Este modelo de enseñanza es cubierto por la UNED.

En términos generales, el reflejo sobre la mejora del bienestar social en esta etapa se encuentra sobre la alfabetización y la educación obligatoria, que es sobre la que se avanza en cobertura, principalmente, seguida de la enseñanza infantil no obligatoria. Por el contrario, la integración de las discapacidades, a través de la enseñanza especial no se realiza correctamente y las dotaciones para la educación básica de adultos son escasas, con lo que la reducción del desequilibrio educativo es pobre. La estructura demográfica insular presenta baja capacitación en términos de instrucción escolar formalizada. Todo ello va en detrimento del bienestar social de la Isla.

\subsection{4.- EFECTOS SOBRE LA DOTACIÓN DE SERVICIOS DE SALUD. 1970-1986}

El presente epígrafe va destinado a analizar la evolución de la situación del equipamiento sanitario, afectado por los procesos demográficos que genera la actividad turística insular.

Como se ha señalado anteriormente, el equipamiento social de Lanzarote al comienzo de esta etapa está marcado por la insuficiencia y concentración en zonas de relevancia administrativa (Plan Insular, 1973, Tomo VI.7., pp. 224). A su vez, el fenómeno de la 
insularidad incide también de manera importante en el equipamiento y dotaciones sanitarias. Por lo que se hace necesario no sólo establecer la evolución de estás, sino también observar el nivel de ruptura del aislamiento insular para alcanzar la indispensable autosuficiencia en el campo sanitario y asistencial.

Señalar que las islas tienen una concurrencia competencial múltiple en su estructura pública Sanitaria, pues, presenta, establecimientos de propiedad y financiación nacional e insular.

\subsubsection{1.- DOTACIÓN HOSPITALARIA Y EXTRAHOSPITALARIA.}

Al comienzo de esta etapa (1970), el mapa sanitario se basa en el distrito comarcal de Arrecife, que comprende toda la isla. Así, se enfrenta la década de los años setenta con dos hospitales generalistas en la capital administrativa, Arrecife, que en conjunto ofertan 130 camas. Por lo que la isla dispone de 3 camas por cada 1.000 habitantes. Dato que parece suficiente, pues el nivel de ocupación diaria, de dichas camas, no llega al $50 \%$ $(43,3 \%)$. En este momento la población flotante diaria (población de derecho más los turistas diarios) no agrava la presión sobre el número de camas hospitalarias, pues la actividad turística, hacia lo que será un modelo de masas, está comenzando.

Tabla 40. Oferta hospitalaria. Camas. Lanzarote 1970-1986

\begin{tabular}{|c|c|c|c|c|c|c|}
\hline AÑO & Hospitales & Tipo & $\begin{array}{l}N^{0} \text { de } \\
\text { Camas }\end{array}$ & Camas $/ 1.000 \mathrm{~h}$ & Estancias & $\begin{array}{l}\text { Índice de } \\
\text { Ocupación }\end{array}$ \\
\hline \multirow[b]{2}{*}{1970} & H. Insular (Cabildo) & H. General & 95 & 2,31 & 15.016 & 43,3 \\
\hline & Clínica Casa del Mar152 & H. General & 35 & 0,85 & $\begin{array}{r}\text { No } \\
\text { const. }\end{array}$ & -- \\
\hline TOTAL & 2 & H. General & 130 & 3,16 & 15.016 & 31,7 \\
\hline Población Derecho & 41.146 & & & & & \\
\hline $\begin{array}{l}\text { Turistas } \\
\text { equivalentes al día }\end{array}$ & 436 & & & & \multirow{2}{*}{\multicolumn{2}{|c|}{$\begin{array}{l}\text { \% de Variación de LNZ } \\
\text { con respecto a: }\end{array}$}} \\
\hline Población diaria* & 41.582 & & & 3,13 & & \\
\hline Canarias ** & & & 2.258 & 1,55 & & \\
\hline España ** & & & $\begin{array}{l}52.76 \\
9\end{array}$ & 2,01 & & \\
\hline O.M.S. & & & & $8-10$ & & $-60,5$ \\
\hline
\end{tabular}

(*) Población diaria: población de derecho + turistas equivalentes día.

152 Perteneciente al Instituto Social de la Marina 
$\left.{ }^{* *}\right)$ Los datos que aparecen en 1970 para el cómputo de España y Canarias, han sido obtenidos tras sumar las camas en establecimientos de maternidad, psiquiátricos, y sanatorios antituberculosos, pues es la información que se recoge. Aunque se han señalado en la tabla, no se consideran fiables, ya que arrojan un indicador muy escaso para la España de 1970, lo que hace suponer que hay camas no contabilizadas.

Nota: el índice de ocupación se ha calculado de la siguiente forma: [N estancias / ( $n^{0}$ de camas * 365$\left.)\right]^{\star} 100$;

Fuente: "Número, tipo y capacidad de los establecimientos sanitarios en la isla de Lanzarote". Plan Insular, 1973, Documento VI. Ordenación Económica y Social. Punto 7. Dotación Sanitaria (pp. 292 y 297). "Establecimientos sanitarios y benéficos no sanitarios. Capacidad (camas). Por tipo de establecimiento y provincias". Total Nacional y Canarias, 1970. Anuario Estadístico de España, 1971. INE

\begin{tabular}{|c|c|c|c|c|c|c|}
\hline AÑO & Hospitales & Tipo & $\begin{array}{l}N^{0} \text { de } \\
\text { Camas }\end{array}$ & Camas/1.000h. & Estancias & $\begin{array}{l}\text { Índice de } \\
\text { Ocupación }\end{array}$ \\
\hline \multirow{2}{*}{1975} & H. Insular (Cabildo) & H. General & 96 & 2,17 & No const. & --- \\
\hline & Clínica Casa del Mar & H. General & 35 & 0,79 & No const. & --- \\
\hline TOTAL & 2 & H. General & 131 & 2,96 & No const. & --- \\
\hline Población Derecho & \multicolumn{3}{|c|}{44.337} & & & \\
\hline $\begin{array}{l}\text { Turistas } \\
\text { equivalentes al día }\end{array}$ & & \multicolumn{2}{|r|}{--} & & \multirow{2}{*}{\multicolumn{2}{|c|}{$\begin{array}{l}\% \text { de Variación de LNZ } \\
\text { con respecto a: }\end{array}$}} \\
\hline Población diaria* & & \multicolumn{2}{|c|}{44.337} & 2,96 & & \\
\hline Canarias & & & 6.668 & 5,11 & & \\
\hline España & & & 190.444 & 5,29 & & \\
\hline O.M.S. & & & & $8-10$ & & $-63,1$ \\
\hline
\end{tabular}

* Población diaria: población de derecho + turistas equivalentes día.

Nota: No se han facilitado registros de la Clínica del Mar en 1975, por lo que se ha tomado el referente de 1970 que es el que consta. Fuente: "Número de Camas del Hospital Insular, 1975". Facilitadas por la Dirección del Hospital Insular de Lanzarote; "Establecimientos sanitarios y unidades de hospitalización (camas). Por tipo de establecimiento y provincias". Total Nacional y Canarias, 1975. Anuario Estadístico de España, 1978. INE

\begin{tabular}{|c|c|c|c|c|c|c|}
\hline AÑO & Hospitales & Tipo & $\begin{array}{l}N^{0} \text { de } \\
\text { Camas }\end{array}$ & Camas/1.000h. & Estancias & $\begin{array}{l}\text { Indice de } \\
\text { Ocupación }\end{array}$ \\
\hline \multirow[b]{2}{*}{1981} & H. Insular (Cabildo) & H. General. & 96 & 1,86 & No const. & --- \\
\hline & $\begin{array}{l}\text { Residencia Nuestra } \\
\text { Sra. de los Volcanes } \\
\text { (Seguridad Social) }\end{array}$ & H. General. & 35 & 0,69 & No const. & --- \\
\hline TOTAL & 2 & H. General & 131 & 2,58 & No const. & --- \\
\hline Población Derecho & \multicolumn{3}{|c|}{50.721} & & & \\
\hline $\begin{array}{l}\text { Turistas } \\
\text { equivalentes al día }\end{array}$ & \multicolumn{3}{|c|}{5.252} & & \multirow{2}{*}{\multicolumn{2}{|c|}{$\begin{array}{l}\% \text { de Variación de LNZ } \\
\text { con respecto } \mathrm{a}^{* *} \text { : }\end{array}$}} \\
\hline Población diaria* & \multicolumn{3}{|c|}{55.973} & 2,34 & & \\
\hline Canarias & & \multicolumn{2}{|l|}{7.566} & 5,53 & & \\
\hline España & & \multicolumn{2}{|l|}{193.895} & 5,15 & & \\
\hline O.M.S. & & & & $8-10$ & \multicolumn{2}{|l|}{$-67,8$} \\
\hline
\end{tabular}

* Población diaria: población de derecho + turistas equivalentes día.

** Calculado en relación a las camas por 1.000 habitantes de derecho. 
Nota: No se han facilitado registros para 1981, del Hospital del Insalud, por lo que se ha tomado el referente de 1970 que es el que consta.

Fuente: "Número de Camas del Hospital Insular, 1981". Facilitadas por la Dirección del Hospital Insular de Lanzarote; "Establecimientos sanitarios con régimen de internado. Unidades de hospitalización (camas). Total nacional, 1981" y "Camas en funcionamiento según especialidad, por provincias". Total Canarias 1981". Anuario Estadístico de España, 1985. INE

\begin{tabular}{|c|c|c|c|c|c|c|}
\hline AÑO & Hospitales & Tipo & $\begin{array}{l}N^{\circ} \text { de } \\
\text { Camas }\end{array}$ & Camas/1.000h. & Estancias & $\begin{array}{l}\text { Índice de } \\
\text { Ocupación }\end{array}$ \\
\hline \multirow[b]{2}{*}{1986} & H. Insular (Cabildo) & H. General. & 96 & 1,72 & No consta & -- \\
\hline & $\begin{array}{l}\text { Residencia Nuestra } \\
\text { Sra. de los Volcanes } \\
\text { (Seguridad Social) }\end{array}$ & H. General. & 112 & 2,01 & No consta & --- \\
\hline TOTAL & 2 & H. General & 208 & 3,73 & -- & -- \\
\hline Población Derecho & \multicolumn{3}{|c|}{55.764} & & & \\
\hline $\begin{array}{l}\text { Turistas } \\
\text { equivalentes al día }\end{array}$ & \multicolumn{3}{|c|}{16.493} & & \multirow{2}{*}{\multicolumn{2}{|c|}{$\begin{array}{l}\% \text { de Variación de LNZ } \\
\text { con respecto a: }\end{array}$}} \\
\hline Población diaria* & \multicolumn{3}{|c|}{72.257} & 2,88 & & \\
\hline Canarias & & \multicolumn{2}{|l|}{---} & 5,5 & \multicolumn{2}{|r|}{$-32,2$} \\
\hline España & & \multicolumn{2}{|l|}{171.860} & 5,3 & \multicolumn{2}{|r|}{$-29,6$} \\
\hline O.M.S. & & & & 8-10 & & $2-53,4$ \\
\hline
\end{tabular}

* Población diaria: población de derecho + turistas equivalentes día.

Fuente: "Camas instaladas en los centros sanitarios de Canarias, según dependencia, por islas. Lanzarote. 1985". Estadísticas básicas de Canarias, 1980-1985. CEDOC. "Ratio camas/1000h de España y Canarias, 1986" en Avance PIOT Lanzarote, 1987, Tomo 5, Cap. II. Cuadro 5.2. Cabildo de Lanzarote, 1987 (pp. 113). "Número de Camas del Hospital Insular". Facilitadas por la Dirección del Hospital Insular de Lanzarote; "Camas en funcionamiento según la finalidad del establecimiento sanitario, 1986. Canarias y España". Anuario Estadístico de España, 1994. INE.

En 1975 los datos son más optimistas pues la Clínica Casa del Mar pasa a pertenecer al Insalud (1978) y toma el nombre de Residencia Nuestra Señora de los Volcanes, a la que se le amplía su equipamiento, recogiendo especialidades médicas relacionadas con la maternidad y la infancia, principalmente. "Todos los pacientes que no podían ser atendidos por falta de medios técnicos o déficits de recursos humanos eran trasladados a Las Palmas de Gran Canaria a través del Servicio de Salvamente Aéreo Militar (SAR), el cual era activado desde la delegación del Gobierno" (Fika, Ma. L., y otro, 2004, pp. 262). 
Tabla 41. Equipamientos y servicios. Hospital nuestra señora de los volcanes (Insalud). Lanzarote. 1975

\begin{tabular}{|l|}
\hline Tipo \\
\hline \hline Laboratorio (1) \\
\hline Radiología \\
\hline Quirófanos (2) \\
\hline S. Cirugía y Traumatología \\
\hline S. de Esterilización \\
\hline S. Medicina interna \\
\hline S. Ginecología \\
\hline S. Pediatría. \\
\hline
\end{tabular}

Fuente: Fika, M.L. y otros. "De la Residencia Sanitaria Nuestra Señora de los Volcanes al Hospital General de Lanzarote". XI Jornadas de estudios sobre Lanzarote y Fuerteventura. Cabildo Insular de Fuerteventura, Fuerteventura, 2004 (pp. 262). Elaboración propia.

El número de camas que se contabilizan, entre los dos hospitales de la isla, es prácticamente el mismo de hace cinco años. Es, por tanto, el Hospital Insular, gestionado por el Cabildo Insular de Lanzarote, el que sigue teniendo mayor capacidad asistencial en la mitad de los años setenta.

Hasta la década de los años ochenta no se tienen nuevos datos. Su primera mitad está marcada por los cambios que traen la instauración del modelo democrático, la Constitución y el Estado de las Autonomías. Es por tanto un momento de procesos de coordinación entre Estado y Comunidades Autónomas, con el objeto de garantizar el derecho a la salud (C.E. Art. 43.2, 53.1 y 53.3), para lo que se pretende crear y poner en funcionamiento zonas de salud (R.D. 137/1984) con funciones integradas (prevención, asistencia y rehabilitación).

Así pues, entre 1981 y 1986 el mapa sanitario de Lanzarote muestra la ampliación del equipamiento extrahospitalario y hospitalario, sin embargo, el mayor cambio lo observa el primero, pues la isla se divide ahora, en 1986, en cinco zonas de salud, contabilizándose un centro de salud en cada una, aunque solo dos se han puesto en funcionamiento y el resto está en fase inicial de construcción. Se crea una estructura jerárquica, donde uno de los centros de salud de la capital (Arrecife) coordina al resto y estos a su vez a los pequeños consultorios o ambulatorios que se mantendrán en núcleos menores (rurales). 
Tabla 42. Mapa sanitario. Centros extrahospitalarios. Lanzarote, 1986

\begin{tabular}{|l|c|c|c|c|}
\hline \multirow{2}{*}{ Zona de Salud } & $\begin{array}{c}\text { Cobertura } \\
\text { prevista } \\
\text { (habitantes) }\end{array}$ & Centros de Salud & Estado & Ambulatorios \\
\hline \hline Norte & 7.000 & 1 & En construcción & 3 \\
\hline Centro & 9.000 & 1 & En construcción & 2 \\
\hline Arrecife Oeste & 32.000 & 1 & Funcionando & \multirow{2}{*}{$\begin{array}{c}\text { Asistencia } \\
\text { ambulatoria }\end{array}$} \\
\cline { 1 - 4 } Arrecife Este & 8.000 & 1 & En construcción & 1 \\
\cline { 1 - 3 } Sur & 88.064 & 1 & Funcionando & 6 \\
\hline Total & 55.764 & 5 & & \\
\hline $\begin{array}{l}\text { Población } \\
\text { Derecho }\end{array}$ & 72.257 & & & \\
\hline Población diaria & & & & \\
\hline
\end{tabular}

Fuente: Avance PIOT, Lanzarote, 1987. Tomo 5. Cap. II. Equipamientos y servicios comunitarios. Cabildo de Lanzarote, 1987 (pp. 103). Elaboración propia

La cobertura dotacional extrahospitalaria prevista en esta nueva estructura en bastante amplia, no sólo cubre la población registrada en la isla, sino que plantea cobertura suficiente para la población diaria que asume. La presión poblacional sobre estos recursos se estima en este momento, 1986, del orden del $82 \%$, (según se deduce de los datos recogidos en la anterior tabla) por lo que queda margen para ampliar la asistencia a más población $(18 \%)$.

Los centros hospitalarios de la isla al final de esta etapa (1986), siguen siendo dos, ambos con funciones generales, pues no existen centros especializados. Se ha ampliado el número de camas, especialmente desde el INSALUD, el Hospital del Cabildo Insular no demuestra capacidad de ampliación desde hace más de una década. Con todo, no llegan a 4 las camas disponibles por cada mil habitantes de derecho $(3,7)$, lo que no supone un gran avance desde 1970, pero sí que ha crecido el número de habitantes diarios que soporta la isla, pues la cantidad de turistas equivalente diarios que acoge, ahora, es enorme, incrementa la población en casi un $30 \%$, y por tanto la presión sobre las dotaciones sanitarias, reduciendo aún más la capacidad de los hospitales, en casi una cama por cada mil habitantes $(2,8)$. Esta presión no se está teniendo en cuenta en las ampliaciones dotacionales. 
Gráfico 28. Comparación de los ratios camas hospitalarias por cada mil habitantes de derecho y sobre la población total estimada. Lanzarote. 1970-1986.

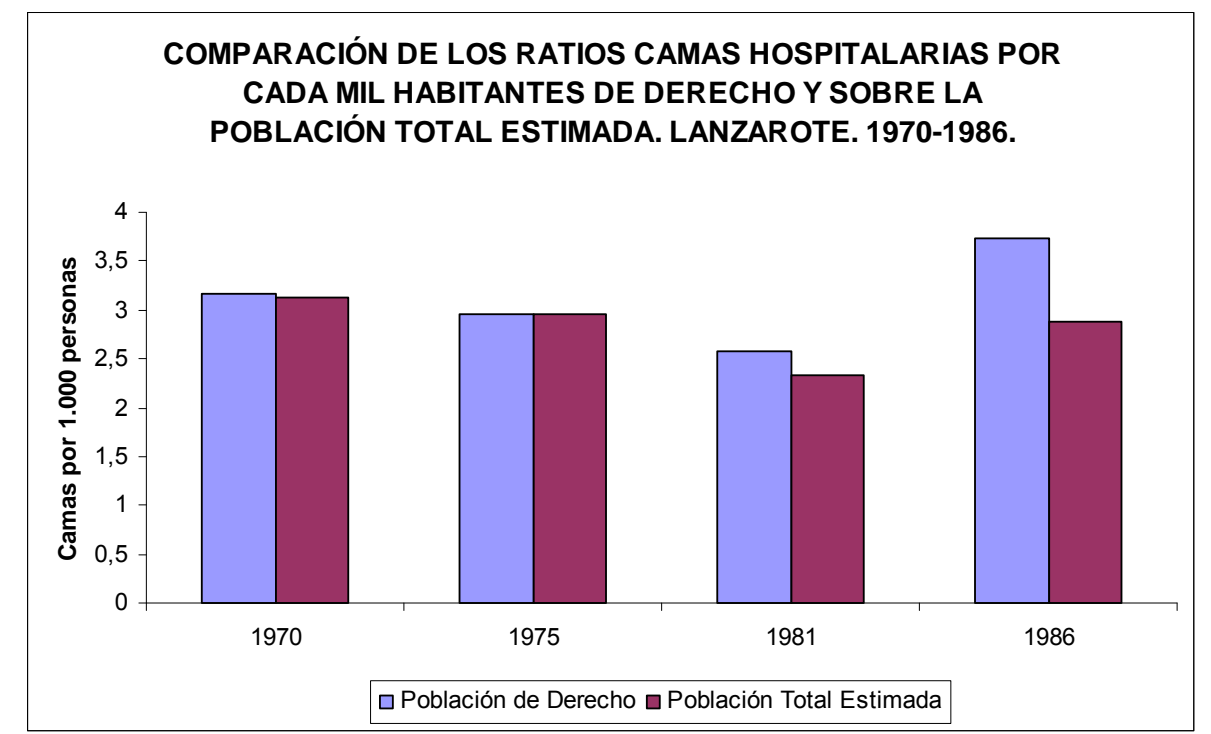

Fuente: Estadísticas básicas de Canarias, 1980-1985. CEDOC, AUIA, Avance PIOT Lanzarote, 1987 y Anuario Estadístico de España, 1994. INE. Elaboración propia.

Así, el indicador camas hospitalarias por 1.000 habitantes (de derecho), expresa la deficitaria capacidad en la isla para el último año de esta etapa, muy por debajo del ratio nacional $(5,3)$, alrededor de un $32 \%$, del de la comunidad autónoma $(5,5)$ un $29,6 \%$, y a una gran distancia del estándar de la Organización Mundial de la Salud, situado entre 8/10 camas por 1.000 habitantes, que comparado con él supondría un 53,4\% por debajo.

Gráfico 29. Comparación del ratio camas hospitalarias por cada mil habitantes. España, Canarias y Lanzarote. 1970-1986.

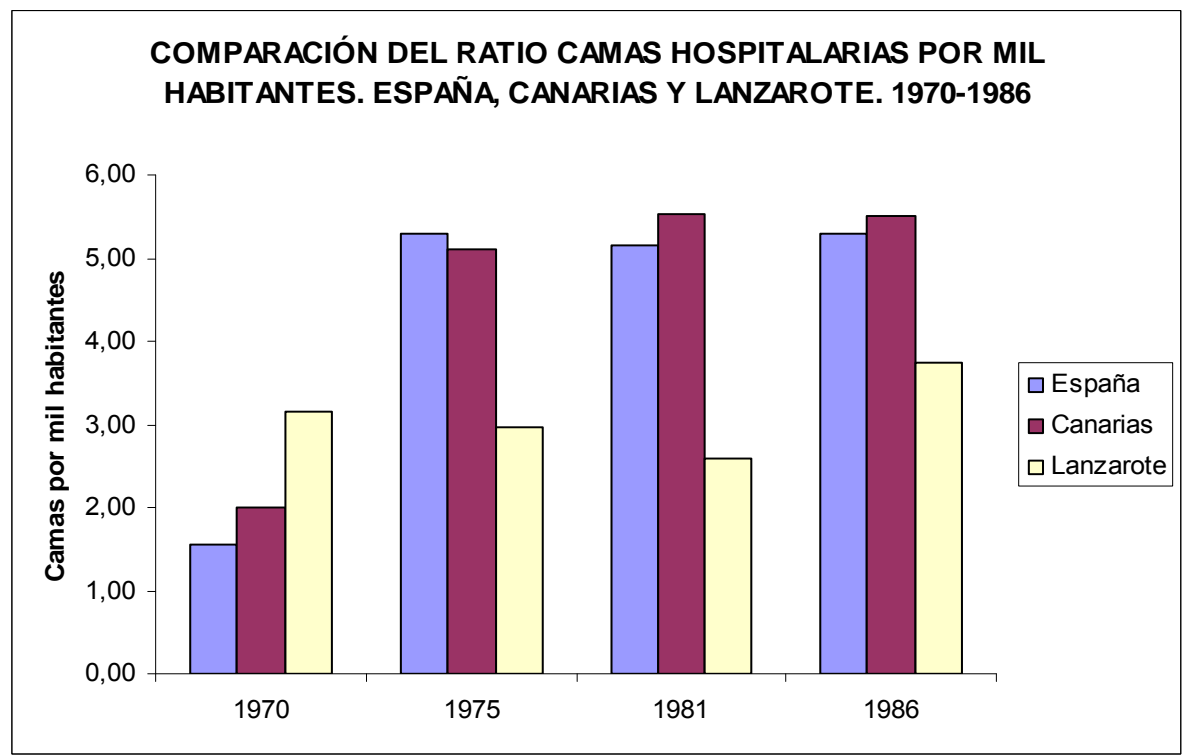

Fuente: Estadísticas básicas de Canarias, 1980-1985. CEDOC, AUIA, Avance PIOT Lanzarote, 1987 y Anuario Estadístico de España, 1994. INE. Elaboración propia. 
El Hospital Insular (gestionado por el Cabildo Insular) ha ido derivando hacia un centro de asistencia y residencia de ancianos, aunque contempla especialidades médicas que no existen en el otro hospital (gestionado por la Seguridad Social) y que añaden servicio.

Tabla 43. Especialidades hospitalarias. Lanzarote, 1986

\begin{tabular}{||l|l|}
\hline Residencia Nuestra Sra. de los Volcanes & Hospital Insular \\
\hline \hline Tipo & Tipo \\
\hline Laboratorio (1) & Residencia general \\
\hline Radiología & Unidad de larga estancia \\
\hline Quirófanos (2) & Unidad agudos corta estancia \\
\hline S. Cirugía y Traumatología & Medicina General, primaria \\
\hline S. de Esterilización & Planificación familiar \\
\hline S. Medicina interna & Valoración ancianos \\
\hline S. Ginecología & Cirugía general (2 quirófanos) \\
\hline S. Pediatría. & Unidad hemodiálisis \\
\hline & Asistencia social \\
\hline
\end{tabular}

Fuente: Fika, M.L. y otros. "De la Residencia Sanitaria Nuestra Señora de los Volcanes al Hospital General de Lanzarote". XI Jornadas de estudios sobre Lanzarote y Fuerteventura. Cabildo Insular de Fuerteventura, Fuerteventura, 2004 (pp. 262).

"Tipo de asistencia del Hospital Insular". Avance PIOT Lanzarote, 1987, Tomo 5, Cap. II. Cuadro 5.2. Cabildo de Lanzarote, 1987 (pp. 114).

Señalar que aunque el número de camas hospitalarias se ha incrementado y existen dos centros de salud al final de esta etapa, no podemos completar el análisis, pues solo se nos han facilitado el número de facultativos del Hospital Insular, por tanto no se puede estimar un cómputo general para la isla, que esté próximo a la realidad. Aún así, a través de los datos de los que se dispone, se analiza, en las próximas líneas, el personal facultativo (médicos).

\section{a.- El personal facultativo.}

La etapa comienza con escasez en el número de médicos, principalmente son generalistas y los especialistas suelen estar itinerantes, es decir, asisten en los dos hospitales de la isla ${ }^{153}$. Este personal se localiza en zonas urbanas; tendencia generalizada pues son los ámbitos que concentran el mejor equipamiento y las compensaciones económicas, sociales

153 Esta información perteneciente a la década de los años setenta, ha sido obtenida a través de una entrevista (pues no existe en estadísticas oficiales) realizada en el año 2010, al Sr. Sosa Núñez, J., perteneciente al personal de administración y servicios del Hospital Insular, jubilado desde el año 2001 tras 50 años de servicios en esta institución, que le han permitido tener un conocimiento exhaustivo del funcionamiento de la misma. 
y profesionales son más intensas, desatendiendo amplias zonas que coinciden con municipios rurales o no capitalizados. Así pues, en el medio urbano insular (que concentra el $51 \%$ de la población en 1970) se estiman 881 habitantes por médico, lo que supone que cada médico asiste al $2 \%$ de la población. Frente a esto, el medio rural, con el $49 \%$ de la población, solo posee 6 médicos, cada uno de los cuáles, atiende a más de 3.000 personas, es decir, un $8 \%$ de la población total para cada facultativo.

Tabla 44. Médicos según ámbito. Lanzarote. 1969

\begin{tabular}{||c|r|r||r|c||}
\hline Municipio & \multicolumn{1}{|c|}{ Médicos } & Población & Habitantes/Médico & Habitantes/Médicos (\%). \\
\cline { 1 - 3 } Medio Urbano & 24 & 21.135 & 881 & 2,1 \\
\cline { 1 - 3 } Arrecife & 6 & 20.011 & 3.335 & 8,1 \\
\hline Medio Rural & 1 & 2.986 & 2.986 & 100,0 \\
\hline Haría & 1 & 3.550 & 3.550 & 100,0 \\
\hline S. Bartolomé & 1 & 5.977 & 5.977 & 100,0 \\
\hline Teguise & 1 & 3.018 & 3.018 & 100,0 \\
\hline Tías & 1 & 2.822 & 2.822 & 100,0 \\
\hline Tinajo & 1 & 1.658 & 1.658 & 100,0 \\
\hline Yaiza & 30 & 41.146 & 1.372 & 3,3 \\
\hline Total & & & \multicolumn{2}{|c|}{} \\
\hline \hline
\end{tabular}

Fuente: Plan Insular, 1973. Documento VI. Ordenación Económica y Social. Punto 7. Dotación Sanitaria. Cuadro n 7 (pp. 302). Elaboración propia.

La presión es enorme sobre los servicios y profesionales sanitarios para el cómputo insular, típico de sociedades poco desarrolladas. Lanzarote está a años luz de las posibilidades de atención médica de su población frente a España y a países europeos desarrollados, como Italia o Bélgica.

Tabla 45. Habitantes por médico. Europa, España y Lanzarote. 1965-1969

\begin{tabular}{|l|c|c|}
\hline Países & 1965 & 1969 \\
\hline \hline Italia & 570 & --- \\
\hline Bélgica & 680 & --- \\
\hline Francia & 900 & --- \\
\hline España & 800 & --- \\
\hline \hline Lanzarote & --- & 1.372 \\
\hline \hline
\end{tabular}

Fuente: FOESSA, Anuario 67. N. U. Recogido en Plan Insular, 1973. Documento VI. Ordenación Económica y Social. Punto 7. Dotación Sanitaria. Cuadro $n^{0} 6$ (pp. 300); Elaboración propia.

Es por ello que el problema básico, ahora que comienza el despegue de la actividad turística en la isla es, por un lado la centralización del equipamiento hospitalario general y por otro lado, la escasez de especialidades médicas (maternidad y antituberculosos, 
principalmente $)^{154}$, que obliga a costosos desplazamientos por salud a la capital de la provincia, Las Palmas.

Tabla 46. Médicos por tipo. Arrecife. Lanzarote. 1969

\begin{tabular}{|l|r|l|r||}
\hline Clínica del Mar & \multicolumn{1}{l|}{ N $^{\mathbf{O}}$} & Hospital Insular & \multicolumn{1}{l||}{$\mathbf{N}^{\mathbf{0}}$} \\
\hline Medicina General & 7 & Cirugía & 2 \\
\hline Pediatría & 1 & General & 3 \\
\hline Oftalmología & 1 & & \\
\hline Digestivo & 1 & & \\
\hline Anestesiología & 1 & & \\
\hline Cirugía General & 2 & & \\
\hline Toco-Ginecología & 3 & & \\
\hline Estomatología & 2 & & \\
\hline Traumatología y Ortopedia & 1 & & \\
\hline Pulmón y corazón & 1 & & \\
\hline Otorrinolaringología & 1 & & \\
\hline \hline Total Especialidades & 21 & Total Especialidades & \\
\hline Total Médicos & 19 & Total Médicos & \\
\hline \hline TOTAL No DE MÉDICOS & 24 & & \\
\hline
\end{tabular}

Fuente: Plan Insular, 1973. Documento VI. Ordenación Económica y Social. Punto 7. Dotación Sanitaria. (pp. 299). Para el Hospital Insular la información ha sido facilitada por personal de administración y servicios de la época (en activo en el año 1975, no en la actualidad, bajo permiso de la dirección. A través de una entrevista realizada al Sr. Sosa Núñez, J. (fecha: 15/04/2010)

La presión sobre el personal sanitario seguirá elevada durante toda la etapa de análisis, agravada por el incremento de población que suponen los turistas, que hace que el número de habitantes por médico se eleve considerablemente, del orden del $10-11 \%$, en 1981 y 1986 respectivamente.

154 Plan Insular, 1973. Capítulo VI. 7. Cuadro nº 2 (pp. 293). 
Tabla 47. Número de facultativos por tipo y ratio habitantes/médicos. España, Canarias y Lanzarote. 1970-1986

\begin{tabular}{|c|c|c|c|c|c|c|c|c|c|}
\hline \multirow[b]{2}{*}{ Año } & \multirow[b]{2}{*}{$\begin{array}{l}\text { Atención } \\
\text { Primaria }\end{array}$} & \multirow[b]{2}{*}{ Especialistas } & \multirow[b]{2}{*}{ TOTAL } & \multicolumn{3}{|c|}{$\begin{array}{l}\text { En relación a la población de } \\
\text { derecho }\end{array}$} & \multicolumn{3}{|c|}{ En relación a la población total ${ }^{*}$} \\
\hline & & & & $\begin{array}{l}\text { Ratio } \\
\text { Lanzarote }\end{array}$ & $\begin{array}{l}\text { Ratio } \\
\text { Canarias }\end{array}$ & $\begin{array}{l}\text { Ratio } \\
\text { España }\end{array}$ & $\begin{array}{l}\text { Ratio } \\
\text { Lanzarote }\end{array}$ & $\begin{array}{l}\text { Ratio } \\
\text { Canarias }\end{array}$ & $\begin{array}{l}\text { Ratio } \\
\text { España }\end{array}$ \\
\hline 1970 & 9 & 21 & 30 & 1.372 & 1.315 & 948 & 1.386 & 1.338 & 961 \\
\hline 1975 & 9 & 21 & 30 & 1.478 & 952 & 660 & 1.478 & 952 & 668 \\
\hline 1981 & 9 & 21 & 30 & 1.691 & 938 & 634 & 1.866 & 986 & 652 \\
\hline 1986 & No consta & 42 & 42 & 1.549 & 357 & 294 & 1.720 & 395 & 303 \\
\hline
\end{tabular}

$\left.{ }^{*}\right)$ Población total: población de derecho + turistas equivalentes día.

Fuente: Para 1970: "Médicos por especialidades, 1969". Plan Insular de Lanzarote, 1973. Documento Vl. Ordenación Económica y Social. Punto 7. Dotación Sanitaria. (pp. 299); "Médicos con ejercicio profesional, por provincias. Total Canarias y España, 1970". Anuario estadístico de España, 1971. INE; Para 1975 y 1981: "Plantilla del Hospital Nuestra Sra. de los Volcanes hasta 1987". Fika, M.L. y otros. "De la Residencia Sanitaria Nuestra Señora de los Volcanes al Hospital General de Lanzarote". XI Jornadas de estudios sobre Lanzarote y Fuerteventura. Cabildo Insular de Fuerteventura, Fuerteventura, 2004 (pp. 267); Entrevista en profundidad a Sosa Núñez, J., personal de administración y servicios del Hospital Insular de Lanzarote (en activo en el año 1975, no en la actualidad); "Profesionales sanitarios colegiados. Médicos. Total nacional y detalle provincial (Las Palmas y Tenerife), 1975". Anuario Estadístico de España, 1976. "Personal Sanitario en Instituciones propias de la seguridad social (abiertas y cerradas). Médicos. Canarias y Total Nacional, 1981". Estadísticas Básicas de Canarias, 1980-1985. ISTAC; Para 1986: "Profesionales sanitarios colegiados. Médicos. Total nacional y detalle provincial (Las Palmas y Tenerife), 1986". Anuario Estadístico de España, 1987.

Gráfico 30. Comparación de los ratios población de derecho y población total estimada por médico. Lanzarote. 1970-1986

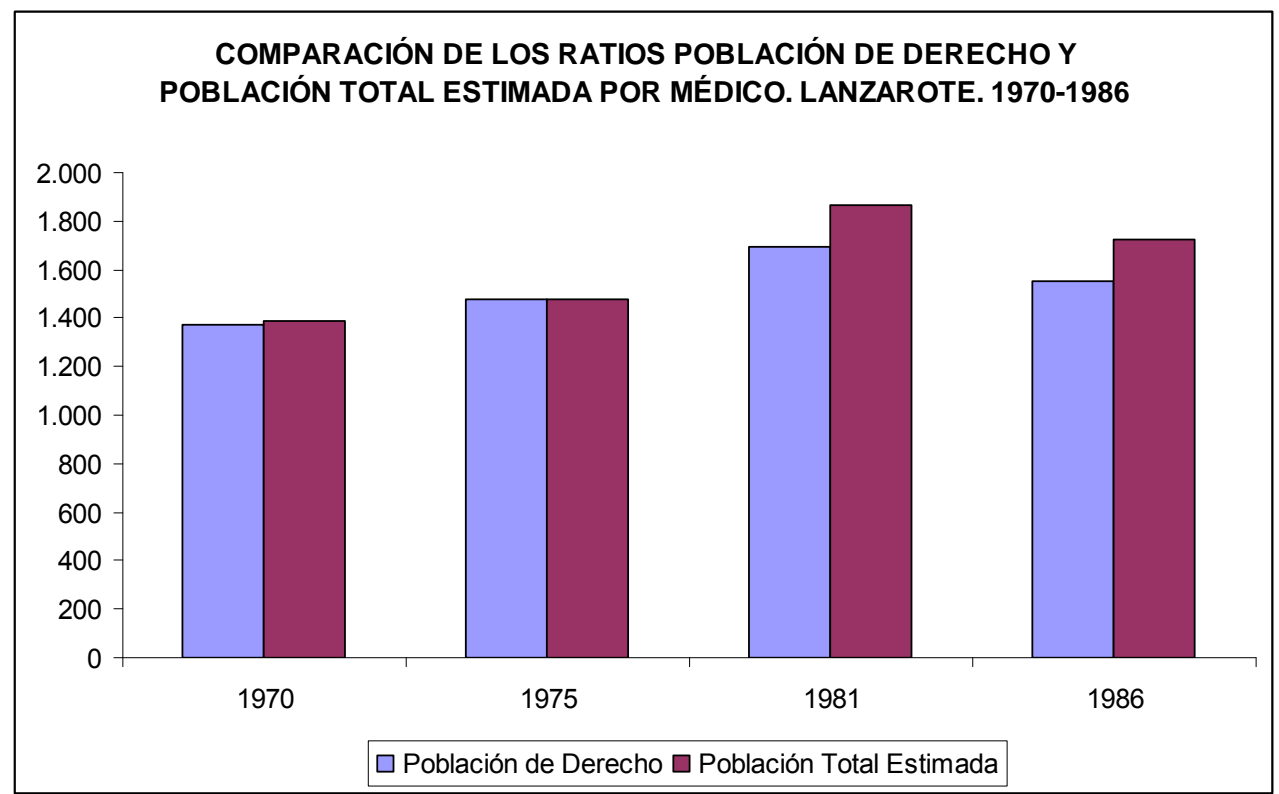

Fuente: Elaboración propia a partir de la información recogida en la Tabla 46.

En la década del los años ochenta, aunque Lanzarote presenta una dinámica de constante incremento del número de médicos, su dotación siempre se encuentra muy por debajo de la de Canarias y España, de forma notable en 1981, que comparativamente supone el que un 
médico en Lanzarote tenga un $80,3 \%$ más de pacientes potenciales de derecho con respecto al conjunto de la Comunidad Autónoma, y un $166,7 \%$ con respecto al cómputo nacional.

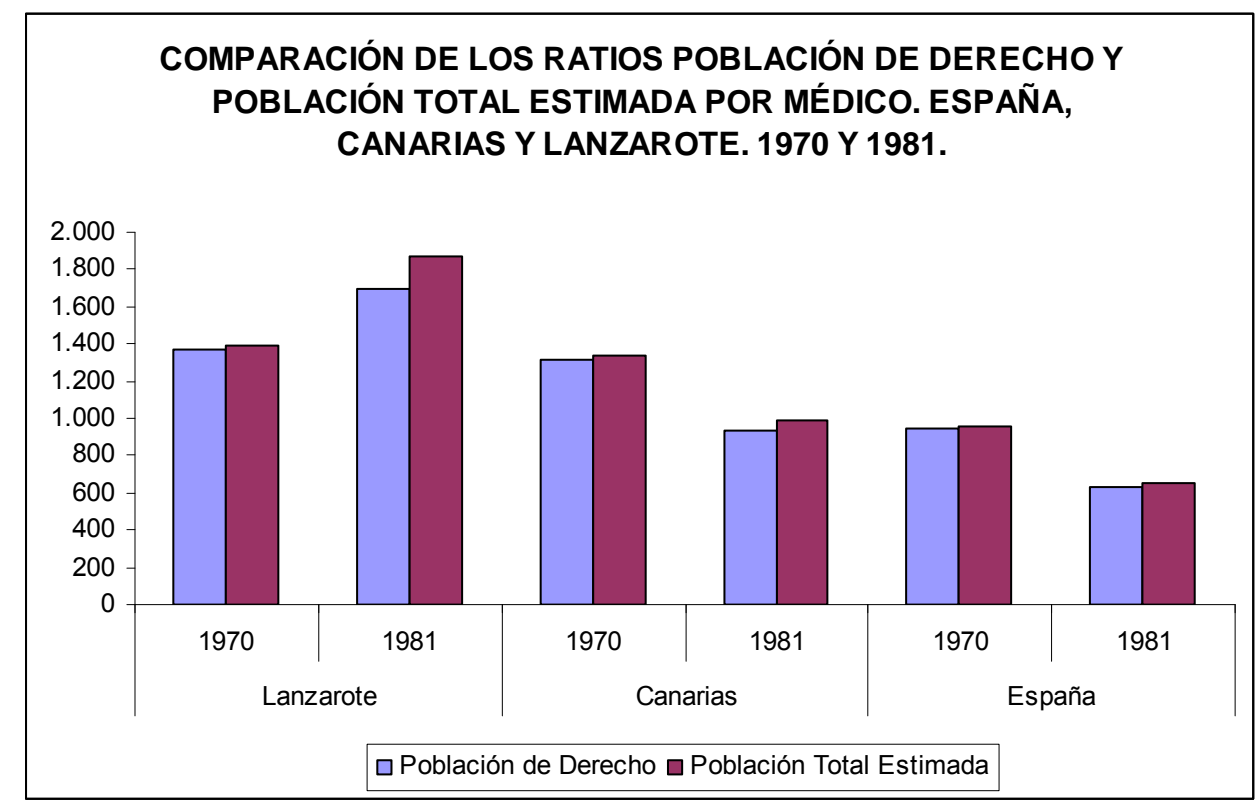

Fuente: Elaboración propia a partir de la información recogida en la Tabla 46.

En estos años ya ha aparecido cierta oferta privada, localizada en la capital y en los núcleos turísticos, "volcada hacia la demanda turística extranjera, consultas privadas (...) que ofrecen, en forma muy elemental, una primera asistencia sanitaria”. (Cabildo Insular de Lanzarote. Avance PIOT, 1987. Tomo 5, Cap. II, pp. 109). A pesar de su conocida existencia, no se ha podido acceder a documentos oficiales que registren datos sobre su número, capacidad, profesionalidad y equipamiento, por lo que no pueden ser analizados, ni sumados a la oferta pública.

\subsubsection{2.- EL EQUIPAMIENTO DE BIENESTAR.}

En cuanto al equipamiento de bienestar social que ha concentrado hasta 1986, estos siguen siendo escasos. A lo que se le ha dado mayor cobertura hasta el momento es a la infancia, la adolescencia y los ancianos. Se dispone del número de servicios, pero no podemos saber la capacidad de atención, el número de profesionales, demanda del servicio y equipamiento, pues los datos recogidos por las fuentes oficiales son escasos en este momento. En cuanto a la capacidad de las dependencias, el Avance del PIOT de Lanzarote (1987, Tomo 5, Cap. II, pp. 118-121), señala que son las dotaciones destinadas a la tercera edad las que tienen alguna entidad real en la isla, y únicamente en el ámbito de 
asistencia con internamiento se cubre la demanda (a través de la oferta del Hospital Insular, del Cabildo). En cuanto a la prevención e información de toxicomanías, se acaba de poner en marcha el servicio.

Tabla 48. Servicios sociales según tipo. Lanzarote. 1986

\begin{tabular}{||l|l|l||}
\hline Tipo & Función & Número \\
\hline \hline De Base & & 1 \\
\hline Afines. & Diversos aspectos sanitarios & 2 \\
\hline Minusválidos & Centro de día & 1 \\
\hline \multirow{2}{*}{ Infancia y Adolescencia } & Escuelas-hogar & 1 \\
\cline { 2 - 3 } & Hogar funcional de menores & 4 \\
\hline \multirow{2}{*}{ Inserción marginados } & Toxicomanías & 1 \\
\hline \multirow{2}{*}{ Ancianidad } & Residencias & 1 \\
\cline { 2 - 3 } & Hogares y clubs & 1 \\
\hline TOTAL SERVICIOS & & 12 \\
\hline
\end{tabular}

Fuente: "Número de servicios sociales en Canarias según tipos y lugar de ubicación, por islas. Lanzarote. 1985". Estadísticas Básicas de Canarias, 1980-1985. CEDOC; Avance PIOT Lanzarote, 1987, Tomo 5, Cap. II. Cuadro 5.2. Cabildo de Lanzarote, 1987 (pp. 113).

\subsubsection{3.- CONCLUSIONES}

En esta etapa, que hemos denominado de despegue y consolidación, la isla carece de dotaciones sanitarias suficientes para dar servicio a la población que acoge, hecho este que se ve agravado por la entrada de turistas diarios, que aumentan la presión sobre dichas dotaciones. En términos generales las características de la etapa son las siguientes:

1. Escasez de camas hospitalarias. Este equipamiento se incrementa ligeramente en el periodo, pero no lo suficiente para absorber la constante y creciente demanda de la población, debido a la fuerte dinámica de crecimiento demográfico a lo largo de la etapa, unido al incremento del turismo diario en la isla. El estándar de calidad está por debajo del de Canarias y de España y muy por detrás de las recomendaciones de la O.M.S. 
Gráfico 32. Camas hospitalarias por mil habitantes y comparación con el estándar de la O.M.S. España, Canarias y Lanzarote. 1986.

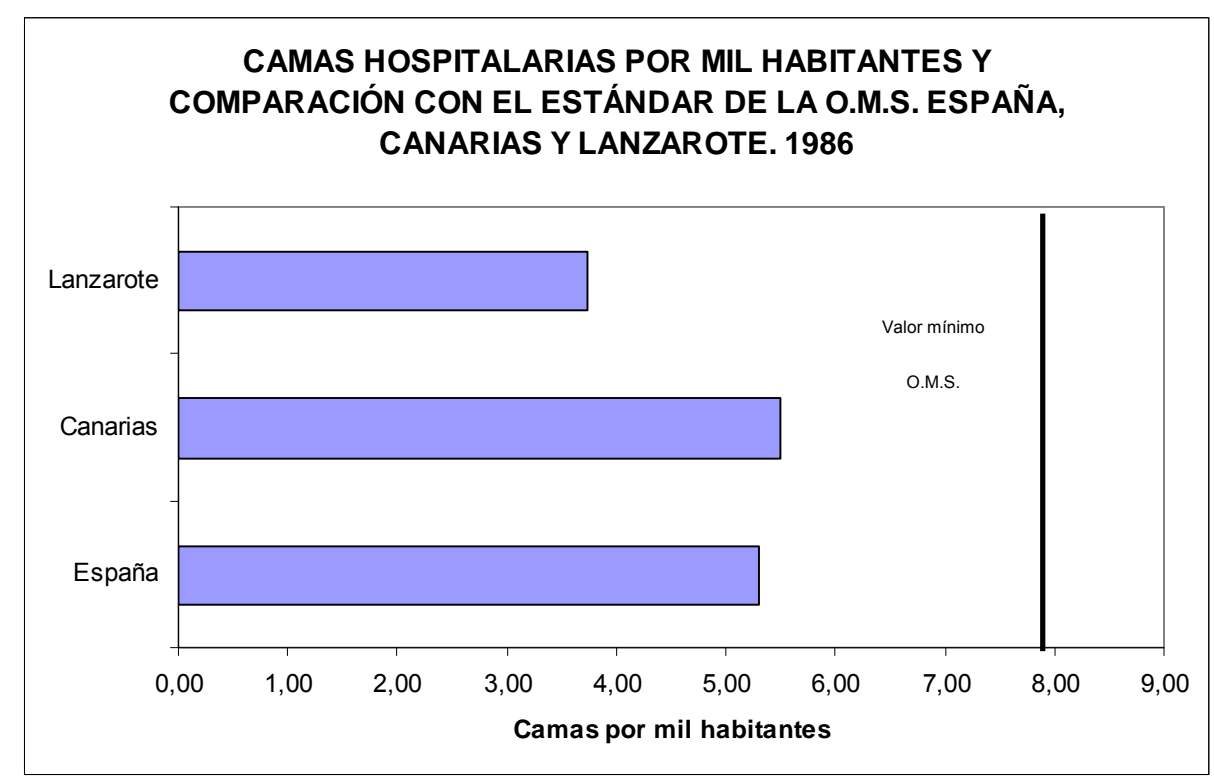

Fuente: Elaboración propia a partir de la información recogida en la Tabla 39.

2. El Cabildo insular es el que proporciona la mayor oferta de camas hospitalarias. Asume el peso de la atención sanitaria a lo largo de la etapa, de forma significativa.

3. De la centralización inicial del equipamiento extrahospitalario en el distrito comarcal de la capital, Arrecife, se pasa a un proceso de descentralización, al final de la etapa, dividiendo el territorio insular en cinco zonas de salud, que tiene como resultado la ampliación de la cobertura y la ruptura con los desequilibrios territoriales existentes.

4. El personal facultativo (médicos) se encuentra estrangulado, principalmente los médicos rurales. La presión sobre los mismos se reduce ligeramente al final de la etapa, aunque el constante crecimiento de los turistas equivalentes diarios en la isla supone una demanda potencial que reduce las posibilidades de disponibilidad de médicos. La falta de datos en relación a la existencia de consultas privadas no permite ajustar los indicadores, pero podemos afirmar que suponen un alivio de la presión potencial, pues están volcadas hacia la demanda turística extranjera. En relación a la disponibilidad de médicos por habitantes de la Comunidad Autónoma y el país, Lanzarote se encuentra muy por debajo. 
Gráfico 33. Evolución del número de habitantes por médico en relación a la población de derecho y a la población total estimada. Lanzarote. 1970-1986.

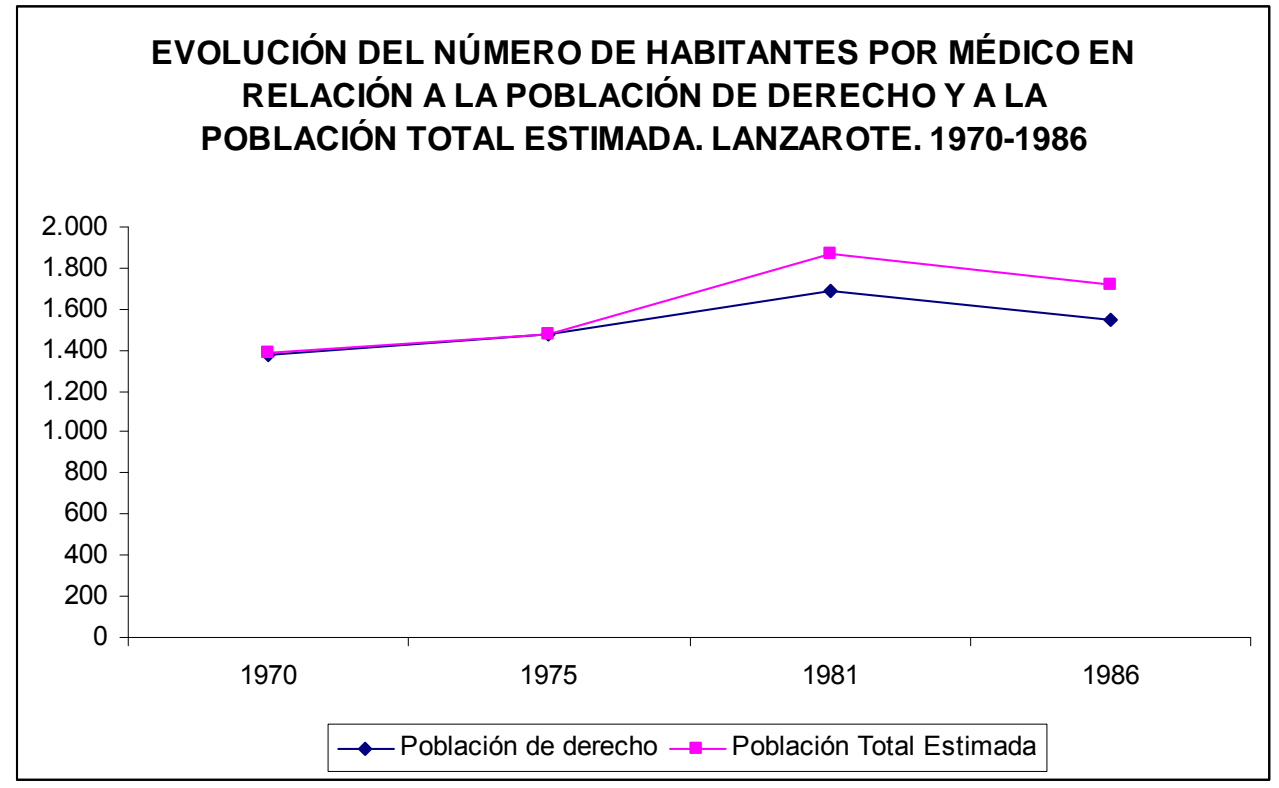

Fuente: Elaboración propia a partir de la información recogida en la Tabla 46.

5. Escasez de especialidades médicas. Éstas se concentran en la capital de provincia, lo que supone mantener una plataforma para traslados de enfermos hacia Las Palmas.

A lo largo de toda la etapa, la oferta sanitaria no se ajusta a la demanda, para alcanzar estándares internacionales de calidad, y permanece estrangulada. Los turistas agravan la situación, entran en competencia con la población local por los escasos recursos sanitarios, lo que afecta directamente al bienestar de la población de acogida.

\subsection{5.- EFECTOS SOBRE LA ACTIVIDAD ECONÓMICA Y EL EMPLEO. 1970-1986}

El objeto de este análisis es ver en qué medida la actividad turística que acoge la isla, ha incidido en los indicadores de empleo y paro insulares a lo largo de las tres etapas de análisis en las que se estructura este trabajo.

La información estadística utilizada es la obtenida, principalmente, a través de la explotación de los datos censales y padronales, desde 1970 hasta 2006, por lo que difieren de los que se pueden extraer de la Encuesta de Población Activa y de los registrados por el INEM. Hecho éste habitual, en tanto en cuanto que sendas consultas se realizan siguiendo criterios metodológicos diferentes en razón de la diferencia de fines. Se recurrirá también a otros documentos e informes de diferentes organismos.

Señalar que se ha analizado por separado la década del setenta puesto que el nivel de desagregación de los datos que presenta el Censo y el Padrón, realizado en ese año, es 
mucho menor que en los siguientes, lo que nos supone un análisis parcial de la población activa en dicha década.

\subsubsection{1.- POBLACIÓN ACTIVA Y ESTRUCTURA SECTORIAL}

La isla de Lanzarote acaba la década de los años sesenta con una baja tasa de población activa, del $31,77 \%$, frente al promedio regional que suponía el 35,5\%. La explicación de esta circunstancia la encontramos, por un lado, en la gran juventud de su población y, por otro lado, en la escasa contabilización estadística del trabajo femenino, especialmente agrícola. Pero debemos tener en cuenta que por esta época el trabajo de la mujer sólo podía ser agrario, en la medida en que el papel social de género establecido no veía adecuado el trabajo femenino fuera del hogar y remunerado.

\section{a.- Los ocupados}

Tabla 49. Población activa insular, según municipios y tipos de ocupación. Lanzarote. 1965

\begin{tabular}{|c|c|c|c|c|c|c|c|c|}
\hline Municipios & $\begin{array}{l}\text { Agricultores } \\
\text { Autónomos }\end{array}$ & $\begin{array}{l}\text { Braceros } \\
\text { Agrícolas }\end{array}$ & $\begin{array}{c}\text { Pesca } \\
\text { (capturas) }\end{array}$ & Construcción & Industria & Servicios & TOTAL & $\begin{array}{l}\text { Población } \\
\text { Activa sobre } \\
\text { el total (\%) }\end{array}$ \\
\hline Arrecife & --- & --- & 1.597 & 779 & 800 & 2.053 & 5.229 & 29,57 \\
\hline Haría & 549 & 453 & 90 & 36 & --- & 252 & 1.380 & 35,58 \\
\hline S.Bartolomé & 354 & 67 & 164 & 349 & --- & 298 & 1.232 & 36,13 \\
\hline Teguise & 898 & 190 & 508 & 281 & --- & 496 & 2.373 & 32,25 \\
\hline Tías & 324 & 136 & 251 & 86 & --- & 166 & 963 & 32,66 \\
\hline Tinajo & 344 & 129 & 59 & 171 & --- & 174 & 877 & 33,78 \\
\hline Yaiza & 61 & 96 & 219 & 61 & --- & 120 & 557 & 30,67 \\
\hline TOTAL & 2.530 & 1.071 & 2.888 & 1.763 & 800 & 3.559 & 12.611 & 31,77 \\
\hline $\begin{array}{l}\% \text { Sobre } \\
\text { Total }\end{array}$ & 20,1 & 8,5 & 22,9 & 14 & 6,3 & 28,2 & 100,0 & \\
\hline
\end{tabular}

Fuente: Centro de Investigación Económica y Social de la Caja Insular de Ahorros (CIES). "Plan Insular de Ordenación de la isla de Lanzarote". Boletín n 11. Apéndice estadístico y gráfico. Cuadro n 20. Las Palmas de Gran Canaria. Octubre de 1971; Elaboración propia.

Si el análisis lo adoptamos tomando los tres sectores económicos, 1965 nos arroja la siguiente distribución comparada con Canarias y España: 
Tabla 50. Ocupación por sectores. Lanzarote, Canarias y España. 1965 (\%)

\begin{tabular}{||l|r|r|r||}
\cline { 2 - 4 } \multicolumn{1}{c|}{} & Lanzarote & Canarias & \multicolumn{1}{c||}{ España } \\
\hline \hline Primario & 51,45 & 41,0 & 35,6 \\
\hline Secundario & 20,32 & 23,0 & 32,9 \\
\hline Terciario & 28,23 & 36,0 & 31,5 \\
\hline
\end{tabular}

Fuente: El dato de la Nación se refiere a 1966, según la "Encuesta de Población Activa" del I.N.E. El dato regional (Canarias) e Insular es una estimación hecha por Centro de Investigación Económica y Social de la Caja Insular de Ahorros (CIES). Boletín $n^{0} 11$. Lanzarote. Octubre de 1971 (pp.54).

Mapa 6. Población activa municipal. Lanzarote. 1965.

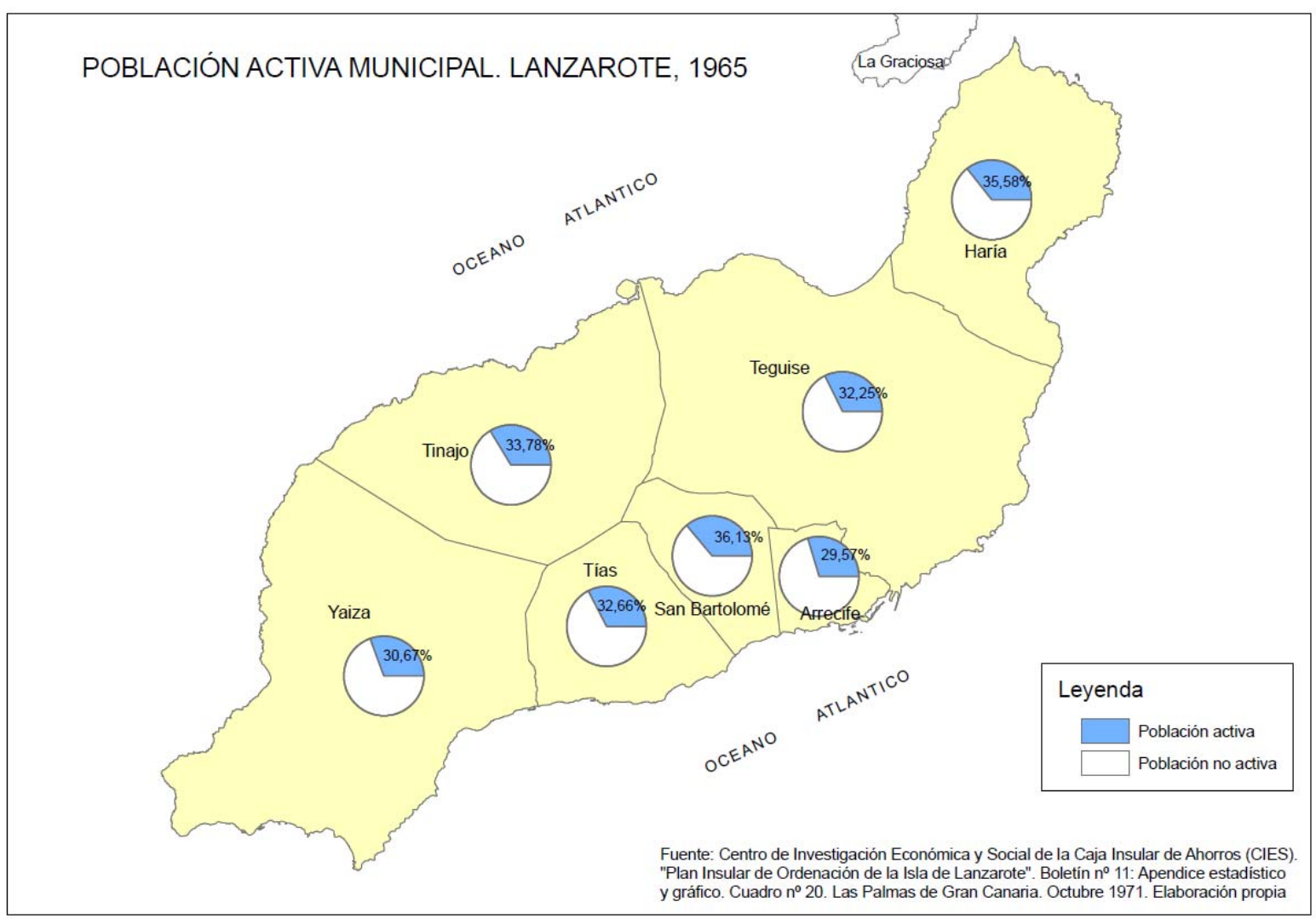

El rotundo peso del sector primario (51,5\% sobre el total de la población activa de la isla), unido al escaso peso específico del secundario (20,3\% incluida la construcción) y el terciario $(28,2 \%)$, nos hace poder hablar de una sociedad eminentemente rural, "con un sistema económico poco evolucionado" (C.I.E.S. 1971, pp. 54), frente a Canarias, donde el primario no presenta tanto peso relativo en el empleo (41\%) y el sector servicios ya ha despuntando y alcanzado mayor presencia (36\%) que en Lanzarote.

En el caso de España, la población activa se reparte de forma semejante entre los tres grandes sectores, concentrando en servicios más población que Lanzarote, pero menos 
que Canarias, que aún no se ha convertido en la potencia en servicios turísticos que posteriormente será.

Gráfico 34. Población ocupada por sectores de actividad. Lanzarote, Canarias y España. 1965 (\%)

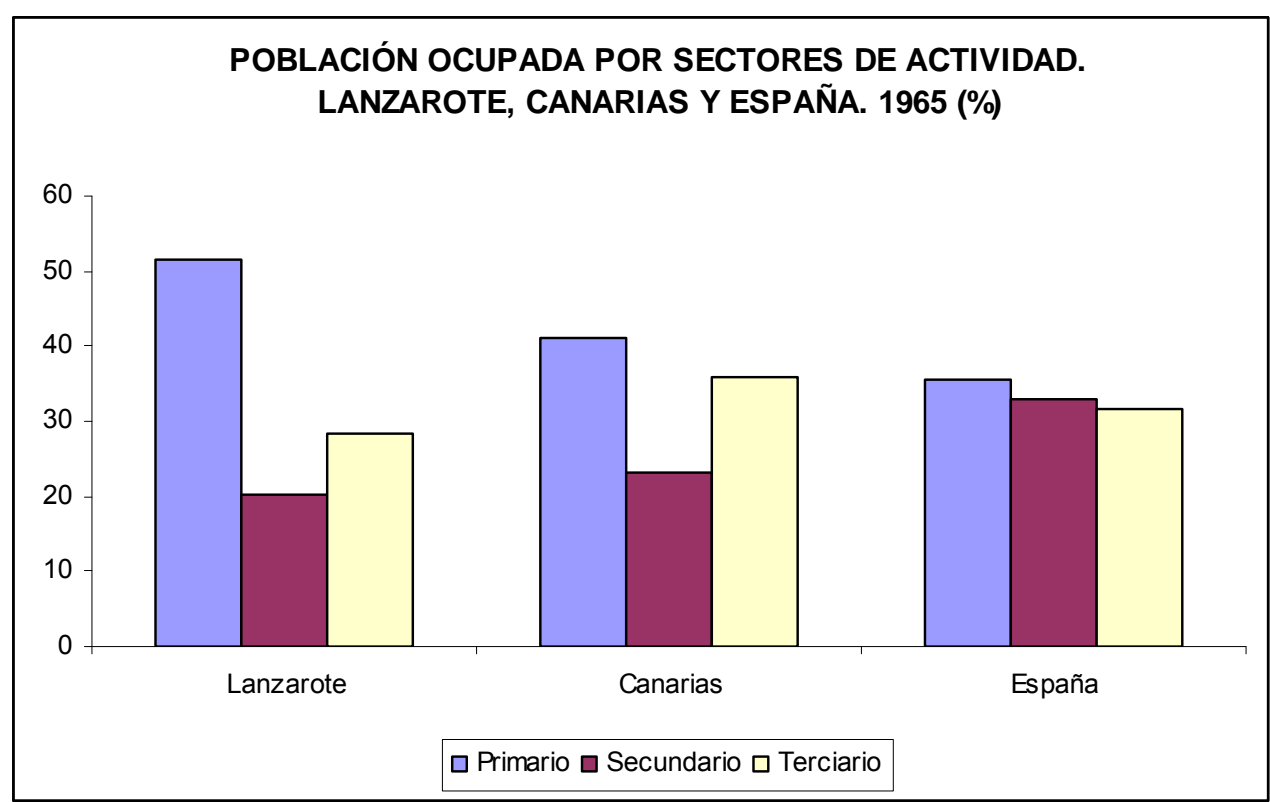

Fuente: Elaboración propia a partir de las estimaciones de CIES para Lanzarote y los resultados de la EPA (Tabla 49).

Será en la década del setenta cuando comiencen a ser notorios los cambios. La encuesta C.I.E.S. nos revela que el estatus campesino se sitúa por esta época en $23,61 \%$ y la actividad pesquera acoge casi el $13 \%$ de la población activa (C.I.E.S. 1971, pp. 55). 
Tabla 51. Población activa estimada, según municipios y niveles ocupacionales. Lanzarote. 1970

\begin{tabular}{|c|c|c|c|c|c|c|c|c|}
\hline & Arrecife & Haría & S.Bartolomé & Teguise & Tías & Tinajo & Yaiza & TOTAL \\
\hline 1. Jornaleros Agrícolas & --- & 32 & 27 & 28 & 19 & --- & 66 & 172 \\
\hline 2. Agricultores Independientes & 76 & 852 & 516 & 741 & 358 & 359 & 262 & 3.035 \\
\hline Status Campesino & 76 & 884 & 543 & 769 & 377 & 359 & 328 & 3.207 \\
\hline Marino & 1.015 & --- & 81 & 199 & 261 & 25 & 66 & 1.708 \\
\hline TOTAL SECTOR I & 1.091 & 884 & 624 & 968 & 638 & 384 & 394 & 4.915 \\
\hline Obreros no Cualificados & 888 & 229 & 232 & 709 & 108 & 231 & 43 & 2.436 \\
\hline Personal Servicios & 202 & 163 & 84 & 88 & --- & 25 & --- & 573 \\
\hline Obreros Cualificados & 736 & 33 & 144 & 244 & --- & 102 & --- & 1.348 \\
\hline Empleados Subalternos & 1.015 & --- & 27 & 88 & 51 & --- & --- & 1.261 \\
\hline Industria y Comercio & 101 & 33 & --- & 58 & 76 & --- & 22 & 229 \\
\hline Titulados medios y similares & 253 & --- & --- & 58 & 52 & --- & 22 & 401 \\
\hline Titulados superiores y similares & 406 & -- & 27 & --- & --- & --- & -- & 438 \\
\hline TOTAL SECTOR II y III & 3.601 & 458 & 514 & 1.245 & 287 & 358 & 87 & 6.736 \\
\hline Sin repuesta & 1.168 & 132 & 84 & 455 & 17 & 129 & 66 & 1.933 \\
\hline TOTAL & 5.860 & 1.474 & 1.222 & 2.668 & 942 & 871 & 547 & 13.584 \\
\hline
\end{tabular}

Nota: no se incluye el trabajo de la mujer casada, no cabeza de familia.

Fuente: Encuesta del Centro de Investigación Económico y Social (C.I.E.S.) de la Caja Insular de Ahorros de Canarias (1970). CIES. "Plan de Ordenación Territorial de la Isla de Lanzarote". Boletín n 11. Las Palmas de Gran Canaria. Octubre, 1971 (pp. 56). Elaboración propia

Tabla 52. Evolución de la población activa 1965 y 1970. Lanzarote. (\%)

\begin{tabular}{|l|r|r|r|}
\hline Sectores & \multicolumn{1}{|l|}{1 1965 } & \multicolumn{1}{l|}{1 1970 } & \multicolumn{1}{l|}{$\begin{array}{l}\text { Variación del Peso } \\
\text { Relativo Interperiodo }\end{array}$} \\
\hline \hline Agricultores autónomos & 20,06 & 26,05 & 5,99 \\
\hline Braceros & 8,49 & 1,48 & $-7,01$ \\
\hline Pesca & 22,90 & 14,66 & $-8,24$ \\
\hline Sector II y III & 48,55 & 57,81 & 9,26 \\
\hline
\end{tabular}

Nota: el conjunto de no respuestas (14,24\%) fue distribuido de acuerdo con la normalidad obtenida de las respuestas, obteniendo as éstas cifras para el año 1970.

Fuente: Encuesta del Centro de Investigación Económico y Social (C.I.E.S.) de la Caja Insular de Ahorros de Canarias (1970). CIES. "Plan de Ordenación Territorial de la Isla de Lanzarote". Boletín n 11. Las Palmas de Gran Canaria. Octubre, 1971. (pp. 56). Elaboración propia. 


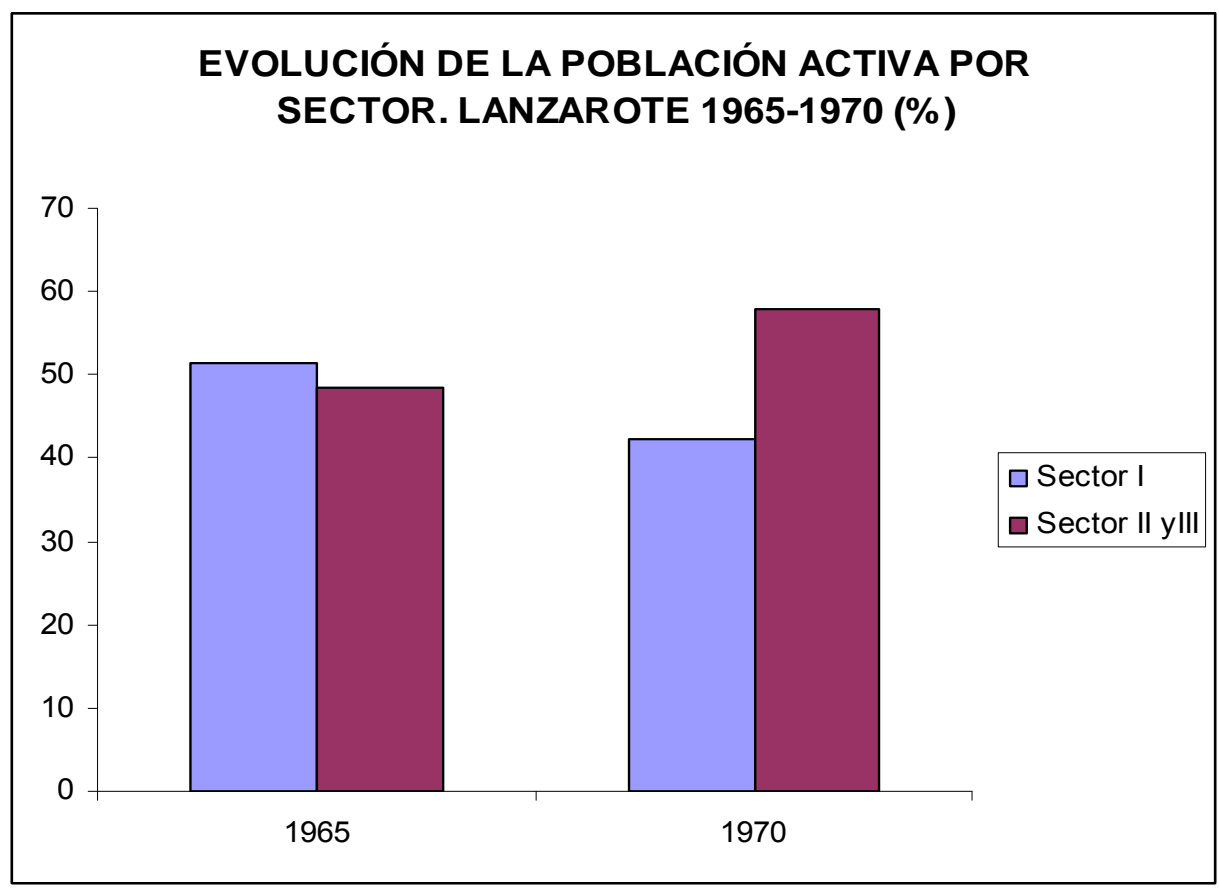

Fuente. Elaboración propia a partir de las estimaciones de CIES para Lanzarote y los resultados de la EPA (Tabla 51).”.

Hay que señalar la tendencia a la baja del sector primario que empieza a notarse ya en el año 70 , con respecto a 1965 , sufriendo una variación del 10,36\%. A la vez se ve favorecido el sector secundario y terciario, creciendo en nueve enteros en el quinquenio. La isla ha entrado en un claro proceso de desagrarización y terciarización de su economía, junto a la desruralización asociada. El Centro de Investigación Económica y Social (C.I.E.S. 1971, pp.56) atribuye estos cambios a los siguientes procesos o factores:

- Práctica desaparición de los braceros agrícolas, pasando a engrosar la categoría de agricultores autónomos.

- Abandono de la pesca de costa (de bajura, con barquillas) y mayor racionalización de las faenas pesqueras de la flota de altura.

- Incremento de las actividades de construcción.

El pequeño propietario agrícola ha emigrado al subsector de la construcción y a las tareas menos cualificadas de los servicios (PIOT. 1991, TOMO 5, pp.15), esto sucedía a finales de los años setenta y principios de los ochenta.

A partir de 1975, la población activa de la isla está representada por el sector servicios, en detrimento del resto, concentrando, en la década de los años ochenta, a más del $50 \%$ de la población ocupada insular. 
Es significativo señalar la dinámica de la población ocupada en la construcción que sufre un elevado incremento entre 1981 y 1986, alrededor del 108\%, siendo el segundo sector con más peso en la población ocupada, al final de esta etapa (24\%).

Tabla 53. Estructura sectorial del empleo. Ocupados. Lanzarote, Canarias y España. 1981-1986

\begin{tabular}{|c|c|c|c|c|c|c|c|c|c|c|c|c|}
\hline & \multicolumn{4}{|c|}{ LANZAROTE } & \multicolumn{4}{|c|}{ CANARIAS } & \multicolumn{4}{|c|}{ ESPAÑA (mil) } \\
\hline & 1981 & $\%$ & 1986 & $\%$ & 1981 & $\%$ & 1986 & $\%$ & 1981 & $\%$ & 1986 & $\%$ \\
\hline AGRARIO* & 2.401 & 16,5 & 1.583 & 7,6 & 51.580 & 14,6 & 52.775 & 13,5 & 2.055 & 17,8 & 1.723 & 15,2 \\
\hline INDUSTRIAL & 1.790 & 12,3 & 2.038 & 9,8 & 42.122 & 11,9 & 38.575 & 9,8 & 3.025 & 26,2 & 2.762 & 24,3 \\
\hline CONSTRUCCIÓN & 2.384 & 16,4 & 4.953 & 23,9 & 37.697 & 10,7 & 43.325 & 11,0 & 1.031 & 8,9 & 920 & 8,1 \\
\hline SERVICIOS & 7.987 & 54,8 & 11.811 & 57,0 & 218.558 & 61,9 & 255.075 & 65,0 & 5.397 & 46,8 & 5.937 & 52,3 \\
\hline No clasificados & --- & --- & 344 & 1,7 & 3.035 & 0,9 & --- & 0,7 & --- & -- & --- & -- \\
\hline TOTAL & 14.562 & 100,0 & 20.729 & 100,0 & 352.992 & 100,0 & 392.975 & 100,0 & 11.521 & 100,0 & 11.359 & 100,0 \\
\hline
\end{tabular}

(*) Sólo agricultura.

Fuente: Para 1981: "Población ocupada según edad, sexo y sectores económicos”. Totales Autonómicos. Censo de Población. 1981, INE; "Estructura sectorial del empleo, 1981". Avance del Plan Insular. Datos Estadísticos, 1987. Lanzarote. Oficina de Turismo. Consejería de Turismo y Transporte; EPA, "Resultados nacionales. Ocupados por sexo y sector económico. IV trimestre 1981 y 1986 ". INE. Para 1986: "Población de derecho de 14 y más años ocupada, según edad y rama de actividad, por sexo. Lanzarote". Padrón municipal de habitantes 1986. Centro de Estadística y Documentación de Canarias (CEDOC). Datos Estadísticos, 1987. Lanzarote. Oficina de Turismo. Consejería de Turismo y Transporte; "Ocupados por sector económico. Canarias y Total Nacional, 1986. Media del año". EPA. INE

Elaboración propia.

Gráfico 36. Evolución de la población ocupada por sectores. España, Canarias y Lanzarote. 1981-1986 (\%)

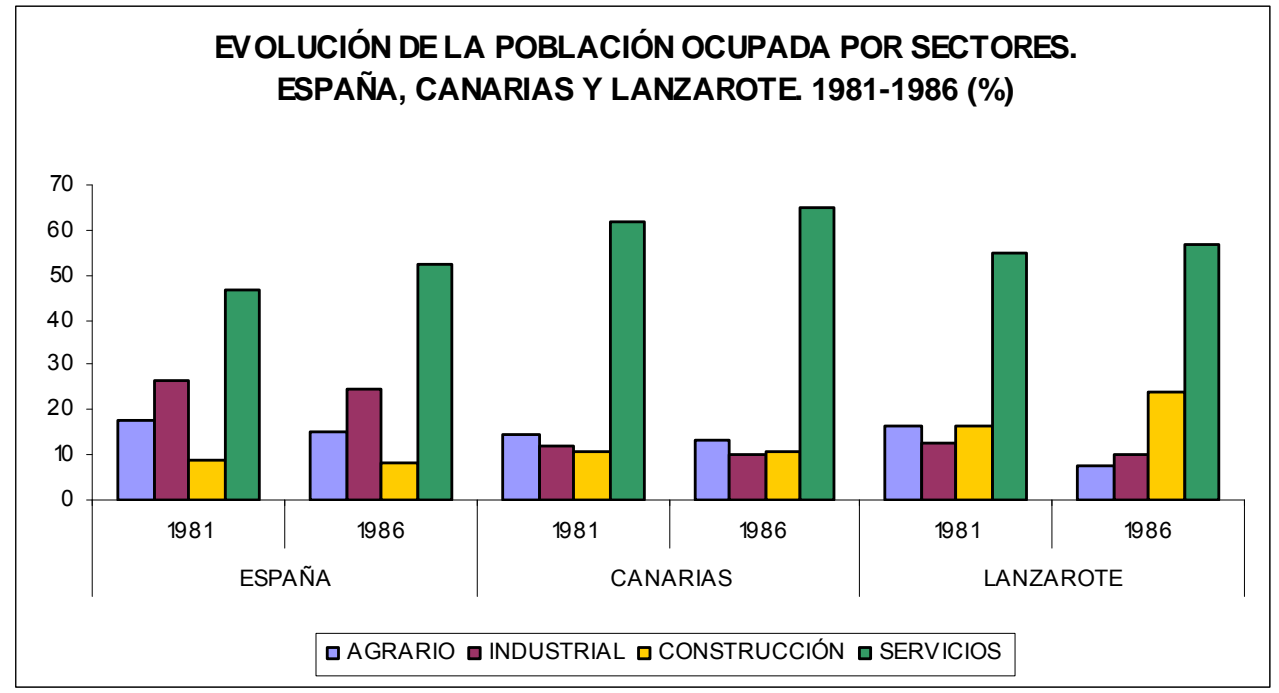

Fuente: Elaboración propia a partir de Censos, Padrones municipales y Encuesta de población activa. CEDOC e INE. 
Tabla 54. Incremento quinquenal de la población ocupada por sector económico. Lanzarote, Canarias y España. 1981-1986. (\%)

\begin{tabular}{|l|r|r|r|}
\cline { 2 - 4 } \multicolumn{1}{c|}{} & \multicolumn{1}{c|}{ LANZAROTE } & CANARIAS & \multicolumn{1}{c|}{ ESPAÑA } \\
\hline \hline AGRARIO & $-34,07$ & 2,32 & $-16,1$ \\
\hline INDUSTRIAL & 13,85 & $-8,40$ & $-8,7$ \\
\hline CONSTRUCCIÓN & 107,76 & 14,93 & $-10,8$ \\
\hline SERVICIOS & 47,88 & 16,71 & 10,0 \\
\hline
\end{tabular}

Fuente: Elaboración propia a partir de los datos de ocupados por sector.

En una década se pasó del predominio de actividades propias del sector primario, al asentamiento de actividades propias del terciario turístico y la construcción, desarticulándose la economía tradicional de subsistencia, basada en la agricultura y la pesca. "Lo anormal del caso radica en la intensidad y rapidez con que se ha producido el fenómeno. En cuanto al volumen de empleo, el sector terciario posee hoy el lugar que antaño ocupara la actividad agrícola". (Barrera, C. 1994, pp. 260). El trasvase de trabajadores del sector agrario a la construcción y los servicios supone mejoras en las condiciones laborales y salariales, a través de la cuales, la población insular puede incrementar sus posibilidades de acceso al bienestar.

Tabla 55. Evolución de la población activa por sectores económicos. Lanzarote. 1965-1986 (\%)

\begin{tabular}{|l|r|r|r|r|r||}
\cline { 2 - 6 } \multicolumn{1}{c|}{} & \multicolumn{1}{c|}{$1965^{*}$} & \multicolumn{1}{c|}{$1970^{*}$} & \multicolumn{1}{c|}{1975} & \multicolumn{1}{c|}{1981} & \multicolumn{1}{c|}{1986} \\
\hline \hline Sector I & 51,4 & 42,2 & 26,7 & 17,7 & 17,3 \\
\hline Sector II & 24,3 & 28,9 & 30,6 & 26,6 & 19,3 \\
\hline Sector III & 24,3 & 28,9 & 34,5 & 55,7 & 59,2 \\
\hline
\end{tabular}

*Al aparecer los datos del Sector II (secundario) y III (terciario) unidos para 1965 y 1970, estos se han desagregados realizando una media simple y siendo conscientes de que sólo supone una estimación que nos permitirá elaborar la curva evolutiva hasta el final de los periodos analizados.

Fuente: Encuesta del Centro de Investigación Económico y Social (C.I.E.S.) de la Caja Insular de Ahorros de Canarias (1970). En "Plan de Ordenación Territorial de la Isla de Lanzarote". Boletín n 11. Las Palmas de Gran Canaria. Octubre, 1971. (pp. 56); "Población activa según sectores de actividad y sexo, por islas. Lanzarote, 1981. Estadísticas Básicas de Canarias, 1980-1985. CEDOC; "Estructura sociolaboral de Lanzarote, 1986". Datos estadísticos de 1986. Delegación Insular de turismo de Lanzarote. Consejería de Turismo y transporte. Gobierno de Canarias, 1986. http://www.datosdelanzarote.com; Elaboración propia. 
Gráfico 37. Evolución de la población activa por sectores económicos. Lanzarote. 1965-1986

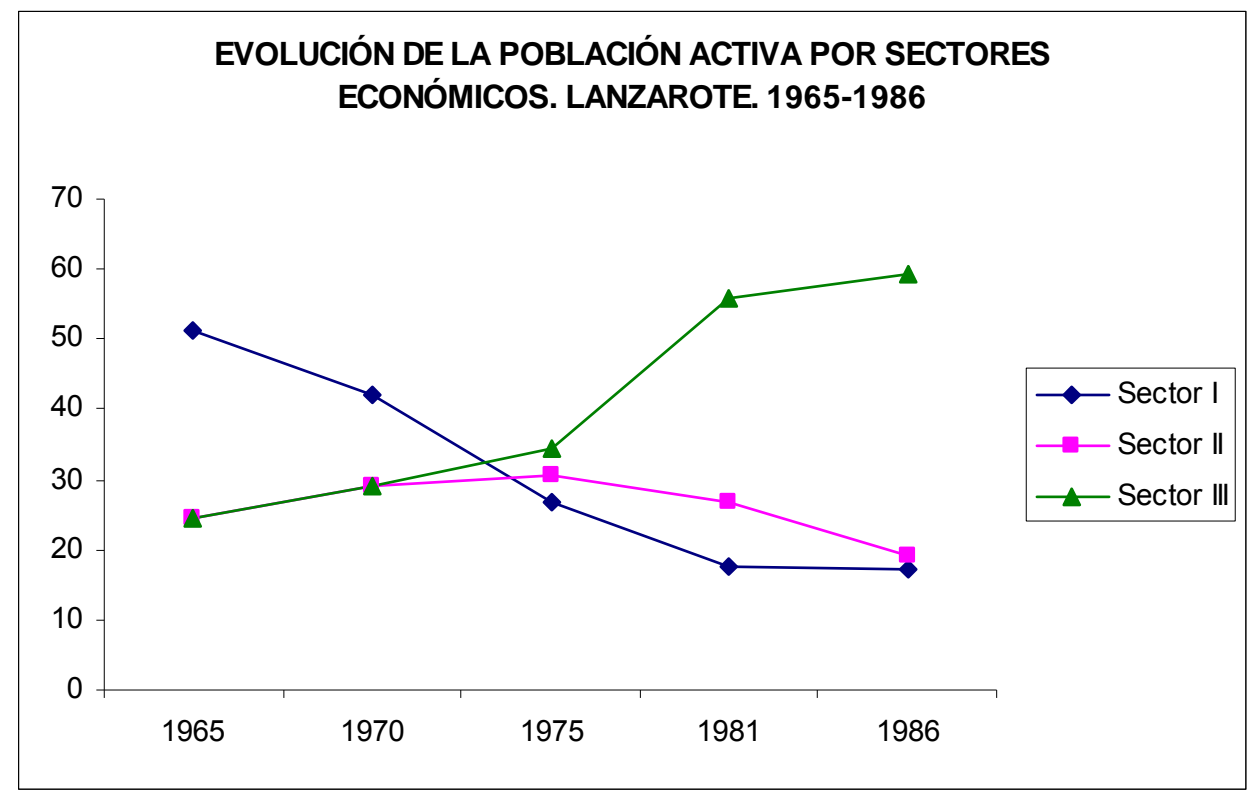

Fuente. Elaboración propia a partir de Estadísticas Básicas de Canarias, del CEDOC, y de los Informes CIES.

Lanzarote presenta la misma dinámica que la de su Comunidad Autónoma y España, dónde es el sector servicios el protagonista en la estructura sectorial, aunque es significativo señalar que el incremento de la ocupación en el sector de la construcción que experimenta la isla entre 1981 y 1986 es enorme (108\%) con respecto a lo que sucede en Canarias (15\%) y el país, dónde paradójicamente observa un crecimiento negativo de casi un $11 \%$.

\section{b.- El desempleo}

Por otro lado, en relación a la evolución del desempleo en la isla y las tasas de ocupación, se entra en la década del setenta, en palabras de Barrera, C. y Sosa M. (1994, pp. 252) con "una tasa baja de ocupación, heredada de la década anterior. Tasa ésta que a lo largo de los setenta seguirá bajando, debido a una contracción del mercado y la economía".

A la vez que bajan las tasas de ocupación, que se supone fruto del crecimiento de la población que sufre la isla por esta época, se da un incremento del paro. En los primeros años de la década del setenta se ha calibrado el paro, en las Islas Orientales, entre el $2 \%$ y el $3 \%$. Cifras éstas que irán al alza hasta la actualidad, puesto que, como señala Barrera, C. y Sosa, M. (1994, pp. 258), “(...) a medida que el modo de producción capitalista se impone y generaliza en Lanzarote, el desempleo tiende al alza de manera constante". Aunque éste incremento puede ser explicado, además, por las siguientes causas:

- El descenso de las emigraciones (y retorno de los emigrados), junto con el aumento de las inmigraciones hacia la isla. 
- Intento de acceso al mercado de trabajo, en las décadas del setenta y el ochenta, de la generación nacida en los cincuenta y setenta.

Una de las conclusiones, por tanto, que se arrojan del comentario anterior es que, la población que engrosa la situación de desempleado, es una población joven.

A partir de la década de los años ochenta, los datos de desempleo insulares mantienen un peso relativo superior al nacional y al de su comunidad autónoma, pues mientras casi el $19 \%$ de los activos de la isla están en paro, en Canarias y España se sitúan en el $17 \%$ y el $14 \%$ respectivamente, al menos hasta la mitad de la década (1986), en la que la tasa de paro insular desciende, situándose en $13,4 \%$, por debajo de la autonómica (en un 10\%) y de la nacional (en un $8 \%$ ), pues la isla vive un boom turístico acompañado de rápidos incrementos del número de plazas de alojamiento, y por tanto del empleo en la construcción y en los servicios turísticos (los ocupados en ambos sectores se incrementan en 108\% y $48 \%$ respectivamente), absorbiendo población inmigrante, por trabajo, del resto del archipiélago y de la península, principalmente, como se ha señalado en anteriores capítulos. Por tanto, también se incrementa la actividad.

Tabla 56. Tasa de actividad y paro por sexo. Lanzarote, Canarias y España. 1981-1986 (\%)

\begin{tabular}{|l|r|r|r|r|r|r||}
\cline { 2 - 8 } \multicolumn{1}{c|}{} & \multicolumn{2}{c|}{ LANZAROTE } & \multicolumn{2}{c|}{ CANARI AS } & \multicolumn{2}{c|}{ ESPAÑ A } \\
\cline { 2 - 8 } \multicolumn{1}{c|}{} & \multicolumn{1}{c|}{1981} & \multicolumn{1}{c|}{1986} & \multicolumn{1}{c|}{1981} & \multicolumn{1}{c|}{1986} & \multicolumn{1}{c|}{1981} & \multicolumn{1}{c|}{1986} \\
\hline \hline Tasa de actividad & 47,5 & 50,4 & 46,8 & 48,0 & 46,6 & 34,6 \\
\hline Varones & 50,0 & 75,8 & 73,4 & 35,2 & 73,5 & 70,3 \\
\hline Mujeres & 12,3 & 24,2 & 21,0 & 12,8 & 27,6 & 29,6 \\
\hline Número de parados & 2.450 & 2.689 & 72.551 & 117.837 & $2.031,9^{*}$ & $2.954,8^{*}$ \\
\hline \hline Tasa de paro & 18,6 & 13,4 & 16,9 & 23,7 & 14,4 & 21,5 \\
\hline Varones & 16,7 & 10,4 & 14,0 & 21,5 & 13,8 & 18,4 \\
\hline Mujeres & 26,7 & 23,1 & 26,6 & 29,7 & 17,9 & 25,7 \\
\hline \hline
\end{tabular}

$\left({ }^{*}\right)$ En miles de personas.

Fuente: "Población parada, Lanzarote, 1981.". Censo de 1981 y Padrón Municipal de Habitantes, 1986. En INE y Cabildo Insular de Lanzarote. Avance PIOT, 1987). Tomo 4. Documentos, n 3, Tabla 3.1, 1987; "Población activa y tasas de actividad de Canarias según sexo, por islas, y Total Nacional, 1981”. Estadísticas Básicas de Canarias, 1980-1985. Tomo I. Centro de Estadística y documentación de Canarias (CEDOC); "Paro registrado en Canarias según grupos de edad y sexo, por islas. 1981". Estadísticas Básicas de Canarias, 1980-1985. Tomo I. Centro de Estadística y documentación de Canarias (CEDOC); "Población de derecho de 16 y más años de Lanzarote y la Comunidad Autónoma de Canarias según sexo y relación con la actividad económica, 1986". Anuario Estadístico de Canarias, 1986. Centro de Estadística y documentación de Canarias (CEDOC); "Población parada y Tasa de paro. Datos nacionales (en miles). 1986". EPA y Padrón municipal de habitantes, 1986. INE. Elaboración Propia. 
Gráfico 38. Evolución de la tasa de paro. Lanzarote, Canarias y España. 1981-1986

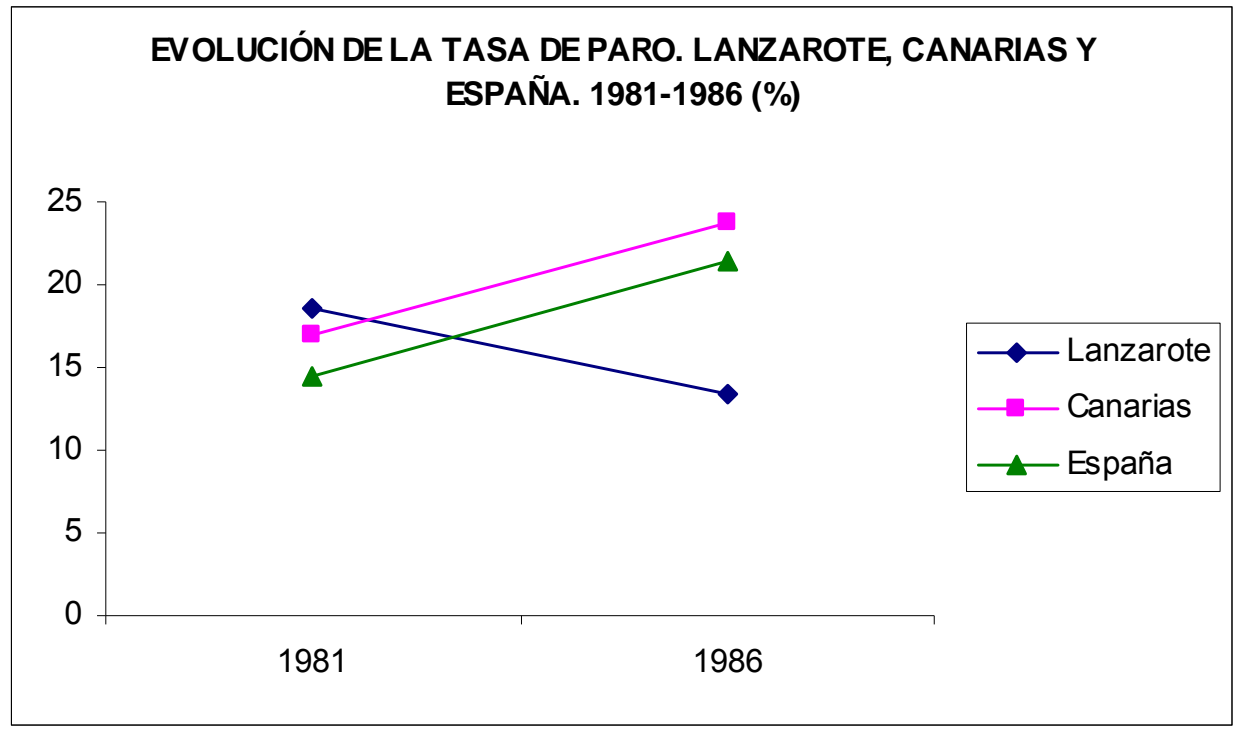

Fuente: Elaboración propia a partir del paro registrado. CEDOC e INE.

Por otro lado, el perfil social del parado es femenino, al igual que se observa en el resto de España, por lo que las menores tasas de actividad son también femeninas.

Gráfico 39. Evolución de la tasa de paro por sexo. Lanzarote, Canarias y España. 1981-1986

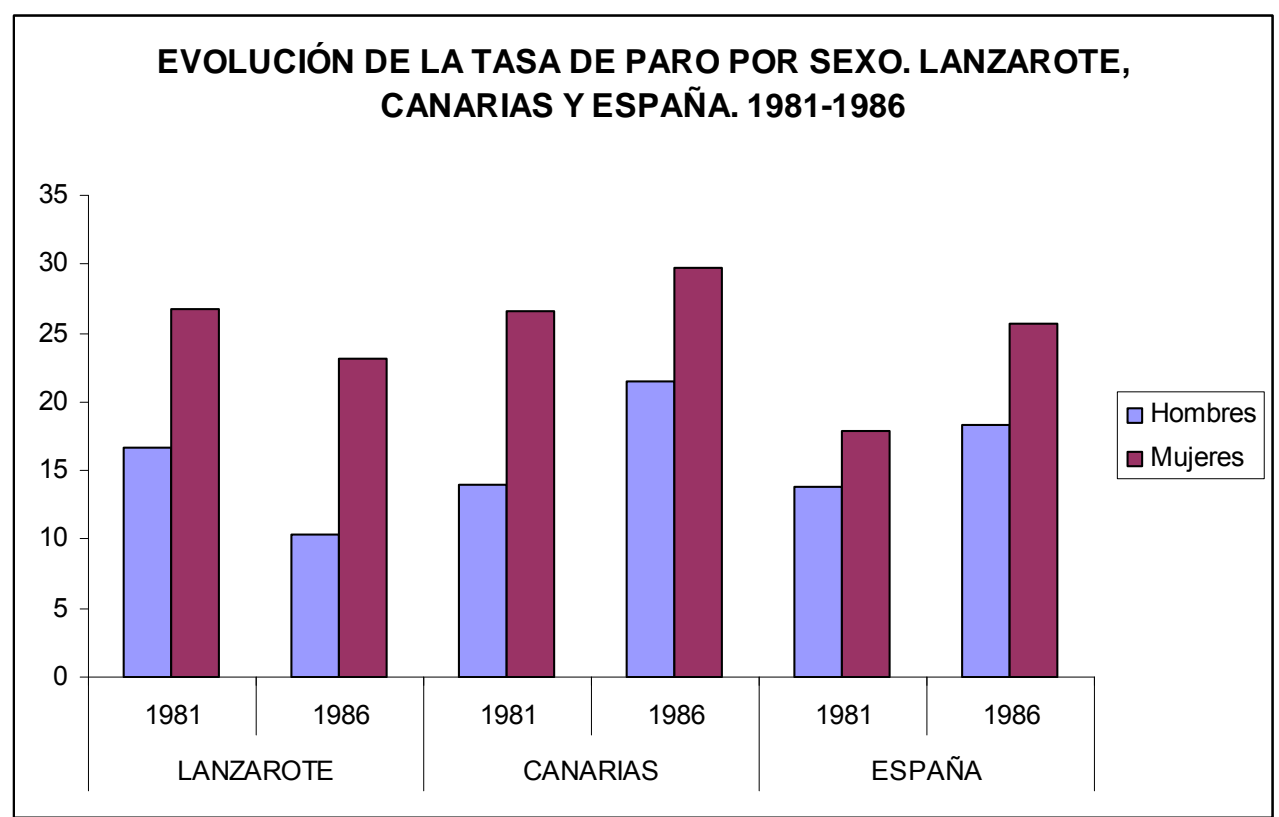

Fuente: Elaboración propia a partir del paro registrado. CEDOC e INE.

En este quinquenio, al igual que se observa una curva de descenso en las tasas de paro, también se hace notable dicho descenso por sexo, principalmente en lo que respecta al paro femenino insular, frente a Canarias y España que engrosan sus tasas. 
En relación a los sectores donde se localiza el desempleo, el comienzo de la década del ochenta hará sentir los efectos de la segunda crisis del petróleo, aumentando el paro en la industria, la construcción y los servicios, mientras que se mantiene casi el pleno empleo en el sector primario (PIOT, Tomo 4. Área Económica, 1987, pp. 9-10).

Tabla 57. Estructura sectorial del paro. Lanzarote, Canarias y España. 1981-1986 (\%)

\begin{tabular}{|l|c|c||c|c||c|c||}
\cline { 2 - 8 } \multicolumn{1}{c|}{} & \multicolumn{2}{c||}{ LANZ AROTE } & \multicolumn{2}{c||}{ CAN ARI AS } & \multicolumn{2}{c||}{ ESPAÑ A } \\
\cline { 2 - 8 } \multicolumn{1}{c|}{} & 1981 & 1986 & 1981 & 1986 & 1981 & 1986 \\
\hline \hline AGRICULTURA & 0,2 & 8,0 & 7,93 & 5,6 & 13,3 & 8,6 \\
\hline INDUSTRIAL & 23,7 & 20,1 & 13,65 & 6,5 & 28,3 & 15,6 \\
\hline CONSTRUCCIÓN & 27,7 & 13,9 & 35,26 & 4,0 & 26,2 & 12 \\
\hline SERVICIOS & 10,2 & 10,1 & 42,17 & 31,7 & 28,8 & 23 \\
\hline No clasificados & --- & --- & 0,99 & 42,3 & 3,4 & -- \\
\hline
\end{tabular}

Fuente: "Paro agrícola, industria, construcción y servicios. \% s/p. activa del sector, 1981 y 1986". PIOT. Tomo 4. Área económica, 1987, (pp. 29); "Parados que han trabajado antes, según rama de actividad económica, sexo y edad. Canarias, 1981". Censo de Población y viviendas de Canarias, 1981. INE; "Parados por sexo, edad y rama de actividad. Total Nacional, 1981". Censo de Población de 1981. INE; "Parados por sector económico. Canarias y Total Nacional, 1986. Media del año". EPA. INE.

Gráfico 40. Evolución del paro por sectores económicos. Lanzarote. 1981-1986 (\%)

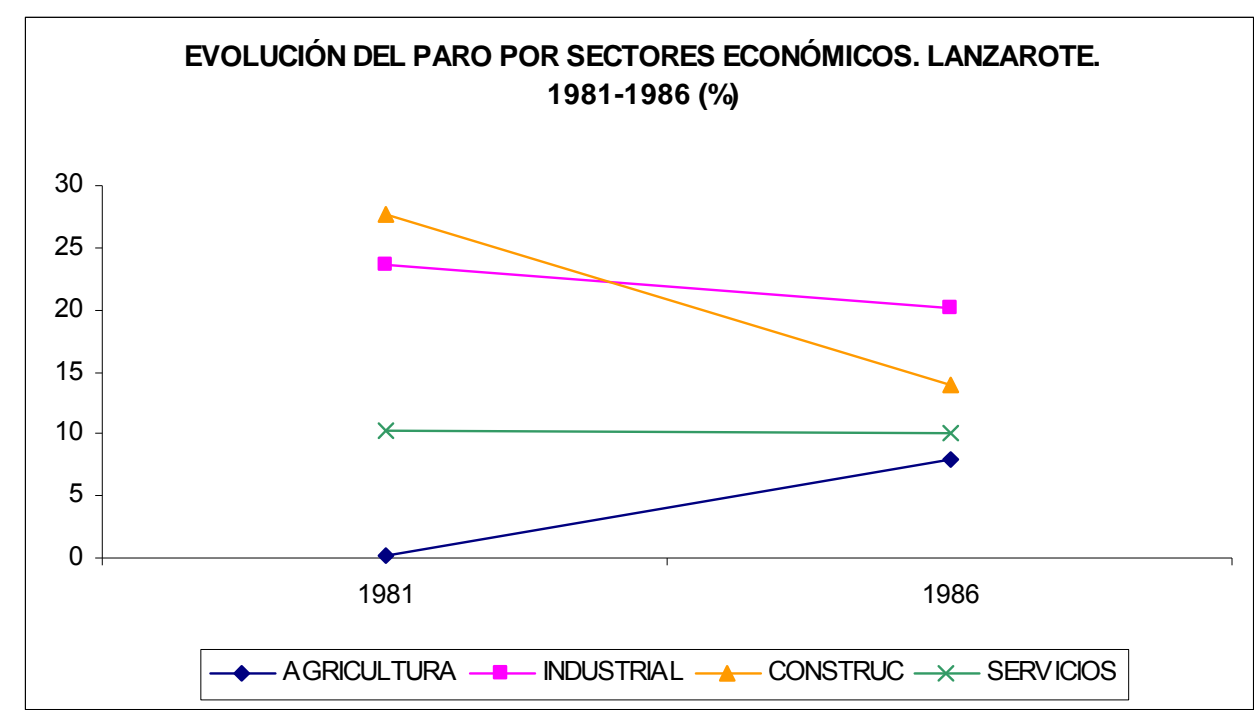

Fuente. Avance PIOT, 1987, Censo de Población, y Encuesta de Población activa. Cabildo de Lanzarote e INE.

Esta dinámica con la que empieza la década de los años ochenta se irá modificando y a la mitad de la misma (1986), las tasas de paso se reducirán en todos los sectores económicos menos en el agrícola. La economía insular ya ha entrado en un proceso de desagrarización notable, lo que explica el ascenso del paro agrícola en este quinquenio, pues aún queda población activa en el sector que tendrá que reconvertirse, ya que las oportunidades de empleo, ahora, se concentran en otras actividades. 
Gráfico 41. Estructura sectorial del paro. Lanzarote, Canarias y España. 1981-1986 (\%)

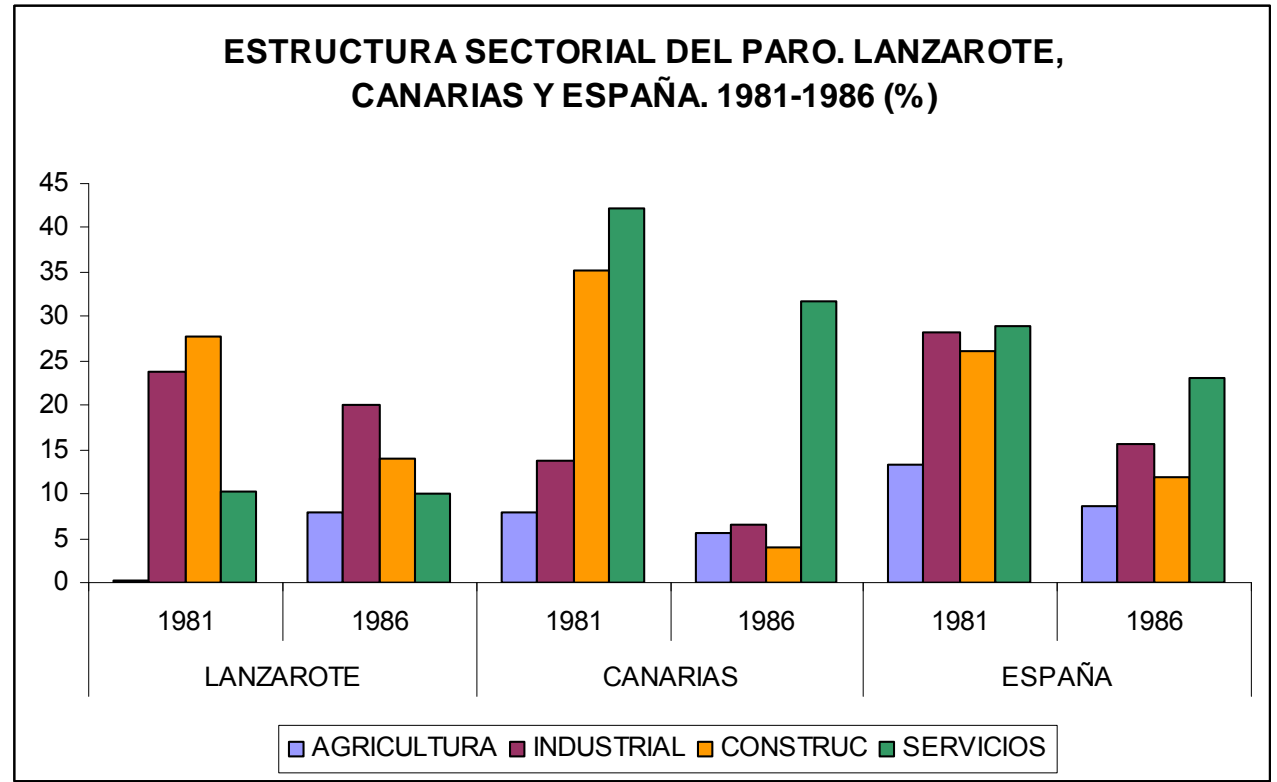

Fuente. Avance PIOT, 1987, Censo de Población, y Encuesta de Población activa. Cabildo de Lanzarote e INE.

Por tanto, y en relación a lo señalado, la isla pasa de unos niveles de paro insignificantes (2-3\%) al comienzo de esta etapa (1970) a todo lo contrario en el transcurso de la misma. Así, al final del periodo (1986), la situación del desempleo se ha multiplicado, alcanzando en quince años el $11,5 \%$ de la población activa. Todo ello a pesar de la irrupción en la economía insular de la actividad turística, que básicamente, provoca la entrada masiva de trabajadores externos. La dinámica de ascenso del desempleo en esta etapa, es similar para la Comunidad Autónoma y España.

\subsubsection{2.- POBLACIÓN, OFERTA Y DEMANDA TURÍSTICA, EMPLEO Y PARO}

¿Es factible el aumento de la oferta turística como medida de creación de empleo y por tanto de incremento del bienestar? Para contestar esta pregunta se han calculado los porcentajes de incremento de los principales indicadores de empleo junto con los de oferta y demanda turística. Sin olvidar que hay un elemento que puede afectar a los indicadores socioeconómicos como es el aumento de la población potencialmente activa. 
Tabla 58. Incremento de la población potencialmente activa, la oferta y demanda turística, el empleo y el paro. Lanzarote, Canarias y España entre 1970 y 1986 (\%)

\begin{tabular}{|l|c|c|c|c|c|}
\cline { 2 - 6 } \multicolumn{1}{c|}{} & $\begin{array}{c}\text { Incremento de } \\
\text { P.P.A. }\end{array}$ & $\begin{array}{c}\text { Incremento de } \\
\text { Plazas }\end{array}$ & $\begin{array}{c}\text { Incremento de } \\
\text { Afluencia }\end{array}$ & $\begin{array}{c}\text { Incremento de } \\
\text { Ocupados }\end{array}$ & $\begin{array}{c}\text { Incremento de } \\
\text { Parados }\end{array}$ \\
\hline \hline LANZAROTE & & $2.089,9$ & $1.646,7$ & 57,3 & 559,1 \\
\hline CANARIAS & 40,3 & 665,2 & 539,5 & 11,2 & $1.175,3$ \\
\hline ESPAÑA & 18,0 & 107,6 & 96,6 & $-1,5$ & 692,8 \\
\hline
\end{tabular}

Fuente: P. P. A: Población potencialmente activa (de 16 a 64 años) estimada a partir del Censo de Población de 1970 y del Padrón Municipal de 1986, para Canarias y España (INE); "Personas económicamente activas y en situación de paro, 1970. España y Canarias. Censo de Población, 1970. INE. Elaboración propia a partir de datos de capítulos anteriores.

En relación a los datos obtenidos, la respuesta a la pregunta formulada en este epígrafe no arroja una respuesta positiva, es decir, no es factible el aumento de la oferta turística como medida de incremento del empleo y por tanto del bienestar social derivado del mismo, pues entre 1970-1986, la explosión de la oferta turística, por un lado, que se estima con un crecimiento de más del $2.000 \%$ y, por otro lado, la demanda (entrada de turistas) con una evolución porcentual de más de $1.600 \%$ en los quince años que abarca la etapa, conducen a una situación de elevación del número de ocupados pero con un incremento del paro realmente alarmante, pues entre el inicio y el final de este periodo su crecimiento ha sido $559 \%$, este fenómeno se produce a pesar de la fuerte dinámica en la actividad turística y la construcción que vive la isla. El incremento del paro está por encima del crecimiento de la población potencialmente activa, que tendrá dificultades para insertarse en el mercado laboral.

En comparación, aunque Canarias y España moderan el crecimiento de su oferta y demanda turística, sufren, al igual que Lanzarote, un incremento del número de parados, e incluso un crecimiento negativo del número de ocupados como es el caso de la nación ($1,5 \%)$.

\subsubsection{3.- CONCLUSIONES}

Lanzarote despunta su economía turística en la década de los años setenta y al inicio de la década del ochenta ya se había instalado como territorio receptor de masas turísticas, centrando todo su esfuerzo de desarrollo en el sector servicios, basado en la actividad turística. Así, las dinámicas de actividad y empleo, y a modo de conclusión, se concretan en los siguientes puntos:

1. Continua reducción de la actividad y de la población empleada en el sector primario. Y creciente descomposición de la fuerza de trabajo agraria. El fenómeno es general en toda Canarias. 
2. Aumento de la actividad en el sector secundario, en las ramas de la construcción.

3. Fuerte engrosamiento de la población activa dentro del sector terciario.

4. Reducción de las tasas de paro a lo largo de la década de los años ochenta, por debajo de Canarias y España, por incremento de la actividad.

5. El número de parados aumenta, y se concentra en la industria y en la construcción, derivado del aumento de las inmigraciones.

6. El incremento de la oferta y la demanda turística no es directamente proporcional al incremento del empleo y al decremento del desempleo.

La rápida incorporación de la actividad turística y los elevados incrementos constantes de la oferta, modifican en un breve espacio de tiempo la estructura económica y laboral insular, concentrándose ahora en la construcción y los servicios, principalmente turísticos, lo que revierte en incrementos de la actividad, e inicialmente la práctica inexistencia de desempleo se modifica hacia incrementos constantes del paro, por la incorporación continua de trabajadores externos.

La situación del empleo mejora y con ella las posibilidades y oportunidades vitales de la población, siendo una etapa positiva para alcanzar mayores cuotas de bienestar social a través del empleo derivado de la nueva actividad que irrumpe, el turismo.

\subsection{6.- EFECTOS SOBRE LA RIQUEZA. LA RENTA. 1970-1986}

En la medida que el turismo es un acto que supone desplazamiento momentáneo, con realización de gasto de renta, cuyo objetivo principal es conseguir satisfacción y servicio, que se ofrecen a través de una actividad productiva, generada mediante una previa inversión, se convierte en un hecho económico. Significa, por tanto, "un consumo de renta anteriormente obtenida, un consumo de bienes y servicios, y una generación de riqueza" (Figuerola, M. 1979, p. 34); en relación a su intensidad así será su afección sobre la economía nacional, regional, local o insular.

Muchos países, a lo largo de su historia reciente, han visto el turismo como una forma de salir de su situación de subdesarrollo. La expansión de esta actividad ha significado, y aún significa para algunos, una valiosa aportación de divisas cuando se padecen crónicos déficits en la balanza de pagos o cuando no existe la suficiente capacidad de gestión, inversión o de equipos productivos que impulsen el crecimiento. (...) Es por ello que el turismo se verá como la actividad que podrá proporcionar el soporte imprescindible, cuando se carezca de otro sector productivo que atraiga los medios de pagos para compensar las entradas de bienes y servicios que el país exige para un normal desenvolvimiento 
(Figuerola, M. 1979, pp. 55-56). Este es el caso de España y de sus territorios turísticos durante esta etapa.

Para ver si este proceso se produce en Lanzarote, este epígrafe tiene como objetivo medir la variación y establecer la evolución de la renta familiar en la isla. Para ello se toma como punto de arranque un estudio realizado en 1970, a través de la técnica de encuesta, por el Centro de Investigación Económico y Social de Canarias, que tiene como universo de investigación la isla de Lanzarote, con una muestra estratificada, proporcional a los siete municipios insulares. A partir de los resultados municipales se derivan conclusiones para el ámbito insular. La intención es dar idea de la situación con la que arranca la isla.

Posteriormente se toman los estudios sobre renta municipal elaborados por el Banesto, en la década de los años ochenta y noventa, que nos permiten la comparación por su continuidad metodológica. A través de los cuales se emitirá una conclusión de ámbito insular.

Así, nos acercaremos a la situación y la evolución de la capacidad adquisitiva familiar y por tanto de las posibilidades de la población de acceso a bienes y servicios que repercuten en su bienestar.

\subsubsection{1.- EVOLUCIÓN DE LA RENTA.}

Lanzarote, al final de la década de los años sesenta, se presenta como un sistema económico cerrado al exterior. Posee una economía relativamente simple, aunque la dificultad la encontramos en que su "subdesarrollo económico viene relacionado con un enorme subdesarrollo informativo e incluso un desconocimiento de las variables mínimas exigidas para cualquier cuantificación seria de las actividades productivas" (C.I.E.S., Boletín $\mathrm{n}^{\circ}$ 11. 1971, pp. $\left.143^{155}\right)$.

C.I.E.S, para 1970, establece la Renta Insular Interior Neta en 858.738 .672 pesetas al año. El siguiente cuadro establece una pirámide de ingresos monetarios familiares.

${ }^{155}$ C.I.E.S., para este estudio, realiza su propia encuesta de presupuestos familiares y consumo familiar. 
Tabla 59. Rentas monetarias per cápita y por hogar, por municipio. Lanzarote, Provincia de Las Palmas y Canarias. 1970 (ptas/mes)

\begin{tabular}{|l|l|l|l|l|l|l|l|l|l|l||}
\cline { 2 - 9 } \multicolumn{1}{c|}{} & Arrecife & Haría & S.Bartolomé & Teguise & Tías & Tinajo & Yaiza & Lanzarote & $\begin{array}{l}\text { Las } \\
\text { Palmas }\end{array}$ & Canarias \\
\hline $\begin{array}{l}\text { Per } \\
\text { Cápita }\end{array}$ & 1.786 & 1.180 & 1.660 & 1.105 & 1.170 & 1.196 & 1.467 & 1.556 & 1.527 & 1.743 \\
\hline $\begin{array}{l}\text { Por } \\
\text { hogar }\end{array}$ & 9.335 & 4.346 & 7.886 & 4.606 & 5.069 & 5.400 & 8.510 & 7.452 & 7.132 & 7.618 \\
\hline
\end{tabular}

Fuente: Encuesta C.I.E.S. e Informe SIE. Elaboración C.I.E.S. 1971

Tabla 60. Distribución de ingresos monetarios familiares por municipios I mes. Lanzarote. 1970. (\%)

\begin{tabular}{|l||c|c|c|c|c|c|c|c||}
\hline Ingresos & Arrecife & Haría & S. Bartolomé & Teguise & Tías & Tinajo & Yaiza & Lanzarote \\
\hline \hline Sin respuesta & 4,76 & 2,22 & 2,23 & 4,26 & --- & 11,72 & 20,00 & 5,75 \\
\hline$<4.000$ & 14,29 & 46,67 & 28,89 & 44,68 & 36,10 & 35,29 & 28,00 & 25,45 \\
\hline $\mathbf{4 . 0 0 1 - 6 . 0 0 0}$ & 18,61 & 37,78 & 15,56 & 34,04 & 25,00 & 29,41 & 12,00 & 22,12 \\
\hline $\mathbf{6 . 0 0 1 - 8 . 0 0 0}$ & 21,65 & 11,11 & 17,78 & 8,51 & 22,20 & 5,88 & 4,00 & 16,61 \\
\hline $\mathbf{8 . 0 0 1 - 1 2 . 0 0 0}$ & 22,51 & 2,22 & 24,44 & 5,32 & 11,10 & 8,82 & 16,00 & 16,91 \\
\hline $\mathbf{1 2 . 0 0 1 - 1 5 . 0 0 0}$ & 6,49 & --- & 4,44 & 3,19 & 2,80 & 5,88 & 12,00 & 5,60 \\
\hline $\mathbf{1 5 . 0 0 1 - 2 0 . 0 0 0}$ & 6,93 & --- & 4,44 & --- & 2,80 & 2,94 & 4,00 & 4,65 \\
\hline$>\mathbf{2 0 . 0 0 1}$ & 4,76 & --- & 2,22 & --- & --- & --- & 4,00 & 2,91 \\
\hline
\end{tabular}

Fuente: Encuesta C.I.E.S. e Informe SIE. Elaboración C.I.E.S. 1971

Tabla 61. Distribución de los ingresos monetarios familiares por mes.

Provincia de Las Palmas y Comunidad Autónoma. 1970. (\%)

\begin{tabular}{||l||r|r||}
\hline Ingresos & Las Palmas & Canarias \\
\hline \hline$<3.100$ & 27 & 22 \\
\hline $3.101-6.000$ & 31 & 30 \\
\hline $6.001-9.000$ & 16 & 18 \\
\hline $9.001-12.000$ & 9 & 12 \\
\hline $12.001-15.000$ & 7 & 7 \\
\hline $15.001-20.000$ & 5 & 6 \\
\hline$>20.001$ & 5 & 5 \\
\hline
\end{tabular}

Fuente: Encuesta C.I.E.S. e Informe SIE. Elaboración C.I.E.S. 
Gráfico 42. Distribución del ingreso monetario familiar por mes. Lanzarote. 1970 (\%).

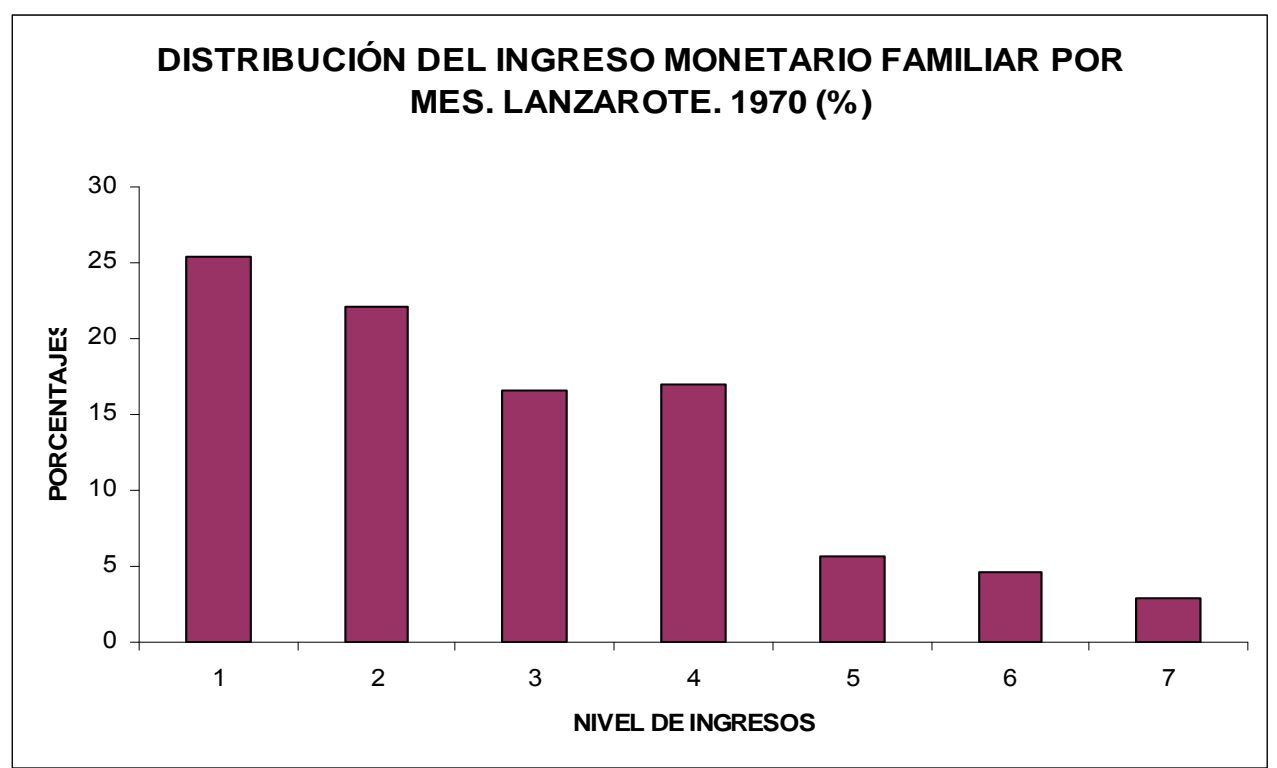

Fuente: Encuesta C.I.E.S. e Informe SIE. Elaboración propia.

La mayor parte de la población insular, aproximadamente el $64 \%$, posee unos ingresos inferiores a 8.000 ptas/mes. Este grupo, a su vez puede ser dividido en tres subgrupos de ingresos, los que poseen menos de 4.000 ptas/mes, que suponen el $25,45 \%$ del total de las familias; los que ingresan entre 4.001 y 6.000 ptas/mes, que suponen el $22,12 \%$ insular y los que ingresan entre 6.001 y 8.000 ptas/mes, que suponen el $16,61 \%$.

Más de un cuarto de las familias de la isla poseen unos ingresos medios familiares inferiores a 4.000 ptas. Lo que este cuadro representa es una pirámide de ingresos "clásica de un grupo social altamente estratificado, ya que las diferencias de ingreso entre los más numerosos (menos de 4.000 ptas/mes) y los menos numerosos (más de 20.001 ptas/mes) son muy acusadas". (C.I.E.S., Boletín $n^{\circ} 11.1971$, pp. 192). Entre los municipios rurales esta estratificación se hace más marcada, puesto que un porcentaje importante de las familias no llegan a 4.000 ptas/mes. Es el municipio que se contempla con categoría urbana, Arrecife, junto con San Bartolomé (que se le atribuye categoría semiurbana), los que se situarán por encima de la media de renta per cápita insular ${ }^{156}$. La conclusión que de ello sacamos es, casi con seguridad, que estas circunstancias se deben a la pauperización a la que estaban sometidos los campesinos (C.I.E.S., Boletín no 11. 1971, pp. 193).

\footnotetext{
156 En el Plan de Ordenación Insular. III. 1969 (pp. 6/17), aparece reflejada la distribución de la isla por estratos territoriales clasificados en: urbano, intermedio y rural, asignándole únicamente categoría urbana a Arrecife, intermedia a San Bartolomé y rural al resto de la isla.
} 
Mapa 7. Nivel de renta disponible por habitante de los municipios de Lanzarote. 1970.

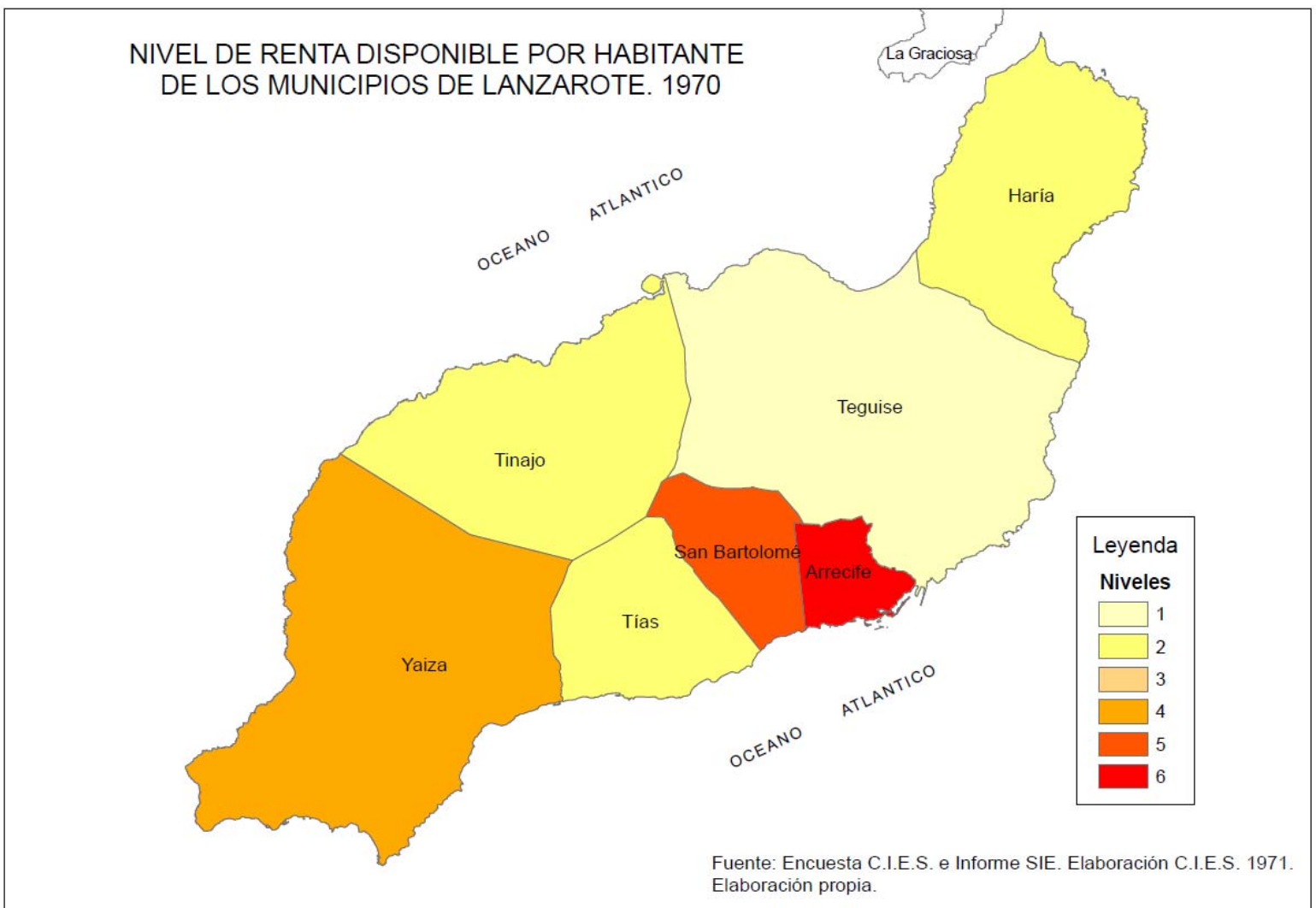

Con respecto a la provincia, Las Palmas, Lanzarote presenta una renta por hogar media superior en aproximadamente un $4,5 \%$, no así en comparación con la media de Canarias, sobre la que la isla se encuentra un $2,2 \%$ por debajo.

Gráfico 43. Distribución del ingreso monetario familiar por mes. Canarias, provincia Las Palmas y Lanzarote. 1970 (\%)

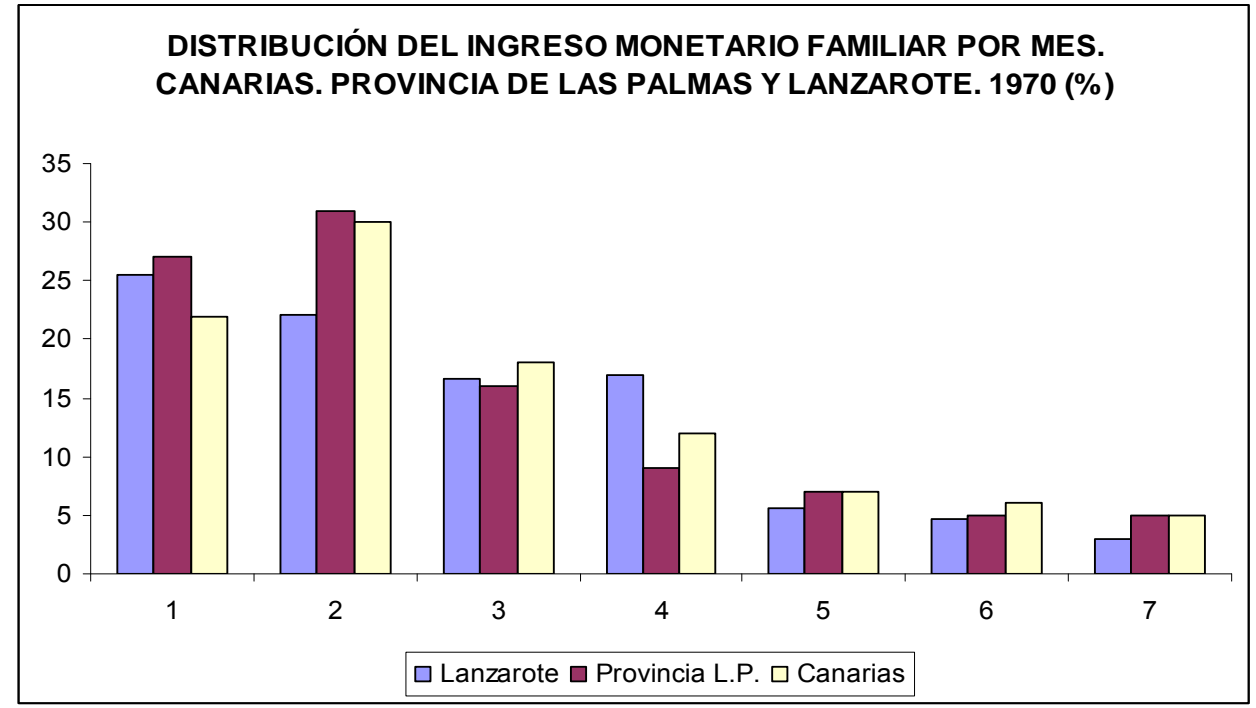

Fuente: Encuesta C.I.E.S. e Informe SIE. Elaboración propia. 
Desde esta situación de partida descrita, veamos las variaciones acontecidas posteriormente. Para ello se han tomado los estudios de renta municipal elaborados por el Banesto en la década de los años ochenta, que nos arrojan datos sobre la renta por habitante ${ }^{157}$ en relación a una serie de intervalos monetarios clasificados bajo una jerarquización de 10 niveles (en pesetas corrientes de cada año). Estos estudios nos van a permitir aproximarnos y dar idea de las variaciones en el poder adquisitivo de la población de Lanzarote, que ya en esta década registra una actividad económica turística insipiente.

Tabla 62. Nivel de renta por habitante de los municipios de Lanzarote, Canarias y España. 1981.

\begin{tabular}{|c|c|c|c|c|c|c|c|c|c|c|c|}
\hline Ptas & Nivel & Arrecife & Haría & S.Bartolomé & Teguise & Tías & Tinajo & Yaiza & Lanzarote* $^{*}$ & Canarias & España \\
\hline$\leq 170.000$ & $\overline{c 1}$ & & & & & & & & & & \\
\hline $170.001-200.000$ & 2 & & & & & & & & & & \\
\hline $200.001-230.000$ & 3 & & & & & & & & & & \\
\hline $230.001-280.000$ & 4 & & & & & & & & & & \\
\hline $280.001-350.000$ & 5 & & & & & & & & & & \\
\hline $350.001-420.000$ & 6 & & & & & & & & & & \\
\hline $420.001-500.000$ & 7 & & & & & & & & & & \\
\hline $500.001-620.000$ & 8 & & & & & & & & & & \\
\hline $620.001-750.000$ & 9 & & & & & & & & & & \\
\hline$>750.000$ & 10 & & & & & & & & & & \\
\hline
\end{tabular}

* El nivel de renta per cápita de la isla se ha calculado a través de una media ponderada en relación al peso poblacional.

Fuente: "Relación de los municipios por áreas comerciales con indicación de su nivel de renta por habitante (en pesetas corrientes de cada año). Área de Arrecife (Las Palmas), 1981”. Anuario del Mercado Español, 1983. Banco Español de Crédito (Banesto).

157 La metodología de Banesto está basada en la utilización de series de indicadores que reflejan las variaciones de renta (población de Derecho, número de teléfonos en funcionamiento y peticiones, número de licencias comerciales, número de oficinas bancarias e índice de precios de consumo. 
Mapa 8. Nivel de renta disponible por habitante de los municipios de Lanzarote. 1981

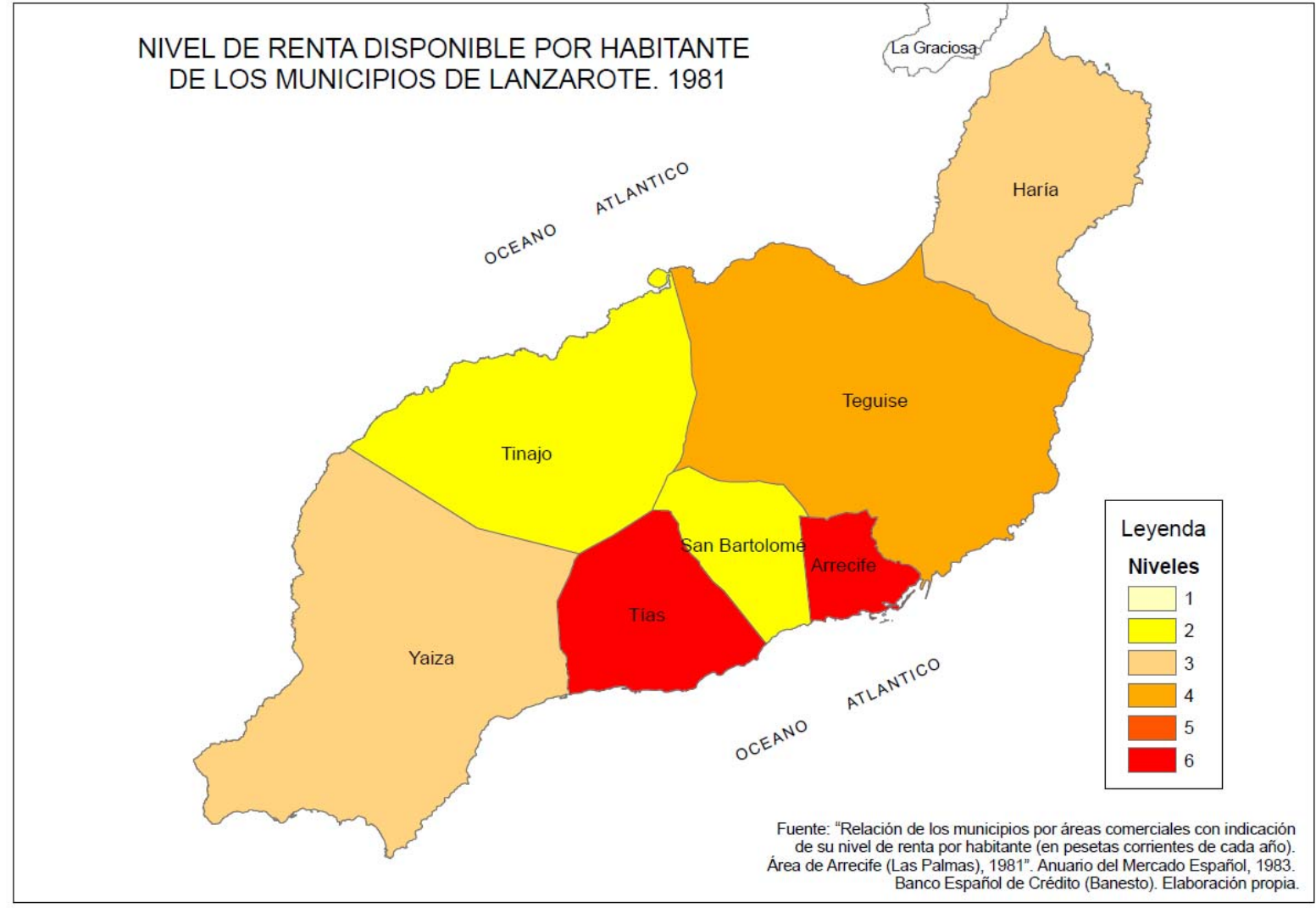

Tabla 63. Nivel de renta por habitante de los municipios de Lanzarote, Canarias y España. 1986.

\begin{tabular}{|c|c|c|c|c|c|c|c|c|c|c|c|}
\hline Ptas & Nivel & Arrecife & Haría & S.Bartolomé & Teguise & Tías & Tinajo & Yaiza & Lanzarote* & Canarias & España \\
\hline$\leq 330.000$ & 1 & & & & & & & & & & \\
\hline $330.001-385.000$ & 2 & & & & & & & & & & \\
\hline $385.001-440.000$ & 3 & & & & & & & & & & \\
\hline $440.001-525.000$ & 4 & & & & & & & & & & \\
\hline $525.001-660.000$ & 5 & & & & & & & & & & \\
\hline $660.001-825.000$ & 6 & & & & & & & & & & \\
\hline $825.001-990.000$ & 7 & & & & & & & & & & \\
\hline $990.001-1.210 .000$ & 8 & & & & & & & & & & \\
\hline $1.210 .001-1.430 .000$ & 9 & & & & & & & & & & \\
\hline$>1.430 .000$ & 10 & & & & & & & & & & \\
\hline
\end{tabular}

* El nivel de renta per cápita de la isla se ha calculado a través de una media ponderada en relación al peso poblacional.

Fuente: "Relación de los municipios por provincias, con indicación de su nivel de renta por habitante (en pesetas corrientes de cada año). Las Palmas, 1986". Anuario del Mercado Español, 1988. Banco Español de Crédito (Banesto). 


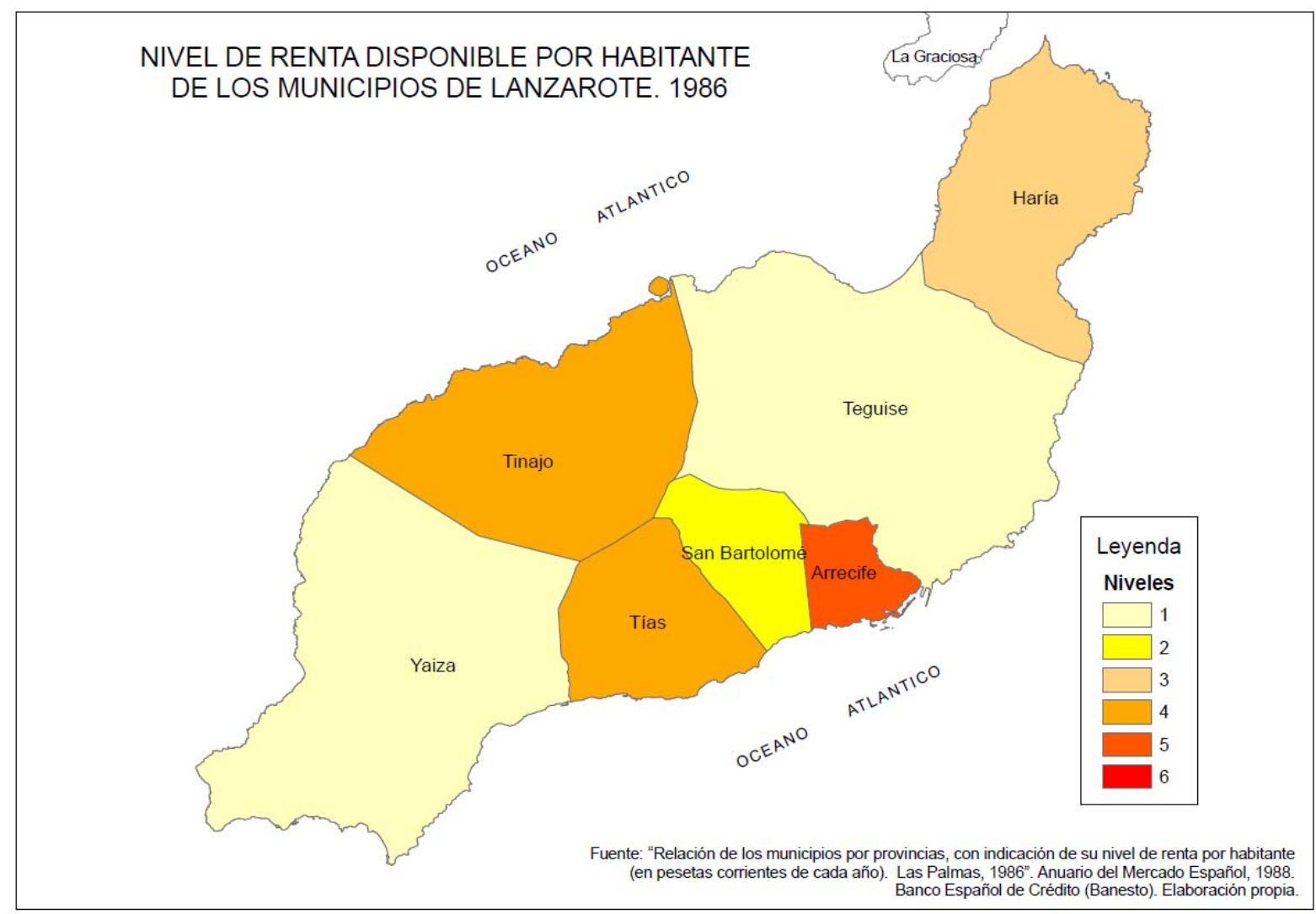

Aunque de manera general los niveles de renta media por habitante, entre 1981 y 1986 , se han elevado significativamente en la isla, su distribución municipal observa una notable jerarquización, en la que el municipio capitalino, Arrecife, centro administrativo y comercial de la Isla, mantendrá su liderazgo, en relación al nivel medio de renta por habitante, frente al resto de municipios, a lo largo de toda la etapa. Seguido de Tías, municipio que no había sobresalido hasta esta fecha, puesto que su economía, anteriormente basada en el sector primario, ha dado un fuerte giro hacia las inversiones turísticas, y concentra ahora más del $70 \%$ del alojamiento turístico, alcanzando niveles de renta similares al de la capital insular.

Los ámbitos municipales pobres son básicamente los que presentan economías con elevada presencia del sector primario, aunque algunos se están reorientando hacia la industria turística, como es el caso de Teguise, cuyo cambio será observable en la siguiente década. 
Tabla 64. Oferta turística por municipio. Lanzarote. 1986. (\%)

\begin{tabular}{|l|c|}
\hline MUNICIPIO & Plazas de alojamiento \\
\hline \hline Arrecife & 3,1 \\
\hline Haría & 0,5 \\
\hline San Bartolomé & 0,0 \\
\hline Teguise & 14,8 \\
\hline Tías & 70,8 \\
\hline Tinajo & 3,0 \\
\hline Yaiza & 7,8 \\
\hline
\end{tabular}

Fuente: "Indicadores de la oferta. Enero, 1987". Cabildo Insular de Lanzarote. "Avance Plan Insular de Ordenación del Territorio de Lanzarote, 1987". Tomo 5. Sociedad y Turismo. Capítulo IV. 3.1. (pp. 20).

Gráfico 44. Plazas de alojamiento turístico por municipio. Lanzarote. 1986 (\%).

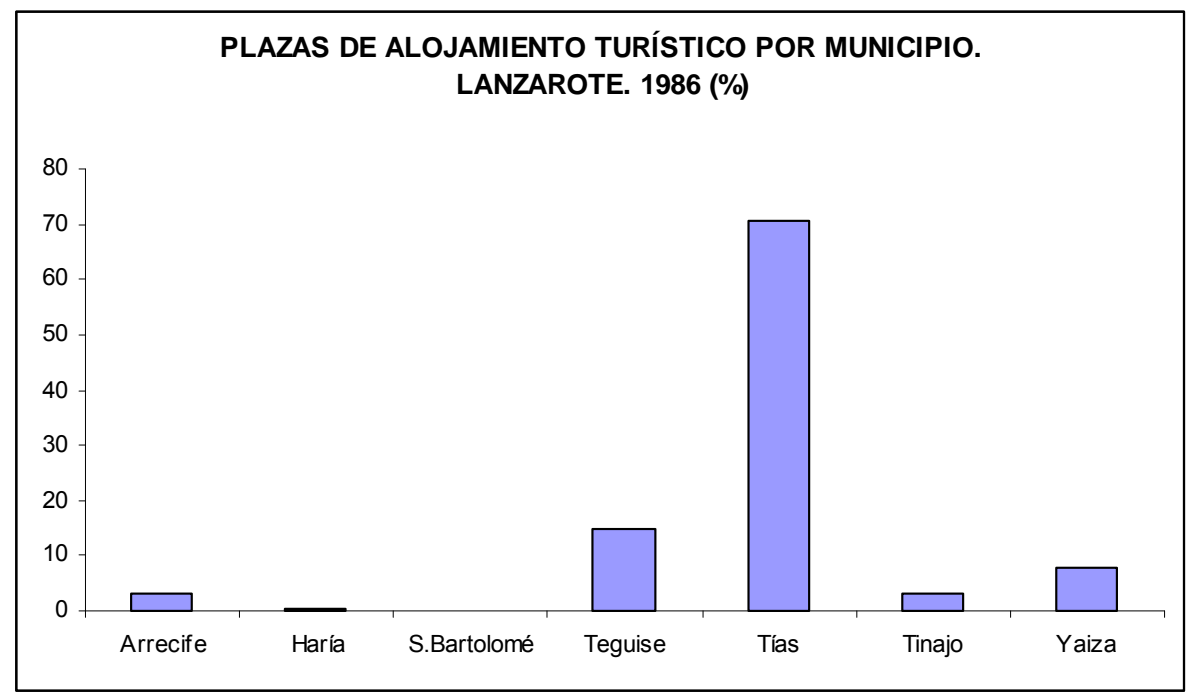

Fuente: Avance PIOT de Lanzarote, 1987. Cabildo Insular de Lanzarote. Elaboración propia.

Desde finales de los setenta, la economía conejera no ha dejado de crecer. 1983, se marca como el año de "transición a una etapa de desarrollo acelerado", de crecimiento de la economía, del sector turístico, de la construcción, y de la pérdida de productividad de los sectores económicos primarios (agricultura y pesca) en la Isla, puesto que en estos sectores las posibilidades de inversión sin riesgos y rápidos beneficios son limitadas. Por tanto, es el año en el que se "desplazan los sectores estructurantes tradicionales". A partir de esta fecha y en los cinco años siguientes, "la aportación al Producto Interior de Lanzarote del Turismo casi se dobla". (Cabildo Insular de Lanzarote. Avance PIOT. Tomo 4. Área Económica. 1987, pp. 3, 12 y 16). 
En términos generales, a lo largo de toda la etapa, el municipio capitalino seguirá sobresaliendo del resto, pero el fenómeno notable lo marcarán los municipios que incorporan actividad turística, que serán aquellos que poseen costas poco escarpadas, cómo es el caso de Tías, que dentro de la economía de servicios turísticos insular llevará la delantera, creciendo su nivel de renta de forma explosiva durante este periodo.

Aproximadamente, podemos afirmar que la renta media per cápita insular pasa de situarse en el intervalo de entre 230.001-280.000 ptas, en 1981 a, encontrarse entre 385.001440.000 ptas, en 1986. Un importante salto cuantitativo en tan corto periodo de tiempo.

\subsubsection{2.- CONCLUSIONES}

Esta etapa, 1970-1986, de despegue y consolidación de la economía turística insular, se caracteriza por presentar una constante elevación de la renta per cápita y familiar, con crecimientos rápidos en cortos periodos de tiempo.

Esta dinámica económica, aunque repercute en la totalidad de la isla, presenta una notable jerarquización municipal, pues los incrementos de renta significativos se concentran, principalmente, en dos puntos de su territorio: el centro administración y comercial (Arrecife) y en los municipios que concentran la oferta turística, que en este periodo es principalmente uno, Tías.

Por tanto, la riqueza se ha incrementado rápidamente por la nueva actividad que irrumpe, aunque la fuerte jerarquización indica un proceso de diferenciación y marginalidad a la que se ven sometidas determinadas administraciones locales, por no acometer intervenciones encaminadas hacia los servicios al turismo.

En términos generales, la isla eleva sus ingresos y con ello las posibilidades y oportunidades de la población de acceso a bienes y servicios que mejoren su bienestar. La incorporación de esta actividad, el turismo, y el constante y elevado ritmo de crecimiento de la oferta y la demanda de dichos servicios ha sido la vía de salida del subdesarrollo insular en términos económicos.

\subsection{7.- EFECTOS SOBRE LA CAPACIDAD ENERGÉTICA. 1970-1986}

La capacidad energética de un territorio a la hora de acometer la implantación de nuevas actividades económicas como el turismo, es de vital importancia. Así pues, es necesario analizar el estado y evolución de la producción y consumo energético en la isla de Lanzarote, que se caracteriza por la carencia de fuentes de energía primaria convencional, lo que la convierte, junto con el resto del archipiélago en dependiente del exterior, acentuando su vulnerabilidad energética, pues necesita dicha energía para potabilizar agua y abastecer el consumo energético en su totalidad. 
Dejando al margen los consumos ligados al transporte, nos centraremos, principalmente, en el sistema eléctrico insular, en cuanto que fuente básica de servicios para el bienestar de la población local, cuyo funcionamiento se ha visto afectado por la presión turística y demográfica asociada, que sufre desde su despegue hasta su madurez como destino turístico. Y sin olvidar que la cuestión energética se ha considerado uno de los más importantes problemas infraestructurales en la isla (Avance PIOT, 1987, Tomo 2.VII, pp. 63).

El objeto de este análisis es ver en qué medida la transformación producida en la isla por el turismo ha incidido en sus cambios energéticos y en los servicios a los residentes, tanto en facilidad de acceso como en disponibilidad.

\subsubsection{1.- POTENCIA Y PRODUCCIÓN}

A finales de los años sesenta, las fuentes de producción de energía eléctrica en la isla son de dos tipos principalmente: la generada por la Planta Dual Potabilizadora y Desaladora de agua y de producción de energía eléctrica (Termoeléctrica de Lanzarote) e instalaciones de pequeños grupos diesel (en algunos municipios) y pequeños motores (Plan Insular de Lanzarote, 1973, Doc. I.3. pp. 149). Prácticamente toda la producción eléctrica de la isla se realiza mediante centrales térmicas de combustión interna, ello se debe a las condiciones geográficas (insularidad) y la falta casi total de recursos energéticos no renovables, aunque sí posee sol, viento, mar y energía geotérmica, no explotados en esta etapa. "Estas centrales se caracterizan por su gran rapidez de instalación, periodos de amortización muy cortos y alto coste del Kwh producido" (Avance PIOT, 1987. Tomo 2. Cap. 4.G (pp. 235), perjudicando, por tanto, el precio de la energía que paga el ciudadano. 
Mapa 10. Redes eléctricas y sistema energético de Lanzarote. 1973.

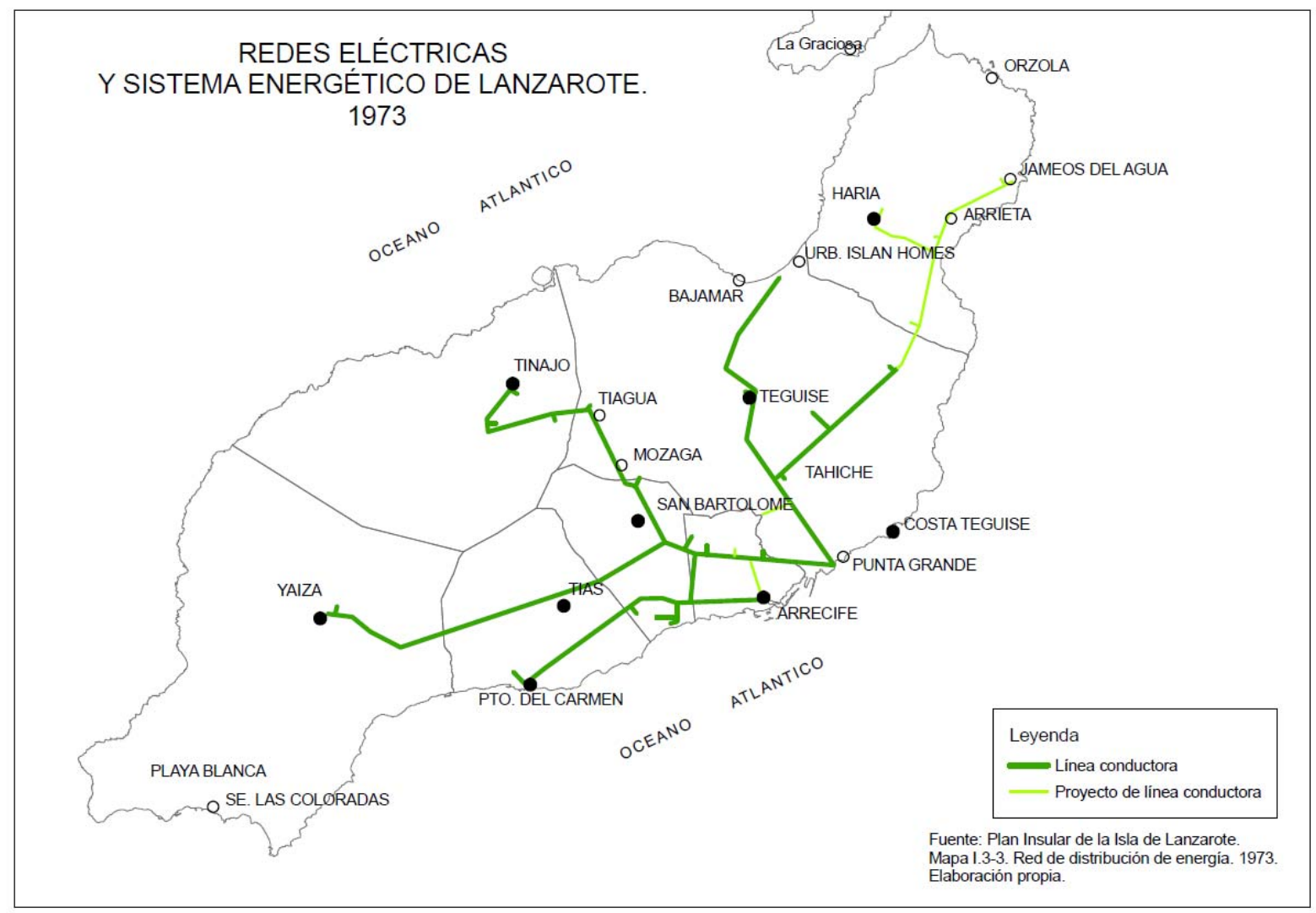

Al comienzo de la década de lo años ochenta la situación ha mejorado, pues existen dos centrales eléctricas que proporcionan el suministro para toda la isla, de las cuales parten líneas de transporte eléctrico, hacia el norte, centro y sur de la isla. Esta última continúa a través de un cable submarino hacia la isla vecina, Fuerteventura, proporcionándole suministro eléctrico. Por tanto, se define un sistema Lanzarote-Fuerteventura.

Tabla 65. Potencia instalada. Lanzarote, Canarias y España. 1970-1986 (kw)

\begin{tabular}{|c|r|r|r|r|r||}
\hline Año & LANZAROTE & Kw/Residente & Kw/P.Total $^{*}$ & $\begin{array}{l}\text { Incremento quinquenal } \\
\text { (Kw/P.Total) (\%) }\end{array}$ & $\begin{array}{c}\text { Variación. (Kw/P.Total) } \\
\text { respecto estándar (\%) }\end{array}$ \\
\hline 1970 & 2.700 & 0,07 & 0,07 & & $-94,10$ \\
\hline 1975 & 2.700 & 0,06 & 0,06 & $-6,21$ & $-94,46$ \\
\hline 1981 & 12.330 & 0,26 & 0,23 & 290,78 & $-78,37$ \\
\hline 1986 & 22.120 & 0,40 & 0,29 & 28,64 & $-72,17$ \\
\hline
\end{tabular}




\begin{tabular}{|r|r|r|r|r||}
\hline Año & CANARIAS & Kw/Residente & Kw/P.Total & $\begin{array}{l}\text { Incremento quinquenal } \\
\text { (Kw/P.Total) (\%) }\end{array}$ \\
\hline \hline 1970 & 221.739 & 0,20 & 0,20 & 85,34 \\
\hline 1975 & 467.983 & 0,36 & 0,35 & 2,26 \\
\hline 1981 & 527.779 & 0,39 & 0,37 & 20,92 \\
\hline 1986 & 715.070 & 0,49 & 0,45 & \\
\hline
\end{tabular}

\begin{tabular}{|r||l|r|r|r||}
\hline Año & ESPAÑA & Kw/Residente & Kw/P.Total & $\begin{array}{l}\text { Incremento quinquenal } \\
\text { (Kw/P.Total) (\%)) }\end{array}$ \\
\hline \hline 1970 & 17.924 .000 & 0,53 & 0,52 & 34,90 \\
\hline 1975 & 25.466 .771 & 0,71 & 0,70 & 20,98 \\
\hline 1981 & 32.788 .242 & 0,87 & 0,86 & 25,00 \\
\hline 1986 & 42.003 .412 & 1,09 & 1,08 & \\
\hline
\end{tabular}

(*) P.Total: población residente + turistas equivalentes diarios

Fuente: Para 1970: Potencia Instalada en 1968 en Lanzarote. Plan Insular de Lanzarote, 1973. Doc. I.3. (pp. 149). Ministerio de Vivienda, 1973; "Potencia instalada. Total Nacional y Provincia de Las Palmas y Tenerife, 1970". Estadística de la Industria de Energía Eléctrica, 1970. Ministerio de Industria, Turismo y Comercio. www.mityc.es/energia/balances/; Para 1975: "Potencia Instalada bruta, Lanzarote, 1975". Avance Plan Insular de Lanzarote, 1987. Tomo 2. Cap. 4. Cuadro 4.3 (pp. 236); "Potencia instalada. Total Nacional y Provincia de Las Palmas y Tenerife, 1975". Estadística de la Industria de Energía Eléctrica, 1975. Ministerio de Industria, Turismo y Comercio. www.mityc.es/energia/balances/; Para 1981: "Potencia Instalada bruta, Lanzarote, 1981". Avance Plan Insular de Lanzarote, 1987. Tomo 2. Cap. 4. Cuadro 4.3 (pp. 236); "Potencia instalada en Kw al 31-12 de cada año por UNELCO en Canarias según Centrales, 1981". Estadísticas Básicas de Canarias, 1980-1985. CEDOC; "Potencia instalada. Total Nacional, 1981". Estadística de la Industria de Energía Eléctrica, 1981. Ministerio de Industria, Turismo y Comercio. www.mityc.es/energia/balances/; Para 1986: "Potencia Instalada bruta, Lanzarote, 1986". Avance Plan Insular de Lanzarote, 1987. Tomo 2. Cap. 4. Cuadro 4.3 (pp. 236); "Potencia instalada (kw) y producción de energía eléctrica por UNELCO en Canarias según centrales. Total UNELCO, 1986". Anuario estadístico de Canarias, 1986. CEDOC; "Potencia instalada. Total Nacional, 1986". Estadística de la Industria de Energía Eléctrica, 1986. Ministerio de Industria, Turismo y Comercio. www.mityc.es/energia/balances/;

La capacidad de producción eléctrica de Lanzarote se va a ir ampliando a lo largo del periodo, de forma muy significativa en la década de los años ochenta (pues la potencia instalada se incrementa en un $356,7 \%$ entre 1975 y 1981), aunque siempre es escasa, debido al constante incremento de población tanto residente como turista que soporta. Es por ello que "entre 1984 y 1986 se importa energía desde Fuerteventura, pero a partir de este momento no puede contarse con los generadores de la isla vecina" (Avance PIOT Lanzarote, 1987, Tomo 2. Cap. 4, pp. 237) puesto que ésta también sufre un fuerte desarrollo.

El equipamiento para consumo doméstico con "estándares" nacionales se establece en los años ochenta en 1,1 Kw/hab., correspondiente a la electrificación media, que prevé el reglamento de baja tensión. La isla no tiene potencia suficiente para cubrir el estándar medio vigente, se encuentra en un $94,10 \%$ por debajo en 1970 , en relación a la población 
total diaria (que incluye los turistas equivalentes al día) y en 1986 continúa alejado un $72 \%$. El conjunto del archipiélago sufre las mismas carencias.

Gráfico 45. Evolución de la potencia instalada por habitante. España, Canarias y Lanzarote. 1970-1986 (Kw/P.Total)

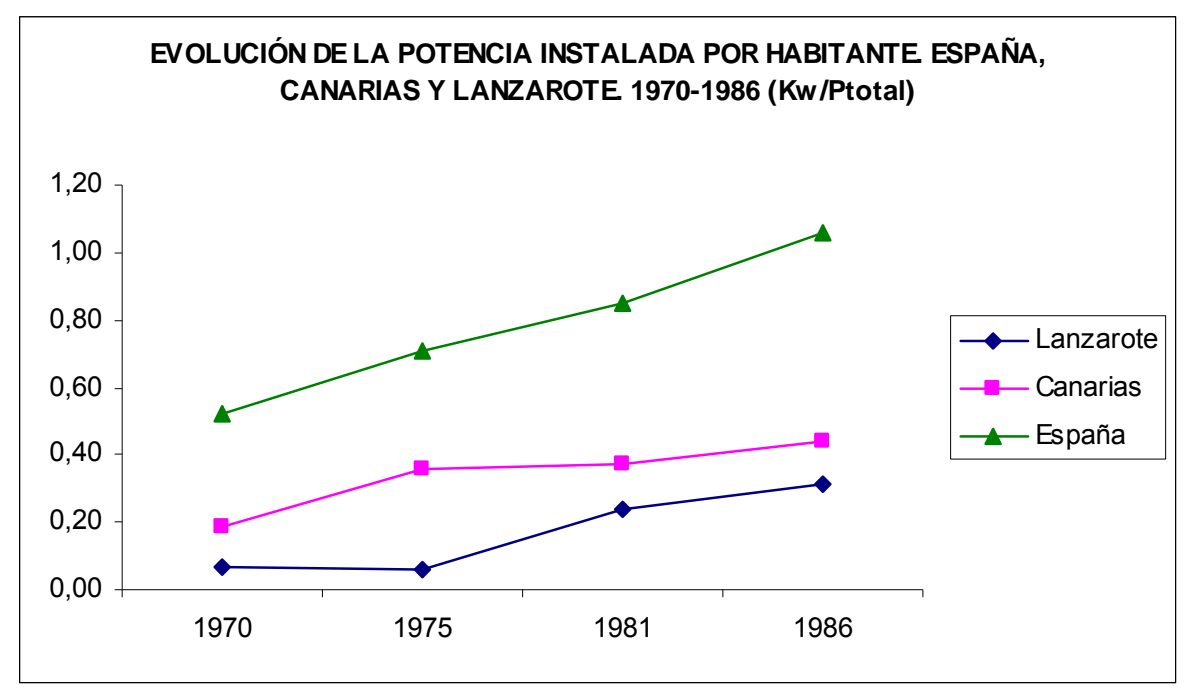

Fuente: Plan insular de Lanzarote, 1973. Ministerio de la Vivienda; Anuario Estadístico de Canarias del CEDOC y Estadísticas de la Energía Eléctrica del Ministerio de Industria. Elaboración propia.

La potencia instalada, por habitante, sufre un fuerte incremento entre 1975 y 1981 (300\% $\mathrm{Kw} / \mathrm{Ptotal})$, muy superior al de Canarias (85,3\% Kw/Ptotal) y España (35\% Kw/Ptotal), pues en el quinquenio anterior la recepción de población turista se incrementó en más de un $200 \%$ y este quinquenio soporta un crecimiento del $120 \%$. Esta fuerte demanda demográfica impulsa la mejora de la capacidad de producción eléctrica que favorece a la población local, pero que siempre es insuficiente por los fuertes y rápidos incrementos demográficos. Es por ello que ni Lanzarote ni Canarias podrán cubrir el estándar de electrificación media en esta etapa. 
Gráfico 46. Incremento interperiodo de la potencia instalada en relación a la población total estimada. España, Canarias y Lanzarote. 1970-1986 (Kw/P.Total)

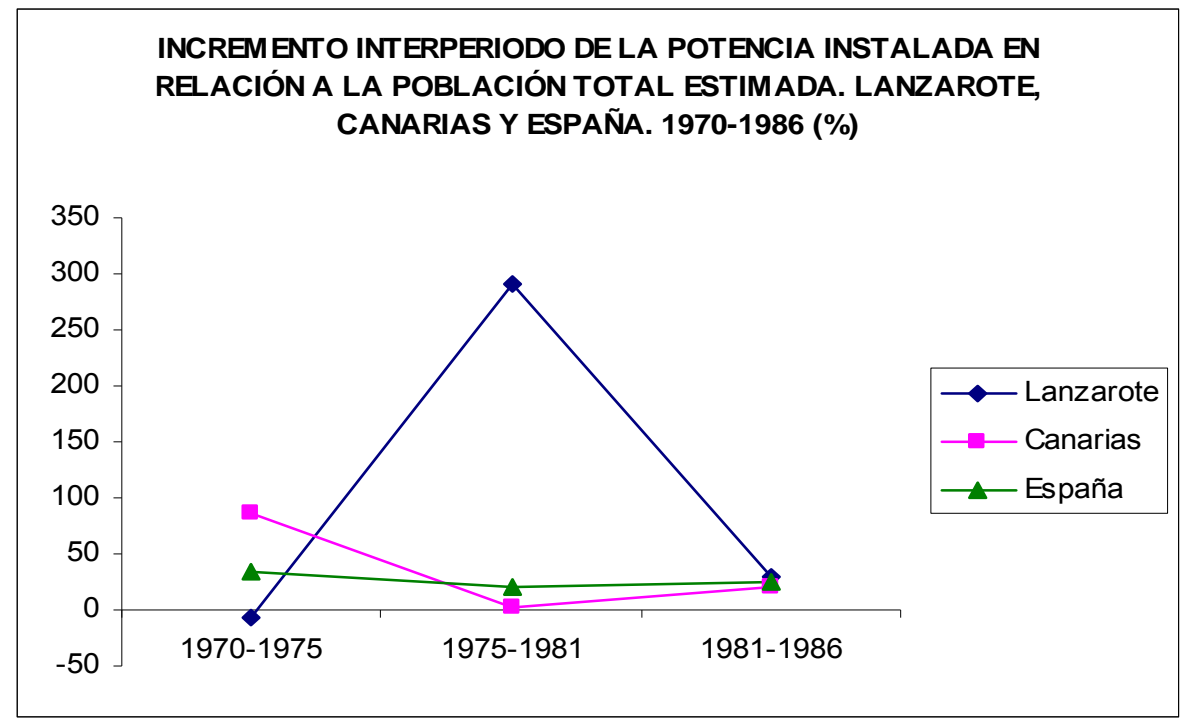

Fuente. Plan insular de Lanzarote, 1973. Ministerio de la Vivienda; Anuario Estadístico de Canarias del CEDOC y Estadísticas de la Energía Eléctrica del Ministerio de Industria. Elaboración propia.

En relación a la producción eléctrica, señalar que todos los documentos de esta época hacen notar que el suministro siempre va a remolque de la demanda, al igual que en casi todas las islas del archipiélago. 
Tabla 66. Producción de energía eléctrica disponible. Lanzarote, Canarias y España. 1970-1986 (mwh)

\begin{tabular}{|c||r|r|r|r|r||}
\hline Año & LANZAROTE & Kwh/Residente & Kwh/P.Total & \multicolumn{1}{|c||}{$\begin{array}{l}\text { Variación (\%) } \\
\text { LAZ-CAN }^{*}\end{array}$} & $\begin{array}{l}\text { Variación (\%) } \\
\text { LAZ-ESP* }^{*}\end{array}$ \\
\hline $\mathbf{1 9 7 0}$ & 10.025 & 243,64 & 241,09 & $-60,34$ & $-85,24$ \\
\hline 1975 & 22.805 & 514,36 & 476,53 & $-45,05$ & $-78,96$ \\
\hline 1981 & 68.846 & 1357,35 & $1.229,99$ & 5,76 & $-53,98$ \\
\hline 1986 & 154.199 & 2765,21 & $2.134,04$ & 29,16 & $-30,06$ \\
\hline
\end{tabular}

\begin{tabular}{|c||c|r|r||r|r|r||}
\hline \multicolumn{1}{|c|}{ Año } & CANARIAS & Kwh/Residente & \multicolumn{1}{|c|}{ Kwh/P.Total ${ }^{* *}$} & \multicolumn{1}{|l|}{ ESPAÑA } & Kwh/Residente & Kwh/P.Total $^{* *}$ \\
\hline \hline $\mathbf{1 9 7 0}$ & 696.119 & 618,53 & 607,88 & 56.490 .000 & $1.655,74$ & $1.633,82$ \\
\cline { 2 - 7 } $\mathbf{1 9 7 5}$ & 1.130 .293 & 866,79 & 866,79 & 82.481 .276 & $2.290,33$ & $2.264,99$ \\
\cline { 2 - 7 } $\mathbf{1 9 8 1}$ & 1.672 .656 & $1.223,00$ & $1.163,04$ & 103.565 .672 & $2.748,39$ & $2.672,47$ \\
\cline { 2 - 7 } $\mathbf{1 9 8 6}$ & 2.662 .417 & $1.828,58$ & $1.652,22$ & 121.183 .877 & $3.149,81$ & $3.051,31$ \\
\hline \hline
\end{tabular}

$\left(^{*}\right)$ La variación porcentual está calculada en relación la Kw/P. Total.

$\left({ }^{*}\right)$ Población total: población residente + turistas equivalentes diarios.

Fuente: Para 1970: Producción eléctrica en 1968 en Lanzarote. Plan Insular de Lanzarote, 1973. Doc. I.3. (pp. 149). Ministerio de Vivienda, 1973; "Productos industriales básicos. Energía eléctrica, Total Nacional, 1970". Anuario Estadístico de España, 1972. INE; Para 1975: "Producción eléctrica. Lanzarote, 1975". Plan Insular de Ordenación de la Oferta Turística de la isla de Lanzarote, 1982, Tomo III (pp. 248). Secretaría de Estado de Turismo, 1982; "Producción de energía eléctrica. Total Nacional, 1975". Tabla 2.1.11. Anuario Estadístico de España, 1982. INE; Para 1981: "Producción absorbida por Lanzarote, 1982". Avance Plan Insular de Lanzarote, 1987. Tomo 2. Cap. 4. Cuadro 4.4 (pp. 238); "Producción disponible de energía eléctrica. Total Nacional y Provincia de Las Palmas y Tenerife, 1981". Estadística de la Industria de Energía Eléctrica, 1981. Ministerio de Industria, Turismo y Comercio. www.mityc.es/energia/balances/ ; Para 1986: "Producción absorbida por Lanzarote, 1986". Avance Plan Insular de Lanzarote, 1987. Tomo 2. Cap. 4. Cuadro 4.4 (pp. 238); "Producción disponible de energía eléctrica. Total Nacional y Provincia de Las Palmas y Tenerife, 1986". Estadística de la Industria de Energía Eléctrica, 1986. Ministerio de Industria, Turismo y Comercio. $\underline{\text { www.mityc.es/energia/balances/. }}$

Aunque ésta no ha dejado de crecer, las posibilidades de producción están muy alejadas de las de la Comunidad Autónoma hasta la década de los años ochenta, superándola en 1986 en un $29 \%$ (kwh/PTotal). Sin embargo, con respecto a España, aunque acorta distancias a lo largo de toda la etapa, al final de la misma sigue produciendo aproximadamente el $30 \%$ menos (kwh/PTotal). 
Gráfico 47. Evolución de la producción de energía eléctrica por habitante. Lanzarote, Canarias y España. 1970-1986 (Kwh/PTotal)

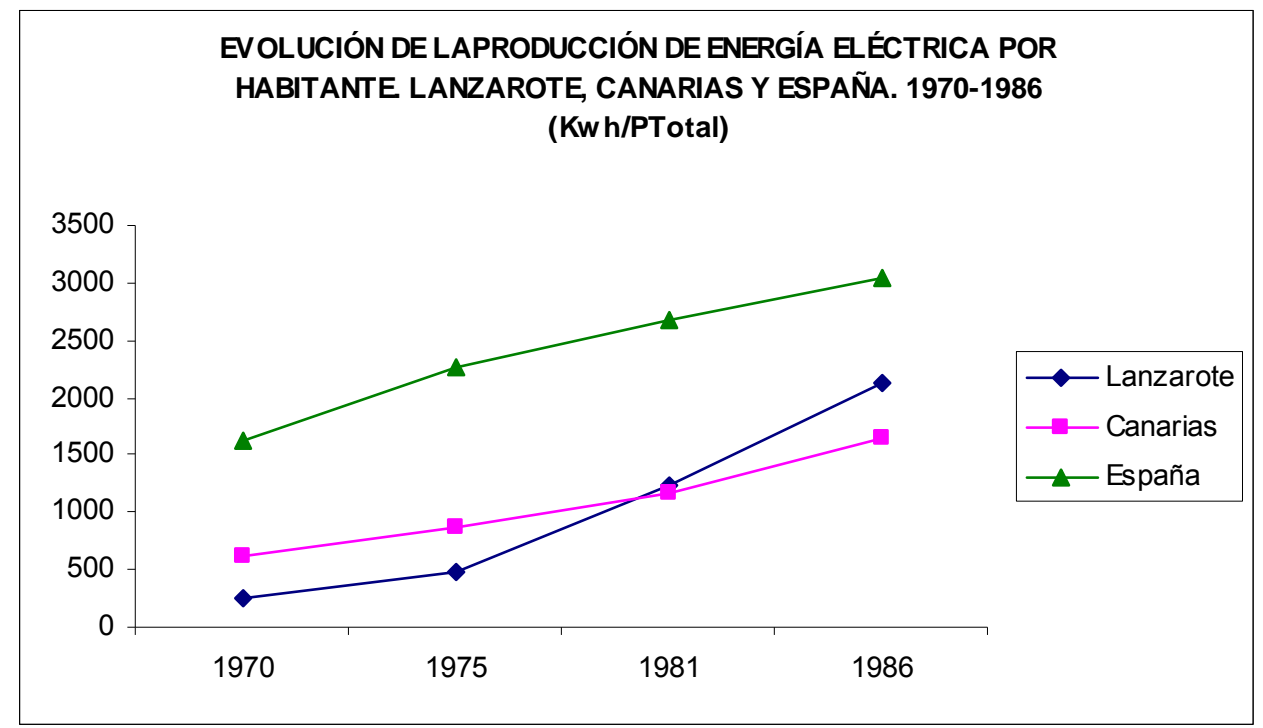

Fuente: Plan insular de Lanzarote, 1973. Ministerio de la Vivienda; Anuario Estadístico de Canarias del CEDOC y Estadísticas de la Energía Eléctrica del Ministerio de Industria. Elaboración propia.

\subsubsection{2.- CONSUMO ENERGÉTICO}

Las variaciones en el consumo per cápita (Kwh/Ptotal) son notables en el ámbito insular, pues los incrementos de demanda debido a la fuerte entrada de turistas e inmigrantes a la isla hace que éstos se disparen, especialmente entre 1975 y 1981 (150\%), quinquenio en el que se observa explosión en el número de visitantes $(120 \%)$ por turismo, como se ha descrito anteriormente (epígrafe 5.1.1.2.). Este enorme crecimiento del consumo no tiene parangón con la Comunidad Autónoma (43\%) ni con la dinámica seguida por España $(44,5 \%)$, para el mismo periodo, cuyos incrementos de consumo son muy inferiores. 
Tabla 67. Consumo eléctrico e intensidad energética. Lanzarote. 1970-1986 (mwh)

\begin{tabular}{||c|r|r|r|r|r||}
\hline \hline Año & LANZAROTE & $\begin{array}{l}\text { Consumo } \\
\text { Kwh/residentes }\end{array}$ & $\begin{array}{l}\text { Consumo } \\
\text { Kwh/PTotal }^{*}\end{array}$ & $\begin{array}{l}\text { Incremento quinquenal } \\
\text { (Kw/P.Total) (\%) }\end{array}$ & $\begin{array}{l}\text { Intensidad } \\
\text { Energética** }^{*}\end{array}$ \\
\hline \hline 1970 & 10.025 & 243,64 & 241,45 & & --- \\
\hline 1975 & 18.558 & 418,57 & 418,57 & 73,61 & --- \\
\hline 1981 & 58.519 & $1.153,74$ & $1.045,49$ & 149,78 & 456,398 \\
\hline 1986 & 131.069 & $2.350,42$ & $1.813,93$ & 73,50 & 411,790 \\
\hline \multicolumn{7}{|l|}{ Variación (\%) del consumo entre 1970 y 1986 (Kw/P.Total) } & 652,39 & \multicolumn{1}{l}{} \\
\hline
\end{tabular}

$\left.{ }^{*}\right)$ Población Total: población residente + turistas equivalentes diarios.

${ }^{* *}$ Intensidad energética eléctrica: energía eléctrica consumida / PIB. En millones de euros.

Nota: Para los años 1970 y 1975, no existen datos sobre PIB para la isla de Lanzarote. Por tanto se puede calcular la intensidad energética al comienzo de la etapa.

Fuente: Para 1970: Consumo eléctrico 1968 en Lanzarote. Plan Insular de Lanzarote, 1973. Doc. I.3. (pp. 150). Ministerio de Vivienda, 1973; Para 1975: "Consumo eléctrico, Lanzarote, 1975". Plan Insular de Ordenación de la Oferta Turística de la isla de Lanzarote, 1982, Tomo III (pp. 248); Para 1981: "Venta de energía eléctrica Lanzarote, 1982". Avance Plan Insular de Lanzarote, 1987. Tomo 2. Anexo 4.2. (pp. 5); "PIB estimado para 1981, en ptas corrientes de cada año. Millones de Ptas. En Avance PIOT. Tomo 4. Economía, 1987 (pp. 24). Cabildo Insular de Lanzarote; Para 1986: "Venta de energía eléctrica Lanzarote, 1986". Avance Plan Insular de Lanzarote, 1987. Tomo 2. Anexo 4.2. (pp. 4); "PIB estimado para 1986, en ptas corrientes de cada año. Millones de Ptas. En. Avance PIOT. Tomo 4. Economía, 1987 (pp. 24). Cabildo Insular de Lanzarote.

Tabla 68. Consumo eléctrico e intensidad energética. Canarias. 1970-1986 (mwh)

\begin{tabular}{|c||c|r|r|r|r|}
\hline Año & CANARIAS & $\begin{array}{l}\text { Consumo } \\
\text { Kwh/residentes }\end{array}$ & $\begin{array}{l}\text { Consumo } \\
\text { Kwh/PTotal }\end{array}$ & $\begin{array}{l}\text { Incremento quinquenal } \\
\text { (Kw/P.Total) (\%)) }\end{array}$ & $\begin{array}{l}\text { Intensidad } \\
\text { Energética**. }^{* *}\end{array}$ \\
\hline \hline 1970 & 562.223 & 499,56 & 490,96 & & -- \\
\hline 1975 & 913.848 & 700,81 & 700,81 & 42,74 & 952,226 \\
\hline 1981 & 1.574 .166 & $1.150,98$ & $1.094,56$ & 56,19 & 423,794 \\
\hline 1986 & 2.197 .959 & $1.509,59$ & $1.363,99$ & 24,62 & 316,666 \\
\hline \multicolumn{7}{|l|}{ Variación (\%) del consumo entre 1970 y 1986 (Kw/P.Total) } & 177,82 & \\
\hline
\end{tabular}

$\left.{ }^{*}\right)$ Población Total: población residente + turistas equivalentes diarios.

$\left.{ }^{* *}\right)$ Intensidad energética eléctrica: energía eléctrica consumida / PIB. En millones de euros.

Nota: Para el año 1970 no existen datos sobre PIB para Canarias 1970. Por tanto no se puede calcular la intensidad energética al comienzo de la etapa.

Fuente: Para 1970: “Consumo neto de energía eléctrica por tarifas y provincias. Las Palmas y Tenerife, 1970". Estadística de la Industria de Energía Eléctrica, 1970. Ministerio de Industria, Turismo y Comercio. www.mityc.es/energia/balances/; "PIB estimado al coste de los factores, en Millones de ptas corrientes de cada año, 1970". Banco Bilbao "Renta nacional de España y su distribución provincial, 19551975 (pp. 42 y 43); Para 1975 y 1981: "Consumo neto de energía eléctrica. Provincia de Las Palmas y Tenerife, 1975 y 1981 ". Estadística de la Industria de Energía Eléctrica, 1975. Ministerio de Industria, Turismo y Comercio; "PIB por regiones, en millones de ptas corrientes. Canarias, 1975". En Banco Bilbao "Renta nacional de España y su distribución provincial, 1955-1975 (pp. 42 y 43 ) y :"PIB regional a precios corrientes, en millones de ptas. Canarias, 1981". Contabilidad Regional de España. Base 1981. Serie Homogénea, 1980-1996. INE; Para 1986: "Consumo neto de energía eléctrica, Provincia de Las Palmas y Tenerife, 1986". Estadística de la Industria de Energía Eléctrica, 1986. Ministerio de Industria, Turismo y Comercio; "PIB regional a precios corrientes, en millones de ptas. Canarias, 1986". Contabilidad Regional de España. Base 1986. Serie Homogénea, 1980-1996. INE. 
Tabla 69. Consumo eléctrico e intensidad energética. España. 1970-1986 (mwh)

\begin{tabular}{|c|c|c|c|c|c|}
\hline Año & ESPAÑA & $\begin{array}{l}\text { Consumo } \\
\text { Kwh/residentes }\end{array}$ & $\begin{array}{l}\text { Consumo } \\
\text { Kwh/PTotal }\end{array}$ & $\begin{array}{l}\text { Incremento quinquenal } \\
\text { (Kw/P.Total) (\%)) }\end{array}$ & $\begin{array}{l}\text { Intensidad } \\
\text { Energética*. }^{* *}\end{array}$ \\
\hline 1970 & 45.300 .653 & $1.327,78$ & $1.310,20$ & & 3108,955 \\
\hline 1975 & 68.953 .488 & $1.914,70$ & $1.893,51$ & 44,52 & 2029,448 \\
\hline 1981 & 93.196 .401 & $2.473,21$ & $2.404,89$ & 27,01 & 1403,971 \\
\hline 1986 & 107.952 .602 & $2.805,90$ & $2.718,16$ & 13,03 & 0,00055568 \\
\hline \multicolumn{4}{|c|}{ Variación (\%) del consumo entre 1970 y 1986 (Kw/P.Total) } & 107,46 & \\
\hline
\end{tabular}

$\left(^{\star}\right)$ Población Total: población residente + turistas equivalentes diarios.

${ }^{* *}$ Intensidad energética eléctrica: energía eléctrica consumida / PIB. En millones de euros.

Fuente: Para 1970:“Consumo neto de energía eléctrica. Total nacional, 1970”. Estadística de la Industria de Energía Eléctrica, 1970. Ministerio de Industria, Turismo y Comercio. www.mityc.es/energia/balances/; "PIB estimado al coste de los factores, en Millones de pesetas corrientes de cada año, 1970". Banco Bilbao "Renta nacional de España y su distribución provincial, 1955-1975 (pp. 42 y 43); Para 1975: "Consumo neto de energía eléctrica. Total Nacional, 1975". Estadística de la Industria de Energía Eléctrica, 1975. Ministerio de Industria, Turismo y Comercio. www.mityc.es/energia/balances/; "PIB estimado al coste de los factores, en Millones de pesetas corrientes de cada año, 1975". En Banco Bilbao "Renta nacional de España y su distribución provincial, 1955-1975 (pp. 42 y 43 ); Para 1981: "Consumo neto de energía eléctrica. Total Nacional, 1981". Estadística de la Industria de Energía Eléctrica, 1981. Ministerio de Industria, Turismo y Comercio. www.mityc.es/energia/balances/; "PIB a precios corrientes en millones de pesetas, España, 1981". Contabilidad Regional de España. Base 1981. Serie Homogénea, 1980-1996. INE; Para 1986: "Consumo neto de energía eléctrica. Total Nacional, 1986". Estadística de la Industria de Energía Eléctrica, 1986. Ministerio de Industria, Turismo y Comercio. www.mityc.es/energia/balances/; "PIB a precios corrientes en millones de pesetas, España, 1986". Contabilidad Regional de España. Base 1986. Serie Homogénea, 1980-1996. INE;

Gráfico 48. Incremento interperiodo del consumo eléctrico en relación a la población total estimada. España, Canarias y Lanzarote. 1970-1986 (\%).

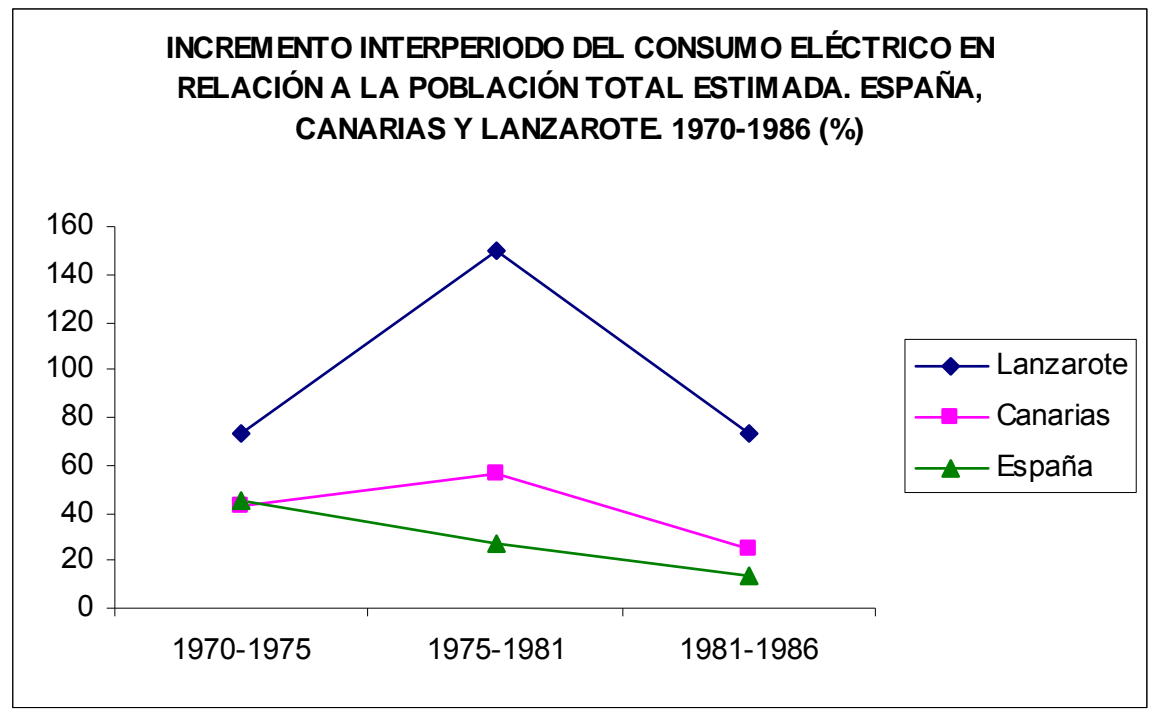

Fuente: Plan insular de Lanzarote, 1973. Ministerio de la Vivienda; Anuario Estadístico de Canarias del CEDOC y Estadísticas de la Energía Eléctrica del Ministerio de Industria. Elaboración propia. 
Al final de esta etapa, en Lanzarote se consume más energía por habitante que en Canarias, del orden del 33\% (kwh/Ptotal) aproximadamente, aunque la media nacional de consumo por habitante (kwh/Ptotal) se sitúa alrededor de un tercio $(33,3 \%)$ por encima de la insular.

Gráfico 49. Evolución del consumo de energía eléctrica por habitante. España, Canarias y Lanzarote. 1970-1986 (Kwh/PTotal).

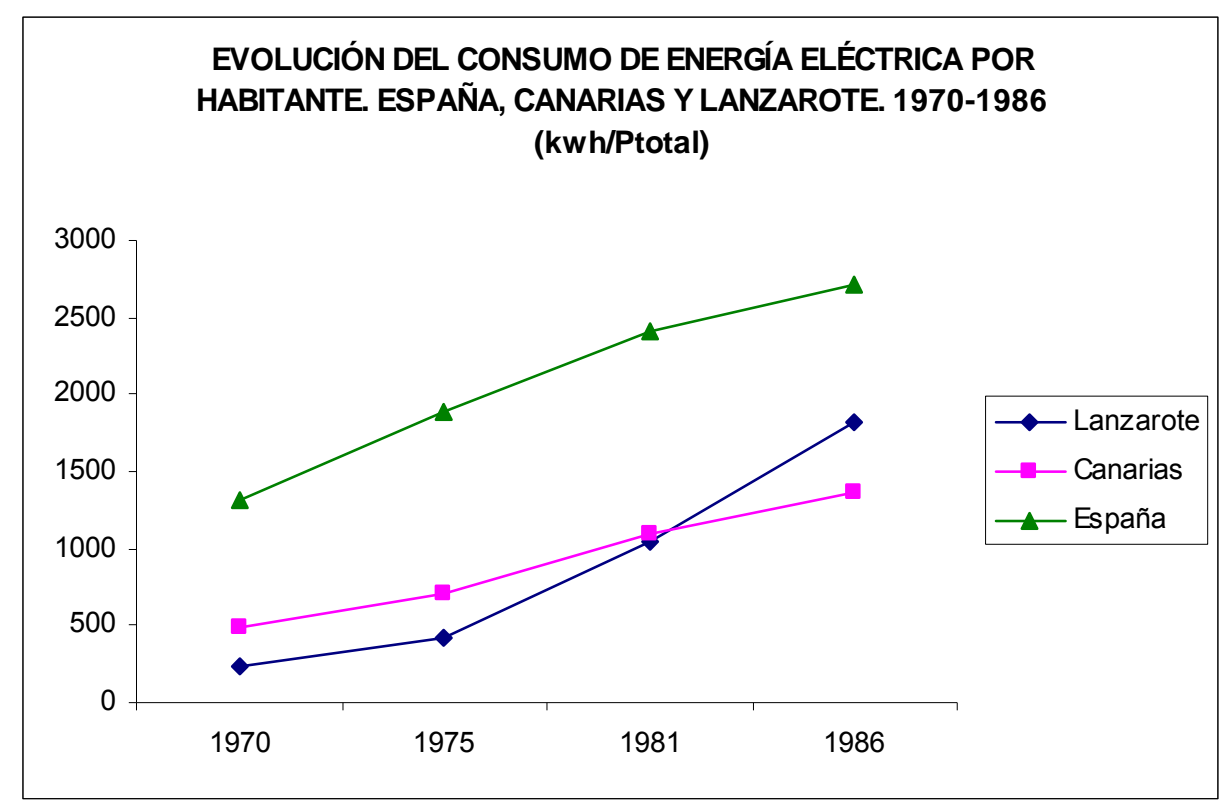

Fuente: Plan insular de Lanzarote, 1973. Ministerio de la Vivienda; Anuario Estadístico de Canarias del CEDOC y Estadísticas de la Energía Eléctrica del Ministerio de Industria. Elaboración propia.

Tanto la producción (oferta) como el consumo (demanda) han tenido fuertes incrementos desde el comienzo de la etapa hasta el final de la misma, por encima de los que se observan para Canarias y España. Aunque el crecimiento relativo del consumo en relación al incremento de la producción ha ido por debajo, la tendencia no es negativa, en esta etapa.

Tabla 70. Resumen. Variación de la oferta y demanda de energía eléctrica por habitante (kwh). España, Canarias y Lanzarote. 1970-1986. (\%)

\begin{tabular}{|l|r|r|}
\cline { 2 - 3 } \multicolumn{1}{c|}{} & Producción & Consumo \\
\hline LANZAROTE & 785,16 & 652,39 \\
\hline CANARIAS & 171,80 & 177,82 \\
\hline ESPAÑA & 86,76 & 107,46 \\
\hline
\end{tabular}

Fuente. Tabla resumen a partir de datos anteriores. Elaboración propia. 
Gráfico 50. Variación de la oferta y la demanda de energía eléctrica por habitante. España, Canarias y Lanzarote. 1970-1986 (\%).

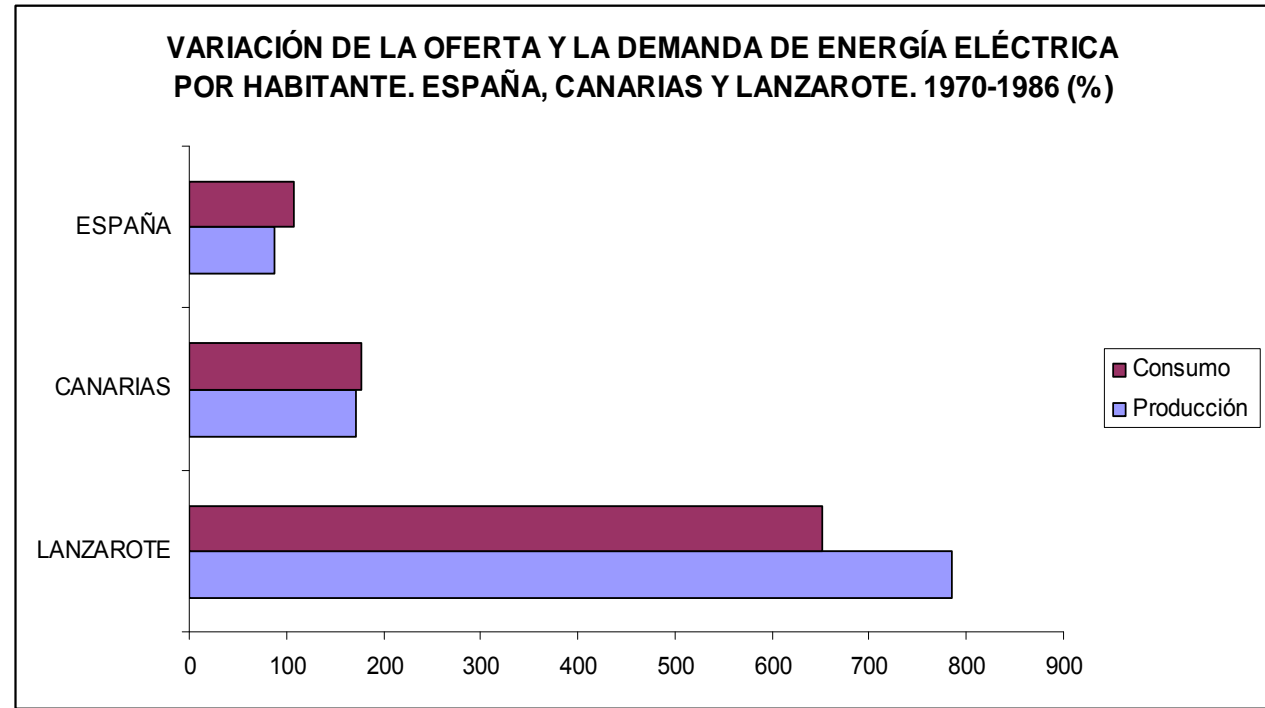

Fuente. Plan insular de Lanzarote, 1973. Ministerio de la Vivienda; Anuario Estadístico de Canarias del CEDOC y Estadísticas de la Energía Eléctrica del Ministerio de Industria. Elaboración propia.

Por otro lado, en relación a la intensidad energética eléctrica, y aunque sólo disponemos de datos sobre producto interior bruto (PIB) para el último quinquenio de esta etapa (19811986), podemos señalar que Lanzarote, junto con Canarias y España, han ido reduciendo el indicador señalado, lo que quiere decir que se consume menos energía por PIB, se gana en eficiencia en términos energéticos. Los resultados indican que la isla hace mejor utilización de la energía eléctrica para producir que Canarias y España.

\subsubsection{3.- CONCLUSIONES}

Lanzarote está caracterizado por la carencia de fuentes de energía primaria convencional, lo que la convierte en dependiente del exterior. Sus posibilidades de generación de energía propia se encuentran en recursos no renovables (sol, viento, mar y energía geotérmica) que no son explotados en esta época. Así, esta primera etapa de crecimiento y consolidación de Lanzarote como destino turístico de masas, viene marcada por fuertes cambios en su capacidad energética, derivados de las necesidades existentes y del constante incremento de la presión demográfica. Por tanto, señalamos lo siguiente:

1. Bajo rendimiento energético de la isla durante toda la etapa, alejado de los estándares normativos, derivado de la insuficiente potencia instalada que se mantiene muy por debajo de la media de Canarias y España. Por lo que, inicialmente, la isla no tiene capacidad de producción eléctrica para satisfacer la demanda vigente, agravada por la presión turística. 
2. El desarrollo y crecimiento de la actividad turística presiona e impulsa cambios en la capacidad de producción de energía eléctrica, afectando con ello positivamente el bienestar de la población local. Con un fuerte incremento de la producción, pero insuficiente, dependiendo de importaciones energéticas desde Fuerteventura, manteniéndose por debajo de la producción media nacional, por habitante, y superando a su Comunidad Autónoma sólo al final de la etapa.

3. Constante crecimiento del consumo por habitante, con fuertes picos en los periodos de explosión de la demanda turística, llegando a superar la media de Canarias al final de la etapa, aunque nunca la nacional.

4. El crecimiento de la producción (oferta) se mantiene por encima del consumo (demanda).

5. Debido a los fuertes y rápidos incrementos de turistas, estos constituyen, a su vez, un freno en la disponibilidad de recursos energéticos para la población local.

6. Incremento de la eficiencia en términos de energía eléctrica.

En términos generales, el turismo ha impulsado la transformación energética de la isla, para beneficio de la población local, a la vez que se convierte en un fuerte competidor por los escasos recursos energéticos, pues crece más rápidamente que las posibilidades de incrementar la producción energética insular.

\subsection{8.- EFECTOS SOBRE EL CICLO DEL AGUA. 1970-1986}

El agua, en cuanto recurso natural, es un factor clave para el desarrollo socioeconómico de un territorio y en la consecución de bienestar tanto para la población residente como para la población invitada. Es este papel el que genera mayor complejidad, tanto en las fases de despegue y consolidación de la actividad como en el funcionamiento del destino a lo largo de su vida. Lanzarote se sitúa en un territorio árido en el que la escasez de agua es uno de los factores limitantes fundamentales para el desarrollo.

Es por ello que en este epígrafe el análisis se centrará en la disponibilidad del recurso "agua" y su demanda.

\subsubsection{1.- LA DISPONIBILIDAD DE AGUA. OFERTA}

Las características geográficas de Lanzarote son las que condicionan su situación particular en relación a la provisión de recursos hídricos, caracterizados históricamente por su escasez, debido a su clima árido y escasas e irregulares precipitaciones, que hacen que no existan fuentes naturales de cierta importancia. 
Así, la isla desde la década de los años sesenta ya había recurrido a la desalación de agua del mar. Es por ello que todo el periodo de análisis está marcado por la creación y ampliación de plantas desalinizadoras.

La primera planta de este tipo se crea en 1965 por iniciativa privada ${ }^{158}$, lo que supuso un impulso a la actividad productiva, producía agua potable y electricidad. "Pero en 1970 la situación vuelve a ser crítica", puesto que la producción es inferior a la demanda, lo que se atribuye a "la falta de una labor de planificación previsora por parte de la Administración Pública que la ha privado de una actuación continua y coherente" (Plan Insular, Documento I.3.II.2.5. 1973, pp.131). Lo que quiere decir que a los cinco años de la puesta en marcha de esta infraestructura, la isla vuelve a tener problemas por escasez de agua "derivados del incremento de la población y los procesos de urbanización para acometer el despegue de la actividad turística"159.

En 1970, el único municipio que posee suministro de agua corriente es Arrecife, la capital de la isla y puerto principal. En los municipios rurales, más del $90 \%$ de las viviendas poseen aljibes y la mayor fuente suministradora es la desalinizadora citada.

158 Termolanza.

159 Plan Insular, Documento I.3.II.2.5. 1973, pp.132. 
Mapa 11. Infraestructuras del ciclo del agua en Lanzarote. 1973.

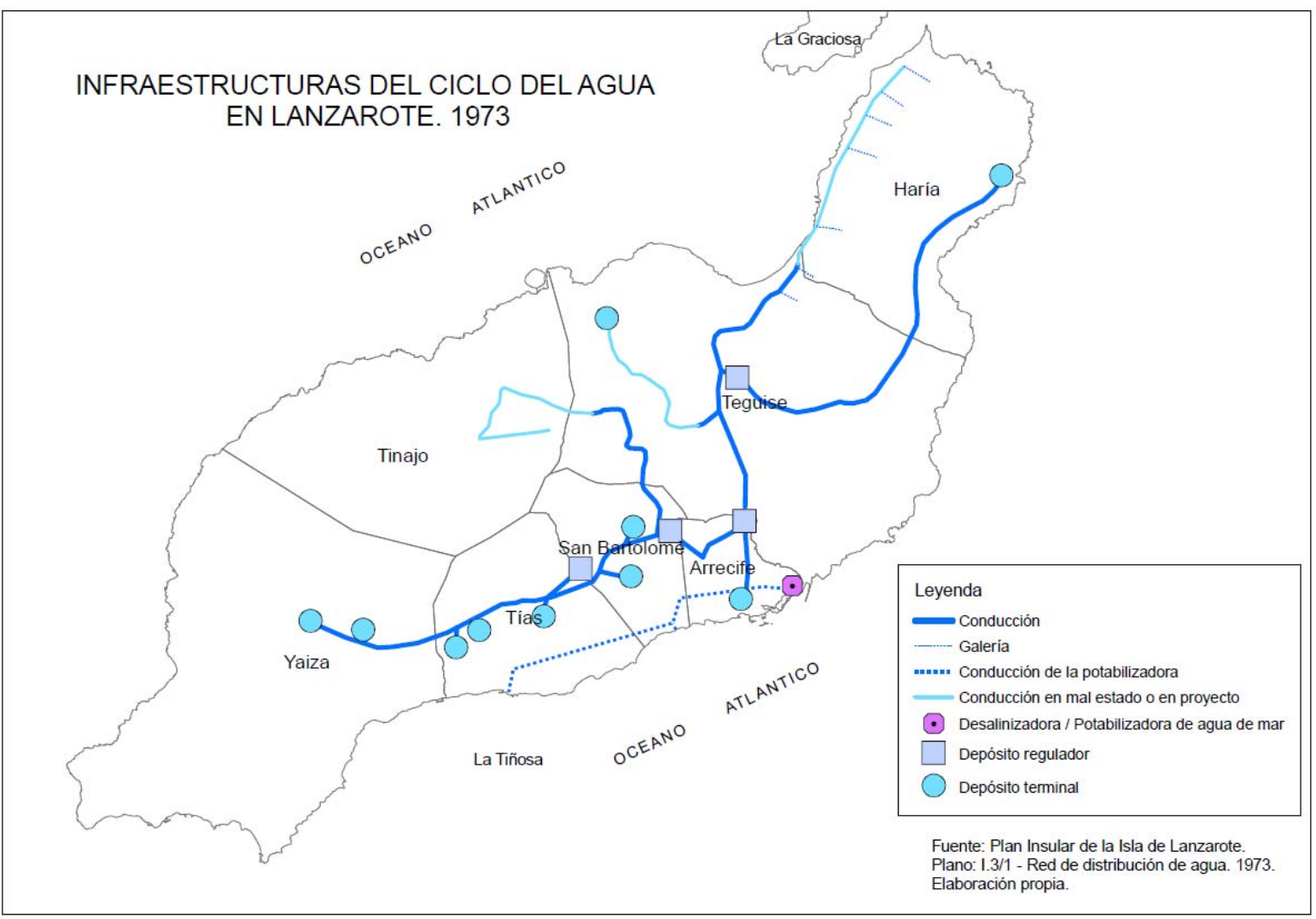

La capacidad de producción es escasa, lo que llega al ámbito doméstico es irrisorio si se tiene en cuenta el estándar que establece el Plan Insular de 1973 (Doc. I.3, pp. 145) de consumo de agua por habitante y día, 112 I/habitantes*día, como criterio para proyectar un abastecimiento que cumpla debidamente con la cobertura de las necesidades mínimas. La realidad se encuentra en un $69 \%$ I/habitantes*día por debajo del estándar. Eso sin contar con la población turista, que hay que tenerla en cuenta a la hora de planificar la capacidad futura de las infraestructuras para desalinización, que por esta época se le estima un estándar de consumo mayor al de la población local, de aproximadamente 400 I/habitantes* ${ }^{*} a^{160}$, un $357 \%$ por encima del estándar que se define para la población local.

160 Plan Insular de 1973 (Doc. I.3, pp. 145) 
Tabla 71. Fuentes de captación y producción de agua potable. Oferta. Lanzarote. 1970-1986 $\left(\mathrm{hm}^{3} / \mathrm{año}\right)$.

\begin{tabular}{|c|c|c|c|c|c|c|c|c|c|c|c|c|c|}
\hline \multirow{2}{*}{ Año } & \multicolumn{2}{|c|}{ Galerías 1} & \multicolumn{2}{|l|}{ Pozos } & \multicolumn{2}{|c|}{ Aljibes F. ${ }^{2}$} & \multicolumn{2}{|c|}{ Aljibes Of } & \multicolumn{4}{|c|}{ Potabilización } & \multirow{2}{*}{ TOTAL } \\
\hline & Abs & $\%$ & Abs & $\%$ & Abs & $\%$ & Abs & $\%$ & Pública & $\%$ & Privada & $\%$ & \\
\hline 1970 & 0,138743 & 18,4 & 0,020000 & 2,6 & 0,104000 & 13,8 & 0,005600 & 0,7 & 0 & 0 & 0,48700 & 64,5 & 0,755348 \\
\hline 1975 & --- & --- & --- & --- & --- & -- & --- & --- & 0,985500 & 81,8 & 0,21900 & 18,2 & 1,204500 \\
\hline 1981 & --- & --- & --- & --- & --- & --- & --- & --- & 2,153500 & 78,7 & 0,58400 & 21,3 & 2,737500 \\
\hline 1986 & 0,18 & 3,8 & 0,04 & 0,8 & --- & --- & -- & --- & 3,173675 & 66,4 & 1,388825 & 29,0 & 4,782500 \\
\hline
\end{tabular}

1. Tres galerías practicadas en los acantilados de Famara.

2. Aljibes familiares. Se aporta una cifra media establecida en el Plan Insular de 1973, Doc. I.3. (pp. 140). Existen aljibes oficiales, en las cercanías de la capital, Arrecife.

Fuente: Para 1970: Plan Insular, Documento I.3.II.2.5. 1973 (pp.141). Cabildo Insular de Lanzarote. Para 1975, 1981 y 1986. "Producción neta al consumo de agua en 1986" y "Producción media de agua, 1975, 1981, Cuadro 3.1". Avance PIOT, 1987. Tomo 2. Cap. III y VI (pp. 47 y 186). Cabildo Insular de Lanzarote.

Para poder alcanzar la cobertura de las necesidades básicas reales en relación al estándar, la isla debe incrementar su producción en un $52 \%\left(1,533 \mathrm{Hm}^{3} / a n ̃ o\right)$.

Ante la fuerte demanda de agua que no podía satisfacer la planta existente, en 1974 se crea un Consorcio por los siete Ayuntamientos de la isla y el Cabildo, que compran los activos de la producción de agua a la desalinizadora existente (Termolanza) y por tanto pasa a manos públicas la producción, distribución y depuración de aguas en la isla. Su misión, por tanto, será la explotación de los recursos hidráulicos, la producción de agua potable, su explotación y distribución, ayudas económicas para el primer establecimiento de redes, y asesoramiento técnico, para el abastecimiento de la isla (Plan Insular de Ordenación de la Oferta turística de Lanzarote, 1982, Tomo III, pp. 272). Se renuncia a la producción de electricidad (que pasa a la Unión Eléctrica de Canarias-UNELCO), hasta la construcción por parte del Estado (MOPU) de la desalinizadora de mayor capacidad de la isla (denomina Lanzarote I y puesta en marcha en 1975) que es dual, depura agua y produce electricidad.

A lo largo de esta etapa, fruto de una política permisiva, y vinculada al proceso de urbanización, se permite la implantación de desaladoras (política que llega prácticamente hasta nuestros días) de pequeña escala en complejos turísticos y a su servicio, con objeto de no coartar el desarrollo turístico, pues son de rápida implantación.

En esta época, más del $95 \%$ del agua que se produce es desalada. Así, la producción de agua se incrementa durante todo la etapa, debido a la creación y puesta en producción de nuevas plantas desalinizadoras. 


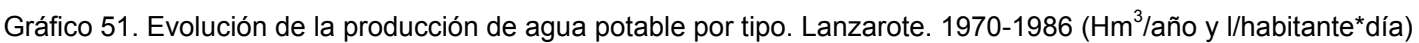

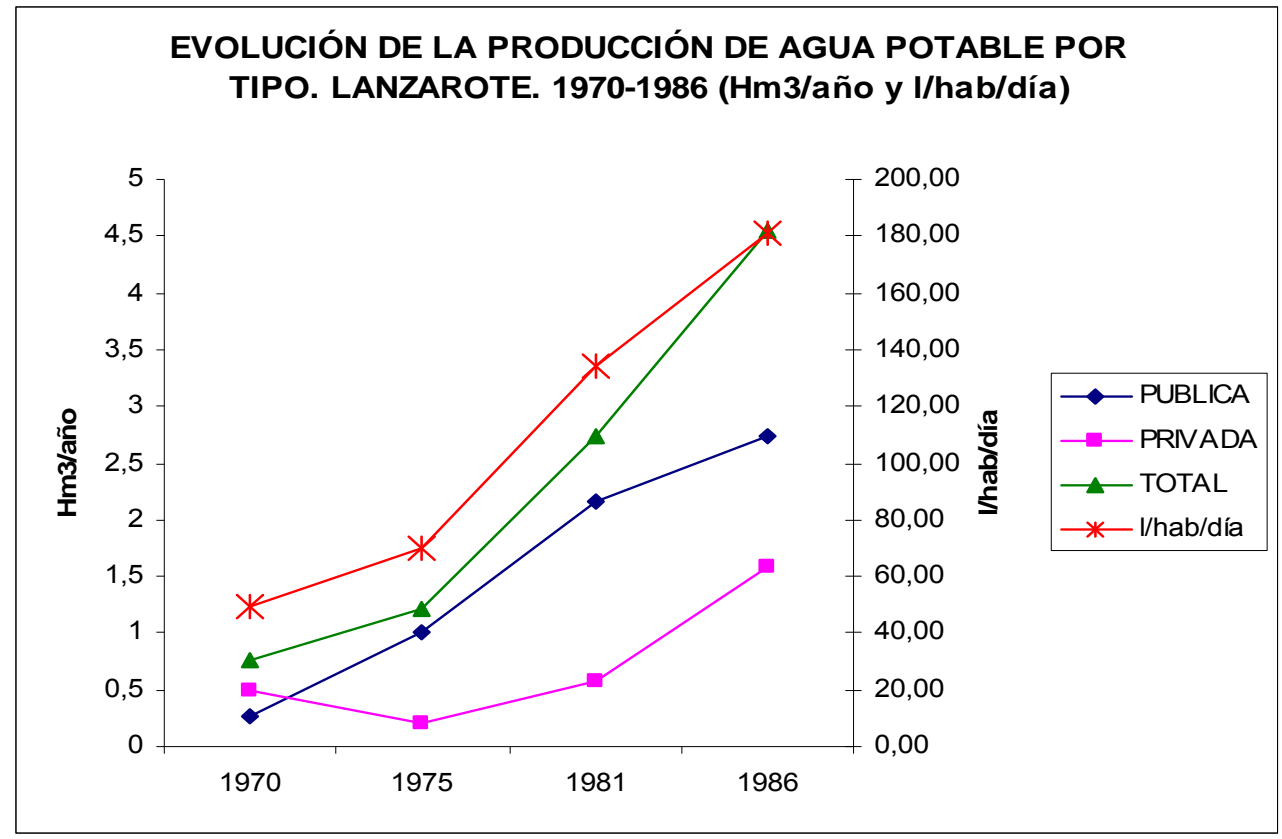

Fuente: Plan insular de Lanzarote, 1973 y Avance PIOT de Lanzarote, 1987. Cabildo Insular de Lanzarote. Elaboración propia.

El principal crecimiento de la producción pública (Consorcio de agua) se produce entre 1970-1975, aumentando en más de un $276 \%$, correspondiendo con un incremento de la oferta turística del orden del $361 \%$ (véase epígrafe 5.1 .1 .1 ), agua necesaria para la construcción y para los turistas que aumentan en un $218 \%$.

Tabla 72. Incremento interperiodo de la producción de agua. Oferta. Lanzarote. 1970-1986 (\%)

\begin{tabular}{|l|c|c|c||}
\hline Año & Pública & Privada & TOTAL \\
\hline \hline $1970-1975$ & 272,7 & $-58,9$ & 59,5 \\
\hline $1975-1981$ & 115,4 & 192,0 & 127,3 \\
\hline $1981-1986$ & 57,6 & 137,8 & 74,7 \\
\hline
\end{tabular}

Fuente. Elaboración propia a partir de datos anteriores.

En el quinquenio posterior (1975-1981), se tendrá que abordar el abastecimiento de un incremento de la oferta turística del $59 \%$, creciendo de nuevo la producción de agua pública en más de un $115 \%$, preparándose así la isla para futuras demandas, pues en 1986 se produce un nuevo "boom turístico". En este quinquenio y en el posterior quién mayor incremento de producción observa es la producción privada, por encima de la pública, pues algunos de los diferentes complejos turísticos que aparecen ponen en marcha su propia planta de desalinización. 
Gráfico 52. Incremento de la producción de agua potable por tipo. Lanzarote. 1970-1986 (\%)

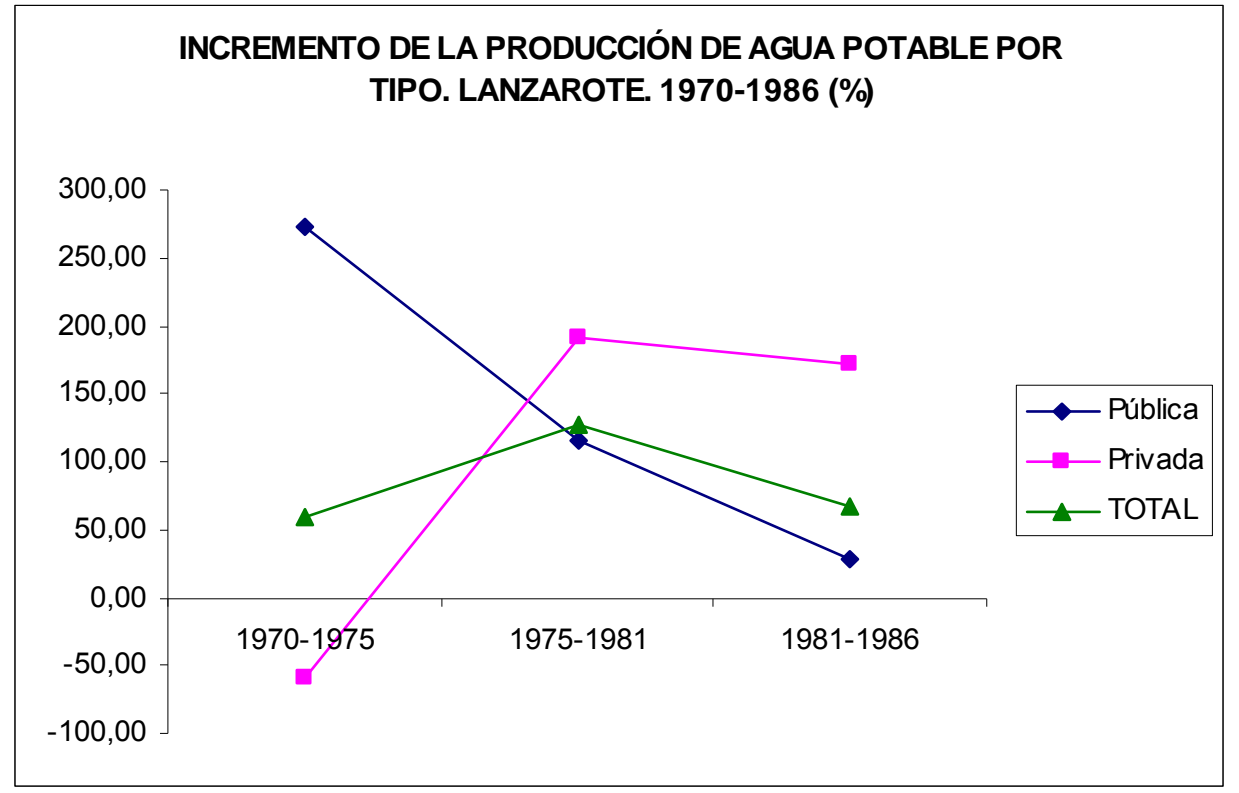

Fuente: Plan insular de Lanzarote, 1973 y Avance PIOT de Lanzarote, 1987. Cabildo Insular de Lanzarote. Elaboración propia.

Tabla 73. Producción media diaria de agua y población a abastecer. Lanzarote. 1970-1986 ( $\mathrm{m}^{3} /$ día $)$

\begin{tabular}{|l|r|r|r|r||}
\hline \multicolumn{1}{|c|}{ Año } & \multicolumn{1}{c|}{1970} & \multicolumn{1}{c|}{1975} & \multicolumn{1}{c|}{1981} & \multicolumn{1}{c|}{1986} \\
\hline \hline Producción (m3/ día) & $2.069,45$ & $3.300,00$ & $7.500,00$ & $13.102,74$ \\
\hline Población Derecho & 41.146 & 44.337 & 50.721 & 55.764 \\
\hline Turistas equivalentes al día & 436 & 2.844 & 5.252 & 16.493 \\
\hline Población a abastecer* & 41.582 & 47.181 & 55.973 & 72.257 \\
\hline Producción/habitantes*día (m3/ día) & 0,04977 & 0,06994 & 0,13399 & 0,18134 \\
\hline l/residentes*día & 50,3 & 74,43 & 147,87 & 234,97 \\
\hline l/habitantes*día & 49,77 & 69,94 & 133,99 & 181,34 \\
\hline Incremento quinquenal I/habitantes ${ }^{*}$ día (\%) & & 40,54 & 91,57 & 35,33 \\
\hline
\end{tabular}

$\left.{ }^{*}\right)$ Población a abastecer diaria= población de derecho + turistas equivalentes al día.

Nota: al no haberse podido calcular los turistas equivalentes al día en 1975, se ha hecho la media entre turistas equivalentes al día en 1970 y 1981, con la finalidad de poder calcular los indicadores para ese año.

Fuente: Elaboración propia.

El incremento en la producción descrito posibilita el aumento de la disponibilidad per cápita, pasando de casi 50 I/habitantes*día en 1970 a 181 I/habitantes*día en 1986 . El principal incremento se produce entre 1975 y 1981, debido al crecimiento de la oferta privada de producción de agua desalada, que da servicio a la población turística. 
Así pues, comparativamente, a partir de 1975, la producción de agua desalinizada es superior en la producción privada que en la pública (Consorcio), del $246 \%$ en relación a la población que abastecen (I/habitantes ${ }^{*}$ día), teniendo en cuenta que la primera da servicio a los turistas y la segunda al resto de la población. Esta diferencia porcentual se irá reduciendo a lo largo de la etapa hasta el $38 \%$, pues se incrementa la producción de agua desalada pública, lo que permite la mejora del abastecimiento de la población local, pero nunca llega a estar por encima de la que dispone el turista. Se produce, por tanto, más agua para el turismo que para los residentes, que tienen el consumo más limitado, pero también comportamientos más austeros.

Tabla 74. Producción media diaria de agua, privada y pública, y población que abastece. Lanzarote. 1975-1986

\begin{tabular}{|c|c|c|c|c|c|c|c|}
\hline \multirow[b]{2}{*}{ Año } & \multicolumn{3}{|c|}{$\begin{array}{c}\text { Producción M. Diaria Privada y } \\
\text { Turistas }\end{array}$} & \multicolumn{3}{|c|}{$\begin{array}{l}\text { Producción Media Diaria Pública y P. } \\
\text { Residente* }\end{array}$} & \multirow{2}{*}{$\begin{array}{c}\begin{array}{c}\text { Índice de } \\
\text { Variación } \\
\text { (l/habitante }{ }^{*} \text { día) }\end{array} \\
(\%)\end{array}$} \\
\hline & $\mathrm{m}^{3 *} \mathrm{dí}^{\mathrm{a}}$ & $\begin{array}{c}\text { Turistas } \\
\text { equivalentes al día }\end{array}$ & I/turistas ${ }^{\star}$ día & $m^{m^{3 *} d i ́ a}$ & $\begin{array}{l}\text { Población } \\
\text { Residente }\end{array}$ & I/residentes*día & \\
\hline 1975 & 600 & 2.844 & 210,97 & 2700 & 44337 & 60,9 & 246,42 \\
\hline 1981 & 1600 & 5.252 & 304,65 & 5900 & 50721 & 116,32 & 161,90 \\
\hline 1986 & 3805 & 16.493 & 230,70 & 9298 & 55764 & 166,73 & 38,37 \\
\hline
\end{tabular}

$\left.{ }^{*}\right)$ Incluye pozos y galerías.

Fuente. Elaboración propia a partir de datos anteriores.

Gráfico 53. Producción privada y pública de agua por población que abastece. Lanzarote. 1975-1986 (I/habitante*día)

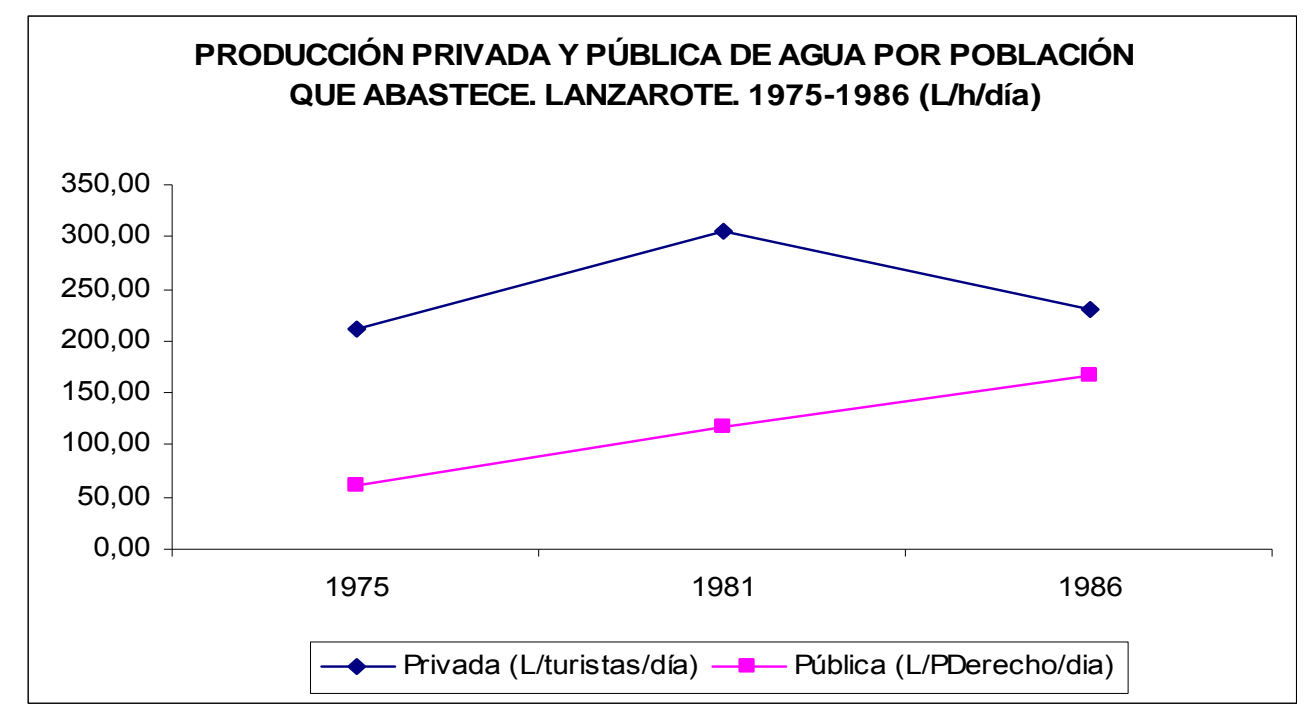

Fuente: Elaboración propia a partir de la Tabla 74. 
Al final de esta etapa, no quedará ninguna planta que, a la vez que desaliniza el agua, produzca electricidad.

Aunque la producción unitaria de agua pública, en relación a la población de derecho, se elevada, hay que tener en cuenta que en 1981 se estiman pérdidas en la red de transporte del orden del 21\% y en 1986 del 15\%, (Cabildo Insular de Lanzarote. Avance PIOT. Tomo 2. Infraestructuras y abastecimiento. 1987, pp. 208) por lo que la disponibilidad real es menor.

Por otro lado, en 1970, no existe una red de conducción de agua corriente a todas las viviendas de la isla. Sigue siendo el municipio capitalino el que sí disponga de la misma, por lo que el déficits de esta infraestructura se concentra en las poblaciones rurales.

Tabla 75. Viviendas con agua corriente por municipio. Lanzarote 1970-1981 (\%)

\begin{tabular}{|l|r|r|}
\hline Municipio & 1970 & \multicolumn{1}{|c|}{1981} \\
\hline Arrecife & 54,9 & 100,0 \\
\hline Haría & 0,0 & 50,0 \\
\hline S. Bartolomé & 6,7 & 100,0 \\
\hline Teguise & 0,0 & 2,0 \\
\hline Tías & 0,0 & -- \\
\hline Tinajo & 0,0 & 70,0 \\
\hline Yaiza & 4,0 & 10,0 \\
\hline TOTAL & 27,6 & 85,8 \\
\hline \hline
\end{tabular}

Fuente: Encuesta CIES, 1970. Boletín No 11. Centro de Investigación Económico y Social, 1971; Plan Insular, Documento I.3.II.2.5. 1973 (pp.140). Cabildo Insular de Lanzarote; Datos municipales: "Plan de Plan Insular de Ordenación de la Oferta turística de Lanzarote, Tomo III, 1982, pp. 274.; Estimación porcentual Total: "Viviendas familiares ocupadas según sus instalaciones y servicios". Censo de Viviendas, 1981. INE.

En la década de los años ochenta todavía no llega el agua corriente a todas las viviendas, aunque se ha ido subsanando el déficits con el que se inicia la etapa principalmente en los municipios más cercanos a la capital, por la ampliación de la red de servicio público. A ello se une el que la producción de agua privada sigue siendo superior a la pública a pesar del crecimiento de la desalinización que viene del sector público, por lo que la prioridad la sigue teniendo el turista, tanto al comienzo de la etapa como al final de la misma. 


\subsubsection{2.- EL CONSUMO DE AGUA. DEMANDA}

Con respecto al consumo de agua en la isla, los documentos de Avance del PIOT (Cabildo Insular de Lanzarote. Avance PIOT. Tomo 2. 1987, pp. 186) recogen el gasto medio diario por habitante (I/habitantes*día), calculado a través de estimaciones demográficas propias sobre el número de turistas en la isla (que no se detallan metodológicamente). Es por ello que en el siguiente cuadro señalamos los datos principales que recoge dicho documento y que nos sirven de referencia hasta el año 1981, analizando a parte 1986, año en el que se disponen de otras fuentes de medición del consumo y al que se le ha aplicado la población total insular estimada a partir del cálculo del número de turistas diarios cuya metodología, propia, se ha descrito en anteriores epígrafes (5.1.1.2.). Adicionalmente, debemos tener en cuenta que los datos de consumo publicados por los organismos oficiales, en la década de los ochenta, son los que facilita la empresa INALSA. S.A. que está dedicada a la producción y distribución del agua generada por desalación con financiación pública, por lo que suponemos que el consumo al año debe ser mayor pues existe producción privada de agua en desaladoras de pequeña escala.

Tabla 76. Consumo medio diario de agua y producción. Lanzarote. 1970-1981 (I/habitantesdía).

\begin{tabular}{||c|r|r|r|r|}
\hline Año & $\begin{array}{l}\text { Consumo } \\
\text { I/habitante*día }\end{array}$ & $\begin{array}{l}\text { Incremento quinquenal } \\
\text { Consumo (\%) }\end{array}$ & $\begin{array}{l}\text { Producción } \\
\text { l/habitante*día }\end{array}$ & Población residente \\
\hline 1970 & --- & -- & 49,84 & 41.146 \\
\hline 1975 & 67 & -- & 69,94 & 44.337 \\
\hline 1981 & 124 & 85,07 & 128,35 & 50.721 \\
\hline
\end{tabular}

Fuente: De 1970 a 1981: Cabildo Insular de Lanzarote. Avance PIOT de Lanzarote. Tomo 2. "Área de Infraestructuras y abastecimiento". Cap. 3. Infraestructuras hidráulico-sanitarias. Punto 3. c) Demanda de agua. 1987 (pp. 186)

A partir de estos datos, podemos señalar cambios bruscos en el consumo (l/habitante*día), pues éste casi se dobla en el periodo comprendido entre 1975-1981, con un incremento aproximado del $85 \%$, ya que la isla eleva su actividad en el camino hacia la consolidación como destino turístico de masas. El crecimiento porcentual del consumo se ralentizará posteriormente. 
Tabla 77. Consumo medio diario de agua, producción y población a abastecer. Lanzarote. 1986 ( $\left.\mathrm{m}^{3} / \mathrm{año}\right)$

\begin{tabular}{||c|c|c|c|c|l|l|c|c|}
\hline Año & CONSUMO & $\begin{array}{c}\text { Población } \\
\text { Residente }\end{array}$ & $\begin{array}{c}\text { Turistas } \\
\text { equivalentes } \\
\text { al día }\end{array}$ & $\begin{array}{c}\text { Población } \\
\text { a } \\
\text { abastecer }^{*}\end{array}$ & I/Residente*día & I/habitante*día & $\begin{array}{c}\text { Producción } \\
\text { I/habitante*día }\end{array}$ & $\begin{array}{c}\text { Disponibilidad } \\
\text { después de } \\
\text { pérdidas en } \\
\text { red.(I/hab*día) }\end{array}$ \\
\hline \hline 1986 & 3.304 .345 & 55.764 & 16.493 & 72.257 & 162,34 & $125,29^{* *}$ & 181,34 & 154,13 \\
\hline
\end{tabular}

$\left(^{\star}\right)$ Población a abastecer diaria: población de derecho + turistas equivalentes al día. $\left.{ }^{* *}\right)$ Media estimada en relación al consumo en $\mathrm{m}^{3}$ al año.

Nota. En 1986 los consumos son los registrados por INALSA, que no contemplan el consumo de la producción privada de agua.

Fuente: "Evolución del consumo de agua, Lanzarote, 1986 y 1991 (m³/día)". Datos Estadísticos, 1992. Centro de datos. Cabildo Insular de Lanzarote, 1992; "Resumen de datos de agua. Consumo, Lanzarote 1996.". Centro de datos del Cabildo Insular de Lanzarote. www.datosdelanzarote.com; Elaboración propia.

La producción se limita a adaptarse al nivel de consumo, al menos es lo que parece hasta el año 1981, ya que, posteriormente, la distribución media del consumo, por habitante y día, nos arroja excedentes en la producción. Aunque hay que añadir las pérdidas en red anteriormente señaladas, y la información obtenida tras entrevistas con fuentes internas de INALSA, que señalan que la isla posee escasa capacidad de almacenaje de agua potabilizada (unos dos días), lo que quiere decir que la disponibilidad real de agua está por debajo del consumo que registran las entidades públicas, como se puede observar en el siguiente cuadro, al menos hasta 1981.

Gráfico 54. Consumo, producción y disponibilidad de agua después de pérdidas en red. Lanzarote. 1970-1986 (I/habitante*día)

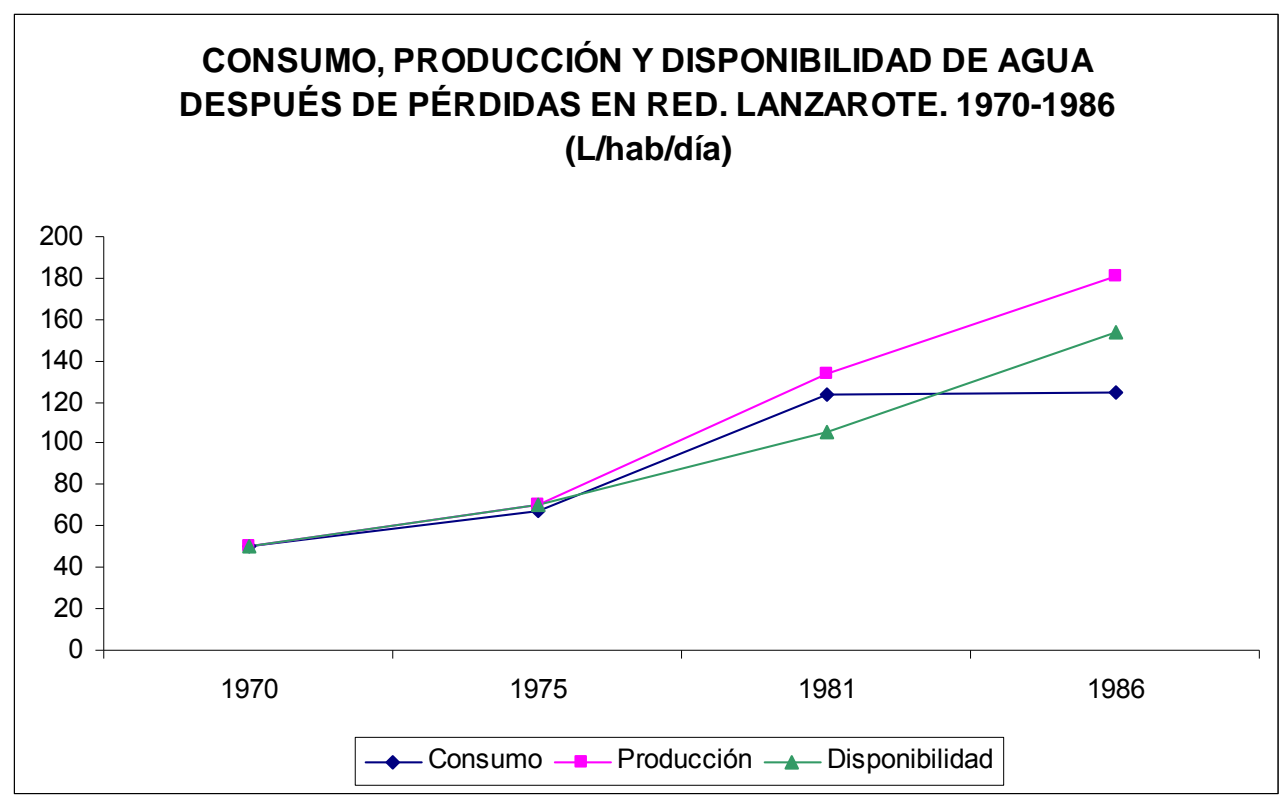

Fuente: Plan insular de Lanzarote, 1973 y Avance PIOT de Lanzarote, 1987. Cabildo Insular de Lanzarote e INALSA. Elaboración propia. 
No se ha podido constatar la existencia de registros en relación al consumo de agua según tipo de actividad, pero a pesar de ello nos atrevemos a afirmar que toda la producción de agua potable privada, propiedad de los complejos turísticos que funcionan en la isla, se consume y además, dichos complejos tienen acceso a la red pública, de la que también toman. No obstante estudios realizados en los años noventa serán los que nos proporcionen estimaciones sobre el volumen que consumen de la red pública. La realidad, por tanto es que el turista tiene la posibilidad de tener mayor acceso al agua que la población residente.

La comparación con Canarias y España, en esta etapa no ha sido posible, por la falta de registros en relación a la producción y el consumo de agua en estos marcos.

\subsubsection{3.- CONCLUSIONES}

La etapa de desarrollo y consolidación de la actividad turística en la isla de Lanzarote viene marcada por la escasez agua. El esfuerzo se centrará en la producción de agua desalada a través de plantas potabilizadoras cuya implantación, inicialmente de iniciativa privada, permitirá impulsar la actividad productiva industrial y turística en la isla. Así esta etapa está caracterizada por lo siguiente:

1. Escasez de agua para consumo doméstico.

2. El agua corriente potabilizada no llega a la totalidad de las viviendas. Uso de aljibes. El único municipio que posee agua corriente durante toda la etapa es el capitalino.

3. Incremento constante de la producción de agua desalada, desde instalaciones públicas (para toda la población) y privadas (únicamente destinadas a urbanizaciones turísticas).

4. Las redes de trasporte deben ser mejoradas pues las pérdidas son significativas.

5. Se produce más agua para abastecer al turismo que para abastecer a la población residente, por lo que se proporciona mayor bienestar a los primeros.

6. Fuertes incrementos del consumo a lo largo de toda la etapa.

7. El consumo de agua del turista (I/habitantes ${ }^{*}$ día) se estima mayor que el del residente, en un $357 \%$.

8. Se consume la totalidad del agua que se produce prácticamente durante toda la etapa. Ésta se inicia con una situación crítica derivada de una oferta inferior a la demanda, pues no se llega a cubrir el estándar para consumo mínimo por habitante y día. Al final de periodo esta dinámica parece romperse, pues la oferta será ligeramente superior a la demanda. 
En términos generales, el consumo de agua está determinado por la producción, aunque la demanda sea elevada. La población local se beneficiará de la instalación de plantas desaladoras pues son necesarias para la implantación de actividad turísticas de masas, y a la vez, el turista se constituye en un competidor por los escasos recursos hidráulicos de la isla. Por tanto, la actividad turística en este periodo será la que impulse la producción de agua potable que beneficiará a la población residente, a la vez que competirán por el recurso.

\subsection{9.- EFECTOS SOBRE LAS VÍAS DE COMUNICACIÓN. CARRETERAS. 1970-1986}

El transporte tiene una importancia fundamental en el territorio, lo configura y establece las posibilidades de movilidad y grado de accesibilidad de la población. Es por ello que es un factor determinante del grado de desarrollo social y cultural de las regiones, en su consecución del bienestar, y absolutamente imprescindible en la incorporación y crecimiento de actividades turísticas y productivas a la economía.

El objeto de este análisis es ver en qué medida la actividad turística que acoge la isla, ha incidido en el desarrollo de las comunicaciones terrestres insulares, facilitando la movilidad de la población local o congestionando las vías y por tanto dificultándola. Para ello observaremos las variaciones en la calidad del vial, en las intensidades medias diarias de tráfico, así como en la evolución de los índices de motorización y las redes de transporte público.

\subsubsection{1.- CAPACIDAD DEL VIARIO. OFERTA}

Al comienzo de la etapa de expansión turística, como a lo largo de su evolución, la capacidad de las comunicaciones internas será esencial para abordar la modificación en la accesibilidad y la movilidad que este desarrollo trae pareja. El dato positivo será que, dadas sus características topográficas, ningún núcleo habitado carece de comunicación viaria (Plan Insular, 1973, Tomo I. Información Urbanística de suelo. Infraestructuras (pp. 152). Ministerio de Vivienda).

En Lanzarote existen en ese momento dos tipos de carreteras, en relación a su dependencia: las carreteras locales del Ministerio de Obras Públicas y los caminos vecinales del Cabildo Insular. 
En cuanto al ancho de carreteras, durante toda la década de los años setenta la red tiene un ancho insuficiente ${ }^{161}$. Aunque se observa mejoras durante toda la etapa, al final de la misma (1986) aún sigue siendo inadecuado e insuficiente puesto que más del $60 \%$ de la red viaria tiene menos de 6 metros de ancho, lo que dificulta la mejora de las condiciones de seguridad y accesibilidad. No posee vías de gran capacidad.

Tabla 78. Ancho de calzada y kilómetros de carreteras. Lanzarote. 1970-1986.

\begin{tabular}{|c|c|c|c|c|}
\hline \multicolumn{5}{|c|}{ LANZAROTE } \\
\hline \multirow{2}{*}{$\begin{array}{l}\text { Tipo } \\
\text { Año }\end{array}$} & \multicolumn{3}{|c|}{ Una calzada (\%) } & \multirow{2}{*}{$\begin{array}{l}\text { TOTAL } \\
\mathrm{Km} .\end{array}$} \\
\hline & $<6$ & $6-7$ & $7-9$ & \\
\hline 1970 & 100,0 & 0,0 & 0,0 & 343,16 \\
\hline 1975 & --- & --- & --- & \\
\hline $1981^{*}$ & 86,0 & 8,2 & 5,8 & 373,0 \\
\hline 1986 & 62,3 & 28,0 & 9,7 & 439,3 \\
\hline
\end{tabular}

(*) Para la isla de Lanzarote sólo está referido a las Carreteras Locales, que son del MOPU, y corresponde a 111,8 Km de carreteras. El resto de la red son caminos vecinales $(261,2 \mathrm{~km})$ que se han supuesto menores de $6 \mathrm{~m}$ de ancho.

Fuente: "Ancho de Carreteras Locales, 1981". Plan Insular de Ordenación de la Oferta Turística de Lanzarote, Tomo III, Secretaría de Estado de turismo, 1982 (pp. 200); "Indicadores de la Red de Carreteras, 1986". Avance PIOT, Tomo 2. Cap. VIII. 2. Cuadro 2.2. 1987 (pp. 156),

Este indicador señala infraestructuras propias de sociedades rurales, no preparadas para la fuerte intensidad de movilidad por carretera que provoca el constante crecimiento de la oferta turística y su demanda, junto con el crecimiento demográfico asociado. Aunque desde su despegue en 1970 hasta su consolidación al final de esta etapa, ha incremento sus kilómetros de carretera en un $28 \%$ y su ancho de vía. Se aplica una política basada en la filosofía del desarrollismo, "cuyo objetivo será la reserva de suelo necesaria para la creación y ensanche de vías" (Plan Insular de la isla de Lanzarote, 1973. Tomo I. 3. Información Urbanística de suelo. Infraestructuras (pp. 139).

Si Lanzarote posee en 1986 el $100 \%$ de carreteras de una calzada, no presenta una diferencia significativa respecto a Canarias, pues ésta posee más del $96 \%$ de los kilómetros de carreteras dentro de las de una calzada. Aunque tiene mayor ancho de vía que la isla. Ambos ámbitos están teniendo evoluciones positivas, necesarias para absorber la demanda de movilidad interna.

161 “(...) Todas son vías de dos carriles que oscilan de 2,50 a 2,75 metros. Estas anchuras que hasta hace unos años eran suficientes comienzan a ser insuficientes, habida cuenta de que las intensidades medias diaria superan los 2.000 vehículos en varias vías". Plan Insular de la isla de Lanzarote, 1973. Tomo I. Información Urbanística de suelo. Infraestructuras. Síntesis de la Información. Anexo 6. Epígrafe 3.1.2. Características técnicas (pp. 154). Ministerio de Vivienda, 1973. 
Tabla 79. Ancho de calzada. Lanzarote y Canarias. 1970-1986 (\%)

\begin{tabular}{|c|c|c|c|c||c|c|c|c|c||}
\cline { 2 - 10 } \multicolumn{1}{||}{} & \multicolumn{4}{c||}{ LANZAROTE } & \multicolumn{6}{c|}{ CANARIAS } \\
\hline Tipo & \multicolumn{2}{|c|}{ Una calzada (\%) } & TOTAL & \multicolumn{2}{|c|}{ Una calzada (\%) } & Vías de Gran Capacidad (\%) & TOTAL \\
\hline Año & $<6$ & $\mathbf{6 - 7}$ & $\mathbf{7 - 9}$ & $\mathrm{Km}$. & $<5$ & $\mathbf{5 - 6 , 9 9}$ & $\mathbf{2 7}$ & Doble, AP y AV & $\mathbf{k m}$ \\
\hline 1986 & 62,3 & 28,0 & 9,7 & 439,3 & 10,9 & 72,8 & 12,3 & 3,4 & 4.472 \\
\hline
\end{tabular}

Fuente: "Indicadores de la Red de Carreteras, 1986". Avance PIOT, Tomo 2. Cap. VIII. 2. Cuadro 2.2. 1987 (pp. 156); "Red de Carreteras de Canarias según anchura de pavimento. Total Canarias, 1986 (km)". Estadísticas Básicas de Canarias 1987-1992”. Instituto Canario de Estadística, 1992. ISTAC.

Las mejoras del vial en esta etapa, en la isla, no van a responder a una estrategia de planificación global del transporte y las comunicaciones insulares, sino que los proyectos de mejora y ampliación que se abren constituyen actuaciones independientes entre sí (Esteban, A., 1998, pp. 2). Es por ello que la población local se beneficiará de mayor y mejor accesibilidad desde algunos puntos estratégicos para el movimiento de los turistas, situados principalmente entre la costa sureste de la isla y la capital de la misma (centroeste) pero no se beneficiará de una estrategia de comunicaciones global. Las mejoras están encaminadas a ampliar la puesta en valor turístico del territorio insular, el bienestar social derivado es indirecto.

Mapa 12. Carreteras insulares. Lanzarote. 1973

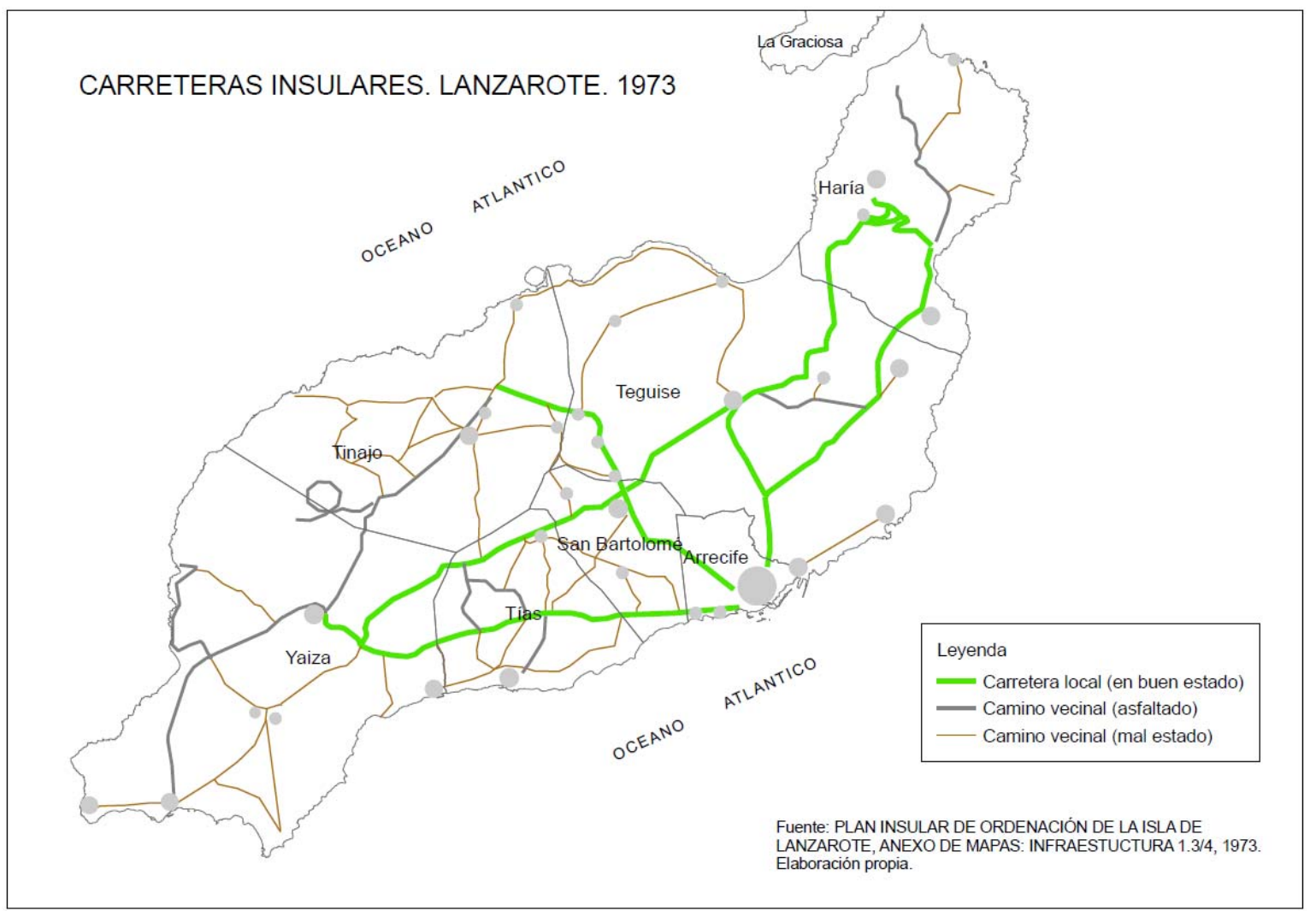




\subsubsection{2.- NIVEL DE MOTORIZACIÓN E INTENSIDAD DEL TRÁFICO. DEMANDA}

En relación al índice de motorización, aunque Lanzarote comienza la etapa presentando niveles de motorización inferiores a Canarias y España, la explosión del parque de vehículos (turismos) supone el rápido crecimiento de dicho índice (en la población residente y responde a vehículos de tipo turismo), superando al final del periodo (1986) a su Comunidad Autónoma y al país.

Tabla 80. Número de vehículos (turismos) e Índice de motorización. Lanzarote, Canarias y España. 1970-1986

\begin{tabular}{|c|c|c|c|c|c|c|c|c|c|}
\hline & \multicolumn{3}{|c|}{ Número de Turismos } & \multicolumn{6}{|c|}{ Índice de Motorización } \\
\hline & \multirow{2}{*}{ Lanzarote } & \multirow{2}{*}{ Canarias } & \multirow{2}{*}{ España } & \multicolumn{2}{|c|}{ Lanzarote } & \multicolumn{2}{|c|}{ Canarias } & \multicolumn{2}{|c|}{ España } \\
\hline & & & & Residentes & P.Total ${ }^{*}$ & Residentes & P. Total ${ }^{*}$ & Residentes & P.Total* \\
\hline 1970 & 1.448 & 94.233 & 2.377 .726 & 0,04 & 0,03 & 0,08 & 0,08 & 0,07 & 0,07 \\
\hline 1975 & --- & 172.247 & 4.806 .833 & --- & --- & 0,13 & 0,13 & 0,13 & 0,13 \\
\hline 1981 & --- & 297.731 & 7.943 .325 & --- & --- & 0,22 & 0,21 & 0,21 & 0,20 \\
\hline 1986 & $19.650^{* *}$ & 343.061 & 9.761 .968 & $0,26^{* *}$ & 0,27 & 0,24 & 0,21 & 0,25 & 0,25 \\
\hline
\end{tabular}

\begin{tabular}{|c|c|c|c|}
\hline Año & Turismos & Vehículos en alquiler & $\begin{array}{l}\text { Vehículos turismos para } \\
\text { la población residente }\end{array}$ \\
\hline \hline 1986 & 19.650 & $25 \%$ & 14.738 \\
\hline
\end{tabular}

$\left.{ }^{*}\right)$ P. Total: Población residente + Turistas equivalentes al día

$\left({ }^{* *}\right)$ El total de vehículos-turismos se contabiliza en 19.650 , pero teniendo en cuenta que se considera que el $25 \%$ son de alquiler se toma la cifra descontando este porcentaje para establecer, aproximadamente, el índice de motorización de la población residente en relación a los vehículos de tipo "turismos", quedándose en 14.738

Fuente: "Parque de vehículos" Plan Insular de la isla de Lanzarote, 1973. Tomo I.3.2. Cuadro 4. Ministerio de Vivienda. Cabildo Insular de Lanzarote, 1973 (pp. 155); "Parque automóvil en Lanzarote, 1986". Avance Plan Insular, Tomo 2. VIII. 2.D). Cuadro 2.4, 1987 (pp. 163);"Parque nacional automóvil, por provincias y clases. Provincia de Las Palmas y de Tenerife, 1971, 1975 y 1981". Anuario Estadístico, 1971, 1975 y 1981. Centro de documentación. Ministerio de Fomento, España; "Parque móvil de Canarias según tipo de vehículo, por provincias. Turismos, 1986". Anuario Estadísticos de Canarias, 1986. CEDOC; "Automóviles en circulación. Turismos. Total Nacional, 1970, 1975, 1981 y 1986”. Anuario Estadístico de España, 1971, 1976, 1982 y 1987. INE; Elaboración propia.

Este rápido crecimiento del número de vehículos (turismos) por habitante tiene su explicación en la demanda de transporte por carretera derivado del incremento de las visitas por turismo, el crecimiento de plazas de alojamiento y la atracción de población asociada a trabajar. Este hecho hace que la presión sea de 27 vehículos (turismos) por 100 personas que acoge la isla a diario. Similar al índice que presenta la población local (cada 100 residentes hay 26 vehículos (turismos). 
Gráfico 55. Índice de motorización (turismos) sobre la población residente y la población total estimada. España, Canarias y Lanzarote. 1986

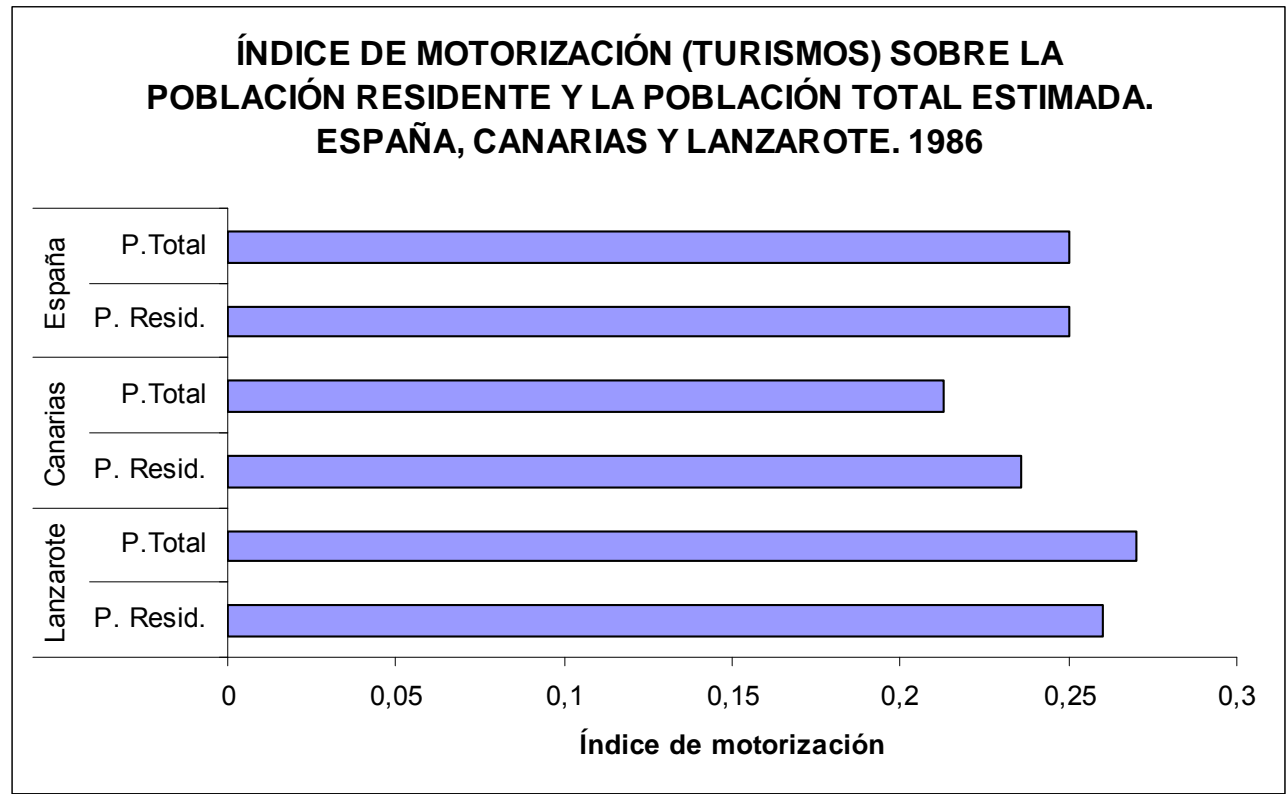

Fuente. Parque de vehículos de categoría turismos. Plan Insular de la isla de Lanzarote, 1973; Avance PIOT de Lanzarote, 1987; Anuario Estadístico de Canarias, CEDOC y Anuario Estadístico del Ministerio de Fomento. Elaboración propia.

Por otro lado, aunque no se han encontrado registro para el año 1970, nos atrevemos a afirmar que los vehículos de alquiler han experimentado un importante crecimiento desde el comienzo de la etapa, contabilizándose en 1986 un "parque de autos de alquiler que fluctúa entre los 4.000 y 5.000 coches. El crecimiento de este tipo de autos se debe a la funcionalidad que presentan en relación al turismo insular y a las carencias de otro tipo de transporte eficiente" (Cabildo Insular de Lanzarote. Avance PIOT. Tomo 2. 1987, pp. 164). Representan por tanto un $25 \%$ del parque de vehículos (turismos) de la isla. De existir una alternativa de transporte eficiente, se podría reducir este porcentaje y con ello el índice de motorización general que soporta la isla y mejorar la calidad de escena.

Paralelamente al proceso descrito, la intensidad media diaria de vehículos experimenta un fuerte y constante incremento en las principales vías de la isla, que comunican a la capital con los focos de localización de la economía turística. 
Tabla 81. Evolución de la intensidad media diaria de vehículos, por tramos. Lanzarote. 1975$1985(\%)$

\begin{tabular}{|c|c|c|c|c|c|c|c|c|}
\hline AÑO & Arrecife- & $\begin{array}{c}\text { Incremento } \\
\text { quinquenal } \\
(\%)\end{array}$ & $\begin{array}{c}\text { Aeropuerto- } \\
\text { Tías }\end{array}$ & $\begin{array}{c}\text { Incremento } \\
\text { quinquenal } \\
(\%)\end{array}$ & $\begin{array}{c}\text { Arrecife- } \\
\text { Costa de } \\
\text { Teguise }\end{array}$ & $\begin{array}{c}\text { Incremento } \\
\text { quinquenal } \\
(\%)\end{array}$ & $\begin{array}{c}\text { Arrecife- } \\
\text { Tahíche }\end{array}$ & $\begin{array}{c}\text { Incremento } \\
\text { quinquenal } \\
(\%)\end{array}$ \\
\hline \hline 1975 & 8.641 & --- & 2.326 & -- & -- & -- & 3.706 & -- \\
\hline 1980 & 13.689 & 58,42 & 3.279 & 40,97 & 6.573 & -- & 5.207 & 40,50 \\
\hline 1985 & 19.500 & 42,45 & 6.025 & 83,75 & -- & -- & 6.677 & 28,23 \\
\hline
\end{tabular}

Fuente: "Mapa de aforo de carreteras de Lanzarote, 1975, 1980, 1985". González, A; Couceiro, A. y otros (1989). "Evolución del transporte y la infraestructura viaria en la isla de Lanzarote". IV. Jornadas de Estudios de Lanzarote y Fuerteventura. Tomo II, 1995 (pp. 13-50). Cabildo Insular de Lanzarote y de Fuerteventura. http://www.memoriadelanzarote.com.; "Intensidad media diaria de tráfico en puntos representativos de la isla de Lanzarote (1975-2000)". Tabla 6. En Hernández, J. A. (2006). "Tendencias de la movilidad terrestre en la isla de Lanzarote (1991-2001)”. XII Jornadas de Estudios sobre Lanzarote y Fuerteventura. Tomo III, Vol. 2. (pp. 156-178) Cabildo Insular de Lanzarote y de Fuerteventura, 2008. http://www.memoriadelanzarote.com.

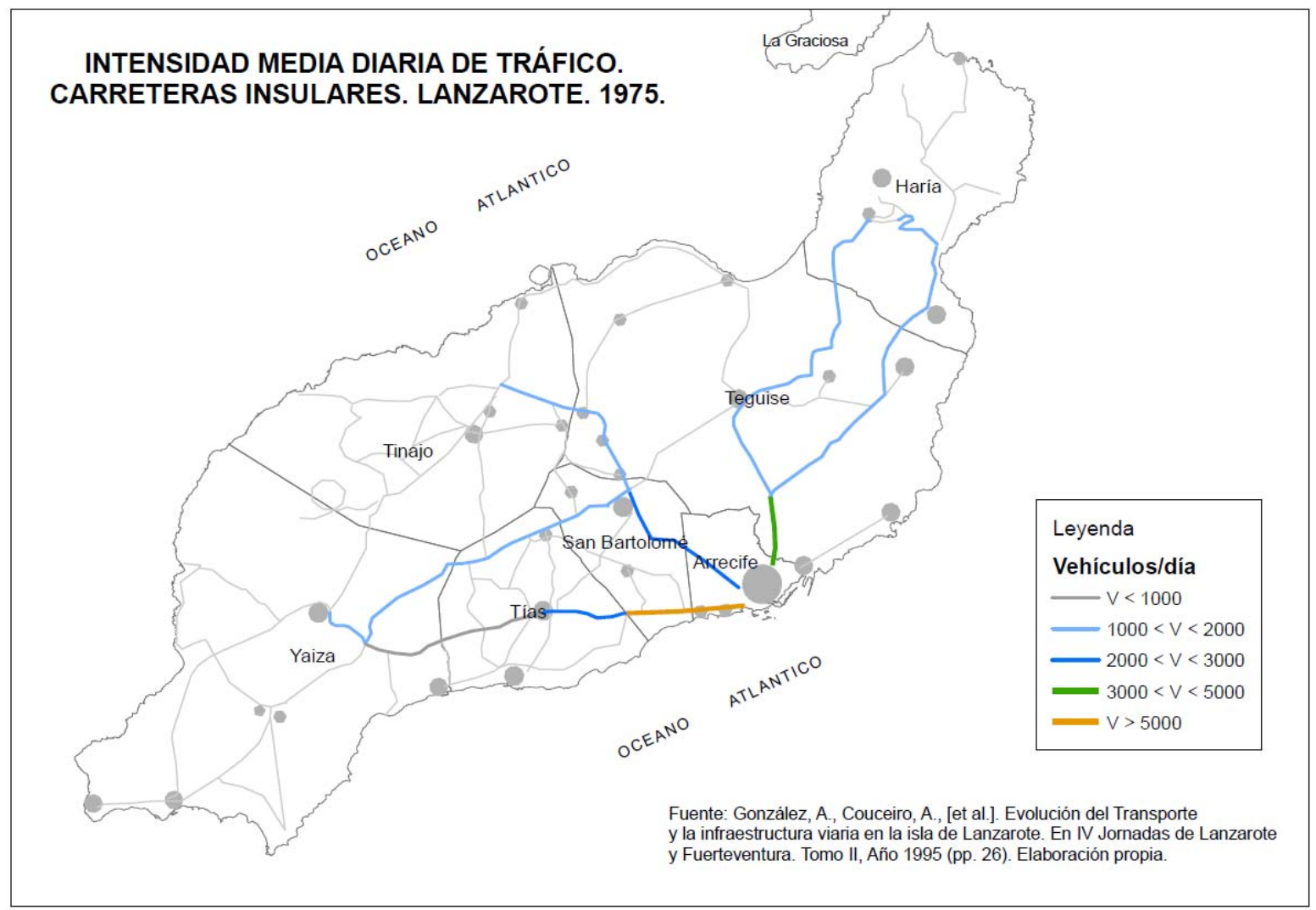

La mayor presión observada en el tráfico diario, a lo largo de la etapa, se produce en los tramos que van al aeropuerto, con incrementos de más del $40 \%$, y el que conecta la principal zona de servicios turísticos y de playa de la isla (municipio de Tías), que concentra alta movilidad por movimientos de trabajadores y turistas, con incrementos que han llegado entre 1980 y 1985 a más del $80 \%$. 
Gráfico 56. Intensidad media diaria de vehículos por tramos. Lanzarote. 1975-1985

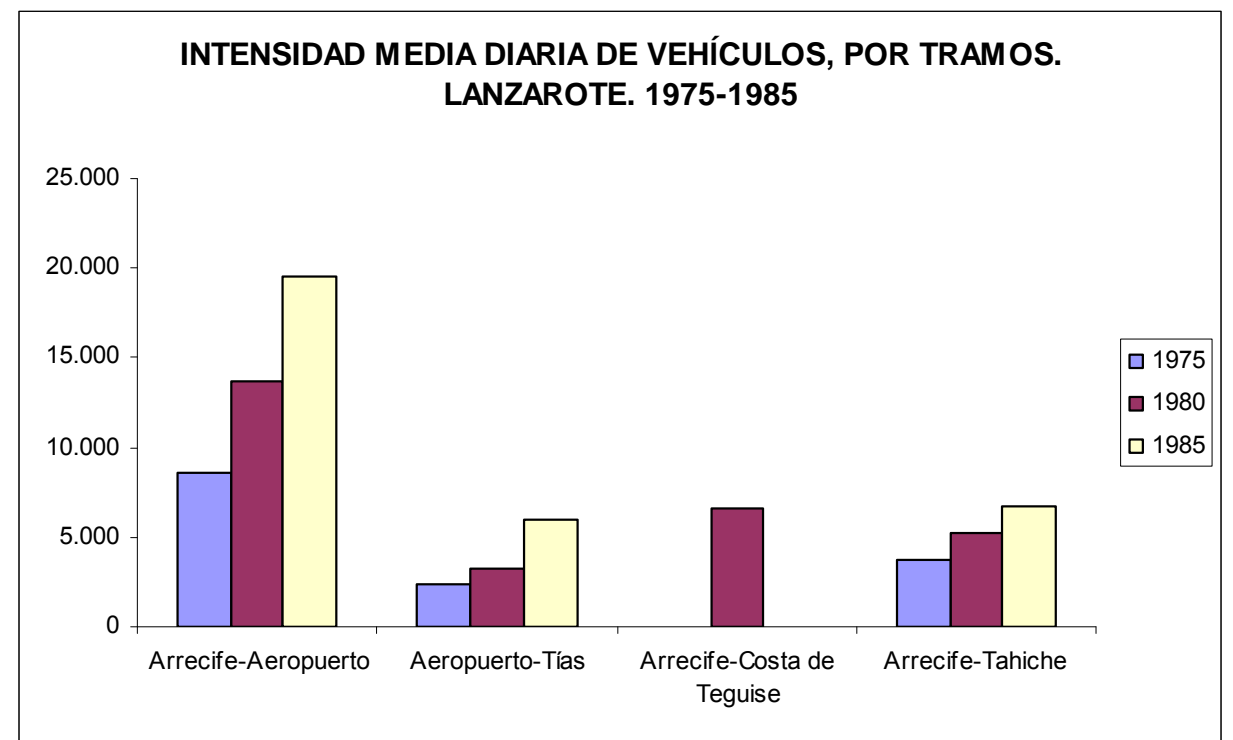

Fuente. González, A; Couceiro, A. y otros (1989) y Hernández, J. A. (2006). Elaboración propia.

Mapa 14. Intensidad media diaria de tráfico. Carreteras insulares. Lanzarote. 1985

INTENSIDAD MEDIA DIARIA DE TRÁFICO. CARRETERAS INSULARES. LANZAROTE. 1985.

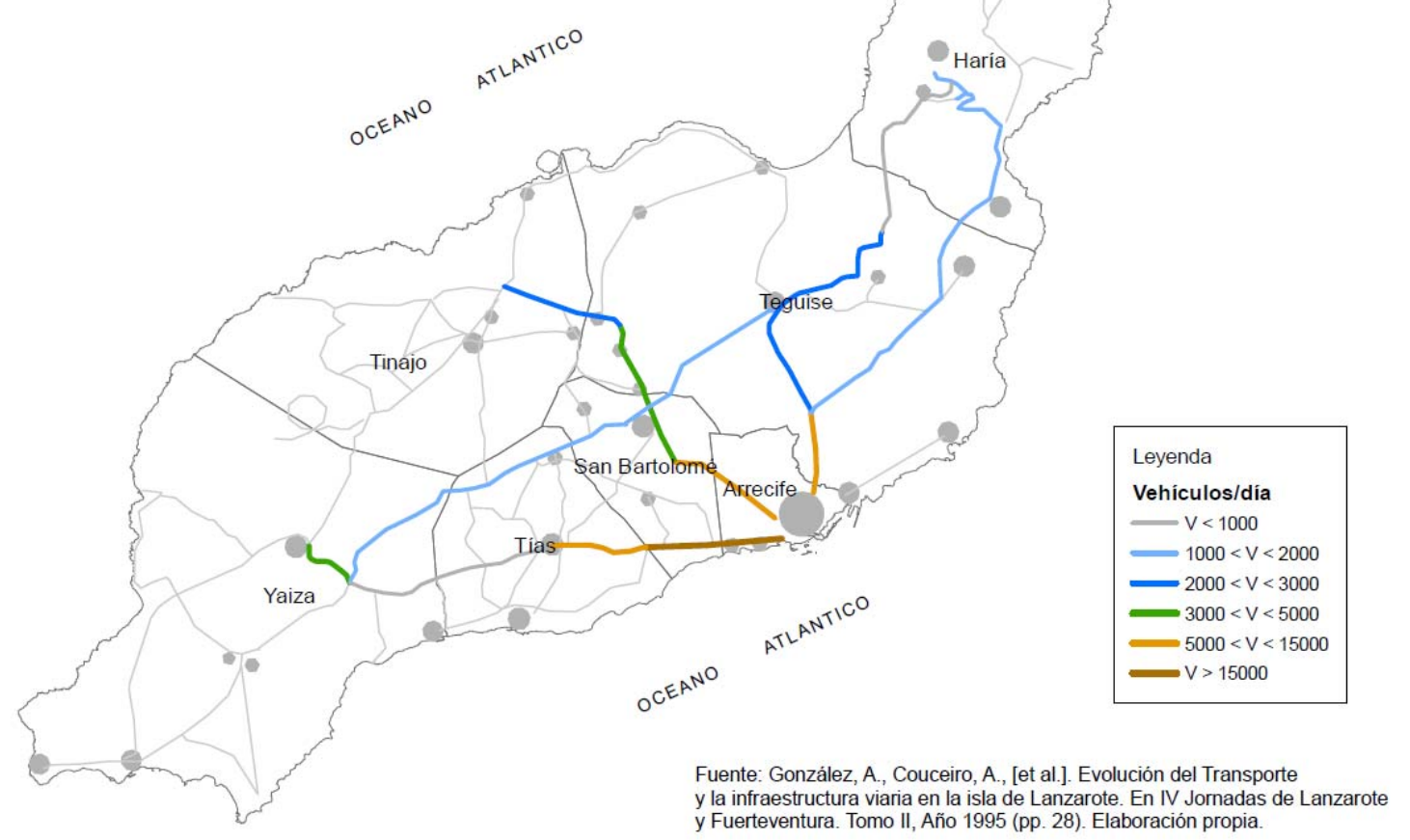




\subsubsection{3.- TRANSPORTE COLECTIVO REGULAR DE PASAJEROS}

La situación del transporte público regular, por carretera, es en general deficitaria en toda la etapa. Existe una compañía concesionaria para dar este servicio a toda la isla.

En la década de los años setenta la movilidad de los residentes se considera relativamente baja (Plan Insular de Lanzarote, 1973. Tomo 1. Anexo 8, pp. 200), aunque, sin contar con los turista que aún no son muchos, el número de autobuses regulares es de 1 por cada 1.469 habitantes. Esta situación, es aún más grave al final de la etapa, pues en 1986, los datos arrojan una reducción del número de autobuses de servicio regular, aproximadamente del 39\%, por lo que por cada bus se contabilizan más de 3.200 personas, eso sin contar los turistas, que en estos momentos suponen un incremento de población diaria en la isla alrededor del $35 \%$, agravando, por tanto, la situación y convirtiéndose en un agente competidor por los escasos servicios públicos.

Tabla 82. Transporte público (interurbano) de viajeros. Lanzarote. 1970 y 1986

\begin{tabular}{||c|c|c|c|c|c|c||}
\cline { 2 - 7 } \multicolumn{1}{c|}{} & Buses & Líneas & Residentes & Residentes/bus & $\begin{array}{c}\text { Viajeros } \\
\text { Potenciales* }\end{array}$ & Habitantes/bus \\
\hline 1970 & 28 & 9 & 41.146 & $1.469,50$ & 41.582 & $1.485,07$ \\
\hline 1986 & 17 & 12 & 55.764 & $3.280,24$ & 72.257 & $4.250,41$ \\
\hline
\end{tabular}

$\left(^{*}\right)$ Viajeros potenciales: Población total (residentes + turistas equivalentes al día).

Fuente: "Transporte regular de viajeros por carretera, 1969". Plan Insular de la isla de Lanzarote. 1973, Tomo 1. Información Urbanística de suelo. Anexo 8. Información general (pp. 199-201); "Transporte público de viajeros". Cabildo Insular de Lanzarote. Avance PIOT. Tomo 2. Área de Infraestructuras y abastecimiento. Cap. VIII. Comunicaciones. VIII. 4.1. Transporte público regular. 1987 (pp. 165); Elaboración propia.

El dato positivo en esta etapa es el incremento de las líneas, es decir, en 1986 hay más zonas conectadas al transporte público que al comienzo de la etapa. Aunque, como podemos observar en el mapa siguiente, las zonas mejor comunicadas, por número de viajes diarios son las que salen de la capital de la isla (centro) hacia el sur, conectando los asentamientos de población que concentran los crecimientos del alojamiento y la actividad turística, en detrimento de asentamientos de población local donde no se acogen dichos desarrollos. "Cinco líneas concentran el $71 \%$ de la oferta de transporte público regular interurbano que se ofrece en Lanzarote y absorben al 63,5\% de los pasajeros. (...). Cuatro de las cinco líneas están dirigidas hacia zonas turísticas y básicamente transportan a trabajadores de estas zonas, y un porcentaje de turistas que en días de mal tiempo se dirigen de compras a la capital, por resultar más barato" (AUIA, Avance PIOT, 1987. Tomo 2, pp. 169). 
A través de esta oferta no se puede satisfacer la necesidad de movilidad de la población, pues las ofertas de trabajo se concentran en las zonas turísticas y en la capital, así como los equipamientos básicos (sanidad, educación, etc.).

Mapa 15. Transporte público. Guaguas. Lanzarote. 1987

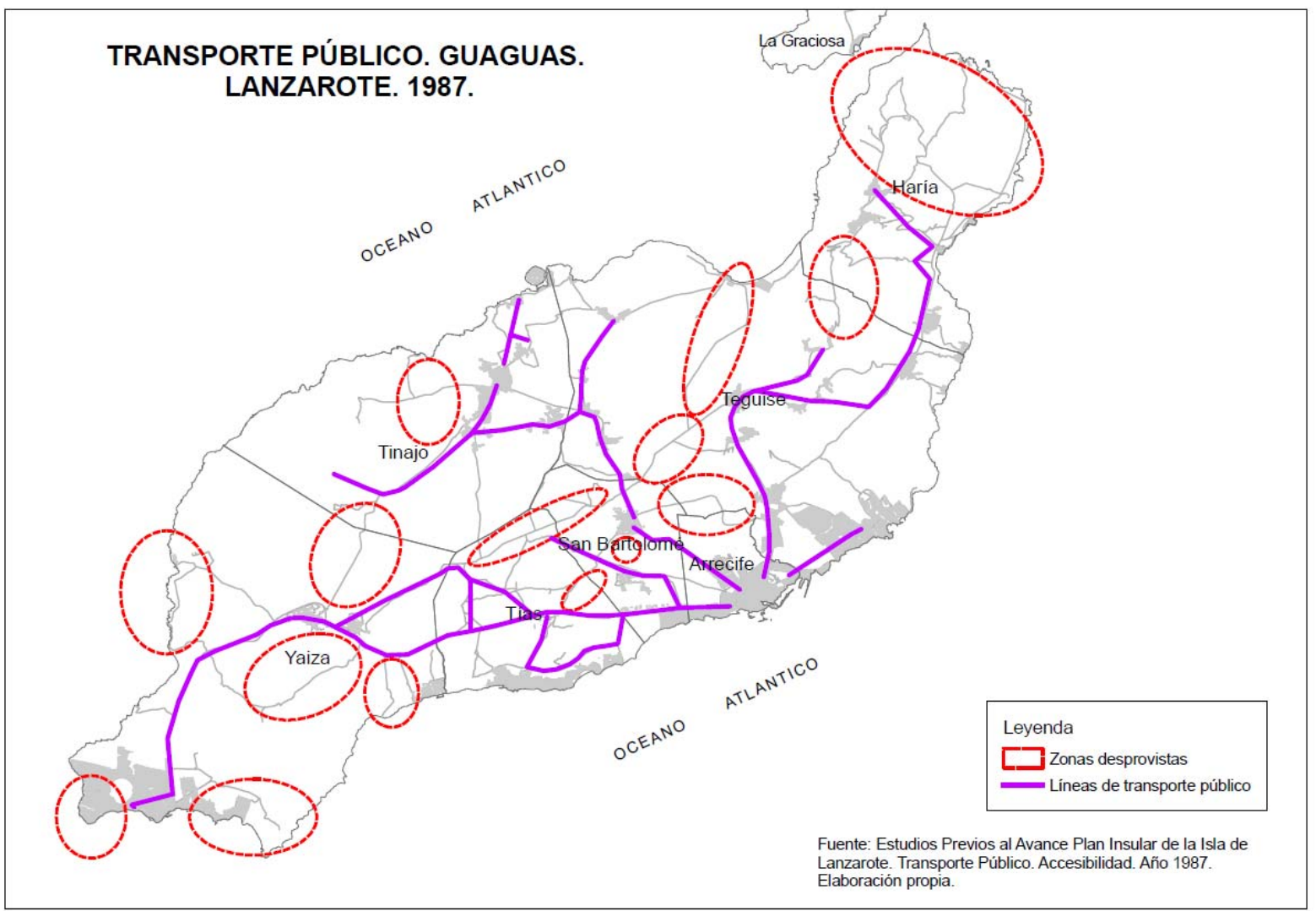

\subsubsection{4.- CONCLUSIONES}

En lo que respecta a las comunicaciones por carrera, esta primera etapa de desarrollo y consolidación de la actividad turística se caracteriza por lo siguiente:

1. Insuficiente ancho de vía e inadecuado para la intensidad de circulación en la red que une las zonas de actividad turística con la capital por el litoral.

2. Tendencia a lo largo de toda la etapa hacia mejoras sustanciales del ancho del vial, por tanto de la seguridad y la accesibilidad, necesaria para dar servicio a la demanda de movilidad por carretera que genera la constante y creciente entrada de turistas y de población asociada con fines laborales.

3. Incremento constante del número de turismos y del nivel de motorización de la isla, por encima de Canarias y de España. 
4. Fuerte incremento de la intensidad media diaria de vehículos en tramos que conectan zonas de concentración de servicios turísticos.

5. Oferta de servicio regular de transporte de pasajeros desfavorable. Sin aportación positiva al bienestar y a las posibilidades de acceso y movilidad de la población.

6. Es el transporte privado lo que se impulsa en la isla, engordado por el parque de vehículos en alquiler (para dar servicio a la demanda turística, que supone el $25 \%$ del parque móvil de tipo "turismos").

Las posibilidades de movilidad, accesibilidad y participación de la sociedad local en el nuevo modelo de vida que impulsa la actividad turística se incrementan de forma positiva, con la fuerte irrupción en la escena del vehículo privado como principal y fundamental medio para responder a las dificultades del transporte público, que no añade posibilidades de servicio. Todo ello tendrá repercusiones positivas en el bienestar de la población. Aunque, a consecuencia se incrementa la dependencia hacia el exterior, derivada del incremento en el consumo de carburantes y una creciente ocupación de espacio con la construcción de carreras, junto a la mayor contaminación y emisión de gases de efecto invernadero. Un modelo agresivo para un espacio de alto valor ambiental.

\subsubsection{0.- CONCLUSIONES A LA PRIMERA ETAPA. DESPEGUE Y CONSOLIDACIÓN.} 1970-1986

La década de los años setenta en Lanzarote, se caracteriza por ser un periodo donde se ubican los primeros procesos de transformación hacia lo que, una década y media después, va a ser una economía basada en el terciario turístico.

Comienza, por tanto, bajo una economía eminentemente agraria, con carencias en aspectos básicos para la subsistencia, como es la escasez de agua, seguido de poca capacidad y potencia energética, elevado nivel de analfabetismo, dificultades de trasporte en el interior de la isla y un pobre equipamiento social.

Esta primera etapa, que abarca desde 1970 a 1986, será la de producción del espacio turístico y vendrá marcada por el Plan Insular de la isla de Lanzarote, de 1973, cuyo modelo de planificación está dirigido a la expansión turística, es decir, en el que la puesta en valor turística del territorio responde a modelos de desarrollo intensivos (proliferación inmobiliaria), surgidos de forma espontánea por la presión de la demanda; crecimientos rápidos y a gran escala. Todo ello posible por su carácter de Norma Subsidiaria, en la que el suelo de "reserva urbana" o "apto para urbanizar" se desarrolla a través de Planes Parciales. A lo que se añade el que la clasificación del suelo y las normas de ordenación quedan con carácter provisional hasta la redacción del Planeamiento Municipal, que se redactará por esta época sin tener que asumir referencias a nivel insular, como señalan 
diferentes análisis oficiales ya citados. Por tanto, en la política urbanística prevalece un concepto maximizador y fundamentalmente cuantitativo, legislando y planificando para promover el territorio turísticamente en el exterior y no para controlar la especulación y el desorden urbanístico.

Mapa 16. Zonas de uso turístico previsto, 1973 y 1987

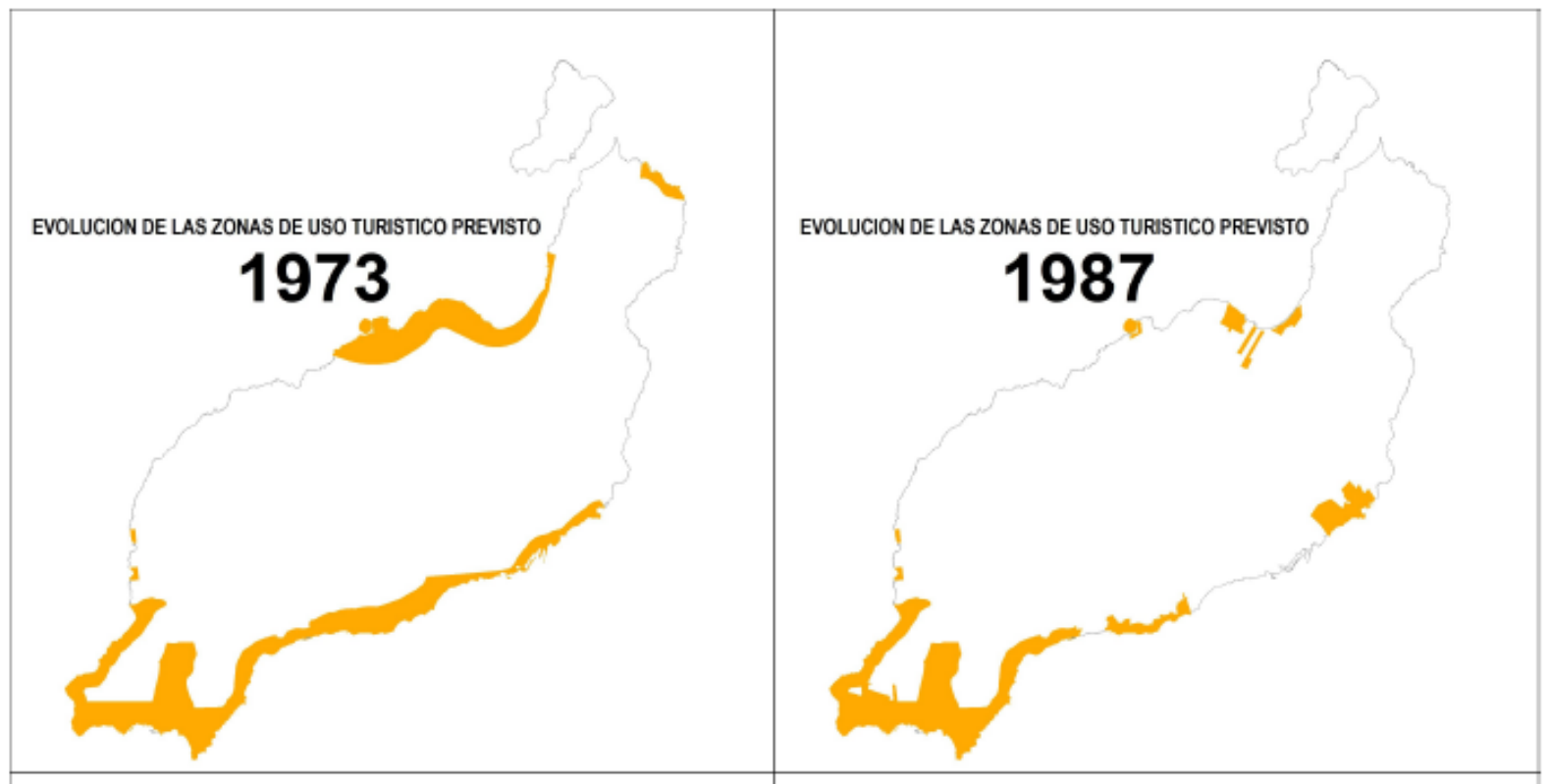

Fuente: Cabildo Insular de Lanzarote. Resumen del Plan Territorial Especial de Ordenación Turística Insular de Lanzarote, 2006. (Elaborado por AUIA). [En línea] Lanzarote: Cabildo de Lanzarote, 2006. (p. 7) [Ref. de 17 de junio de 2011] Disponible en Web: http://www.datosdelanzarote.com/itemDetalles.asp?idFamilia=24\&idltem=3023.

En el año 1982 se aprueba el Plan Insular de Ordenación turística de la Isla de Lanzarote, que no se va a realizar con criterios operativos, por lo que no va a tener ninguna competencia de intervención.

Por otro lado, el periodo está marcado por grandes dificultades infraestructurales y pequeños inversionistas locales, lo que dificulta el arranque de grandes inversiones, es dependiente de capitales exteriores que irrumpirán de forma generalizada ante la práctica inexistencia de medidas de control sobre usos de suelo y medidas fiscales.

Así, el modelo socioeconómico que se crea está centrado en la actividad turística, es dependiente del exterior, condicionado a las circunstancias del mercado y dirigido hacia un turismo de masas. Por lo que se observa una dinámica general de rápido crecimiento de la oferta y la demanda turística en cortos periodos de tiempo, con enormes incrementos de las plazas de alojamiento entre 1970 y 1986 (2.090\%), dirigidas hacia la creación, principalmente, de plazas extrahoteleras, apoyados en la continua y creciente presión de los visitantes turistas, que, aunque fluctuantes, presentan un incremento de algo más del 
$1.600 \%$ entre el comienzo y el final de la etapa. El ritmo de crecimiento de la oferta será superior a la demanda en buena parte de este periodo.

Gráfico 57. Evolución de la oferta y la demanda turística. Lanzarote. 1970-1986

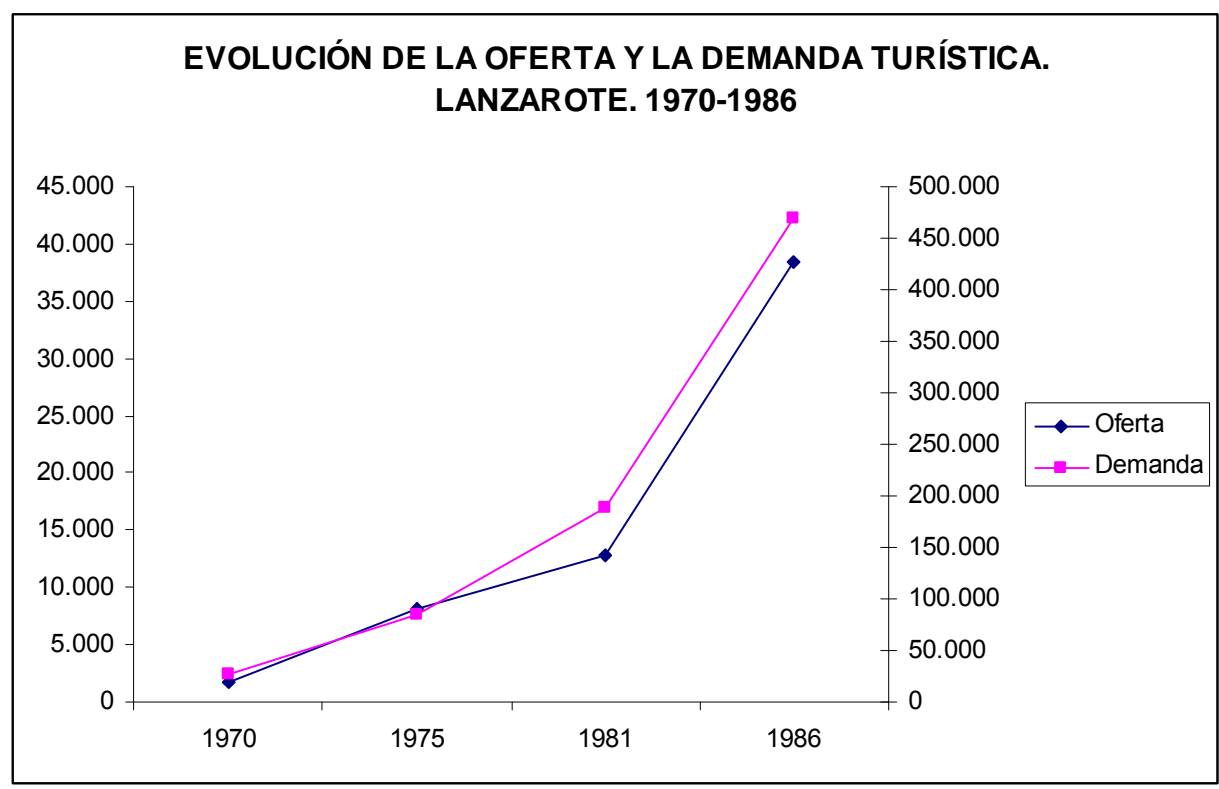

Fuente: Avance PIOT, 1987, ISTAC, IET e INE. Basado en Tabla 10 y 11. Elaboración propia.

Gráfico 58. Plazas de alojamiento turístico por tipo. Porcentaje sobre el total. Lanzarote. 1970-1986 (\%)

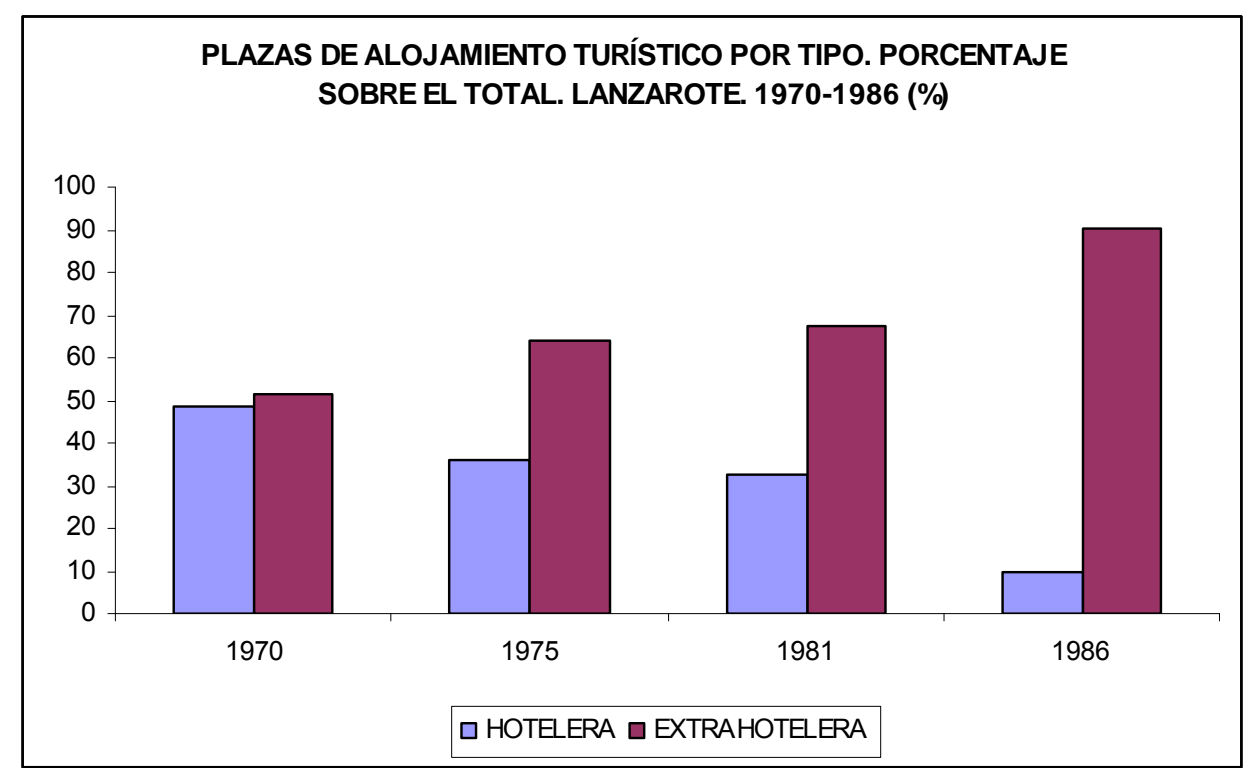

Fuente: Avance PIOT, 1987, ISTAC, IET e INE. Basado en Tabla 10. Elaboración propia.

El nivel de intensidad de la actividad, en la Isla, es muy superior al que presenta Canarias en su conjunto y España, a lo largo de toda la etapa. Estos últimos reducirán mucho antes sus incrementos porcentuales de oferta turística. 
Este bullir de actividad convierte a Lanzarote en un foco de atracción de mano de obra, elevando rápidamente su población residente, alcanzando la inmigración su mayor incremento en la primera mitad de la década de los años ochenta $(144 \%)$ y caracterizada en este momento por proceder de fuera de las Islas Canarias (57\%).

Por tanto, y en relación a ésta dinámica del sector, desde el punto de vista socioeconómico se observa lo siguiente:

A) La continúa reducción de la población autóctona frente a la foránea (inmigrantes y turistas), encaminándose hacia desequilibrios demográficos. Lo que supone que haya, al final de la etapa, aproximadamente 59 foráneos por cien autóctonos (alt/at).

Gráfico 59. Evolución de la población foránea y autóctona. Lanzarote. 1970-1986

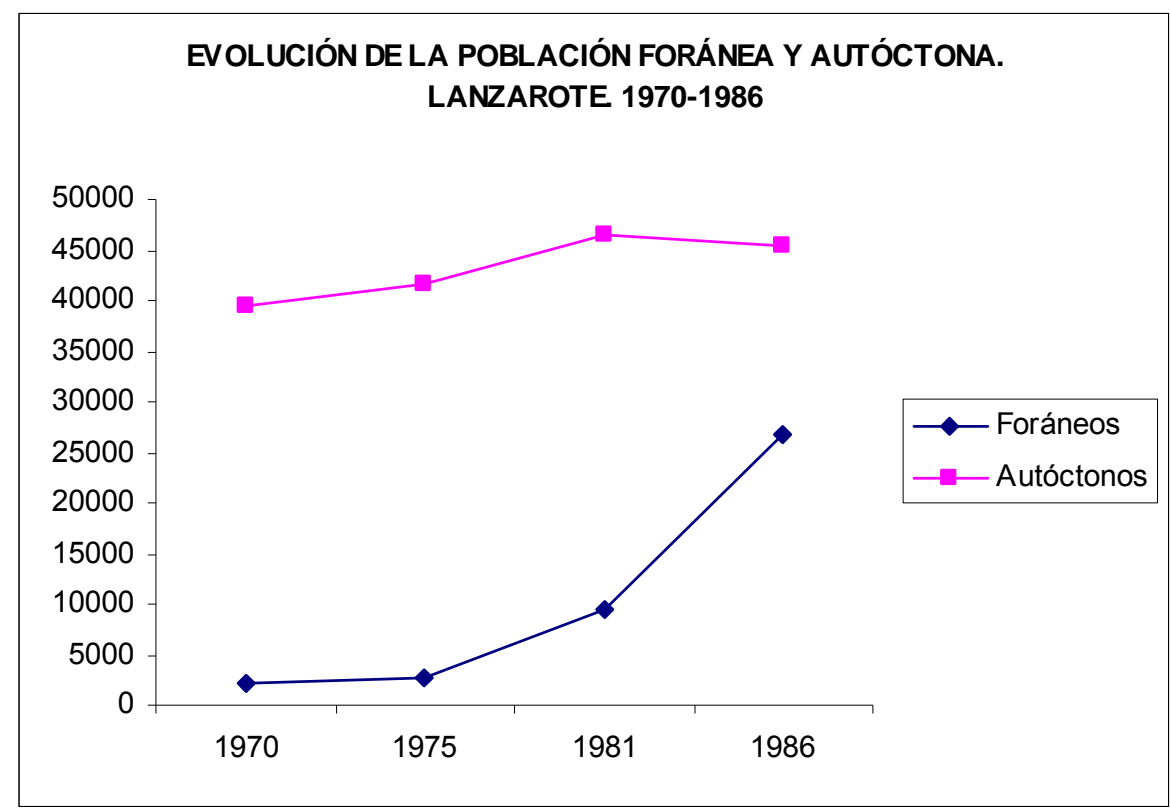

Fuente: Censos y Padrones municipales. ISTAC e INE. Basado en Tabla 27. Elaboración propia.

B) Crecimiento continuado de la escolarización y del nivel de instrucción de los residentes, como medida necesaria para asumir los nuevos retos económicos y laborales, reduciéndose considerablemente el analfabetismo y elevándose la formación profesional de primer ciclo. Con aportación positiva, pero no elevada, por parte de la inmigración que viene de la Península Ibérica. Los niveles formativos son escasos, en general, al igual que en Canarias y España. 
Gráfico 60. Evolución del nivel de instrucción. Lanzarote. 1970-1986 (\%)

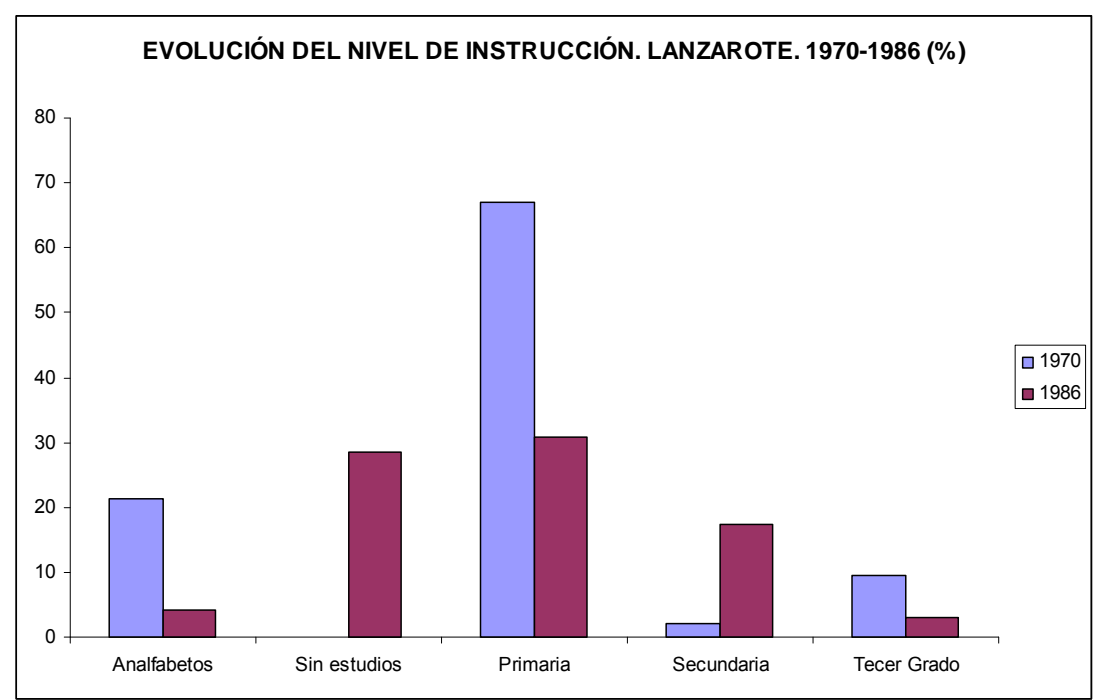

Fuente: Encuesta CIES, 1973; Explotaciones de Censos y Padrones municipales del CEDOC y el ISTAC; INE. Basados en las Tablas 29 y 30 . Elaboración propia.

Cualitativamente, se caracteriza por el desajuste entre la oferta de formación profesional y las necesidades del mercado laboral, marcado por la construcción y el turismo.

C) La estructura laboral se va encaminando, rápidamente, hacia su concentración en el sector servicios y la construcción. Se amplia la oferta laboral y crece la actividad, lo que es muy positivo, aunque ésta irá acompañada de una significativa elevación del número de parados (concentrados en la industria y la construcción), básicamente por una continua incorporación de trabajadores externos. Es por ello que, el incremento de la oferta y la demanda turística, no es proporcional al crecimiento del empleo.

Gráfico 61. Incremento de la oferta y demanda turística. Los ocupados y los parados. Lanzarote. 1970-1986 (\%)

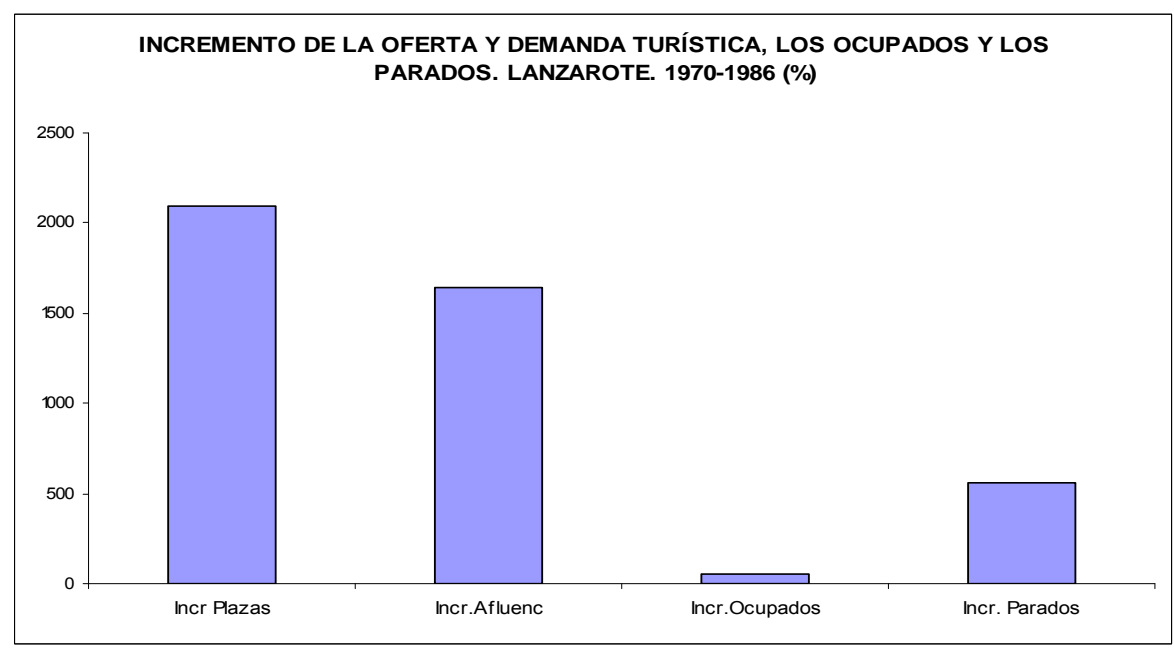

Fuente: Elaboración propia a partir del indicador de crecimiento interperiodo calculado y recogido en la Tabla 58. 
D) Rápido crecimiento de la riqueza, por la constante elevación de la renta per cápita y familiar disponible, con una fuerte diferenciación, que marca la jerarquía, entre municipios con economía turística y sin ella. Así, es Tías el municipio que avanza de forma notable por concentrar el $70 \%$ de la oferta turística. Aunque aún no supera, en cuanto a renta media por habitante, a Arrecife, capital y centro administrativo insular.

Al final de esta etapa, la aportación del turismo al PIB de Lanzarote casi se dobla, aunque aún se mantendrá por debajo de la renta media por habitante de Canarias y España. La fuerte jerarquización municipal se irá suavizando en los próximos años, aunque siempre estará marcada por la concentración de la oferta turística.

Gráfico 62. Municipios según nivel de renta media por habitante. Lanzarote. 1986

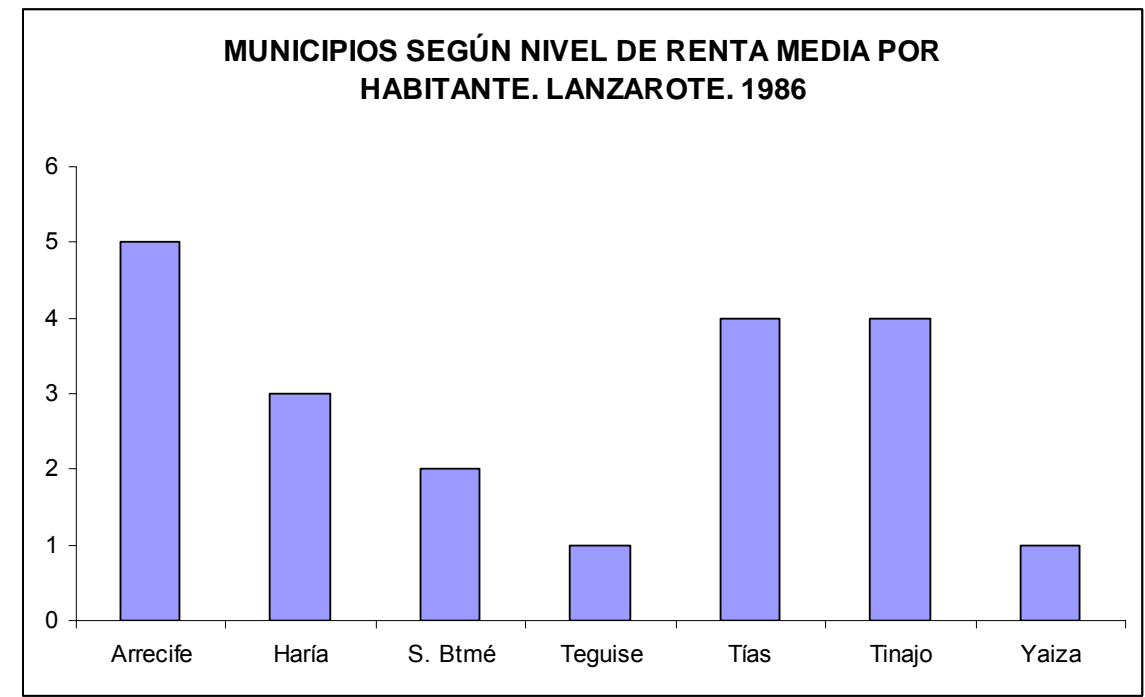

Fuente: Estimación propia a partir del Anuario del Mercado Español, 1988. Banesto. Basado en la Tabla 63. Elaboración propia.

Por otro lado, en relación al equipamiento y las infraestructuras, las mejoras y los estrangulamientos se van a explicar por agentes exógenos (inmigrantes y turistas) y se encuentran, principalmente en los siguientes aspectos:

A) Rendimiento energético por debajo de los estándares normativos, con fuertes incrementos de la capacidad de producción por presión demográfica (residentes y turistas) que impulsa la nueva actividad económica, pero insuficiente, generando dependencia de energía eléctrica externa. Con la elevación constante y rápida del consumo, estos niveles llegan a ser superiores a los de Canarias. A pesar de ello, se estima que la Isla mejora su eficiencia energética eléctrica a lo largo de la etapa. 
Gráfico 63. Producción de energía eléctrica disponible y consumo, en relación a la población residente y a la población total estimada. Lanzarote. 1970-1986 (kwh).

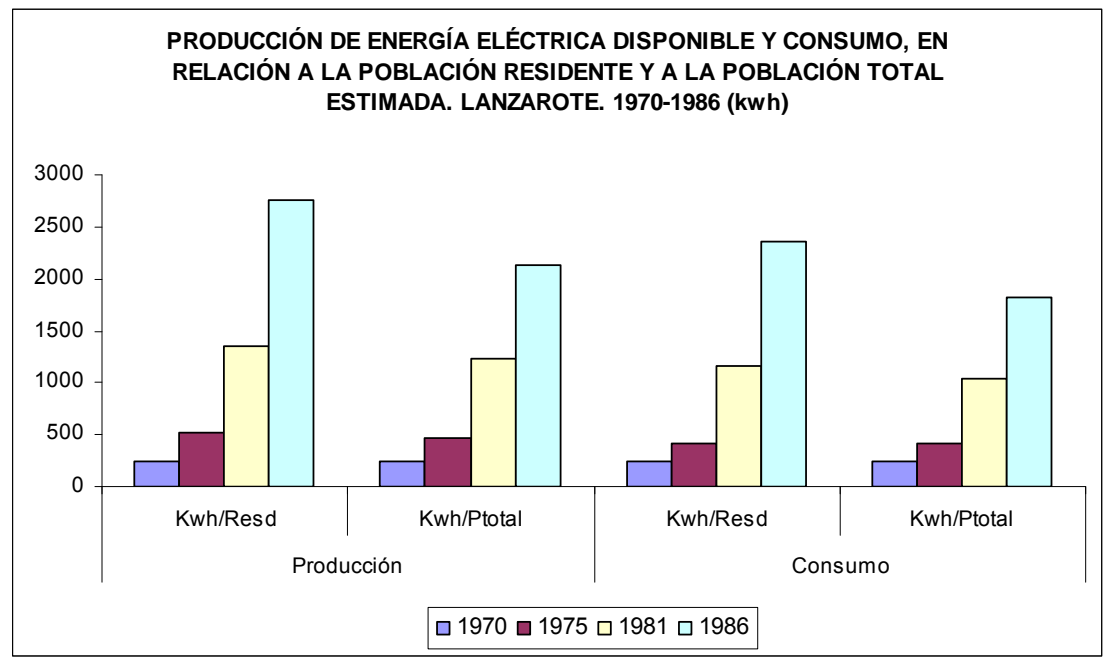

Fuente: Plan insular, 1973 del Ministerio de la Vivienda; Anuario Estadístico de Canarias del CEDOC: Avance PIOT, 1987. Cabildo Insular de Lanzarote; Gráfico basado en las Tablas 66 y 67 . Elaboración propia.

B) Derivado de la escasez de fuentes naturales de agua, la Isla define y asienta un modelo basado en la desalación de agua del mar como vía para el abastecimiento, impulsado por la presión que sobre este recurso genera la actividad turística. Por lo que la implantación y ampliación de la desalación, principalmente desde el sector público, junto con la creación de plantas privadas, para este fin, en los complejos turísticos (que sólo abastecen al turista), será una constante en este periodo. Con ello, la disponibilidad de agua potable para la población residente mejora considerablemente, aunque es inferior a la que dispone el turista, que siempre tiene prioridad. Se consume todo lo que se produce.

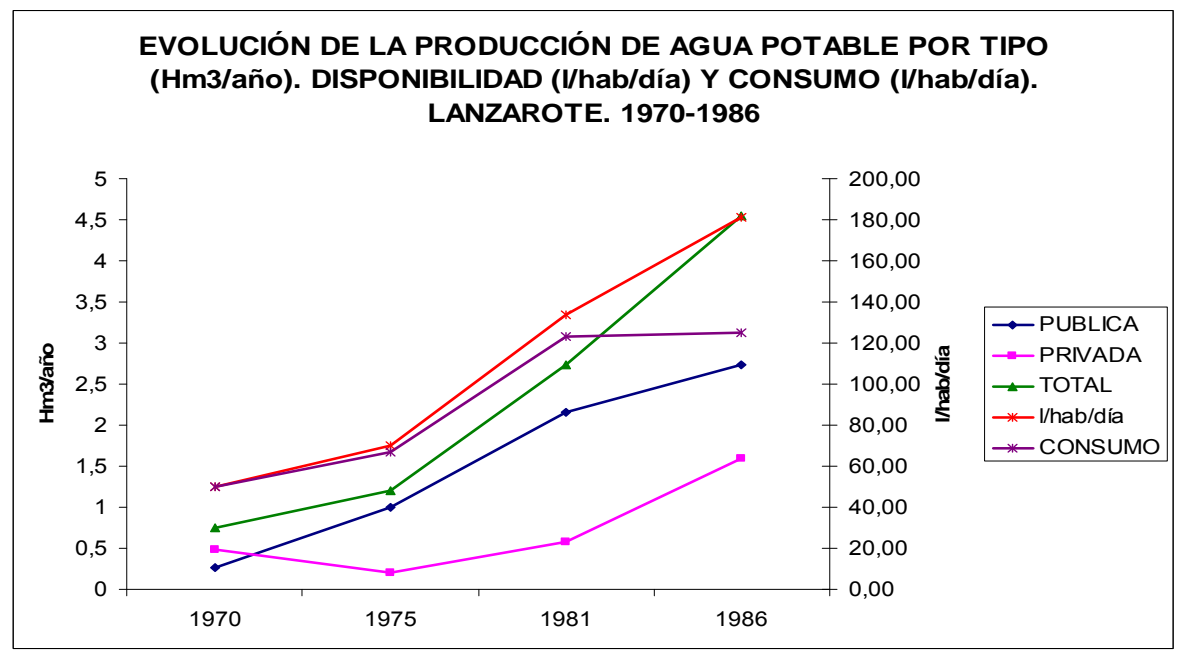

Fuente: Plan Insular, 1973 y Avance PIOT, 1987. Cabildo Insular de Lanzarote e INALSA.; Gráfico basado en las Tablas 74, 76 y 77. Elaboración propia. 
C) La ampliación y modernización del equipamiento sanitario será un reto para la isla que no podrá abordar en esta etapa, marcada por una escasa oferta hospitalaria (siempre por debajo del estándar de la O.M.S.) y el fuerte estrangulamiento del personal facultativo (médicos) en relación a la población a asistir, que no para de crecer. Por tanto el desajuste entre oferta y demanda es notable, con fuerte dependencia para la asistencia especializada del desvío de pacientes a la capital de provincia, Las Palmas. Los efectos de la presión demográfica (residentes y turistas) incrementarán los estrangulamientos y el malestar derivado.

\section{Gráfico 65. Evolución de las camas hospitalarias por mil residentes y sobre la demanda potencial. Comparación con el estándar de la O.M.S. Lanzarote. 1970-1986}

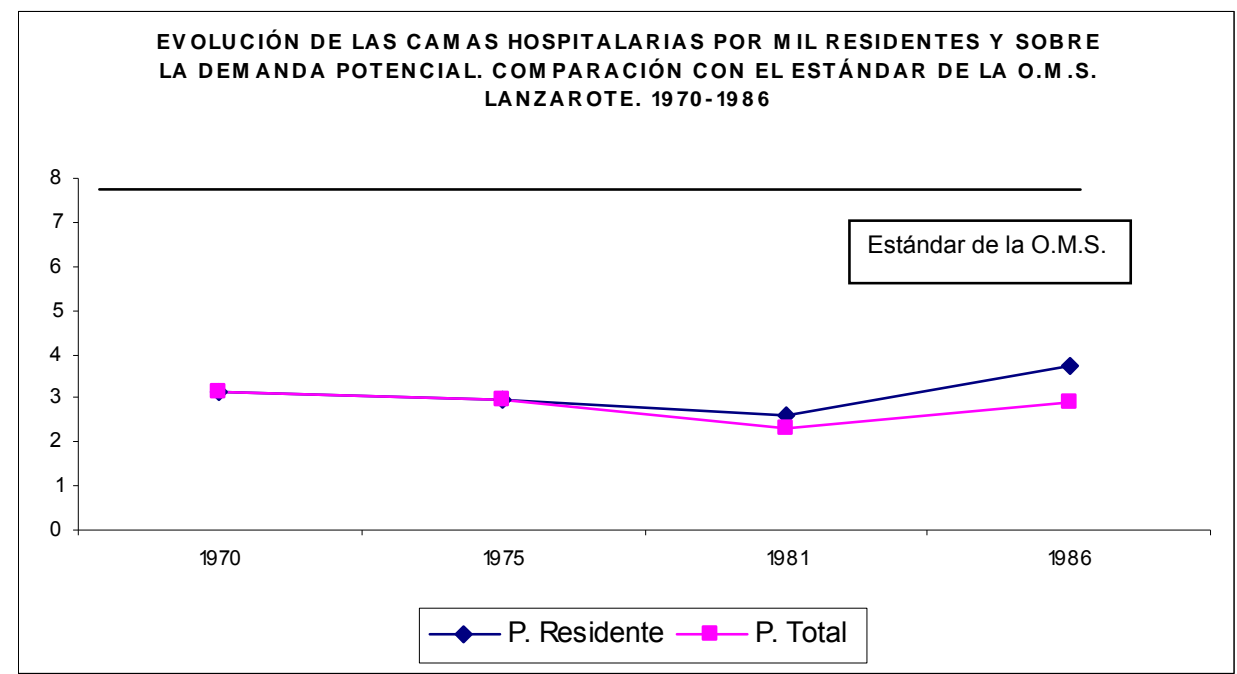

Fuente: Estadísticas básicas de Canarias, 1980-1985. CEDOC, AUIA, Avance PIOT Lanzarote, 1987. Gráfico basado en la Tabla 40. Elaboración propia. 
Gráfico 66. Evolución del número de habitantes por médico en relación a la población de derecho y a la población total estimada. Lanzarote. 1970-1986

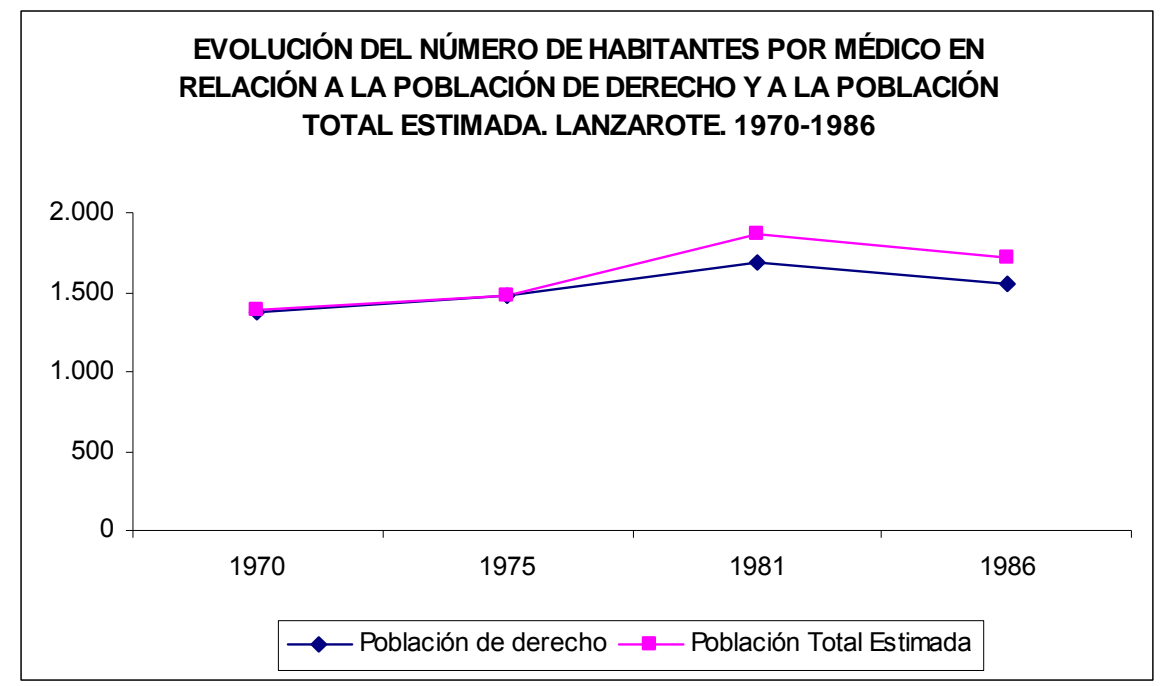

Fuente: Plan insular de Lanzarote, 1973 del Ministerio de la Vivienda; Fika, M.L. (2004) y Sosa Núñez, J. (2010). Gráfico basado en la Tabla 47. Elaboración propia.

D) Progresiva reducción de los estrangulamientos dotacionales en la enseñanza obligatoria, tendentes a su completa eliminación. No así para la educación especial y de adultos que está desbordada, pues el número de puestos es inferior a la demanda y el número de profesores escasos. En esta etapa, se asume como prioridad para la mejora del bienestar social, necesario, el invertir en el equipamiento para la educación básica, en la infancia. La integración de adultos y las discapacidades se abordarán más adelante.

Gráfico 67. Relación alumno por unidades y profesores, y nivel de cobertura (\%), por tipo de enseñanza. Lanzarote. Curso 1985-1986.

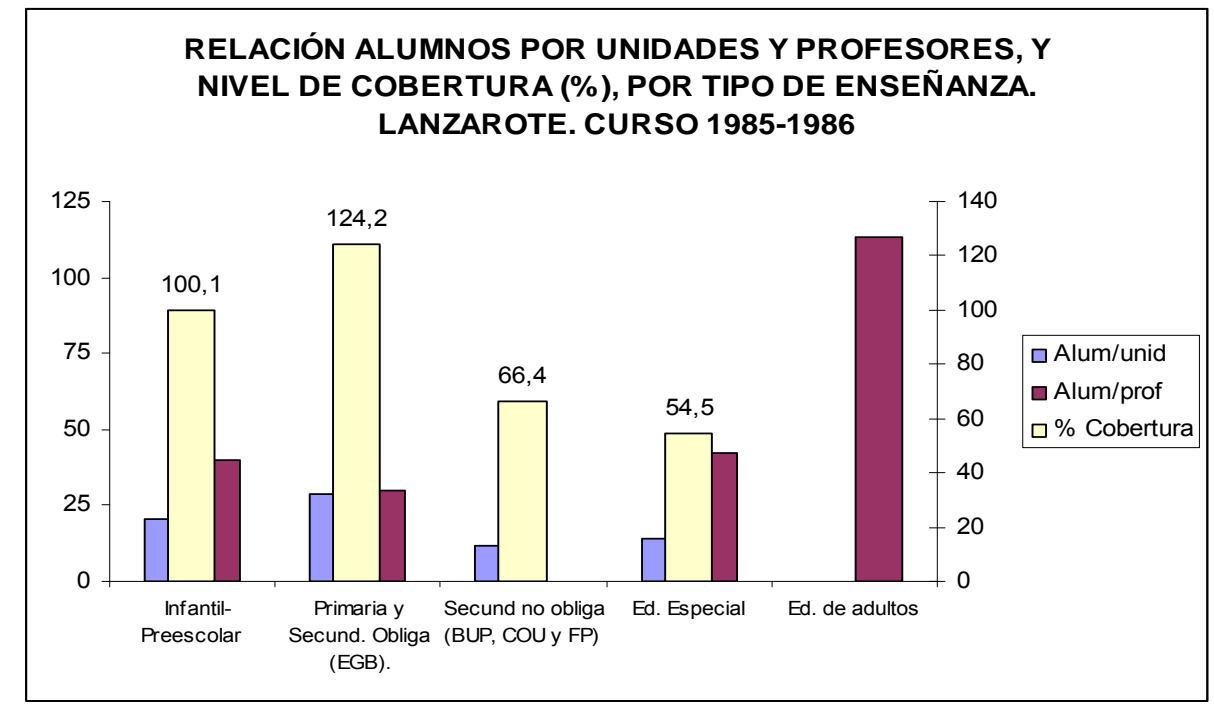

Fuente: AUIA, Avance PIOT de Lanzarote, 1987 y Estadísticas insulares y municipales de Canarias. CEDOC e ISTAC. Gráfico basado en la Tabla 37. Elaboración propia. 
E) Mejoras de la seguridad y accesibilidad a través del ancho del vial y ampliación de los kilómetros de carretera, derivado de la fuerte demanda de movilidad que impulsa la actividad turística, aunque el ancho de vía es insuficiente para la intensidad de circulación en la red que une las zonas de concentración de esta actividad con la capital, por el litoral, que se irá ampliando paulatinamente. Sin embargo, todos los núcleos habitados poseen conexiones, aunque con escasas condiciones de seguridad en las carreteras rurales.

F) Elevación rápida y constante del índice de motorización de los residentes, apoyado en el crecimiento de la renta disponible, que permite a la población acceder a nuevos consumos, que mejoran su acceso al bienestar, alcanzando valores por encima de Canarias y España. El parque móvil de vehículos (turismos) en alquiler no será significativo hasta finales de la etapa.

Se va establecido, así, un modelo destinado al transporte privado, que tendrá repercusiones futuras sobre el medioambiente, sumando a una insuficiente oferta de servicio regular de transporte de pasajeros, que no añade posibilidades de servicio público para la movilidad tanto de residentes como de turistas.

Gráfico 68. Evolución del índice de motorización de la población residente en relación a la población total estimada. Lanzarote. 1970-1986

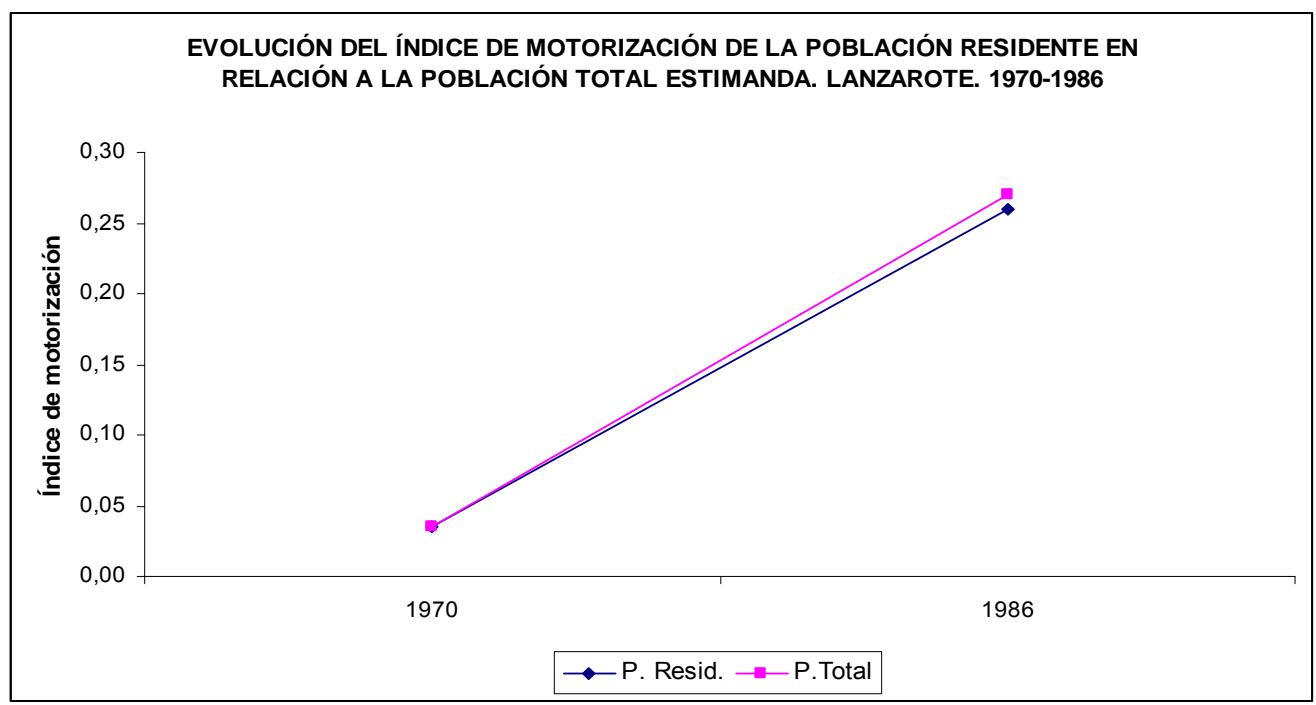

Fuente. Parque de vehículos de categoría turismos. Plan Insular de la isla de Lanzarote, 1973; Avance PIOT de Lanzarote, 1987; Anuario Estadístico de Canarias, CEDOC; Gráfico basado en la Tabla 80. Elaboración propia.

En términos generales, los beneficios de la implantación de actividades turísticas en Lanzarote, en esta primera etapa, que abarca desde 1970 a 1986, sobre el bienestar de la población residente, son notables. Las posibilidades y oportunidades vitales que este territorio ofrecía a su población se han modificado completamente, de forma positiva, en algo más de una década. El servicio al turista trae nuevas oportunidades para la sociedad 
anfitriona, pero también, éste se convierte en un fuerte competidor por los escasos recursos insulares, generando desarrollos que tienen como prioridad dar servicio al mismo, y en segundo lugar a la población residente.

\section{2.- SEGUNDA ETAPA. BOOM TURÍSTICO Y NUEVO PIOT. 1986-1996}

El Boom al que aquí nos referimos se produce entre 1983 y 1986 donde "el número de visitantes aumentó en un 222\%, el producto interior bruto creció a un ritmo acumulativo anual de un $7 \%$ en términos reales, lo que convierte a Lanzarote en un polo positivo de generación de empleo"162, con respecto a lo que vivía el resto de España.

Tras este "boom" va a llegar una fuerte crisis del sector a finales de $1988^{163}$. Esta crisis no fue tanto debida a la falta de afluencia turística, la demanda seguía existiendo, sino al excesivo y caótico crecimiento de la construcción y puesta en oferta de alojamiento turístico en el mercado (Oficina del Plan Insular. Dossier de Prensa. 1992, pp. 10). Se produjo un descenso del nivel de ocupación de hoteles y apartamentos, eso hizo caer los precios. La consecuencia de ello no fue otra que el que los hoteleros y promotores sufrieran desajustes financieros y se viese comprometida su capacidad para afrontar los créditos. Este fue un sector directamente afectado, pero no el único, puesto que en este momento Lanzarote ya había acogido de lleno el monocultivo del turismo y la crisis se extendió al resto de la economía insular (empleo, poder adquisitivo familiar, equipamientos, etc.) que ya dependía de forma determinante del mismo. Lo que llevó a pensar que el sector turístico insular tenía que modificar sus características siempre y cuando quisiera tener futuro, puesto que el sector oficial se había limitado a tratar de incrementar la estadística de visitantes, es decir, un crecimiento cuantitativo y no cualitativo.

La situación, por tanto, obliga a un análisis y replanteamiento, por parte de la Administración pública, y en su caso del Cabildo Insular de Lanzarote, de la forma en que ha venido teniendo lugar el proceso de desarrollo turístico. La opción de regular a través de una nueva estrategia de planificación turística va a aparecer como un remedio para curar heridas, o sea, se interviene después de que ha tenido lugar un desarrollo excesivo.

Así, en el cambio de década 80-90, surge el Plan Insular de Ordenación del Territorio, que se empieza a elaborar en 1986 y es definitivamente aprobado en 1991 al amparo de la Ley $1 / 1987$, de 13 de marzo, reguladora de los Planes Insulares y aprobado por el Gobierno

162 Oficina del Plan Insular. Dossier de prensa (1992). "La crisis turística y el Plan Insular". Excmo. Cabildo Insular de Lanzarote. (pp. 10).

163 Oficina del Plan Insular. Dossier de prensa (1992). "Antecedentes". Excmo. Cabildo Insular de Lanzarote. (pp. 1). 
de Canarias, mediante Decreto 63/1991_, por "el grave proceso de deterioro ambiental y paisajístico que sufre la isla provocado por un turismo de masas que hace crecer el parque turístico y consume el territorio" ${ }^{164}$, junto con otra de las revelaciones que genera la crisis que no es más que la gran limitación del poder autorregulador en función del deterioro de la tasa de ganancia, factor éste que primó sobre los demás: socio-culturales y patrimoniales. Aunque se reconoce desde la Administración un aspecto que condiciona el bienestar social: "la reducción de ingresos públicos dificulta resolver los graves déficits infraestructurales de la isla: la pérdida de calidad de la afluencia turística repercutirá en un aumento de su capacidad de agresión sobre el delicado sistema insular" (Oficina del Plan Insular. Dossier de prensa. 1992, pp. 11). Estaban básicamente preocupados por el descenso de la calidad y competitividad del turismo lanzaroteño. Por tanto, se establece entre sus objetivos básicos, racionalizar y delimitar el desarrollo turístico de la isla (Revisión del PIOT de Lanzarote. Documento de aprobación provisional, 1999, pp. 8).

Todo ello revela el equivocado planteamiento generado en el período anterior, confiar en el papel autorregulador del mercado, "dando a la iniciativa pública un papel subsidiario y suministrador de servicios complementarios" (Oficina del Plan Insular. Dossier de prensa. 1992, pp. 11), a lo que se une una política desarrollista.

Se reconoce, por tanto, desde el Plan Insular ("Breve diagnóstico de la situación actual de Lanzarote". Cap. III, 1991; pp. 31) el que "no se está produciendo una correcta interrelación entre el turismo y el conjunto de la economía (...), con importantes consecuencias en la estructura social de la isla, en la cual empiezan a generarse conflictos latentes". Y se afirma, como hecho constatado, el que los factores de producción dominantes son foráneos, lo que hace a la isla económicamente dependiente del exterior y "con una estructura socio-económica desestructurada, sin que prácticamente existan relaciones intersectoriales"; la economía lanzaroteña se ha especializado en el sector turístico, o sea, en una economía sin diversificación, en la preponderancia de la construcción en el mercado de trabajo, y en la completa desarticulación de las bases de producción y comercialización del sector primario (agricultura y pesca) y la industria; por otro lado, se admite desde el Plan Insular ("Breve diagnóstico de la situación actual de Lanzarote". Cap. III. 1991, pp. 37) la existencia en la isla de un cierto clima social que se encamina hacia el desequilibrio, apareciendo "tensiones latentes" entre la población, "generadas (...) por el rápido crecimiento económico".

164 http://www.cabildo.com/moratoria/exi.htm 
Todas las circunstancias anteriormente citadas "amenazan con ser periódicas y destructivas" (PIOT. "Breve diagnóstico de la situación actual de Lanzarote". Cap. III. 1991, pp. 13).

¿Qué hizo, en base a lo dicho hasta ahora, el PIOT de 1991, buscando solucionar los problemas que venían de la etapa anterior? "Delimitó el suelo máximo para los núcleos de población turística en base a las clasificaciones del Suelo Rústico Insular y fijó unos límites cuantitativos máximos de plazas "alojativas" turísticas por municipios y núcleos de población turística, todo ello al amparo del Art. $4^{\circ}$ de la citada Ley $1 / 1987$, teniendo en cuenta el planeamiento vigente y las realidades físicas preexistentes". Estas capacidades máximas de alojamiento turístico suponen la condición de "directriz vinculante, de aplicación directa e inmediata para el planeamiento municipal" (Revisión del PIOT. Documento de aprobación provisional, 1999, pp. 8). A la vez, "introduce una programación de ritmos de implantación de usos, considerados en términos de plazas "alojativas" turísticas y residenciales, cuya naturaleza era de directriz vinculante" (pp. 9).

Mapa 17. Zonas de uso turístico previsto. 1991

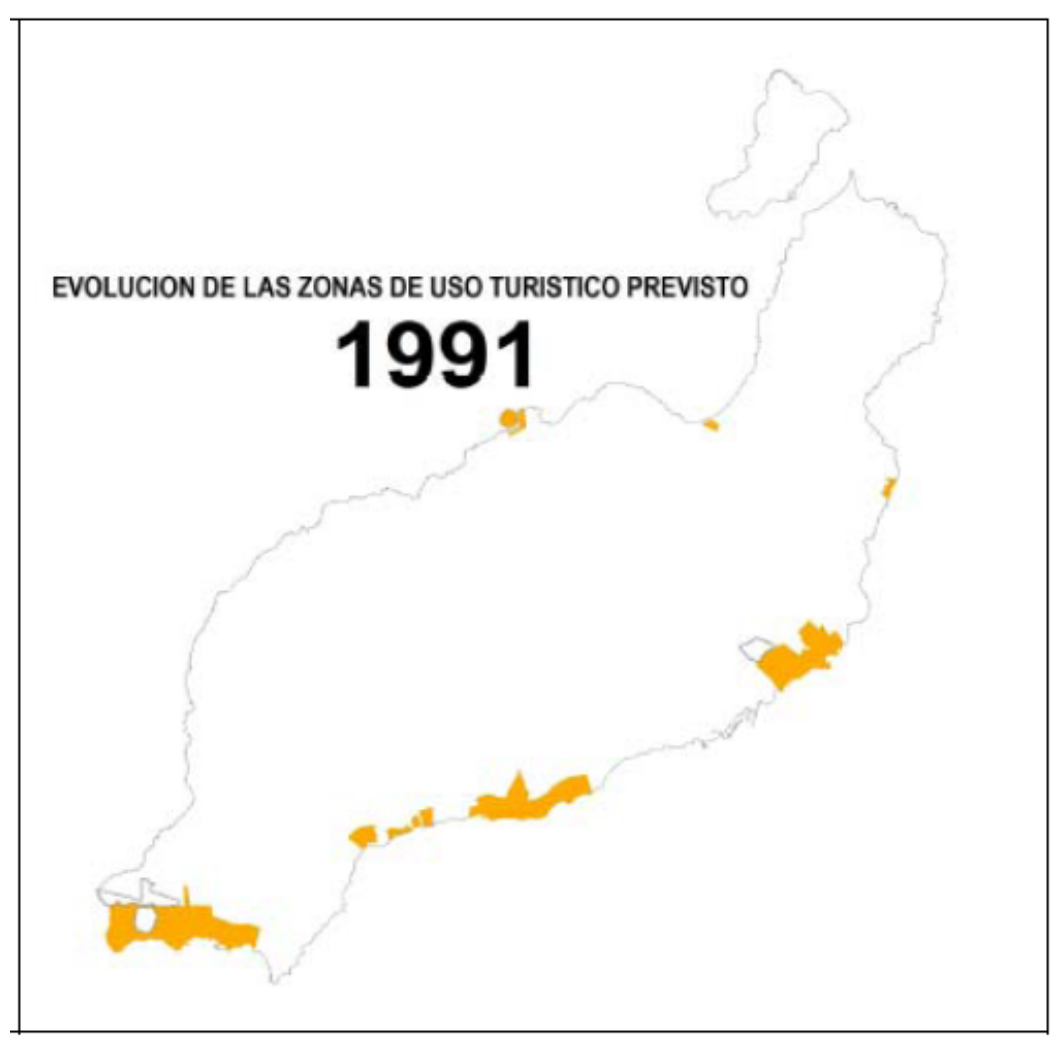

Fuente: Cabildo Insular de Lanzarote. Resumen del Plan Territorial Especial de Ordenación Turística Insular de Lanzarote, 2006. (Elaborado por AUIA). [En línea] Lanzarote: Cabildo de Lanzarote, 2006. (p. 7) [Ref. de 17 de junio de 2011] Disponible en Web: http://www.datosdelanzarote.com/itemDetalles.asp?idFamilia=24\&idltem $=3023$ 
Fue un ambicioso proyecto que estableció una programación del desarrollo de la edificabilidad hasta el año 2002 (por cuatrienios 1994-1998-2002), adaptando la capacidad de alojamiento turístico y residencial a cada municipio, con la intención de hacer compatible el ritmo de la oferta con la inversión pública y que no desborde el ritmo de la demanda. Se supuso ésta, como la única forma de evitar nuevas crisis de sobreproducción (Art. 2.4.1.1 y 4.1.2.2. $)^{165}$

La programación vinculante, que el PIOT (1991) estableció, necesitaba del planeamiento municipal, necesariamente, para que fuese efectiva. Los Ayuntamientos debían, en el plazo máximo de dos años, hacer, concretar o adaptar sus Planes Generales de Ordenación Urbana a la legislación urbanística vigente y a lo establecido en el PIOT -la planificación urbanística municipal debe estar coordinada con la insular- y en ellos los plazos de ejecución de los techos de edificabilidad, para todo su suelo urbano - ya sea en fase de consolidación o urbanizable - A la vez, se obliga "también a los propietarios y promotores de Planes Parciales en ejecución a adaptar sus planes de etapas a aquella programación sin necesidad de esperar a la previa formulación o adaptación del planeamiento general municipal” (Revisión del PIOT de 1991. Documento de aprobación provisional, 1999, pp. 910).

En el año 2000 , todavía quedaban Ayuntamientos ${ }^{166}$ que no habían finalizado la elaboración de su P.G.O.U. con lo que seguía, a final del siglo XX, sin existir adecuación entre la estrategia urbanística insular y la municipal.

\footnotetext{
165 Recogido en la Revisión del PIOT. Documento de aprobación provisional, 1999, pp. 10.

166 Como es el caso del Ayuntamiento de Teguise, el municipio de mayor extensión de Lanzarote, y con fuerte consolidación de una economía turística.
} 
Tabla 83. Estado del Planeamiento Municipal. Lanzarote, 1999.

\begin{tabular}{||l|l||}
\hline \hline MUNICIPIO & PLANES GENERALES \\
\hline \hline ARRECIFE & PGMO. Adaptada a la legislación vigente. No adaptado al PIOT \\
\hline HARÍA & Sin planeamiento \\
\hline SAN BARTOLOMÉ & Normas Subsidiarias de PM de julio de 1995. Adaptadas al PIOT. \\
\hline TEGUISE & Sin planeamiento \\
\hline TíAS & Normas Subsidiarias de PM. Marzo 1989. No adaptadas al PIOT. \\
\hline TINAJO & Sin planeamiento \\
\hline YAIZA & PGMO de marzo de 1973. Sin adaptación al PIOT. \\
\hline
\end{tabular}

Fuente: Revisión del PIOT de 1991. Documento de aprobación provisional, 1999 (pp. 11).

Como ya se indicaba en 1999, en el documento de aprobación provisional del PIOT (pp. 12) "todo ello hace que las previsiones y sus principales magnitudes establecidas en el PIOT para los principales núcleos turísticos de la Isla carezcan de virtualidad".

Para terminar esta breve aproximación al proceso en esta etapa, es importante tener en cuenta la estructura prevista para el desarrollo turístico de este PIOT, cuyo reflejo gráfico se aprecia en la página siguiente. 
Mapa 18. Ordenación de núcleos de población turísticos y no turísticos. Lanzarote. 1987.

ORDENACIÓN DE NÚCLEOS DE POBLACIÓN TURÍSTICOS Y NO TURISTICOS. LANZAROTE. 1987.

Leyenda

Núcleos de población no turísticos

Zonas de alta densidad (max. $100 \mathrm{~h} / \mathrm{Ha}$.)

Zonas de baja densidad (max. $30 \mathrm{~h} / \mathrm{Ha}$ y $50 \mathrm{~h} / \mathrm{Ha}$.

Zonas industriales

Núcleos del litoral

Núcleos de población turisticos

Suelo consolidado

Suelo urbanizado

Suelo parcialmente urbanizado

Suelo sin urbanizar

$\checkmark$ Suelo rústico

A Aeropuerto

PC Puerto comercial
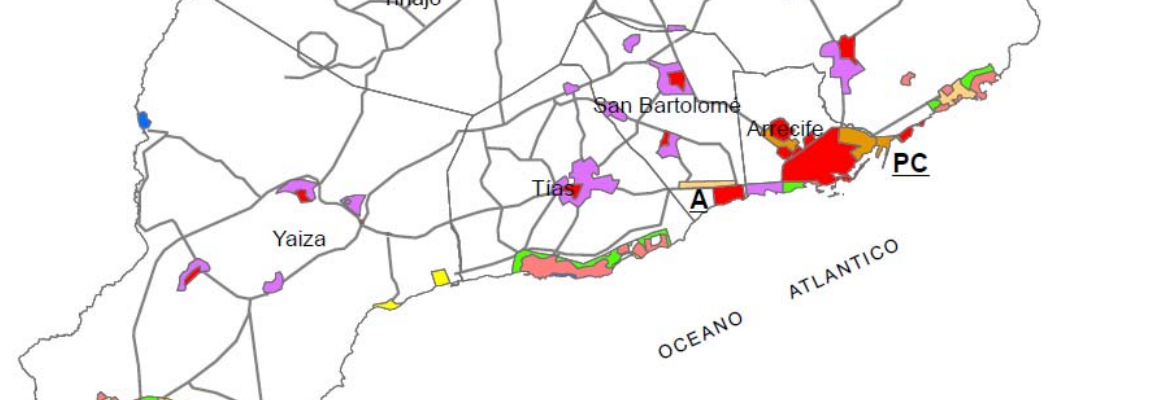

Fuente: ESTUDIOS PREVIOS AL AVANCE PLAN INSULAR DE LA ISLA DE LANZAROTE ORDENACIÓN DE LOS NÚCLEOS DE POBLACIÓN TURISTICOS Y NO TURISTICOS. 1987 Elaboración propia.

\subsection{1.- LA OFERTA Y LA DEMANDA TURÍSTICA. 1986-1996}

\subsubsection{1.- EVOLUCIÓN DE LAS PLAZAS DE ALOJAMIENTO TURÍSTICO}

Este periodo es significativo por el freno que se va a observar respecto al crecimiento de la oferta de plazas de alojamiento turístico, pues como ya ha sido señalado, la crisis por sobreproducción del año 1988 se seguirá sintiendo después de la aprobación del PIOT de 1991. En los cuadros siguientes se recoge la evolución de la demanda turística. 
Tabla 84. Oferta de plazas de alojamiento turístico, según tipo. España, Canarias y Lanzarote 1986-1996.

\begin{tabular}{|c|c|c|c|c|c|c|c|c|c|}
\hline \multicolumn{10}{|c|}{ ESPAÑ A } \\
\hline & HOTELERA & $\begin{array}{c}\% \\
\text { sobre } \\
\text { Total }\end{array}$ & $\begin{array}{c}\text { Incremento } \\
\text { quinquenal } \\
\text { (\%) }\end{array}$ & $\begin{array}{c}\text { EXTRA- } \\
\text { HOTELERA } \\
*\end{array}$ & $\begin{array}{c}\% \\
\text { sobre } \\
\text { Total }\end{array}$ & $\begin{array}{c}\text { Incremento } \\
\text { quinquenal } \\
(\%)\end{array}$ & TOTAL & $\begin{array}{c}\text { Incremento } \\
\text { quinquenal } \\
(\%)\end{array}$ & $\begin{array}{c}\text { Índice en } \\
\text { base } \\
100=1970\end{array}$ \\
\hline 1986 & 864.834 & 55,39 & 6,55 & 696.461 & 44,61 & 99,53 & 1.561 .295 & 34,51 & 207,63 \\
\hline 1991 & 972.808 & 49,87 & 12,48 & 978.073 & 50,13 & 40,43 & 1.950 .881 & 24,95 & 259,44 \\
\hline 1996 & 1.087 .529 & 50,98 & 11,79 & 1.045 .524 & 49,02 & 6,90 & 2.133 .053 & 9,34 & 283,67 \\
\hline
\end{tabular}

* La oferta extrahotelera está compuesta de número de plazas en Camping y apartamentos turísticos

Fuente: De 1969 a 1991: "Establecimientos hoteleros. Número de Plazas". Datos históricos; "Apartamentos y Camping" Estadísticas de Turismo. Ministerio de Transporte, Turismo y Comunicaciones. IET, 1991; Para 1996 y 2000: Establecimientos hoteleros por Comunidades autónomas, según capacidad". Turismo en Cifras. 1996 y 2000. IET. Elaboración propia.

\begin{tabular}{|c|c|c|c|c|c|c|c|c|c|}
\hline \multicolumn{10}{|c|}{ CANARIAS } \\
\hline AÑO & HOTELERA & $\begin{array}{c}\% \\
\text { sobre } \\
\text { Total }\end{array}$ & $\begin{array}{c}\text { Incremento } \\
\text { quinquenal } \\
(\%)\end{array}$ & $\begin{array}{c}\text { EXTRA- } \\
\text { HOTELERA }\end{array}$ & $\begin{array}{c}\% \\
\text { sobre } \\
\text { Total }\end{array}$ & $\begin{array}{c}\text { Incremento } \\
\text { quinquenal } \\
(\%)\end{array}$ & TOTAL & $\begin{array}{c}\text { Incremento } \\
\text { quinquenal } \\
(\%)\end{array}$ & $\begin{array}{c}\text { Índice en } \\
\text { base } \\
100=1970\end{array}$ \\
\hline 1986 & 96.126 & 37,67 & 29,58 & 159.041 & 62,33 & 14,68 & 255.167 & 19,87 & 765,21 \\
\hline 1991 & 120.356 & 32,01 & 25,21 & 255.639 & 67,99 & 60,74 & 375.995 & 47,35 & $1.127,56$ \\
\hline 1996 & 116.190 & 35,40 & $-3,46$ & 212.064 & 64,60 & $-17,05$ & 328.254 & $-12,70$ & 984,39 \\
\hline
\end{tabular}

* Base 1970

Fuente: "Plazas Hoteleras y Extrahoteleras. 1987, 1991 y 1996". Bases de datos insular y municipal. ISTAC. Elaboración propia.

\begin{tabular}{|c|c|c|c|c|c|c|c|c|c|}
\hline \multicolumn{10}{|c|}{ LANZAROTE } \\
\hline AÑO & HOTELERA & $\begin{array}{c}\% \\
\text { sobre } \\
\text { Total }\end{array}$ & $\begin{array}{c}\text { Incremento } \\
\text { quinquenal } \\
(\%)\end{array}$ & $\begin{array}{c}\text { EXTRA- } \\
\text { HOTELERA }\end{array}$ & $\begin{array}{c}\% \\
\text { sobre } \\
\text { Total }\end{array}$ & $\begin{array}{c}\text { Incremento } \\
\text { quinquenal } \\
(\%)\end{array}$ & TOTAL & $\begin{array}{c}\text { Incremento } \\
\text { quinquenal } \\
(\%)\end{array}$ & $\begin{array}{c}\text { Índice en } \\
\text { base } \\
100=1970\end{array}$ \\
\hline 1986 & 3.646 & 9,47 & $-12,44$ & 34.852 & 90,53 & 301,38 & 38.498 & 199,67 & $2.189,87$ \\
\hline 1991 & 10.413 & 21,83 & 185,60 & 37.277 & 78,17 & 6,96 & 47.690 & 23,88 & $2.712,74$ \\
\hline 1996 & 15.495 & 29,33 & 48,80 & 37.335 & 70,67 & 0,16 & 52.830 & 10,78 & $3.005,12$ \\
\hline
\end{tabular}

*Base 1970.

Fuente: Para 1986: "Oferta de Alojamiento. Enero de 1987". Avance del Plan Insular. Tomo 5. Análisis y diagnóstico de la situación actual. Capítulo IV. "Consideraciones sobre las características y niveles de la oferta turística Lanzaroteña; Para 1991-1996: "Oferta de plazas alojativas según tipo, por municipios. Total Insular. 1992 y 1996" Oficina de Turismo Interior. Cabildo de Lanzarote. Anuario Estadístico de Lanzarote, 1992 y 1996. Cabildo de Lanzarote. Elaboración propia.

El periodo 86-91 será importante para la aprobación de plazas puesto que está en elaboración la nueva Ordenación territorial de la isla, que pretende controlar el ritmo de crecimiento. Aunque el quinquenio rompe con la intensidad de crecimiento de la etapa anterior, pues observa una reducción significativa, aunque la proliferación inmobiliaria continuará dinámica (pasa del 200\%, entre 1981 y 1986, al 24\% entre 1986 a 1991). 
Será a partir de 1991 cuando estos incrementos sufrirán una fuerte caída debido a la aplicación del PIOT (1991), caracterizándose el primer quinquenio de la década de los años noventa por una fuerte ralentización del crecimiento de las plazas de alojamiento, que estará situado alrededor del 11\% a lo largo del mismo (1991-1996). Se entra en la década con un Plan de Ordenación Insular, pero, como ya se ha señalado, con una fuerte crisis económica insular, derivada de la sobreproducción que supuso los últimos años de la década de los ochenta, a lo que se une la ralentización del crecimiento de la demanda, como veremos en el epígrafe siguiente.

Gráfico 69. Incremento de la oferta de alojamiento turístico. Lanzarote. 1981-1996 (\%)

INCREMENTO DE LA OFERTA DE ALOJAMIENTO TURÍSTICO.

LANZAROTE 1981-1996 (\%)

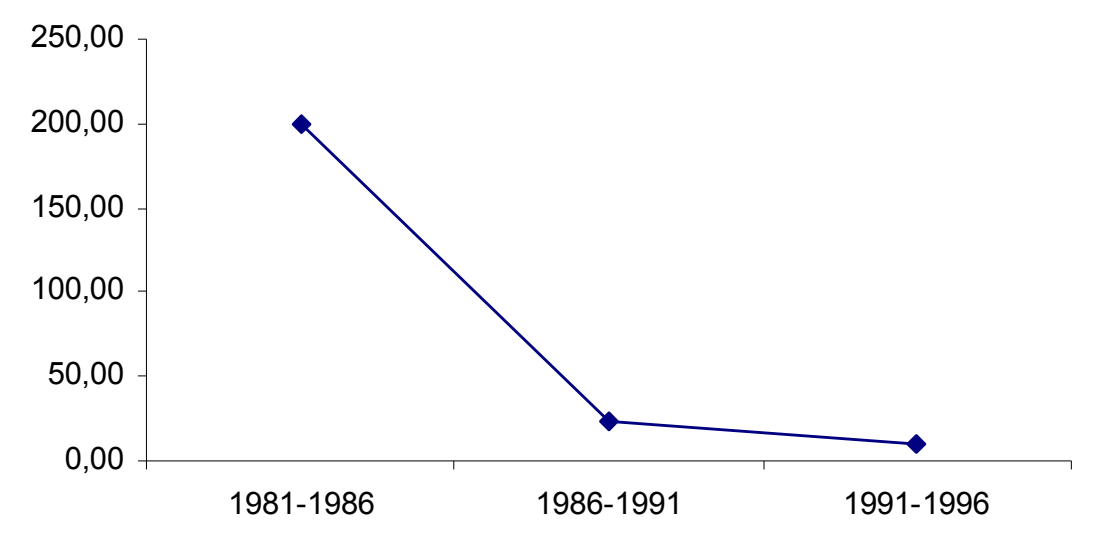

Fuente: Avance PIOT, 1987; Anuario Estadístico de Lanzarote. Oficina de Turismo interior, Cabildo Insular de Lanzarote. Gráfico basado en la Tabla 84. Elaboración propia.

Aunque la isla sigue apostando por una oferta extrahotelera, la capacidad hotelera se incrementa notablemente en este periodo, suponiendo, en 1996 , el $30 \%$ de la oferta de alojamiento insular, frente al 9\% que suponía una década antes (1986). Estos datos reflejan un cambio en la estrategia turística insular, que va otorgando mayor importancia a la inversión hotelera y que aparece como unos de los objetivos estratégicos de la nueva ordenación del territorio. 
Gráfico 70. Incremento de la oferta de alojamiento turístico por tipo, sobre el total. Lanzarote. 1986-1996 (\%)

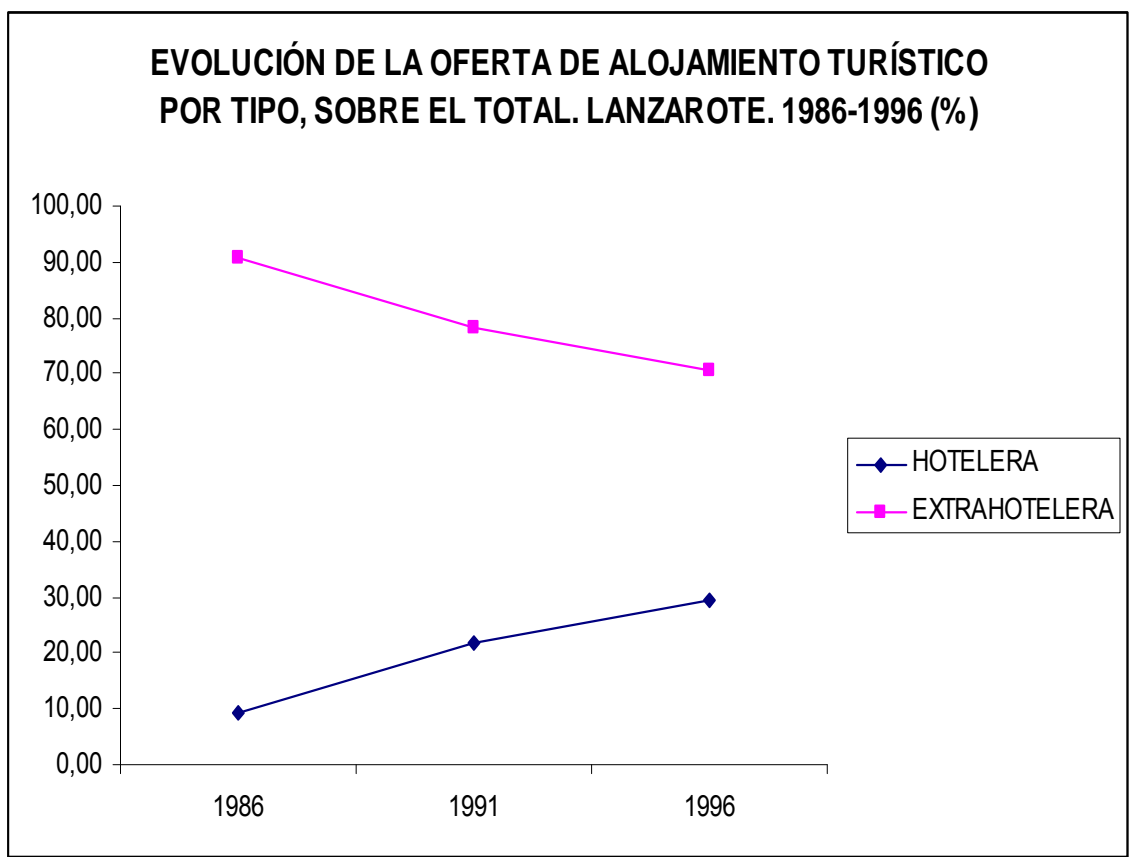

Fuente: Avance PIOT, 1987; Anuario Estadístico de Lanzarote. Oficina de Turismo interior, Cabildo Insular de Lanzarote. Gráfico basado en la Tabla 84. Elaboración.

Gráfico 71. Incremento de plazas de alojamiento turístico por tipo. Lanzarote. 1986-1996 (\%).

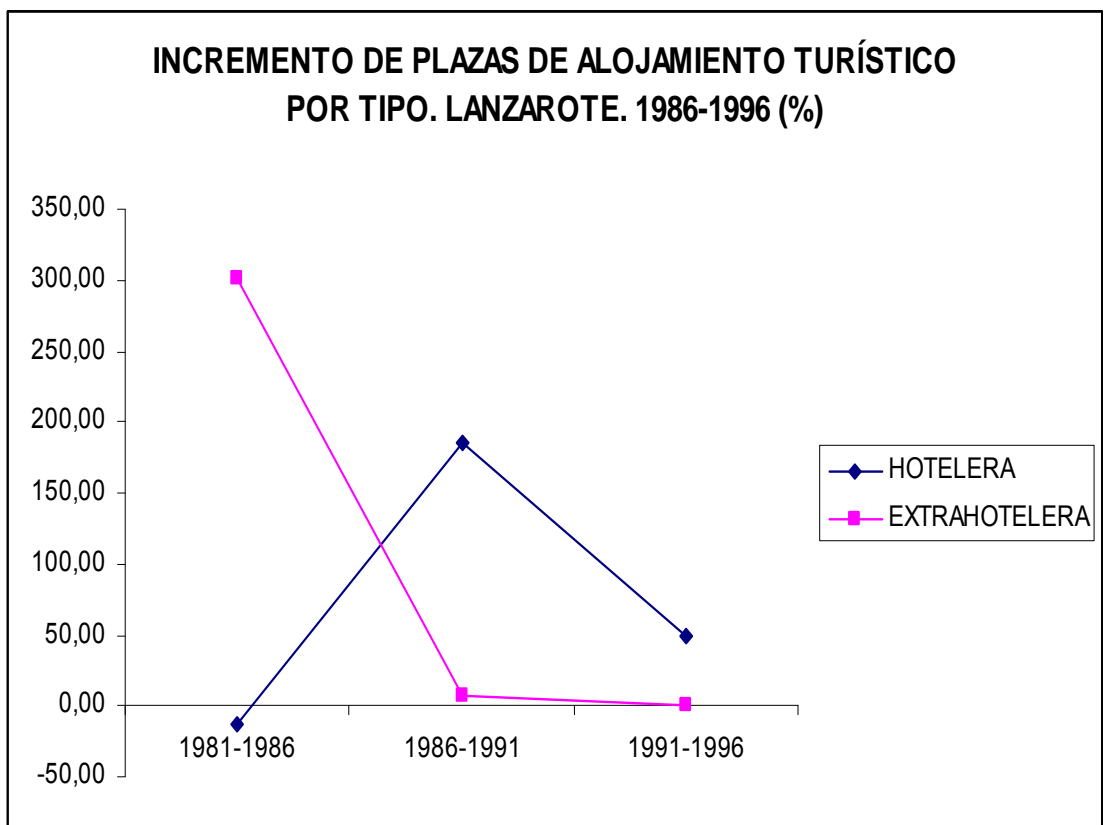

Fuente: Avance PIOT, 1987; Anuario Estadístico de Lanzarote. Oficina de Turismo interior, Cabildo Insular de Lanzarote. Gráfico basado en la Tabla 84. Elaboración propia.

La dinámica descrita para la isla, se aproxima a la seguida por la nación, cuyo crecimiento de las plazas de alojamiento turístico gira alrededor del 25\% entre 1986 y 1991 y del 9\% en 
el quinquenio siguiente. Muy diferente a la que presenta la Comunidad Autónoma, que marca mucha distancia en relación a España y Lanzarote en dos momentos: a) entre 1986 y 1991: crecimiento de plazas de alojamiento turístico del $47 \%$. Un $22 \%$ por encima; b) entre 1991-1996: el número de plazas no solo no crece, sino que Canarias pierde casi el $13 \%$ de su capacidad de alojamiento turístico, principalmente por la pérdida del tipo extrahotelero $(17 \%)$.

Gráfico 72. Incremento de plazas de alojamiento turístico. España, Canarias y Lanzarote. 1986-1996 (\%).

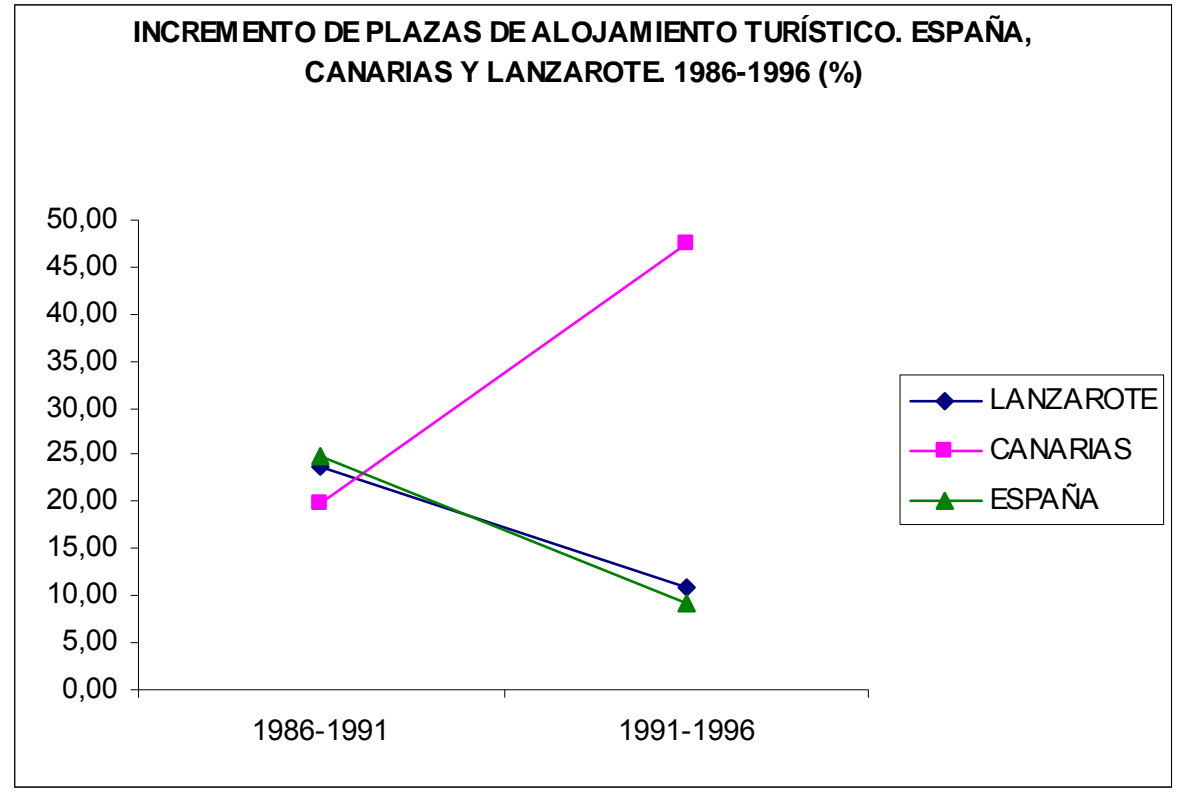

Fuente: Avance PIOT, 1987; Anuario Estadístico de Lanzarote. Oficina de Turismo interior, Cabildo Insular de Lanzarote; Bases de datos insular y municipal. ISTAC; Estadísticas de Turismo del Ministerio de Transporte, Turismo y Comunicaciones. IET; Gráfico basado en la Tabla 84. Elaboración propia.

Canarias, al igual que la Isla, sigue apostando por una oferta extrahotelera, que supone el $65 \%$ del alojamiento en el año 1996. A diferencia de España que, aunque en el periodo anterior (1970-1986) su mayor apuesta era el alojamiento hotelero, en este periodo (19861996) la oferta entre ambos tipos se iguala. 
Gráfico 73. Oferta de alojamiento turístico por tipo. España, Canarias y Lanzarote. 1986-1996 (\%).

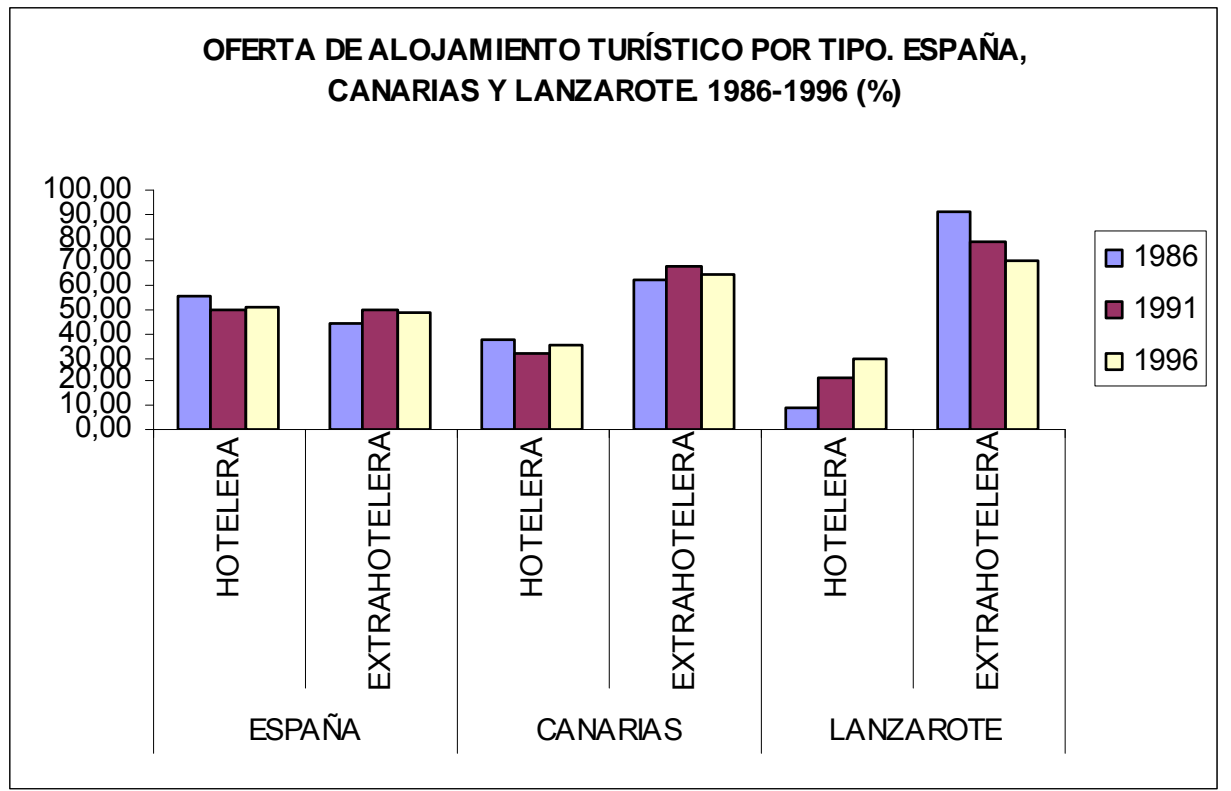

Fuente: Avance PIOT, 1987; Anuario Estadístico de Lanzarote. Oficina de Turismo interior, Cabildo Insular de Lanzarote; Bases de datos insular y municipal. ISTAC; Estadísticas de Turismo del Ministerio de Transporte, Turismo y Comunicaciones. IET; Gráfico basado en la Tabla 84. Elaboración propia.

\subsubsection{2.-}

La caída en el incremento de las entradas de turistas a la isla llegará en la década de los años noventa, aunque ya se observa un pequeño descenso a final de los años ochenta. A pesar de que su volumen no deja de crecer.

Tabla 85. Turistas entrados e incremento interperiodo. España, Canarias y Lanzarote. 19861996

\begin{tabular}{||c|c|c|c||}
\hline Año & ESPAÑA & Incremento quinquenal (\%) & Índice en base $\mathbf{1 0 0}=\mathbf{1 9 7 0}$ \\
\hline \hline 1986 & 47.388 .793 & 18,09 & 196,59 \\
\hline 1991 & 53.494 .964 & 12,89 & 221,92 \\
\hline 1996 & 54.408 .900 & 1,71 & 225,71 \\
\hline
\end{tabular}

Fuente: Para 1986 y 1991: "Viajeros procedentes del extranjero que han entrado en España, 1986 y 1991" Tabla II. I. Datos históricos. Anuario Estadístico, 1993. IET; Para 1996: "Entrada de visitantes a España, 1996", Turismo Receptor. Movimientos turísticos en Fronteras. En "25 años de turismo español en cifras. 1978-2003". IET; Elaboración propia. 


\begin{tabular}{|r|r|r|r|}
\hline Año & CANARIAS & Incremento quinquenal (\%) & Índice en base 100=1970 \\
\hline \hline 1986 & 5.068 .242 & 85,35 & 639,49 \\
\hline 1991 & 6.610 .820 & 30,44 & 834,12 \\
\hline 1996 & 9.804 .540 & 48,31 & $1.237,09$ \\
\hline
\end{tabular}

Fuente: Para 1986 y 1991: "Número de turistas entrados en Canarias, 1987. Estadísticas Básicas de Canarias, 1987-1992. ISTAC; Para 1996: "Pasajeros entrados en Canarias, 1996". FRONTUR CANARIAS. ISTAC; Elaboración propia.

\begin{tabular}{||l|l|c|c||}
\hline \hline Año & LANZAROTE & Incremento quinquenal (\%) & Índice en base 100=1970 \\
\hline \hline $\mathbf{1 9 8 6}$ & 468.331 & 149,56 & 1746,72 \\
\hline $\mathbf{1 9 9 1}$ & 1.036 .341 & 121,28 & $3.865,21$ \\
\hline $\mathbf{1 9 9 6}$ & 1.494 .050 & 44,17 & $5.572,32$ \\
\hline
\end{tabular}

Fuente: Para 1986: "Número de turistas entrados, Lanzarote, 1981. Cabildo Insular de Lanzarote. Avance PIOT. Análisis y Diagnóstico de la situación actual. Tomo 4. Área Económica. Informe Área Socioeconómica, Documento 1. Cuadro 2.1. 1987 (pp. 17); Para 1991: "Estancias medias según nacionalidad e isla. Lanzarote, 1991 (hoteles)". Encuesta turística de Canarias. Estadísticas Básicas de Canarias, 1978-1992. ISTAC; Para 1996: "Evolución de la Afluencia turística, 1996". Anuario Estadístico de Lanzarote, 1996 (pp. 40 ); Elaboración propia.

Será entre 1991-1996 cuando se produzca el mayor descenso del crecimiento de la afluencia turística a la isla, que arroja un valor del $44,2 \%$, frente al $120 \%$ del quinquenio anterior. Ello va a definir este periodo como de crisis en el sector, con repercusiones sobre los ingresos económicos, la construcción, el empleo, etc.

En este caso, la dinámica insular refleja la de Canarias y no la nacional, que incrementa su afluencia, escasamente, en $1,7 \%{ }^{167}$.

167 Debemos tener en cuenta que para el cómputo nacional sólo se contabilizan visitantes extranjeros, cosa que no sucede para Canarias y Lanzarote. 
Gráfico 74. Incremento de la demanda turística. España, Canarias y Lanzarote. 1986-1996 (\%).

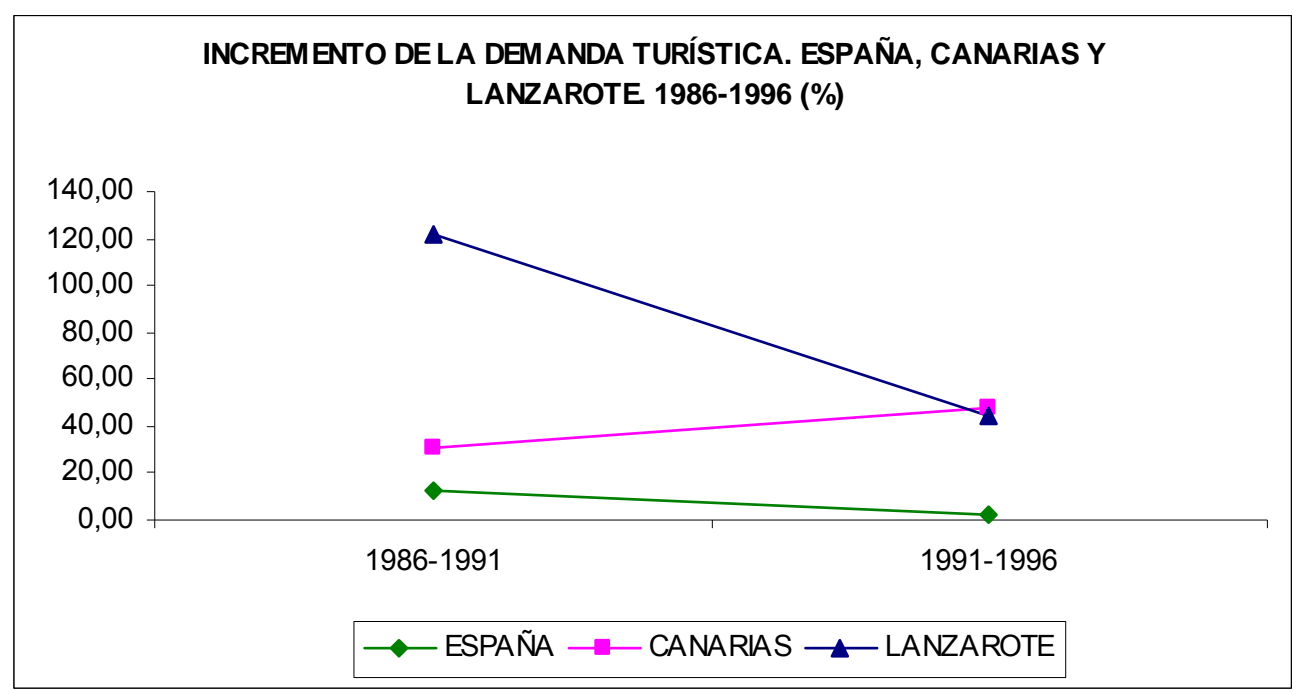

Fuente: Avance PIOT, 1987; Anuario Estadístico de Lanzarote. Oficina de Turismo interior, Cabildo Insular de Lanzarote; Bases de datos insular y municipal. ISTAC; Estadísticas de Turismo del Ministerio de Transporte, Turismo y Comunicaciones. IET; Gráfico basado en la Tabla 85. Elaboración propia".

Al igual que en la etapa anterior, se hace ahora, de nuevo, necesario, para el estudio de la demanda turística, establecer el volumen de turistas equivalentes (diarios) y la relación con respecto a la población insular (ratio turistas/residentes). Influyendo, dicha demanda, por otro lado, en el ratio turistas/plazas (t/p).

Para estimar el volumen de turistas equivalentes diarios en la isla, en este período, los datos existentes se refieren a estancias medias en establecimientos hoteleros, no ofreciendo estimaciones para el extrahotelero, pues como ya se ha indicado anteriormente, estas no existen hasta el año 2001 (INE).

Por esta razón, y dado que no disponemos de datos directos, se ha calculado la relación en la estancia media entre el turista alojado en el establecimiento hotelero y el alojado en el establecimiento extrahotelero, tal y como se aprecia en el cuadro siguiente, para 2001 y 2006 (INE), apreciándose que la diferencia en las cifras proporcionadas es constante: 150\% a nivel de España, $20 \%$ para Canarias y $32 \%$ para el ámbito insular, Lanzarote. Estas diferencias son las que aplicaremos a nuestros cálculos de la estancia media extrahotelera en el período (1986-1996). 
Tabla 86. Estancia media en establecimientos hoteleros. España, Canarias y Lanzarote. 20012006.

\begin{tabular}{|c|c|c|c|c|c|c|c|c|c|}
\hline & ESPAÑ A & & & CANARIAS & & & LANZAROTE & & \\
\hline Año & Tipo & Días & $\begin{array}{c}\text { Variación } \\
(\%)\end{array}$ & Tipo & Días & $\begin{array}{c}\text { Variación } \\
(\%)\end{array}$ & Tipo & Días & $\begin{array}{c}\text { Variación } \\
(\%)\end{array}$ \\
\hline \multirow{2}{*}{2001} & Hotelera & 3,8 & \multirow{2}{*}{150} & Hotelera & 7,8 & \multirow{2}{*}{20} & Hotelera & 7,3 & \multirow{2}{*}{---} \\
\hline & Extrahotelera & 9,5 & & Extrahotelera & 9,4 & & Extrahotelera & --- & \\
\hline \multirow{2}{*}{2006} & Hotelera & 3,3 & \multirow{2}{*}{150} & Hotelera & 6,9 & \multirow{2}{*}{20} & Hotelera & 6,6 & \multirow{2}{*}{32} \\
\hline & Extrahotelera & 8,1 & & Extrahotelera & 8,3 & & Extrahotelera & 8,7 & \\
\hline
\end{tabular}

Fuente: "Estancia media de los viajeros por zonas, Comunidades Autónomas y total Nacional, 2001" y "Estancia media de los viajeros por Comunidades Autónomas y total Nacional, 2006". Encuesta de ocupación hotelera, 2001 y 2006 . INE; "Estancia media de los viajeros en apartamentos, por Comunidades Autónomas y total Nacional. 2001" y "Estancia media de los viajeros en apartamentos, por zonas, Comunidades Autónomas y total Nacional. 2006". Encuesta de ocupación de apartamentos turísticos, 2001 y 2006. INE; Elaboración propia.

Tabla 87. Número de viajeros-turistas equivalentes al día. España. 1986-1996

\begin{tabular}{||c|c|c|c|c|r|r|r|r|c||}
\hline Año & Viajeros & $\begin{array}{c}\text { Viajeros. } \\
\text { Pernoctan en } \\
\text { Hoteles }\end{array}$ & $\begin{array}{c}\text { Viajeros que No } \\
\text { Pernoctan en } \\
\text { Hoteles ( }\end{array}$ & $\begin{array}{c}\text { Pernoctaciones } \\
\text { Hoteleras }\end{array}$ & $\begin{array}{c}\text { Estancia } \\
\text { media } \\
\text { Hotelera } \\
(1)\end{array}$ & $\begin{array}{c}\text { Estancia Media } \\
\text { Extrahotelera } \\
(2)\end{array}$ & $\begin{array}{c}\text { Pernoctaciones } \\
\text { ExtraHotel (3) }\end{array}$ & $\begin{array}{c}\text { Pernoctaciones } \\
\text { Totales (H+Exh) }\end{array}$ & $\begin{array}{c}\text { Turistas } \\
\text { equivalentes } \\
\text { al día }\end{array}$ \\
\hline \hline $\mathbf{1 9 8 6}$ & 47.388 .793 & 29.911 .551 & 17.477 .242 & 129.514 .100 & 7,4 & 18,5 & 323.785 .250 & 453.299 .350 & $\mathbf{1 . 2 4 1 . 9 1 6}$ \\
\hline $\mathbf{1 9 9 1}$ & 53.494 .964 & 35.971 .000 & 17.523 .964 & 150.315 .000 & 4,2 & 10,4 & 183.072 .103 & 333.387 .103 & $\mathbf{9 1 3 . 3 8 9}$ \\
\hline $\mathbf{1 9 9 6}$ & 54.408 .900 & 38.731 .000 & 15.677 .900 & 158.259 .000 & 4,1 & 10,2 & 160.153 .932 & 318.412 .932 & $\mathbf{8 7 2 . 3 6 4}$ \\
\hline
\end{tabular}

$\left({ }^{*}\right)$ Viajeros que no pernoctan en hoteles: diferencia entre los Viajeros totales y los viajeros que pernoctan en hoteles.

(1) Estancia media hotelera: cociente entre el número de pernoctaciones causadas en hoteles y viajeros que pernoctan en hoteles.

(2) Estancia media extrahotelera: estancia media hotelera incrementada un 150\%, según las estimaciones de 2001 del INE.

(3) Pernoctaciones extrahoteleras: producto de la estancia media extrahotelera por los viajeros que no pernoctan en hoteles.

Fuente: Para 1986 y 1991: "Viajeros procedentes del extranjero que han entrado en España, 1986 y 1991" Tabla II. I. Datos históricos. Anuario Estadístico, 1993. IET; "Viajeros que pernoctaron y pernoctaciones causadas en establecimientos hoteleros, 1986 y 1991 ". Anuario estadístico de España, 1987 y 1992. INE; Para 1996: "Entrada de visitantes a España, 1996", Turismo Receptor. Movimientos turísticos en Fronteras. En "25 años de turismo español en cifras. 1978-2003". IET. "Estancia media en establecimientos hoteleros, 1996". Resumen año, 1996. Movimiento de viajeros en establecimientos hoteleros, 1996. INE; Elaboración propia. 
Tabla 88. Número de viajeros-turistas equivalentes al día. Canarias. 1986-1996

\begin{tabular}{||c|c|r|r|r|r|r|r|r|c||}
\hline Año & Viajeros & $\begin{array}{c}\text { Viajeros. } \\
\text { Pernoctan en } \\
\text { Hoteles }\end{array}$ & $\begin{array}{c}\text { Viajeros que No } \\
\text { Pernoctan en } \\
\left.\text { Hoteles ( }{ }^{*}\right)\end{array}$ & $\begin{array}{c}\text { Pernoctaciones } \\
\text { Hoteleras }\end{array}$ & $\begin{array}{c}\text { Estancia } \\
\text { media } \\
\text { Hotelera } \\
(1)\end{array}$ & $\begin{array}{c}\text { Estancia Media } \\
\text { Extrahotelera } \\
(2)\end{array}$ & $\begin{array}{c}\text { Pernoctaciones } \\
\text { ExtraHotel (3) }\end{array}$ & $\begin{array}{c}\text { Pernoctaciones } \\
\text { Totales (H+Exh) }\end{array}$ & $\begin{array}{c}\text { Turistas } \\
\text { equivalentes } \\
\text { al día }\end{array}$ \\
\hline \hline $\mathbf{1 9 8 6}$ & 5.068 .242 & 180.038 & 4.888 .204 & 1.689 .247 & 9,4 & 11,3 & 55.037 .607 & 56.726 .854 & $\mathbf{1 5 5 . 4 1 6}$ \\
\hline $\mathbf{1 9 9 1}$ & 6.610 .820 & 3.434 .643 & 3.176 .177 & 31.598 .720 & 9,02 & 10,8 & 34.439 .895 & 66.038 .615 & $\mathbf{1 8 0 . 9 2 8}$ \\
\hline $\mathbf{1 9 9 6}$ & 9.804 .540 & 960.485 & 8.844 .055 & 24.103 .518 & 8,2 & 9,8 & 87.025 .501 & 111.129 .019 & $\mathbf{3 0 4 . 4 6 3}$ \\
\hline
\end{tabular}

(1) Estancia media hotelera de 1981 a 1996: cociente entre el número de pernoctaciones causadas en hoteles y viajeros que pernoctan en hoteles.

(2) Estancia media extrahotelera: estancia media hotelera incrementada un 150\%, según las estimaciones de 2001 del INE.

(3) Pernoctaciones extrahoteleras: producto de la estancia media extrahotelera por los viajeros que no pernoctan en hoteles.

$\left(^{*}\right)$ En 1991, sólo se dispone del número de viajeros y la estancia media hotelera. La Estancia media extrahotelera calculada en relación a la variación de la hotelera entre 1991 y 1986. (Estancia Media Extrahotelera $\left.=(9,02 / 9,4)^{\star} 11,3\right)$.

Fuente: Para 1986: "Número de turistas entrados en Canarias, 1987. Estadísticas Básicas de Canarias, 1987-1992. ISTAC; "Viajeros entrados y pernoctaciones en establecimientos de Canarias según la categoría del establecimiento y meses, Total Canarias. 1986". Anuario Estadístico de Canarias, 1986. CEDOC; Para 1991: "Estancia media (en hoteles) según nacionalidad e islas. Total Canarias, 1991". Encuesta turística de Canarias en Estadísticas básicas de Canarias. 1987-1992. ISTAC; Para 1996: "Pasajeros entrados en Canarias, 1996". FRONTUR CANARIAS. ISTAC; "Pernoctaciones y estancia media, Canarias, 1996". Movimiento de Viajeros en Establecimientos Hoteleros (MVEH). Resumen de 1996. Elaboración propia.

Tabla 89. Número de viajeros-turistas equivalentes al día. Lanzarote. 1986-1996

\begin{tabular}{||c|c|r|r|r|r|r|r|r|c||}
\hline $\mathbf{A n ̃ o}$ & Viajeros & $\begin{array}{c}\text { Viajeros. } \\
\text { Pernoctan en } \\
\text { Hoteles }\end{array}$ & $\begin{array}{c}\text { Viajeros que } \\
\text { No Pernoctan } \\
\text { en Hoteles (*) }\end{array}$ & $\begin{array}{c}\text { Pernoctaciones } \\
\text { Hoteleras }\end{array}$ & $\begin{array}{c}\text { Estancia } \\
\text { media } \\
\text { Hotelera } \\
(1)\end{array}$ & $\begin{array}{c}\text { Estancia } \\
\text { Media } \\
\text { Extrahotelera } \\
(2)\end{array}$ & $\begin{array}{c}\text { Pernoctaciones } \\
\text { ExtraHotel (3) }\end{array}$ & $\begin{array}{c}\text { Pernoctaciones } \\
\text { Totales (H+Exh) }\end{array}$ & $\begin{array}{c}\text { Turistas } \\
\text { equivalentes } \\
\text { al día }\end{array}$ \\
\hline \hline $\mathbf{1 9 8 6}$ & 468.351 & --- & --- & -- & 10,0 & 13,2 & -- & 6.019 .936 & $\mathbf{1 6 . 4 9 3}$ \\
\hline $\mathbf{1 9 9 1}$ & 1.036 .341 & 319.713 & 716.628 & 2.813 .478 & 8,8 & 11,6 & 8.324 .346 & 11.137 .824 & $\mathbf{3 0 . 5 1 5}$ \\
\hline $\mathbf{1 9 9 6}$ & 1.494 .050 & 440.844 & 1.053 .206 & 4.285 .200 & 9,7 & 12,8 & 13.485 .250 & 17.770 .450 & $\mathbf{4 8 . 6 8 6}$ \\
\hline
\end{tabular}

(1) Estancia media extrahotelera: estancia media hotelera incrementada un 32\%, según las estimaciones de 2006 del INE.

(2) Pernoctaciones extrahotelera: producto de la estancia media extrahotelera por los viajeros que no pernoctan en hoteles.

$\left(^{*}\right)$ Para 1986 no se registran datos sobre el número de pernoctaciones, por que se han calculado a partir del porcentaje de pernoctaciones en 1985 por tipo de establecimiento, recogido en Cabildo Insular de Lanzarote. Avance PIOT. Tomo 5. Cap. IV. "3.1. La oferta turística en Lanzarote". 1987 (pp. 21). (Pernoctaciones Hoteleras= 8,6\% y Pernoctaciones Extrahoteleras = 91,4\%). Aplicándose el siguiente cálculo: Viajeros= [(\% pernoctaciones hoteleras/ Estancia Media Hotelera $)+(\%$ Pernoctaciones Extrahoteleras / Estancia Media Extrahotelera)] ${ }^{*}$ pernoctaciones.

$\left({ }^{* *}\right)$ Para 1991, sólo se tienen datos en relación al grado de ocupación hotelero $(64,01 \%)$, a partir del cuál se han calculado el número de

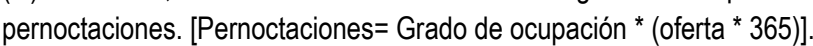

Fuente: Para 1986: "Número de turistas entrados, Lanzarote, 1981. Cabildo Insular de Lanzarote. Avance del PIOT. Análisis y Diagnóstico de la situación actual. Tomo 4. Área Económica. Informe Área Socioeconómica, Documento 1. Cuadro 2.1. 1987 (pp. 17); "Estancia media en establecimientos hoteleros de Lanzarote, 1986". Cabildo Insular de Lanzarote. Avance PIOT, Documento 4: Economía. "Área socioeconómica. Documento № 1: El turismo. Punto 5. Conclusiones". 1987 (pp. 52); Para 1991: "Estancias medias según nacionalidad e isla. Lanzarote, 1991 (hoteles)". Encuesta turística de Canarias. Estadísticas Básicas de Canarias, 1978-1992. ISTAC; "Ocupación global hotelera. Media anual, 1991, Lanzarote". Datos Estadísticos, 1992. Centro de Datos. Cabildo Insular de Lanzarote; Para 1996: "Evolución de la Afluencia turística, 1996". Anuario Estadístico de Lanzarote, 1996 (pp. 40); "Viajeros entrados en establecimientos hoteleros, estancia media y pernoctaciones, 1996. Lanzarote". Encuesta de alojamiento turístico en establecimientos hoteleros. ISTAC; Elaboración propia. 
Una vez calculados los turistas equivalentes al día, se ha podido elaborar el indicador que pone en relación el volumen de población residente con la estimación del volumen de turistas equivalentes diarios, y observar su evolución, que se refleja en la siguiente tabla:

Tabla 90. Turistas entrados y relación turistas/residentes (t/r). España, Canarias y Lanzarote. 1986-1996.

\begin{tabular}{||l|l|r|r|r|c||}
\hline Año & ESPAÑA & $\begin{array}{c}\text { Incremento quinquenal } \\
(\%)\end{array}$ & $\begin{array}{c}\text { Índice en base } \\
\mathbf{1 0 0}=\mathbf{1 9 7 0}\end{array}$ & $\begin{array}{c}\text { Turistas equivalentes al } \\
\text { día }\end{array}$ & $\begin{array}{c}\text { Ratio } \\
\text { (t/r) }\end{array}$ \\
\hline \hline 1986 & 47.388 .793 & 18,09 & 196,59 & 1.241 .916 & 32,28 \\
\hline 1991 & 53.494 .964 & 12,89 & 221,92 & 913.389 & 23,50 \\
\hline 1996 & 54.408 .900 & 1,71 & 150,26 & 872.364 & 21,99 \\
\hline
\end{tabular}

Fuente: Ratio (t/r) aparece de la relación entre el número de turistas equivalentes diarios y la población de derecho (residentes) en tantos por mil. Elaboración propia a partir de la tabla anterior.

\begin{tabular}{||l|l|r|r|r|c||}
\hline \hline Año & CANARIAS & $\begin{array}{c}\text { Incremento quinquenal } \\
(\%)\end{array}$ & $\begin{array}{c}\text { Índice en base } \\
\mathbf{1 0 0}=\mathbf{1 9 7 0}\end{array}$ & $\begin{array}{c}\text { Turistas equivalentes al } \\
\text { día }\end{array}$ & $\begin{array}{c}\text { Ratio } \\
(\mathrm{t} / \mathrm{r})\end{array}$ \\
\hline \hline 1986 & 5.068 .242 & 82,35 & 639,49 & 155.416 & 106,74 \\
\hline 1991 & 6.610 .820 & 30,44 & 834,12 & 180.928 & 121,12 \\
\hline 1996 & 9.804 .540 & 48,31 & $1.237,09$ & 304.463 & 189,52 \\
\hline
\end{tabular}

Fuente: Ratio ( $t / r)$ aparece de la relación entre el número de turistas equivalentes diarios y la población de derecho (residentes) en tantos por mil. Elaboración propia a partir de la tabla anterior.

\begin{tabular}{||c|c|r|r|r|c|}
\hline Año & LANZAROTE & $\begin{array}{c}\text { Incremento quinquenal } \\
(\%)\end{array}$ & $\begin{array}{c}\text { Índice en base } \\
\mathbf{1 0 0}=\mathbf{1 9 7 0}\end{array}$ & $\begin{array}{c}\text { Turistas equivalentes al } \\
\text { día }\end{array}$ & $\begin{array}{c}\text { Ratio } \\
\text { (t/r) }\end{array}$ \\
\hline \hline 1986 & 468.331 & 149,56 & 1746,72 & 16.493 & 295,76 \\
\hline 1991 & 1.036 .341 & 121,28 & 3865,21 & 30.515 & 470,11 \\
\hline 1996 & 1.494 .050 & 44,17 & 5572,32 & 48.686 & 629,19 \\
\hline
\end{tabular}

Fuente: Ratio ( $t / r$ ) aparece de la relación entre el número de turistas equivalentes diarios y la población de derecho (residentes) en tantos por mil. Elaboración propia a partir de la tabla anterior.

En relación al equilibrio poblacional, la relación turista/residente $(\mathrm{t} / \mathrm{r})$ viene en crescendo desde el periodo anterior, alcanzando el máximo valor en 1996, con 629 turistas equivalentes cada día por mil residentes. Lo que quiere decir que en comparación con 1986 se ha incrementado en un $112,7 \%$. Más del triple de la media de Canarias, que se sitúa en 
el mismo año (1996) en casi 190 turistas al día por mil residentes. Ambos ámbitos muy alejados de la dinámica nacional.

El estado y evolución de este indicador viene a apoyar la afirmación que, posteriormente (al final de la década de los años noventa) documentos publicados por el Cabildo Insular de Lanzarote arrojan, "el crecimiento poblacional impulsado por el turismo como un elemento de no sostenibilidad insular". Que trataremos con detalle en el epígrafe 5.2.2.

Gráfico 75. Evolución de la relación turistas/residentes. España, Canarias y Lanzarote. 1986-1996

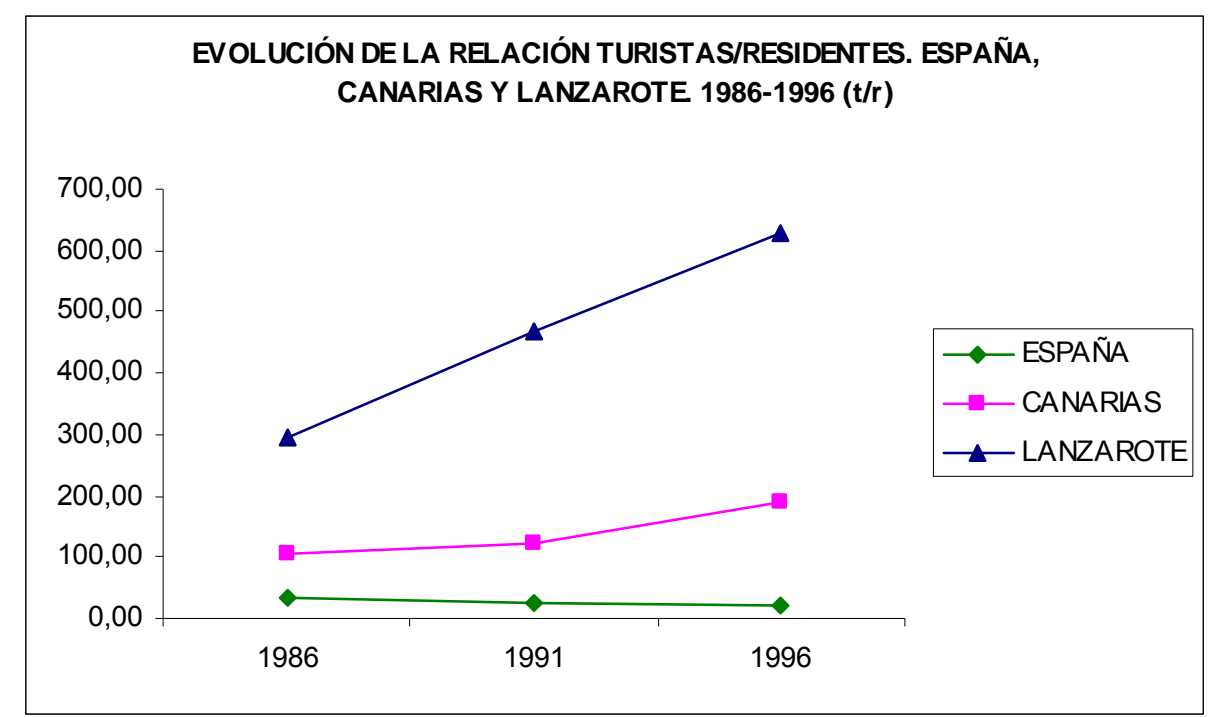

Fuente: Elaboración propia a partir de la información recogida en la Tabla anterior número 90.

Por otro lado, para observar la evolución de la demanda sobre la oferta, el ratio turistas/plazas de alojamiento, arroja incrementos considerables con respecto al periodo anterior, puesto que a la mitad de década de los ochenta (1986) tenemos 16 turistas por plaza y una década después (1996) 28 turistas por plaza, lo que supone una variación del $80 \%$ con respecto a 1986. Dato este optimista, puesto que es derivado de la contención del crecimiento de las plazas de alojamiento que ha supuesto la entrada en vigor del nuevo PIOT en 1991, que crecen (un $11 \%$ entre 1991 y 1996), aunque ya no tanto, ni al mismo ritmo, como en la etapa anterior. Mientras, la llegada de turistas sigue aumentando, aunque a menor ritmo. Se ralentiza el crecimiento de la oferta, frente a la demanda. 
Tabla 91. Ratio turistas/plazas. España, Canarias y Lanzarote. 1986-1996

\begin{tabular}{|c|c|c|c|c|c|c|c|c|c|}
\hline \multirow[b]{2}{*}{ Años } & \multicolumn{3}{|l|}{ ESPAÑ A } & \multicolumn{3}{|c|}{ CANARIAS } & \multicolumn{3}{|c|}{ LANZAROTE } \\
\hline & $\mathrm{N}^{0}$ Plazas & Turistas & $\begin{array}{l}\text { Ratio } \\
(t / p)\end{array}$ & $\mathrm{N}^{0}$ Plazas & Turistas & $\begin{array}{l}\text { Ratio } \\
\text { (t/p) }\end{array}$ & $\mathrm{N}^{0}$ Plazas & Turistas & $\begin{array}{l}\text { Ratio } \\
\text { (t/p) }\end{array}$ \\
\hline 1986 & 1.561 .295 & 47.388 .793 & 30,3 & 255.167 & 5.068 .242 & 19,9 & 38.498 & 468.331 & 12,3 \\
\hline 1991 & 1.950 .881 & 53.494 .964 & 27,4 & 375.995 & 6.610 .820 & 17,6 & 47.690 & 1.036 .341 & 21,7 \\
\hline 1996 & 2.133 .053 & 54.408 .900 & 25,5 & 328.254 & 9.804 .540 & 29,9 & 52.830 & 1.494 .050 & 28,3 \\
\hline
\end{tabular}

Fuente: Elaboración propia a partir de los datos de viajeros entrados y plazas de alojamiento.

En relación a la dinámica de Canarias, la isla mantiene el ratio más elevado, hasta el año 1996, en el que la relación demanda/oferta (t/p) de alojamiento superará la insular en un $5 \%$. En esta mitad de década de los años noventa ambos territorios poseen dinámicas similares.

El ratio turista/plazas nacional aunque ha venido manteniéndose por encima del insular prácticamente a lo largo de todo el periodo de análisis, es en 1996 cuando se sitúa por debajo de los valores insulares, 25 turistas por plaza frente a los 28 de la isla. Esto se produce por la reducción del incremento de la demanda (que sólo crece un 1,7\% entre 1986 y 1996), unido al crecimiento de la oferta de alojamiento, que crece alrededor del $9 \%$.

Gráfico 76. Evolución de la relación turistas/plazas. España, Canarias y Lanzarote. 1986-1996.

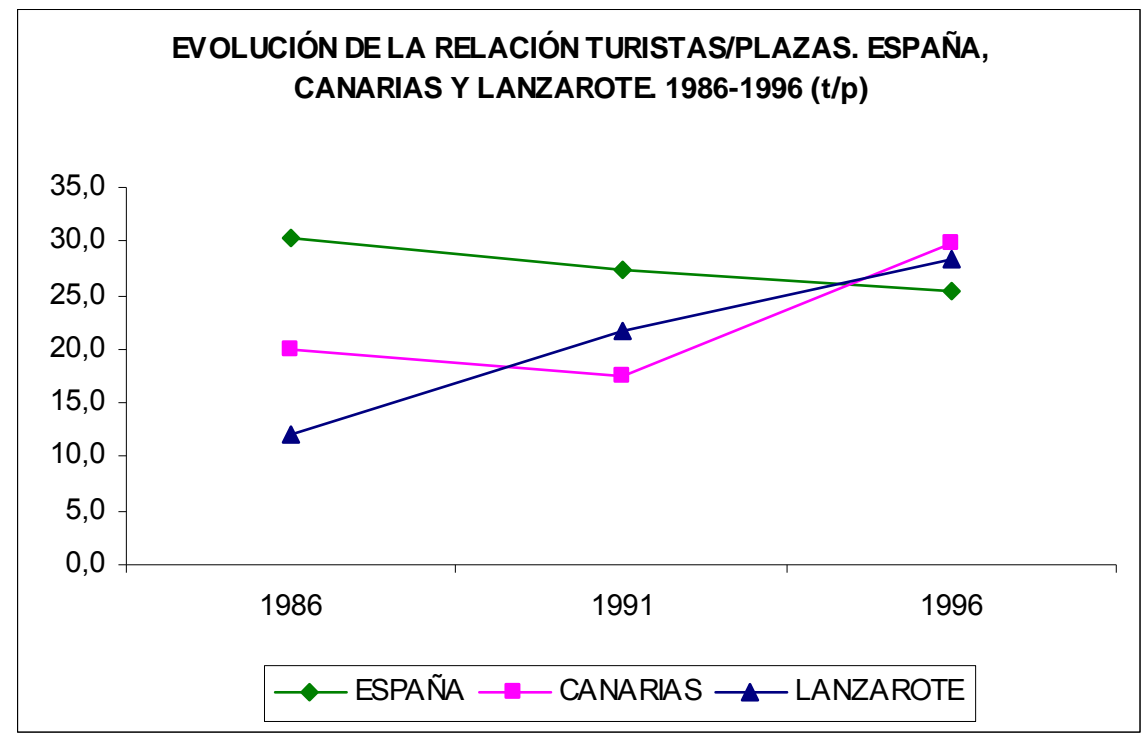

Fuente: Elaboración propia a partir de los datos de viajeros entrados y plazas de alojamiento. Gráfico basado en la Tabla 91.

¿Qué valor deben arrojar los ratios calculados para acercarnos a un estado de sostenibilidad insular? Esta es una pregunta que sigue sin respuesta a finales del año 1996, 
cuando termina esta etapa de análisis, y que su cálculo excede los objetivos de este análisis.

\subsubsection{3.- CONCLUSIONES}

En términos generales este periodo que comprende desde 1986 a 1996, vendrá caracterizado por la regulación y freno del enorme crecimiento de la oferta turística que hereda la isla de la década de los años setenta y ochenta, que es puesto en marcha por la aprobación en 1991 de un nuevo Plan Insular de Ordenación del Territorio. Las características de la etapa se concretan de forma general en lo siguiente:

1.- Fuerte bajada del crecimiento de la oferta turística. La planificación ahora cambió de signo con respecto a la etapa anterior, si antes se buscaba la rápida incorporación de la isla a una economía turística, ahora la tendencia es a regular y racionalizar su crecimiento bajo una estrategia insular. Se crece, pero en menor porcentaje y de forma más lenta. La misma dinámica se observa en España, no así en Canarias, donde no se reduce el crecimiento de la oferta hasta el periodo 1991-1996, que toma signo negativo, por lo que disminuye su planta de alojamiento turístico.

2.- Cambio en las inversiones, que ahora serán hoteleras, adquiriendo mayor presencia en el peso relativo del total de la oferta turística $(30 \%)$, reduciéndose la participación de la extrahotelera. España y Canarias observan la misma dinámica que la isla.

3.- Crisis en el sector por reducción del crecimiento de las entradas de turistas al final de la etapa. Los incrementos de la demanda turística se reducen. Comparativamente, será más grave para España. 


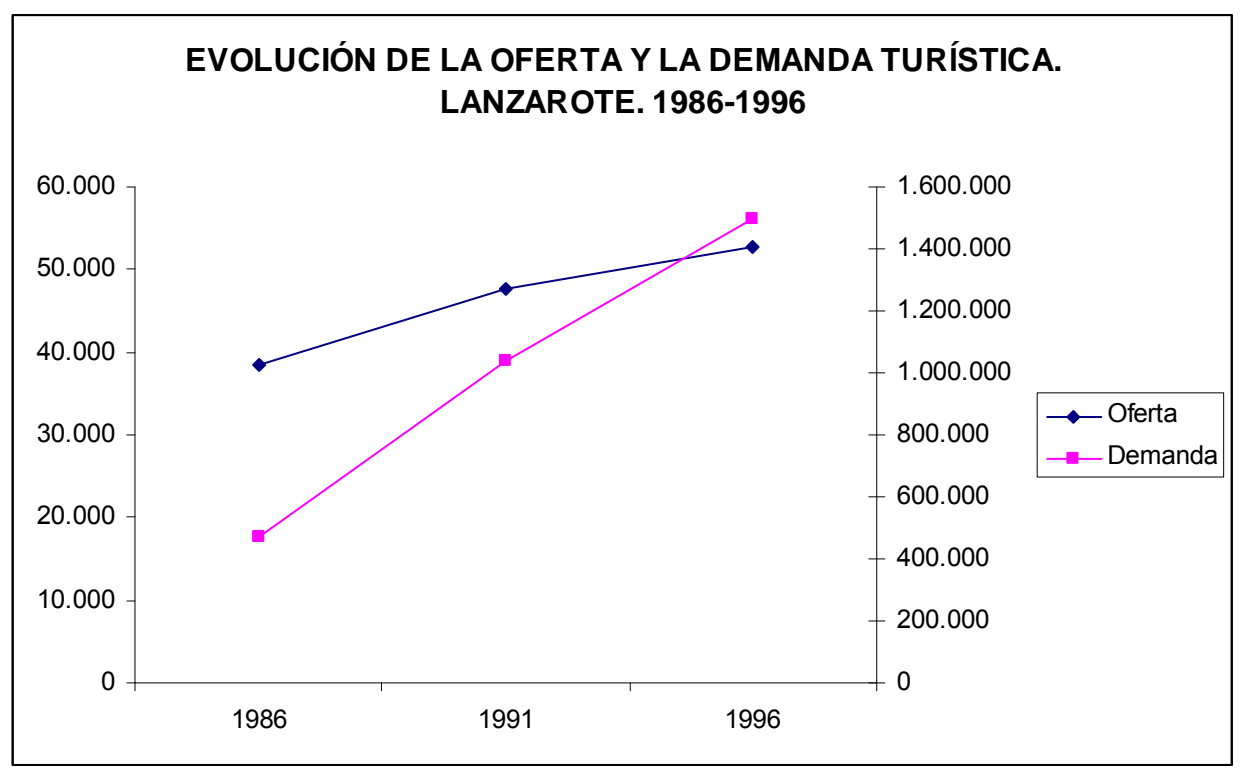

Fuente: Avance PIOT, 1987; Anuario Estadístico de Lanzarote. Oficina de Turismo interior, Cabildo Insular de Lanzarote; Bases de datos insular y municipal. ISTAC; Estadísticas de Turismo del Ministerio de Transporte, Turismo y Comunicaciones. IET; Gráfico basado en las Tablas 84 y 85 . Elaboración propia.

4.- El equilibrio poblacional en relación al volumen de turistas sobre el volumen de residentes, sigue creciendo aunque más lentamente que en el periodo anterior. Lanzarote en esta etapa de regulación de la oferta y a pesar de crisis de recepción turística, observa un $38,7 \%$ de la población diaria como turista, muy por encima de Canarias y España.

5.- El ritmo de crecimiento de la demanda es muy superior al de la oferta, por lo que la relación turistas/plazas de alojamiento va en aumento, fruto de la contención del crecimiento de la planta de alojamiento, que modifica la relación (t/p) en un $80 \%$. Similar a la dinámica que contempla Canarias al final del periodo y por encima de España.

\subsection{2.- EFECTOS SOBRE LA ESTRUCTURA DEMOGRÁFICA BÁSICA. 1986-1996}

\subsubsection{1.- EVOLUCIÓN DE LA POBLACIÓN}

Con respecto a la etapa anterior, ésta presenta mayores crecimientos de población, principalmente en el último quinquenio, en el que se sitúa en el $19 \%$.

La población se va a incrementar ahora más que nunca, a pesar de la regulación del crecimiento de la oferta turística que supone la nueva ordenación territorial (PIOT de 1991) y de la crisis por sobreproducción que sufre el sector insular, con la que se entra en la década de los años noventa. 
Tabla 92. Población total. España, Canarias y Lanzarote 1986-1996 (\%).

\begin{tabular}{|c|c|r||r|r||r|r||}
\hline Año & ESPAÑ A & $\begin{array}{c}\text { Incremento } \\
\text { quinquenal (\%) }\end{array}$ & CANARIAS & $\begin{array}{r}\text { Incremento } \\
\text { quinquenal (\%) }\end{array}$ & LANZAROTE & $\begin{array}{c}\text { Incremento } \\
\text { quinquenal (\%) }\end{array}$ \\
\hline \hline 1986 & 38.473 .418 & 2,1 & 1.456 .000 & 6,5 & 55.764 & 9,9 \\
\hline 1991 & 38.872 .268 & 1,0 & 1.493 .784 & 2,6 & 64.911 & 16,4 \\
\hline 1996 & 39.669 .394 & 2,1 & 1.606 .534 & 7,5 & 77.379 & 19,2 \\
\hline
\end{tabular}

Fuente: Censos de Población y Viviendas de España y de Canarias, 1991 (Población de Derecho). INE e ISTAC.; "Estadísticas Insulares y Municipales". Base de datos ISTAC; Padrón Municipal de habitantes "Población de derecho. Resultados Nacionales y provinciales". 1986 y 1996. ISTAC e INE. Elaboración propia.

Mientras Lanzarote tiene un crecimiento demográfico continuado, los incrementos de la población entre los periodos de análisis para Canarias y España no presentan el mismo ritmo, sino que son oscilantes entre los dos quinquenios, y sus dinámicas distan mucho de la insular, puesto que mientras la isla mantiene un crecimiento sostenido entre el $10 \%$ y el $20 \%$, Canarias oscila entre el $3 \%$ y el $7 \%$ y el país sólo incrementa su población del orden del $2 \%$.

Gráfico 78. Incremento interperiodo de la población de derecho. España, Canarias y Lanzarote. 1986-1996 (\%).

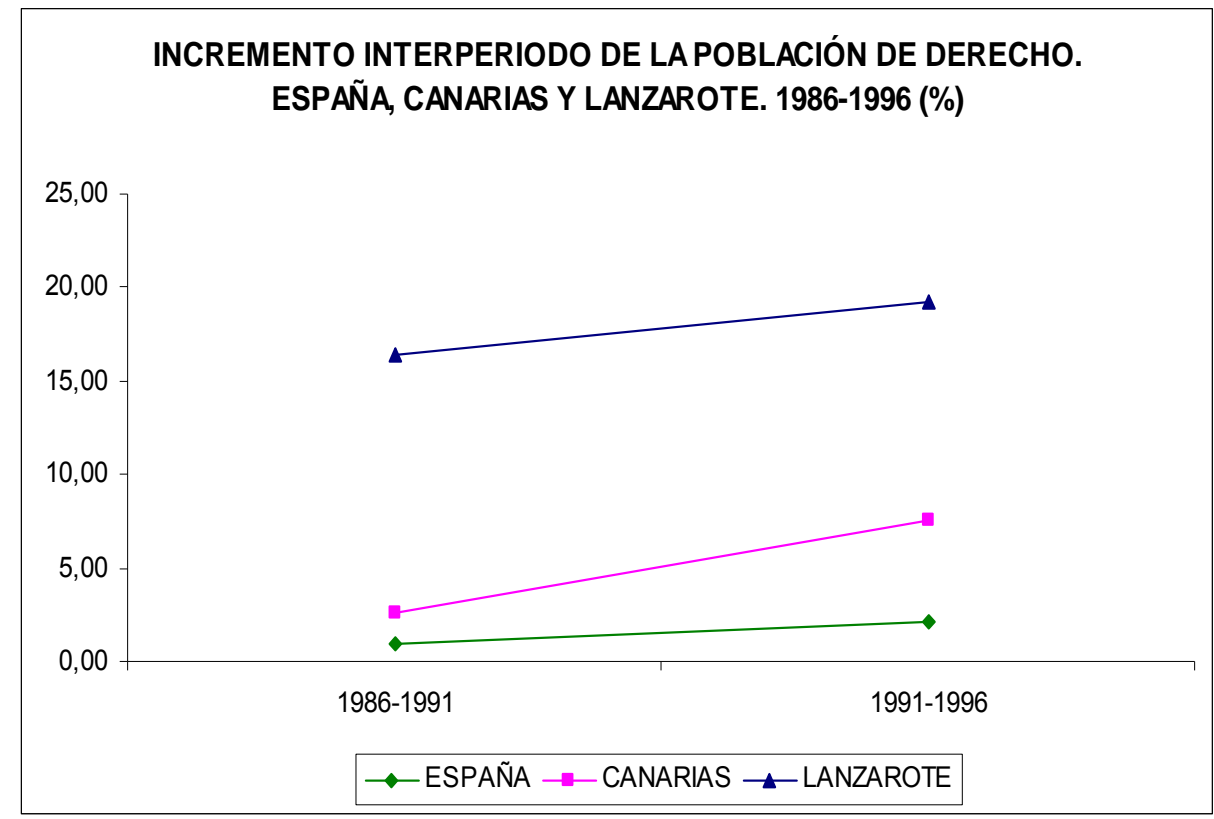

Fuente: Censos de Población y Viviendas de España y de Canarias, y Padrón municipal de habitantes, INE; Explotaciones estadísticas de Censos y Padrones del ISTAC. Gráfico basado en la Tabla 92. Elaboración propia.

Este crecimiento se produce a pesar del paro que por esta época sufre el sector turístico (caída de la afluencia de turistas entre 1991-1996) y la construcción (caída del crecimiento de la oferta de alojamiento turístico a partir de 1991 con la aprobación del PIOT). 
En cuanto a las dinámicas municipales, sigue siendo el municipio capitalino el que concentra más de la mitad de la población de la isla (entre el $55 \%$ y el $49 \%$ ), por su calidad de centro administrativo y comercial, seguido de Teguise (con casi el $12 \%$ de media en el periodo) y Tías (con el $11 \%$ de media en esta etapa) municipios éstos últimos que concentran la mayor actividad turística.

Tabla 93. Población por municipios. Lanzarote. 1986-1996.

\begin{tabular}{|c|c|c|c|c|c|c|c|c|c|c|c|c|c|c|c|}
\hline Año & Arrecife & $\%$ & Haría & $\%$ & $\begin{array}{c}\text { San } \\
\text { Bartolomé }\end{array}$ & $\%$ & Teguise & $\%$ & Tías & $\%$ & Tinajo & $\%$ & Yaiza & $\%$ & LANZAROTE \\
\hline 1986 & 30.694 & 55,0 & 2.760 & 4,9 & 5.229 & 9,4 & 6.475 & 11,6 & 5.383 & 9,7 & 3.229 & 5,8 & 1.994 & 3,6 & 55.764 \\
\hline 1991 & 33.906 & 52,2 & 2.851 & 4,4 & 6.217 & 9,6 & 8.189 & 12,6 & 7.556 & 11,6 & 3.517 & 5,4 & 2.675 & 4,1 & $\mid 64.911$ \\
\hline 1996 & 38.091 & 49,2 & 3.531 & 4,6 & 9.852 & 12,7 & 8.691 & 11,2 & 10.096 & 13,0 & 3.755 & 4,9 & 3.363 & 4,3 & $\mid 77.379$ \\
\hline $\begin{array}{l}\text { Incremento } \\
1986-1996 \\
(\%)\end{array}$ & \multicolumn{2}{|c|}{24,1} & \multicolumn{2}{|c|}{27,9} & \multicolumn{2}{|c|}{88,4} & \multicolumn{2}{|c|}{34,2} & \multicolumn{2}{|c|}{87,6} & \multicolumn{2}{|c|}{16,3} & \multicolumn{2}{|c|}{68,7} & 38,8 \\
\hline
\end{tabular}

Fuente. "Población de derecho por municipios, 1986, 1991 y 1996". Estadísticas Insulares y Municipales. Base de Datos. ISTAC. (www.istac-r.canarias.es. Consulta online: 2003).

El municipio de San Bartolomé ocupa el cuarto lugar, aunque es el que experimenta el mayor porcentaje de crecimiento demográfico en el periodo (88\%), derivado de su cercanía a la Capital, Arrecife, y al municipio de Tías con fuerte economía turística, además de poseer desarrollos en la costa de primera y segunda residencia.

Gráfico 79. Evolución de la población municipal sobre el total insular. Lanzarote. 1986-1996 (\%)

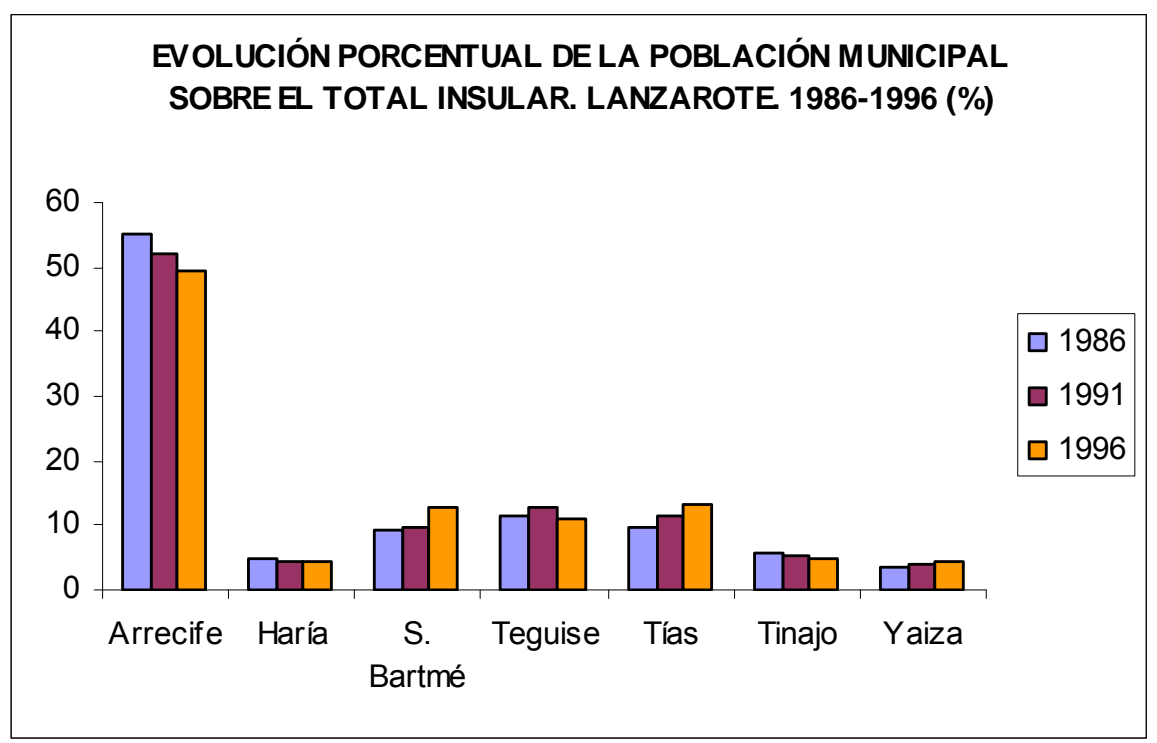

Fuente: Estadísticas Insulares y Municipales. Bases de Datos del. ISTAC. Gráfico basado en la Tabla 93. Elaboración propia. 
Mapa 19. Evolución demográfica municipal. Lanzarote. 1986-1996 (base=1970)

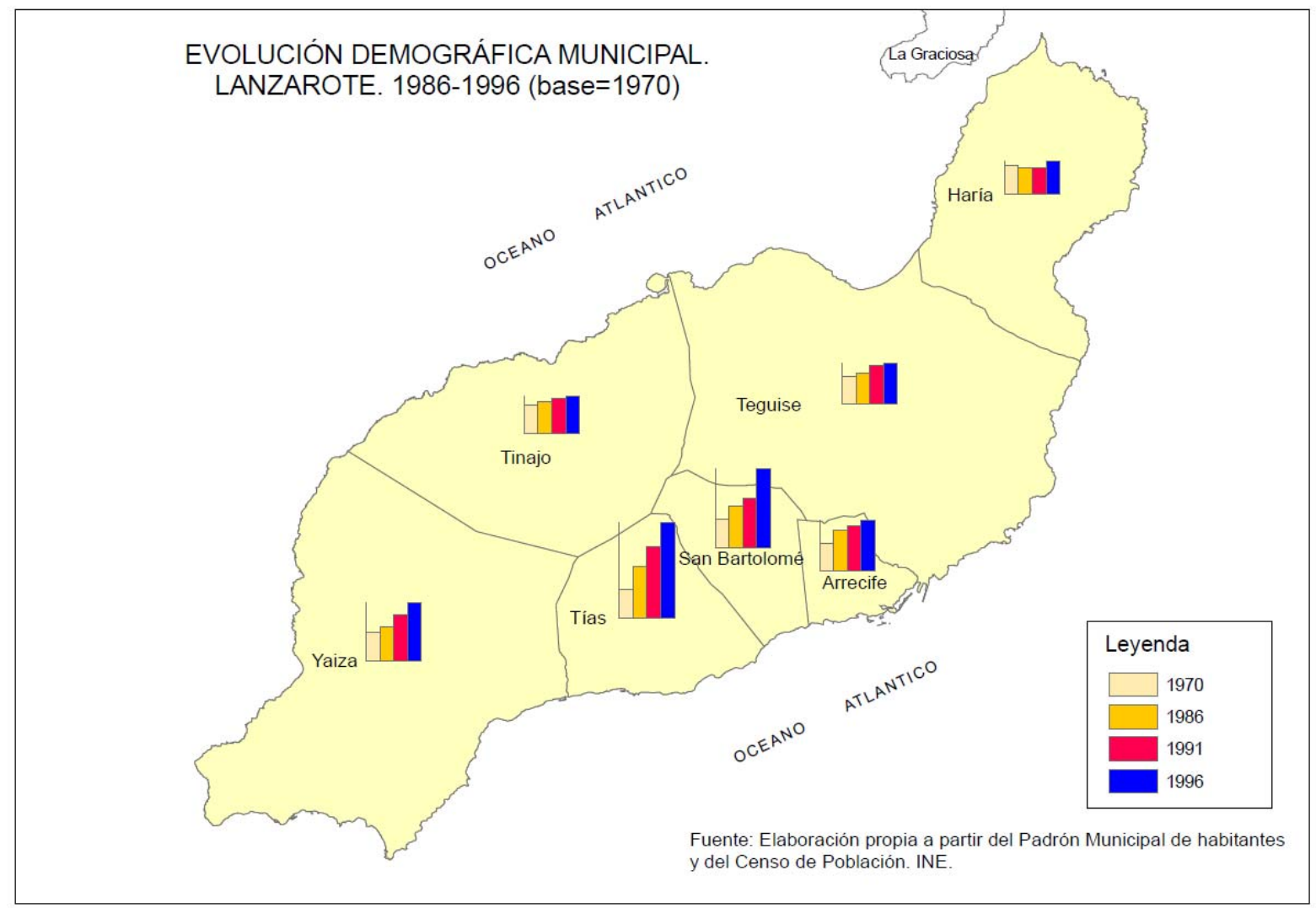

\section{a.- El movimiento natural}

La isla ya hizo la transición demográfica en la etapa anterior, está por tanto instalada en un régimen demográfico moderno. Seguirá reducida su tasa de mortalidad a lo largo de esta etapa, estabilizándose en cinco defunciones por cada mil habitantes. Lo que llama la atención es que se mantiene por debajo de las Tasas de Canarias y España.

Tabla 94. Evolución de las tasas quinquenales de mortalidad. España, Canarias y Lanzarote. 1986-1995 (\%)

\begin{tabular}{|l|c|c|c|}
\cline { 2 - 4 } \multicolumn{1}{c|}{} & ESPAÑ A & CANARIAS & LANZAROTE \\
\hline \hline $1986-1990$ & 8,2 & 6,4 & 5,5 \\
\hline $1991-1995$ & 8,5 & 6,8 & 5,2 \\
\hline
\end{tabular}

Fuente: Defunciones. Total Nacional y Comunidades Autónomas. Movimiento Natural de la Población. 1986-1995; Movimiento Natural de la Población por Islas. 1986-1996. ISTAC; Elaboración propia. 
Gráfico 80. Evolución de la tasa de mortalidad media. España, Canarias y Lanzarote. 1986-1995

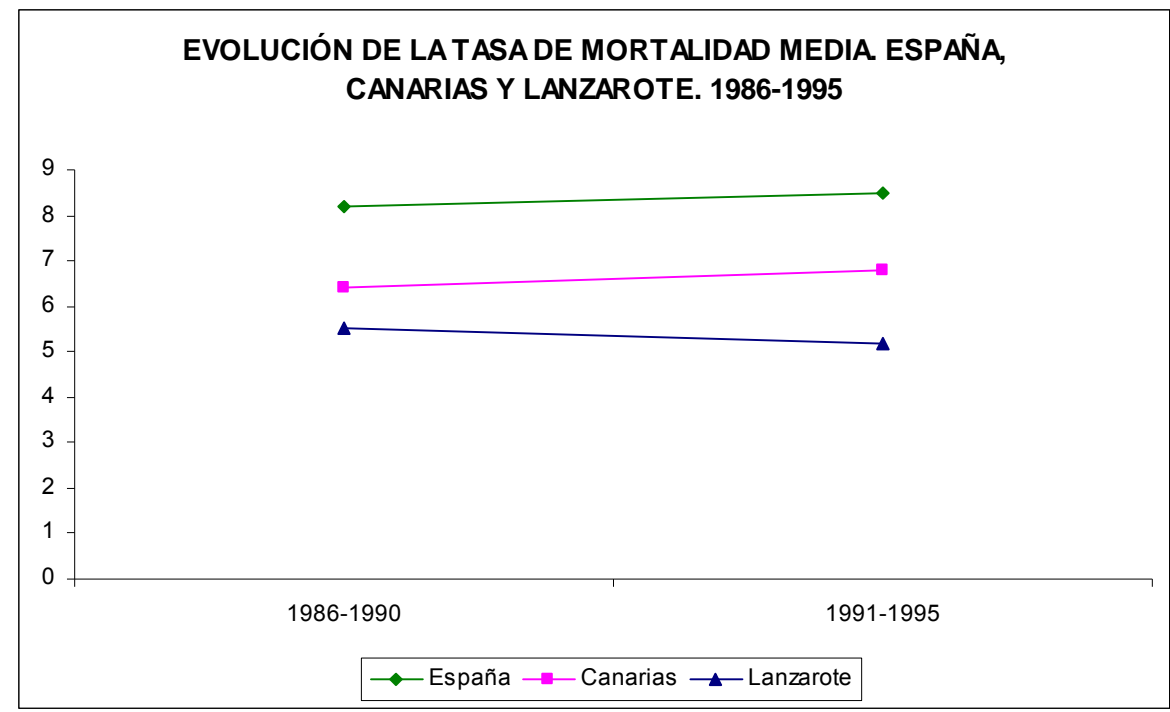

Fuente: Movimiento Natural de la Población. ISTAC e INE. Gráfico basado en la Tabla 94. Elaboración propia.

Al igual que con la mortalidad, también sigue reduciendo su tasa de natalidad en esta etapa, aunque se mantiene elevada, por encima de Canarias (alrededor del 3\%o y de España (entre el 5\% y el 3\%o). La explicación de este fenómeno está en la entrada de emigrantes en edad de trabajar y formar familias, que hace que las dinámicas natalistas insulares sean más altas.

Tabla 95. Evolución de las tasas quinquenales de natalidad. España, Canarias y Lanzarote. 1986-1995 (\%o).

\begin{tabular}{|l|r|r|r|}
\cline { 2 - 4 } \multicolumn{1}{c|}{} & ESPAÑ A & CANARIAS & LANZAROTE \\
\hline $1986-1990$ & 10,7 & 12,7 & 15,4 \\
\hline $1991-1995$ & 9,6 & 11,5 & 12,6 \\
\hline
\end{tabular}

Fuente: Nacimientos, Total Nacional y Comunidades Autónomas. Movimiento Natural de la Población. 1986-1995; Movimiento Natural de la Población por Islas. 1986-1996. Base de datos Insular y Municipal. ISTAC. Elaboración propia. 
Gráfico 81. Evolución de la tasa de natalidad media. España, Canarias y Lanzarote. 1986-1995

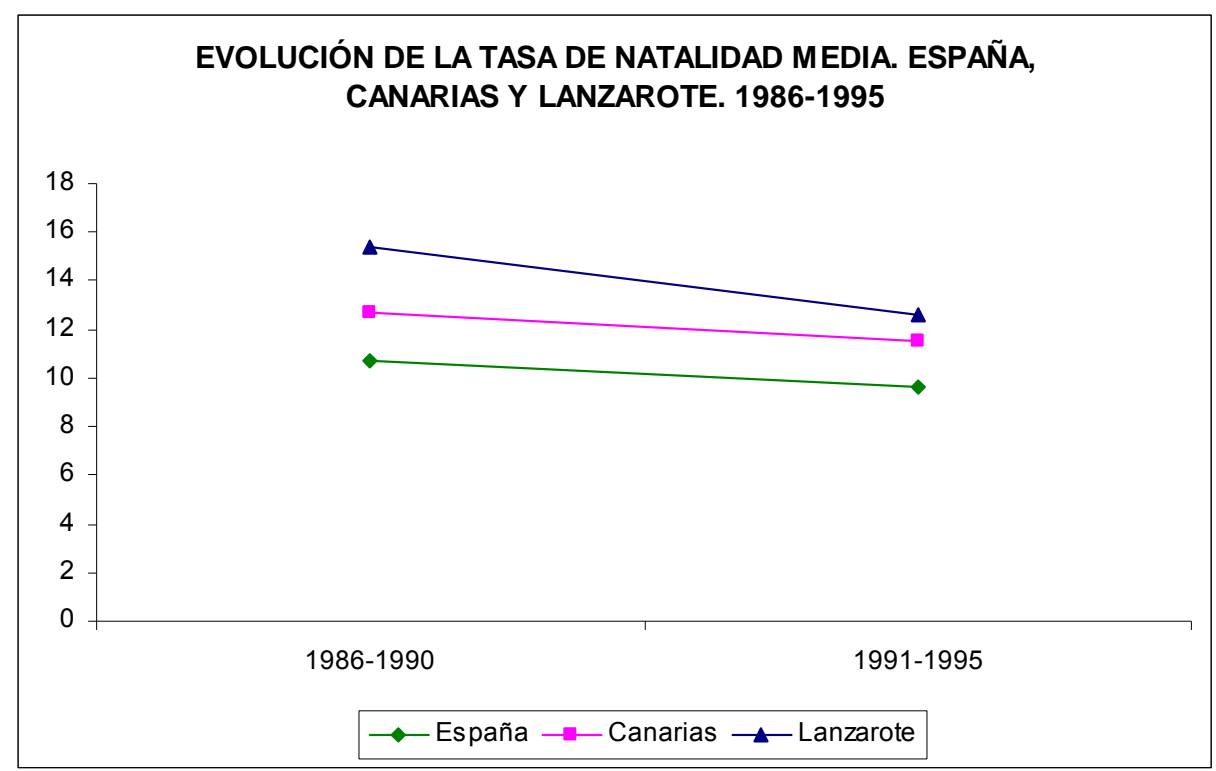

Fuente: Movimiento Natural de la Población. ISTAC e INE. Gráfico basado en la Tabla 95. Elaboración propia.

El elevado crecimiento de la población en esta etapa (19\%), tampoco puede ser explicado por el crecimiento vegetativo, que ha seguido reduciéndose desde la etapa anterior y continúa con su ciclo de descenso, a pesar de encontrarse por encima del crecimiento natural de la Comunidad Autónoma (en más del 3\%) y de España (próximo al 7\%o).

Tabla 96. Evolución de las tasas quinquenales de crecimiento vegetativo de Lanzarote. 19861995 (\%o).

\begin{tabular}{|l|r|r|r|}
\cline { 2 - 4 } \multicolumn{1}{c|}{} & ESPAÑ A & CANARIAS & LANZAROTE \\
\hline \hline $1986-1990$ & 2,5 & 6,3 & 9,9 \\
\hline $1991-1995$ & 1,1 & 4,7 & 7,4 \\
\hline
\end{tabular}

Nota: la Tasa de crecimiento vegetativo es la diferencia entre la Tasa de Natalidad y la de Mortalidad.

Fuente: Elaboración propia a partir de las tasas de natalidad y mortalidad para los diferentes quinquenios analizados 
Gráfico 82. Evolución del crecimiento vegetativo. España, Canarias y Lanzarote. 1986-1995.

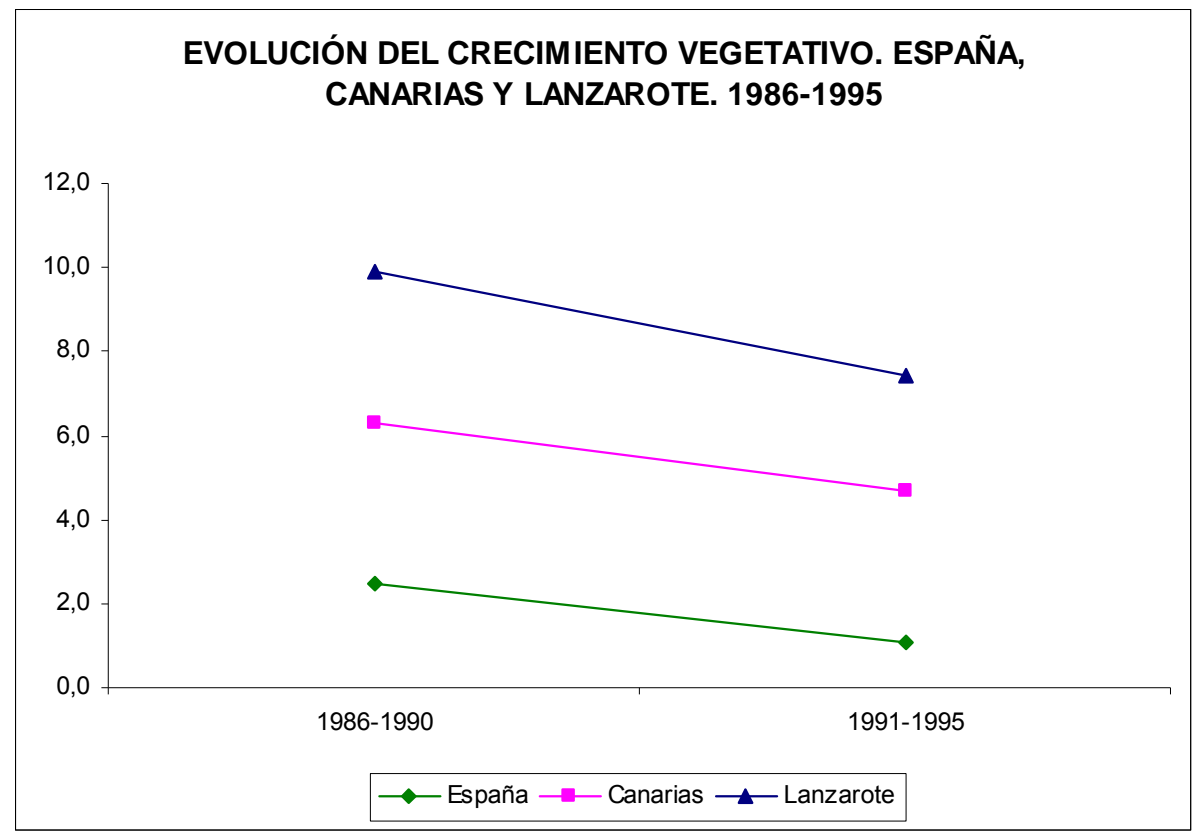

Fuente: Movimiento Natural de la Población. ISTAC e INE. Gráfico basado en la Tabla 96. Elaboración propia.

La explicación, por tanto del incremento de la población sigue estando en la incorporación de población procedente del exterior.

b.- Los factores exógenos. Las migraciones

Al final de este periodo la inmigración neta va a suponer casi el 33\% de la población residente en la isla, tal y como se aprecia en el cuadro siguiente. En una década se ha incrementado en un $146 \%$. Este contingente de población continúa creciendo al calor de los incrementos de la oferta de alojamiento turístico, que aunque se ha reducido con respecto al periodo anterior (recogido en el epígrafe 5.1.1.1.) sigue manteniendo a la isla como un foco de atracción de mano de obra. 
Tabla 97. Población residente según lugar de nacimiento. Inmigrantes netos. Lanzarote. 19861996

\begin{tabular}{|c|c|c|c|c|c|c|c|c|c|c|c|}
\hline \multirow{2}{*}{ AÑO } & \multicolumn{2}{|c|}{$\begin{array}{l}\text { EN OTRA } \\
\text { ISLA }\end{array}$} & \multicolumn{2}{|c|}{$\begin{array}{c}\text { EN OTRA } \\
\text { CCAA }\end{array}$} & \multicolumn{2}{|c|}{$\begin{array}{l}\text { EN OTRO } \\
\text { PAÍS }\end{array}$} & \multicolumn{3}{|c|}{ INMIGRANTES NETOS } & \multirow{2}{*}{$\begin{array}{l}\text { POBLACIÓN } \\
\text { AUTÓCTONA }\end{array}$} & \multirow{2}{*}{$\begin{array}{c}\text { POBLACIÓN } \\
\text { DERECHO }\end{array}$} \\
\hline & Total & $\%$ & Total & $\%$ & Total & $\%$ & TOTAL & $\%$ & $\begin{array}{c}\text { Incremento } \\
\text { quinquenal } \\
(\%)\end{array}$ & & \\
\hline 1986 & 4.447 & 43,0 & 4.735 & 45,8 & 1.148 & 11,1 & 10.330 & 18,1 & & 45.434 & 55.764 \\
\hline 1991 & 6.485 & 39,9 & 7.395 & 45,6 & 2.353 & 14,5 & 16.233 & 25,0 & 57,1 & 48.678 & 64.911 \\
\hline 1996 & 8.012 & 31,5 & 12.500 & 49,2 & 4.893 & 19,3 & 25.405 & 32,8 & 56,5 & 51.974 & 77.379 \\
\hline $\begin{array}{c}\text { Incremento } \\
1986-1996 \\
(\%)\end{array}$ & \multicolumn{2}{|c|}{80,2} & \multicolumn{2}{|c|}{164,0} & \multicolumn{2}{|c|}{326,2} & \multicolumn{3}{|c|}{146,0} & 14,4 & 35,7 \\
\hline
\end{tabular}

Nota: los porcentajes están calculados sobre el total de población insular para el año indicado.

Fuente: Para 1986: "Migrantes. Población que no ha residido siempre en el mismo municipio, según año de llegada y lugar de procedencia". "Población de derecho según edad y lugar de nacimiento". Padrón Municipal de 1986. ISTAC.; Para 1991 y 1996 : "Población de derecho según lugar de nacimiento. Lanzarote. 1991 y 1996". Censo de población y vivienda de 1991; Encuesta de Población de Canarias. 1996. Elaboración propia.

A diferencia del periodo anterior, el incremento de la inmigración se va a moderar, no crece tanto pero sigue siendo muy fuerte en valores absolutos, además de mantener un incremento cada seis años considerable, alrededor del 57\%, pero con cierta tendencia a la baja (de medio punto). Esta ralentización se explica por la caída del crecimiento del alojamiento turístico en ésta época y una crisis de afluencia turística, que afectará principalmente al empleo en la construcción, como comprobaremos en el epígrafe 5.2.5.1. 
Gráfico 83. Evolución de la inmigración. Lanzarote. 1986-1996

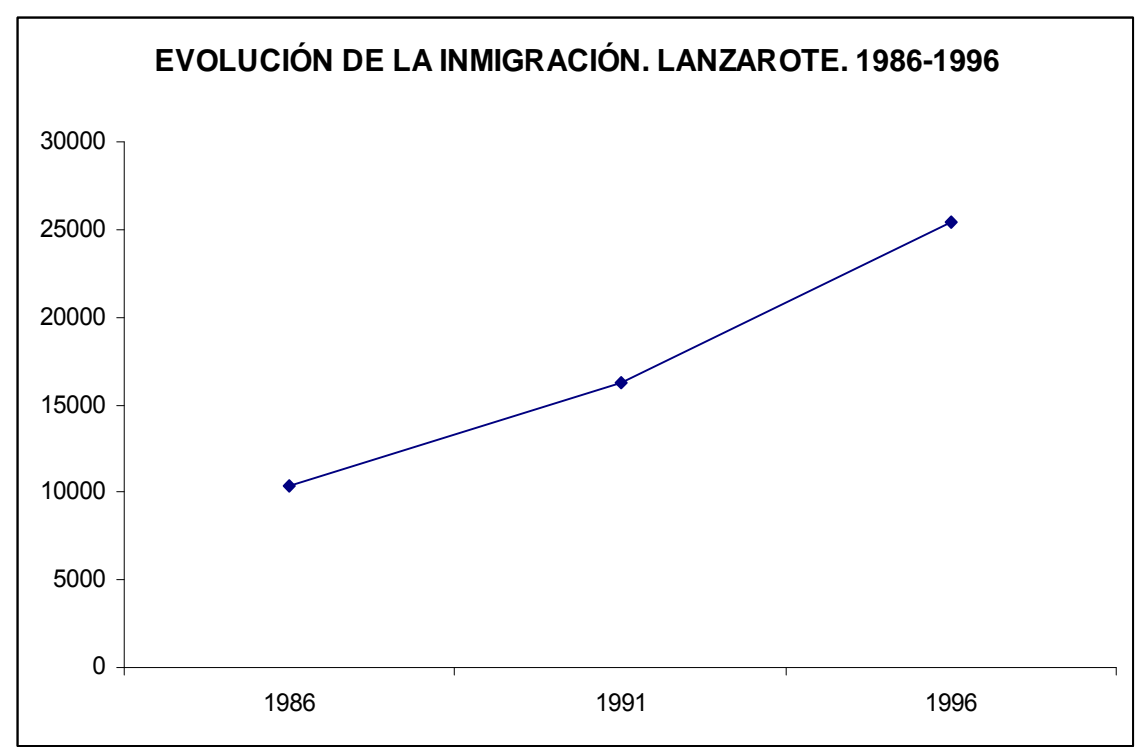

Fuente: Censo de Población y Padrón municipal de habitantes. Explotaciones del ISTAC; INE; Gráfico basado en la Tabla 97. Elaboración propia.

La inmigración proveniente de la Península Ibérica será la protagonista a lo largo de esta etapa, alcanzando al final de la misma (1996) un peso relativo del $49 \%$ con respecto a todo el contingente de población entrada en la isla. La recepción de población insular canaria desciende, queda en segundo lugar (31\%) y los procedentes de fuera de España, aunque con menos volumen de recepción (19\%), van en aumento.

Gráfico 84. Evolución de la inmigración según origen. Lanzarote. 1986-1996 (\%)

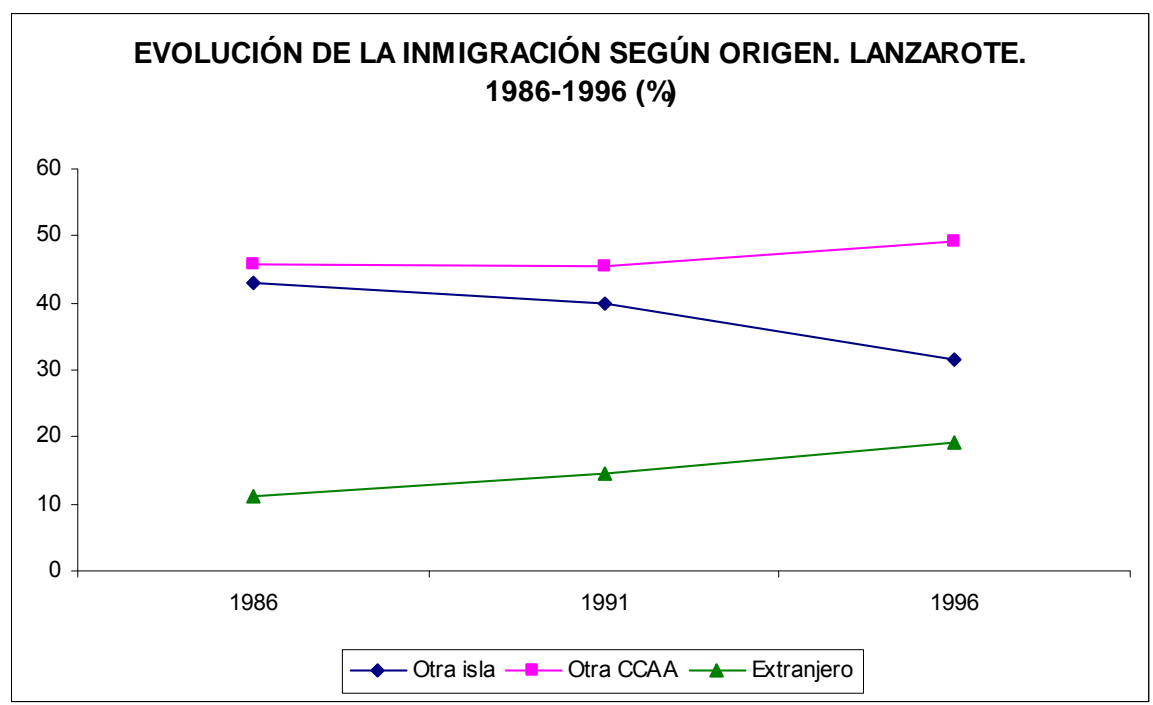

Fuente: Censo de Población y Padrón municipal de habitantes. Explotaciones del ISTAC; INE; Gráfico basado en la Tabla 97. Elaboración propia. 


\section{c.- La población autóctona}

Los diagnósticos del Cabildo Insular de Lanzarote publicados por esta época afirman que "no se está produciendo una correcta interrelación entre el turismo y el conjunto de la economía con importantes consecuencias sobre la estructura social, donde empiezan a generarse conflictos latentes y se reconoce un cierto clima social encaminado hacia el desequilibrio"168.

Si bien los análisis sobre clima social deben abordarse desde una metodología diferente a la que aquí se viene utilizando, lo que sí podemos constatar desde este trabajo son cambios en la estructura social a través de la tendencia continua que lleva la isla hacia el desequilibrio demográfico, puesto que en este periodo podemos afirmar, sin lugar a dudas, que el peso de la población autóctona se dirige hacia la marginalidad con respecto a otros contingentes de población que acoge la isla.

Tabla 98. Población inmigrante y población autóctona. Absolutos y relativos. Lanzarote. 19861996.

\begin{tabular}{||c|c||c|c||r|r|r||}
\hline \multirow{2}{*}{ AÑO } & \multirow{2}{*}{$\begin{array}{c}\text { POBLACIÓN } \\
\text { TOTAL }\end{array}$} & \multicolumn{2}{|c||}{ INMIGRACIÓN TOTAL } & \multicolumn{3}{|c|}{ POBLACIÓN AUTÓCTONA } \\
\cline { 5 - 7 } & & Absolutos & $\%$ & Absolutos & $\%$ & $\begin{array}{c}\text { Incremento } \\
\text { quinquenal (\%) }\end{array}$ \\
\hline \hline 1986 & 55.764 & 10.330 & 18,1 & 45.434 & 81,5 & \\
\hline 1991 & 64.911 & 16.233 & 25,0 & 48.678 & 75,0 & 7,1 \\
\hline 1996 & 77.379 & 25.405 & 32,8 & 51.974 & 67,2 & 6,8 \\
\hline
\end{tabular}

Fuente: Elaboración propia a partir de la población por lugar de nacimiento. ISTAC e INE.

El padrón de habitantes de 1996 arroja la cifra de 67\% de población autóctona, frente al $33 \%$ que supone el peso de las personas nacidas fuera de la isla. Así mientras en el primer quinquenio de la década de los noventa la inmigración se ha incrementado del orden del $56 \%$, el ritmo de crecimiento de la población autóctona no llega al $7 \%$ y la tendencia que presenta es a la baja. El dato optimista con respecto a ésta dinámica de crecimiento de los autóctonos entre 1981 y 1986 es que en esta etapa se rompe, puesto que el incremento de la afluencia de alóctonos se reduce.

168 Cabildo Insular de Lanzarote. "Breve diagnóstico de la situación actual de Lanzarote". Capítulo III, pp. 13, 31 y 37. Lanzarote, 1991 
Gráfico 85. Evolución de la población autóctona y alóctona. Lanzarote. 1986-1996 (\%)

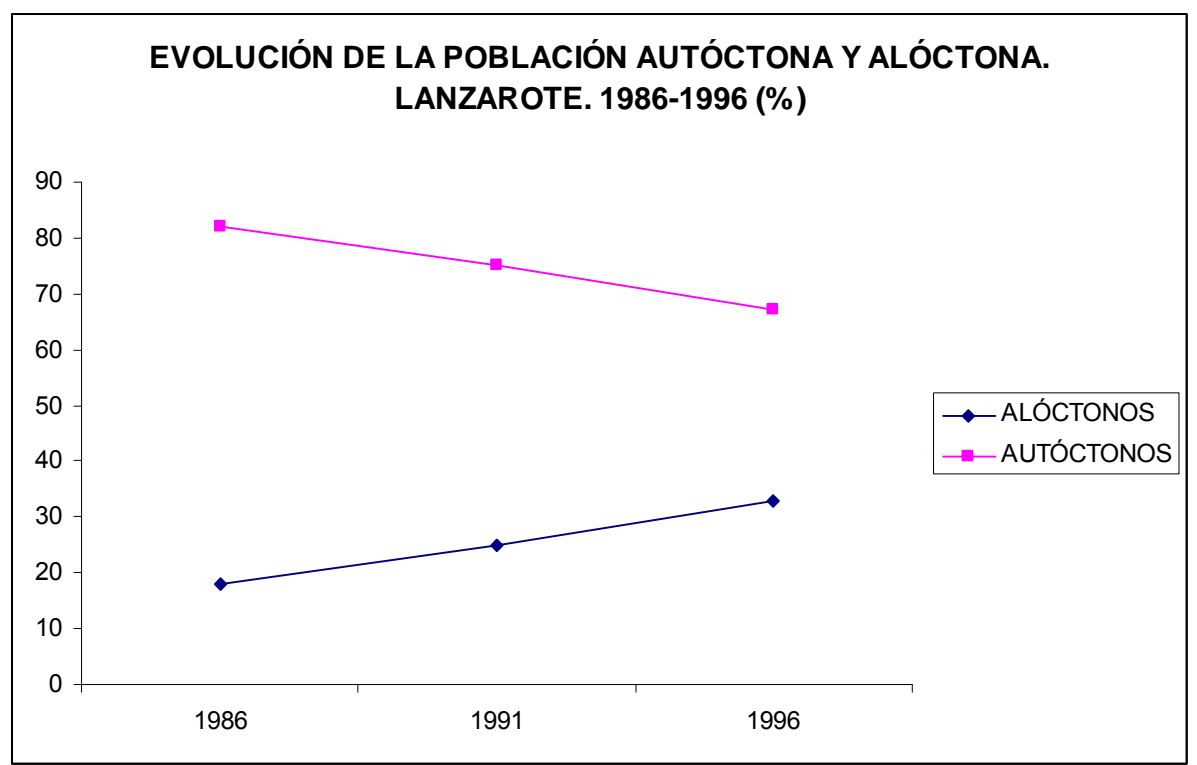

Fuente: Elaboración propia a partir de la población por lugar de nacimiento. ISTAC e INE. Gráfico basado en la Tabla 98.

Gráfico 86. Incremento interperiodo de la población autóctona y alóctona. Lanzarote. 1986-1996 (\%)

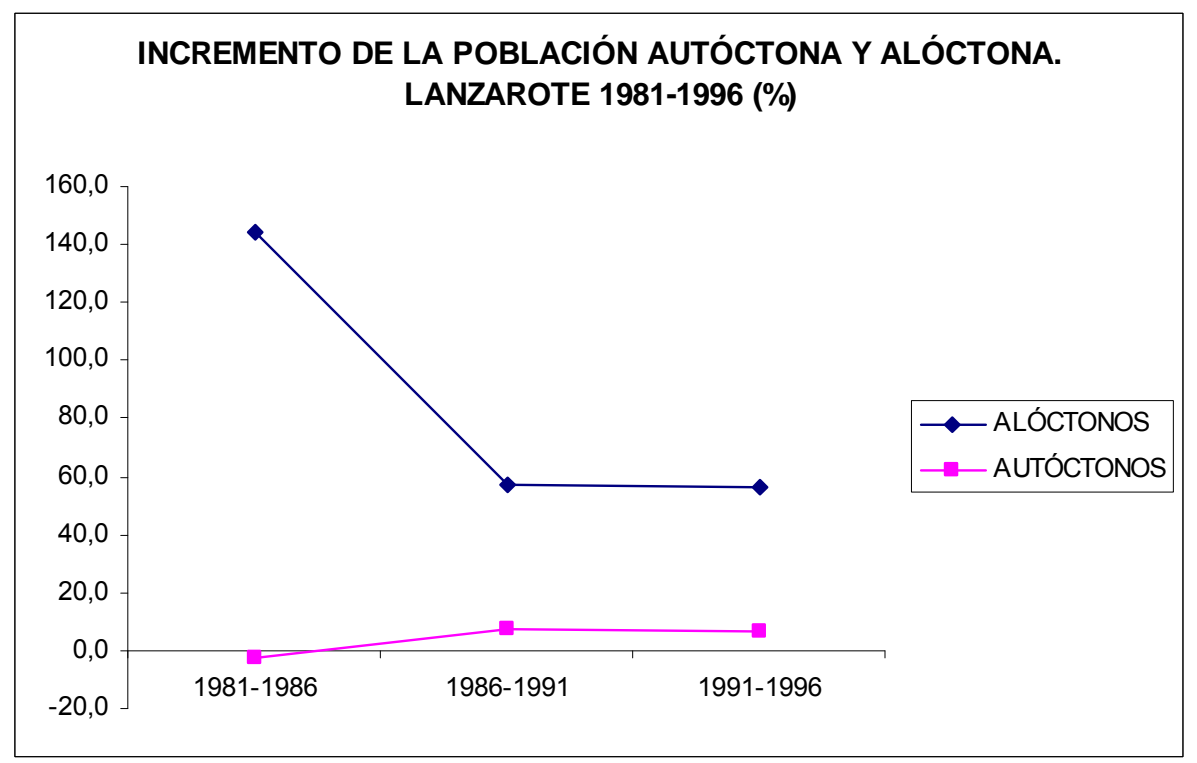

Fuente: Elaboración propia a partir de la población por lugar de nacimiento. ISTAC e INE. Gráfico basado en la Tabla 98.

\section{d.- Autóctonos, alóctonos y turistas}

La relación entre autóctonos y alóctonos señalada se confirma a través del ratio (al/at), puesto que éste afirma el crecimiento continuado y rápido del desequilibrio en la medida en que, si 1986 presenta 227 alóctonos por mil autóctonos, en seis años este indicador sube diez puntos, lo que quiere decir que los nacidos en la isla han pasado del $77 \%$ al $67 \%$. El incremento del ratio es aún más elevado en el quinquenio siguiente. En 1996 se observa el 
mayor desequilibrio hasta el momento, puesto que la población alóctona supone ahora alrededor de 489 personas por mil autóctonos.

Tabla 99. Relación entre autóctonos, alóctonos y turistas. Lanzarote. 1986-1996

\begin{tabular}{|r||c|r|r|r|r|r|r||}
\hline AÑo & Residentes & Autóctonos & Alóctonos & $\begin{array}{c}\text { Turistas } \\
\text { equivalentes al día }\end{array}$ & Habitantes/día & \multicolumn{1}{|c||}{ al/at $^{*}$} & alt/at $^{*}$ \\
\hline \hline 1986 & 55.764 & 45.434 & 10.330 & 16.493 & 72.257 & 227,36 & 590,37 \\
\hline 1991 & 64.911 & 48.678 & 16.233 & 30.515 & 95.426 & 333,48 & 960,35 \\
\hline 1996 & 77.379 & 51.974 & 25.405 & 48.686 & 126.065 & 488,80 & $1.425,54$ \\
\hline
\end{tabular}

*Calculado por cada mil autóctonos

Fuente: Residentes. Población registrada (Censos y Padrones); Habitantes al día: suma de autóctonos, alóctonos (inmigrantes) y turistas; (Alt): alóctonos más turistas equivalentes al día=población foránea. Elaboración propia.

Este desequilibrio demográfico se agrava si ponemos en relación la población foránea (alóctonos y turistas equivalentes diarios) con la población autóctona, que si bien ya era alarmante en 1986, ahora supone una enorme ruptura porcentual con respecto a los nacidos en la isla.

Gráfico 87. Evolución de los ratios alóctonos/autóctonos (al/at) y foráneos/autóctonos (fr/at). Lanzarote. 1986-1996.

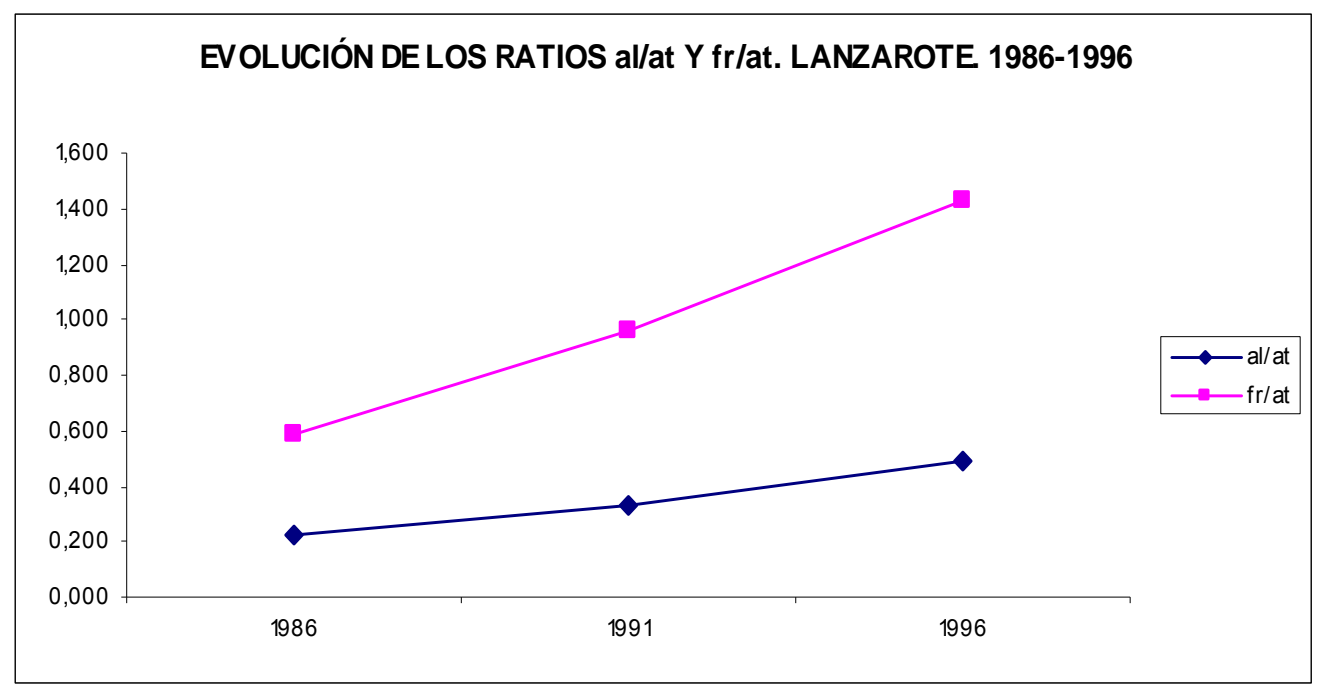

Fuente: Elaboración propia a partir del cálculo de indicadores recogidos en la Tabla 99.

El comienzo de la década de los años noventa (1991) supone el punto de inflexión en el cambio de esta relación, pues los foráneos han alcanzado el $51 \%$ de peso relativo sobre la población total estimada. Alcanza un ratio de 960 foráneos diarios por mil autóctonos. Estas cifras seguirán en crecimiento, de forma que, en 1996, el 58,8 \% de la población que acoge a diario la isla es foránea (turistas equivalentes al día más inmigrantes), se estiman 1.426 
por mil autóctonos (fr/at). El desequilibrio demográfico en relación a los autóctonos (nacidos en la isla) es enorme.

Gráfico 88. Evolución de la población foránea y autóctona. Lanzarote. 1986-1996

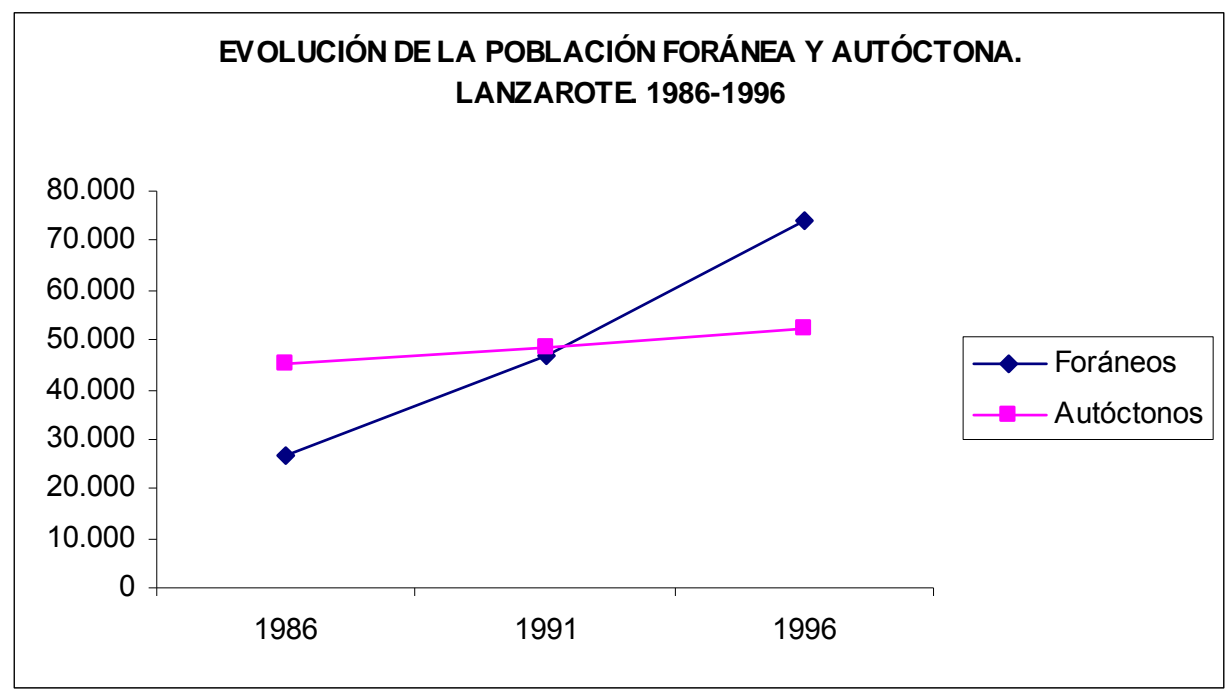

Fuente: Elaboración propia a partir del cálculo de indicadores recogidos en la Tabla 99.

\subsubsection{2.- CONCLUSIONES}

Las dinámicas de crecimiento de la población insular siguen presentando un fuerte ritmo de crecimiento, más intenso aún que en la etapa anterior y sin parangón con respecto a Canarias y España. La explicación de estos fuertes procesos demográficos se sigue encontrando en variables exógenas: las inmigraciones.

Las características, por tanto, de la década (1986-1996), en términos generales, se concretan en lo siguiente:

1.- Continua entrada de trabajadores, que se concreta en un constante y elevado incremento porcentual de la inmigración. Aún cuando el ritmo del crecimiento de la planta de alojamiento turístico se ha ralentizado enormemente, reduciendo, por tanto, la demanda de trabajadores en la construcción, la entrada de población no se reduce, porque en contrapartida, aumenta considerablemente la recepción de turistas a los que hay que dar servicio.

2.- Reducción constante y progresiva de la población autóctona sobre la residente. El índice de evolución de la población autóctona es al final de esta etapa muy inferior al de la población alóctona. Se ha pasado de un $81 \%$ de población autóctona (nacida en la isla) sobre la residente en 1986 (aproximadamente 45.400 personas), al 67\% en una década de evolución (aproximadamente 52.000 personas, en 1996). 
3.- Fuerte desequilibro demográfico por la presión de la población foránea (inmigrantes y turistas equivalentes) que soporta a diario la isla (143 por cada 100 autóctonos), cuya tendencia es al alza. Quedando los autóctonos reducidos al $41 \%$ de la población que acoge la isla, a diario, al final de la etapa, señalándose como punto de inflexión hacia este cambio el año 1991.

La presión sobre equipamientos, infraestructuras y servicios en Lanzarote, en esta etapa como en la anterior, ha de ser explicada por factores demográficos exógenos.

\subsection{3.- EFECTOS SOBRE LA CUALIFICACIÓN Y EL EQUIPAMIENTO EDUCATIVO. 1986-} 1996

\subsubsection{1.- EVOLUCIÓN DEL NIVEL DE INSTRUCCIÓN}

Al igual que en la etapa anterior, la información estadística recoge los niveles de instrucción de la población a partir de diez años, por lo que la contabilización de grupos infantiles con estudios en cursos y con años de vida académica pendiente sigue distorsionado los pesos relativos de los niveles formativos intermedios. Es por ello que la mayor fiabilidad la tenemos en la evolución de los extremos de la jerarquía educativa.

Lanzarote ya no es un espacio social donde el analfabetismo tenga una participación sobresaliente, como ocurría en la década de los años setenta, sino que este estado es significativo ahora por su continuo descenso, aunque en esta etapa de análisis no se consigue su erradicación por completo, sí ha perdido al más de un punto entre 1986 (5\%) y 1996 (3,9\%). Este ciclo de descenso es similar en el conjunto del archipiélago y España, sin grandes variaciones porcentuales entre los tres ámbitos. 
Tabla 100. Evolución del nivel de instrucción. España, Canarias y Lanzarote. Absolutos y relativos.1986-1996.

\begin{tabular}{|c|c|c|c|c|c|}
\hline & ESPAÑ A & & & & \\
\hline INSTRUCCIÓN169 & 1986 & $\%$ & 1991 & $\%$ & 1996 \\
\hline Analfabetos & 1.290 .318 & 3,89 & 1.119.076 & 3,25 & \multirow{8}{*}{ NO CONSTA } \\
\hline Sin Estudios & 12.985 .870 & 39,19 & 7.448 .640 & 21,64 & \\
\hline Primer Grado & 8.228 .298 & 24,83 & 11.723 .287 & 34,05 & \\
\hline $2^{\circ} \mathrm{Grado} 1^{\circ} \mathrm{Ciclo}$ & 4.733 .205 & 14,28 & 6.589 .928 & 19,14 & \\
\hline $2^{\circ}$ Grado $2^{\circ}$ Ciclo & 3.791 .193 & 11,44 & 5.170 .695 & 15,02 & \\
\hline E Universitarias y Equivalentes & 901.550 & 2,72 & 1.084 .303 & 3,15 & \\
\hline Facultades, E.T.S. y $3^{\circ}$ Ciclo & 846.864 & 2,56 & 1.290 .673 & 3,75 & \\
\hline No Clasificados o No Especificado. & 360.161 & 1,09 & --- & --- & \\
\hline TOTAL & 33.137 .459 & & 34.426 .602 & & \\
\hline
\end{tabular}

\begin{tabular}{||l||c|c||c|c||c|c||}
\cline { 2 - 8 } \multicolumn{1}{c|}{} & \multicolumn{2}{l|}{ CANARIAS } \\
\hline \hline INSTRUCCIÓN & 1986 & $\%$ & 1991 & $\%$ & 1996 & $\%$ \\
\hline Analfabetos & 70.873 & 5,76 & 55.338 & 4,29 & 54.011 & 3,81 \\
\hline Sin Estudios & 451.156 & 36,70 & 295.093 & 22,86 & 255.589 & 18,03 \\
\hline Primer Grado & 301.088 & 24,49 & 400.859 & 31,05 & 347.131 & 24,49 \\
\hline $2^{\circ}$ Grado $1^{0}$ Ciclo & 188.959 & 15,37 & 275.240 & 21,32 & 387.654 & 27,35 \\
\hline $2^{\circ}$ Grado 2 ${ }^{\circ}$ Ciclo & 128.018 & 10,41 & 181.629 & 14,07 & 263.116 & 18,56 \\
\hline E Universitarias y Equivalentes & 35.722 & 2,91 & 41.617 & 3,22 & 56.367 & 3,98 \\
\hline Facultades, E.T.S. y 30 Ciclo & 25.097 & 2,04 & 41.318 & 3,20 & 53.605 & 3,78 \\
\hline No Clasificados o No Especificado. & 28.464 & 2,32 & --- & -- & --- & -- \\
\hline TOTAL & 1.229 .377 & & 1.291 .094 & & 1.417 .473 & \\
\hline \hline
\end{tabular}

169 La clasificación establecida considera lo siguiente: Primer grado (EGB $1^{\circ}$ etapa, educación especial, primaria, preaprendizaje industrial y alfabetización de adultos); Segundo grado: $1^{\circ}$ Ciclo (EGB $2^{\circ}$ etapa o ESO, grado elemental conservatorio de música, Artes y oficios, Bachiller elemental, otros medios elementales), $\underline{2}^{\circ}$ Ciclo (BUP y COU, FPI y II, Grado Medio Conservatorio, Oficialía Industrial, etc.); Tercer grado (Escuelas Universitarias y equivalentes) y Nivel Universitario (Facultades, Escuelas técnicas superiores y postgraduados y doctores). 


\begin{tabular}{||l||r|r||r|r||c|c||}
\cline { 2 - 8 } \multicolumn{1}{l|}{} & \multicolumn{2}{l|}{ LANZAROTE } \\
\hline \hline INSTRUCCIÓN & 1986 & $\%$ & 1991 & $\%$ & 1996 & $\%$ \\
\hline Analfabetos & 2.355 & 5,02 & 1.955 & 3,55 & 2.664 & 3,96 \\
\hline Sin Estudios & 15.867 & 33,84 & 11.297 & 20,50 & 7.573 & 11,25 \\
\hline Primer Grado & 17.208 & 36,70 & 19.989 & 36,27 & 22.110 & 32,85 \\
\hline $2^{\circ}$ Grado ${ }^{\circ}$ Ciclo & 4.928 & 10,51 & 11.807 & 21,42 & 19.143 & 28,44 \\
\hline $2^{\circ}$ Grado $2^{\circ}$ Ciclo & 4.787 & 10,21 & 7.134 & 12,94 & 11.226 & 16,68 \\
\hline E Universitarias y Equivalentes & 1.131 & 2,41 & 1.549 & 2,81 & 2.352 & 3,49 \\
\hline Facultades, E.T.S. y $3^{\circ}$ Ciclo & 546 & 1,20 & 1.305 & 2,52 & 2.167 & 3,32 \\
\hline No Clasificados o No Especificado. & 43 & 0,09 & --- & -- & --- & -- \\
\hline TOTAL & 46.882 & & 55.119 & & 67.300 & \\
\hline \hline
\end{tabular}

Nota: Es a partir de 1991 cuando ya aparecen postgraduados registrados dentro de los niveles educativos superiores; Para 1996 tenemos agrupado LODE y LOGSE. No existe dicha desagregación estadística a través del Padrón Municipal de habitantes para el cómputo nacional.

Para 1986: "Población de 10 y más años según título académico". Resultados Autonómicos e Islas. Padrón Municipal de habitantes de 1986. Explotación del ISTAC y del INE para el total nacional.

Para 1991: "Población de 10 y más años según estudios realizados y sexo, por grupos de edad. Comunidad Autónoma e Islas". Censo de Población de 1991. Explotación del ISTAC; "Población de 10 y más años por Sexo, Grupos de edad y Nivel de instrucción. Total Nacional" y "Población de $2^{\circ}$ y $3^{\circ}$ grado nivel de instrucción por Sexo, Grupos de edad y grado de instrucción. Total Nacional". Censo de Población de 1991. INE.

Para 1996: "Población de 10 y más años según estudios realizados por grupos de edad y sexo". Encuesta de Población. Canarias 1996. ISTAC. Elaboración propia.

Gráfico 89. Evolución del nivel de instrucción. Lanzarote. 1986-1996 (\%).

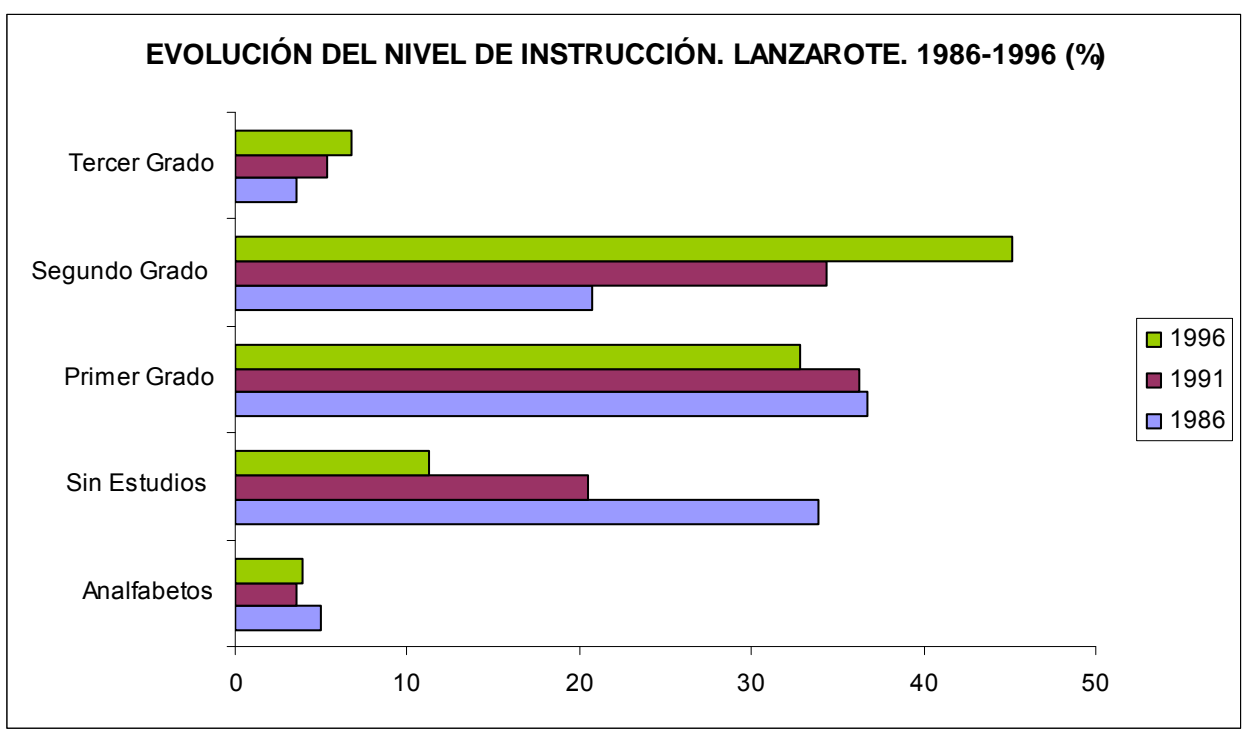

Fuente: Censo y Padrón municipal de habitantes. INE; Encuesta de Población de Canarias, ISTAC; Gráfico basado en la Tabla 100. Elaboración propia. 
En el otro extremo, la población con formación superior en la isla continúa en ascenso desde la etapa anterior. Su peso relativo se ha doblado a lo largo de esta década, pasando del $3,6 \%$ en 1986 , al $6,8 \%$ en 1996 .

Gráfico 90. Evolución del analfabetismo y la educación superior. Extremos. Lanzarote. 1986-1996 (\%).

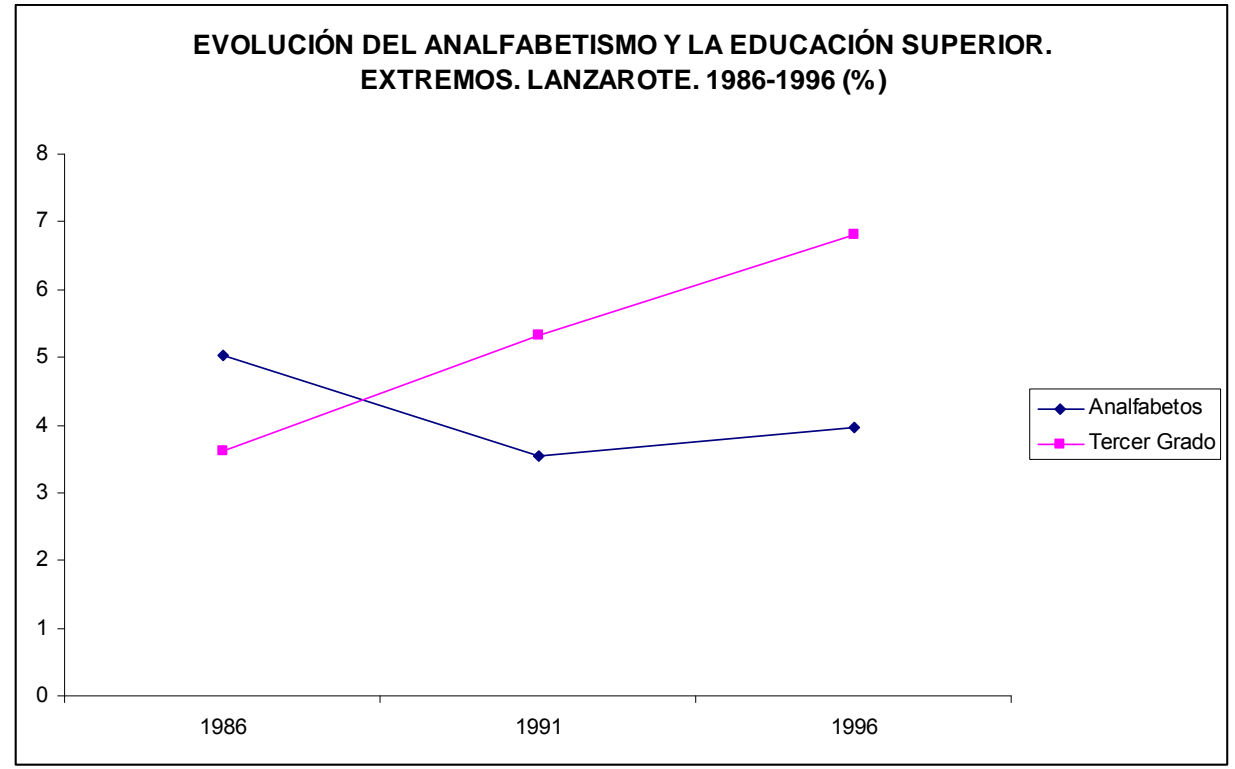

Fuente: Censo y Padrón municipal de habitantes. INE; Encuesta de Población de Canarias, ISTAC; Gráfico basado en la Tabla 100. Elaboración propia.

Una vez señalado esto, el escollo se encuentra en el nivel formativo intermedio entre ambos extremos (analfabetos y formación superior), en relación a la dificultad de acercarnos al peso relativo de la población sin estudios y con estudios básicos en Lanzarote, por la limitación estadística antes citada. Siendo consciente de ello, nos atrevemos a señalar la evolución positiva, ascendente, que, por un lado, la formación de segundo grado, $1^{\circ}$ ciclo, ha tenido en esta década, es decir crece el número de personas que han completado la educación general básica obligatoria ${ }^{170}$ y por otro lado la instrucción escolar de $2^{\circ}$ ciclo, que incluye la formación profesional.

Al contrario que en la etapa anterior, la población sin estudios o que sólo ha alcanzado la primaria se ha reducido en relación al peso porcentual sobre la población de diez y más años. La dinámica se muestra descendente aunque su proporción está distorsionada por no realizase sobre el total de población mayor de 14 años de edad, que es cuando termina el ciclo formativo obligatorio. Aún así, es sabido que el alto porcentaje de personas sin los

170 Segundo Grado $1^{\circ}$ ciclo (EGB $2^{\circ}$ etapa o ESO, grado elemental conservatorio de música, Artes y oficios, Bachiller elemental, otros medios elementales). 
estudios básicos acabados es típico de sociedades con mercados laborales incipientes y que además no precisan de altos niveles formativos en su oferta, lo que lleva al abandono prematuro de los ciclos de formación ante la facilidad de acceso al mercado laboral. Y las sociedades que basan su actividad económica principalmente en el sector servicios centrado en el turismo producen estás formas jerárquicas en su nivel de instrucción (el mayor engrosamiento está en la base). Lanzarote responde a estas características al igual que el conjunto del archipiélago.

Gráfico 91. Evolución de la población sin estudios, la educación básica y media. Lanzarote. 1986-1996 (\%).

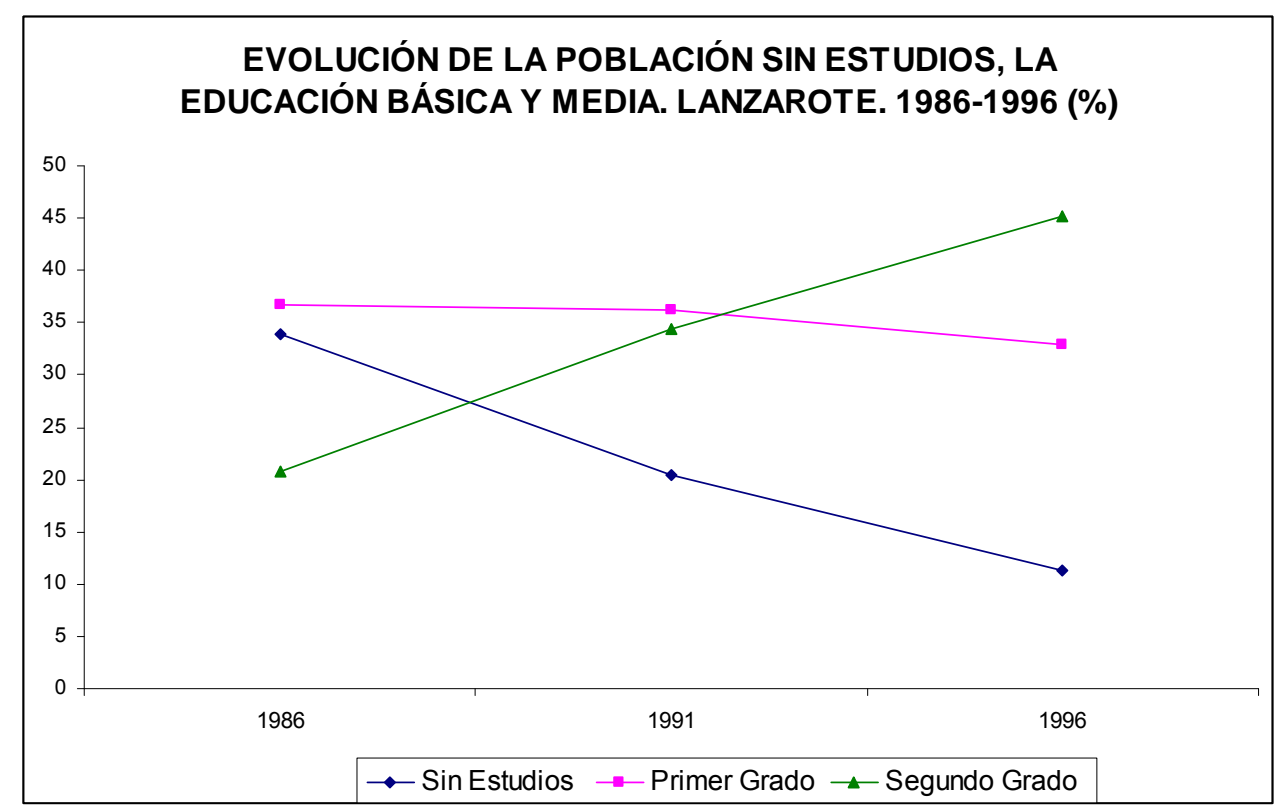

Fuente: Censo y Padrón municipal de habitantes. INE; Encuesta de Población de Canarias, ISTAC; Gráfico basado en la Tabla 100. Elaboración propia.

La línea de desarrollo descrita para la isla, es la misma que sigue el ámbito autonómico y nacional. El mayor peso relativo lo ostenta la población que ha terminado la educación obligatoria, con porcentajes superiores en Canarias que en España. 
Gráfico 92. Evolución del nivel de instrucción. España, Canarias y Lanzarote. 1986-1996 (\%)

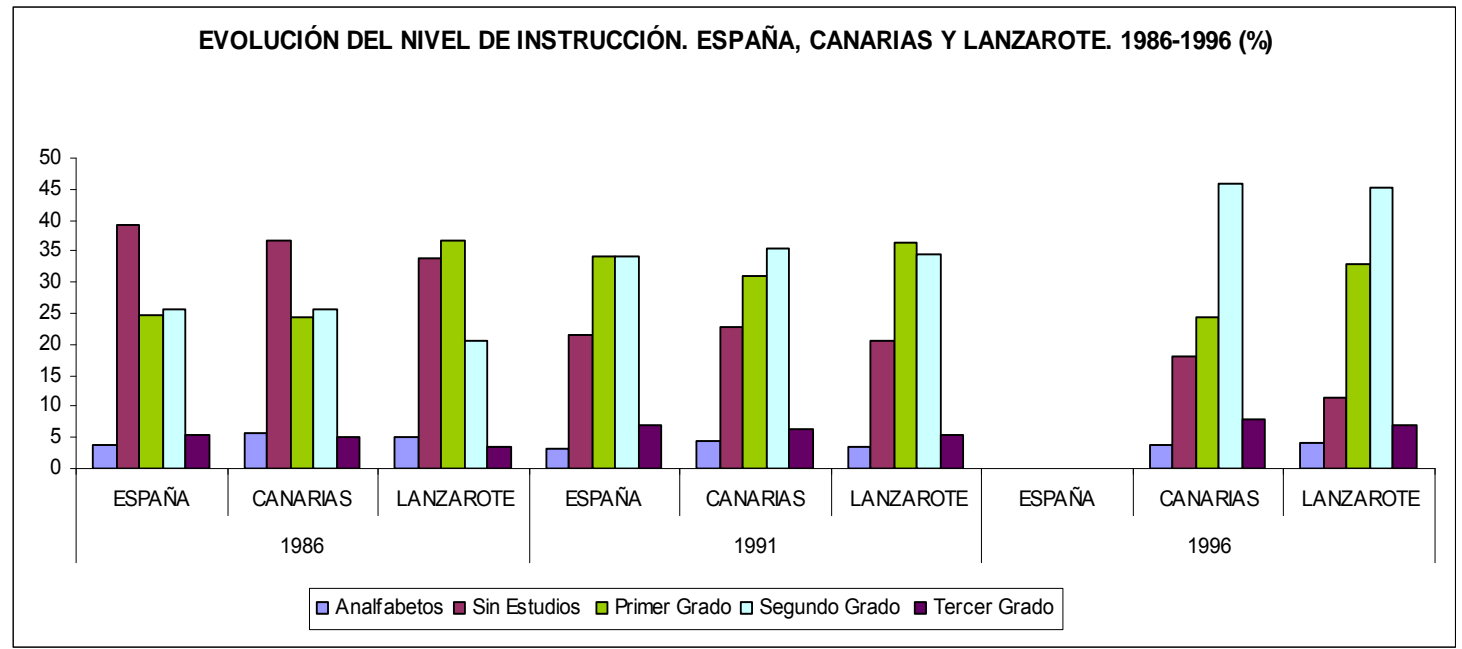

Fuente: Censo y Padrón municipal de habitantes. INE; Encuesta de Población de Canarias, ISTAC; Gráfico basado en la Tabla 100. Elaboración propia.

En términos generales, Lanzarote alcanza el nivel formativo de su población más alto desde 1970, educación básica obligatoria seguida por la formación profesional, pues sigue concentrando actividad en la construcción y en un sector servicios destinado a un turismo de masas que no solicita alta capacitación entre sus trabajadores.

La aportación que hace la inmigración a esta dinámica se analizará en las próximas líneas.

\section{a.- Nivel de instrucción de los inmigrantes}

El análisis de la evolución del nivel de instrucción de los inmigrantes en este periodo (19861996), está limitado por la falta de desagregación de datos del Censo de 1991, pero sí podemos constatar la evolución que ha tenido el nivel cultural de los inmigrantes entrados a Lanzarote entre censos (1981 y 1991), a través de una explotación realizada por el Instituto de Estadística de Canarias (ISTAC). 
Tabla 101. Inmigrantes por nivel de instrucción y lugar de procedencia entre 1981 y 1991. Lanzarote. (\%).

\begin{tabular}{|l|c|c|c|c|c||}
\cline { 2 - 7 } \multicolumn{1}{c|}{} & \multicolumn{5}{c|}{ PROCEDENCIA } \\
\hline \hline INSTRUCCIÓN & Otra isla & Resto de España & Europa & Otros Países & TOTAL \\
\hline \hline Analfabetos y Sin estudios & 12,3 & 7,3 & 4,8 & 8,5 & 10,7 \\
\hline Primaria & 60,1 & 59,1 & 35,8 & 41,7 & 59,3 \\
\hline Secundaria & 17,1 & 23,7 & 38,4 & 33,0 & 20,2 \\
\hline Enseñanza. Universitaria & 10,4 & 10,4 & 20,0 & 16,6 & 10,2 \\
\hline & 100,0 & 100,0 & 100,0 & 100,0 & 100,0 \\
\hline
\end{tabular}

Nota: no se disponen de datos anuales.

Fuente: "Nivel cultural de los inmigrantes llegados entre 1981 y 1991. Lanzarote". Censo de Población y Viviendas. 1991. Explotación del Instituto Canario de Estadística (ISTAC).

Lo que se desprende de esta comparación es la consolidación en la isla de un perfil inmigratorio de escasa cualificación, puesto que el protagonista es el inmigrante con educación primaria, principalmente llegado de Canarias y de España. La población migrante cuyo lugar de procedencia es Europa trae la mayor formación.

Gráfico 93. Inmigrantes por nivel de instrucción entre 1981-1991. Lanzarote (\%).

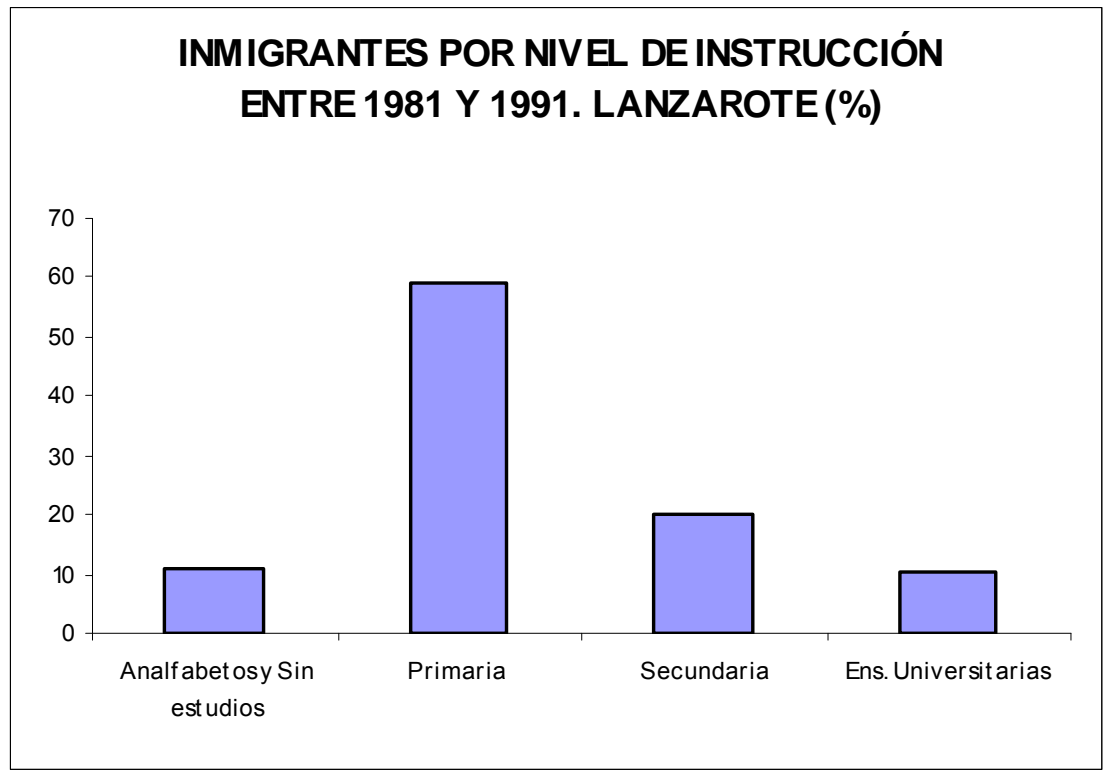

Fuente: Censo de Población y Viviendas. Explotación del Instituto Canario de Estadística (ISTAC). Gráfico basado en la Tabla 101. Elaboración propia.

No será hasta la mitad de la década de los años noventa cuando el perfil formativo de la inmigración se modifique, pasando a caracterizarse por niveles de instrucción medios, el 
$52 \%$ poseen formación profesional y el $29 \%$ sólo ha alcanzado la primaria. Los inmigrantes con estudios superiores siguen siendo muy reducidos $(9 \%)$, pues el mercado laboral se ha centrado en la construcción y los servicios al turismo, ramas éstas que no demandan altos niveles de instrucción.

Tabla 102. Inmigrantes por nivel de instrucción y lugar de procedencia. Lanzarote. Absolutos y relativos. 1996

\begin{tabular}{|c|c|c|c|c|c|c|c|c|c|c|}
\hline \multirow[b]{3}{*}{ INSTRUCCIÓN } & \multicolumn{10}{|c|}{ PROCEDENCIA } \\
\hline & \multicolumn{2}{|c|}{ Otra isla } & \multicolumn{2}{|c|}{ Resto de España } & \multicolumn{2}{|c|}{ Europa } & \multicolumn{2}{|c|}{ Otros Países } & \multicolumn{2}{|c|}{ TOTAL } \\
\hline & Abs & $\%$ & Abs & $\%$ & Abs & $\%$ & Abs & $\%$ & Abs & $\%$ \\
\hline No sabe leer ni escribir & 169 & 2,20 & 146 & 1,49 & 10 & 0,48 & 52 & 3,80 & 377 & 1,80 \\
\hline Sin estudios o incompleta & 631 & 8,20 & 633 & 6,48 & 110 & 5,28 & 164 & 11,99 & 1.538 & 7,35 \\
\hline Primaria & 2.538 & 32,99 & 2.806 & 28,71 & 360 & 17,29 & 426 & 31,14 & 6.130 & 29,30 \\
\hline Secundaria & 3.666 & 47,65 & 5.323 & 54,46 & 1.316 & 63,21 & 631 & 46,13 & 10.936 & 52,28 \\
\hline Enseñanza. Universitaria & 689 & 8,96 & 867 & 8,87 & 286 & 13,74 & 95 & 6,94 & 1.937 & 9,26 \\
\hline TOTAL & \multicolumn{2}{|c|}{7.693} & \multicolumn{2}{|c|}{9.775} & \multicolumn{2}{|c|}{2.082} & \multicolumn{2}{|c|}{1.368} & \multicolumn{2}{|c|}{20.918} \\
\hline
\end{tabular}

\begin{tabular}{|c|c|c|c|c|}
\hline & \multicolumn{4}{|c|}{ PESO SOBRE EL TOTAL } \\
\hline & Otra isla & Resto de España & Europa & Otros Países \\
\hline INSTRUCCIÓN & $\%$ & $\%$ & $\%$ & $\%$ \\
\hline No sabe leer ni escribir & 0,81 & 0,70 & 0,05 & 0,25 \\
\hline Sin estudios o incompleta & 3,02 & 3,03 & 0,53 & 0,78 \\
\hline Primaria & 12,13 & 13,41 & 1,72 & 2,04 \\
\hline Secundaria & 17,53 & 25,45 & 6,29 & 3,02 \\
\hline Enseñanza Universitaria & 3,29 & 4,14 & 1,37 & 0,45 \\
\hline$\%$ Sobre el Total & 38,78 & 46,73 & 9,95 & 6,54 \\
\hline TOTAL & \multicolumn{4}{|c|}{20.918} \\
\hline
\end{tabular}

Fuente: “Población migrante de 6 y más años según estudios realizados por lugar de procedencia. Lanzarote”. Encuesta de población de Canarias, 1996. Elaboración propia. 
Gráfico 94. Inmigrantes por nivel de instrucción. Lanzarote. 1996 (\%)

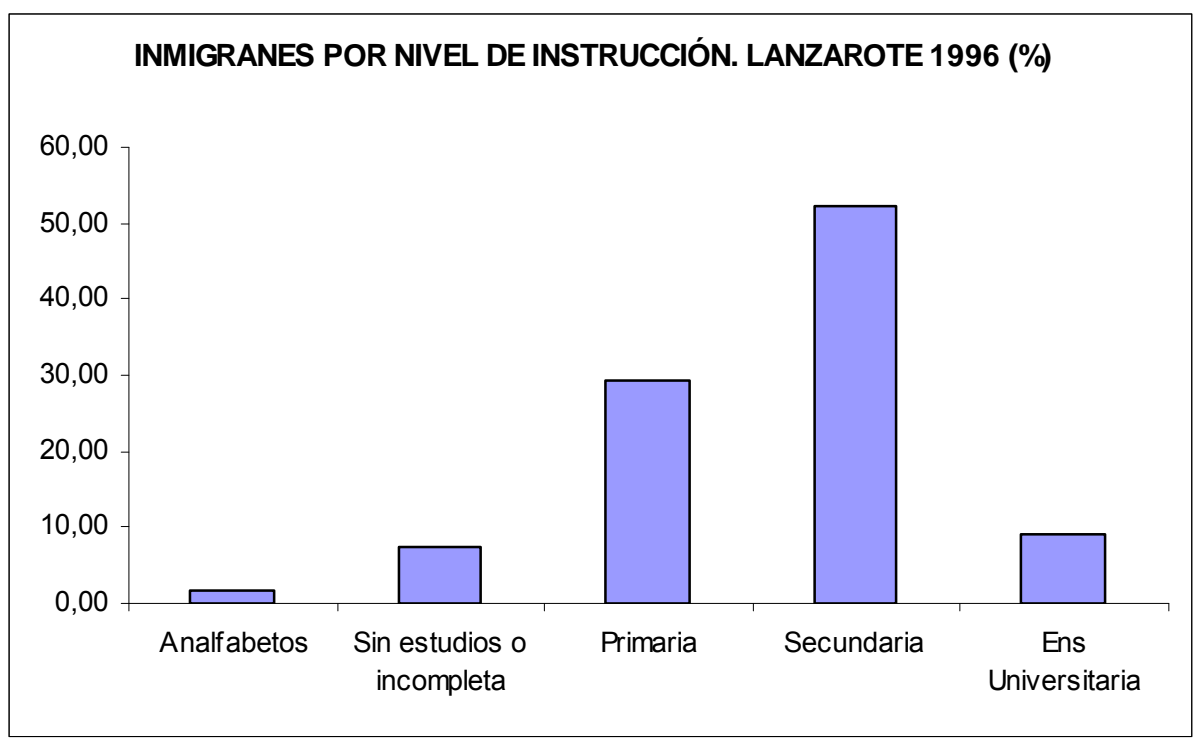

Fuente: Encuesta de población de Canarias, 1996. Gráfico basado en la Tabla 102. Elaboración propia.

En comparación con los datos que arrojan las medias entre Censos, el mayor nivel de instrucción en 1996 sigue estando entre los inmigrantes procedentes de otras comunidades autónomas (resto de España), como se puede ver en la siguiente tabla, que en su mayoría poseen formación de grado medio $(25,5 \%)$, frente a la inmigración insular con este nivel, que no llega al $18 \%$.

La inmigración Europea se sigue caracterizando por formación de grado medio (63\%), y la procedente de países externos a Europa se reparte entre primaria (31\%) y secundaria $(46 \%)$.

La aportación a la formación universitaria está compartida entre la inmigración procedente de otras islas del archipiélago y del resto de España, pues aunque siempre escasa, la diferencia entre ambos ámbitos territoriales de origen no llega al 1\%, y juntos, sobre el total, aportan el $7,4 \%$. 
Gráfico 95. Inmigrantes por nivel de instrucción y procedencia. Lanzarote. 1996 (\%)

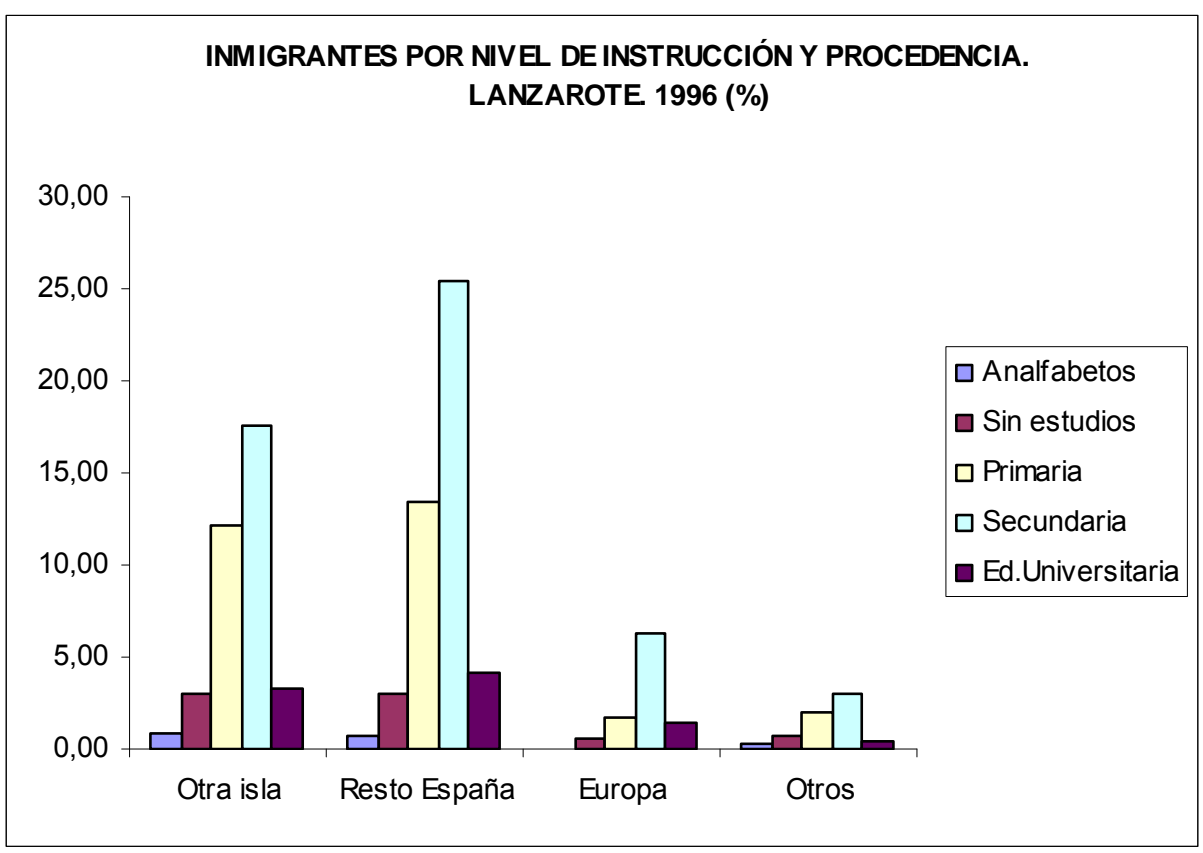

Fuente: Encuesta de población de Canarias, 1996. Gráfico basado en la Tabla 102. Elaboración propia

A pesar de ello, el análisis detallado por origen, nos revela que el perfil de los inmigrantes con procedencia de la Unión Europea (no así para los que vienen de terceros países), al final de esta etapa, concentra niveles de instrucción más elevados. Por lo que la inmigración externa a las islas y a España produce mejorados en el nivel formativo de la población que acoge la isla, en 1996, pero sólo supone el 10\% de la inmigración.

Las opciones laborales que oferta la isla no atraen población con alta instrucción, la formación básica y profesional de los inmigrantes marca esta etapa, frente a la anterior, marcada por la primaria y la población sin estudios.

\subsubsection{2.- EL EQUIPAMIENTO EDUCATIVO}

La mitad de la década de los años ochenta llega con escolarización plena, niveles aceptables en los equipamientos que corresponden a la educación obligatoria, y déficits en los servicios educativos referidos a colectivos especiales. A ello se unía la inadecuación entre sociedad, economía y formación profesional.

Vamos por tanto a describir la dinámica del equipamiento educativo en esta etapa, principalmente entre 1991 y 1996. Que se enmarca en la Ley Orgánica 8/1985, de 3 de julio, reguladora del Derecho a la Educación (LODE), la Ley Orgánica 1/1990, de 3 octubre, de Ordenación General del Sistema Educativo (LOGSE) y en el Real Decreto 1004/1991, de 14 de junio, por el que se establecen los requisitos mínimos de los Centros que impartan 
enseñanzas de régimen general no universitarias. Señalar que tras la entrada en vigor de la LOGSE, el sistema educativo queda dividido de la siguiente forma:

- Educación infantil: de carácter no obligatorio, son aquellos equipamientos destinados a la educación de los niños de entre 0 y 6 años, constando de dos ciclos educativos: de 0 a 3 y de 3 a 6 años de edad.

- Educación primaria: de carácter obligatorio y "gratuito". Comprende seis cursos distribuidos en tres ciclos de dos cursos cada uno. Se incluyen a los escolares entre 6-12 años.

- Educación secundaria: comprende la obligatoria y la no-obligatoria. La primera, la ESO, comprende dos ciclos de 2 años cada uno: 12-14 y 14-16. La no obligatoria tiene una duración de dos años, en la que existían dos vías posibles: Bachillerato y Formación Profesional especifica, de grado medio y superior.

- Educación Superior: comprende los cursos que se imparten en centros universitarios, y se accede a la mayoría de ellos a través de pruebas de selección.

El primer dato significativo que encontramos es que, si en 1986 la oferta para preescolar (entre 3 y 6 años de edad) era suficiente, ahora, cinco años después, en 1991, está levemente estrangulada, puesto que la relación de alumnos por aula supera los 25 que es el estándar marcado por ley para este tipo de educación (R. D. 1004/1991. Art. 13.1). El déficit se estima en $0,5 \%$ (casi 10 plazas). Esta rápida variación (pues sucede en cinco-seis años) se debe principalmente a la entrada de mano de obra externa a la isla (que traen a sus familias y que también conforman nuevas familias) y la actividad laboral femenina, que hace necesaria la institucionalización temprana de los hijos. El porcentaje de cobertura ante la demanda potencial es tan sólo del $50 \%$. 
Tabla 103. Oferta y demanda docente por tipo. Lanzarote. 1991

\begin{tabular}{|c|c|c|c|c|c|}
\hline \multicolumn{2}{|c|}{ Nivel } & Preescolar & $\begin{array}{c}\text { Primaria y Secundaria } \\
\text { Obligatoria (EGB). }\end{array}$ & $\begin{array}{c}\text { Secundaria no } \\
\text { obligatoria (BUP, } \\
\text { COU, F.P.) }\end{array}$ & $\begin{array}{l}\text { E. P. } \\
\text { Adultos }\end{array}$ \\
\hline \multicolumn{2}{|l|}{ Centros } & --- & 48 & 9 & 9 \\
\hline \multicolumn{2}{|l|}{ Unidades } & 77 & 467 & 188 & 12 \\
\hline \multicolumn{2}{|c|}{ Puestos (oferta) } & $1.957^{*}$ & --- & --- & --- \\
\hline \multicolumn{2}{|l|}{ Profesores } & 80 & 551 & 312 & 18 \\
\hline \multicolumn{2}{|l|}{ Alumnos } & 1.967 & 10.148 & 4.288 & 882 \\
\hline \multicolumn{2}{|c|}{$\begin{array}{l}\text { Población de Derecho } \\
\text { (demanda) }\end{array}$} & 3.909 & 10.148 & --- & --- \\
\hline \multicolumn{2}{|c|}{$\begin{array}{l}\text { Nivel de Cobertura. } \\
\text { Oferta (\%) }\end{array}$} & 50,1 & 100,0 & --- & --- \\
\hline \multirow{2}{*}{$\begin{array}{l}\text { Superávit } 0 \\
\text { déficit }\end{array}$} & Absolutos & -10 & --- & --- & --- \\
\hline & $\%$ & $-0,5$ & --- & --- & --- \\
\hline \multicolumn{2}{|c|}{ Alumnos/Unidad } & 25,5 & 21,7 & 22,8 & 73,5 \\
\hline \multicolumn{2}{|c|}{ Alumnos/Profesor } & 24,6 & 18,4 & 13,7 & 49,0 \\
\hline
\end{tabular}

$\left({ }^{*}\right)$ Al no existir datos sobre el número de plazas ofertadas, los puestos se han calculado a partir del déficits estimado.

Nota: El número de centros que se recoge incluyen los públicos, privados y concertados. La población de derecho (demanda) ha sido estimada a partir de las cohortes quinquenales de edad, del Censo de Población de 1991. INE.

Fuente: "Centros según nivel por cursos académicos, curso 1991-1992", "Alumnos según nivel por cursos académicos, curso 19911992", "Profesores según nivel por curso académico, 1991-1992", "Grupos según nivel por cursos académicos, 1991-1992”. Lanzarote. Estadísticas Insulares y Municipales de Canarias (IX Educación, pp. 87-91). 1991. ISTAC (en esta estadística del ISTAC no constan el número de centros que imparten preescolar, ni centros específicos, con lo cual se ha supuesto que se conservan el mismo número que en 1986); Consejería de Educación y Cultura "Estudio de la realidad educativa y cultural". Área de Educación. Programa de educación de adultos. Cabildo Insular de Lanzarote, 1990.

En el caso de la Educación General Básica, se ha unido ambos ciclos obligatorios (primaria y secundaria), y se ha tomado el estándar de 30 alumnos por aula (unidad) que establece la Ley Orgánica 1/1990, (Disposición Adicional Tercera. Art.3. a)). Aunque dicha Ley modifica la edad de escolarización obligatoria (de 6 a 16 años), se toma aquí para analizar la capacidad de la isla en 1991 el referente anterior, de 6 a 14 años, puesto que esta Ley acaba de entrar en vigor y aún no se ha llevado a efecto. La escolarización es plena, al igual que lo era en 1986. Los datos en relación a la densidad de alumnos por aulas son muy positivos, puesto que no se llega a cubrir el estándar legal, lo que supone que la oferta de plaza (puestos) es superior a la demanda. Esto permite que la isla pueda dar respuesta si sobreviene un rápido incremento de la demanda fruto de los procesos migratorios, en el nivel de enseñanza obligatorio.

En términos generales, la educación secundaria no obligatoria presenta niveles suficientes, sin saturación en las aulas, con un ratio por debajo de 23 alumnos/unidad. Esta situación es 
similar si se analiza por separado la capacidad docente en bachillerato y en formación profesional:

a. Para la primera, la relación alumno/unidad está por debajo del estándar (Ley 1/1990. Art. 27.1 establece 35 alumno por unidad) en 10 alumnos. La isla ha pasado de tener dos centros, en el municipio de Arrecife, a abrir nuevos y localizarlos en otros municipios.

b. Para la segunda, el estándar legal se establece entre profesores y alumnos (Ley 1/1990. Art. 35.1: 1 profesor por cada 30 alumnos), siendo esta relación muy baja, a cada profesor le corresponde aproximadamente 10. Además que la baja densidad de alumnos en las aulas permite mejorar mucho la atención y calidad hacia el educando.

Tabla 104. Capacidad docente. Bachillerato y Formación profesional. Lanzarote. 1991

\begin{tabular}{|l|c|c|c|c|c|c|}
\hline Tipo & Centros & Unidades & Profesores & Alumnos & Alumnos/Unidad & Alumnos/profesor \\
\hline \hline B.U.P & 7 & 108 & 244 & 2.675 & 24,7 & 10,9 \\
\hline F.P. & 2 & 80 & 168 & 1.613 & 20,2 & 9,6 \\
\hline
\end{tabular}

Fuente: "Centros según nivel por cursos académicos, curso 1991-1992", "Alumnos según nivel por cursos académicos, curso 19911992", "Profesores según nivel por curso académico, 1991-1992", "Grupos según nivel por cursos académicos, 1991-1992". Lanzarote. Estadísticas Insulares y Municipales de Canarias (IX Educación, pp. 87-91), 1991. ISTAC.

Por otro lado, el dato positivo con respecto a la etapa anterior, es que en la década de los años noventa, Lanzarote se ha abierto a nuevas posibilidades educativas profesionales para su población. Puesto que en 1987 se había creado la Escuela de Hostelería de Teguise $^{171}$, que aparece cuando la isla ya se encuentra ante una economía turística consolidada (inaugurada oficialmente en el curso 89/90). Este nuevo equipamiento reduce la desconexión entre ciclos formativos profesionales y demanda laboral, tan grave en la etapa anterior.

A ello se añade, en 1993, las enseñanzas de Técnico de Empresas y Actividades Turísticas (TEAT), con la creación de la Escuela de Turismo (como centro adscrito a la Escuela Oficial de Turismo de Canarias), adquiriendo grado universitario (B.O.C. 11.10.93) con la posterior adscripción a la Universidad de Las Palmas de Gran Canaria (curso 1998/1999).

171 La Escuela de Hostelería de Teguise (EHOTEG), aparece bajo la tutela del Ayuntamiento de Teguise; http://www.teguise.com/escTurismo/historia.htm. 
Por esta época entra en funcionamiento otro centro universitario, la E.U. de Enfermería, adscrita a la Universidad de Las Palmas de Gran Canaria, puesta en marcha en el año 1991.

Tabla 105. Centros universitarios por año de creación. Lanzarote

\begin{tabular}{|l|l|c|}
\hline \hline Tipo & Nombre & Año \\
\hline \hline $\begin{array}{l}\text { E.U de Grado Medio } \\
\text { (Diplomatura) }\end{array}$ & E. U. de Turismo de Lanzarote & 1993 \\
\hline $\begin{array}{l}\text { E.U de Grado Medio } \\
\text { (Diplomatura) }\end{array}$ & E. U. de Enfermería & 1991 \\
\hline
\end{tabular}

Fuente: http://www.cabildodelanzarote.com/eutl/; www.ulpgc.es

No debemos olvidar que a ellas se une la sede de la UNED, que sigue funcionando con regularidad desde su creación.

Con estos centros, no sólo se acerca la isla a mejorar y adaptar su capital humano al mercado laboral y económico que ha desarrollado, basado en el turismo, si no que, además, se ha empezado a dar pasos hacia la descentralización de los estudios universitarios en la capital de provincia, reduciéndose los efectos de la insularidad, posibilitando la formación especializada y ampliando las posibilidades y oportunidades de la población local en la medida en que se permite reducir costes a las familias para formación de los hijos.

En relación a 1996, la isla ha ampliado la cobertura en educación infantil no obligatoria (preescolar), reduciendo la relación alumno por unidad en relación a 1991 (que en relación al estándar se encontraba estrangulada), lo que quiere decir que reduce la densidad en el aula. Aunque no presenta suficiente capacidad como para responder a la demanda potencial (población entre 3 y 6 años), pero sí a la demanda real, pues en relación a las unidades quedan puestos sin ocupar, o sea, plazas libres, por lo que no se pueden señalar déficits. 
Tabla 106. Oferta y demanda docente. Infantil, E.G.B y Medias. Lanzarote. 1996

\begin{tabular}{|l||c|c|c||}
\hline \multicolumn{1}{|c|}{ Nivel } & Preescolar * & $\begin{array}{c}\text { Primaria y Secundaria } \\
\text { Obligatoria (EGB-ESO). }\end{array}$ & $\begin{array}{c}\text { Secundaria no } \\
\text { obligatoria (BUP, COU y } \\
\text { F.P.) }\end{array}$ \\
\hline \hline Centros & --- & 44 & 10 \\
\hline Unidades & 120 & 516 & 121 \\
\hline Puestos (oferta) & --- & -- & 422 \\
\hline Profesores & --- & 713 & 3.021 \\
\hline Alumnos & 2.701 & 11.978 & 3.921 \\
\hline Población de Derecho (demanda) & 4.071 & 12.383 & 4.235 \\
\hline $\begin{array}{l}\text { Capacidad según número de } \\
\text { unidades }\end{array}$ & 3.000 & 15.480 & 24,9 \\
\hline Alumnos/Unidad & 22,5 & 18,9 & 7,16 \\
\hline Alumnos/Profesor & --- & 18,8 & \\
\hline
\end{tabular}

$\left(^{*}\right)$ La educación de preescolar (entre 3 y 6 años) está dentro de Centros de Educación primaria.

Nota: El número de centros que se recoge incluyen los públicos, privados y concertados. La población de derecho (demanda) ha sido estimada a partir de las cohortes quinquenales de edad, del Censo de Población de 1991. INE.

Fuente: "Centros docentes no universitarios por islas y cursos. 1997-1998", "Aulas de educación de adultos y profesores, curso 19961997", "Grupos de alumnos en primaria y secundaria. Curso 1997-1998". Anuario Estadístico de Canarias. 2001. ISTAC. Elaboración propia.

Tabla 107. Evolución de la capacidad docente en preescolar. Lanzarote. 1986-1996

\begin{tabular}{||c||c|r||c|c||}
\hline Año & Unidades & $\begin{array}{c}\text { Incremento } \\
\text { quinquenal } \\
(\%)\end{array}$ & Alumnos & $\begin{array}{c}\text { Incremento } \\
\text { quinquenal } \\
(\%)\end{array}$ \\
\hline \hline 1986 & 79 & & 1.642 & \\
\hline 1991 & 77 & $-2,5$ & 1.967 & 19,8 \\
\hline 1996 & 120 & 55,8 & 2.701 & 37,3 \\
\hline
\end{tabular}

Fuente: Elaboración propia a partir de la tabla anterior.

La dinámica de este servicio a lo largo de la década, por tanto, es positiva en relación a que la isla ha ido dando respuesta adecuada a las demandas sociales derivadas principalmente del cambio del papel femenino, y el crecimiento de la oferta ha crecido en relación a la demanda, sin poderse señalar déficits en toda la etapa.

Tampoco se pueden señalar déficits en relación a la enseñanza básica obligatoria. Que ha mantenido durante toda la etapa una evolución positiva, con porcentajes de incremento adecuados a previsiones de demanda, de modo que la capacidad de ocupación por unidad 
escolar no sólo no se ha desbordado, sino que se ha reducido la presión sobre las mismas, no llegando a cubrir de manera amplia el estándar de calidad normalizado.

Tabla 108. Evolución de la capacidad en la enseñanza obligatoria. Lanzarote. 1986-1996

\begin{tabular}{||c||c|c||c|c||c|r||r||}
\hline Año & Unidades & $\begin{array}{c}\text { Incremento } \\
\text { quinquenal } \\
(\%)\end{array}$ & Profesores & $\begin{array}{c}\text { Incremento } \\
\text { quinquenal } \\
(\%)\end{array}$ & Alumnos & $\begin{array}{c}\text { Incremento } \\
\text { quinquenal } \\
(\%)\end{array}$ & Alumnos/unidades \\
\hline \hline 1986 & 402 & & 356 & & 10.700 & & 28,5 \\
\hline 1991 & 467 & 16,2 & 551 & 54,8 & 10.148 & $-5,2$ & 21,7 \\
\hline 1996 & 516 & 10,5 & 713 & 29,4 & 11.978 & 18,0 & 18,9 \\
\hline
\end{tabular}

Fuente: Elaboración propia a partir de las Tablas 36 y 105.

Como en momentos anteriores, la información sobre el resto de equipamiento educativo no universitario, a lo largo de todo el periodo es escasa y a mitad de los años noventa sigue siendo así. Por tanto, se señalan las dinámicas que se han podido constatar:

Tabla 109. Capacidad docente. Resto de oferta no universitaria. Lanzarote. 1996

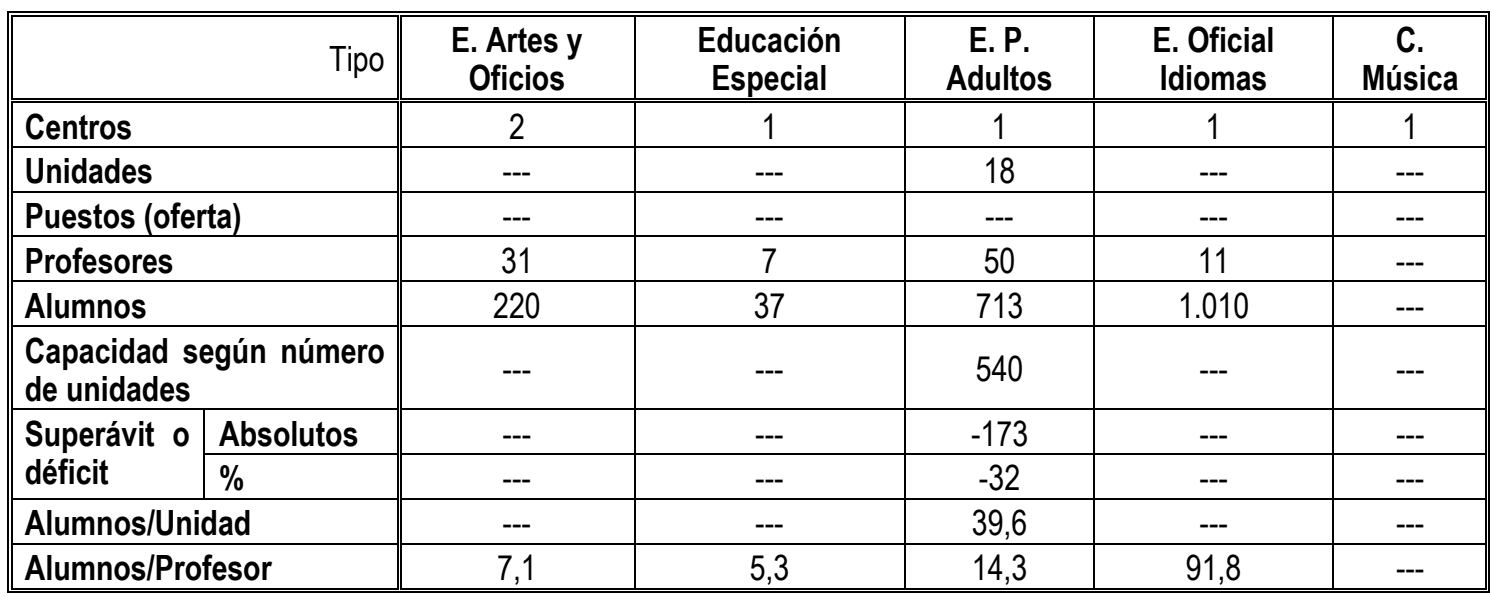

Fuente: "Profesores y alumnos de Educación Especial, Escuelas oficiales de Idiomas y Escuelas de Artes Aplicadas y Oficios Artísticos. Cursos 1996-1997. Lanzarote". "Aulas de educación de adultos y profesores, curso 1996-1997. Lanzarote". Anuario Estadístico de Canarias. 2001. ISTAC. Elaboración propia.

Los centros de educación de adultos, en 1996 están colapsados, puesto que, tomando como estándar 30 alumnos por aula, hay casi 40 alumnos, el déficits se calcula en $32 \%$, situación que salva por la elevada contratación de profesorado que muestra. Este estado de estrangulamiento es al que se viene asistiendo en toda la etapa, en la que, aunque se ha producido un incremento positivo del número de unidades docentes, el volumen de alumnos que asiste es enorme, sólo salvado por la incorporación constante de nuevo profesorado. 
Tabla 110. Evolución de la capacidad en la Enseñanza de Adultos. Lanzarote. 1986-1996

\begin{tabular}{|c||c|c||c|c||c|c||c||}
\hline Año & Unidades & $\begin{array}{c}\text { Incremento } \\
\text { quinquenal } \\
(\%)\end{array}$ & Profesores & $\begin{array}{c}\text { Incremento } \\
\text { quinquenal } \\
(\%)\end{array}$ & Alumnos & $\begin{array}{c}\text { Incremento } \\
\text { quinquenal } \\
(\%)\end{array}$ & Alumnos/unidades \\
\hline 1986 & No consta & & 4 & & 452 & & -- \\
\hline 1991 & 12 & --- & 18 & 350 & 882 & 95,1 & 73,5 \\
\hline 1996 & 18 & 50 & 50 & 177,8 & 713 & $-19,2$ & 39,6 \\
\hline
\end{tabular}

Fuente: Elaboración propia a partir de la información recogida en las Tablas 38 y 108.

El estado de la educación especial es la gran incógnita del periodo, pues los datos son escasos. Del año 1991 no se ha conseguido suficiente información, por lo que no se puede emitir consideraciones a mitad del periodo. No es hasta 1996 cuando podemos encontrar un centro especializado, donde la relación profesor alumno es muy satisfactoria puesto que cada uno se encarga de 5 alumnos, aunque no sabemos cuántos centros públicos tienen unidades especializadas en este tipo de enseñanza. La falta de información al respecto es penosa, puesto que esta área supone un elemento de integración social de las discapacidades, fundamental en el bienestar de las sociedades.

Tabla 111. Evolución de la capacidad en la Enseñaza. Especial. Lanzarote. 1986-1996

\begin{tabular}{|c|c|c|c|c|}
\hline Año & Unidades & Profesores & Alumnos & Alumnos/profesor \\
\hline \hline 1986 & 15 & 5 & 211 & 42,2 \\
\hline 1996 & -- & 7 & 37 & 5,3 \\
\hline
\end{tabular}

Fuente: Elaboración propia a partir de la información recogida en las Tablas 38 y 108.

La Escuela Oficial de Idiomas, creada en 1994, es un equipamiento social que tiene una enorme demanda en la Isla, lógico dentro de una economía turística donde el manejo de idiomas mejora la competitividad de los trabajadores. Tal es la demanda que su capacidad se encuentra estrangulada, puesto que se trabaja con casi 92 alumnos por profesor, difícil mantener calidad en la formación con esta presión.

\subsubsection{3.- CONCLUSIONES}

Los cambios en el perfil de instrucción de la población que acoge la isla y en la capacidad del equipamiento educativo se van a producir durante esta etapa.

A modo de conclusión, la dinámica en relación a la cualificación se caracteriza por lo siguiente: 
1. Crecimiento continuado del nivel formativo de la población, por reducción del analfabetismo y crecimiento de la formación superior que alcanza, en 1996, un peso relativo nunca antes recogido. A ello se une el descenso de la población sin estudio, y la evolución positiva de aquellos que han completado lo enseñanza general básica obligatoria que se establece como el perfil instructivo mayoritaria entre los residentes de Lanzarote. A su vez, la formación profesional también crece en estos años aunque su peso en el conjunto sigue siendo escaso.

2. Canarias y España presentan dinámicas similares a la isla a lo largo de este periodo.

3. La dinámica inmigratoria es de escaso nivel formativo durante la mayor parte de la etapa. El cambio se produce en 1996, más de la mitad de la inmigración, que es nacional, posee estudios de grado medio, junto con la europea que es el nivel donde se concentra. La población entrada de países externos a Europa no amplia el nivel de instrucción insular, sino que, por lo contrario, lo empobrece.

En cuanto al equipamiento educativo, la etapa está marcada por:

4. Las dotaciones destinadas a la enseñanza obligatoria, no solo son suficientes sino que, además, existe la posibilidad de dar cobertura a nueva demanda a corto plazo.

5. En relación al equipamiento para la educación no obligatoria, esenciales en una sociedad de bienestar que ha conseguido la escolarización plena en los niveles obligatorios, se constata lo siguiente: a) suficiencia en el nivel de preescolar para el último año de análisis (cuya demanda ha ido creciendo en toda la etapa, puesto que los papales femeninos clásicos se han ido modificando por exigencia del mercado laboral); b) estrangulamientos dotacionales en la educación para adultos y escasa dotación para la educación especial o pedagogía terapéutica. La aportación del sistema educativo a la integración de los adultos y las discapacidades es pobre. 
Gráfico 96. Relación alumnos por unidad y profesor, y estándar, por tipo de enseñanza. Lanzarote. 1991-1996

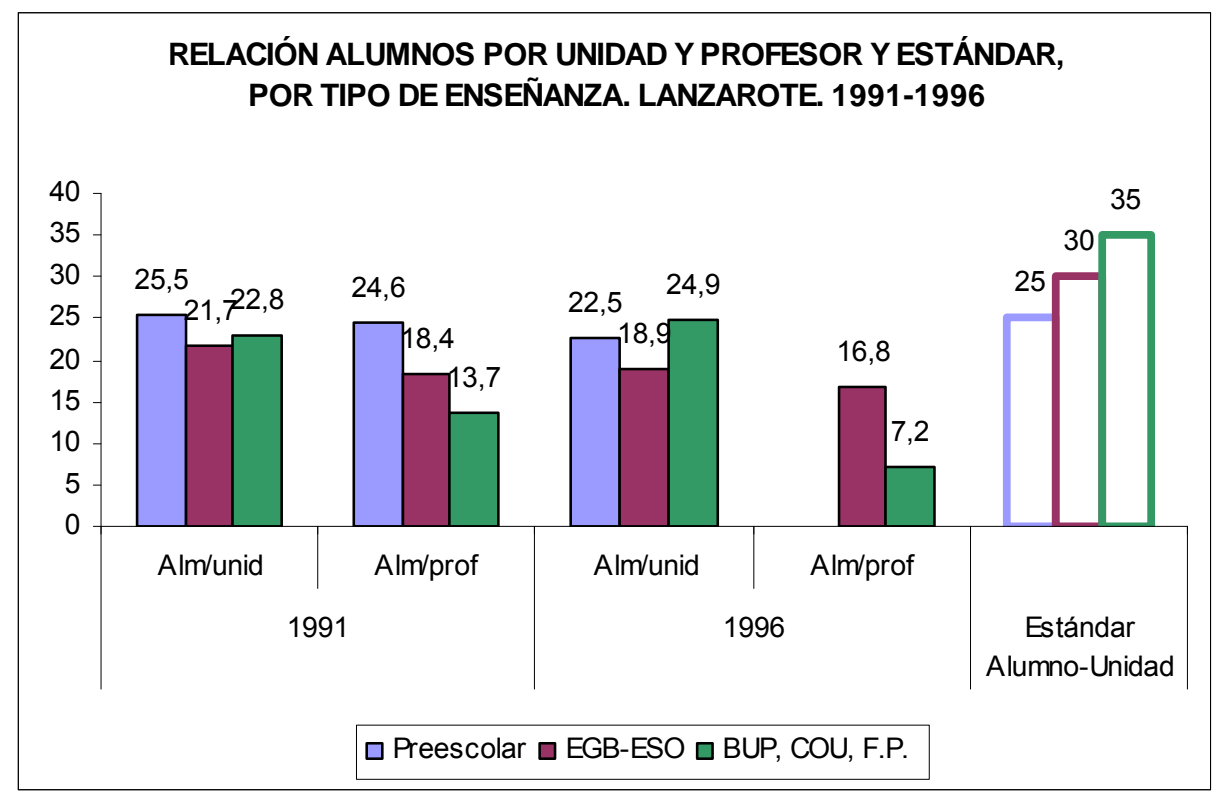

Fuentes: Estadísticas Insulares y Municipales de Canarias, 1991 y Anuario Estadístico de Canarias. 2001. ISTAC. Consejería de Educación y Cultura del Cabildo Insular de Lanzarote. Gráfico basado en las tablas 103 y 106. Elaboración propia.

6. Ruptura de la dinámica de la etapa anterior. Adecuación de la oferta formativa no obligatoria al mercado laboral en la Isla, con la creación de Centros de formación en hostelería y turismo.

7. Ruptura con el aislamiento insular en relación a las posibilidades y oportunidades de acceso a la formación superior, tras la localización de dos Escuelas Universitarias.

En términos generales, el reflejo positivo sobre la mejora del bienestar social en esta etapa se encuentra sobre tres aspectos: uno derivado de la adquisición de mayor nivel formativo de la población, otro debido al esfuerzo por la adecuación de la formación al mercado laboral y económico, centrado en el servicio al turismo. $Y$ en tercer lugar, la más que suficiente cobertura de los equipamientos en enseñanza preescolar, obligatoria y secundaria no obligatoria, que se constata al final del mismo.

Por el contrario, los medios existentes para la integración de las discapacidades, no pueden ser evaluados, se desconocen; y la educación básica de adultos ha desbordado las dotaciones existentes al respecto. Ambos aspectos deprimen el estado del bienestar social de la isla. 


\subsection{4.- EFECTOS SOBRE LA DOTACIÓN DE SERVICIOS DE SALUD. 1986-1996}

\subsubsection{1.- DOTACIÓN HOSPITALARIA Y EXTRAHOSPITALARIA}

En 1985, comienza la construcción de lo que va a ser el nuevo Hospital General de Lanzarote (INSALUD). Estas obras de edificación coinciden con el boom de la construcción con el que finaliza la anterior etapa, por lo que hay dificultad para el abastecimiento de materiales y mano de obra, así pues no se terminará hasta cuatro años después, en 1989, cuando entra en funcionamiento. Esta nueva instalación constituyó un gran paso hacia la modernización de los medios sanitarios de los que disponía la isla (la ampliación de especialidades es tan grande que no se ha recogido ${ }^{172}$ ) pues, en equipamiento, se pone a nivel de los hospitales provinciales, lo que posibilitó reducir las evacuaciones de urgencia a hospitales de referencia en la capital de provincia. Su anterior ubicación se convertirá en centro de salud.

Con esta nueva dotación, el incremento de las camas hospitalarias va a ser notable con respecto a la etapa anterior (25\%), pero va a nacer ya estrangulado, pues la variación en el estándar de calidad (camas/1.000h), entre 1986 y 1991 no es significativa. Esto tiene su explicación en el rápido ritmo de crecimiento demográfico que sufre la isla en este quinquenio $(16 \%)$, debido al elevado incremento de la oferta turística (121\%), pues las previsiones con las que se aprueba la nueva dotación superan la realidad del momento en que se pone en funcionamiento.

172 Para ampliación documental sobre este aspecto consultar Filka, M.L. y otros. "De la Residencia Sanitaria Nuestra Señora de los Volcanes al Hospital General de Lanzarote". XI Jornadas de estudios sobre Lanzarote y Fuerteventura. Cabildo Insular de Fuerteventura, Fuerteventura, 2004 (pp. 264, 270-271). "Hospiten. 40 años de historia", http://www.hospiten.es 
Tabla 112. Oferta hospitalaria. Lanzarote. 1986-1996

\begin{tabular}{|c|c|c|c|c|c|c|}
\hline Año & TIPO & Tipo & $\begin{array}{l}\mathbf{N}^{0} \text { de } \\
\text { Camas }\end{array}$ & $\begin{array}{l}\text { Camas/ } \\
1.000 \mathrm{~h} .\end{array}$ & Estancias & $\begin{array}{l}\text { Índice de } \\
\text { Ocupación }\end{array}$ \\
\hline \multirow{3}{*}{1986} & $\begin{array}{l}\text { Hospital Insular } \\
\text { (Cabildo) }\end{array}$ & General & 96 & 1,72 & No consta & --- \\
\hline & $\begin{array}{l}\text { Hospital General } \\
\text { (Insalud) }\end{array}$ & General & 112 & 2,01 & No consta & --- \\
\hline & TOTAL & General & 208 & 3,73 & --- & -- \\
\hline Población Derecho & \multicolumn{3}{|l|}{55.764} & & & \\
\hline $\begin{array}{l}\text { Turistas equivalentes } \\
\text { al día }\end{array}$ & \multicolumn{3}{|l|}{16.493} & & \multirow{2}{*}{\multicolumn{2}{|c|}{$\begin{array}{l}\% \text { de Variación de } \\
\text { Lanzarote con respecto } a^{* *}:\end{array}$}} \\
\hline Población diaria* & \multicolumn{3}{|l|}{72.257} & 2,88 & & \\
\hline Canarias & & & --- & 5,5 & \multicolumn{2}{|l|}{$-32,2$} \\
\hline España & & & 171.860 & 5,3 & \multicolumn{2}{|l|}{$-29,6$} \\
\hline O.M.S. & & & & $8-10$ & $-53,4$ & \\
\hline \multirow{3}{*}{1991} & $\begin{array}{l}\text { Hospital Insular } \\
\text { (Cabildo) }\end{array}$ & General & 93 & 1,43 & No consta & -- \\
\hline & $\begin{array}{l}\text { Hospital General } \\
\text { (Insalud) }\end{array}$ & General & 164 & 2,53 & No consta & -- \\
\hline & TOTAL & General & 260 & 3,96 & --- & --- \\
\hline Población Derecho & \multicolumn{3}{|l|}{64.911} & & & \\
\hline $\begin{array}{l}\text { Turistas equivalentes } \\
\text { al día }\end{array}$ & \multicolumn{3}{|l|}{30.515} & & \multirow{2}{*}{\multicolumn{2}{|c|}{$\begin{array}{l}\% \text { de Variación de } \\
\text { Lanzarote con respecto a**: }\end{array}$}} \\
\hline Población diaria* & \multicolumn{3}{|l|}{95.426} & 2,88 & & \\
\hline Canarias & & & 7.749 & 5,19 & \multicolumn{2}{|l|}{$-23,7$} \\
\hline España & & & 164.451 & 4,23 & \multicolumn{2}{|l|}{$-6,4$} \\
\hline O.M.S. & & & & $8-10$ & \multicolumn{2}{|l|}{$-50,5$} \\
\hline
\end{tabular}




\begin{tabular}{|c|c|c|c|c|c|c|}
\hline \multirow{3}{*}{1996} & $\begin{array}{l}\text { Hospital Insular } \\
\text { (Cabildo) }\end{array}$ & General & 93 & 1,20 & & \\
\hline & $\begin{array}{l}\text { Hospital General } \\
\text { (Insalud) }\end{array}$ & General & 164 & 2,12 & 48.641 & 83,29 \\
\hline & TOTAL & General & 238 & 3,32 & & 83,29 \\
\hline Población Derecho & 77.379 & & & & & \\
\hline $\begin{array}{l}\text { Turistas equivalentes al } \\
\text { día }\end{array}$ & 48.686 & & & & \multirow{2}{*}{\multicolumn{2}{|c|}{$\begin{array}{l}\% \text { de Variación de } \\
\text { Lanzarote con respecto } \\
\mathrm{a}^{* *} \text { : }\end{array}$}} \\
\hline Población diaria* & 126.065 & & & 2,04 & & \\
\hline Canarias & & & 7.572 & 4,71 & \multicolumn{2}{|l|}{$-29,5$} \\
\hline España & & & 151.345 & 3,82 & \multicolumn{2}{|l|}{$-13,1$} \\
\hline O.M.S. & & & & $8-10$ & \multicolumn{2}{|l|}{$-58,5$} \\
\hline
\end{tabular}

* Población diaria: población de derecho + turistas equivalentes al día.

** Calculado en relación a las camas por mil habitantes de derecho.

Fuente: Para 1986: "Camas instaladas en los centros sanitarios de Canarias, según dependencia, por islas. Lanzarote. 1985". Estadísticas básicas de Canarias, 1980-1985. CEDOC. "Ratio camas/1000h de España y Canarias, 1986" en Avance PIOT Lanzarote, 1987, Tomo 5, Cap. II. Cuadro 5.2. Cabildo de Lanzarote, 1987 (pp. 113); "Camas en funcionamiento según la finalidad del establecimiento sanitario, 1986. Canarias y España". Anuario Estadístico de España, 1994. INE; Para 1991: "Número de camas del Hospital General de Lanzarote, 1990". Fika, M.L. y otros. "De la Residencia Sanitaria Nuestra Señora de los Volcanes al Hospital General de Lanzarote". XI Jornadas de estudios sobre Lanzarote y Fuerteventura. Cabildo Insular de Fuerteventura, Fuerteventura, 2004 (pp. 270); "Camas en funcionamiento según la finalidad del establecimiento sanitario, 1991. Canarias y España". Anuario Estadístico de España, 1994. INE; Para 1996: "Estructura y oferta de servicios de Atención Especializada. Lanzarote, 1995-97". Centro de datos del Cabildo Insular de Lanzarote. http://www.datosdelanzarote.com; "Camas en funcionamiento, por CC.A.A., y Total de España, por periodo y entidad jurídica de quien dependen, 1997". Estadística de Establecimientos Sanitarios con Régimen de Internado, Serie 1997-2007. INE. Elaboración propia.

Así, a lo largo de esta década la relación camas por 1.000 habitantes se mantendrán entre 3 y 4 camas, permaneciendo siempre por debajo del ratio autonómico, nacional y del estándar de calidad de la Organización Mundial de la Salud, es decir, su capacidad dotacional sanitaria es deficitaria. Dicho déficit, se hace aún más notable si es calculado sobre la población total estimada (población de derecho y turistas equivalentes) que soporta a diario la isla, ya que los visitantes-turistas llegan a incrementar el volumen demográfico insular hasta en un $63 \%$ en 1996 , con respecto a la población registrada, y con ello la presión sobre las dotaciones hospitalarias, reduciendo la disponibilidad en algo más de una cama por mil habitantes. 
Gráfico 97. Comparación de los ratios camas hospitalarias por mil habitantes de derecho y sobre la población total estimada. Lanzarote. 1986-1996

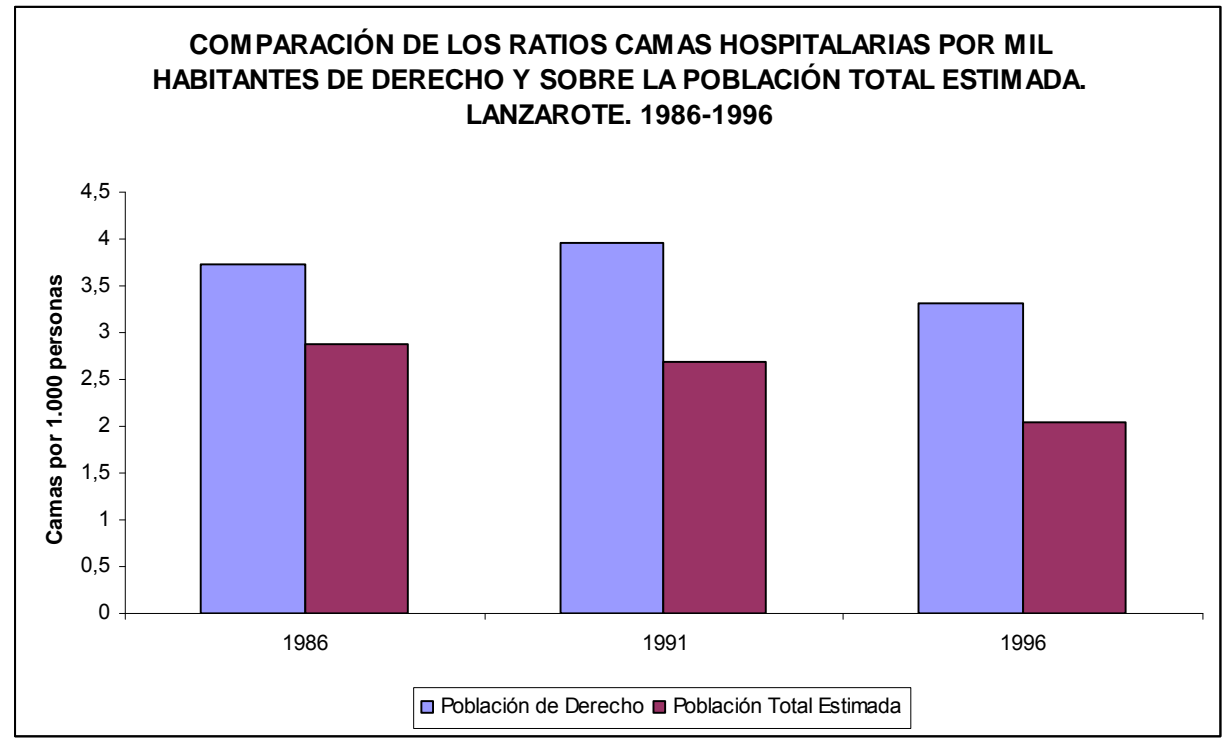

Fuente: Fika, M.L. (2004); Sosa Núñez, J. (2010); Avance PIOT, 1987 y Centro de datos del Cabildo Insular de Lanzarote; Gráfico basado en la Tabla 112.

Gráfico 98. Comparación del ratio camas hospitalarias por mil habitantes. España, Canarias y Lanzarote. 1986-1996

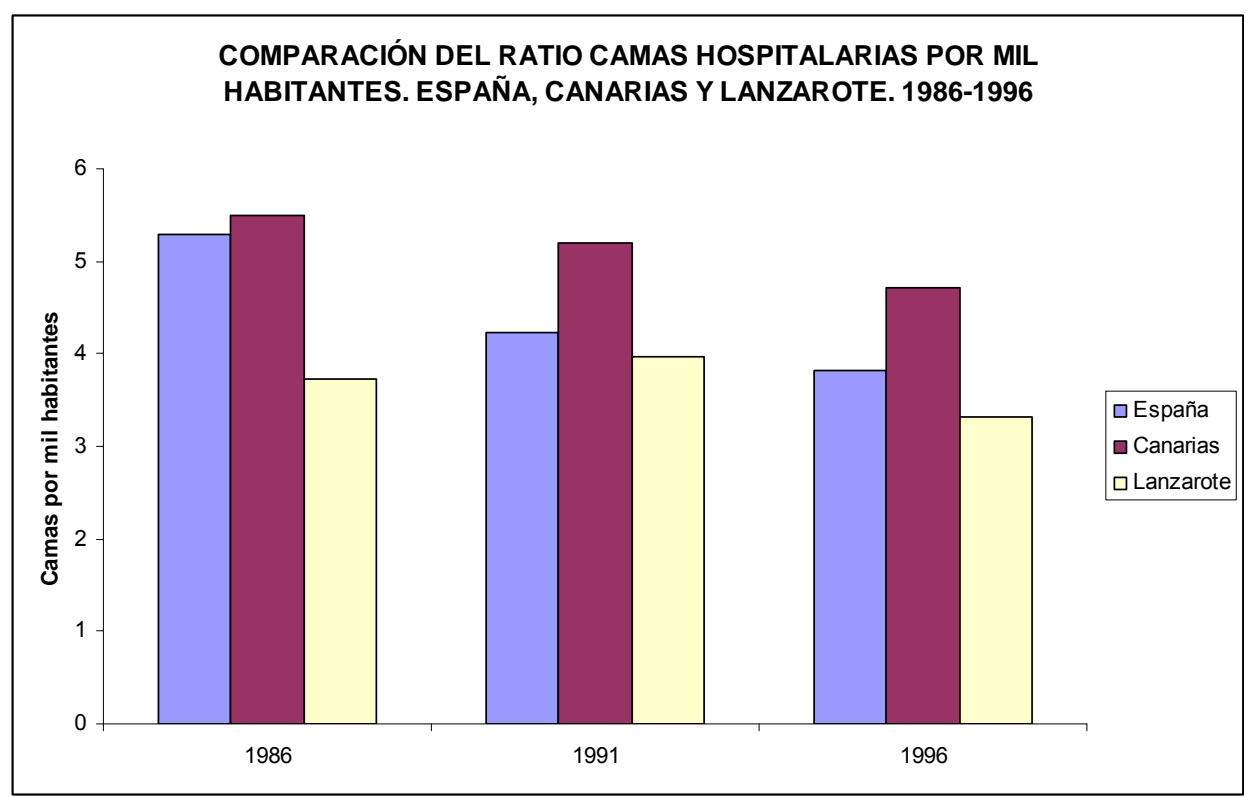

Fuente: Fika, M.L. (2004); Sosa Núñez, J. (2010); Avance PIOT, 1987 y Centro de datos del Cabildo Insular de Lanzarote; Estadísticas básicas de Canarias, 1980-1985. ISTAC; Anuarios estadísticos de España y Estadística de Establecimientos Sanitarios con Régimen de Internado, INE; Gráfico basado en la Tabla 112. Elaboración propia. 


\section{a.- El personal facultativo}

Lo que sí va a sufrir una modificación significativa en estos diez años que cubre la segunda etapa definida, será el número de facultativos que ejercen en la isla. Se pasa de una presión de más de 1.500 personas por médico al comienzo del periodo, a unas 560 personas al final del mismo, lo que supone una variación del $63 \%$. Con ello la isla se acerca más que nunca al ratio de España (555) y presenta mayor capacidad que Canarias (574).

Tabla 113. Número de facultativos por tipo y ratio habitantes/médicos. España, Canarias y Lanzarote. 1986-1996.

\begin{tabular}{|c|c|c|c|c|c|c|c|c|c|}
\hline \multirow[b]{2}{*}{ Año } & \multirow[b]{2}{*}{$\begin{array}{l}\text { Atención } \\
\text { Primaria }\end{array}$} & \multirow[b]{2}{*}{ Especialistas } & \multirow[b]{2}{*}{ TOTAL } & \multicolumn{3}{|c|}{$\begin{array}{l}\text { En relación a la población de } \\
\text { derecho }\end{array}$} & \multicolumn{3}{|c|}{ En relación a la población total* } \\
\hline & & & & $\begin{array}{c}\text { Ratio } \\
\text { Lanzarote }\end{array}$ & $\begin{array}{l}\text { Ratio } \\
\text { Canarias }\end{array}$ & $\begin{array}{l}\text { Ratio } \\
\text { España }\end{array}$ & $\begin{array}{c}\text { Ratio } \\
\text { Lanzarote }\end{array}$ & $\begin{array}{l}\text { Ratio } \\
\text { Canarias }\end{array}$ & $\begin{array}{l}\text { Ratio } \\
\text { España }\end{array}$ \\
\hline 1986 & No consta & 42 & 42 & 1.549 & 357 & 294 & 1.720 & 395 & 303 \\
\hline 1991 & No consta & 64 & 64 & 1.014 & 669 & 701 & 1.491 & 750 & 717 \\
\hline 1996 & 56 & 74 & $138^{\star *}$ & 561 & 574 & 555 & 914 & 682 & 569 \\
\hline
\end{tabular}

(*) Población total: población de derecho + turistas equivalentes día.

** Se incluyen ocho médicos más (no clasificados) que posee el Hospital Insular.

Fuente: Para 1986: "Plantilla del Hospital Nuestra Sra. de los Volcanes hasta 1987". Fika, M.L. y otros. "De la Residencia Sanitaria Nuestra Señora de los Volcanes al Hospital General de Lanzarote". XI Jornadas de estudios sobre Lanzarote y Fuerteventura. Cabildo Insular de Fuerteventura, Fuerteventura, 2004 (pp. 267); "Profesionales sanitarios colegiados. Médicos. Total nacional y detalle provincial (Las Palmas y Tenerife), 1986”. Anuario Estadístico de España, 1987; Para 1991: "Personal facultativo. Hospital General de Lanzarote. 1989-1990". Fika, M.L. y otros. "De la Residencia Sanitaria Nuestra Señora de los Volcanes al Hospital General de Lanzarote”. XI Jornadas de estudios sobre Lanzarote y Fuerteventura. Cabildo Insular de Fuerteventura, Fuerteventura, 2004 (pp. 264, 270-271); "Médicos que prestan servicio en establecimientos sanitarios con régimen de internado, Canarias y España, 1991". Anuario Estadístico de España, 1992. INE; Para 1996: "Recursos humanos del Servicio Canario de Salud. Lanzarote, 1997". Centro de datos del Cabildo Insular de Lanzarote. http://www.datosdelanzarote.com; "Actividad de atención especializada. Personal Médico. Canarias, 1996". Estadística de Establecimientos Sanitarios en Régimen de Internado. Servicio Canario de Salud. ISTAC; "Personal de establecimientos sanitarios por categoría. España, 1997". Estadísticas de establecimientos sanitarios en régimen de internado. Serie 1997-2007. INE. Elaboración propia.

Será en la isla donde el aumento de la población a través del número de turistas equivalentes al día tenga mayor repercusión. Supone el que, al final de esta etapa (1996), en Lanzarote, un médico tenga que asumir como pacientes potenciales casi un $63 \%$ más en relación a la población registrada o de derecho. Fenómeno éste que se extiende también a la Comunidad Autónoma, aunque en mucha menor proporción (19\%) y que no es significativo frente a la variación nacional. Datos estos que vienen a señalar cómo el turista se convierte en un elemento que provoca mayor estrangulamiento sobre la limitada capacidad de servicio insular. 
Gráfico 99. Comparación de los ratios población de derecho y población total estimada por médico. España, Canarias y Lanzarote. 1986-1996.

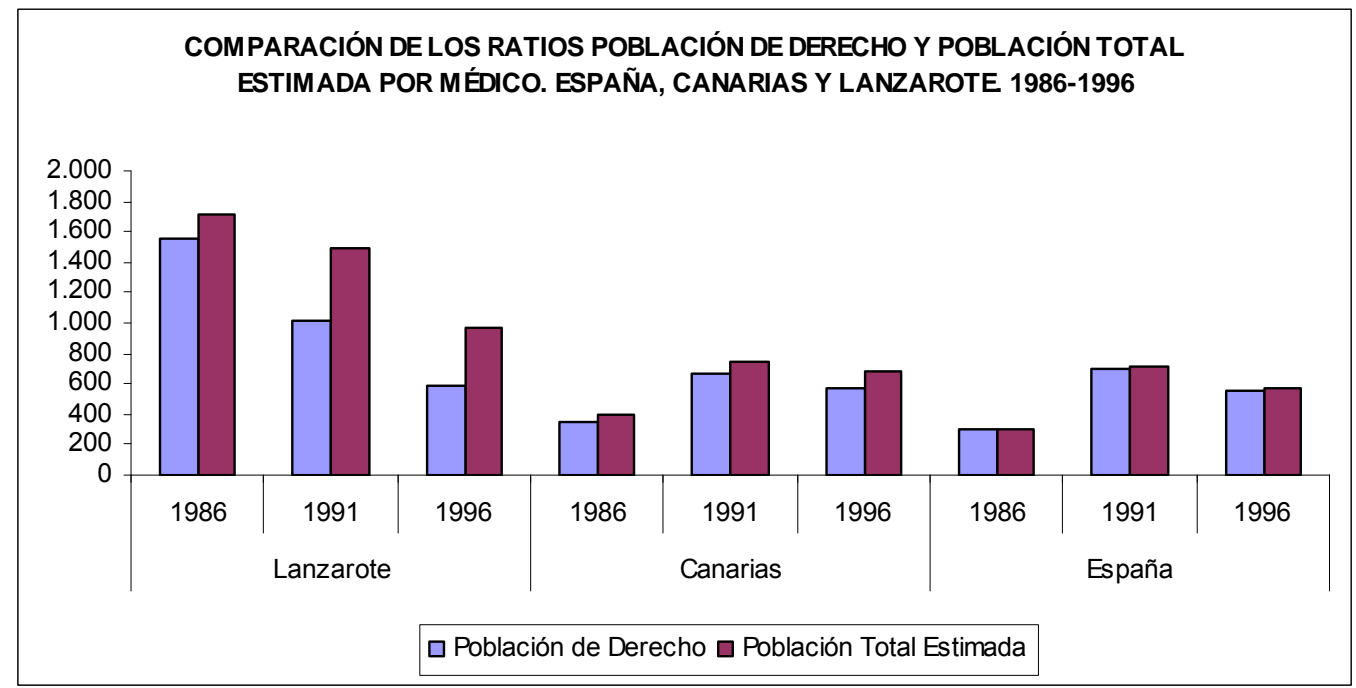

Fuente: Basado en los indicadores calculados en la Tabla 113. Elaboración propia.

A pesar de estas ampliaciones siguen existiendo desplazamientos por salud a la capital de la provincia, Las Palmas, pues la Isla seguirá sin concentrar suficientes especializadas médicas.

\subsubsection{2.- EL EQUIPAMIENTO DE BIENESTAR}

En cuanto al equipamiento de bienestar, las dotaciones destinadas a la tercera edad, siguen teniendo una entidad importante, gestionadas por el Hospital Insular (Cabildo Insular), tanto residencias (2) como centros de día (1).

En esta década van a ser tres los ámbitos nuevos en cuanto apertura y ampliación de los servicios sociales, gestionados por el Cabildo: a) las drogodependencias: invirtiendo en información y deshabituación; b) la violencia de género: área de información, centro de acogida, y dispositivos de emergencia; c) menores: especialmente centros para menores extranjeros no acompañados, como consecuencia del fenómeno inmigratorio de la llegada de pateras al Archipiélago Canario, para los que existen dos centros con 20 plazas. A ello se unen cuatro centros más para amparo y guarda (que poseen entre 10 y 15 plazas). La Isla puede, por tanto, asistir, aproximadamente, a un total de 75 niños en diferentes circunstancias. 
Tabla 114. Servicios sociales según tipo. Lanzarote. 1986-1996

\begin{tabular}{|c|c|c|c|c|}
\hline Tipo & Función & 1986 & 1991 & 1996 \\
\hline De Base & & 1 & & \\
\hline \multirow[t]{2}{*}{ Afines } & Diversos aspectos sanitarios & 2 & & \\
\hline & Centro de día & & & 1 \\
\hline Minusválidos & Servicio de información y gestión discapacidad & 1 & 1 & 1 \\
\hline \multirow{2}{*}{ Menores y Familia } & Centro-hogar de menores (acogida/amparo) & 1 & 3 & 3 \\
\hline & Hogar funcional de menores & 4 & & \\
\hline \multirow{3}{*}{ Mujer } & Centro Información Víctima Violencia Género & & 1 & 1 \\
\hline & Dispositivo emergencia mujeres agredidas & & 1 & \\
\hline & Centro de acogida por violencia de género & & 1 & 1 \\
\hline \multirow{3}{*}{ Drogodependencias } & Centro de información & 1 & 1 & 1 \\
\hline & Centro de deshabituación & & 1 & \\
\hline & Centro prevención e incorporación social & & & \\
\hline \multirow{3}{*}{ Ancianidad } & Centro de día & 1 & 1 & 1 \\
\hline & Residencia & 1 & 2 & 1 \\
\hline & Hogares y Clubs & 1 & & \\
\hline Delitos & Centro de Asistencia a Víctimas del Delito & & & 1 \\
\hline \multicolumn{2}{|l|}{ TOTAL SERVICIOS } & 12 & & \\
\hline
\end{tabular}

Fuente: “Número de servicios sociales en Canarias según tipos y lugar de ubicación, por islas. Lanzarote. 1985”. Estadísticas Básicas de Canarias, 1980-1985. CEDOC; Avance PIOT Lanzarote, 1987, Tomo 5, Cap. II. Cuadro 5.2. Cabildo de Lanzarote, 1987 (pp. 113). Área de drogodependencias de Lanzarote. Consejería de Servicios Sociales. Cabildo Insular de Lanzarote. http://www.cabildodelanzarote.com.

\subsubsection{3.- CONCLUSIONES}

Esta etapa que marca el quinquenio previo y posterior a la aprobación del PIOT de 1991, está caracterizada por una ampliación de los servicios de salud de la isla, que vienen fuertemente estrangulados del periodo anterior. Es por ello que, en términos generales esta década se concreta en lo siguiente:

1. Modernización y ampliación de las dotaciones y servicios especializados hospitalarios, que seguirá manteniendo déficits a lo largo de la etapa, permaneciendo por debajo del estándar de calidad de la O.M.S. 
Gráfico 100. Camas hospitalarias por mil habitantes y comparación con e estándar de la O.M.S. España, Canarias y Lanzarote. 1996

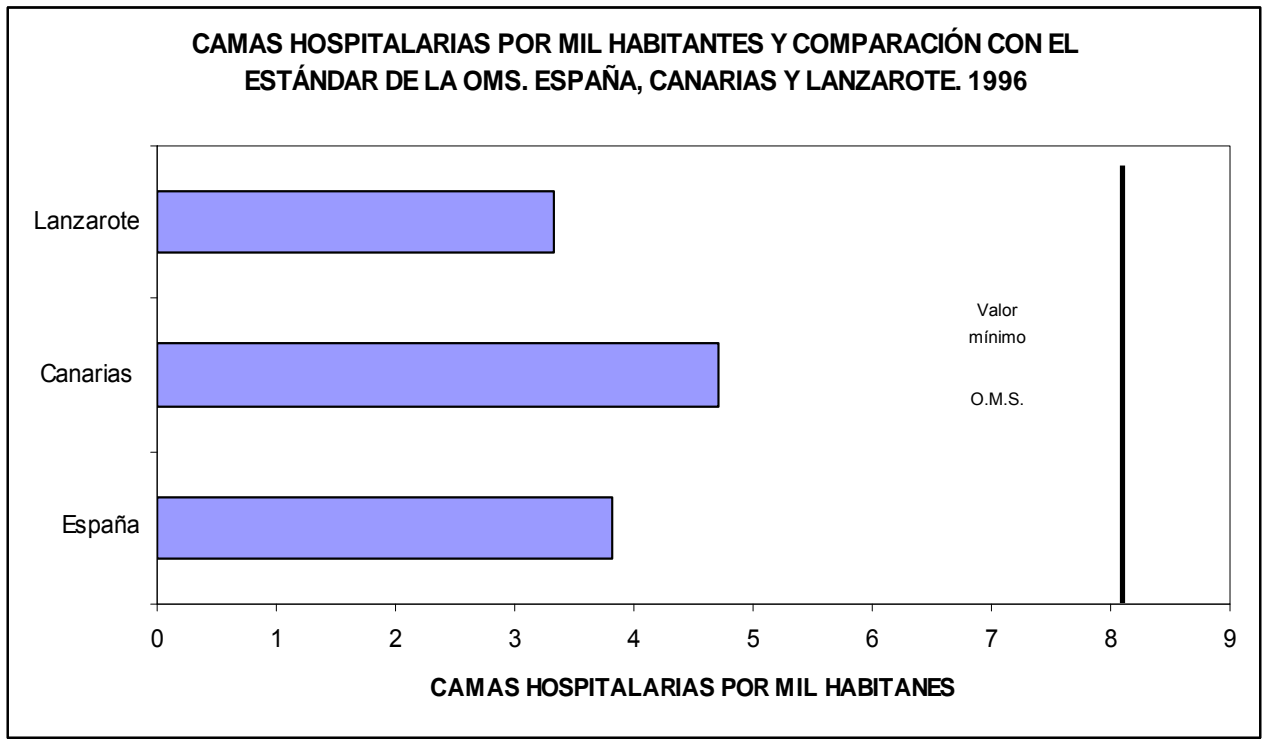

Fuente: Basado en los indicadores calculados en la Tabla 1121. Elaboración propia.

2. Reducción de la presión por demanda de facultativos (médicos) de forma significativa, aunque el constante crecimiento de los turistas equivalentes diarios en la isla supone una demanda potencial que reduce las posibilidades de disponibilidad de médicos, y tiene como resultado el que no se puedan alcanzar menores distancias con respecto a Canarias y España al final de la etapa.

Gráfico 101. Evolución del número de habitantes por médico en relación a la población de derecho y la población total estimada. Lanzarote. 1986-1996

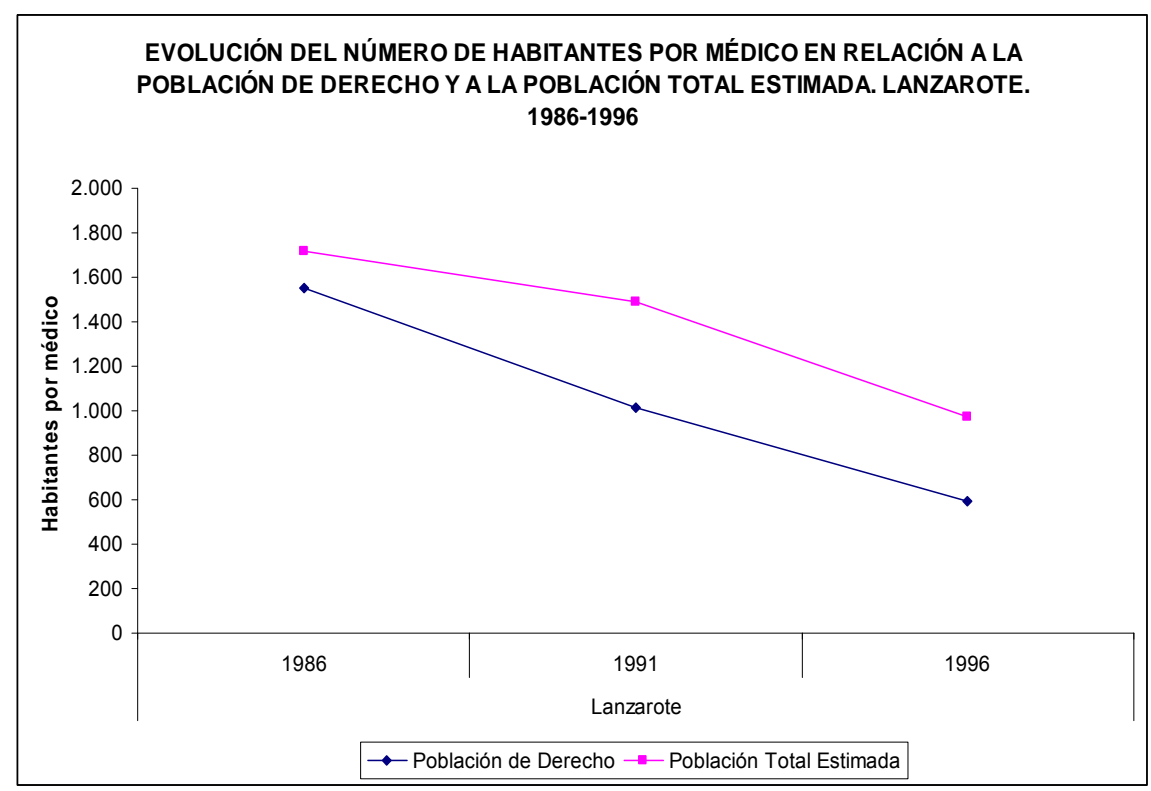

Fuente: Basado en los indicadores calculados en la Tabla 113. Elaboración propia. 
Gráfico 102. Número de habitantes por médico en relación a la población de derecho y la población total estimada. España, Canarias y Lanzarote. 1986-1996

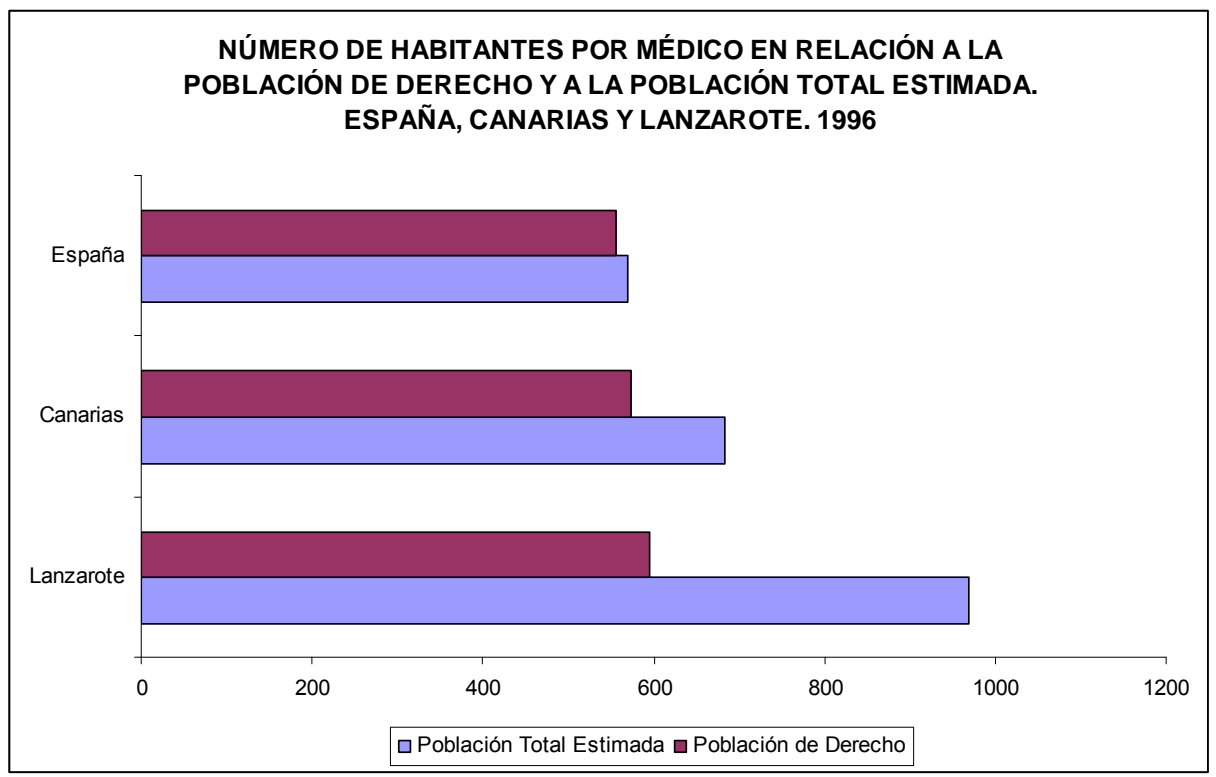

Fuente: Basado en los indicadores calculados en la Tabla 113. Elaboración propia.

3. Mantenimiento de la plataforma para traslados de enfermos hacia la capital de la provincia, Las Palmas, por insuficientes especialidades médicas.

4. Ampliación de los servicios sociales hacia aspectos anteriormente no intervenidos (violencia de género y menores no acompañados).

5. La inmigración de indocumentados y de menores no acompañados, presiona sobre los servicios sociales, creándose una oferta de centros públicos.

Estos diez años son significativos en la medida en que muestran como los crecimientos demográficos derivados de los impulsos de la oferta turística superan la capacidad de respuesta pública, en la medida en que la puesta en marcha de nuevo equipamiento sanitario hospitalario no alivia la presión, nacen ya estrangulados. Se invierte en actividad turística sin la capacidad pública suficiente para asumir sus efectos sobre las dotaciones sanitarias. Lo que se realiza se hace a posteriori, cuando los estrangulamientos son difícilmente corregibles. 


\subsection{5.- EFECTOS SOBRE LA ACTIVIDAD ECONÓMICA Y EL EMPLEO. 1986-1996}

\subsubsection{1.- POBLACIÓN ACTIVA Y ESTRUCTURA SECTORIAL}

El objeto de este análisis es ver en qué medida la actividad turística que acoge la isla, ha incidido en los indicadores de empleo y paro insulares.

En epígrafes anteriores se había señalado las circunstancias en las que se encuentra la isla al iniciar su andadura hacia una economía marcada por los servicios al turismo de masas (baja tasa de población activa, del $31,77 \%$, frente al promedio regional que suponía el $35,5 \%)$. Una vez completada esta primera fase, ante la crisis de sobreproducción y la contención del crecimiento de la oferta que plantea la nueva planificación que marca esta segunda fase, ¿en qué estado se encuentra la población activa insular con respecto a sus características iniciales?, teniendo en cuenta que el perfil demográfico insular sigue caracterizándose por la gran juventud de su población y la contabilización del trabajo femenino ya no es marginal como ocurría al final de la década de los años sesenta. La siguiente Tabla arroja las primeras ideas al respecto.

Tabla 115. Tasa de actividad. Lanzarote, Canarias y España. 1986-1996 (\%)

\begin{tabular}{|c|c|c|c||c|c|c||c|c|c|}
\cline { 2 - 11 } \multicolumn{1}{c|}{} & \multicolumn{3}{c||}{ LANZAROTE } & \multicolumn{3}{c||}{ CANARIAS } & \multicolumn{3}{c|}{ ESPAÑA } \\
\cline { 2 - 11 } & 1986 & 1991 & 1996 & 1986 & 1991 & 1996 & 1986 & 1991 & 1996 \\
\hline Tasa de actividad & 50,4 & 63,0 & 62,0 & 48,0 & 51,7 & 55,0 & 34,6 & 50,2 & 51,3 \\
\hline
\end{tabular}

Fuente: "Población de derecho de 16 y más años de Lanzarote y la Comunidad Autónoma de Canarias según sexo y relación con la actividad económica, 1986". Anuario Estadístico de Canarias, 1986. Centro de Estadística y documentación de Canarias (CEDOC); Para 1991: "Población de 16 y más años por relación con la actividad económica y sexo, por municipios. Total Lanzarote, 1991". Censo de población y viviendas, 1991 (explotación municipal). INE; "Tasa actividad y paro por sexo. Comunidad Autónoma de Canarias y Resultados Nacionales, 1991". Censo de población y viviendas, 1991. INE; Para 1996: "Población Insular de 16 y más años según relación con la actividad económica por grupos de edad y sexo. Lanzarote y Canarias, 1996". Encuesta de Población de Canarias 1996. ISTAC; "Activos por sexo y grupo de edad. Total nacional, 1996". EPA, 1996. INE (no existe tal desagregación en el Padrón municipal de habitantes del año 1996); Elaboración Propia.

La actividad no ha parado de crecer como demuestra la evolución de su tasa a lo largo de esta etapa, que recoge el cuadro anterior. Por lo que el dinamismo del empleo insular es notable con respecto a los datos que se estimaban al comienzo de la incorporación de actividad turística en el este territorio, incluso presenta tasas mayores a las de su Comunidad Autónoma y España. Lanzarote ha dado un fuerte giro a su mercado laboral, presentándose como una zona con fuerte dinámica en el crecimiento de su población activa. 
Tabla 116. Población activa municipal por sectores económicos. Lanzarote. 1965 y 1991 (\%).

\begin{tabular}{|c|c|c|c|c|c|c|c|c|c|c|c|c|c|c|c|c|}
\hline & \multicolumn{2}{|c|}{$\begin{array}{l}\text { Activos por } \\
\text { Sector }\end{array}$} & \multicolumn{2}{|c|}{ Arrecife } & \multicolumn{2}{|c|}{ Haría } & \multicolumn{2}{|c|}{$\begin{array}{c}\text { San } \\
\text { Bartolomé }\end{array}$} & \multicolumn{2}{|c|}{ Teguise } & \multicolumn{2}{|c|}{ Tías } & \multicolumn{2}{|c|}{ Tinajo } & \multicolumn{2}{|c|}{ Yaiza } \\
\hline & 1965 & 1991 & 1965 & 1991 & 1965 & 1991 & 1965 & 1991 & 1965 & 1991 & 1965 & 1991 & 1965 & 1991 & 1965 & 1991 \\
\hline Agrario & 51,5 & 5,6 & $24, .6$ & 4,5 & 16,8 & 9,0 & 9,0 & 5,1 & 24,6 & 11,5 & 10,9 & 2,9 & 8,2 & 5,3 & 5,7 & 7,3 \\
\hline Industria & 6,3 & 7,7 & 100,0 & 8,9 & 0,0 & 8,0 & 0,0 & 8,4 & 0,0 & 7,6 & 0,0 & 3,6 & 0,0 & 7,9 & 0,0 & 4,2 \\
\hline Construcción & 14,0 & 16,3 & 44,2 & 16,3 & 2,0 & 13,7 & 19,8 & 20,3 & 15,9 & 15,0 & 4,9 & 10,3 & 9,7 & 25,5 & 3,5 & 19,3 \\
\hline Servicios & 28,2 & 70,5 & 57,7 & 70,3 & 7,1 & 69,4 & 8,4 & 66,2 & 13,9 & 65,9 & 4,7 & 83,2 & 4,9 & 61,3 & 3,4 & 69,2 \\
\hline TOTAL ACT & IVOS & & 41,5 & 50,8 & 10,9 & 3,9 & 9,8 & 9,8 & 18,8 & 12,6 & 7,6 & 13,0 & 6,9 & 5,3 & 4,4 & 4,6 \\
\hline
\end{tabular}

Fuente: Extensión Agraria ( $\mathrm{M}^{\circ}$ de Agricultura). Plan General de Ordenación de Arrecife. Elaboración: Centro de Investigación Económica y Social de la Caja Insular de Ahorros. Octubre de 1971. "Ocupados o parados, por municipios, que han trabajado antes por rama de actividad económica, 1991". Censo de Población de 1991, INE.

Prácticamente ya no quedan municipios eminentemente rurales, el escaso sector agrario que existe se concentra principalmente en Teguise.

El sector de la construcción ha modificado de madera significativa su peso espacial pues ha pasado a tener presencia en todos los municipios insulares, tanto en los que poseen plazas principalmente para uso residencial (San Bartolomé), como los que combinan alojamiento de ambos tipos, residencial y turístico (Haría, Teguise, Tías, Tinajo y Yaiza). La excepción es el municipio capitalino, Arrecife, que reduce el peso relativo de su población residente con actividad en la construcción, frente a la que se observaba al final de la década de los años sesenta.

En conjunto, todos lo municipios, concentran su población activa en el sector servicios, entre el $70 \%$ y el $80 \%$, cuando veinte años antes su peso relativo era insignificante en el ámbito municipal (a excepción de Arrecife, que ha concentrado la actividad comercial y administrativa de la isla). Así, sobresale Tías (83\%) como el municipio de más elevado crecimiento de la actividad laboral en este sector ya que es, principalmente, donde se concentra el mayor número de plazas de alojamiento turístico.

\section{a.- Los ocupados}

En relación al análisis de la estructura sectorial del empleo, es significativo señalar la dinámica de la población ocupada en la construcción que sufre, al contrario que en la etapa anterior, una notable variación en su peso relativo, pues si en 1986 concentraba el $24 \%$ de los ocupados, al final de la etapa sólo concentran el 9,4\% de los ocupados, el sector pierde trabajadores. 
Tabla 117. Estructura sectorial del empleo. Ocupados. Lanzarote, Canarias y España. 19861996.

\begin{tabular}{|c|c|c|c|c|c|c|}
\hline LANZAROTE & 1986 & $\%$ & 1991 & $\%$ & 1996 & $\%$ \\
\hline AGRARIO & 1.583 & 7,6 & 1.216 & 5,5 & 1.138 & 3,7 \\
\hline INDUSTRIAL & 2.038 & 9,8 & 1.592 & 7,2 & 1.905 & 6,1 \\
\hline CONSTRUCCIÓN & 4.953 & 23,9 & 3.042 & 13,8 & 2.935 & 9,4 \\
\hline SERVICIOS & 11.811 & 57,0 & 16.168 & 73,5 & 24.667 & 79,4 \\
\hline No clasificados & 344 & 1,7 & -- & --- & 419 & 1,3 \\
\hline TOTAL & 20.729 & 100,0 & 22.015 & 100,0 & 31.064 & 100,0 \\
\hline CANARIAS & 1986 & $\%$ & 1991 & $\%$ & 1996 & $\%$ \\
\hline AGRARIO & 52.775 & 13,5 & 36.363 & 8,53 & 37.438 & 7,2 \\
\hline INDUSTRIAL & 38.575 & 9,8 & 47.054 & 11,03 & 39.978 & 7,7 \\
\hline CONSTRUCCIÓN & 43.325 & 11,0 & 47.276 & 11,08 & 52.597 & 10,1 \\
\hline SERVICIOS & 255.075 & 65,0 & 295.828 & 69,36 & 379.034 & 72,8 \\
\hline No clasificados & -- & 0,7 & --- & --- & 11.945 & 2,3 \\
\hline TOTAL & 392.375 & 100,0 & 426.521 & 100,0 & 520.992 & 100,0 \\
\hline ESPAÑA & 1986 & $\%$ & 1991 & $\%$ & 1996 & $\%$ \\
\hline AGRARIO & 1.723 .300 & 15,2 & 1.257 .032 & 10,2 & 1078,6 & 8,4 \\
\hline INDUSTRIAL & 2.762 .200 & 24,3 & 3.110 .084 & 23,0 & 2592,3 & 20,1 \\
\hline CONSTRUCCIÓN & 920.200 & 8,1 & 1.378 .249 & 10,3 & 1227,9 & 9,5 \\
\hline SERVICIOS & 5.937 .900 & 52,3 & 6.736 .441 & 56,5 & 7971,3 & 62,0 \\
\hline No clasificados & -- & -- & & -- & & --- \\
\hline TOTAL & 11.359 .200 & 100,0 & 12.481 .806 & 100,0 & 12.871 .500 & 100,0 \\
\hline
\end{tabular}

Fuente: Para 1986: "Población de derecho de 14 y más años ocupada, según edad y rama de actividad, por sexo". Padrón municipal de habitantes 1986. Centro de Estadística y Documentación de Canarias (CEDOC). Datos Estadísticos, 1987. Lanzarote. Oficina de Turismo. Consejería de Turismo y Transporte; "Población ocupada por sectores económicos. Resultados Autonómicos y Nacionales, 1986". EPA. INE (sólo consta agricultura).

Para 1991: "Población ocupada según edad, sexo y sectores económicos". Totales Autonómicos y Provinciales. Censo de Población. 1991, INE.; "Población de 16 y más años ocupada según ramas de actividad. Lanzarote". Censo de Población y viviendas, 1991. ISTAC; "Ocupados por sexo, rama de actividad económica y grupos de edad. Total nacional, 1991". Censo de población y viviendas, 1991. INE; Para 1996: "Población de 16 y más años ocupada según rama de actividad, por grupos de edad y sexo. Canarias y Lanzarote, 1996". Encuesta de población de Canarias, 1996. ISTAC; "Distribución porcentual de la población ocupada por sector de actividad. Resultados Nacionales, 1996". EPA. INE (para el cómputo nacional no se tiene explotación desde el Padrón Municipal de Habitantes). Elaboración propia. 
Gráfico 103. Estructura sectorial del empleo. Ocupados. España, Canarias y Lanzarote. 1986-1996 (\%)

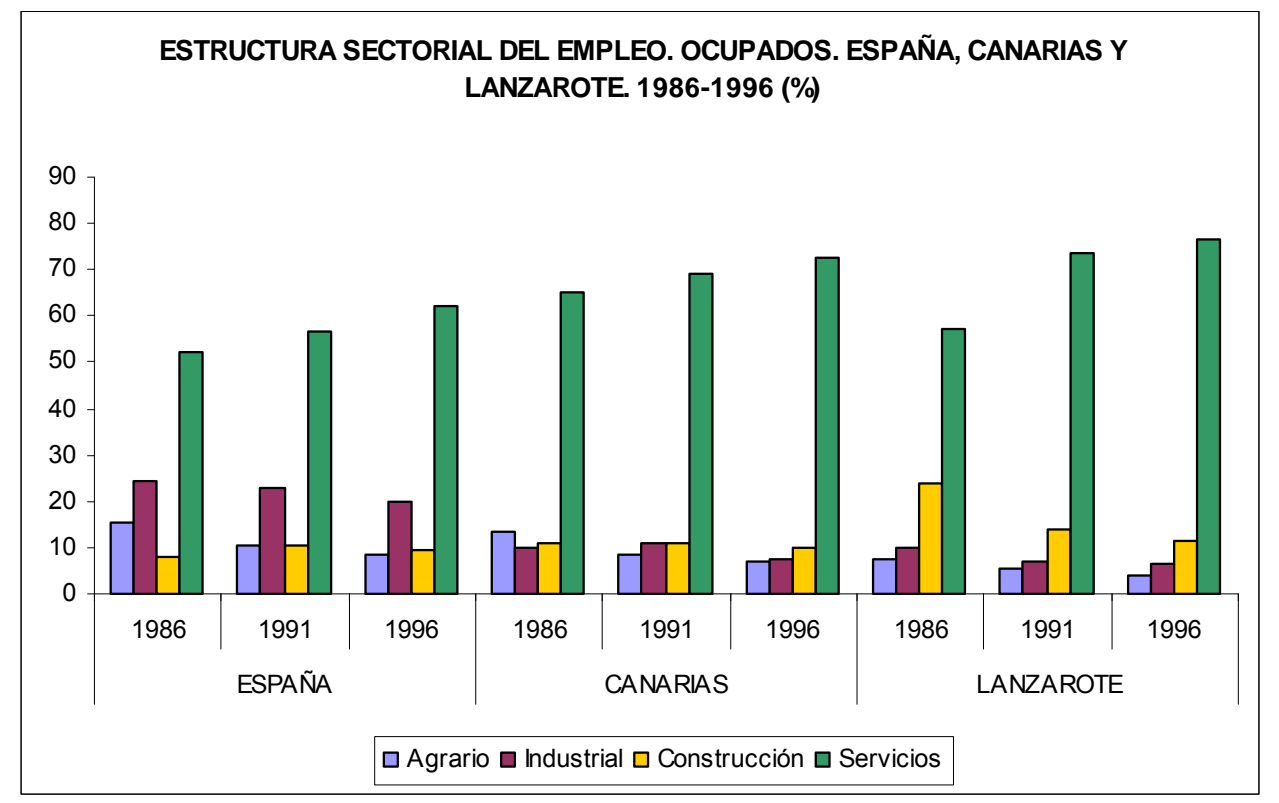

Fuente. Censos y Padrones municipales. Explotaciones del ISTAC e INE. Gráfico basado en la Tabla 117. Elaboración propia.

Fenómeno éste que se supone derivado de una crisis de sobreproducción que hace temblar la economía insular, que afecta principalmente al sector de la construcción y que arrastrará la isla varios años. El transvase de esta población se hará hacia el sector servicios que presenta el mayor peso relativo por sectores, a lo largo de toda la etapa, concentrando entre el $73 \%$ y el $79 \%$ de la población ocupada en el último quinquenio de análisis (19911996).

Tabla 118. Incremento interperiodo de la población ocupada por sector económico. Lanzarote, Canarias y España. 1986-1996. (\%)

\begin{tabular}{|c|c|c|c|c|c|c|c|c|c|}
\hline & \multicolumn{3}{|c|}{ LANZAROTE } & \multicolumn{3}{|c|}{ CANARIAS } & \multicolumn{3}{|c|}{ ESPAÑ A } \\
\hline & 1986-1991 & $1991-1996$ & 1986-1996 & 1986-1991 & $1991-1996$ & $1986-1996$ & 1986-1991 & 1991-1996 & $1986-1996$ \\
\hline AGRARIO & $-23,2$ & $-6,4$ & $-28,1$ & 31,1 & 2,96 & $-29,1$ & $-22,6$ & $-19,1$ & $-37,4$ \\
\hline INDUSTRIAL & $-21,9$ & 19,9 & $-6,3$ & 22,0 & $-15,04$ & 3,6 & 8,5 & $-13,5$ & $-6,2$ \\
\hline CONSTRUCCIÓN & $-38,6$ & 4,9 & $-35,6$ & 9,1 & 11,26 & 21,4 & 45,4 & $-8,2$ & 33,4 \\
\hline SERVICIOS & 36,89 & 34,01 & 83,4 & 16,0 & 28,13 & 48,6 & 24,3 & 8,0 & 34,2 \\
\hline
\end{tabular}

Fuente: Elaboración propia a partir de los datos de ocupados por sector.

En relación a la dinámica autonómica y nacional, es la misma que la de Lanzarote en relación al peso relativo de la población que se concentra en el sector servicios. El sector de la construcción en Canarias recupera población ocupada en el último quinquenio, al igual que en la isla, observando un incremento del 11,3\%, superior a Lanzarote que sólo presenta un incremento del $5 \%$ aproximadamente. 
El empleo en la construcción entró en crisis en Canarias al final de la década de los ochenta, no así para España que incrementa los ocupados en este sector entre 1986 y 1991, para luego reducir dichos efectivos en el siguiente quinquenio (1991-1996), observando un incremento negativo del $8 \%$, es decir, entra en crisis el sector cuando Canarias ya se ha recuperado.

La agricultura perderá empleo constantemente a lo largo de toda la etapa, en los tres ámbitos territoriales, Lanzarote, Canarias y España, al igual que el empleo industrial.

Comparativamente, la etapa desde que se inicia (1986) hasta que acaba (1996) se caracteriza por los crecimientos negativos, insulares, de la población ocupada en tres grandes sectores: agrario, industrial y construcción. Éste último posee una dinámica muy significativa pues pasa de un crecimiento de los ocupados de hasta el $107 \%$ en cinco años (1981-1986), a caer, en estos diez años (-36\%), fruto del freno que sufre el sector a finales de los años ochenta, como ya se ha señalado, derivado de una crisis de sobreproducción. Toda esta población que antes tenía actividad en alguno de estos tres sectores, que reducen su aportación al empleo, se recolocará en el sector servicios, pues es el que observa una explosión en el crecimiento de la población ocupada (83\%).

La dinámica insular, frente a la autonómica y la nacional, a lo largo de la etapa, es significativamente diferente en relación a los ocupados en tres sectores: industria (donde Canarias no pierde población ocupada), construcción y servicios (donde Canarias y España incrementan positivamente su población ocupada).

En cuanto a las tendencias de mayor significación en la evolución de la estructura ocupacional según profesiones, las profesiones donde se concentra la actividad y el empleo, en el primer quinquenio de los años noventa, son la hostelería y la construcción, aunque llama la atención como las profesiones protagonistas por poseer un mayor peso relativo dentro del total de ocupados en la isla, han sufrido un descenso importante hacia la mitad de la década del noventa. Hablamos de los trabajadores de la Hostelería y resto de servicios - que en 1991 participan en un 26,5\% y en 1996 descienden hasta una participación sobre el total de ocupados del 19,5\% (casi siente puntos) - . La Construcción, la Industria, la Minería y el Transporte también descienden, pero en un porcentaje no significativo. Fenómeno éste derivado de una caída del sector turístico sufrida al final de la década de los años ochenta, es decir, que se viene arrastrando de la etapa anterior y que ha afectado al empleo en esta. 
Tabla 119. Ocupados por sexo y profesión. Resultados insulares. 1991-1996 (\%).

\begin{tabular}{|c|c|c|c|c|c|c|}
\hline \multicolumn{7}{|l|}{ LANZAROTE } \\
\hline \multirow{2}{*}{ PROFESIONES } & \multicolumn{3}{|l|}{1991} & \multicolumn{3}{|l|}{1996} \\
\hline & Total & Varones & Mujeres & Total & Varones & Mujeres \\
\hline Profesionales Técnicos y similares & 10,1 & 47,6 & 52,4 & 13,7 & 50,6 & 49,4 \\
\hline Directivos AA.PP y Empresas & 1,6 & 81,1 & 18,9 & 6,0 & 73,8 & 26,2 \\
\hline Personal de Administración & 12,7 & 50,2 & 49,8 & 11,2 & 42,6 & 57,4 \\
\hline Comercio & 14,2 & 51,0 & 49,0 & 8,8 & 37,9 & 62,1 \\
\hline T. Hostelería y resto de servicios & 26,5 & 59,5 & 40,5 & 19,5 & 29,9 & 31,7 \\
\hline Agricultura y Ganadería & 4,7 & 86,8 & 13,2 & 3,0 & 91,5 & 8,5 \\
\hline T. Construcción, industria, minería y transportes & 21,8 & 98,0 & 2,0 & 21,5 & 94,8 & 5,2 \\
\hline Peones y trabajadores No especializados & 8,1 & 94,1 & 5,9 & 15,7 & 50,0 & 50,0 \\
\hline Fuerzas Armadas & 0,9 & 100,0 & 0,0 & 0,5 & 96,3 & 0,7 \\
\hline No Clasificables & --- & ---- & --- & 0,2 & 57,8 & 2,2 \\
\hline TOTAL & 100,0 & \multicolumn{2}{|c|}{100,0} & 100,0 & \multicolumn{2}{|c|}{100,0} \\
\hline
\end{tabular}

Fuente: Para 1981. "Población ocupada, según rama de actividad económica y profesión, por sexo". Censo de Población de 1981. Resultados Autonómicos y Provinciales. INE Para 1991: "Población de 16 y más años ocupada según profesión, por grupos de edad y sexo". Censo de Población de 1991. ISTAC. Para 1996: "Población de 16 y más años ocupada según profesión (grandes grupos y subgrupos principales), por grupos de edad y sexo". Encuesta de Población. Canarias 1996. ISTAC. Elaboración Propia.

Por el contrario asciende vertiginosamente el número de profesionales no especializados, casi un $8 \%$ en cinco años ( $8,1 \%$ en 1991 , al $15,7 \%$ en 1996$)$, sobre el total de ocupados. Estos constituyen el tercer grupo con más peso entre los ocupados de la isla. Se hace así notable la fuerte presencia que en Lanzarote tienen aquellas profesiones con menores niveles de cualificación o sin ella, debido a la implantación masiva del sector servicios, basado en la hostelería y el turismo, que ha dado un fuerte impulso a la actividades clasificadas dentro de la rama de la construcción.

Los profesionales de la agricultura y la ganadería, siguen sufriendo bajas en sus filas, fruto de lo que ya hemos comentado anteriormente, el fuerte proceso de terciarización de la economía que viene sufriendo la isla desde finales de la década del sesenta.

\section{b.- El desempleo}

Comparativamente, la isla presenta menores tasas de paro, generales y por sexo, con respecto a su Comunidad Autónoma y el país a lo largo de toda la etapa, excepto en 1991 que es más elevada que la nacional, año este que recoge lo que Lanzarote viene sufriendo (ya desde finales de la década de los ochenta): una crisis del sector turístico por sobreproducción, que afecta al empleo. 
Tabla 120. Tasa de actividad y paro por sexo. Lanzarote, Canarias y España. 1986-1996 (\%)

\begin{tabular}{|l|l|l|l||l|l|l||l|l|l||}
\cline { 2 - 11 } \multicolumn{1}{c|}{} & \multicolumn{3}{l|}{ LANZAROTE } & \multicolumn{2}{l||}{ CAN ARI AS } & \multicolumn{2}{l||}{ ESPAÑ A } \\
\cline { 2 - 11 } & 1986 & 1991 & 1996 & 1986 & 1991 & 1996 & 1986 & 1991 & 1996 \\
\hline \hline Tasa de actividad & 50,4 & 63,0 & 62,0 & 48,0 & 51,7 & 55,0 & 34,6 & 50,2 & 51,3 \\
\hline Varones & 75,8 & 82,9 & 76,0 & 35,2 & 70,4 & 70,2 & 70,3 & 68,3 & 65,1 \\
\hline Mujeres & 24,2 & 41,8 & 47,2 & 12,8 & 33,5 & 40,4 & 29,6 & 33,3 & 38,2 \\
\hline \hline $\begin{array}{l}\text { Número de } \\
\text { parados }\end{array}$ & 2.689 & 4.222 & 6.268 & 117.837 & 111.699 & 129.650 & 2.954 .800 & 2.032 .402 & 3.646 .300 \\
\hline \hline Tasa de paro & 13,4 & 19,24 & 16,8 & 23,7 & 27,1 & 25,4 & 21,5 & 18,9 & 22,1 \\
\hline Varones & 10,4 & 17,87 & 14,7 & 21,5 & 25,2 & 22,6 & 18,4 & 14,9 & 17,4 \\
\hline Mujeres & 23,1 & 22,16 & 20,3 & 29,7 & 30,9 & 30,3 & 25,7 & 26,8 & 29,6 \\
\hline
\end{tabular}

Fuente: Para 1986: "Población de derecho de 16 y más años de Lanzarote y la Comunidad Autónoma de Canarias según sexo y relación con la actividad económica, 1986". Anuario Estadístico de Canarias, 1986. Centro de Estadística y documentación de Canarias (CEDOC); "Población parada y Tasa de paro. Datos nacionales (en miles). 1986". Padrón municipal de habitantes, 1986. INE; Para 1991: "Población de 16 y más años por relación con la actividad económica y sexo, por municipios. Total Lanzarote, 1991". Censo de población y viviendas, 1991 (explotación municipal). INE; "Tasa actividad y paro por sexo. Comunidad Autónoma de Canarias y Resultados Nacionales, 1991". Censo de población y viviendas, 1991. INE; Para 1996: "Población Insular de 16 y más años según relación con la actividad económica por grupos de edad y sexo. Lanzarote y Canarias, 1996". Encuesta de Población de Canarias 1996. ISTAC; "Activos y parados por sexo y grupo de edad. Total nacional, 1996". EPA, 1996. INE (no existe tal desagregación en el Padrón municipal de habitantes del año 1996); Elaboración Propia.

Gráfico 104. Evolución de la tasa de paro. Lanzarote, Canarias y España. 1986-1996 (\%)

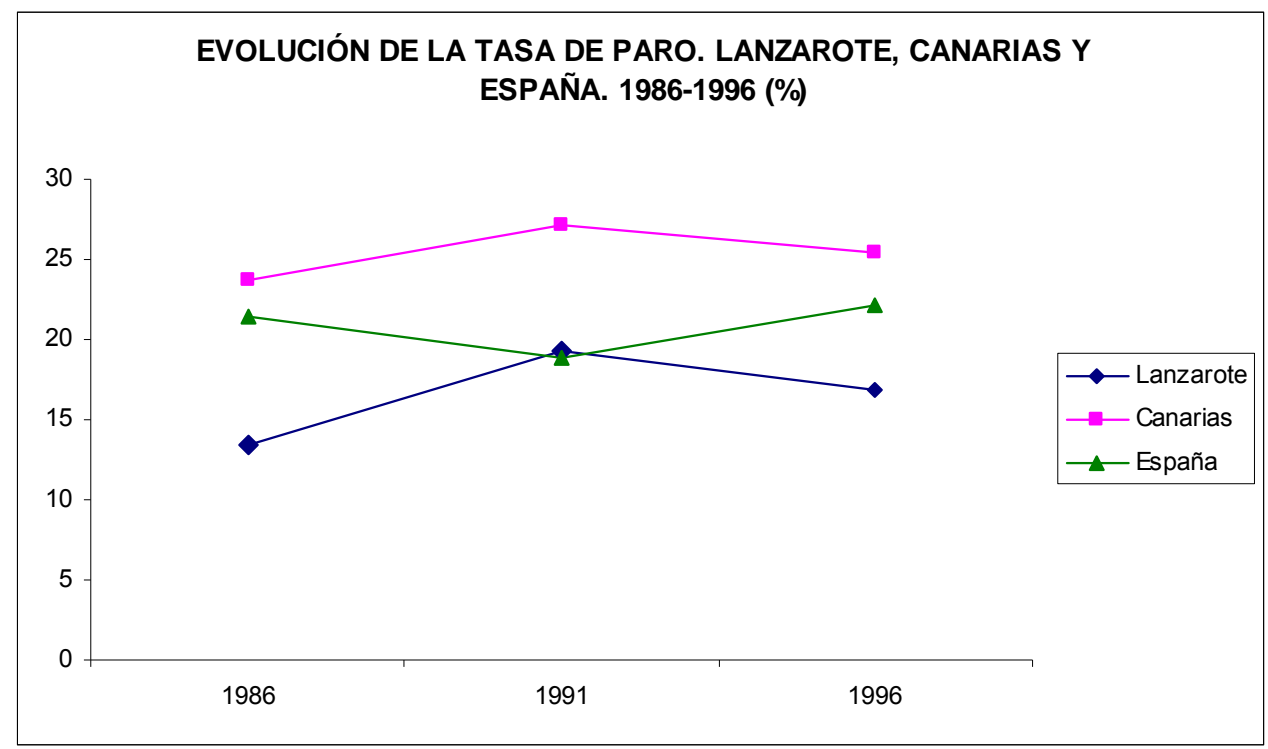

Fuente: Censos y Padrones municipales. Explotaciones del ISTAC e INE; Encuesta de población activa. Gráfico basado en la Tabla 120. Elaboración propia.

Por otro lado, el perfil social del parado, al igual que en la etapa anterior, es femenino, como en el resto de España. Ahora bien, es significativo como la mujer tiene más peso entre la población activa de la isla que en el resto de España. 
Gráfico 105. Evolución de la tasa de paro por sexo. Lanzarote, Canarias y España. 1986-1996

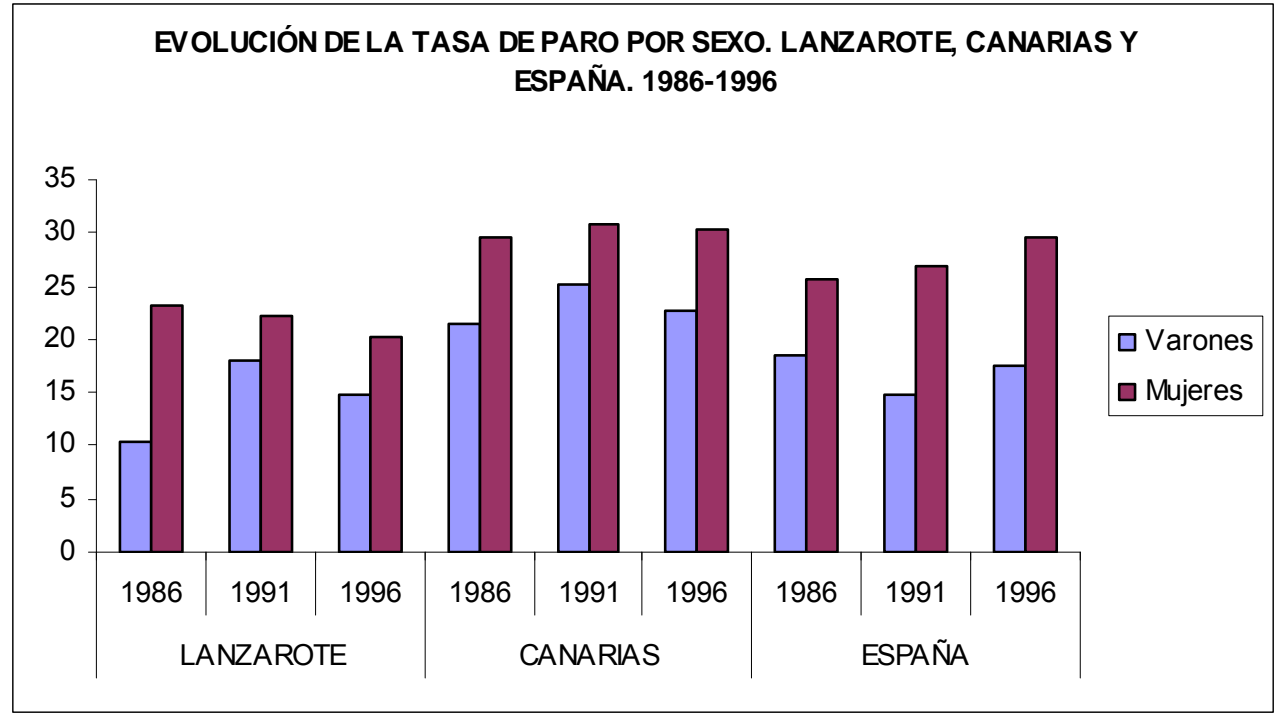

Fuente: Gráfico basado en la Tabla 119. Elaboración propia.

Al final de la década del ochenta ya se ha perdido empleo en el sector primario y será a lo largo de la década del noventa cuando se reduzca sus niveles de desempleo, puesto que estos trabajadores se irán relocalizando en otras áreas de actividad, perdiendo ésta definitivamente importancia en la economía, el empleo y la sociedad insular. Esta dinámica es similar a la que sigue el sector industrial, que ha perdido mucha presencia en la economía de la Isla al final de la etapa, concentrando el segundo menor porcentaje de paro.

Tabla 121. Estructura sectorial del paro. Lanzarote, Canarias y España. 1986-1996 (\%)

\begin{tabular}{|l||c|c|c||c|c|c||c|c|c||}
\cline { 2 - 12 } \multicolumn{1}{c|}{} & \multicolumn{3}{l||}{ LANZAROTE } & \multicolumn{3}{l||}{ CANARIAS } & \multicolumn{3}{l|}{ ESPAÑ A } \\
\cline { 2 - 12 } \multicolumn{1}{c|}{} & 1986 & 1991 & 1996 & 1986 & 1991 & 1996 & 1986 & 1991 & 1996 \\
\hline \hline AGRARIO & 8,0 & 5,6 & 3,5 & 5,6 & 8,6 & 8,6 & 8,6 & 13,8 & 6,6 \\
\hline INDUSTRIAL & 20,1 & 7,7 & 5,0 & 6,5 & 11,2 & 15,6 & 15,6 & 27,0 & 9,9 \\
\hline CONSTRUCCIÓN & 13,9 & 16,2 & 12,1 & 4,0 & 26,5 & 12,0 & 12 & 14,9 & 9,8 \\
\hline SERVICIOS & 10,1 & 70,5 & 70,8 & 31,7 & 53,8 & 54,6 & 23 & 44,3 & 30,7 \\
\hline No clasificados & ------ & 8,6 & 42,3 & -- & 16,8 & -- & -- & 42,9 \\
\hline
\end{tabular}

Fuente: Para 1986: "Paro agrícola, industria, construcción y servicios. \% s/p. activa del sector, 1986. Lanzarote". PIOT de Lanzarote. Tomo 4. Área económica, 1987, (pp. 29); "Parados por sectores económicos. Resultados Nacionales y Autonómicos, 1986". EPA. INE: Para 1991: "Población municipal de 16 y más años en paro, por sector de actividad y sexo. Lanzarote, 1991". Censo de Población y viviendas, 1991. ISTAC; "Parados que han trabajado antes por Comunidades Autónomas, Sexo, Rama de actividad y Grupos de edad. Canarias, 1991". Censo de Población y Viviendas, 1991. INE; "Parados que han trabajado antes por Sexo, Rama de actividad y Grupos de edad. Resultados nacionales, 1991". Censo de Población y viviendas, 1991. INE; Para 1996: "Paro registrado por sectores económicos e islas, a diciembre de cada año". Anuario Estadístico de Canarias, 1999. ISTAC; "Paro registrado en miles. Total Nacional". Anuario Estadístico de España, 1997. Elaboración propia. 
No así ocurrirá en el resto de los sectores de actividad económica pues pasada la década del ochenta el desempleo se empieza a fijar de forma notable en el sector servicios, alcanzando el $70 \%$ del desempleo registrado en 1991 (frente al 10\% que registraba en la década anterior) y ya no bajará en el resto de la etapa. Lógico, pues es el que concentra la mayor actividad, por tanto uno de los más dinámicos.

El sector que fluctúa es la construcción, que inicia la década del ochenta con una aportación al desempleo de casi el 30\% sobre el total, bajando notablemente (hasta el 10\%) a lo largo de la década, para sufrir un repunte en 1991 (16\% sobre el total), derivado de la crisis de sobreproducción que vive la isla desde el final de los años ochenta. Aunque a lo largo del primer quinquenio de la década de los años noventa volverá a observar una notable reducción, situándose en el $12 \%$ sobre el paro total insular.

Gráfico 106. Evolución del paro por sectores económicos. Lanzarote. 1986-1996 (\%).

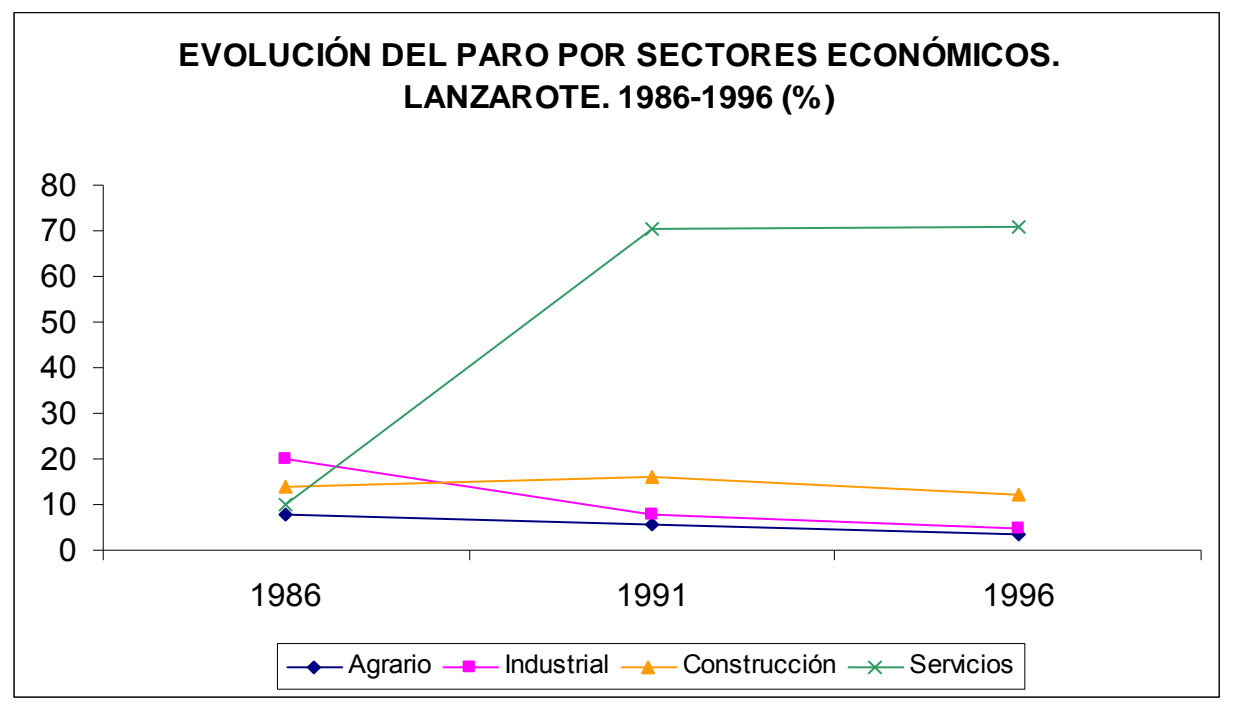

Fuente: Avance PIOT de Lanzarote, 1987. Cabildo Insular de Lanzarote; Censo de Población, 1991, INE; Anuario Estadístico de Canarias, 1999. ISTAC; Gráfico basado en la información recogida en la Tabla 121. Elaboración propia.

Comparativamente, en el caso de la construcción, el desempleo es mayor en la Comunidad Autónoma hasta 1996 donde se iguala al insular (12\%), no es así para el país, donde el porcentaje de parados de la construcción, sobre el total, permanece por debajo del insular. El sector servicios de Canarias y de España presenta menos paro relativo que el de Lanzarote (entre 20 y 30 puntos menos respectivamente) a partir de la década de los años noventa. 
Gráfico 107. Evolución del paro por sectores económicos. Lanzarote, Canarias y España. 1986-1996 (\%)

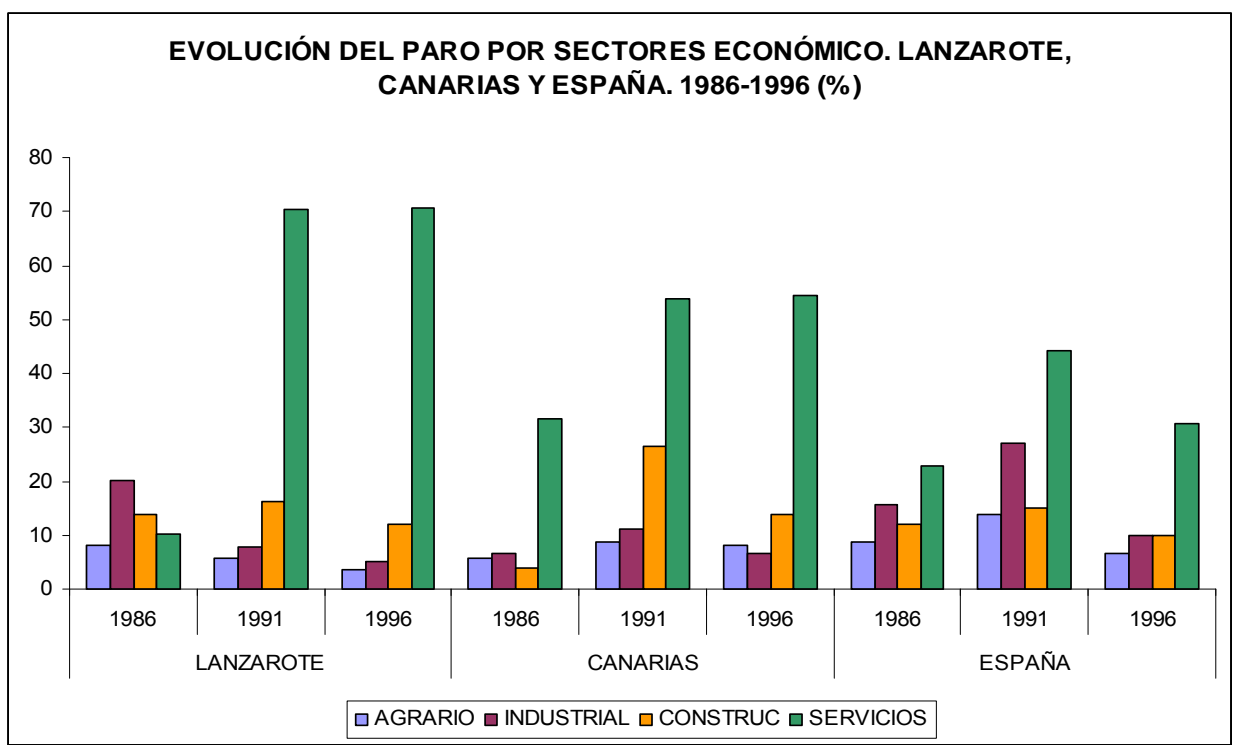

Fuente: Avance PIOT de Lanzarote, 1987. Cabildo Insular de Lanzarote; Censo de Población, 1991 y Anuario Estadístico de España, 1997, INE; Anuario Estadístico de Canarias, 1999. ISTAC; Gráfico basado en la información recogida en la Tabla 121. Elaboración propia

\subsubsection{2.- POBLACIÓN, OFERTA Y DEMANDA TURÍSTICA, EMPLEO Y PARO}

Al igual que para la etapa anterior, en esta volvemos a realizar la misma pregunta: ¿es factible el aumento de la oferta turística como medida de creación de empleo y por tanto de incremento del bienestar? Para contestar se han calculado los porcentajes de incremento de los principales indicadores de empleo junto con los de oferta y demanda turística. Sin olvidar que hay un elemento que puede afectar a los indicadores socioeconómicos como es el aumento de la población potencialmente activa (entre 16 y 64 años), puesto que Lanzarote sigue siendo un polo de atracción de personas por motivaciones laborales.

Tabla 122. Incremento de la población potencialmente activa, la oferta y demanda turística, el empleo y paro. Lanzarote, Canarias y España. Entre 1986 y 1996(\%)

\begin{tabular}{|l|r|r|r|r|c||}
\cline { 2 - 6 } \multicolumn{1}{c|}{} & $\begin{array}{l}\text { Incremento } \\
\text { P.P.A. }\end{array}$ & $\begin{array}{l}\text { Incremento } \\
\text { Plazas }\end{array}$ & $\begin{array}{l}\text { Incremento } \\
\text { Afluencia }\end{array}$ & $\begin{array}{l}\text { Incremento } \\
\text { Ocupados }\end{array}$ & $\begin{array}{l}\text { Incremento } \\
\text { Parados }\end{array}$ \\
\hline \hline LANZAROTE & 53,3 & 37,2 & 219,0 & 36,6 & 133,1 \\
\hline CANARIAS & 21,5 & 28,6 & 95,5 & 32,8 & 10,0 \\
\hline ESPAÑA & 8,4 & 36,6 & 14,8 & 13,3 & 23,4 \\
\hline
\end{tabular}

Fuente: ( $\left.{ }^{*}\right)$ P.P.A. = Población potencialmente activa (de 16 a 64 años) estimada a partir de datos censales (1991) y padronales (1986 y 1996). Elaboración propia a partir de datos de capítulos anteriores.

En relación a los datos obtenidos, la respuesta a la pregunta formulada en este epígrafe no arroja una respuesta positiva, al igual que en la etapa anterior, es decir, el aumento de la 
oferta y la demanda turística no constituye una vía para el descenso del desempleo y mejora del bienestar social derivado del mismo. Pues a pesar del incremento de la afluencia y las plazas de alojamiento, entre 1986 y 1996, el número de parados crece en la isla $(133,1 \%)$ sin parangón con respecto al mismo periodo para Canarias (10\%) y España $(23,4 \%)$. Y aunque, lógicamente, hacen crecer la actividad y el número de ocupados $(36,6 \%)$, la demanda de trabajadores que genera no es suficiente para absorber el potencial de fuerza de trabajo (población en edad de trabajar) que existe en la isla y que ha crecido, a lo largo de la etapa, por encima de la población ocupada $(53,3 \%)$.

Elaborando las variaciones interperiodo (por quinquenio), que en este caso parece significativo comentar, pues esta etapa está marcada por la crisis de sobreproducción de 1988 y por la nueva estrategia territorial que constituye el PIOT aprobado en 1991, que limita los crecimiento en materia de oferta turística, como vía para contener y que no se repitan crisis de este tipo, como ya se ha señalado, las conclusiones no se modifican con respecto a la respuesta de la pregunta que plantea este epígrafe.

Tabla 123. Incremento interperiodo. Población, oferta y demanda turística, empleo y paro. Lanzarote 1986-1996 (\%)

\begin{tabular}{|c|c|c|c|c|c|}
\hline \multicolumn{6}{|c|}{ LANZAROTE } \\
\hline & $\begin{array}{c}\text { Incremento } \\
\text { P.P.A.* }\end{array}$ & $\begin{array}{c}\text { Incremento } \\
\text { Plazas }\end{array}$ & $\begin{array}{c}\text { Incremento } \\
\text { Afluencia }\end{array}$ & $\begin{array}{c}\text { Incremento } \\
\text { Ocupados }\end{array}$ & $\begin{array}{c}\text { Incremento } \\
\text { Parados }\end{array}$ \\
\hline 1986-1991 & 21,3 & 60,2 & 121,3 & 6,2 & 36,9 \\
\hline 1991-1996 & 26,3 & 10,8 & 44,2 & 41,1 & 29,8 \\
\hline \multicolumn{6}{|c|}{ CANARIAS } \\
\hline & $\begin{array}{c}\text { Incremento } \\
\text { P.P.A. }\end{array}$ & $\begin{array}{c}\text { Incremento } \\
\text { Plazas }\end{array}$ & $\begin{array}{c}\text { Incremento } \\
\text { Afluencia }\end{array}$ & $\begin{array}{l}\text { Incremento } \\
\text { Ocupados }\end{array}$ & $\begin{array}{c}\text { Incremento } \\
\text { Parados }\end{array}$ \\
\hline 1986-1991 & 8,6 & 47,4 & 30,4 & 8,5 & $-5,2$ \\
\hline 1991-1996 & 11,9 & $-12,7$ & 48,3 & 22,2 & 1,5 \\
\hline \multicolumn{6}{|l|}{ ESPAÑA } \\
\hline & $\begin{array}{l}\text { Incremento } \\
\text { P.P.A. }{ }^{*}\end{array}$ & $\begin{array}{l}\text { Incremento } \\
\text { Plazas }\end{array}$ & $\begin{array}{l}\text { Incremento } \\
\text { Afluencia }\end{array}$ & $\begin{array}{l}\text { Incremento } \\
\text { Ocupados }\end{array}$ & $\begin{array}{c}\text { Incremento } \\
\text { Parados }\end{array}$ \\
\hline 1986-1991 & 3,3 & 25,0 & 12,9 & 15,0 & $-31,2$ \\
\hline 1991-1996 & 4,9 & 9,3 & $-32,3$ & $-1,4$ & 20,0 \\
\hline
\end{tabular}

Fuente: (*) P.P.A.: Población potencialmente activa (de 16 a 64 años) estimada a partir de datos censales (1981 y 1991) y padronales (1986 y 1996). Elaboración propia a partir de datos de capítulos anteriores.

Entre 1991-1996, la oferta y demanda turística reduce su incremento notablemente con respecto a los periodos anteriores, que no deja de crecer y con ello la población potencialmente activa, nutrida además por población externa, y los parados, que parecen 
crecer al mismo ritmo. En éste quinquenio la isla va a ir saliendo de los efectos de la crisis de sobre producción que generó el fuerte crecimiento de la oferta turística de finales de los ochenta, incrementando su población activa.

El incremento constante de las plazas de alojamiento turístico y la entrada de turistas tiene efectos positivos sobre el nivel de ocupados, pero genera presión sobre el territorio y efecto llamada, incrementándose la presión demográfica sobre la oferta de empleo y elevándose el paro. Los recursos humanos no se integran adecuadamente dentro de la cadena productiva de esta economía turística, carencia que se admite en el PIOT aprobado en 1991 y que se agrava a lo largo de la década, por lo que, la nueva ordenación del territorio no contribuye a su reconducción.

\subsubsection{3.- CONCLUSIONES}

Esta etapa, caracterizada por una economía insular centrada en el sector de la construcción, que va siendo sustituida progresivamente por el sector servicios, principalmente de hostelería y turismo, consolidada en el periodo anterior y marcada ahora por una crisis de sobreproducción turística y la aprobación en 1991 de un nuevo Plan Insular de Ordenación del Territorio (PIOT) tendente al control del crecimiento de la oferta turística, presenta en conclusión la siguiente dinámica en su estructura laboral:

1. Predominio del sector servicios basado en la actividad turística, que concentra los indicadores socioeconómicos sectoriales: actividad, empleo y paro, principalmente. Seguido de la construcción.

2. Crisis en el sector de la construcción, con reducción del número de ocupados, y trasvase de dicha población al sector servicios.

3. Crecimiento del número de trabajadores no especializados, por tanto del empleo con baja cualificación.

4. Reducción constante del empleo en el sector primario: agricultura y ganadería, cuya aportación es meramente anecdótica.

5. Concentración del desempleo en el sector servicios, en mayor medida que en Canarias y en España.

6. El incremento de la oferta y demanda turística no es directamente proporcional a la reducción del paro y el aumento del empleo, a lo que se añade el que la isla no puede absorber los fuertes incrementos de la población en edad de trabajar.

La dinámica socioeconomía insular es pues de incremento del paro, que podría derivar o tener consecuencias negativas sobre el nivel de marginalidad y pobreza en la isla, pues el 
empleo es una vía de integración y participación en la sociedad. Todo ello a pesar del crecimiento de la actividad que provoca la ampliación de la oferta turística. Es por ello que dicha dinámica previsiblemente puede mermar las posibilidades de mejora del bienestar social insular, como destino de masas maduro.

\subsection{6.- EFECTOS SOBRE LA RIQUEZA. LA RENTA. 1986-1996}

A finales de la década de los años ochenta, prácticamente toda la economía insular depende del turismo. La gran mayoría de las ramas de actividad productivas están implicadas parcial o totalmente. Lanzarote, por tanto, no posee diversificación productiva, y sabemos que "una economía es tanto más resistente a las crisis cuanto mayor sea su grado de diversificación, y mayores, por tanto, las opciones que ofrezca el uso y explotación de los recursos naturales, humanos y financieros. El monocultivo conlleva peligros (...)". (PIOT. Tomo 4. Área Económica. 1987, pp. 4).

\subsubsection{1.- EVOLUCIÓN DE LA RENTA}

Del análisis de los estudios de renta municipal por habitante elaborados por el Banesto en la década de los años ochenta, concluíamos, en la etapa anterior, el continuado crecimiento económico que experimenta la isla hasta finales de la misma.

Tabla 124. Nivel de renta media por habitante de los municipios y de Lanzarote, Canarias y España. 1986.

\begin{tabular}{|c|c|c|c|c|c|c|c|c|c|c|c|}
\hline Ptas & Nivel & Arrecife & Haría & San Bartolomé & Teguise & Tías & Tinajo & Yaiza & Lanzarote & Canarias & España \\
\hline$\leq 330.000$ & 1 & & & & & & & & & & \\
\hline $330.001-385.000$ & 2 & & & & & & & & & & \\
\hline $385.001-440.000$ & 3 & & & & & & & & & & \\
\hline $440.001-525.000$ & 4 & & & & & & & & & & \\
\hline $525.001-660.000$ & 5 & & & & & & & & & & \\
\hline $660.001-825.000$ & 6 & & & & & & & & & & \\
\hline $825.001-990.000$ & 7 & & & & & & & & & & \\
\hline $990.001-1.210 .000$ & 8 & & & & & & & & & & \\
\hline $1.210 .001-1.430 .000$ & 9 & & & & & & & & & & \\
\hline$>1.430 .000$ & 10 & & & & & & & & & & \\
\hline
\end{tabular}

Nota: El nivel de renta per cápita de la isla se ha calculado a través de una media ponderada en relación al peso poblacional.

Fuente: "Relación de los municipios por provincias, con indicación de su nivel de renta por habitante (en pesetas corrientes de cada año). Las Palmas, 1986". Anuario del Mercado Español, 1988. Banco Español de Crédito (Banesto). 
Si la década de los años ochenta acabó con una distribución municipal de la renta media por habitante notablemente jerarquizada, la década de los noventa se abre con múltiples cambios.

Tabla 125. Nivel de renta media por habitante de los municipios y de Lanzarote, Canarias y España. 1991.

\begin{tabular}{|c|c|c|c|c|c|c|c|c|c|c|c|}
\hline Ptas & Nivel & Arrecife & Haría & San Bartolomé & Teguise & Tías & Tinajo & Yaiza & Lanzarote & Canarias & s España \\
\hline$\leq 440.000$ & 1 & & & & & & & & & & \\
\hline $440.001-515.000$ & 2 & & & & & & & & & & \\
\hline $515.001-585.000$ & 3 & & & & & & & & & & \\
\hline $585.001-700.000$ & 4 & & & & & & & & & & \\
\hline $700.001-880.000$ & 5 & & & & & & & & & & \\
\hline $880.001-1.100 .000$ & 6 & & & & & & & & & & \\
\hline $1.100 .001-1.320 .000$ & 7 & & & & & & & & & & \\
\hline $1.320 .001-1.615 .000$ & 8 & & & & & & & & & & \\
\hline $1.615 .001-1.900 .000$ & 9 & & & & & & & & & & \\
\hline$>1.900 .000$ & 10 & & & & & & & & & & \\
\hline
\end{tabular}

Nota: El nivel de renta per cápita de la isla se ha calculado a través de una media ponderada en relación al peso poblacional.

Fuente: "Niveles de renta media por habitante en 1991, de las Comunidades Autónomas, Provincias y Municipios". Anuario del Mercado Español, 1993. Banco Español de Crédito (Banesto).

La mayor parte de los municipios de la isla que observaban en el año 1986 unas rentas per cápita bajas, cinco años después han experimentado un salto cuantitativo significativo, con lo que ya no ostenta el municipio capitalino, Arrecife, el liderazgo económico. La excepción es el municipio de Haría, que se localiza al norte de la isla (con costa mayoritariamente escarpada no adecuada para un modelo turístico de sol y playa), que no ha alcanzado los niveles de renta de sus vecinos, pues su oferta turística es escasa $(0,6 \%)$. 
Mapa 20. Nivel de renta disponible por habitante de los municipios de Lanzarote. 1991.

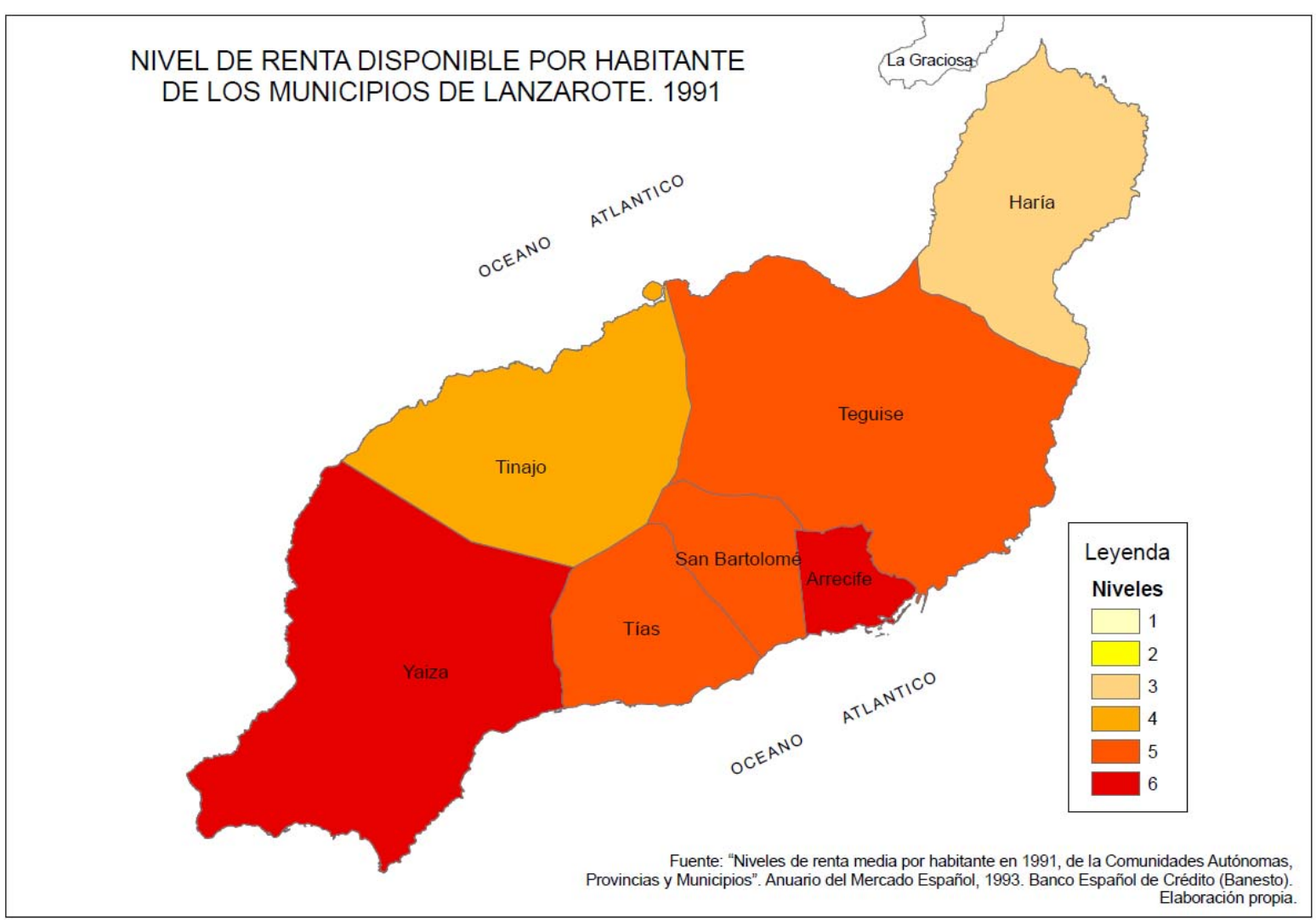

En 1991, la fuerte jerarquización en la distribución de la renta municipal se ha roto, por tanto se ha producido un proceso de nivelación, derivado de la explosión urbanística impulsada por la actividad turística. 
Tabla 126. Oferta turística por municipio. Lanzarote. 1986-1996. (\%)

\begin{tabular}{|c|c|c|c|c|c|c|c|c|}
\hline & \multicolumn{2}{|c|}{1986} & \multicolumn{2}{|c|}{1991} & \multicolumn{2}{|c|}{1996} & \multirow{2}{*}{$\begin{array}{c}\text { Variación } \\
\text { 1986-1991 (\%) }\end{array}$} & \multirow{2}{*}{$\begin{array}{c}\text { Variación } \\
1991-1996 \text { (\% }\end{array}$} \\
\hline MUNICIPIO & Absolutos & $\%$ & Absolutos & $\%$ & Absolutos & $\%$ & & \\
\hline Arrecife & 1.193 & 3,1 & 954 & 2,0 & 1.335 & 2,5 & $-20,1$ & 40,0 \\
\hline Haría & 192 & 0,5 & 48 & 0,1 & 292 & 0,6 & $-75,2$ & 512,3 \\
\hline San Bartolomé & 0 & 0,0 & 48 & 0,1 & 34 & 0,1 & --- & $-28,7$ \\
\hline Teguise & 5.698 & 14,8 & 9.443 & 19,8 & 13.887 & 26,3 & 65,7 & 47,1 \\
\hline Tías & 27.257 & 70,8 & 30.140 & 63,2 & 28.778 & 54,5 & 10,6 & $-4,5$ \\
\hline Tinajo & 1.155 & 3,0 & 1.192 & 2,5 & 930 & 1,8 & 3,2 & $-22,0$ \\
\hline Yaiza & 3.003 & 7,8 & 5.866 & 12,3 & 7.574 & 14,3 & 95,3 & 29,1 \\
\hline TOTAL & 38.498 & 100,0 & 47.690 & 100,0 & 52.830 & 100,0 & 23,9 & 10,8 \\
\hline
\end{tabular}

Fuente: "Indicadores de la oferta. Enero, 1987". Cabildo Insular de Lanzarote. Avance PIOT de Lanzarote". Tomo 5. Sociedad y Turismo. Capítulo IV. 3.1. 1987 (pp. 20). "Oferta de plazas alojativas según tipo, por municipios. Total Insular, 1991 y 1996 ". Oficina de turismo interior. Anuario Estadístico de Lanzarote, 1992 y 1996. Centro de datos. Cabildo de Lanzarote. Elaboración propia.

Gráfico 108. Evolución de las plazas de alojamiento turístico por municipio. Lanzarote. 1986-1996 (\%).

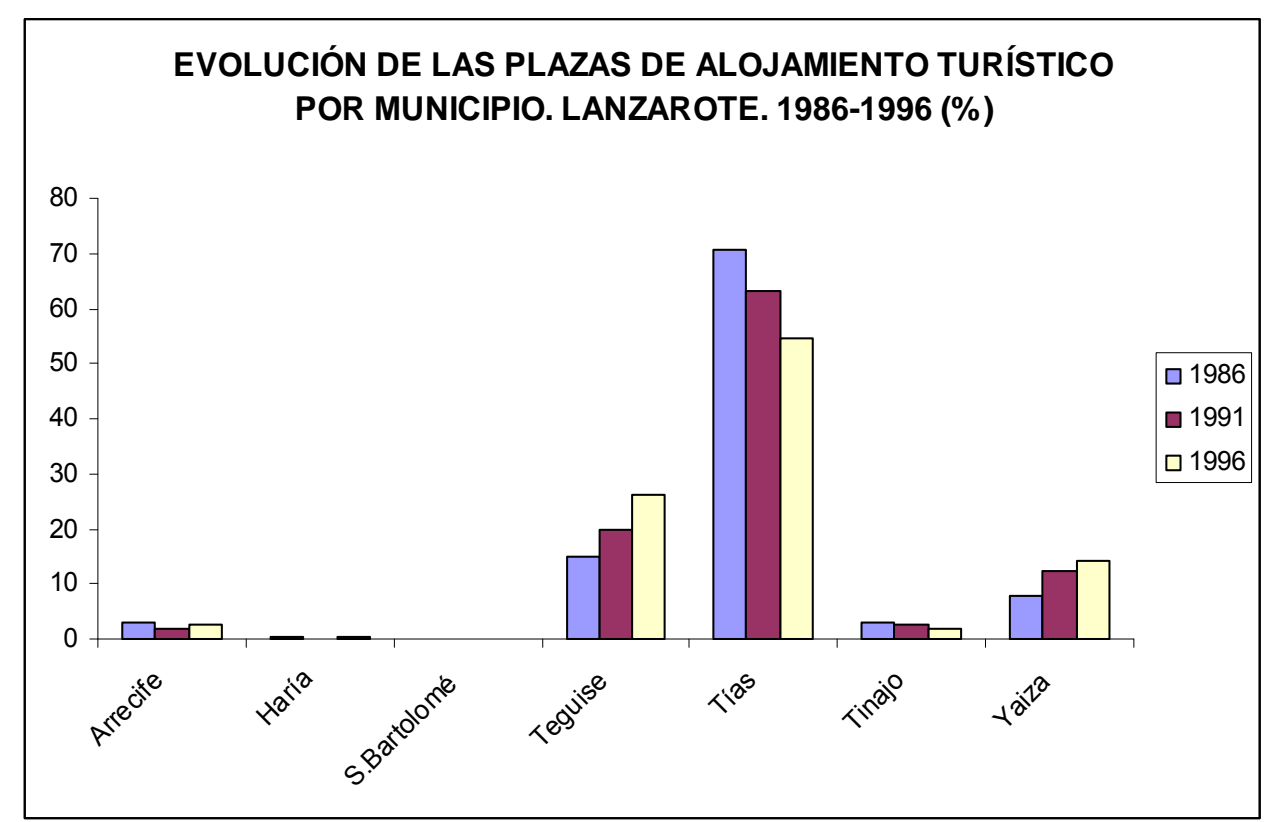

Fuente: Avance PIOT de Lanzarote, 1987; Anuario estadístico de Lanzarote. Cabildo Insular de Lanzarote. Gráfico basado en la información recogida en la Tabla 126. Elaboración propia.

A pesar de la dinámica descrita sólo hay dos municipios que se encuentran al mismo nivel en renta media por habitante que la provincia (Las Palmas) y Canarias, estos son: Arrecife (centro administrativo y comercial de la isla) y Yaiza (municipio del sur que ha sufrido una fuerte explosión de la actividad urbanística destinada al turismo). 
Gráfico 109. Renta media familiar disponible por habitante. Lanzarote, sus municipios, la provincia y Canarias. 1991

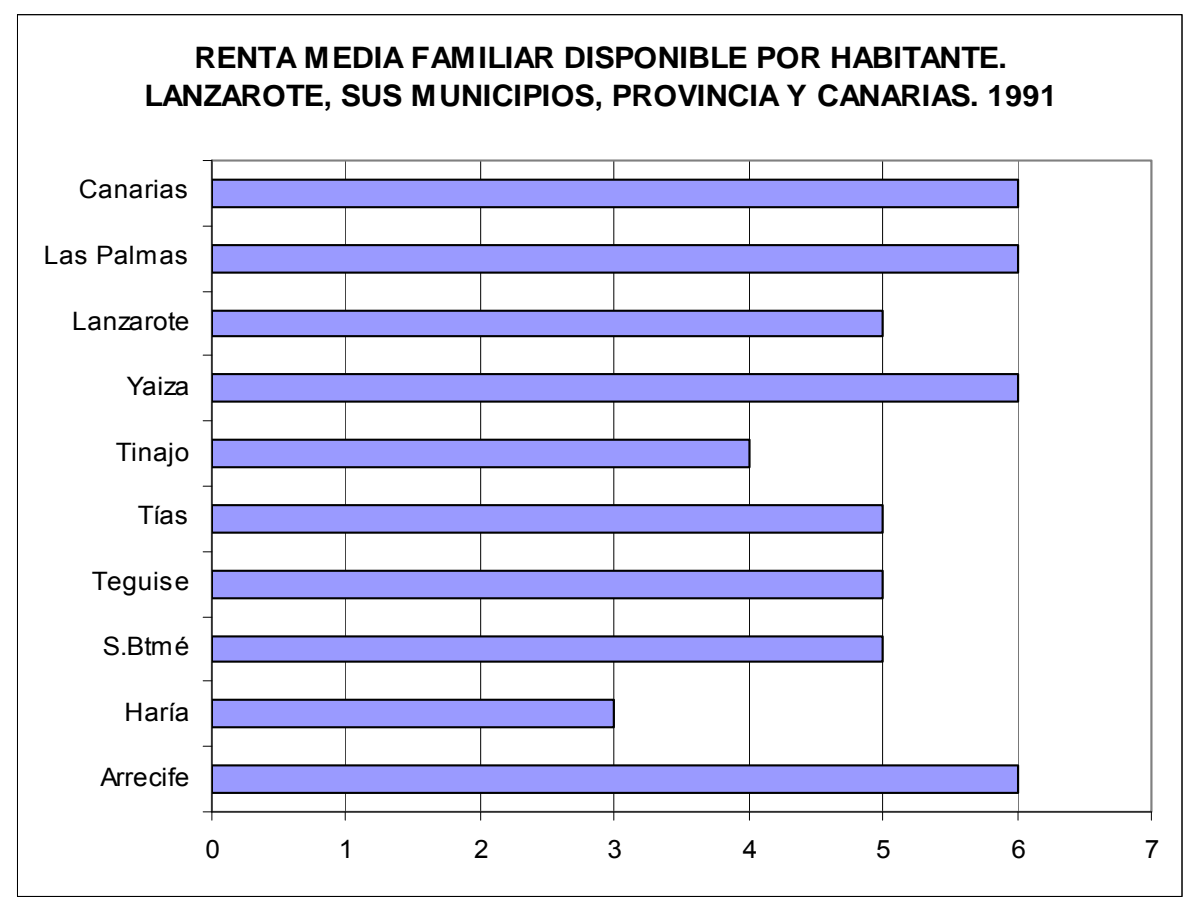

Fuente: Anuario del Mercado Español, 1993. Banco Español de Crédito (Banesto); Gráfico basado en la Tabla 125. Elaboración propia.

En relación a los datos presentados por el Banesto, la renta media familiar por habitante de Lanzarote, en 1991, se sitúa aproximadamente en el nivel 5 (700.001-880.000 ptas corrientes de cada año), por debajo a la de su provincia y comunidad autónoma.

Para poder dar idea de en qué situación acaba este periodo, el último referente, para 1996, sólo puede ser extraído del Anuario Comercial publicado por la Caixa en 1998, que en la década de los años noventa toma el relevo y continúa y mejora la metodología desarrollada por el Servicio de Estudios de Banesto. 
Tabla 127. Nivel de renta disponible por habitante de los municipios y de Lanzarote, Canarias y España. 1996.

\begin{tabular}{|c|c|c|c|c|c|c|c|c|c|c|c|}
\hline Ptas & Nivel & Arrecife & Haría & San Bartolomé & Teguise & Tías & Tinajo & Yaiza & Lanzarote & Canarias & España \\
\hline$\leq 900.000$ & 1 & & & & & & & & & & \\
\hline $900.000-1.000 .000$ & 2 & & & & & & & & & & \\
\hline $1.000 .000-1.125 .000$ & 3 & & & & & & & & & & \\
\hline $1.125 .000-1.250 .000$ & 4 & & & & & & & & & & \\
\hline $1.250 .000-1.400 .000$ & 5 & & & & & & & & & & \\
\hline $1.400 .000-1.600 .000$ & 6 & & & & & & & & & & \\
\hline $1.600 .000-1.800 .000$ & 7 & & & & & & & & & & \\
\hline $1.800 .000-2.000 .000$ & 8 & & & & & & & & & & \\
\hline $2.000 .000-2.200 .000$ & 9 & & & & & & & & & & \\
\hline$>2.200 .000$ & 10 & & & & & & & & & & \\
\hline
\end{tabular}

* El nivel de renta per cápita de la isla se ha calculado a través de una media ponderada en relación al peso poblacional.

Fuente: "Nivel económico: renta familiar disponible por habitante, 1996. Comunidades Autónomas, Provincias y Municipios". Anuario Comercial de España. Servicios de Estudios de la Caja de Ahorros y pensiones de Barcelona (Caixa). 1998.

De dicho estudio se deriva el que sean dos los municipios de la isla que casi han doblado la renta familiar por habitante y que por tanto, se sitúan a la cabeza de la jerarquía municipal insular, estos son Teguise y Tías, precisamente aquellos que concentran la mayor oferta de alojamiento turístico. El resto de los municipios se encuentran en desventaja económica, aunque todos observan un incremento de renta con respecto al año 1991, a excepción del municipio capitalino, Arrecife, que no presenta un crecimiento de la renta familiar disponible significativo en el último quinquenio y que además es el que concentra el mayor crecimiento y volumen de residentes. 
Mapa 21. Nivel de renta disponible por habitante de los municipios de Lanzarote. 1996

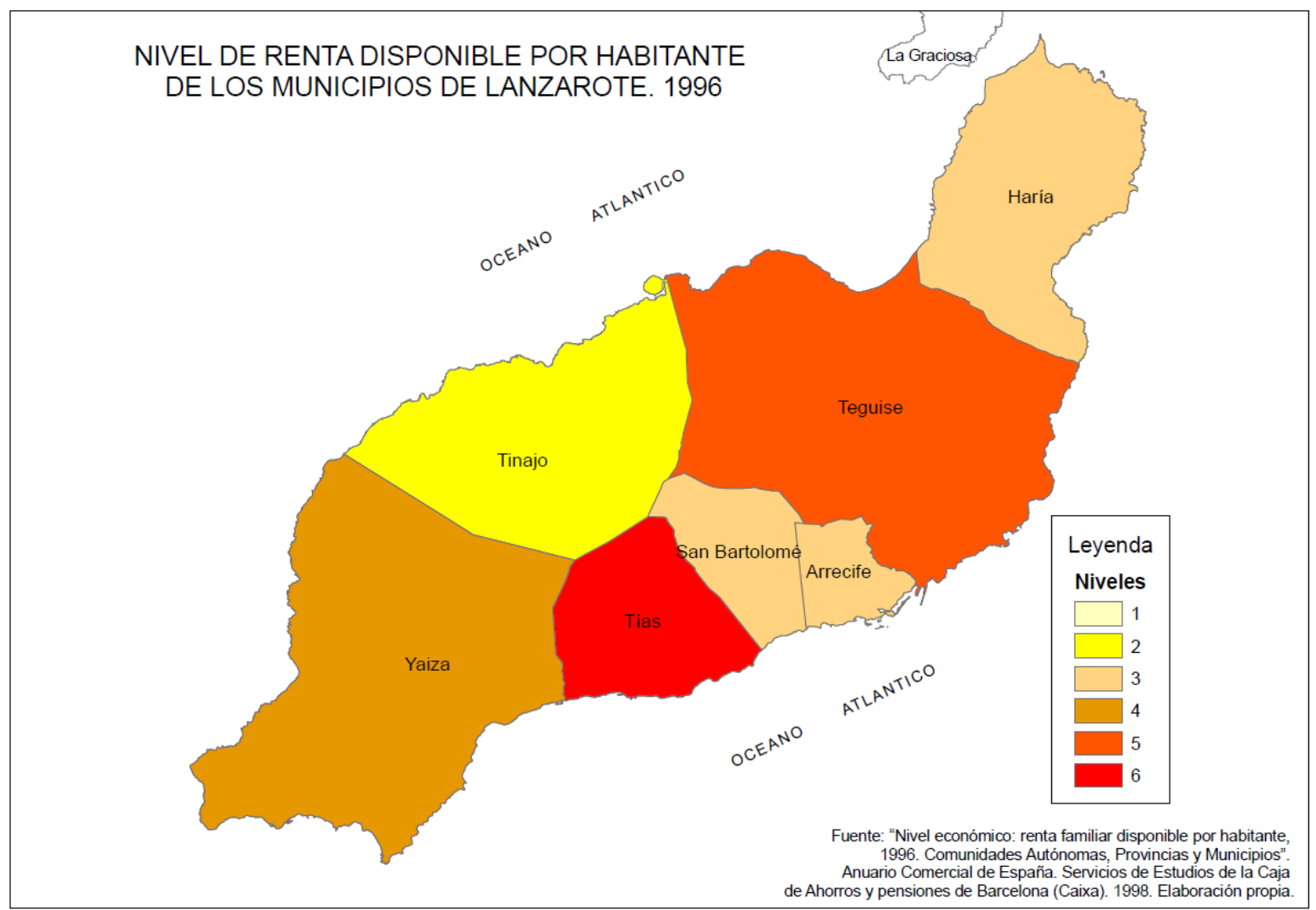

En relación a los valores municipales, la renta familiar disponible por habitante en la isla estaría entre el nivel 3 y 4 , en 1996. Similar a la de la Provincia (Las Palmas) y la Comunidad Autónoma. Lanzarote y Canarias se encuentran por debajo de la estimada para España. 


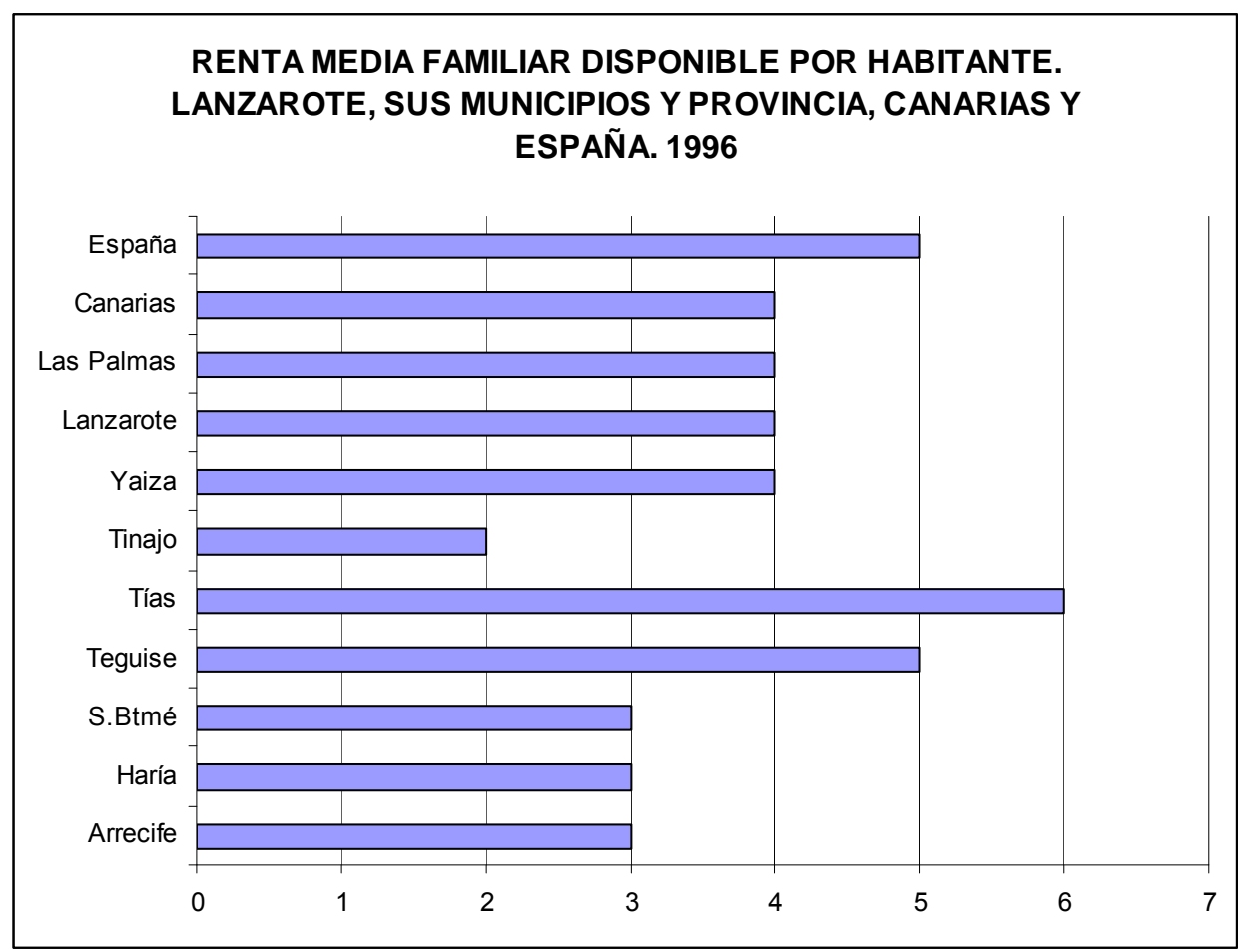

Fuente: Anuario Comercial de España. Caixa. 1998. Gráfico basado en la información recogida en la Tabla 127. Elaboración propia.

\subsubsection{2.- CONCLUSIONES}

En esta etapa, cuando Lanzarote ya está consolidada como destino turístico de masas, los incrementos de la renta familiar disponible municipal, al igual que en la etapa anterior son positivos, aunque el fuerte crecimiento al que se ha asistido, ahora, es más débil, a excepción de los municipios que concentran la mayor oferta turística, que alcanzan y superan el nivel medio de renta familiar disponible por habitante de España, no así la isla que queda por debajo, pero sin embargo casi se ha acercado a los niveles de renta estimados para su provincia (Las Palmas) y Comunidad Autónoma.

El dato significativo para la etapa, que se desprende de esta evolución, es cierta ruptura en la fuerte jerarquización, en relación a la renta, entre los municipios de la isla. Es decir, se reducen las distancias entre la mayoría de ellos.

La fuerte concentración de la actividad insular, alrededor de los servicios al turismo, sigue teniendo reflejo positivo desde el punto de vista económico, con fluctuaciones periódicas que tienden a marcar o relajar las diferencias en los niveles municipales. Lo que permite mejorías en las oportunidades y posibilidades de la población en el acceso a bienes y servicios y al bienestar. 


\subsection{7.- EFECTOS SOBRE LA CAPACIDAD ENERGÉTICA. 1986-1996}

\subsubsection{1.- POTENCIA Y PRODUCCIÓN}

El sistema de infraestructuras básicas de Lanzarote tiene como una de sus piezas claves, tanto en el pasado como ahora, las infraestructuras de producción de energía eléctrica, que no han dejado de apoyarse -y seguirá siendo así - en factores tecnológicos susceptibles de fallo.

En 1986, el Gobierno de Canarias elabora el Plan Energético de Canarias (PECAN), en el que se definen las coordenadas de la política energética en el Archipiélago. No plantea modificaciones en relación a la forma en la que se ha de generar la energía eléctrica, que seguirá siendo a través de centrales térmicas, como en el periodo anterior, pero ahora se propone el carbón como alternativa al petróleo, que incrementa la vulnerabilidad. En 1989, se elabora otro PECAN (aprobado en 1990), centrado en dar una solución definitiva al abastecimiento eléctrico en las islas, apostando por el gas natural, por su eficiencia y menor repercusión en el medio ambiente (proponiendo la implantación de centrales eléctricas de ciclo combinado $)^{173}$, pero las ideas que presenta nunca llegaron a materializarse ${ }^{174}$. Posteriormente, a este Plan, la política energética en Canarias pasó a un segundo o tercer plano (PECAN, 2002, pp. 8).

En cuando a recursos energéticos renovables aún no explotados, la posible inserción de la energía eólica dentro del sistema se enmarca dentro de programas de ahorro. Su participación en estos momentos, dentro de la energía primaria en Canarias será meramente testimonial. En 1991, el sistema energético de Lanzarote se amplía con la puesta en marcha de un parque eólico en el norte de la isla, pero su capacidad es muy reducida (aún en la actualidad) frente a la generación convencional (Avance PIOT de Lanzarote. 2010, pp. 168) ${ }^{175}$. En 1996 su aportación al sistema es sólo del 4,4\% (AUIA. Lanzarote en la Biosfera, 1998, Documento 7, pp. 27). La energía fotovoltaica, que se

173 "Dicho documento de planificación se centrara especialmente en las tecnologías de generación eléctrica, para dar un soporte documental a la solución que se proponía, basada esencialmente en centrales de ciclo combinado consumiendo gas natural". Plan Energético de Canarias, 2002.. Consejería de la Presidencia e Innovación Tecnológica. Gobierno de Canarias. Mayo de 2003 (pp. 7).

174 Este documento preveía que en el año 2000 ya estarían operativas sendas plantas de regasificación en las islas de Tenerife y Gran Canaria. (...) Se planificó previendo la instalación de centrales de ciclo combinado que se pensaron para consumir gas natural y, alternativa y temporalmente, gasóleo (...) y reducir el nivel de dependencia de un solo combustible". Plan Energético de Canarias (PECAN), 2006. Consejería de Industria, Comercio y Nuevas Tecnologías. Gobierno de Canarias (pp. 107).

175 Plan Insular de Ordenación del Territorio de Lanzarote (2010). Avance. Memoria de información territorial. Cabildo de Lanzarote. 2010. www.cabildodelanzarote.com. 
contabiliza en la década de los años noventa es aún más insignificante que la aportación que hace al sistema la eólica, puramente anecdótica ${ }^{176}$.

La capacidad insular de producción de energía eléctrica, al igual que en el periodo anterior, no dejará de crecer en esta etapa, que incluye cambios, pues a partir de 1986 se dejará de importar energía desde Fuerteventura, ya que esta isla también experimenta un fuerte desarrollo y deberá dar respuesta a su creciente demanda ${ }^{177} .1987$ será un año de restricciones a la demanda por razones de producción (Avance PIOT, 1987. Documento 8. Propuestas Sectoriales, pp. 186).

Tabla 128. Potencia instalada. Lanzarote, Canarias y España. 1986-1996 (kw)

\begin{tabular}{|c|c|r|r||r|c||}
\hline Año & LANZAROTE & Kw/Residente & $\begin{array}{l}\text { Incremento } \\
\text { quinquenal (\%) }\end{array}$ & Kw/Población Total & $\begin{array}{l}\text { Incremento } \\
\text { quinquenal (\% }\end{array}$ \\
\hline \hline 1986 & 22.120 & 0,40 & 52,57 & 0,31 & 28,71 \\
\hline 1991 & 87.500 & 1,35 & 239,83 & 0,92 & 199,53 \\
\hline 1996 & 108.400 & 1,40 & 3,92 & 0,88 & $-6,22$ \\
\hline \hline Año & CAN ARIAS & Kw/Residente & $\begin{array}{c}\text { Incremento } \\
\text { quinquenal (\% }\end{array}$ & Kw/Población Total ${ }^{*}$ & $\begin{array}{c}\text { Incremento } \\
\text { quinquenal (\% }\end{array}$ \\
\hline 1986 & 715.070 & 0,49 & 27,27 & 0,44 & 20,92 \\
\hline 1991 & 1.151 .717 & 0,77 & 56,99 & 0,69 & 54,98 \\
\hline 1996 & 1.622 .657 & 1,01 & 31,00 & 0,85 & 23,47 \\
\hline \hline Año & ESPAÑ A & Kw/Residente & $\begin{array}{c}\text { Incremento } \\
\text { quinquenal (\% }\end{array}$ & Kw/Población Total & $\begin{array}{c}\text { Incremento } \\
\text { quinquenal (\% }\end{array}$ \\
\hline 1986 & 42.003 .412 & 1,09 & 25,47 & 1,06 & 25,00 \\
\hline 1991 & 45.936 .076 & 1,18 & 8,24 & 1,15 & 9.17 \\
\hline 1996 & 49.236 .797 & 1,24 & 5,03 & 1,21 & 5,19 \\
\hline \hline
\end{tabular}

(*) Población Total: población residente + turistas equivalentes diarios.

Fuente: Para 1986: "Potencia Instalada bruta, Lanzarote, 1986". Avance PIOT, Cabildo de Lanzarote, 1987. Tomo 2. Cap. 4. Cuadro 4.3 (pp. 236); "Potencia instalada (kw) y producción de energía eléctrica por UNELCO en Canarias según centrales. UNELCO, 1986". Anuario estadístico de Canarias, 1986. CEDOC; "Potencia instalada. Total Nacional, 1986". Estadística de la Industria de Energía Eléctrica, 1986. Ministerio de Industria, Turismo y Comercio. Para 1991 y 1996: "Potencia instalada 1991 y Evolución de la potencia eléctrica instalada en Canarias, por islas". Estadísticas Energéticas de Canarias, 2006. Dirección General de Industria y Energía, Gobierno de Canarias; "Potencia instalada. Total Nacional, 1991 y 1996". Estadística de la Industria de Energía Eléctrica, 1991 y 1996. Ministerio de Industria, Turismo y Comercio.

176 "La producción de energía solar térmica representa menos de una centésima parte de la energía térmica consumida en la isla, mientras que la producción fotovoltaica representa menos de una diezmilésima de la producción eléctrica insular". AUIA. Lanzarote en la Biosfera. Documento 7.3. Sectores Ambientales Clave. Energía. Cabildo Insular de Lanzarote, 1998 (pp. 28)

177 La isla sigue poseyendo un sistema eléctrico unificado Lanzarote-Fuerteventura con potencia instalada conjunta. Es una red de simple circuito que recorre ambas islas de norte a sur. Desde la central de Lanzarote (Central Térmica de Punta Grande) hasta la Subestación de Matas Blancas al sur de Fuerteventura (155 km). 
El equipamiento para consumo doméstico con "estándares" nacionales se establece en los años ochenta en 1,1 kw/hab., correspondiente a la electrificación media que prevé el reglamento de baja tensión. La isla inicia la etapa sin potencia suficiente para cubrir el estándar medio vigente, pues en 1986 se encuentra en un $72 \%$ por debajo de la misma, en relación a su población residente. Media ésta que superará ampliamente el resto de la etapa.

Mapa 22. Redes eléctricas y sistema energético de Lanzarote. 1987

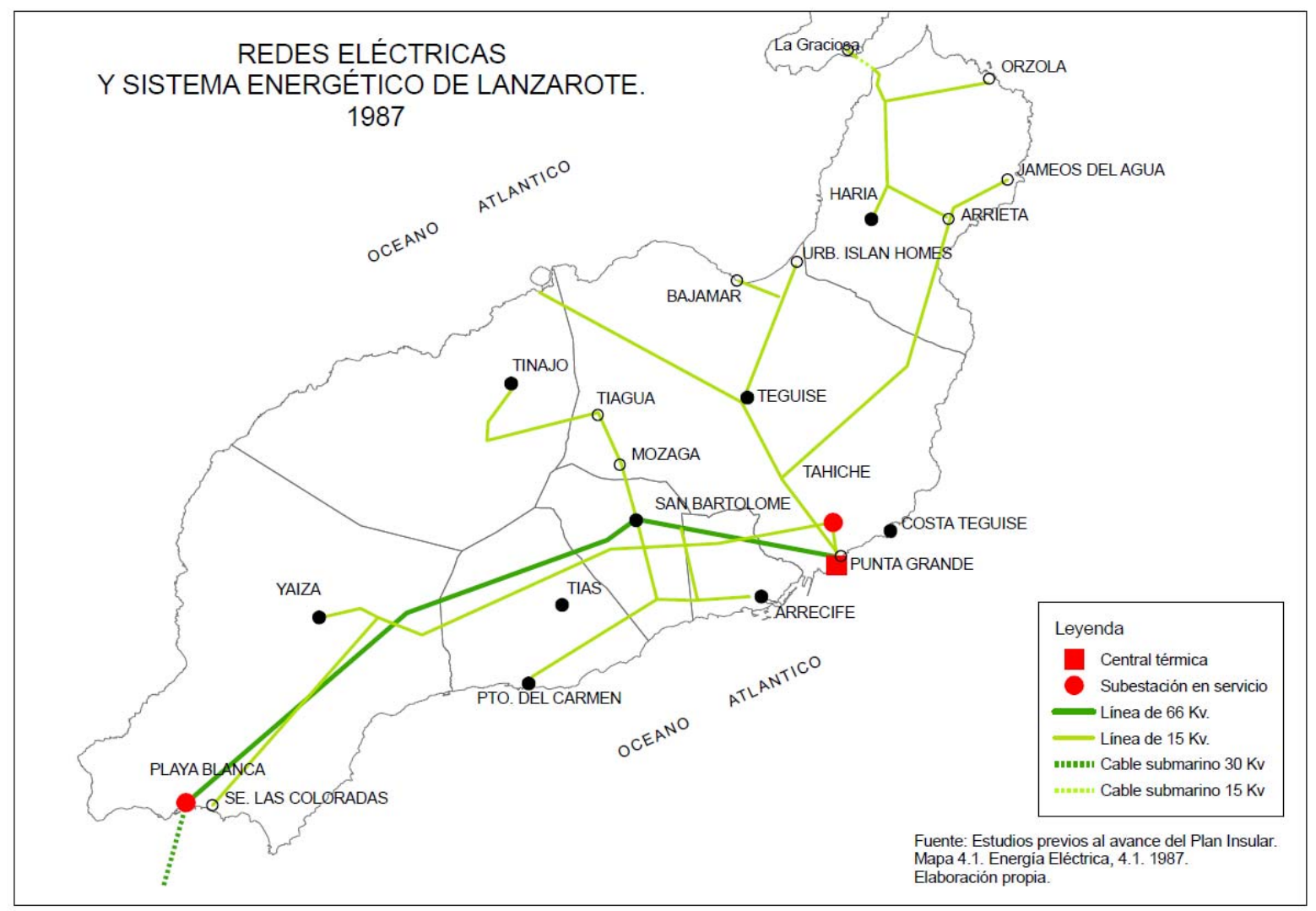

El mayor incremento porcentual de la potencia instalada por residente se observa en el primer quinquenio del periodo analizado (1986-1991), del orden del 239,8\%, muy superior al de Canarias (57\%) y España (8,2\%). Pero debemos de tener en cuanta que no deja de crecer el número de turistas diarios equivalentes (estimados) que asume la isla, que ejercen presión sobre esta capacidad, ni la inmigración asociada.

Las mejoras conseguidas hasta la entrada de la década de los años noventa se ven mermadas a la mitad de la misma, pues la potencia instalada en relación a la población total estimada (residentes y turistas equivalentes diarios) se reduce casi un $6,2 \%$. Esta reducción tiene su explicación en el incremento a lo largo del último quinquenio (1991-1996) de la población residente (19\%) y de los turistas (44\%). 
Gráfico 111. Incremento interperiodo de la potencia instalada en relación a la población total estimada. Lanzarote, Canarias y España. 1986-1996 (\%)

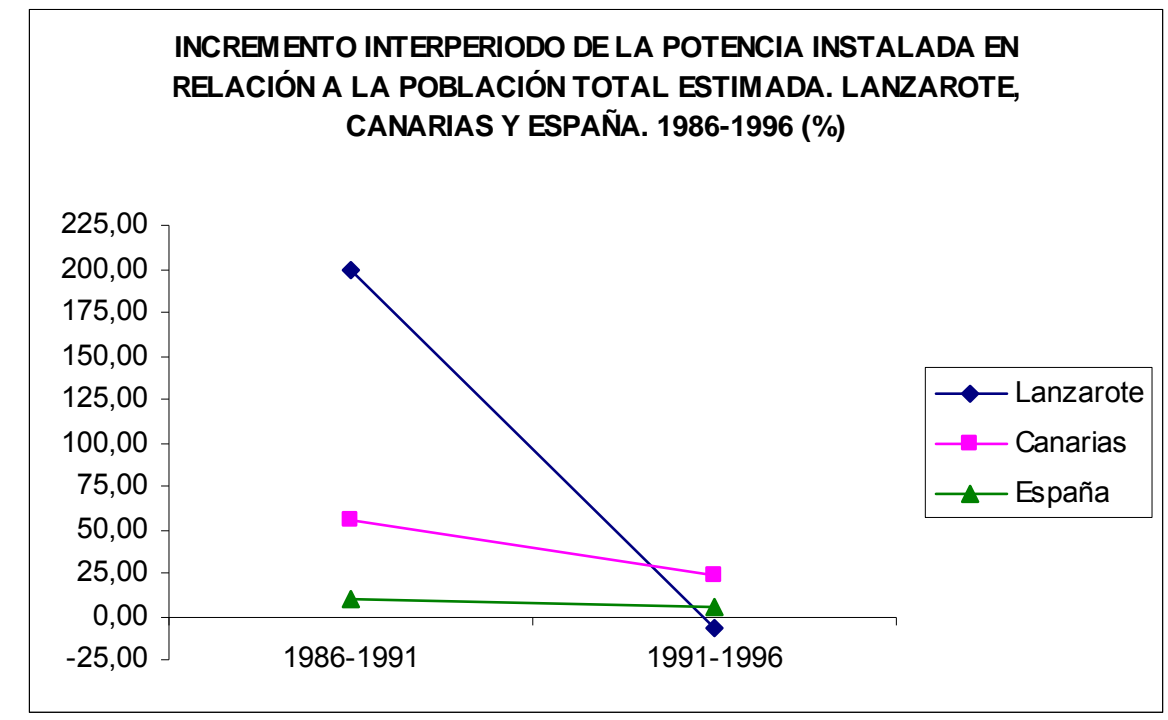

Fuente: Gráfico basado en la información recogida en la Tabla 128. Elaboración propia.

La isla no tiene capacidad para incrementar la potencia instalada con la misma rapidez con que se incrementa la población diaria estimada que asume. La demanda de energía eléctrica ha ido por encima de las posibilidades de producción (Avance Plan Insular, 1987. Tomo 2. Cap. VII, pp. 228). Que aunque en 1991, en relación a la población equivalente o total estimada (población de derecho más turistas equivalentes diarios), es superior a la capacidad de Canarias (0,92 y 0,69 kw/Ptotal, respectivamente), Lanzarote sufre una evolución negativa, al contrario que su Comunidad Autónoma y España que incrementan de forma continuada su capacidad de producción eléctrica por habitante. 
Gráfico 112. Evolución de la potencia instalada en relación a la población total estimada. Lanzarote, Canarias y España. 1-861996 (kw/P.Total)

\section{EVOLUCIÓN DE LA POTENCIA INSTALADA EN RELACIÓN A \\ LA POBLACIÓN TOTAL ESTIMADA. LANZAROTE, CANARIAS Y ESPAÑA. 1986-1996 (Kw/Ptotal)}

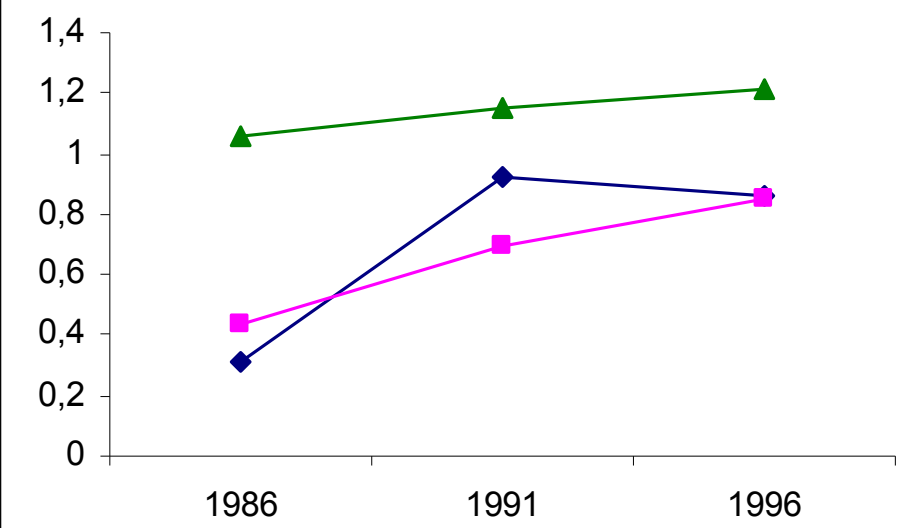


Tabla 129. Producción de energía eléctrica disponible. Lanzarote, Canarias y España. 19861996 (mwh)

\begin{tabular}{|c|c|c|c|c|}
\hline Año & LANZAROTE & Kwh/Residente & Kwh/P.Total* & $\begin{array}{c}\text { Incremento } \\
\text { kwh/habitante (\%)** }\end{array}$ \\
\hline 1986 & 154.199 & $2.765,21$ & $2.045,22$ & \\
\hline 1991 & 303.864 & $4.681,24$ & $3.184,29$ & 35,77 \\
\hline 1996 & 419.250 & $5.418,14$ & $3.325,67$ & 4,25 \\
\hline \multicolumn{4}{|c|}{ Variación (\%) de la Producción entre 1986-1996 (kwh/P.Total) } & 62,61 \\
\hline Año & CANARIAS & Kwh/Residente & Kwh/P.Total* & $\begin{array}{c}\text { Incremento } \\
\text { kwh/habitante }(\%)^{* *}\end{array}$ \\
\hline 1986 & 2.662 .417 & $1.828,58$ & $1.684,04$ & \\
\hline 1991 & 3.709 .084 & $2.483,01$ & $2.214,76$ & 31,51 \\
\hline 1996 & 5.219 .857 & $3.249,14$ & $2.731,48$ & 23,33 \\
\hline \multicolumn{4}{|c|}{ Variación (\%) de la Producción entre 1986-1996 (kwh/P.Total) } & 62,20 \\
\hline Año & ESPAÑ A & Kwh/Residente & Kwh/P.Total ${ }^{*}$ & $\begin{array}{c}\text { Incremento } \\
\text { kwh/habitante (\%)** }\end{array}$ \\
\hline 1986 & 121.183.877 & $3.149,81$ & $3.123,46$ & \\
\hline 1991 & 149.743 .478 & $3.852,16$ & $3.763,76$ & 20,50 \\
\hline 1996 & 166.155 .525 & $4.188,51$ & $4.098,38$ & 8,89 \\
\hline \multicolumn{4}{|c|}{ Variación (\%) de la Producción entre 1986-1996 (kwh/P.Total) } & 31,21 \\
\hline
\end{tabular}

(*) Población total: población residente + turistas equivalentes diarios.

$\left(^{* *}\right)$ La variación porcentual está calculada en relación la Kw/P. Total.

Fuente: Para 1986: "Producción absorbida por Lanzarote, 1986". Avance Plan Insular de Lanzarote, 1987. Tomo 2. Cap. 4. Cuadro 4.4 (pp. 238); "Producción disponible de energía eléctrica. Total Nacional y Provincia de Las Palmas y Tenerife, 1986". Estadística de la Industria de Energía Eléctrica, 1986. Ministerio de Industria, Turismo y Comercio. www.mityc.es/energia/balances/; Para 1991: "Producción de energía eléctrica, 1991", en Evolución de la producción, consumo y abonados a la energía eléctrica, 1987-2008. Centro de datos. Cabildo Insular de Lanzarote. www.datosdelanzarote.com; "Producción disponible de energía eléctrica. Total Nacional y Provincia de Las Palmas y Tenerife, 1991". Estadística de la Industria de Energía Eléctrica, 1991. Ministerio de Industria, Turismo y Comercio. www.mityc.es/energia/balances/; Para 1996: "Producción de energía eléctrica, 1996", en Evolución de la producción, consumo y abonados a la energía eléctrica, 1987-2008. Centro de datos. Cabildo Insular de Lanzarote. www.datosdelanzarote.com; "Producción disponible de energía eléctrica. Total Nacional y Provincia de Las Palmas y Tenerife, 1996". Estadística de la Industria de Energía Eléctrica, 1996. Ministerio de Industria, Turismo y Comercio. www.mityc.es/energia/balances/; 
Gráfico 113. Evolución de la producción de energía eléctrica por habitante. Lanzarote, Canarias y España. 1986-1996 (Kwh/Ptotal)

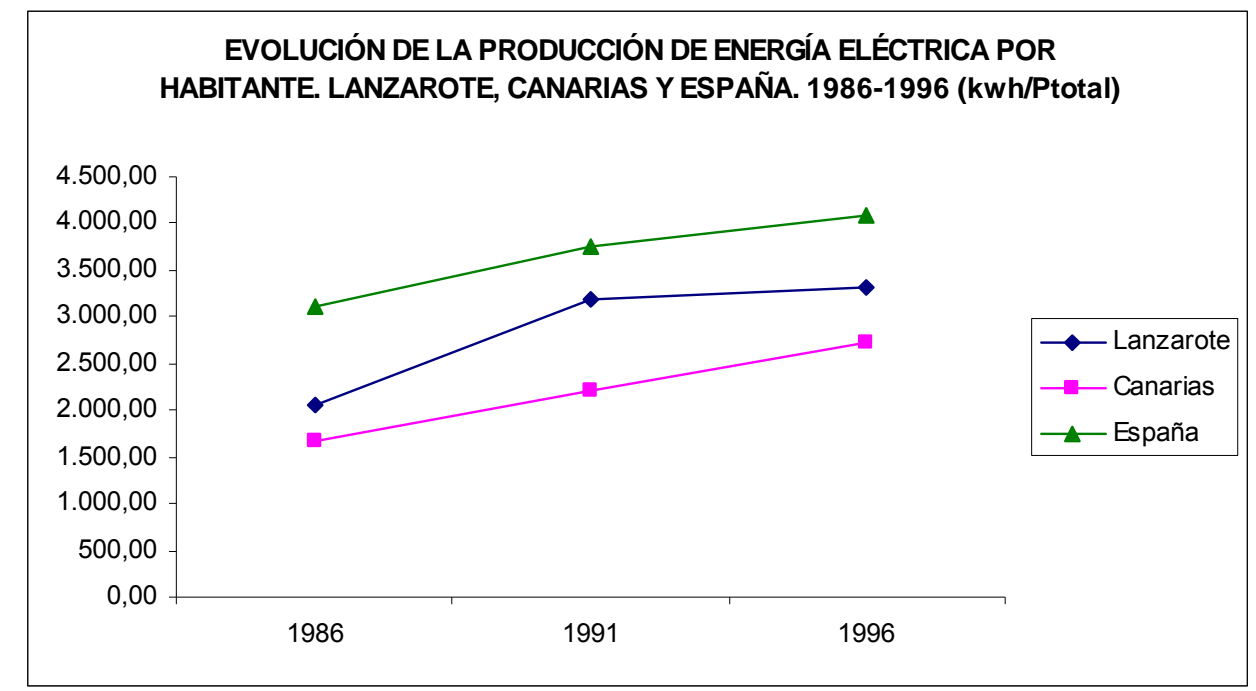

Fuente: Gráfico basado en la información recogida en la Tabla 129. Elaboración propia.

En cuanto a la dinámica nacional, el país observa incrementos de la producción más moderados $(20,5 \%)$ que en las islas (Canarias $31,5 \%$ y Lanzarote $35,7 \%$ ), pues la demanda demográfica no es tan elevada, aunque, al igual que Lanzarote, ralentiza su incremento de producción energética en el último quinquenio del análisis, pero tiene más capacidad de producción que las islas.

\subsubsection{2.-}

El consumo de energía eléctrica en Lanzarote sigue siendo muy elevado ${ }^{178}$. El consumidor más importante ha sido y es el sistema de desalación de agua ${ }^{179}$.

El incremento que sufre en el primer quinquenio de esta etapa es de 65,6\%, frente a los de Canarias $(50,7 \%)$ y España (22\%), debido al crecimiento demográfico y al boom turístico de finales de la década de lo años ochenta que afecta también a la construcción de nuevas camas de alojamiento y por lo tanto a los consumos energéticos industriales.

178 La desalación de agua es la actividad que más energía demanda del Archipiélago. El sector del agua tiene la característica adicional de que puede constituirse en elemento de regulación del propio sistema eléctrico en algunas islas" PECAN, 2002, pp. 13.

179 "Representa algo más del 17\% del consumo total en 1996". AUIA (1998). Lanzarote en la Biosfera. Documento 7.3. "Sectores Ambientales Claves. Energía". Cabildo Insular de Lanzarote, 1998. 
Tabla 130. Consumo eléctrico e intensidad energética eléctrica. Lanzarote, Canarias y España. 1986-1996 (mwh)

\begin{tabular}{|c|c|c|c|c|c|}
\hline Año & LANZAROTE & $\begin{array}{l}\text { Consumo } \\
\text { Kwh/residentes }\end{array}$ & $\begin{array}{l}\text { Consumo } \\
\text { Kwh/P.Total }\end{array}$ & $\begin{array}{l}\text { Incremento quinquenal. } \\
\text { (Kw/P.Total) (\%) }\end{array}$ & $\begin{array}{l}\text { Intensidad } \\
\text { Energética Eléctrica* }\end{array}$ \\
\hline 1986 & 131.069 & $2.350,42$ & $1.813,93$ & 73,50 & 411,790 \\
\hline 1991 & 286.678 & $4.416,48$ & $3.004,19$ & 65,62 & 565,013 \\
\hline 1996 & 393.808 & $5.089,34$ & $3.123,85$ & 3,98 & 408,716 \\
\hline \multicolumn{4}{|c|}{ Variación (\%) del consumo entre 1986 y 1996 (Kw/P.Total) } & 72,21 & \\
\hline
\end{tabular}

\begin{tabular}{|c|c|c|c|c|c|}
\hline Año & CANARIAS & $\begin{array}{l}\text { Consumo } \\
\text { Kwh/residentes. }\end{array}$ & $\begin{array}{l}\text { Consumo } \\
\text { Kwh/P.Total* }\end{array}$ & $\begin{array}{l}\text { Incremento quinquenal. } \\
\text { (Kw/P.Total) (\%) }\end{array}$ & $\begin{array}{l}\text { Intensidad } \\
\text { Energética Eléctrica** }\end{array}$ \\
\hline 1986 & 2.197 .959 & $1.509,59$ & $1.363,99$ & 24,62 & 316,666 \\
\hline 1991 & 3.443 .048 & $2.304,92$ & $2.055,90$ & 50,73 & 300,305 \\
\hline 1996 & 4.472 .482 & $2.783,93$ & $2.340,39$ & 13,84 & 247,283 \\
\hline \multicolumn{4}{|c|}{ Variación (\%) del consumo entre 1986 y 1996 (Kw/P.Total) } & 71,58 & \\
\hline
\end{tabular}

\begin{tabular}{|c|c|l|l|l|l||}
\hline \hline Año & ESPAÑ A & $\begin{array}{l}\text { Consumo } \\
\text { Kwh/residentes. }\end{array}$ & $\begin{array}{l}\text { Consumo } \\
\text { Kwh/P.Total }\end{array}$ & $\begin{array}{l}\text { Incremento quinquenal. } \\
\text { (Kw/P.Total) (\%) }\end{array}$ & $\begin{array}{l}\text { Intensidad } \\
\text { Energética Eléctrica** }^{*}\end{array}$ \\
\hline \hline 1986 & 107.952 .602 & $2.805,90$ & $2.718,16$ & 13,39 & 555,680 \\
\hline 1991 & 132.061 .884 & $3.397,30$ & $3.319,33$ & 22,12 & 400,042 \\
\hline 1996 & 155.501 .079 & $3.919,93$ & $3.835,58$ & 15,55 & 328,162 \\
\hline \multicolumn{2}{|l|}{ Variación (\%) del consumo entre 1986 y 1996 (Kw/P.Total). } & 41,11 & \multicolumn{1}{|l}{} \\
\hline
\end{tabular}

$\left(^{\star}\right)$ Población Total: población residente + turistas equivalentes diarios.

$\left.{ }^{* *}\right)$ Intensidad energética eléctrica: energía eléctrica consumida / PIB (en millones de euros).

Fuente: Para 1986: "Venta de energía eléctrica Lanzarote, 1986". Avance Plan Insular de Lanzarote, 1987. Tomo 2. Anexo 4.2. (pp. 4); "Consumo neto de energía eléctrica. Total Nacional, Provincia de Las Palmas y Tenerife, 1986". Estadística de la Industria de Energía Eléctrica, 1986. Ministerio de Industria, Turismo y Comercio. www.mityc.es/energia/balances/; "PIB estimado para 1986, en pesetas corrientes de cada año. Millones de Ptas. En Cabildo Insular de Lanzarote. Avance PIOT de la isla de Lanzarote. Tomo 4. Economía, 1987 (pp. 24); "PIB regional a precios corrientes, en millones de pesetas. Canarias, 1986" y "PIB a precios corrientes en millones de pesetas, España, 1986". Contabilidad Regional de España. Base 1986. Serie Homogénea, 1980-1996. INE;

Para 1991: "Consumo de energía eléctrica, 1991", en Evolución de la producción, consumo y abonados a la energía eléctrica, 19872008. Centro de datos. Cabildo Insular de Lanzarote. www.datosdelanzarote.com; "Consumo neto de energía eléctrica. Total Nacional, Provincia de Las Palmas y Tenerife, 1991". Estadística de la Industria de Energía Eléctrica, 1991. Ministerio de Industria, Turismo y Comercio. www.mityc.es/energia/balances/; "PIB (euros) a precios de mercado, Lanzarote, 1991". En Pedro Calero Lemes, 2005. Cita textual: "Dado que no tenemos el PIB real calculado para Lanzarote. Se han combinado dos variables: la base imponible del IRPF para Lanzarote y las estimaciones del PIB para toda Canarias por parte del INE. Aunque lo óptimo sería el cálculo real del PIB". http://pedrocalerolemes.blogspot.com/2005/12/aproximacin-al-pib-de-lanzarote.html; "PIB regional a precios corrientes, en millones de pesetas. Canarias, 1991" y "PIB a precios corrientes en millones de pesetas, España, 1991". Contabilidad Regional de España. Base 1986. Serie Homogénea, 1980-1996. INE;

Para 1996: "Consumo de energía eléctrica, 1996", en Evolución de la producción, consumo y abonados a la energía eléctrica, 19872008. Centro de datos. Cabildo Insular de Lanzarote. www.datosdelanzarote.com; "Consumo neto de energía eléctrica. Total Nacional, Provincia de Las Palmas y Tenerife, 1996". Estadística de la Industria de Energía Eléctrica, 1996. Ministerio de Industria, Turismo y Comercio. www.mityc.es/energia/balances/; "PIB (euros) a precios de mercado, Lanzarote, 1996". En Pedro Calero Lemes, 2005. Cita textual: "Dado que no tenemos el PIB real calculado para Lanzarote. Se han combinado dos variables: la base imponible del IRPF para Lanzarote y las estimaciones del PIB para toda Canarias por parte del INE. Aunque lo óptimo sería el cálculo real del PIB". http://pedrocalerolemes.blogspot.com/2005/12/aproximacin-al-pib-de-lanzarote.html; "PIB a precios de mercado. Precios corrientes, en miles de euros. Canarias y España, 1996". Contabilidad Regional de España. Serie homogénea 1995-2009. INE. 
Pasado este momento, cae el crecimiento del consumo eléctrico por habitante, situándose entre 1991 y 1996 en casi el 4\%. Es decir, sigue aumentando el consumo aunque la capacidad de producción por habitante haya observado un incremento negativo $(6,2 \%)$. No así, en Canarias y España, donde el crecimiento del consumo es más elevado, pero ha seguido incrementándose la potencia instalada por habitante.

Gráfico 114. Incremento interperiodo del consumo de energía eléctrica en relación a la población total estimada. Lanzarote, Canarias y España. 1986-1996 (\%).

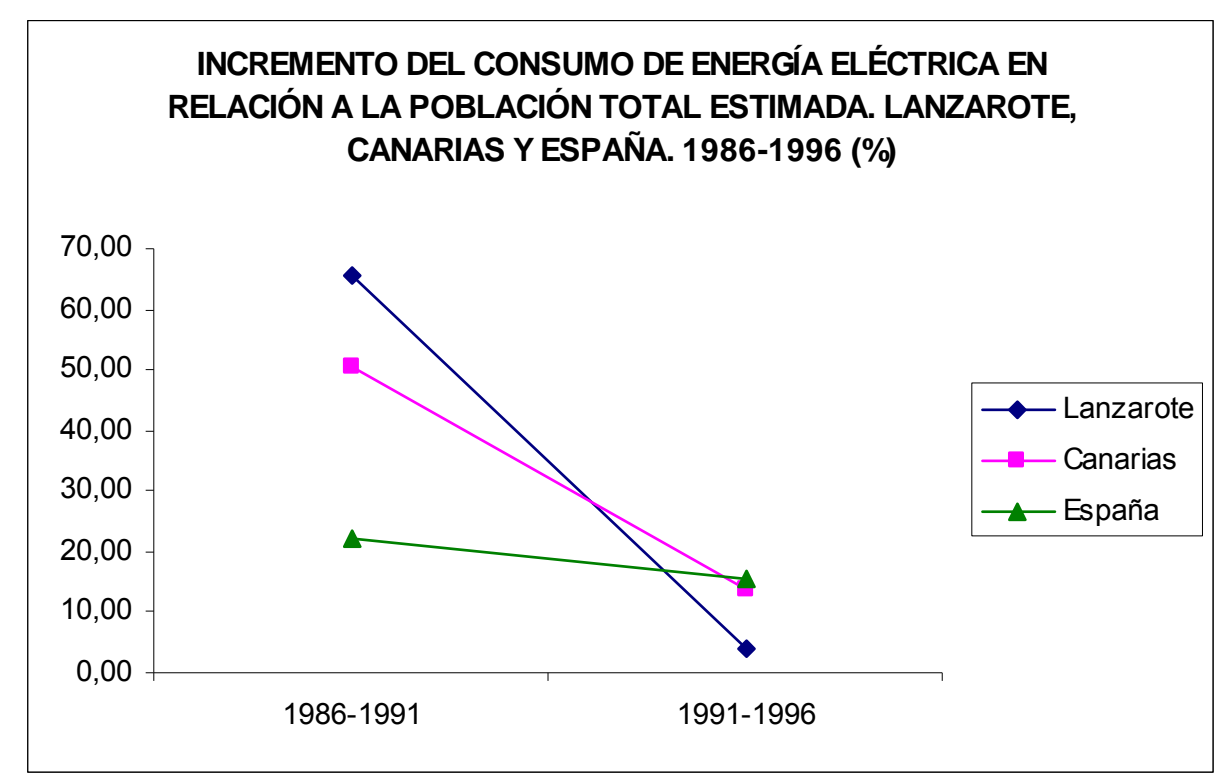

Fuente: Gráfico basado en la información recogida en la Tabla 130. Elaboración propia-

Si bien esta etapa comenzaba para Lanzarote con consumos por habitante superiores a Canarias, del orden del 33\% (Kw/PTotal) aproximadamente, al final de la misma (1996) la situación no ha cambiado, aunque, ahora, la isla posee menos distancia en relación a la media nacional que se sitúa alrededor del $18,6 \%$ por encima. 
Gráfico 115. Evolución del consumo de energía eléctrica por habitante. Lanzarote, Canarias y España. 1986-1996 (\%).

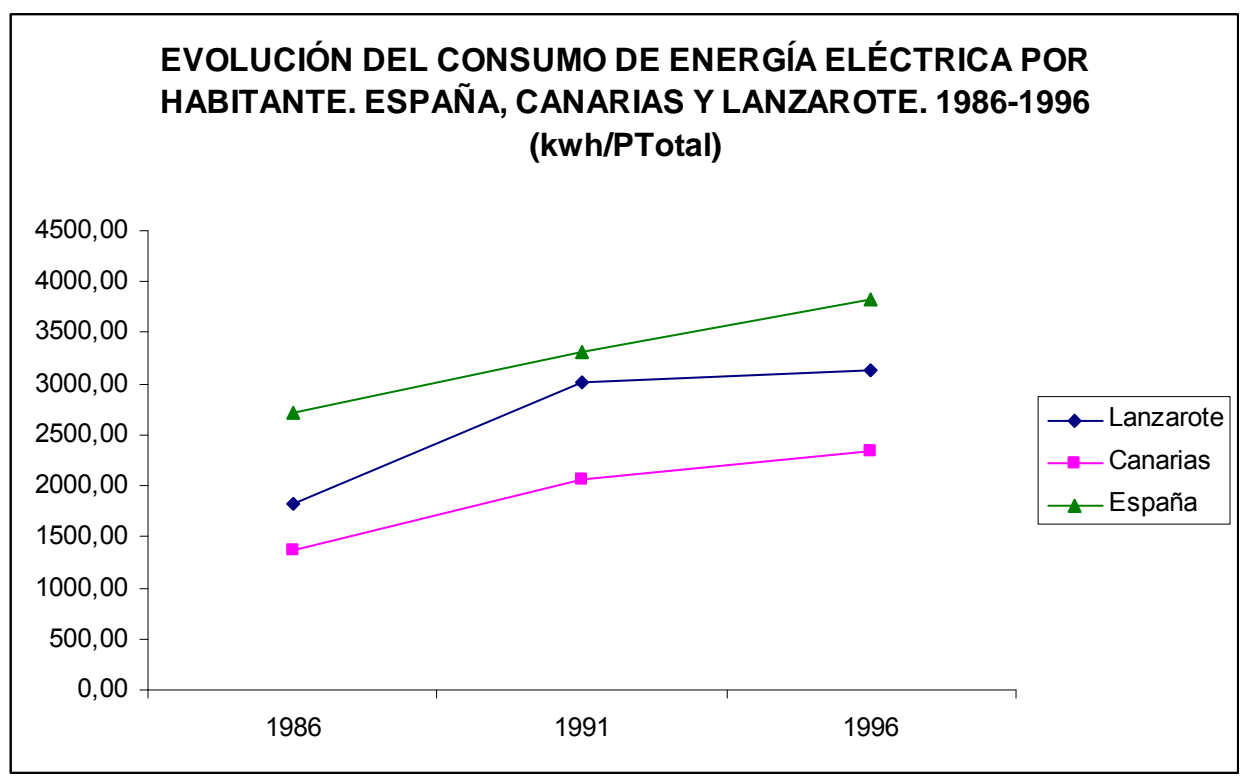

Fuente: Gráfico basado en la información recogida en la Tabla 130. Elaboración propia.

Tal y como manifiestan análisis publicados por el Cabildo insular de Lanzarote, anteriormente citados, el crecimiento de la producción ha ido evolucionando por debajo del consumo. Pues en el periodo temporal que recorre esta etapa (1986-1996) el incremento de la producción eléctrica ha supuesto un $62,6 \%$, frente a la demanda de consumo que se ha incrementado en un $72,2 \%$, en relación a la población total estimada o equivalente (residentes y turistas equivalentes diarios). Lanzarote supera a Canarias en su ritmo de crecimiento, pero el dato a destacar es la magnitud del salto registrado en Canarias con respecto a España en estos diez años.

Tabla 131. Resumen. Variación de la oferta y demanda de energía eléctrica por habitante equivalente (kwh/P. Total). España, Canarias y Lanzarote. 1986-1996. (\%)

\begin{tabular}{|l|r|r|}
\hline & Producción & Consumo \\
\hline \hline LANZAROTE & 62,61 & 72,21 \\
\hline CANARIAS & 62,20 & 71,58 \\
\hline ESPAÑA & 31,21 & 41,11 \\
\hline
\end{tabular}

Fuente. Tabla resumen a partir de datos anteriores. Elaboración propia. 
Gráfico 116. Variación de la oferta y demanda de energía eléctrica por habitante equivalente (kwh/P. Total). España, Canarias y Lanzarote. 1986-1996 (\%)

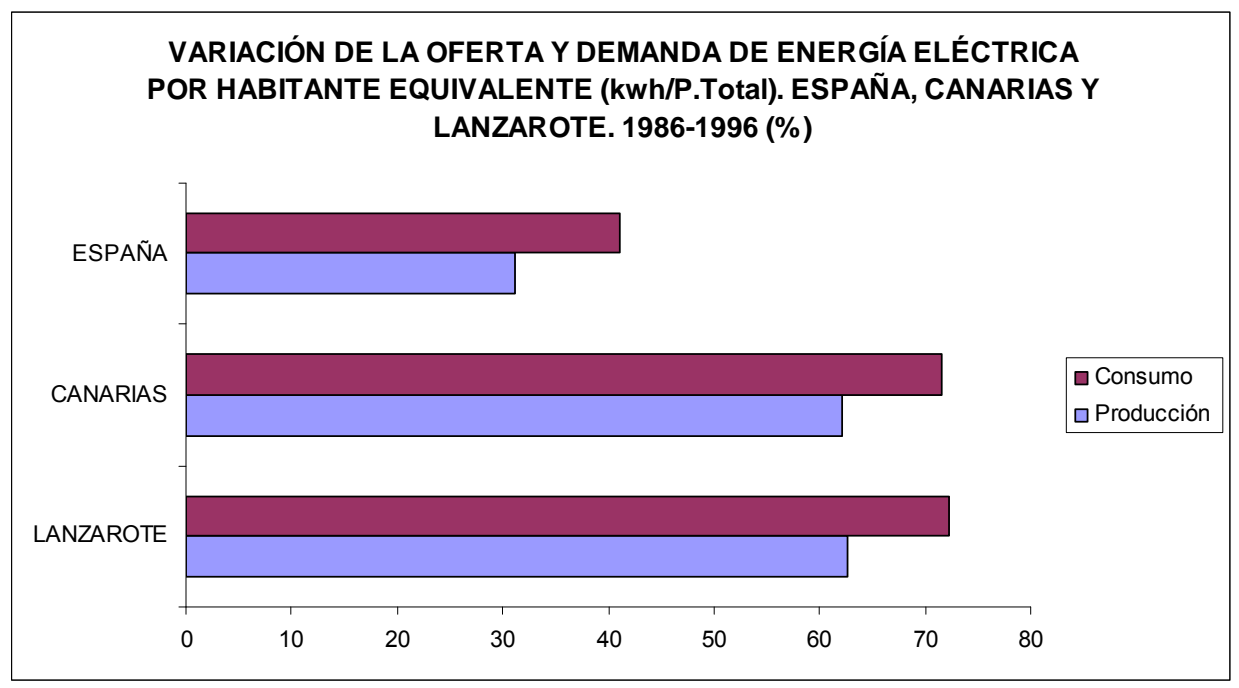

Fuente: Gráfico de resumen basado en la información recogida en las Tablas 127 y 130. Elaboración propia.

Esta enorme variación relativa tiene sentido si se explica por dos factores: la forma de vida de la población se ha modificado, se supone un proceso de modernización que deriva hacia estos altos consumo como consecuencia de la elevación de los niveles de renta ${ }^{180}$. Y un segundo impuso derivado de las dinámicas del ciclo turístico que incrementa la demanda y presiona sobre la producción. Por lo que la tendencia es ahora negativa con respecto a la etapa anterior (en la que este fenómeno era la inversa), y teniendo en cuenta que la aportación de las energías renovables al sistema enérgico insular es prácticamente insignificante (AUIA. Lanzarote en la Biosfera, Documento 7.3, 1998, pp. 28), desaparece cualquier posibilidad de autonomía energética insular, con consecuencias negativas hacia la calidad medioambiental y el bienestar social.

El elevado valor del consumo por habitante se convierte en un problema por la ineficiencia energética que está implicando, para una isla que, por un lado, posee alta dependencia energética exterior, que limita su capacidad de respuesta ante el aumento de la presión demográfica, junto con sus fuertes efectos negativos ambientales, por otro lado, pues los principales contaminantes se generan por la utilización de combustibles fósiles para la generación de energía eléctrica (95,6\% a través del fuel-oil y el gas-oil).

Así, si la etapa anterior se caracterizaba por el incremento de la eficiencia en términos energéticos eléctricos, en ésta cambia de signo, pues entre 1986 y 1991 cae dicha

180 AUIA. Lanzarote en la Biosfera. Documento 7.3 "Sectores ambientales claves. Energía". Cabildo de Lanzarote, 1998 (pp. 29). 
eficiencia. Aspecto éste que puede ser debido a que Lanzarote experimenta en el año 1986 un fuerte crecimiento de la demanda y la oferta turística, seguido de una crisis por sobreproducción (que se inicia en 1988 y de la que se tardará varios años en salir), mientras que la población que acoge no deja de crecer. La repercusión sobre el bienestar de los residentes no será positiva.

En relación al último quinquenio del periodo de análisis (1991-1996), se observa cierta recuperación de la eficiencia energética eléctrica, pues el índice recupera valores semejantes a los de 1986, lo que quiere decir que se consume menos energía eléctrica por PIB. A pesar de ello, la isla a lo largo de toda la etapa presenta peor utilización de la energía eléctrica para producir que Canarias y España. Ámbitos éstos que han seguido mejorando su eficiencia en términos energéticos, es decir consumen menos energía eléctrica por PIB, hacen mejor utilización.

\subsubsection{3.- CONCLUSIONES}

Este periodo está marcado por un boom turístico, al que seguirá una crisis del sector turístico por sobreproducción al final de la década de los años ochenta, y por la entrada en vigor en 1990 del Plan Energético de Canarias (PECAN-89), y en 1991 de un nuevo Plan Insular de Ordenación del Territorio. Los aspectos de modificación en los niveles de oferta y demanda turística tendrán efectos en la capacidad de producción y en el consumo de energía eléctrica en la isla, así como en la eficiencia., por lo que este periodo comenzará con restricciones a la demanda por razones de producción, que aunque mejorarán a lo largo de la etapa, el camino recorrido no llevará hacia una mayor eficiencia energética eléctrica.

Así, las características de esta etapa pueden ser sintetizadas de la siguiente forma:

1. Producción basada en energías no renovables. Dependencia energética absoluta.

2. Fuertes incrementos de la capacidad de producción energética por habitante hasta la mitad de la etapa y ligero freno posterior, en relación al final del periodo, derivado del crecimiento de la población residente junto con los turistas equivalentes diarios.

3. Capacidad de producción por habitante superior a la media de Canarias, hasta final de la etapa en que iguala su potencia instalada por habitante. Se mantiene lejos de la nacional.

4. Incremento constante del consumo de energía eléctrica per cápita, por encima de la media de Canarias, aunque por debajo de la nacional, pues la presión demográfica (residentes y turistas equivalentes diarios) no deja de crecer.

5. La demanda de energía eléctrica ha ido por encima de las posibilidades de producción. 
6. Pérdida de eficiencia en términos energéticos eléctricos, en comparación con Canarias y España, derivada del alto valor de consumo por habitante, a lo que se une la alta dependencia energética, de fuentes externas, que caracteriza a la isla.

La presión demográfica y la sobreproducción turística generan restricciones en momentos puntuales por razones de producción, por lo que los incrementos constantes de la capacidad son necesarios. Así, aunque indirectamente el turismo puede, en un primer momento, impulsar beneficios a la población local ya que por su presión en la demanda mejora la oferta, se convierte ahora en un fuerte competidor, puesto que la capacidad de intervención de la administración para dar respuesta a las nuevas demandas es más lenta que su crecimiento.

La tendencia en el periodo, por tanto, es negativa: la demanda es superior a la oferta, la aportación de las energías renovables es insignificante, la posibilidad de autonomía energética no existe, la población residente parece haber modificado sus costumbres austeras y de ahorro. Consecuentemente el bienestar social asociado no será positivo.

\subsection{8.- EFECTOS SOBRE EL CICLO DEL AGUA. 1986-1996}

\subsubsection{1.- LA DISPONIBILIDAD DE AGUA. OFERTA}

En 1989 el Consorcio crea la empresa Insular de Aguas de Lanzarote, S.A. (INALSA), cuyo cometido es la producción, abastecimiento y reutilización de agua en la isla. Desde su constitución ha venido desempeñando de "facto" la titularidad del servicio de abastecimiento de agua en la isla, si bien no se constata la existencia de título habilitante al efecto $^{181}$, es decir, no existe documento legal de la adjudicación de concesión. Sin embargo, a partir de su constitución será el referente en la producción de agua desalada.

Al mismo tiempo, al amparo de la Ley territorial 12/1990, de 26 de julio, de Aguas (B.O.C. N ${ }^{\circ} 94$ de 27 de julio de 1990), la Comunidad Autónoma de Canarias asume en su plenitud la Ordenación de los recursos y aprovechamientos hidráulicos del Archipiélago. Y se crea, así mismo, en cada isla, un Consejo Insular de Aguas $^{182}$, como entidad de Derecho Público, con personalidad jurídica propia y plena autonomía funcional, que asume, en régimen de descentralización y participación, la dirección, ordenación, planificación y gestión unitaria de las aguas en los términos de la citada Ley 12/1990 (en concepto de organismo de cuenca).

181 Informe jurídico cedido por el Comité de Empresa de INALSA, S.A., 2009.

182 El Estatuto Orgánico del Consejo de Lanzarote es aprobado por Decreto 135/1997 de 11 de julio. Sus funciones están recogidas en dicho Decreto y en el Art. 10 de la Ley 12/1990, de 26 de julio, de Aguas de Canarias. 
En esta etapa, no se recoge información en relación a la producción de agua en acuíferos naturales. Distintos técnicos han informado acerca de su salinización, por sobreexplotación. Así mismo no se tiene información de los pozos y aljibes familiares en funciones. Los grandes depósitos de recogida de agua de lluvia están en desuso. Por ello, sólo existen datos en relación a la capacidad de producción de agua potable a través de las desalinizadoras que operan, principalmente públicas (del Consorcio).

Mapa 23. Infraestructuras del ciclo del agua. Lanzarote. 1987

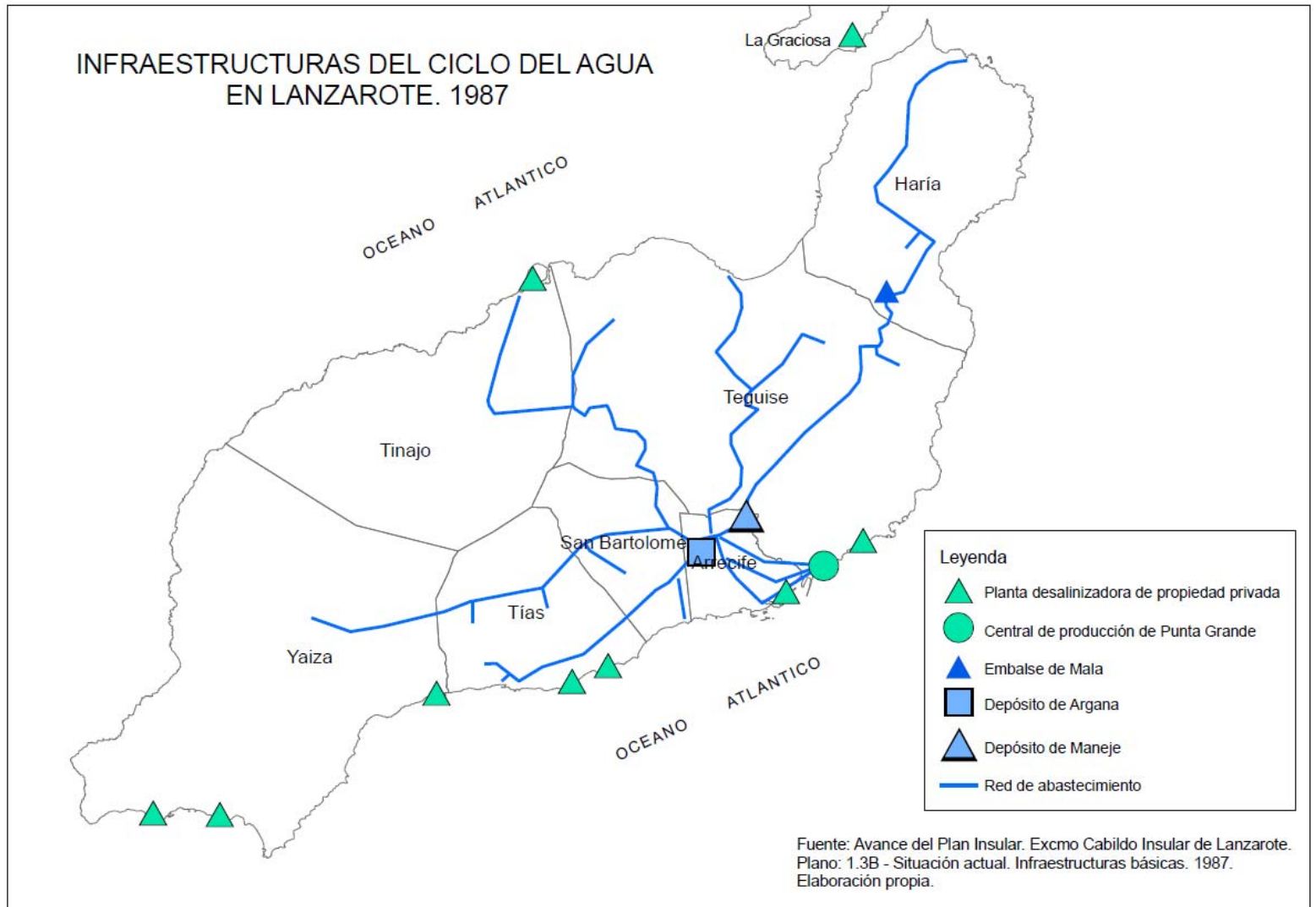

El fenómeno que acontece es el notable incremento del número de pequeñas plantas potabilizadoras propiedad de complejos turísticos ${ }^{183}$, que al principio de la etapa (1986) se estiman en nueve ${ }^{184}$. Aunque, desde el Consejo Insular de Aguas de Lanzarote, no se han facilitado datos de producción de estas plantas, para 1991 y 1996, pues muchas de ellas no responden a la solicitud anual que realiza este organismo de planificación. Por lo que sólo se ha podido recoger la producción pública (datos de INALSA).

183 Según fuentes internas de INALSA.

184 El Consorcio no ha facilitado los datos para 1996. 
Tabla 132. Producción pública de agua potable. Oferta. Lanzarote. 1986-1996 ( $\left.\mathrm{hm}^{3} / a n ̃ o\right)$.

\begin{tabular}{||c|c|}
\hline Año & Potabilización Pública \\
\hline \hline 1986 & 3,173675 \\
\hline 1991 & 6,057176 \\
\hline 1996 & 10,269800 \\
\hline
\end{tabular}

Fuente: Para 1986: "Producción neta al consumo de agua en 1986" Cuadro 3.1". Avance PIOT, 1987. Tomo 2. Cap. III y VI (pp. 47). Cabildo Insular de Lanzarote.; Para 1991: "Producción de agua pública, 1991". Memoria Anual de Insular de Aguas de Lanzarote, S.A. (INALSA), 1994; Para 1996: "Producción de agua en plantas potabilizadoras de Lanzarote según mes, 1996". Centro de datos. Cabildo Insular de Lanzarote. www.datosdelanzarote.com; Los datos sobre producción privada en potabilizadores han sido facilitados por INALSA para los años 1991 y 1996.

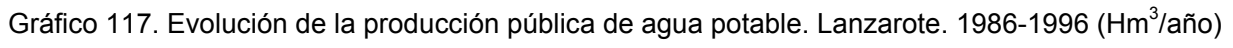

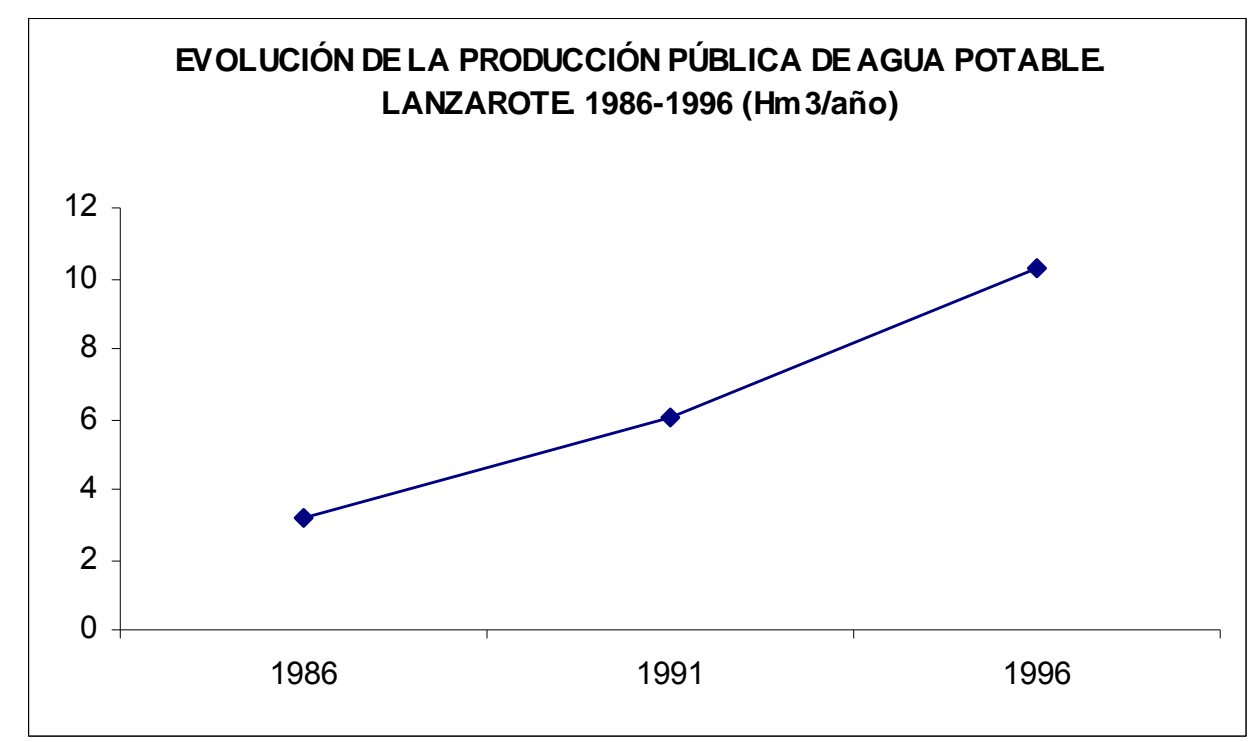

Fuente: Gráfico basado en la información recogida en la Tabla 132. Elaboración propia.

Los incrementos de la producción de agua pública son muy elevados y constantes, en estos diez años suponen un crecimiento estimado del 223\%. La constante elevación podemos observarla en los periodos quinquenales realizados, siendo entre 1986 y 1991 el de mayor envergadura, un $91 \%$. Las demandas de agua son brutales derivadas del boom turístico que vive la isla a finales de la década de los años ochenta, que incrementan tanto su población residente, pues los inmigrantes aumentan en un 57\% (ver epígrafe 5.2.2.1.2.), como los turistas equivalentes diarios, que observan incrementos del orden del $85 \%$ (ver epígrafe 5.2.1.2.). 
Tabla 133. Incremento interperiodo de la producción pública de agua. Oferta. Lanzarote. 1986$1996\left(\mathrm{hm}^{3} / \mathrm{año}\right)(\%)$

\begin{tabular}{||l|c|}
\hline Año & Incremento quinquenal (\%) \\
\hline \hline $1986-1991$ & 90,9 \\
\hline $1991-1996$ & 69,6 \\
\hline \hline $1986-1996$ & 223,6 \\
\hline
\end{tabular}

Fuente. Elaboración propia a partir de los datos recogidos en la Tabla 133.

Esta presión demográfica, derivada de la intensa actividad que directa e indirectamente supone el turismo, ha dado lugar a la ampliación del número y capacidad de las plantas desaladoras en la isla, que aunque ha favorecido el estado de abastecimiento de la población residente, en contrapartida produce efectos negativos en el consumo de energía y en la contaminación (emisiones de $\mathrm{CO}_{2}$, salmuera, etc.) Así, el incremento de la producción pública de agua desalada (litros por residente y día), que en esta etapa crece del orden del $118 \%$, va a permitir que sus habitantes disfruten de mayor disponibilidad, a diferencia de la etapa anterior.

Tabla 134. Producción media diaria de agua pública y población residente. Lanzarote. 1986$1996\left(\mathrm{~m}^{3 *}\right.$ día)

\begin{tabular}{|c|c|c|c|c|c|c|}
\hline Año & Producción* & Producción/Residentes*día & $\begin{array}{l}\text { Población } \\
\text { Residente }\end{array}$ & I/Residente*día & & $\begin{array}{l}\text { \% Incremento } \\
\text { I/Residente*día }\end{array}$ \\
\hline 1986 & $9.298,00$ & 0,60089 & 55.764 & 166,74 & $1986-1991$ & 53,3 \\
\hline 1991 & $16.595,00$ & 0,17390 & 64.911 & 255,66 & 1991-1996 & 42,2 \\
\hline 1996 & $28.136,44$ & 0,22319 & 77.379 & 363,62 & $1986-1996$ & 118,1 \\
\hline
\end{tabular}

$\left({ }^{*}\right)$ Este volumen de producción solo contempla la generada desde el ámbito público (Consorcio).

Nota: 1986 contiene la producción pública y la privada. Para 1991 y 1996 no se han facilitado datos de la producción privada de agua, por lo que sólo se contempla la pública (potabilizada) generada por el Consorcio de Aguas de Lanzarote.

Fuente: Elaboración propia. 
Gráfico 118. Evolución de la producción de agua pública por residente. Lanzarote. 1986-1996 (I/residentes*día).

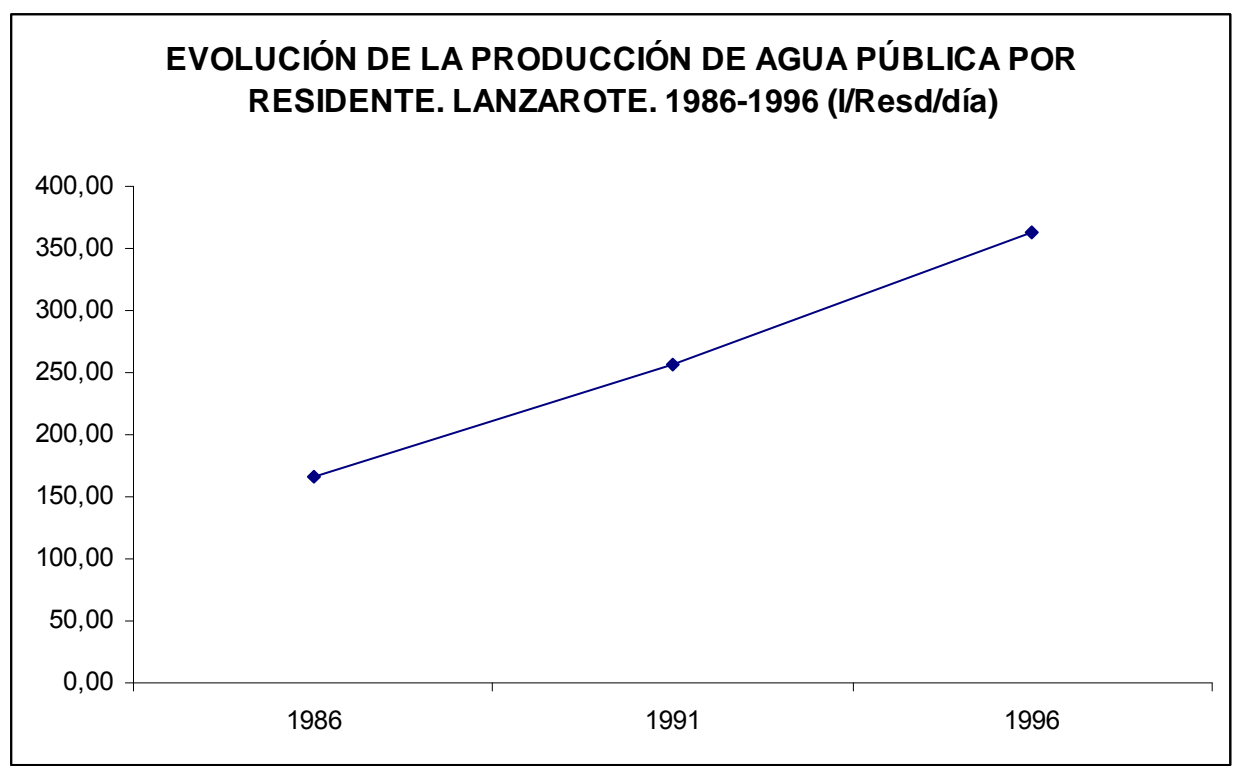

Fuente: Gráfico basado en la información recogida en la Tabla 134. Elaboración propia

Sin embargo, estas conclusiones en relación a la disponibilidad de agua llevan matices, pues, y suponiendo que toda el agua que se produce se distribuye (ya que la capacidad de almacenamiento es muy escasa), se debe tener en cuenta que se estiman pérdidas por fugas en la red de distribución y transporte del orden del $15 \%$ en 1986 y del $30,7 \%$ en $1996^{185}$, por lo que la estimación realizada en la tabla anterior sería menor (en disponibilidad real de I/habitantes*día). Aplicando esta reducción, el indicador calculado para consumo doméstico por habitante-residente y día arroja una disponibilidad, en 1986, de 115,6 litros, frente a los 252 litros brutos por residente en 1996.

Aunque se genere tal volumen bruto de agua desalada, seguirá siendo necesario incrementar la producción si se pretende alcanzar una disponibilidad aceptable para el bienestar de los residentes, que sufren restricciones, pues fuentes internas de INALSA ${ }^{186}$ apuntan que "las zonas rurales no tienen agua corriente a diario, aproximadamente se les abastece tres días a la semana" (en estos años). "Restricciones que no sufren ni el municipio de Arrecife, ni Tías, ni las zonas de Costa de Teguise" (municipio de Teguise), pues concentran la población urbana y turística, añadiendo que la prioridad en el abastecimiento, en épocas de alta ocupación (mes de agosto principalmente), la tienen los

185 Estimaciones realizadas por AUIA, Avance PIOT de Lanzarote, 1987. Tomo 2. Infraestructuras y abastecimiento (pp. 208) y para 1996 a partir de datos recogidas por el Plan Hidrológico de Lanzarote, 2000 (Memoria). BOC. № 138; 22-102001, pp. 15935.

186 Entrevista semiestructurada realizada a M.A. Figueras Alfonso, Jefe del Servicio de Redes de INALSA (Agosto de 2010). 
núcleos turísticos de la isla y en segundo lugar el resto de núcleos. Lo que confirma dos cosas, primero no existe garantía en el suministro y la actividad turística es un fuerte competidor por el agua.

Tabla 135. Disponibilidad de agua desalada pública, en destino final, para consumo de la población diaria estimada. Lanzarote. 1991-1996 (I/residente*día)

\begin{tabular}{||c||c|c||}
\hline \hline Año & I/habitante*día(1) & $\begin{array}{c}\text { Disponibilidad final después } \\
\text { de pérdidas (I/habitantes*día) }\end{array}$ \\
\hline \hline 1986 & 181,34 & 154,14 \\
\hline 1991 & 173,90 & 139,12 \\
\hline 1996 & 223,19 & 154,67 \\
\hline
\end{tabular}

Nota: Pérdidas por fugas aplicadas: Año 1986 (15\%); Año 1991 (20\%); Año 1996 (30,7\%)

(1) En relación a la población total estimada (residentes y turistas equivalentes diarios).

Fuente: Cabildo Insular de Lanzarote. Avance PIOT de Lanzarote. Tomo 2. Infraestructuras y abastecimiento. 1987 (pp. 208 ) y para 1996 a partir de datos recogidas por el Plan Hidrológico de Lanzarote, 2000 (Memoria). BOC. № 138; 22-10-2001, pp. 15935. Elaboración propia a partir de datos anteriores.

Gráfico 119. Producción de agua en relación a la población estimada y disponibilidad final. 1986-1996 (I/habitante*día).

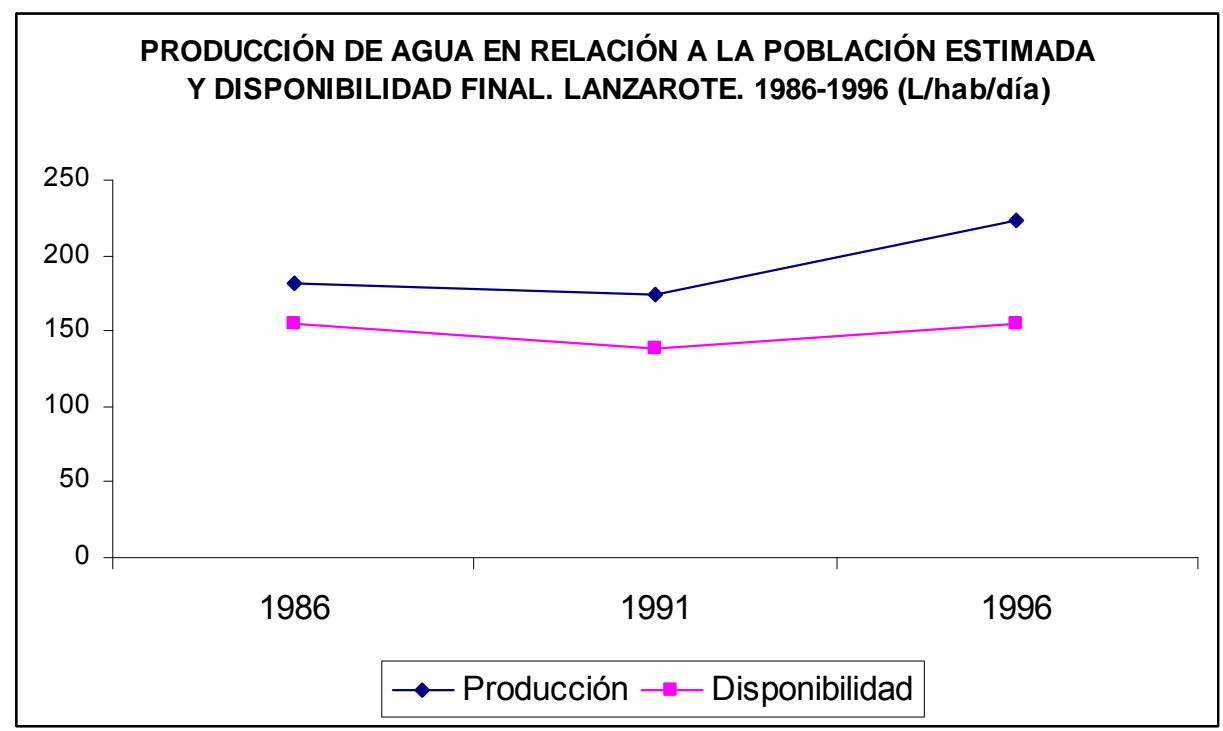

Fuente: Gráfico basado en la información recogida en la Tabla 135. Elaboración propia

La producción privada de agua desalada es importante, en la medida que supone un complemento que alivia la presión sobre el suministro y permite para el turista mayor disponibilidad de agua que para el residente, aspecto éste que se constata también tras el análisis del consumo en el próximo epígrafe. 
Para este periodo no se ha podido establecer comparación con Canarias y España, para los años que se toman, no obstante en el Libro Blanco del agua (año 2000) se recogen estimaciones nacionales para el año 1993 y 1998. En la próxima etapa si se hará dicha comparación a través de los registros que, a partir de 1996, recoge la Encuesta sobre suministro y tratamiento del agua del INE.

\subsubsection{2.- EL CONSUMO DE AGUA. DEMANDA}

En esta etapa tampoco se van a disponer de estadísticas detalladas en relación al consumo de la población residente y de la industria turística. Así, los datos que se recogen suponen el consumo medio diario de la población total (residente y turistas equivalentes diarios) estimada para la isla.

Tabla 136. Consumo medio diario de agua, producción y población a abastecer. Lanzarote. 1986-1996 ( $\left.m^{3} / a n ̃ o\right)$

\begin{tabular}{|c|c|c|c|c|c|c|c|c|}
\hline Año & CONSUMO & $\begin{array}{l}\text { Población } \\
\text { Residente }\end{array}$ & $\begin{array}{c}\text { Turistas } \\
\text { equivalentes } \\
\text { al día }\end{array}$ & $\begin{array}{c}\text { Población a } \\
\text { abastecer }\end{array}$ & $\begin{array}{c}\text { I/ } \\
\text { residentes*día }\end{array}$ & I/habitante*día & $\begin{array}{c}\text { Incremento } \\
\text { quinquenal del } \\
\text { Consumo } \\
\text { (l/habitantes*día) (\%) }\end{array}$ & $\begin{array}{c}\text { Producción } \\
\text { l/habitante día }\end{array}$ \\
\hline 1986 & 3.304.345 & 55.764 & 16.493 & 72.257 & 162,34 & 125,29 & --- & 181,34 \\
\hline 1991 & 4.448 .620 & 64.911 & 30.515 & 95.426 & 187,76 & 127,72 & 1,94 & 173,90 \\
\hline 1996 & 7.494 .325 & 77.379 & 48.686 & 126.064 & 265,35 & 162,87 & 30,46 & 223,19 \\
\hline & & & & & & 1986-1996 & 33,00 & \\
\hline
\end{tabular}

Nota. Estos consumos son los registrados por INALSA, que no contemplan el consumo de la producción privada de agua y que se desconocen para ese año.

(1) Calculado en relación a la población total estimada (residentes + turistas equivalentes al día)

(2) Media estimada.

Fuente: "Evolución del consumo de agua, Lanzarote, 1986 y 1991 (m²/día)". Datos Estadísticos, 1992. Centro de datos. Cabildo Insular de Lanzarote, 1992; "Resumen de datos de agua. Consumo, Lanzarote 1996.". Centro de datos del Cabildo Insular de Lanzarote. www.datosdelanzarote.com; Elaboración propia.

Esta estimación señala que la producción media diaria de agua por habitante (l/habitantes*día) supera el consumo medio por habitante y día, aunque en este periodo, que va desde 1986 hasta 1996, la población a abastecer diaria (residentes y turistas equivalentes diarios) se ha incrementado en un $74 \%$ y el consumo un $33 \%$. A pesar de ello, el sistema de abastecimiento es frágil, por los siguientes motivos: a) la escasa capacidad de almacenaje de agua de la isla (para dos o tres días); b) los estrangulamientos en relación a la demanda de agua se producen con mayor intensidad en los meses de mayor ocupación turística (principalmente agosto); c) el volumen de pérdidas por fugas en la red provoca que el volumen de agua que llega finalmente al consumidor se reduzca 
considerablemente, lo que genera que la disponibilidad real sea menor que la media diaria de los consumos registrados. Es por tanto que el sistema subsiste al límite.

Gráfico 120. Consumo y producción media diaria de agua en relación a la población total diaria estimada. Lanzarote. 19861996 (I/habitante*día).

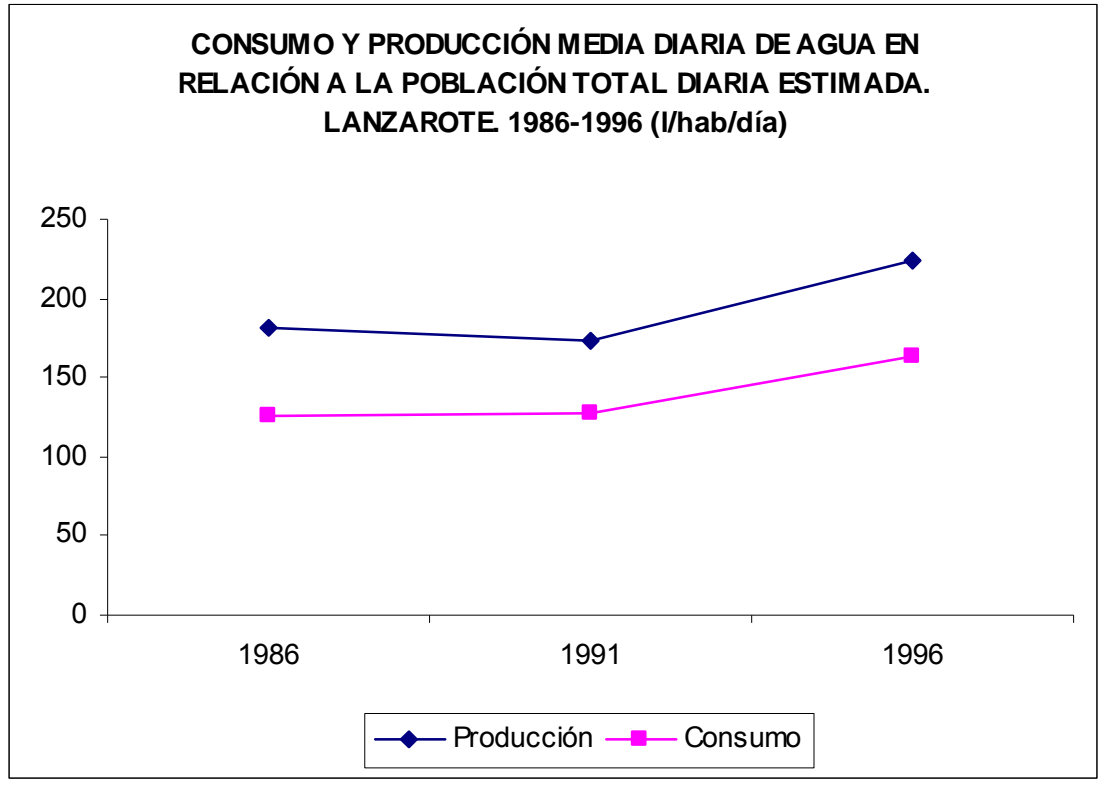

Fuente: INALSA y Centro de datos del Cabildo Insular de Lanzarote. Gráfico elaborado a partir de las estimaciones realizadas en la Tabla 136. Elaboración propia.

Gráfico 121. Consumo y disponibilidad de agua después de pérdidas en red. Lanzarote. 1986-1996 (I/habitante*día)

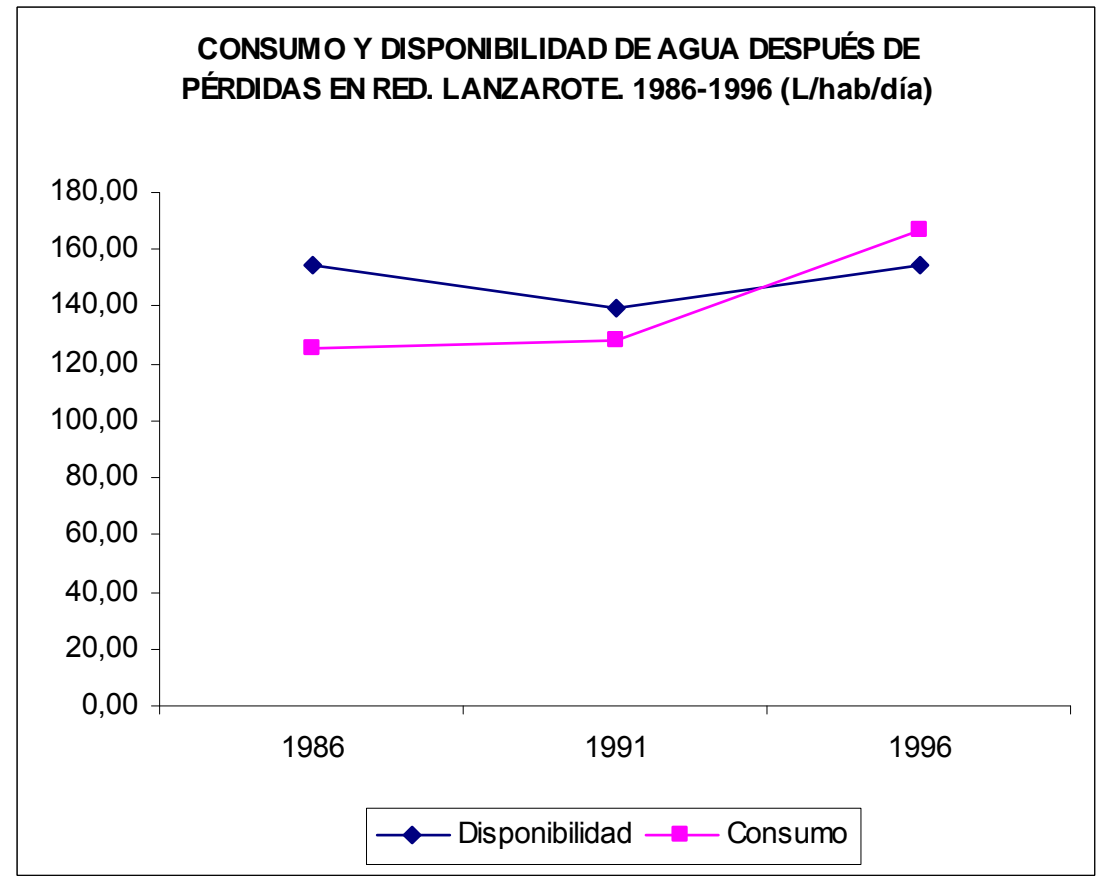

Fuente: INALSA y Centro de datos del Cabildo Insular de Lanzarote. Gráfico elaborado a partir de las estimaciones realizadas en la Tabla 136. Elaboración propia. 
Debemos de tener en cuenta, que los registros sobre consumo de agua no contemplan el consumo de la producción privada que añade abastecimiento sólo a los turistas, es por ello que el fuerte incremento de la demanda turística que vive la isla, en esta etapa, no se va a ver reflejado, en su totalidad, en los registros de consumo consultados. Aunque sí se poseen estimaciones oficiales acerca del consumo unitario por turista y residente al día que podemos ver en la siguiente tabla, que nos viene a señalar la notable demanda diaria, a la que no se podría dar respuesta únicamente con la producción pública de agua desalada, pues en 1996 el consumo diario de los turistas supera en un $66,7 \%$ el de los residentes. La austeridad de la población local compensa el elevado consumo diario de agua de los turistas.

Tabla 137. Consumo unitario por residente y turista. Lanzarote. 1986 y 1996 (I/habitantes*día)

\begin{tabular}{|c|c|c|c|c|c|c|c|}
\hline Año & \multicolumn{2}{|c|}{ Residente } & \multicolumn{2}{|c|}{ Turista } & \multirow{2}{*}{$\begin{array}{l}\text { TOTAL } \\
222\end{array}$} & \multirow{2}{*}{$\begin{array}{c}\text { Variación } \\
\text { Turista-Residente (\%) } \\
33,7\end{array}$} & \multirow{2}{*}{$\begin{array}{c}\begin{array}{c}\text { Producción Pública } \\
\text { I/habitante*día* }\end{array} \\
181,34\end{array}$} \\
\hline 1986 & 95 & $\begin{array}{c}\text { Incremento } \\
\text { quinquenal (\%) }\end{array}$ & 127 & $\begin{array}{c}\text { Incremento } \\
\text { quinquenal (\%) }\end{array}$ & & & \\
\hline 1996 & 138 & 45,26 & 230 & 81,10 & 368 & 66,7 & 223,19 \\
\hline
\end{tabular}

Fuente: Programa LIFE. Aplicación de la Agenda 21 a Lanzarote. "Documento 7. Los Sectores Ambientales Clave". Cabildo de Lanzarote, 1998 (pp. 14).

A pesar del crecimiento de los consumo unitarios (I/habitantes*día), en 1996 se destina menos agua, en términos relativos, al consumo de los residentes que al principio de la etapa (alrededor de 6,5 puntos). Los incrementos en esta década de la producción de agua desalada $(202,6 \%)$ y del consumo $(126,8 \%)$, son superiores al ritmo de crecimiento demográfico $(38,8 \%)$. El factor de presión en el crecimiento de la producción y del consumo no es el ámbito doméstico.

Tabla 138. Crecimiento del consumo, la producción, los residentes y turistas. Lanzarote. 19861996

\begin{tabular}{|c|c|c|c|c|c|c|c|c|}
\hline \multirow[t]{2}{*}{ Año } & \multirow{2}{*}{$\begin{array}{l}\text { Consumo } \\
\text { ( } m \text { 3/año) }\end{array}$} & \multirow{2}{*}{$\begin{array}{l}\text { Población } \\
\text { Residente }\end{array}$} & \multicolumn{2}{|c|}{$\begin{array}{c}\text { Consumo Residentes } \\
\left.\text { ( } \mathrm{m}^{3} / \mathrm{anno}\right)\end{array}$} & \multicolumn{4}{|c|}{ Incrementos 1986-1996 (\%) } \\
\hline & & & Absolutos & $\%$ & & & & \\
\hline 1986 & 3.304.345 & 55.764 & $1.933 .619,7$ & 58,52 & Producción & Consumo & Residentes & $\begin{array}{l}\text { Turistas equivalente } \\
\text { al día }\end{array}$ \\
\hline 1996 & 7.494.325 & 77.379 & $3.897 .580,23$ & 52,00 & 202,60 & 126,80 & 38,76 & 195,19 \\
\hline
\end{tabular}

Nota: El consumo de los residentes $\left(\mathrm{m}^{3}\right)$ al año ha sido calculado en relación a las estimaciones unitarias (l/día) que se recogen en la anterior tabla

Fuente: Elaboración propia a partir de datos anteriores 
Adicionalmente se hace necesario señalar que la isla posee un sistema de tarifas diversificado según los usos del agua, de manera que para usos turísticos e industriales el precio del $\mathrm{m}^{3}$ de agua es mayor $\left(300 \mathrm{ptas} / \mathrm{m}^{3}\right)$ que para uso doméstico $\left(125 \mathrm{ptas} / \mathrm{m}^{3}\right)$, tarifas que se han mantenido estables desde el año 1984. Por lo que, según fuente oficiales, si más de dos terceras partes de los ingresos por ventas de agua en red vienen del sector turístico-industrial (pues consume más de la mitad del agua distribuida), quiere decir que el financiador del sistema de abastecimiento de agua de Lanzarote es el turismo y todo el proceso industrial que de él se deriva (Programa LIFE. Aplicación de la Agenda 21 a Lanzarote. 1998, Doc. 7, pp. 10). Luego el efecto de este sector, sobre la posibilidad de abastecimiento de agua a través de la potabilización, a precios razonables para los residentes, se puede considerar positivo en términos de bienestar.

La comparación en el consumo con Canarias y España no se realizará hasta la etapa siguiente por escasez de registros hasta 1996.

\subsubsection{3.- CONCLUSIONES}

Esta etapa marcada por un nuevo boom turístico, que hace estallar la oferta y demanda turística, junto con un nuevo modelo de ordenación del territorio aprobado en 1991, así como la aparición del Consejo Insular del Agua de Lanzarote (1990), como órgano encargado de la ordenación, planificación y gestión hidráulica de la isla, junto con la empresa pública de producción, abastecimiento y reutilización del agua, INALSA (1989), se caracteriza por lo siguiente (teniendo en cuenta que las conclusiones se refieren a la producción pública, pues no se ha tenido acceso a datos sobre la producción privada de agua desalada ):

1.- Ampliación de la capacidad de desalación y fuerte incremento de la producción de agua desalinizada, derivado de la presión demografía asociada al boom turístico de finales de los años ochenta. Cuyos efectos serán:

a. Positivos en relación a la mayor disponibilidad de agua para los residentes.

b. Negativos en cuando al crecimiento del consumo, de la energía asociada y la contaminación.

2.- Las fugas en las redes reducen la disponibilidad final, que es inferior al consumo registrado.

3.- Los depósitos de recogida de agua de lluvia están en desuso.

4.- Es muy limitada la capacidad de almacenamiento de agua desalada por lo que se consume lo que se produce diariamente. 
5.- No se garantiza el suministro. Los mayores cortes se producen en los núcleos rurales, son los más desabastecidos frente a los asentamientos urbanos y turísticos que reciben agua corriente a diario.

6.- La austeridad en el consumo de los residentes permite mayores consumos en otros ámbitos. Los turistas se presentan como competidores en la disponibilidad al agua potable de la población residente.

7.- El principal factor de presión en el crecimiento de la producción y el consumo de agua en la isla, es el turístico-industrial, seguido del residencial-doméstico.

8.- La diversificación del sistema de tarifas, según usos, en el precio del agua muestra a la actividad turística e industrial como la verdadera financiadora del sistema de producción de agua de la isla.

El sector turístico, por tanto, se muestra en este periodo como un elemento de presión sobre el recurso "agua", que conduce a nuevas inversiones y ampliaciones de las plantas potabilizadoras, cuyo efecto positivo sobre el abastecimiento doméstico redunda en el bienestar de los residentes, aunque su abastecimiento no es prioritario y sufren periodos de escasez. Las ampliaciones de estas infraestructuras no tienen efectos negativos sobre la renta familiar pues las tarifas se mantienen estables, pero sí sobre variables energéticas y ambientales. No obstante, el modelo de abastecimiento de agua en la isla no sería posible sin la financiación que realiza el sector turístico del mismo, a través de los precios que asume.

\subsection{9.- EFECTOS SOBRE LAS VÍAS DE COMUNICACIÓN. CARRETERAS. 1986-1996}

\subsubsection{1.- CAPACIDAD DEL VIARIO. OFERTA}

Al igual que la etapa anterior, ésta tampoco se va a caracterizar por la existencia de una planificación global del trasporte y las comunicaciones insulares. Los proyectos sobre carreteras "constituyen actuaciones independientes entre sí, aunque las características técnicas de algunos de ellos puedan estar coordinadas por corresponder a actuaciones parciales sobre determinados corredores insulares de concepción unificada" (Estevan, A., 1998, pp. 2).

Lanzarote al igual que Canarias, incrementa su ancho de vía a lo largo del periodo, pues en 1989 se realiza la ampliación de dos carriles en cada sentido del tramo Arrecife (capital)Aeropuerto, y en 1993 entre la infraestructura aérea y el municipio de Tías (que concentra la mayor oferta de alojamiento turístico de la isla), lo que posibilita la mejor absorción del crecimiento del tráfico, la seguridad y la accesibilidad de los ciudadanos. Aunque la isla no tiene vías de gran capacidad, la población residente se va a ir viendo afectada por la 
presión que ejerce el incremento de vehículos en circulación que provoca la apertura de nuevas plazas turísticas y la atracción de población laboral externa a la isla asociada, junto con el crecimiento del parque de vehículos de coches en alquiler.

Sin embargo, con respecto al periodo anterior, Lanzarote presenta diferencias significativas con respecto a Canarias, pues su ancho de vía, aunque no disponemos de lo datos más que para el año 1986, ya citados (cuyo reflejo se recoge en la figura siguiente), podemos afirmar que es inferior a la media de Canarias en la medida en que en años posteriores (de los que sí se disponen de datos) tampoco la va a superar.

Tabla 139. Ancho de calzada y kilómetros de carretera. Lanzarote y Canarias. 1986.

\begin{tabular}{|c|c|c|c|c|c|c|c|c|c|c|}
\hline \multirow{3}{*}{$\begin{array}{l}\text { Tipo } \\
\text { Año }\end{array}$} & \multicolumn{4}{|c|}{ LANZAROTE } & \multicolumn{6}{|c|}{ CANARIAS } \\
\hline & \multicolumn{3}{|c|}{ Una calzada (\%) } & \multirow{2}{*}{$\begin{array}{l}\text { TOTAL } \\
\mathrm{Km} .\end{array}$} & \multicolumn{3}{|c|}{ Una calzada } & \multirow{2}{*}{$\begin{array}{c}\% \\
\text { Total }\end{array}$} & \multirow{2}{*}{$\begin{array}{c}\text { Vías de Gran } \\
\text { Capacidad (\%) }\end{array}$} & \multirow{2}{*}{$\begin{array}{l}\text { TOTAL } \\
\mathrm{km}\end{array}$} \\
\hline & $<6$ & $6-7$ & $7-9$ & & $<5$ & $5-6,99$ & $\geq 7$ & & & \\
\hline 1986 & 62,3 & 28,0 & 9,7 & 439,3 & 10,9 & 72,8 & 12,3 & 96,0 & 3,4 & 4.472 \\
\hline
\end{tabular}

Fuente: "Indicadores de la Red de Carreteras. Lanzarote, 1986". Cabildo Insular de Lanzarote. Avance PIOT, Tomo 2. Cap. VIII. 2. Cuadro 2.2. 1987 (pp. 156); "Red de Carreteras de Canarias según anchura de pavimento. Total Canarias, 1987, 1991 (km)". Estadísticas Básicas de Canarias 1987-1992". Instituto Canario de Estadística, 1992. ISTAC; "Red de carreteras de Canarias según anchura de pavimento, 1996 (Km)". Anuario Estadístico de Canarias, 1999. ISTAC; Elaboración propia. 
Mapa 24. Carreteras insulares. Lanzarote. 1987

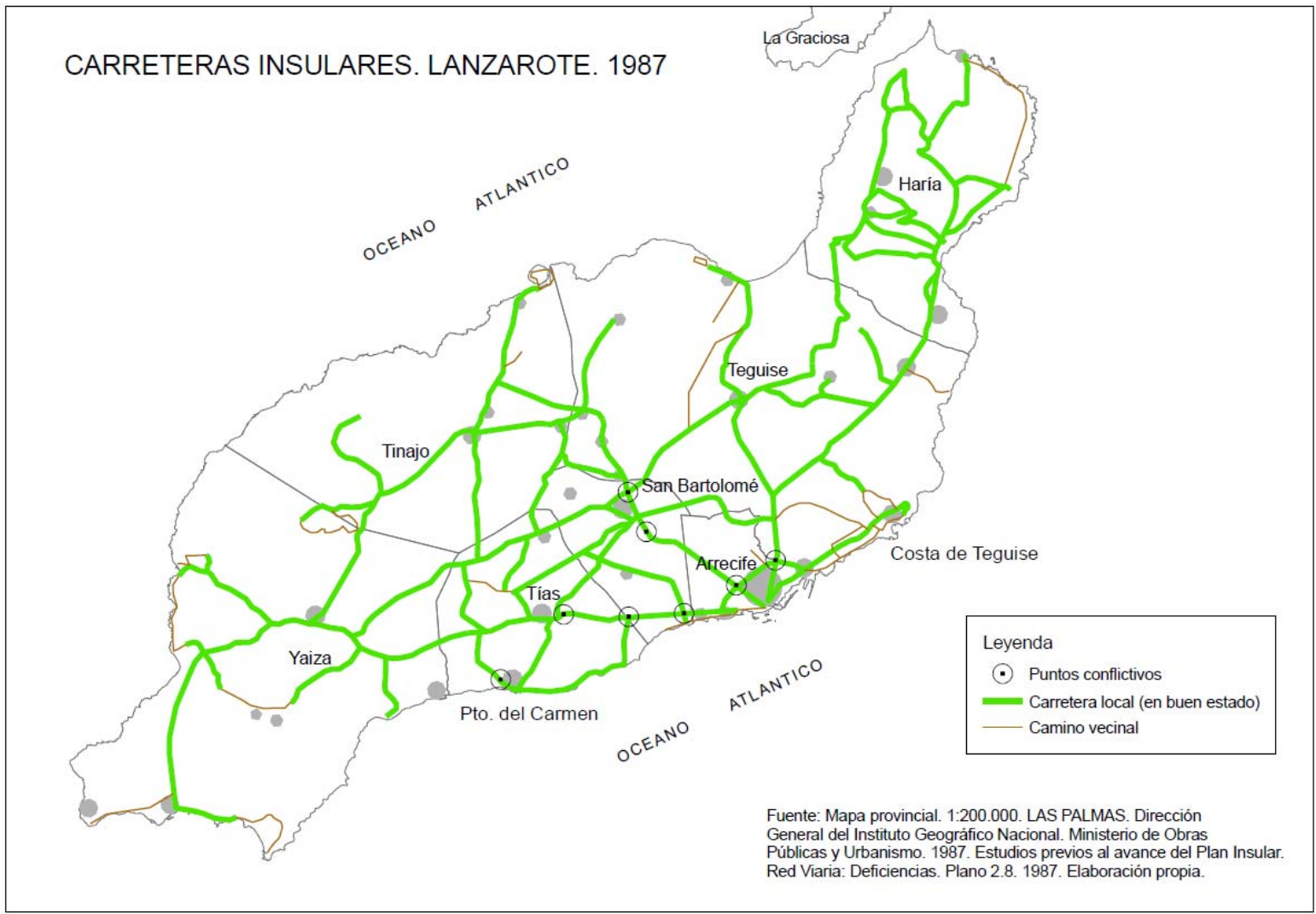

\subsubsection{2.- NIVEL DE MOTORIZACIÓN E INTENSIDAD DEL TRÁFICO}

El incremento de la movilidad terrestre, no sólo estará relacionado con la presión demográfica que vive la isla, sino también con la mejora de la red de carreteras y por tanto de la accesibilidad.

En relación al índice de motorización, Lanzarote ha ido incrementando de forma notable el número de vehículos-turismos por habitantes, de modo que si al principio de la etapa la motorización por residente se estima en 26 por cien, al final de la misma existen 41 vehículos-turismo por cien residentes.

Presenta valores superiores a Canarias y España al comienzo y al final de la etapa, tanto en relación a la población residente como en relación a la población total estimada (incluye turistas equivalentes diarios). 
Tabla 140. Número de vehículos (turismos) e índice de motorización. Lanzarote, Canarias y España. 1986-1996.

\begin{tabular}{|c|c|c|c|c|c|c|c|c|c|c|c|c|}
\hline \multirow{4}{*}{$\begin{array}{l}\text { AÑO } \\
1986\end{array}$} & \multicolumn{6}{|c|}{ Número de Turismos } & \multicolumn{6}{|c|}{ Índice de Motorización** } \\
\hline & \multirow{2}{*}{\multicolumn{2}{|c|}{ Lanzarote }} & \multirow{2}{*}{\multicolumn{2}{|c|}{ Canarias }} & \multirow{2}{*}{\multicolumn{2}{|c|}{ España }} & \multicolumn{2}{|c|}{ Lanzarote } & \multicolumn{2}{|c|}{ Canarias } & \multicolumn{2}{|c|}{ España } \\
\hline & & & & & & & Residentes & P Total & Residentes & P Total & Residentes & P Total \\
\hline & 19.650 & $\% \operatorname{lnc}^{*}$ & 343.061 & $\% \operatorname{lnc} c^{*}$ & 9.761 .968 & $\% \operatorname{lnc} c^{*}$ & 0,26 & 0,27 & 0,24 & 0,21 & 0,25 & 0,25 \\
\hline 1991 & 30.772 & 56,6 & 523.751 & 52,7 & 12.537 .099 & 28,4 & $0,27^{\star *}$ & 0,32 & 0,35 & 0,31 & 0,32 & 0,32 \\
\hline 1996 & 48.769 & 58,5 & 662.337 & 26,5 & 14.753 .809 & 17,7 & $0,41^{* *}$ & 0,39 & 0,41 & 0,35 & 0,37 & 0,36 \\
\hline
\end{tabular}

Nota: Población Total: población de derecho + turistas equivalentes al día.

$\left.{ }^{*}\right) \%$ Inc= porcentaje de incremento quinquenal.

$\left({ }^{*}\right)$ El total de vehículos-turismos se contabiliza en la primera columna en su totalidad, pero teniendo en cuenta las cifras estimadas de automóviles en alquiler recogida en la tabla siguiente, el índice se calcula descontando esta cantidad para establecer, aproximadamente, el índice de motorización de la población residente en relación a los vehículos de tipo "turismos".

Fuente: "Parque automóvil en Lanzarote, 1986". Avance Plan Insular, Tomo 2. VIII. 2.D). Cuadro 2.4, 1987 (pp. 163); "Parque móvil de Canarias según tipo de vehículo, por provincias, 1986". Anuario Estadísticos de Canarias, 1986. CEDOC; "Parque nacional de vehículos al final de cada año. Turismo: 1985, 1991, 1996". Anuario Estadístico, 2004. Ministerio de Fomento. España, 2004; "Parque de vehículos según clases, 1991". Estadísticas Insulares y Municipales de Canarias, 1991. ISTAC; "No de Turismos, por islas y total Canarias, 1996". Parque de vehículos según clases, 1996. Anuario Estadístico de Canarias, 1999. ISTAC; Elaboración propia.

Este considerable incremento (75\%), unido a la inferioridad en el ancho de vía, se traduce en dificultades en la accesibilidad y la seguridad, a lo que hay que añadir la contaminación atmosférica derivada. Aunque desde un punto de vista positivo, indica tanto que la renta de los residentes ha mejorado, como que mejora su movilidad potencial en un ámbito en que el transporte público es muy limitado, como veremos en las próximas líneas. 
Gráfico 122. Índice de motorización (turismos) en relación a la población residente y la población total estimada. España, Canarias y Lanzarote. 1986-1996

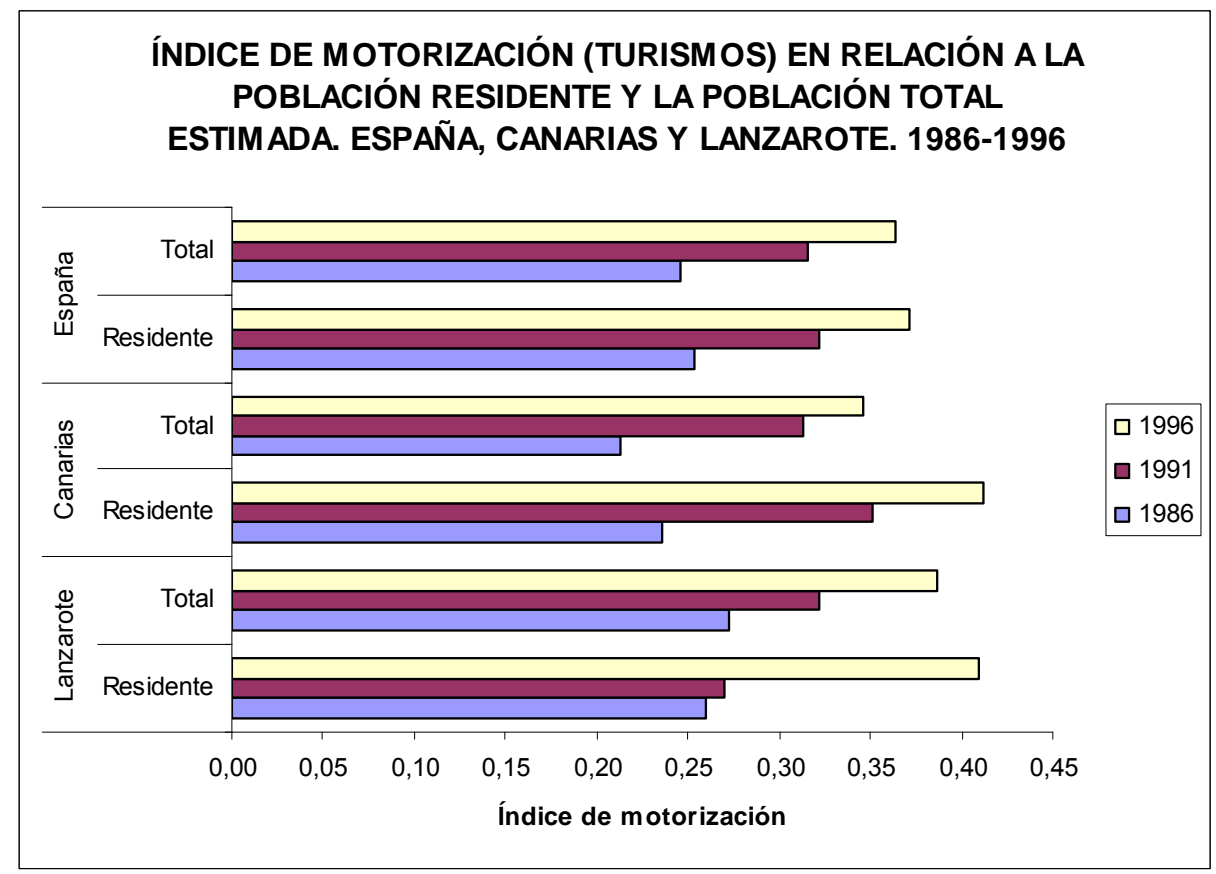

Fuente: Gráfico elaborado a partir de los indicadores calculados en la Tabla 140. Elaboración propia.

Por otro lado, los automóviles en alquiler sin conductor, al igual que en la etapa anterior, siguen experimentando un importante crecimiento, pues entre 1991 y 1996 se contabiliza un incremento del $26 \%$. La cifra significativa la arroja el peso que suponen sobre el total de turismos, pues si al comienzo de la etapa se baraja la cifra del 25\%, en 1991 son casi el $43 \%$ de dicho parque, reduciéndose al $34 \%$ en 1996. Una presión enorme sobre el territorio y las vías de comunicación por carretera, que entra directamente en competencia con el vehículo privado de la población residente y el sobre dimensionamiento que sufre la población autóctona.

Tabla 141. Evolución de los coches de alquiler. Lanzarote, 1991-1996

\begin{tabular}{|r|c|c|c|}
\hline AÑO & Coches de alquiler & Incremento quinquenal (\%). & \% Respecto al Total de turismos \\
\hline \hline 1991 & 13.213 & \multirow{2}{*}{26,4} & 42,9 \\
\cline { 1 - 2 } $\mathbf{1 9 9 6}$ & 16.700 & & 34,2 \\
\hline
\end{tabular}

Fuente: "Comparación del parque de vehículos con la población. Coches de alquiler, 1991". AUIA, Life-Lanzarote 2001-2004. "Bases jurídicas para la regulación de la oferta de vehículos de alquiler sin conductor en Lanzarote". Cabildo Insular de Lanzarote, 2004 (pp. 23); "Parque de vehículos según clase y servicio al que están destinados, 1996". Anuario Estadístico de Lanzarote, 1996. Centro de datos. Cabildo Insular de Lanzarote. Elaboración propia.

A todo lo descrito hay que añadir las intensidades medias diarias de tráfico. En este sentido, y partiendo de los datos existentes, se observa el espectacular crecimiento del 
tráfico que viene ya desde la etapa anterior, registrándose incrementos de más de $110 \%$ en aquellos tramos de vía que conectan las zonas con mayor población residente (Arrecife, la capital), y mayor concentración de actividad económica turística.

Tabla 142. Evolución de la intensidad media diaria de vehículos, por tramos. Lanzarote. 19871995.

\begin{tabular}{|c|c|c|c|c|c|c|c|c|}
\hline AÑO & $\begin{array}{c}\text { Arrecife- } \\
\text { Aeropuerto }\end{array}$ & $\begin{array}{c}\text { Incremento } \\
\text { quinquenal } \\
\text { (\%) }\end{array}$ & $\begin{array}{l}\text { Arrecife- } \\
\text { Tías }\end{array}$ & $\begin{array}{c}\text { Incremento } \\
\text { quinquenal } \\
\text { (\%) }\end{array}$ & $\begin{array}{l}\text { Arrecife- } \\
\text { Costa de } \\
\text { Teguise }\end{array}$ & $\begin{array}{c}\text { Incremento } \\
\text { quinquenal } \\
\text { (\%) }\end{array}$ & $\begin{array}{l}\text { Arrecife- } \\
\text { Tahíche }\end{array}$ & $\begin{array}{c}\text { Incremento } \\
\text { quinquenal } \\
\text { (\%) }\end{array}$ \\
\hline 1987 & 19.500 & \multirow{2}{*}{117,57} & $5.630^{*}$ & \multirow{2}{*}{109,54} & 5.952 & \multirow{2}{*}{183,13} & 7.374 & \multirow{2}{*}{123,05} \\
\hline 1995 & 42.427 & & 11.797 & & 16.852 & & 16.448 & \\
\hline
\end{tabular}

(*) Dato de 1988.

Fuente: "Mapa de aforo de carreteras de Lanzarote. Arrecife-Tías, 1988". González, A; Couceiro, A. y otros (1989). "Evolución del transporte y la infraestructura viaria en la isla de Lanzarote”. IV. Jornadas de Estudios de Lanzarote y Fuerteventura. Tomo II, 1995 (pp. 13-50). Cabildo Insular de Lanzarote y de Fuerteventura. http://www.memoriadelanzarote.com.; En Hernández, J. A. (2006). "Intensidad media diaria de tráfico en puntos representativos de la isla de Lanzarote, 1987 (1975-2000). Tabla 6" y "Tendencias de la movilidad terrestre en la isla de Lanzarote (1991-2001)". En XII Jornadas de Estudios sobre Lanzarote y Fuerteventura. Tomo III, Vol. 2. (pp. 156178). Cabildo Insular de Lanzarote y de Fuerteventura, 2008. http://www.memoriadelanzarote.com; "Evolución de la intensidad media diaria de vehículos (1987-1995)". En Caballero, C. "La movilidad espacial por carretera de la población en la isla de Lanzarote (19901995)". IX Jornadas de Estudios sobre Fuerteventura y Lanzarote. Tomo II (pp. 324-339). Cabildo Insular de Lanzarote y de Fuerteventura, 2001.

Gráfico 123. Intensidad media diaria de vehículo por tramos. Lanzarote. 1987-1995.

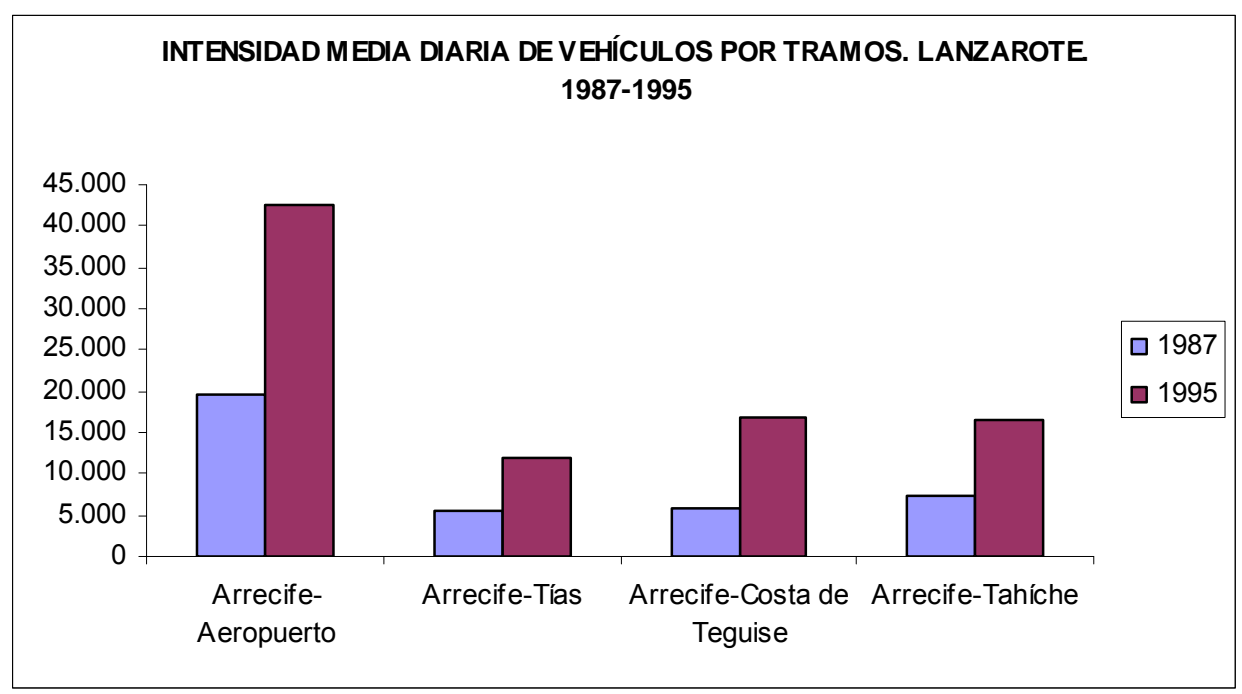

Fuente: González, A; Couceiro, A. y otros (1989); En Hernández, J. A. (2006); Caballero, C. (2001). Elaboración propia.

El elevado crecimiento de la población asociado al crecimiento de la oferta y demanda turística ha desbordado la isla, en detrimento del bienestar de la población local. Así, Lanzarote está abocado a una dinámica de constante crecimiento de la ocupación de espacios con la construcción de nuevas carreteras o la ampliación de las existentes, pues a partir de una intensidad media diaria superior a 10.000 vehículos se justifica el 
desdoblamiento de calzadas, como ocurre en 1989 y 1993, con las vías ArrecifeAeropuerto-Tías (eje centro-sur), indicado anteriormente.

\subsubsection{3.- TRANSPORTE COLECTIVO REGULAR DE PASAJEROS}

La situación del transporte público regular, por carretera, en general ha sufrido un gran cambio con respecto a la etapa anterior, la única compañía concesionaria que da servicio a la isla ha ido modificando cuantitativamente su parque de vehículos (guaguas) para poder abordar el crecimiento de la demanda derivado del incremento de la población turista y residente cuya movilidad ya no puede considerarse baja, como en la etapa anterior.

Tabla 143. Transporte público (interurbano) de viajeros. Lanzarote. 1986-1996

\begin{tabular}{|c|c|c|c|c|c|c|}
\cline { 2 - 7 } \multicolumn{1}{c|}{} & Buses & Líneas & Residentes & Residentes/bus & $\begin{array}{l}\text { Viajeros } \\
\text { Potenciales* }\end{array}$ & Población Total/bus \\
\hline 1986 & 17 & 12 & 55.764 & $3.280,24$ & 72.257 & $4.250,41$ \\
\hline 1996 & 205 & 17 & 77.379 & 377,46 & 126.065 & 614,95 \\
\hline
\end{tabular}

$\left.{ }^{*}\right)$ Viajeros potenciales= Población total (residentes + turistas equivalentes al día).

Fuente: "Transporte público de viajeros". Cabildo Insular de Lanzarote. Avance PIOT de Lanzarote. Tomo 2. Área de Infraestructuras y abastecimiento. Cap. VIII. Comunicaciones. VIII. 4.1. Transporte público regular. 1987 (pp. 165); Caballero, C. (1999). "El transporte colectivo regular de viajeros por carretera en la isla de Lanzarote (1947-1996). VIII Jornadas de Estudios de Lanzarote y Fuerteventura. Tomo I. Cabildo Insular de Lanzarote. Arrecife, 1999 (pp. 563); "Parque de vehículos según clase y servicio al que están destinados, 1996". Anuario Estadístico de Lanzarote, 1996. Centro de datos. Cabildo Insular de Lanzarote; Elaboración propia.

Así, para esta década (1986-1996), los datos arrojan un enorme cambio cuantitativo en la oferta, la flota se ha incrementado un $1.105 \%$, reduciendo el desbordamiento de los autobuses, que supone ahora una presión de casi 378 personas residentes por cada bus. Aunque las estimaciones oficiales señalan que el transporte público regular de pasajeros apenas representa el $7 \%$ de todos los desplazamientos mecanizados, se calcula que, en 1996, los viajeros turistas en este medio recorren mayor distancia media, el 16,1\%

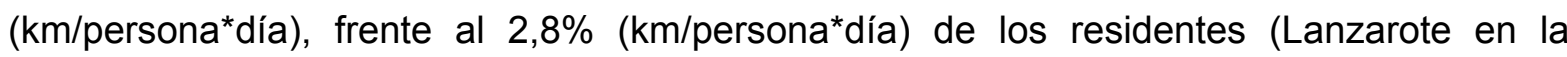
Biosfera, 1998. Doc. 7.4.2 Transporte, pp. 45).

Unido al crecimiento de la flota, también se ha ampliado el número de líneas (cinco en total), por lo que existen en 1996 más zonas conectadas al transporte público que las existentes al principio de la etapa. Estas nuevas líneas tienen como destino asentamientos de población del centro y norte de la isla. Aunque la política en relación a la conectividad de los núcleos de población sigue siendo la misma que la etapa anterior, es decir, las zonas mejor comunicadas son las que salen de la capital de la isla (centro) hacia el sur, por líneas y frecuencia de paso, conectando los asentamientos de población que concentran los crecimientos del alojamiento y la actividad turística, en detrimento de asentamientos de población local donde no se acogen dichos desarrollos. 


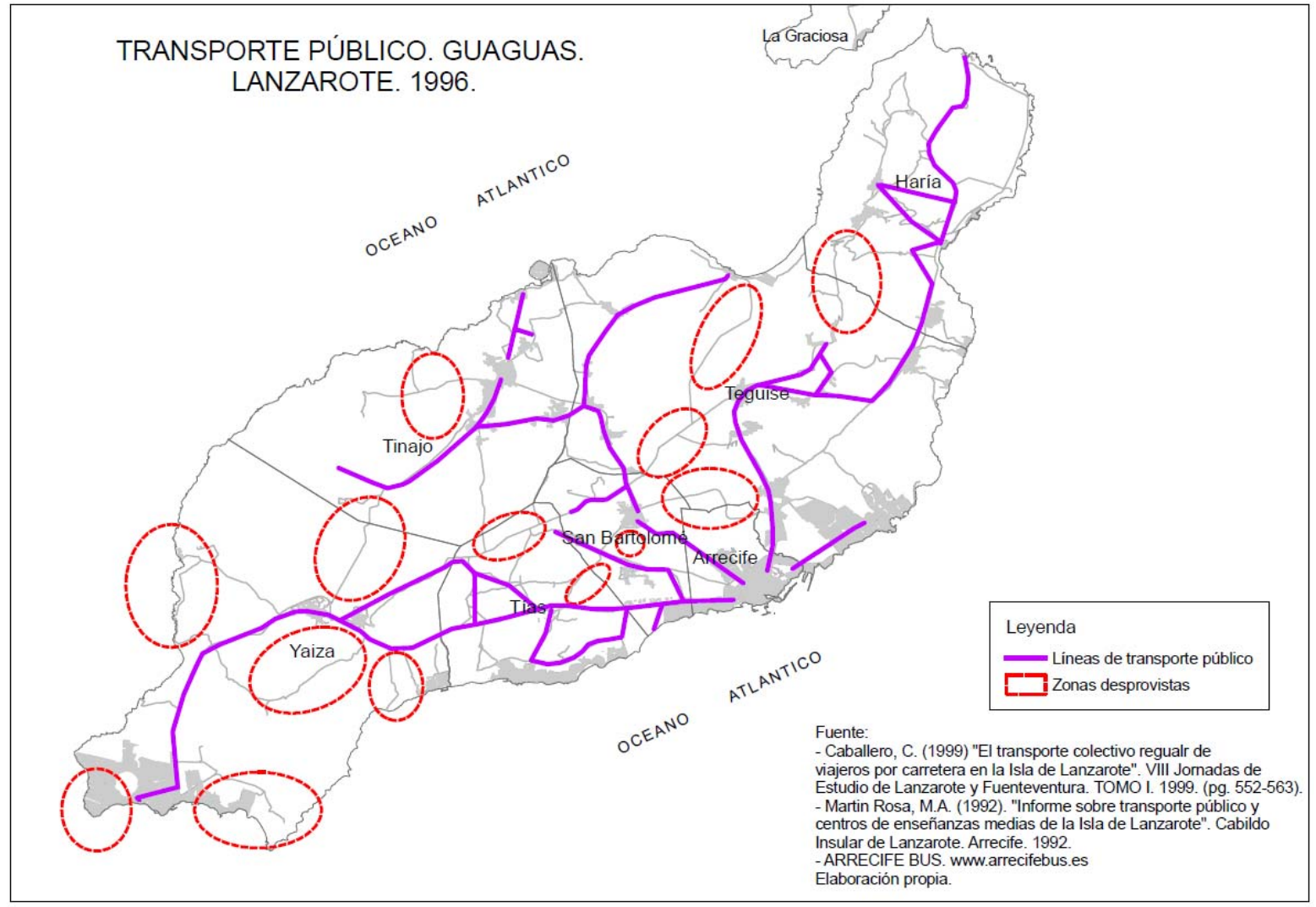

La política insular no incentiva el uso del transporte público frente al privado en la población residente, por lo que la tendencia irá en contra de la reducción de la movilidad motorizada y los efectos negativos derivados sobre el bienestar.

\subsubsection{4.- CONCLUSIONES}

En lo que respecta a las comunicaciones por carrera, este segundo periodo de desarrollo de la actividad turística, donde la oferta y la demanda del sector ha seguido en alza, se caracteriza por lo siguiente:

1. Tendencia a lo largo de toda la etapa hacia mejoras sustanciales del ancho del vial, por tanto de la seguridad y la accesibilidad, necesaria para dar servicio a la demanda de movilidad por carretera que genera la constante y creciente entrada de turistas y de población asociada. Con repercusiones positivas en el bienestar social de la población local.

2. Incremento constante del número de turismos y del nivel de motorización de la isla, por encima de Canarias y de España, junto con la intensidad media diaria de vehículos, que alcanza un valor que da lugar a que el ancho de vía sea insuficiente para unos niveles de servicio adecuados. 
3. El transporte regular por carretera de viajeros mejora su oferta derivado de la presión de la nueva demanda, consiguiendo niveles dotacionales mucho más satisfactorios. Pero siempre potenciando la accesibilidad a los núcleos que concentran la actividad turística.

La saturación de las comunicaciones por carretera que tiene como origen el constante crecimiento de la entrada de población foránea al mercado laboral insular, derivado de los constantes incrementos de la oferta y la demanda turística, estudiada en anteriores capítulos, desemboca en congestión y dificultades de accesibilidad y seguridad derivadas. A ello se une una política de transporte que no parece tener como prioridad la reducción de la movilidad motorizada a través de la incentivación del uso del transporte público, cuya oferta sigue siendo escasa y limitada.

Consecuentemente, el bienestar asociado a esta dinámica será negativo para la población insular residente.

\subsubsection{0.- CONCLUSIONES A LA SEGUNDA ETAPA. BOOM TURÍSTICO Y PIOT. 1986- 1996}

Esta segunda etapa, que cubre la década comprendida entre 1986 y 1996, es heredera de la anterior, pues será en la que se van a observar las consecuencias del modelo de planificación territorial y de la dinámica de crecimiento de la actividad turística derivada del mismo, sobre el bienestar de la población de acogida.

El excesivo crecimiento de la construcción y la oferta de alojamiento turístico en el mercado insular, que se produce entre 1983 y 1986, deriva hacia una crisis de sobreproducción que se sufrirá en esta etapa. El exceso de oferta frente a la demanda producirá desajustes financieros entre hoteleros y promotores, por lo que sus efectos se sentirán en el resto de la economía insular, como indican diferentes informes oficiales señalados anteriormente, pues se ha acogido de lleno el "monocultivo del turismo".

A partir de estos hechos, la opción, como remedio, de regular a través de una nueva estrategia territorial de planificación turística, se materializa con la aprobación en 1991, del Plan Insular de Ordenación del Territorio de la isla de Lanzarote, cuyos objetivos básicos, son racionalizar y delimitar el desarrollo turístico de la isla, poniendo límite al crecimiento de los núcleos de población turística y a las plazas de alojamiento turístico por municipio; estableciendo, en consecuencia, directrices vinculantes de aplicación directa e inmediata para el planeamiento municipal, y de esta forma alcanzar su coordinación con una estrategia insular. Así mismo, este PIOT programa el desarrollo de la edificabilidad hasta el año 2002, por cuatrienios (1994-1998-2002), adaptando la capacidad de alojamiento turístico y residencial a cada municipio, con la intención de hacer compatible el ritmo de la oferta con la inversión pública y que no desborde el ritmo de la demanda, pues el sector 
oficial se había limitado a tratar de incrementar la estadística de visitantes, es decir, un crecimiento cuantitativo y no cualitativo. Se supuso ésta, como la única forma de evitar nuevas crisis de sobreproducción, reconociéndose así que no se está produciendo una correcta interrelación entre el turismo y el conjunto de la economía, con importantes consecuencias en la estructura social de la isla. A lo que se añade la enorme dependencia exterior, en términos económicos y energéticos, principalmente, y sin que existan relaciones intersectoriales, que, de acuerdo con lo señalado por fuentes oficiales, lleva a la desestructuración socio-económica y a la aparición de tensiones y malestar social.

El modelo de turismo de masas, instalado ya en la isla, seguirá manteniendo una dinámica de crecimiento, pero no al ritmo observado en la etapa anterior (que alcanza hasta el $300 \%$ de incremento de la oferta en cinco años), sino que ahora disminuye y se ralentiza (pues oscila entre el $34,5 \%$ y el $9 \%$ de incremento de la oferta en este periodo), ya que no se busca la rápida incorporación insular a una economía turística, sino que la tendencia es a regular y racionalizar su crecimiento sobre una estrategia insular, incidiendo en el aumento de la oferta hotelera y reduciendo la participación de la extrahotelera. La Comunidad Autónoma de Canarias reducirá el crecimiento de la oferta más tarde que Lanzarote.

Gráfico 124. Evolución de la oferta y la demanda turística. Lanzarote. 1986-1996

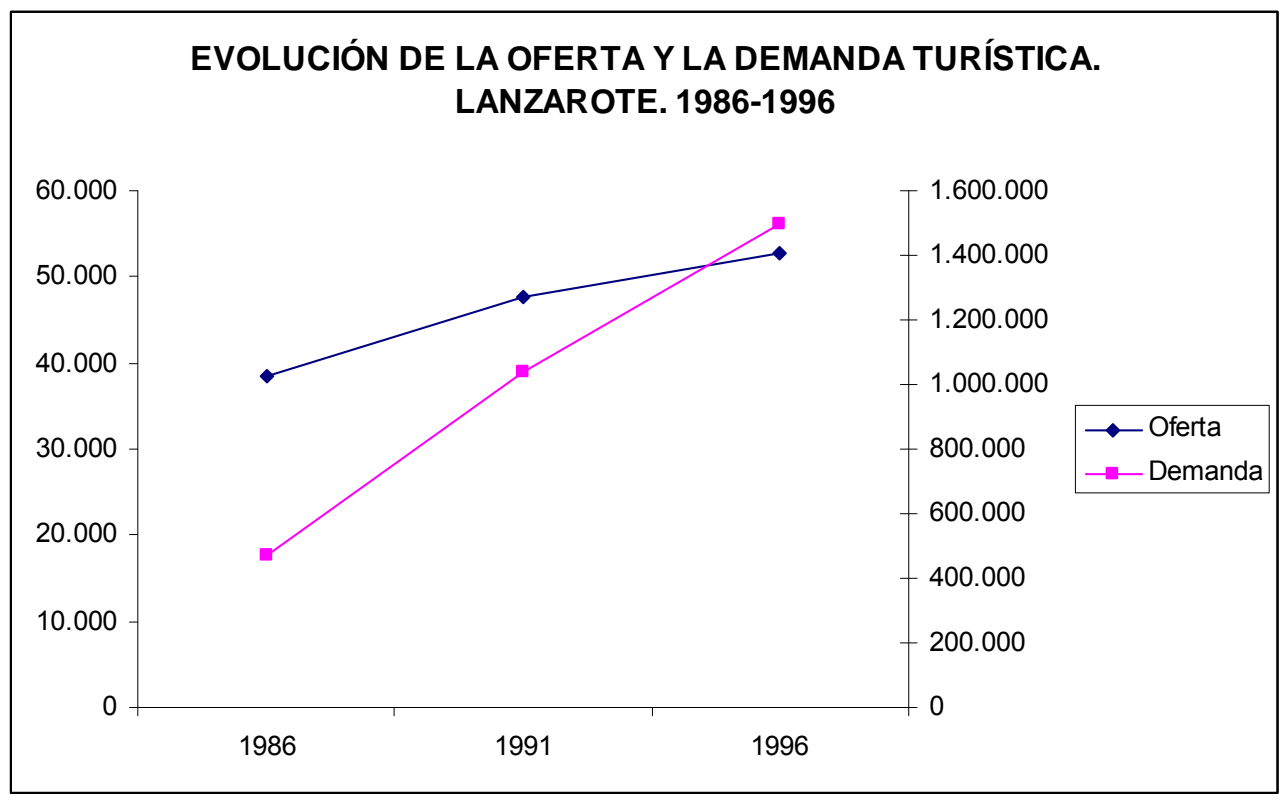

Fuente: Avance PIOT de Lanzarote, 1987 y Anuarios estadísticos de Lanzarote; Estadísticas básicas de Canarias, ISTAC. Gráfico sintético a partir de la Tablas 84 y 85 . Elaboración propia. 
Gráfico 125. Plazas de alojamiento turístico por tipo. Porcentaje sobre el total. Lanzarote. 1986-1996

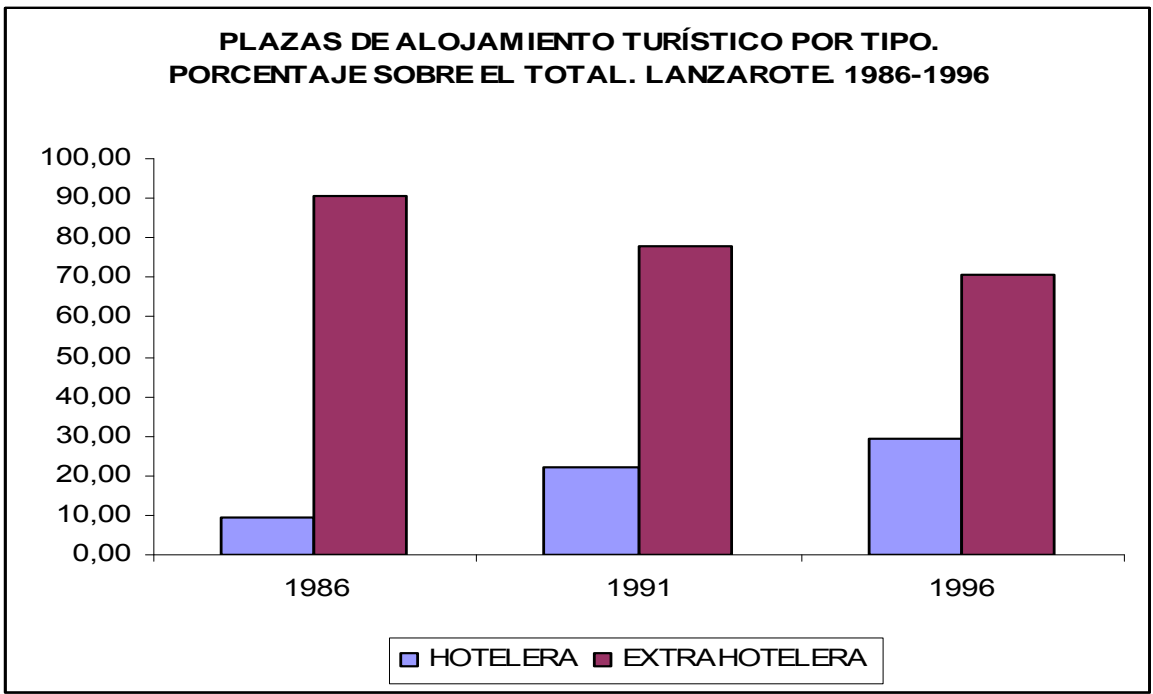

Fuente: Avance PIOT de Lanzarote, 1987 y Anuarios estadísticos de Lanzarote; Estadísticas básicas de Canarias, ISTAC. Gráfico sintético a partir de la Tablas 84 y 85 . Elaboración propia.

A ello se une la reducción del crecimiento de la demanda turística en el último quinquenio de esta etapa, pues crece un 44\%, considerándose crisis de recepción, aunque se encuentra por encima del crecimiento de la oferta, lo que hace que la evolución de la relación entre turistas que entran en la isla y las plazas que se ofertan (t/p) vaya en aumento. Aspecto este último positivo, pues se explota más cada plaza.

Gráfico 126. Incremento de la oferta y la demanda turística. Lanzarote. 1989-1996 (\%)

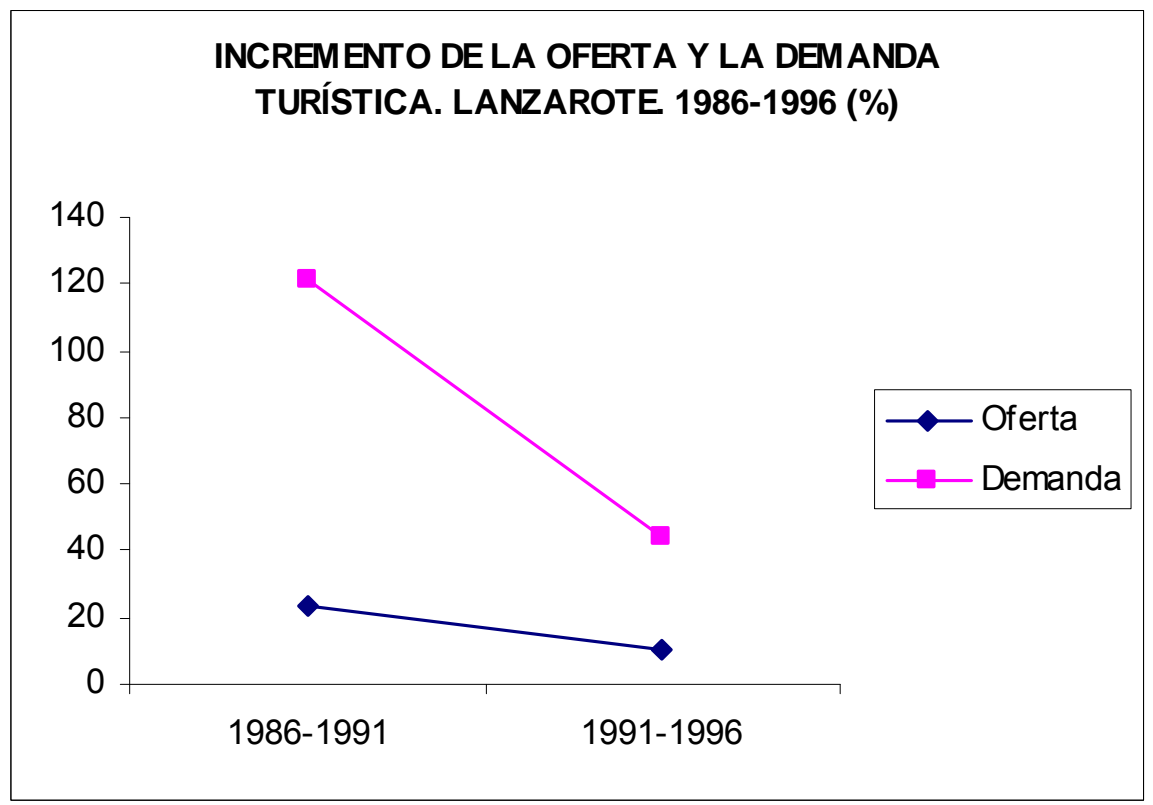

Fuente: Avance PIOT de Lanzarote, 1987 y Anuarios estadísticos de Lanzarote; Estadísticas básicas de Canarias, ISTAC. Gráfico sintético a partir de la Tablas 84 y 85 . Elaboración propia. 
Por tanto, y en relación a esta dinámica del sector, desde el punto de vista socioeconómico se observa lo siguiente:

A) La población autóctona, frente a la foránea (inmigrantes y turistas), seguirá descendiendo a lo largo de toda la etapa, acentuándose los desequilibrios demográficos, llegando a 143 foráneos por cien autóctonos (alt/at).

Gráfico 127. Evolución de la población foránea y autóctona. Lanzarote. 1986-1996

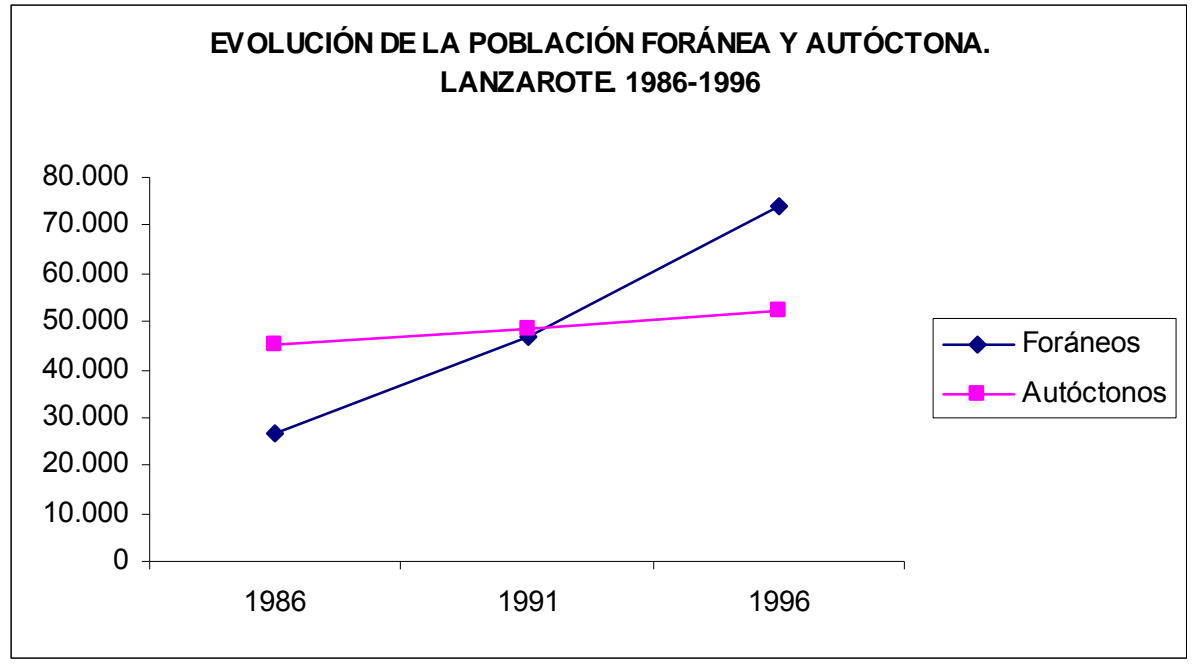

Fuente: Elaboración propia a partir de la población por lugar de nacimiento. ISTAC e INE y de la estimación propia de turistas equivalentes al día. Gráfico basado en la Tabla 99.

B) Crecimiento continuo del nivel de instrucción de los residentes, nunca por encima del grado medio, apoyado por la inmigración, que mayoritariamente es nacional y que imprime una influencia positiva. La dinámica es similar a la que acontece en el ámbito económico y nacional. 


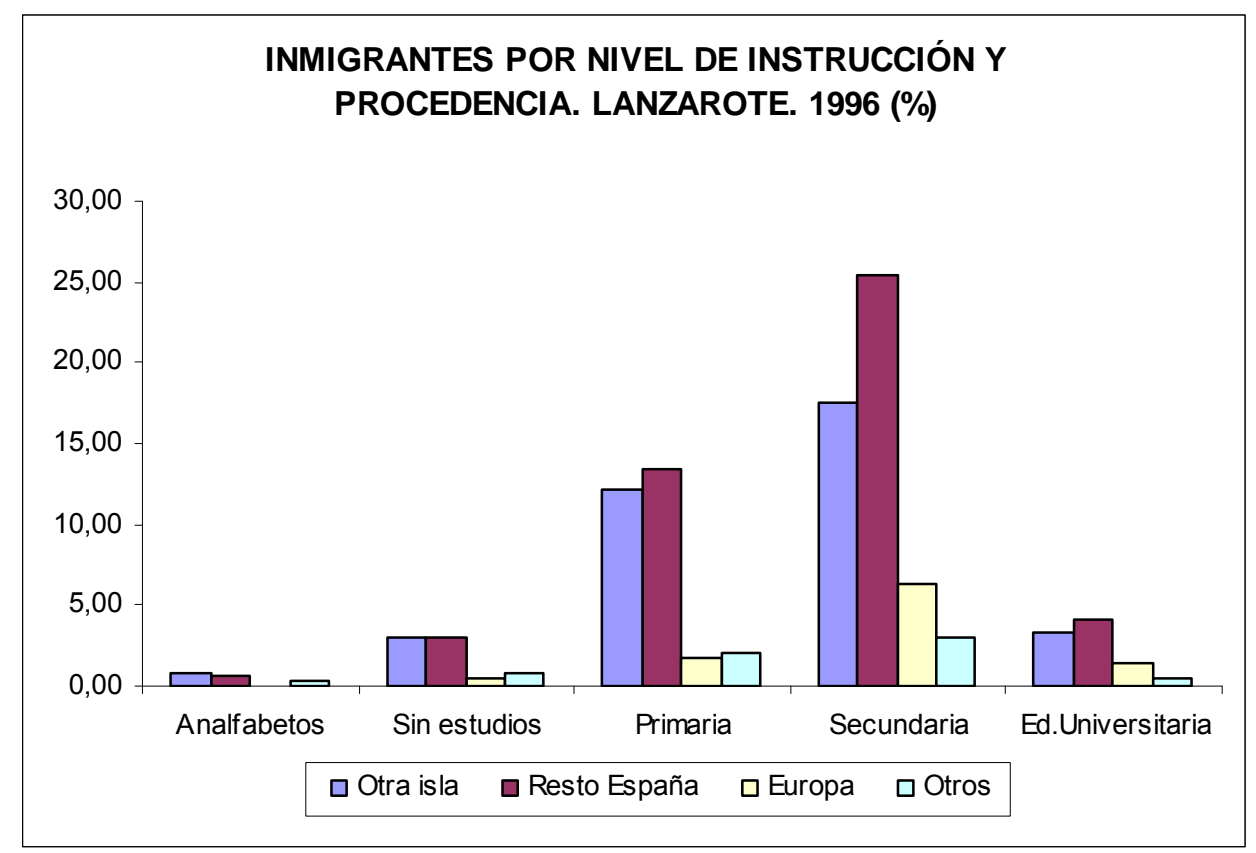

Fuente: Elaboración propia a partir de la población por lugar de nacimiento. ISTAC e INE. Gráfico basado en la Tabla 97.

Cualitativamente, se produce el reajuste necesario entre la oferta de formación profesional y las necesidades del mercado laboral, marcado por la construcción y los servicios al turista, que se demandaba en la etapa anterior, junto con una reducción de los efectos de la insularidad en la enseñanza superior, que redunda en el bienestar de los residentes.

C) La estructura laboral consolidada y concentrada en relación a los indicadores socioeconómicos sectoriales (actividad, empleo y paro) en el sector servicios, basada en la actividad turística, seguido de la construcción. La característica significativa es el crecimiento del número de parados, a pesar de la ampliación de la oferta y la demanda turística, que se vive en esta etapa, por lo que la generación de empleo no es proporcional a la misma. Aspecto éste negativo en cuando a la ampliación y mejora de las posibilidades de bienestar colectivo asociado. A ello se añade el que en momentos de reducción de la demanda turística el potencial de fuerza de trabajo no tiene otro sector donde reubicarse laboralmente, pues la economía depende prácticamente en su totalidad del turismo. 
Gráfico 129. Incremento interperiodo de la población potencialmente activa, la oferta y demanda turística, los ocupados y los parados. Lanzarote. 1989-1996 (\%).

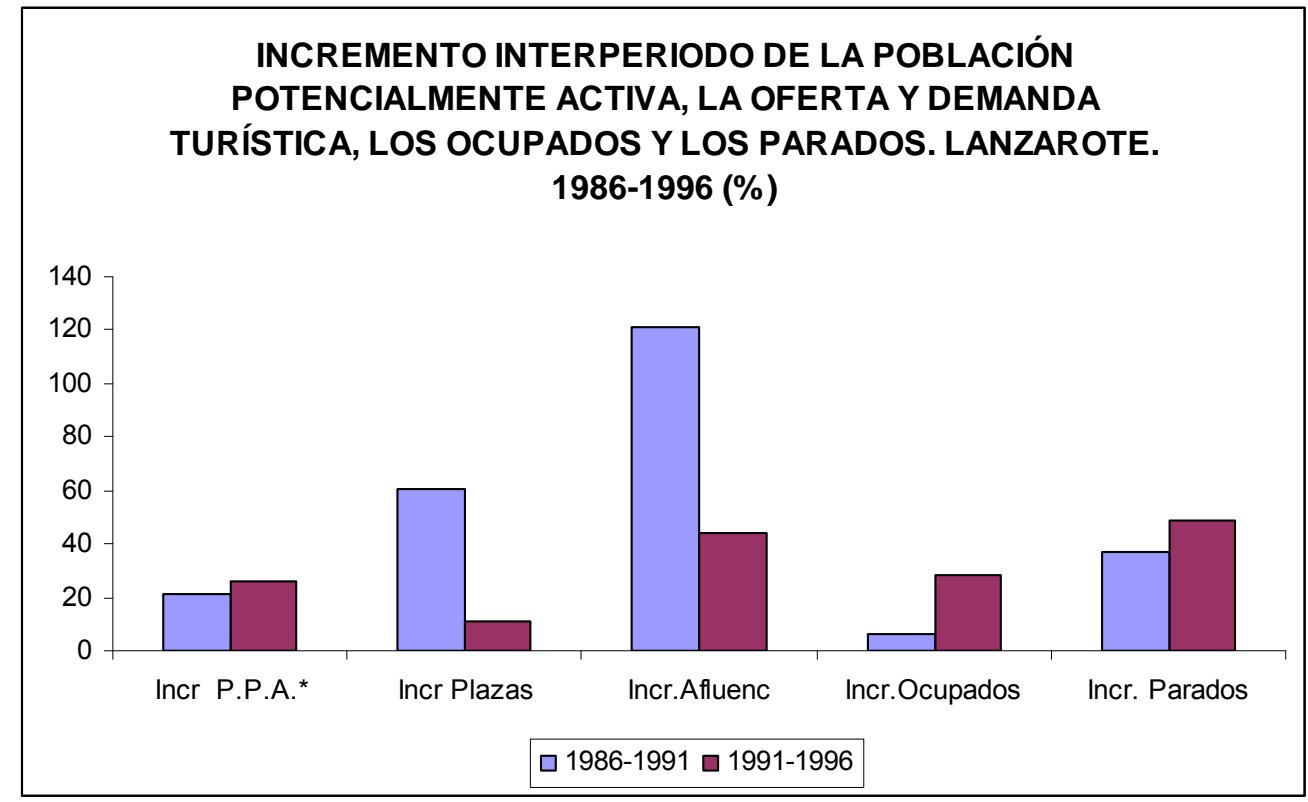

Fuente: Gráfico basado en la tabla 123. Elaboración propia.

D) Menor crecimiento de la renta familiar disponible, frente a periodos anteriores, que aunque sigue siendo positivo, no alcanza el nivel medio nacional. A excepción de los municipios insulares que concentran la mayor oferta turística (Teguise y Tías). A pesar de ello se observa cierto avance en cuanto a un mejor reparto de la riqueza, rompiéndose la fuerte jerarquización municipal que presentaba la etapa anterior (1970-1986). Lo que permite el acercamiento entre municipios en cuanto a las oportunidades y posibilidades en el acceso a bienes y servicios y al bienestar de su población. 
Gráfico 130. Nivel de renta media por habitante. España, Canarias, Las Palmas y municipios de Lanzarote. 1996

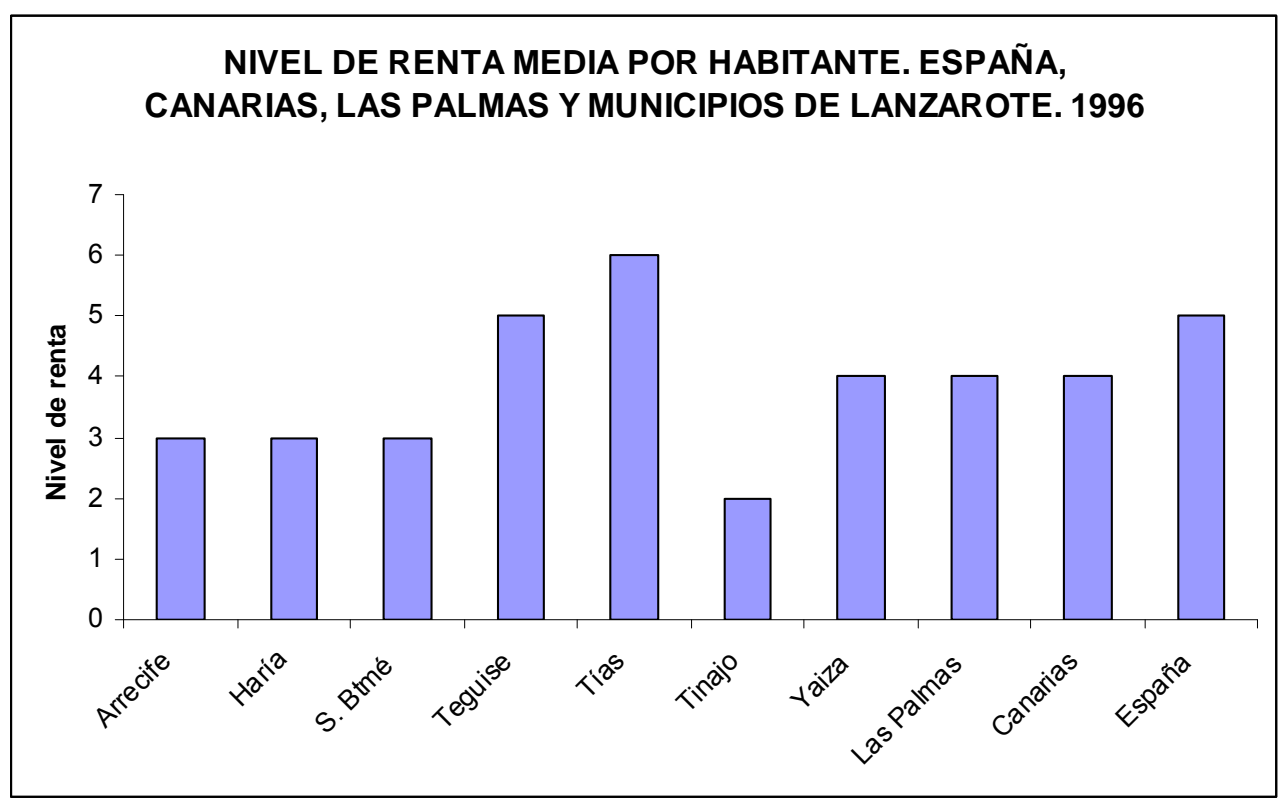

Fuente: Anuario Comercial de España. Caixa. 1998; Gráfico elaborado de la Tabla 127. Elaboración propia

Por otro lado, en relación al equipamiento y las infraestructuras, las mejoras y los estrangulamientos se van a explicar por agentes exógenos (inmigrantes y turistas) y se encuentran principalmente en los siguientes aspectos tratados:

A) Resultados negativos en relación a la capacidad y eficiencia energética eléctrica, por presión demográfica (residentes y turistas equivalentes diarios). La demanda de energía eléctrica (superior a la media de Canarias) ha ido por encima de las posibilidades de producción, por lo que ésta deberá ser constantemente incrementada, en un territorio cuyo sistema energético es absolutamente dependiente de energías no renovables, careciendo de fuentes propias, y donde la aportación al sistema de la renovables es insignificante. 
Gráfico 131. Producción de energía eléctrica disponible y consumo, en relación a la población residente y a la población total estimada. Lanzarote. 1986-1996 (kwh).

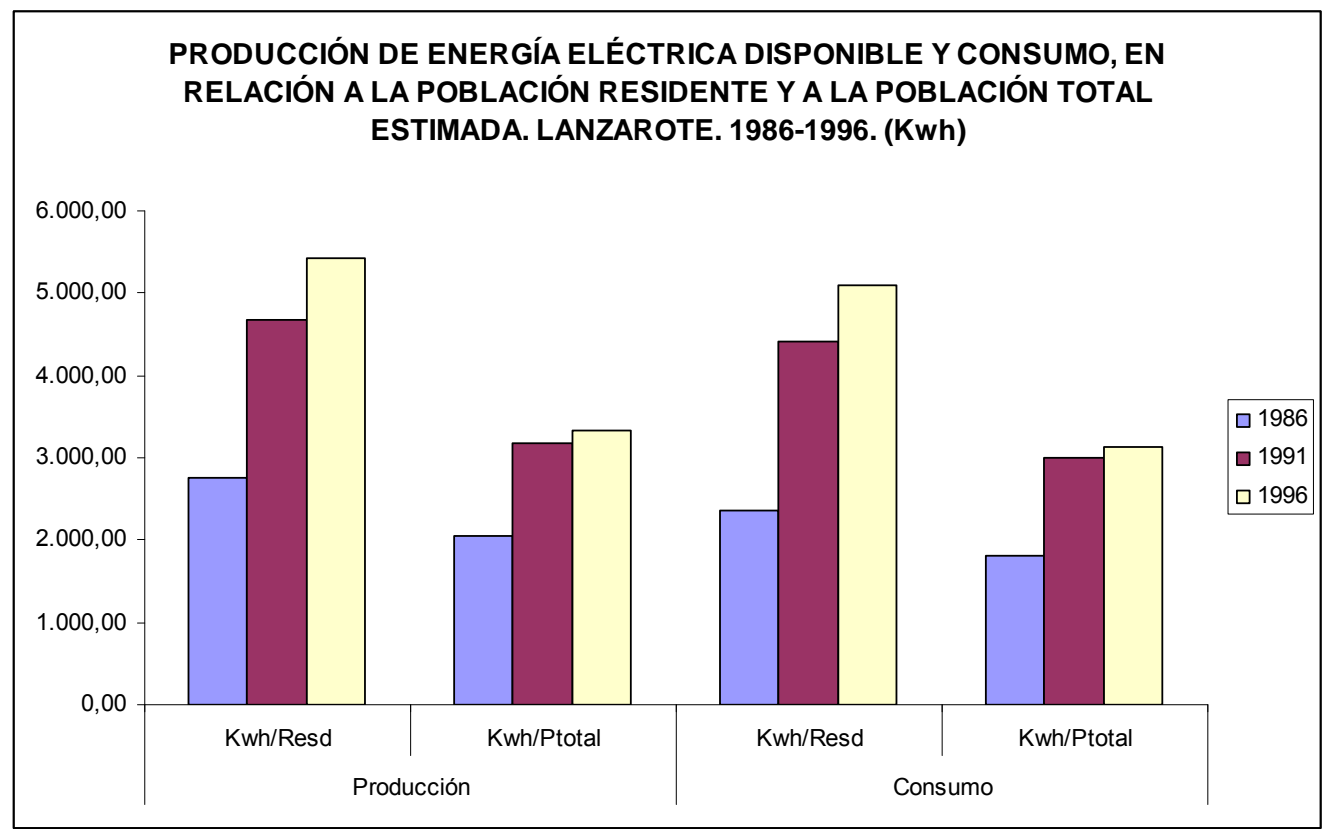

Fuente: Elaboración propia a partir de la información recogida en las Tablas 129 y 130.

B) Ampliación de la producción de agua desalinizada pública y por tanto de la disponibilidad de agua para la población residente, mermada por el volumen de turistas (que presentan un elevado consumo per cápita frente al residente) que sigue teniendo prioridad en el abastecimiento. Se consume prácticamente lo que se produce, pues la capacidad de almacenamiento es muy escasa, produciéndose estrangulamientos en los meses de mayor ocupación turística (agosto). Aunque el turista aparece como competidor, por este recurso escaso, frente a la población local, el modelo de abastecimiento que contempla la isla no sería posible sin la financiación que realiza el sector turístico del mismo, a través de los precios, para su consumo, que asume. Económicamente hablando, es posible gracias al turismo, modificando positivamente el bienestar de los residentes, aunque sus constantes ampliaciones tienen efectos negativos energéticos y ambientales. 
Gráfico 132. Consumo y producción media diaria de agua en relación a la población a abastecer estimada. Lanzarote. 19861996 (I/hab/día).

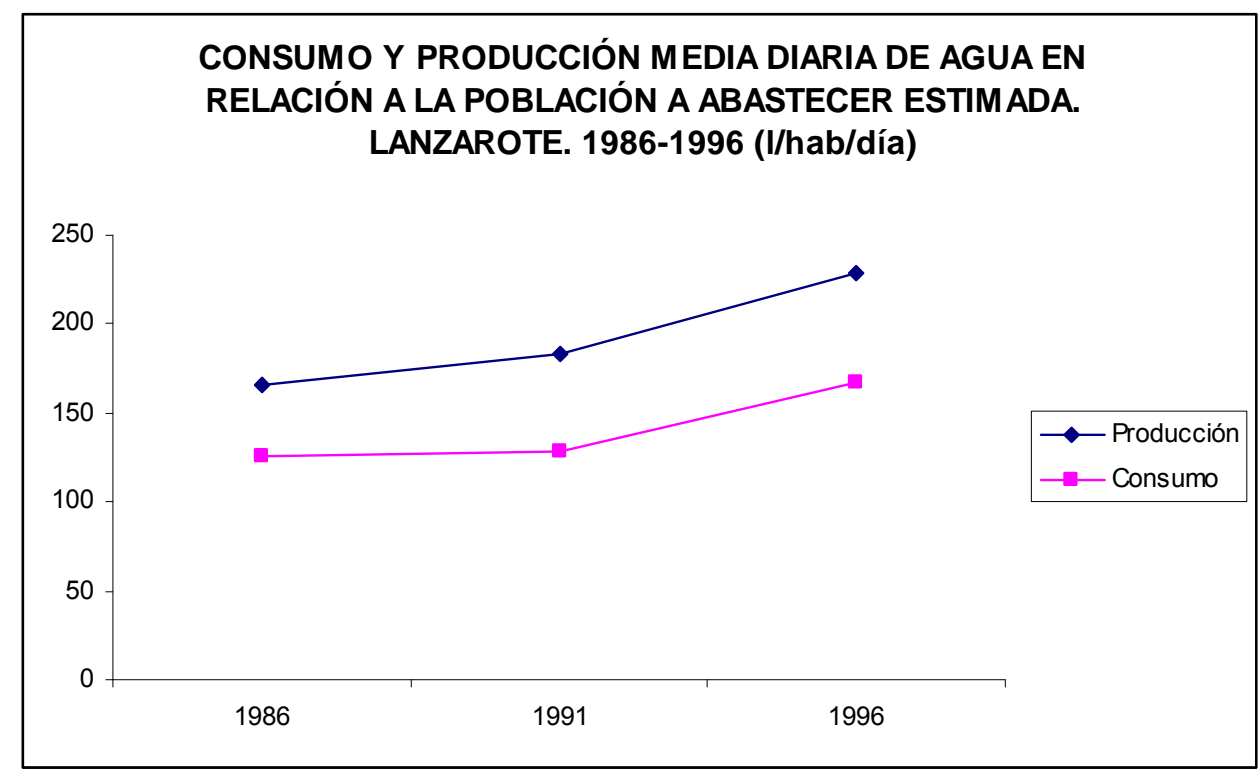

Fuente: INALSA y Centro de datos del Cabildo Insular de Lanzarote. Gráfico elaborado a partir de las estimaciones realizadas en la Tabla 136. Elaboración propia.

C) La oferta sanitaria hospitalaria, aunque se amplía en esta etapa, sigue sin ajustarse a la demanda, siendo insuficiente tanto para el volumen de residentes como para la población total estimada (residente y turistas equivalentes diarios) que acoge diariamente la isla, por lo que permanece estrangulada. Efecto éste que es explicado, en parte, por el retraso en la puesta en marcha de nuevas dotaciones generado por la enorme demanda de materiales y profesionales de la construcción derivada del "boom" turístico del año 1986, que retrasa la mejora de la capacidad de los servicios sanitarios públicos y por tanto tiene un efecto negativo sobre el bienestar social de la población. Lanzarote no conseguirá acercarse al estándar de calidad propuesto por la O.M.S. Aunque sí experimenta una reducción significativa de la presión sobre la demanda de médicos, acercándose al ratio de España y Canarias. 
Gráfico 133. Evolución de las camas hospitalarias por mil residentes y sobre la demanda potencial. Comparación con el estándar de la O.M.S. Lanzarote. 1986-1996

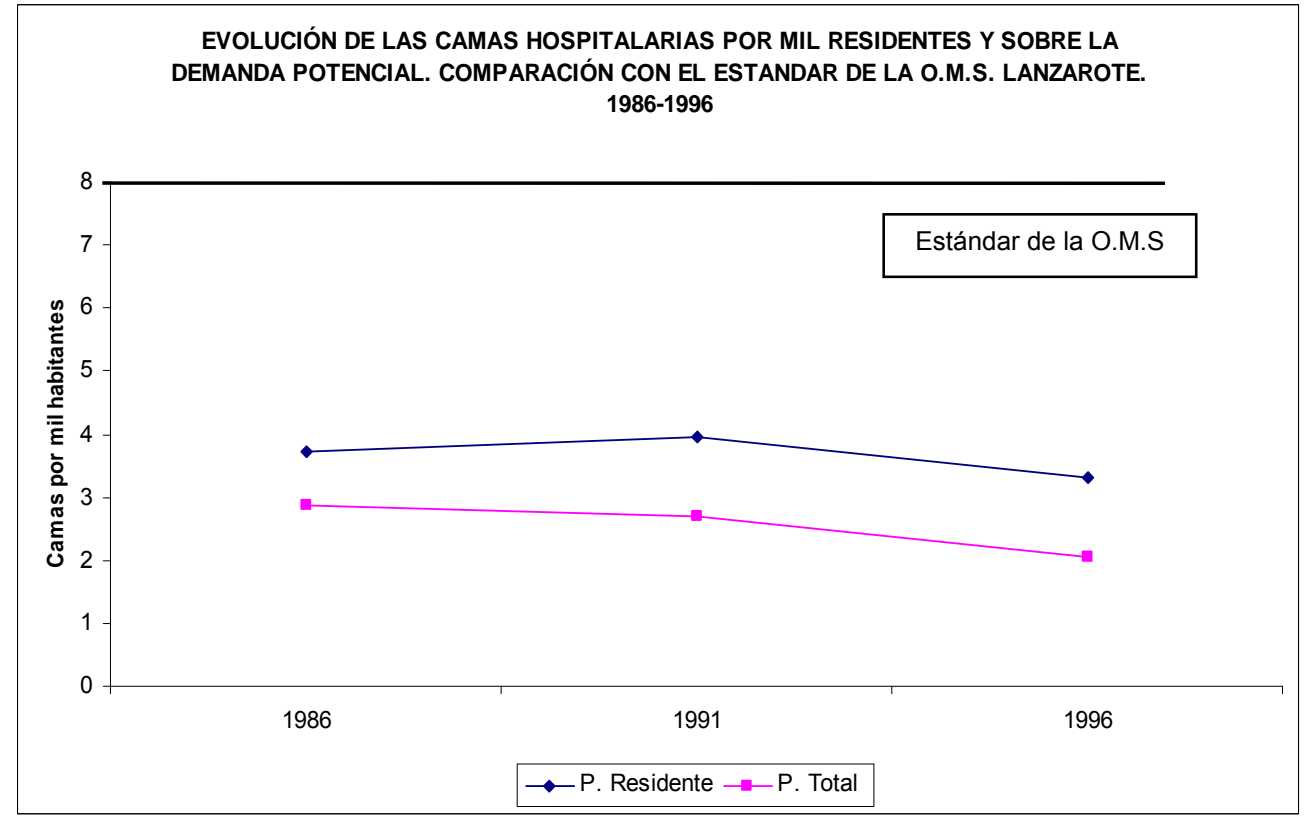

Fuente: Fika, M.L. (2004); Sosa Núñez, J. (2010); Avance PIOT, 1987 y Centro de datos del Cabildo Insular de Lanzarote; Gráfico basado en la Tabla 112. Elaboración propia.

Gráfico 134. Evolución de la población residente y la población total estimada por médico. Lanzarote. 1986-1996

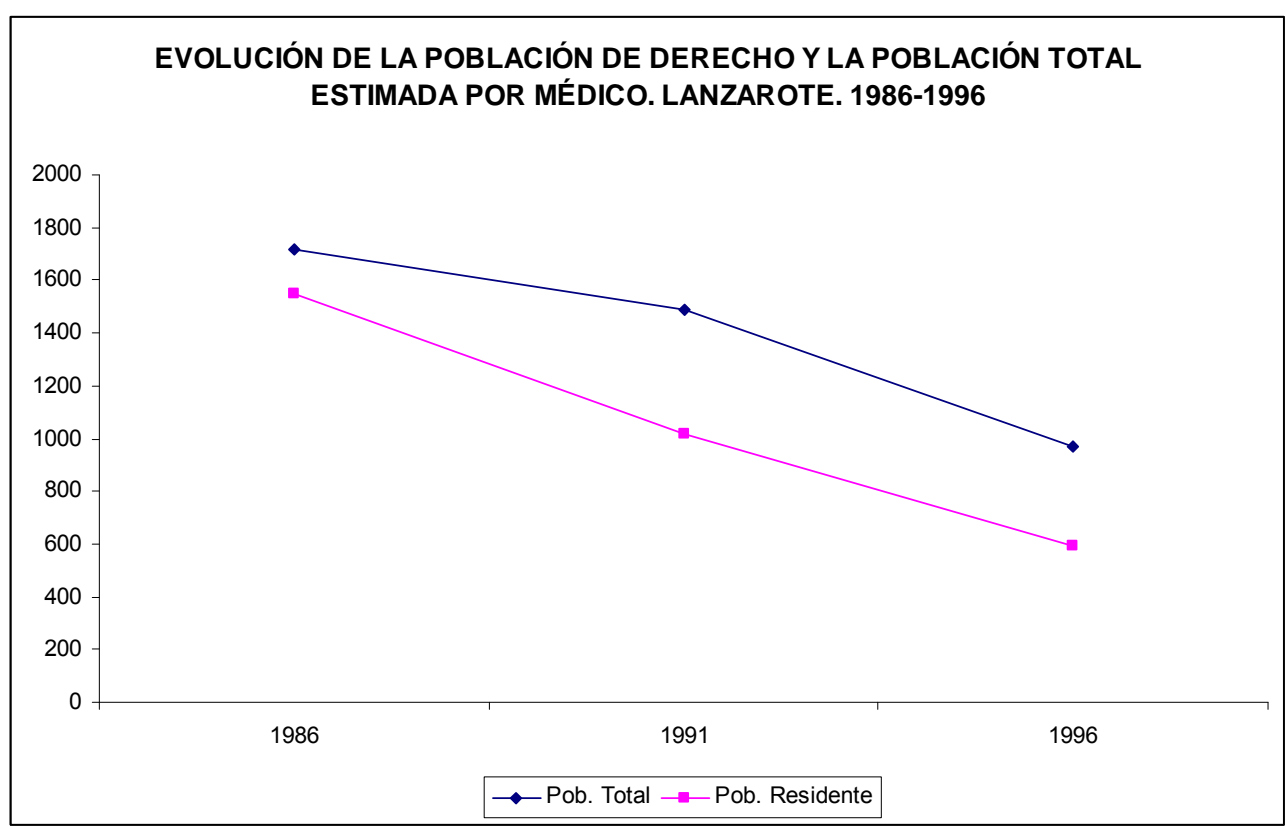

Fuente: Fika, M.L. y otros (2004); Servicio Canario de Salud. Lanzarote y Centro de datos del Cabildo Insular de Lanzarote. Gráfico basado en la Tabla 113. Elaboración propia.

D) Ampliación del equipamiento en enseñanza obligatoria que permite la cobertura total de la demanda e incluso absorber incrementos de la misma a corto plazo. Junto con la 
ampliación en la enseñanza no obligatoria y cobertura de su demanda. Contrariamente es insuficiente el equipamiento educativo destinado a la educación de adultos y a la educación especial, que permanecen estrangulados hasta el final de etapa, donde esta situación se modifica. La isla observa escasa capacidad para la integración de los adultos y las discapacidades. En contrapartida se crean servicios de acogida para la inmigración indocumentada y menores no acompañados.

Gráfico 135. Relación alumnos por unidad y profesor. Estándar, por tipo de enseñanza. Lanzarote. 1986-1996

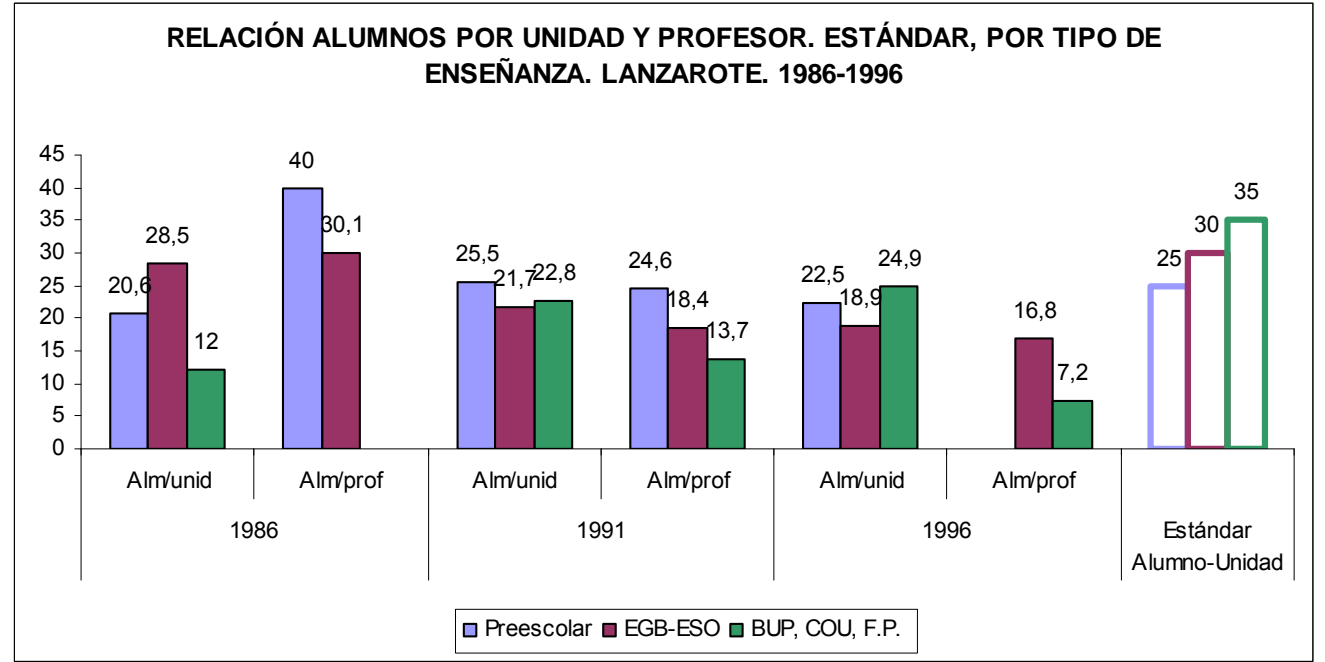

Fuentes: Avance PIOT de Lanzarote, 1987. Cabildo Insular de Lanzarote; Estadísticas Insulares y Municipales de Canarias, 1991. CEDOC; Anuario Estadístico de Canarias. 2001. ISTAC. Consejería de Educación y Cultura del Cabildo Insular de Lanzarote.; Gráfico basado en las tablas 37, 103 y 106. Elaboración propia.

Gráfico 136. Evolución de la relación alumnos por profesor en enseñanza de adultos y especial. Lanzarote. 1986-1996.

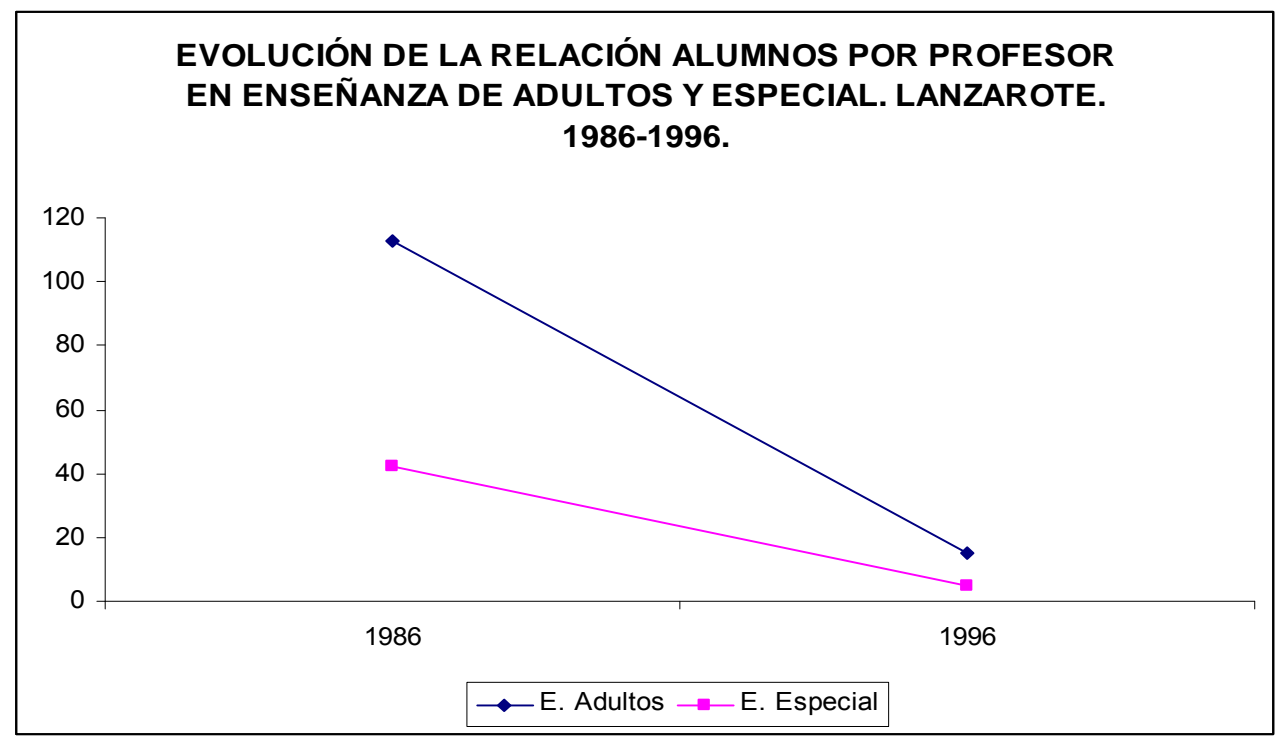

Fuente: Avance PIOT de Lanzarote, 1987. Cabildo Insular de Lanzarote; Anuario estadístico de Canarias, 1986 y 2001. CEDOC e ISTAC. Gráfico basado en las Tablas 39, 110 y 111. Elaboración propia. 
E) Continuidad de las mejoras en seguridad y accesibilidad a través de la ampliación de kilómetros de carreteras y del ancho del vial, aún insuficiente, pues no es adecuado a la intensidad media diaria del tráfico que asume la isla en la principales vías que conectan la capital con las zonas de concentración de la actividad turística. La elevación de la intensidad del tráfico supone efectos no positivos sobre el medioambiente.

F) Se sigue potenciando un modelo basado en el trasporte privado con la consiguiente elevación de los niveles de motorización de los residentes y del volumen de vehículos (en alquiler) para cubrir la creciente demanda turística. Lo que afecta negativamente a la calidad de la escena, pues las mejoras en la oferta de servicio regular de transporte de pasajeros siguen siendo escasas.

Gráfico 137. Evolución del índice de motorización de la población residente en relación a la población total estimada Lanzarote. 1986-1996.

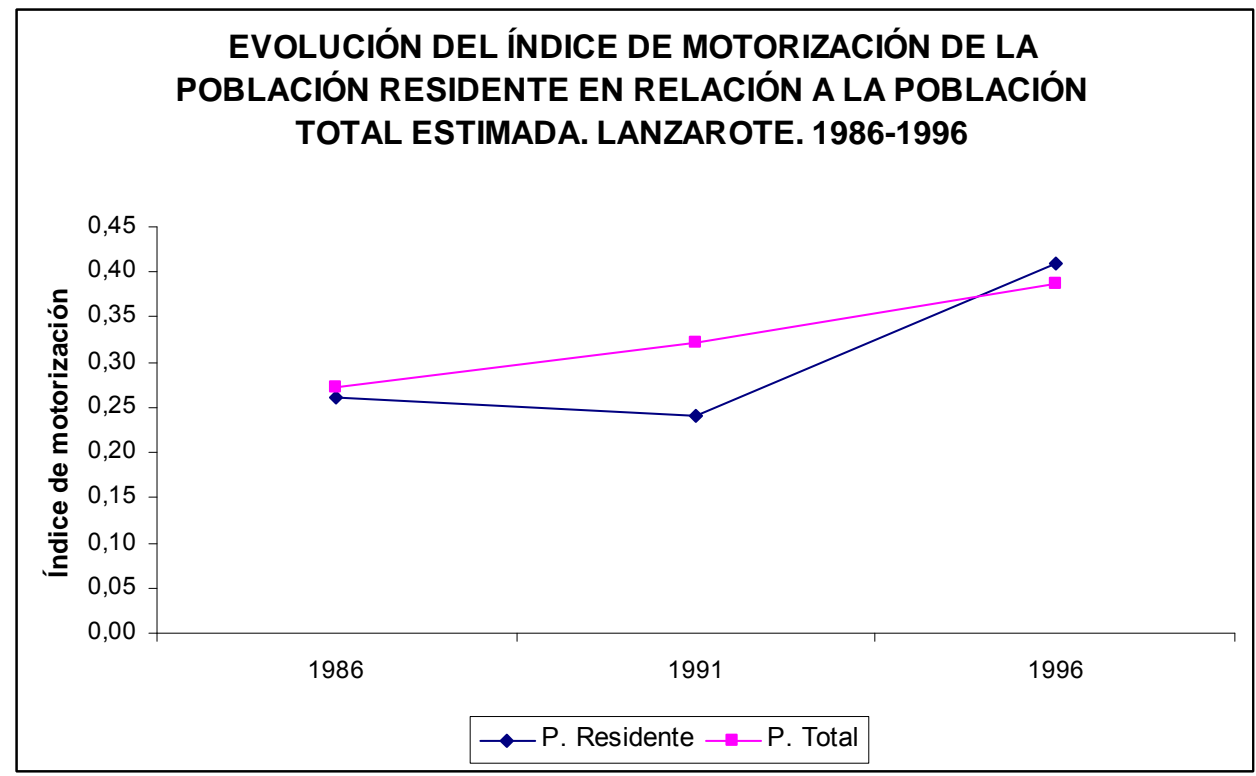

Fuente: Avance PIOT de Lanzarote, 1987. Cabildo Insular de Lanzarote; Estadísticas Insulares y Municipales de Canarias, 1991. ISTAC; Anuario Estadístico de Canarias, 1999. ISTAC; Gráfico basado en la Tabla 140. Elaboración propia.

La contención del volumen de población diario que acoge la isla a través de la limitación del crecimiento de la oferta y la demanda turística se marca como una de las principales vías para el cambio de signo de los efectos sociales negativos sobre el bienestar. 


\section{3.- TERCERA ETAPA. MADUREZ TURÍSTICA Y MORATORIA. 1996-2006}

Ya en 1974, Gaviria (pp. 21), se planteaba la duda de si el fenómeno de concentración turística en ciertas playas iba a perdurar durante muchos años, de forma que se alcanzase la amortización de las inversiones públicas y privadas o, si por el contrario, va a ser una bomba de humo y que a medida que los lugares vayan siendo visitados por la mayoría de los ingleses, alemanes y demás extranjeros, éstos no vuelvan a dicho lugar y se vayan a otros nuevos. Lo que llevaría a la decadencia de los primeros que fueron lanzados, bien como consecuencia de no haber sabido renovar sus características y ofrecer algo diferente o bien como consecuencia de la saturación y del incremento de las disfunciones y molestias por la baja calidad del medio ambiente, consecuencia de la masificación no organizada del espacio.

Los destinos turísticos de masas maduros pueden decidir entre varios caminos posibles:

1. La drástica reconversión de las múltiples facetas del producto turístico — se vuelve a oír hablar de turismo de calidad frente al turismo de masas-.

2. Seguir aumentando el número de camas, es decir, una política que ante la crisis lo que hace es aumentar la oferta, no diversificarla.

3. Mantenerse como está, manteniendo la oferta existente e intentar cubrir posibles déficits en equipamientos y servicios.

Lanzarote decide empezar con la revisión del PIOT de 1991, pues se hizo necesario reconocer que la elaboración y aprobación de éste había sido demasiado larga, con lo que el coste en tiempo en el que se había incurrido hizo que, rápidamente, las principales magnitudes con las que se había planificado quedasen obsoletas en sus referencias temporales.

Bajo esta idea se plantea en 1996 la reforma y revisión del PIOT aprobado en 1991, encontrándose entre sus justificaciones las siguientes ${ }^{187}$ :

1. Revisar las magnitudes que sirvieron de base a la programación de plazas "alojativas" del PIOT aprobado a 9 de abril de 1991.

2. El proceso de adaptación del Planeamiento Municipal y de los Planes Parciales vigentes no se había desarrollado conforme a las previsiones temporales — dos

${ }_{187}$ Revisión del PIOT de 1991. Documento de aprobación provisional, 1999, pp. 11-13. 
años - establecidas por el PIOT. En 1999, sigue existiendo descoordinación entre la planificación urbanística insular y la municipal188.

3. Adaptación del PIOT a la Ley 7/1995 de Ordenación del Turismo de Canarias. Ley ésta que convierte la Ordenación del Territorio en un instrumento de política sectorial, considerándolo en su artículo 58.1 como un "instrumento de ordenación urbanístico turística y de los recursos naturales del archipiélago", con habilitación para establecer "previsiones específicas de desarrollo turístico, identificando cada uno de los atractivos y núcleos, capacidad máxima y límites de la oferta alojativa".

4. Tras la asunción por parte del Planificador Público, el Cabildo de Lanzarote, de lo expuesto en el documento de "Estrategia de Lanzarote en la Biosfera, 1998", es necesario el plantear nuevos objetivos de desarrollo "sostenible", no suficientemente presentes en el PIOT aprobado en 1991, puesto que con los actuales se entiende que, al final del camino elegido, se encuentra la no sostenibilidad y la irreversibilidad de la situación de degradación —medioambiental, social, cultural y patrimonial y finalmente económica- de la isla.

"Uno de los motivos que permite afirmar el camino hacia la no sostenibilidad es el fuerte crecimiento de población impulsado por el turismo, que ha desbordado todas las expectativas por su potencia y rapidez de incremento, estimándose un aumento del $62 \%$ entre población residente y flotante en 10 años aproximadamente (entre 1986 y 1997). Estableciéndose el equilibrio poblacional en 0,56 t/r (turistas presentes por cada residente), el triple de la media de Canarias, desencadenando, desde el punto de vista urbanístico, una serie de consecuencias de entidad" (Revisión del PIOT. Documento de aprobación provisional, 1999, pp. 14).

Aparecen así la $5^{\circ}$ y $6^{\circ}$ justificación de esta revisión:

5. Los riesgos de mantener en el futuro patrones de desarrollo del pasado. Analizándose el escenario de riesgo desde diferente hipótesis basadas en prospectivas realizadas por la OMT.

6. Para preservar los equilibrios básicos del sistema insular y mejorar la calidad de vida de la población lanzaroteña como objetivos básicos de la Estrategia Lanzarote en la Biosfera se hace imprescindible moderar la presión humana sobre dicho sistema, reorientar su evolución con criterios de sostenibilidad, contener el aumento de la

188 Solo el municipio de San Bartolomé adaptó sus Normas Subsidiarias al PIOT. 
población y limitar el crecimiento de la afluencia turística a escalas y ritmos compatibles con su capacidad de asimilación.

Los objetivos que estable la revisión del PIOT son los siguientes ${ }^{189}$ :

a) Limitar el incremento de nueva oferta de alojamiento turístico — por ser la principal locomotora del crecimiento físico insular (no económico) y fuente directa de generación de nuevos impactos ambientales críticos-.

b) Limitar la nueva oferta "alojativa" turística, en el nuevo periodo de programación que abarca el PIOT, a las instalaciones hoteleras.

c) Favorecer la rehabilitación de la oferta turística obsoleta.

d) Cualificar la nueva oferta de alojamiento turístico y residencial de las zonas turísticas y garantizar la reserva de suelo para el imprescindible desarrollo de la oferta turística complementaria, prevista en el plan.

e) Introducir en las zonas turísticas condiciones de calidad ambiental en las nuevas instalaciones turísticas y residenciales.

f) Mejorar los sistemas de control urbanístico y turístico.

g) Favorecer el proceso de formulación y adaptación del planeamiento municipal a la legislación urbanística vigente, así como su adaptación y del planeamiento de desarrollo a las determinaciones vinculantes del PIOT.

Llama la atención la inexistencia de algún objetivo tendente a alcanzar una contención del aumento de la población insular, pero sí a limitar el crecimiento de la afluencia turística, puesto que el planificador entiende que la contención del ritmo de crecimiento turístico es el factor clave para evitar el aumento de la población flotante y el desbordamiento del sistema insular, pues la presión demográfica en la isla tiene dos vertientes: afluencia turística y afluencia de inmigrantes. Variable esta última que a principios del s. XXI no ha decrecido.

Se establecen por tanto nuevos criterios de programación para el periodo objeto de la misma, 2000-2010, sin establecer o modificar clasificaciones de suelo. Señalamos los siguientes:

1. Se suprimen los periodos cuatrienales para la programación de los crecimientos.

189 Revisión del PIOT. Documento de aprobación provisional, 1999, pp. 22 y 23 
2. El límite máximo de plazas turísticas para el conjunto insular hasta el 2010 , en términos absolutos, se fija en 67.795 plazas, frente a las 95.437 que se establecía como umbral máximo, y considerando el planeamiento vigente, en el PIOT de 1991 hasta el año 2002 (A.U.I.A. Revisión del Plan Insular de Ordenación Territorial de Lanzarote, 1999, pp. 25 y 33). Esto supone una reducción bruta de 27.642 (28,96\%). A la vez se establecen dos cosas:

a) La nueva planta turística ha de ser hotelera.

b) Se transforman plazas turísticas a residenciales, con carácter definitivo, afectando a 17.943 camas turísticas (previstas en los ordenamientos municipales vigentes y contempladas en el PIOT de 1991) $)^{190}$.

3. Se establecen cautelas globales frente a un crecimiento desproporcionado de la residencia estable en los Planes Parciales/Especiales de las zonas turísticas.

Mapa 26. Zonas de uso turístico previsto. Lanzarote. 1991-2006

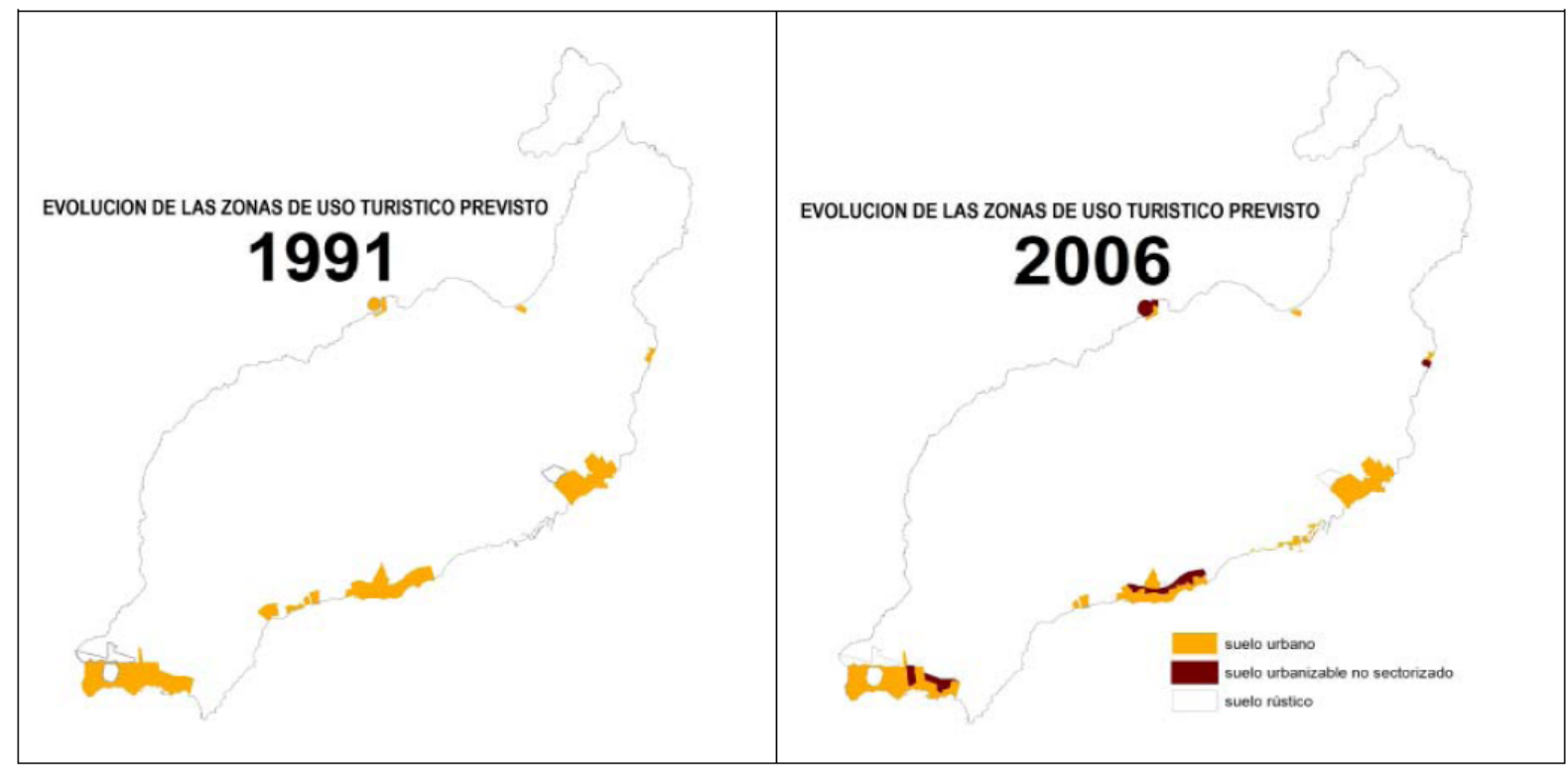

Fuente: Cabildo Insular de Lanzarote. Resumen del Plan Territorial Especial de Ordenación Turística Insular de Lanzarote, 2006. (Elaborado por AUIA). [En línea] Lanzarote: Cabildo de Lanzarote, 2006. (p. 7) [Ref. de 17 de junio de 2011] Disponible en Web: http://www.datosdelanzarote.com/itemDetalles.asp?idFamilia=24\&idltem=3023

190 Ante la Moratoria, "plazas que estaban en el mercado de manera irregular, intentan legalizarse, pues entre 1996 y 1997 se realiza una revisión censal y se desclasifican alrededor de 4.000 plazas turísticas que habrían pasado a residenciales por efecto de la crisis del quinquenio anterior" (finales de los años ochenta). Es decir, intentarán recuperar su posición en el mercado turístico., "pero no obtendrán autorización por incumplimiento de los estándares turísticos de la Ley 7/1995 de Ordenación del Turismo de Canarias. La Oficina de Turismo Interior del Cabildo Lanzarote, estima que entre 1.000-2.000 plazas son las que se encuentran en estas circunstancias". (Días Feria y otros. "Lanzarote 2001. Evolución reciente de la edificación y el turismo", Cabildo Insular de Lanzarote, 2001, pp. 26-27) 
En caso de desbordamiento, el Plan Insular podrá establecer como determinaciones vinculantes para el planeamiento urbanístico municipal, general o parcial, nuevos techos y ritmos de realización de las plazas "alojativas" residenciales estables previstas en los correspondientes planes (Decreto 95/2000, Art. 1.1.1.4.4).

La adaptación del planeamiento urbanístico al Plan Insular comienza a convertirse en un hecho a partir del año 2000, excepto en uno de los municipios, con elevada importancia turística en la isla en estos momentos, Yaiza, que en el año 2006 continuará con un Plan General de 1973.

Tabla 144. Planeamiento urbanístico municipal vigente, según tipo, año de aprobación y gobierno. Lanzarote. 2006

\begin{tabular}{|l|l|c|l||}
\hline \hline MUNICIPIO & Planeamiento General & Año aprobación & GOBIERNO (2006) \\
\hline \hline Arrecife & Plan General & 2004 & Partido Independiente de Lanzarote (PIL) \\
\hline Haría & Delimitación de Suelo Urbano & 2000 & Coalición Canaria (CC) \\
\hline San Bartolomé & Normas Subsidiarias & 1995 & PP y CC. \\
\hline Teguise & Normas Subsidiarias & 2003 & Partido Independiente de Lanzarote (PIL) \\
\hline Tías & Plan General & 2005 & PSOE \\
\hline Tinajo & Plan General & 2004 & Coalición Canaria (CC) \\
\hline Yaiza & Plan General & 1973 & Coalición Canaria (CC) \\
\hline \hline
\end{tabular}

Fuente: Ministerio de Vivienda. Dirección General de Urbanismo y Política del Suelo. Fecha de referencia: diciembre de 2006. Centro de datos del Cabildo Insular de Lanzarote. www.datosdelanzarote.com.

El Tribunal Superior de Justicia de Canarias anulará el Decreto 95/2000 de aprobación definitiva de la revisión parcial del PIOT (la Moratoria Turística) en noviembre de 2006 por "no ajustarse a derecho" (Sentencia 105/2005 de 11 de febrero de TSJC) ${ }^{191}$, tras el recurso presentado por empresarios-propietarios de suelo turístico y el Ayuntamiento de Yaiza ${ }^{192}$. Consecuentemente esta fecha marca el límite temporal con el que finaliza los análisis que se realizan en esta tesis.

191 "Por entender que esta normativa no tenía una precisión económica suficiente para indemnizar a los promotores" (...). "De esta manera, rechazaba el argumento de la "innecesariedad del estudio económico" ya que la moratoria "transforma uso turístico en uso residencial y el informe pericial obrante en autos muestra claramente la diferencia de valor de uno y otro uso". La Provincia. Diario de Las Palmas. 16/12/2009. http://www.laprovincia.es/lanzarote/2009/12/16/supremo-anulamoratoria-cabildo-lanzarote/275406.html

192 Las reacciones de los distintos agentes sociales que operan en la isla ante la aprobación por el Cabildo Insular de Lanzarote de la Moratoria, están recogidas en un informe realizado por ExtraMedia Consultores. La Moratoria turística de Lanzarote. Aspectos sociales. Lanzarote, 1999. Disponible en Web: http://www.datosdelanzarote.com/itemDetalles.asp?idFamilia=26\&idltem=232 
Este periodo, por tanto, estará marcado por la orientación legislativa y política hacia la sostenibilidad del territorio, asumiéndose, como base de esta idea, el concepto de capacidad de carga, entendida como "el conjunto de factores que permiten el uso turístico de una zona sin un declive inaceptable de la experiencia obtenida por los visitantes, una excesiva presión sobre los recursos turísticos de la misma, una alteración ecológica, territorial y paisajística inaceptables, ni una afección excesiva sobre la sociedad residente, y disponiendo de los equipamientos, servicios e infraestructuras generales precisos para el desarrollo de la actividad y de la población de servicios que demande". Capacidad que "habrá de ser considerada y analizada en los instrumentos de planeamiento que prevean la ocupación de suelo, y en los planes insulares de ordenación urbana" (Ley 19/2003, Directriz 25.1, con carácter ND).

\subsection{1.- LA OFERTA Y LA DEMANDA TURÍSTICA. 1996-2006}

\subsubsection{1.- EVOLUCIÓN DE LAS PLAZAS DE ALOJAMIENTO TURÍSTICO}

El periodo 1996-2006 se va a caracterizar por la reducción del crecimiento de plazas de alojamiento turístico con respecto a las etapas anteriores, pues crecerá en la década, aproximadamente, un $23,5 \%$, siendo ésta reducción más marcada para las de tipo extrahotelero (que se incrementan en diez años un $7,4 \%$ frente a la hotelera $62,6 \%$ ).

Esta dinámica de elevada reducción del crecimiento de la oferta desde el año 1991 viene explicada por dos aspectos principales:

1) El primero derivado de sucesivas crisis del sector: a) la de sobreproducción con la que la isla entre en la década de los años noventa y b) la reducción de la demanda turística a la que se enfrenta al comienzo del s. XXI;

2) La política de control del crecimiento de la oferta a través de la ordenación del territorio aplicada en estos quince años, sostenida bajo la idea de que ésta constituye la principal impulsora del crecimiento físico (no económico) insular ${ }^{193}$ : a) el PIOT aprobado en el año 1991 establece un ritmo y un techo a éste crecimiento (señalado en líneas anteriores); b) La asunción de objetivos de sostenibilidad que lleva a una nueva limitación de la oferta a través de la revisión parcial del Plan Insular de Ordenación de la isla o también Ilamado Moratoria Turística de Lanzarote, que entra en vigor en el año 2000 (descrita en líneas anteriores) y permanecerá vigente hasta el 2006.

193 AUIA (1999). "Revisión del Plan Insular de Ordenación Territorial de Lanzarote. Documento de aprobación provisional". Excmo. Cabildo Insular de Lanzarote, 1999 (pp. 22). 
Tabla 145. Oferta de plazas de alojamiento turístico, según tipo. España, Canarias y Lanzarote. 1996-2006.

\begin{tabular}{|c|c|c|c|c|c|c|c|c|c|}
\hline \multicolumn{10}{|c|}{ ESPAÑ A } \\
\hline & HOTELERA & $\begin{array}{l}\% \text { sobre } \\
\text { el Total }\end{array}$ & $\begin{array}{l}\text { Incremento } \\
\text { quinquenal \% }\end{array}$ & $\begin{array}{c}\text { EXTRA- } \\
\text { HOTELERA }^{* *}\end{array}$ & $\begin{array}{l}\% \text { sobre } \\
\text { el Total }\end{array}$ & $\begin{array}{l}\text { Incremento } \\
\text { quinquenal \% }\end{array}$ & TOTAL & $\begin{array}{l}\text { Incremento } \\
\text { quinquenal \% }\end{array}$ & $\begin{array}{lr}\text { Índice } & \text { en } \\
\text { base } & 100 \\
=1970 & \end{array}$ \\
\hline 1996 & 1.087 .529 & 50,98 & 11,79 & 1.045 .524 & 49,02 & 6,90 & 2.133 .053 & 9,34 & 283,67 \\
\hline 2001 & 1.315 .697 & 55,28 & 20,98 & 1.064 .439 & 44,72 & 1,81 & 2.380 .136 & 11,58 & 316,53 \\
\hline 2006 & 1.642 .417 & 54,84 & 24,83 & 1.352 .390 & 45,16 & 27,05 & 2.994.807 & 25,83 & 398,27 \\
\hline
\end{tabular}

*Año 1970

Fuente: Para 1996 y 2001: Establecimientos hoteleros por Comunidades autónomas, según capacidad". Turismo en Cifras. 1996 y 2000. IET. Elaboración propia. Para 2006: "El turismo Español en Cifras. 2007”. IET.

\begin{tabular}{||c|c|c|c|c|c|c|c|c|c||}
\hline \hline \multicolumn{10}{|c|}{ CANARIAS } \\
\hline \hline AÑO & HOTELERA & $\begin{array}{l}\% \text { sobre } \\
\text { el Total }\end{array}$ & $\begin{array}{l}\text { Incremento } \\
\text { quinquenal } \%\end{array}$ & $\begin{array}{l}\text { EXTRA- } \\
\text { HOTELERA }\end{array}$ & $\begin{array}{l}\% \text { sobre } \\
\text { el Total }\end{array}$ & $\begin{array}{l}\text { Incremento } \\
\text { quinquenal } \%\end{array}$ & TOTAL & $\begin{array}{l}\text { Incremento } \\
\text { quinquenal } \%\end{array}$ & $\begin{array}{l}\text { Índice } \\
\text { base } \\
=1970 \\
100\end{array}$ \\
\hline \hline 1996 & 116.190 & 35,40 & $-3,46$ & $\mathbf{2 1 2 . 0 6 4}$ & 64,60 & $-17,05$ & $\mathbf{3 2 8 . 2 5 4}$ & $-12,70$ & 984,39 \\
\hline \hline 2001 & 129.315 & 35,93 & 11,30 & $\mathbf{2 3 0 . 5 7 0}$ & 64,07 & 8,73 & $\mathbf{3 5 9 . 8 8 5}$ & 9,64 & 1079,24 \\
\hline \hline 2006 & 199.099 & 46,50 & 53,96 & $\mathbf{2 2 9 . 0 7 1}$ & 53,50 & $-0,65$ & $\mathbf{4 2 8 . 1 7 0}$ & 18,97 & 1284,02 \\
\hline
\end{tabular}

${ }^{*}$ Año 1970

Fuente: Para 1996 y 2001: "Plazas Hoteleras y Extrahoteleras. 1996, 2001". Bases de datos insular y municipal. ISTAC. Para 2006: Oferta Hotelera en "Turismo Español en Cifras. 2007". IET; Oferta Extrahotelera "Plazas Hoteleras y Extrahoteleras. 2006". Bases de datos insular y municipal. ISTAC. Elaboración propia.

\begin{tabular}{|c|c|c|c|c|c|c|c|c|c|}
\hline \multicolumn{10}{|c|}{ LANZAROTE } \\
\hline AÑO & HOTELERA & $\begin{array}{l}\% \text { sobre } \\
\text { el Total }\end{array}$ & $\begin{array}{l}\text { Incremento } \\
\text { quinquenal \% }\end{array}$ & $\begin{array}{l}\text { EXTRA- } \\
\text { HOTELERA** }^{*}\end{array}$ & $\begin{array}{l}\% \text { sobre } \\
\text { el Total }\end{array}$ & $\begin{array}{l}\text { Incremento } \\
\text { quinquenal \% }\end{array}$ & TOTAL & $\begin{array}{l}\text { Incremento } \\
\text { quinquenal \% }\end{array}$ & $\begin{array}{l}\text { Índice en } \\
\text { base } 100 \\
=1970\end{array}$ \\
\hline 1996 & 15.495 & 29,33 & 48,80 & 37.335 & 70,67 & 0,16 & 52.830 & 10,78 & $3.648,48$ \\
\hline 2001 & 19.803 & 33,15 & 27,80 & 39.932 & 66,85 & 6,96 & 59.735 & 13,07 & $4.125,35$ \\
\hline 2006 & 25.196 & 38,59 & 27,23 & 40.097 & 61,41 & 0,41 & 65.293 & 9,30 & $4.509,19$ \\
\hline
\end{tabular}

*Año 1970

Fuente: "Oferta de plazas alojativas según tipo, por municipios. Total Insular. 1996, 2001 y 2006". Oficina de Turismo Interior. Cabildo de Lanzarote. Anuario Estadístico de Lanzarote, 1996, 2001 y 2006. Cabildo de Lanzarote. Elaboración propia. 
Gráfico 138. Incremento de la oferta de alojamiento turístico. Lanzarote. 1996-2006 (\%)

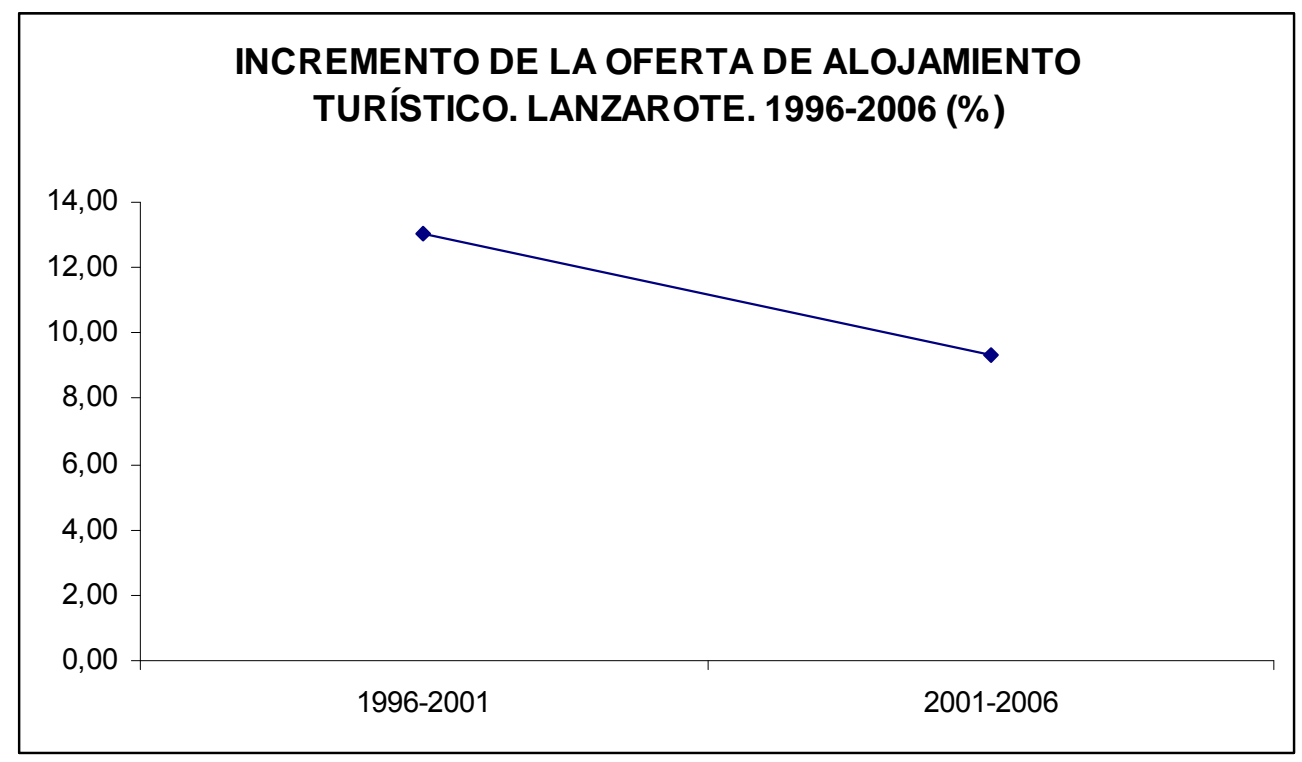

Fuente: Elaboración propia a partir de la información recogida en la Tabla 145.

Gráfico 139. Evolución de la oferta de alojamiento por tipo, sobre el total. Lanzarote. 1996-2006 (\%)

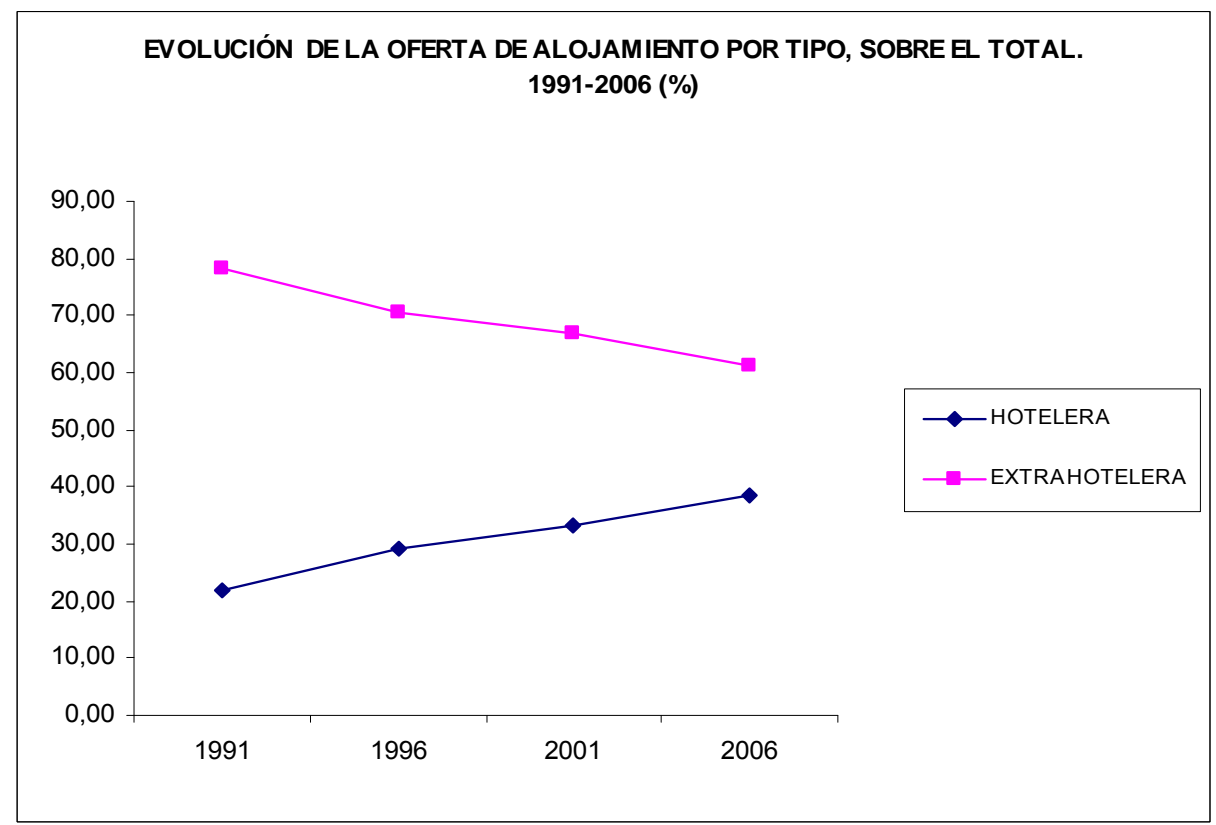

Fuente: Elaboración propia a partir de la información recogida en la Tabla 145. 
Gráfico 140. Incremento de las plazas de alojamiento turístico por tipo. Lanzarote. 1996-2006 (\%).

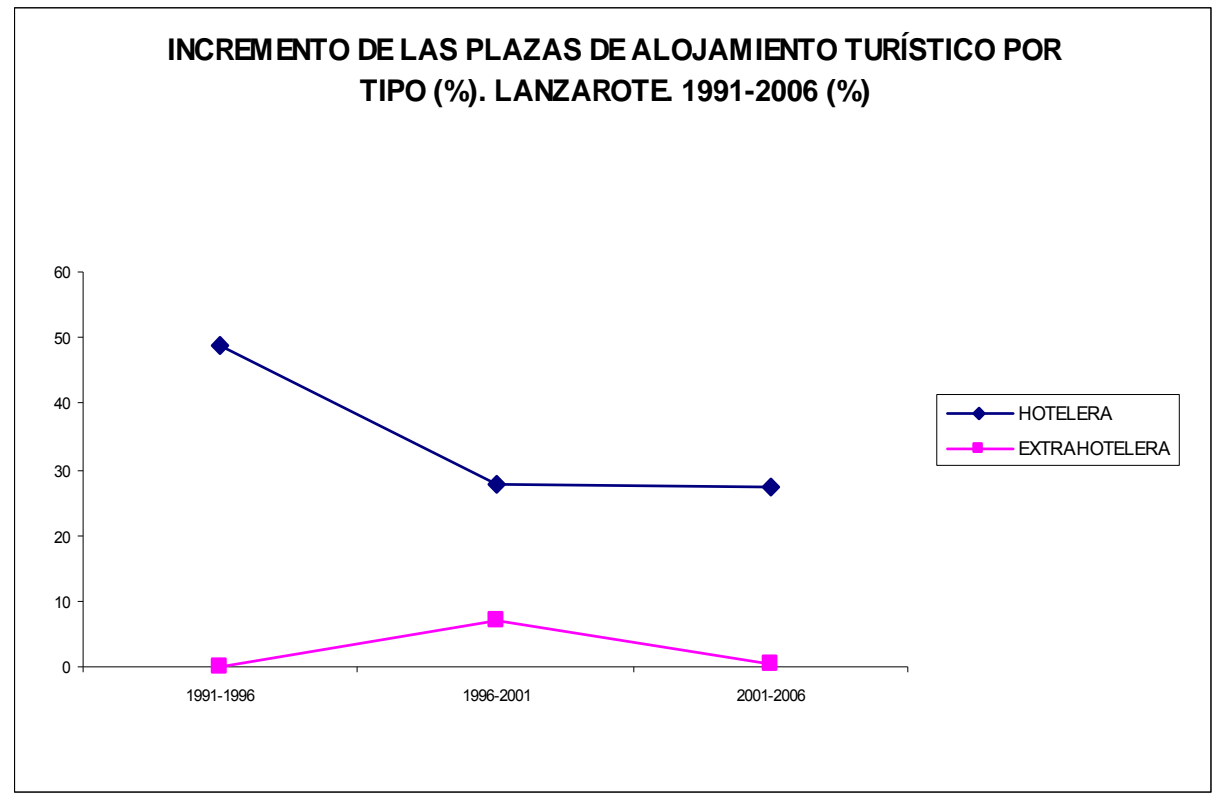

Fuente: Elaboración propia a partir de la información recogida en la Tabla 145.

Tanto Lanzarote, como Canarias en su conjunto, junto al país, ralentizan ahora el crecimiento de su planta de alojamiento turístico, en comparación con las décadas anteriores. Aunque, la dinámica de crecimiento de la nación, en el nuevo siglo (2001-2006), supera en un $16 \%$ el incremento que experimenta la isla y en un $7 \%$ el de Canarias, por primera vez. Los efectos sobre los distintos ámbitos del bienestar social los iremos tratando en los próximos epígrafes.

Gráfico 141. Incremento interperiodo de plazas de alojamiento turístico. España, Canarias y Lanzarote. 1996-2006 (\%)

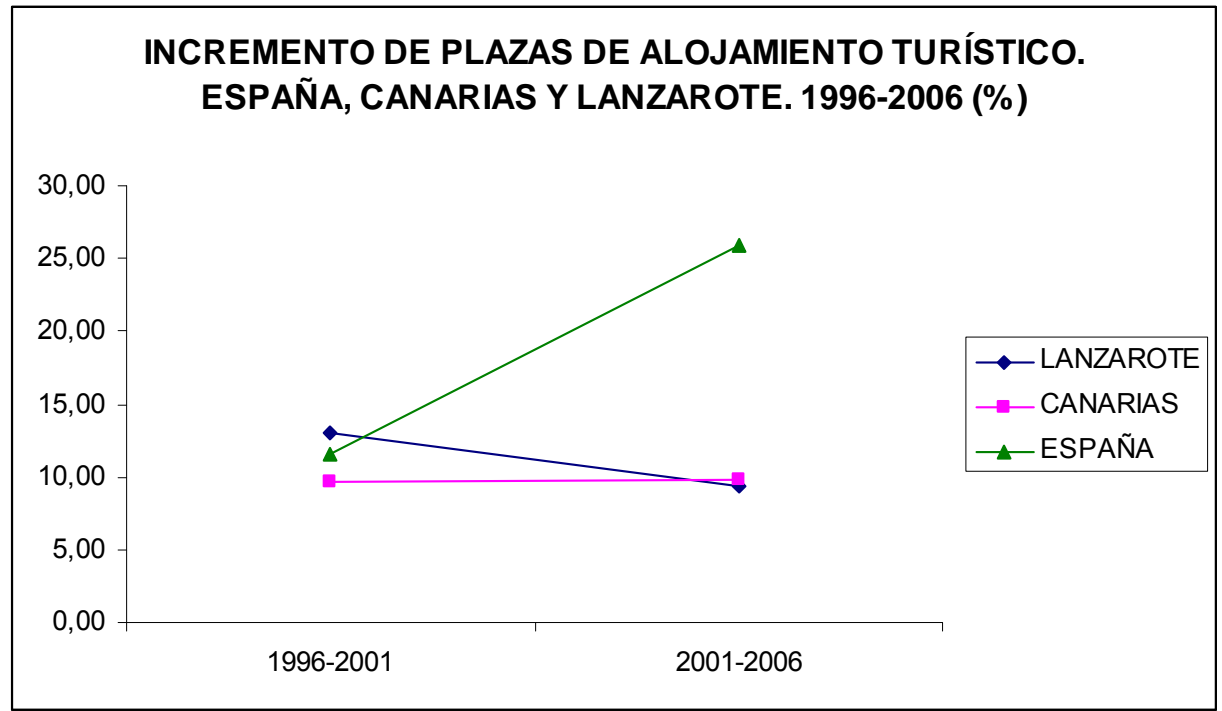

Fuente: Elaboración propia a partir de la información recogida en la Tabla 145. 
La isla apuesta por crecer en plazas hoteleras y reducir las extrahoteleras, que aunque siguen teniendo mayor peso relativo en el cómputo total de plazas turísticas, su crecimiento interperiodo es escaso), fenómeno éste que arranca de la etapa anterior y se hace muy marcado en ésta.

Impulsa una política basada en la búsqueda de un "turismo de calidad", conforme a la Ley 7/1995 de Ordenación del Turismo de Canarias, que regula la tipología de los establecimientos destinados a tal fin (pero no define ningún objetivo en relación a una programación de la edificación turística), invirtiendo en el crecimiento de la oferta hotelera de cuatro y cinco estrellas ${ }^{194}$. Aunque aún la extrahotelera es superior $(38,6 \%$ y $61,4 \%$ respectivamente) ésta no sufre crecimientos quinquenales significativos, encontrándose por encima del peso que tiene en Canarias, Comunidad que ha tendido a ir igualando cuantitativamente la presencia de ambos tipos de alojamiento. Frente a ellas, la dinámica nacional con su apuesta por el turismo hotelero lleva a que en el s. XXI su oferta se sitúe un $10 \%$ por encima de la extrahotelera.

Este nuevo enfoque que regula la cualificación de la oferta de alojamiento turístico, pretende, a su vez, potenciar los hoteles-escuelas, la formación profesional y la Escuela Oficial y estudios superiores de turismo, en aras a mejorar la capacitación de los profesionales del sector y la calidad del servicio que prestan.

194Ley 7/1995, de 6 de abril, de Ordenación del Turismo de Canarias. Título III. Capítulo II. Art. 55 c) transformación de los apartamentos en establecimientos hoteleros; Y Decreto 95/2000, de 29 de Mayo, de Aprobación de la revisión parcial del PIOT de Lanzarote; Y Art. 3.3.2.4., 1A) Determinaciones: A.1-Toda la nueva oferta alojativa turística será exclusivamente oferta hotelera. 
Gráfico 142. Oferta de alojamiento turístico por tipo. España, Canarias y Lanzarote. 1996-2006 (\%)

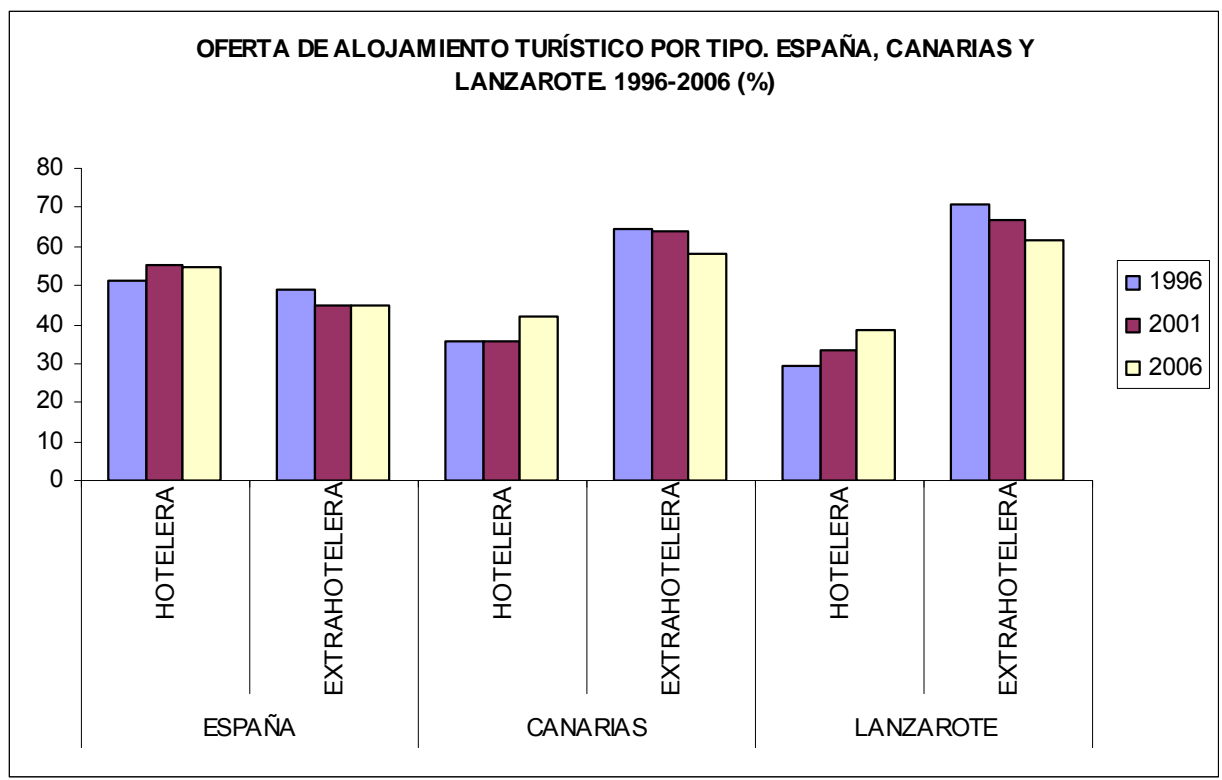

Fuente: Elaboración propia a partir de la información recogida en la Tabla 145.

La estabilización de la oferta de plazas y su transformación en hotelera como apuesta por un turismo de calidad, pueden permitir segmentar el tipo de turista que se recibe, y romper con el turismo de masas, basado en el crecimiento de la oferta y la demanda y el abaratamiento de servicios para conseguir ocupar las plazas. Derivando hacia posibles beneficios sobre la calidad del servicio y de los ingresos insulares por la actividad, que redundaría en mejoras del bienestar

Aunque la Moratoria Turística Insular, en el nuevo siglo, empieza alcanzando dos de sus objetivos (limitar el crecimiento de nueva oferta de alojamiento turístico y limitar los mismos a las instalaciones hoteleras), por su escaso tiempo de vigencia (hasta 2006) no podrá alcanzar la magnitud prevista y la isla volverá al PIOT de 1991, hasta el año 2014 en que se espera la entrada en vigor de un nuevo Plan Insular de Ordenación de Lanzarote (PIOL). Las consecuencias sobre el bienestar social derivado serán comentadas en los próximos epígrafes temáticos.

\subsubsection{2.-}

El final de la década de los noventa se presenta con una dinámica de descenso del incremento porcentual de entradas de turistas a la Isla, que entre 1996 y 2001 va a suponer la mitad en relación al periodo 1991-1996 (23,5\% y 44\% respectivamente). Esta ralentización del crecimiento desaparece en el primer quinquenio del s. XXI y se convierte en pérdida de visitantes, un crecimiento negativo del 3,5\% entre el año 2001 y el 2006, reduciéndose así la presión demográfica en la isla (que ya se observa desde el 2001 con 
respecto al año 1996), pues pasa de 433 turistas al día por mil residentes a 294 turistas, lo que supone una caída del 35\% con respecto a 2001.

Tabla 146. Turistas entrados e incremento interperiodo. España, Canarias y Lanzarote. 19962006

\begin{tabular}{||c|r|r|c|}
\hline \hline Año & ESPAÑ A & $\begin{array}{c}\text { Incremento } \\
\text { quinquenal (\%) }\end{array}$ & $\begin{array}{c}\text { Índice en base } \\
100=1970\end{array}$ \\
\hline \hline 1996 & $\mathbf{5 4 . 4 0 8 . 9 0 0}$ & 1,71 & 225,71 \\
\hline $\mathbf{2 0 0 1}$ & $\mathbf{7 5 . 5 6 3 . 5 6 8}$ & 38,88 & 313,47 \\
\hline $\mathbf{2 0 0 6}$ & $\mathbf{9 6 . 1 5 2 . 2 1 0}$ & 27,25 & 398,88 \\
\hline
\end{tabular}

*Año 1970

Fuente: Para 1996: "Entrada de visitantes a España, 1996", Turismo Receptor. Movimientos turísticos en Fronteras. En "25 años de turismo español en cifras. 1978-2003". IET; Para 2001 y 2006: "Entrada de visitantes por tipología, indicador y periodo. Total visitantes, 2001 y 2006". Turismo receptor. Entrada de visitantes serie 2001-2010. INE. Elaboración propia.

\begin{tabular}{||l|r|r|c||}
\hline Año & CAN ARI AS & $\begin{array}{c}\text { Incremento } \\
\text { quinquenal (\%) }\end{array}$ & $\begin{array}{c}\text { Índice en base } \\
100=1970\end{array}$ \\
\hline \hline 1996 & $\mathbf{9 . 8 0 4 . 5 4 0}$ & 48,31 & $1.237,09$ \\
\hline $\mathbf{2 0 0 1}$ & $\mathbf{1 0 . 1 3 7 . 2 0 2}$ & 3,39 & $1.279,06$ \\
\hline $\mathbf{2 0 0 6}$ & $\mathbf{9 . 5 3 0 . 0 3 9}$ & $-5,99$ & $1.202,46$ \\
\hline
\end{tabular}

*Año 1970

Fuente: Para 1996: "Pasajeros entrados en Canarias, 1996". FRONTUR CANARIAS. ISTAC; Para 2001-2006: "Pasajeros entrados en Canarias, 2001-2006". FRONTUR CANARIAS. ISTAC; Elaboración propia.

\begin{tabular}{||c||r|r|r||}
\hline Año & LANZAROTE & $\begin{array}{c}\text { Incremento } \\
\text { quinquenal (\%) }\end{array}$ & $\begin{array}{c}\text { Índice en base } \\
100=1970\end{array}$ \\
\hline \hline $\mathbf{1 9 9 6}$ & $\mathbf{1 . 4 9 4 . 0 5 0}$ & 44,17 & $5.572,32$ \\
\hline $\mathbf{2 0 0 1}$ & $\mathbf{1 . 8 4 4 . 9 0 3}$ & 23,48 & $6.880,89$ \\
\hline $\mathbf{2 0 0 6}$ & $\mathbf{1 . 7 8 0 . 1 6 1}$ & -3.51 & $6.639,42$ \\
\hline
\end{tabular}

*Año 1970

Fuente: Para 1996. "Evolución de la afluencia turística". Anuario Estadístico de Lanzarote, 1996, pp. 40; Para 2001 y 2006 : "Afluencia turística por meses. Total isla". Oficina de Turismo Interior Anuario Estadístico de Lanzarote 2001 y 2006 . Cabildo de Lanzarote. 
Gráfica 143. Incremento de la demanda turística. Lanzarote. 1996-2006 (\%)

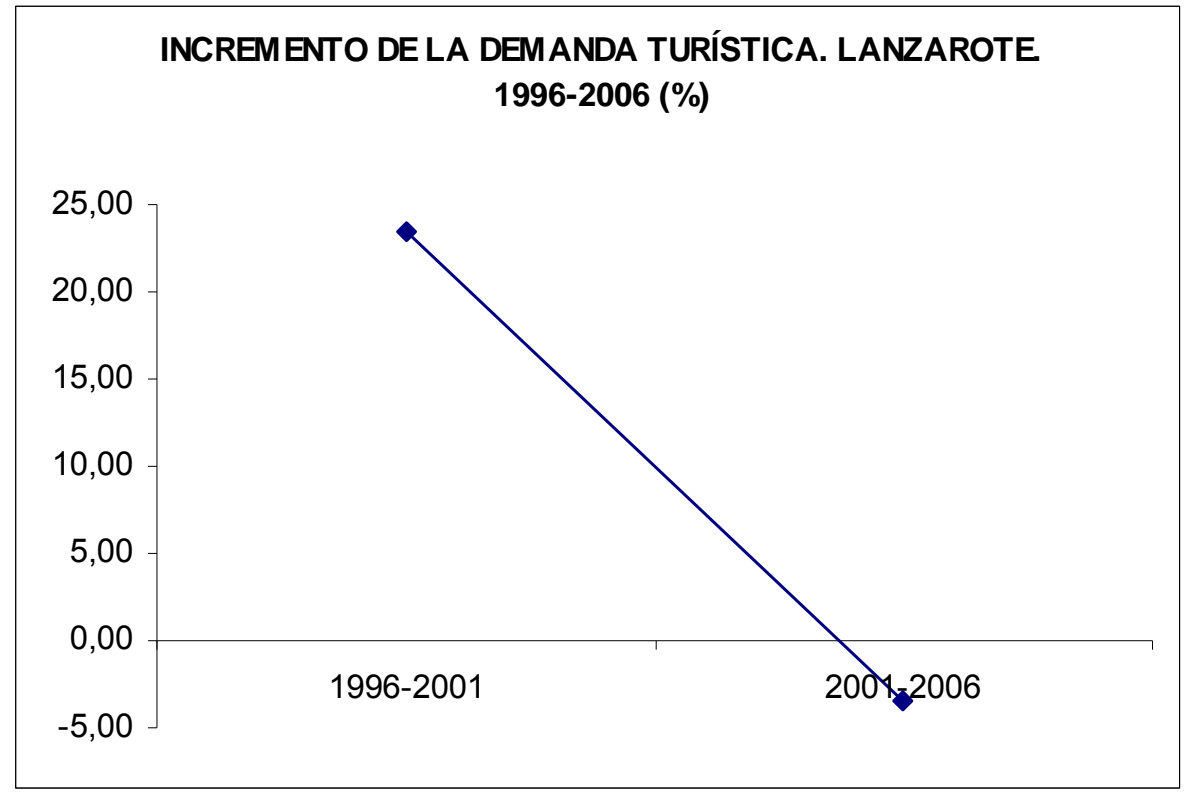

Fuente: Elaboración propia a partir de la información recogida en la Tabla 146.

Así mismo, Canarias, aunque termina el periodo anterior observado una dinámica similar a la de Lanzarote (crecimiento de la afluencia), con la entrada del nuevo siglo cae en picado su crecimiento porcentual de turistas con respecto al periodo 1991-1996.

En el quinquenio 1996-2001 la afluencia turística en el conjunto del archipiélago se incrementará un $3,4 \%$, mientras que Lanzarote se mantiene muy por encima $(23,5 \%)$. Canarias seguirá descendiendo alcanzando, al igual que en Lanzarote, un crecimiento negativo del volumen de visitas entre 2001-2006 (-6,0\%), tres puntos porcentuales por debajo de la isla. Aun así, al igual que en la etapa anterior, la presión demográfica seguirá siendo mucho menor para Canarias que para Lanzarote. Por tanto, no sólo no crecen las visitas por turismo, sino que tanto la Isla como el conjunto del archipiélago pierden turistas, lo que señala un periodo de recesión del sector, que tendrá reflejo en la economía y el empleo insular y autonómico. Pero eso será analizado más adelante.

Esta recesión en el crecimiento de la afluencia también se produce en el ámbito nacional, principalmente en el año 2001 con respecto a 2006, pero sin alcanzar los valores negativos de la Isla y su Comunidad Autónoma. 
Gráfico 144. Incremento de la demanda turística. España, Canarias y Lanzarote. 1996-2006 (\%).

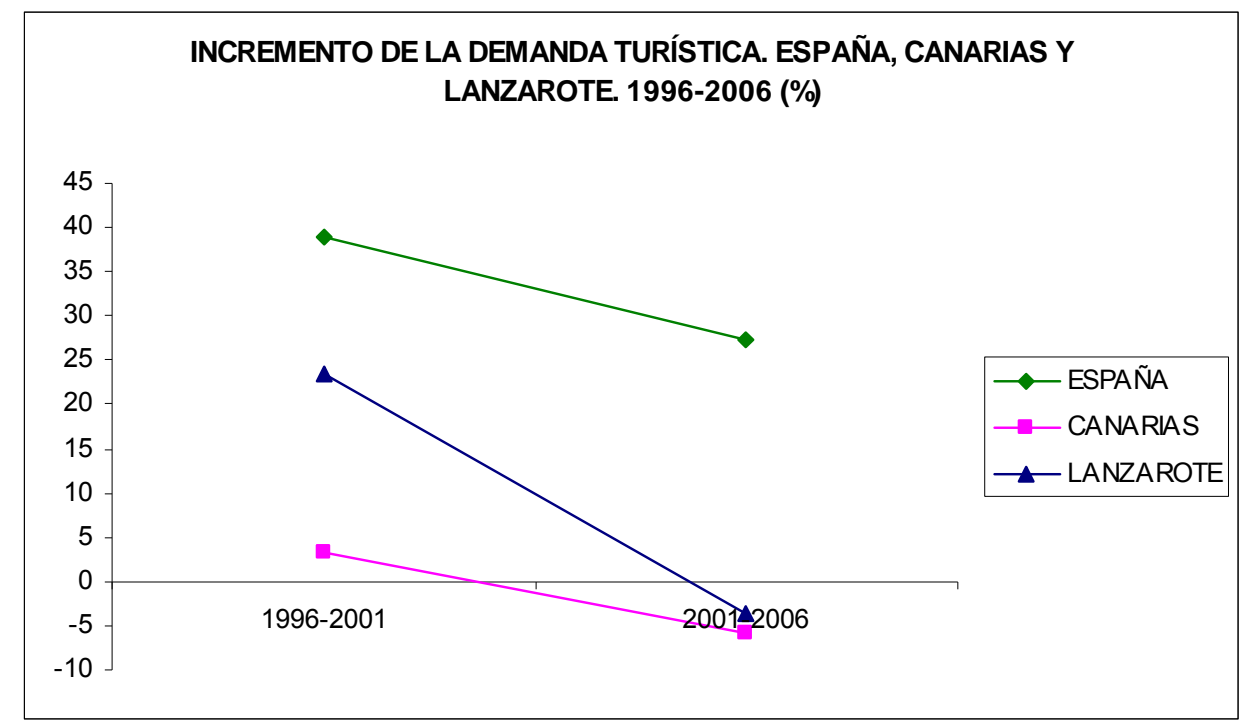

Fuente: Elaboración propia a partir de la información recogida en la Tabla 146.

El nuevo estado de la demanda, calificado de crisis desde diferentes ámbitos, no tiene una explicación monocausal, sino que es el efecto de varios fenómenos que podemos sintetizar, principalmente, en los siguientes (BOC, $\mathrm{n}^{\circ} 130,2$ de mayo de 2006 , pp. 4 y 5$)^{195}$, entre el año 2001 y 2006 :

- Mercados emisores, los turistas extranjeros entrados a Canarias y en particular a Lanzarote, tienen su origen principalmente en dos países, en relación al volumen de llegadas: Gran Bretaña y Alemania.

- El número de turistas británicos presenta un escaso crecimiento $(1,14 \%)^{196}$ en las islas, no así en destinos nacionales sin tradición turística, debido a la proliferación de compañías áreas de bajo coste localizadas en aeropuertos secundarios.

- La demanda procedente de Alemania ha sufrido un enorme descenso en el quinquenio $(-27,63 \%)$, aunque este fenómeno se viene observando desde 1999 , achacado a la situación de estancamiento económico que vive el país.

195 Boletín Oficial del Parlamento de Canarias, VI Legislatura, n 130. "Comunicación sobre las condiciones y evolución del mercado turístico en el trienio 2003-2006, en cumplimiento de la disposición transitoria segunda, apartado quinto, de la Ley 19/2003, de 14 de abril, por la que se aprueban las Directrices de Ordenación General y las Directrices de Ordenación del Turismo de Canarias". A 2 de Mayo de 2006. http://www.parcan.es

196 Fuente: "Afluencia de turistas según país de origen, 2001 y 2006". Anuario Estadístico de Lanzarote, 2001 y 2006. Centro de datos. Cabildo Insular de Lanzarote. http://www.datosdelanzarote.com 
- Destinos emergentes y competidores. Países del mediterráneo oriental (Turquía, Egipto, Croacia, Bulgaria, Túnez o Marruecos) que presentan una oferta de sol y playa similar a la de Canarias, con ofertas económicas muy competitivas y calidad equiparable, por lo que están registrando crecimientos de la afluencia más elevados y se han convertido en focos de atención para el turista alemán y británico (según declaraciones de los touroperadores).

- Situación económica. En términos generales los principales mercados emisores no han estado boyantes en los últimos años de este análisis. A ello hay que añadir dos factores principales: a) apreciación del euro, que ha supuesto una variación en los precios encareciendo los destinos nacionales para los europeos. Lo que hace más apetecible los destinos emergentes; b) depreciación del dólar, que abaratará para los europeos los viajes a destinos cuyas monedas estén referidas a esta divisa (por el ejemplo, el Caribe).

Así, al igual que las etapas anteriores, éstas fluctuaciones y recesiones observadas en la evolución de la demanda turística, incidirán, de nuevo, en la relación turista/residente ( $\mathrm{t} / \mathrm{r}$ ) y en el ratio turistas/plazas ( $t / p)$. Por lo que se hace necesario cuantificar estas relaciones, estimando, en primer lugar, el volumen de turistas equivalentes diarios que corresponde al conjunto de pernoctaciones turísticas, tanto hoteleras como extrahoteleras, que se calculan en las próximas líneas.

Señalar que, los datos existentes, se refieren a estancias medias en establecimientos hoteleros, no existiendo estimaciones para el extrahotelero hasta el año 2001, realizadas por el Instituto Nacional de Estadística. La metodología, por tanto, a seguir, hasta el año 1996 (con el que iniciamos esta etapa) es la misma que ha sido descrita en las anteriores (ver epígrafe 5.1.1.2), pues la dificultad para su cálculo sigue radicando en el valor medio de la estancia, ya que está afectada por el tipo de alojamiento donde se producen las pernoctaciones, ya sea hotelero o extrahotelero.

A partir del año 2001 tenemos información tanto de estancias medias como de pernoctaciones hoteleras y extrahoteleras recogidas por los organismos oficiales (INE), a partir de las cuales establecemos el número de turistas equivalentes diarios que soporta el territorio. 
Tabla 147. Estancia media en establecimientos hoteleros. España, Canarias y Lanzarote. 20012006.

\begin{tabular}{|c|c|c|c|c|c|c|c|c|c|}
\hline & ESPAÑA & & & CANARIAS & & & LANZAROTE & & \\
\hline Año & Tipo & Días & $\begin{array}{c}\text { Variación } \\
(\%)\end{array}$ & Tipo & Días & $\begin{array}{c}\text { Variación } \\
(\%)\end{array}$ & Tipo & Días & $\begin{array}{c}\text { Variación } \\
(\%)\end{array}$ \\
\hline \multirow{2}{*}{2001} & Hotelera & 3,8 & \multirow{2}{*}{150} & Hotelera & 7,8 & \multirow{2}{*}{20} & Hotelera & 7,3 & \multirow{2}{*}{--} \\
\hline & Extrahotelera & 9,5 & & Extrahotelera & 9,4 & & Extrahotelera & --- & \\
\hline \multirow{2}{*}{2006} & Hotelera & 3,3 & \multirow{2}{*}{150} & Hotelera & 6,9 & \multirow{2}{*}{20} & Hotelera & 6,6 & \multirow{2}{*}{32} \\
\hline & Extrahotelera & 8,1 & & Extrahotelera & 8,3 & & Extrahotelera & 8,7 & \\
\hline
\end{tabular}

Fuente: "Estancia media de los viajeros por zonas, Comunidades Autónomas y total Nacional, 2001" y "Estancia media de los viajeros por Comunidades Autónomas y total Nacional, 2006". Encuesta de ocupación hotelera, 2001 y 2006 . INE; "Estancia media de los viajeros en apartamentos, por Comunidades Autónomas y total Nacional. 2001" y "Estancia media de los viajeros en apartamentos, por zonas, Comunidades Autónomas y total Nacional. 2006". Encuesta de ocupación de apartamentos turísticos, 2001 y 2006. INE; Elaboración propia.

Tabla 148. Número de viajeros-turistas equivalentes al día. España. 1986-1996.

\begin{tabular}{||c|c|c|c|c|c|c|c|c|c||}
\hline Año & Viajeros & $\begin{array}{c}\text { Viajeros que } \\
\text { Pernoctan en } \\
\text { Hoteles }\end{array}$ & $\begin{array}{c}\text { Viajeros que No } \\
\text { Pernoctan. en } \\
\text { Hoteles }\left(^{*}\right)\end{array}$ & $\begin{array}{c}\text { Pernoctación } \\
\text { Hotelera }\end{array}$ & $\begin{array}{c}\text { Estancia } \\
\text { media } \\
\text { Hotelera (1) }\end{array}$ & $\begin{array}{c}\text { Estancia Media } \\
\text { ExtraHotelera (2) }\end{array}$ & $\begin{array}{c}\text { Pernoctación. } \\
\text { ExtraHotel } \\
(3)\end{array}$ & $\begin{array}{c}\text { Pernoctaciones. } \\
\text { Totales (H+Exh) }\end{array}$ & $\begin{array}{c}\text { Turistas } \\
\text { equivalentes al } \\
\text { día }\end{array}$ \\
\hline \hline $\mathbf{1 9 9 6}$ & $\mathbf{5 4 . 4 0 8 . 9 0 0}$ & 38.731 .000 & 15.677 .900 & 158.259 .000 & 4,1 & 10,2 & 160.153 .932 & 318.412 .932 & 872.364 \\
\hline $\mathbf{2 0 0 1}$ & $\mathbf{7 5 . 5 6 3 . 5 6 8}$ & 59.904 .301 & 15.659 .267 & 228.681 .570 & 3,8 & 9,5 & 148.763 .037 & 377.444 .607 & 1.034 .095 \\
\hline $\mathbf{2 0 0 6}$ & $\mathbf{9 6 . 1 5 2 . 2 1 0}$ & 81.855 .900 & 14.296 .310 & 267.027 .859 & 3,3 & 8,1 & 115.800 .111 & 382.827 .970 & 1.048 .844 \\
\hline
\end{tabular}

$\left.{ }^{*}\right)$ Viajeros que no pernoctan en hoteles: diferencia entre los Viajeros totales y los viajeros que pernoctan en hoteles.

(1) Estancia media hotelera de 1996: cociente entre el número de pernoctaciones causadas en hoteles y viajeros que pernoctan en hoteles.

(2) Estancia media extrahotelera: estancia media hotelera incrementada un 150\%, según las estimaciones de 2001 del INE.

(3) Pernoctaciones extrahotelera: producto de la estancia media extrahotelera por los viajeros que no pernoctan en hoteles.

Fuente: Para 1996: "Entrada de visitantes a España, 1996", Turismo Receptor. Movimientos turísticos en Fronteras. En "25 años de turismo español en cifras. 1978-2003". IET. "Estancia media en establecimientos hoteleros, 1996". Resumen año, 1996. Movimiento de viajeros en establecimientos hoteleros, 1996. INE; Para 2001 y 2006: "Entrada de visitantes". Turismo receptor. 2001, 2006. INE; "Estancia media de los viajeros por residencia en establecimientos hoteleros y apartamentos turísticos. Total España". Encuesta de ocupación hotelera, 2001 y 2006 y Encuesta de ocupación en apartamentos turísticos, 2001 y 2006. INE. Elaboración propia. 
Tabla 149. Número de viajeros-turistas equivalentes al día. Canarias. 1986-1996

\begin{tabular}{|r|r|r|r|r|r|r|r|r|r||}
\hline Año & Viajeros & $\begin{array}{c}\text { Viajeros que } \\
\text { Pernoctan en } \\
\text { Hoteles }\end{array}$ & $\begin{array}{c}\text { Viajeros que No } \\
\text { Pernoctan. en } \\
\text { Hoteles }\left(^{*}\right)\end{array}$ & $\begin{array}{l}\text { Pernoctación } \\
\text { Hotelera }\end{array}$ & $\begin{array}{c}\text { Estancia } \\
\text { media } \\
\text { Hotelera (1) }\end{array}$ & $\begin{array}{c}\text { Estancia Media } \\
\text { ExtraHotelera (2) }\end{array}$ & $\begin{array}{c}\text { Pernoctación. } \\
\text { ExtraHotel } \\
(3)\end{array}$ & $\begin{array}{c}\text { Pernoctaciones. } \\
\text { Totales (H+Exh) }\end{array}$ & $\begin{array}{c}\text { Turistas } \\
\text { equivalentes al } \\
\text { día }\end{array}$ \\
\hline \hline $\mathbf{1 9 9 6}$ & $\mathbf{9 . 8 0 4 . 5 4 0}$ & 960.485 & 8.844 .055 & 24.103 .518 & 8,2 & 9,8 & 87.025 .501 & 111.129 .019 & $\mathbf{3 0 4 . 4 6 3}$ \\
\hline $\mathbf{2 0 0 1}$ & $\mathbf{1 0 . 1 3 7 . 2 0 2}$ & 4.819 .191 & 5.318 .011 & 37.780 .198 & 7,8 & 9,4 & 49.989 .303 & 87.769 .501 & $\mathbf{2 4 0 . 4 6 4}$ \\
\hline $\mathbf{2 0 0 6}$ & $\mathbf{9 . 5 3 0 . 0 3 9}$ & 6.810 .235 & 2.719 .804 & 47.172 .390 & 6,9 & 8,3 & 22.574 .373 & 69.746 .763 & 191.087 \\
\hline
\end{tabular}

(1) Estancia media hotelera de 1996: cociente entre el número de pernoctaciones causadas en hoteles y viajeros que pernoctan en hoteles.

(2) Estancia media extrahotelera: estancia media hotelera incrementada un 150\%, según las estimaciones de 2001 del INE.

(3) Pernoctaciones extrahoteleras: producto de la estancia media extrahotelera por los viajeros que no pernoctan en hoteles.

Fuente: Para 1996: "Pasajeros entrados en Canarias, 1996". FRONTUR CANARIAS. ISTAC; "Pernoctaciones y estancia media, Canarias, 1996". Movimiento de Viajeros en Establecimientos Hoteleros (MVEH). Resumen de 1996; Para 2001-2006: "Pasajeros entrados en Canarias, 2001-2006". FRONTUR CANARIAS. ISTAC; "Viajeros que pernoctan en hoteles y pernoctaciones hoteleras. Canarias". Encuesta de ocupación hotelera, 2001 y 2006. INE; "Estancia media de los viajeros por Comunidades Autónomas. Canarias, 2001 y 2006". Encuesta de ocupación hotelera y Encuesta de ocupación en apartamentos turísticos, 2001 y 2006 . INE. Elaboración propia.

Tabla 150. Número de viajeros-turistas equivalentes al día. Lanzarote. 1986-1996.

\begin{tabular}{|r|r|r|r|r|r|r|r|r|r||}
\hline \hline Año & Viajeros & $\begin{array}{c}\text { Viajeros que } \\
\text { Pernoctan en } \\
\text { Hoteles }\end{array}$ & $\begin{array}{c}\text { Viajeros que No } \\
\text { Pernoctan. en } \\
\text { Hoteles (*) }\end{array}$ & $\begin{array}{c}\text { Pernoctación } \\
\text { Hotelera }\end{array}$ & $\begin{array}{c}\text { Estancia } \\
\text { media } \\
\text { Hotelera (1) }\end{array}$ & $\begin{array}{c}\text { Estancia Media } \\
\text { ExtraHotelera (2) }\end{array}$ & $\begin{array}{c}\text { Pernoctación. } \\
\text { ExtraHotel } \\
(3)\end{array}$ & $\begin{array}{c}\text { Pernoctaciones. } \\
\text { Totales (H+Exh) }\end{array}$ & $\begin{array}{c}\text { Turistas } \\
\text { equivalentes al } \\
\text { día }\end{array}$ \\
\hline \hline $\mathbf{1 9 9 6}$ & $\mathbf{1 . 4 9 4 . 0 5 0}$ & 440.844 & 1.053 .206 & 4.285 .200 & 9,7 & 12,8 & 13.485 .250 & 17.770 .450 & $\mathbf{4 8 . 6 8 6}$ \\
\hline $\mathbf{2 0 0 1}$ & $\mathbf{1 . 8 4 4 . 9 0 3}$ & 678.917 & 1.165 .986 & 4.983 .251 & 7,3 & 9,7 & 11.297 .005 & 16.280 .256 & 44.603 \\
\hline $\mathbf{2 0 0 6}$ & $\mathbf{1 . 7 8 0 . 1 6 1}$ & 858.464 & 921.697 & 5.665 .862 & 6,6 & 8,7 & 8.029 .824 & 13.695 .687 & $\mathbf{3 7 . 5 2 2}$ \\
\hline
\end{tabular}

(2) Estancia media extrahotelera de 1996: estancia media hotelera incrementada un 32\%, según las estimaciones de 2006 del INE.

(3) Pernoctaciones extrahotelera: producto de la estancia media extrahotelera por los viajeros que no pernoctan en hoteles.

Fuente: Para 1996: "Evolución de la Afluencia turística, 1996". Anuario Estadístico de Lanzarote, 1996 (pp. 40); "Viajeros entrados en establecimientos hoteleros, estancia media y pernoctaciones, 1996. Lanzarote". Encuesta de alojamiento turístico en establecimientos hoteleros. ISTAC; Para 2001 y 2006: "Afluencia turística por meses. Total isla". Oficina de Turismo Interior Anuario Estadístico de Lanzarote 2001 y 2006. Centro de datos. Cabildo Insular de Lanzarote; "Viajeros que pernoctan en hoteles. Lanzarote, 2001 y 2006 "y "Pernoctaciones y estancia media de los viajeros por zonas. Lanzarote, 2001 y 2006". Encuesta de ocupación hotelera, 2001 y 2006. INE; "Estancia media de los viajeros por zonas. Lanzarote, 2006". Encuesta de ocupación en apartamentos turísticos, 2006. INE. Elaboración propia.

Una vez calculados los turistas equivalentes al día, se ha podido elaborar el indicador que pone en relación el volumen de población residente con la estimación del volumen de turistas equivalentes diarios, y observar su evolución, que se refleja en la siguiente tabla y que comentaremos en las próximas líneas: 
Tabla 151. Turistas entrados. España, Canarias y Lanzarote. 1996-2006

\begin{tabular}{||c|r|r|r|r|r||}
\hline \hline Año & ESPAÑ A & $\begin{array}{c}\text { Incremento } \\
\text { quinquenal (\%) }\end{array}$ & $\begin{array}{c}\text { İ́ndice en base } \\
100=1970\end{array}$ & $\begin{array}{c}\text { Turistas } \\
\text { equivalentes al dia }\end{array}$ & Ratio (t/r) \\
\hline \hline 1996 & 54.408 .900 & 1,71 & 150,26 & 872.364 & 21,99 \\
\hline 2001 & 75.563 .568 & 38,88 & 174,66 & 1.034 .095 & 25,32 \\
\hline 2006 & 96.152 .210 & 27,25 & 194,94 & 1.048 .844 & 23,46 \\
\hline
\end{tabular}

Fuente: Ratio (t/r) aparece de la relación entre el número de turistas equivalentes diarios y la población registrada (residentes), en tantos por mil. Elaboración propia a partir de la tabla anterior.

\begin{tabular}{||c|r|r|r|r|r||}
\hline Año & CAN ARI AS & $\begin{array}{c}\text { Incremento } \\
\text { quinquenal (\%) }\end{array}$ & $\begin{array}{c}\text { Índice en base } \\
100=1970\end{array}$ & $\begin{array}{c}\text { Turistas } \\
\text { equivalentes al día }\end{array}$ & Ratio (t/r) \\
\hline \hline 1996 & 9.804 .540 & 48,31 & $1.237,09$ & 304.463 & 189,52 \\
\hline 2001 & 10.137 .202 & 3,39 & $1.279,06$ & 240.464 & 141,91 \\
\hline 2006 & 9.530 .039 & $-5,99$ & $1.202,46$ & 191.087 & 95,74 \\
\hline
\end{tabular}

Fuente: Ratio (t/r) aparece de la relación entre el número de turistas equivalentes diarios y la población registrada (residentes), en tantos por mil. Elaboración propia a partir de la tabla anterior.

\begin{tabular}{||c||r|r|r|r|r||}
\hline Año & LANZAROTE & $\begin{array}{c}\text { Incremento } \\
\text { quinquenal (\%) }\end{array}$ & $\begin{array}{c}\text { İ́ndice en base } \\
100=1970\end{array}$ & $\begin{array}{c}\text { Turistas } \\
\text { equivalentes al día }\end{array}$ & Ratio (t/r) \\
\hline \hline 1996 & 1.494 .050 & 44,17 & $5.572,32$ & 48.686 & 629,19 \\
\hline 2001 & 1.844 .903 & 23,48 & $6.880,89$ & 44.603 & 432,85 \\
\hline 2006 & 1.780 .161 & -3.51 & $6.639,42$ & 37.522 & 294,39 \\
\hline
\end{tabular}

Fuente: Ratio ( $\mathrm{t} / \mathrm{r}$ ) aparece de la relación entre el número de turistas equivalentes diarios y la población registrada (residentes), en tantos por mil. Elaboración propia a partir de la tabla anterior.

Entre 1996 y 2006, se observa un movimiento de descenso en la relación turistas-residentes $(\mathrm{t} / \mathrm{r})$, al contrario de lo que ha vivido la isla en las etapas anteriores donde ha mantenido una dinámica de elevación constante. Este nuevo movimiento se observa a partir del año 2001, hasta alcanzar en 2006 valores idénticos a los que mostraba la isla dos décadas antes (en 1986 se estiman 296 turistas por mil residentes), debido al crecimiento negativo que experimenta la demanda. Esto se traduce en una reducción considerable de la población que diariamente soporta Lanzarote, pues la etapa acaba arrojando la cantidad de 295 turistas por mil residentes, frente a los 629 con la que se inicia, lo que deberá aliviar notablemente la presión de la población sobre el territorio insular y sus recursos. Por lo que las crisis de demanda se pueden convertir en una oportunidad para regular el sistema territorial insular (infraestructuras, equipamientos, servicios, nivel de empleo, etc.) 
La misma dinámica es observada para Canarias, que sufre un descenso del número de entradas por turismo a lo largo de esta etapa, pasando de 189 turistas por mil residentes a mitad de la década de los años noventa (1996), a casi 96 turistas una década después (2006), aunque el descenso es más acusado para Lanzarote. El territorio nacional no sufre cambios, el valor que sigue arrojando el ratio no es significativo.

Gráfico 145. Evolución de la relación turistas/ residentes. España, Canarias y Lanzarote. 1996-2006 (t/r)

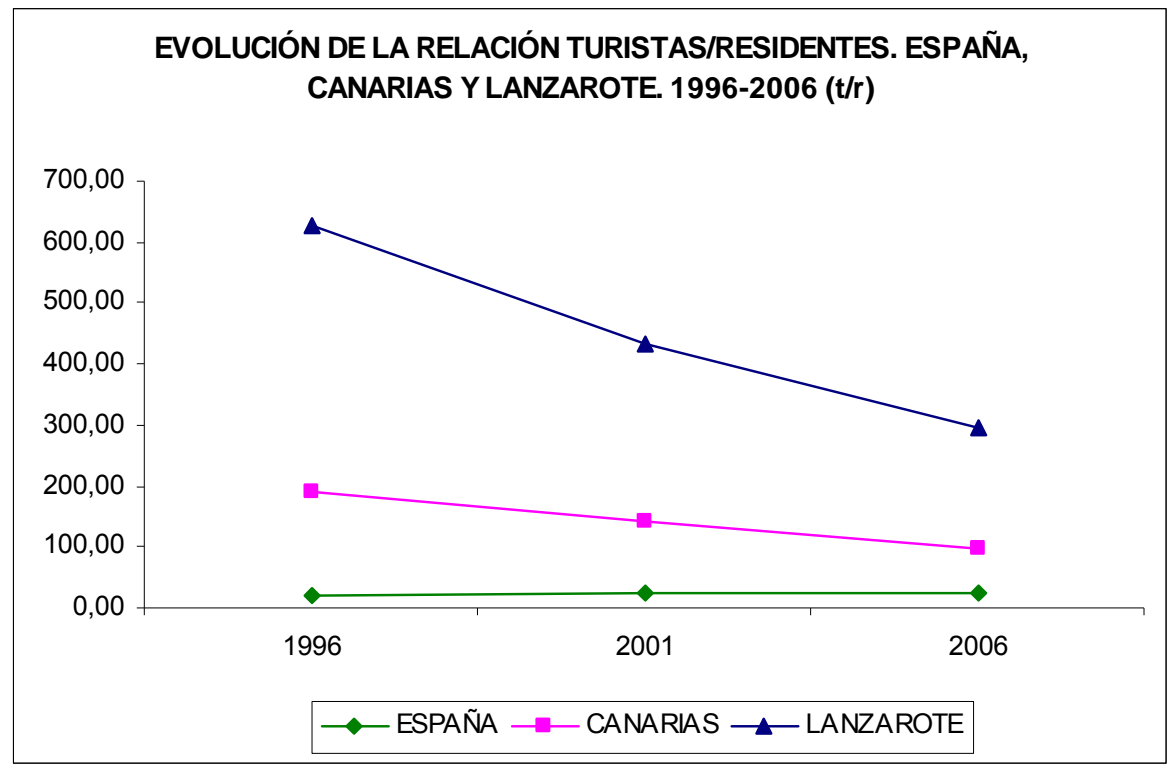

Fuente: Elaboración propia a partir del cálculo del indicador (t/r), recogido en la Tabla 151.

En cuanto a la relación entre el volumen de turistas y el volumen de plazas de alojamiento en la isla, que nos permite observar la evolución de la demanda sobre la oferta, ésta es ligeramente fluctuante, manteniéndose en valores similares a 1996 (entre 32 y 27 turistas por plaza) debido a que a partir de 2001, con la entrada en vigor de la "Moratoria turística" se ralentiza la creación de nuevas plazas de alojamiento y, a la vez, se produce la caída de visitantes descrita anteriormente.

Tabla 152. Ratio turistas/plazas. España, Canarias y Lanzarote. 1986-1996

\begin{tabular}{|c|c|c|c|c|c|c|c|c|c|}
\hline & \multicolumn{3}{|c|}{ ESPAÑ A } & \multicolumn{3}{|c|}{ CANARIAS } & \multicolumn{3}{|c|}{ LANZAROTE } \\
\hline Año & $\mathrm{N}^{0}$ Plazas & Turistas & $\begin{array}{l}\text { Ratio } \\
(\mathrm{t} / \mathrm{p})\end{array}$ & $\mathrm{N}^{0}$ Plazas & Turistas & $\begin{array}{l}\text { Ratio } \\
\text { (t/p) }\end{array}$ & $\mathrm{N}^{0}$ Plazas & Turistas & $\begin{array}{l}\text { Ratio } \\
\text { (t/p) }\end{array}$ \\
\hline 1996 & 2.133 .053 & 54.408 .900 & 25,5 & 328.254 & 9.804 .540 & 29,9 & 52.830 & 1.494 .050 & 28,3 \\
\hline 2001 & 2.380 .136 & 75.563 .568 & 31,7 & 359.885 & 10.137.202 & 28,2 & 58.132 & 1.844 .903 & 31,7 \\
\hline 2006 & 2.994 .807 & 96.152 .210 & 32,1 & 428.170 & 9.530 .039 & 22,3 & 65.293 & 1.780 .161 & 27,3 \\
\hline
\end{tabular}

Fuente: Elaboración propia a partir de los datos de viajeros entrados y plazas de alojamiento. 
La dinámica insular varía con respecto a la autonómica, que no fluctúa en esta etapa, sino que la relación turistas/plazas va descendiendo, pasando de 30 turistas por plaza en 1996 a 22 en 2006, debido a que la afluencia turística a las islas desciende (6\%), pero Canarias incrementa su volumen de plazas de alojamiento en un $18 \%$, el doble de la dinámica insular. Lanzarote ha invertido su signo con respecto a Canarias, frenando el crecimiento de nueva planta de alojamiento turístico.

El signo de la dinámica nacional es ascendente con respecto a la relación entre demanda y oferta turística, pues se contabilizan más plazas pero también más turistas, por lo que el rendimiento por plaza es mayor que el que presenta el archipiélago.

Gráfico 146. Evolución de la relación turistas/plazas. España, Canarias y Lanzarote. 1996-2006 (t/p)

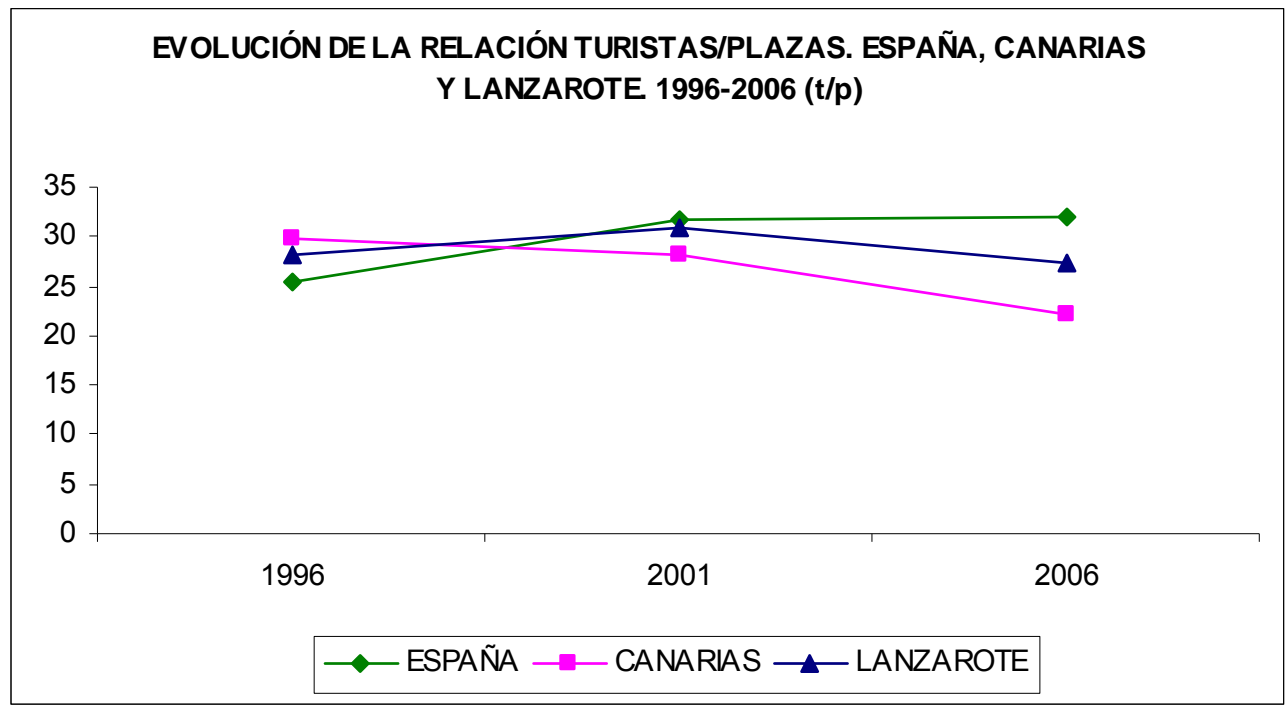

Fuente: Elaboración propia a partir del cálculo del indicador (t/p), recogido en la Tabla 152.

\subsubsection{3.- CONCLUSIONES}

En esta tercera etapa, Lanzarote se muestra como un destino turístico de masas maduro, planteándose modificar y diversificar su oferta, establecer un techo de crecimiento para la misma hasta el 2010, regular la afluencia turística en relación a la capacidad de asimilación de la isla y encaminar el territorio hacia la sostenibilidad. Para ello será necesario hacer revisión del PIOT de 1991, y adaptarlo a las necesidades insulares a final del siglo. Se opta por demorar los crecimientos, pero no se alcanzará el éxito esperado. Las características, por tanto, de la actividad turística en este periodo, y de forma general, se concretan en los siguientes puntos:

1.- Oscilación del crecimiento de la oferta turística, durante la etapa (1996-2006), con tendencia a la baja, escaso incremento entre 2001 y 2006, por primera vez en la historia turística de la isla, como fruto de la política de control de dicho crecimiento, durante los 
últimos quince años, a través del Plan de Ordenación de 1991 y su revisión posterior, la Moratoria del año 2001, que ponen techo al crecimiento, pues es esta oferta la que provoca el fuerte crecimiento físico insular, pero además como reacción ante las crisis de demanda. Ésta dinámica es contraria a la llevada por Canarias y España, que siguen incrementando su oferta.

2.- El crecimiento de las plazas de alojamiento de la isla se concentra únicamente en la oferta hotelera, conforme a la regulación tipológica de la Ley 7/1995 de Ordenación del Turismo de Canarias. Lanzarote se acerca a la dinámica de Canarias que presenta la misma tendencia; que siempre ha sido propia de España.

3.- Descenso continuado del incremento de las entradas de turistas, que al final del periodo, entre 2001-2006, entra en un crecimiento negativo. La fuerte caída de la afluencia viene explicada por factores externos, no controlables desde la política insular, como es el estancamiento de la economía alemana, la emergencia de nuevos destinos muy competitivos en precios, la apreciación del euro y la depreciación del dólar. Por lo que la isla se enfrenta a una nueva crisis económica derivada de la evolución del sector, del que es totalmente dependiente y está sujeto a procesos exógenos.

La caída no será tan violenta para Canarias. Esta Comunidad Autónoma y las islas que la componen deben enfrentar una fuerte crisis de receptividad, que tendrá efectos negativos pero también positivos sobre indicadores de bienestar social insular que trataremos en los próximos epígrafes. Diferente es para España, que incrementa, aún, su afluencia en el último quinquenio analizado.

Gráfico 147. Evolución de la oferta y la demanda turística. Lanzarote. 1996-2006

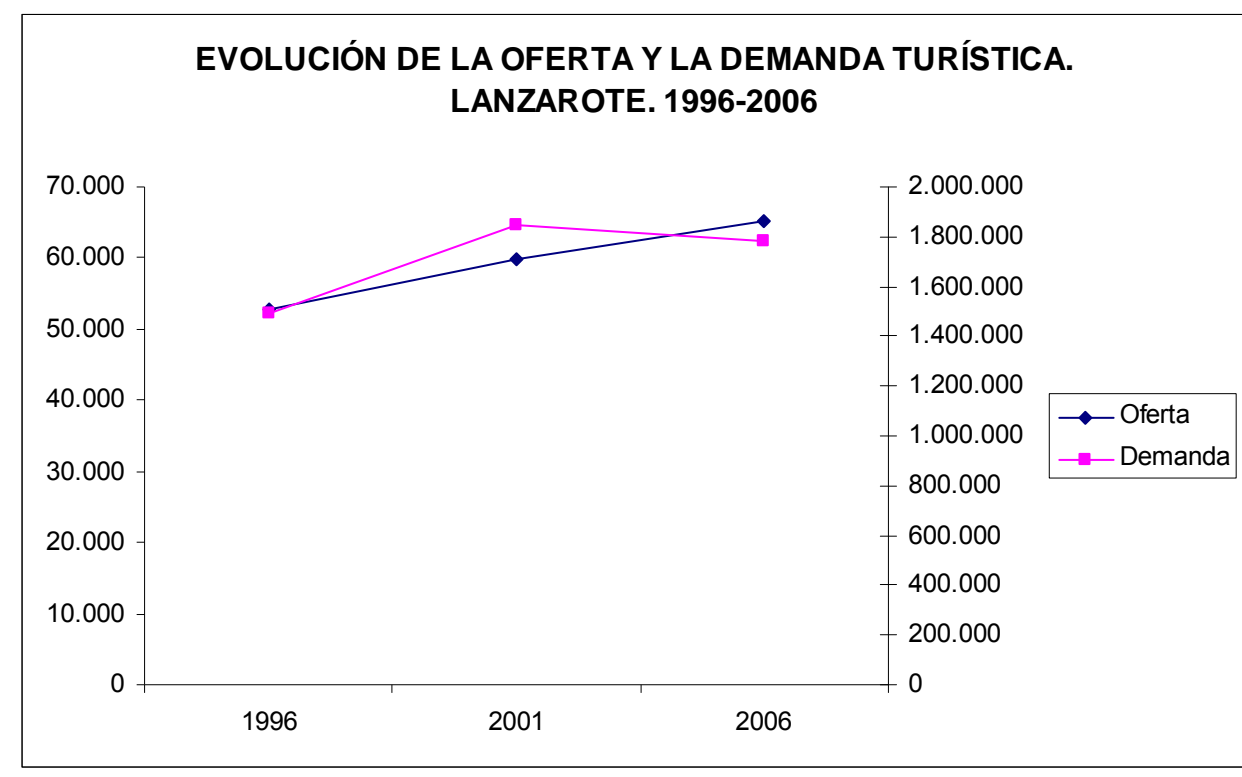

Fuente: Gráfico resumen basado en las Tablas 145 y 146. Elaboración propia. 
4.- La crisis de afluencia que vive la isla, presenta una primera mirada positiva en sus efectos, pues el equilibrio poblacional en relación al volumen de turistas equivalentes diarios sobre el volumen de residentes ahora se reduce, de forma brusca al final del periodo. Lo que significa la reducción de la presión humana sobre los recursos insulares. El cambio en Lanzarote es más violento que en Canarias, que también reduce este indicador en el último quinquenio. Las crisis de demanda turística son una oportunidad para alcanzar mejoras sobre el bienestar social insular, por reducción de la presión demográfica sobre el territorio.

5.- La evolución de la demanda de afluencia sobre la oferta turística (t/p), derivada de la contención del crecimiento del número de plazas, con la entrada en vigor de la "Moratoria turística", en el año 2001, y la crisis de afluencia, posibilita una mayor explotación de cada una de ellas, aunque el crecimiento de este indicador, desde la etapa anterior, no va a redundar en la reducción del número de parados y el bienestar social derivado.

Aspectos como la limitación del crecimiento (oferta) y la regulación del tipo, parte de una política que apuesta por romper con el modelo turístico de masas, intentando reducir el porcentaje de turistas estándar que lo caracteriza, mantener una afluencia sin notables altibajos, que redunde en la calidad del servicio, y en diferentes aspectos socioeconómicos y de bienestar de la sociedad insular. Las crisis de afluencia, aunque reviertan en crisis económicas, pueden convertirse en una oportunidad para regular el mercado turístico local, (vía reducción de plazas para alcanzar mayor explotación de las restantes) y la presión humana que sufren las sociedades anfitrionas especializadas en turismo de masas.

Este proceso descrito confirma una conclusión tradicional de este tipo de estudios, cual es que la calidad y no la cantidad debe presidir las políticas de desarrollo turístico, pues es la forma de alcanzar cierto equilibrio en el volumen de población que soporta a diario la isla, que se alimenta del crecimiento de la oferta de plazas de alojamiento, cuyos efectos pueden exceder su capacidad de carga y con ello elevar el malestar social.

\subsection{2.- EFECTOS SOBRE LA ESTRUCTURA DEMOGRÁFICA BÁSICA. 1996-2006}

\subsubsection{1.- EVOLUCIÓN DE LA POBLACIÓN}

Es esta última etapa del análisis cuando la isla experimenta el mayor crecimiento de la población con respecto a las dos etapas anteriores. Principalmente entre 1996 y el 2001, cuando el incremento de población alcanza un 33\% en cinco años. Crecimiento espectacular comparado con Canarias y España que sólo crecen un 5,5\% y un 3\% respectivamente.

Este potente crecimiento, imparable desde los años setenta, lógicamente condiciona los procesos dentro del sistema insular, por lo que incidirá de forma determinante sobre el estado del bienestar social; pues no ha derivado de un crecimiento natural, sino que es impulsado por factores exógenos (turistas e inmigrantes), tal y como se viene señalando en 
las etapas anteriores y que vuelve a marcarse en esta, como veremos en las próximas líneas. Así, en el año 1998, la Estrategia Lanzarote en la Biosfera (Doc. 1., pp. 27-35) señala como imprescindible moderar la presión humana sobre el sistema insular, para evitar el deterioro de la calidad de vida, proponiendo la limitación del crecimiento de la oferta turística como vía para contener el aumento de la población flotante (turistas y residentes), con el establecimiento de escalas y ritmos compatibles con la capacidad de asimilación de la isla, en términos de necesidades humanas, económicas y ecológicas. Todo esto será contemplado y normalizado en el Decreto 95/2000 de aprobación definitiva de la revisión parcial del PIOT (o Moratoria Turística)

Tabla 153. Población total registrada. España, Canarias y Lanzarote 1996-2006 (\%).

\begin{tabular}{||c||r|r||r|r|r|r||}
\hline Año & ESPAÑA & $\begin{array}{c}\text { Incremento } \\
\text { quinquenal (\%) }\end{array}$ & CANARIAS & $\begin{array}{r}\text { Incremento } \\
\text { quinquenal (\%) }\end{array}$ & LANZAROTE & $\begin{array}{r}\text { Incremento } \\
\text { quinquenal (\%) }\end{array}$ \\
\hline \hline $\mathbf{1 9 9 6}$ & 39.669 .394 & 2,1 & 1.606 .534 & 7,5 & 77.379 & 19,2 \\
\hline $\mathbf{2 0 0 1}$ & 40.847 .371 & 3,00 & 1.694 .477 & 5,5 & 103.044 & 33,2 \\
\hline $\mathbf{2 0 0 6}$ & 44.708 .964 & 9,5 & 1.995 .833 & 17,8 & 127.457 & 23,7 \\
\hline
\end{tabular}

Fuente: Censos de Población y Viviendas de España y de Canarias, 2001 (Población de Derecho). INE e ISTAC.; Padrón Municipal de habitantes "Población de derecho. Resultados Nacionales y provinciales"1996, 2006. INE; "Población de derecho 2001 y 2006. Padrón municipal de habitantes", Anuario estadístico de Lanzarote 2006. Centro de datos. Cabildo Insular de Lanzarote. Elaboración propia.

Así, asistimos a la reducción del crecimiento de la población entre 2001 y 2006 aproximadamente alrededor de un $10 \%$ con respecto al quinquenio anterior (1996-2001). El incremento poblacional ha supuesto en estos últimos cinco años casi un $24 \%$, cifra aún muy elevada, pero optimista en cuando al resultado obtenido de la contención del crecimiento de la oferta turística por la Moratoria unido a una crisis de recepción, aunque muy distante de los crecimientos que experimentan Canarias (18\%) y España $(9,5 \%)$. 
Gráfico 148. Incremento interperiodo de la población de derecho. España, Canarias y Lanzarote. 1996-2006 (\%).

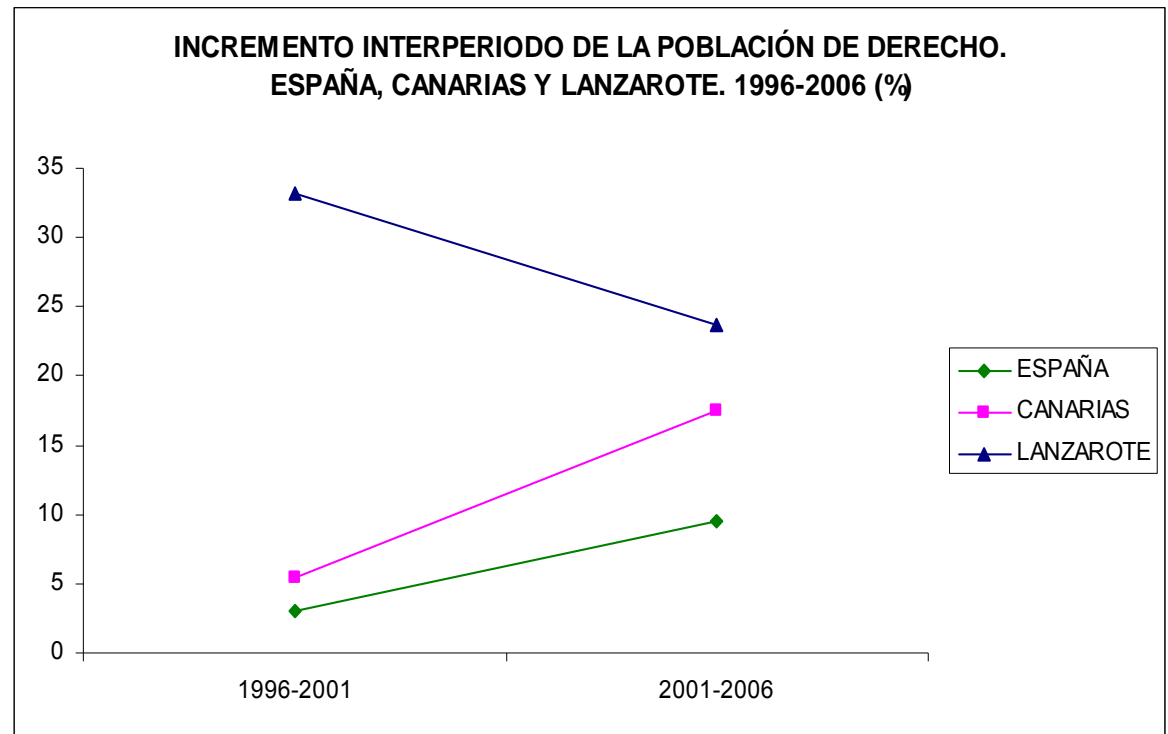

Fuente: Censos de Población y Viviendas y Padrón Municipal de habitantes. INE; Anuario estadístico de Lanzarote 2006. Centro de datos. Cabildo Insular de Lanzarote. Elaboración propia a partir de la Tabla 152.

Brevemente señalar que la dinámica municipal de la Isla sigue apuntando, como anteriormente, al municipio capitalino, Arrecife, como el de mayor concentración de la población ( $46 \%$ de media en el periodo), seguido ahora por Tías y San Bartolomé, tal y como se puede ver en la tabla siguiente.

Tabla 154. Población por municipios. Lanzarote. 1996-2006

\begin{tabular}{|l|c|c|c|c|c|c|c||}
\hline \multirow{2}{*}{ Municipio } & \multicolumn{2}{|c|}{1996} & \multicolumn{2}{c|}{2001} & \multicolumn{2}{c|}{2006} & \multirow{2}{*}{$\begin{array}{c}\text { Incremento entre } \\
1986-1996 \text { (\%) }\end{array}$} \\
\cline { 2 - 8 } & Absolutos & $\%$ & Absolutos & $\%$ & Absolutos & $\%$ & 44,9 \\
\hline Arrecife & 38.091 & 49,2 & 45.549 & 44,2 & 55.203 & 43,3 & 41,7 \\
\hline Haría & 3.531 & 4,6 & 4.285 & 4,2 & 5.004 & 3,9 & 78,7 \\
\hline San Bartolomé & 9.852 & 12,7 & 14.835 & 14,4 & 17.610 & 13,8 & 91,2 \\
\hline Teguise & 8.691 & 11,2 & 12.905 & 12,5 & 16.616 & 13,0 & 77,1 \\
\hline Tías & 10.096 & 13,1 & 14.442 & 14,0 & 17.884 & 14,0 & 45,8 \\
\hline Tínajo & 3.755 & 4,9 & 4.670 & 4,5 & 5.476 & 4,3 & 187,4 \\
\hline Yaiza & 3.363 & 4,4 & 6.358 & 6,2 & 9.664 & 7,6 & $\mathbf{6 4 , 7}$ \\
\hline TOTAL & 77.379 & 103.044 & 127.457 &. \\
\hline
\end{tabular}

Fuente. Estadísticas Insulares y Municipales. Base de Datos 1996 y Censo de población y viviendas de Canarias, 2001 ISTAC. INE; Padrón Municipal de Habitantes, 2006 (en Anuario Estadístico de Lanzarote. 2006. Centro de Datos. Cabildo Insular de Lanzarote). INE. 
Gráfico 149. Evolución de la población municipal sobre el total insular. Lanzarote. 1996-2006 (\%).

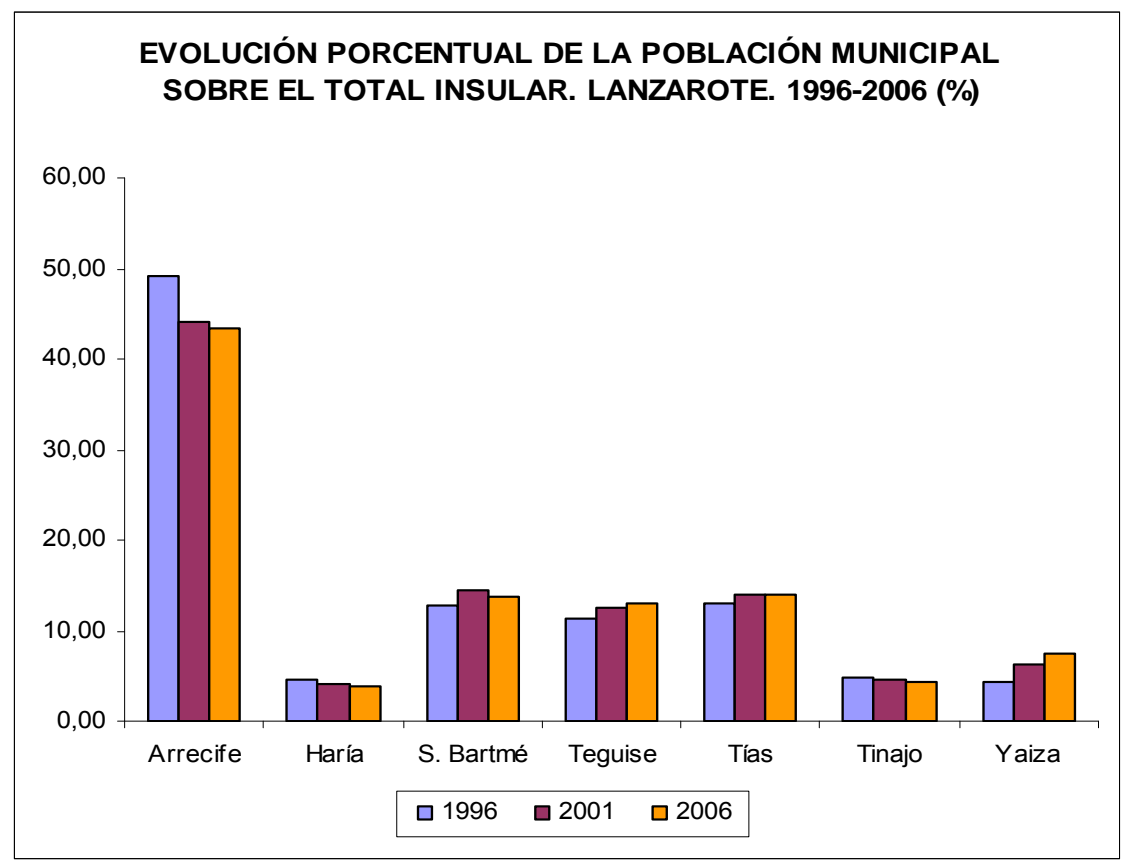

Fuente: Censos de Población y Viviendas y Padrón Municipal de habitantes. INE; Anuario estadístico de Lanzarote 2006. Centro de datos. Cabildo Insular de Lanzarote. Elaboración propia a partir de la Tabla 154.

Con respecto a las etapas anteriores, el fuerte incremento demográfico en ésta toca todos los municipios de la isla, pero significativamente aquellos cuyas costas habían tenido menos crecimiento de la oferta turística en los periodos anteriores, como son el municipio de Teguise y de Yaiza principalmente, que registran un elevadísimo aumento demográfico en diez años (91,2\% y 187,4 respectivamente) pues han recibido un impulso en su planta turística alojativa. 
Mapa 27. Evolución demográfica municipal. Lanzarote. 1996-2006 (1970=100)

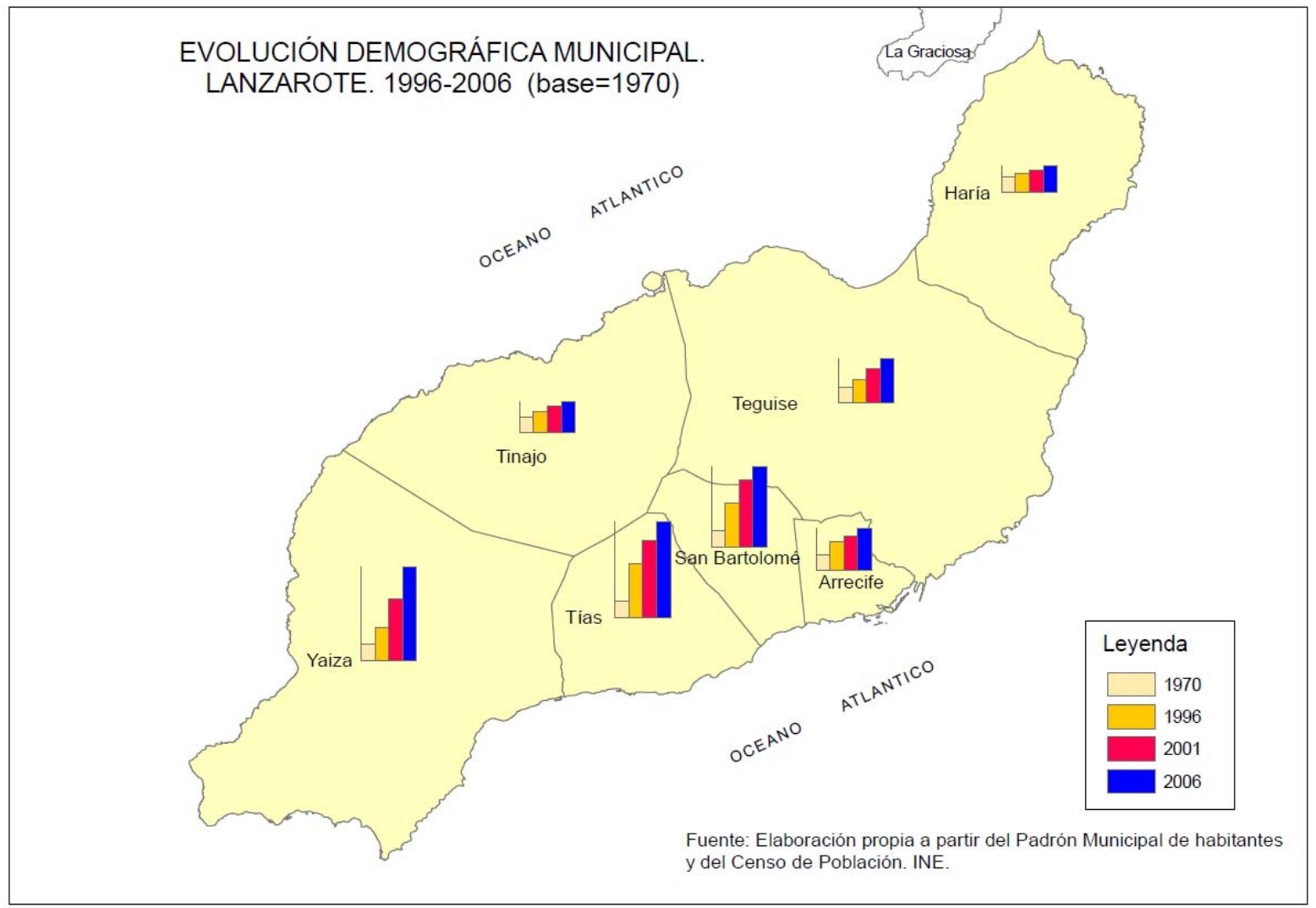

\section{a.- El movimiento natural}

Las tasas de mortalidad quinquenales analizadas han seguido una dinámica de descenso tanto en Lanzarote como en España y Canarias, desde los años setenta. Característica que se mantiene en esta etapa. La isla presenta tasas bastante más bajas que las del conjunto autonómico y la mitad que la que registra España entre el año 2001 y 2005.

Tabla 155. Evolución de las tasas quinquenales de mortalidad. España, Canarias y Lanzarote. 1996-2005 (\%)

\begin{tabular}{|l|c|c|c|}
\cline { 2 - 4 } \multicolumn{1}{c|}{} & ESPAÑA & CANARIAS & LANZAROTE \\
\hline $\mathbf{1 9 9 6 - 2 0 0 0}$ & 8,9 & 6,9 & 5,5 \\
\hline $\mathbf{2 0 0 1 - 2 0 0 5}$ & 8,7 & 6,7 & 4,7 \\
\hline
\end{tabular}

Fuente: Nacimientos y Defunciones. Total Nacional y Comunidades Autónomas. Movimiento Natural de la Población. 1996-2005; "Defunciones según sexos, municipios, islas y años. Lanzarote". Estadística de defunciones. Resultados anuales 1996-2005. ISTAC. http://www2.gobiernodecanarias.org/istac 
Gráfico 150. Evolución de la tasa de mortalidad media. España, Canarias y Lanzarote. 1996-2005

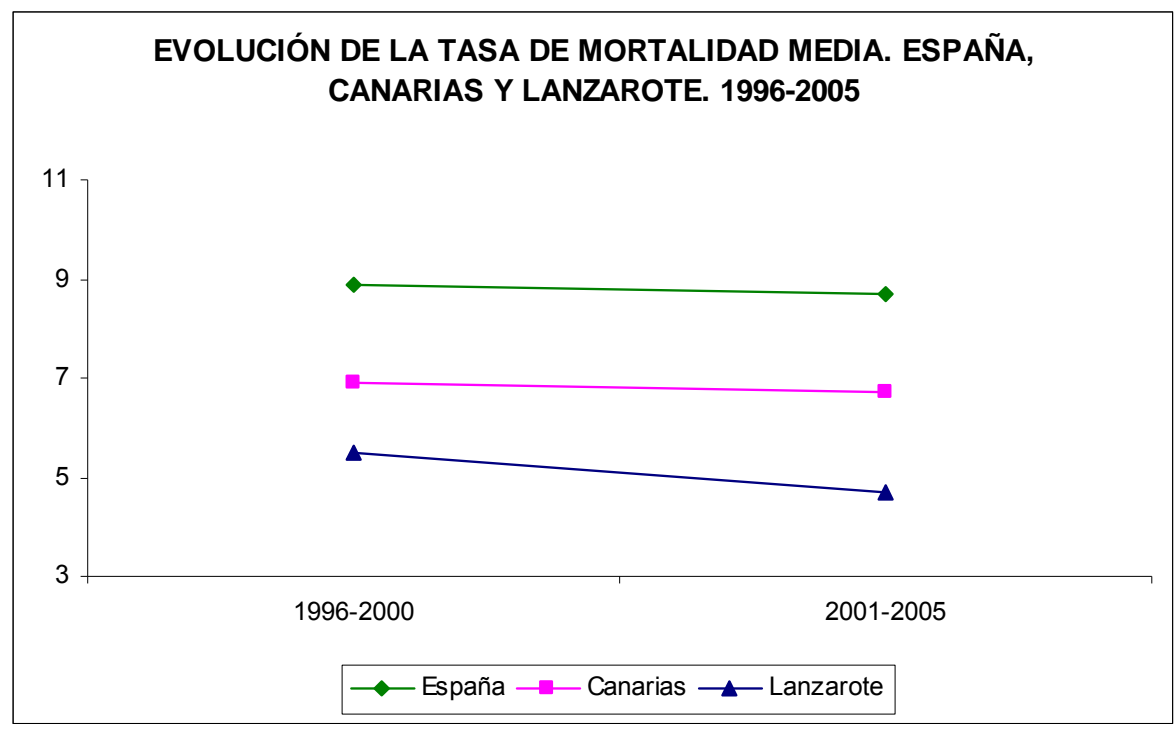

Fuente: Movimiento Natural de la Población. ISTAC e INE. Gráfico referido a la Tabla 155. Elaboración propia.

Teniendo en cuenta la similitud de las condiciones socio sanitarias de Lanzarote con su entorno, el motivo de esta baja tasa de mortalidad se debe fundamentalmente a un cuestión de estructura demográfica, pues la población de Lanzarote es más joven que la de Canarias y, a su vez, la población del archipiélago es más joven que en España ${ }^{197}$.

Tabla 156. Evolución del índice de juventud. España, Canarias y Lanzarote. 1996-2005 (\%)

\begin{tabular}{|l|r|r|r|}
\cline { 2 - 4 } \multicolumn{1}{c|}{} & ESPAÑA & CANARIAS & LANZAROTE \\
\hline \hline $\mathbf{1 9 9 6}$ & 16,04 & 19,11 & 20,37 \\
\hline $\mathbf{2 0 0 1}$ & 14,23 & 15,97 & 18,10 \\
\hline $\mathbf{2 0 0 6}$ & 14,20 & 15,20 & 17,08 \\
\hline
\end{tabular}

Fuente: "Población de 14 y más años". Encuesta de Población de Canarias, 1996; Censo de Población y Viviendas, 2001 y Padrón Municipal de Habitantes, 1996 y 2005. ISTAC e INE. Elaboración Propia.

Esta estructura demográfica insular, caracterizada por su juventud, presenta la siguiente forma en los diferentes años analizados en esta etapa: en 1996, casi el $75 \%$ de la población tiene menos de 45 años, proporción muy superior a la media de Canarias $(65,8)$ y de España (60\%), no obstante en el año 2005 este porcentaje se reduce en casi 3 puntos, de lo que se deriva el que la población de Lanzarote está envejeciendo ligeramente, pero no lo

197 Cabildo Insular de Lanzarote. (2009) "Morir en Lanzarote". Centro de Datos, 2009 (pp. 3). http://www.datosdelanzarote.com 
hace en los grupos de edades más avanzadas (más de 65 años) sino en los segmentos medios de la pirámide de población y más concretamente en el grupo entre 30 y 44 años cuyo peso ha pasado de ser el $25 \%$ en 1996 al casi $31 \%$ del total de la población del año 2005, porcentaje superior en casi 3 puntos al valor arrojado por el conjunto del archipiélago y superior en 6 puntos en relación a España. Es decir, la isla reduce el riesgo de muerte. Estas características pueden ser observadas con mayor detalle en la siguiente tabla.

Tabla 157. Estructura de la población por edad. Grandes grupos. España, Canarias y Lanzarote. 1996-2005 (\%)

\begin{tabular}{|c|c|c|c|c|c|c|c|c|c|}
\hline & \multicolumn{3}{|c|}{1.996} & \multicolumn{3}{|c|}{2.001} & \multicolumn{3}{|c|}{2.005} \\
\hline & Lanzarote & Canarias & España & Lanzarote & Canarias & España & Lanzarote & Canarias & España \\
\hline $0-14$ & 20,44 & 19,11 & 16,04 & 18,10 & 15,97 & 14,23 & 17,08 & 15,20 & 14,20 \\
\hline $15-24$ & 18,43 & 18,01 & 16,34 & 15,38 & 15,39 & 14,28 & 13,72 & 13,45 & 12,25 \\
\hline $25-44$ & 36,00 & 32,62 & 29,95 & 40,08 & 36,00 & 32,12 & 41,49 & 37,16 & 33,60 \\
\hline $45-64$ & 17,46 & 19,86 & 22,06 & 18,66 & 20,69 & 22,26 & 20,15 & 22,11 & 23,33 \\
\hline $65-84$ & 6,90 & 9,46 & 14,13 & 7,00 & 10,72 & 15,27 & 6,81 & 10,91 & 14,77 \\
\hline 85 y más & 0,77 & 0,95 & 1,49 & 0,79 & 1,23 & 1,85 & 0,74 & 1,17 & 1,85 \\
\hline
\end{tabular}

Fuente: "Población por edad". Encuesta de Población de Canarias, 1996; Padrón municipal de habitantes, 1996 y 2005; y Censo de Población y Viviendas, 2001. ISTAC e INE.

Gráfico 151. Estructura de la población por edad. Grandes grupos. Lanzarote. 1996-2005 (\%)

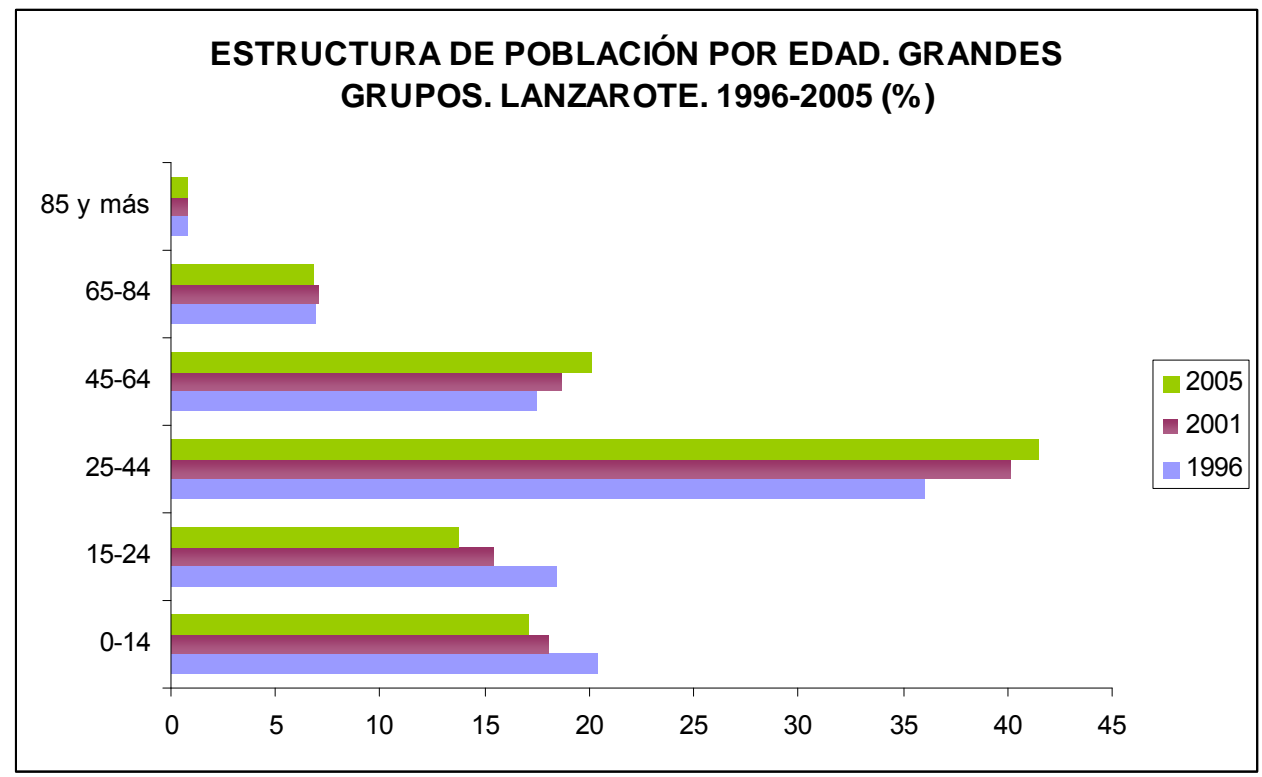

Fuente: Encuesta de Población de Canarias, 1996; Padrón municipal de habitantes, 1996 y 2005; y Censo de Población y Viviendas, 2001. ISTAC e INE. Referido a la Tabla 157. Elaboración propia. 
Gráfico 152. Estructura de la población por edad. Grandes grupos. España, Canarias y Lanzarote. 1996-2005 (\%)

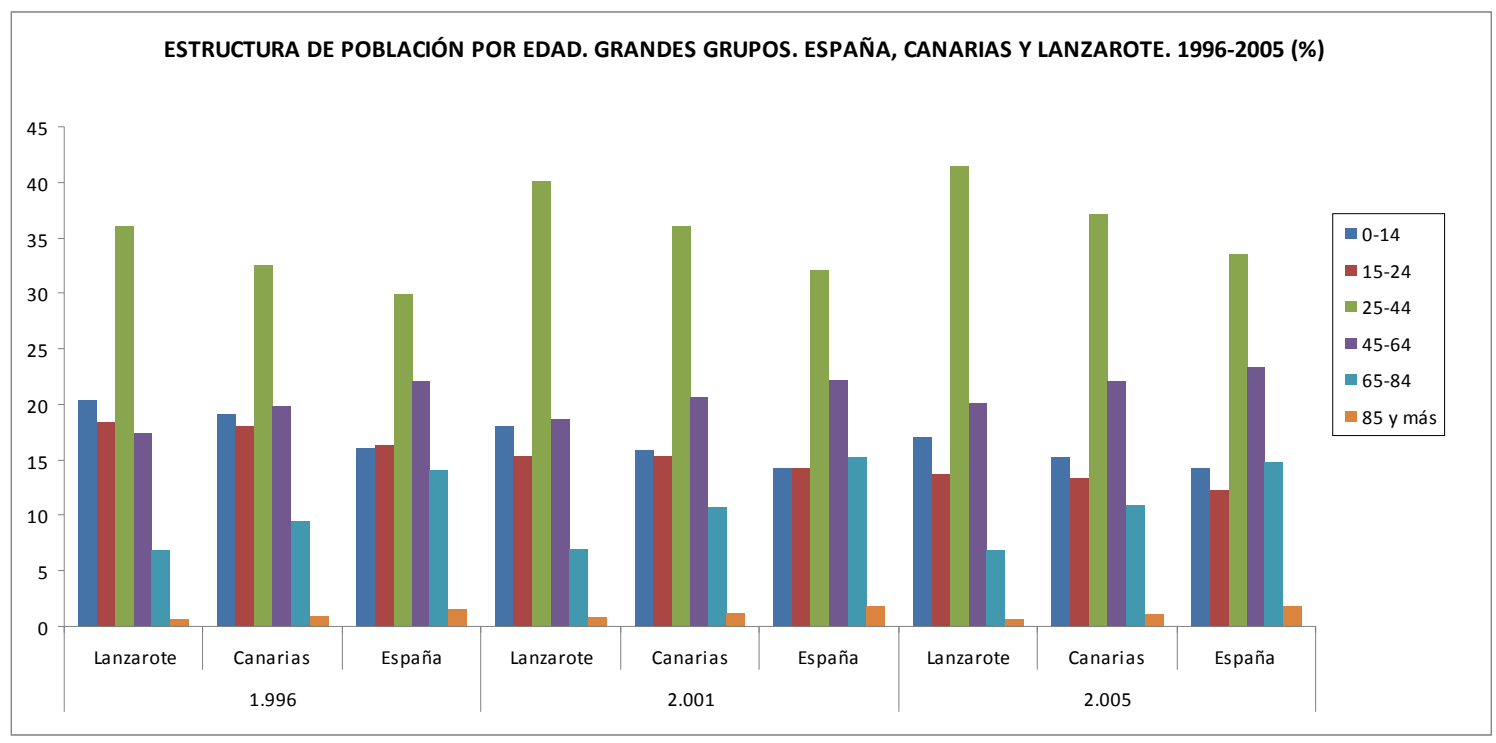

Fuente: Encuesta de Población de Canarias, 1996; Padrón municipal de habitantes, 1996 y 2005; y Censo de Población y Viviendas, 2001. ISTAC e INE. Referido a la Tabla 156. Elaboración propia

No cabe duda de que la inmigración es la causa principal de este fenómeno que incide en la estructura demográfica insular. Y que no sólo explica la mortalidad, sino también las altas tasas de natalidad que han venido caracterizando a Lanzarote con respecto a Canarias y España, derivadas de la constante incorporación de población externa en edad de formar familias.

Tabla 158. Evolución de las tasas quinquenales de natalidad. España, Canarias y Lanzarote. 1996-1985 (\%).

\begin{tabular}{|l||c|c|c||}
\cline { 2 - 4 } \multicolumn{1}{c|}{} & ESPAÑA & CANARIAS & LANZAROTE \\
\hline $\mathbf{1 9 9 6 - 2 0 0 0}$ & 9,4 & 10,7 & 13,4 \\
\cline { 2 - 4 } $\mathbf{2 0 0 1 - 2 0 0 5}$ & 10,3 & 10,6 & 13,2 \\
\hline
\end{tabular}

Fuente: Anuario Estadístico de España 1966: "Clasificaciones censales. Población calculada a 1 de julio de cada año". INE; Para 1986 a 1995: Registro Civil. González, A. 1993, pp. 470; Para 1996-2005: Movimiento Natural de la Población. INE; "Nacimientos". Base de datos Insular y Municipal. ISTAC. Elaboración propia. 
Gráfico 153. Evolución de la tasa de natalidad media. España, Canarias y Lanzarote. 1996-2005

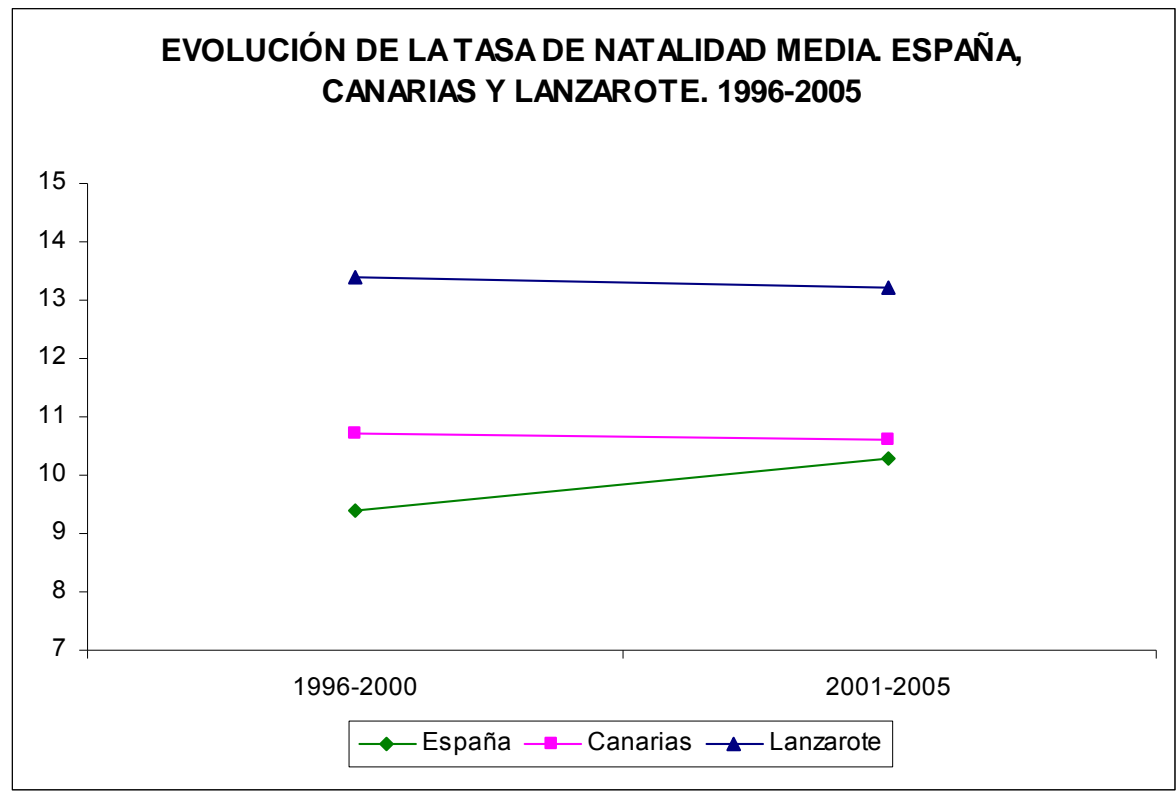

Fuente: Movimiento Natural de la Población. ISTAC e INE. Gráfico referido a la Tabla 158. Elaboración propia.

La isla registra, en 1996 y el año 2005, el 39,3\% y el 40,5\% respectivamente, de su población en edades comprendidas entre los 20 y 39 años. Cohorte de edad que concentra más del $90 \%$ del total de nacimientos que se producen.

Tabla 159. Población entre 20 y 39 años de edad. España, Canarias y Lanzarote. 1996-2005 (\%).

\begin{tabular}{|l|c|c|c|}
\cline { 2 - 4 } \multicolumn{1}{c|}{} & $\mathbf{1 9 9 6}$ & $\mathbf{2 0 0 1}$ & $\mathbf{2 0 0 5}$ \\
\hline ESPAÑA & 31,9 & 32,8 & 32,7 \\
\hline CANARIAS & 35,7 & 37,1 & 36,1 \\
\hline LANZAROTE & 39,3 & 40,8 & 40,5 \\
\hline
\end{tabular}

Fuente: "Población por edad". Encuesta de Población de Canarias, 1996; Padrón municipal de habitantes, 1996 y 2005. Y Censo de Población y Viviendas, 2001. ISTAC e INE.

Por todo lo descrito, el crecimiento vegetativo de Lanzarote seguirá elevado, al igual que en las etapas anteriores, por encima de los valores registrados en Canarias y España, pues se ha ido reduciendo la tasa de mortalidad, mientras que la natalidad mantiene tasas elevadas. 
Tabla 160. Evolución de las tasas quinquenales de crecimiento vegetativo. España, Canarias y Lanzarote. 1996-2005 (\%o).

\begin{tabular}{|l||c|c|c|}
\cline { 2 - 4 } \multicolumn{1}{c|}{} & ESPAÑA & CANARIAS & LANZAROTE \\
\hline $\mathbf{1 9 9 6 - 2 0 0 0}$ & 0,5 & 3,8 & 7,9 \\
\hline $\mathbf{2 0 0 1 - 2 0 0 5}$ & 1,6 & 3,9 & 8,5 \\
\hline
\end{tabular}

Nota: La Tasa de crecimiento vegetativo es la diferencia entre la Tasa de Natalidad y la de Mortalidad.

Fuente: Elaboración propia a partir de las tasas de natalidad y mortalidad para los diferentes quinquenios analizados

Con respecto al archipiélago, el conjunto de España ha reducido su distancia en relación al crecimiento natural, ya que ha incrementado su tasa de natalidad entre el año 2001 y 2005 y reducido su tasa de mortalidad, pues el país abre un periodo de incorporación de población externa con fines principalmente laborales, que lo hacen rejuvenecer.

Gráfico 154. Evolución del crecimiento vegetativo. España, Canarias y Lanzarote. 1996-2005

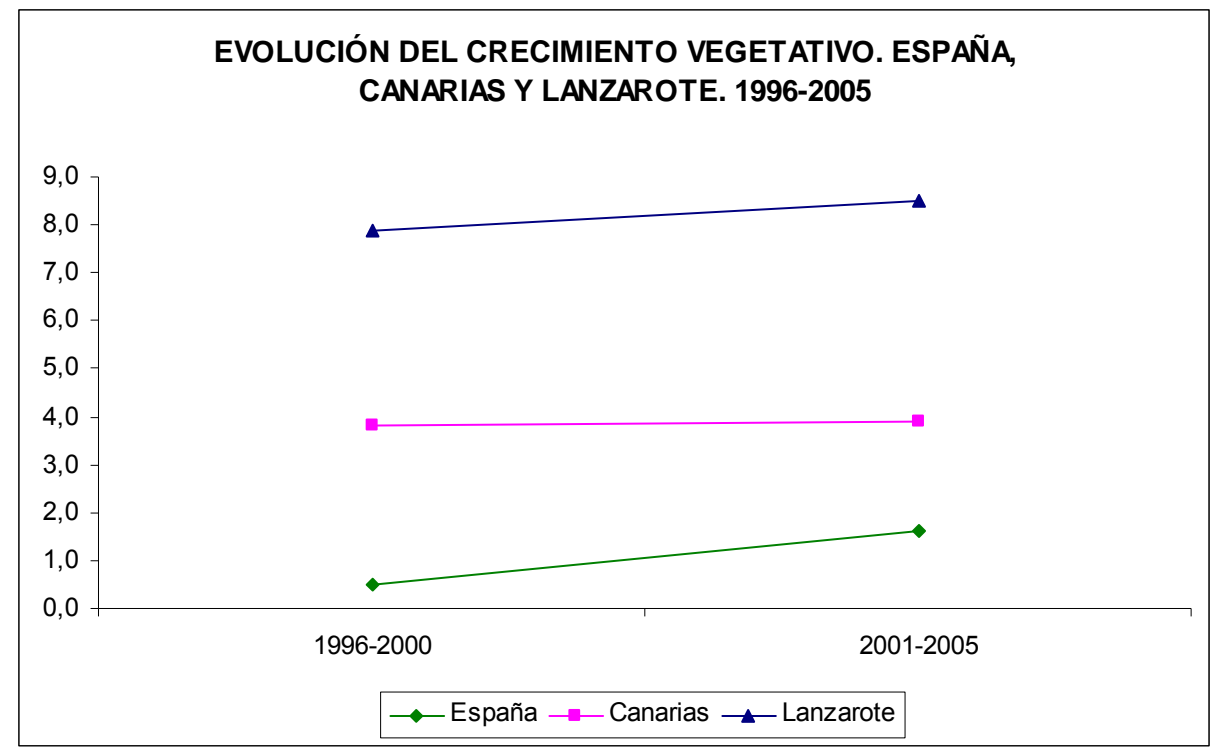

Fuente: Movimiento Natural de la Población. ISTAC e INE. Gráfico referido a la Tabla 160. Elaboración propia.

El incremento de la población insular, que en este periodo se sitúa entre el $33 \%$ y el $23 \%$, no se explica a través de su saldo natural, sino de la incorporación de población externa, que ha ido creciendo constantemente desde 1970, modificando la estructura demográfica de Lanzarote, aportando juventud y creando nuevas familias.

b.- Los factores exógenos. Las migraciones

EI s. XXI comienza con un fuerte crecimiento porcentual de la inmigración que supone en 2001 el $59 \%$ de la población residente, un incremento cercano al $140 \%$ con respecto a 1996 . De nuevo vive la isla una oleada de entradas de mano de obra, similar a la acontecida entre 
1981 y 1986 (143,9\%), el incremento de la presión demográfica es enorme. Estamos ante un patrón de crecimiento del pasado.

Tabla 161. Población residente según lugar de nacimiento. Inmigrantes netos. Lanzarote. 19962006.

\begin{tabular}{|c|c|c|c|c|c|c|c|c|c|c|c|}
\hline \multirow{2}{*}{ AÑO } & \multicolumn{2}{|c|}{$\begin{array}{l}\text { EN OTRA } \\
\text { ISLA }\end{array}$} & \multicolumn{2}{|c|}{$\begin{array}{c}\text { EN OTRA } \\
\text { CCAA }\end{array}$} & \multicolumn{2}{|c|}{$\begin{array}{l}\text { EN OTRO } \\
\text { PAÍS }\end{array}$} & \multicolumn{3}{|c|}{ INMIGRANTES NETOS* } & \multirow{2}{*}{$\begin{array}{l}\text { POBLACIÓN } \\
\text { AUTÓCTONA }\end{array}$} & \multirow{2}{*}{$\begin{array}{l}\text { POBLACIÓN } \\
\text { TOTAL }\end{array}$} \\
\hline & Total & $\%$ & Total & $\%$ & Total & $\%$ & TOTAL & $\%$ & $\begin{array}{l}\text { Incremento } \\
\text { quinquenal } \\
(\%)\end{array}$ & & \\
\hline 1996 & 8.012 & 31,5 & 12.500 & 49,2 & 4.893 & 19,3 & 25.405 & 32,8 & 56,5 & 51.974 & 77.379 \\
\hline 2001 & 29.324 & 48,2 & 18.098 & 29,8 & 13.355 & 22,0 & 60.777 & 59,0 & 139,2 & 42.267 & 103.044 \\
\hline 2006 & 10.963 & 16,7 & 21.920 & 33,4 & 32.676 & 49,8 & 65.559 & 51,4 & 7,9 & 61.898 & 127.457 \\
\hline $\begin{array}{c}\text { Incremento } \\
1996-2006 \\
(\%)\end{array}$ & \multicolumn{2}{|c|}{36,8} & \multicolumn{2}{|c|}{75,4} & \multicolumn{2}{|c|}{567,8} & \multicolumn{3}{|c|}{158,1} & 19,1 & 64,7 \\
\hline
\end{tabular}

$\left(^{*}\right)$ Los porcentajes han sido calculados sobre la población total insular que existe en el año indicado.

Fuente: Para 1996: "Población de derecho según lugar de nacimiento. Lanzarote. 1996" y Encuesta de Población de Canarias, 1996. ISTAC. Para 2001: "Relación entre el lugar de nacimiento y el lugar de residencia. Lanzarote". Censo de Población. 2001. ISTAC; Para 2006: Padrón municipal de habitantes a 1-1-2006, "Población por lugar de nacimiento, Lanzarote" (ISTAC/INE). Elaboración propia.

Esta explosión demográfica que arroja valores de crecimiento similares a los registrados en la etapa de implantación y consolidación de la actividad turística en la isla (1970-1986), es consecuencia del anuncio de la puesta en marcha de una moratoria turística, pues provocó una fiebre de la construcción antes de la entrada en vigor de la nueva limitación. Tal y como señalan estudios técnicos publicados por el Cabildo de Lanzarote "cualquier modificación de planeamiento supone un sobre impulso inicial de la edificación (el promotor intenta cubrirse frente a un déficit de aprovechamiento) ${ }^{198 "}$ Con ello se vuelve a producir un efecto llamada de trabajadores, derivado de la ampliación de la oferta entre el año 1997 y $2002^{199}$.

Con la revisión del PIOT vigente a partir del año 2001, el último quinquenio de análisis (2001-2006) será distinto en este sentido, puesto que el incremento de la población inmigrante se va a reducir de forma notable, sólo crece un $8 \%$, aunque el peso de este contingente de población seguirá suponiendo más de la mitad de la población residente $(51,4 \%)$.

198 Díaz Feria, L.; Martín Rosa, M.A. y Laiz Herreras, N. (2001). "Lanzarote 2001. Análisis de la evolución reciente de la edificación y el turismo". Excmo. Cabildo Insular de Lanzarote. 2001 (pp. 4)

199 "(...) Entre las fases de proyecto y edificación, la industria turística ha concentrado en cinco años (aproximadamente entre 1997-2002) la programación estimada para diez (...) aproximándose al cumplimiento del límite decenal, (...) no se ha alcanzado el ritmo tranquilo de edificación que también se pretendía, (...) se ha producido una aceleración edificatoria estimable en un margen de 2.000-3.000 plazas concentradas en cinco años". Díaz Feria, L. y otros. 2001, (pp. 5) 
Gráfico 155. Evolución de la inmigración. Lanzarote. 1996-2006

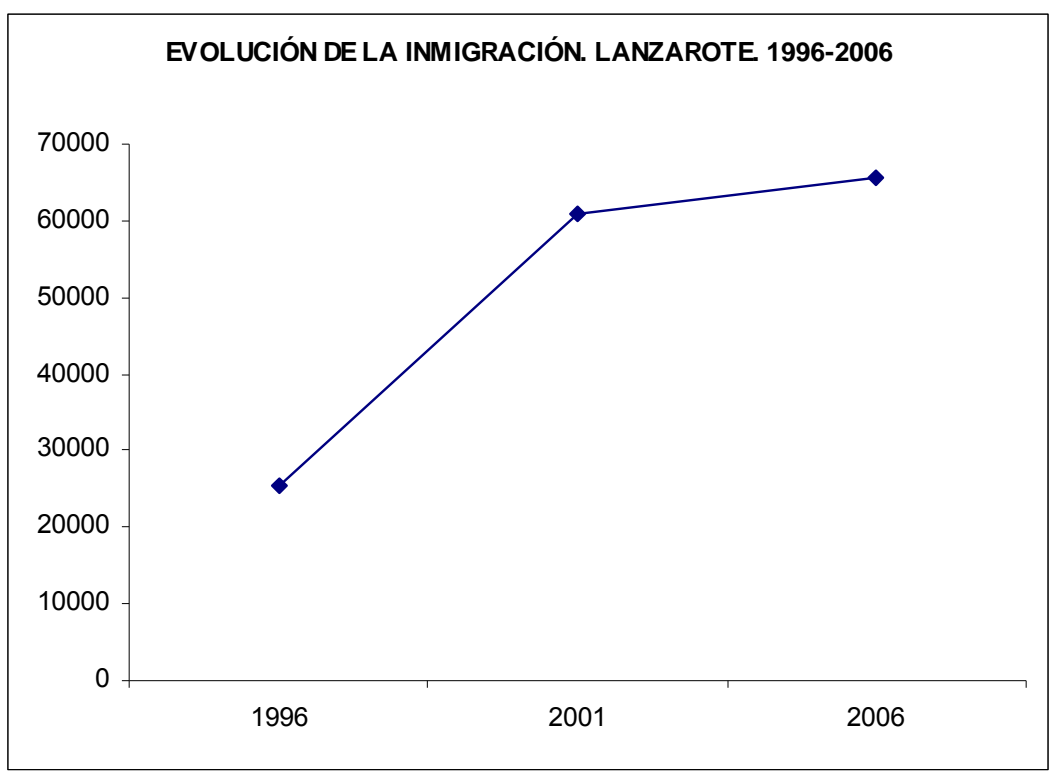

Fuente: Encuesta de Población de Canarias, 1996. ISTAC; Censo de Población. 2001. ISTAC y Padrón municipal de habitantes 2006, explotación del ISTAC. INE). Gráfico referido a la Tabla 161. Elaboración propia.

La etapa se caracteriza por la recuperación de la inmigración de origen canario hacia Lanzarote, situándose en el $48 \%$ del total de inmigrantes recibidos (2001). Aunque esta situación no se va a mantener. A mitad de la primera década de este siglo (2006) la inmigración protagonista será la que tiene por origen otros países, alcanzando un peso de casi el $50 \%$ del total de inmigrantes netos que residen en la isla.

Gráfico 156. Evolución de la inmigración según origen. Lanzarote. 1996-2006 (\%)

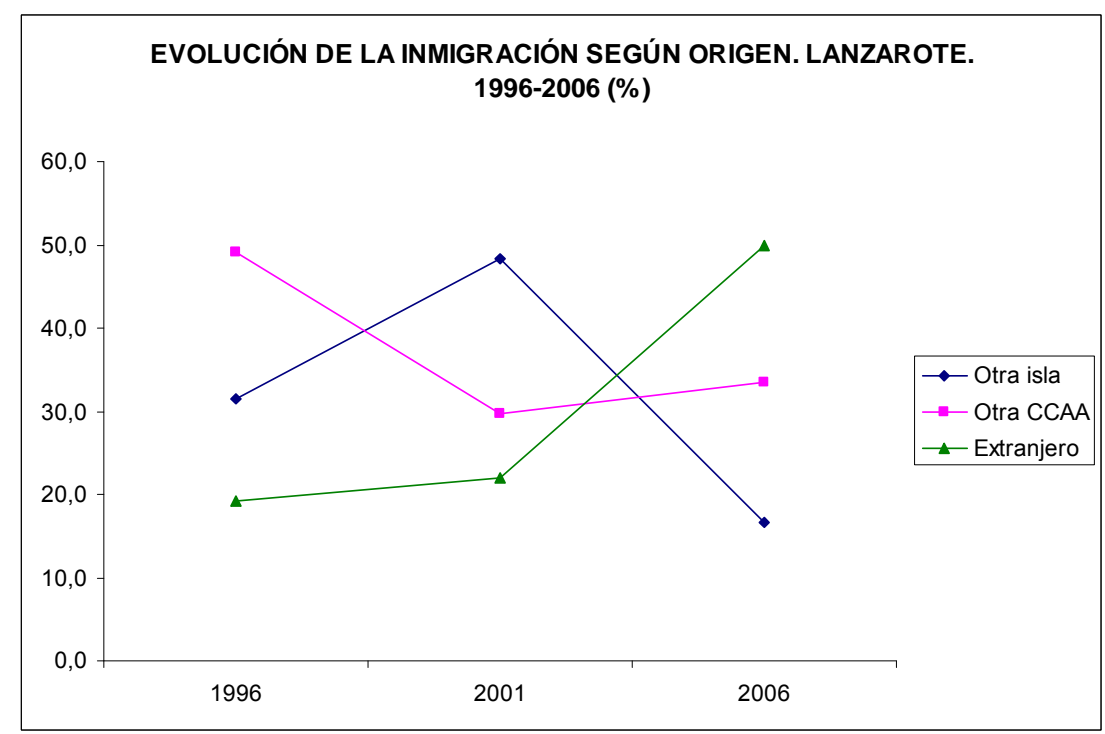

Fuente: Encuesta de Población de Canarias, 1996. ISTAC; Censo de Población. 2001. ISTAC y Padrón municipal de habitantes 2006, explotación del ISTAC. INE). Gráfico referido a la Tabla 160. Elaboración propia. 
En relación a la población extranjera residente señalamos los siguientes aspectos evolutivos:

(a) El periodo comienza con un alto volumen de población extranjera residente procedente de otros países de Europa (56\%), pero este volumen irá reduciéndose con la entrada del nuevo siglo hasta el 38\%; (b) Se dará paso a un notable incremento de la inmigración procedente de América (1.108,7\% desde que comienza la etapa hasta que termina), que supone al final del periodo el $40 \%$ de los extranjeros residentes (principalmente procedentes de América del Sur, del orden del $84 \%$ en 2006), reduciéndose los europeos al $38 \%$; (c) La inmigración de origen africano se mantendrá entre el $15 \%$ y el $16 \%$, del total de residentes extranjeros en la isla, durante toda la etapa.

Tabla 162. Población según lugar de nacimiento. Inmigración externa neta. Lanzarote. 19962006

\begin{tabular}{||r||r|r||r|r|r|r||r|r|r||}
\cline { 2 - 10 } \multicolumn{1}{c||}{} & \multicolumn{5}{c||}{ Valores absolutos y relativos } & \multicolumn{3}{c||}{ Incrementos (\%) } \\
\hline \hline Origen & 1996 & $\%$ & 2001 & $\%$ & 2006 & $\%$ & $1996-2001$ & $\mathbf{2 0 0 1 - 2 0 0 6}$ & $1996-2006$ \\
\hline \hline EUROPA & 2.736 & 55,92 & 6.637 & 48,77 & 12.476 & 38,18 & 142,58 & 87,98 & 355,99 \\
\hline África & 772 & 15,78 & 1.949 & 14,32 & 5.075 & 15,53 & 152,46 & 160,39 & 557,38 \\
\hline América & 1.086 & 22,19 & 4.234 & 31,11 & 13.126 & 40,17 & 289,87 & 210,01 & $1.108,66$ \\
\hline Asia & 290 & 5,93 & 769 & 5,65 & 1.971 & 6,03 & 165,17 & 156,31 & 579,66 \\
\hline Otros & 9 & 0,18 & 21 & 0,15 & 28 & 0,09 & 133,33 & 33,33 & 211,11 \\
\hline TOTAL & 4.893 & 13.610 & \multicolumn{3}{|c|}{32.676} & & &
\end{tabular}

Fuente: "Población según lugar de nacimiento, 1996". Encuesta de Población de Canarias, 1996. ISTAC; "Población por sexo y lugar de nacimiento, 2001 y 2006". Padrón Municipal de Habitantes, 2001 y 2006. ISTAC. 
Gráfico 157. Evolución de la población residente según lugar de nacimiento. Extranjeros. Lanzarote. 1996-2006 (\%)

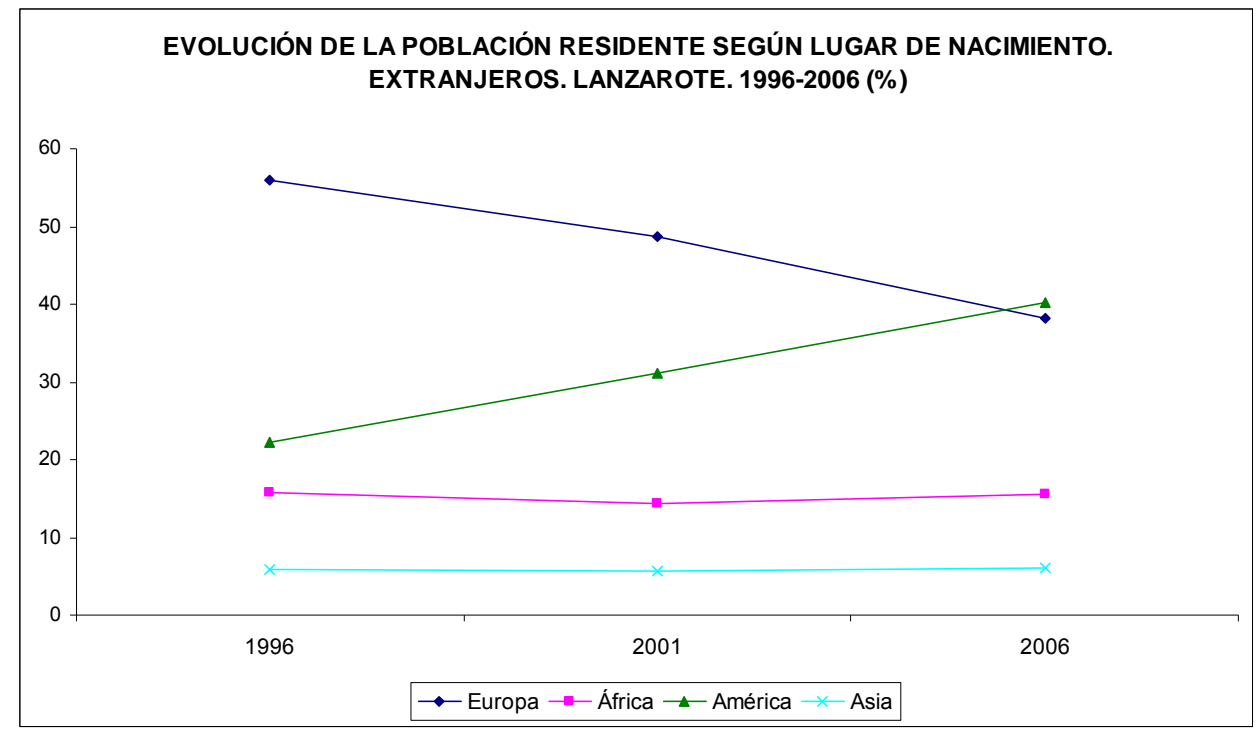

Fuente: Encuesta de Población de Canarias, 1996. ISTAC; Padrón Municipal de Habitantes, 2001 y 2006 . ISTAC e INE. Gráfico referido a la Tabla 162. Elaboración propia.

Debemos tener en cuenta que Canarias no se caracterizan por una inmigración perecedera, sino que la población que llega externa, tiende a estabilizarse y no retornar. A ello se añade la pluralidad de orígenes que acoge, pues hay representación de todos los continentes, con las dificultades para la integración social de los mismos que esto entraña, derivada de la diversidad sociocultural, que supone todo un reto para la isla.

Los diferentes estudios realizados acerca de la localización de la población inmigrante en el mercado laboral, tanto por el Instituto de Estadística de Canarias (ISTAC) como por el Observatorio de Empleo de Canarias (OBECAN), señalan que el empleo de éstos está vinculado con el desarrollo de actividades relacionadas con el turismo. La Encuesta de Población de Canarias, realizada en 1996 (ISTAC, 1999, pp. 15-16), recoge, por un lado, que en el conjunto de archipiélago "9 de cada diez extranjeros trabajan en el sector servicios, porcentaje muy superior al que se da en el resto del Estado español, que se sitúa alrededor del 63,7 \% de media", seguido de la construcción y que además la población ocupada extranjera "se integran en un mercado laboral segmentado en buena medida en función de su origen" ${ }^{200}$, es decir, el nivel de los puestos de trabajo que ocupan varían en relación a que procedan de países más o menos desarrollados.

200 ISTAC (1999). "Encuesta del población. Canarias, 1996. Población extranjera”. Gobierno de Canarias. Diciembre de 1999. http://www.datosdelanzarote.com. 
Los efectos positivos y negativos que esta realidad conlleva para la sostenibilidad del Estado de Bienestar insular, en las diferentes áreas analizadas se tratarán en los epígrafes correspondientes.

\section{c.- La población autóctona}

En el año 1996, los nacidos en la isla y que continúan residiendo en ella suponen el $67,2 \%$ casi la cuarta parte de la población residente ha nacido fuera -, para reducirse drásticamente a comienzos del nuevo siglo, arrojando en 2001 una cifra de población autóctona del $41 \%$, es decir, en cinco años (1996 y 2001) experimenta una rápida y elevada caída próxima al 19\%, derivada de la nueva entrada de población externa que se produce, como hemos señalado anteriormente, tras el incremento de la actividad en la construcción a consecuencia del anuncio de la puesta en marcha de la llamada "moratoria turística", que limita el crecimiento de la oferta de nuevas plazas de alojamiento.

Tabla 163. Población inmigrante y población autóctona. Absolutos y relativos. Lanzarote. 19861996

\begin{tabular}{|c|c|c|c|c|c|c|}
\hline \multirow{2}{*}{ AÑO } & \multirow{2}{*}{$\begin{array}{l}\text { POBLACIÓN } \\
\text { TOTAL }\end{array}$} & \multicolumn{2}{|c|}{ INMIGRACIÓN TOTAL } & \multicolumn{3}{|c|}{ POBLACIÓN AUTÓCTONA } \\
\hline & & Absolutos & $\%$ & Absolutos & $\%$ & $\begin{array}{c}\text { Incremento } \\
\text { quinquenal (\%) }\end{array}$ \\
\hline 1996 & 77.379 & 25.405 & 32,8 & 51.974 & 67,2 & \\
\hline 2001 & 103.044 & 60.777 & 59,0 & 42.267 & 41,0 & $-18,7$ \\
\hline 2006 & 127.457 & 65.559 & 51,4 & 61.898 & 48,6 & 46,4 \\
\hline
\end{tabular}

Fuente: Elaboración propia a partir de la población por lugar de nacimiento. INE e ISTAC.

La población autóctona, en términos relativos, se recuperará levemente al final de la etapa a consecuencia de la reducción del crecimiento del número de residentes nacidos fuera de la isla (alóctonos), pues entre el año 2001 y 2006 sólo crecen aproximadamente un 8\%, periodo de vigencia de la "Moratoria". Así, en el final de la etapa, los autóctonos (o nacidos en la isla) tienen un peso relativo del $48,6 \%$, menos de la mitad de la población residente en la isla. La distancia relativa entre las dos poblaciones (autóctonos y alóctonos) se ha reducido considerablemente. 
Gráfico 158. Evolución de la población autóctona y alóctona. Lanzarote. 1996-2006 (\%)

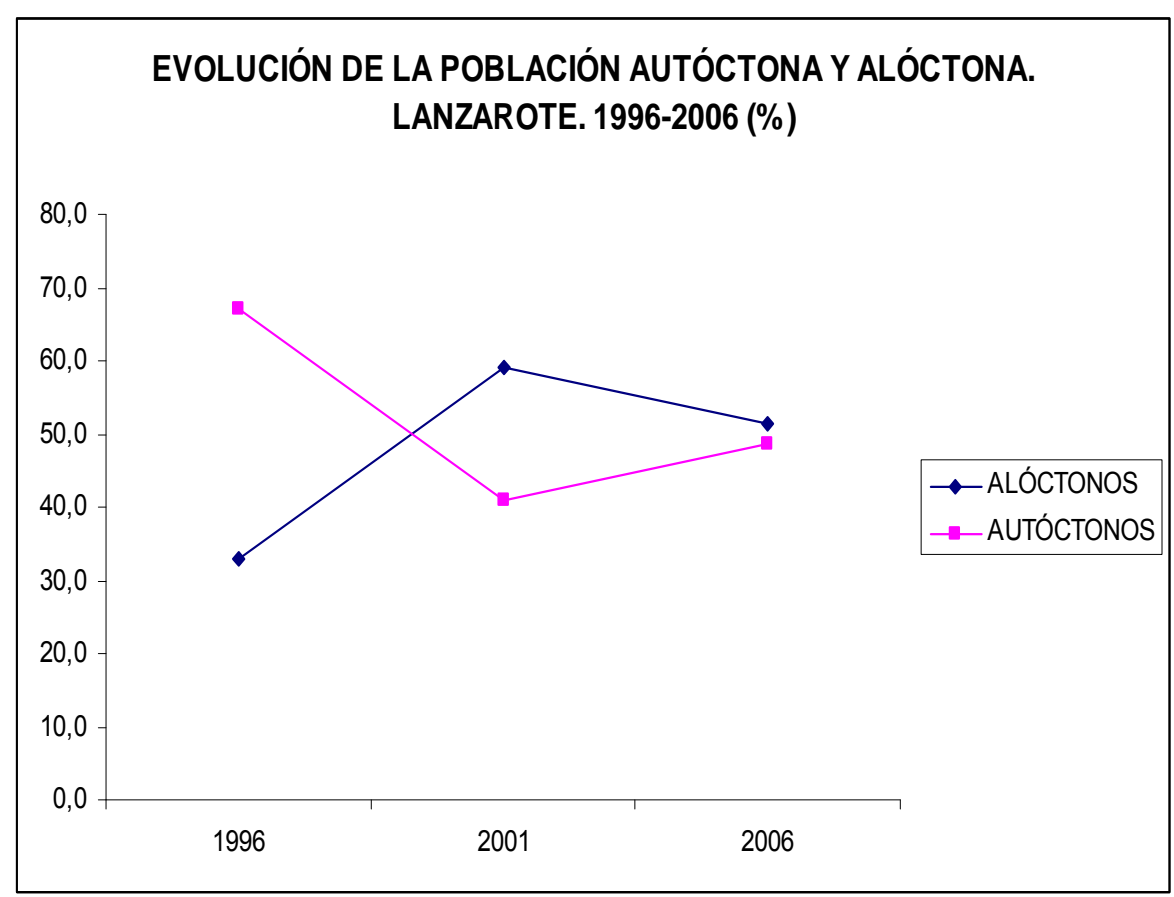

Fuente: Elaboración propia a partir de la población por lugar de nacimiento. INE e ISTAC. Expresión gráfica de las Tablas 161 y 163.

Gráfico 159. Incremento interperiodo de la población autóctona y alóctona. Lanzarote. 1996-2006 (\%)

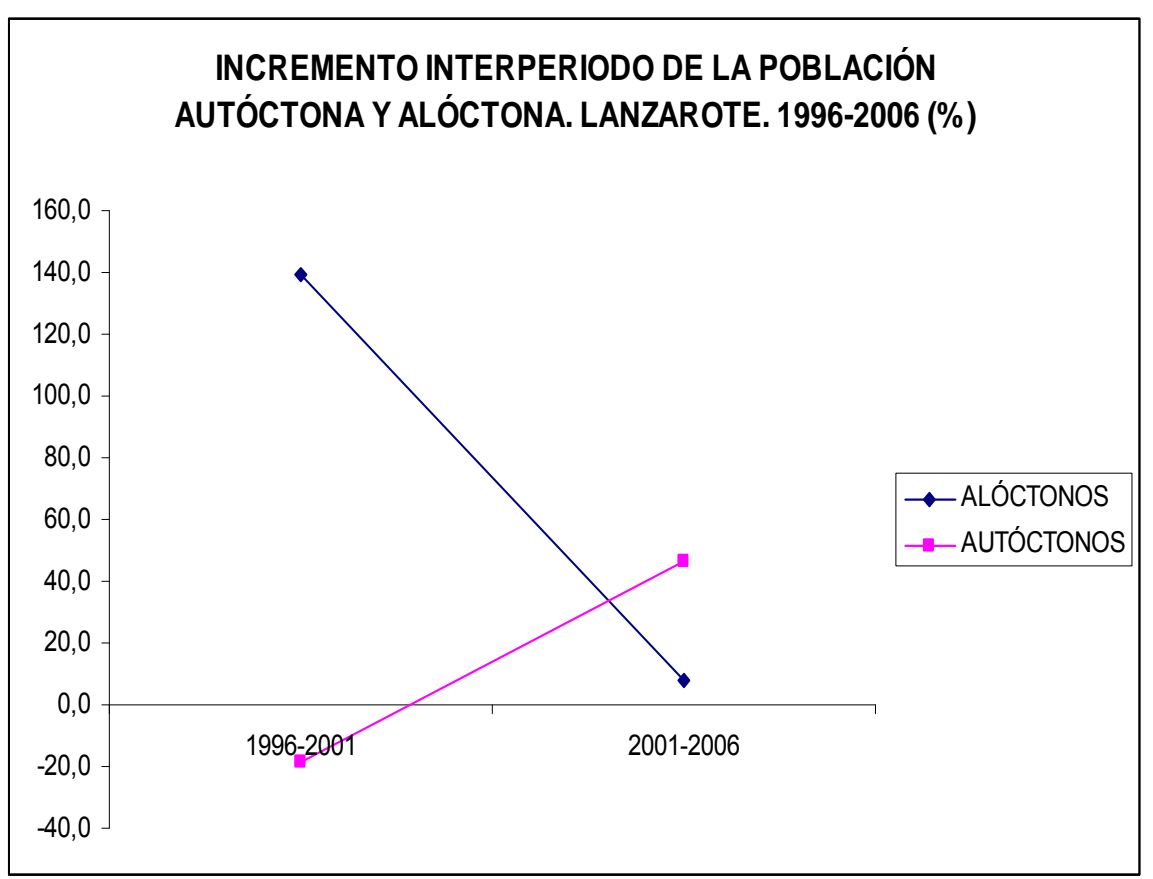

Fuente: Elaboración propia a partir de la población por lugar de nacimiento. INE e ISTAC. Expresión gráfica de las Tablas 161 y 163.

El control del crecimiento de la oferta de alojamiento turística en Lanzarote, revertirá positivamente en la reducción de los desequilibrios demográficos. 


\section{d.- Autóctonos, alóctonos y turistas}

La explosión en el crecimiento de la población en esta etapa, y las variaciones en los pesos relativos entre autóctonos y alóctonos, anteriormente descritos, se confirman a través del ratio (al/at), que señala entre 1996 y 2001, el paso de una relación de 489 alóctonos (inmigrantes) por mil autóctonos a 1.438, explicado por la causa descrita anteriormente (el anuncio de la modificación del planeamiento supone un sobre impulso inicial de la edificación, atrayendo personas externas por la nueva demanda de manos de obra). Un enorme salto cuantitativo, que se reduce al final de la etapa igualándose prácticamente la relación.

Tabla 164. Relación entre autóctonos, alóctonos y turistas. Lanzarote. 1996-2006

\begin{tabular}{||c|c|c|c|c|c|c|c||}
\hline AÑo & Residentes & Autóctonos & Alóctonos & $\begin{array}{c}\text { Turistas } \\
\text { equivalente al día }\end{array}$ & Hab/día & al/at & fr/at \\
\hline \hline $\mathbf{1 9 9 6}$ & 77.379 & 51.974 & 25.405 & 48.686 & 126.065 & 488,80 & $1.425,54$ \\
\hline $\mathbf{2 0 0 1}$ & 103.044 & 42.267 & 60.777 & 44.603 & 147.647 & $1.437,93$ & $2.493,20$ \\
\hline $\mathbf{2 0 0 6}$ & 127.457 & 61.898 & 65.559 & 37.522 & 164.979 & $1.059,15$ & $1.665,34$ \\
\hline
\end{tabular}

* Calculado por cada mil autóctonos.

Fuente: Residentes. Población registrada (Censos y Padrones); Habitantes al día: suma de autóctonos (at), alóctonos (al)) y turistas; Alóctonos más turistas equivalentes al día=población foránea (fr). Elaboración propia.

Gráfico 160. Evolución de los ratios alóctonos/autóctonos y foráneos/autóctonos. Lanzarote. 1996-2006

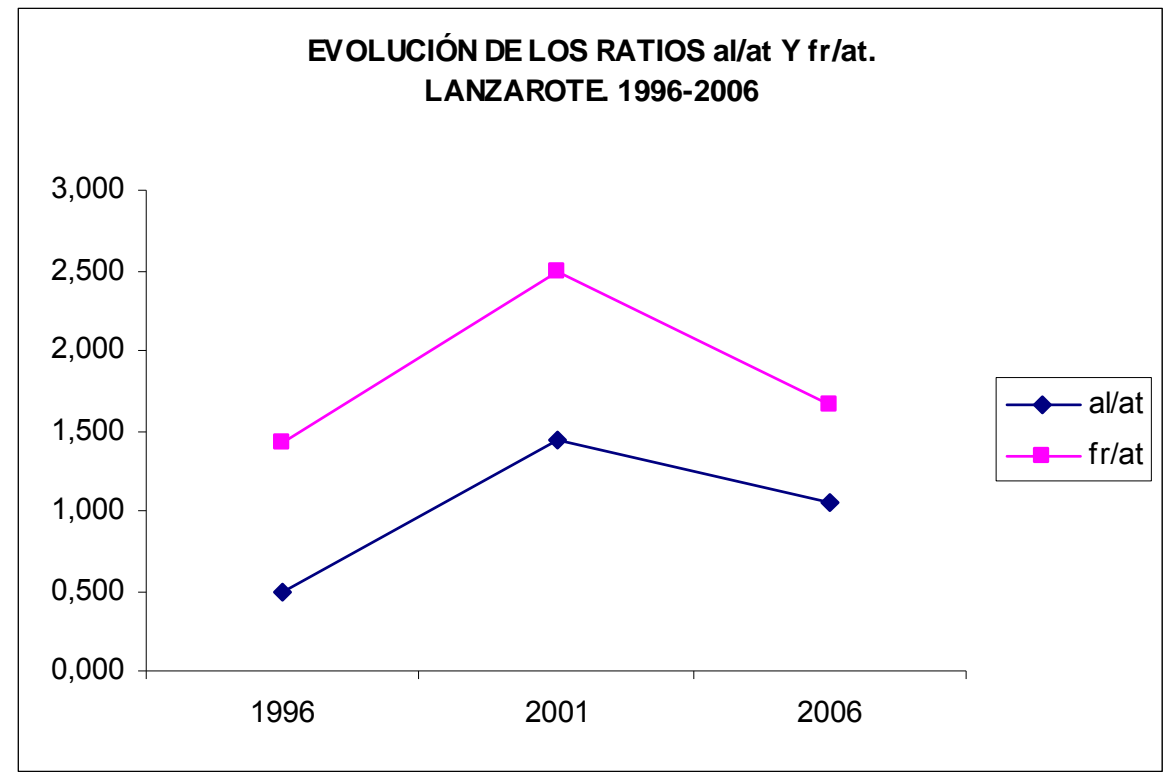

Fuente: Indicadores de relación entre autóctonos y foráneos calculados en la Tabla 164. Elaboración propia. 
Si tenemos en cuenta además la población foránea (alóctonos y turistas equivalentes diarios estimados) que soporta, el desequilibrio demográfico que alcanza la isla en la última década de este análisis es muy notable, y dista mucho de los observados en las etapas anteriores. El año 2001 es el momento de mayor distancia entre la población autóctona y la foránea (2.493 foráneos por mil autóctonos), pues creció la inmigración y la demanda turística (turistas equivalentes diarios) por los motivos alegados anteriormente. Esta situación no durará demasiado pues, en el año 2006 se detecta una crisis de recepción turística unida a la limitación del crecimiento de nueva oferta turística que imprime en la Isla la reforma del PIOT o Moratoria puesta en marcha al comienzo de la década. Se reduce el número de turistas equivalentes diarios y el crecimiento de la inmigración hasta estimaciones de 1.665 foráneos por mil autóctonos.

Gráfico 161. Evolución de la población foránea y autóctona. Lanzarote. 1996-2006

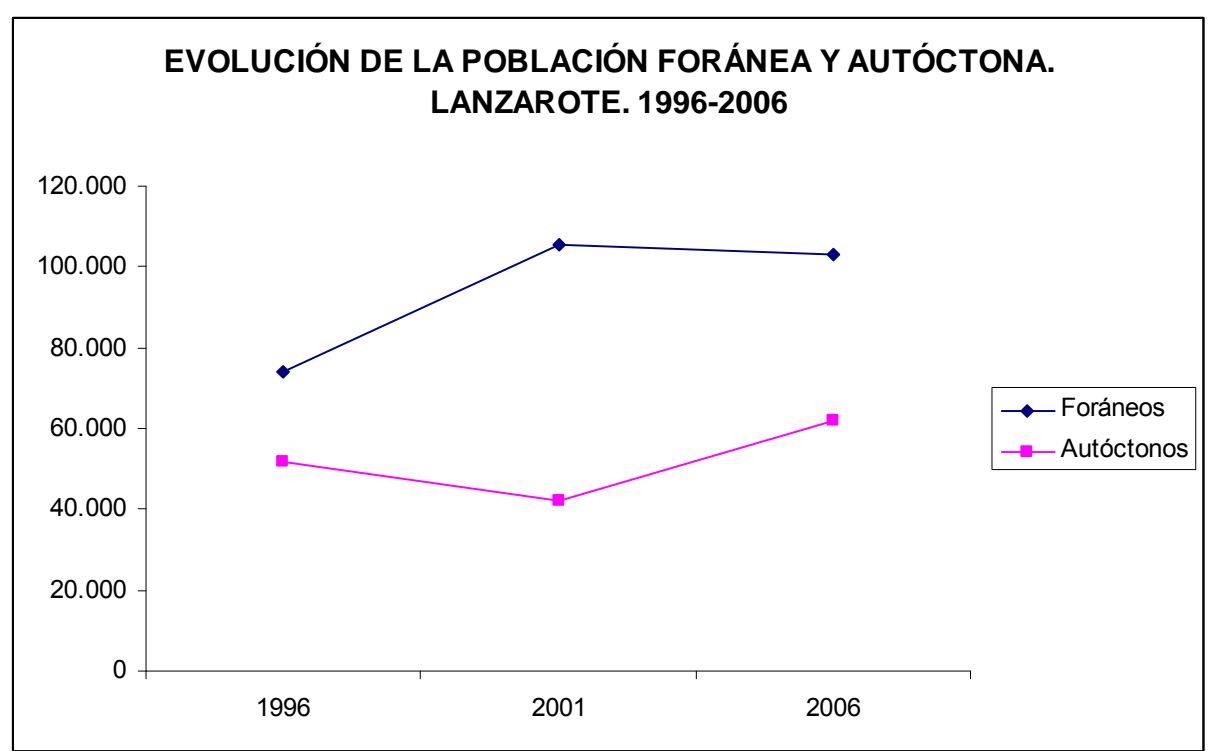

Fuente: Padrón municipal de habitantes. Explotación del ISTAC; Estimación de los turistas equivalentes diarios. Elaboración propia a partir de la Tabla 163.

\subsubsection{2.- CONCLUSIONES}

Esta tercera etapa, comprendida entre 1996 y el año 2006, en la que la isla de Lanzarote es un destino turístico maduro y ha asumido compromisos hacia la sostenibilidad, presenta dinámicas demográficas de fuerte crecimiento, similares a las ya vividas en su primera etapa de desarrollo y consolidación de la actividad turística, principalmente en la década de los años ochenta, y que sigue siendo explicada por incorporación de población externa.

La necesidad de moderar la presión humana sobre el territorio, alegada desde documentos oficiales (como la Estrategia Lanzarote en la Biosfera) no parece haberse alcanzado, a pesar de la puesta en marcha de cambios en la ordenación del territorio insular que limitan 
no sólo la oferta de nueva planta de alojamiento turístico sino también su ritmo de crecimiento, pues los desequilibrios demográficos seguirán estando presentes, de forma notable, en la relación entre autóctonos y foráneos.

Este periodo tiene dos etapas diferentes en relación al crecimiento y equilibrio demográfico:

1. La primera comprendida entre 1996 y 2001: nueva explosión demográfica. Más intensa que ninguna de las anteriormente vividas, derivada de una fuerte corriente de entrada de inmigrantes, que observan un incremento similar al acontecido entre 1981 y 1986. La dinámica demográfica inmigratoria del pasado se repite antes de que acabe el siglo, pues el anuncio de nueva limitación en el crecimiento de nueva planta de alojamiento turístico, a través de la llamada "Moratoria", supuso un estallido de la actividad de la construcción antes de su entrada en vigor (pues el promotor intenta cubrirse ante la posibilidad de un déficit de aprovechamiento). Inicialmente tuvo el efecto contrario al esperado. Este crecimiento no tiene parangón con respecto al resto del archipiélago y a España.

Ello tiene como consecuencia un fuerte desequilibrio poblacional derivado de la brusca reducción de la población autóctona, que si bien el proceso que ha seguido ha sido de descenso, ahora cae bruscamente, frente al cómputo de población residente insular. Si a ello añadimos el número de turistas diarios, que ha crecido en este quinquenio, supone la existencia de más de 2 foráneos por cada autóctono.

2. La segunda etapa comprendida entre 2001 y 2006 caracterizada también por el crecimiento de la población, pero a un ritmo más moderado que el quinquenio anterior. Esta moderación del crecimiento tiene su explicación en un hecho histórico en la isla, nunca antes registrado, que resulta del fuerte descenso del incremento porcentual de la inmigración a lo largo del quinquenio, que aunque crece ya no lo hace a los ritmos del pasado, pues la entrada en vigor de la Moratoria limita la actividad en la construcción y puesta en marcha de nueva planta de alojamiento turístico, unido a la crisis de afluencia que la isla vive en el 2006. Ambas cosas reducen las posibilidades de empleo.

La población autóctona crece por primera vez frente a la alóctona (inmigrantes). A ella se une el descenso del número de turistas recibidos. Ambos indicadores (alóctonos y turistas) se reducen, por lo que la relación foráneo-autóctono desciende a 1,7 foráneos por cada persona nacida en la isla. El sistema reduce, aunque escasamente, sus desequilibrios demográficos.

El perfil de la inmigración, en razón a su procedencia, se modifica a lo largo de esta etapa, el mayor peso lo tienen los que vienen de otros países, y no de otras Comunidades Autónomas españolas como sucedía en la etapa anterior, aunque a lo largo de esta década dejarán de tener como origen preferente otros países de Europa 
(principalmente Reino Unido y Alemania). Los incrementos porcentuales significativos se observan en la incorporación de población procedente de Latinoamérica seguida de población africana. La multiculturalidad que acoge la isla es un hecho. La integración social de los mismos, por su diversidad cultural, es el gran reto.

Los desequilibrios demográficos, en relación al número de autóctonos y foráneos no dejan de crecer en sociedades de actividad turística bajo un modelo de masas, que incrementa constantemente su oferta y demanda turística. Las políticas de ordenación territorial que limitan este crecimiento son una primera vía para la contención de la presión demográfica sobre el territorio, ya que pueden reducir los rápidos incrementos por incorporación de población externa, pero deben ir acompañadas de otros procesos, pues no han sido suficientes en la isla de Lanzarote, de lo que derivan efectos no positivos sobre diferentes ámbitos del bienestar social.

\subsection{3.- EFECTOS SOBRE LA CUALIFICACIÓN Y EL EQUIPAMIENTO EDUCATIVO. 1996- 2006}

\subsubsection{1.- EVOLUCIÓN DEL NIVEL DE INSTRUCCIÓN}

En este periodo, para el análisis del nivel de instrucción alcanzado por la población, nos vemos en la obligación de acudir a diferentes fuentes, con el sesgo metodológico que eso entraña, entre otras cosas porque la agrupación de la población por edad y nivel de instrucción se realiza de distinta forma en el Padrón de 1996 y en el Censo de Población del año 2001. A partir de este año no existen explotaciones padronales que recojan datos acerca de esta característica de la población, por lo que para poder realizar comparación y observar la evolución que este indicador ha tenido al final de la etapa, se ha acudido a las estimaciones que realizan los Institutos de Estadística (INE e ISTAC) a través de la "Encuesta de condiciones de vida de los hogares" del año 2007, siendo conscientes que son diferentes estudios con distintas finalidades y por tanto, metodológicamente, la comparación debe tomarse con precaución.

Por otro lado, a lo largo del periodo sigue vigente la Ley Orgánica 1/1990, de 3 octubre, de Ordenación General del Sistema Educativo (LOGSE), lo que significa que la educación obligatoria sigue siendo hasta los 14 años de edad. Hasta el año 2006 no entra en vigor la Ley Orgánica 2/2006, de 3 de mayo, de Educación (LOE) que amplía la educación obligatoria hasta los 16 años de edad. Ambas normativas serán referentes en cada momento del análisis.

Los registros señalados nos muestran la siguiente evolución: 
Tabla 165. Evolución del nivel de instrucción. Absolutos y relativos. España, Canarias y Lanzarote. 1996-2007

\begin{tabular}{|c|c|c|c|c|c|c|}
\hline \multicolumn{7}{|c|}{ ESPAÑ A } \\
\hline INSTRUCCIÓN201 & 1996 & 2001 & $\%$ & 2007 & & $\%$ \\
\hline Analfabetos & \multirow{9}{*}{$\begin{array}{c}\text { No } \\
\text { consta }\end{array}$} & 865.865 & 2,53 & Analfabetos & -- & -- \\
\hline Sin Estudios & & 4.380 .660 & 12,80 & \multirow{2}{*}{ Ed. Primaria o Inferior } & \multirow{2}{*}{12.426 .362} & \multirow{2}{*}{33,20} \\
\hline Primer Grado & & 7.898 .877 & 23,08 & & & \\
\hline $2^{\circ}$ Grado $1^{\circ}$ Ciclo & & 9.257 .566 & 27,05 & $2^{\circ}$ Grado $1^{\circ}$ Ciclo & 8.421 .480 & 22,50 \\
\hline $2^{\circ}$ Grado $2^{\circ}$ Ciclo & & 7.180 .175 & 20,98 & $2^{\circ}$ Grado $2^{\circ}$ Ciclo & 7.897 .477 & 21,10 \\
\hline E Universitarias y Equivalentes & & 2.275 .890 & 6,65 & \multirow{2}{*}{ Ed. Superior } & \multirow{2}{*}{8.646 .053} & \multirow{2}{*}{23,10} \\
\hline Facultades, E.T.S. y $3^{\circ}$ Ciclo & & 2.361 .449 & 6,90 & & & \\
\hline No Clasificados o No Especificado & & 3.422 & 0,01 & No Clasificados. No Especificado & 37.429 & 0,10 \\
\hline TOTAL & & 34.223 .904 & & TOTAL & 37.428 .800 & \\
\hline
\end{tabular}

\begin{tabular}{||l|c|c||c|c||c|c||}
\hline \multicolumn{7}{|c||}{ CAN ARIAS } \\
\hline \hline INSTRUCCIÓN & 1996 & $\%$ & 2001 & $\%$ & 2007 & $\%$ \\
\hline Analfabetos & 53.881 & 4,14 & 50.154 & 3,61 & 53.430 & 3,08 \\
\hline Sin Estudios & 244.204 & 18,74 & 179.188 & 12,90 & 178.938 & 10,32 \\
\hline Primer Grado & 252.671 & 19,39 & 321.236 & 23,13 & 306.974 & 17,71 \\
\hline $2^{\circ}$ Grado $1^{\circ}$ Ciclo & 379.876 & 29,15 & 403.488 & 29,06 & 538.171 & 31,05 \\
\hline $2^{\circ}$ Grado $2^{\circ}$ Ciclo & 262.359 & 20,14 & 281.988 & 20,31 & 423.898 & 24,46 \\
\hline E Universitarias y Equivalentes & 58.649 & 4,50 & 83.313 & 6,00 & 116.640 & 6,73 \\
\hline Facultades, E.T.S. y 3 ${ }^{\circ}$ Ciclo & 51.323 & 3,94 & 69.256 & 4,99 & 115.149 & 6,64 \\
\hline No Clasificados o No Especificado & --- & --- & --- & -- & --- & -- \\
\hline TOTAL & 1.302 .963 & & 1.388 .623 & & 1.733 .201 & \\
\hline
\end{tabular}

201 La clasificación establecida considera lo siguiente: Primer grado (EGB $1^{\circ}$ etapa, educación especial, primaria, preaprendizaje industrial y alfabetización de adultos); Segundo grado: $1^{\circ}$ Ciclo (EGB $2^{\circ}$ etapa o ESO, grado elemental conservatorio de música, Artes y oficios, Bachiller elemental, otros medios elementales), $\underline{2}^{\circ}$ Ciclo (BUP y COU, FPI y II, Grado Medio Conservatorio, Oficialía Industrial, etc.); Tercer grado (Escuelas Universitarias y equivalentes) y Nivel Universitario (Facultades, Escuelas técnicas superiores y postgraduados y doctores). 


\begin{tabular}{||l||c|c||c|c||c|c||}
\hline \hline \multicolumn{7}{|c|}{ LANZAROTE } \\
\hline \hline INSTRUCCIÓN & 1996 & $\%$ & 2001 & $\%$ & 2007 & $\%$ \\
\hline Analfabetos & 2.658 & 4,31 & 2.084 & 2,68 & 2.768 & 2,46 \\
\hline Sin Estudios & 7.216 & 11,71 & 8.111 & 7,87 & 13.318 & 11,84 \\
\hline Primer Grado & 17.192 & 27,90 & 18.811 & 18,26 & 21.634 & 19,24 \\
\hline $2^{\circ}$ Grado ${ }^{\circ}$ Ciclo & 18.741 & 30,42 & 25.515 & 24,76 & 38.588 & 34,32 \\
\hline $2^{\circ}$ Grado $2^{\circ}$ Ciclo & 11.226 & 18,22 & 15.632 & 15,17 & 21.771 & 19,40 \\
\hline E Universitarias y Equivalentes & 2.482 & 4,03 & 4.573 & 4,44 & 8.307 & 7,40 \\
\hline Facultades, E.T.S. y 30 Ciclo & 2.102 & 3,41 & 2.733 & 2,81 & 6.063 & 5,40 \\
\hline No Clasificados o No Especificado & ---- & --- & --- & --- & --- & -- \\
\hline TOTAL & 61.617 & & 77.618 & & 112.450 & \\
\hline \hline
\end{tabular}

Nota: No existe ésta desagregación estadística a través del Padrón Municipal de habitantes de 1996 para el cómputo nacional. Fuente: Para 1996: "Población de 15 y más años según estudios realizados por grupos de edad (LOGSE) y sexo". Canarias y Lanzarote. Encuesta de Población de Canarias 1996. ISTAC.; Para 2001: "Población en viviendas familiares de 16 y más años clasificada por nivel de estudios"; Censo de Población 2001. INE; "Población en viviendas familiares de 16 años o más, según nivel de estudios por sexo y edad. Total Nacional e islas". Censo de Población de 2001, explotación del ISTAC. Para 2007: "Población de Lanzarote de 16 años y más según nivel de estudios terminados (2007). Distribución por comarcas y comparación con Canarias". Encuesta de Ingresos y Condiciones de Vida de los Hogares Canarios 2007. Instituto Canario de Estadística (ISTAC), www.datosdelanzarote.com.; "Enseñanza y formación. Adultos por nivel de formación alcanzado. De 16 y más años de edad, 2007". Encuesta de condiciones de vida, 2007. INE; Elaboración propia.

El analfabetismo en Lanzarote sigue estando presente, aunque de forma muy reducida desde finales de siglo, encontrándose por debajo de la media del peso que observa el conjunto del archipiélago y el país. Va quedando como un fenómeno propio de las edades maduras.

En el otro extremo, la formación superior, al igual que avanza en las etapas anteriores también lo hace en ésta. Las nuevas generaciones parecen llegar más lejos en su nivel de formación. Se registra casi un $13 \%$. Aunque siempre por debajo de la media de la Comunidad Autónoma y de España. 
Gráfico 162. Evolución del analfabetismo y la educación superior. Extremos. Lanzarote. 1996-2007 (\%).

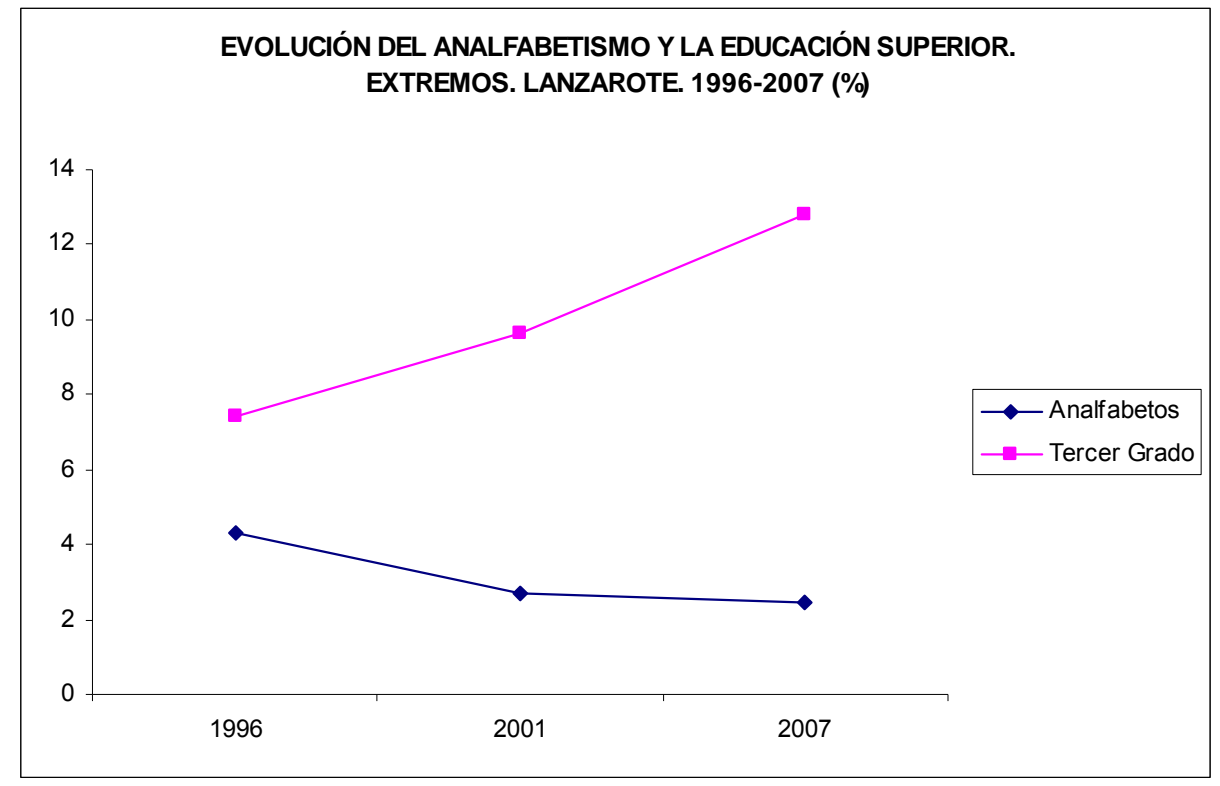

Fuente: Encuesta de Población de Canarias 1996. ISTAC; Censo de Población 2001. INE; Encuesta de Ingresos y Condiciones de Vida de los Hogares Canarios 2007. ISTAC e INE; Elaboración propia a partir de la Tabla 165.

No cabe duda de que el nivel de capacitación, medido a través de la instrucción formalizada alcanzada, ha aumentado entre los residentes en la isla. Aunque la dinámica económica sigue basada en la oferta y la demanda turística de masas, por lo que el nivel de instrucción generalizado sigue siendo, al igual que en la etapa anterior, el Segundo Grado- $1^{\circ}$ Ciclo, es decir la Educación General Básica, obligatoria, que ha completado la población de 16 y más años de edad. La diferencia con respecto al periodo anterior se encuentra en la disminución del colectivo "sin estudios", que hasta principios de los noventa tuvo un peso notable.

Con respecto al comienzo de la etapa, la instrucción en formación profesional también ha crecido, pero nunca por encima del peso relativo que parece tener la población de más de dieciséis años que declara únicamente haber realizado la primera etapa (primaria) dentro de la Educación General Básica. Al contrario que en el conjunto del archipiélago, donde sí es superior. 
Gráfico 163. Evolución del nivel de instrucción. Lanzarote. 1996-2007 (\%).

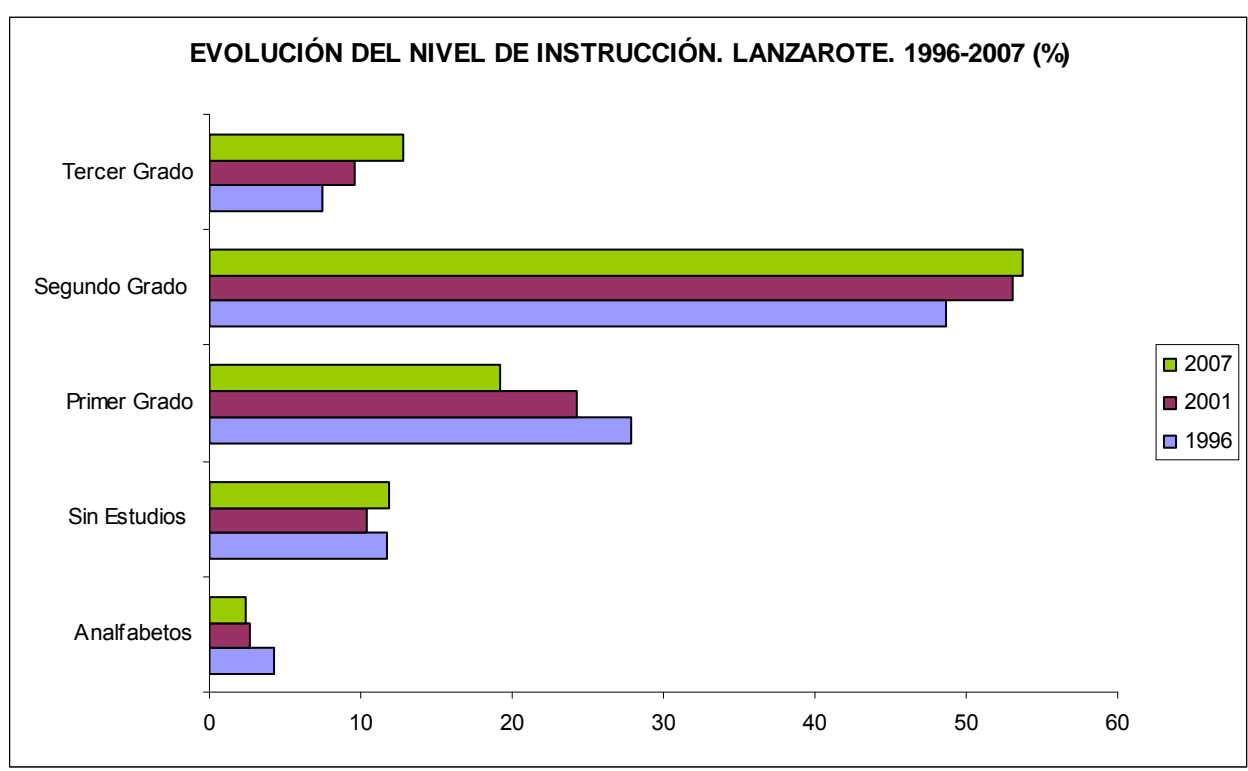

Fuente: Encuesta de Población de Canarias 1996. ISTAC; Censo de Población 2001. INE; Encuesta de Ingresos y Condiciones de Vida de los Hogares Canarios 2007. ISTAC e INE; Elaboración propia a partir de la Tabla 165.

La irrupción de actividades terciarias urbanas y turísticas ha permitido e impulsado la alfabetización y el crecimiento de los niveles formativos, necesario para el desarrollo de esta economía, pero la línea de ascenso ha estado y está condicionada por un mercado de trabajo que no exige elevada capacitación, así, la ganancia cultural de la población se encuentra en niveles elementales: completar la educación general obligatoria. Es por ello que, en términos generales, Lanzarote se sigue caracterizando por ser un espacio social con bajos niveles de instrucción de su recurso humano. La hipótesis de partida acerca de esta evolución se verifica.

Sus pesos relativos son menores a los que presenta la Comunidad Autónoma y España en formación profesional y superior. 
Gráfico 164. Evolución del nivel de instrucción. España, Canarias y Lanzarote. 2001-2007 (\%).

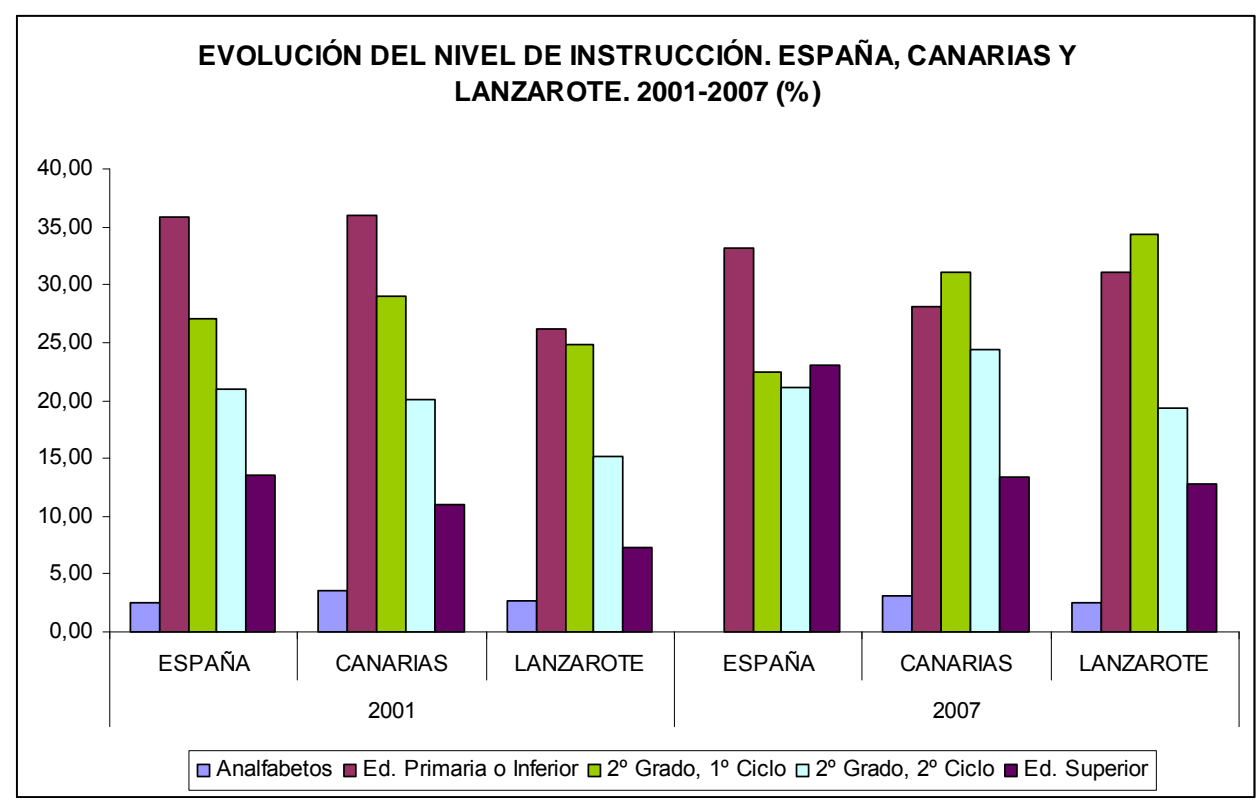

Fuente: Encuesta de Población de Canarias 1996. ISTAC; Censo de Población 2001. INE; Encuesta de Ingresos y Condiciones de Vida de los Hogares Canarios 2007. ISTAC e INE; Elaboración propia a partir de la Tabla 164

Esta situación no podía ser de otra forma, pues, en relación a los datos recogidos por el Instituto Canario de Evaluación y Calidad Educativa (ICEC), Canarias posee una de las Tasas más elevadas de abandono escolar prematuro, ${ }^{202}$ que asciende al 36,9\%, por encima de la media estatal (31\%). Fenómeno observado en aquellas Comunidades Autónomas "donde se ha producido un rápido crecimiento (...) vinculado al sector servicios, que posibilita altas posibilidades a los jóvenes de encontrar empleos de baja cualificación" (ICEC ${ }^{203}, 2009$, pp. 139-140).

La aportación que ha este estado hace la inmigración la trataremos en las próximas líneas.

\section{a.- Nivel de instrucción de los inmigrantes}

En relación a ésta característica demográfica, el periodo 1996-2006, se ve limitado a la hora de evaluar la evolución que ha seguido la instrucción de la población externa que acoge la isla, procedente de otros países, ya que sólo se han podido recoger datos de base hasta el año 2001 a través del Censo de Población. Las estadísticas oficiales posteriores no

202 Se entiende por abandono escolar prematuro, el porcentaje de personas de 18 a 24 años que no están escolarizadas, y que tienen como estudios máximos educación secundaria obligatoria 0 anteriores niveles educativos, es decir que no han completado el nivel de educación secundaria en su segunda etapa: Bachillerato y Ciclos Formativos de Grado Medio (ICEC, 2009, pp. 139).

203 ICEC: Instituto Canario de Evaluación y Calidad Educativa. 
registran dicha desagregación, así como tampoco lo hace el Observatorio de la Inmigración de Canarias, organismo consultado.

La inmigración de la Comunidad Autónoma y del resto de España seguirá siendo importante hasta el año 2006, fecha en la que se registra el predominio de los inmigrantes procedentes de otros países, constituyendo casi el $50 \%$ de las inmigraciones netas (nacidos en otros países) como se ha señalado en epígrafes anteriores, por tanto, al final de la etapa, éste será el colectivo que influya de manera importante en el perfil de instrucción de la población residente en la isla.

Tabla 166. Inmigrantes por nivel de instrucción. Absolutos y relativos. Lanzarote. 1996-2001

\begin{tabular}{|l|r|r||r|l|c|}
\hline INSTRUCCIÓN & \multicolumn{1}{|c|}{1996} & \multicolumn{1}{l|}{$\%$} & \multicolumn{1}{l|}{$\mathbf{2 0 0 1}$} & \multicolumn{1}{l|}{$\%$} & Incremento quinquenal (\%) \\
\hline \hline No sabe leer ni escribir & 377 & 1,80 & 929 & 2,94 & 146,42 \\
\hline Sin estudios o incompleta & 1.538 & 7,35 & 9.442 & 29,86 & 513,91 \\
\hline Primaria & 6.130 & 29,30 & 10.275 & 32,49 & 67,62 \\
\hline Secundaria & 10.936 & 52,28 & 7.422 & 23,47 & $-32,13$ \\
\hline Enseñanzas Universitarias & 1.937 & 9,26 & 3.558 & 11,25 & 83,69 \\
\hline \hline TOTAL & $\mathbf{2 0 . 9 1 8}$ & & $\mathbf{3 1 . 6 2 6}$ & & \\
\hline
\end{tabular}

Fuente: Para 1996: "Población migrante de 6 y más años según estudios realizados por lugar de procedencia". Encuesta de población de Canarias, 1996. ISTAC; Para 2001: "Población en viviendas familiares extranjera de 16 y más años clasificada por nivel de estudios, según sexo y nacionalidad" y "Población en viviendas familiares que ha residido fuera del municipio, clasificada por lugar anterior de residencia, según sexo y nivel de estudios. Lanzarote, 2001" (para los movimientos insulares y nacionales). Censo de población de 2001. Explotación del ISTAC. Elaboración propia.

El Censo de población del año 2001 nos arroja cambios cualitativos en el perfil de inmigración pues parece que han tomado mayor presencia los niveles de instrucción "sin estudios o incompleta" (30\%) y "primaria" (32.5\%), es decir, ha entrado población con poco tiempo de escolarización y que no ha acabado la enseñanza obligatoria. Esta notoria variación en los perfiles puede explicarse a través del efecto que genera el anuncio de la puesta en marcha de una moratoria que impulsa, entre el año 1998 y 2002, la construcción, derivando hacia nuevas entradas de población a trabajar en un sector en crecimiento, nuevamente, que no solicita cualificación.

El retroceso en los niveles de instrucción generales de la inmigración neta (nacidos fuera de la isla) es evidente, ha supuesto el engrosamiento de los estratos bajos de la jerarquía educativa, volviendo a recuperar valores de 1981 (los inmigrantes con estudios incompletos suponían el $29,3 \%$ ). Aunque no va a afectar a las Enseñanza Universitarias, que amplían su peso relativo $(11 \%)$, mayor que nunca en los últimos treinta y cinco años, con un incremento quinquenal del $84 \%$. 
Gráfico 165. Evolución del nivel de estudios de la población inmigrante. Lanzarote. 1996-2001 (\%)

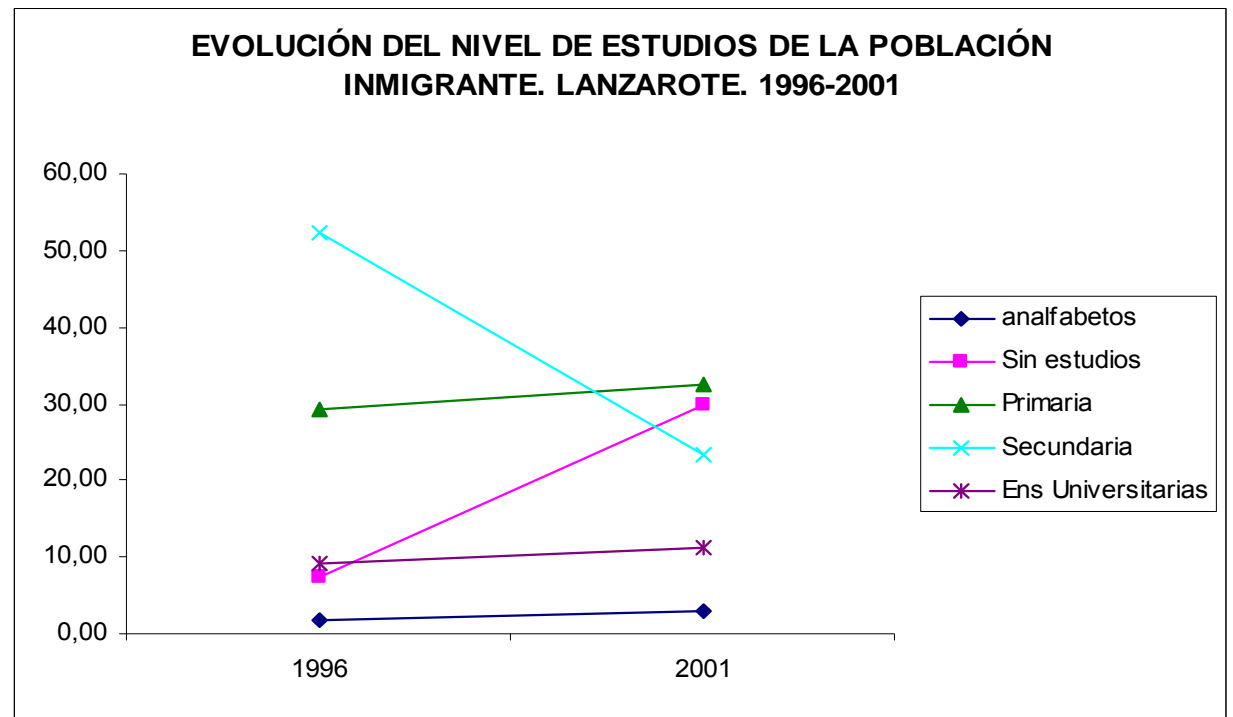

Fuente: Encuesta de población de Canarias, 1996. ISTAC; Censo de población de 2001, explotación del ISTAC. Elaboración propia a partir de la Tabla 166.

El efecto de esta inmigración sobre el nivel educativo no está siendo positivo con la entrada del nuevo siglo. Parece ser que el incremento de actividad en la construcción que provoca la ampliación de la oferta turística produce éste fenómeno. Veremos si la procedencia del inmigrante es una variable que condiciona.

Tabla 167. Inmigrantes por nivel de instrucción y lugar de procedencia. Lanzarote. 1996-2001 (\%).

\begin{tabular}{|c|c|c|c|c|c|c|c|c|}
\hline \multirow[b]{3}{*}{ INSTRUCCIÓN } & \multicolumn{8}{|c|}{ PROCEDENCIA } \\
\hline & \multicolumn{2}{|c|}{ Otra isla } & \multicolumn{2}{|c|}{ Resto de España } & \multicolumn{2}{|c|}{ Europa } & \multicolumn{2}{|c|}{ Otros Países } \\
\hline & 1996 & 2001 & 1996 & 2001 & 1996 & 2001 & 1996 & 2001 \\
\hline No sabe leer ni escribir & 169 & 318 & 146 & 431 & 10 & 47 & 52 & 133 \\
\hline Sin estudios o incompleta & 631 & 2.896 & 633 & 4.063 & 110 & 744 & 164 & 1.739 \\
\hline Primaria (EGB o ESO) & 2.538 & 2.461 & 2.806 & 4.648 & 360 & 1.373 & 426 & 1.793 \\
\hline Secundaria (FP I, II...) & 3.666 & 1.629 & 5.323 & 3.079 & 1.316 & 1.303 & 631 & 1.411 \\
\hline Enseñanzas Universitarias & 689 & 1.051 & 867 & 1.457 & 286 & 633 & 95 & 417 \\
\hline TOTAL & 7.693 & 8.355 & 9.775 & 13.678 & 2.082 & 4.100 & 1.368 & 5.493 \\
\hline
\end{tabular}

Fuente: Para 1996: "Población migrante de 6 y más años según estudios realizados por lugar de procedencia”. Encuesta de población de Canarias, 1996. ISTAC; Para 2001: "Población en viviendas. familiares extranjera de 16 y más años clasificada por nivel de estudios, según sexo y nacionalidad" y "Población en viviendas familiares que ha residido fuera del municipio, clasificada por lugar anterior de residencia, según sexo y nivel de estudios. Lanzarote" (para los movimientos insulares y nacionales). Censo de población de 2001. ISTAC. Elaboración propia. 
Tabla 168. Inmigrantes por nivel de instrucción y lugar de procedencia. Valores relativos e incremento quinquenal. Lanzarote. 1996-2001 (\%).

\begin{tabular}{|c|c|c|c|c|c|c|c|c|c|c|c|c|}
\hline \multirow[b]{3}{*}{ INSTRUCCIÓN } & \multicolumn{12}{|c|}{ PROCEDENCIA } \\
\hline & \multicolumn{3}{|c|}{ Otra isla } & \multicolumn{3}{|c|}{ Resto de España } & \multicolumn{3}{|c|}{ Europa } & \multicolumn{3}{|c|}{ Otros Países } \\
\hline & 1996 & 2001 & $\begin{array}{c}\text { Incremento } \\
\text { quinquenal } \\
(\%)\end{array}$ & 1996 & 2001 & $\begin{array}{l}\text { Incremento } \\
\text { quinquenal } \\
\text { (\%) }\end{array}$ & 1996 & 2001 & $\begin{array}{c}\text { Incremento } \\
\text { quinquenal } \\
(\%)\end{array}$ & 1996 & 2001 & $\begin{array}{c}\text { Incremento } \\
\text { quinquenal } \\
.(\%)\end{array}$ \\
\hline $\begin{array}{l}\text { No sabe leer } \\
\text { ni escribir }\end{array}$ & 2,20 & 3,81 & 88,17 & 1,49 & 3,15 & 195,21 & 0,48 & 1,15 & 370,00 & 3,80 & 2,42 & 155,77 \\
\hline $\begin{array}{l}\text { Sin estudios o } \\
\text { incompletos }\end{array}$ & 8,20 & 34,66 & 358,95 & 6,48 & 29,70 & 541,86 & 5,28 & 18,15 & 576,36 & 11,99 & 31,66 & 960,37 \\
\hline $\begin{array}{l}\text { Primaria (EGB } \\
\text { o ESO) }\end{array}$ & 32,99 & 29,46 & $-3,03$ & 28,71 & 33,98 & 65,65 & 17,29 & 33,49 & 281,39 & 31,14 & 32,64 & 320,89 \\
\hline $\begin{array}{l}\text { Secundaria } \\
\text { (FP I, II...) }\end{array}$ & 47,65 & 19,50 & $-55,56$ & 54,46 & 22,51 & $-42,16$ & 63,21 & 31,78 & $-0,99$ & 46,13 & 25,69 & 123,61 \\
\hline $\begin{array}{l}\text { Enseñanzas } \\
\text { Universitarias }\end{array}$ & 8,96 & 12,58 & 52,54 & 8,87 & 10,65 & 68,05 & 13,74 & 15,44 & 121,33 & 6,94 & 7,59 & 338,95 \\
\hline TOTAL & 100,0 & 100,0 & 100,0 & 100,0 & 100,0 & 100,0 & 100,0 & 100,0 & 100,0 & 100,0 & 100,0 & 100,0 \\
\hline
\end{tabular}

Nota: Calculado sobre los términos absolutos de cada lugar de origen.

Fuente: Elaboración propia.

Los datos registrados señalan que, en términos generales, entre 1996 y el año 2001, la categoría que experimenta un incremento notable es la que no posee estudios, para todos los lugares de procedencia analizados, pero no en la misma proporción. La inmigración que tiene como origen Europa es la que menos participa en este proceso.

La inmigración mayoritaria, que es nacional, repartida entre la que llega del resto del archipiélago y de las comunidades autónomas, pierde nivel de instrucción, se concentran entre categorías sin estudios y primaria. Aunque vuelve a marcarse la distancia entre los llegados de Canarias y de España, pues en 2001 estos últimos se concentran más en niveles medios (EGB y FP). 
Gráfico 166. Evolución del nivel formativo primaria y secundaria de la población inmigrante nacional. Lanzarote. 1996-2001 (\%)

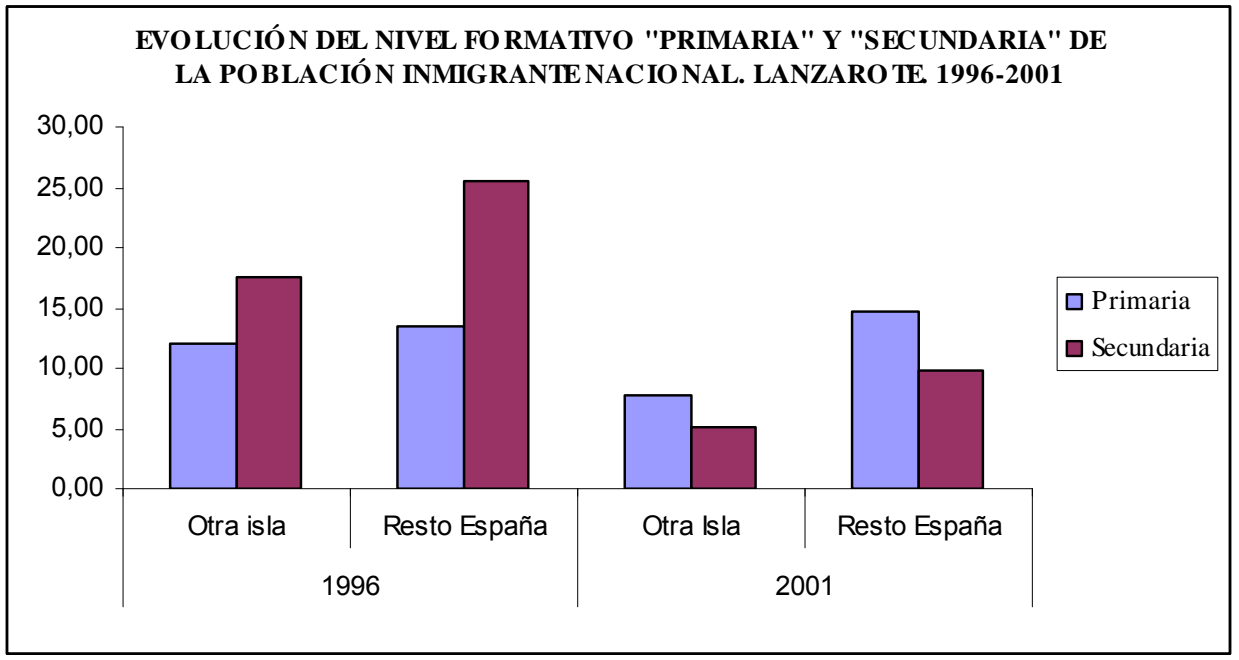

Fuente: Encuesta de población de Canarias, 1996. ISTAC; Censo de población de 2001 explotación del ISTAC. Elaboración propia a partir de las Tablas 167 y 168.

Los europeos, comparativamente con el resto, son los que mayor aportación hacen a la formación, pues se reparten entre primaria (enseñanza obligatoria, 33,5\%) y secundaria (formación profesional, 32\%) mayoritariamente. Mientras que las entradas de población externas a Europa se caracterizan por repartirse entre los niveles bajos (sin estudios, 31\%), primaria (educación obligatoria completa, 32\%) y formación profesional (26\%).

Gráfico 167. Nivel de instrucción de los inmigrantes extranjeros. Lanzarote. 1996-2001 (\%).

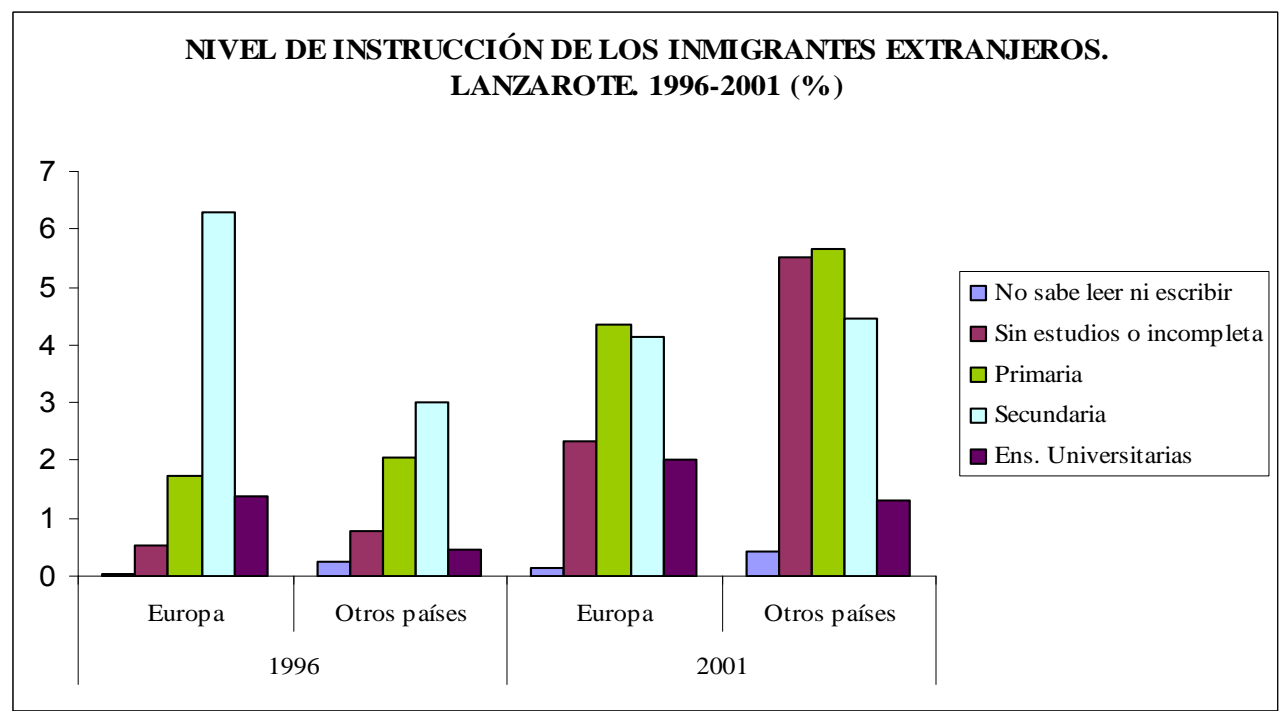

Fuente: Encuesta de población de Canarias, 1996. ISTAC; Censo de población de 2001 explotación del ISTAC. Elaboración propia a partir de las Tablas 166 y 167. 
En cuanto a los niveles de instrucción superiores, ya no destaca la inmigración nacional frente a la insular, como había ocurrido en la década de los años ochenta, sino que a lo largo de los años noventa la distancia en términos relativos se reduce de forma significativa y en 2001 la inmigración insular supera en formación superior a la nacional (13\% y $11 \%$ respectivamente). Esta diferenciación ha desaparecido. Frente a estos dos orígenes se sitúa la población europea que se concentra en un $15 \%$ en niveles formativos universitarios.

Gráfico 168. Nivel de instrucción de la población inmigrante por procedencia. Lanzarote. 1996-2001 (\%)

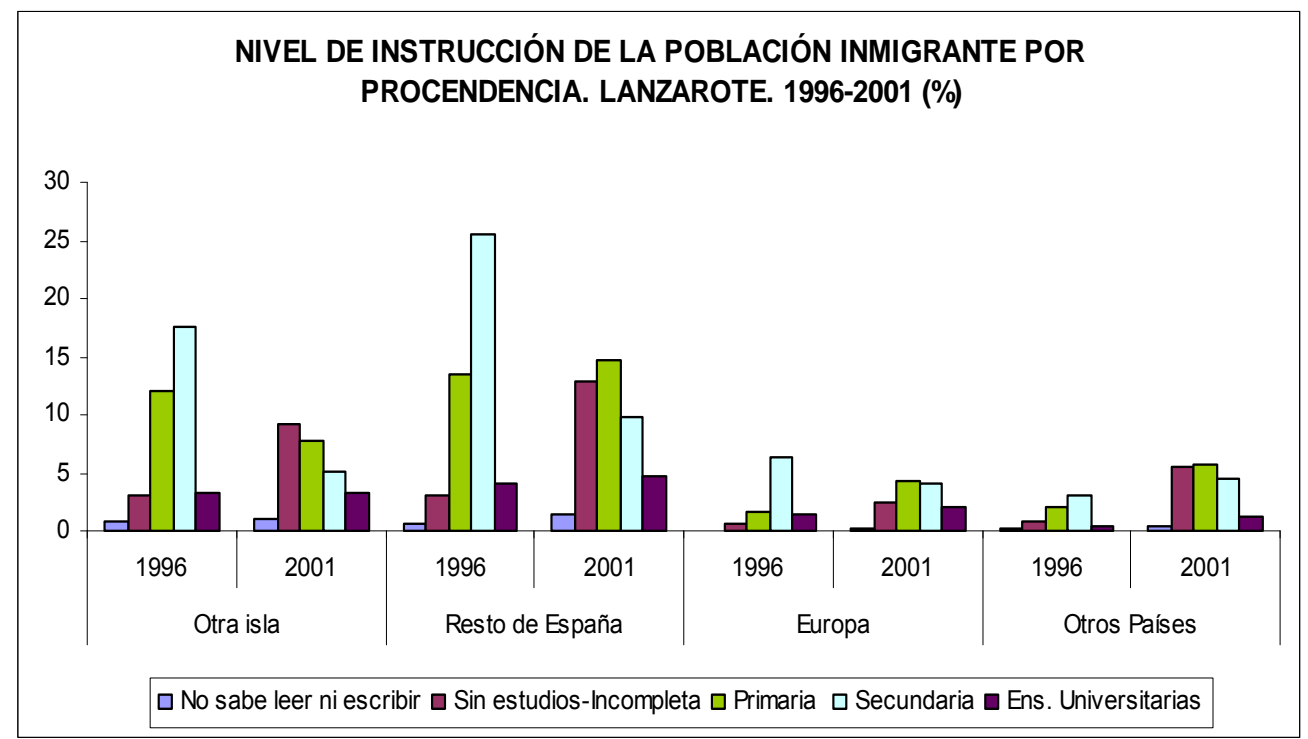

Fuente: Encuesta de población de Canarias, 1996. ISTAC; Censo de población de 2001 explotación del ISTAC. Elaboración propia a partir de las Tablas 166 y 167.

Comparativamente con la dinámica nacional de principios de siglo, la inmigración extranjera insular se sitúa en niveles formativos más bajos. Los extranjeros en España se caracterizan por concentrarse en niveles de instrucción de secundaria $(31,73 \%)$, principalmente los europeos $(84 \%)$ frente a los de otros países (52\%). No ocurre así para Canarias, donde la población extranjera tiene niveles de instrucción más bajos, se concentran entre educación primaria y secundaria en el caso de los europeos (31\% y $33 \%$ respectivamente), y en el caso de los procedentes de otros países externos a Europa está muy marcada la población analfabeta y sin estudios (32\%), la formación profesional sólo aglutina al $27 \%$ de las llegadas.

Es por ello que la dinámica de Lanzarote de principios de siglo al respecto, se aleja mucho de la nacional, y es similar a la que presenta el conjunto del archipiélago. 
Tabla 169. Inmigrantes por lugar de procedencia y nivel de instrucción. Valores absolutos y relativos. España, Canarias y Lanzarote. 2001

\begin{tabular}{||l|r|l|r|l||}
\hline & \multicolumn{5}{|c||}{ España 2001 } \\
\hline \hline INSTRUCCIÓN & Europa & \multicolumn{1}{|c|}{$\%$} & Otros países & $\%$ \\
\hline Analfabetos y sin estudios & 6.300 & 3,05 & 41.300 & 12,60 \\
\hline Primaria & 26.800 & 12,96 & 65.000 & 19,84 \\
\hline Secundaria & 173.700 & 83,99 & 169.600 & 51,75 \\
\hline Enseñanzas Universitarias & 66.400 & 32,11 & 51.700 & 15,78 \\
\hline Total por procedencia & 206.800 & 327.700 \\
\hline Total & \multicolumn{5}{|c|}{534.500} \\
\hline
\end{tabular}

\begin{tabular}{|c|c|c|c|c|c|c|c|c|}
\hline \multirow[b]{2}{*}{ INSTRUCCIÓN } & \multicolumn{4}{|c|}{ Canarias 2001} & \multicolumn{4}{|c|}{ Lanzarote 2001} \\
\hline & Europa & $\%$ & Otros países & $\%$ & Europa & $\%$ & Otros países & $\%$ \\
\hline Analfabetos y sin estudios & 8.876 & 20,37 & 13.093 & 31,83 & 791 & 19,29 & 1872 & 34,08 \\
\hline Primaria & 13.368 & 30,68 & 11.878 & 28,88 & 1.373 & 33,49 & 1793 & 32,64 \\
\hline Secundaria & 14.476 & 33,23 & 11.279 & 27,42 & 1.303 & 31,78 & 1411 & 25,69 \\
\hline Enseñanzas Universitarias & 6.846 & 15,71 & 4.882 & 11,87 & 633 & 15,44 & 417 & 7,59 \\
\hline Total por procedencia & \multicolumn{2}{|c|}{43.566} & \multicolumn{2}{|c|}{41.132} & \multicolumn{2}{|c|}{4.100} & \multicolumn{2}{|l|}{5.493} \\
\hline Total & \multicolumn{4}{|c|}{84.698} & \multicolumn{4}{|c|}{9.593} \\
\hline
\end{tabular}

Fuente: "Población en viviendas familiares extranjera de 16 y más años clasificada por nivel de estudios, según sexo y nacionalidad. Canarias y Lanzarote, 2001". Censo de Población y viviendas de Canarias, 2001. ISTAC; "Extranjeros de 16 y más años que habitan en viviendas familiares por nacionalidad, nivel de formación alcanzado y valor absoluto y porcentaje". Encuesta de migraciones 2001 (Metodología EPA-2002). Total nacional. 2001. INE. Elaboración propia.

La diversificación económica nacional dista mucho de la insular. Aspecto este que se convierte en la clave explicativa de la atracción de población de uno u otros niveles de instrucción. 
Gráfico 169. Inmigrantes por lugar de procedencia y nivel de instrucción. España, Canarias y Lanzarote (\%)

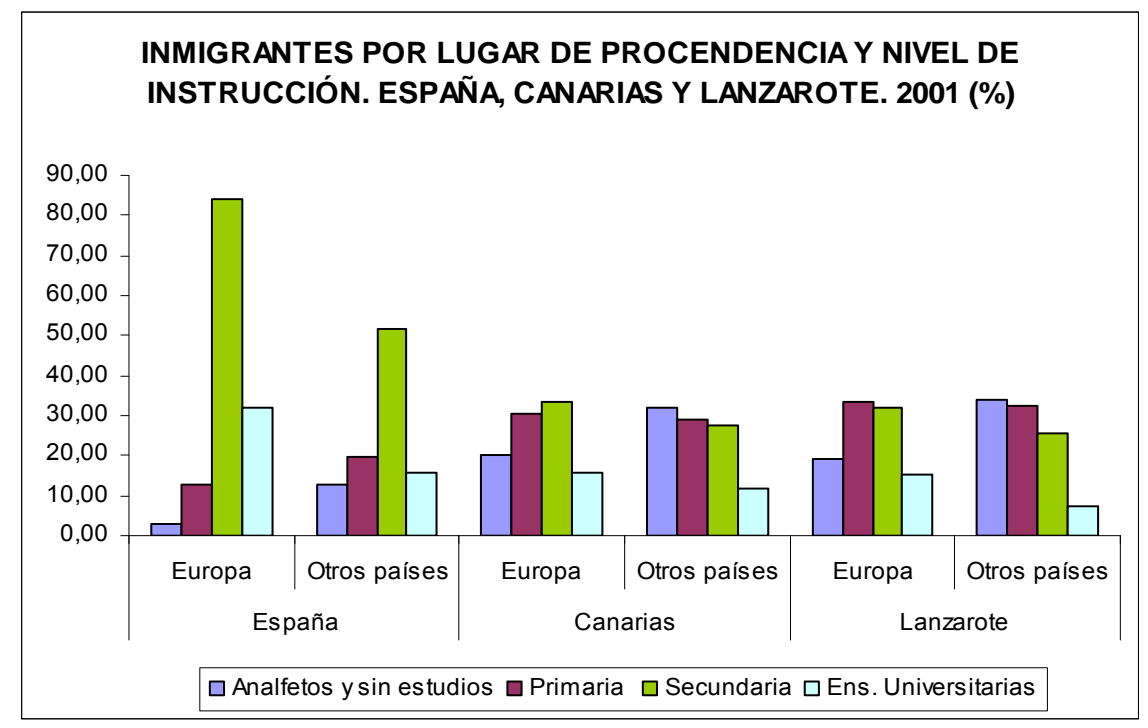

Fuente: Censo de Población y viviendas de Canarias, 2001. ISTAC e INE; Encuesta de migraciones 2001 INE. Elaboración propia a partir de la Tabla 169.

Tal y como hemos señalado en las líneas anteriores, entre el año 2001 y el año 2006 con el que cerramos este periodo, toman protagonismo, en la Isla, las inmigraciones que tiene como procedencia "otros países" y que suponen el $50 \%$ (frente al $33 \%$ que vienen de otras Comunidades Autónomas y el $17 \%$ de otras islas canarias). Es por tanto ésta la que más afectará al perfil de la instrucción de la población residente. Ahora bien, para éste último año no se poseen fuentes estadísticas que desagreguen los niveles de formación por países de origen, así que hemos tomado de referencia los datos del año 2001, considerando que los perfiles educativos por origen se mantienen por las dinámicas internas propias de la inmigración, que reproducen los niveles socioeconómicos de partida y por no existir variaciones significativas en el tipo de oferta laboral insular.

Tabla 170. Extranjeros por continente de origen y nivel de instrucción. Lanzarote. 2001 (\%)

\begin{tabular}{||l|r|r|r|r||}
\hline \hline INSTRUCCIÓN & EUROPA & AMÉRICA & ÁFRICA & ASIA \\
\hline \hline No sabe leer ni escribir & 1,2 & 1,2 & 6,6 & 1,8 \\
\hline Sin estudios o incompleta & 18,2 & 25,6 & 49,8 & 34,9 \\
\hline Primaria (EGB o ESO) & 33,5 & 34,4 & 27,7 & 31,0 \\
\hline Secundaria (FP I, II...) & 31,8 & 29,9 & 12,9 & 24,1 \\
\hline Enseñanzas Universitarias & 15,4 & 8,9 & 3,1 & 8,2 \\
\hline TOTAL & $\mathbf{4 2 , 7}$ & $\mathbf{3 9 , 6}$ & $\mathbf{1 2 , 5}$ & $\mathbf{5 , 1}$ \\
\hline
\end{tabular}

Fuente: "Población en viviendas familiares extranjera de 16 y más años clasificada por nivel de estudios, según sexo y nacionalidad. Lanzarote, 2001". VII.- Características de la Población Extranjera Residente en Canarias en Viviendas Familiares. Censo de Población y vivienda, 2001. ISTAC. 
Es la inmigración europea, por tanto, la que contribuye con mayor nivel de instrucción al espacio social de Lanzarote, por lo que se le supone mayor capacitación, seguida de la americana, procedente de América del Sur en más de un $80 \%$ (principalmente de Colombia con un peso del $43 \%$ en 2006). La inmigración africana (principalmente marroquí con un peso del $64 \%$ en $2006^{204}$ ) es la que aporta mayor disfunción al tejido socio-cultural insular pues es la de más baja capacitación y supone en el 2006 el 15,5\% del total de los extranjeros registrados en el Padrón municipal de habitantes ${ }^{205}$.

Estas significativas diferencias se plasmarán en la estructura del mercado laboral insular.

En términos generales, el crecimiento de la oferta turística y de la actividad de la construcción previa a la Moratoria turística ha traído consigo un proceso de pauperización cultural de la inmigración, medido a través del nivel de instrucción. Fenómeno éste muy acusado entre los que provienen de otras islas del archipiélago y del resto de comunidades autónomas españolas, junto con las que llegan de terceros países (externos a Europa y principalmente africanos) que elevan la baja capacitación. Limita la instrucción como centro neurálgico para generar desarrollo y cambio y finalmente merma la competitividad.

\subsubsection{2.- EL EQUIPAMIENTO EDUCATIVO}

El punto de referencia que tomaremos para la comparación será la normativa vigente en este periodo, que en parte viene del periodo anterior: Ley Orgánica 1/1990, de 3 octubre, de Ordenación General del Sistema Educativo (LOGSE) y los Reales Decretos 1004/1991, de 14 de junio, y 1537/2003, de 5 de diciembre, por el que se establecen los requisitos mínimos de los centros que impartan enseñanzas escolares de régimen general.

En primer lugar, señalar que los datos publicados en estadísticas oficiales, al igual que en el periodo anterior, no van a contemplar número de plazas existentes por nivel de instrucción impartido, aunque disponemos de unidades, que nos permite establecer el potencial. A partir del año 2001, este nivel de detalle desaparece y se publica información acerca de Centros oficiales de Enseñanza no Universitaria, sin distinguir entre los niveles impartidos por cada centro, por lo que no se puede saber si existen déficits en relación a los tipos de enseñanza.

Por tanto, se estima el estado dotacional en relación al número de alumnos, unidades y profesores y el estándar que marca la Ley para éstas variables hasta 2001, haciendo referencias más generales para el año 2006, pues no se han proporcionado datos destallados acerca de la capacidad del equipamiento por niveles.

204 El último dato registrado es del Padrón Municipal de habitantes del año 2010. Con respecto al registro del 2006, esta comunidad se incrementa en un $32 \%$.

205 Padrón Municipal de Habitantes, 2006."Población extranjera por lugar de nacimiento y sexo. Islas". ISTAC. 
Tabla 171. Oferta y demanda docente por tipo. Lanzarote. 2001

\begin{tabular}{|c|c|c|c|c|c|c|c|c|c|}
\hline Nivel & Preescolar & Primaria & ESO & $\begin{array}{c}\text { Secundaria no } \\
\text { obligatoria } \\
\text { (BUP y F.P.) }\end{array}$ & $\begin{array}{l}\text { E. Arte y } \\
\text { Oficios }\end{array}$ & P.G.S.* & $\begin{array}{l}\text { Educación } \\
\text { Especial }\end{array}$ & $\begin{array}{l}\text { E. P. } \\
\text { Adultos }\end{array}$ & $\begin{array}{l}\text { E. } 0 . \\
\text { Idiomas }\end{array}$ \\
\hline Centros & 46 & 47 & 19 & 16 & 1 & 7 & 1 & 1 & 1 \\
\hline Unidades & 151 & 351 & 217 & 132 & --- & 11 & --- & 18 & --- \\
\hline Puestos (oferta) & --- & --- & --- & --- & --- & 165 & --- & --- & --- \\
\hline Profesores & --- & 779 & 481 & --- & 40 & --- & 9 & 60 & 14 \\
\hline Alumnos & 3.329 & 7.659 & 5.557 & 2.821 & 16 & 133 & 41 & 634 & 1.275 \\
\hline $\begin{array}{l}\text { Población de Derecho } \\
\text { (demanda) }\end{array}$ & 3.515 & 6.906 & 6.087 & --- & --- & --- & --- & --- & --- \\
\hline $\begin{array}{l}\text { Capacidad según } \\
\text { número de unidades }\end{array}$ & 3.775 & 8.775 & 6.510 & 4.620 & --- & --- & --- & $540^{* *}$ & --- \\
\hline Alumnos/Profesor & --- & 9,8 & 11,5 & --- & 0,4 & --- & 4,5 & 26,8 & 91,1 \\
\hline Alumnos/Unidad & 22,1 & 21,8 & 25,6 & 21,4 & --- & 12,1 & --- & 89,4 & --- \\
\hline
\end{tabular}

$\left({ }^{*}\right)$ P.G.S.: Programa de Garantía Social; $\left({ }^{* *}\right)$ Calculado sobre 30 alumnos por unidad.

Nota: Preescolar o Infantil de 3 a 5 años de edad; Para los profesores de educación de adultos se ha tomado el dato del curso 19992000 (no consta para el curso 00-01). Resto, curso 2000-2001 en Anuario estadístico de canarias, 2001. ISTAC.

Capacidad según normativa (Real Decreto 1004/1991): preescolar (25 alumnos/unidad), primaria (25 alumnos/unidad), ESO (30 alumnos/unidad), secundaria no obligatoria (35 alumnos/unidad).

Fuente: "Centros docentes no universitarios, que imparten cada etapa educativa. Curso 2001-2002" en Estadísticas por Temas. "Educación, formación e investigación". ISTAC; "Centros docentes no universitarios por islas y cursos. 00-01", "Aulas de educación de adultos y profesores, Curso 00-01", "Alumnos en educación de adultos, curso 00-01". Anuario estadístico de Canaria. 2001. ISTAC; "Oferta y demanda de Programas de Garantía social" en Plan Sur: acción Lanzarote, 2001 (pp. 64). Consejería de Educación, Cultura y Deportes. Gobierno de Canarias, 2001.

Tabla 172. Oferta y demanda docente no universitaria. Lanzarote. 2007

\begin{tabular}{|c|c|c|c|c|c||}
\hline Centros & Unidades & $\begin{array}{c}\text { Puestos } \\
\text { (oferta) }\end{array}$ & Profesores & Alumnos & $\begin{array}{c}\% \\
\text { ocupación }\end{array}$ \\
\hline \hline 82 & 1.047 & 28.838 & --- & 25.829 & 89,6 \\
\hline
\end{tabular}

Tabla 173. Evolución del número de alumnos por nivel. Lanzarote. 1996-2006

\begin{tabular}{|c|c|c|c|c|c|c|c|c|}
\hline & Infantil & $\begin{array}{c}\text { Incremento } \\
\text { quinquenal (\%) }\end{array}$ & Primaria & $\begin{array}{c}\text { Incremento } \\
\text { quinquenal (\%) }\end{array}$ & EGB-ESO & $\begin{array}{c}\text { Incremento } \\
\text { quinquenal (\%) }\end{array}$ & $\begin{array}{c}\text { Secundaria no } \\
\text { obligatoria } \\
\text { (Bachiller y F.P.)* }^{*}\end{array}$ & $\begin{array}{c}\text { Incremento } \\
\text { quinquenal (\%). }\end{array}$ \\
\hline 1996 & 2.701 & & 7.097 & & 4.881 & & 3.021 & \\
\hline 2001 & 3.329 & 23,3 & 7.659 & 7,9 & 5.557 & 13,8 & 2.821 & $-6,6$ \\
\hline 2006 & 4.365 & 31,1 & 8.507 & 11,1 & 5.955 & 7,2 & 3.027 & 7,3 \\
\hline
\end{tabular}

$\left.{ }^{*}\right)$ Bachillerato y Ciclos Formativos de Grado Medio y Superior

Fuente: "Evolución de los alumnos matriculados en Lanzarote según nivel de estudios. Curso 2006-2007". Centro de Datos del Cabildo insular de Lanzarote. www.datosdelanzarote.com . Elaboración propia. 
La dinámica demográfica insular, marcada por la actividad turística que atrae constantemente trabajadores, hace que los ritmos de crecimiento de la población escolar sean elevados, principalmente en la primera escolarización (infantil) que mantiene ritmos de incremento de hasta el $31 \%$ entre 2001 y 2006 . No ha pasado igual en los niveles formativos medios (bachillerato y formación profesional) que no pertenecen a la enseñanza obligatoria, donde se registra un descenso de la matriculación entre 1996 y el 2001, es decir abandono de la escolarización a partir de los 14 años. Típico de economías desarrolladas y sociedades de consumo como la española, donde prima la incorporación al trabajo y la obtención de ingresos económicos, fruto de periodos anteriores donde existía una fuerte demanda laboral que lo hacía posible y que entre el año 1996 y 2001 vuelve a darse con fuerza por la demanda de trabajadores que supuso la rápida ampliación de la oferta de plazas turísticas antes de la entrada en vigor de la Moratoria (2001). Invirtiéndose este proceso posteriormente, es decir, la población de la Isla alarga su etapa de estudiante, fenómeno que no parece ir paralelo a la evolución del número de parados (que puede motivar el seguir estudiando) ya que entre el año 2001 y 2006 su incremento es negativo $(-9,5 \%)^{206}$.

En cuanto al nivel de servicio, la etapa anterior, marcada por la suficiencia de las dotaciones en enseñanza obligatoria y secundaria no obligatoria, continuará en esta etapa, pues las densidades de alumnos en las aulas son moderadas, siempre por debajo del estándar legal, sin grandes variaciones sobre 1996. Para el año 2006 no se han facilitado datos de unidades por tipo de instrucción.

Tabla 174. Ratio alumno/unidad escolar. Lanzarote. 1996-2001

\begin{tabular}{|l|c|c||}
\hline Tipo & $\begin{array}{c}\mathbf{1 9 9 6} \\
\text { Alumno/Unidad }\end{array}$ & $\begin{array}{c}\mathbf{2 0 0 1} \\
\text { Alumno/Unidad }\end{array}$ \\
\hline \hline Preescolar & 22,5 & 22,1 \\
\hline Primaria & 21,6 & 21,8 \\
\hline ESO & 25,9 & 25,6 \\
\hline Secundaria no obligatoria (Bachiller y F.P.) & 24,9 & 21,4 \\
\hline
\end{tabular}

Fuente: Elaboración propia.

La siguiente figura muestra el proceso de descentralización, que ha marcado la década de los años noventa hasta el nuevo siglo, con respecto a la enseñanza secundaria no obligatoria y a la educación superior. Es este sentido podemos afirmar la existencia de una dinámica de difusión del bienestar.

206 Para más información véase el capítulo sobre desempleo para esta etapa. 
Mapa 28. Centros docentes de educación no obligatoria. Lanzarote. 1970-2002

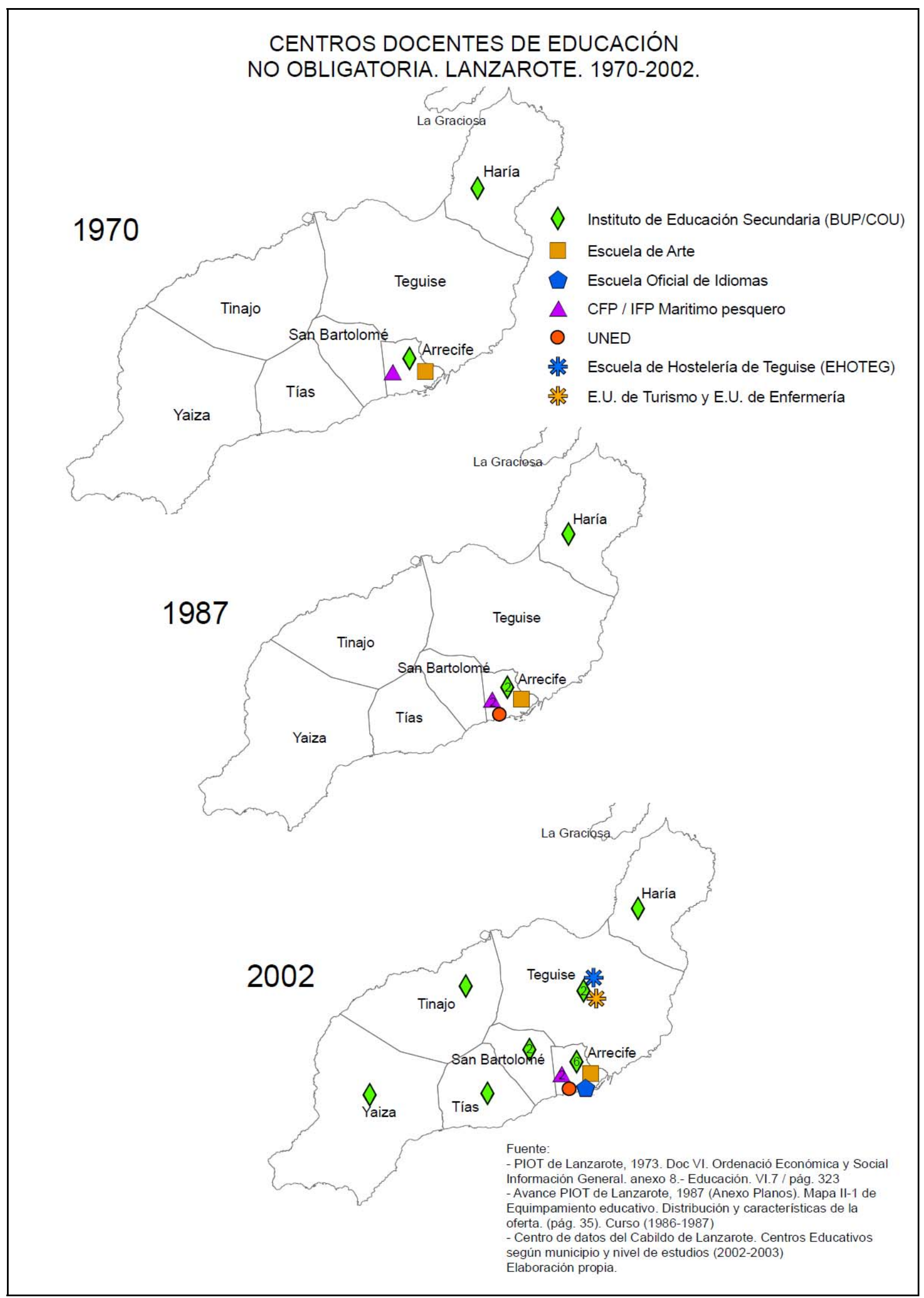


Ahora bien, aunque parece que en términos cuantitativos las coberturas en educación obligatoria están satisfechas, la situación se agrava desde el punto de vista cualitativo, pues los problemas educativos insulares se centran en atender la heterogeneidad cultural e idiomática del nuevo alumnado procedente del exterior, que se estima alrededor el 18,7\% del total del alumnado de la isla. Más del doble que la media de Canarias (9\%) y de España $(8,6 \%)^{207}$. Para lo que se hace necesario mejorar la dotación de recursos materiales de los centros existentes ${ }^{208}$, principalmente en el municipio capitalino, Arrecife, que concentra el $54 \%$ de la alumnos extranjeros, seguido de Tías, municipio que dispone de la mayor oferta turística de la isla y que se ha convertido en el lugar de residencia por excelencia de las inmigraciones europeas (con más del $40 \%$ de los escolares provenientes de la Unión Europea $^{209}$ ).

Tabla 175. Alumnado extranjero por continente y municipio. Lanzarote. 2006

\begin{tabular}{|c|c|c|c|c|c|}
\hline Continente & 2006 & $\%$ & Municipio & 2006 & $\%$ \\
\hline África & 636 & 13,47 & Arrecife & 2.571 & 54,44 \\
\hline América & 2.400 & 50,82 & Haría & 52 & 1,10 \\
\hline Asia & 301 & 6,37 & S. Bartolomé & 437 & 9,25 \\
\hline Europa & 1.384 & 29,30 & Teguise & 371 & 7,86 \\
\hline Oceanía & 2 & 0,04 & Tías & 850 & 18,00 \\
\hline & & & Tinajo & 41 & 0,87 \\
\hline & & & Yaiza & 401 & 8,49 \\
\hline TOTAL EXTRANJEROS & \multicolumn{2}{|c|}{4.723} & \multicolumn{3}{|c|}{$18,69 \%$} \\
\hline TOTAL ALUMNOS & \multicolumn{5}{|c|}{25.264} \\
\hline
\end{tabular}

Fuente: "Alumnado extranjero según continente. Lanzarote, 2006-2007" y Alumnado de Educación no universitaria en Lanzarote, 20062007". Centro de Datos del Cabildo Insular de Lanzarote. www.datosdelanzarote.com.

Interesa aquí analizar el estado y evolución de los servicios educativos adicionales que propone la isla y que son fundamentales para procesos de integración y recuperación de

${ }^{207}$ Fuente: "Alumnos extranjeros por CCAA y Total de España" y "Alumnos por CCAA y Total de España, por titularidad del Centro, 2006-2007". Enseñanzas anteriores a la Universidad. INE

208. "Alrededor de 3.200 alumnos procedentes del extranjero se han matriculado este años 2005-06 en los centros de Primaria y Secundaria de la isla. Esta cifra supone el $15 \%$ de la población escolar, cifrada en unos 21.000 estudiantes. Se trata del porcentaje más elevado de Canarias, pues se sitúa a diez punto por encima de la media regional (...)". "En España los inmigrantes suponen el 6,5\% del alumnado no universitario". Medidas de acción social para paliar los efectos de la inmigración en la isla de Lanzarote. 2005-2007. Informe diagnóstico. Cabildo Insular de Lanzarote, 2006 (pp. 4).

209 La distribución de los escolares extranjeros por nacionalidad y municipio de residencia en Lanzarote, puede consultarse en: Instituto Canario de Evaluación y Calidad Educativa (ICEC). "Inmigración, escolarización y educación multicultural en Canarias". Consejería de Educación. Gobierno de Canarias, 2003; No se registran estudio de detalla más recientes. 
capital humano. Es sobre estas dotaciones donde más deficitarios son los datos, a lo largo de toda esta etapa. Nos centraremos en la Educación de Adultos, el Programa de Garantía Social, la Educación Especial, y la Escuela Oficial de Idiomas.

Así, en primer lugar, en cuanto a la enseñanza de adultos, la información publicada por el Instituto de Estadística de Canarias, para el 2001, reduce la información en relación a años anteriores, por lo que no se ha accedido a datos que indiquen número de aulas destinas a tal fin, así que hemos partido de entender que se mantienen el mismo número del año 1996, como base para analizar el 2001. En relación al año 2006, la Encuesta de Infraestructuras y equipamientos de Lanzarote, realizada por el Cabildo y publicada en el año 2007, contabiliza unidades o aulas, pero no realiza desagregación según tipo de enseñanza impartida, por lo que para este año la información es escasa y mala.

Manteniendo el mismo nivel de equipamiento, este servicio permanece estrangulado (2001), al igual que en la etapa anterior, calculado en relación a un estándar de 30 alumnos por aula, pues los datos registrados nos arrojan una media de entre 35 y 36 alumnos/aula, es decir, la demanda es superior a la oferta. Es necesario señalar que ésta discapacidad del sistema se ha ido reduciendo, pues los déficits dotacionales no tienen el mismo peso que en el periodo anterior a consecuencia de la reducción de la matriculación entre 1996 y 2001 , aspecto este del todo coherente pues el crecimiento de la construcción previo a la Moratoria incrementó las posibilidades de encontrar trabajo y Lanzarote no se caracteriza por una población que simultanee estudios y trabajo (Lanzarote en la Biosfera, Libro 2. Población y Convivencia. 1998, pp. 32 $)^{210}$. El curso 2006-2007 comenzará con una recuperación de la demanda de adultos.

210 Cabildo de Lanzarote. "Lanzarote en la Biosfera. Una estrategia hacia el desarrollo sostenible de la isla". Aplicación de la Agenda Local 21. Programa Life de la Unión Europea. 1998. 
Tabla 176. Características equipamentales de la enseñanza de adultos. Lanzarote. 1996-2001

\begin{tabular}{||r|r|r|r|r||}
\cline { 2 - 5 } \multicolumn{1}{c|}{} & 1996 & $\mathbf{2 0 0 1}$ & \% Incremento & 2006 \\
\hline Centros & 1 & 1 & 0,0 & 1 \\
\hline Unidad & 18 & 18 & 0,0 & \\
\hline Profesores & 50 & 60 & 20,0 & \\
\hline Alumnos & 713 & 634 & $-11,0$ & 712 \\
\hline Capacidad/unidad & 540 & 540 & -- & \\
\hline Déficits (\%) & 32 & 17,4 & -- & \\
\hline Alumno/unidad & 39,6 & 35,2 & $-11,0$ & \\
\hline Alumno/profesor & 14,3 & 10,6 & $-26,1$ & \\
\hline
\end{tabular}

$\left.{ }^{\star}{ }^{\star}\right)$ Para el año 2006 no se detallan los centros ni las unidades, o en su defecto plazas, existentes para este tipo de educación. Fuente: Para 1996 y 2001: elaboración propia a partir de datos anteriores; Para 2006 "Evolución de los alumnos matriculados en Lanzarote según nivel de estudios, 2003-2007. Centro de datos. Cabildo de Lanzarote. www.datosdelanzarote.com. Elaboración propia.

En segundo lugar, aparece el programa de garantía social, para poder reinsertar a las personas que han pasado la edad de escolarización obligatoria sin alcanzar la formación básica, es decir, para reconducir el fracaso escolar. Está bien dotado, puesto que la demanda entre 2001 y 2006 sólo cubre entre el $80 \%$ y el $84 \%$ de la oferta. Sin embargo, el fracaso escolar va en aumento, en cinco años se ha incrementado un $8,3 \%$.

Tabla 177. Evolución del programa de garantía social. Lanzarote. 2001-2006

\begin{tabular}{|c|c|c|c|c|c|c|c|c|}
\hline Tipo & Centros & Unidades & $\begin{array}{c}\text { Puestos } \\
\text { (oferta) }\end{array}$ & Profesores & Alumnos & Alumno/profesor & Alumno/unidad & $\begin{array}{c}\text { Nivel de } \\
\text { Cobertura (\%) }\end{array}$ \\
\hline \hline 2001 & 7 & 11 & 165 & -- & 133 & --- & 12,1 & 80 \\
\hline 2006 & --- & 11 & 165 & -- & 140 & -- & 12,7 & 84 \\
\hline
\end{tabular}

Fuente. Elaboración propia a partir de datos anteriores.

En tercer lugar, la educación especial sigue registrando sólo un centro especializado, que parece suficiente, en la medida en que se calcula un ratio de 4,5 alumnos por profesor en el 2001, lo que supone un leve descenso en relación a 1996. Este descenso de casi un punto permite mejorar la atención individualizada, por parte del profesor hacia el alumno, elevando las posibilidades de integración social del discapacitado.

En cuanto lugar, la Escuela Oficial de Idiomas, sigue teniendo una enorme demanda, de modo que su nivel de estrangulamiento sigue creciendo en toda la etapa, registrándose un ratio de 91 alumnos por profesor, que no sufre una variación significativa entre el año 1996 y el 2001. La calidad de la enseñanza, por tanto, sigue quedando en entredicho por la enorme demanda que soporta el profesorado. 
Tabla 178. Evolución del ratio profesorlalumno en la Educación Especial y en la E. O. de Idiomas. Lanzarote. 1996-2001

\begin{tabular}{|c|c|c||c|c||}
\cline { 2 - 5 } \multicolumn{1}{c|}{} & \multicolumn{2}{c|}{ EDUCACIÓN ESPECIAL } & \multicolumn{2}{c|}{ ESCUELA O. DE IDIOMAS } \\
\hline \multirow{2}{*}{ Año } & Alumno/profesor & $\begin{array}{c}\text { Incremento } \\
\text { quinquenal (\%) }\end{array}$ & Alumno/profesor & $\begin{array}{c}\text { Incremento } \\
\text { quinquenal (\%) }\end{array}$ \\
\hline \hline 1996 & 5,3 & & 91,8 & \\
\cline { 2 - 5 } 2001 & 4,5 & $-15,1$ & 91,1 & $-0,8$ \\
\hline
\end{tabular}

Fuente: Elaboración propia.

La irrupción de actividades terciarias urbanas y turísticas ha permitido e impulsado la alfabetización y el crecimiento de los niveles formativos, necesario para el desarrollo de esta economía, pero la línea de ascenso ha estado y está condicionada por un mercado de trabajo que no exige elevada capacitación, así, la ganancia cultural de la población se encuentra en niveles elementales: completar la educación general obligatoria. Es por ello que, en términos generales, Lanzarote se sigue caracterizando por ser un espacio social con bajos niveles de instrucción de su capital humano. Siempre menor que la media que presenta su Comunidad Autónoma y España en formación profesional y superior. La hipótesis de partida acerca de esta evolución se verifica.

\subsubsection{3.- CONCLUSIONES}

Esta última etapa, en la que Lanzarote se considera un destino turístico de masas maduro, se producen modificaciones en el perfil de instrucción de la población que acoge, no así en el nivel de servicio de las dotaciones educativas.

A modo de conclusión, la dinámica en relación a la cualificación se caracteriza por lo siguiente:

1. Crecimiento del nivel de instrucción concentrándose en la educación general básica obligatoria. La población con niveles básicos (primaria) no sufre modificaciones en el nuevo siglo y el ascenso de la formación profesional se iguala en peso a esta última.

2. Las nuevas generaciones parecen llegar más lejos en su nivel de formación. Aunque siempre por debajo de la media de la Comunidad Autónoma y de España.

3. El nuevo siglo comienza con un retroceso hacia niveles de instrucción de la inmigración similares a los del año 1981, es decir, sin formación o básica. La incorporación de población externa con estos perfiles (procedente de otras islas del archipiélago, del resto de Comunidades Autónomas y de países externos a Europa) deriva del periodo previo a la aprobación de la Moratoria turística, pues hubo un impulso en la construcción de nueva planta de alojamiento turístico. Ésta dinámica, por tanto, va en detrimento de la 
capacidad insular para abrir procesos de desarrollo y de cambio sustentados por sus recursos humanos, pues vuelve a engrosar los estratos más bajos de la jerarquía educativa. Posteriormente a la puesta en marcha de la Moratoria, la dinámica será a la inversa.

En cuanto al equipamiento educativo, la etapa está marcada por:

4. Las dotaciones destinadas a la enseñanza obligatoria, no solo son suficientes sino que además, existe la posibilidad de dar cobertura a nueva demanda a corto plazo.

5. En relación al equipamiento para la educación no obligatoria, esencial para el bienestar, se constata lo siguiente: a) suficiencia en el nivel de preescolar (cuya demanda ha ido creciendo en toda la etapa, puesto que los papales femeninos clásicos se han ido modificando por exigencia del mercado laboral) y se ha dado adecuada respuesta; b) contradicción entre las diferentes fuentes de información estadística en relación a centros de educación permanente de adultos, que parece seguir sufriendo estrangulamientos dotacionales; c) relajación de la presión de la demanda en la educación especial o pedagogía terapéutica, por incorporación de profesorado, no por creación de centros.

Gráfico 170. Alumno por unidad y profesor y estándar, por tipo de enseñanza. Lanzarote. 1996-2001.

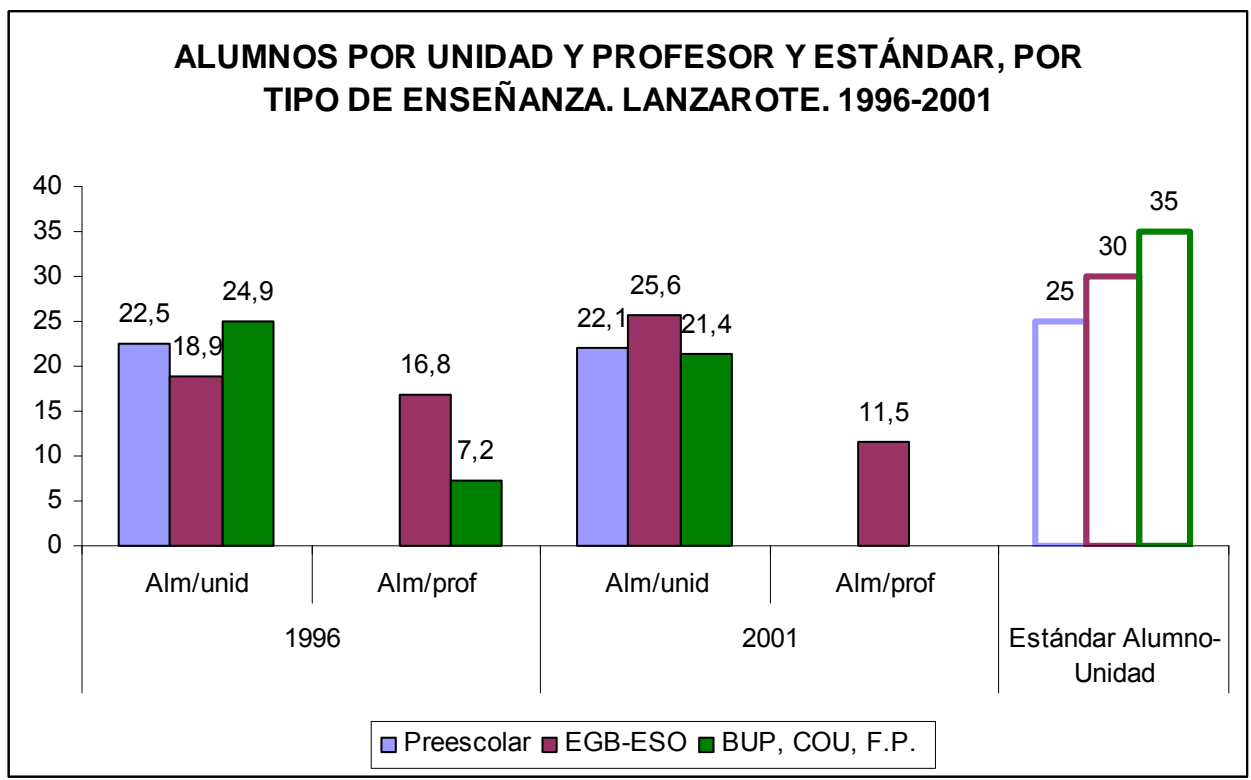

Fuente: Elaboración propia a partir de la Tabla 106 y 171.

6. Los Centros Universitarios, creados en la etapa anterior, siguen funcionando con normalidad en la isla. 
En términos generales, la irrupción de actividades del terciario turístico que impulsó la alfabetización y el crecimiento de lo niveles formativos en el pasado, se valora ahora, cuando Lanzarote es un destino turístico maduro y la actividad toma nuevos impulsos, como un freno para la elevación de los mismos, pues la línea de ascenso de la instrucción está condicionada por un mercado de trabajo que no exige elevada capacitación, así la ganancia cultural de la población residente en la isla se mantendrá en los niveles de educación obligatoria, lo que no redunda en su profesionalización generalizada. La hipótesis de partida acerca de esta evolución se verifica. La alta concentración en estos niveles reduce las habilidades y posibilidades de la población para generar desarrollo por incapacidad o pobreza cultural. La regulación del crecimiento de la oferta y la demanda turística será la que permita reducir la entrada de población con baja capacitación.

El reflejo positivo sobre la mejora del bienestar social en esta etapa es el mantenimiento de niveles dotacionales que permiten dar suficiente cobertura a la demanda tanto en la enseñanza obligatoria como en la infantil (no obligatoria), pues se ha respondido adecuadamente a la presión que supone el crecimiento demográfico por factores externos (inmigrantes en edad de formar familias) y a la elevada juventud de su población.

Por el contrario, los medios existentes para la integración de las discapacidades, no pueden ser correctamente evaluados, la educación básica de adultos ha desbordado las dotaciones existentes al respecto y la escuela de idiomas tiene una enorme presión de demanda formativa sobre su profesorado. Esta realidad resta al estado del bienestar social que la isla había alcanzado en la mitad de los años noventa.

Consecuentemente, podemos confirmar que es la calidad y no la cantidad la que debe presidir las políticas de desarrollo turístico, para una correcta adaptación a lo nuevo. La contención de la oferta y la demanda turística es la vía para la mejora del bienestar social, para que sus efectos colaterales no desborden áreas del bienestar.

\subsection{4.- EFECTOS SOBRE LA DOTACIÓN DE SERVICIOS DE SALUD. 1996-2006}

Esta etapa está marcada por la ampliación del equipamiento sanitario público y privado. El dato significativo a señalar es que en 1999 aparece un nuevo hospital en la isla, de carácter privado y situado en el principal núcleo turístico, Puerto del Carmen (municipio de Tías).

\subsubsection{1.- DOTACIÓN HOSPITALARIA Y EXTRAHOSPITALARIA}

La oferta hospitalaria observa un aumento considerable en esta etapa, principalmente en el último quinquenio (2001-2006) en el que se incrementa un $21 \%$ el número de camas. Sin embargo, debido al constante aumento de la población que acoge la isla, el crecimiento de la capacidad no revierte en mejoras sustanciales, puesto que no llega a superar las 3 camas 
por mil habitantes, es decir, el ratio nos indica un descenso, principalmente entre 1996 y 2001 , con un incremento negativo del $18 \%$, que se mantendrá hasta el final de la etapa.

La isla sigue encontrándose muy por debajo del estándar recomendado por la Organización Mundial de la Salud (8-10 camas/1.000h), en más de 5 camas.

Tabla 179. Oferta hospitalaria. Lanzarote. 1996-2006

\begin{tabular}{|c|c|c|c|c|c|c|}
\hline Año & TIPO & Tipo & $\begin{array}{l}\mathrm{N}^{0} \text { de } \\
\text { Camas }\end{array}$ & $\begin{array}{l}\text { Camas/ } \\
1.000 \mathrm{~h} .\end{array}$ & Estancias & $\begin{array}{l}\text { Índice de } \\
\text { Ocupación }\end{array}$ \\
\hline \multirow{3}{*}{1996} & $\begin{array}{l}\text { Hospital Insular } \\
\text { (Cabildo) }\end{array}$ & General & 93 & 1,20 & & \\
\hline & $\begin{array}{l}\text { Hospital General } \\
\text { (Insalud) }\end{array}$ & General & 164 & 2,12 & 48.641 & 83,29 \\
\hline & TOTAL & General & 257 & 3,32 & & \\
\hline Población. Derecho & 77.379 & & & & & \\
\hline $\begin{array}{l}\text { Turistas } \\
\text { equivalentes al día. }\end{array}$ & 48.686 & & & & \multirow{2}{*}{\multicolumn{2}{|c|}{$\begin{array}{l}\% \text { de Variación de } \\
\text { Lanzarote con respecto } \\
a^{* *} \text { : }\end{array}$}} \\
\hline Población diaria* & 126.065 & & & 2,04 & & \\
\hline Canarias & & & & 4,71 & $-29,51$ & \\
\hline España & & & & 3,82 & $-1,8$ & \\
\hline O.M.S. & & & & $8-10$ & $-58,5$ & \\
\hline \multirow{4}{*}{2001} & $\begin{array}{l}\text { Hospital Insular } \\
\text { (Cabildo) }\end{array}$ & General & 93 & 0,90 & & \\
\hline & $\begin{array}{l}\text { Hospital General } \\
\text { (Insalud) }\end{array}$ & General & 166 & 1,61 & 53.672 & 88,50 \\
\hline & $\begin{array}{l}\text { Hospital General } \\
\text { (Hospiten) Privado }\end{array}$ & General & 21 & 0,20 & 6.129 & 79,96 \\
\hline & TOTAL & General & 280 & 2,72 & 59.801 & \\
\hline Población. Derecho & 103.044 & & & & & \\
\hline $\begin{array}{l}\text { Turistas } \\
\text { equivalentes al día. }\end{array}$ & 44.603 & & & & \multirow{2}{*}{\multicolumn{2}{|c|}{$\begin{array}{l}\% \text { de Variación de } \\
\text { Lanzarote con respecto } \\
a^{* *} \text { : }\end{array}$}} \\
\hline Población diaria* & 147.647 & & & 1,90 & & \\
\hline Canarias & & & & 4,55 & $-40,2$ & \\
\hline España & & & & 3,58 & $-24,0$ & \\
\hline O.M.S. & & & & $8-10$ & $-66,0$ & \\
\hline
\end{tabular}




\begin{tabular}{|c|c|c|c|c|c|c|}
\hline \multirow{4}{*}{2006} & $\begin{array}{l}\text { Hospital Insular } \\
\text { (Cabildo) }\end{array}$ & General & 93 & 0,73 & & \\
\hline & $\begin{array}{l}\text { Hospital General } \\
\text { (Insalud) }\end{array}$ & General & 226 & 1,77 & 55.741 & 70,13 \\
\hline & $\begin{array}{l}\text { Hospital General } \\
\text { (Hospiten) Privado }\end{array}$ & General & 21 & 0,16 & 6.129 & 79,96 \\
\hline & TOTAL & General & 340 & 2,67 & 61.843 & \\
\hline Población. Derecho & 127.457 & & & & & \\
\hline $\begin{array}{l}\text { Turistas } \\
\text { equivalentes al día. }\end{array}$ & 37.522 & & & & \multirow{2}{*}{\multicolumn{2}{|c|}{$\begin{array}{l}\% \text { de Variación de } \\
\text { Lanzarote con respecto } \\
a^{* *}:\end{array}$}} \\
\hline Población diaria* & 164.979 & & & 2,06 & & \\
\hline Canarias & & & & 3,55 & \multicolumn{2}{|r|}{$-24,8$} \\
\hline España & & & & 3,27 & \multicolumn{2}{|r|}{$-18,3$} \\
\hline O.M.S. & & & & $8-10$ & \multicolumn{2}{|r|}{$-66,6$} \\
\hline
\end{tabular}

* Población diaria: población de derecho + turistas equivalentes al día.

** Calculado en relación a las camas por mil habitantes de derecho.

Fuente: "Estructura y oferta de servicios de Atención Especializada. Lanzarote, 1995-97, 2001 y 2006". Centro de datos del Cabildo Insular de Lanzarote; "Memoria del Servicio Canario de Salud, 2002 y 2006". Centro de datos del Cabildo Insular de Lanzarote. http://www.datosdelanzarote.com; "Profesionales, servicios, dotación y datos asistenciales. Hospiten, Lanzarote, 2008". Grupo Hospiten España, 2008. http://www.hospiten.es; Camas en funcionamiento, por CC.A.A. y Total de España, por periodo y entidad jurídica de quien dependen". Estadística de Establecimientos Sanitarios con Régimen de Internado, Serie 1997-2007. INE.

Tabla 180. Evolución de las camas hospitalarias. Lanzarote. 1996-2006

\begin{tabular}{|c|c|c|c|}
\hline Año & Camas & Incremento quinquenal (\%) & $\begin{array}{c}\text { Incremento quinquenal del Ratio } \\
\text { Camas/1.000h (\%) }\end{array}$ \\
\hline \hline 1996 & 257 & & \\
\hline 2001 & 280 & 8,95 & $-18,07$ \\
\hline 2006 & 340 & 21,43 & $-1,84$ \\
\hline
\end{tabular}

Fuente: Elaboración propia.

El déficit se refuerza si tenemos en cuenta los turistas equivalentes al día que acoge la isla, que, al menos hasta el año 2001, van a suponer un aumento de la presión sobre la oferta general, aproximadamente en 1 cama, alejándonos aún más de los estándares de calidad (en unas 6 camas). Sin embargo, esta presión se reduce en el último año analizado (2006) puesto que la crisis de afluencia de las visitas a la isla, reduce el número de turistas diarios estimados. 
Gráfico 171. Comparación de los ratios camas hospitalarias por mil habitantes de derecho y sobre la población total estimada. Lanzarote. 1996-2006

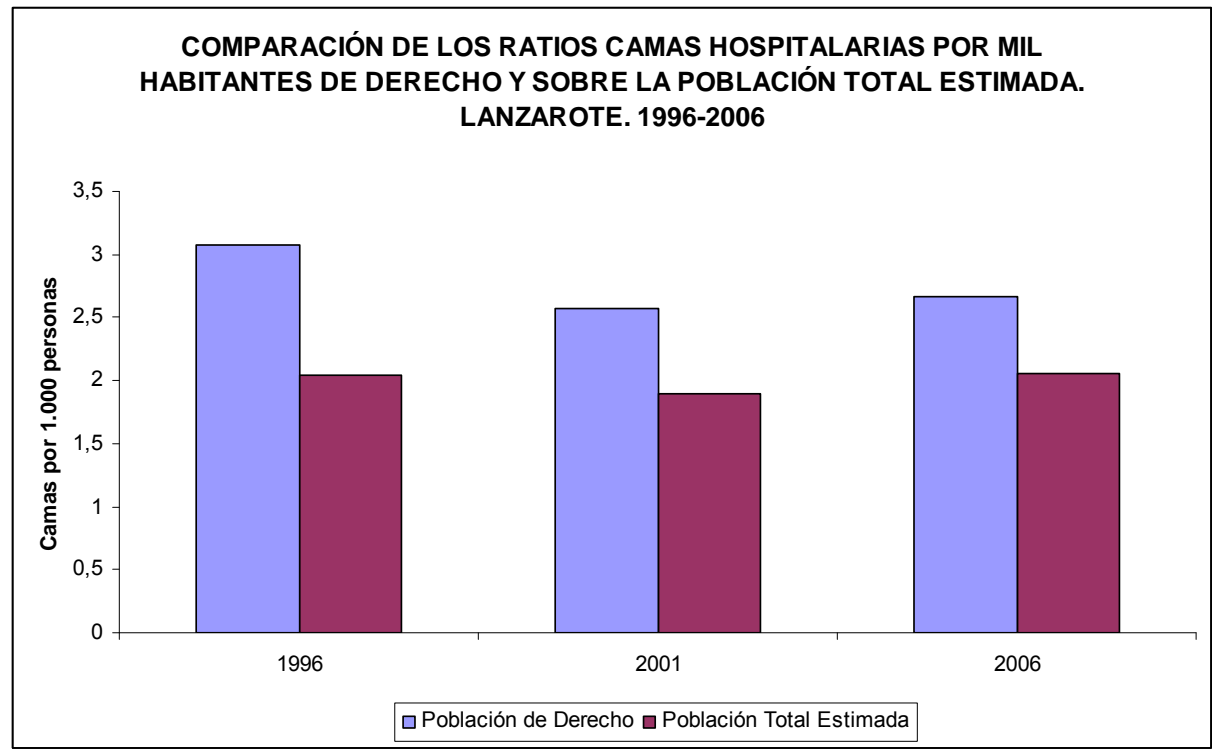

Fuente: Elaboración propia a partir de la Tabla 179.

El ratio insular camas hospitalarias por mil habitantes será inferior al de Canarias, entre 1 y 2 camas, y respecto al de España en 1 cama, durante toda esta etapa. La dinámica de descenso de este ratio, descrita para la Isla, es igual para Canarias y España. El incremento de las dotaciones en salud no se está produciendo a la velocidad en la que crece la población, la capacidad de servicio ha ido empobreciéndose.

Gráfico 172. Comparación del ratio camas hospitalarias por mil habitantes. España, Canarias y Lanzarote. 1996-2006

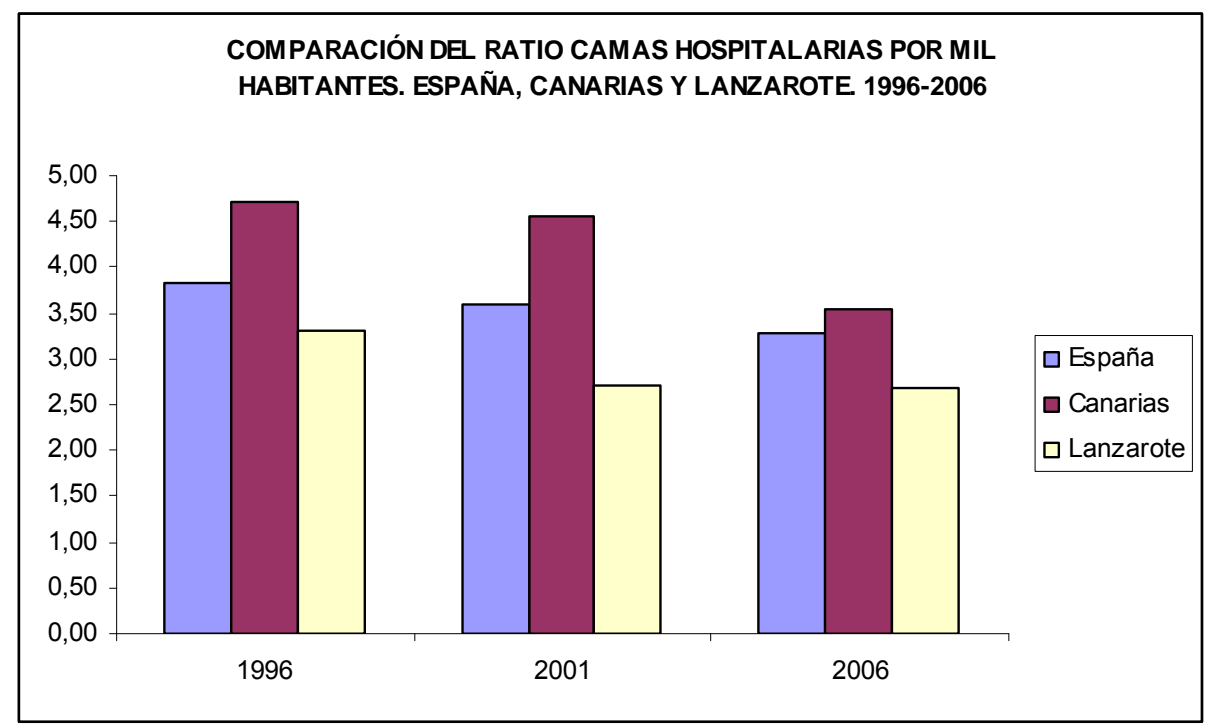

Fuente: Elaboración propia a partir de la Tabla 179. 
No ocurre así, en la oferta extrahospitalaria, que, aunque el número de centros de salud se mantiene desde la etapa anterior, lo que se amplia es el número de consultorios o ambulatorios. Estas nuevas dotaciones se instalarán en zonas donde se concentra actividad turística, por ejemplo Costa de Teguise (municipio de Teguise) y en núcleos con tradición rural que no son cabeza municipal, pero han crecido en el volumen de residentes, por ejemplo Tahíche (municipio de Teguise). El proceso, por tanto, para este tipo de oferta, ha sido de descentralización y difusión del bienestar en relación al crecimiento demográfico de los diferentes municipios y los núcleos donde ésta se concentra, como se puede observar en la siguiente tabla y mapa.

Tabla 181. Evolución de la zona básica de salud. Centros extrahospitalarios públicos, en funcionamiento. Lanzarote. 1986-1996-2006

\begin{tabular}{|c|c|c|c|c|}
\hline ZONA DE SALUD & INSTALACIONES & 1986 & 1996 & 2006 \\
\hline \multirow{2}{*}{ Arrecife I } & Centro de Salud Santa Coloma & Sí & Sí & Sí \\
\hline & Consultorio Playa Honda & No & Sí & Sí \\
\hline Arrecife II & Centro de Salud de Valterra & No & Sí & Sí \\
\hline \multirow{3}{*}{ Haría } & Centro de Salud de Haría & No & Sí & Sí \\
\hline & Consultorio de Haría & Sí & No & No \\
\hline & Consultorio Local de Mala & No & Sí & Sí \\
\hline \multirow{3}{*}{ San Bartolomé-Tinajo } & Centro de Salud de San Bartolomé & No & Sí & Sí \\
\hline & Consultorio de San Bartolomé & Sí & No & No \\
\hline & Consultorio Local de Tinajo & Sí & Sí & Sí \\
\hline \multirow{5}{*}{ Teguise } & Centro de Salud de Teguise & No & Sí & Sí \\
\hline & Consultorio de Teguise & Sí & No & No \\
\hline & Consultorio Local de La Graciosa & Sí & Sí & Sí \\
\hline & Consultorio Local de Tahíche & No & No & Sí \\
\hline & Consultorio Local de Costa de Teguise & No & No & Sí \\
\hline \multirow{2}{*}{ Tías } & Centro de Salud de Tías & Sí & Sí & Sí \\
\hline & Consultorio Local de Puerto del Carmen & No & Sí & Sí \\
\hline \multirow{3}{*}{ Yaiza } & Centro de Salud de Yaiza & No & Sí & Sí \\
\hline & Consultorio Local de Playa Blanca & No & Sí & Sí \\
\hline & Consultorio Local de Uga & Sí & Sí & Sí \\
\hline
\end{tabular}

Fuente: Avance PIOT, Lanzarote, 1987. Tomo 5. Cap. II. Equipamientos y servicios comunitarios. Cabildo de Lanzarote, 1987 (pp. 103); "Estructura y oferta de Servicios de Atención Primaria de Salud, 1997 y 2006". Centro de datos. Cabildo Insular de Lanzarote. www.datosdelanzarote.com. 
Mapa 29. Evolución de las dotaciones en atención primaria (sanidad). Lanzarote. 1986, 1996, 2006

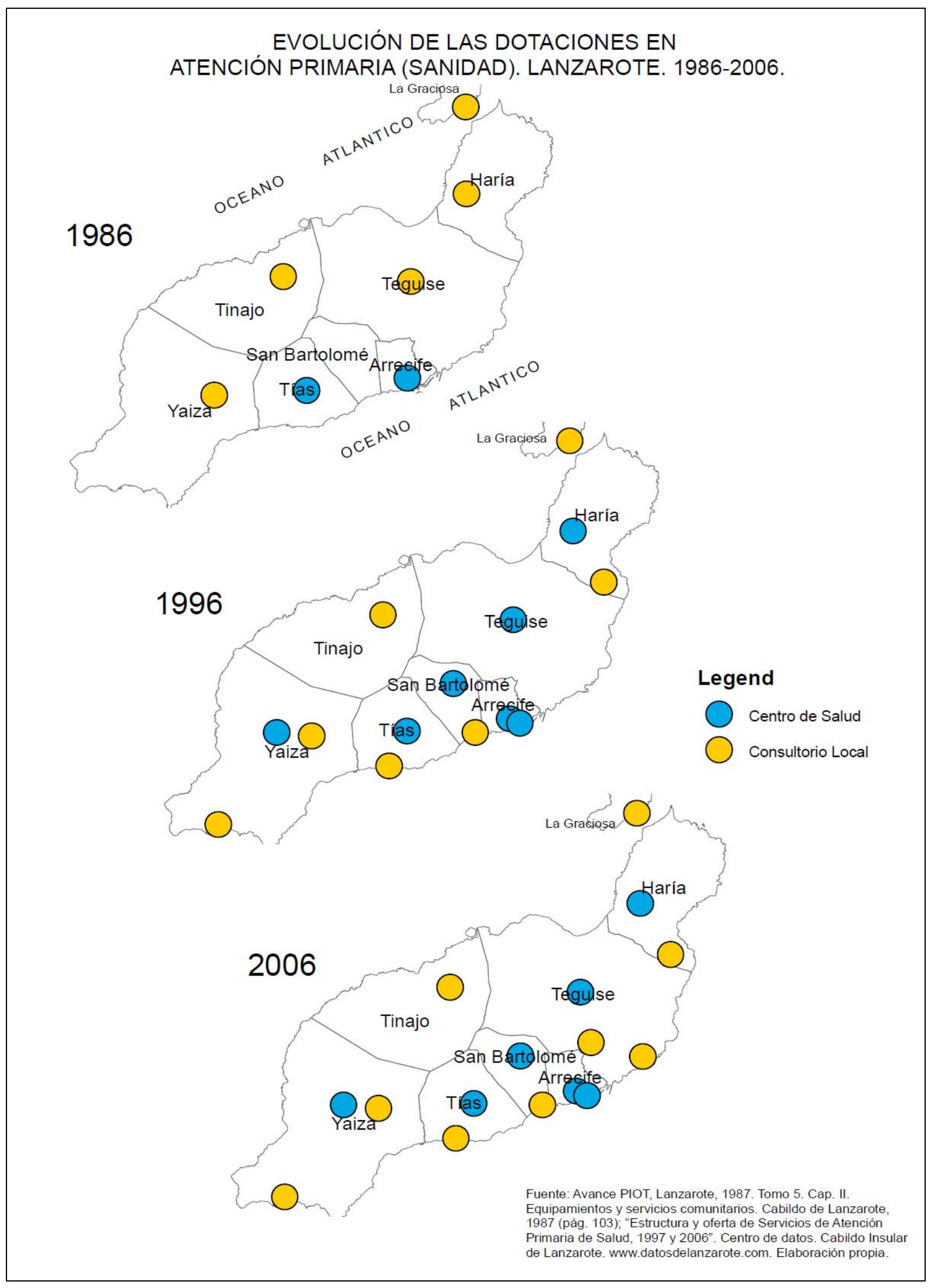


A su vez, el número de facultativos de atención primaria va en crescendo a lo largo de todo el periodo, significativamente en el último quinquenio, en el que crecen casi un $56 \%$. Aun así, la presión sobre los mismos es enorme a lo largo de toda la etapa, como nos señala el ratio habitantes/médicos en relación a la población total estimada, principalmente en los primeros seis años en los que se incrementa un $22 \%$.

Tabla 182. Oferta extrahospitalaria. Lanzarote. 1996-2006

\begin{tabular}{|c|c|c|c|c|c|c|c|}
\hline & \multicolumn{4}{|c|}{ Atención Primaria } & \multirow[b]{2}{*}{ Población derecho } & \multirow[b]{2}{*}{$\begin{array}{c}\text { *Ratio } \\
\text { Habitantes/Médicos }\end{array}$} & \multirow[b]{2}{*}{$\begin{array}{l}\text { Variación } \\
\text { Ratio (\%) }\end{array}$} \\
\hline Año & $\begin{array}{c}\text { Centro } \\
\text { de Salud }\end{array}$ & Consultorios & Facultativos & $\begin{array}{c}\text { Incremento } \\
\text { quinquenal (\%) }\end{array}$ & & & \\
\hline 1996 & 7 & 7 & 56 & & 77.379 & 1.382 & \\
\hline 2001 & 7 & 8 & 61 & 8,9 & 103.044 & 1.689 & 22,21 \\
\hline 2006 & 7 & 9 & 95 & 55,7 & 127.457 & 1.342 & $-20,54$ \\
\hline
\end{tabular}

$\left(^{\star}\right)$ Calculado en relación a la población total.

Fuente: "Estructura y oferta de servicios de Atención Primaria de Salud. Lanzarote, 1997, 2001 y 2006", "Actividad asistencial de Atención Primaria según Zonas Básica de Salud. Lanzarote, 1995-1997, 2001 y 2006 " y "Evolución de la actividad asistencial primaria, 1998-2008. Lanzarote". Centro de datos del Cabildo Insular de Lanzarote. http://www.datosdelanzarote.com. Elaboración propia.

El aumento del número de médicos en 2006 supondrá una reducción en el número de habitantes por médico de asistencia primaria, del orden del 20,5\%. Es decir, se hace más ligera la presión sobre los facultativos con respecto a 1996 y 2001, a pesar del incremento de población residente en el último quinquenio. Dicha presión no baja de 1.300 personas por médico de atención primaria en toda la etapa.

Gráfico 173. Evolución del ratio habitantes/médicos de atención primaria. Lanzarote. 1996-2006

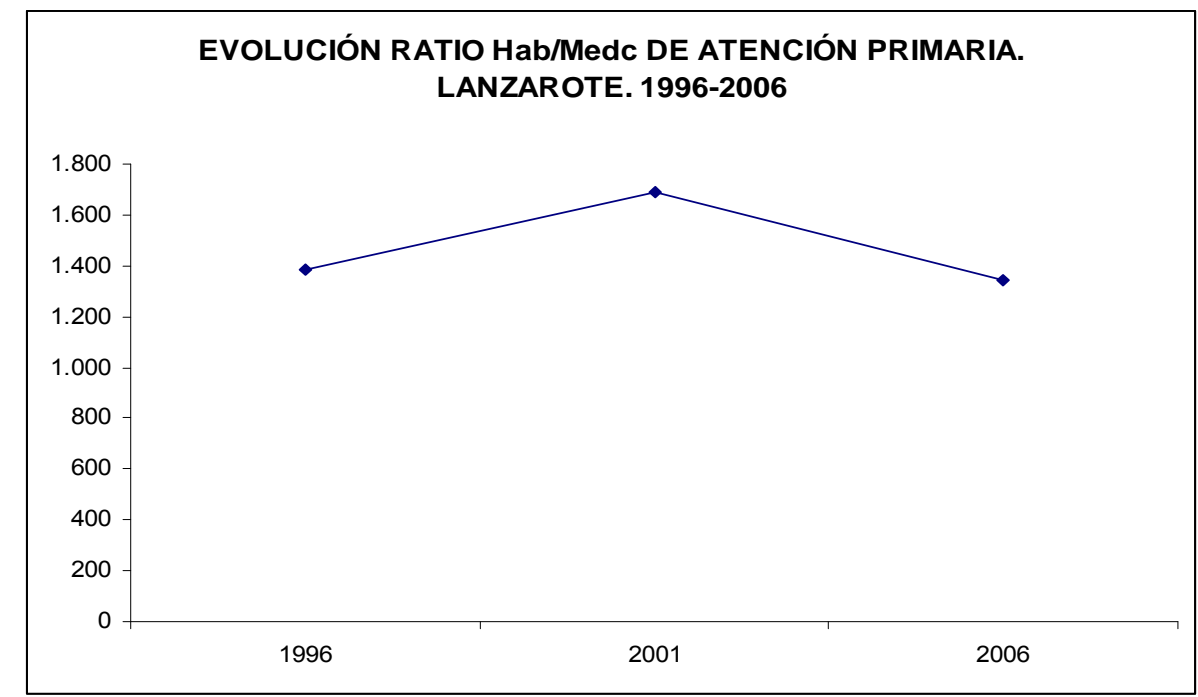

Fuente: Elaboración propia a partir de la Tabla 182. 
Veámoslo, a continuación, en relación a la totalidad de médicos que desempeñan actividad profesional en la isla.

\section{a.- El personal facultativo}

El dato positivo es la acogida de un gran número de especialidades médicas en la isla, que han hecho que se reduzca el desvío de enfermos a la capital de provincia. Así, se ha conseguido reducir el índice general o ratio habitantes/médicos entre el comienzo de la etapa y el final de la misma. De modo que la relación media durante el periodo se establece en 558 habitantes por médico, siempre por encima de la media de Canarias en el periodo y de la España (546 y 521 respectivamente).

Tabla 183. Número de facultativos por tipo y ratio habitantes/médicos. Lanzarote. 1996-2006

\begin{tabular}{|c|c|c|c|c|c|c|c|c|c|}
\hline \multirow[b]{2}{*}{ Año } & \multirow[b]{2}{*}{$\begin{array}{l}\text { Atención } \\
\text { Primaria }\end{array}$} & \multirow[b]{2}{*}{ Especialistas } & \multirow[b]{2}{*}{ TOTAL** } & \multicolumn{3}{|c|}{$\begin{array}{l}\text { En relación a la población de } \\
\text { derecho }\end{array}$} & \multicolumn{3}{|c|}{ En relación a la población total' } \\
\hline & & & & $\begin{array}{c}\text { Ratio } \\
\text { Lanzarote }\end{array}$ & $\begin{array}{l}\text { Ratio } \\
\text { Canarias }\end{array}$ & $\begin{array}{l}\text { Ratio } \\
\text { España }\end{array}$ & $\begin{array}{l}\text { Ratio } \\
\text { Lanzarote }\end{array}$ & $\begin{array}{l}\text { Ratio } \\
\text { Canarias }\end{array}$ & $\begin{array}{l}\text { Ratio } \\
\text { España }\end{array}$ \\
\hline 1996 & 56 & 74 & 138 & 561 & 574 & 555 & 914 & 682 & 569 \\
\hline 2001 & 61 & 104 & 173 & 596 & 533 & 527 & 854 & 608 & 540 \\
\hline 2006 & 95 & 143 & 246 & 518 & 530 & 482 & 671 & 581 & 493 \\
\hline
\end{tabular}

* Población total: población de derecho + turistas equivalentes día.

** Se incluyen ocho médicos más (no clasificados) que mantiene el Hospital Insular durante todo el periodo.

Fuente: "Recursos humanos del Servicio Canario de Salud. Lanzarote, 1997", "Evolución de la Estructura y Oferta de Servicios de Atención Especializada. Lanzarote, 1998-2006. Servicio Canario de Salud". "Recursos Humanos del Hospital Insular, 1996, 2001, 2006". Centro de datos del Cabildo Insular de Lanzarote. http://www.datosdelanzarote.com; "Actividad de atención especializada. Personal Médico. Canarias, 1996, 2001, 2006". Estadística de Establecimientos Sanitarios en Régimen de Internado. Servicio Canario de Saludo. ISTAC; "Personal de establecimientos sanitarios por categoría. España, 1997, 2001, 2006". Estadísticas de establecimientos sanitarios en régimen de internado. Serie 1997-2007. INE. Elaboración propia.

La isla, en términos generales, está peor dotada que Canarias y España, aunque la dinámica del país en estos diez años está marcada por la reducción de la presión de la población asistida por médico, que también caracteriza a Lanzarote. No así para el año 2001, puesto la isla experimenta un incremento de su población residente (con respecto a 1996, ya que se acelera la construcción de un nueva planta alojativa turística, que impulsa la entrada de población a trabajar) en un $33 \%$ que afectará a la capacidad del servicio. Estado que desaparece cinco años después, por la ampliación del personal facultativo, que hace que se llegue al final de la etapa (2006), con el ratio insular, en relación a la población residente, situado por debajo del de Canarias, lo que supone un gran avance en la calidad del servicio respecto a la situación del conjunto del archipiélago.

Sin embargo, si el análisis se realiza en relación a la población total estimada (población residente y turistas equivalentes diarios), la isla vuelve a alejarse de la media de España y 
de Canarias, pues los turistas, en cuanto pacientes potenciales, añaden presión sobre el servicio, por lo que siguen definiéndose como competidores por los escasos recursos sanitarios insulares. Suponen, por tanto, un incremento de la presión sobre los médicos de alrededor del $29,5 \%$ al final de la etapa, frente a Canarias donde el turista sólo supone un incremento de pacientes por médico de alrededor del 9,6\%.

\section{Gráfico 174. Comparación de los ratios población de derecho y población total estimada por médico. España, Canarias y Lanzarote. 1996-2006}

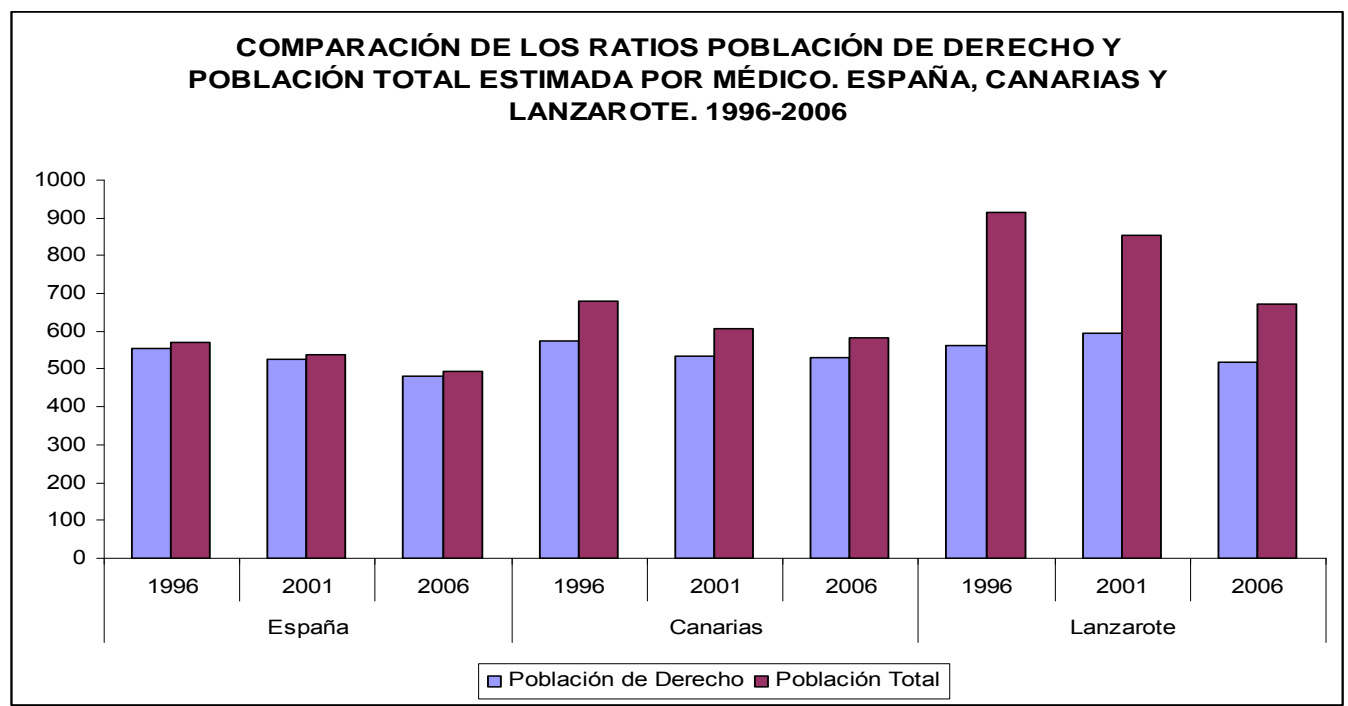

Fuente: Elaboración propia a partir de la Tabla 183.

\subsubsection{2.- EL EQUIPAMIENTO DE BIENESTAR}

Las dotaciones en relación a servicios sociales varían desde la etapa anterior. Ampliándose ahora el número de centros y su diversidad, en relación al crecimiento de la demanda.

La actividad se focaliza en el área de menores y de la mujer, principalmente. En el caso de menores irán variando y reajustando centros en relación a la demanda, en diferentes lugares de la isla. En el segundo caso, se crean dispositivos y centros destinados a la asistencia ante la violencia de género. Todos los que aquí se señalan, en la siguiente tabla, están gestionados por el Cabildo y se localizan principalmente, en su mayoría, en el municipio de Arrecife.

El equipamiento social más disperso son las residencias de ancianos, que se reparten entre cuatro municipios: Arrecife (capital administrativa de la isla), dos municipios de características rurales: Haría y Tinajo (donde la oferta de plazas turística es significativa por su reducida dimensión); y el municipio de mayor oferta de alojamiento turístico, Tías. 
Tabla 184. Servicios sociales según tipo. Lanzarote. 1996-2006

\begin{tabular}{|c|c|c|c|c|}
\hline Tipo & Función & 1996 & 2001 & 2006 \\
\hline \multirow{2}{*}{ Minusválidos } & Centro de día & 1 & & \\
\hline & Servicio de información y gestión discapacidad & 1 & 1 & 1 \\
\hline \multirow{4}{*}{ Menores y Familia } & Centros de Menores (acogimiento/adopción/integración) & 3 & 3 & 3 \\
\hline & $\begin{array}{l}\text { Dispositivo de Emergencia Menores No Acompañados } \\
\text { (amparo/integración) }\end{array}$ & & 6 & \\
\hline & Centro de Acogida de Menores Extranjeros (amparo/integración) & & 1 & 2 \\
\hline & Centro de acogida inmediata (amparo/guarda) & & 1 & 1 \\
\hline \multirow{3}{*}{ Mujer } & Centro de Información para Víctimas de Violencia Género & 1 & & 1 \\
\hline & Dispositivo emergencia mujeres agredidas & & 1 & 1 \\
\hline & Centro de acogida víctimas por violencia de género & 1 & 1 & 1 \\
\hline \multirow{3}{*}{ Drogodependencias } & Centro de información & 1 & 1 & 1 \\
\hline & Centro de deshabituación (rehabilitación) & & 1 & 4 \\
\hline & Centro prevención e incorporación social & & & 1 \\
\hline \multirow{3}{*}{ Ancianidad } & Centro de día & 1 & 1 & 1 \\
\hline & Residencias & 1 & 2 & 4 \\
\hline & Hogares y clubs & --- & --- & --- \\
\hline Delitos & Centro de Asistencia a Víctimas del Delito & 1 & 1 & 1 \\
\hline \multicolumn{2}{|l|}{ TOTAL SERVICIOS } & 9 & 20 & 21 \\
\hline
\end{tabular}

Fuente. Servicio de Planificación del Área de Bienestar Social del Cabildo de Lanzarote. http://www.cabildodelanzarote.com.

Fuentes internas del Cabildo Insular de Lanzarote, señalan que la totalidad de las solicitudes son atendidas, es decir, existen plazas suficientes, por lo que no se conocen estrangulamientos tanto en el servicio de menores, que en el caso de menores extranjeros no acompañados se ha respondido con rapidez a la demanda, como en el de la mujer. No sucede de la misma forma con la ancianidad.

\subsubsection{3.- CONCLUSIONES}

En esta etapa, cuando Lanzarote ya es un destino turístico de masas maduro, sigue sin poseer dotaciones sanitarias suficientes para dar servicio, con niveles inferiores a los nacionales y del conjunto del archipiélago, derivado del constante crecimiento demográfico que sufre en cortos periodos de tiempo, cuya rapidez dificulta la adaptación de los servicios públicos a las nuevas demandas. En términos generales, las características de la etapa son las siguientes: 
1. Incremento de camas hospitalarias tanto públicas como privadas. Aumento que, al igual que en el pasado no llega a absorber la constante y creciente demanda de la población, debido a la fuerte dinámica de crecimiento demográfico que sigue experimentando la isla, el estándar de calidad está muy por debajo de las recomendaciones de la O.M.S. EI nivel de estrangulamiento es el mismo en todo el periodo.

Gráfico 175. Camas hospitalarias por mil habitantes y comparación con el estándar de la O.M.S. España, Canarias y Lanzarote. 2006.

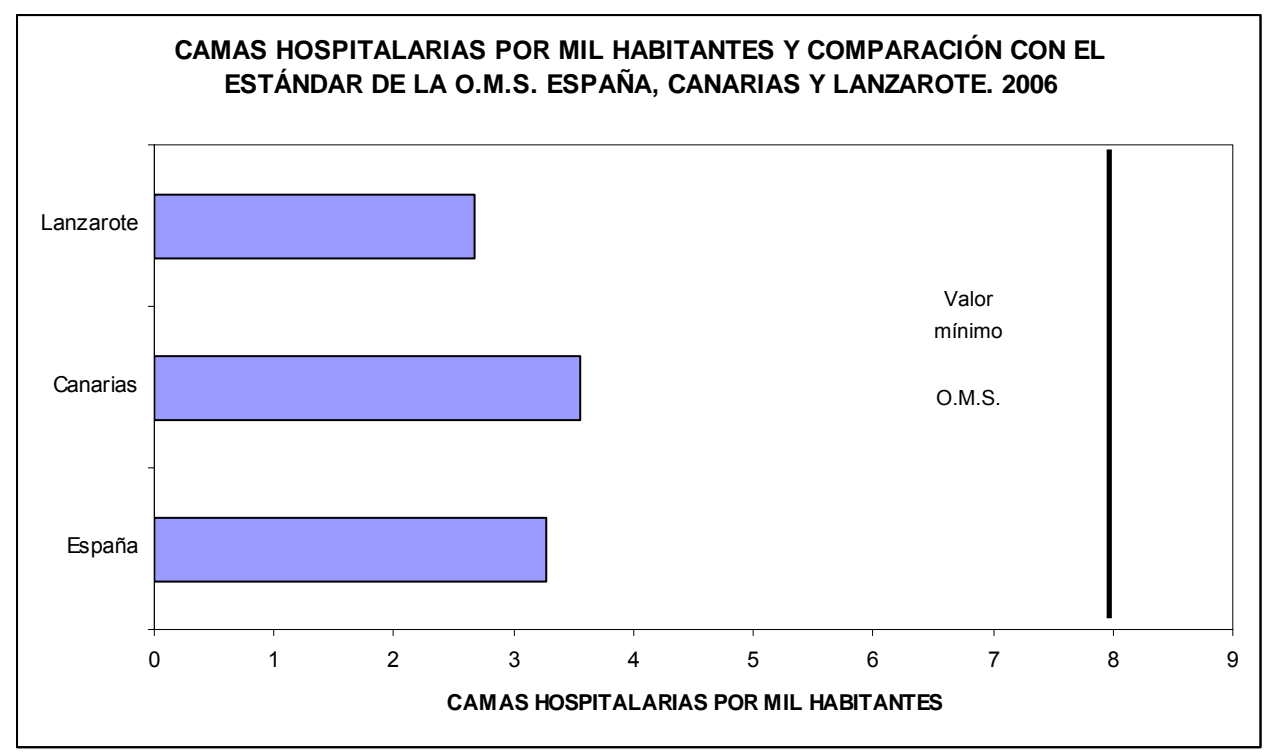

Fuente: Elaboración propia a partir de la Tabla 179.

2. Aumento del número de centros ambulatorios (consultorios), destinados a núcleos de actividad turística y tradicionalmente rurales, a consecuencia de su crecimiento demográfico residencial.

3. El estrangulamiento dotacional se encuentra en la atención primaria, que está desbordada en cuando a la capacidad de médicos. en esta área, en relación a los habitantes.

4. Aumento del número de médicos, a niveles cercanos a los de la Comunidad Autónoma y a España, y de especialidades, reduciendo el desvío a hospitales provinciales de referencia.

5. Los turistas constituyen un aumento de la presión sobre los médicos e incrementan el estrangulamiento dotacional hospitalario.

6. Los servicios sociales han respondido con rapidez y suficiencia ante la fuerte demanda de menores extranjeros no acompañados, el área de la mujer, pero no sobre la ancianidad. 
A lo largo de toda la etapa, consecuentemente, la oferta hospitalaria y extrahospitalaria no se ajusta a la demanda y permanece estrangulada. Los turistas agravan la situación, entran en competencia con la población local por los escasos recursos sanitarios, que sólo se ven aliviados por la reducción de entrada de población externa (inmigrantes) y por la crisis de afluencia turística (reducción de la demanda). Ésta situación estructural se explica, consecuentemente, por factores exógenos, por lo que la ampliación de la oferta de alojamiento turístico, como vía de impulso a la actividad económica, traerá consecuencias negativas para las dotaciones sanitarias, pues se impulsa un crecimiento demográfico difícilmente asumible a corto plazo por los servicios públicos de esta índole.

\subsection{5.- EFECTOS SOBRE LA ACTIVIDAD ECONÓMICA Y EL EMPLEO. 1996-2006}

\subsubsection{1.- POBLACIÓN ACTIVA Y ESTRUCTURA SECTORIAL DEL EMPLEO}

El objeto de este análisis es ver en qué medida la actividad turística que acoge la isla, en su madurez como destino turístico, ha incidido en los indicadores básicos del empleo, pues recordemos que la oferta del sector no deja de crecer en todo el periodo.

¿Cómo evoluciona la población activa insular tras los efectos que produce la Moratoria antes y durante su vigencia y ante la crisis de demanda que va a sufrir la isla en esta etapa?

En este punto es necesario realizar una nota metodológica, pues ante la imposibilidad de encontrar fuentes homogéneas, directas e iguales para los tres ámbitos de estudio ${ }^{211}$, sobre ocupados y parados, nos vemos obligados a acudir a diferentes estadísticas y encuestas que, aunque su origen está en organismos habilitados para tales tareas, metodológicamente son estudios diferentes. Esto hace que sea difícil la comparación entre Lanzarote, Canarias y España a lo largo del tiempo. Es por ello que para medir la dinámica del paro se han utilizado los registros de los Institutos de Empleo (datos de la Agencia Canaria de Empleo (ACE), del Observatorio Canario del Empleo y la formación Profesional (OBECAN) y el INEM, que sí nos permiten la comparación diacrónica entre los tres ámbitos.

Una vez dicho esto y observando el siguiente cuadro, las tasas de actividad han seguido una dinámica ascendente desde el pasado hasta el año 2006, al igual que se observa para el conjunto de Canarias y España. Continúan siendo más altas en Lanzarote que en el resto de los ámbitos de comparación. El mercado laboral insular parece gozar de salud, aunque el incremento de la actividad sólo ha sido de un punto, frente a los tres puntos que observa España. La actividad crece pero más lentamente como refleja la siguiente tabla.

211 Por ejemplo: la EPA no arroja resultados insulares hasta el año 2002. 
Tabla 185. Tasa de actividad. Lanzarote, Canarias y España. 1996-2006 (\%)

\begin{tabular}{||c|c|c|c|c|c|c||c|c|c|}
\cline { 2 - 10 } \multicolumn{1}{c|}{} & \multicolumn{3}{c|}{ LANZAROTE } & \multicolumn{3}{c||}{ CANARIAS } & \multicolumn{3}{c|}{ ESPAÑA } \\
\cline { 2 - 10 } \multicolumn{1}{c|}{} & $\mathbf{1 9 9 6}$ & $\mathbf{2 0 0 1}$ & $\mathbf{2 0 0 6}$ & $\mathbf{1 9 9 6}$ & $\mathbf{2 0 0 1}$ & $\mathbf{2 0 0 6}$ & $\mathbf{1 9 9 6}$ & $\mathbf{2 0 0 1}$ & $\mathbf{2 0 0 6}$ \\
\hline \hline Tasa de actividad & 62,0 & 62,9 & 63,9 & 55,0 & 59,6 & 60,8 & 51,3 & 55,9 & 58,3 \\
\hline
\end{tabular}

$\left(^{*}\right)$ Para el año 2006 se utiliza la EPA para los tres ámbitos, por lo que la comparación con años anteriores debe hacerse con precaución.

Fuente: Para 1996: "Población Insular de 16 y más años según relación con la actividad económica por grupos de edad y sexo. Lanzarote y Canarias, 1996". Encuesta de Población de Canarias 1996. ISTAC; "Activos por sexo y grupo de edad. Total nacional, 1996". EPA, 1996. INE (no existe tal desagregación en el Padrón municipal de habitantes del año 1996);

Para 2001: "Población en viviendas familiares de 16 y más años clasificada en relación con la actividad económica, según sexo y edad. Lanzarote, 2001". Censo de población y viviendas de 2001. ISTAC; "Tasa de actividad y paro según sexo y edad. Resultados Autonómicos y nacionales, 2001". Censo de población y viviendas, 2001. INE; Para 2006: "Tasa de actividad, Lanzarote y Canarias, 2006". EPA. Estimaciones en pequeñas áreas de Canarias. Resultados trimestrales (media anual). ISTAC (Datos online y consulta personalizada. Fecha: 10-05-2011. En www.gobiernodecanarias.org/istac; consultas.istac@gobiernodecanarias.org,); "Tasa de actividad. España, 2006". EPA. INE (www.ine.es). Elaboración Propia.

\section{a.- Los ocupados}

Del análisis de la estructura sectorial del empleo, a partir de 1996, no se observan modificaciones significativas en relación al sector que concentra la actividad.

Sin embargo, es significativo señalar el descenso continuo de la población ocupada en el sector agrario, hasta niveles insignificantes (con un crecimiento negativo en el último quinquenio de casi un $75 \%$, frente al $13 \%$ de Canarias), lo que hace que Lanzarote sea completamente dependiente del exterior, de las importaciones, también en relación a productos de alimentación básicos. Junto con el sector industrial, son los que se encuentran en constante decadencia. Lógico dentro del proceso de terciarización turística de la economía ya vivido en la isla y sobre el que se sigue fundamentando la política insular. Las producciones agroalimentarias se desploman a finales de la década de los ochenta -pues las nuevas generaciones se incorporan a ámbitos laborales con menor inestabilidad e incertidumbre. En el campo sólo van quedando los mayores-, desaparecen los mercados de exportación y se abandonan la mayoría de las producciones dedicadas a consumo local. La excepción será la vid, cultivo que además se va recuperando derivado de la demanda de vino que genera la actividad turística (actualmente supone el $70 \%$ de la superficie agraria insular). El turismo abrió las puertas al mercado del vino local, que no ha dejado de crecer hasta la actualidad. Pero también impulsó una política de intervención directa para intentar paliar la desaparición del paisaje rural, derivado de la original forma de cultivo existente y que constituye uno de los atractivos turísticos paisajísticos para el visitante. Es decir, el patrimonio cultural es digno de ser mantenido por su poder de atracción de visitantes, eso es folklorización, mercantilización de la cultura local, desde las teorías críticas y la izquierda freudomarxista. 
Tabla 186. Estructura sectorial del empleo. Ocupados. Lanzarote, Canarias y España. 19962006.

\begin{tabular}{|c|c|c|c|c|c|c|}
\hline LANZAROTE & 1996 & $\%$ & 2001 & $\%$ & $2006^{*}$ & $\%$ \\
\hline AGRARIO & 1.138 & 3,7 & 1.174 & 2,5 & 610 & 1,1 \\
\hline INDUSTRIAL & 1.905 & 6,1 & 2.453 & 5,3 & 1.649 & 3,1 \\
\hline CONSTRUCCIÓN & 2.935 & 9,4 & 6.982 & 15,2 & 9.292 & 17,4 \\
\hline SERVICIOS & 24.667 & 79,4 & 35.464 & 77,0 & 41.932 & 78,4 \\
\hline NO CLASIFICADOS & 419 & 1,3 & --- & --- & & \\
\hline TOTAL & 31.064 & 100,0 & 46.073 & 100.0 & 53.483 & 100 \\
\hline CANARIAS & 1996 & $\%$ & 2001 & $\%$ & 2006 & $\%$ \\
\hline AGRARIO & 37.438 & 7,2 & 33.935 & 5,0 & 29.575 & 3,4 \\
\hline INDUSTRIAL & 39.978 & 7,7 & 48.941 & 7,2 & 61.550 & 7,0 \\
\hline CONSTRUCCIÓN & 52.597 & 10,1 & 95.881 & 14,0 & 124.125 & 14,1 \\
\hline SERVICIOS & 379.034 & 72,8 & 504.577 & 73,8 & 665.150 & 75,5 \\
\hline NO CLASIFICADOS & 11.945 & 2,3 & -- & --- & -- & -- \\
\hline TOTAL & 520.992 & 100,0 & 683.354 & 100,0 & 880.400 & 100,0 \\
\hline ESPAÑA & 1996 & $\%$ & 2001 & $\%$ & 2006 & $\%$ \\
\hline AGRARIO & 1078,6 & 8,4 & 939.415 & 5,8 & 944.275 & 4,8 \\
\hline INDUSTRIAL & 2592,3 & 20,1 & 1.985 .809 & 12,2 & 3.292 .100 & 16,6 \\
\hline CONSTRUCCIÓN & 1227,9 & 9,5 & 3.136 .500 & 19,2 & 2.542 .925 & 12,9 \\
\hline SERVICIOS & 7971,3 & 62,0 & 10.267 .989 & 62.9 & 12.968 .375 & 65,7 \\
\hline NO CLASIFICADOS. & & --- & --- & --- & --- & -- \\
\hline TOTAL & 12.871 .500 & 100,0 & 16.329 .713 & 100.0 & 19.747 .675 & 100 \\
\hline
\end{tabular}

(*) Para la isla en el año 2006 se ha utilizado el empleo registrado por sectores, pues la EPA no realiza tal desagregación.

Fuente: Para 1996: "Población de 16 y más años ocupada según rama de actividad, por grupos de edad y sexo. Canarias y Lanzarote, 1996" y "Distribución porcentual de la población ocupada por sector de actividad". Encuesta de población de Canarias, 1996. ISTAC; "Población ocupada, 1996. Total nacional". EPA. INE

Para 2001: "Población en viviendas familiares ocupada de 16 y más años clasificada por actividad, sexo y edad. Lanzarote y Canarias, 2001". Censo de Población y Viviendas de Canarias, 2001. ISTAC-INE; "Ocupados de 16 y más años según la profesión (petición a medida) Total nacional. 2001". Censo de población y viviendas, 2001. INE

Para 2006: "Empleo registrado según situaciones profesionales, indicadores y ramas de actividad (CNAE-93). Municipios por islas y periodos. Media anual, 2006. Lanzarote". Instituto Canario de Estadística (ISTAC) (www.gobiernodecanarias.org/istac; consultas.istac@gobiernodecanarias.org); "Ocupados por grupo de edad, sexo y sector económico. Total Nacional y Comunidad Autónoma. 2006". EPA, 2006. INE;

Elaboración propia.

En relación al sector industrial, la isla no posee materias primas por lo que la presencia industrial se basará en la manufactura, aunque muy limitada pues "no encontrará una valorización tan fácil ni tan rápida como en las ramas generadoras de la oferta de alojamiento o de servicios anexas". Este hecho aumenta la dependencia de las importaciones. La industria pesquero-conservera, que tuvo gran importancia en la isla, en 
1986 sufre una crisis estructural que no se resuelve, pues existen sectores con mayores beneficios, el turístico, aunque con menos productividad (Cabildo Insular de Lanzarote. Avance PIOT. Tomo 4. Economía. 1987, pp.17-57). Posteriormente encontramos intentos honrosos de ampliar el sector industrial, llevados a cabo por la puesta en marcha de un Completo Agroindustrial en el municipio de Teguise, invirtiendo en queserías y productos derivados de la "batata", sin éxito, principalmente por problemas de comercialización.

En el año 2006, hasta la actualidad, el mayor volumen de empleos registrados ${ }^{212}$ en la industria se encuentra en el subsector de la manufactura $(78 \%)$ destinada principalmente a: alimentación y a la fabricación de productos metálicos y minerales y a energía (electricidad, gas y agua).

Refrendando lo dicho hasta aquí, la estructura sectorial del empleo ha ido variando en consonancia.

Tabla 187. Empleo registrado en la industria. Lanzarote. 2006 (\%)

\begin{tabular}{|l|c|}
\hline TIPO & $\%$ \\
\hline \hline EXTRACTIVA & 1,0 \\
\hline \hline MANUFACTURERA & 78,1 \\
\hline Productos alimenticios y bebidas & 20,2 \\
\hline Productos metálicos & 18,4 \\
\hline Productos minerales no Metálicos & 15,3 \\
\hline Edición, artes gráficas y reproducción & 14,5 \\
\hline \hline ENERGíA & 20,9 \\
\hline Energía eléctrica, gas, vapor y agua caliente & 67,0 \\
\hline Captación, depuración y distribución de agua & 33,0 \\
\hline \hline TOTAL & 1.649 \\
\hline \hline
\end{tabular}

Nota: téngase en cuenta que la unidad de análisis de esta fuente son los puestos de trabajo y no los individuos ocupados.

Fuente: "Empleo registrado según situaciones profesionales, indicadores y ramas de actividad (CNAE-93). Municipios por islas y periodos (trimestrales). Media anual. Lanzarote, 2006". Instituto Canario de Estadística (ISTAC). Tesorería General de la Seguridad Social, Mutualidad General de Funcionarios Civiles del Estado, Mutualidad General Judicial e Instituto Social de las Fuerzas Armadas. Consulta online (12-01-2012) en: www.gobiernodecanarias.org/istac; consultas.istac@gobiernodecanarias.org. Elaboración propia.

Por otro lado, es notable la recuperación del empleo registrado en la construcción entre 1996 y 2001 , que pasa del $9,4 \%$ al $15,2 \%$ respectivamente, siendo el sector que presenta el mayor dinamismo en términos relativos. Pues el anuncio de la modificación del

212 Téngase en cuenta que la unidad de análisis de esta fuente son los puestos de trabajo y no los individuos ocupados. 
planeamiento, a través de la Moratoria insular (que no entra en vigor hasta el 2001), va a suponer un sobre impulso inicial de la edificación, creciendo la oferta de plazas de alojamiento turístico, en este quinquenio alrededor del $13 \%$, apoyado en un fuerte crecimiento de la afluencia turística $(23,5 \%)$.

Este sobre impulso va a poner en quiebra los objetivos de la Moratoria, pues en el año 2001 ya está en funcionamiento el $88,1 \%$ del total de plazas que se establecían como límite alojativo para el 2010. Con los datos del año $2006^{213}$, la ralentización del crecimiento del alojamiento turístico no ha tenido éxito, es por ello que el empleo registrado (contratos) en la construcción sigue subiendo en términos relativos.

Tabla 188. Oferta y demanda turística en relación al límite alojativo turístico hasta el 2010 (moratoria). Lanzarote. 1996-2006

\begin{tabular}{|c||c|c||c|r|r|}
\hline Año & OFERTA & $\begin{array}{c}\text { Incremento } \\
\text { quinquenal (\%) }\end{array}$ & DEMANDA & $\begin{array}{c}\text { Incremento } \\
\text { quinquenal (\%) }\end{array}$ & $\begin{array}{c}\text { Peso respecto a Techo } \\
\text { 2010-Moratoria (\%) }\end{array}$ \\
\hline \hline 1996 & 52.830 & & 1.494 .050 & & 88,1 \\
\hline $\mathbf{2 0 0 1}$ & 59.735 & 13,1 & 1.844 .903 & 23,5 & 96,3 \\
\hline $\mathbf{2 0 0 6}$ & 65.293 & 9,3 & 1.780 .161 & $-3,5$ & 67.795 \\
\hline
\end{tabular}

Fuente: Elaboración propia a partir de datos anteriores.

Así, Lanzarote tiene mayor porcentaje de empleos registrados en este sector en el año 2006 $(17,4 \%)$ que el conjunto del archipiélago (14\%) y de España (13\%). Este último, observa un proceso de descenso del peso relativo de trabajadores en la construcción (crecimiento negativo), dinámica que aún no ha llegado a las islas.

213 La Moratoria Turística no se anulará hasta noviembre de 2006, por no ajustarse a derecho. 
Gráfico 176. Estructura sectorial del empleo. Ocupados. España, Canarias y Lanzarote. 1996-2006 (\%).

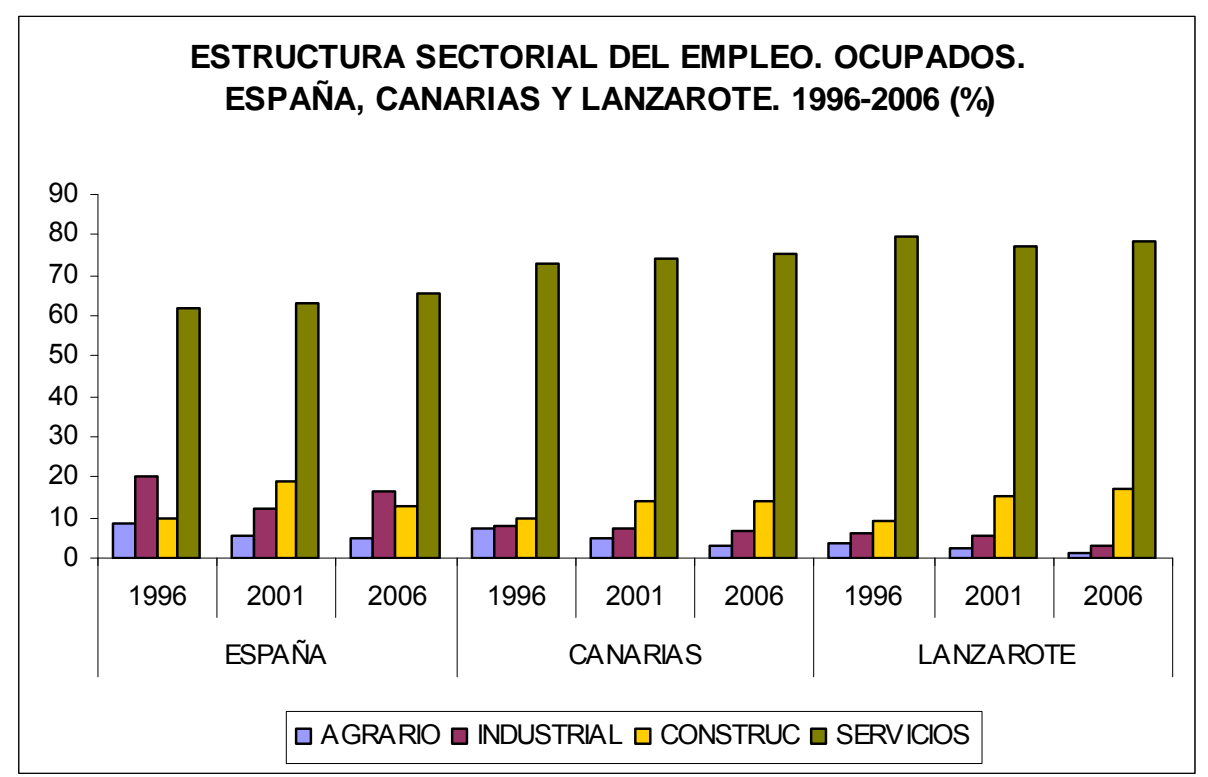

Fuente: Encuesta de población de Canarias, 1996. ISTAC; Encuesta de población activa; Censo de Población, INE. Elaboración propia a partir de la Tabla 186.

El sector servicios sigue concentrando el mayor porcentaje de ocupados en Lanzarote (78\%), al igual que en Canarias (75,5\%) y en España $(65,7)$, aunque el peso que tiene en el empleo nacional es menor al del archipiélago, hecho que se explica por la diversificación económica del país frente a la economía canaria. Aunque es el sector de la construcción quien sigue experimentando los mayores incrementos a lo largo de toda la etapa en la Isla (entre el $132 \%$ y el $33,1 \%$ ), muy por encima de Canarias y España.

Tabla 189. Incremento interperiodo de la población ocupada por sector económico. Lanzarote, Canarias y España. 1996-2006. (\%)

\begin{tabular}{|l|c|c||c|c||c|c||}
\cline { 2 - 8 } \multicolumn{1}{c|}{} & \multicolumn{2}{c|}{ LANZAROTE } & \multicolumn{2}{c||}{ CANARIAS } & \multicolumn{2}{c|}{ ESPAÑA } \\
\cline { 2 - 8 } \multicolumn{1}{c||}{} & $\mathbf{1 9 9 6 - 2 0 0 1}$ & $\mathbf{2 0 0 1 - 2 0 0 6}$ & $\mathbf{1 9 9 6 - 2 0 0 1}$ & $\mathbf{2 0 0 1 - 2 0 0 6}$ & $\mathbf{1 9 9 6 - 2 0 0 1}$ & $\mathbf{2 0 0 1 - 2 0 0 6}$ \\
\hline \hline AGRARIO & $-41,0$ & $-48,0$ & $-9,4$ & $-12,9$ & $-3,1$ & 0,5 \\
\hline INDUSTRIAL & $-27,0$ & $-32,8$ & 22,4 & 25,8 & 22,5 & 65,8 \\
\hline CONSTRUCCIÓN & 132,3 & 33,1 & 82,3 & 29,5 & 52,8 & $-18,9$ \\
\hline SERVICIOS & 54,1 & 18,2 & 33,1 & 31,8 & 26,0 & 26,3 \\
\hline
\end{tabular}

Fuente: Elaboración propia a partir de los datos de ocupados por sector, en Tabla 185.

Así se define el empleo insular en relación a actividades con fuerte vinculación turística, desde 1970 hasta la actualidad, pues utilizando como fuente la afiliación a la Seguridad Social, en 2006, la hostelería, el comercio y la construcción cuentan con una importancia relativa superior al resto de actividades. "El trinomio hostelería, comercio y construcción 
representan en Lanzarote el 63\% del empleo, mientras que en Canarias la participación es de 16 puntos porcentuales más baja" (Marrero, J.R. y otros, 2007, pp. 9).

Tabla 190. Empleo registrado por actividades económicas principales. Lanzarote. 2006 (\%)

\begin{tabular}{|l|c|c||}
\hline ACTIVIDAD & $\mathbf{N}^{\circ}$ & $\%$ \\
\hline \hline Construcción & 9.292 & 17,4 \\
\hline Comercio & 11.195 & 20,9 \\
\hline Hostelería & 13.226 & 24,7 \\
\hline TOTAL & $\mathbf{3 3 . 7 1 3}$ & $\mathbf{6 3 , 0}$ \\
\hline \hline TOTAL DE EMPLEOS REGISTRADOS & $\mathbf{5 3 . 4 8 2}$ & 100,0 \\
\hline
\end{tabular}

Nota: téngase en cuenta que la unidad de análisis de esta fuente son los puestos de trabajo y no los individuos ocupados.

Fuente: "Empleo registrado según situaciones profesionales, indicadores y ramas de actividad (CNAE-93). Municipios por islas y periodos (trimestrales). Media anual. Lanzarote, 2006". Instituto Canario de Estadística (ISTAC), Tesorería General de la Seguridad Social, Mutualidad General de Funcionarios Civiles del Estado, Mutualidad General Judicial e Instituto Social de las Fuerzas Armadas. www.gobiernodecanarias.org/istac; consultas.istac@gobiernodecanarias.org. Elaboración propia.

Por tanto, la oferta del mercado laboral de la isla está sujeta a una demanda inestable por su vinculación directa con el turismo, actividad afectada por el imaginario colectivo que le atribuye valor y significación, no sólo al viaje por ocio en sí mismo, sino también al destino. El empleo y la economía insular están sujetos al "cliente" y a su satisfacción, por lo que "en múltiples ocasiones podrá ser el mismo cliente el que ejerza control sobre la producciónconsumo". Dado que el sujeto que consume es fundamental, "las características del mismo, sus demandas específicas entran a formar parte de la gestión del empleo", sometido a una demanda inestable (Marrero, J.R. y otros, 2007, pp. 5-7), registrándose elevada precariedad si relacionamos ésta con los contratos temporales, que crecen en términos absolutos, aunque la tendencia relativa, sobre el total de contratos registrados, es de descenso.

Tabla 191. Contratos temporales según ramas de actividad principales. Lanzarote. 2001-2006

\begin{tabular}{|l|c|c|c|c||c||}
\hline & \multicolumn{2}{|c|}{2001} & \multicolumn{2}{c||}{ 2006 } & Incremento \\
\cline { 1 - 5 } RAMAS & Abs. & \% & Abs. & \% & 2006 (\%) \\
\hline Construcción & 10.084 & 23,5 & 11.452 & 21,0 & 13,6 \\
\hline Hostelería & 13.767 & 32,0 & 15.174 & 27,9 & 10,2 \\
\hline Comercio & 5.596 & 13,0 & 7.210 & 13,2 & 28,8 \\
\hline Total Trinomio & 29.447 & 68,5 & 33.836 & 62,0 & 14,9 \\
\hline \hline Total Temporales & 43.009 & $\mathbf{8 8 , 5}$ & 54.584 & $\mathbf{8 5 , 9}$ & 26,9 \\
\hline \hline CONTRATOS REGISTRADOS & 48.614 & 100,0 & 63.522 & 100,0 & 30,7 \\
\hline
\end{tabular}

Fuente: "Contratos registrados por sexo, edad, rama de actividad y sector económico. Anual acumulado, 2001 y 2006 ". Observatorio Canario del Empleo y la Formación Profesional (OBECAN). Sección Estadísticas/contratos.

http://www2.gobiernodecanarias.org/empleo/funcatra/observatoriol. (Consulta 01-02-2012). 
A ello se une la necesidad de un trabajador con capacidad de empatía y de competencia interactiva (fundamental en actividades comerciales y de hostelería), que no viene derivada, generalmente, de sistemas educativos formales de media y alta cualificación técnica, lo que justifica que el sistema sociocultural insular se caracterice por bajos niveles de instrucción (ver epígrafe. 5.3.3). Y "los niveles de estudio más bajos suelen asociarse a mayor precariedad en la contratación" (Marrero, J.R. y otros, 2007, pp. 43).

En relación a los municipios, la temporalidad del empleo, en términos relativos, se concentra en Arrecife (42,4\%), la capital y centro administrativo de la isla, seguido de los municipios de mayor participación en la oferta y demanda turística como es Tías, el municipio turístico por excelencia, que en 2006 registra menos temporalidad que Yaiza (16,5 y 17\% respectivamente), pues este último incrementa su explotación turística a lo largo de este siglo, y finalmente Teguise (13,9\%). Obsérvese la siguiente Tabla.

Tabla 192. Contratos temporales por municipios. Lanzarote. 2001-2006

\begin{tabular}{|l|r|r|r|r||}
\cline { 2 - 5 } \multicolumn{1}{c|}{} & \multicolumn{1}{|c|}{$\mathbf{2 0 0 1}$} & \multicolumn{1}{c|}{$\%$} & \multicolumn{1}{c|}{$\mathbf{2 0 0 6}$} & \multicolumn{1}{c|}{$\%$} \\
\hline \hline ARRECIFE & 17.703 & 41,1 & 23.170 & 42,4 \\
\hline HARÍA & 481 & 1,1 & 374 & 0,7 \\
\hline S. BARTOLOMÉ & 3.143 & 7,3 & 4.526 & 8,3 \\
\hline TEGUISE & 5.799 & 13,5 & 7.564 & 13,9 \\
\hline TIAS & 8.591 & 20,0 & 9.004 & 16,5 \\
\hline TINAJO & 511 & 1,2 & 677 & 1,2 \\
\hline YAIZA & 6.827 & 15,9 & 9.269 & 17,0 \\
\hline \hline TOTAL & 43.055 & 100,0 & 54.584 & 100,0 \\
\hline TOTAL CONTRATOS & 48.660 & 63.522 \\
\hline
\end{tabular}

Fuente: "Contratos por municipio, sector económico y tipo. Lanzarote, 2001 y 2006". Observatorio Canario del empleo y de la formación profesional (OBECAN). http://www2.gobiernodecanarias.org/empleo/funcatra/observatorio/ (visitado 02-10-2011). Elaboración propia.

La alta temporalidad se muestra principalmente en el sector de la construcción, pues de todos los contratos que se realizan en esta rama, más del $90 \%$ son temporales, excepto en el municipio de Yaiza, con fuerte producción de plazas de alojamiento turístico con la entrada de siglo, donde llegan casi al $100 \%$. 
Tabla 193. Contratos temporales según sectores y municipios. Lanzarote. 2001-2006

\begin{tabular}{|c|c|c|c|c|c|c|c|}
\hline & \multicolumn{3}{|c|}{2001} & \multicolumn{3}{|c|}{2006} \\
\hline & & \multicolumn{2}{|c|}{ Temporales } & \multirow{2}{*}{$\begin{array}{l}\text { TODOS } \\
\text { Absolutos }\end{array}$} & \multicolumn{2}{|c|}{ Temporales } & \multirow{2}{*}{$\frac{\text { TODOS }}{\text { Absolutos }}$} \\
\hline & & Absolutos & $\%$ & & Absolutos & $\%$ & \\
\hline \multirow{4}{*}{ ARRECIFE } & Agricultura & 91 & 55,2 & 165 & 100 & 60,6 & 165 \\
\hline & Industria & 387 & 76,6 & 505 & 469 & 68,9 & 681 \\
\hline & Construcción & 3662 & 94,6 & 3.870 & 5.455 & 88,8 & 6140 \\
\hline & Servicios & 13.563 & 89,2 & 15.204 & 17.146 & 85,0 & 20.180 \\
\hline \multicolumn{2}{|c|}{ TOTAL TEMPORALES } & 17.703 & 89,7 & & 23.170 & 85,3 & \\
\hline \multicolumn{2}{|c|}{ TOTAL CONTRATOS } & 19.744 & 100,0 & & 27.166 & 100,0 & \\
\hline
\end{tabular}

\begin{tabular}{|c|c|c|c|c|c|c|c|}
\hline & \multicolumn{3}{|c|}{2001} & \multicolumn{3}{|c|}{2006} \\
\hline & & \multicolumn{2}{|c|}{ Temporales } & \multirow{2}{*}{$\begin{array}{l}\text { TODOS } \\
\text { Absolutos }\end{array}$} & \multicolumn{2}{|c|}{ Temporales } & \multirow{2}{*}{$\frac{\text { TODOS }}{\text { Absolutos }}$} \\
\hline & & Absolutos & $\%$ & & Absolutos & $\%$ & \\
\hline \multirow{4}{*}{ HARÍA } & Agricultura & 0 & 0 & 0 & 7 & 46,7 & 15 \\
\hline & Industria & 16 & 94,1 & 17 & 7 & 70,0 & 10 \\
\hline & Construcción & 173 & 96,6 & 179 & 92 & 90,2 & 102 \\
\hline & Servicios & 292 & 79,6 & 367 & 268 & 79,5 & 337 \\
\hline \multicolumn{2}{|c|}{ TOTAL TEMPORALES } & 481 & 85,4 & & 374 & 80,6 & \\
\hline \multicolumn{2}{|c|}{ TOTAL CONTRATOS } & 563 & 100,0 & & 464 & 100,0 & \\
\hline
\end{tabular}

\begin{tabular}{|c|c|c|c|c|c|c|c|}
\hline & \multicolumn{3}{|c|}{2001} & \multicolumn{3}{|c|}{2006} \\
\hline & & \multicolumn{2}{|c|}{ Temporales } & \multirow{2}{*}{\begin{tabular}{|l} 
TODOS \\
Absolutos
\end{tabular}} & \multicolumn{2}{|c|}{ Temporales } & \multirow{2}{*}{$\begin{array}{l}\text { TODOS } \\
\text { Absolutos }\end{array}$} \\
\hline & & Absolutos & $\%$ & & Absolutos & $\%$ & \\
\hline \multirow{4}{*}{ SAN BARTOLOMÉ } & Agricultura & 2 & 100,0 & 2 & 20 & 57,1 & 35 \\
\hline & Industria & 96 & 82,1 & 117 & 91 & 72,2 & 126 \\
\hline & Construcción & 732 & 93,6 & 782 & 1.364 & 91,7 & 1.487 \\
\hline & Servicios & 2.313 & 86,5 & 2.675 & 3.051 & 78,7 & 3.877 \\
\hline \multicolumn{2}{|c|}{ TOTAL TEMPORALES } & 3.143 & 87,9 & & 4.526 & 81,9 & \\
\hline \multicolumn{2}{|c|}{ TOTAL CONTRATOS } & 3.576 & 100,0 & & 5.525 & 100,0 & \\
\hline
\end{tabular}




\begin{tabular}{|c|c|c|c|c|c|c|c|}
\hline & \multicolumn{3}{|c|}{2001} & \multicolumn{3}{|c|}{2006} \\
\hline & & \multicolumn{2}{|c|}{ Temporales } & \multirow{2}{*}{$\frac{\text { TODOS }}{\text { Absolutos }}$} & \multicolumn{2}{|c|}{ Temporales } & \multirow{2}{*}{$\begin{array}{l}\text { TODOS } \\
\text { Absolutos }\end{array}$} \\
\hline & & Absolutos & $\%$ & & Absolutos & $\%$ & \\
\hline \multirow{4}{*}{ TEGUISE } & Agricultura & 40 & 95,2 & 42 & 23 & 76,7 & 30 \\
\hline & Industria & 24 & 75,0 & 32 & 50 & 63,3 & 79 \\
\hline & Construcción & 1.137 & 95,3 & 1.193 & 1.497 & 93,4 & 1.602 \\
\hline & Servicios & 4.598 & 88,8 & 5.176 & 5.994 & 89,0 & 6.736 \\
\hline \multicolumn{2}{|c|}{ TOTAL TEMPORALES } & 5.799 & 90,0 & & 7.564 & 89,5 & \\
\hline \multicolumn{2}{|c|}{ TOTAL CONTRATOS } & 6.443 & 100,0 & & 8.447 & 100,0 & \\
\hline
\end{tabular}

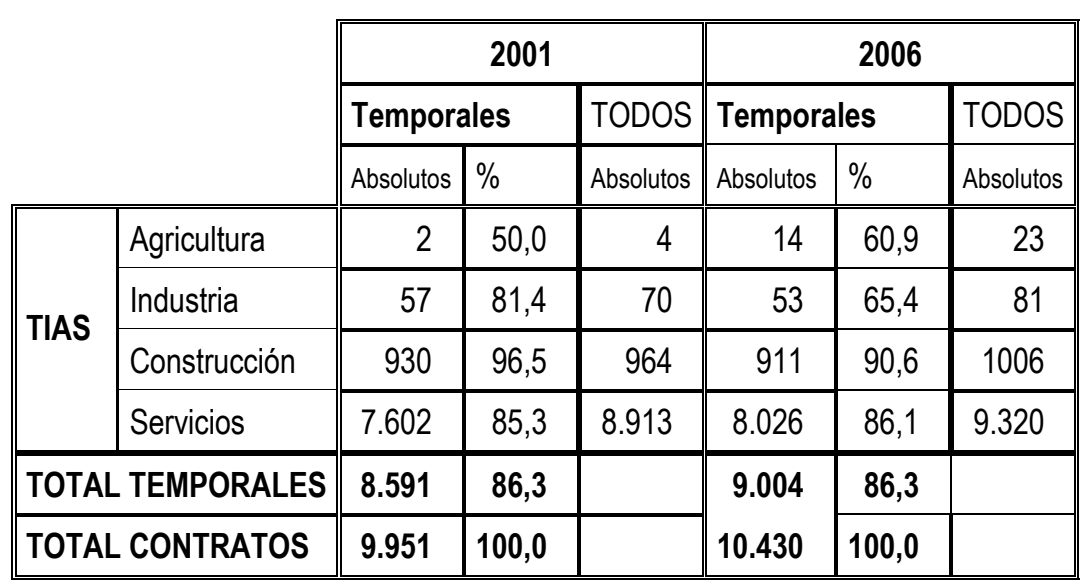

\begin{tabular}{|c|c|c|c|c|c|c|c|}
\hline & \multicolumn{3}{|c|}{2001} & \multicolumn{3}{|c|}{2006} \\
\hline & & \multicolumn{2}{|c|}{ Temporales } & \multirow{2}{*}{$\frac{\text { TODOS }}{\text { Absolutos }}$} & \multicolumn{2}{|c|}{ Temporales } & \multirow{2}{*}{$\begin{array}{l}\text { TODOS } \\
\text { Absolutos }\end{array}$} \\
\hline & & Absolutos & $\%$ & & Absolutos & $\%$ & \\
\hline \multirow{4}{*}{ TINAJO } & Agricultura & 0 & 0 & 0 & 5 & 83,3 & 6 \\
\hline & Industria & 37 & 82,2 & 45 & 36 & 62,1 & 58 \\
\hline & Construcción & 302 & 93,5 & 323 & 263 & 87,4 & 301 \\
\hline & Servicios & 172 & 52,9 & 325 & 373 & 68,6 & 544 \\
\hline \multicolumn{2}{|c|}{ TOTAL TEMPORALES } & 511 & 73,7 & & 677 & 74,5 & \\
\hline \multicolumn{2}{|c|}{ TOTAL CONTRATOS } & 693 & 100,0 & & 909 & 100,0 & \\
\hline
\end{tabular}




\begin{tabular}{|c|c|c|c|c|c|c|c|}
\hline & \multicolumn{3}{|c|}{2001} & \multicolumn{3}{|c|}{2006} \\
\hline & & \multicolumn{2}{|c|}{ Temporales } & \multirow{2}{*}{$\begin{array}{l}\text { TODOS } \\
\text { Absolutos }\end{array}$} & \multicolumn{2}{|c|}{ Temporales } & \multirow{2}{*}{$\begin{array}{l}\text { TODOS } \\
\text { Absolutos }\end{array}$} \\
\hline & & Absolutos & $\%$ & & Absolutos & $\%$ & \\
\hline \multirow{4}{*}{ YAIZA } & Agricultura & 2 & 22,2 & 9 & 18 & 75,0 & 24 \\
\hline & Industria & 33 & 84,6 & 39 & 45 & 86,5 & 52 \\
\hline & Construcción & 3.148 & 99,5 & 3.163 & 1.898 & 92,4 & 2.055 \\
\hline & Servicios & 3.644 & 81,4 & 4.479 & 7.308 & 86,5 & 8.450 \\
\hline \multicolumn{2}{|c|}{ TOTAL TEMPORALES } & 6.827 & 88,8 & & 9.269 & 87,6 & \\
\hline \multicolumn{2}{|c|}{ TOTAL CONTRATOS } & 7.690 & 100,0 & & 10.581 & 100,0 & \\
\hline
\end{tabular}

Fuente: "Contratos por municipio, sector económico y tipo, 2001 y 2006. Lanzarote". Observatorio Canario del empleo y de la formación profesional (OBECAN). http://www2.gobiernodecanarias.org/empleo/funcatra/observatorio/. (On line. Visitado 02-10-2011). Elaboración propia.

A todo lo señalado hasta ahora se une un mercado laboral caracterizado por la alta contratación de población foránea, en constante crecimiento, es decir personas que previamente a la contratación no residían en Lanzarote, así que en su madurez como destino turístico este hecho se ha acentuado $(57,3 \%)$, con fuerte presencia de personas de otras nacionalidades $(39,3 \%)$. El mercado de trabajo se nutre de inmigración.

Tabla 194. Contratos a personas no residentes. Lanzarote 2002-2006

\begin{tabular}{|c|c|c|c|c|c|c|}
\hline & 2002 & $\%$ & 2004 & $\%$ & 2006 & $\%$ \\
\hline Extranjeros & 13.919 & 27,39 & 18.320 & 31,85 & 24.986 & 39,33 \\
\hline Otras CCAA & 6.028 & 11,86 & 7.277 & 12,65 & 7.506 & 11,82 \\
\hline Otras Islas & 3.464 & 6,82 & 3.287 & 5,71 & 3.900 & 6,14 \\
\hline TOTAL FORÁNEOS & 23.411 & 46,07 & 28.884 & 50,21 & 36.392 & 57,29 \\
\hline TOTAL CONTRATOS & 50.818 & 100,00 & 57.528 & 100,00 & 63.522 & 100,00 \\
\hline
\end{tabular}

Nota: Personas no empadronadas en Lanzarote en el momento del alta del contrato.

Fuente: Marrero, J.R.; Hernández, R.; León, J.S.; Santana, M.A. (2007). "La situación del empleo en el sector turístico de Lanzarote". Cabildo Insular de Lanzarote y Universidad de la Laguna. Lanzarote, 2007 (pp. 47). Elaboración propia

Aunque en palabras de Marrero, J.R. (2007, pp. 48) este incremento porcentual del total de contratos que se realizan a extranjeros también puede ser explicado como un "incremento de su precariedad, pues para ocupar los mismos empleos, los inmigrantes extranjeros precisan de un número cada vez mayor de contratos". 
Gráfico 177. Evolución de los contratos a personas según origen. Foráneos. Lanzarote. 2002-2006

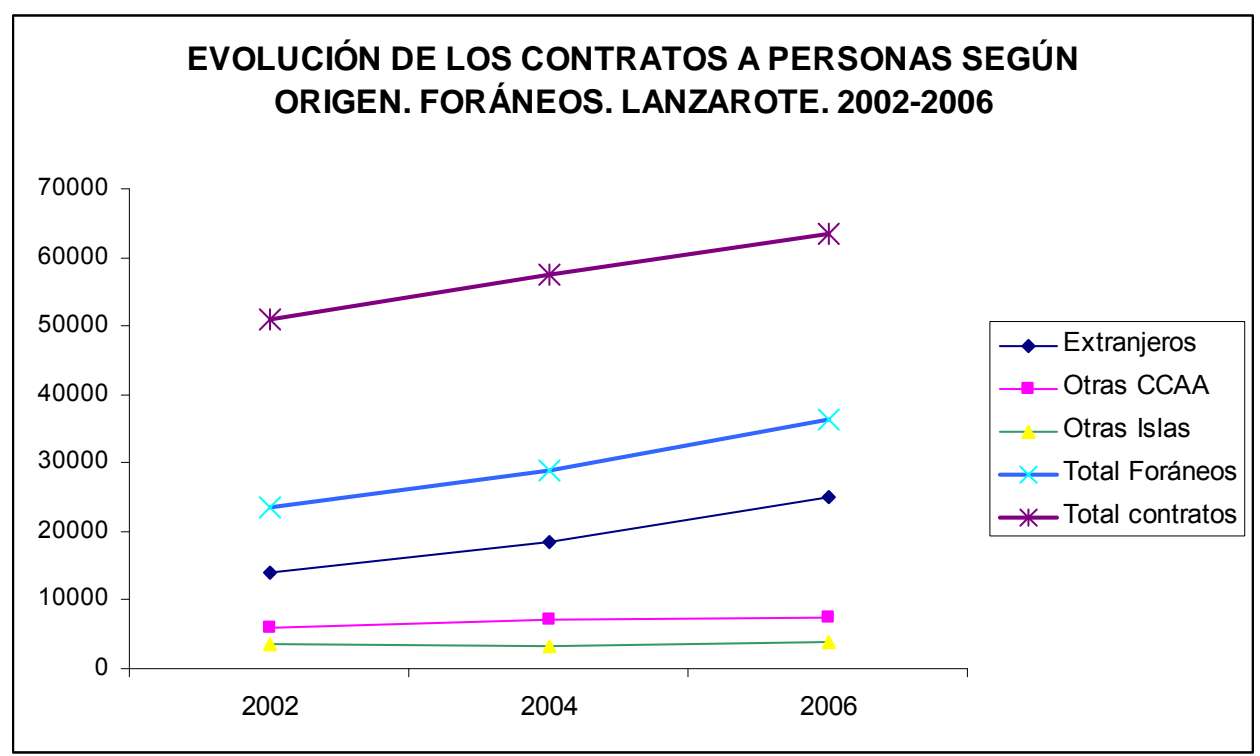

Fuente: Elaboración propia a partir de los datos recogidos de OBECAN, Tabla 193.

En el ámbito municipal, el Observatorio Canario del Empleo (OBECAN), para el año 2006, señala que de los 87 municipios que existen en Canarias:

a) en 20 municipios se superan la media $(5,3 \%)$ de contratación de personas de otras Comunidades Autónomas y seis son de la isla de Lanzarote.

b) en 25 municipios se supera la media (19,3\%) de contratación a extranjeros. En ellos están incluidos los siete municipios de Lanzarote. A la cabeza estarán tres municipios de la Isla que concentran la mayor parte de la oferta y la demanda turística, como Yaiza, Tías o Teguise. 
Tabla 195. Contratos a extranjeros en municipios que superan la media de Canarias. 2006 (\%)

\begin{tabular}{|c|c|c|c|}
\hline \multicolumn{2}{|c|}{$\begin{array}{l}\text { Municipios que superan la medida de contratación a } \\
\text { personas procedentes de otras CCAA. } 2006\end{array}$} & \multicolumn{2}{|c|}{$\begin{array}{l}\text { Municipios que superan la media de contratación a } \\
\text { extranjeros (\%de contratos a extranjeros sobre el total firmado } \\
\text { en cada municipio). }\end{array}$} \\
\hline YAIZA & 21,5 & YAIZA & 49,6 \\
\hline PÁJARA & 19,5 & TIAS & 48,2 \\
\hline LA OLIVA & 14,4 & TEGUISE & 45,2 \\
\hline ANTIGUA & 12,4 & LA OLIVA & 44,9 \\
\hline TUINEJE & 12,1 & PÁJARA & 42,8 \\
\hline PUERTO DEL ROSARIO & 11,4 & ANTIGUA & 42,3 \\
\hline TEGUISE & 11,1 & ADEJE & 40,9 \\
\hline TIAS & 11,0 & ARONA & 38,1 \\
\hline ARRECIFE & 9,7 & TINAJO & 36,6 \\
\hline ADEJE & 9,1 & SANTIAGO DEL TEIDE & 35,3 \\
\hline SAN BARTOLOMÉ & 8,0 & SAN MIGUEL DE ABONA & 33,6 \\
\hline ARONA & 7,7 & MOGAN & 33,4 \\
\hline BETANCURIA & 7,1 & ARRECIFE & 32,6 \\
\hline AGAETE & 7,1 & GUÍA DE ISORA & 29,8 \\
\hline SANTIAGO DEL TEIDE & 6,8 & VALLE GRAN REY & 29,8 \\
\hline ALAJERO & 6,4 & PUERTO DEL ROSARIO & 29,6 \\
\hline TINAJO & 6,3 & HARÍA & 29,5 \\
\hline GRANADILLA & 6,0 & SAN BARTOLOMÉ & 28,2 \\
\hline GUÍA DE ISORA & 6,0 & TUINEJE & 28,1 \\
\hline SAN MIGUEL DE ABONA & 6,0 & GRANADILLA & 27,8 \\
\hline MEDIA DE CANARIAS & 5,3 & SAN BARTOLOMÉ DE TIRAJANA & 26,6 \\
\hline & & ALAJERO & 23,2 \\
\hline & & ARICO & 23 \\
\hline & & VILAFLOR & 21,6 \\
\hline & & SAN SEBASTIAN DE LA GOMERA & 20,2 \\
\hline & & MEDIA DE CANARIAS & 19,3 \\
\hline
\end{tabular}

Fuente: OBECAN “Informe sobre migración laboral en Canarias. Análisis de la contratación, 2006". Consejería de Industria, Empleo y Comercio. Gobierno de Canarias, 2006. 
Por otro lado, análisis realizados por el Instituto Canario de Estadística (ISTAC) en 1996, ${ }^{214}$ afirman que la población ocupada extranjera, en Canarias, "se integra en un mercado laboral segmentado en buena media en función de su origen", el nivel de los puestos de trabajo que ocupan varían en relación a que procedan de países más o menos desarrollados, lo que supone mayor o menor precariedad en la contratación según origen: "los inmigrantes procedentes de los países menos desarrollados ocupan puestos más bajos o marginales (...) porque son las oportunidades de empleo de las que disponen y por su escaso poder social de negociación". Antes de comprobar si al final de la etapa ésta situación de la inmigración sigue siendo así, partimos de datos generales sobre las características en la contratación de extranjeros en Lanzarote.

El Observatorio Canaria del Empleo (OBECAN), para el año 2006, recoge el 87,4\% de los contratos a extranjeros como temporales, siendo la comunidad de mayor contratación la procedente de Iberoamérica, seguida de la africana y en tercer lugar de países de la Unión Europea. En comparación con el conjunto del archipiélago, sobresale el mayor peso relativo que tiene la contratación de africanos en Lanzarote (18\% y $27 \%$ respectivamente).

Tabla 196. Contratos a extranjeros por tipo y sectores económicos principales. Lanzarote. 2006

\begin{tabular}{|c|c|c|c|}
\hline ACTIVIDAD & CONTRATO & Abs. & $\%$ \\
\hline \multirow{3}{*}{ Comercio } & Duración determinada & 1.978 & \\
\hline & Indefinidos & 567 & \\
\hline & TOTAL & 2.545 & 10,19 \\
\hline \multirow{3}{*}{ Construcción } & Duración determinada & 5.588 & \\
\hline & Indefinidos & 496 & \\
\hline & TOTAL & 6.084 & 24,35 \\
\hline \multirow{3}{*}{ Hostelería } & Duración determinada & 6.429 & \\
\hline & Indefinidos & 1.167 & \\
\hline & TOTAL & 7.596 & 30,40 \\
\hline & TOTAL TRINOMIO & 16.225 & 64,94 \\
\hline & CONTRATOS TEMPORALES & 21.842 & 87,42 \\
\hline & CONTRATOS INDEFINIDOS & 3.144 & 12,58 \\
\hline & TOTAL CONTRATOS & 24.986 & \\
\hline
\end{tabular}

Fuente: "Contratos registrados a trabajadores asalariados cuya nacionalidad es diferente a la española. Según sector económico, tipo de contrato y meses (acumulado). Lanzarote, 2006". OBECAN, Sección Estadísticas-Extranjeros. [En línea] http://www2.gobiernodecanarias.org/empleo/funcatra/observatorio/. (Visitado 2-02-2012). Elaboración propia.

${ }^{214}$ ISTAC (1999). "Encuesta de población. Canarias, 1996. Población extranjera". Gobierno de Canarias. Diciembre de 1999 (pp. 15). http://www.datosdelanzarote.com. 
Tabla 197. Contratos a extranjeros por origen. Lanzarote y Canarias. 2006 (\%)

\begin{tabular}{|l|r|r|}
\cline { 2 - 3 } \multicolumn{1}{c|}{} & CANARIAS & LANZAROTE \\
\hline U.E. & 24,8 & 18,0 \\
\hline Ampliación UE & 2,7 & 1,1 \\
\hline Resto de Europa & 3,5 & 2,5 \\
\hline África & 18,2 & 27,1 \\
\hline Norteamérica & 0,1 & 0,1 \\
\hline Iberoamérica & 46,1 & 46,6 \\
\hline Asia & 4,2 & 4,6 \\
\hline Oceanía & 0,0 & 0,03 \\
\hline \hline TOTAL & 151.790 & $\mathbf{2 4 . 9 8 6}$ \\
\hline
\end{tabular}

Fuente: "Perfil de los contratos por Continente". Informe sobre migración laboral. Análisis de la contratación. Canarias. OBECAN, 2006. http://www2.gobiernodecanarias.org/empleo/funcatra/observatorio/ Elaboración propia.

Para comprobar si diez años después (2006) sigue existiendo segmentación de la contratación a extranjeros en relación al origen, se han solicitado registros más detallados ha dicho Observatorio, en relación a "origen (por países), sector económico y tipo de contrato". Se recogen, en la siguiente Tabla, los países que concentran más del $70 \%$ de la contratación (pues la isla posee trabajadores de multitud de países), es decir, los que registran más peso en términos absolutos y relativos.

Tabla 198. Contratos a extranjeros según país de origen, sector económico y temporalidad. Lanzarote. 2006

\begin{tabular}{|c|c|c|c|c|c|c|}
\hline & \multirow{3}{*}{\begin{tabular}{|r|} 
Contratos \\
35 \\
\end{tabular}} & \multirow{3}{*}{$\begin{array}{c}\% \\
21,0\end{array}$} & \multirow{3}{*}{\begin{tabular}{r|} 
Temporales \\
29
\end{tabular}} & \multirow{3}{*}{\begin{tabular}{|r|}
$\%$ \\
82,9
\end{tabular}} \\
\hline & & & & & & \\
\hline \multirow{7}{*}{ AGRICULTURA } & Iberoamérica & Colombia & & & & \\
\hline & \multirow{4}{*}{ África } & Marruecos & 58 & 34,7 & 33 & 56,9 \\
\hline & & Mauritania & 16 & 9,6 & 6 & 37,5 \\
\hline & & Senegal & 9 & 5,4 & 4 & 44,4 \\
\hline & & Total & 83 & 49,7 & 43 & 51,8 \\
\hline & Europa & Rumania & 9 & 5,4 & 5 & 55,6 \\
\hline & \multicolumn{2}{|c|}{ Total selección } & 127 & 76,0 & 77 & 60,6 \\
\hline \multicolumn{3}{|l|}{ TOTAL } & 167 & 100,0 & 99 & 59,3 \\
\hline
\end{tabular}

Nota: El porcentaje de temporales está calculado en relación al total de contratos por país de origen.

Fuente: "Contratos a extranjeros, Lanzarote 2006, por nacionalidad, sector y tipo de contrato". OBECAN. Solicitud a medida vía Web a: obecan.sce@gobiernodecanarias.org (29-02-2012). Elaboración propia. 


\begin{tabular}{|c|c|c|c|c|c|c|}
\hline & & & Contratos & $\%$ & Temporales & $\%$ \\
\hline \multirow{12}{*}{ INDUSTRIA } & \multirow{5}{*}{ Iberoamérica } & Argentina & 21 & 8,2 & 12 & 57,1 \\
\hline & & Colombia & 55 & 21,4 & 35 & 63,6 \\
\hline & & Cuba & 17 & 6,6 & 12 & 70,6 \\
\hline & & Ecuador & 22 & 8,6 & 16 & 72,7 \\
\hline & & Total & 115 & 44,7 & 75 & 65,2 \\
\hline & & Marruecos & 30 & 11,7 & 17 & 56,7 \\
\hline & África & Guinea-Bissau & 10 & 3,9 & 10 & 100,0 \\
\hline & & Total & 40 & 15,6 & 27 & 67,5 \\
\hline & \multirow{3}{*}{ Europa } & Alemania & 18 & 7,0 & 9 & 50,0 \\
\hline & & Reino Unido & 12 & 4,7 & 8 & 66,7 \\
\hline & & Total & 30 & 11,7 & 17 & 56,7 \\
\hline & \multicolumn{2}{|c|}{ Total selección } & 185 & 72,0 & 119 & 64,3 \\
\hline \multicolumn{3}{|l|}{ TOTAL } & 257 & 100,0 & 178 & 69,3 \\
\hline
\end{tabular}

Nota: El porcentaje de temporales está calculado en relación al total de contratos por país de origen.

Fuente: "Contratos a extranjeros, Lanzarote 2006, por nacionalidad, sector y tipo de contrato". OBECAN. Solicitud a medida vía Web a: obecan.sce@gobiernodecanarias.org (29-02-2012). Elaboración propia.

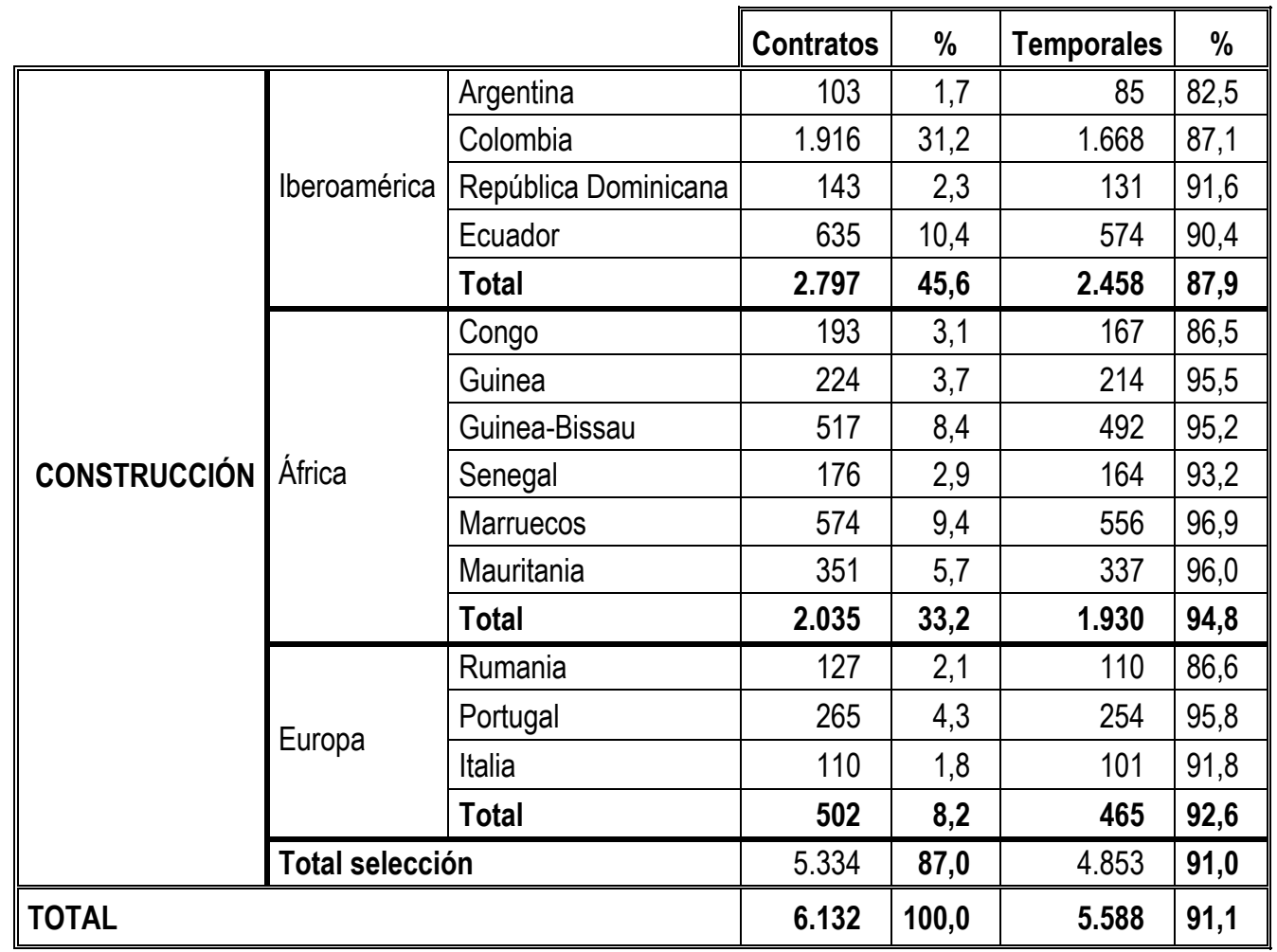

Nota: El porcentaje de temporales está calculado en relación al total de contratos por país de origen.

Fuente: "Contratos a extranjeros, Lanzarote 2006, por nacionalidad, sector y tipo de contrato". OBECAN. Solicitud a medida vía Web a: obecan.sce@gobiernodecanarias.org (29-02-2012). Elaboración propia. 


\begin{tabular}{|c|c|c|c|c|c|c|}
\hline & \multirow{3}{*}{\begin{tabular}{|c|} 
Contratos \\
117 \\
\end{tabular}} & \multirow{3}{*}{$\begin{array}{r}\% \\
4,6\end{array}$} & \multirow{3}{*}{\begin{tabular}{c|} 
Temporales \\
82
\end{tabular}} & \multirow{3}{*}{$\frac{\%}{70,1}$} \\
\hline & & & & & & \\
\hline \multirow{13}{*}{ COMERCIO } & \multirow{5}{*}{ Iberoamérica } & Argentina & & & & \\
\hline & & Colombia & 585 & 23,0 & 494 & 84,4 \\
\hline & & Cuba & 109 & 4,3 & 97 & 89,0 \\
\hline & & Ecuador & 158 & 6,2 & 125 & 79,1 \\
\hline & & Total & 969 & 38,1 & 798 & 82,4 \\
\hline & \multirow{3}{*}{ Asia } & China & 128 & 5,0 & 69 & 53,9 \\
\hline & & India & 187 & 7,3 & 97 & 51,9 \\
\hline & & Total & 315 & 12,4 & 166 & 52,7 \\
\hline & África & Marruecos & 250 & 9,8 & 208 & 83,2 \\
\hline & \multirow{3}{*}{ Europa } & Italia & 164 & 6,4 & 138 & 84,1 \\
\hline & & Reino Unido & 132 & 5,2 & 95 & 72,0 \\
\hline & & Total & 296 & 11,6 & 233 & 78,7 \\
\hline & \multicolumn{2}{|c|}{ Total selección } & 1.830 & 71,9 & 1.405 & 76,8 \\
\hline \multicolumn{3}{|l|}{ TOTAL } & 2.545 & 41,5 & 1.978 & 77,7 \\
\hline
\end{tabular}

Nota: El porcentaje de temporales está calculado en relación al total de contratos por país de origen.

Fuente: "Contratos a extranjeros, Lanzarote 2006, por nacionalidad, sector y tipo de contrato". OBECAN. Solicitud a medida vía Web a: obecan.sce@gobiernodecanarias.org (29-02-2012). Elaboración propia.

\begin{tabular}{|c|c|c|c|c|c|c|}
\hline & \multirow{3}{*}{$\begin{array}{c}\text { Contratos } \\
199\end{array}$} & \multirow{3}{*}{$\begin{array}{l}\% \\
2,4\end{array}$} & \multirow{3}{*}{$\begin{array}{c}\text { Temporales } \\
165\end{array}$} & \multirow{3}{*}{\begin{tabular}{|r|}
$\%$ \\
82,9
\end{tabular}} \\
\hline & & & & & & \\
\hline \multirow{20}{*}{ HOSTELERÍA } & \multirow{7}{*}{ Iberoamérica } & Argentina & & & & \\
\hline & & Colombia & 1.436 & 17,1 & 1.277 & 88,9 \\
\hline & & República Dominicana & 308 & 3,7 & 285 & 92,5 \\
\hline & & Ecuador & 465 & 5,5 & 394 & 84,7 \\
\hline & & Perú & 189 & 2,3 & 169 & 89,4 \\
\hline & & Uruguay & 165 & 2,0 & 146 & 88,5 \\
\hline & & Total & 2.762 & 32,9 & 2.436 & 88,2 \\
\hline & \multirow{3}{*}{ Asia } & China & 497 & 5,9 & 394 & 79,3 \\
\hline & & Filipinas & 102 & 1,2 & 69 & 67,6 \\
\hline & & Total & 599 & 7,1 & 463 & 77,3 \\
\hline & \multirow{3}{*}{ África } & Marruecos & 1.794 & 21,4 & 1.609 & 89,7 \\
\hline & & Mauritania & 336 & 4,0 & 304 & 90,5 \\
\hline & & Total & 2.130 & 25,4 & 1.913 & 89,8 \\
\hline & \multirow{6}{*}{ Europa } & Alemania & 373 & 4,4 & 321 & 86,1 \\
\hline & & Francia & 111 & 1,3 & 99 & 89,2 \\
\hline & & Italia & 506 & 6,0 & 430 & 85,0 \\
\hline & & Portugal & 129 & 1,5 & 113 & 87,6 \\
\hline & & Reino Unido & 468 & 5,6 & 374 & 79,9 \\
\hline & & Total & 1.587 & 18,9 & 1.337 & 84,2 \\
\hline & \multicolumn{2}{|c|}{ Total selección } & 7.078 & 84,3 & 6.149 & 86,9 \\
\hline \multicolumn{3}{|l|}{ TOTAL } & 8.397 & 100,0 & 7.230 & 86,1 \\
\hline
\end{tabular}

Nota: El porcentaje de temporales está calculado en relación al total de contratos por país de origen.

Fuente: "Contratos a extranjeros, Lanzarote 2006, por nacionalidad, sector y tipo de contrato". OBECAN. Solicitud a medida vía Web a: obecan.sce@gobiernodecanarias.org (29-02-2012). Elaboración propia. 
Como caracteriza a este mercado laboral, ya señalado, los contratos en su gran mayoría son temporales. Ahora bien, en relación a los principales sectores económicos la presencia por procedencia varía así como el peso de la temporalidad en los contratos. Señalamos los rasgos principales:

a) En el sector de la construcción, los inmigrantes europeos son escasos en términos absolutos. Este concentra a iberoamericanos y africanos. Siendo los Argentinos los que muestran menor temporalidad (82,5\%) frente a los contratados de África Central, como el Congo $(86,5 \%)$.

b) En la rama de la hostelería es significativo la elevada temporalidad de los contratados a africanos (90\%), principalmente a los que procedente de Mauritania y Marruecos, frente a los europeos que trabajan en el sector ( $84 \%$ de temporalidad). Los asiáticos, aunque con escasa representatividad en términos absolutos son los que demuestran más estabilidad en sus empleos pues el $77 \%$ de los contratos son temporales.

c) En el sector comercio, los trabajadores asiáticos, principalmente venidos de India, son los que rompen la norma con respecto al peso de la temporalidad en sus empleos. En estabilidad les seguirán los europeos $(78,7 \%$ de contratos temporales). La mayor precariedad en este sector son los contratos realizados a africanos (aunque escasos cuantitativamente), principalmente con procedencia de Marruecos ( $83 \%$ son temporales).

d) Aunque en el sector agrícola tienen poca representación en la economía, los contratos que se realizan se hacen a marroquíes en primer lugar, seguido de ciudadanos colombianos. Paradójicamente tiene menos temporalidad en la contratación. En la dureza de este sector no se encuentran ni europeos ni asiáticos.

e) La escasa industria en la isla, entre los extranjeros que contrata, mayoritariamente están Latinoamericanos. Encontramos presencia de alemanes y británicos, aunque escasa en términos absolutos, sí poseen menor temporalidad (50\%) frente al resto de los orígenes. La causa podría estar en los tipos de trabajos que realizan, con más especialización y formación los europeos.

En términos generales, la presencia de extranjeros europeos en el mercado laboral insular se centra en actividades de hostelería y comercio, y tienen menos temporalidad que los africanos y latinoamericanos, centrados en la construcción. Por tanto gozan de menos precariedad. Su acceso a las actividades económicas remuneradas no se realiza de la misma forma. La segregación por origen existe. 
Gráfico 178. Contrato a extranjeros según sector económico y país de origen. Lanzarote. 2006 (\%).

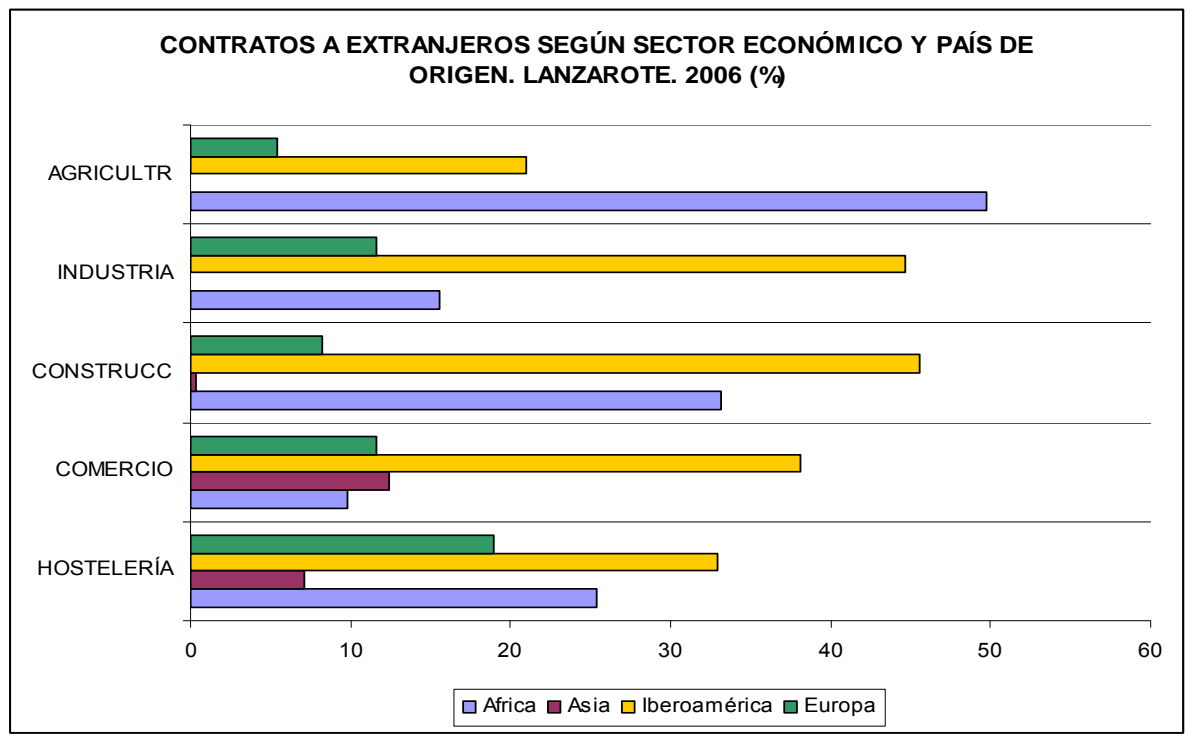

Fuente: Elaboración propia a partir de los datos recogidos de OBECAN en las Tablas 196, 197 y 198.

La inestabilidad basada en la temporalidad del empleo, junto con el condicionamiento a la satisfacción del cliente, que caracteriza el mercado laboral de una economía turística de masas como la insular, es muestra de precariedad y por tanto contrario a criterios de bienestar social de la población residente. A ello se añade segregación ocupacional en relación al país de origen, sea este más o menos desarrollado.

\section{b.- El desempleo}

En relación al desempleo, comparativamente, la isla presenta menores tasas de paro, generales y por sexo, con respecto a su Comunidad Autónoma y España (salvo en 2006). La dinámica es similar en relación al conjunto del archipiélago para toda la etapa, con reducción del paro registrado entre 1996 y 2001 y elevación en el quinquenio siguiente. 
Tabla 199. Tasa de actividad y paro por sexo. Lanzarote, Canarias y España. 1996-2006 (\%)

\begin{tabular}{|c|c|c|c|c|c|c|c|c|c|}
\hline & \multicolumn{3}{|c|}{ LANZAROTE } & \multicolumn{3}{|c|}{ CANARIAS } & \multicolumn{3}{|c|}{ ESPAÑA } \\
\hline & 1996 & 2001 & 2006 & 1996 & 2001 & 2006 & 1996 & 2001 & 2006 \\
\hline $\begin{array}{l}\text { Tasa de } \\
\text { actividad }\end{array}$ & 62,0 & 62,9 & 63,9 & 55,0 & 59,9 & 60,8 & 51,3 & 55,9 & 58,3 \\
\hline Varones & 76,0 & 78,7 & 75,5 & 70,2 & 72,3 & 71,5 & 65,1 & 68,2 & 69,1 \\
\hline Mujeres & 47,2 & 55,7 & 56,9 & 40,4 & 47,8 & 50,7 & 38,2 & 43,7 & 47,9 \\
\hline $\begin{array}{l}\mathrm{N}^{0} \text { de parados } \\
\text { registrados }\end{array}$ & 4.175 & 2.802 & 5.922 & 118.530 & 85.446 & 122.153 & 2.747 .049 & 1.988 .715 & 2.022 .873 \\
\hline Tasa de paro & 16,8 & 12,4 & 9,7 & 25,4 & 16,9 & 11,7 & 22,1 & 14,16 & 8,5 \\
\hline Varones & 14,7 & 10,8 & 8,3 & 22,6 & 14,5 & 9,4 & 17,4 & 11,1 & 6,3 \\
\hline Mujeres & 20,3 & 14,9 & 11,6 & 30,3 & 20,5 & 14,8 & 29,6 & 18,7 & 11,6 \\
\hline
\end{tabular}

Nota: las tasas de Lanzarote han sido calculadas en relación a la población ocupada y parada recogida en la Encuesta de Población de Canarias de 1996 y en el Censo de Población de 2001.

Fuente: Para 1996: "Paro registrado (diciembre de cada año). Lanzarote y Canarias, 1996" Anuario Estadístico de Canarias, 1996. ISTAC; "Paro registrado por el INEM (diciembre de cada año). Total nacional". Movimiento laboral registrado, 1996. INE;

Para 2001 y 2006: "Paro registrado (demanda de empleo). Lanzarote y Canarias. 2001 y 2006 " OBECAN.

http://www2.gobiernodecanarias.org/empleo/funcatra/observatorio/; "Tasa de actividad y paro según sexo y edad. Resultados Autonómicos y nacionales, 2001". Censo de población y viviendas, 2001. INE; "Paro registrado por el INEM (diciembre de cada año). Total nacional". Movimiento laboral registrado, 2001 y 2006. INE. "Tasa de actividad y paro según sexo y edad. Resultados Autonómicos. Canarias, 2001". Censo de población y viviendas, 2001. "Tasa de actividad y paro de España, 2006". EPA. INE. Elaboración Propia.

Gráfico 179. Evolución de la tasa de paro. Lanzarote. Canarias y España. 1996-2006 (\%).

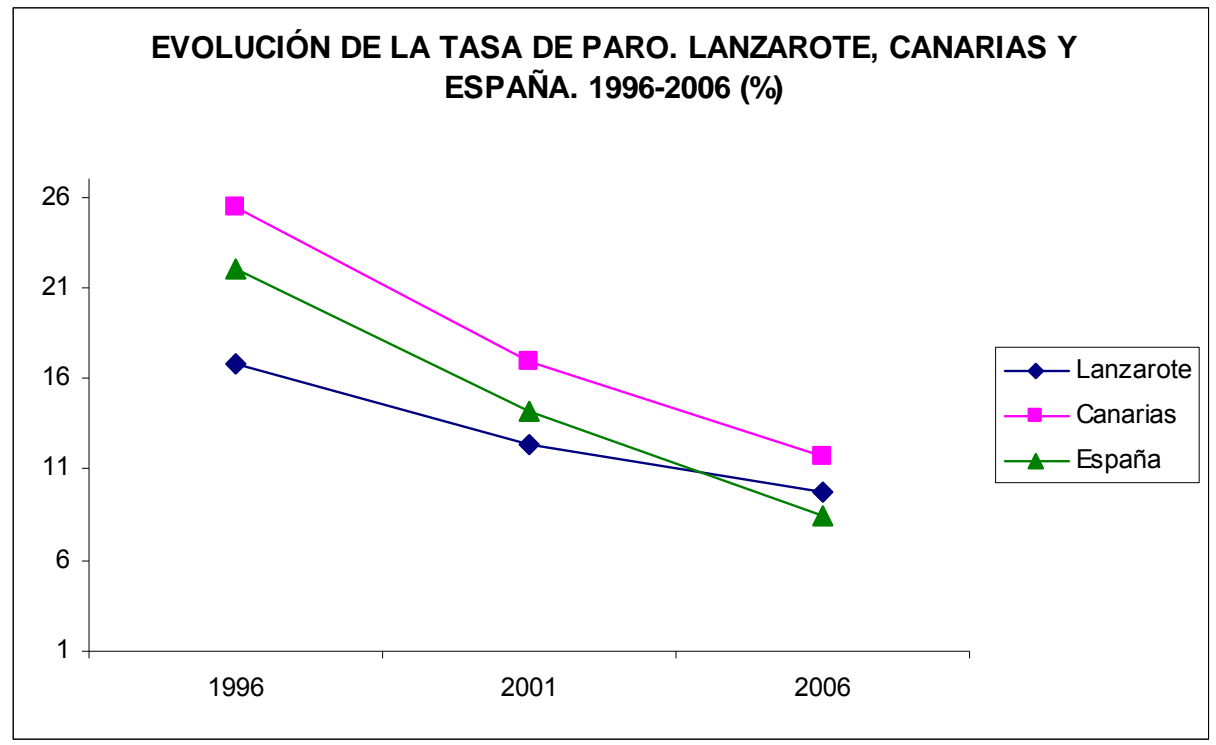

Fuente: OBECAN e INE. Elaboración propia a partir de la Tabla 199.

Esta variación en el paro insular registrado, que se reduce, entre 1996 y 2001, responde al dinamismo sobre la actividad laboral que genera el sobre impulso de la construcción, previo a la entrada en vigor de la Moratoria. 
En ésta etapa, la inmigración pasa de tener un peso relativo sobre el total de población del $32,8 \%$ en 1996, a pesar un 59\% en 2001 (ver epígrafe 5.3.2.). Sin embargo las tasas de actividad observan una dinámica ascendente, pues el número de activos se eleva y los ocupados registran un incremento del $48,3 \%$ en este quinquenio, por el motivo antes señalado.

El ascenso y descenso del número de parados registrados (demanda de empleo) es propio de un mercado laboral inestable derivado de su vinculación turística, como muestran las siguientes Figuras, donde la fluctuación del desempleo está en relación a los movimientos de ascenso y descenso de la afluencia turística ${ }^{215}$ (OBECAN, 2001 y 2006).

Gráfico 180. Paro registrado y afluencia turística, por meses. Lanzarote. 2001

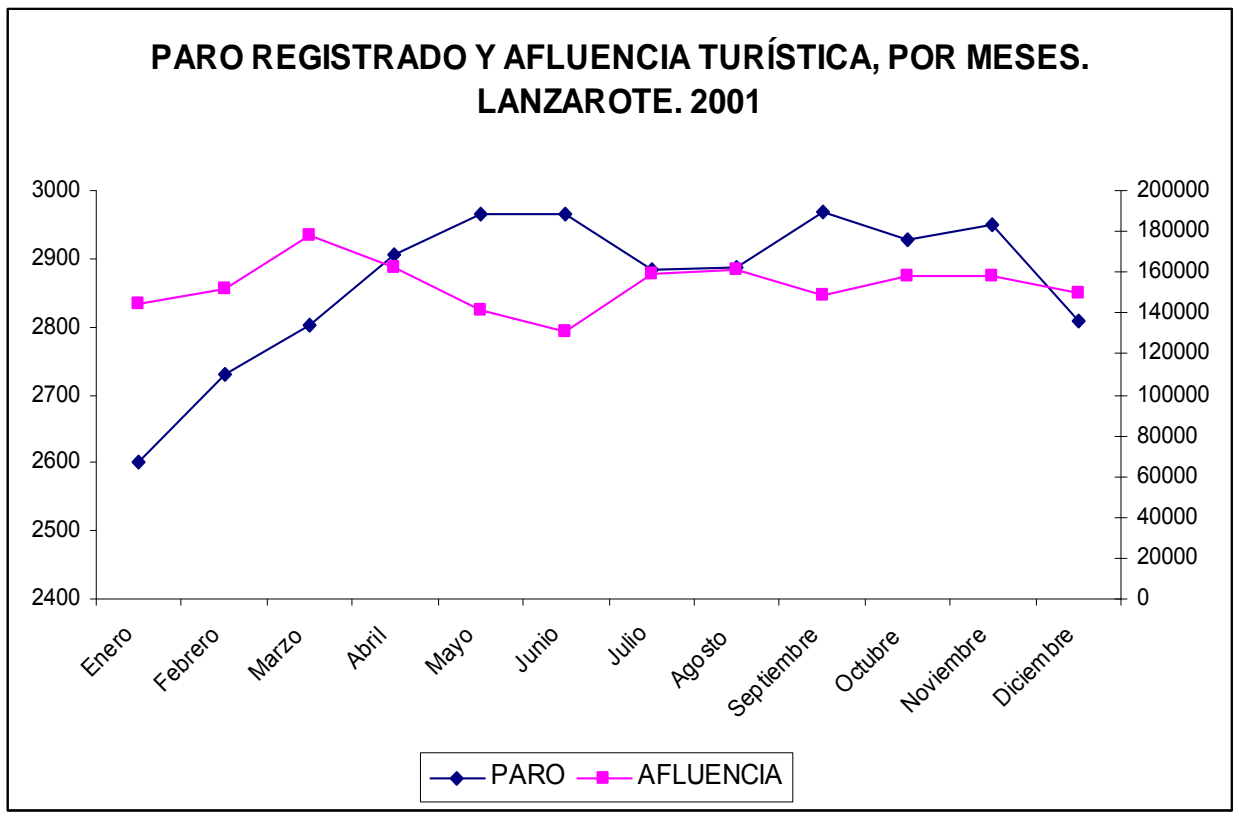

Fuente. OBECAN y Anuario Estadístico de Lanzarote 2001. Elaboración propia a partir de las Tablas 146 y 199.

215 Datos de OBECAN. "Paro registrado (demanda de trabajo) por islas y meses, 2001 y 2006 ". Consultado en página Web http://www2.gobiernodecanarias.org/empleo/funcatra/observatorio. Sección estadísticas (visitado a 3-10-2011) 


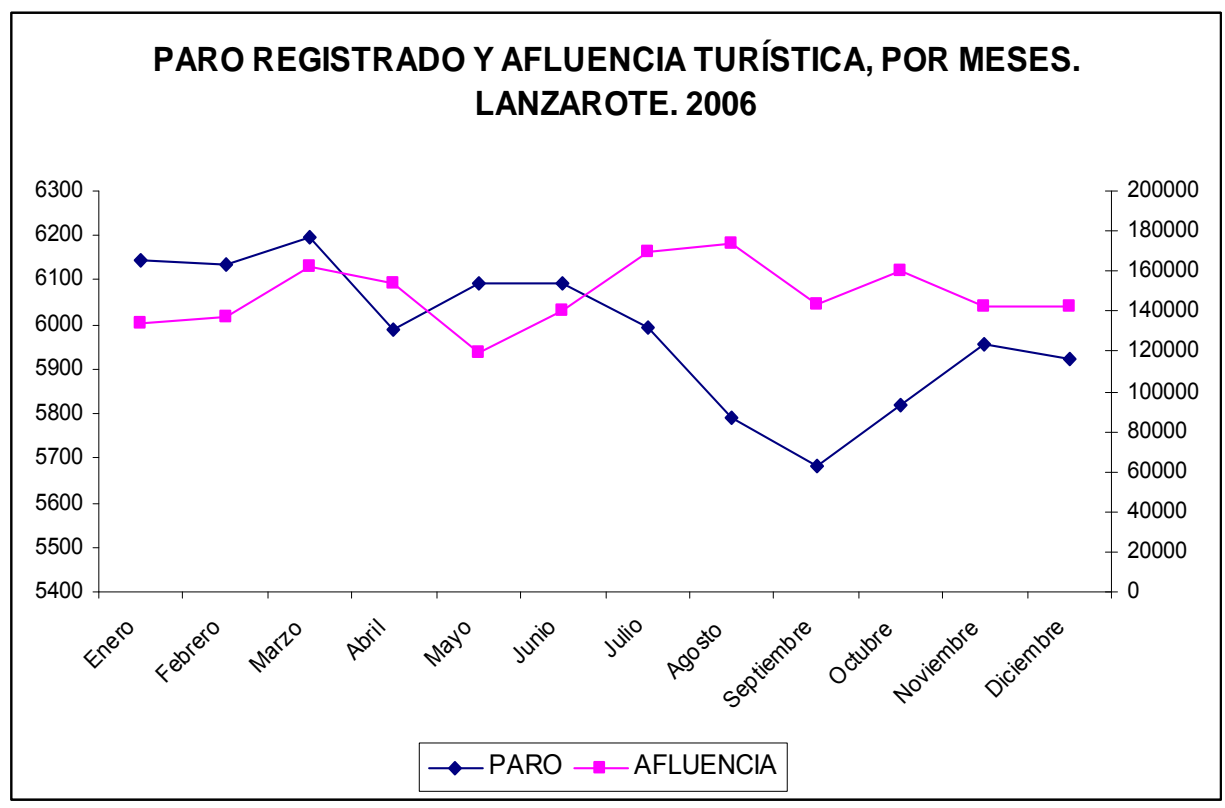

Fuente. OBECAN y Anuario Estadístico de Lanzarote 2006. Elaboración propia.

En este sentido, los municipios que concentran el mayor volumen de oferta presentarán la misma inestabilidad en el empleo y en el bienestar derivado.

A partir del año 2001, con la ya señalada aprobación de la Revisión del PIOT de 1991, Moratoria Turística, el estado del desempleo va a ir cambiando, registrándose en el 2006 un elevado incremento del crecimiento del paro registrado, pues Lanzarote no sólo está afectada por una nueva planificación del crecimiento, sino también por una crisis de recepción (afluencia turística) que vuelve a poner al mercado laboral en jaque ${ }^{216}$.

El perfil social del parado, sigue siendo femenino, al igual que en las etapas anteriores y como en el resto de España. Es significativo señalar la reducción de la tasa de actividad masculina insular (entre 2001 y 2006) y el incremento notable de la femenina, dinámica ésta que también se observa para Canarias, aunque en menor proporción, no así para España. La fuerte concentración de la ocupación y el desempleo dentro del sector servicios ha sido determinante, pues este se ha ido estableciendo como propio del rol femenino, a diferencia de los comienzos de la actividad.

216 Recordemos que más del $40 \%$ de la población de la isla se encuentra en edades comprendidas entre 20 y 39 años de edad. Tal registro, como hemos señalado en epígrafes anteriores, es explicado por la inmigración. 
Gráfico 182. Evolución de la tasa de paro por sexo. Lanzarote, Canarias y España. 1996-2006

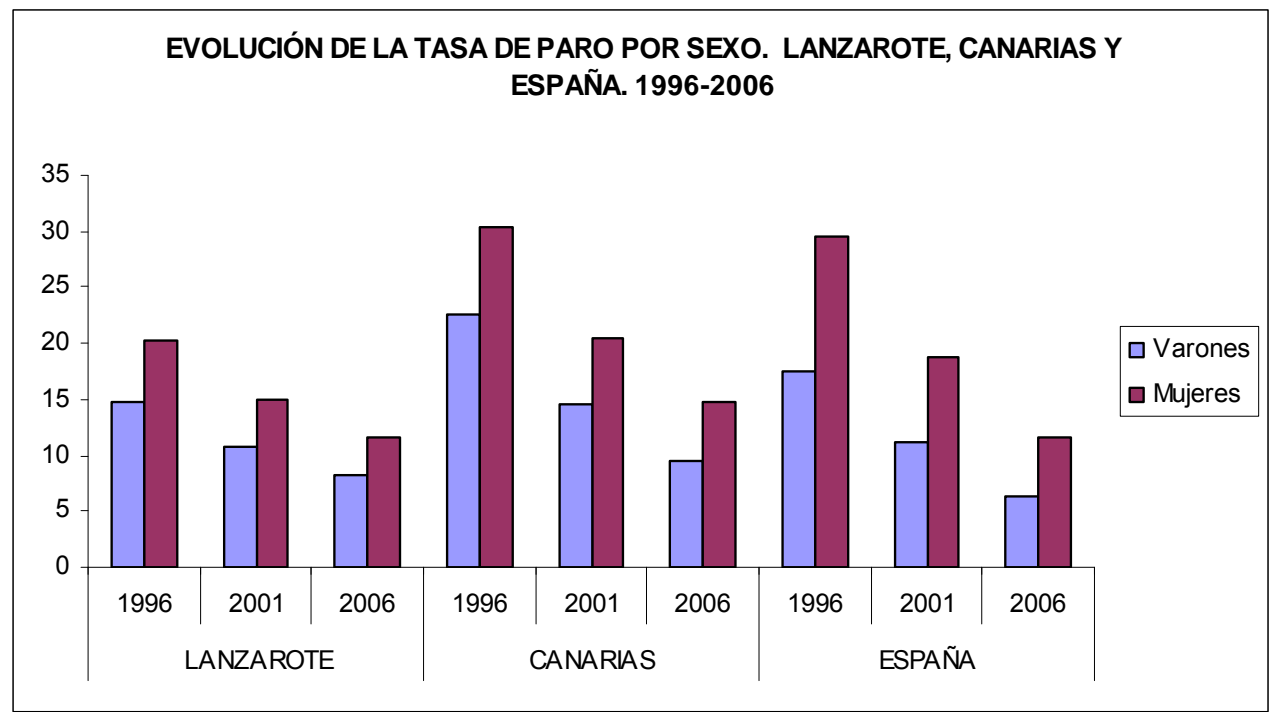

Fuente. OBECAN e INE. Elaboración propia a partir de la Tabla 199.

En relación a la distribución del desempleo por sectores económicos, se han tomado los registros existentes en las oficinales de empleo con la intención de observar la tendencia del paro por sectores, pudiendo hacer comparación con Canarias y España.

Tabla 200. Estructura sectorial del paro. Lanzarote, Canarias y España. 1996-2006 (\%)

\begin{tabular}{|c|c|c|c|c|c|c|c|c|c|c|c|c|c|c|c|c|c|c|}
\hline & \multicolumn{6}{|c|}{ LANZAROTE } & \multicolumn{6}{|c|}{ CANARIAS } & \multicolumn{6}{|c|}{ ESPAÑA } \\
\hline & \multicolumn{2}{|c|}{1996} & \multicolumn{2}{|c|}{2001} & \multicolumn{2}{|c|}{2006} & \multicolumn{2}{|c|}{1996} & \multicolumn{2}{|c|}{2001} & \multicolumn{2}{|c|}{2006} & \multicolumn{2}{|c|}{1996} & \multicolumn{2}{|c|}{2001} & \multicolumn{2}{|c|}{2006} \\
\hline & Abs & $\%$ & Abs & $\%$ & Abs & $\%$ & Abs. & $\%$ & Abs. & $\%$ & Abs. & $\%$ & Abs. & $\%$ & Abs. & $\%$ & Abs. & $\%$ \\
\hline AGRARIO & 22 & 0,5 & 39 & 1,4 & 69 & 1,2 & 2.571 & 2,3 & 1.792 & 2,1 & 3.401 & 2,9 & 77.216 & 2,8 & 49.504 & 2,5 & 61.494 & 3,0 \\
\hline INDUSTRIAL & 182 & 4,5 & 112 & 4,0 & 156 & 2,6 & 7.988 & 7,1 & 5.017 & 5,9 & 5.526 & 4,59 & 515.895 & 18,8 & 313.367 & 15,8 & 282.148 & 14,0 \\
\hline CONSTRUCCIÓN & 378 & 9,3 & 335 & 11,9 & 753 & 12,7 & 15.533 & 13,9 & 12.142 & 14,2 & 15.476 & 12,7 & 346.790 & 12,6 & 217.276 & 10,9 & 236.771 & 11,7 \\
\hline SERVICIOS & 3.151 & 77,2 & 2.202 & 78,4 & 4.611 & 77,9 & 65.799 & 58,8 & 54.669 & 64,0 & 82.781 & 67,8 & 1.341.129 & 48,8 & 1.143.111 & 57,5 & 1.224 .869 & 60,6 \\
\hline $\begin{array}{l}\text { Sin empleo } \\
\text { anterior }\end{array}$ & 348 & 8,5 & 120 & 4,3 & 333 & 5,6 & 19.959 & 17,8 & 11.826 & 13,8 & 14.969 & 12,3 & 466.018 & 17,0 & 265.457 & 13,4 & 217.591 & 10,8 \\
\hline
\end{tabular}

Fuente: "Paro registrado por sectores económicos, por islas. Diciembre de cada año. Lanzarote y Canarias". Direcciones provinciales del INEM y OBECAN. En Anuario Estadístico de Canarias, 1999, 2001 y 2006. ISTAC; "Paro registrado por el INEM, por sectores económicos. Diciembre de cada año. 1996, 2001, 2006. Total Nacional”. INE. Elaboración propia. 
Gráfico 183. Evolución de paro registrado por sectores económicos. Lanzarote. 1996-2006 (\%).

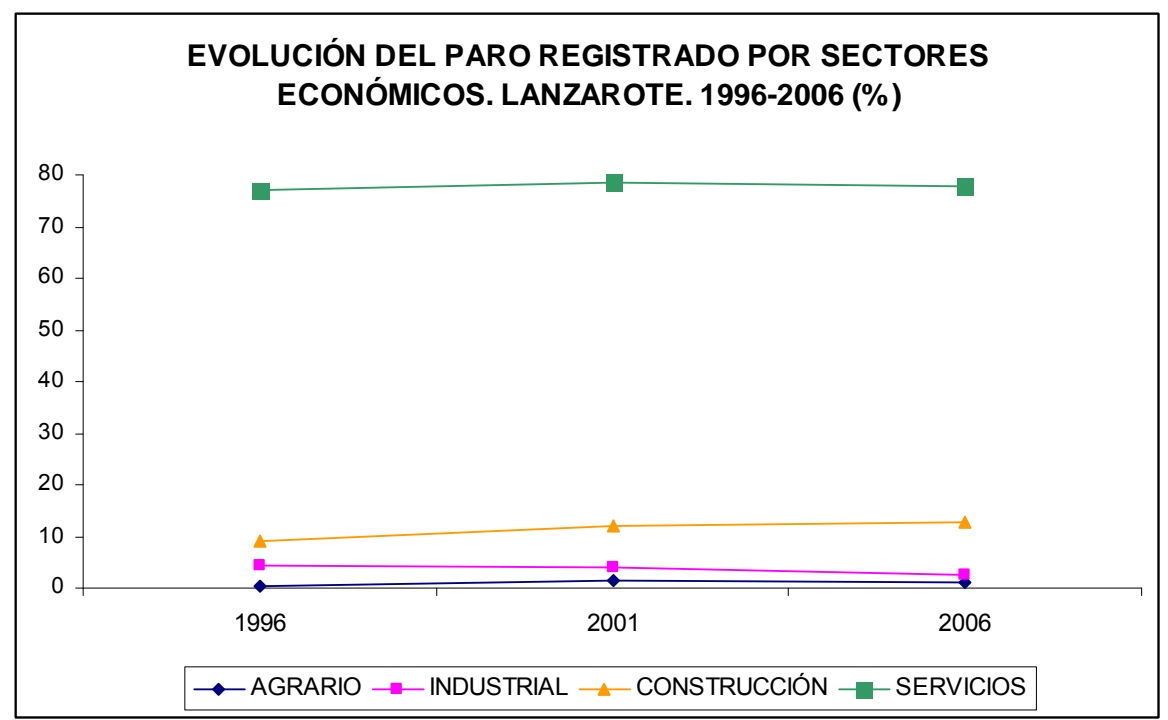

Fuente: Elaboración propia a partir de los datos de OBECAN, recogidos en la Tabla 200.

Como es propio en una economía terciarizada, y se percibe en la Figura anterior, el paro se sigue localizando en el sector servicios, de forma muy marcada para la Isla, frente a la Comunidad Autónoma y España, pues no ha diversificado su economía y el ámbito de los servicios está basado en la hostelería y el comercio (como se ha señalado en el análisis del empleo registrado en estas ramas que supone más del $45 \%$ en 2006), es decir, en servicios a personas y no a empresas. Sectores como el agrario y la industria no tienen fuerza, por su escasa participación en la economía, para arrastrar el empleo, es decir, relocalizar los activos laborales, en momentos de elevada reducción de la afluencia turística.

Gráfico 184. Evolución el paro registrado por sectores económicos. Lanzarote, Canarias y España. 1996-2006 (\%).

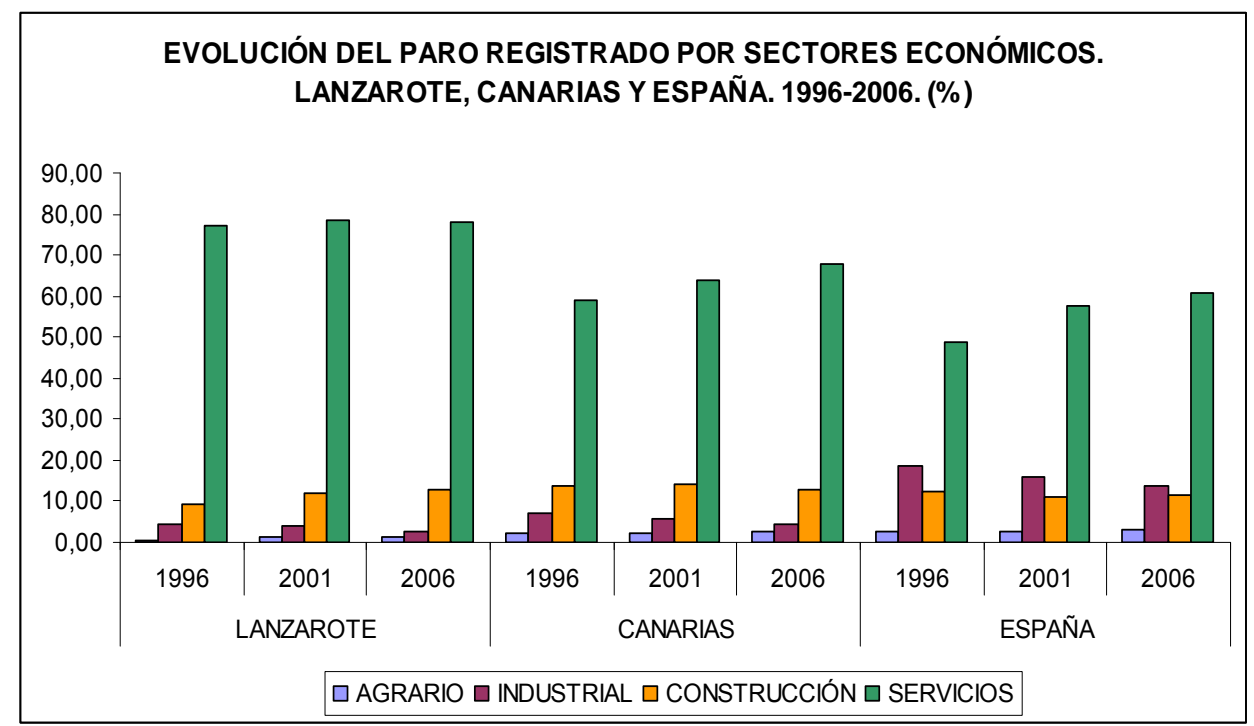

Fuente: OBECAN e INE. Elaboración propia a partir de la Tabla 200. 
Las consabidas crisis cíclicas de la afluencia desacreditan el modelo turístico de masas (acompañado de fuertes crecimientos de la planta alojativa turística), como quedó demostrado tras la crisis de sobreproducción que vive la isla a finales de la década de los ochenta (comentada en la etapa anterior), pues al moverse a ritmo de demanda dificulta la estabilidad en los empleos, base fundamental del bienestar social.

El descenso del paro registrado sólo es posible, al final de este periodo, si se producen emigraciones pues el mercado laboral no tiene forma de absorber el volumen de desempleados. Y la Moratoria no alcanzó uno de sus objetivos principales, demorar el crecimiento y ralentizarlo (difícil en su escaso tiempo de vigencia), pues si tal hubiese sido el caso podría registrarse incrementos menores en la entrada de población externa (inmigración neta) y con ello del paro derivado.

\subsubsection{2.- POBLACIÓN, OFERTA Y DEMANDA TURÍSTICA, EMPLEO Y PARO}

Al igual que se ha realizado en las etapas anteriores, en esta volvemos a preguntar si ¿es factible el aumento de la oferta turística como medida de creación de empleo? ¿Ambos factores son directamente proporcionales, generando un estado de bienestar asociado?

Partimos, por tanto, como en periodos anteriores, del cálculo de los porcentajes de incremento de los principales indicadores de empleo junto con los de oferta y demanda turística, realizándose en periodos quinquenales que nos permiten observar el estado generado por la Moratoria turística. Se toma como referencia los datos de la etapa anterior, que se han añadido en este caso. Sin olvidar que hay un elemento que puede afectar a los indicadores socioeconómicos como es el aumento de la población potencialmente activa (entre 16 y 64 años), que se produce no sólo por crecimiento natural, sino también, y a partir del año 2001, en mayor medida, derivado de la constante entrada de trabajadores externos. Toda esta información se recoge en las siguientes Tablas.

Tabla 201. Población potencialmente activa según lugar de nacimiento. Lanzarote 1996-2006.

\begin{tabular}{|l|c|l||l|l||l|l||}
\cline { 2 - 8 } \multicolumn{1}{c|}{} & 1996 & $\%$ & $\mathbf{2 0 0 1}$ & $\%$ & $\mathbf{2 0 0 6}$ & $\%$ \\
\hline \hline En otra isla & 6.171 & & 7.682 & & 9.230 & \\
\hline En otra CCAA & 10433 & & 15.887 & & 19.503 & \\
\hline En el Extranjero & 4.105 & & 11.072 & & 27.645 & \\
\hline TOTAL EXTERNOS & $\mathbf{2 0 . 7 0 9}$ & $\mathbf{3 7 , 2}$ & $\mathbf{3 4 . 6 4 1}$ & $\mathbf{4 8 , 3}$ & $\mathbf{5 6 . 3 7 8}$ & $\mathbf{5 8 , 7}$ \\
\hline \hline EN LANZAROTE & 34.973 & $\mathbf{6 2 , 8}$ & $\mathbf{3 7 . 0 9 0}$ & $\mathbf{5 1 , 7}$ & $\mathbf{3 9 . 7 4 0}$ & $\mathbf{4 1 , 3}$ \\
\hline \hline TOTAL POTENCIAL & $\mathbf{5 5 . 6 8 2}$ & & $\mathbf{7 1 . 7 3 1}$ & & $\mathbf{9 6 . 1 1 8}$ & \\
\hline
\end{tabular}

Nota: La población potencialmente activa recoge la población entre 15 y 64 años de edad; Los porcentajes han sido calculados sobre el total potencial.

Fuente: "Población por sexo, edad y lugar de nacimiento, Lanzarote, 1996, 2001, 2006". Encuesta de Población de Canarias, 1996, Censo de Población, 2001 y Padrón municipal de habitantes de 2006. ISTAC. 
Tabla 202. Incremento quinquenal de la población, la oferta y la demanda turística, el empleo y el paro. Lanzarote 1986-1996 (\%)

\begin{tabular}{|c|c|c|c|c|c|}
\hline \multicolumn{6}{|c|}{ LANZAROTE } \\
\hline & $\begin{array}{c}\text { Incremento de } \\
\text { P.P.A. }\end{array}$ & $\begin{array}{l}\text { Incremento de } \\
\text { Plazas }\end{array}$ & $\begin{array}{l}\text { Incremento de } \\
\text { Afluencia }\end{array}$ & $\begin{array}{l}\text { Incremento de } \\
\text { Ocupados }\end{array}$ & $\begin{array}{l}\text { Incremento de } \\
\text { Parados }\end{array}$ \\
\hline 1991-1996 & 26,3 & 10,8 & 44,2 & 41,1 & 29,9 \\
\hline 1996-2001 & 39,5 & 13,1 & 23,5 & 62,7 & $-31,2$ \\
\hline $2001-2006$ & 24,8 & 9,3 & $-3,5$ & 37,9 & 110,89 \\
\hline \multicolumn{6}{|c|}{ CANARIAS } \\
\hline & $\begin{array}{l}\text { Incremento de } \\
\text { P.P.A. }\end{array}$ & $\begin{array}{l}\text { Incremento de } \\
\text { Plazas }\end{array}$ & $\begin{array}{l}\text { Incremento de } \\
\text { Afluencia }\end{array}$ & $\begin{array}{l}\text { Incremento de } \\
\text { Ocupados }\end{array}$ & $\begin{array}{l}\text { Incremento de } \\
\text { Parados }\end{array}$ \\
\hline 1991-1996 & 11,9 & $-12,7$ & 48,3 & 22,2 & 16,1 \\
\hline 1996-2001 & 7,46 & 9,6 & 3,4 & 31,2 & $-23,6$ \\
\hline $2001-2006$ & 19,92 & 18,9 & $-6,0$ & 28,8 & 42,9 \\
\hline \multicolumn{6}{|c|}{ ESPAÑ A } \\
\hline & $\begin{array}{l}\text { Incremento de } \\
\text { P.P.A. }\end{array}$ & $\begin{array}{l}\text { Incremento de } \\
\text { Plazas }\end{array}$ & $\begin{array}{l}\text { Incremento de } \\
\text { Afluencia }\end{array}$ & $\begin{array}{l}\text { Incremento de } \\
\text { Ocupados }\end{array}$ & $\begin{array}{l}\text { Incremento de } \\
\text { Parados }\end{array}$ \\
\hline $1991-1996$ & 4,9 & 9,3 & $-32,3$ & $-1,4$ & 20,0 \\
\hline $1996-2001$ & 3,64 & 11,6 & 16,2 & 26,9 & -27.6 \\
\hline $2001-2006$ & 10,51 & 25,8 & 11,6 & 20,9 & 1,71 \\
\hline
\end{tabular}

$\left(^{\star}\right)$ Se ha calculado sobre el paro registrado (a diciembre de cada año) por motivos metodológicos de las fuentes.

Nota: P.P.A.: Población potencialmente/económicamente activa (de 16 a 64 años de edad) a partir de datos padronales (Población según sexos y edades año a año, 1996, 2001 y 2006). Elaboración propia a partir de datos anteriores.

En términos generales, y en relación a los datos analizados, podemos afirmar lo siguiente:

Esta etapa partía de un quinquenio donde el crecimiento de la población potencialmente activa (entre 16 y 64 años) y el paro se incrementan prácticamente al mismo ritmo, por lo que los incrementos de oferta y demanda turística, aunque hacen crecer los ocupados, también provocan entrada de población externa que no permite reducir, finalmente, el número de parados. Por lo que el paro no se reduce proporcionalmente al incremento de la afluencia (aunque sí fluctúa con ella).

El periodo que va desde 1996 al año 2001 será el que marque la diferencia, pues con un menor crecimiento de la afluencia, frente a la etapa anterior $(23,5 \%)$, se consigue la reducción del desempleo registrado, a pesar del incremento de la población potencialmente activa $(39,5 \%)$. Esto es derivado del sobre impulso que la actividad en la construcción va a experimentar (generando un incremento de las plazas turísticas del $13 \%$ en cinco años) previamente a la entrada en vigor de la Moratoria, como se ha señalado en anteriores líneas. Efectos éstos que se van a sentir sobre el empleo en el quinquenio siguiente (2001$2006)$, con un estadillo del paro registrado $(111 \%)$, por crisis de la demanda turística $(-3,5 \%)$ 
y menor crecimiento de la nueva planta alojativa $(9,3 \%)$, limitada por la entrada en vigor de la Moratoria, por lo que el potencial de fuerza trabajo existente a partir del sobre impulso de la actividad en la construcción de final de s. XX, no conseguirá relocalizarse dentro del mercado laboral insular, limitado al trinomio construcción, hostelería y comercio. Debemos recordar aquí que este mercado laboral se nutre de población externa a la isla (en 2006 el $58,7 \%$ de la población en edad para trabajar no había nacido en la isla y se realizaron un $57,3 \%$ de contratos a foráneos) que constantemente se incorpora.

El empleo fluctúa en relación a la demanda turística, pero nunca es proporcional a ella. Los impulsos que recibe la oferta generan desequilibrios en los mercados de trabajo por su efecto llamada. Ante esto sigue existiendo la necesidad de establecer ritmos controlados del crecimiento, para poder ir incorporando nuevos activos de forma asimilable por los distintos ámbitos del bienestar (sanidad, educación, energías, agua, transporte, etc.), principalmente dentro de una economía nutrida con fuerza de trabajo externa.

No sucederá de la misma forma en territorios menos dependientes del turismo y con mayor diversificación económica, como España.

\subsubsection{3.- CONCLUSIONES}

Con una economía terciarizada, prácticamente en su totalidad, y sin diversificación, las características del empleo en Lanzarote, siguen fundamentadas en el modelo turístico de masas, que en esta última etapa, marcada por la aprobación de una moratoria turística, son las siguientes:

1. Práctica desaparición de los ocupados en el sector primario, abandono de las producciones agroalimentarias y completa dependencia de la importación de productos de alimentación básicos. No se impulsan las marcas locales para el consumo turístico a excepción del vino, manteniéndose dichos cultivos subvencionados por ser también mantenedores del paisaje rural original y propio de Lanzarote, que constituye un atractivo para la visitas, lo que supone una folklorización o mercantilización de la cultura local.

2. La presencia industrial es escasa y con tendencia a mayor reducción, pues no encuentra una valorización tan rápida y fácil como en las ramas de servicio anexas al turismo. Está basada en la manufactura destinada a alimentación, productos metálicos y minerales y a la energía.

3. Crecimiento de los ocupados en la construcción en términos relativos, por encima de otra actividad, previamente a la entrada en vigor de la Moratoria, por sobre impulso de la edificación (ante el miedo de los promotores por un posible déficit de aprovechamiento una vez que esté en vigor). La consecuencia será la quiebra de los 
objetivos de la Moratoria, pues cuando entra en vigor ya se ha construido el $88 \%$ del umbral de crecimiento que planea.

4. Predominio absoluto del sector terciario sobre el empleo y sobre el paro, vinculado al turismo (hostelería y comercio), en más del $77 \%$, pues el sector agrario e industrial se fue desmantelando desde la década de los ochenta por escasa rentabilidad frente a los servicios al turismo. Muy por encima del peso que tiene en el conjunto del archipiélago y el ámbito nacional.

5. El incremento constante de la oferta y demanda turística no se muestra directamente proporcional a la reducción del paro y al empleo.

6. Aumento de la tasa de actividad femenina, y descenso de la masculina, por concentración de la actividad en los servicios (hostelería y comercio) que se han ido definiendo como propios del rol femenino.

7. El mercado laboral insular ha quedado basado en actividades de fuerte vinculación turística, sometido a la satisfacción del cliente, y a la inestabilidad de este mercado, que se reflejan tanto en las variaciones del empleo y del paro como en la precariedad en los contratos (por temporalidad). Basado en el servicio a personas y no a empresas, se fundamenta en el trinomio construcción, hostelería y comercio. Así, los ascensos y descensos tanto del paro como del empleo van en relación a la afluencia turística, afectando al bienestar a través del empleo, pues sectores como el agrario y la industria no tienen fuerza, por su escasa participación en la economía, para arrastrar el empleo y relocalizar los activos laborales en momentos de elevada reducción de la afluencia turística.

8. El mercado laboral se nutre de población foránea. Creciendo la contratación de extranjeros sobre el resto de orígenes (las otras Islas u otras Comunidades Autónomas españolas), con elevada incidencia en los municipios turísticos de Lanzarote, que superan la media de Canarias en contratación de extranjeros. Además, este mercado está segmentado en relación al origen del trabajador, donde los empleados europeos son los que menos temporalidad presentan en los contratos, centrando su actividad en hostelería y comercio, siendo insignificante o inexistente su presencia contractual en otros sectores. Lo que supone mayor vulnerabilidad socioeconómica en los trabajadores con procedencia en terceros países, por tener menor poder social de negociación.

En términos generales y en relación a los objetivos de este trabajo, los mercados laborales movidos al ritmo del crecimiento de la actividad turística de masas, sin otras vías, con alta temporalidad en el empleo y nutridos por constante incorporación de 
población externa, no permiten la adecuada integración social de estos activos y su continua aportación al sistema de bienestar social para mantener los niveles de equipamiento y servicios en consonancia con el volumen de población. De ahí la necesidad de establecer ritmos controlados de crecimiento de la oferta y la demanda turística en este tipo de economías, basados en calidad y no en cantidad.

\subsection{6.- EFECTOS SOBRE LA RIQUEZA. LA RENTA. 1996-2006}

\subsubsection{1.- EVOLUCIÓN DE LA RENTA}

Para dar idea de la evolución de la renta municipal, en comparación con el total insular, Canarias y España, se han tomado aquí las estimaciones realizadas por la Caixa en el Anuario Comercial de España. En ellos se calcula la renta familiar disponible por habitante (o nivel económico) a partir de 17 variables explicativas de dicha renta. Por lo que a la hora de su interpretación señalan lo siguiente: "la renta familiar disponible por habitante no debe interpretarse siempre como indicador del nivel medio de los ingresos disponibles de los habitantes del municipio (principalmente en municipios pequeños), ya que dicha renta es el resultado de dividir por la cifra de población residente la renta total generada en el mismo, independientemente de quién la reciba y de su residencia". Por lo que en cuando que es renta disponible, hablamos de la cantidad de renta que se puede gastar después de restar los impuestos directos, y en cuanto que hace media en relación al número de habitantes registrados, obtenemos la renta per cápita (promedio), pero no podemos saber cuántos reciben más o menos de la renta global ${ }^{217}$ o total generada. Aún así, este indicador elaborado por la Caixa, nos permite determinar la evolución de la riqueza en los ámbitos de estudio señalados, hasta el año 2003, pues para el año 2006 ya no se realiza, lo que nos obliga a consultar otras fuentes de difícil comparación por su diferencia metodológica y consecuentemente tratarlo aparte. Es por ello que, en el Capítulo 4 de esta tesis, se realizará un proceso de homogeneización a un único indicador económico y así obtener una estimación de la evolución correspondiente desde 1970 hasta 2006.

\footnotetext{
217 Renta global: medición de la capacidad económica de cada quién a partir de la suma de todos los ingresos sin importar su fuente.
} 
Tabla 203. Nivel de renta disponible por habitante de los municipios y de Lanzarote, Canarias y España. 1996 (ptas)

\begin{tabular}{|c|c|c|c|c|c|c|c|c|c|c|c|}
\hline Euros* & Nivel & Arrecife & Haría & S.Bartolomé & Teguise & Tías & Tinajo & Yaiza & Lanzarote & Canarias & España \\
\hline$\leq 5.410$ & 1 & & & & & & & & & & \\
\hline $5.410-6.010$ & 2 & & & & & & & & & & \\
\hline $6.010-6.762$ & 3 & & & & & & & & & & \\
\hline $6.762-7.513$ & 4 & & & & & & & & & & \\
\hline 7.513-8.414 & 5 & & & & & & & & & & \\
\hline $8.414-9.616$ & 6 & & & & & & & & & & \\
\hline $9.676-10.818$ & 7 & & & & & & & & & & \\
\hline $10.818-12.020$ & 8 & & & & & & & & & & \\
\hline $12.020-13.222$ & 9 & & & & & & & & & & \\
\hline$>13.222$ & 10 & & & & & & & & & & \\
\hline
\end{tabular}

$\left(^{*}\right)$ Inicialmente el dato viene en pesetas, se ha hecho la transformación a Euros (1 Euro= 166,386 ptas).

Nota: El nivel de renta per cápita de la isla se ha calculado a través de una media ponderada en relación al peso poblacional.

Fuente: "Nivel económico: renta familiar disponible por habitante, 1996. Comunidades Autónomas, Provincias y Municipios". Anuario Comercial de España, 1998. Servicios de Estudios de la Caja de Ahorros y pensiones de Barcelona (Caixa).

Tabla 204. Nivel de renta disponible por habitante de los municipios y de Lanzarote, Canarias y España. 2001 (euros).

\begin{tabular}{|c|c|c|c|c|c|c|c|c|c|c|c|}
\hline Euros & Nivel & Arrecife & Haría & S.Bartolomé & Teguise & Tías & Tinajo & Yaiza & Lanzarote $^{*}$ & Canarias & España \\
\hline$<6.400$ & 1 & & & & & & & & & & \\
\hline $6.400-7.300$ & 2 & & & & & & & & & & \\
\hline $7.300-8.225$ & 3 & & & & & & & & & & \\
\hline $8.225-8.800$ & 4 & & & & & & & & & & \\
\hline $8.800-9.700$ & 5 & & & & & & & & & & \\
\hline $9.700-10.650$ & 6 & & & & & & & & & & \\
\hline $10.650-11.500$ & 7 & & & & & & & & & & \\
\hline $11.500-12.500$ & 8 & & & & & & & & & & \\
\hline $12.500-13.500$ & 9 & & & & & & & & & & \\
\hline$>13.500$ & 10 & & & & & & & & & & \\
\hline
\end{tabular}

* El nivel de renta per cápita de la isla se ha calculado a través de una media ponderada en relación al peso poblacional.

Fuente: "Nivel económico: renta familiar disponible por habitante, 2001. Comunidades Autónomas, Provincias y Municipios". Anuario Económico de España, 2003. Servicios de Estudios de la Caja de Ahorros y pensiones de Barcelona (Caixa).

Si en la etapa anterior se había observado cierto grado de nivelación en las rentas familiares por habitante de los municipios de la Isla, los análisis para 2001 dejan claro la dinámica de las economías turísticas, pues han sido los municipios que concentran la oferta de alojamiento turístico (véase la Tabla 205) los que registran el nivel económico más alto a lo largo de todo el análisis, situándose en la cúspide jerárquica en relación a la riqueza que concentran. Estos municipios son tres, Teguise, Tías y Yaiza, cuyo nivel de renta familiar 
disponible se encuentra por encima del autonómico. Al mismo nivel se encuentra San Bartolomé pero por diferentes motivos a los anteriores, pues no concentra oferta turística, pero sí posee una localización territorial estratégica ya que linda con los municipios anteriores y Arrecife. Situación geográfica que le ha permitido un crecimiento demográfico considerable y de su parque de viviendas por primera residencia.

Mapa 30. Nivel de renta media por habitante de los municipios de Lanzarote. 2001.

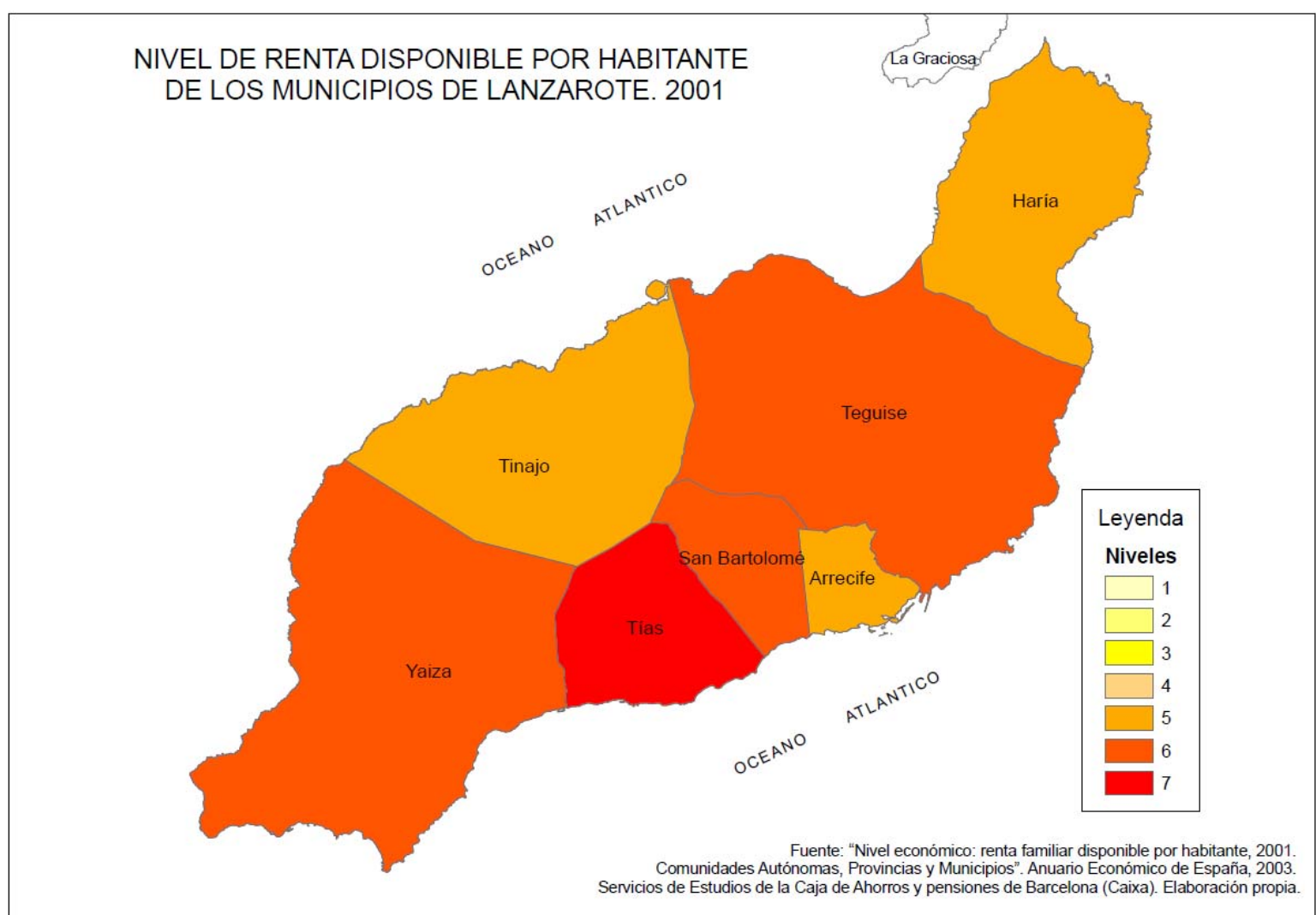

Será únicamente el municipio de Tías el que llega a superan el nivel nacional. La isla se equipara al conjunto de la provincia y Canarias (nivel 5), pero siempre manteniéndose por debajo del nivel económico nacional (6) a pesar de la fuerte incidencia del turismo y de la construcción en el comienzo del siglo. 
Tabla 205. Oferta turística por municipio. Lanzarote. 1996-2006. (\%)

\begin{tabular}{|c|c|c|c|c|c|c|c|c|}
\hline & \multicolumn{2}{|c|}{1996} & \multicolumn{2}{|c|}{2001} & \multicolumn{2}{|c|}{2006} & \multirow{2}{*}{$\begin{array}{c}\text { Variación } \\
\text { 1996-2001 (\%) }\end{array}$} & \multirow{2}{*}{$\begin{array}{c}\text { Variación } \\
\text { 2001-2006 (\%) }\end{array}$} \\
\hline MUNICIPIO & Abs. & $\%$ & Abs. & $\%$ & Abs. & $\%$ & & \\
\hline Arrecife & 1.335 & 2,5 & 1.179 & 2,0 & 1.672 & 2,6 & $-11,7$ & 41,8 \\
\hline Haría & 292 & 0,6 & 334 & 0,6 & 394 & 0,6 & 14,4 & 18,0 \\
\hline San Bartolomé & 34 & 0,1 & 30 & 0,1 & 101 & 0,2 & $-11,8$ & 236,7 \\
\hline Teguise & 13.887 & 26,3 & 15.973 & 26,7 & 15.623 & 23,9 & 15,0 & $-2,2$ \\
\hline Tías & 28.778 & 54,5 & 29.284 & 49,0 & 28.737 & 44,0 & 1,8 & $-1,9$ \\
\hline Tinajo & 930 & 1,8 & 930 & 1,6 & 962 & 1,5 & 0,0 & 3,4 \\
\hline Yaiza & 7.574 & 14,3 & 12.005 & 20,1 & 17.804 & 27,3 & 58,5 & 48,3 \\
\hline TOTAL & 52.830 & 100,0 & 59.735 & 100,0 & 65.293 & 100,0 & 13,1 & 9,3 \\
\hline
\end{tabular}

Fuente: "Oferta de plazas alojativas según tipo, por municipios. Total Insular, 1996, 2001 y 2006". Oficina de turismo interior. Anuario Estadístico de Lanzarote, 1996, 2001 y 2006. Centro de datos. Cabildo de Lanzarote. Elaboración propia.

Gráfico 185. Evolución de las plazas de alojamiento turístico por municipio. Lanzarote 1996-2006 (\%).

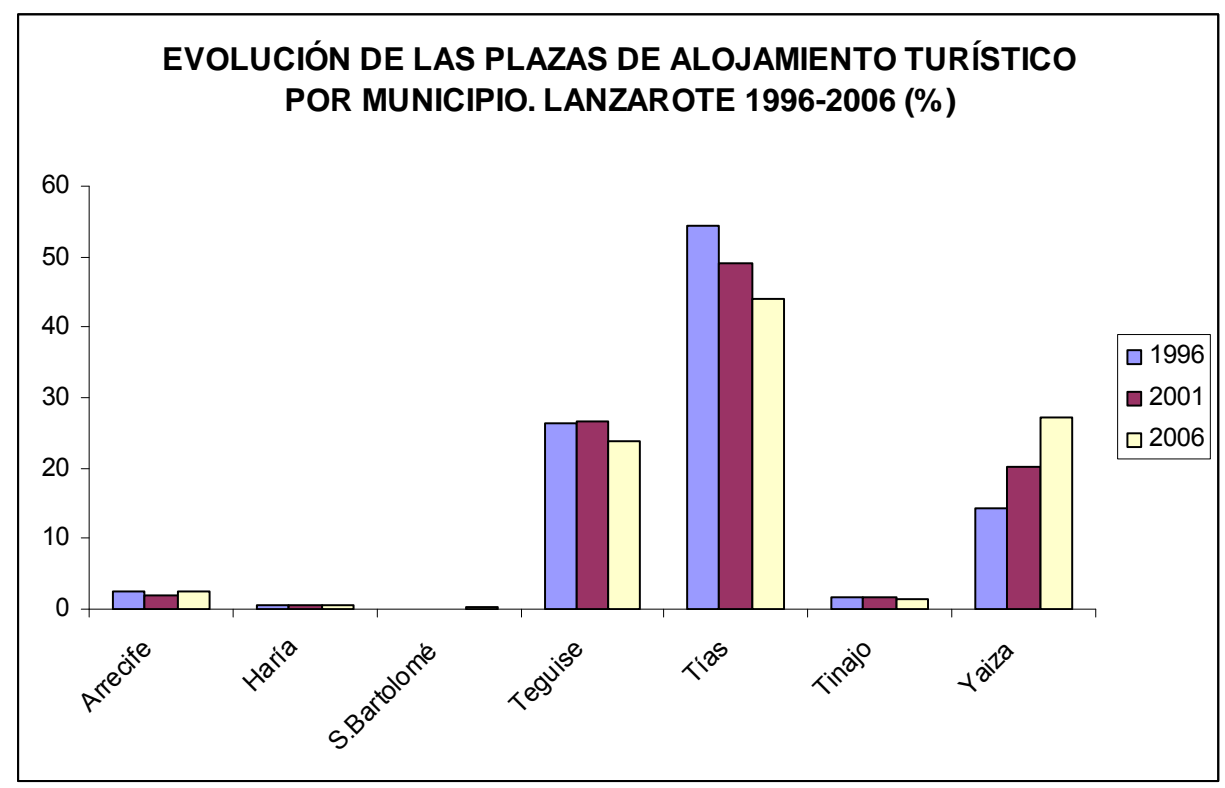

Fuente: Elaboración propia a partir de la Tabla 205.

Las estimaciones acerca del nivel de renta disponible realizadas por los Anuarios de la Caixa solo llegan hasta el año 2003, y aunque existen estimaciones posteriores metodológicamente no pueden ser comparadas con las que venimos utilizando a lo largo de estos años.

El periodo 2001-2003 muestra cierto estancamiento en la evolución de la riqueza que contempla este indicador, al que contribuye el crecimiento demográfico, que se produce por nueva inmigración. Factores como la reducción del crecimiento de la oferta, limitada por los 
nuevos Planes, por un lado, y la tendencia a la baja que se empieza a observar en la afluencia (por efecto de destinos internacionales emergentes muy competitivos en calidad y precio) por otro, y que también impulsa el descenso de la estancia media en la isla de forma significativa (tanto hotelera como extrahotelera), explican este estado.

Tabla 206. Nivel de renta disponible por habitante de los municipios y de Lanzarote, Canarias y España. 2003 (euros).

\begin{tabular}{|c|c|c|c|c|c|c|c|c|c|c|c|}
\hline Euros & Nivel & Arrecife & Haría & S.Bartolomé & Teguise & Tías & Tinajo & Yaiza & Lanzarote ${ }^{*}$ & Canarias & España \\
\hline$<7.200$ & 1 & & & & & & & & & & \\
\hline $7.200-8.300$ & 2 & & & & & & & & & & \\
\hline $8.300-9.300$ & 3 & & & & & & & & & & \\
\hline $9.300-10.200$ & 4 & & & & & & & & & & \\
\hline $10.200-11.300$ & 5 & & & & & & & & & & \\
\hline $11.300-12.100$ & 6 & & & & & & & & & & \\
\hline $12.100-12.700$ & 7 & & & & & & & & & & \\
\hline $12.700-13.500$ & 8 & & & & & & & & & & \\
\hline 13-500-14.500 & 9 & & & & & & & & & & \\
\hline$>2.264 .000$ & 10 & & & & & & & & & & \\
\hline
\end{tabular}

* El nivel de renta per cápita de la isla se ha calculado a través de una media ponderada en relación al peso poblacional.

Fuente: "Nivel económico: renta familiar disponible por habitante, 2003. Comunidades Autónomas, Provincias y Municipios". Anuario Económico de España, 2005. Servicios de Estudios de la Caja de Ahorros y pensiones de Barcelona (Caixa). 
Mapa 31. Nivel de renta media por habitante de los municipios de Lanzarote. 2003.

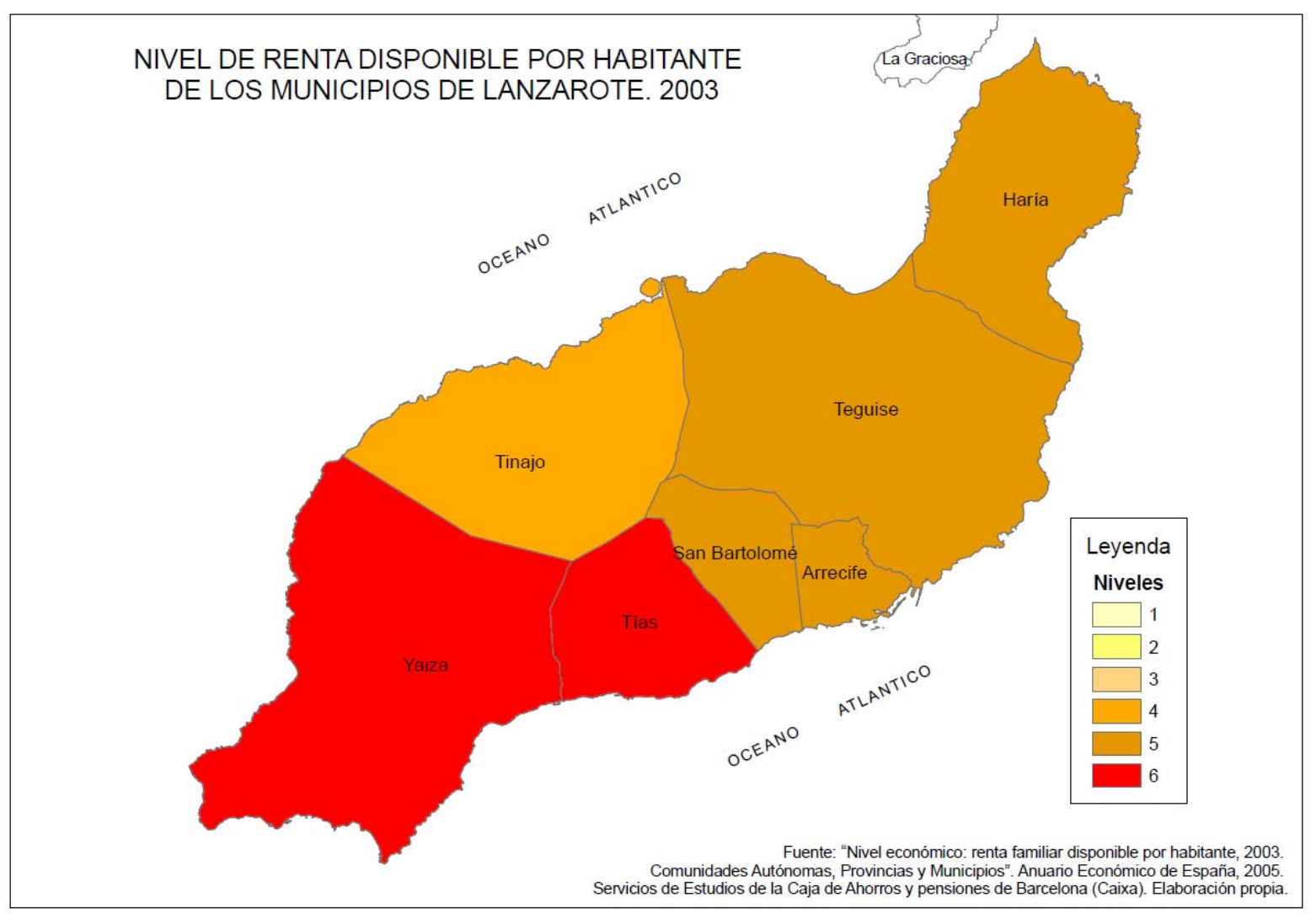

La cúspide jerárquica, en este último año de análisis, la siguen ocupando los municipios que concentran la mayor oferta turística de alojamiento en términos relativos, es decir Tías y Yaiza. Aunque, tal y como se observa en la siguiente Figura y en el Mapa 31, la isla ha roto con la fuerte dinámica de jerarquización municipal en relación a la renta, tendencia ésta observada desde 1991. Pues aunque se ralentiza el crecimiento de la oferta de alojamiento turístico, en el último quinquenio analizado, no se hace así con la oferta residencial (sobre la que, además, se potencia la dispersión territorial a como consecuencia de lo que permite la revisión parcial del PIOT (Moratoria Turística) a partir del año 2000. 
Gráfico 186. Nivel de renta disponible por habitante. Lanzarote, sus municipios y Provincia, Canarias y España. 2003

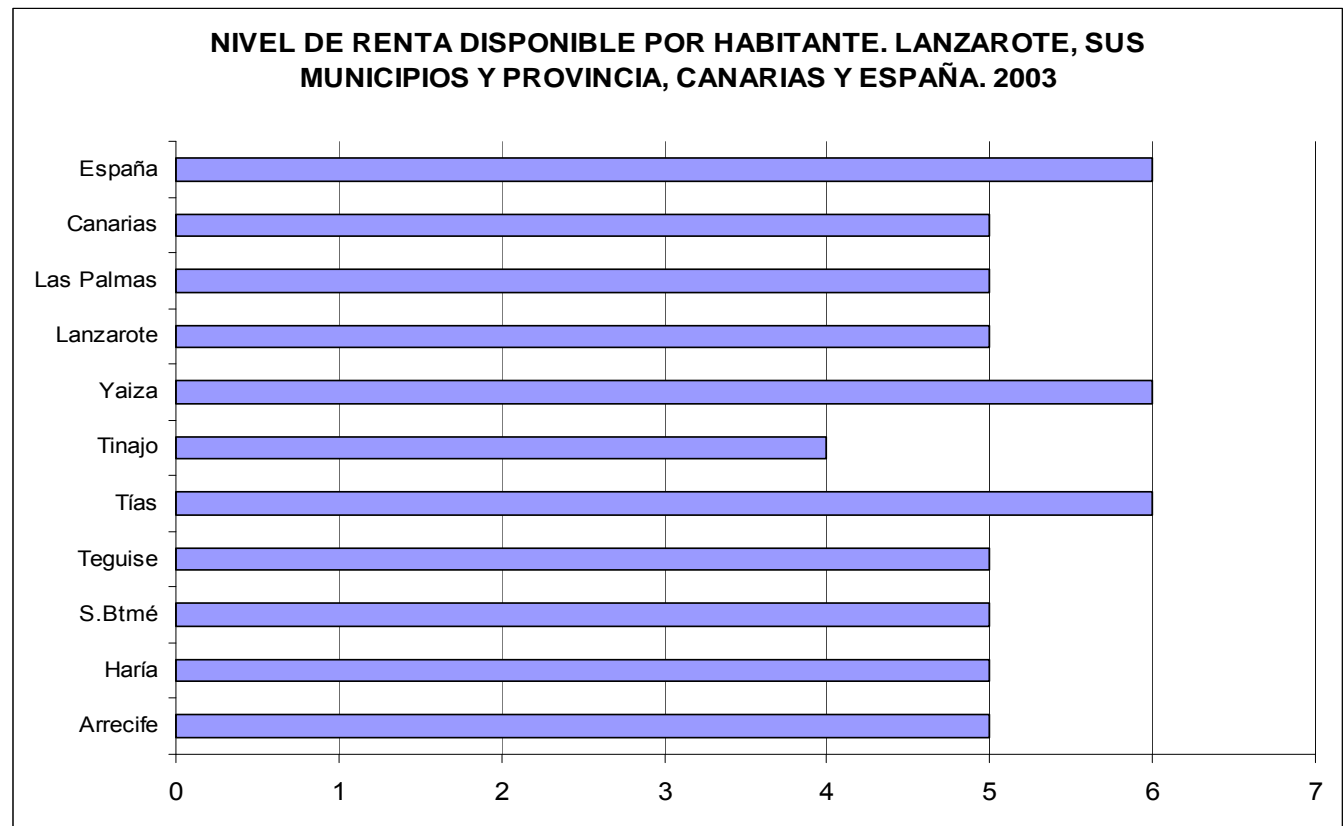

Fuente: Anuario Económico de España, 2005. Caixa. Elaboración propia.

\subsubsection{2.- CONCLUSIONES}

En esta etapa, que abarca la década comprendida entre 1996 y 2006, cuando Lanzarote es un destino turístico de masas maduro, la elevación de la renta familiar disponible municipal sigue observando cierto ascenso ( $\mathrm{y}$ en ocasiones estancamiento), pero ya no con el fuerte crecimiento de antaño, por lo nuevos crecimientos demográficos, la limitación del crecimiento de la oferta y la competencia que soporta por los nuevos destinos internacionales.

Los municipios que concentran la oferta turística, seguirán destacando sobre los demás, pero no de la forma anterior, pues ahora el salto cuantitativo es menor, también con respecto a la provincia, Canarias y España. Se reduce la distancia y se observa un proceso de nivelación ocurrido a pesar de la limitación de los crecimientos de la oferta turística, pues sigue creciendo la residencial, lo que propicia una mayor dispersión del hábitat y la mejora de los indicadores económicos de los municipios no turísticos.

La dependencia económica de la construcción y de los servicios al turismo ha adquirido una proporción desaconsejable por la fragilidad que representa para la economía insular, que está absolutamente limitada por las fluctuaciones de estos sectores, que dan soporte a una inmigración de baja cualificación y a un empleo de baja productividad, que a su vez revierte negativamente sobre la evolución de la renta y el PIB per cápita. Y con ello sobre las oportunidades y posibilidades de los residentes en el acceso a bienes y servicios que mejoren su bienestar. 


\subsection{7.- EFECTOS SOBRE LA CAPACIDAD ENERGÉTICA. 1996-2006.}

\subsubsection{1.- POTENCIA Y PRODUCCIÓN}

La evolución del sector energético condiciona el bienestar y la economía de las familias y de las empresas.

En el año 2001, se comienza la redacción de un nuevo Plan Energético para Canarias (PECAN), el existente es del año $1989^{218}$, cuyo borrador inicial se publica en mayo de 2003. La redacción final es del año 2006 y contempla un horizonte de planificación hasta $2015^{219}$.

Debemos recordar aquí que, ya en el PECAN de 1989, se planificó la introducción de gas natural en Canarias, en centrales de ciclo combinado, propuesta necesaria para conciliar economía y medio ambiente (opción ambiental menos negativa). A partir de ese momento el sistema eléctrico se planificó previendo la instalación de tales centrales (al menos para Tenerife y Gran Canaria), para consumir gas natural y, alternativa y temporalmente, gasóleo. En el año 2006 "las primeras centrales de producción eléctrica de ciclo combinado ya se encuentran operativas, pero el gas natural no está disponible, ni lo estará a corto plazo, lo que obliga al funcionamiento (...) con gasóleo" (PECAN, 2006, pp. 108), por lo que aún no se ha podido reducir el coste de generación de la electricidad y tampoco la emisión de gases de efecto invernadero (los objetivos del Protocolo de Kioto no se cumplirán). Una de las dificultades para este suministro es logística, pues los condicionantes medioambientales son cada vez más estrictos, obligando a realizar grandes adaptaciones, "encareciendo las nuevas instalaciones de generación, transformación, transporte y almacenamiento, lo que a su vez genera barreras de entrada para nuevos operadores en el sistema" (PECAN, 2006, pp. 12).

A partir del año 2003 los cambios en el sector energético serán escasos en el archipiélago. En el plano legislativo lo más significativo es el Real Decreto 1747/2003 que regula el sector eléctrico de los sistemas extrapeninsulares, de la Ley 54/1997 del Sector Eléctrico ${ }^{220}$ (que supone una importante liberalización de las actividades eléctricas), definiendo, por un lado, las reglas básicas de funcionamiento económico (mecanismos de compatibilidad

\footnotetext{
218 "(...) la planificación en el sector energético no ha despertado en los poderes públicos del Archipiélago durante todos estos años el interés que se merece, pese a que en las sociedades avanzadas es considerado un sector estratégico y pese a que su evolución condiciona el bienestar y la economía de las familias y las empresas". Plan Energético de Canarias (PECAN), 2002. Gobierno de Canarias, Mayo de 2003, (pp. 9).

219 La revisión de este Plan se ha publicado a principios del año 2012.

220 Establece en el artículo. 12, que las actividades para el suministro de energía eléctrica, en territorios insulares y extrapeninsulares, serán objeto de una reglamentación singular que atenderá las especificidades derivadas de su ubicación territorial. (Real Decreto 1747/2003).
} 
económica) de estos sistemas aislados (Art. 7,8,9,10 y 11), donde la generación de energía tiene mayores costes que en el territorio peninsular, y poder mantener tarifas y precios equivalentes, aplicando el principio de no discriminación. Y por otro lado, en su artículo 2.2. establece que la "planificación de la actividad de producción comprenderá la estimación de la potencia necesaria que debe ser instalada para cubrir la demanda prevista bajo criterios de seguridad de suministro, diversificación energética, mejora de la eficiencia y protección del medio ambiente, identificando los diferentes tipos de tecnología". Para ello implanta la figura del Operador del Sistema (gestión técnica) y del Operador del Mercado (gestión comercial).

Las infraestructuras de producción de energía eléctrica son una de las piezas claves dentro del sistema de infraestructuras básicas de Lanzarote. Recordemos que este sistema eléctrico es una red conjunta Lanzarote-Fuerteventura en simple circuito, que recorre ambas islas de norte a sur, desde la central de Lanzarote (Central Térmica de Punta Grande) hasta la subestación de Matas Blancas en el sur de Fuerteventura $(155 \mathrm{Km} \text {. })^{221}$, con lo que ambas islas comparten potencia.

Aunque desde el año 1991 se han ido apoyando y desarrollando las energía renovables (principalmente eólica ${ }^{222}$ ), éstas siguen teniendo una capacidad muy reducida con respecto a la generación convencional (Avance PIOT de Lanzarote. 2010, pp. 168) ${ }^{223}$.

La potencia instalada de la isla, no deja de crecer a lo largo de todo el tiempo que cubren estos análisis, a ritmos muy superiores a los que presenta Canarias y España. En el primer quinquenio del s. XXI la isla recibirá un nuevo impulso, incrementándose la capacidad de producción en un 59,7\% entre 2001-2006.

Tabla 207. Potencia instalada. Lanzarote, Canarias y España. 1996-2006 (kw).

\begin{tabular}{|c||r|r||r|r||r|r||}
\hline Año & LANZAROTE & $\begin{array}{c}\text { Incremento } \\
\text { quinquenal (\%) }\end{array}$ & Kw/Residente* $^{*}$ & $\begin{array}{c}\text { Incremento } \\
\text { quinquenal (\%) }\end{array}$ & Kw/P.Total $^{* *}$ & $\begin{array}{c}\text { Incremento } \\
\text { quinquenal (\%) }\end{array}$ \\
\hline \hline 1996 & 108.400 & 23,90 & 1,40 & 3,92 & 0,86 & $-6,22$ \\
\hline 2001 & 144.900 & 33,67 & 1,41 & 0,38 & 0,98 & 14,13 \\
\hline 2006 & 231.400 & 59,70 & 1,82 & 29,11 & 1,40 & 42,92 \\
\hline
\end{tabular}

${ }^{221}$ Ambas islas están unidas eléctricamente por un enlace submarino de $66 \mathrm{KV}$ (14 MW) y han experimentado los mayores crecimientos del archipiélago en los últimos años (8,1\% LZ y 10,6\% en FV, crecimiento anual medio desde el año 2003 al 2008). PTEOIE, 2008. Memoria Informativa, pp. 375-376.

$222 \mathrm{Al}$ final de la etapa existen dos parques eólicos, situados en el norte y en el centro de la isla.

223 Plan Insular de Ordenación del Territorio de Lanzarote (2010). Avance. Memoria de información territorial. Cabildo de Lanzarote. 2010. www.cabildodelanzarote.com. 


\begin{tabular}{||c||c|r||r|r||r|r||}
\hline Año & CANARIAS & $\begin{array}{c}\text { Incremento } \\
\text { quinquenal (\%) }\end{array}$ & Kw/Residente* & $\begin{array}{c}\text { Incremento } \\
\text { quinquenal (\%) }\end{array}$ & Kw/P.Total** & $\begin{array}{c}\text { Incremento } \\
\text { quinquenal (\%) }\end{array}$ \\
\hline 1996 & 1.622 .657 & 40,89 & 1,01 & 31,00 & 0,85 & 23,47 \\
\hline 2001 & 1.809 .895 & 11,54 & 1,07 & 5,75 & 0,94 & 6,29 \\
\hline 2006 & 2.752 .079 & 52,06 & 1,38 & 29,10 & 1,26 & 34,54 \\
\hline Año & ESPAÑA & $\begin{array}{c}\text { Incremento } \\
\text { quinquenal (\%) }\end{array}$ & Kw/Residente & $\begin{array}{c}\text { Incremento } \\
\text { quinquenal (\%) }\end{array}$ & Kw/P.Total** & $\begin{array}{c}\text { Incremento } \\
\text { quinquenal (\%) }\end{array}$ \\
\hline 1996 & 49.236 .797 & 7,18 & 1,24 & 5,03 & 1,21 & 5,19 \\
\hline 2001 & 55.386 .657 & 12,49 & 1,36 & 9,35 & 1,32 & 7,52 \\
\hline 2006 & 84.374 .763 & 52,34 & 1,89 & 39,18 & 1,84 & 39,43 \\
\hline
\end{tabular}

$\left({ }^{*}\right)$ Se establece como la relación entre la potencia instalada y el número de residentes.

$\left.{ }^{* *}\right)$ P.Total: población residente + turistas equivalentes diarios. Se establece la potencia por habitante equivalente (kw/p. total). Fuente: Para 1996: "Potencia instalada 1996". Tabla 2.1.1. Evolución del apotencia eléctrica instalada en Canarias, por islas. Estadísticas Energéticas de Canarias, 2006. Dirección General de Industria y Energía, Gobierno de Canarias;

"Potencia instalada. Total Nacional, 1996". Estadística de la Industria de Energía Eléctrica, 1996. Ministerio de Industria, Turismo y Comercio. www.mityc.es/energia/balances/; Para 2001: "Potencia instalada. Provincia de Las Palmas, Tenerife (Anexo I.06) y Total Nacional, 2001". Estadística de la Industria de Energía Eléctrica, 2001. Ministerio de Industria, Turismo y Comercio. www.mityc.es/energia/balances/; Para 2006: "Potencia instalada. Provincia de Las Palmas, Tenerife (Anexo I.06) y Total Nacional, 2006". Estadística de la Industria de Energía Eléctrica, 2006. Ministerio de Industria, Turismo y Comercio. www.mityc.es/energia/balances/.

Estos nuevos impulsos en la potencia instalada vienen derivados de la ampliación de la Central Térmica de Punta Grande (entre los términos municipales de Arrecife y Teguise, situada a 200 metros de un núcleo de población consolidado, lo que dificulta el crecimiento de la superficie que puede ocupar), que es la infraestructura energética de producción de primer nivel jerárquico en la Isla. Se instalan nuevos motores diesel, alimentados con gasóleo y fuel-oil, creciendo la contaminación asociada y la dependencia energética insular del exterior, así como la afección sobre los precios ${ }^{224}$.

224 "Para superar la punta de demanda del año 2004 se instalan nuevos grupos electrógenos" en la Central Térmica y las subestaciones (Gesplan, PTEOIE-LZ224, 2008, Memoria Informativa, pp. 376 
Tabla 208. Potencia instalada por tipo de infraestructura eléctrica. Lanzarote. 2006.

\begin{tabular}{|c|c|c|c|c|c|c|}
\hline Térmica & \multicolumn{2}{|c|}{$\begin{array}{l}\text { Potencia (MW) } \\
\text { (178 MW operativos) }\end{array}$} & Generación & Combustible & Localización & $\begin{array}{l}\text { Capacidad- } \\
\text { Almacenaje }\end{array}$ \\
\hline \multirow{2}{*}{$\begin{array}{l}\text { Central Térmica } \\
\text { de Punta Grande }\end{array}$} & 1997 & 2008 & \multirow{2}{*}{ Motores diesel (7) } & \multirow{2}{*}{$\begin{array}{l}\text { Fuel-oil (300T/día) } \\
\text { Gasoil (14T/día) }\end{array}$} & \multirow{2}{*}{ Noreste-Arrecife } & \multirow{2}{*}{30 días } \\
\hline & 98 & 214 & & & & \\
\hline Parques eólicos & \multicolumn{2}{|c|}{ Potencia (MW) } & Propiedad & Servicio & Localización & Situación \\
\hline \multirow{2}{*}{ Los Valles } & 1993 & 2006 & \multirow{2}{*}{$\begin{array}{l}\text { Pública. (Eólicas de } \\
\text { Lanzarote. S.A.) }\end{array}$} & \multirow{2}{*}{ Conectada a Red } & \multirow{2}{*}{ Teguise } & \multirow{2}{*}{ Activa } \\
\hline & 5,28 & 7,5 & & & & \\
\hline \multirow{2}{*}{ Montaña Mina } & 1991 & 2006 & \multirow{2}{*}{ Privada (PECSA) } & \multirow{2}{*}{ Conectada a Red } & \multirow{2}{*}{ San Bartolomé } & \multirow{2}{*}{ Activa } \\
\hline & 1,125 & 1,125 & & & & \\
\hline TOTAL EÓLICA & 6,405 & 8,625 & & Conectada a Red & & \\
\hline Fotovoltaica & Año & $\begin{array}{l}\text { Potencia } \\
\text { (MW) }\end{array}$ & Propiedad/Gestión & Servicio & Localización & Situación \\
\hline Pedro Barba & 1991 & 25,5 & $\begin{array}{l}\text { Consejería de } \\
\text { Industria. Gob. de } \\
\text { Canarias }\end{array}$ & No vuelca a Red & Isla-La Graciosa & Fuera de Servicio \\
\hline La Florida & 2005 & 20,0 & Privada & $\begin{array}{l}\text { No vuelca a Red (en } \\
\text { tramitación) }\end{array}$ & San Bartolomé & Activa \\
\hline Planta de Tinajo & 2006 & 20,0 & Privada & $\begin{array}{l}\text { No vuelca a Red (en } \\
\text { tramitación) }\end{array}$ & Tinajo & Activa \\
\hline $\begin{array}{l}\text { Planta Colegio } \\
\text { de Tahíche }\end{array}$ & 2001 & 2,5 & Pública (municipal) & $\begin{array}{l}\text { No vuelca a Red (en } \\
\text { tramitación) }\end{array}$ & Teguise & Activa \\
\hline Planta Biblioteca & 2004 & 2,5 & Pública (municipal) & $\begin{array}{l}\text { No vuelca a Red (en } \\
\text { tramitación) }\end{array}$ & San Bartolomé & Activa \\
\hline $\begin{array}{l}\text { Planta Parque } \\
\text { Nacional de } \\
\text { Timanfaya }\end{array}$ & 2005 & 1,2 & $\begin{array}{l}\text { Patronato del P. N. } \\
\text { de Timanfaya }\end{array}$ & $\begin{array}{l}\text { No vuelca a Red (en } \\
\text { tramitación) }\end{array}$ & Yaiza & Activa \\
\hline \multicolumn{2}{|l|}{ TOTAL FOTOVOLTAICA } & 46,2 & $---\cdot$ & $\begin{array}{l}\text { No vuelca a Red } \\
\text { (en tramitación) }\end{array}$ & ---- & Activa \\
\hline Biometanización & Año & $\begin{array}{l}\text { Potencia } \\
\text { (MW) }\end{array}$ & Propiedad/Gestión & Servicio & Localización & Situación \\
\hline $\begin{array}{l}\text { Comp. Ambiental } \\
\text { de Zonzamas }\end{array}$ & 2004 & 5,0 & Pública (Cabildo) & Fuera de Servicio & Municipio Teguise & $\begin{array}{l}\text { Activación } \\
\text { prevista: } 2008\end{array}$ \\
\hline \multicolumn{3}{|c|}{ POTENCIA OPERATIVA EN RED } & \multicolumn{4}{|c|}{ 186,625 MW (térmica y eólica) } \\
\hline \multicolumn{3}{|c|}{ POTENCIA TOTAL EN SERVICIO } & \multicolumn{4}{|c|}{$232,825 \mathrm{MW}$} \\
\hline
\end{tabular}

Fuente: Gesplan y otros. "Plan Territorial Especial de Ordenación de las Infraestructuras Energéticas de Lanzarote (PTEOIE-LZ). Memoria Informativa, 2008” (pp. 376-386). Centro de datos. Cabildo Insular de Lanzarote. www.datosdelanzarote.com. 
Mapa 32. Redes eléctricas y sistemas energéticos de Lanzarote. 2006

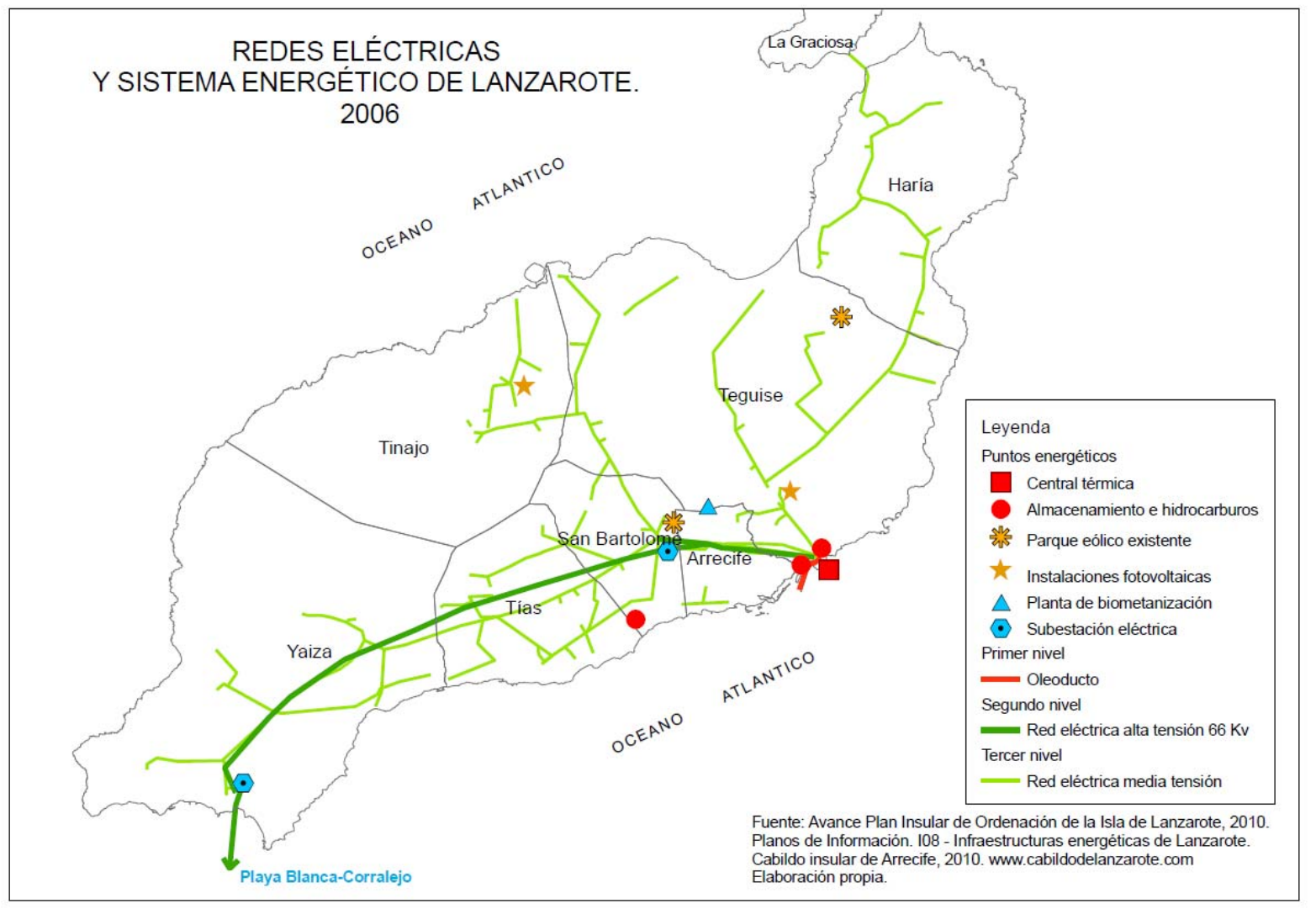

La capacidad de producción por habitante equivalente (residentes y turistas) está muy afectada por la presión que ejerce el constante crecimiento de la población residente, del $23,7 \%$ entre el año 2001 y 2006 , en menor medida que la demanda añadida que suponen los turistas equivalentes diarios que acoge la isla (expresada en el Gráfico siguiente), pues en el mismo quinquenio disminuyen (-15,9\%), ya que desde el año 2001 se observa la reducción de las pernoctaciones, así como el volumen de entradas al año, lo que explica la menor presencia diaria en la isla (ver epígrafe 5.3.1.2. Demanda turística). 
Gráfico 187. Evolución de la potencia instalada por habitante. Lanzarote. 1996-2006 (kw/hab).

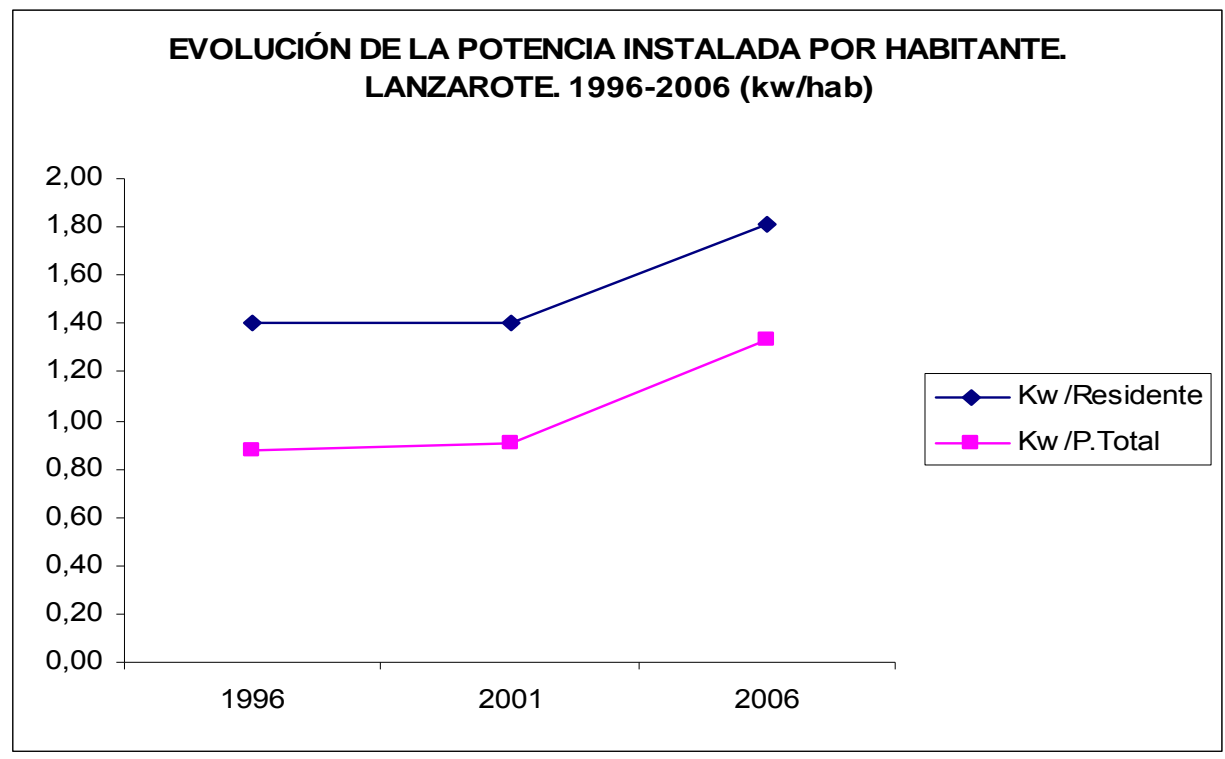

Fuente: Elaboración propia a partir de la Tabla 207.

No será hasta el año 2006 cuando su capacidad de producción por habitante equivalente se sitúe por encima de la de Canarias, en un 7\% aproximadamente, aunque la distancia con España seguirá siendo enorme (28\%).

Gráfico 188. Evolución de la capacidad de producción de energía eléctrica por habitante. Lanzarote, Canarias y España. 1996-2006 (kw/hab).

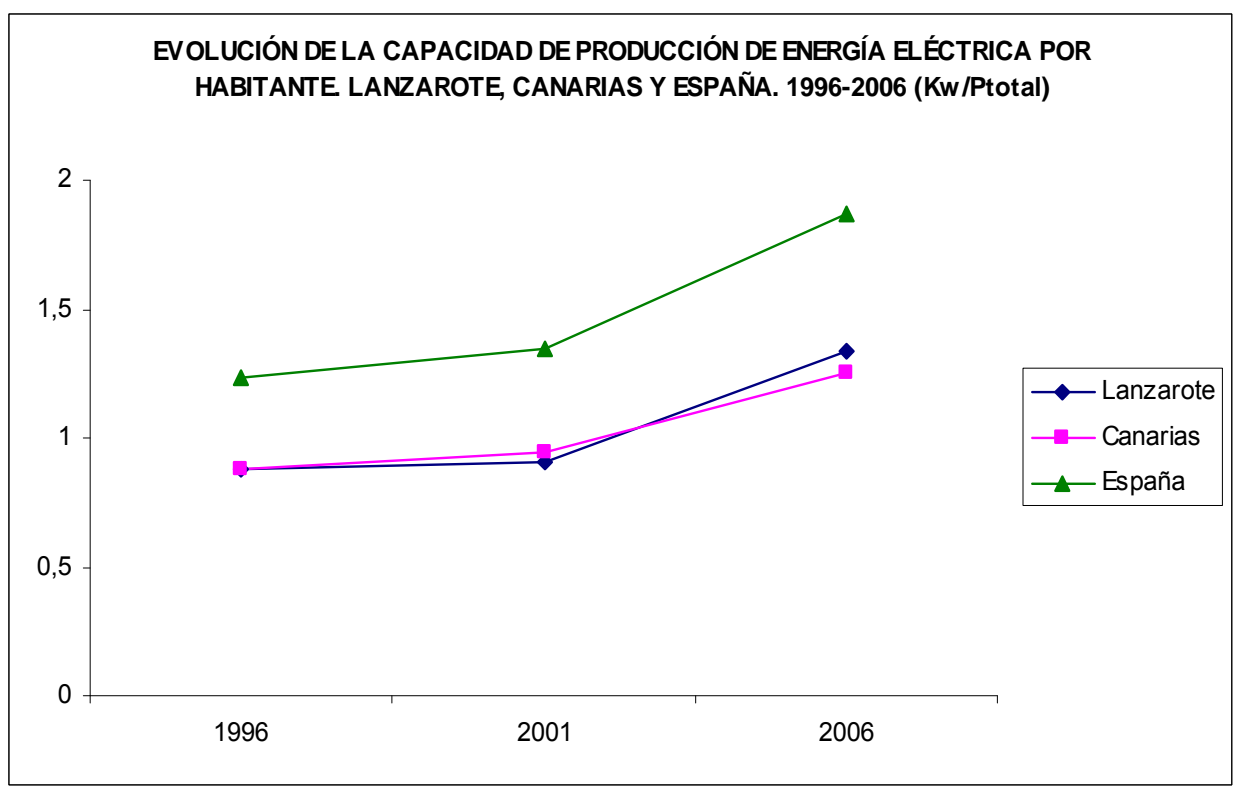

Fuente: Elaboración propia a partir de la Tabla 207. 
Los crecimientos de la potencia instalada, han permitido el constante incremento de la producción en términos relativos, por encima de los niveles del periodo anterior (1991-1996), tanto en relación a la población residente como a la total estimada o equivalente (residentes y turistas) que asume diariamente la isla. Su aumento será constante en esta etapa, pero moderado con respecto a las anteriores.

Tabla 209. Producción de energía eléctrica disponible. Lanzarote, Canarias y España. 19962006 (Mwh)

\begin{tabular}{|c||c|c|c|c|}
\hline Año & $\begin{array}{c}\text { LANZAROTE } \\
\text { (Mwh) }\end{array}$ & Kwh/Residente & Kwh/P.Total $^{* *}$ & $\begin{array}{c}\text { Incremento quinquenal } \\
\text { kwh/P.Total (\%) }\end{array}$ \\
\hline \hline $\mathbf{1 9 9 6}$ & 419.250 & $5.418,14$ & $3.325,67$ & 4,25 \\
\hline $\mathbf{2 0 0 1}$ & 608.110 & $5.901,46$ & $4.118,67$ & 23,84 \\
\hline $\mathbf{2 0 0 6}$ & 763.280 & $5.988,53$ & $4.626,53$ & 12,33 \\
\hline \hline \multicolumn{4}{|l}{ Variación (\%) de la producción entre 1996-2006 (kwh/P.Total) } & $\mathbf{3 9 , 1 2}$ \\
\hline
\end{tabular}

\begin{tabular}{||l||c|c|c|c|}
\hline Año & $\begin{array}{c}\text { CANARIAS } \\
\text { (Mwh) }\end{array}$ & Kwh/Residente & Kwh/PTotal & $\begin{array}{c}\text { Incremento quinquenal } \\
\text { kwh/P.Total (\%) }\end{array}$ \\
\hline \hline $\mathbf{1 9 9 6}$ & 5.219 .857 & $3.249,14$ & $2.731,48$ & 23,33 \\
\hline $\mathbf{2 0 0 1}$ & 6.642 .749 & $3.920,24$ & $3.433,05$ & 25,68 \\
\hline $\mathbf{2 0 0 6}$ & 8.957 .171 & $4.487,94$ & $4.095,79$ & 19,30 \\
\hline \hline \multicolumn{2}{|l}{ Variación (\%) de la producción entre 1996-2006 (kwh/P.Total) } & $\mathbf{4 9 , 9 5}$ \\
\hline
\end{tabular}

\begin{tabular}{||c||c|c|c|c|}
\hline Año & $\begin{array}{c}\text { ESPAÑA } \\
\text { (Mwh) }\end{array}$ & Kwh/Residente & Kwh/PTotal & $\begin{array}{c}\text { Incremento quinquenal } \\
\text { kwh/P.Total (\%) }\end{array}$ \\
\hline \hline $\mathbf{1 9 9 6}$ & 166.155 .525 & $4.188,51$ & $4.098,38$ & 8,89 \\
\hline $\mathbf{2 0 0 1}$ & 200.091 .176 & $4.898,51$ & $4.777,56$ & 16,57 \\
\hline $\mathbf{2 0 0 6}$ & 279.298 .046 & $6.247,03$ & $6.103,83$ & 27,76 \\
\hline \multicolumn{2}{|l|}{ Variación (\%) de la producción entre 1996-2006 (kwh/P.Total) } & $\mathbf{4 8 , 9 3}$ \\
\hline
\end{tabular}

${ }^{*}$ ) La variación porcentual está calculada en relación la Kw/P. Total; $\left({ }^{\star *}\right)$ Población total: población residente + turistas equivalentes diarios. Fuente: Para 1996: "Producción de energía eléctrica, 1996", en Evolución de la producción, consumo y abonados a la energía eléctrica, 1987-2008. Centro de datos. Cabildo Insular de Lanzarote. www.datosdelanzarote.com; "Producción disponible de energía eléctrica. Total Nacional y Provincia de Las Palmas y Tenerife, 1996". Estadística de la Industria de Energía Eléctrica, 1996. Ministerio de Industria, Turismo y Comercio. www.mityc.es/energia/balances/; Para 2001: "Producción de energía eléctrica, 2001", en Evolución de la producción, consumo y abonados a la energía eléctrica, 1987-2008. Centro de datos. Cabildo Insular de Lanzarote. www.datosdelanzarote.com; "Producción disponible de energía eléctrica. Total Nacional y Provincia de Las Palmas y Tenerife, 2001". Estadística de la Industria de Energía Eléctrica, 2001. Ministerio de Industria, Turismo y Comercio. www.mityc.es/energia/balances/; Para 2006: "Producción de energía eléctrica, 2006", en Evolución de la producción, consumo y abonados a la energía eléctrica, 19872008. Centro de datos. Cabildo Insular de Lanzarote. www.datosdelanzarote.com; "Producción disponible de energía eléctrica. Total Nacional y Provincia de Las Palmas y Tenerife, 2006". Estadística de la Industria de Energía Eléctrica, 2006. Ministerio de Industria, Turismo y Comercio. www.mityc.es/energia/balances/; 
Lanzarote se sitúa por encima de Canarias en la producción de energía eléctrica por habitante durante toda la etapa, entre un $20 \%$ al comienzo y el $8,5 \%$ al final de la misma. No ocurre lo mismo frente al cómputo nacional, al que la Isla ni siquiera se aproxima.

\section{Gráfico 189. Evolución de la producción de energía eléctrica por habitante. Lanzarote, Canarias y España. 1996-2006 (kw/PTotal).}

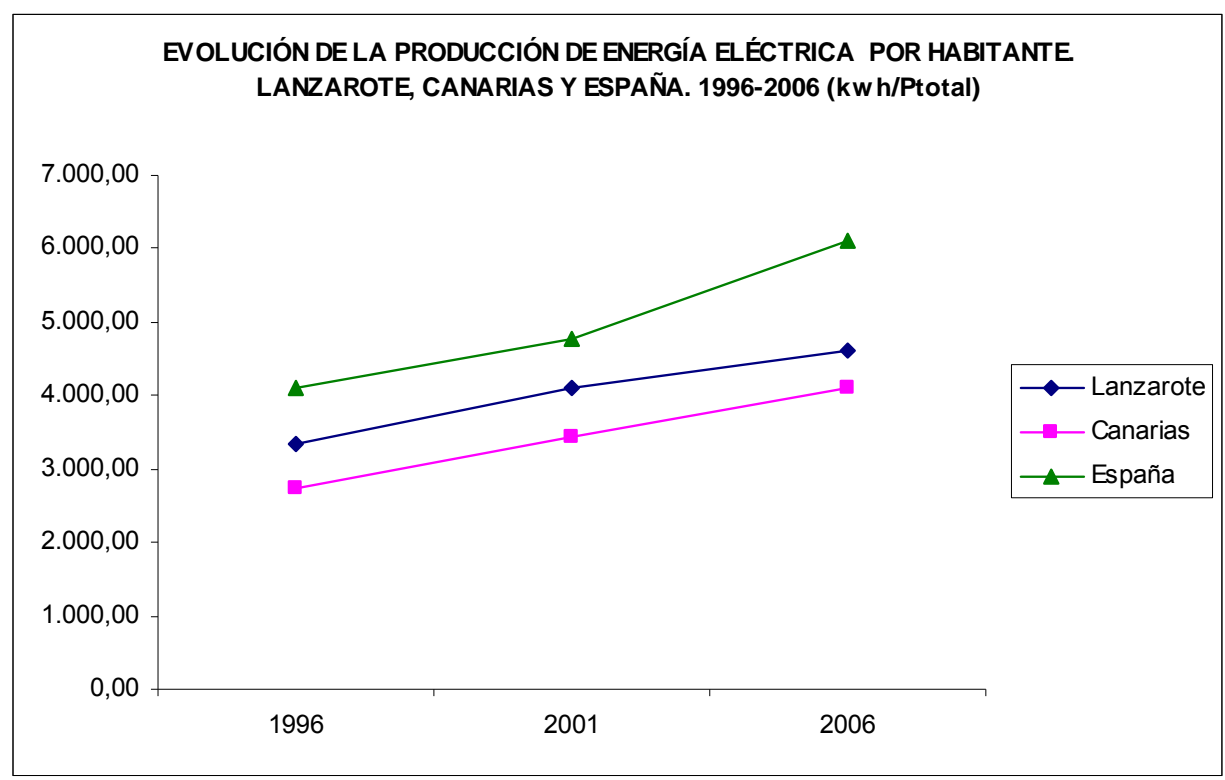

Fuente: Elaboración propia a partir de la Tabla 209.

A pesar de estos incrementos en la producción, el sistema eléctrico LanzaroteFuerteventura, subsiste al límite, pues como señala el PTEOIE-LZ "la red de Lanzarote se encuentra saturada en el tramo Punta Grande-San Bartolomé-Mácher", es decir en dirección sur-este (la línea que da servicio a Arrecife (capital), San Bartolomé, colindante a Arrecife y que ha tenido un significativo crecimiento demográfico en los últimos años) y Mácher, (situado en el municipio de Tías) que hace continuo urbano con la zona de concentración de actividad turística), a ello se añade problemas de espacio para la ampliación de la Central Térmica (Punta Grande, municipio de Arrecife) y "en Fuerteventura se tienen problemas de caída de tensión debido a las grandes distancias existentes. Esta situación se debe a los elevados crecimientos de la demanda y a los retrasos acumulados en las puestas en marcha de las instalaciones de los proyectos de refuerzos de red que se vienen tramitando desde los años 90". La isla dispone del enlace submarino para situaciones de fallo de uno de los grupos de la isla de Fuerteventura, aunque para paliar esta situación de precariedad se ubican, en la subestación de Playa Blanca (extremo sur de la isla, en el municipio de Yaiza), en el año 2006 dos motores de refuerzo que funcionan prácticamente de continuo. "La red está tan saturada que no se cumple con el mantenimiento de los motores de la central térmica (cada 4.000h de trabajo) ante la imposibilidad de parar el sistema", pues en 
el año 2008 Lanzarote consumía entre 5 y $15 \mathrm{Mw}$ de potencia procedentes de la isla de Fuerteventura (Gesplan, PTEOIE-LZ. Memoria Informativa, 2008, pp. 376-378).

La energía eólica, que constituye el segundo nivel que en esta etapa vuelca su producción a red, es pagada al productor a un precio tan alto, que ha hecho que la demanda de implantación por parte del inversor privado se dispare a lo largo de la primera década del s. XXI. (Gesplan, PTEOIE-LZ, Memoria Informativa, 2008, pp. 383).

\subsubsection{2.- CONSUMO ENERGÉTICO}

Con la entrada del nuevo siglo el consumo de energía eléctrica vuelve a sufrir un incremento notable (24,4\% entre 1996 y 2001), en relación a la población total, con respecto al quinquenio anterior. Este hecho puede atribuirse al incremento de la población residente en casi un 33\% y que seguirá aumentando en el quinquenio siguiente. De modo que, a pesar de la reducción del número de visitantes por turismo que sufre la isla entre 2001 y 2006 (aproximadamente del 3,5\%), los niveles de consumo eléctrico no parecen reducirse, sino todo lo contrario, se incrementan casi un $23 \%$, fenómeno éste que sólo puede ser explicado por el crecimiento de la población residente en este quinquenio.

Tabla 210. Consumo eléctrico e intensidad energética. Lanzarote, Canarias y España. 19962006 (Mwh)

\begin{tabular}{|l|c|c||c|c||c||}
\hline Año & LANZAROTE & $\begin{array}{c}\text { Consumo } \\
\text { (Kwh/residentes) }\end{array}$ & $\begin{array}{c}\text { Consumo } \\
\text { (Kwh/P.Total) }\end{array}$ & $\begin{array}{c}\text { Incremento quinquenal } \\
(\%)\end{array}$ & $\begin{array}{c}\text { Intensidad } \\
\text { Energética** }^{*}\end{array}$ \\
\hline \hline $\mathbf{1 9 9 6}$ & 393.808 & $5.089,34$ & $3.123,85$ & 3,98 & 408,716 \\
\hline 2001 & 573.708 & $5.567,60$ & $3.885,67$ & 24,39 & 312,267 \\
\hline 2006 & 789.372 & $6.193,24$ & $4.784,68$ & 23,14 & 294,589 \\
\hline \hline \multicolumn{2}{|l}{ Variación (\%) del Consumo entre 1996-2006 (kwh/P.Total) } & 42,76 \\
\hline
\end{tabular}

\begin{tabular}{|l|c|c||c|c|c||}
\hline Año & CANARIAS & $\begin{array}{c}\text { Consumo } \\
\text { (Kwh/residentes) }\end{array}$ & $\begin{array}{c}\text { Consumo } \\
\text { (Kwh/P.Total) }\end{array}$ & $\begin{array}{c}\text { Incremento quinquenal } \\
\text { (\%) }\end{array}$ & $\begin{array}{c}\text { Intensidad } \\
\text { Energética** }^{*}\end{array}$ \\
\hline $\mathbf{1 9 9 6}$ & 4.472 .482 & $2.783,93$ & $2.340,39$ & 13,84 & 247,283 \\
\hline $\mathbf{2 0 0 1}$ & 6.295 .926 & $3.715,56$ & $3.253,81$ & 39,03 & 227,533 \\
\hline $\mathbf{2 0 0 6}$ & 8.649 .151 & $4.333,60$ & $3.954,95$ & 21,55 & 220,224 \\
\hline \hline
\end{tabular}




\begin{tabular}{|l||c|c|c|c|c|}
\hline Año & ESPAÑA & $\begin{array}{c}\text { Consumo } \\
\text { (Kwh/residentes) }\end{array}$ & $\begin{array}{c}\text { Consumo } \\
\text { (Kwh/P.Total) }\end{array}$ & $\begin{array}{c}\text { Incremento } \\
\text { quinquenal (\%) }\end{array}$ & $\begin{array}{c}\text { Intensidad } \\
\text { Energética }^{* *}\end{array}$ \\
\hline $\mathbf{1 9 9 6}$ & 155.501 .079 & $3.919,93$ & $3.835,58$ & 15,55 & 328,162 \\
\hline $\mathbf{2 0 0 1}$ & 207.207 .228 & $5.072,72$ & $4.947,47$ & 28,99 & 304,413 \\
\hline $\mathbf{2 0 0 6}$ & 251.639 .470 & $5.628,39$ & $5.499,38$ & 11,16 & 255,657 \\
\hline \hline \multicolumn{2}{|l}{ Variación (\%) del Consumo entre 1996-2006 (kwh/P.Total) } & $\mathbf{4 3 , 7 0}$ \\
\hline
\end{tabular}

Nota: el Incremento interperiodo calculado (\%) es en relación al consumo por estimado para la población total estimada o equivalente que acoge la isla a diario $\left(^{*}\right)$.

$\left.{ }^{*}\right)$ Población Total: población residente + turistas equivalentes diarios.

$\left.{ }^{* *}\right)$ Intensidad energética eléctrica: energía eléctrica consumida / PIB (en millones de euros).

Fuente: Para 1996: "Consumo de energía eléctrica, 1996”, en Evolución de la producción, consumo y abonados a la energía eléctrica, 1987-2008. Centro de datos. Cabildo Insular de Lanzarote. www.datosdelanzarote.com; "Consumo neto de energía eléctrica. Total Nacional, Provincia de Las Palmas y Tenerife, 1996". Estadística de la Industria de Energía Eléctrica, 1996. Ministerio de Industria, Turismo y Comercio. www.mityc.es/energia/balances/; "PIB (euros) a precios de mercado, Lanzarote, 1996". En Pedro Calero Lemes, 2005. Cita textual: "Dado que no tenemos el PIB real calculado para Lanzarote. Se han combinado dos variables: la base imponible del IRPF para Lanzarote y las estimaciones del PIB para toda Canarias por parte del INE. Aunque lo óptimo sería el cálculo real del PIB". http://pedrocalerolemes.blogspot.com/2005/12/aproximacin-al-pib-de-lanzarote.html; "PIB a precios de mercado. Precios corrientes, en miles de euros. Canarias y España, 1996". Contabilidad Regional de España. Serie homogénea 1995-2009. INE. Para 2001: "Consumo de energía eléctrica, 2001", en Evolución de la producción, consumo y abonados a la energía eléctrica, 1987-2008. Centro de datos. Cabildo Insular de Lanzarote. www.datosdelanzarote.com; "Consumo neto de energía eléctrica. Total Nacional, Provincia de Las Palmas y Tenerife, 2001". Estadística de la Industria de Energía Eléctrica, 2001. Ministerio de Industria, Turismo y Comercio. www.mityc.es/energia/balances/; "VAB a precios de mercado según isla, en miles de euros, 2001". Instituto Canario de Estadística. Centro del Datos del Cabildo Insular de Lanzarote http://www.datosdelanzarote.com/itemDetalles.asp?idFamilia=17\&idltem=4250; "PIB a precios de mercado. Canarias, en miles de euros, 2001". Contabilidad Regional de España. INE; "PIB a precios de mercado y sus componentes. Precios corrientes, en millones de euros. Tabla 1. Demanda, Oferta y Rentas. 2001". Contabilidad Nacional de España. Serie homogénea 1995-2009. INE

Para 2006: "Consumo de energía eléctrica, 2006", en Evolución de la producción, consumo y abonados a la energía eléctrica, 19872008. Centro de datos. Cabildo Insular de Lanzarote. www.datosdelanzarote.com; "Consumo neto de energía eléctrica. Total Nacional, Provincia de Las Palmas y Tenerife, 2006". Estadística de la Industria de Energía Eléctrica, 2006. Ministerio de Industria, Turismo y Comercio. www.mityc.es/energia/balances/; "VAB a precios de mercado según isla, en miles de euros, 2006". Instituto Canario de Estadística. Centro del Datos del Cabildo Insular de Lanzarote

http://www.datosdelanzarote.com/itemDetalles.asp?idFamilia=17\&idltem=4250; "PIB a precios de mercado. Canarias, en miles de euros, 2006 (estimación provisional)". Contabilidad Regional de España. INE; "PIB a precios de mercado y sus componentes. Precios corrientes, en millones de euros. Tabla 1. Demanda, Oferta y Rentas. 2006". Contabilidad Nacional de España. Serie homogénea 19952009. INE. 
Gráfico 190. Incremento interperiodo del consumo de energía eléctrica en relación a la población total estimada. Lanzarote, Canarias y España. 1996-2006 (kwh/Ptotal)

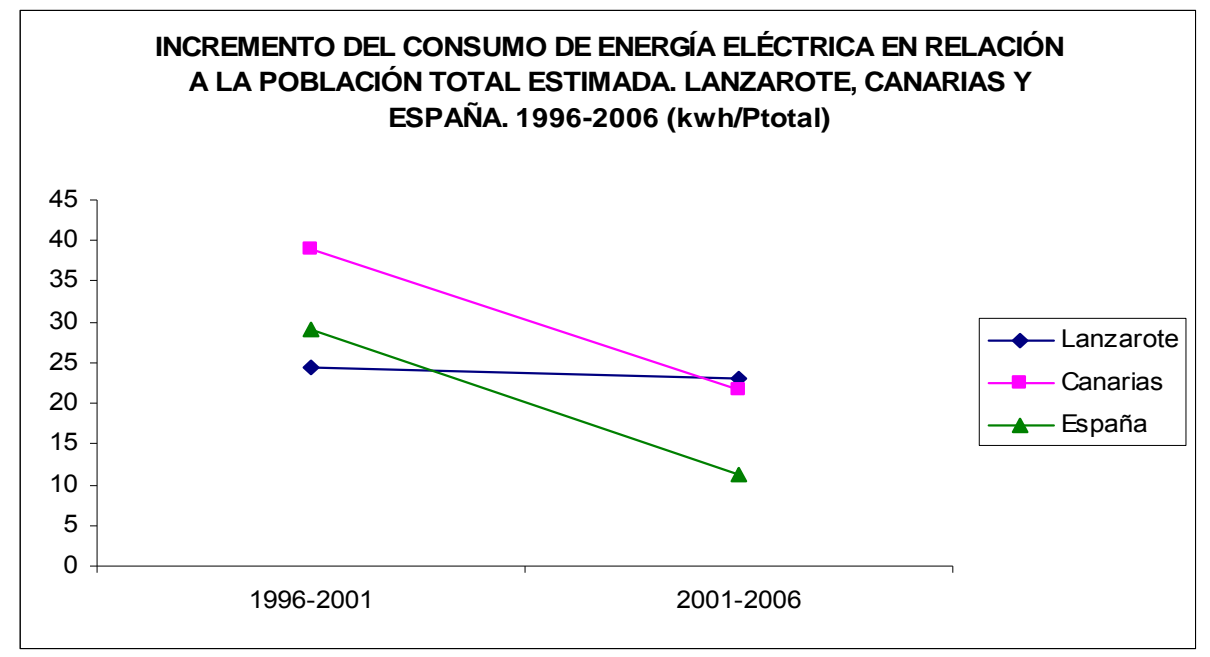

Fuente: Elaboración propia a partir de la Tabla 210.

Aunque el incremento del consumo interperiodo en relación a la población total estimada se muestra inferior al de Canarias y España hasta el año 2001, éste se situará por encima al final de la etapa. El consumo eléctrico en la Isla, por habitante estimado (kwh/PTotal), a lo largo de todo el periodo será superior al de su Comunidad Autónoma (en casi un $21 \%$ en 2006), no así con respecto a España que presenta mayores consumos per cápita, estando Lanzarote un $13 \%$ por debajo en el mismo año, como se aprecia en el siguiente Gráfico.

Gráfico 191. Evolución del consumo de energía eléctrica por habitante. Lanzarote, Canarias y España. 1996-2006 (kwh/Ptotal)

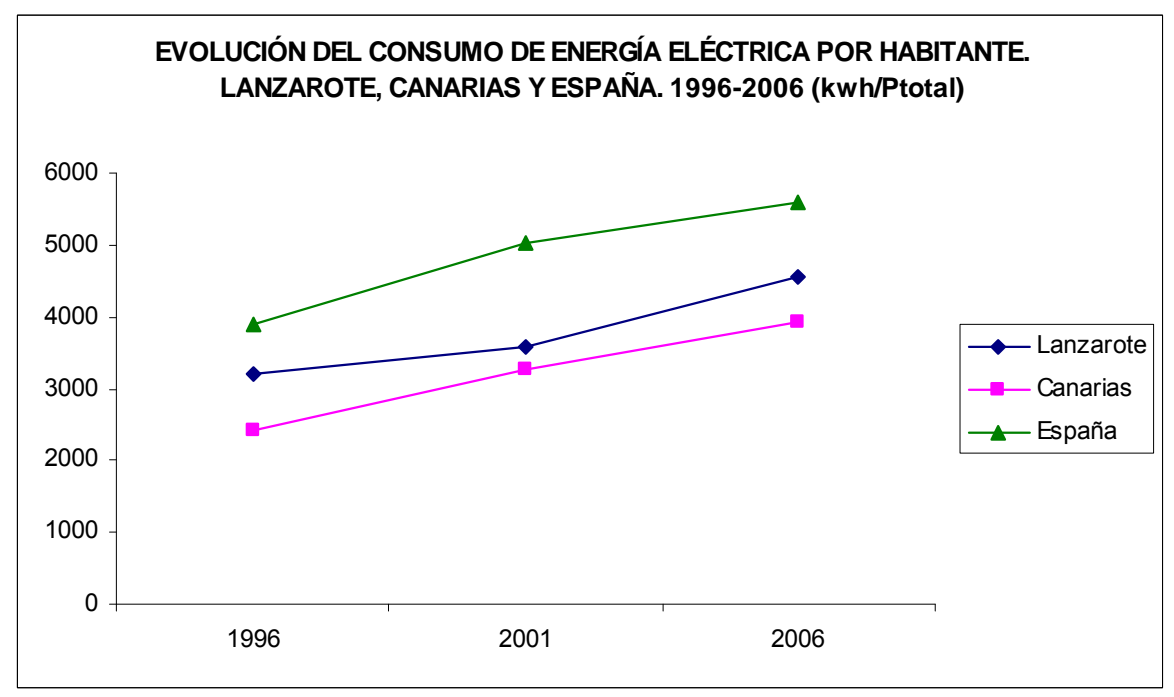

Fuente: Elaboración propia a partir de la Tabla 210. 
Al igual que se ha señalado en el etapa anterior, en ésta también el crecimiento de la producción ha seguido evolucionando por debajo del consumo. Pues en el periodo temporal que recorre esta etapa (1996-2006) el incremento de la producción eléctrica ha supuesto un $39,1 \%$, frente a la demanda de consumo que se ha incrementado en un $42,7 \%$, en relación a la población total estimada o equivalente (residentes y turistas equivalentes diarios). El dato a destacar es el enorme incremento del consumo en Canarias frente a España en esta década.

Tabla 211. Resumen. Variación de la oferta y demanda de energía eléctrica por habitante equivalente (kwh/P.total). España, Canarias y Lanzarote. 1996-2006. (\%)

\begin{tabular}{|l|c|c|}
\cline { 2 - 3 } \multicolumn{1}{c|}{} & Producción & Consumo \\
\hline LANZAROTE & 39,12 & 42,76 \\
\hline CANARIAS & 49,95 & 61,84 \\
\hline ESPAÑA & 48,93 & 43,70 \\
\hline
\end{tabular}

Fuente: Tabla resumen a partir de datos anteriores (Tablas 208 y 209). Elaboración propia.

Gráfico 192. Variación de la oferta y la demanda de energía eléctrica por habitante equivalente (kwh/Ptotal). Lanzarote, Canarias y España. 1996-2006 (\%)

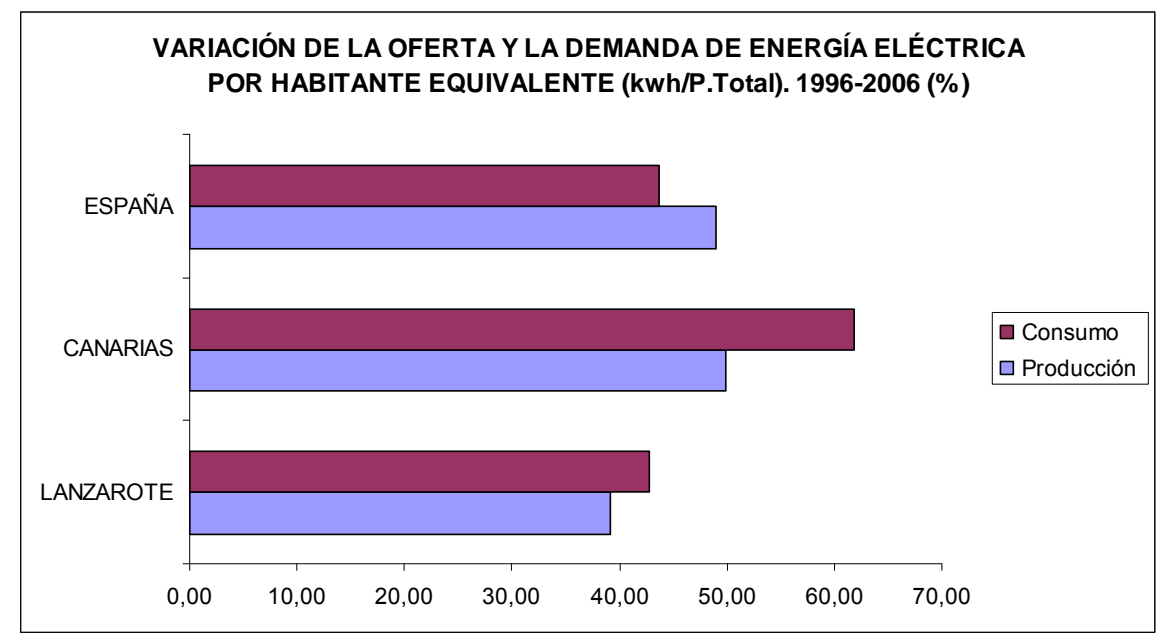

Fuente: Elaboración propia a partir de la Tabla resumen $n^{\prime 0} 211$

El proceso de modernización vivido en la isla, junto con los fuertes y sobre todo rápidos crecimientos de la población que soporta a diario, no permite la adaptación de la producción a la misma velocidad que la demanda.

El sistema subsiste al límite, es muy dependiente del exterior en su generación energética, sin posibilidad de autonomía. La producción por energías renovables aún es escasa y su precio muy elevado, con consecuencias negativas derivadas hacia la calidad medioambiental y el bienestar social, ya que los principales contaminantes (de efecto 
invernadero) se siguen generando por la utilización de combustibles fósiles para la generación de energía eléctrica, 95,4\% a través del fuel-oil y el gas-oil (de los cuales el $95,5 \%$ corresponde al primero) y el 4,6\% restante a través de la energía eólica. Las mejoras son escasas con respecto al decenio que cubre la segunda etapa de esta tesis (1986-1996).

En relación a la intensidad energética, parece que el sistema productivo insular mejora en eficiencia en términos energéticos eléctricos, aunque después del último boom turístico acontecido al final de los años ochenta ha quedado con niveles de consumo de energía eléctrica por PIB superiores al de Canarias y España, por lo que hace peor utilización de esta energía para producir.

\subsubsection{3.- CONCLUSIONES}

Esta última etapa, en la que Lanzarote forma parte de los destinos turísticos maduros nacionales, no se ha producido grandes cambios en su sistema energético. La dinámica se va a caracterizar por lo siguiente:

1. Recuperación y nuevo impulso de la capacidad insular de producción de energía eléctrica (por encima del crecimiento de Canarias y España), a través de la ampliación de la Central Térmica con nuevos equipos electrógenos (alimentado con fuel-oil y gasoil), con limitaciones para ocupar más espacio, entre otros motivos por colindar con núcleos residenciales consolidados, a los que afecta directamente la emisión de gases de la central. Esta forma de obtener mayor potencia es la vía más rápida para poder responder a las puntas de demanda, manteniéndose el sistema constantemente al límite, sin posibilidad de paros para mantenimiento y con escasa capacidad para almacenaje, importando energía de Fuerteventura, pues no es suficiente para cubrir las demandas (esta isla sufre caídas de tensión derivadas de las largas distancias, al ser un sistema único para Lanzarote y Fuerteventura). Este hecho pone en duda la seguridad en el suministro, esencial para el bienestar de la población que diariamente acoge la isla.

2. La ampliación través de grupos electrógenos, como principal vía generadora de potencia, no permite la reducción de la emisión de gases de efecto invernadero, con los efectos negativos derivados sobre el medioambiente. $Y$ se sigue potenciando la dependencia energética del exterior.

3. Desarrollo de instalaciones de energías renovables, principalmente eólica, la única que se vuelca a red, pero aún con capacidad reducida frente a la generación convencional y muy cara. Las instalaciones fotovoltaicas o no están en servicio o no vuelcan a red, por lo que se pierde capacidad.

4. El aumento de la presión sobre el sistema (potencia, producción y consumo) viene derivado de los rápidos e intensos crecimientos de la población residente y en menor 
medida del volumen de turistas equivalentes diarios que acoge la isla, ya que, éstos últimos, registran un crecimiento negativo al final de la etapa.

5. A pesar de la reducción de la afluencia turística, se producen notables incrementos quinquenales del consumo eléctrico, pues la presión demográfica crece, principalmente, por la incorporación de nuevos residentes, a lo que se añade los cambios en los hábitos de consumo producidos en el decenio anterior.

6. Fuerte incremento del consumo de energía eléctrica, derivado, principalmente, del notable crecimiento de la población residente insular.

Las dotaciones energéticas se amplían para abordar los rápidos crecimientos de la demanda, que no permiten la adaptación de la producción a la misma velocidad por lo que la solución rápida es a través de un mayor uso de combustibles fósiles. Mayor dotación, más posibilidad de suministro, a cambio de mayor contaminación. Bienestar energético, malestar medioambiental. La reducción de la población residente, o la reducción significativa de su crecimiento, junto con la afluencia turística y el cambio en los hábitos de consumo se marcan como las vías posibles para evitar que el sistema energético de Lanzarote subsista al límite y pueda darse suministro con mayor garantía de seguridad y calidad.

\subsection{8.- EFECTOS SOBRE EL CICLO DEL AGUA. 1996-2006}

\subsubsection{1.- LA DISPONIBILIDAD DE AGUA. OFERTA}

Los acuíferos naturales de la isla han dejado de explotarse, pues, por un lado, el agua que se extrae no tiene calidad y habría que invertir en tecnología de potabilización para una producción meramente testimonial (con los caudales existentes no se alcanzarían 300 $\mathrm{m}^{3} /$ día de producción), su destino es el mar. Los tradicionales métodos de recogida de agua (como las maretas ${ }^{225}$ ) se conservan, ya que constituyen parte del patrimonio histórico cultural de la isla, pero no se les atribuye otra función ${ }^{226}$, quedaron en desuso al final de la primera etapa de análisis, años ochenta. Es por ello que el agua potable viene sólo de la desalación.

Por otro lado, se va a avanzar en la gestión del agua, pues el 05 de noviembre del año 1997, se constituye la Comisión Gestora del Consejo Insular de Aguas de Lanzarote, cuyas atribuciones y normas de funcionamiento se rigen por lo dispuesto en el Estatuto Orgánico,

\footnotetext{
225 Hondonada natural o excavada cerca de la montaña para recoger el agua de lluvia que discurría por las laderas.

226 En 1997, se inicia el Proyecto Maretas por parte del Cabildo Insular de Lanzarote, con el objetivo de restaurarlas con el fin de generar un espacio de trasmisión de la cultura.
} 
aprobado por Decreto 135/1997, de 11 de julio. (B.O.C. NN 107, de fecha 18/08/1997). La constitución de este órgano tiene como cometido exclusivo promover el proceso electoral para elegir a los miembros de la Junta General del Consejo, y su constitución (Disposición Transitoria Primera.1.). Dicha Junta tiene la misión, entre otras, de elaborar el Plan Hidrológico Insular, así como las directrices generales a seguir en la gestión de los recursos hídricos de la isla (Art. 14.1. b.).

Para esta etapa, como en el caso de la anterior, sólo se han podido obtener datos acerca de la producción de agua pública (que es por desalinización), a sabiendas de que al final de la misma pueden existir más de 50 pequeñas potabilizadoras privadas ${ }^{227}$ que dan abastecimiento a complejos turísticos, apoyados siempre en la red pública, es por ello por lo que no podemos analizar comparativamente dichas producciones y el consumo que realizan por autoabastecimiento. A ello se añade dos aspectos: 1) la falta de aprovechamiento de las aguas superficiales en la isla, como señala el Plan Hidrológico de Lanzarote de 2001, pues "no resulta económicamente viable el aprovechamiento de aguas superficiales en Lanzarote (...) al menos a nivel de grandes obras de regulación, por lo que la incidencia de aquéllas será siempre mínima en el balance hidráulico insular de recursos-consumos (...), no obstante, el agua de lluvia y las pequeñas escorrentías locales se recogen en aljibes" que aún funcionan en este sentido (Plan Hidrológico, 2001; BOC, 138; 22-10-2001, pp. $15926)^{228}$; 2) Los recursos hidráulicos subterráneos han ido mermando, por lo que prácticamente no se explotan ${ }^{229}$

Tabla 212. Fuentes de captación y producción de agua potable. Oferta. Lanzarote. 1996-2006 $\left(\mathrm{hm}^{3} / \mathrm{año}\right)$.

\begin{tabular}{||c|c|}
\hline Año & Potabilización Pública \\
\hline \hline $\mathbf{1 9 9 6}$ & 10,269800 \\
\hline $\mathbf{2 0 0 1}$ & 16,143636 \\
\hline $\mathbf{2 0 0 6}$ & 20,620045 \\
\hline
\end{tabular}

Fuente: "Producción de agua en plantas potabilizadoras de Lanzarote, según mes y año, 1996, 2001 y 2006". INALSA. Centro de datos. Cabildo Insular de Lanzarote. www.datosdelanzarote.com.

227 Señalan fuentes internas de INALSA. El Avance del Plan Insular de Ordenación de Lanzarote, de 2010, afirma que existen (en 2010) más de 80 desaladoras en la isla entre públicas y privadas

228 El Plan hidrológico de Lanzarote de 2001, contabiliza "unas 6.000 aljibes, con capacidad media de $30 \mathrm{~m}^{3}$, estimando un aprovechamiento en un año normal del $20 \%$, lo que supone un volumen anual de $36.000 \mathrm{~m}^{3 "}$

229 Plan Hidrológico de Lanzarote, 2000. BOC, 138; pp. 15929 y PIOL, 2010. Memoria de Ordenación, pp. 10 


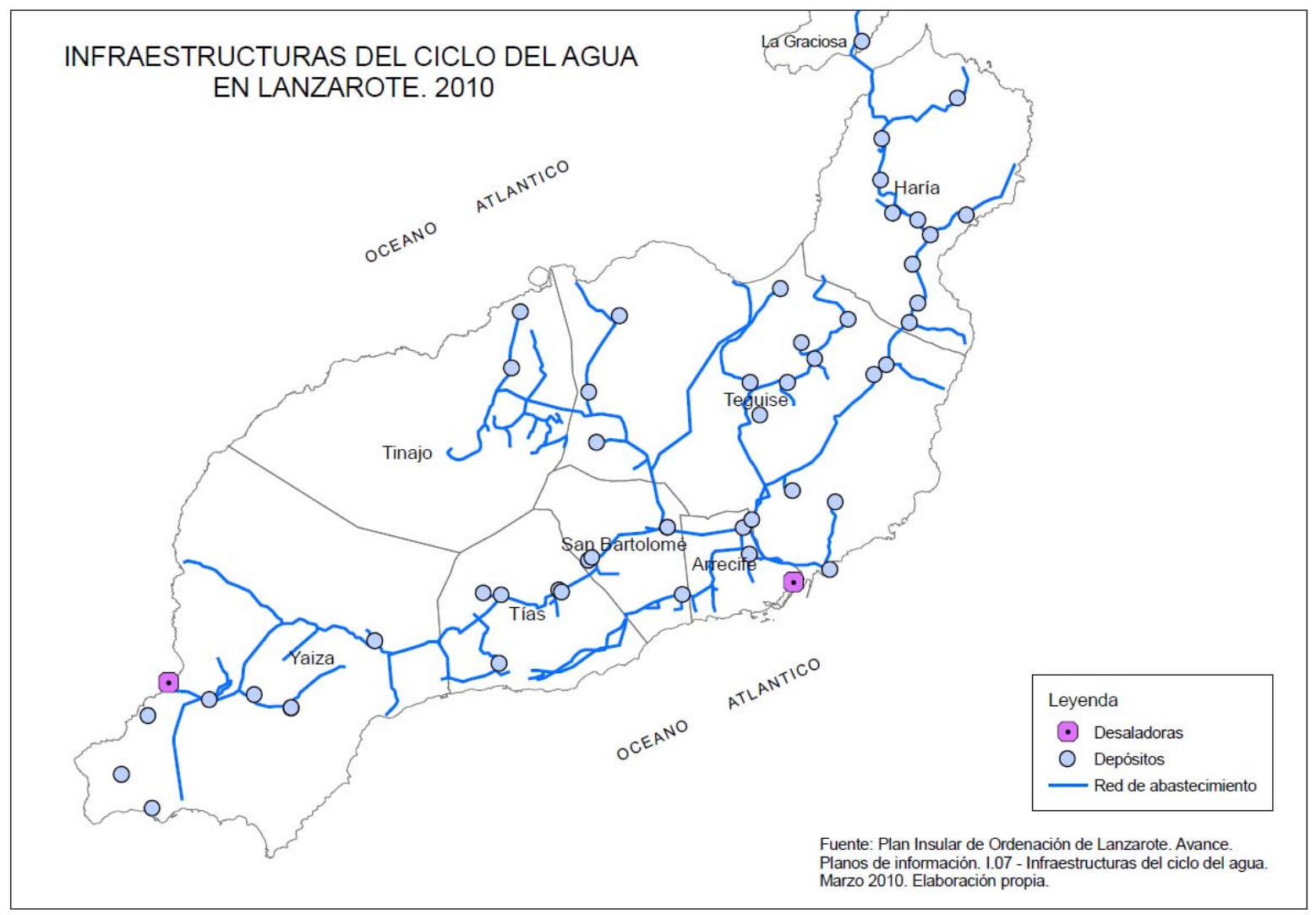

Los incrementos de producción de agua pública potable (por desalación), al igual que en las etapas anteriores, seguirán siendo elevados y constantes, aunque en menor porcentaje, pues en estos últimos diez años se ha multiplicado por dos la producción (100,8\%), mientras que en la década anterior (1986-1996) lo hizo casi por cuatro (223,6\%).

En relación a la dinámica entre el primer y el segundo lustro del decenio (1996-2001) la producción de agua potable se incrementa un $57 \%$, reduciéndose en el segundo quinquenio, debido, fundamentalmente, a la reducción del incremento de la demanda, puesto que la entrada en vigor de la Moratoria a partir del año 2001 va frenando el crecimiento de nueva planta de alojamiento turístico, como se ha señalado en anteriores capítulos, con efecto sobre el incremento demográfico, que es menor en este último lustro (pues la inmigración sólo crece del orden del $8 \%$ aproximadamente) y descienden los turistas entrados (incremento negativo). 
Tabla 213. Incremento interperiodo de la producción pública de agua potable. Oferta. Lanzarote. 1996-2006 (Hmªño) (\%)

\begin{tabular}{||c|c|}
\hline Año & Incremento interperiodo (\%) \\
\hline \hline $1996-2001$ & 57,20 \\
\hline $2001-2006$ & 27,73 \\
\hline \hline $1996-2006$ & 100,78 \\
\hline
\end{tabular}

Fuente. Elaboración propia.

El crecimiento en la producción descrito posibilita el aumento de la disponibilidad de agua per cápita de la población residente y de la turista a lo largo de toda la etapa. Si bien, la actividad turística sigue siendo un competidor por este escaso recurso, ya que en la distribución se priorizará las zonas turísticas y urbanas.

Tabla 214. Producción media diaria y población a abastecer. Lanzarote. 1996-2006 (mª́a)

\begin{tabular}{|c|c|c|c|c|c|c|c|}
\hline Año & Producción & $\begin{array}{l}\text { Población } \\
\text { Residente }\end{array}$ & $\begin{array}{c}\text { Turistas equivalentes } \\
\text { al día }\end{array}$ & $\begin{array}{l}\text { Población Total a } \\
\text { abastecer al día (1) }\end{array}$ & |/ Residente*día & I/habitantes*día & $\begin{array}{l}\text { Incremento } \\
\text { quinquenal } \\
\text { I/habitantes*día } \\
\text { (\%) }\end{array}$ \\
\hline 1996 & $28.136,43836$ & 77.379 & 48.686 & 126.065 & 363,62 & 223,19 & \\
\hline 2001 & $44.229,13973$ & 103.044 & 44.603 & 147.647 & 429,23 & 299,56 & 34,22 \\
\hline 2006 & $56.493,27397$ & 127.457 & 37.522 & 164.979 & 443,23 & 342,43 & 14,31 \\
\hline
\end{tabular}

(1) Población Total a abastecer diaria: población de derecho + turistas equivalentes diarios.

Fuente: Elaboración propia a partir de los datos de producción recogidos en la Tabla 212.

Gráfico 193. Evolución de la producción de agua potable por habitante y día. Lanzarote. 1996-2006

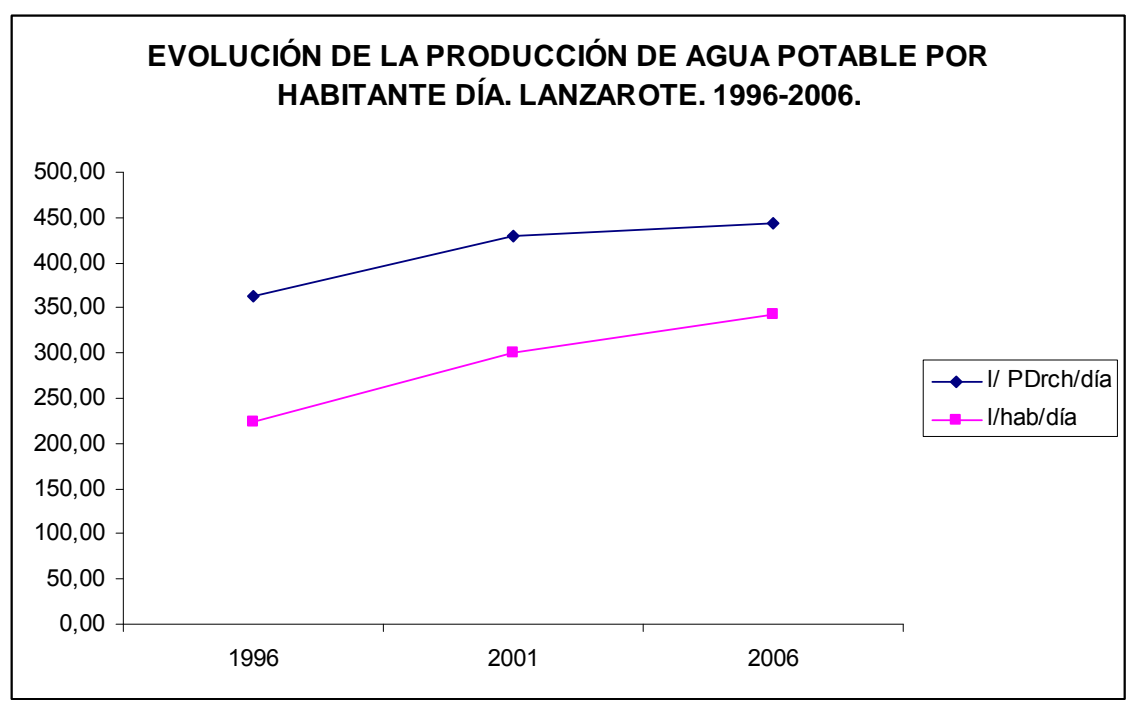

Fuente: Elaboración propia a partir de la Tabla 214. 
A pesar del aumento en la producción y la distribución por habitante y día estimada, la disponibilidad está afectada por importantes pérdidas derivadas de conducciones defectuosas y en mal estado, por fugas en depósitos, consumos no autorizados y deficiente gestión del servicio a los usuarios, que se estiman del orden del $40 \%$ aproximadamente (Avance PIOL, 2010, Memoria de Ordenación, pp. 37), Teniendo en cuenta esto, la disponibilidad de agua potabilizada en destino final, en relación a la población total estimada o equivalente (residentes y turistas equivalentes diarios) quedaría como refleja la siguiente Tabla, aplicando este porcentaje de pérdidas a partir del año 2001 inclusive:

Tabla 215. Producción y disponibilidad de agua desalada en destino final. Lanzarote. 19962006.

\begin{tabular}{|c||c||c||c||}
\hline Año & $\begin{array}{l}\text { Producción Bruta } \\
\text { (m3*día) }\end{array}$ & $\begin{array}{l}\text { Disponibilidad } \\
\text { (m3*día) }\end{array}$ & $\begin{array}{l}\text { Disponibilidad } \\
\text { I/habitante*día }\end{array}$ \\
\hline \hline 1996 & $28.136,43836$ & $16.881,86302^{*}$ & $154,67^{*}$ \\
\hline $\mathbf{2 0 0 1}$ & $44.229,13973$ & $26.537,48384^{* *}$ & $179,74^{* *}$ \\
\hline $\mathbf{2 0 0 6}$ & $56.493,27397$ & $33.895,96438^{* *}$ & $205,46^{* *}$ \\
\hline
\end{tabular}

$\left({ }^{*}\right)$ Para 1996, se ha aplicado un 30,7\% de pérdidas (por transporte, distribución y otros motivos) que estima el Plan Hidrológico de Lanzarote de 2000 (Decreto 167/2001. BOC. № 138; 22-10-2001, p. 15935) y que se ha tomado como referencia en los análisis de la etapa anterior (Ver epígrafe 5.2.8.1).

$\left({ }^{* *}\right)$ Se ha estimado a partir de reducir en un $40 \%$ la producción bruta de agua desalada, por las citadas pérdidas.

Fuente: Elaboración propia a partir de datos anteriores.

Comparativamente, Lanzarote comienza la etapa con una producción de agua bruta (I/habitante*día) menor a la de Canarias, siendo similar en el 2001 y, superando a la comunidad autónoma en el 2006. Encontrándose, a lo largo de toda la etapa por debajo de la producción total de agua disponible (I/habitante*día) de España hasta el último año que cubre este análisis, donde la disponibilidad en relación a la población total estimada (residentes y turistas equivalentes diarios) es prácticamente la misma. 
Tabla 216. Producción media diaria y población a abastecer. Canarias y España. 1996-2006 ( $\left.m^{3} / a n ̃ o\right)$

\begin{tabular}{|c|c|c|c|c|c|c|c|}
\hline \multicolumn{8}{|c|}{ CANARIAS } \\
\hline Año & Producción & $\begin{array}{l}\text { Población } \\
\text { Residente }\end{array}$ & $\begin{array}{c}\text { Turistas equivalentes } \\
\text { al día }\end{array}$ & $\begin{array}{l}\text { Población Total a } \\
\text { abastecer al dia** }\end{array}$ & |/ Residente ${ }^{*}$ ía & I/habitante día & $\begin{array}{l}\text { Incremento } \\
\text { quinquenal } \\
\text { I/habdia (\%) }\end{array}$ \\
\hline 1996 & 170.266 .000 & 1.606 .534 & 236.383 & 1.842 .917 & 290,37 & 253,12 & \\
\hline 2001 & 202.105 .000 & 1.694 .477 & 230.517 & 1.924 .994 & 326,77 & 287,64 & 13,64 \\
\hline 2006 & 247.362 .000 & 1.995 .833 & 206.267 & 2.202 .100 & 339,56 & 307,75 & 6,99 \\
\hline \multicolumn{8}{|c|}{ ESPAÑA } \\
\hline Año & Producción & $\begin{array}{l}\text { Población } \\
\text { Residente }\end{array}$ & $\begin{array}{c}\text { Turistas equivalentes } \\
\text { al día }\end{array}$ & $\begin{array}{l}\text { Población Total a } \\
\text { abastecer al dia** }\end{array}$ & |/ Residente día & I/habitante día & $\begin{array}{l}\text { Incremento } \\
\text { quinquenal } \\
\text { I/hab*dia (\%) }\end{array}$ \\
\hline 1996 & 3.680 .760 .000 & 39.669 .394 & 405.874 & 40.075 .268 & 254,21 & 251,63 & \\
\hline 2001 & 5.584 .860 .000 & 40.847 .371 & 440.630 & 41.288 .001 & 374,59 & 370,59 & 47,27 \\
\hline 2006 & 5.701 .638 .000 & 44.708 .964 & 419.692 & 45.128 .656 & 349,39 & 346,14 & $-6,60$ \\
\hline
\end{tabular}

$\left(^{\star}\right)$ Población a abastecer diaria: población de derecho + población turista diaria.

Fuente: "Disponibilidad total de agua potabilizada por volumen total de agua disponible potabilizada y comunidad autónoma. España y Canarias, 1996, 2001, 2006". Encuesta sobre el Suministro y Tratamiento del agua, 1996, 2001, 2006. INE; Elaboración propia.

Gráfico 194. Evolución de la producción media diaria de agua por habitante. Lanzarote, Canarias y España. 1996-2006 (I/habitantes*día)

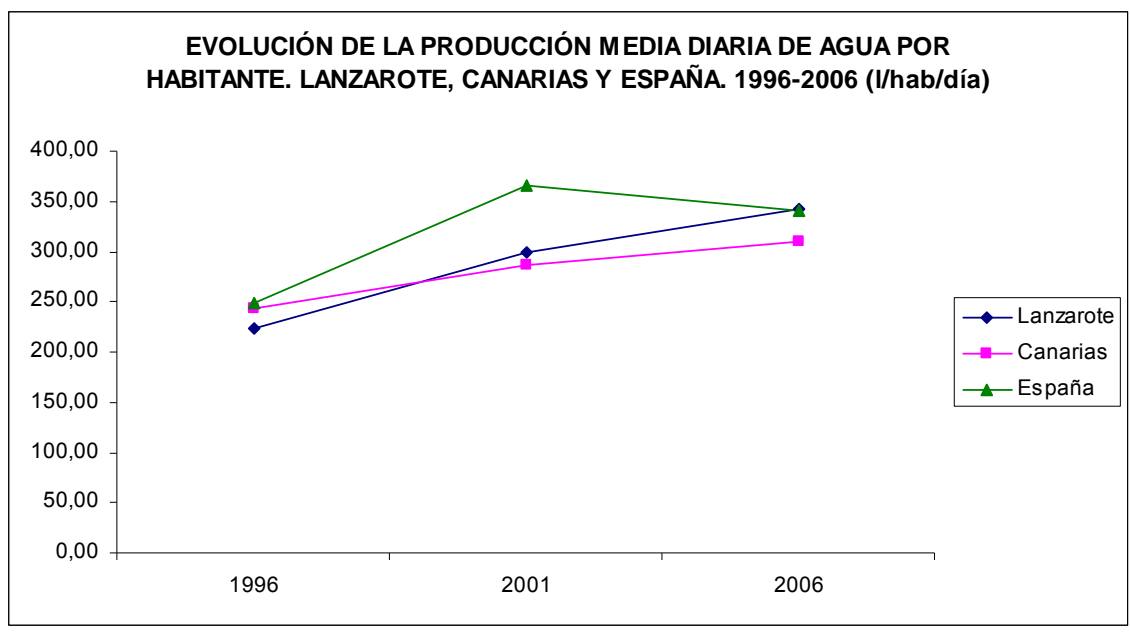

Fuente: Elaboración propia a partir de la Tabla 216.

El aumento de la producción a lo largo de la historia de la desalinización en Lanzarote se ha conseguido por apertura de nuevas plantas hasta el comienzo de la década de los años 
noventa, posteriormente se hace con ampliaciones ${ }^{230}$, que resumimos en el siguiente cuadro, así como las técnicas de desalación utilizadas, tomando nota que, en la actualidad, todas la plantas se han reconvertido e implantado la osmosis inversa:

Tabla 217. Historial de plantas desaladoras de Lanzarote. 1975-1999.

\begin{tabular}{|c|c|c|c|c|c|c|}
\hline Denominación & $\begin{array}{l}\text { Año } \\
\text { puesta } \\
\text { en } \\
\text { servicio }\end{array}$ & $\begin{array}{l}\text { Año de } \\
\text { cierre }\end{array}$ & Ampliaciones & Proceso & $\begin{array}{l}\text { Capacidad } \\
\mathrm{m}^{3 *} \text { día }\end{array}$ & Observaciones \\
\hline Lanzarote I & 1975 & 1990 & --- & M.S.F & 5.000 & $\begin{array}{l}\text { Excedió su vida útil. Desguazada. Alto } \\
\text { coste mantenimiento y producción }\end{array}$ \\
\hline Inalsa I & 1990 & 1999 & --- & O.I. & 5.000 & Piezas reutilizadas. \\
\hline Lanzarote II & 1986 & 1999 & --- & O.I. & 7.000 & $\begin{array}{l}\text { Deja de estar operativa por economía ( } 7 \\
\mathrm{kw} / \mathrm{m}^{3} \text {, caro mantenimiento. y no } \\
\text { fabricación de piezas). }\end{array}$ \\
\hline Lanzarote III & 1991 & Operativa & Sí & O.l. & 29.000 & $\begin{array}{l}\text { Inicialmente } 10.000 \mathrm{~m}^{3} / \mathrm{di} a \text {, sucesivas } \\
\text { ampliaciones triplica producción. }\end{array}$ \\
\hline Lanzarote IV & 1999 & Operativa & Sí & O.l. & 29.000 & $\begin{array}{l}\text { Inicialmente } 5.000 \mathrm{~m} 3 / \mathrm{dia} \text {, sucesivas } \\
\text { ampliaciones multiplica (6) producción. }\end{array}$ \\
\hline Inalsa Sur & 1986 & Operativa & Sí & O.l. & 10.000 & $\begin{array}{l}\text { Empieza con sistema V.C., y en la } \\
\text { década los noventa pasa a O.I. }\end{array}$ \\
\hline $\begin{array}{l}\text { Isla de La } \\
\text { Graciosa }\end{array}$ & 1978 & 1991 & --- & V.C & 250 & $\begin{array}{l}\text { Se abastece de agua a través de } \\
\text { Lanzarote por conducción submarina }\end{array}$ \\
\hline
\end{tabular}

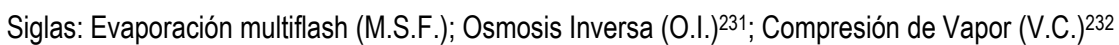

Nota: las cifras de producción de las plantas operativas son actuales (2012). En el año 2012 se estima una producción de agua desalada que ronda los $67.000 \mathrm{~m}^{3} / \mathrm{di}$.

Fuente. Plan Hidrológico de Lanzarote, 2000 (BOC, 138; 22-10-2001, pp. 15932) y Entrevista a Miguel A. Figueras, Jefe de Servicio de Redes de INALSA (en 2009, 2011 y 2012).

Debemos tener en cuenta que en la isla se obliga a que todas las viviendas tengan depósitos de agua (bien a través de aljibes o de tanques en las azoteas), con capacidad mínima de 150 l/persona/día para cinco días, pues no se puede asegurar el flujo continuo (diario) de agua corriente en todos los núcleos de población de la isla (hay asentamientos, principalmente rurales que no disponen de agua corriente diaria, generalmente tienen tres días de la semana y en época de presión turística (principalmente en el mes de agosto) sólo un día de acceso). Situación que señalan fuentes internas de INALSA para esta etapa, pues

230 "En algunos casos hay piezas que se readaptan, se venden o cambian a otras empresas del sector. El resto va a la chatarra". M.A. Figueras. Jefe de Servicio de Redes de INALSA. Entrevista de Agosto de 2010

${ }^{231}$ En la Ósmosis Inversa, se hace pasar el agua de mar a alta presión $\left(55-65 \mathrm{Kg} / \mathrm{cm}^{2}\right)$ a través de una membrana semipermeable con lo que se consigue obtener un agua de baja salinidad ( $<500 \mathrm{mg} / \mathrm{L})$, apta para consumo humano.

232 En la Compresión de Vapor, se evapora el agua de mar en una cámara de vacío a temperaturas por debajo de la temperatura de ebullición, obteniéndose tras la condensación de los vapores un agua destilada (<1 mg/L). 
desde el año 2008, aproximadamente, se han ido sucediendo cortes mayores de agua corriente, en diferentes momentos del año, derivados de un incremento de la demanda que la producción no puede abordar en la actualidad ${ }^{233}$. Debemos añadir que, informes de 1997 (recogidos en la Memoria Inicial del PIOL, 2008, pp. 227) señalan que "los depósitos almacenan una tercera parte de su capacidad, lo que supone una garantía de abastecimiento altamente precaria". No se garantiza el suministro pues el abastecimiento depende de la producción día a día concentrada en dos plantas de producción y vulnerable por tanto a posibles averías (Programa LIFE. Aplicación de la Agenda 21 a Lanzarote. 1998, Doc. 7, pp. 7), pues "el parar las máquinas para realizar mantenimiento genera múltiples conflictos" ${ }^{\prime 234}$.

Las tres plantas que aparecen operativas a lo largo de esta etapa trabajan con un consumo de energía alrededor de $5,2 \mathrm{kwh} / \mathrm{m}^{3}$, estándar que se ha valorado a finales de los noventa como uno de los mejores obtenidos en procesos de desalación con estos volúmenes (Programa LIFE. Aplicación de la Agenda 21 a Lanzarote. 1998, Doc. 7, pp. 6). Análisis posteriores arrojan un consumo de aproximadamente $4,2 \mathrm{kwh} / \mathrm{m}^{3}$ al final de la etapa ${ }^{235}$, es decir, la evolución de las plantas tiende a conseguir mayor producción con menor consumo energético y mayor rentabilidad económica.

Tabla 218. Energía eléctrica consumida en la producción de agua desalada pública. Lanzarote. 1996-2006 (kwh/m*día)

\begin{tabular}{|l|c|c||}
\hline $\begin{array}{c}\text { PLANTAS } \\
\text { INALSA }\end{array}$ & $\begin{array}{c}\text { Capacidad } \\
\mathbf{m}^{3} / \mathrm{día}\end{array}$ & $\begin{array}{c}\text { Consumo eléctrico } \\
\mathbf{k w h} / \mathbf{m}^{3 *} \text { día(1) }^{(1)}\end{array}$ \\
\hline \hline Lanzarote III & 29.000 & 150.800 \\
\hline Lanzarote IV & 29.000 & 150.800 \\
\hline Inalsa Sur & 10.000 & 52.000 \\
\hline TOTAL & 68.000 & 353.600 \\
\hline
\end{tabular}

\begin{tabular}{|c|c|c||}
\hline AÑo & $\begin{array}{c}\text { Producción Bruta } \\
\text { Agua (m²/día) }\end{array}$ & $\begin{array}{c}\text { Consumo Eléctrico por } \\
\text { Producción agua (kwh/m }{ }^{3 *} \text { día) }{ }^{(2)}\end{array}$ \\
\hline \hline 1996 & $28.136,43836$ & $146.309,48$ \\
\hline 2001 & $44.229,13973$ & $229.991,53$ \\
\hline 2006 & $56.493,27397$ & $237.271,75$ \\
\hline
\end{tabular}

(1) Para el $100 \%$ de la capacidad por $5,2 \mathrm{kwh} / \mathrm{m}^{3}$ para cada planta.

(2): Se ha calculado a $5,2 \mathrm{kwh} / \mathrm{m}^{3}$ para el año 1996 y 2001. Para 2006 se aplica $4,2 \mathrm{kwh} / \mathrm{m}^{3}$.

Fuente: Plan Hidrológico de Lanzarote, 2000 (BOC, 138; 22-10-2001, pp. 15932); Lanzarote en la Biosfera, Programa Life, 1998, Documento 7 (pp. 6). Esteban, A. "Análisis de la estructura de costes de INALSA. Síntesis". GEA21. Arrecife, 2006; Entrevista a Miguel A. Figueras Alfonso, Jefe de Servicio de Redes de INALSA (Febrero, 2012).

\footnotetext{
233 Información a través de entrevista semiestructurada realiza a M.A. Figueras, Jefe del Servicio de Redes de INALSA (febrero de 2012).

234 M.A. Figueras. Jefe de Servicio de Redes de INALSA. Entrevista de Agosto de 2010.

235 Esteban, A. "Análisis de la estructura de costes de INALSA. Síntesis". GEA21. Arrecife, 2006 (diapositiva, n 6)
} 
Tabla 219. Energía eléctrica producida y consumo en la producción de agua desalada pública. Lanzarote. 1986-2006.

\begin{tabular}{|c||c|c|c||c|}
\hline Año & $\begin{array}{c}\text { Producción Eléctrica } \\
\text { (Kwh/año) }^{*}\end{array}$ & $\begin{array}{c}\text { Producción Eléctrica } \\
\text { Media diaria } \\
\text { (Kwh/día) }^{(1)}\end{array}$ & $\begin{array}{c}\text { Consumo Eléctrico por } \\
\text { Producción agua } \\
\text { (kwh/m/dia) }\end{array}$ & $\begin{array}{c}\text { Peso del consumo } \\
\text { eléctrico en desalación(2) } \\
\text { (\%) }\end{array}$ \\
\hline \hline 1996 & 419.250 .000 & $\mathbf{1 . 1 4 8 . 6 3 0 , 1 4}$ & $\mathbf{1 4 6 . 3 0 9 , 4 8}$ & 12,74 \\
\hline $\mathbf{2 0 0 1}$ & 608.110 .000 & $\mathbf{1 . 6 6 6 . 0 5 4 , 7 9}$ & $\mathbf{2 2 9 . 9 9 1 , 5 3}$ & 13,80 \\
\hline $\mathbf{2 0 0 6}$ & 763.280 .000 & $\mathbf{2 . 0 9 1 . 1 7 8 , 0 8}$ & $\mathbf{2 3 7 . 2 7 1 , 7 5}$ & 11,35 \\
\hline
\end{tabular}

(1) La producción de electricidad se ha recogido del epígrafe: 5.3.7.1 y se ha divide entre 365 días.

(2) Sobre la producción de electricidad media diaria en la isla.

Fuente: Elaboración propia a partir de datos anteriores

La isla consume entre el $11 \%$ y el $14 \%$ de la electricidad que genera en producir agua por desalación (en plantas públicas). La tendencia en periodos de recesión turística (año 2006) es la reducción del consumo eléctrico y por tanto de los costes fijos que supone ${ }^{236}$.

Tal y como hemos señalado en la etapa anterior, las tarifas aplicadas al consumo son diferentes según el tipo de uso a la que va destinada, pero se han mantenido estables (para todos los sectores) desde 1984 hasta el año 2007, a pesar del crecimiento del coste de la energía. La producción de agua en Lanzarote está fuertemente subvencionada y los precios para los distintos consumidores regulados.

Tabla 220. Evolución de las tarifas de consumo de agua potable. Lanzarote. 1996-2007 (€)

\begin{tabular}{|l|c|c|c|c|}
\hline Tipo de Tarifa & $\mathbf{1 9 9 6}$ & $\mathbf{2 0 0 1}$ & $\mathbf{2 0 0 6}$ & $\mathbf{2 0 0 7}$ \\
\hline \hline Doméstica & 0,75 & 0,75 & 0,75 & 0,80 \\
\hline Industrial & 1,8 & 1,8 & 1,8 & 2,12 \\
\hline
\end{tabular}

Fuente: INALSA "Plan de Viabilidad y Modernización de INALSA. 2008-2012" (pp. 40). Disponible en Web: www.datosdelanzarote.com. Etiqueta: Agua, energía y residuos/agua/documentos.

236 "El consumo energético asociado al ciclo del agua suele representar el $23 \%$ del consumo total del energía eléctrica de la isla. En desalación se consumieron aproximadamente más de 80.000 Mwh/año". Cabildo Insular de Lanzarote. "Plan Insular de Ordenación de Lanzarote (2010). Memoria Inicial, 2008. [Elaborado por Ezquiaga Arquitectura, Sociedad y Territorio, S.L]. Cabildo Insular de Lanzarote, 2008. www.datosdelanzarote.com. Etiquetas: Medio Ambiente y Territorio > Urbanismo $>$ Documentos $>2008$. 


\subsubsection{2.- EL CONSUMO DE AGUA. DEMANDA}

El crecimiento del consumo de agua en la isla ha sido constante a lo largo de toda la etapa, al igual que en Canarias y España, aunque en ésta los incrementos interperiodo son enormes, muy por encima de la Comunidad Autónoma y el país, principalmente en el quinquenio 1996-2001, que asciende al 49\%, aunque posteriormente disminuye dicho crecimiento. Debemos tener en cuenta que el anuncio de la Moratoria provoca un nuevo impulso a la actividad en la construcción y en la entrada de población externa a residir, que puede explicar el retroceso posterior.

Tabla 221.Consumo de agua. Lanzarote, Canarias y España. 1996-2001 (m³/año).

\begin{tabular}{|c|c|c||c|c||c|c||}
\hline Año & LANZAROTE & $\begin{array}{c}\text { Incremento } \\
\text { quinquenal (\%) }\end{array}$ & CANARIAS & $\begin{array}{c}\text { Incremento } \\
\text { quinquenal (\%) }\end{array}$ & ESPAÑA & $\begin{array}{c}\text { Incremento } \\
\text { quinquenal (\%) }\end{array}$ \\
\hline \hline $\mathbf{1 9 9 6}$ & 7.494 .325 & & 113.521 .000 & & 3.076 .117 .000 & \\
\hline $\mathbf{2 0 0 1}$ & 11.175 .707 & 49,12 & 132.590 .000 & 16,80 & 3.870 .650 .000 & 25,83 \\
\hline $\mathbf{2 0 0 6}$ & 13.396 .090 & 19,87 & 154.152 .000 & 16,26 & 3.913 .059 .000 & 1,10 \\
\hline
\end{tabular}

Fuente: "Resumen de datos de agua. Consumo (según datos de INALSA). Lanzarote 1996, 2001 y 2006.". Centro de datos del Cabildo Insular de Lanzarote. www.datosdelanzarote.com; "Volumen de agua registrada y distribuída, Canarias 1996, 2001, 2006.". Distribución del agua según destinos. Canarias, 1996-2007. ISTAC (extracción de la Encuesta sobre el Suministro y Tratamiento del agua del INE); "Volumen total de agua controlada y distribuida, España 1996, 2001, 2006". Encuesta sobre el Suministro y Tratamiento del agua, 1996, 2001, 2006. INE

Haciendo un reparto proporcional al volumen de población residente y del total de personas que se ha estimado que acoge diariamente la isla (residentes y turistas equivalentes diarios), el consumo medio diario en ambos casos se ha ido incrementando, como se puede observar en la siguiente Tabla.

Tabla 222. Consumo medio diario y población a abastecer. Lanzarote. 1996-2006 (I/habitante*día)

\begin{tabular}{|c|c|c|c|c|c|c|c|c|}
\hline Año & $\begin{array}{c}\text { CONSUMO } \\
\text { (m³/año) }\end{array}$ & $\begin{array}{l}\text { Población } \\
\text { Residente }\end{array}$ & $\begin{array}{c}\text { Turistas } \\
\text { equivalentes } \\
\text { al día }\end{array}$ & $\begin{array}{l}\text { Población a } \\
\text { abastecer* }\end{array}$ & I/Resientes*día & I/habitantes*día & \begin{tabular}{||c||} 
Incremento \\
quinquenal \\
I/habitante*día \\
$(\%)$
\end{tabular} & $\begin{array}{c}\text { Disponibilidad* } \\
\text { I/hab*día }\end{array}$ \\
\hline 1996 & 7.494 .325 & 77.379 & 48.686 & 126.065 & 265,35 & 162,87 & & 154,67 \\
\hline 2001 & 11.175.707 & 103.044 & 44.603 & 147.647 & 297,14 & 207,38 & 27,32 & 179,74 \\
\hline 2006 & 13.396.090 & 127.457 & 37.522 & 164.979 & 287,95 & 222,46 & 7,28 & 205,46 \\
\hline
\end{tabular}

$\left(^{*}\right)$ Se ha estimado a partir de reducir, de la producción bruta de agua desalada, diferentes tipo de pérdidas, en un 30,7\% en 1996 y un 40\% a partir del año 2001.

Fuente: Elaboración propia. 
El dato significativo lo arroja la relación entre la disponibilidad de agua (después de reducir la producción bruta en un $30,7 \%$ para 1996 y en $40 \%$ para los años posteriores, por diferentes tipos de pérdidas en red) y el consumo medio en relación a la población total estimada o equivalente que acoge a diario la isla. La disponibilidad después de las pérdidas señaladas no cubre la demanda de consumo media por habitante y día. Es por ello que para responder a la demanda del sector turístico-industrial tendrán que producirse cortes de abastecimiento en núcleos residenciales, principalmente de tipo rural, como de hecho se afirma en las entrevistas realizadas a la Jefatura de Servicio de Redes de INALSA, siendo estos cortes de mayor magnitud temporal en periodos de fuerte ocupación (principalmente de abril a septiembre en el año 2006).

Gráfico 195. Consumo y disponibilidad media de agua después de pérdidas en red. Lanzarote. 1996-2006 (I/habitantes*día)

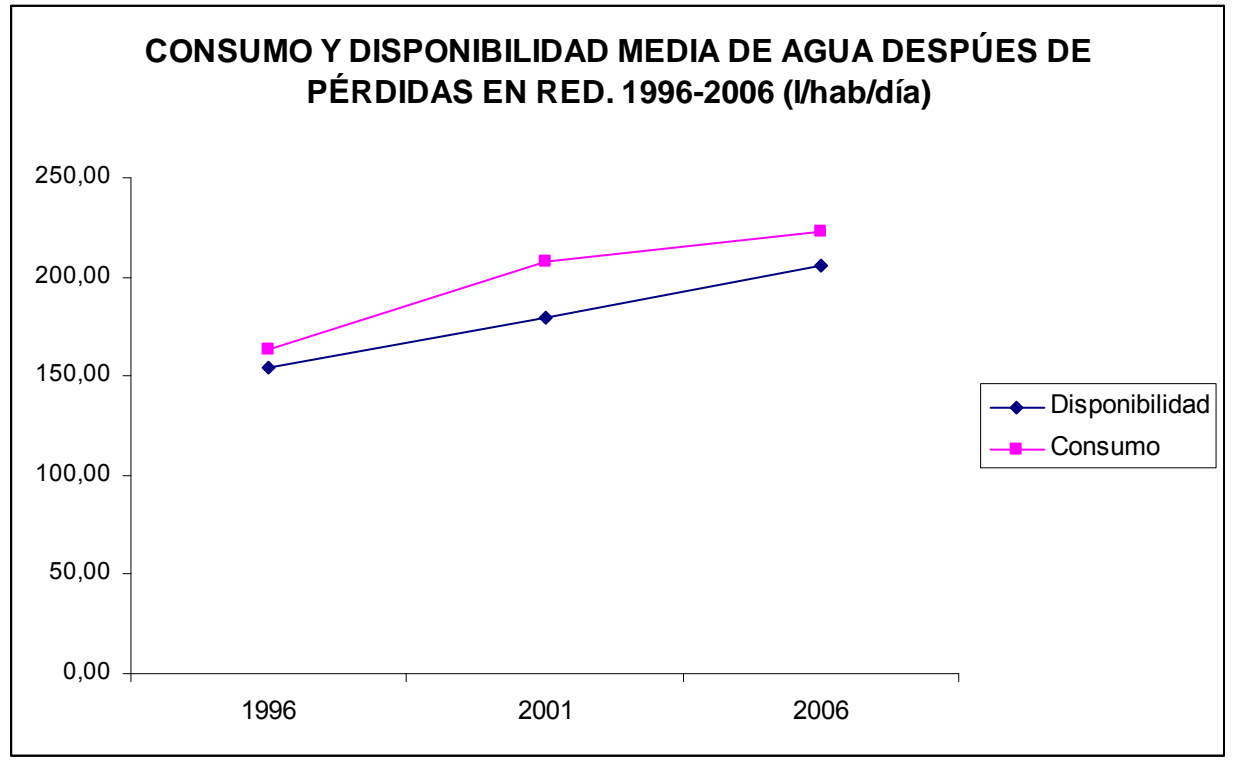

Fuente. Elaboración propia a partir de la Tabla 222.

Lanzarote, a partir del año 2001 supera el consumo de Canarias, que no llega en todo la etapa a los 200 l/habitante*día. No así con respecto a la media de consumo diario de agua del país, que supera los 200 litros. En Lanzarote se consume menos agua de media por habitante que en España, tiene más sed. 
Tabla 223. Consumo medio diario y población a abastecer. Canarias y España. 1996-2006 (I/habitantes*día)

\begin{tabular}{|c|c|c|c|c|c|c|c|c|}
\hline \multicolumn{9}{|c|}{ CANARIAS } \\
\hline Año & $\begin{array}{c}\text { CONSUMO } \\
\text { (m3/año) }\end{array}$ & $\begin{array}{l}\text { Población } \\
\text { Residente }\end{array}$ & $\begin{array}{c}\text { Turistas } \\
\text { equivalentes } \\
\text { al día }\end{array}$ & $\begin{array}{l}\text { Población a } \\
\text { abastecer* }\end{array}$ & I/Resientes ${ }^{*}$ día & I/habitantes*día & $\begin{array}{l}\text { Incremento } \\
\text { quinquenal } \\
\text { l/habitante*día } \\
\text { (\%) }\end{array}$ & $\begin{array}{l}\text { Disponibilidad } \\
\text { I/habitante*día }\end{array}$ \\
\hline 1996 & 113.521 .000 & 1.606 .534 & 304.463 & 1.910 .997 & 193,59 & 162,75 & & 244,10 \\
\hline 2001 & 132.590 .000 & 1.694 .477 & 240.464 & 1.934 .941 & 214,38 & 187,74 & 15,35 & 286,16 \\
\hline 2006 & 154.152 .000 & 1.995 .833 & 191.087 & 2.186 .920 & 211,61 & 193,12 & 2,87 & 309,89 \\
\hline \multicolumn{9}{|c|}{ ESPAÑA } \\
\hline Año & $\begin{array}{c}\text { CONSUMO } \\
\text { (m3/año) }\end{array}$ & $\begin{array}{l}\text { Población } \\
\text { Residente }\end{array}$ & $\begin{array}{c}\text { Turistas } \\
\text { equivalentes } \\
\text { al día }\end{array}$ & $\begin{array}{l}\text { Población a } \\
\text { abastecer* }\end{array}$ & I/Resientes*día & I/habitantes*día & $\begin{array}{l}\text { Incremento } \\
\text { quinquenal } \\
\text { l/habitante*día } \\
\text { (\%) }\end{array}$ & $\begin{array}{l}\text { Disponibilidad* } \\
\text { I/habitante*día }\end{array}$ \\
\hline 1996 & 3.076 .117 .000 & 39.669 .394 & 872.364 & 40.541 .758 & 212,45 & 207,88 & & 248,74 \\
\hline 2001 & 3.870 .650 .000 & 40.847 .371 & 1.034 .095 & 41.881 .466 & 259,61 & 253,20 & 21,80 & 365,34 \\
\hline 2006 & 3.913 .059 .000 & 44.708 .964 & 1.048 .844 & 45.757 .808 & 239,79 & 234,29 & $-7,47$ & 341,38 \\
\hline
\end{tabular}

Fuente: Elaboración propia.

Gráfico 196. Consumo medio diario de agua por habitante. Lanzarote, Canarias y España. 1996-2006 (I/hab*día)

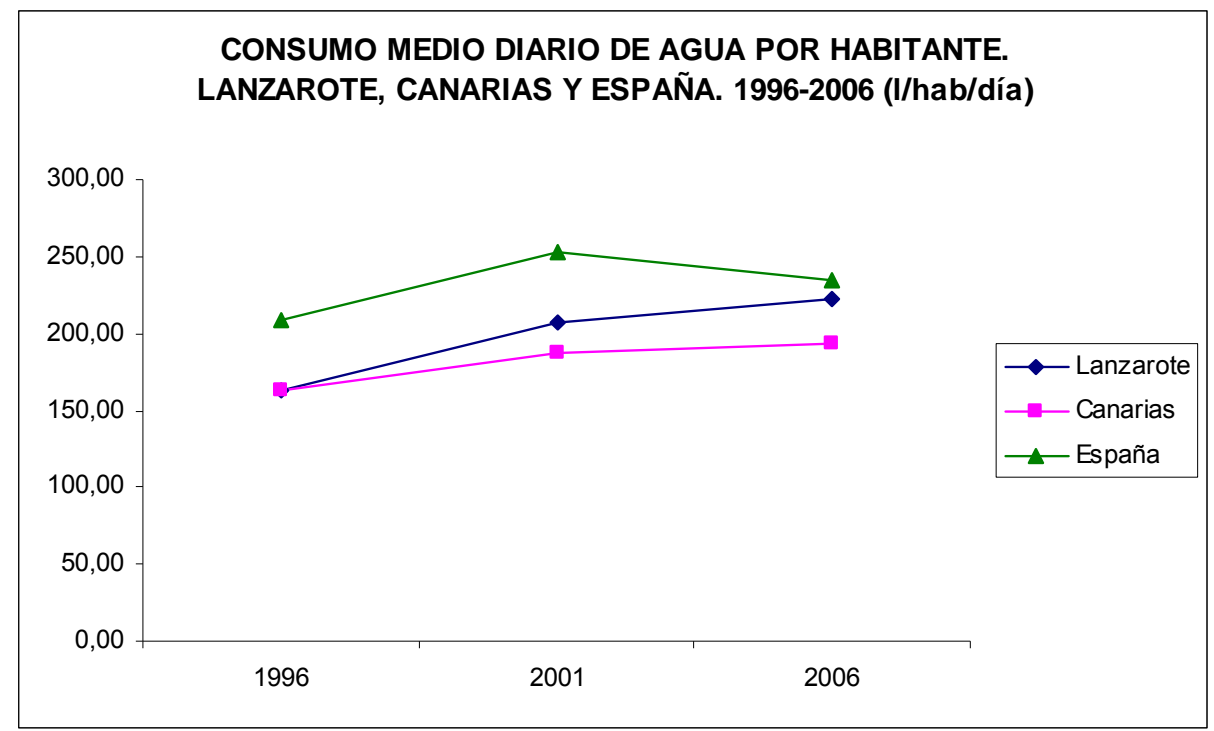

Fuente: Elaboración propia partir de la Tabla 224.

En el año 1996, los informes realizados dentro del Programa LIFE (Aplicación de la Agenda 21 a Lanzarote, Doc. 7, pp. 10), establecen un consumo para los residentes de 138 litros diarios, frente a los 230 litros de los turistas, estimación que se mantendrá aún en 2001 
dentro un nuevo Programa LIFE ${ }^{237}$. Al no disponer de referencias posteriores a esta fecha, para el año 2006 se han calculado los consumos bajo el mismo estándar.

Tabla 224. Consumo unitario por residente y turista. Lanzarote. 1996-2006 (I/habitante*día)

\begin{tabular}{||c|c|c|c|c||}
\cline { 2 - 5 } \multicolumn{1}{c|}{} & Residente & Turista & TOTAL & $\begin{array}{c}\text { Variación } \\
\text { Turista-Residente }\end{array}$ \\
\hline \hline 1996-2001-2006 & 138 & 230 & 368 & 66,7 \\
\hline
\end{tabular}

Fuente: Programa LIFE. Aplicación de la Agenda 21 a Lanzarote. "Documento 7. Los Sectores Ambientales Clave". Cabildo de Lanzarote, 1998 (pp. 14).

A partir de este supuesto hemos calculado el consumo al año del total de residentes y de los turistas equivalentes, para dar idea del volumen de los mismos y qué peso pueden tener los residentes en el consumo total. Así pues, la dificultad estriba en saber qué volumen del agua desalada pública consume el turismo, pues la información, por facturación de INALSA, unifica el turístico y el industrial, además de no disponer de ella para todos los años analizados $^{238}$ a través de la misma fuente.

Tabla 225. Estimación de la evolución del consumo de agua de los residentes y los turistas. Lanzarote. 1996-2006 (mªño)

\begin{tabular}{|c|c|c|c|c|c|c|c|}
\hline \multirow[t]{2}{*}{ Año } & \multirow{2}{*}{$\begin{array}{l}\text { Consumo* } \\
\text { (m³/año) }\end{array}$} & \multirow{2}{*}{$\begin{array}{l}\text { Población } \\
\text { Residente }\end{array}$} & \multirow{2}{*}{$\begin{array}{c}\text { Turistas } \\
\text { equivalentes } \\
\text { al día }\end{array}$} & \multicolumn{2}{|c|}{$\begin{array}{c}\text { Consumo Residentes } \\
\text { (m³/año) }\end{array}$} & \multirow{2}{*}{$\begin{array}{c}\begin{array}{c}\text { Consumo Turistas } \\
\left(\mathrm{m}^{3} / \mathrm{año}\right)\end{array} \\
\text { Abs. }\end{array}$} & \multirow{2}{*}{$\begin{array}{l}\text { TOTAL } \\
\text { (m³/año) }\end{array}$} \\
\hline & & & & Abs. & $\%$ & & \\
\hline 1996 & 7.494 .325 & 77.379 & 48.686 & $3.897 .580,23$ & 52,00 & $4.087 .189,70$ & 7.984.769,93 \\
\hline 2001 & 11.175 .707 & 103.044 & 44.603 & $5.190 .326,28$ & 46,44 & $3.744 .421,85$ & $8.934 .748,13$ \\
\hline 2006 & 13.396 .090 & 127.457 & 37.522 & $6.420 .009,09$ & 47,93 & $3.149 .971,90$ & $9.569 .980,99$ \\
\hline
\end{tabular}

(*) Volumen de consumo del agua producida por desalación pública. "Resumen de datos de agua. Consumo (según datos de INALSA). Lanzarote 1996, 2001 y 2006.". Centro de datos del Cabildo Insular de Lanzarote. www.datosdelanzarote.com;

Nota: El consumo de los residentes y turistas equivalentes $\left(\mathrm{m}^{3}\right)$ al año ha sido calculado en relación a las estimaciones unitarias (I/día) que se recogen en la anterior tabla (Ejemplo: [residentes * $1 /$ día) * 365$]$ ).

Fuente: Elaboración propia a partir de datos anteriores

237 AUIA. LIFE Lanzarote, 2001-2004. Metabolismo social y turístico de Lanzarote. Observatorio de la Reserva de la Biosfera. Cabildo Insular de Lanzarote, 2003 (pp. 54).

238 Que recoge el Centro de datos del Cabildo Insular de Lanzarote, en la sección de "Agua y Energía". www.datosdelanzarote.com, a partir de la facturación que comunica INALSA. 
Tabla 226. Incrementos interperiodo estimados de consumo de agua. 1996-2006(\%)

\begin{tabular}{|c|c|c|c|c|}
\hline Año & $\begin{array}{c}\text { Consumo } \\
\text { Residentes* }^{*}\end{array}$ & $\begin{array}{c}\text { Consumo } \\
\text { Turistas* }^{*}\end{array}$ & $\begin{array}{c}\text { Consumo } \\
\text { General }\end{array}$ & $\begin{array}{c}\text { Producción } \\
\text { Pública }\end{array}$ \\
\hline \hline $1996-2001$ & 33,17 & $-8,39$ & 49,12 & 57,20 \\
\hline $2001-2006$ & 23,69 & $-15,88$ & 19,87 & 27,73 \\
\hline $1996-2006$ & 64,72 & $-22,93$ & 78,75 & 100,78 \\
\hline
\end{tabular}

$\left.{ }^{*}\right)$ A partir de las estimaciones en la evolución del consumo de la anterior tabla.

Fuente: Elaboración propia a partir de datos anteriores.

En relación al resultado de los cálculos realizados, la reducción de los turistas equivalentes diarios en la isla supone ahorros en el consumo de agua para este sector, sin embargo la dinámica demográfica insular, caracterizada por importantes crecimientos derivados de la incorporación de población externa, no permite reducir el consumo. A esto se une el que, desde comienzos de la década de los años noventa se observan cambios dirigidos hacia la pérdida de la cultura tradicional de prudencia en el uso del agua, que caracterizaba a la población autóctona, fenómeno este que puede derivarse de dos aspectos: a) la progresiva relajación de la población con respecto a la disponibilidad, derivada de la instalación de la desalinización que se puede percibir como inagotable, b) la constante incorporación de población externa proveniente de zonas del territorio nacional, europeo e internacional con distinta cultura sobre el uso del agua y sin la conciencia de la escasez de este recurso en la Isla (recordamos que el volumen de población inmigrante se ha estimado en un 59\% y un $51 \%$ para el año 2001 y 2006 respectivamente). Por lo que la cultura local ha tendido a diluirse.

Gráfico 197. Evolución del consumo de agua estimado de residentes y turistas. Lanzarote. 1996-2006 ( $\mathrm{m}^{3}$ /año).

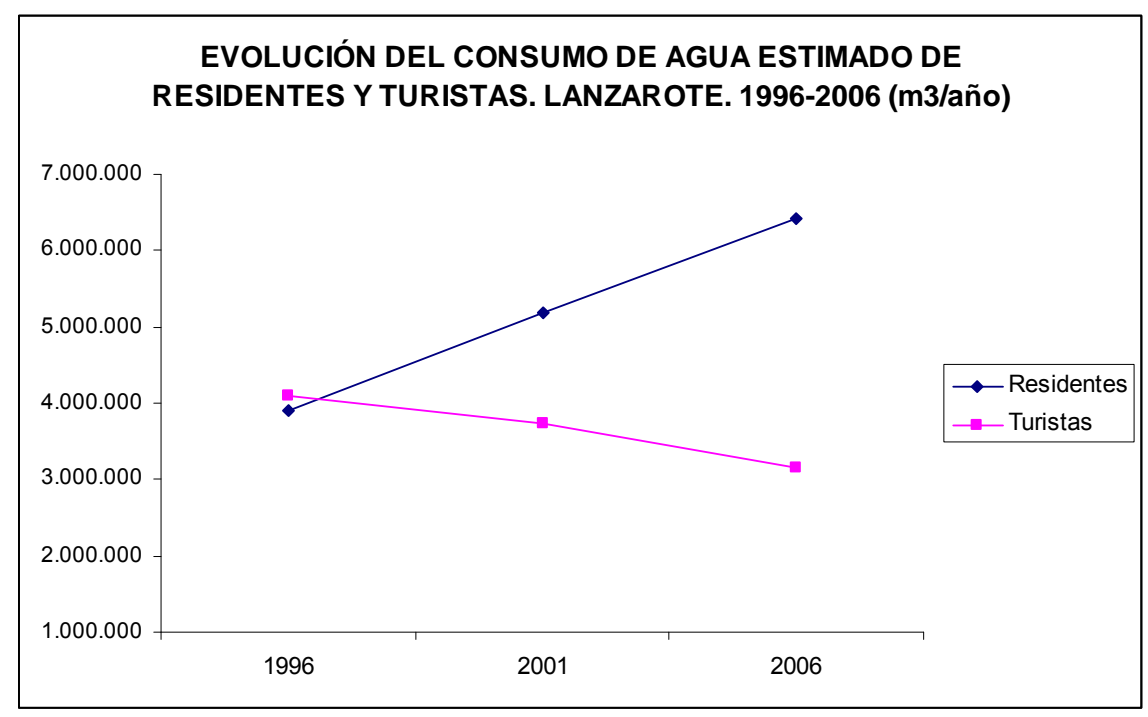

Fuente: Elaboración propia partir de la Tabla 226. 


\subsubsection{3.- CONCLUSIONES}

Lanzarote como destino turístico de masas y en relación a la disponibilidad de agua potable que repercute sobre el bienestar de la población que acoge la isla, se caracteriza en esta última etapa por lo siguiente:

1. Los tradicionales métodos de recogida de agua quedaron en desuso, se conservan como parte del patrimonio histórico insular, por lo que toda el agua viene de la desalación, con incrementos constantes de la producción por habitante y día.

2. Los turistas exigen mayor disponibilidad de caudal, frente a los residentes, lo que obliga a una mayor dotación de infraestructuras y producción, que se ha realizado por apertura de una nueva planta y por sucesivas ampliaciones de las dos que existen.

3. El acceso al agua potable para los residentes no es continuo, se producen cortes periódicos en las zonas rurales, que se intensifican en periodos de mayor presión turística. La prioridad de abastecimiento la tienen las zonas urbanas y turísticas. Se exigen depósitos de almacenamiento en las viviendas.

4. No se garantiza el suministro, éste depende de la producción diaria, por lo que el sistema es altamente vulnerable ante averías y procesos de mantenimiento.

5. Elevadas pérdidas en la red de transporte y distribución y por consumos no autorizados que merman la disponibilidad por habitante y día.

6. Constante incremento del nivel de consumo. El anuncio de una Moratoria impulsa el crecimiento de estos incrementos, aumentando la presión sobre el sistema, cuyos efectos sobre el bienestar derivado no puede ser positivo.

7. La disponibilidad después de las pérdidas (por fugas) no cubre la demanda de consumo medio por habitante y día, afectando a los residentes que son los que sufren los cortes en el abastecimiento.

8. El consumo energético en la producción de agua se reduce, se mejora la eficiencia del sistema, con mayor rentabilidad económica por $\mathrm{m}^{3}$ producido.

9. Las crisis de afluencia turística suponen ahorros en el consumo, pueden reducir la presión sobre el nivel de producción de agua desalada. El efecto contrario origina el constante crecimiento de los residentes por incorporación de población externa.

10. Progresiva pérdida de la cultura tradicional basada en la prudencia y austeridad respecto al uso del agua, posiblemente por percepción social de la desalinización como inagotable, y por procesos de aculturación derivados de la enorme 
incorporación de población procedente de culturas con menos restricciones de agua o sin ellas.

11. Al final del periodo la isla supera en producción y consumo, por habitante y día, la media del archipiélago. Aunque con respecto a España se mantiene por debajo, tiene más sed y peor bienestar asociado.

12. El coste de acceso al agua potable se ha mantenido estable para todos los usos, lo que supone de hecho un fuerte abaratamiento del precio del agua para los consumidores, con una influencia sobre el bienestar muy positiva.

Al igual que en las etapas anteriores, la actividad turística y el movimiento de atracción de personas a trabajar que produce, genera presión sobre el recurso "agua" insular, convirtiéndose el turismo en competidor directo sobre la población residente, por su mayor demanda, que impulsa las ampliaciones de las infraestructuras de desalación y que finalmente posibilita más acceso al recurso por parte de la población local, sin afecciones sobre la renta. En términos generales, la influencia sobre el bienestar es positiva en cuanto a disponibilidad, aunque el sistema es frágil pues los incrementos puntuales de demanda desabastecen al residente (por no ser prioritario). A ello se añade afecciones negativas medioambientales, pues para más desalación hace falta más energía eléctrica y su generación es muy contaminante. La sociedad lanzaroteña, con la multiculturalidad que acoge en este principio de siglo, vive de espalda a su histórica y presente realidad: la escasez de agua y la dependencia de la producción diaria.

\subsection{9.- EFECTOS SOBRE LAS VÍAS DE COMUNICACIÓN. CARRETERAS. 1996-2006}

\subsubsection{1.- CAPACIDAD DEL VIARIO. OFERTA}

Al igual que en las etapas anteriores, Lanzarote seguirá, en ésta, sin disponer de una planificación global del viario, lo que quiere decir que los proyectos de ampliación de vías se harán en relación a la presión que ejerce la intensidad del tráfico en los diferentes tramos de carreteras, así pues, los incrementos en la movilidad son los que han impulsado la mejora de la red de carreteras.

A finales de siglo, se considera la Moratoria Turística como una nueva política que puede ser "(...) absolutamente determinante" en el plano de las comunicaciones por carretera, ya que "el componente turístico de los tráficos insulares es muy importante en todas las carreteras de la isla" (Estevan, A., 1998, pp. 2), e influir en las características y evolución del tráfico.

Desde 1989 vienen realizándose desdoblamientos en diferentes tramos. Los problemas por concentración de tráfico y sobre el que gravitan la mayor parte de las inversiones en curso o 
en proyecto, se centran en las vías que conectan el norte-centro-sur de la Isla (ÓrzolaArrecife-Playa Blanca), que comunican zonas de costa en la que se localizan urbanizaciones turísticas y lugares de interés para la visita, con Arrecife y el Aeropuerto.

Tabla 227. Ancho de calzada y kilómetros de carreteras. Lanzarote y Canarias. 1996-2006 (\%)

\begin{tabular}{|c|c|c|c|c|c|c|c|c|c|c|c|}
\hline \multirow{3}{*}{$\begin{array}{l}\text { Tipo } \\
\text { Año }\end{array}$} & \multicolumn{5}{|c|}{ LANZAROTE } & \multicolumn{6}{|c|}{ CANARIAS } \\
\hline & \multicolumn{3}{|c|}{ Una calzada (\%) } & \multirow{2}{*}{$\begin{array}{c}\text { Gran } \\
\text { Capacidad (\%) } \\
>12\end{array}$} & \multirow{2}{*}{$\begin{array}{c}\text { TOTAL } \\
\mathrm{Km} .\end{array}$} & \multicolumn{3}{|c|}{ Una calzada (\%) } & \multirow{2}{*}{$\begin{array}{c}\% \\
\text { Total }\end{array}$} & \multirow{2}{*}{$\begin{array}{c}\text { Gran } \\
\text { Capacidad (\%) } \\
\text { Doble, AP y AV }\end{array}$} & \multirow{2}{*}{$\begin{array}{c}\text { TOTAL } \\
\mathrm{Km} .\end{array}$} \\
\hline & $<5$ & $5-6,99$ & $\geq 7$ & & & $<5$ & $5-6,99$ & $\geq 7$ & & & \\
\hline 1996 & & & & & & 9,7 & 69,1 & 16,7 & 95,4 & 5,4 & 4.324 \\
\hline 2001 & & & & & & 9,7 & 61,1 & 22,8 & 93,7 & 5,6 & 4.336 \\
\hline 2006 & 5,41 & 31,44 & 62,75 & 0,41 & 456,9 & 7,3 & 51,1 & 34,2 & 92,6 & 7,3 & 4.186 \\
\hline
\end{tabular}

Fuente: "Carreteras insulares y caminos municipales, 2007". Encuesta de Infraestructuras y Equipamientos de Lanzarote, 2007. Centro de datos del Cabildo de Lanzarote, 2007 (www.datosdelanzarote.com); "Red de carreteras de Canarias según anchura de pavimentos, 1996 y 2001 (Km)". Anuario Estadístico de Canarias, 1999 y 2002. ISTAC; "Red de carreteras por CCAA. 2006". Red de carreteras. Serie 1990-2007. INE. Elaboración propia.

Así, el mayor ancho de vía registrado a lo largo de todo el tiempo que cubre este trabajo (1970-2006), se encuentra al final de esta etapa (2006), dónde se ha podido contabilizar la concentración del ancho de vía a partir de los siete metros, en casi un $63 \%$ del total de kilómetros de carreteras existentes y casi dos kilómetros de vías mayores de 12 metros de ancho (exactamente de $16,3 \mathrm{~m}$ ), localizados en el tramo que conecta el centro (la capital) con unas de las principales zonas de desarrollo del alojamiento y la actividad turística situada en la costa del centro-norte de la isla (Arrecife-Costa de Teguise). Una vez más serán los núcleos turísticos los que se benefician, en primer lugar, de la ampliación de las vías, derivado de la intensidad de tráfico que soportan, por movimientos de trabajadores y turistas. Los municipios más rurales, Haría y Tinajo, tienen una elevada dependencia laboral de los grandes núcleos turísticos (situados en las costas de los municipios de Tías, Yaiza y Teguise), con un media de desplazamientos poco numerosos pero a gran distancia.

En comparación con Canarias, Lanzarote concentra, ahora, un mayor porcentaje de kilómetros de carretera de más de siete metros de ancho (34,2\% y $62,7 \%$ respectivamente). 


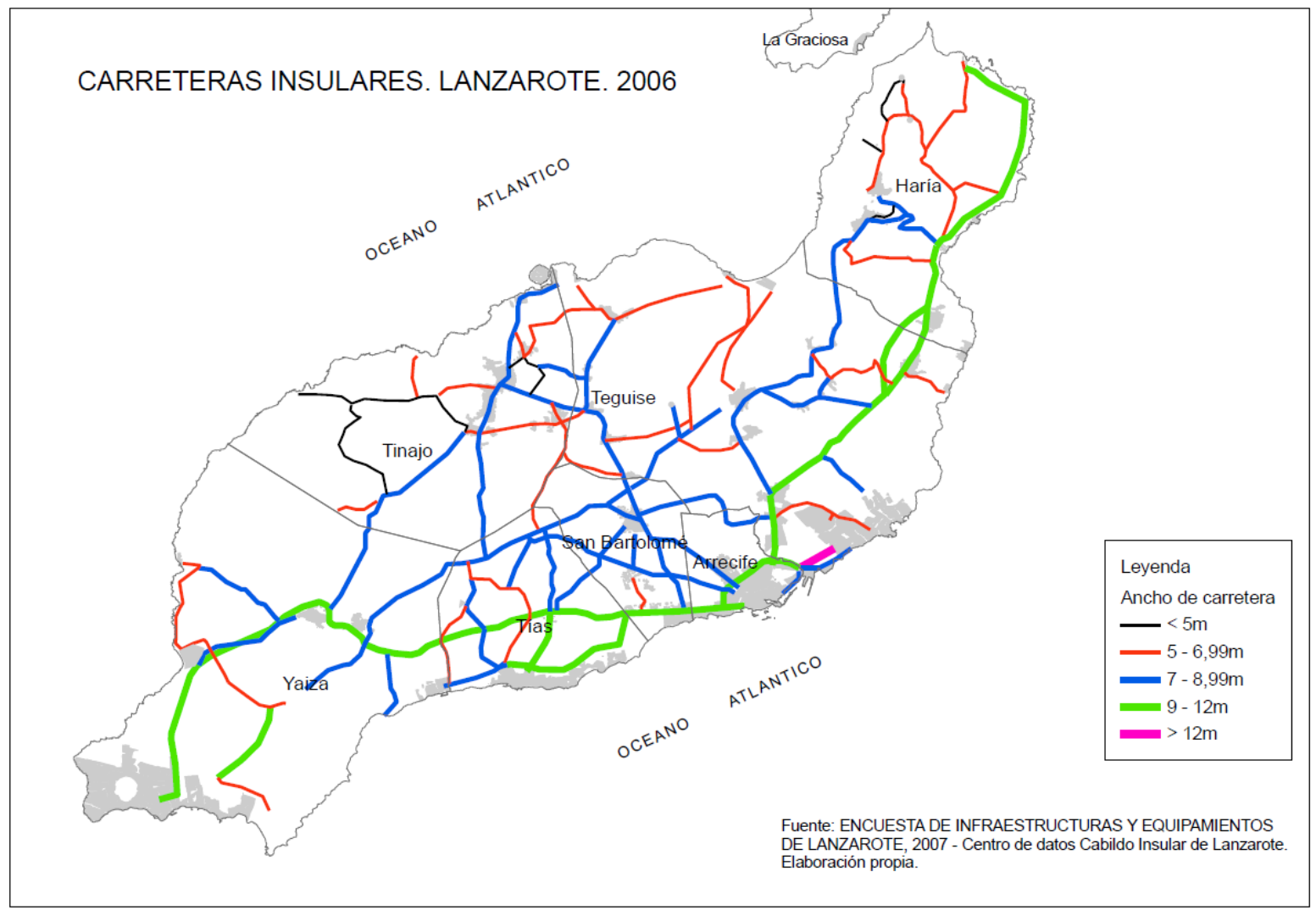

Por otro lado, en palabras de Estevan, A. (1998, pp. 11-12) la evolución cuantitativa del tráfico se considera la razón fundamental para introducir mejoras en materia de capacidad, pues "el incremento de la velocidad media de circulación, más allá de ciertos umbrales ya alcanzados, no es un objetivo a perseguir", ya que en relación a las "dimensiones de la isla no se conseguirían ganancias en tiempo significativas", además se considera su "elevación un elemento de inseguridad pues los tráficos no son homogéneos", existe un elevado número de turistas "desconocedores del viario, que circulan a velocidades moderadas". El planificador considera dicho incremento una irresponsabilidad, pues la construcción de carreteras con sección de 10 metros y bajas intensidades de tráfico, "generará notables incrementos de la velocidad de circulación, que se difundirán hacia todo el viario insular".

\subsubsection{2.- NIVEL DE MOTORIZACIÓN E INTENSIDAD DEL TRÁFICO}

Tal y como se ha señalado en las etapas anteriores, el número de vehículos (turismos) sigue observando altos crecimientos, aunque menores que en la etapa anterior, pues entre 1991 y 1996 el incremento relativo es de casi un 59\%, reduciéndose en los quinquenios siguientes, hasta un crecimiento entre 2001 y 2006 del 22\%. La misma dinámica descrita se observa para Canarias y España. 
Tabla 228. Número de vehículos (turismos). Lanzarote, Canarias y España. 1996-2006.

\begin{tabular}{|c|c|c|c|c|c|c|}
\hline & \multicolumn{6}{|c|}{ Número de Turismos } \\
\hline & \multicolumn{2}{|r|}{ Lanzarote } & \multicolumn{2}{|r|}{ Canarias } & \multicolumn{2}{|r|}{ España } \\
\hline AÑO & Absolutos & $\begin{array}{c}\text { Incremento quinquenal } \\
(\%)\end{array}$ & Absolutos & $\begin{array}{l}\text { Incremento quinquenal } \\
(\%)\end{array}$ & Absolutos & $\begin{array}{c}\text { Incremento quinquenal } \\
(\%)\end{array}$ \\
\hline 1996 & 48.769 & 58,5 & 662.337 & 26,5 & 14.753 .809 & 17,7 \\
\hline 2001 & 69.048 & 41,6 & 835.221 & 26,1 & 18.150 .880 & 23,0 \\
\hline 2006 & 84.173 & 21,9 & 995.376 & 19,2 & 20.908 .725 & 15,2 \\
\hline
\end{tabular}

Fuente: "Número de Turismos, por islas y total Canarias, 1996, 2001 y 2006". Parque de vehículos según clases, 1996. Anuario Estadístico de Canarias, 1999, 2002 y 2008. ISTAC; "Parque nacional de vehículos al final de cada año, 2001 y 2006 ". Anuario Estadístico, 2008. Ministerio de Fomento. España; Elaboración propia.

Gráfico 198. Incremento interperiodo del número de vehículos (turismos). Lanzarote, Canarias y España. 1991-2006 (\%).

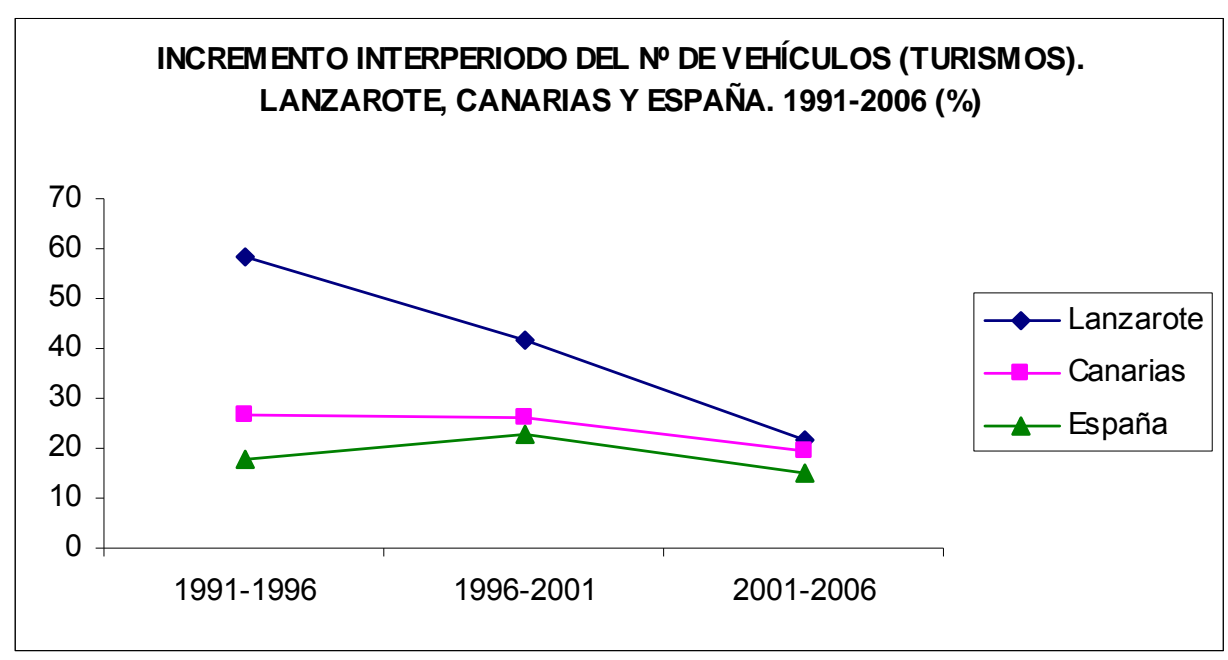

Fuente: Elaboración propia partir de la Tabla 228.

El número de vehículos no para de crecer, por lo que también lo hace el índice de motorización, pues la etapa comienza con 39 vehículos/turismos por cien habitantes (residentes y turistas equivalentes diarios), para terminar con 51. Lanzarote posee índices de motorización (calculados sobre los turismos) superiores a los de España y Canarias, como se viene señalando en diferentes documentos oficiales y artículos especializados ${ }^{239}$.

239 Entre los documentos que realizan la misma afirmación se pueden encontrar los siguientes seleccionados, entre otros: AUIA. Life Lanzarote 2001-2004. "Bases jurídicas para la regulación de la oferta de vehículos de alquiler sin conductor en Lanzarote". Cabildo Insular de Lanzarote, 2003 (pp. 20); Ramos Pérez, D. (2005) "Modelo territorial, Movilidad Insular y Sostenibilidad en Canarias: Una reflexión crítica". Boletín de la A.G.E. No 40, año 2005 (pp. 245-268).Ezquiaga Arquitectura, Sociedad y Territorio S.L. "Memoria de Información Territorial, Marzo 2010. Plan Insular de Ordenación de (continuación) 
Tabla 229. Índice de motorización. Lanzarote, Canarias y España. 1996-2006

\begin{tabular}{|c|c|c|c|c|c|c|}
\hline \multicolumn{7}{|c|}{ ÍNDICE DE MOTORIZACIÓN } \\
\hline & \multicolumn{2}{|c|}{ Lanzarote } & \multicolumn{2}{|c|}{ Canarias } & \multicolumn{2}{|c|}{ España } \\
\hline Año & Residentes & Población Total* & Residentes & Población Total ${ }^{*}$ & Residentes & Población Total* \\
\hline 1996 & 0,41 & 0,39 & 0,41 & 0,35 & 0,37 & 0,36 \\
\hline 2001 & 0,44 & 0,47 & 0,49 & 0,43 & 0,44 & 0,43 \\
\hline 2006 & 0,45 & 0,51 & 0,50 & 0,46 & 0,47 & 0,46 \\
\hline
\end{tabular}

${ }^{*}$ ) Población Total: residentes + turistas equivalentes diarios; Índice de motorización: Número de turismos sobre la población total. Nota: El índice de motorización de la población residente ha sido calculado para Lanzarote en relación al número de automóviles de tipo turismo, después de restar los vehículos de alquiler, sobre la población registrada. Esta operación no se ha podido realizar para el conjunto del Archipiélago y España, pues no se dispone de ese detalle, por lo que la comparación debe hacerse con precaución. Fuente: Elaboración propia.

En lo que a esta tesis respecta, se estima el índice de motorización de la población residente, para cuyo cálculo se ha restado los datos existentes sobre automóviles de alquiler (turismos) del total de vehículos de tipo turismo registrado en la isla. La constante es el crecimiento del índice de motorización de los residentes que oscila entre 41 y 45 turismos por cien residentes, por lo que la movilidad en transporte privado sigue creciendo y con ello la presión sobre la accesibilidad, la contaminación y el bienestar derivado.

Gráfico 199. Índice de motorización (turismos) en relación a la población residente y a la población total estimada. España, Canarias y Lanzarote. 1996-2006

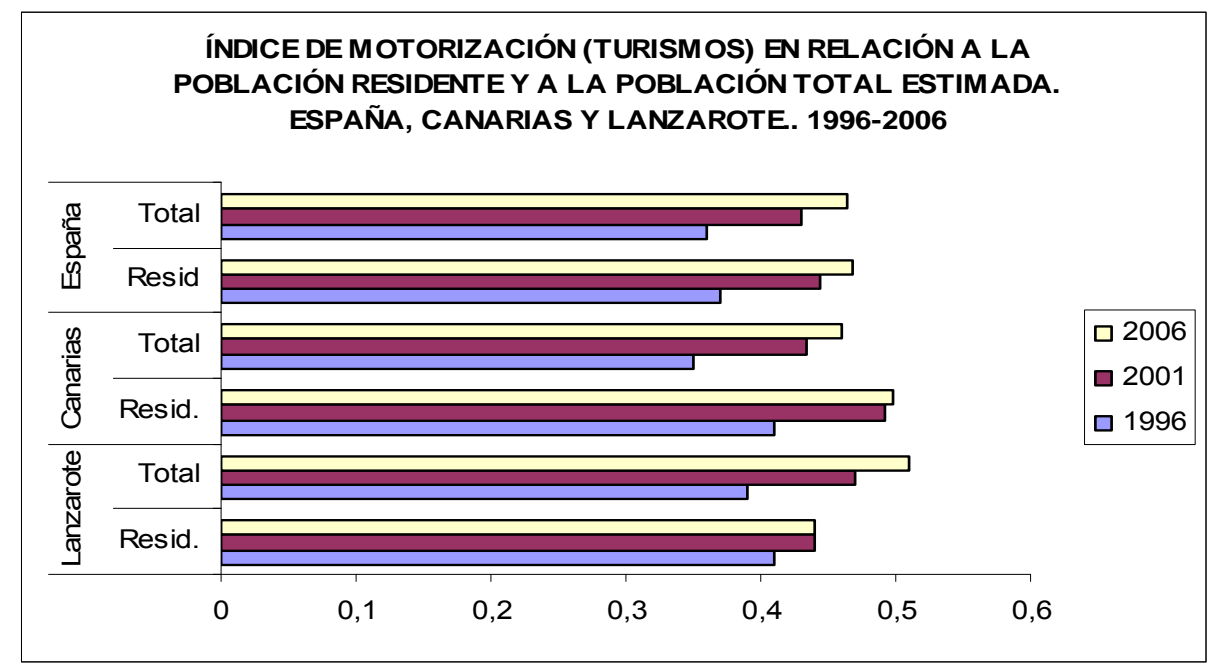

Fuente: Elaboración propia partir de la Tabla 229.

Lanzarote- Avance. Cabildo Insular de Lanzarote, 2010 (pp. 173); En Ramos Pérez, D. (2005) "Modelo territorial, Movilidad Insular y Sostenibilidad en Canarias: Una reflexión crítica”. Boletín de la A.G.E. № 40, año 2005 (pp. 245-268). 
En relación al número de vehículos (turismos) en alquiler, sólo disponemos de registros hasta el año 2001, por lo que únicamente podemos datar incrementos de dicho parque móvil hasta ésta fecha, del orden del $41 \%$ (entre 1996 y 2001), muy superiores al quinquenio anterior (1991-1996) en el que creció un 28\%. Estos crecimientos son superiores al crecimiento de la demanda turística en el mismo periodo, pues ésta aumenta alrededor del 23,5\% (epígrafe 5.3.1.2.). Todo ello ocurre previamente a la entrada en vigor de la Moratoria y de la incursión en el territorio insular de una crisis de recepción turística que será observada posteriormente. Con respecto al año 2006 no se han facilitado datos sobre el parque móvil de alquiler sin conductor, por lo que no podemos extraer conclusiones en relación a la evolución del mismo, a cómo la crisis de la afluencia turística afectó a este volumen y si consecuentemente supuso una mejora de la calidad de la escena. Con respecto al total de automóviles de tipo turismo, el parque de alquiler parece mantenerse con un peso de algo más del $34 \%$.

Tabla 230. Evolución de los coches de alquiler. Lanzarote, 1996-2006

\begin{tabular}{|c|c|c|c||}
\hline AÑO & Coches de alquiler & Incremento quinquenal (\%). & \% Respecto al Total de turismos \\
\hline \hline 1996 & 16.930 & 26,4 & 34,2 \\
\hline 2001 & 23.899 & 41,2 & 34,6 \\
\hline $2006^{*}$ & $28.619^{*}$ & -- & 34,0 * \\
\hline
\end{tabular}

${ }^{*}$ ) Estimación propia en relación a la dinámica que viene siguiendo según su peso sobre el total de turismos registrados en la isla. Para el 2006 se ha supuesto un peso del $34,0 \%$.

Fuente: "Parque de vehículos según clase y servicio al que están destinados, 1996". Anuario Estadístico de Lanzarote, 1996. Centro de datos. Cabildo Insular de Lanzarote. http://www.datosdelanzarote.com.; "Parque de vehículos según clase y servicio al que se destinan, por isla, Lanzarote. 2001”. Parque de vehículos de Canarias, 2001. ISTAC. Elaboración propia.

Por otro lado, la evolución del tráfico sigue experimentando crecimientos, principalmente en el tramo que conecta la capital con el aeropuerto, que en diez años incrementa su tráfico más de un $90 \%$, seguido de las vías que conectan las zonas de principal atractivo para la visita y las costas donde se concentra la actividad turística. A excepción de uno de los puntos principales de acogida de turismo de masas, Puerto del Carmen, en el municipio de Tías, que observa con respecto a 1995 un crecimiento negativo de la intensidad media diaria de tráfico de casi el $6 \%$, posiblemente derivado de la potenciación turística de la costa del municipio de Yaiza, en este siglo. 
Tabla 231. Evolución de la intensidad media diaria de vehículos, por tramos. Lanzarote. 19952006.

\begin{tabular}{|c|c|c|c|c|c|c|c|c|}
\hline AÑO & $\begin{array}{l}\text { Arrecife- } \\
\text { Aeropuerto }\end{array}$ & $\begin{array}{c}\text { Incremento } \\
\text { quinquenal } \\
(\%)\end{array}$ & $\begin{array}{c}\text { Desvío } \\
\text { Puerto del } \\
\text { Carmen }\end{array}$ & $\begin{array}{c}\text { Incremento } \\
\text { quinquenal } \\
(\%)\end{array}$ & $\begin{array}{c}\text { Arrecife- } \\
\text { Costa } \\
\text { Teguise }\end{array}$ & $\begin{array}{c}\text { Incremento } \\
\text { quinquenal } \\
(\%)\end{array}$ & $\begin{array}{l}\text { Arrecife- } \\
\text { Tahíche }\end{array}$ & $\begin{array}{c}\text { Incremento } \\
\text { quinquenal } \\
(\%)\end{array}$ \\
\hline 1995 & 42.427 & \multirow{2}{*}{90,7} & 24.742 & \multirow{2}{*}{$-5,8$} & 16.852 & \multirow{2}{*}{33,5} & 16.448 & \multirow{2}{*}{43,3} \\
\hline 2006 & 80.920 & & 23.320 & & 22.490 & & 23.565 & \\
\hline
\end{tabular}

Fuente: "Intensidad media diaria de tráfico en puntos representativos de la isla de Lanzarote, 2000 (1975-2000)". Tabla 6. En Hernández, J. A. (2006). "Tendencias de la movilidad terrestre en la isla de Lanzarote (1991-2001)". XII Jornadas de Estudios sobre Lanzarote y Fuerteventura. Tomo III, Vol. 2. (pp. 156-178). Cabildo Insular de Lanzarote y de Fuerteventura, 2008. http://www.memoriadelanzarote.com; "Evolución de la intensidad media diaria de vehículos (1995)". En Caballero, C. "La movilidad espacial por carretera de la población en la isla de Lanzarote (1990-1995)". IX Jornadas de Estudios sobre Fuerteventura y Lanzarote. Tomo II (pp. 324-339). Cabildo Insular de Lanzarote y de Fuerteventura, 2001. http://www.memoriadelanzarote.com; "Aforo de las carreteras de Lanzarote, 2007". Infraestructuras y equipamientos. Lanzarote, 2007. Centro de datos. Cabildo de Lanzarote. http://www.datosdelanzarote.com; "Intensidades medias diarias de tráfico en las carreteras de Lanzarote, 2006. Centro de datos del Cabildo de Lanzarote. http://www.datosdelanzarote.com; Elaboración propia.

Gráfico 200. Evolución de la intensidad media diaria de vehículo por tramos. Lanzarote. 1995-2006

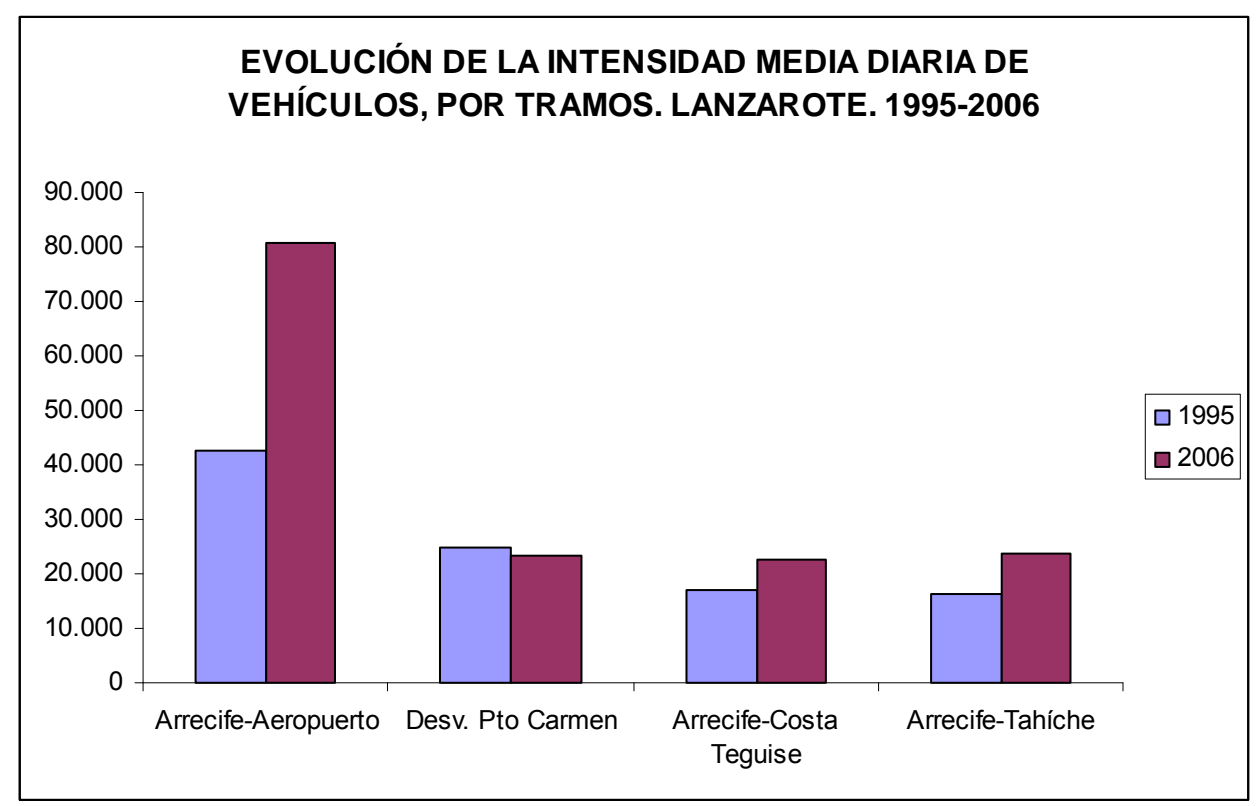

Fuente: Hernández, J. A. (2006); Caballero, C. (2001). Encuesta de Infraestructuras y equipamientos. Lanzarote, 2007. Centro de datos. Cabildo de Lanzarote. Elaboración propia a partir de la Tabla 231. 


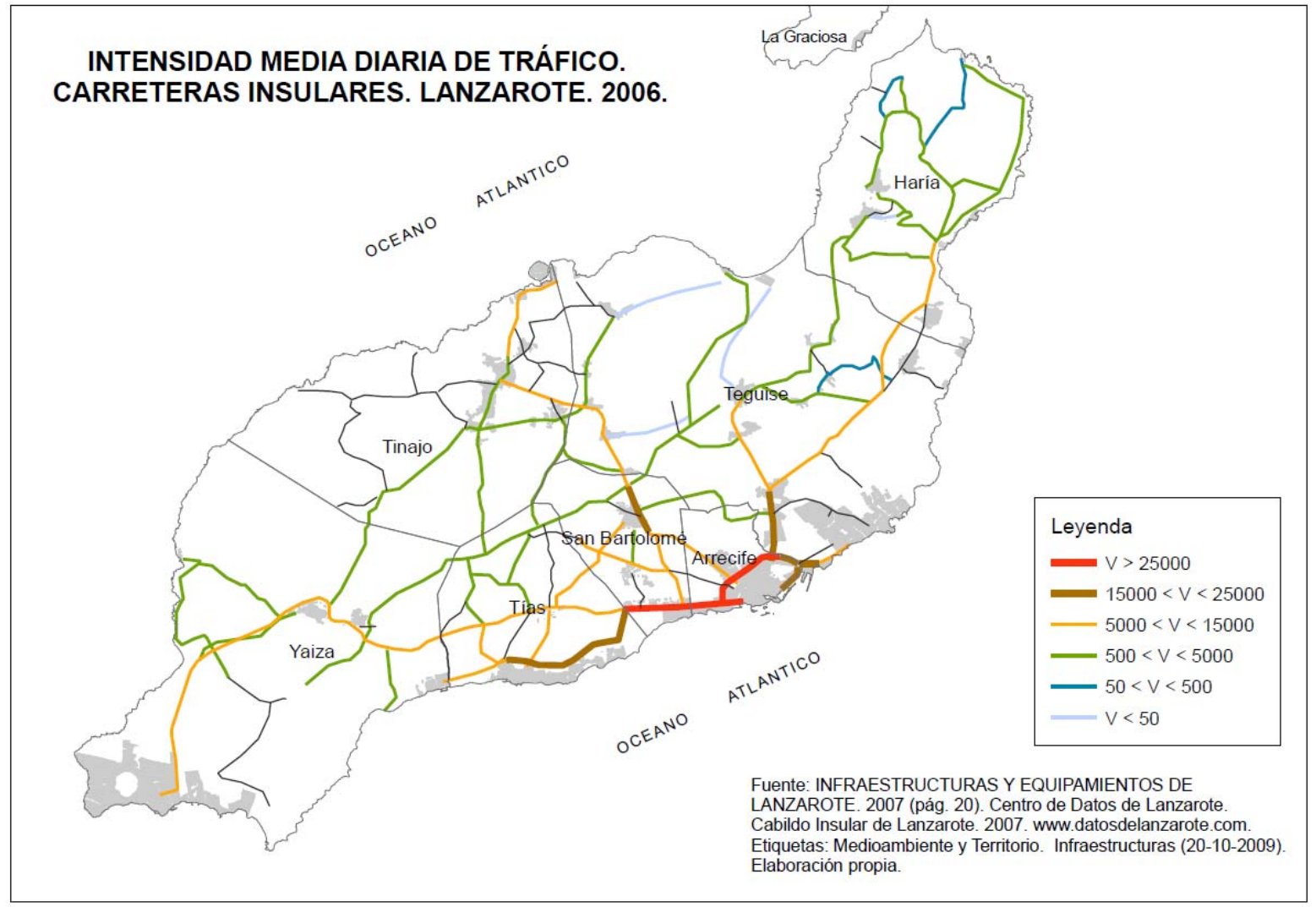

El enorme crecimiento de los automóviles por un lado, del índice de motorización y las intensidades medias de tráfico por otro, no sólo se deriva de la especialización turística del territorio insular, sino que, como ya se ha citado anteriormente, está afectado por el incremento de las rentas acontecido a lo largo del proceso de desarrollo de la actividad hacia un modelo de masas, aunque existen otros procesos socio-territoriales que también lo han impulsado y que se pueden resumir en los siguientes, tomando como referencia el análisis realizado para la Memoria de Información Territorial del PIOL, 2010 (pp. 173):

a. La inexistencia de transporte público eficiente, ni en cantidad ni en calidad, a lo largo de los más de treinta años de análisis que cubre este trabajo. Que afecta tanto a la población local como a la foránea ligada al turismo y al mismo turista.

b. El menor coste del carburante con respecto a la media europea.

c. La segregación de los usos del suelo y la intensidad de los flujos pendulares residencia-trabajo derivados de la dispersión del hábitat y el proceso de periurbanización que acontece en este siglo.

A ello hay que añadir la falta de propuestas de transporte alternativo (itinerarios ciclables) en estos años. 


\subsubsection{3.- TRANSPORTE COLECTIVO REGULAR DE PASAJEROS}

En el año 1998 el Cabildo Insular de Lanzarote aborda la planificación del transporte regular de viajeros en la isla. Este hecho se enfrenta con optimismo pues, "por primera vez en la historia reciente de Lanzarote la operatividad del transporte regular de viajeros puede recibir un impulso decisivo, convirtiéndose en una verdadera alternativa de transporte frente al automóvil privado" (Estevan, A., 1998, pp. 3).

De esta forma, el servicio regular interurbano de transporte de pasajeros sufre, ahora, de nuevo, significativas variaciones pues entre 1996 y 2001 la flota se incrementa del orden del $60 \%$, relajando la presión por el aumento del número de plazas en servicio. Se contabilizan, por tanto, 314 personas residentes por bus, aunque en relación a la población total equivalente, es decir, residentes y turistas diarios (viajeros potenciales), la cifra se eleva a casi 490 personas por bus. A pesar del crecimiento de la flota, la situación seguirá siendo precaria pues se estima que el transporte público regular de viajeros "apenas representa el $7 \%$ de todos los desplazamientos mecanizados de personas en la isla" (AUIA. Life Lanzarote 2001-2004. "Bases jurídicas para la regulación de la oferta de vehículos de alquiler sin conductor en Lanzarote", 2003, pp. 21).

Tabla 232. Transporte público (interurbano) de viajeros. Lanzarote. 1996-2006

\begin{tabular}{|c|c|c|c|c|c|c|}
\cline { 2 - 7 } \multicolumn{1}{c|}{} & Buses & Líneas & Residentes & Residentes/bus & $\begin{array}{c}\text { Viajeros } \\
\text { Potenciales** }^{* *}\end{array}$ & Habitantes/bus \\
\hline \hline $\mathbf{1 9 9 6}$ & 205 & -- & 77.379 & 377,5 & 126.065 & 601,1 \\
\hline $\mathbf{2 0 0 1}$ & $327^{*}$ & 17 & 103.044 & 315,1 & 147.647 & 451,5 \\
\hline $\mathbf{2 0 0 6}$ & 238 & 17 & 127.457 & 535,5 & 164.979 & 693,2 \\
\hline
\end{tabular}

${ }^{*}$ ) No se facilita dicha desagregación para el año 2001, por lo que se ha tomado la referencia más próxima, que es a 31 de diciembre del año 2000.

$\left.{ }^{* *}\right)$ Viajeros potenciales: residentes y turistas equivalentes diarios.

Fuente: "Parque de vehículos según clase y servicio al que están destinados. Autobuses de servicio público, 1996". Anuario Estadístico de Lanzarote, 1996. Centro de datos. Cabildo Insular de Lanzarote; "Parque de vehículos según clase y servicio al que están destinados, por isla. Autobuses de servicio público. Lanzarote, 2000". Estadísticas Económicas. Parque de vehículos, 2000 ISTAC; "Parque de guaguas según servicios al que están destinadas. Islas y años. 2006". Parque de Vehículos de Canarias. ISTAC (Consulta online http://www2.gobiernodecanarias.org/istac/ fecha: 03-01-2011). Elaboración propia.

Además de este escaso uso, en el mapa de la red de líneas públicas podemos observar la escasez de conexiones periféricas, es decir que no tengan obligación de paso por Arrecife. La estructura de esta red no tiene buena cobertura espacial en Tinajo y la zona Norte "afectadas por la escasa frecuencia de paso", no así en los núcleos de concentración de la actividad turística, es decir de la economía y el empleo: Costa Teguise, Puerto del Carmen y 
a principios de este siglo Playa Blanca, aunque la facilidad de acceso a estos puntos será si se tiene como origen Arrecife ${ }^{240}$.

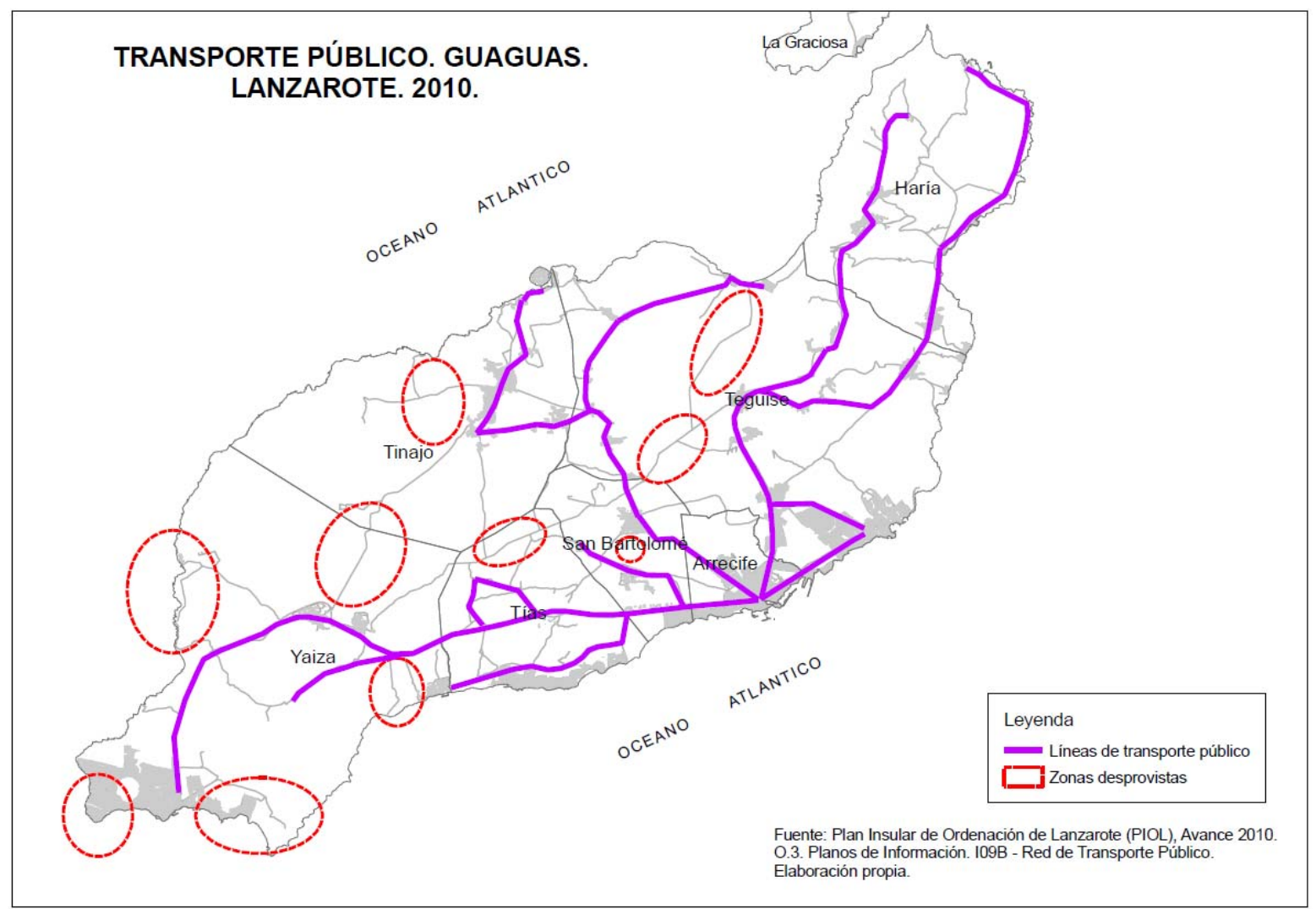

De la Encuesta a Usuarios de Transporte Interurbano, realizada por el Centro de datos del Cabildo Insular de Lanzarote, en el año 2004 (abril), se desprende que el uso del transporte público en la Isla va en relación a la posesión o no de vehículo privado, pues el $88,4 \%$ de los encuestados lo toma porque no dispone de otro medio. Las deficiencias históricas de una alternativa de transporte frente al automóvil han dado lugar a una cultura de la movilidad en relación al mismo. Así mismo, dicho estudio, señala que el $63 \%$ de los usuarios entrevistados no han nacido en la Isla, son principalmente inmigrantes, por lo que la presión que ejercen es la que impulsa la ampliación de las líneas y la flota, ya que los trayectos por motivo de ocio sólo ascienden al 5\%, por lo que la incidencia del turismo en el transporte público es muy pequeña (el uso que hacen es escaso).

240 Plan Estratégico de Transporte de Canarias. Lanzarote (PETCAN), 2006. Consejería de Infraestructura, Transporte y Vivienda. Gobierno de Canarias. 2006 (pp. 131) 
Todos los factores descritos han generado la mitificación del transporte privado y la posesión de vehículo propio como signo de posición social, siendo el uso del transporte público símbolo de carestía ${ }^{241}$ arraigado en la conciencia colectiva y que impide, incluso, el reconocimiento de las mejoras de éste medio de transporte en los últimos años. Sólo a través de la ruptura de esta concepción se podrán alcanzar ciertos cambios en las intensidades del tráfico, en el ahorro energético, la calidad ambiental y el bienestar derivado. Compromisos que se asumen en la nueva ordenación del Territorio (Avance PIOL. Memoria de Ordenación. 2010, pp.39-40).

\subsubsection{4.- CONCLUSIONES}

Del análisis de las carreteras y el transporte en Lanzarote, cuando ya se ha convertido en un destino turístico maduro, podemos extraer las siguientes conclusiones:

1. Ampliación de ancho de vía, desdoblamientos en las vías que conectan el norte-centrosur de la isla, que comunican las zonas de costa en las que se ubican los desarrollos turísticos y los lugares de interés para la visita con Arrecife y el Aeropuerto, impulsados por los incrementos de la movilidad. La oferta se va adecuando a la demanda del tráfico rodado por tramos, sin planificación global del viario. Se mejora la accesibilidad, sin incrementos de la velocidad media de circulación por no constituir una ganancia en tiempo y para garantizar la seguridad, pues los tráficos no son homogéneos.

2. Crecimiento del índice de motorización, alcanzando valores superiores a los de España y Canarias, y de la intensidad media de tráfico, explicado por varios factores entre los que se encuentra: la especialización turística del territorio, los incrementos de renta de los residentes (que permite mayor facilidad al acceso de vehículo privado propio), y el menor coste de los carburantes. Junto a ello, la falta de un transporte público eficiente y de oferta de transportes alternativos (como pueden ser los carriles bici), además de la forma de asentamiento en el territorio marcada por la dispersión del hábitat y los procesos de periurbanización que no asume el transporte público, han hecho del coche privado el principal medio de transporte.

3. Procesos de ampliación de líneas de transporte público, aunque todas con paso obligatorio por la capital (Arrecife), potenciando el servicio en el eje de desarrollo de actividad turística (con mayores frecuencias) y escasa cobertura espacial en los municipios rurales. Esta situación impulsa el escaso uso de este servicio, utilizado principalmente por personas que no pueden acceder a vehículo privado, a lo que se

${ }^{241}$ Conclusión derivada de las Encuestas a Usuarios del Transporte Interurbano. Recogido como fenómeno social en el Plan Insular de Ordenación de Lanzarote (PIOL), Memoria de Ordenación (Avance) de 2010 (pp. 40) y por observación propia. 
añade la construcción en el imaginario colectivo de una percepción peyorativa, de escasa posición social, de los usuarios de estos servicios. El uso que hace el turista es muy escaso, lo trayectos por ocio no impulsan mejoras.

En términos generales la mejora de la accesibilidad y la seguridad en las carreteras deriva del crecimiento de la movilidad impulsada por factores externos (oferta-demanda turística y crecimiento demográfico por inmigración), que favorece las condiciones de bienestar de la población residente, aunque ocupa cada vez mayor territorio y afecta a la calidad del paisaje. Junto a ello el crecimiento de la motorización de la población residente, constituye una clara mejora de su bienestar socioeconómico, aunque el elevado incremento de la movilidad por las causas descritas (mejora de las carreteras y fácil acceso al vehículo privado y escasez de oferta pública, principalmente) ha alcanzado niveles insostenibles con efectos que dificultan el ahorro energético y la reducción de los contaminantes ambientales y el bienestar que de ello se deriva.

\subsubsection{0.- CONCLUSIONES A LA TERCERA ETAPA. 1996-2006. CRISIS TURÍSTICA Y MORATORIA}

Esta tercera y última etapa de análisis, comprendida entre los años 1996 y 2006, en la que Lanzarote se define como un destino turístico de masas maduro, viene marcada, por un lado, por la revisión parcial del Plan Insular de Ordenación del Territorio (PIOT) vigente (de 1991), cuya reforma es aprobada en 2001 y que tomará el nombre de Moratoria Turística (Decreto 95/2000), entre cuyos objetivos se encuentra limitar el crecimiento de la nueva oferta de alojamiento turístico (un 29\% por debajo del límite máximo que establecía el PIOT de 1991 y transformando uso turístico en residencial) por ser la principal impulsora del crecimiento físico insular y fuente directa de generación de impactos (territoriales y ambientales) críticos, encaminándose la isla hacia la no sostenibilidad y la irreversibilidad de la situación de degradación.

Así pues, para preservar los equilibrios básicos del sistema insular, desde objetivos de sostenibilidad, y mejorar la calidad de vida de su población, el planificador entiende como imprescindible moderar la presión humana sobre dicho sistema, conteniendo el crecimiento demográfico, basado en incorporación de población externa, propiciado por el crecimiento de la afluencia turística. Considera, por tanto, la necesidad de controlar la demanda a través de la limitación de la oferta turística a escalas y ritmos compatibles con la capacidad de asimilación del territorio y la sociedad de acogida. Esta llamada "Moratoria" estará vigente hasta finales del año 2006 (anulada por el Tribunal Superior de Justicia de Canarias), lo que justifica la finalización de los análisis de esta tesis en dicha fecha.

La década analizada, en esta tercera etapa, viene marcada por la limitación de la oferta tanto en cantidad (pues aunque crece ya no lo hará a los niveles de las etapas anteriores, y 
con tendencia a unos incrementos cada vez más reducidos), como en calidad, ya que regula el tipo de la nueva oferta hacia la hotelera, como única posibilidad a implantar. Parte, por tanto, de una política que apuesta por romper con el modelo turístico de masas, intentando reducir el porcentaje de turistas estándar que lo caracteriza, con el fin de mantener la afluencia sin grandes altibajos, que se refleje en la calidad del servicio y que permita moderar la presión humana sobre la sociedad de acogida.

Gráfico 201. Evolución de la oferta y la demanda turística. Lanzarote. 1996-2006

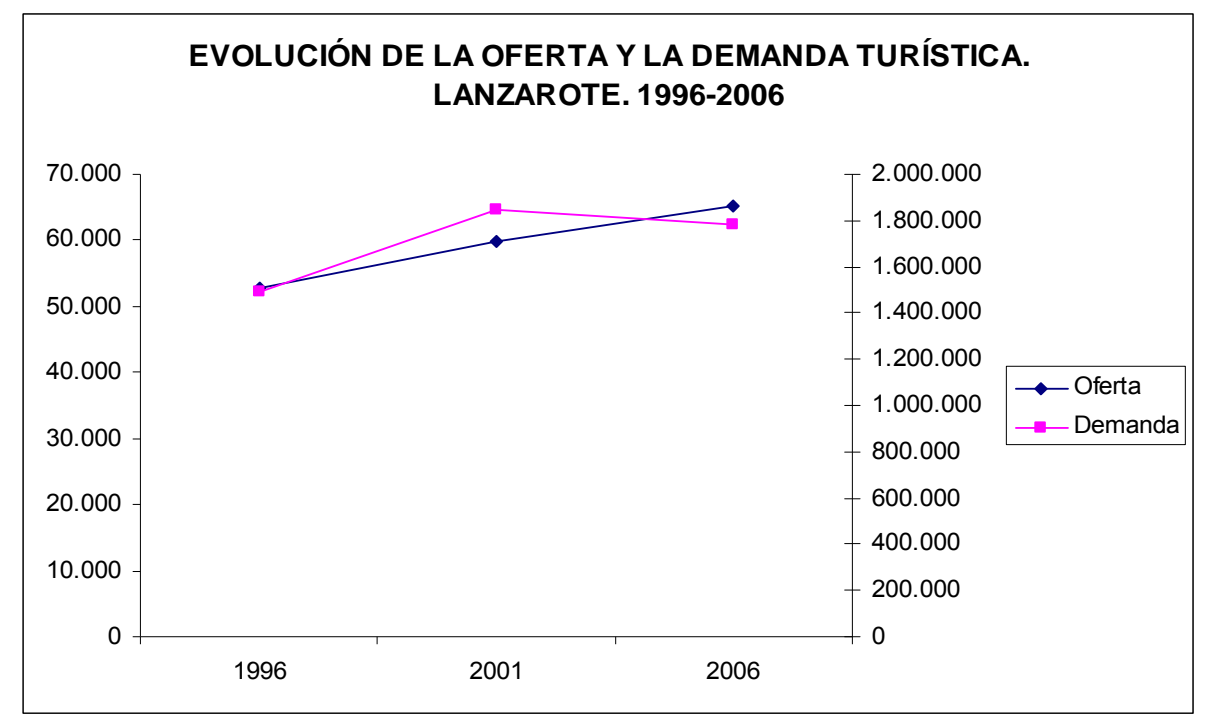

Fuente: Anuario Estadístico de Lanzarote, 1996, 2001 y 2006. Cabildo Insular de Lanzarote. Gráfico sintético a partir de las Tablas 145 y 146. Elaboración propia.

Gráfico 202. Plazas de alojamiento turístico por tipo. Porcentaje sobre el total. Lanzarote. 1996-2006

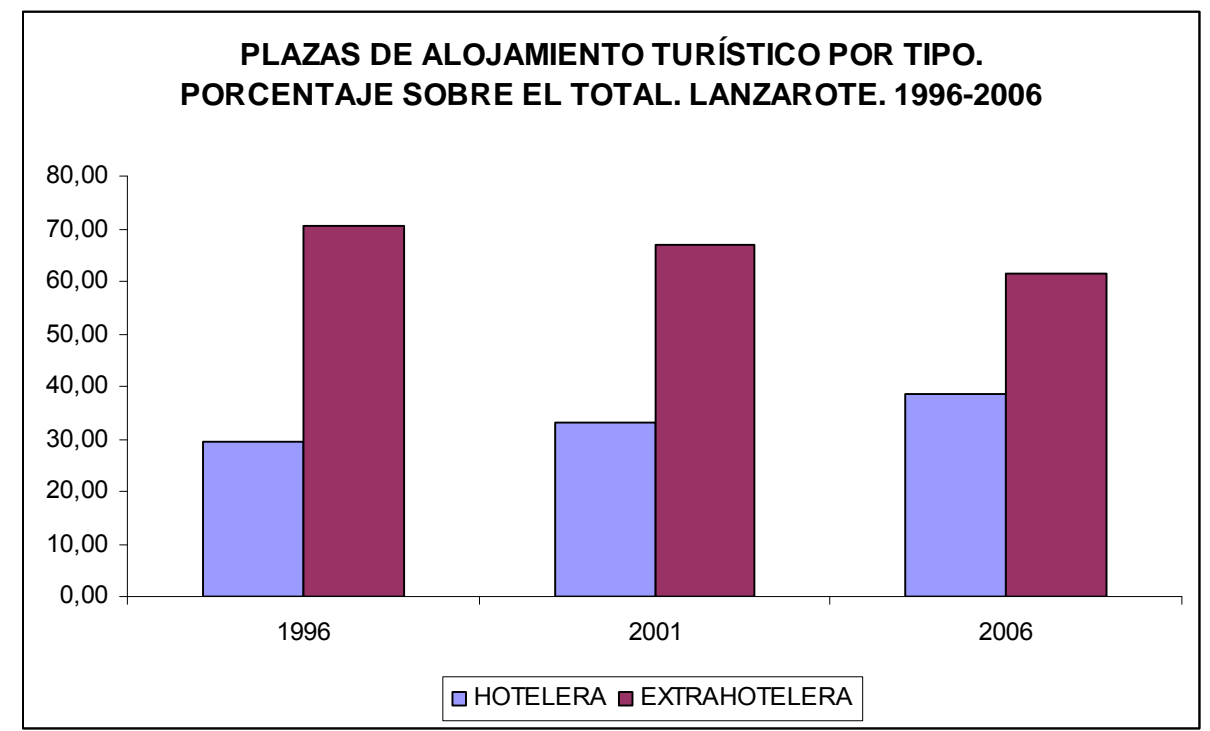

Fuente: Anuario Estadístico de Lanzarote, 1996, 2001 y 2006. Cabildo Insular de Lanzarote. Gráfico sintético a partir de la Tabla 145. Elaboración propia. 
Así, en este periodo, por un lado, derivado de la contención del crecimiento de la oferta de alojamiento turístico, se registra una evolución positiva en la relación entre los turistas que entran en la isla y el volumen de plazas que se ofertan (t/p), que va en aumento, es decir se hace mayor explotación de cada plaza.

Por otro lado, se registra una crisis de afluencia (-3,5\%), comparando el año 2001 con el 2006 (generada, principalmente, por la aparición de líneas de bajo coste que operan en aeropuertos secundarios, países emergentes competidores, y la entrada del euro), que deriva hacia una mejora del equilibrio poblacional, pues la relación turista/residente se reduce y con ello la presión humana sobre el territorio. Esta crisis de afluencia (que en este momento también es autonómica), pueden convertirse en una oportunidad para regular el mercado turístico local y, con él, diferentes aspectos socioeconómicos y de bienestar de la sociedad insular, pues se reduce la presión.

Gráfico 203. Incremento de la oferta y la demanda turística. Lanzarote. 1996-2006 (\%)

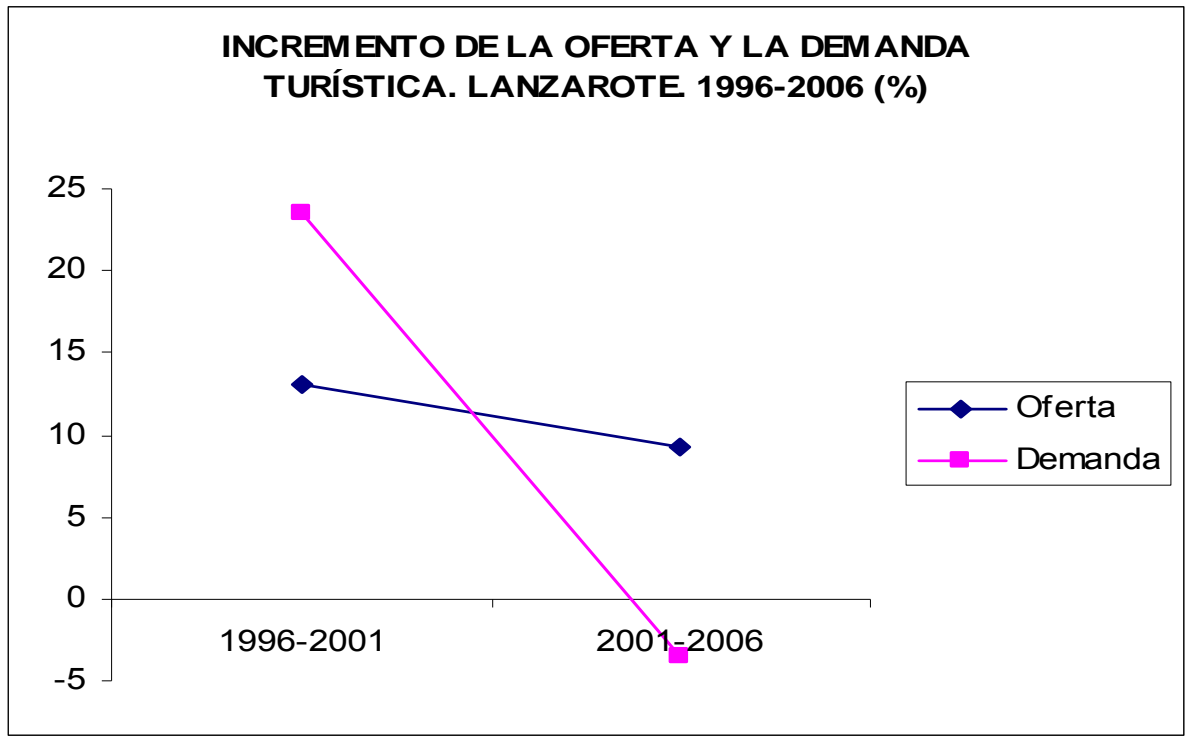

Fuente: Elaboración propia a partir de las Tablas 145 y 146.

En relación a la dinámica registrada por el sector turístico en esta última década, desde el punto de vista socioeconómico se observa lo siguiente:

A) Crecimiento de los desequilibrios demográficos por constante reducción del peso relativo de la población autóctona (nacidos en la isla) frente a los alóctonos (inmigrantes) y al conjunto de población foránea (inmigrantes y turistas equivalentes diarios). Llegando a alcanzar la cifra de 249 foráneos por cien autóctonos. La crisis de afluencia frena este crecimiento y se reducen los desequilibrios. 
Gráfico 204. Evolución de la población autóctona y alóctona. Lanzarote. 1996-2006 (\%)

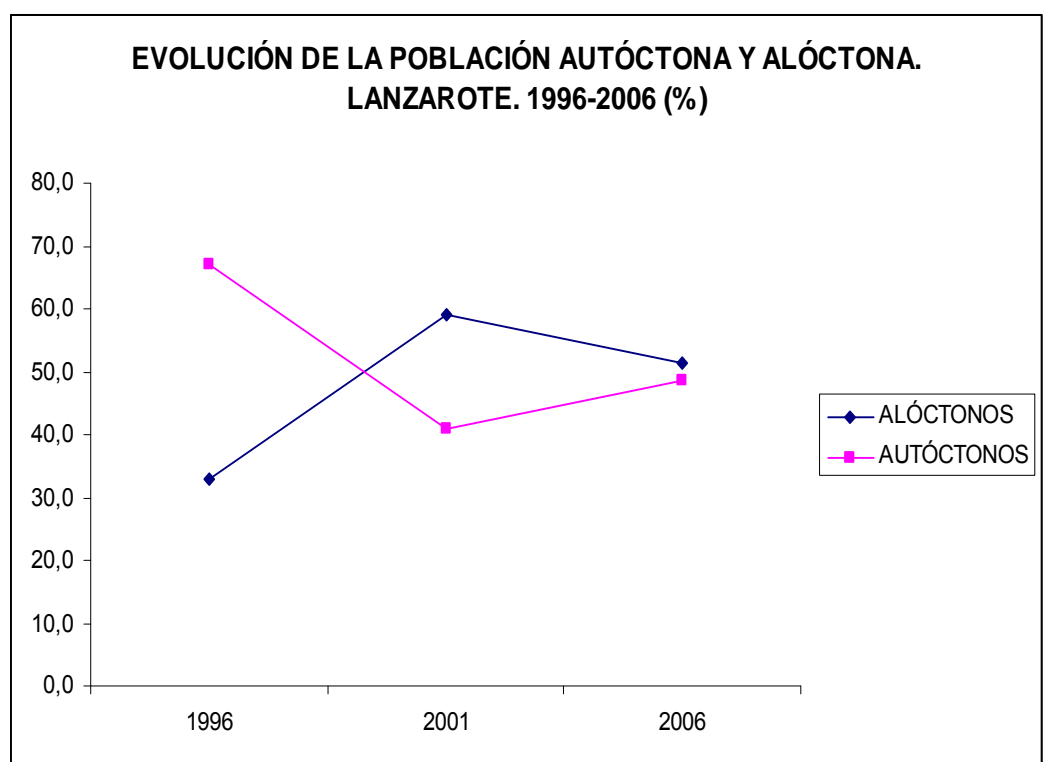

Fuente: Elaboración propia a partir de la población por lugar de nacimiento. INE e ISTAC. Expresión gráfica de las Tablas 161 y 163.

Gráfico 205. Evolución de la población foránea y autóctona. Lanzarote. 1996-2006

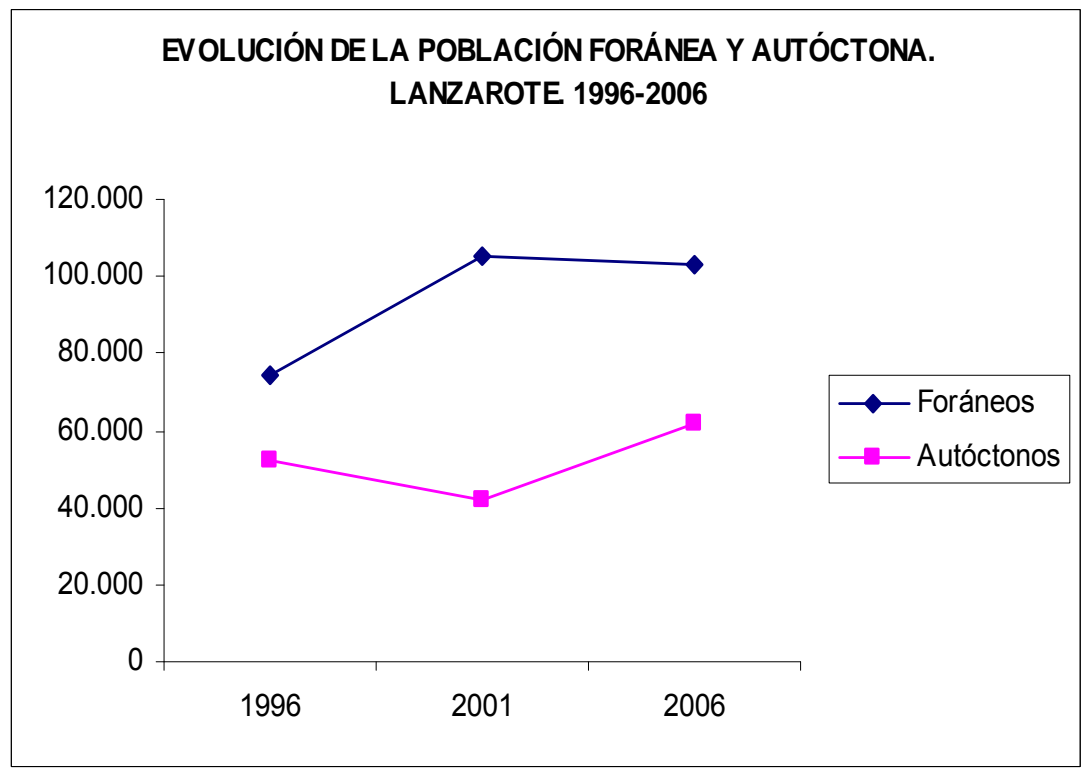

Fuente: Padrón municipal de habitantes. Explotación del ISTAC; Estimación de los turistas equivalentes diarios. Elaboración propia a partir de la Tabla 164.

B) El nivel de instrucción de la población residente se detiene en el grado medio (básica completa y formación profesional de primer ciclo), ya que la actividad turística no demanda profesionales con media-alta formación. Además los impulsos en la construcción de nueva planta turística alimentan la entrada de población externa con niveles formativos elementales, que no suponen ganancia cultural en el recurso humano insular. Aspecto que 
se modifica tras el control del ritmo de crecimiento de la oferta turística. Las nuevas generaciones parecen llegar más lejos en su nivel de formación, aunque no por exigencia del mercado laboral. Lanzarote se sigue caracterizando por ser un espacio social con bajos niveles de instrucción de su capital humano, inferiores a la media del archipiélago y de España.

Gráfico 206. Evolución del nivel de instrucción. Lanzarote. 1996-2007 (\%)

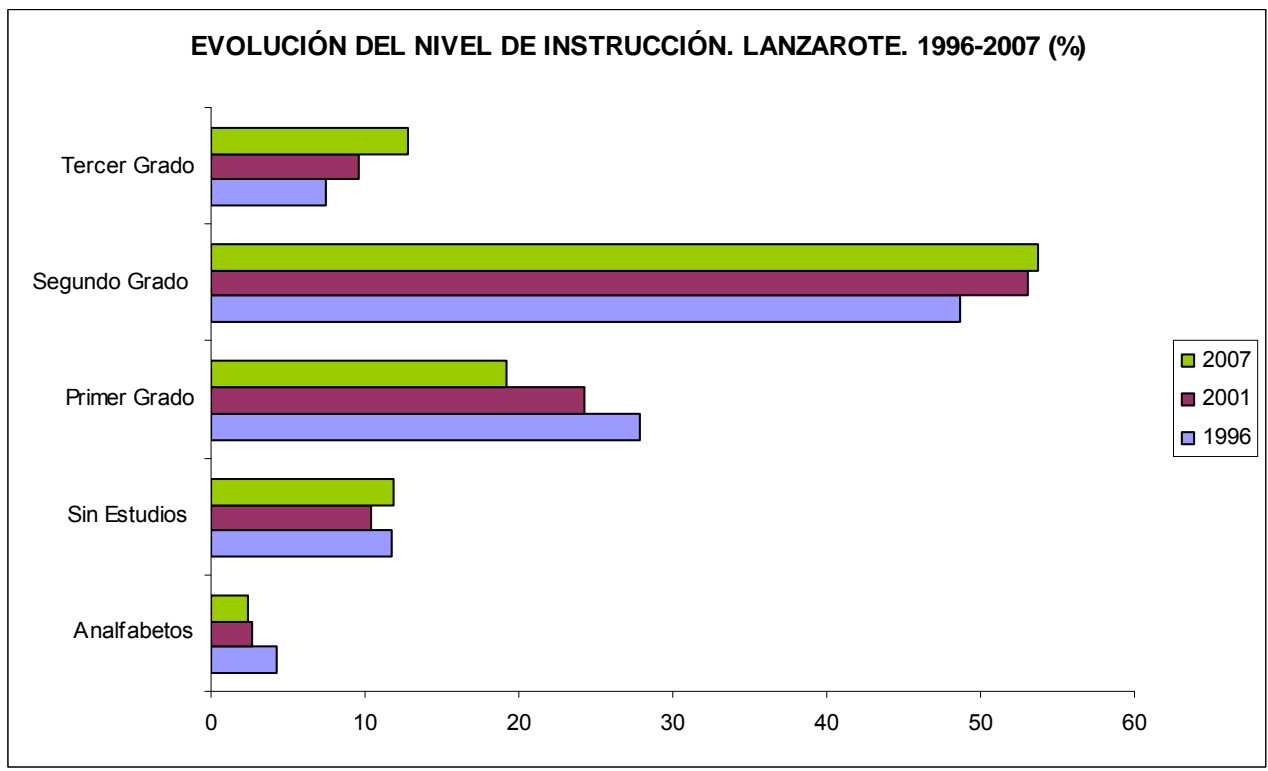

Fuente: Encuesta de Población de Canarias 1996. ISTAC; Censo de Población 2001. INE; Encuesta de Ingresos y Condiciones de Vida de los Hogares Canarios 2007. ISTAC e INE; Elaboración propia a partir de la Tabla 165.

Gráfico 207. Nivel de instrucción de la población inmigrante por procedencia. Lanzarote. 1996-2001 (\%)

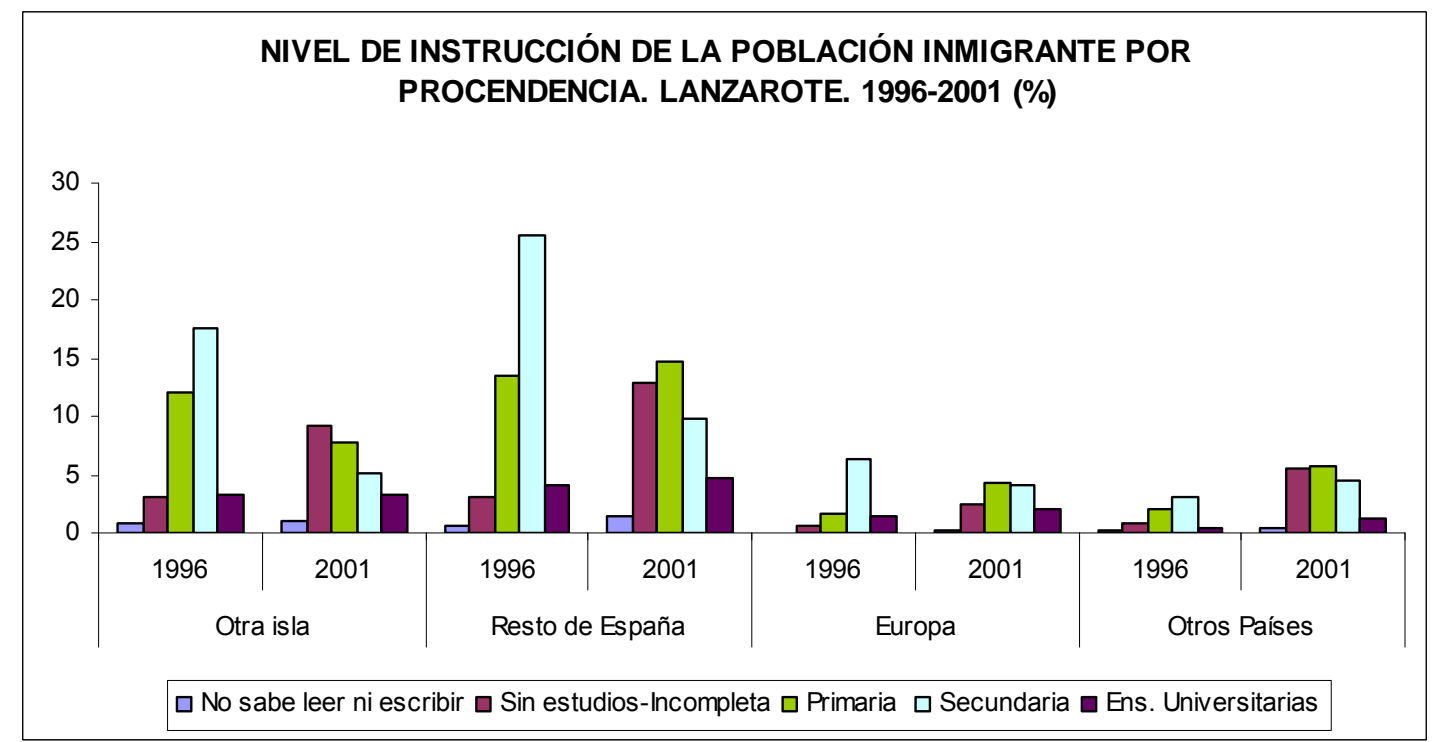

Fuente: Encuesta de población de Canarias, 1996 y Censo de población de 2001 explotación del ISTAC. Gráfico basado en la Tabla 167 y 168. Elaboración propia. 
C) Con una estructura laboral consolidada en el sector servicios basado en la actividad turística, en el servicio a persona y no a empresas, el ascenso o descenso del número de ocupados y de parados es consecuencia directa de la fluctuación de la afluencia turística (aunque no es proporcional a ella), por tanto nos encontramos ante un mercado laboral inestable, marcado por la temporalidad del empleo, con un sector agrario e industrial sin capacidad de arrastre en momentos de baja afluencia, y con consecuencias no positivas sobre el bienestar derivado. Además, dicho mercado está nutrido por población externa (inmigración), y segmentado en relación al país de origen del trabajador, con lo que existe segregación por procedencia. De ahí nace la necesidad de establecer ritmos controlados de crecimiento de la oferta y la demanda turística, basados en calidad y no en cantidad, que puedan evitar grandes variaciones de afluencia y diversificar la economía como vía para la adecuada integración social del activo laboral.

Gráfico 208. Paro registrado y afluencia turística, por meses. Lanzarote. 2006

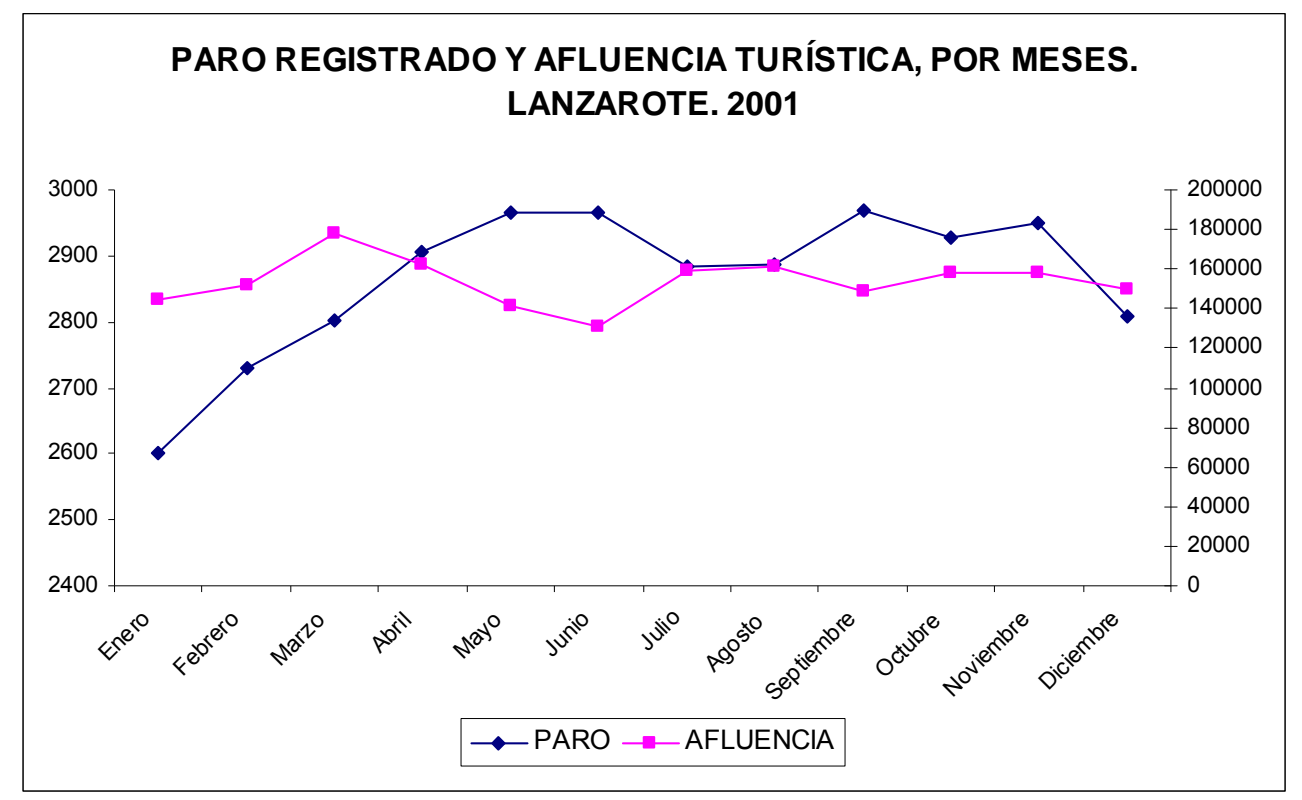

Fuente. OBECAN y Anuario Estadístico de Lanzarote 2001. Elaboración propia a partir de las Tablas 146 y 199.

D) El crecimiento del nivel de renta disponible por habitante sitúa a la isla a nivel de su Comunidad Autónoma, pero la mantiene por debajo del nacional. La jerarquización municipal, aunque ya no tan significativa como lo fue, sigue marcando cierta distancia entre los municipios que concentran la actividad turística y los que carecen de ella. 
Gráfico 209. Nivel de renta disponible por habitante. Lanzarote, sus municipios y provincia, Canarias y España, 2003.

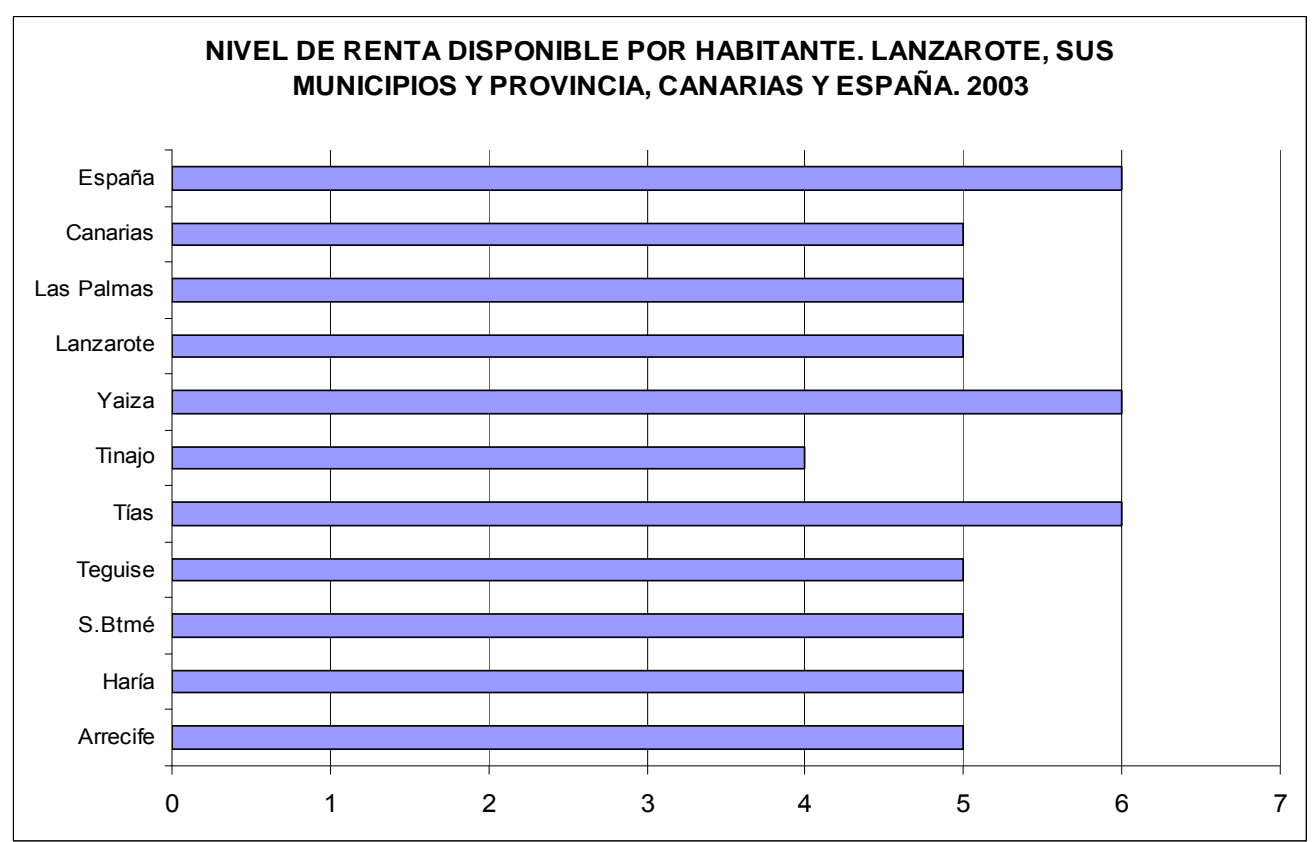

Fuente: Anuario Económico de España, 2005. Caixa. Elaboración propia a partir de la Tabla 206.

Por otro lado, en relación al equipamiento y las infraestructuras, las mejoras y los estrangulamientos seguirán explicándose por agentes exógenos (inmigrantes y turistas) y se encuentran principalmente en los siguientes puntos:

A) Las dotaciones energéticas eléctricas se amplían para abordar los rápidos crecimientos de demanda, por volumen de turistas y crecimiento constante de los residentes, a través de un mayor uso de combustibles fósiles por constituir la vía más rápida de respuesta, por lo que el sistema subsiste al límite, con grandes dificultades para parar por procesos de mantenimiento. A ello se añade una producción por energías renovables aún escasa y cara. Mayor dotación, más posibilidad de suministro, a cambio de mayor dependencia del exterior en la generación y de mayor contaminación. Bienestar energético sin garantía y seguridad en el abastecimiento y malestar medioambiental. Con niveles de consumo de energía eléctrica por PIB superiores a Canarias y España. 
Gráfico 210. Evolución de la producción y el consumo de energía eléctrica por habitante. Lanzarote (kwh/Ptotal).

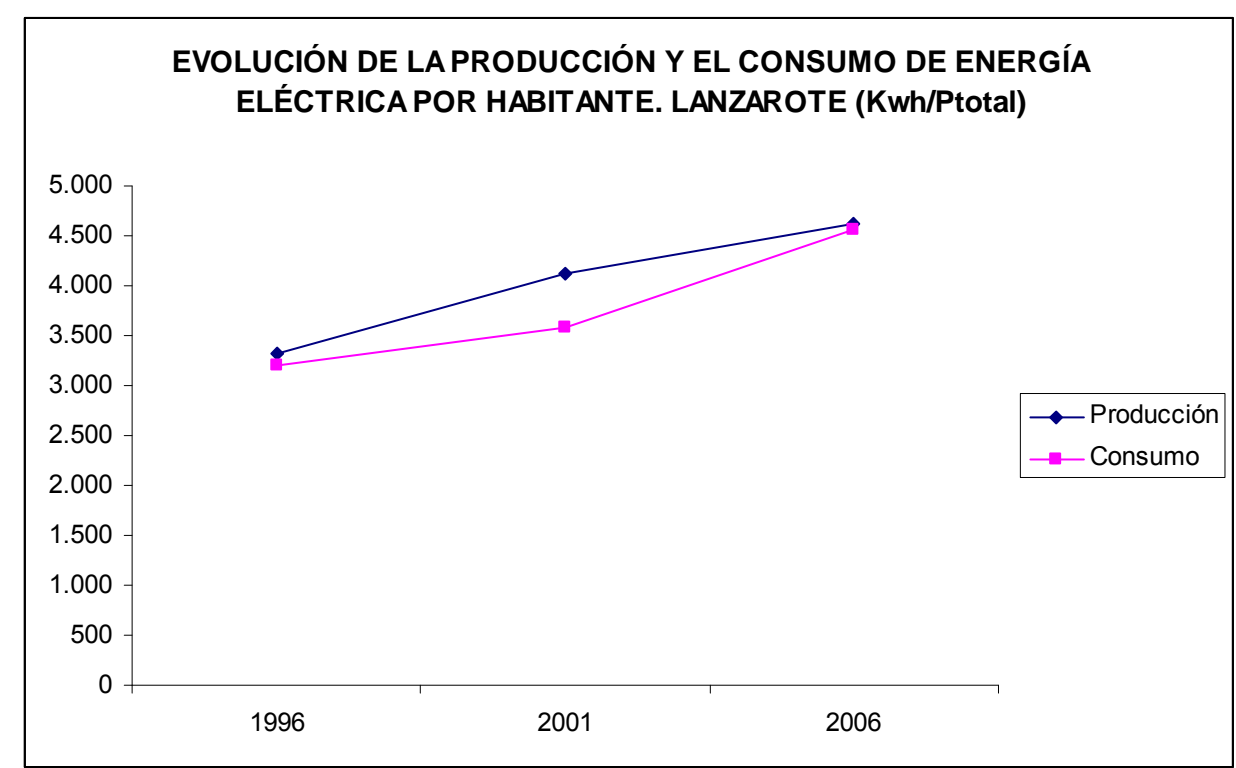

Fuente: Producción y Consumo de energía eléctrica. Centro de datos. Cabildo Insular de Lanzarote. Elaboración propia a partir de las Tablas 209 y 210.

B) Dependencia absoluta de la desalinización en la producción de agua potable, cuya capacidad no deja de crecer (por ampliación de plantas), para poder abordar el incremento de los consumos unitarios y no existe capacidad de almacenamiento, por lo que el abastecimiento depende de la producción diaria. Así el sistema subsiste al límite, con cortes periódicos para los residentes, principalmente en zonas rurales (pues los núcleos turísticosurbanos son prioritarios), sin garantía de suministro y muy vulnerable a posibles averías, ya que parar la producción para realizar el mantenimiento necesario entraña mucha dificultad por los cortes en el suministro que supone. A ello se añade el que el $14 \%$ del consumo eléctrico, aproximadamente, se emplea en la desalación, por tanto depende de la capacidad de producción energética de la Isla.

Con precios regulados en relación al tipo de consumo, el sector turístico se revela como el financiador del sistema de desalinización insular, por tanto, su influencia sobre el bienestar, en este sentido, puede ser positiva.

Adicionalmente, se aprecia un cambio en la cultura local tradicional sobre ahorro en el consumo de agua, que podría explicase por una percepción social de la desalación como fuente inagotable, y como efecto de la multiculturalidad que acoge la isla. Finalmente, y con respecto a España, la disponibilidad de agua para el consumo es inferior, Lanzarote tiene más sed y peor bienestar asociado. 
Gráfico 211. Consumo y disponibilidad de agua después de pérdidas en red. 1996-2006 (I/habdía).

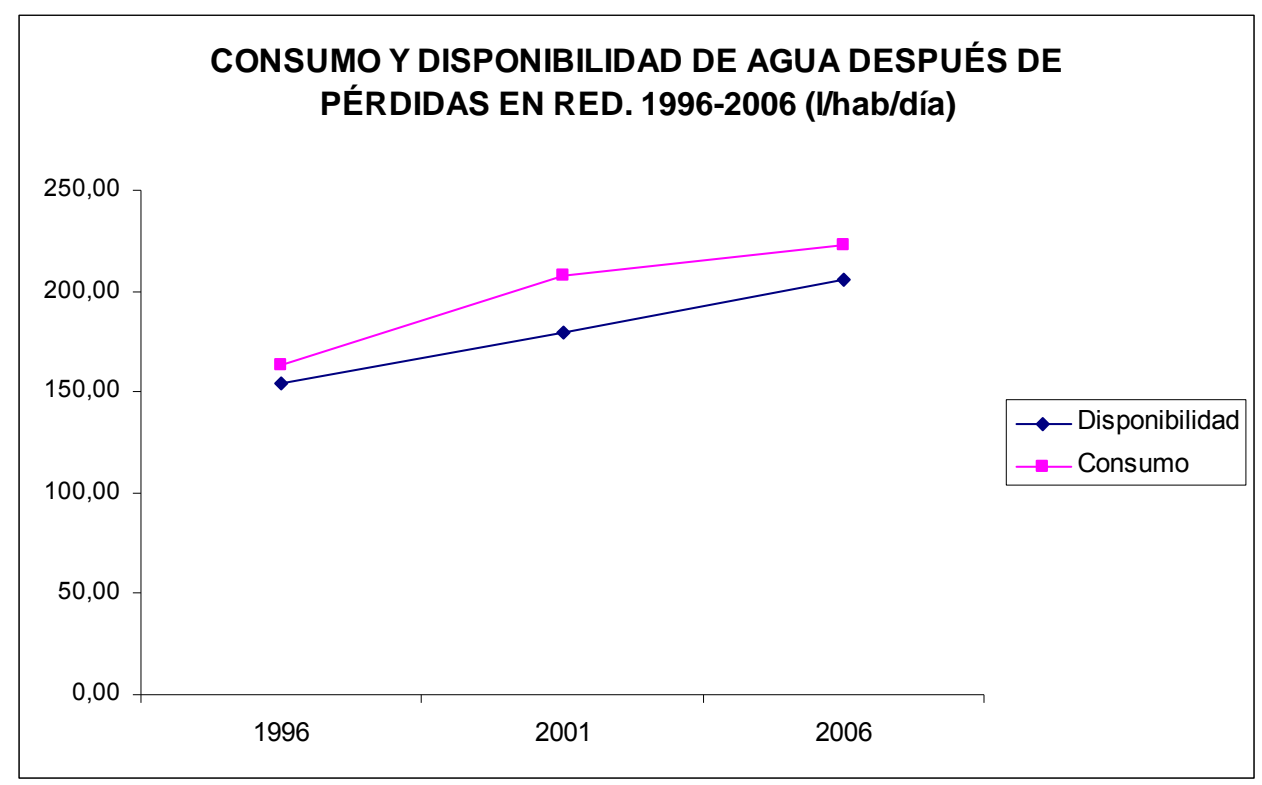

Fuente: INALSA y Centro de datos del Cabildo Insular de Lanzarote. Elaboración propia a partir de la Tabla 222.

C) La oferta sanitaria hospitalaria no llega a ajustarse a la demanda en relación a estándares de calidad marcados por la O.M.S., permaneciendo estrangulada. No ocurre así, en la oferta extrahospitalaria, pues existe cierta difusión del bienestar hacia los núcleos rurales en la medida en que se han ampliado y dispersado el número de consultorios o ambulatorios.

Por otro lado, el número de habitantes residentes por médico se ha aproximado al índice de la Comunidad Autónoma y de España en estos años, aunque con notables variaciones por su enorme sensibilidad frente a los rápidos y elevados ritmos de crecimiento de la población residente (por incorporación externa) que impulsa la constante ampliación de la oferta de alojamiento turístico, con consecuencias negativas para el bienestar social asociado a la capacidad del equipamiento sanitario tanto para residentes como para turistas.

El desarrollo de los servicios sociales se ha centrado en el área de menores (inmigrantes no acompañados) y en la mujer, atendiendo a la totalidad de las solicitudes.

En términos cualitativos, la presión demográfica ha impulsado la ampliación e incorporación de nuevas especialidades hospitalarias, reduciendo el desvío de pacientes a hospitales provinciales de referencia, y por tanto de los efectos negativos de la insularidad. 
Gráfico 212. Evolución de las camas hospitalarias por mil residentes y sobre la demanda potencial. Comparación con el estándar de la O.M.S. Lanzarote. 1996-2006.

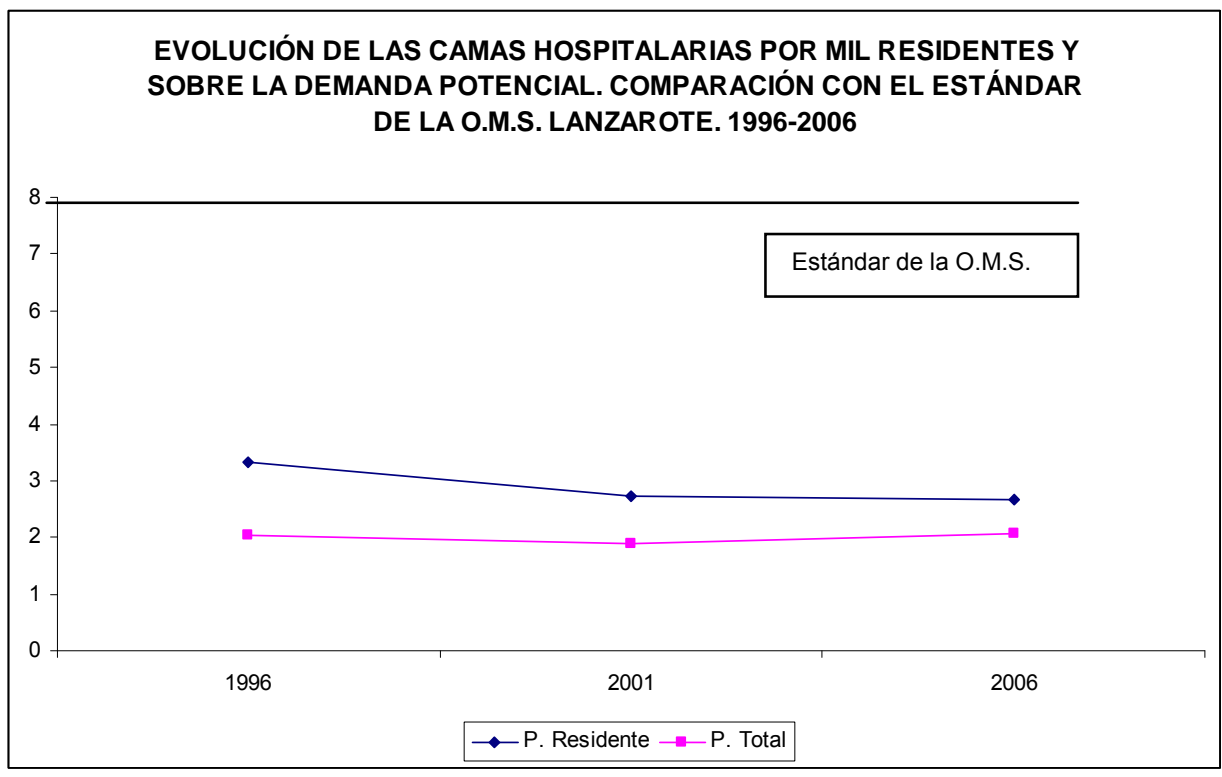

Fuente: Memoria del Servicio Canario de Salud; Centro de datos del Cabildo Insular de Lanzarote y Grupo Hospiten España. Elaboración propia a partir de la Tabla 179.

Gráfico 213. Evolución del ratio habitantes/médico, en relación a la población residente y la población total estimada. Lanzarote. 1996-2006

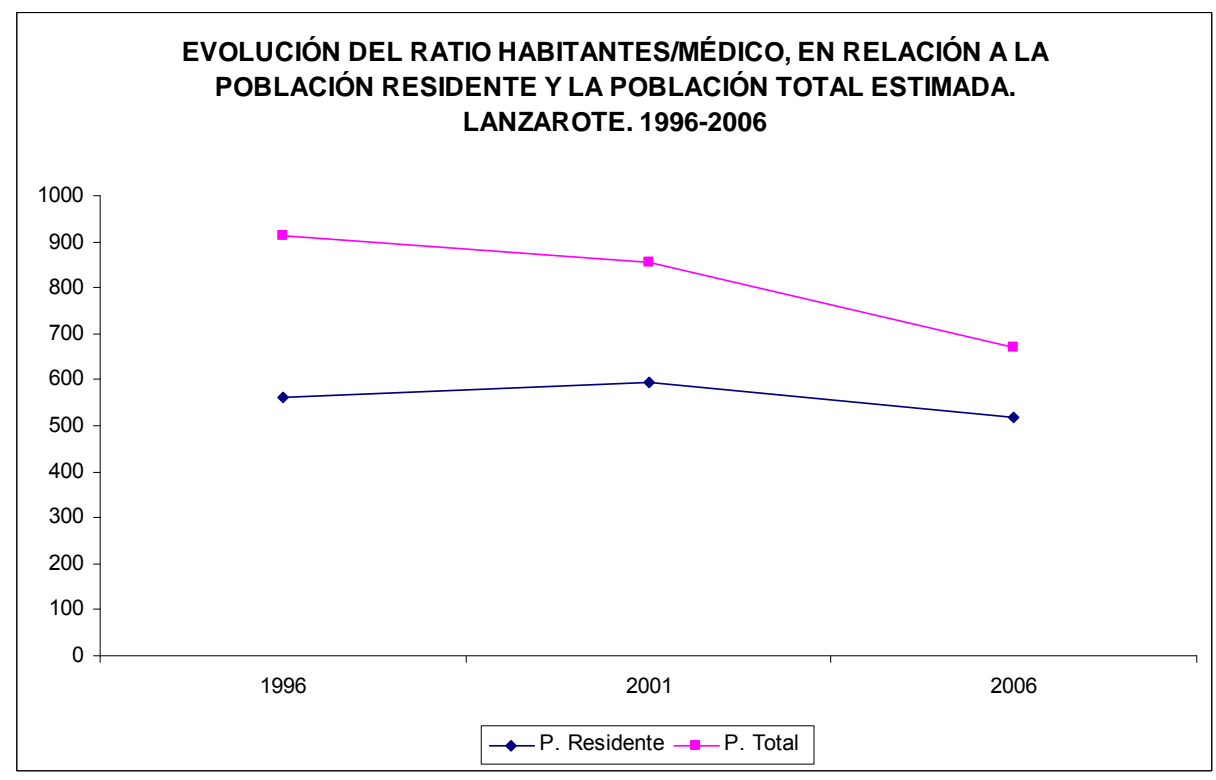

Fuente: Recursos humanos del Servicio Canario de Salud; Recursos Humanos del Hospital Insular, recogido por el. Centro de datos del Cabildo Insular de Lanzarote. Elaboración propia a partir de la Tabla 183.

D) Las dotaciones destinadas a la enseñanza obligatoria y la infantil tienen suficiente capacidad de cobertura, como se observa en el Gráfico 214. Los déficits se detectan en el ámbito no obligatorio, principalmente dentro de la educación de adultos y en la educación 
especial, que en este sentido dificulta las posibilidades de integración social de las discapacidades.

Desde un punto de vista cualitativo, los problemas educativos insulares se centran, en este comienzo de siglo, en atender la enorme heterogeneidad cultural e idiomática del nuevo alumnado procedente del exterior (para la que se necesita profesorado especializado), que, en términos relativos, supone más del doble del que concentra el conjunto del Archipiélago y España.

Gráfico 214. Alumnos por unidad y profesor y estándar, por tipo de enseñanza. Lanzarote. 1996-2001

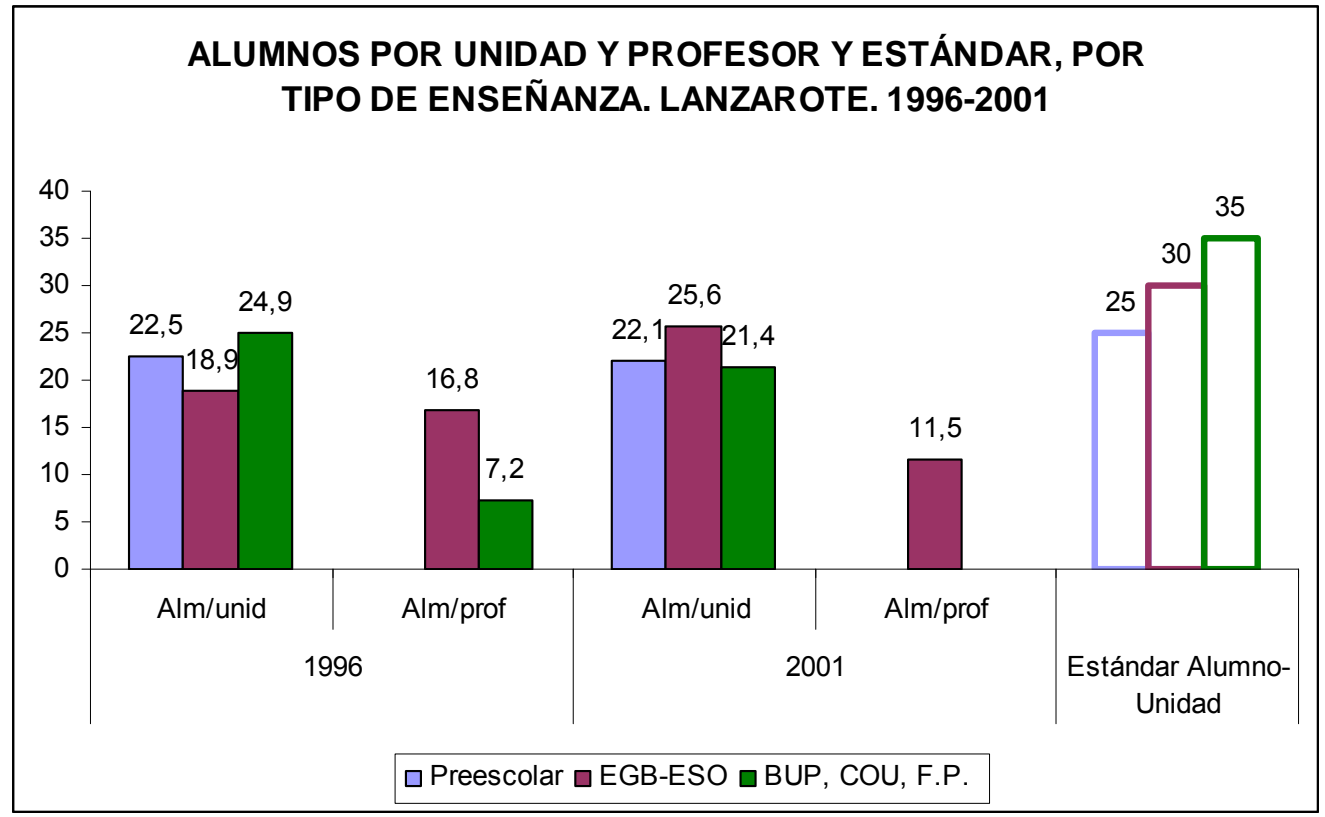

Fuente: Anuario Estadístico de Canarias. 2001. ISTAC; Consejería de Educación, Cultura y Deportes. Gobierno de Canarias. Elaboración propia a partir de las tablas 106 y 171.

E) Mejoras en la accesibilidad, sin incrementos de la velocidad para garantizar la seguridad, a través del ancho de vía, principalmente en los tramos que conectan zonas de concentración de la oferta turística con la capital de la Isla y el aeropuerto, impulsada por los crecimientos de las intensidades medias diarias de tráfico en estos tramos, sin responder a una planificación global del viario.

F) El principal medio de transporte sigue siendo el vehículo privado, con la consecuente continua elevación de los niveles de motorización de la población residente, con efectos negativos medioambientales derivados. El transporte público mejora en cantidad y calidad, aunque la estructura de la red potencia el paso obligatorio de todas las líneas por la capital de la isla, lo que incide es su escaso uso, además de enfrentarse a una concepción colectiva peyorativa por parte de la población residente, que percibe su uso como indicador de clase social. A ello se añade el que los trayectos por ocio son escasos, 
con lo que el turismo no es un factor que impuse mejoras. Adicionalmente los transportes alternativos no se han impulsado suficientemente

Gráfico 215. Evolución del número de vehículos e índice de motorización (turismos) de la población residente y del total de población estimada. Lanzarote. 1996-2006

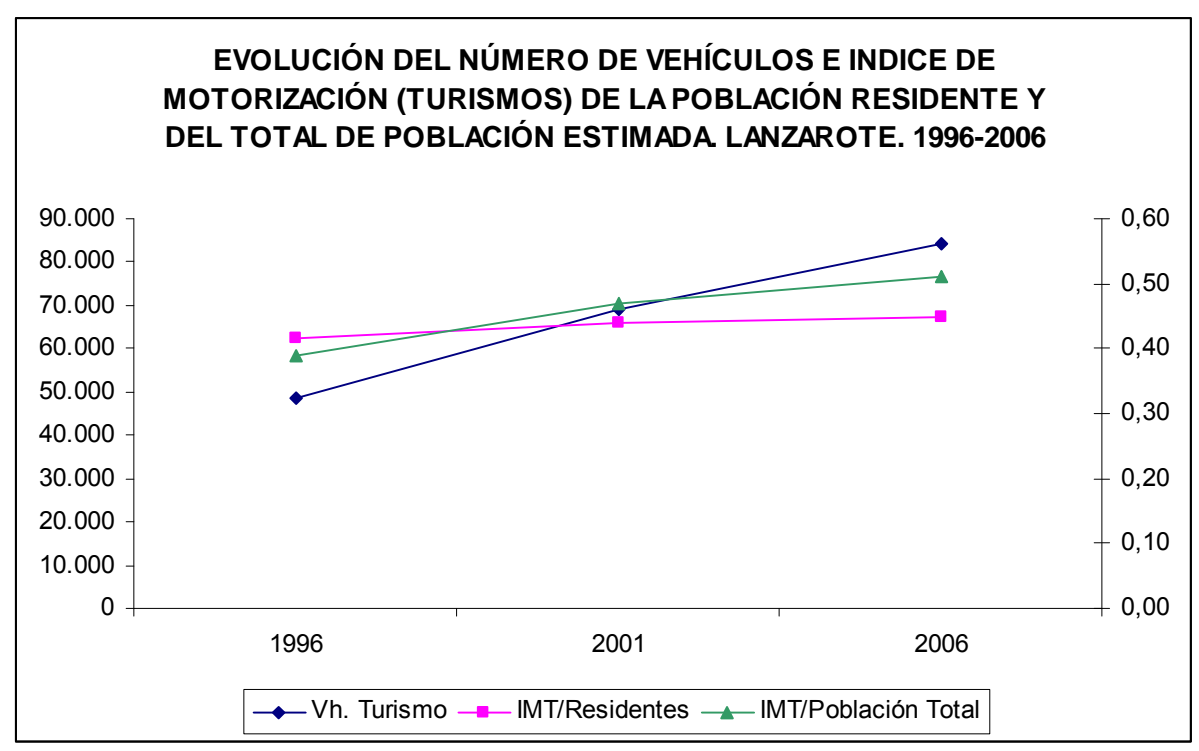

Fuente: Parque de vehículos según clases. Anuario Estadístico de Canarias. ISTAC; Elaboración propia a partir de las Tablas 228 y 229

Gráfico 216. Evolución del índice de motorización (turismos) sobre la población total estimada. España, Canarias y Lanzarote. 1996-2006

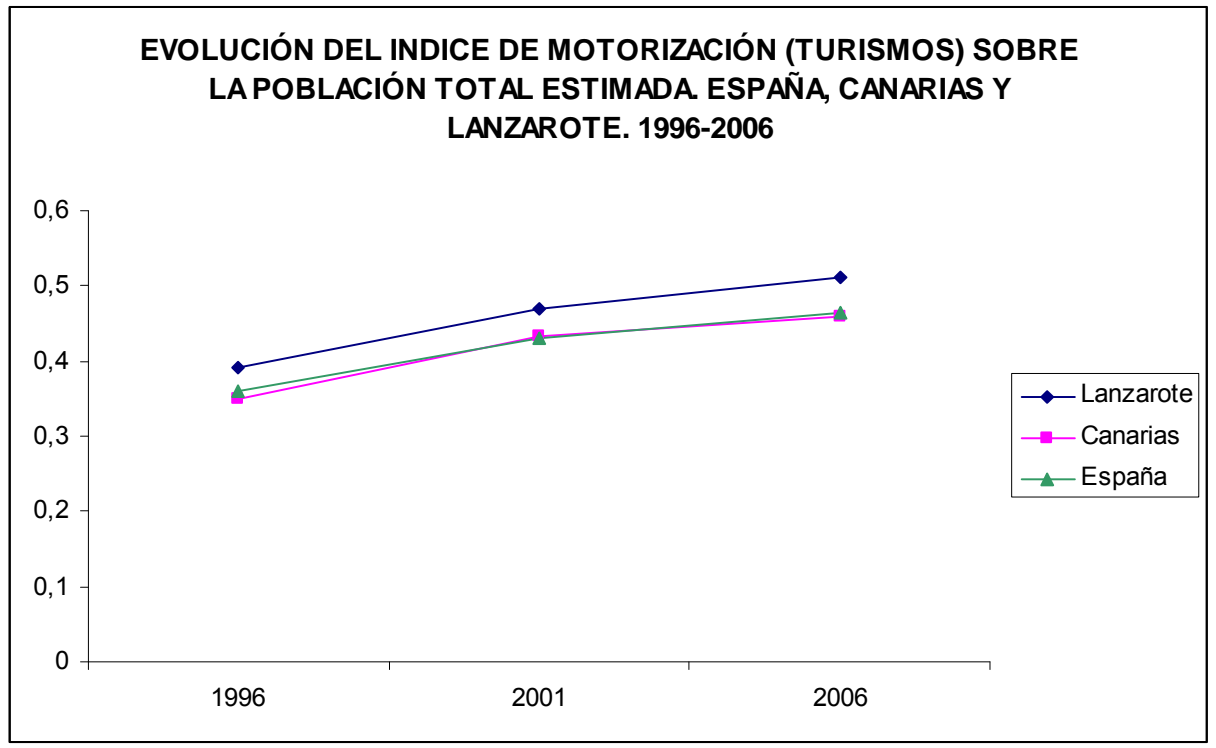

Fuente: Parque de vehículos según clases. Anuario Estadístico de Canarias, ISTAC; y Anuario Estadístico del Ministerio de Fomento. España; Elaboración propia a partir de la Tabla 229. 
En términos generales la contención de los rápidos crecimientos demográficos que vienen aconteciendo en la isla es la principal vía para poder revertir las limitaciones que presenta el territorio en los ámbitos de bienestar señalados. Contención alcanzable por el camino de la limitación de la oferta del alojamiento turístico o ralentización de su crecimiento a ritmos asumibles, en términos que garantice una provisión adecuada de los servicios, como vía para la mejora del bienestar social.

El análisis de los procesos efectuados confirma una conclusión tradicional de este tipo de estudios cual es que la calidad, y no la cantidad, debe presidir las políticas de desarrollo turístico. El modelo turístico de masas es el generador de los desajustes. 


\section{Capítulo 4}

DIMENSIONES DEL CAMBIO INSULAR.

ANÁLISIS INTEGRADO Y APORTACIONES FINALES 



\section{CAPÍTULO 4.- DIMENSIONES DEL CAMBIO INSULAR. ANÁLISIS INTEGRADO Y APORTACIONES FINALES}

\section{1.- INTRODUCCIÓN}

El turismo, en cuanto que comprende las actividades que realizan las personas durante sus viajes y estancias en lugares distintos al de su entorno habitual, por un periodo de tiempo consecutivo inferior a un año con fines de ocio, por negocios y otros, es un fenómeno social que produce afecciones de diverso tipo sobre las sociedades receptoras, por interacción directa o indirecta con las poblaciones locales. Es por ello que el turismo, en sí mismo, y los tipos o modelos de turismo (su industrialización), de forma particular, serán determinantes en el análisis de las afecciones que genera sobre las sociedades anfitrionas, pues suponen la transformación territorial y sociocultural de las mismas. Se establece por tanto, como una poderosa fuente de cambio social, ya que genera transformaciones observables en el tiempo, y afecta, de una manera no efímera, a la estructura o al funcionamiento de la organización de una colectividad dada y modifica el curso de su historia. La dirección que tome el cambio social, es decir, la capacidad de influencia del turismo sobre la sociedad receptora varía en relación a variables endógenas, al estado de evolución y desarrollo en que se encuentra en el momento en que incorpora esta actividad, a las características de su estructura social.

Como factor de cambio, el marco epistemológico utilizado se enmarca dentro de la Teoría Sociológica que concentra discursos que se mueven sobre la disyuntiva de si el turismo es un factor de desarrollo de las sociedades receptoras, o por el contrario, un reflejo del subdesarrollo y dependencia.

Así, el proceso productivo turístico, analizado en ésta tesis, se configura en forma de "turismo masificado o de masas", caracterizado por la afluencia continua (de enorme volumen y medida en estadísticas sobre pernoctaciones) y una oferta estandarizada, alojada en hoteles, apartahoteles y campamentos de turismo, que constituye una masa dirigida y pasiva. Se organiza alrededor de un gran núcleo turístico «ociourbe», con fuerte aparato comercial, relacionado con estancias cortas (itinerante) y gran concentración de servicios adicionales, y segmentos de demanda cuyo poder adquisitivo condiciona la variedad y calidad de dichos servicios. Este modelo de turismo responde a los objetivos definidos como las cuatro "S": sun (sol), sex (sexo), sea (mar) y sand (arena), y en el cual los mayoristas van haciéndose cargo del mercado de un modo creciente y absoluto, convirtiendo su economía en dependiente del exterior. Dicho modelo ha sido estudiado en relación a efectos generados en el estado y la evolución de áreas concretas del bienestar social, sobre un universo insular, Lanzarote, pues una isla reúne, por sus propias circunstancias físicas, 
ambientales y socioeconómicas, un espacio idóneo para la investigación de tales fenómenos complejos.

Partiendo de este marco general descrito, no interesa aquí desentramar el carácter social del turista, sino que el objetivo principal se centra en demostrar cómo ciertas formas de turismo pueden significar pérdida de bienestar para los habitantes de territorios que ven desbordada su capacidad de carga asociada, a consecuencia de la implantación y crecimiento de una actividad turística en forma de "turismo masificado o de masas". Consecuentemente, el beneficio que originalmente presenta el turismo desde la perspectiva del crecimiento económico y la transformación social, se puede ver negativamente compensado por dinámicas de transformación territorial, económica y social que revierten estos beneficios y terminan afectando al bienestar de los ciudadanos residentes en el territorio.

Para ello, este análisis, se adentra en el periodo histórico en el que, Lanzarote, sufre los principales procesos de transformación territorial como consecuencia de una dinámica turística que afecta radicalmente a ésta, arranca del año 1970 con adscripción a políticas desarrollistas que se aplican en la ordenación territorial, para finalizar en el año 2006, cuando la isla es un destino de masas maduro, con nuevas políticas de ordenación basadas en moratorias al crecimiento de la actividad y objetivos de sostenibilidad. A lo largo de este recorrido temporal se analizan los cambios experimentados, en saltos evolutivos quinquenales, en aquellas áreas de afección básicas sobre el bienestar social, es decir sobre condiciones de vida objetivas (estructura demográfica, cualificación y equipamiento educativo, dotaciones de salud, estructura laboral, renta, energía, agua y comunicaciones por carretera), estudiado comparativamente a los procesos de crecimiento de la oferta y la demanda turística, como variable que presiona dichas condiciones de vida, con efectos para la población insular residente y su bienestar. Se ha entendido, por tanto, el bienestar social como un concepto objetivo y objetivable, multidimensional y multidisciplinar, mensurable a través de indicadores sociales objetivos, y referido al acceso a servicios primordiales, recogidos como derechos, que tiene reflejo en el nivel de vida y en el estado de la igualdad de oportunidades, para la mutua adaptación de los individuos y de su entorno social. Por tanto habrá correspondencia entre bienestar, nivel de satisfacción de las necesidades y desarrollo. Sin olvidar que cada uno de los elementos que componen el bienestar se relaciona, afecta y es afectado por los otros componentes.

Este periodo de análisis, que cubre, aproximadamente, treinta y cinco años, tiene como principio ordenador los distintos Planes de Ordenación del Territorio que se han ido sucediendo desde la década de los años setenta y que se han establecido como la guía para determinar tres grandes etapas de desarrollo turístico que van a afectar de diferente forma a las áreas básicas de bienestar analizadas. 
La primera de ellas abarca desde 1970 hasta 1986, marcada por un modelo de planificación (Plan Insular de 1973) que impulsa un fuerte crecimiento de la oferta turística basado en la presión constante sobre la demanda de suelo y el incremento de la afluencia, en el que se permite edificar y urbanizar directamente, a través de Planes Parciales, sin enmarcarse en un ámbito planificado municipal o insular ${ }^{242}$. Es la etapa de producción del espacio turístico, etapa desarrollista, en la que se interpreta el turismo desde una perspectiva compensatoria, propia de corrientes sociológicas humanistas, puesto que se percibe como una actividad que propicia la productividad, principalmente en países en vías de desarrollo, para los que se concibe como una oportunidad de incorporación a las culturas y estructuras productivas de países desarrollados, a la vez que ésta actividad se percibe como favorable a la comprensión y acercamiento entre los pueblos, idea, además, impulsado por organizaciones internacionales como la OCDE y la OMT, el Banco Mundial y la ONU. Por tanto, como señala Hirsh (1985, pp. 15), la búsqueda de crecimiento económico es el factor que actúa como significación social legitimadora básica de las políticas de esta primera etapa, a partir del cual se podrá alcanzar mayores cuotas de bienestar social. Este será el único sentido del turismo y del turismo masivo. La búsqueda de su importante impacto económico atraviesa las políticas nacionales y locales, que mostrarán actitudes positivas hacia la continua expansión de la actividad. Es por ello que este periodo arroja la mayor pendiente en el crecimiento tanto de la oferta como de la demanda turística y es el que modifica, radicalmente, la estructura socioeconómica y territorial de la isla, con efectos sensibles sobre aspectos concretos del bienestar social insular.

La segunda etapa, establecida desde el final de la anterior, 1986, hasta al año 1996, recoge el resultado de los procesos que han venido dándose desde la década de los años sesenta. Periodo que comienza con un análisis y replanteamiento, por parte de la Administración Pública, de cómo ha tenido lugar el proceso de desarrollo turístico, que desemboca en la aprobación, en 1991, del Plan Insular de Ordenación del Territorio de la isla de Lanzarote, pues no se estaba produciendo una correcta interrelación entre el turismo y el conjunto de la economía, con consecuencias sobre la estructura social y el bienestar. Se cuestiona el turismo en cuanto a su capacidad para generar un desarrollo económico continuado.

Este PIOT establece, por primera vez, unas capacidades máximas de alojamiento turístico, que suponen directriz vinculante de aplicación directa e inmediata para el planeamiento municipal, y una programación del desarrollo de la edificabilidad hasta el año 2002,

\footnotetext{
242 Plan Insular de Ordenación del Territorio de 1973 aprobado por Resolución del Ministerio de Vivienda, que asume el carácter de Norma Subsidiaria de Planeamiento con la correspondiente clasificación del suelo y normativa de edificación y convierte la mayor parte de las superficies utilizables de la isla en suelo de reserva urbana a desarrollar por Planes parciales. En 1982 se aprueba un Plan Insular de Ordenación Turística de Lanzarote, pero este no se realiza con criterios operativos y no tiene ninguna competencia de intervención.
} 
adaptando la capacidad de alojamiento turístico y residencial a cada municipio, con la intensión de hacer compatible el ritmo de la oferta con la inversión pública y que no desborde el ritmo de la demanda. Llega cuando la isla ya ha quedado especializada en una economía terciaria-turística, basada en el servicio a personas y no a empresas, por tanto sin diversificación, que ha desarticulado las bases de producción y comercialización del sector primario y la industria. Pasó de la dependencia del sector primario a la dependencia de ingresos por turismo, es decir, a una economía completamente dependiente del exterior. Aplicando la visión que arrojan las Teorías del Conflicto, se podría ahora entender el turismo en términos de "imperialismo", en la medida en que el poder que somete a las regiones menos desarrolladas viene de grandes centros metropolitanos de los países y regiones desarrolladas, que gozan de diversos grados de control sobre la naturaleza y crecimiento del turismo en sociedades anfitrionas y por tanto de su crecimiento económico. La posibilidad de crecimiento económico continuado, ha sometiendo a las sociedades anfitrionas a los intereses de expansión de las sociedades industrializadas.

Así, esta segunda etapa observa un incremento del crecimiento la oferta menor que en la etapa anterior, aunque la demanda (afluencia) seguirá creciendo. Los efectos sobre áreas concretas del bienestar social insular, presentarán variaciones en relación a la primera etapa de implantación y consolidación de la economía turística.

La tercera etapa, que cubre el periodo que va desde 1996 hasta 2006, en la que Lanzarote ya es un destino turístico de masas maduro, está marcado por la orientación legislativa, urbanística y política, hacia la sostenibilidad del territorio, asumiendo como base el concepto de capacidad de carga. Para lo cual se parte de la necesidad de modificar, diversificar y contener su oferta turística, haciéndose necesario revisar la Ordenación del Territorio vigente, aprobando en el año 2000 una Moratoria Turística (Decreto 95/2000), pues se parte de entender que el equilibrio del sistema insular y la calidad de vida y bienestar de su población pasa por moderar la presión humana, conteniendo el ritmo de crecimiento de la oferta y la demanda turística, como vía que permita ritmos compatibles con la capacidad de asimilación insular. La dinámica de crecimiento de la actividad turística que hasta ahora ha llevado la isla, se define con el factor o variable que empuja hacia la no sostenibilidad y la irreversibilidad de la situación de degradación (sociocultural, medioambiental y económica), su ruptura es la que puede revertir el curso del estado del bienestar social insular. Junto con esta nueva planificación, la isla se enfrenta a una crisis del sector turístico por crecimiento negativo de la afluencia. Ambos procesos suponen efectos directos sobre el bienestar social, puesto que el modelo socioeconómico insular está basado en el monocultivo del turismo y es dependiente del exterior. La Moratoria Turística estará vigente cuatro años, será derogada en el año 2006, tiempo insuficiente para obtener resultados reales. Consecuentemente dicha fecha marca el límite temporal con el que finaliza esta tesis. 
La siguiente figura muestra la dinámica de crecimiento de la actividad turística, en su oferta y demanda, que condiciona todos los cambios acontecidos en el periodo en el que este trabajo se inscribe.

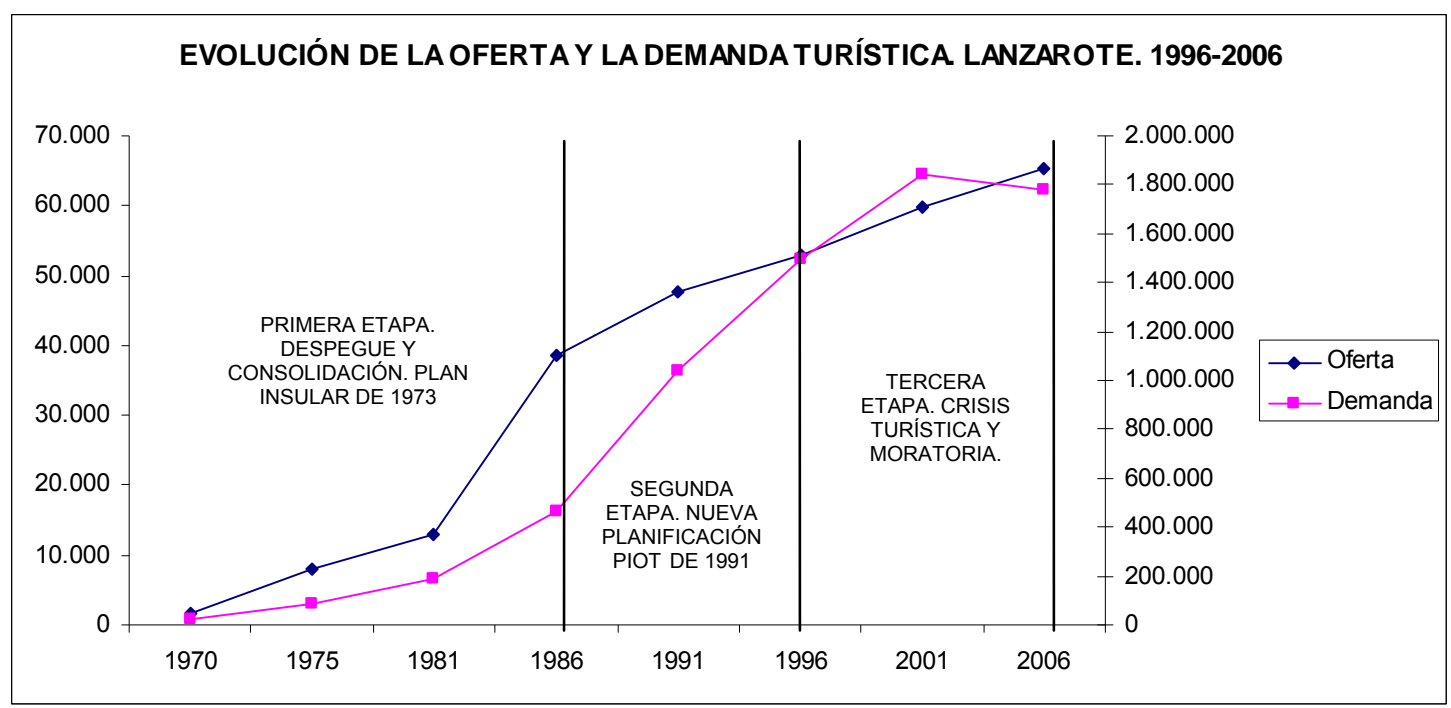

Fuente: Economía Canaria, 1969 y 1970. C.I.E.S; Plan Insular de la Isla de Lanzarote, 1973. Ministerio de Vivienda. Plan de Ordenación de la Oferta turística de la Isla de Lanzarote, 1983; Rodríguez Martín, J.R (1985); Estadísticas Básicas de Canarias, 1978-1992. ISTAC; Avance PIOT de Lanzarote, 1987. Cabildo Insular de Lanzarote; Anuario Estadístico de Lanzarote, 1992, 1996, 2001 y 2006. Centro de datos y Oficina de Turismo Interior Cabildo Insular de Lanzarote. Elaboración propia a partir de las Tablas 10, 17, 84, 85, 145 y 146.

Dicho lo cual, este último capítulo se dirige hacia la reflexión y recopilación de los indicadores medidos y la información recogida a lo largo de su evolución, de forma interrelacionada e integradora, con el fin de extraer la verdadera dimensión del cambio insular, en términos de bienestar, del proceso acaecido en Lanzarote en treinta y cinco años, en su sociedad y territorio, derivado de la implantación del modelo turístico de masas.

Para llevar a cabo esta integración es necesario un hilo conductor, decantándonos por uno de los indicadores muy vinculado al proceso productivo, económico, y al nivel de vida, como es el factor renta, puesto que las bondades del turismo, sobre las sociedades anfitrionas no industrializadas y subdesarrolladas, han partido de la potenciación de este sector como vía de crecimiento y desarrollo económico, entendiendo que es éste el que actúa como significación social legitimadora básica en la implantación de la actividad, ya que genera una serie de repercusiones sobre factores, como la tierra, el trabajo y el capital, que supone una mejora en la cantidad de los inputs de una economía. De ello se espera que deriven incrementos positivos, en general, sobre la renta disponible personal o familiar de su población anfitriona y una vía para alcanzar mejoras en el acceso a bienes y servicios de consumo. 
Como indicador sintético básico de la economía, el factor renta, no es suficiente para concluir sobre los estados del Bienestar en los diferentes momentos de desarrollo de la actividad turística, por lo que junto a su dinámica se integran el resto de áreas que se han establecido como de afección básica, o fundamentales.

Partimos para ello, en las próximas líneas, de la necesaria homogeneización del indicador renta per cápita, imprescindible para su comparación diacrónica y que nos dará pie para, posteriormente, establecer las interrelaciones con el resto de los indicadores tratados en su relación con la evolución turística. $\mathrm{Y}$ obtener una mirada integradora respecto al curso y devenir del estado del Bienestar en la sociedad de Lanzarote, alcanzando la cobertura de los objetivos de esta tesis.

\section{2.- HOMOGENEIZACIÓN DE LAS SERIES Y EVOLUCIÓN DE LA RENTA PER CÁPITA A PRECIOS DE MERCADO}

Una de las carencias graves y características de las estadísticas económicas es la escasa información disponible sobre la renta personal y su distribución, tanto a nivel social como a nivel territorial.

Las primeras informaciones disponibles sobre la distribución municipal o personal de la renta, en las décadas de los sesenta y setenta del siglo XX, provenían de fuentes sindicales o de Estudios Económicos ligados a organismos locales (Diputaciones, Cámaras de Comercio, etc.) y su fiabilidad era difícil de contrastar. A nivel provincial el Servicio de Estudios del Banco Bilbao realizó una tarea encomiable, pero esta información era difícil de trasladar a ámbitos como las islas o los municipios. No es hasta que el Servicio de Estudios del Banco Banesto realiza modelos de adecuación entre la renta provincial y la renta municipal, publicados en sus Anuarios del Mercado Español, que podemos disponer, con un cierto margen de error, pero con suficiente valor en cuanto a niveles relativos de renta per cápita, de una aproximación a la renta per cápita promedio de los municipios españoles mayores a mil habitantes, junto a una serie de información municipal sistematizada que, por ser casi la única disponible, ha sido históricamente de gran utilidad para los análisis territoriales. Sin embargo, los problemas de esta entidad hacen que en 1993, con los datos de 1991, dejen de publicarse estos Anuarios.

Para el año 1996, sin embargo, Banesto fue sustituido en la publicación de una información semejante (Áreas comerciales, índices municipales y provinciales, etc.) por la Caixa que, hasta el año 2003 proporcionó similar información para la aproximación a los niveles de renta municipal y para algunas otras de las variables recogidas en el Anuario de Banesto, aunque con distinta metodología, en particular para determinar los intervalos de renta per cápita asignable a cada municipio (calcula la renta familiar disponible por habitante a partir de la renta familiar total asignable al municipio y la divide entre el volumen de población del 
mismo). En el año 2005 dejan de realizar esta estimación de renta per cápita municipal, siendo el año 2003 el último año para el que disponemos de esta información.

En ambos casos se definían 10 niveles de renta per cápita para los municipios a partir de la aplicación de diferentes modelos a los correspondientes niveles provinciales y nacionales, pero con base a variables y metodologías diferentes. No obstante, el hecho de que en ambos casos sean los datos nacionales, autonómicos o provinciales los que, en su caso, se utilizan para ajustar los modelos y que, para estos últimos existe una estadística oficial del Instituto Nacional de Estadística (Contabilidad Regional de España. INE) que nos hace posible mantener una homogeneidad diacrónica en la comparación, nos permite utilizar las cifras aportadas por fuentes tan diversas a la hora de estimar cuál ha podido ser una aproximación a la evolución económica de los correspondientes municipios y la influencia que han tenido las variables ligadas al turismo en los mismos.

En primer lugar es pertinente, por la tanto, tener en cuenta que la evolución que consideraremos se tiene que homogeneizar a un único indicador, hecho que realizaremos a través de la evolución del PIB per cápita a precios corrientes de mercado, de España, de Canarias y de la provincia de Las Palmas, proporcionados por el INE para el período 19812006 y por la Fundación BBVA para 1970 y 1975, una vez homogeneizados los datos correspondientes por Julio Alcaide $(2003)^{243}$. Como resultado, los datos y la evolución correspondiente se recogen en el cuadro y la figura siguiente.

Tabla 233. Evolución del PIB per cápita a precios corrientes de mercado. Las Palmas, Canarias y España. 1970-2006 (€)

\begin{tabular}{||l||c|c|l|l|l|l|l|l|l||}
\cline { 2 - 10 } \multicolumn{1}{c|}{} & $\mathbf{1 9 7 0}$ & $\mathbf{1 9 7 5}$ & $\mathbf{1 9 8 1}$ & $\mathbf{1 9 8 6}$ & $\mathbf{1 9 9 1}$ & $\mathbf{1 9 9 6}$ & $\mathbf{2 0 0 1}$ & $\mathbf{2 0 0 3}$ & $\mathbf{2 0 0 6}$ \\
\hline \hline Las Palmas & 450 & 999 & 2.546 & 4.588 & 6.580 & 11.785 & 16.513 & 18.242 & 20.749 \\
\hline Canarias & 427 & 956 & 2.571 & 4.733 & 7.001 & 11.476 & 15.764 & 17.424 & 19.923 \\
\hline España & 501 & 1.119 & 2.714 & 5.049 & 8.371 & 12.003 & 16.715 & 18.639 & 22.335 \\
\hline \hline
\end{tabular}

Fuente: Elaboración propia a partir de los datos del INE en Contabilidad Regional de España y Alcaide, J. (2003).

243 Alcaide Inchausti, Julio (2003).- "Evolución Económica de las Regiones y Provincias Españolas en el siglo XX". Fundación BBVA. Bilbao. 2003. 


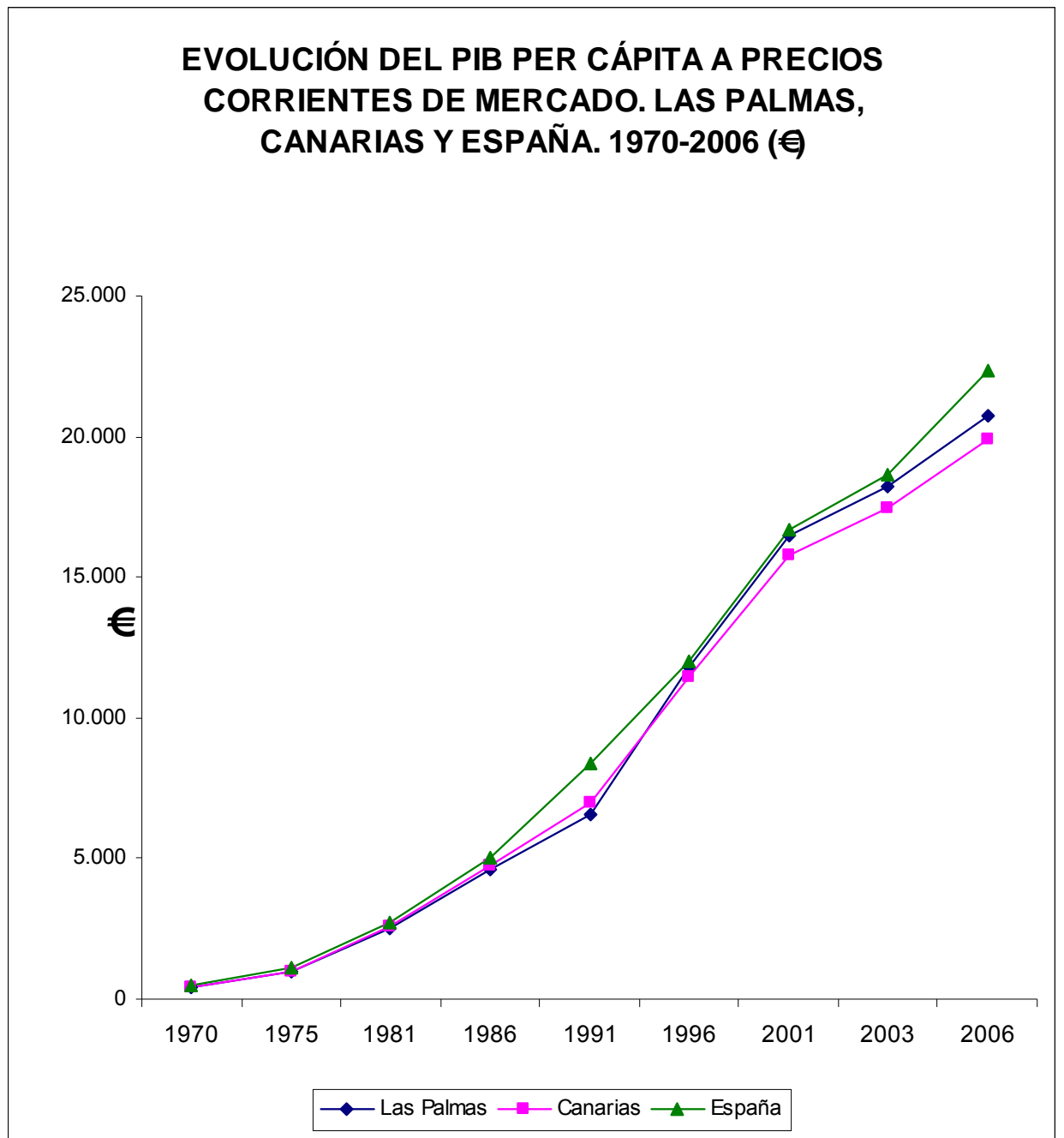

Fuente: Elaboración propia a partir de los datos del INE en Contabilidad Regional de España y Alcaide, J. (2003). Referencia Tabla 233.

Como se aprecia en los datos anteriores sistemáticamente tanto Canarias como la provincia de Las Palmas presentan un PIB per cápita inferior a la media española y con variaciones en cuanto a la preeminencia de una $u$ otra de distinto signo en los diferentes períodos analizados. Más concretamente, en el cuadro siguiente se observa la evolución en términos porcentuales respecto a la señalada media nacional.

Tabla 234. Evolución del PIB per cápita de Las Palmas y Canarias respecto al de España. 1970$2006(\%)$

\begin{tabular}{|l||c|c|c|c|c|c|c|c|c||}
\cline { 2 - 10 } \multicolumn{1}{c|}{} & 1970 & 1975 & 1981 & 1986 & 1991 & 1996 & 2001 & 2003 & 2006 \\
\hline \hline Las Palmas & 90 & 89 & 94 & 91 & 79 & 98 & 99 & 98 & 93 \\
\hline Canarias & 85 & 85 & 95 & 94 & 84 & 96 & 94 & 93 & 89 \\
\hline
\end{tabular}

Fuente: Elaboración propia a partir de los datos del INE en Contabilidad Regional de España y Alcaide, J. (2003). 
Gráfico 219. Evolución del PIB per cápita de Las Palmas y Canarias respecto al de España. 1970-2006 (\%)

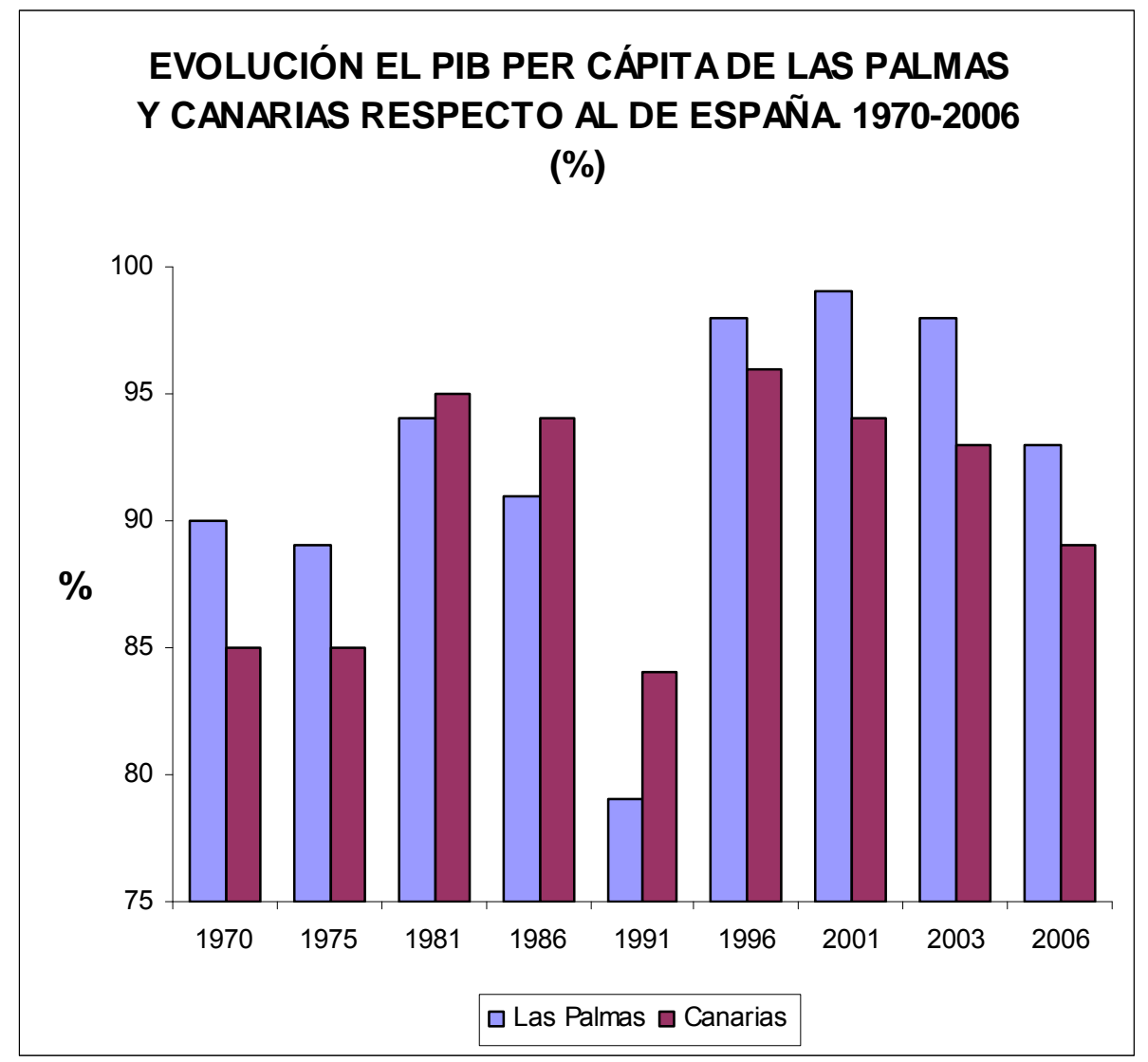

Fuente: Elaboración propia a partir de los datos del INE en Contabilidad Regional de España y Alcaide, J. (2003).Referencia Tabla 234.

La figura, a partir de los datos anteriores, muestra como siempre el PIB per cápita regional y provincial se va a mantener por debajo de la media nacional, pero durante la década de los setenta, Las Palmas supera a la media regional en PIB per cápita, ascendiendo ambas muy significativamente respecto a la media española durante la crisis energética de los ochenta, aunque recayendo posteriormente en la recuperación de la segunda mitad de esta década. En todo caso, Las Palmas se sitúa hasta 1996 por debajo de Canarias, alcanzando en esa fecha su mejor situación, que se mantiene hasta 2006. No obstante, tras la mejora con respecto al PIB per cápita español en el período 1991-2001 (principalmente en su último quinquenio), en toda la década del siglo XXI analizada tanto Canarias como Las Palmas empeoran su situación relativa con respecto a la media española, reflejando claramente lo que ha sido la evolución de la incidencia del turismo y de la construcción en el conjunto de la economía a nivel español, de Canarias y de Las Palmas.

Atendiendo a la información proporcionada por el CIES para 1970, por el Anuario de Banesto para los años 1975, 1981, 1986 y 1991, y por el Anuario Económico de La Caixa para los años 1996, 2001 y 2003, y una vez homogenizada con los datos de la Contabilidad Regional del INE, y de la serie de la Fundación BBVA, obtenemos la siguiente evolución de 
las magnitudes de PIB per cápita a precios corrientes de mercado para los distintos ámbitos, si bien precisando que para cada municipio y período, al igual que para Lanzarote, los datos correspondientes parten de la marca de clase del intervalo en el que se le incluía en el período y fuente correspondiente. Ello nos lleva a que el margen de error en la cifra concreta asignada a cada municipio dependa tanto de la amplitud del intervalo en el que se encuadra como del margen de error del modelo utilizado por la fuente para sus cálculos. Como resultado, el margen de error de las cifras que utilizaremos hay que situarla entre el $10 \%$, para las cifras de mayor magnitud, y de hasta el 20\% para las cifras más reducidas; márgenes que podemos considerar aceptables pero que no se puede olvidar que se han de superponer a los márgenes -por encima del $20 \%$ - de las cifras que la economía sumergida representan sobre la contabilidad oficial en ámbitos ligados al turismo. En todo caso, es la evolución relativa en los estándares de bienestar de la población residente lo que nos interesa a los efectos de esta tesis, y la aportación al bienestar que indudablemente representa la evolución de la renta per cápita municipal puede considerarse aceptablemente recogida por las fuentes y procedimientos seguidos.

La evolución resultante y las cifras correspondientes se recogen en la figura siguiente:

Tabla 235. Evolución del PIB per cápita. Lanzarote y sus municipios, Las Palmas, Canarias y España. 1970-2003 (€).

\begin{tabular}{|c|c|c|c|c|c|c|c|c|}
\hline & 1970 & 1975 & 1981 & 1986 & 1991 & 1996 & 2001 & 2003 \\
\hline Arrecife & 437 & 915 & 2.714 & 4.029 & 6.849 & 9.625 & 15.195 & 17.126 \\
\hline Haría & 289 & 732 & 1.516 & 2.805 & 3.805 & 9.625 & 15.195 & 17.126 \\
\hline San Bartolomé & 270 & 610 & 1.304 & 2.431 & 5.466 & 9.625 & 16.715 & 17.126 \\
\hline Teguise & 270 & 732 & 1.798 & 2.057 & 5.466 & 12.003 & 16.715 & 17.126 \\
\hline Tías & 286 & 1.424 & 2.714 & 3.281 & 5.466 & 13.588 & 18.193 & 18.639 \\
\hline Tinajo & 293 & 732 & 1.304 & 3.281 & 4.445 & 8.606 & 15.195 & 15.533 \\
\hline Yaiza & 359 & 732 & 1.516 & 2.057 & 6.849 & 10.757 & 16.715 & 18.639 \\
\hline LANZAROTE & 381 & 868 & 1.798 & 2.805 & 5.466 & 9.625 & 15.195 & 17.126 \\
\hline LAS PALMAS & 450 & 999 & 2.546 & 4.588 & 6.580 & 11.785 & 16.513 & 18.242 \\
\hline CANARIAS & 427 & 956 & 2.571 & 4.733 & 7.001 & 11.476 & 15.764 & 17.424 \\
\hline ESPAÑA & 501 & 1.119 & 2.714 & 5.049 & 8.371 & 12.003 & 16.715 & 18.639 \\
\hline
\end{tabular}

Fuente: Elaboración propia a partir de los datos del CIES, Anuario BANESTO, Anuario Económico La Caixa, INE: Contabilidad Regional de España y Alcaide, J. (2003). 
Gráfico 220. Evolución del PIB per cápita. Lanzarote y sus municipios, Las Palmas, Canarias y España. 1970-2006 (€)

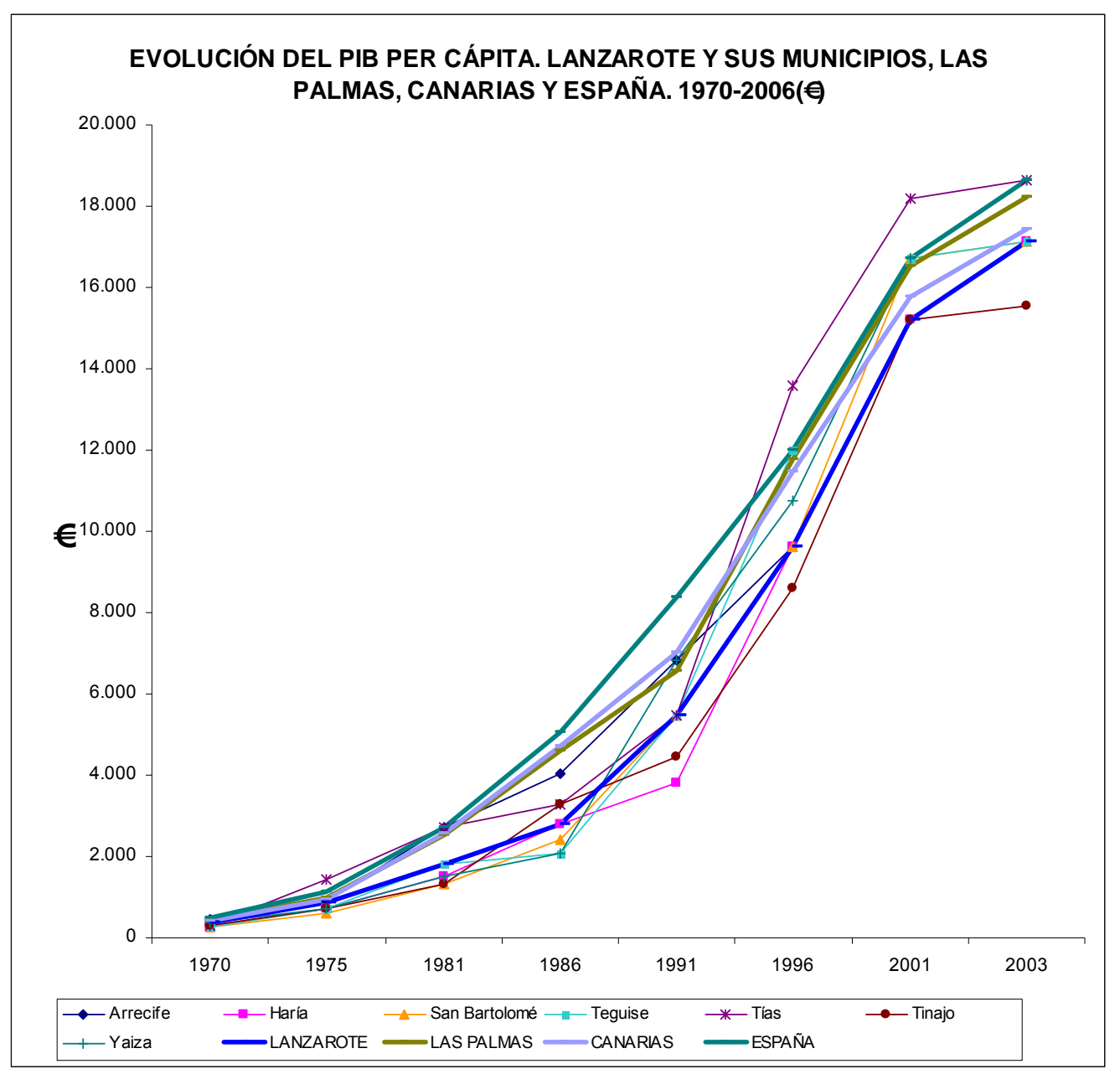

Fuente: Elaboración propia a partir de los datos del CIES, Anuario BANESTO, Anuario Económico La Caixa, INE: Contabilidad Regional de España y Alcaide, J. (2003). Referencia Tabla 235.

Como se constata, la evolución general es relativamente homogénea pero, los efectos que nos interesa considerar específicamente es la evolución relativa de cada municipio dentro de la isla, y la potencial relación de la misma con la evolución turística de Lanzarote, así como la evolución del conjunto de la isla en lo que tenga de diferencial con los restos de ámbitos considerados: provincia de Las Palmas, Canarias y España.

\section{3.- FACTORES INCIDENTES EN LA EVOLUCIÓN DE LAS VARIABLES.}

\section{1.- SU RELACIÓN CON LA OFERTA Y DEMANDA TURÍSTICA. LOS INICIOS DEL CRECIMIENTO TURÍSTICO. DESPEGUE Y CONSOLIDACIÓN.}

Como se constata en la tabla y figura siguiente, los cambios en la evolución relativa del PIB per cápita estimado para Lanzarote respecto a los valores correspondientes a Las Palmas, 
Canarias y España es muy fuerte en los distintos periodos considerados en esta tesis. Diferencial que se aprecia claramente.

Tabla 236. Evolución del PIB per cápita de Lanzarote respecto a Las Palmas, Canarias y España. 1970-2003 (\%)

\begin{tabular}{|l||l|l|l|l|l|l|l|l||}
\hline & 1970 & 1975 & 1981 & 1986 & 1991 & 1996 & 2001 & 2003 \\
\hline LAS PALMAS & 85 & 87 & 71 & 61 & 83 & 82 & 92 & 94 \\
\hline CANARIAS & 89 & 91 & 70 & 59 & 78 & 84 & 96 & 98 \\
\hline ESPAÑA & 76 & 78 & 66 & 56 & 65 & 80 & 91 & 92 \\
\hline
\end{tabular}

Fuente: Elaboración propia a partir de los datos del CIES, Anuario BANESTO, Anuario Económico La Caixa, INE: Contabilidad Regional de España y Alcaide, J. (2003).

Gráfico 221. Evolución del PIB per cápita de Lanzarote respecto a Las Palmas, Canarias y España. 1970-2003 (\%)

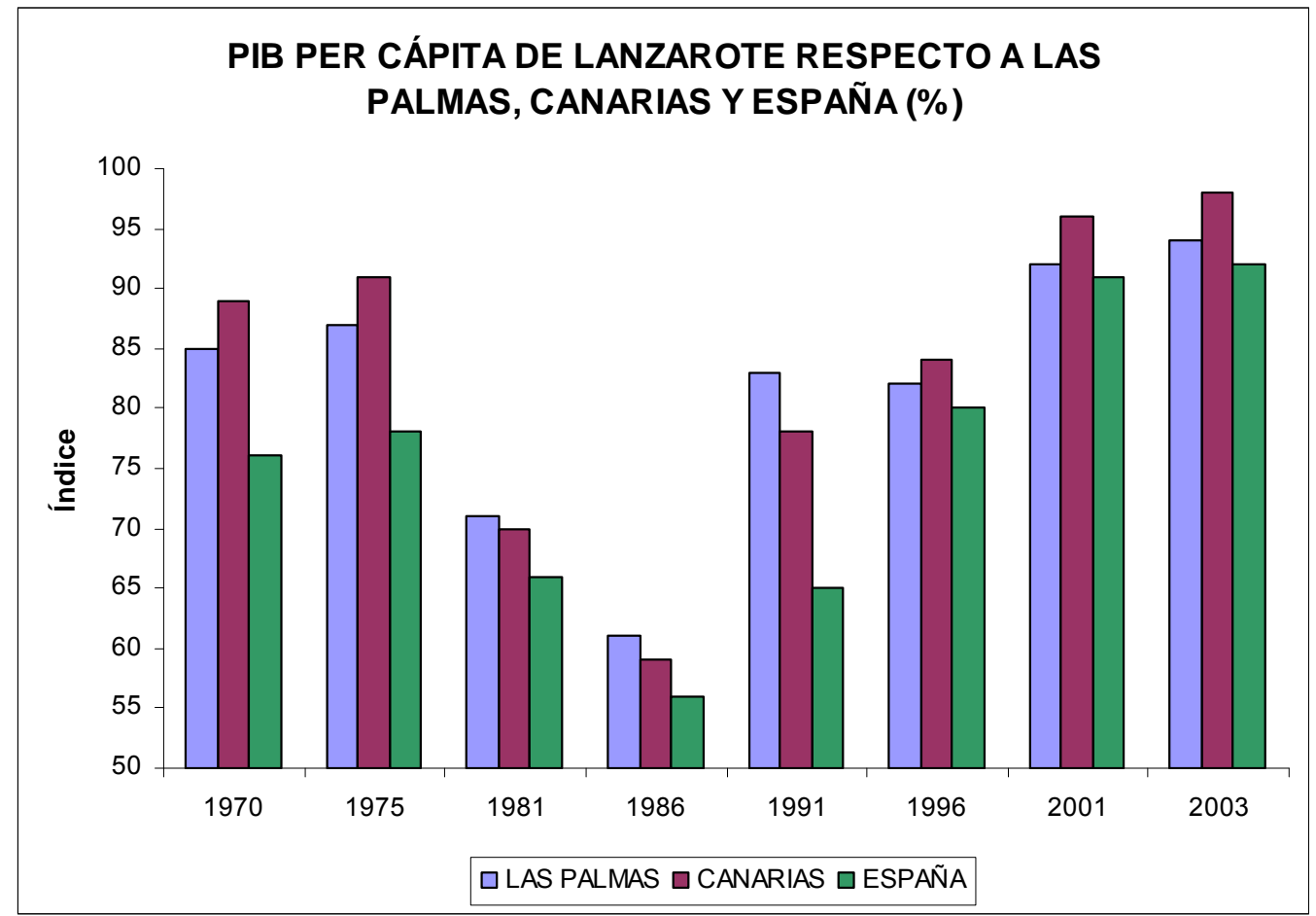

Fuente: Elaboración propia a partir de los datos del CIES, Anuario BANESTO, Anuario Económico La Caixa, INE: Contabilidad Regional de España y Alcaide, J. (2003). Referencia Tabla 236.

Este cambio no es independiente de la evolución relativa seguida por la oferta y demanda turística de la isla, tal y como se aprecia en las dos figuras siguientes. 
Tabla 237. Incremento de la oferta turística en cada periodo. España, Canarias y Lanzarote (\%)

\begin{tabular}{|l||c|c|r|r|r|r|r||}
\cline { 2 - 8 } \multicolumn{1}{c|}{} & 1970 a 1975 & 1975 a 1981 & 1981 a 1986 & 1986 a 1991 & 1991 a 1996 & 1996 a 2001 & 2001 a 2006 \\
\hline \hline España & 7 & 44 & 35 & 25 & 9 & 12 & 26 \\
\hline \hline Canarias & 334 & 47 & 20 & 47 & -13 & 10 & 19 \\
\hline Lanzarote & 361 & 59 & 200 & 24 & 11 & 13 & 9 \\
\hline
\end{tabular}

Fuente: Elaboración propia a partir de IET, INE, CEDOC, ISTAC y Cabildo de Lanzarote (Centro de datos).

Gráfico 222. Incremento de la oferta turística en cada periodo. España, Canarias y Lanzarote (\%)

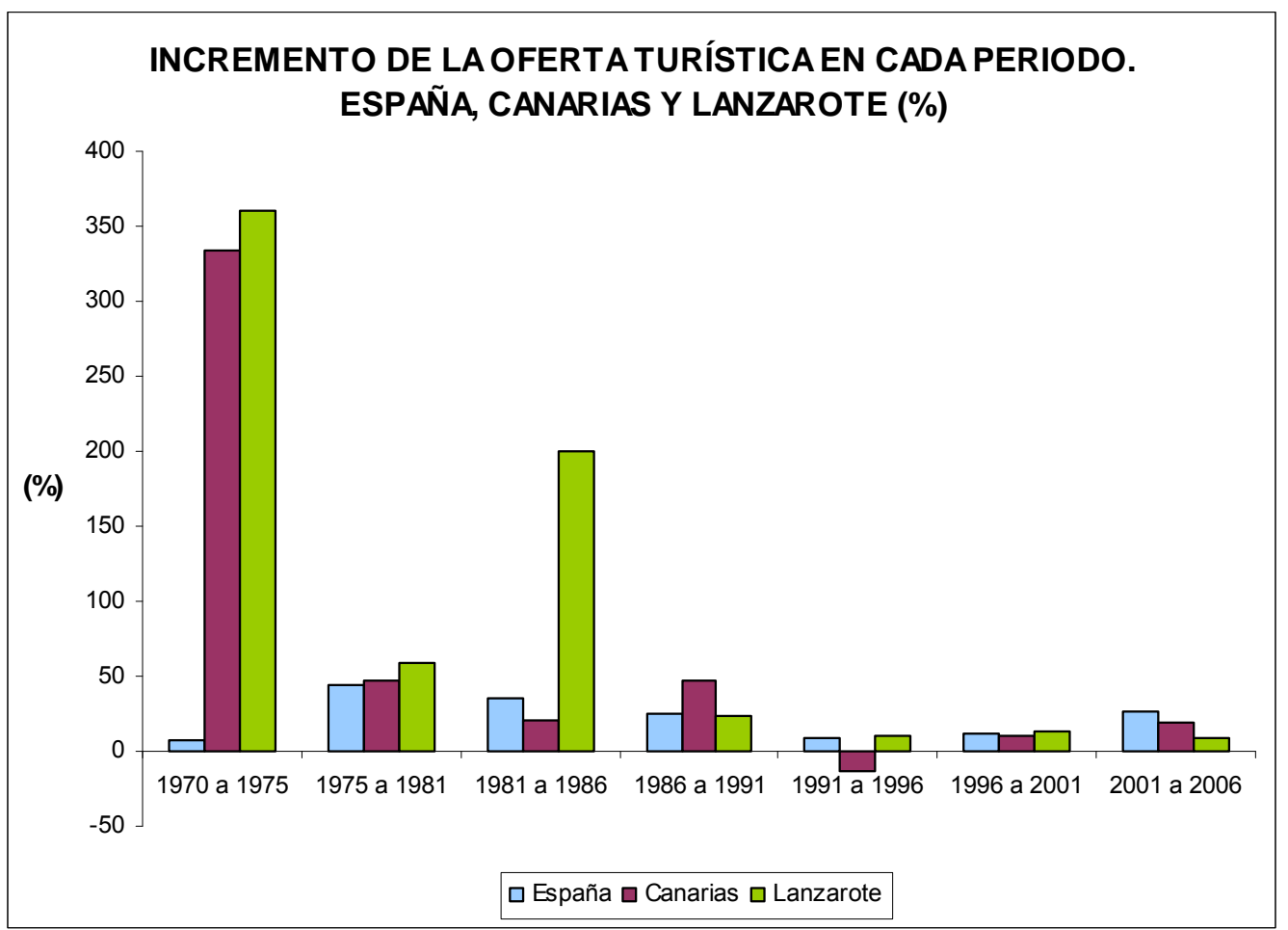

Fuente: Elaboración propia a partir de IET, INE, CEDOC, ISTAC y Cabildo de Lanzarote (Centro de datos). Referencia Tabla 237.

Tabla 238. Incremento de la demanda turística en cada periodo. España, Canarias y Lanzarote (\%)

\begin{tabular}{|l||r|r|r|r|r|r|c||}
\cline { 2 - 8 } \multicolumn{1}{c|}{} & 1970 a 1975 & 1975 a 1981 & 1981 a 1986 & 1986 a 1991 & 1991 a 1996 & 1996 a 2001 & 2001 a 2006 \\
\hline \hline España & 25 & 33 & 18 & 13 & 2 & 39 & 27 \\
\hline Canarias & 154 & 28 & 85 & 30 & 48 & 3 & -6 \\
\hline Lanzarote & 218 & 120 & 150 & 121 & 44 & 23 & -4 \\
\hline
\end{tabular}

Fuente: Elaboración propia a partir de IET, INE, CEDOC, ISTAC y Cabildo de Lanzarote (Centro de datos). 
Gráfico 223. Incremento de la demanda turística en cada periodo. España, Canarias y Lanzarote (\%)

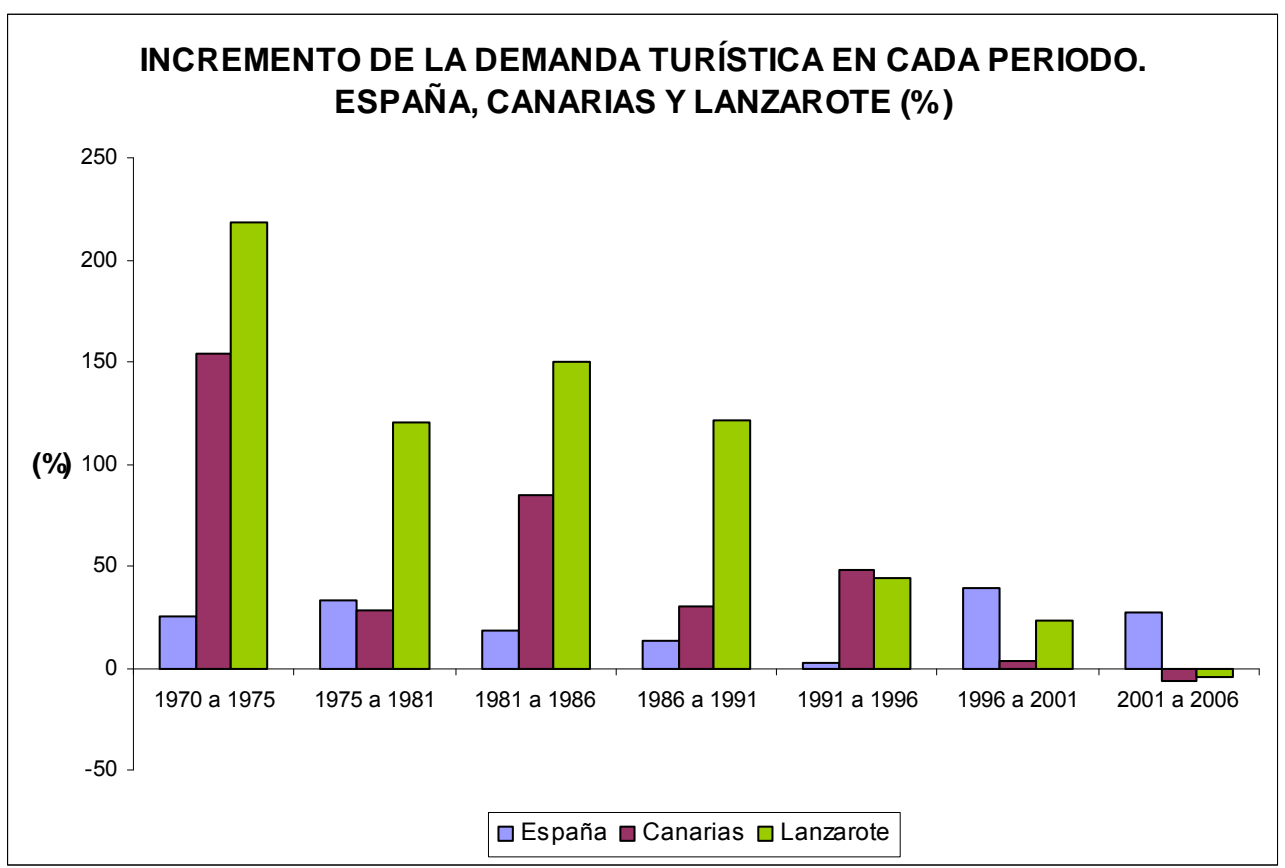

Fuente: Elaboración propia a partir de IET, INE, CEDOC, ISTAC y Cabildo de Lanzarote (Centro de datos). Referencia Tabla 238.

El incremento del PIB per cápita relativo de la renta de Lanzarote con respecto a España y Canarias en el período de 1970 a 1975 coincide con unos fortísimos incrementos de la oferta y demanda turística en la isla que van a dar lugar a una sustancial transformación de la estructura productiva de ésta, significando un cambio radical de la economía de la isla, tal y como se ha apreciado en epígrafes anteriores. Como allí se señalaba (véase apartado 5.1.) en 1964 se acondiciona el Parque Insular de Turismo, en 1965 se pone en funcionamiento la primera potabilizadora-desalinizadora dual (de iniciativa privada) que permite resolver, temporalmente, el grave problema del abastecimiento hídrico en la isla; en 1969 se realiza la reforma y acondicionamiento de la red de caminos vecinales, en 1970 se abre el aeropuerto a vuelos "charter" internacionales, y, sobre todo, en 1968, la Ley Strauss alemana, que eximía de impuestos durante doce años a las compras de terrenos efectuadas por los alemanes en las Islas Canarias (en concepto de ayuda al tercer mundo), iba a significar un fuerte impulso a la inversión exterior en la isla (tanto extranjera como peninsular $y$, en menor medida canaria) a la urbanización litoral y al inicio del auge del turismo como actividad económica significativa, con un incremento del $361 \%$ del número de plazas turísticas y de un $218 \%$ del número de turistas recibidos en el período.

Para viabilizar esta dinámica el Plan Insular de 1973 clasifica más de 8.000 ha de suelo, a desarrollar con el correspondiente plan parcial, con capacidad para unas 450.000 plazas turísticas, lo que favorece numerosas transacciones en el mercado de suelo, de forma que gran parte de los ingresos del período, que justifican el incremento de PIB per cápita relativo 
de la isla respecto a Canarias y España se justifica por los ingresos asociados a las ventas de terrenos a no residentes realizadas. Las plazas turísticas extra-hoteleras son más del $63 \%$ de las totales en Lanzarote en 1975. El crecimiento del PIB per cápita de Lanzarote pasa del $76 \%$ del de España, en 1970 , al $78 \%$ en 1975 ; y del $85 \%$ y $81 \%$ respectivamente de las Palmas y Canarias, en 1970 , al $87 \%$ y $91 \%$ en 1975 . La razón no sólo hay que encontrarla en la fuerte dinámica que registra Lanzarote en el período pasando de una isla agrícola (en 1970 el 42\% de la población empleada lo estaba en la agricultura, mientras que cinco años después esta cifra había caído al 27\%) a una isla crecientemente turística, sino que también la transformación se produce con cambios demográficos mucho menores que los registrados en Canarias (7,8\% de incremento en Lanzarote, frente al 15,9\% en Canarias) por lo que también el PIB per cápita crece en mayor medida en la isla que en Canarias, al crecer menos el denominador de esta magnitud en la isla. Es importante señalar que el porcentaje de población autóctona pasa del $96 \%$ en 1970 al 94\% en 1975, siendo todavía la incidencia de la inmigración muy reducida en la isla.

En este periodo la pesca y la agricultura de exportación (tomate y cebollas) tienen una importancia significativa en la economía y en la generación de PIB, si bien a partir de 1975 empieza el declive del sector agrícola y los problemas para el sector pesquero/conservero, que van a ser incapaces de competir con el auge de los sectores ligados al turismo. De hecho, se produce un progresivo traspaso de capital e inversiones desde el sector pesquero-conservero hacia el sector turístico-inmobiliario, ante la creciente incertidumbre en el primero y las claras alternativas de beneficios especulativos y de rentabilidad turística del segundo.

Mientras todo esto ocurre, la isla lucha por salir del elevado nivel de analfabetismo que la caracteriza, y que agrupa a más de un $20 \%$ de la población en 1970 , junto a bajas tasas de escolarización. Una estructura demográfica de baja capacitación que es un impedimento para dirigir e introducir a sus habitantes en el incipiente mercado laboral que abre la construcción y los servicios. La ampliación de centros escolares será importante en este periodo, alcanzado en los años ochenta las coberturas suficientes, que no había tenido en el pasado, reduciendo considerablemente el analfabetismo y alcanzando tasas de escolarización cercanas al $100 \%$.

Entre 1975 y 1986 Lanzarote empeora relativamente su PIB per cápita con respecto a España. Canarias y la provincia de Las Palmas, incluso con respecto a su situación de 1970, alcanzando en 1986 los valores mínimos desde 1970 a 2006, aunque el PIB per cápita a precios corrientes siga su tendencia creciente desde 1970 hasta el 2006. Parte de este empeoramiento relativo se debe a su fuerte incremento de población relativa (entre 1975 y 1986 Lanzarote incrementa su población en un $26 \%$, mientras que Canarias lo hace en un $12 \%$ y España en un $7 \%$ ). Como observamos en la siguiente figura. 
Tabla 239. Incremento de la población residente en cada periodo. España, Canarias y Lanzarote (\%)

\begin{tabular}{|l|r|r|r|}
\cline { 2 - 4 } \multicolumn{1}{c|}{} & ESPAÑA & CANARIAS & LANZAROTE \\
\hline $1970-1975$ & 5,60 & 15,87 & 7,80 \\
\hline $1975-1981$ & 4,60 & 4,88 & 14,40 \\
\hline $1981-1986$ & 2,10 & 6,46 & 9,90 \\
\hline $1986-1991$ & 1,00 & 2,60 & 16,40 \\
\hline $1991-1996$ & 2,10 & 7,55 & 19,20 \\
\hline $1996-2001$ & 3,00 & 5,47 & 33,20 \\
\hline $2001-2006$ & 9,50 & 17,78 & 23,70 \\
\hline
\end{tabular}

Fuente: Elaboración propia a partir de datos censales y padronales. INE e ISTAC.

Gráfico 224. Incremento de la población residente en cada periodo. España, Canarias y Lanzarote (\%)

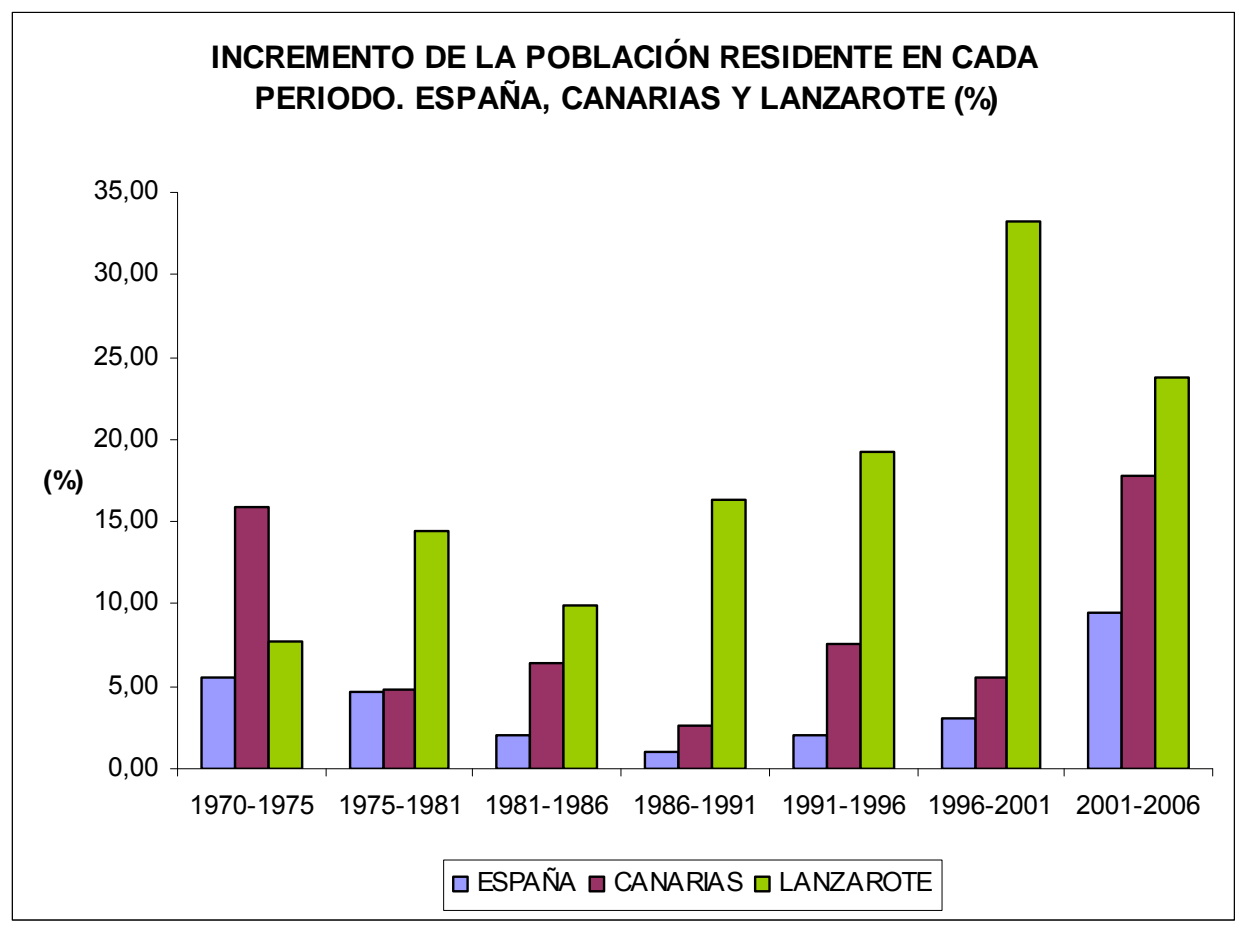

Fuente: Elaboración propia a partir de datos Censales y Padronales. INE e ISTAC. Referencia Tabla 239.

Una parte importante de este incremento poblacional se produce por un fuerte incremento de la inmigración, de origen nacional, pasando a representar la población autóctona en la isla del $94 \%$ en 1975 al $82 \%$ en 1986, multiplicándose por más de cinco los provenientes del extranjero y de la península, y por más de cuatro los provenientes de otras islas canarias. Inmigración que se caracteriza por su baja cualificación educativa, pues los servicios al turismo y la construcción no requieren otro tipo de mano obra. En paralelo, la oferta turística se sigue incrementando en Lanzarote más rápido que en Canarias y que en España, pero a 
tasas mucho más reducidas que en el período 1970-75; e igual sucede con la demanda turística. En todo caso, entre 1981 y 1986 la oferta de alojamiento en la isla se incrementa en un $200 \%$ con respecto al quinquenio anterior, asentándose definitivamente el modelo turístico intensivo de la isla centrado en la expansión inmobiliaria, con un fuerte predominio de la oferta extra-hotelera sobre la hotelera, cuyo peso es significativamente bajo sobre la oferta total al final de la etapa (de representar el $36 \%$ de la oferta total en 1975, la oferta hotelera pasa a representar solamente el $9 \%$ en 1986) aspecto muy relacionado con la menor producción per cápita asociada a este tipo de oferta y a la creciente importancia del sector construcción en el conjunto de la actividad económica de la isla (en 1986 la construcción ha pasado a representar del orden del $24 \%$ de la actividad), que a su vez explica el peso significativo que tiene la población "sin estudios" dentro de la estructura social insular (del $34 \%$ en 1986).

La escasa capacidad dotacional hospitalaria y extrahospitalaria marcará toda esta etapa, pues aunque se realizan ampliaciones, estas quedan constantemente desbordadas por el ritmo de crecimiento demográfico que alcanza la isla a partir del año 1975. Adicionalmente la insularidad es muy notable, fuerte dependencia, pues las especialidades médicas están centralizadas en la capital de la provincia, Las Palmas. A pesar del crecimiento constante de la producción económica, la Administración no se muestra con capacidad suficiente para generar crecimientos dotacionales a la velocidad con la que crece la demanda potencial y ésta situación de estrangulamiento en el número de camas de hospital no se modificará, frente a las mejoras en la capacidad que se computan para el conjunto de Canarias y España, como se muestra en la siguiente figura.

Tabla 240. Evolución de las camas de hospital y comparación con la OMS. España. Canarias y Lanzarote. 1970-2006

\begin{tabular}{|l||r|r|r|r||}
\cline { 2 - 5 } \multicolumn{1}{c|}{} & LANZAROTE & CANARIAS & ESPAÑA & \multicolumn{1}{c|}{ O.M.S. } \\
\hline \hline $\mathbf{1 9 7 0}$ & 3,16 & 1,55 & 2,01 & 8 \\
\hline $\mathbf{1 9 7 5}$ & 2,96 & 5,11 & 5,29 & 8 \\
\hline $\mathbf{1 9 8 1}$ & 2,58 & 5,53 & 5,15 & 8 \\
\hline $\mathbf{1 9 8 6}$ & 3,73 & 5,50 & 5,33 & 8 \\
\hline $\mathbf{1 9 9 1}$ & 3,96 & 5,19 & 4,23 & 8 \\
\hline $\mathbf{1 9 9 6}$ & 3,32 & 4,71 & 3,82 & 8 \\
\hline $\mathbf{2 0 0 1}$ & 2,72 & 4,55 & 3,58 & 8 \\
\hline $\mathbf{2 0 0 6}$ & 2,67 & 3,55 & 3,27 & 8 \\
\hline
\end{tabular}

Fuente: Elaboración propia a partir de datos del INE, ISTAC y Hospital Insular de Lanzarote. 


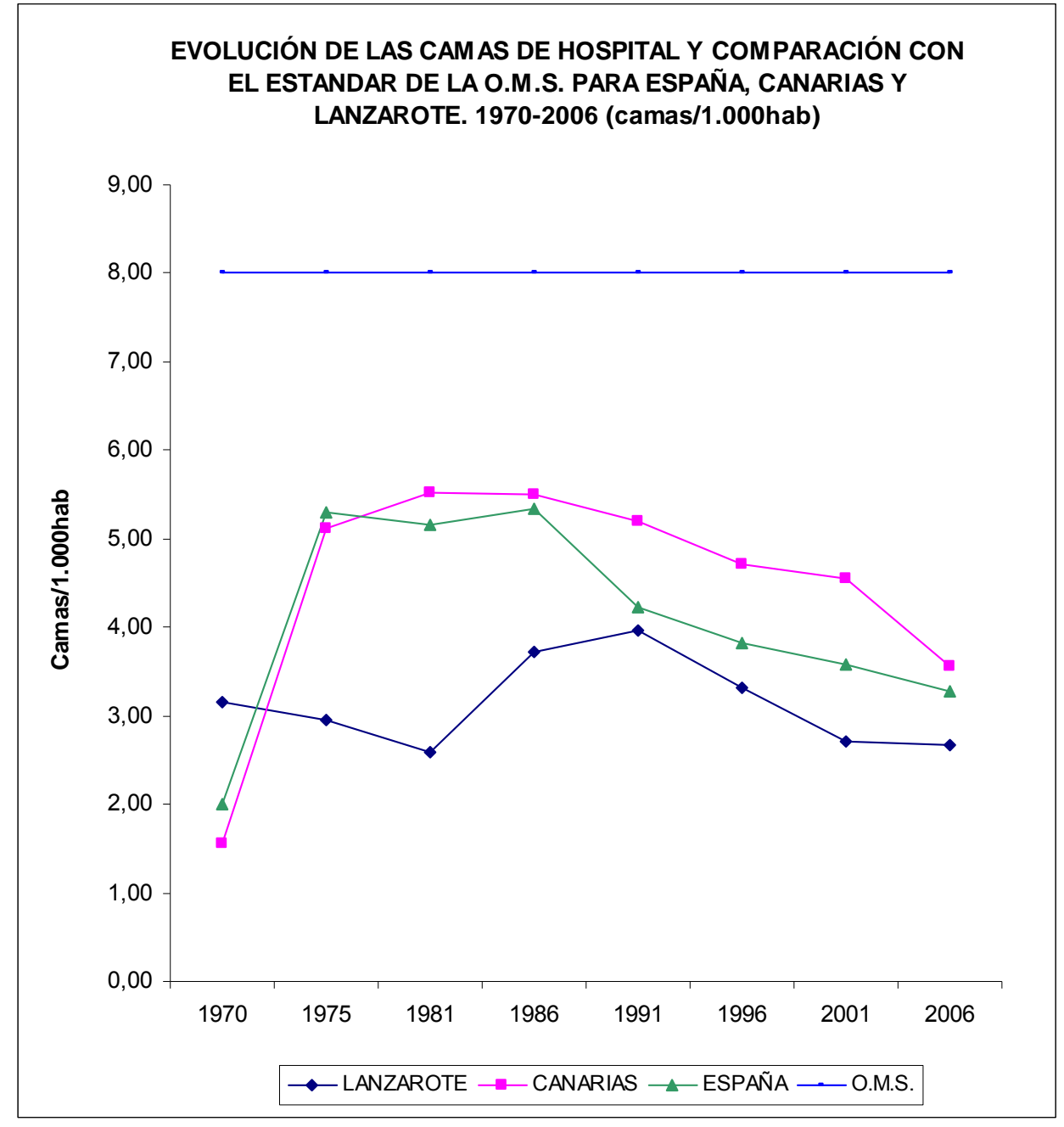

Fuente: Elaboración propia a partir de datos del INE, ISTAC y Hospital Insular de Lanzarote. Referencia Tabla 240.

La intensidad de los crecimientos descritos, presiona notablemente sobre las escasas infraestructuras existentes en este comienzo, en dos ámbitos fundamentales: la generación de energía eléctrica y de agua potable. Ambos aspectos serán los "caballos de batalla" sobre los que la isla tendrá que acometer constantes intervenciones destinadas a la ampliación para poder dar respuesta a los crecimientos de la demanda, tanto en las fases de despegue y consolidación de la actividad como en el funcionamiento del destino a lo largo de su vida. Dicha presión impulsa los cambios, por un lado, en la capacidad de producción eléctrica insular. La vía de generación será la ampliación de la central eléctrica térmica, a través de la instalación de motores diesel alimentados con gasóleo y fuel-oil, altamente contaminantes, modelo que llegará hasta nuestros días y del que depende la desalación del agua (el ciclo del agua consume aproximadamente un $25 \%$ de la electricidad generada) y sin la cual no se puede asistir los nuevos desarrollos. El ritmo de incremento de la potencia, a partir de 1975 estará muy por encima al de Canarias y España, como se 
muestra en la siguiente figura, evolución relativa que no es independiente de los crecimientos de la oferta, la demanda turística y el crecimiento de la población, aunque no llega a cubrir el estándar nacional de electrificación media para consumo doméstico.

Tabla 241. Incremento de la potencia instalada en cada periodo. España, Canarias y Lanzarote (\%).

\begin{tabular}{|l|r|r|r|r|r|c||}
\cline { 2 - 8 } \multicolumn{1}{c|}{} & 1975 a 1981 & 1981 a 1986 & 1986 a 1991 & 1991 a 1996 & 1996 a 2001 & 2001 a 2006 \\
\hline España & 29 & 28 & 9 & 7 & 13 & 52 \\
\hline Canarias & 13 & 36 & 61 & 41 & 12 & 52 \\
\hline Lanzarote & 357 & 79 & 296 & 24 & 24 & 60 \\
\hline \hline
\end{tabular}

Fuente: Elaboración propia a partir de Ministerio de Industria, Turismo y Comercio, Dirección General de Industria y Energía del Gobierno de Canarias, CEDOC e ISTAC.

Gráfico 226. Incremento de la potencia instalada en cada periodo. España, Canarias y Lanzarote (\%).

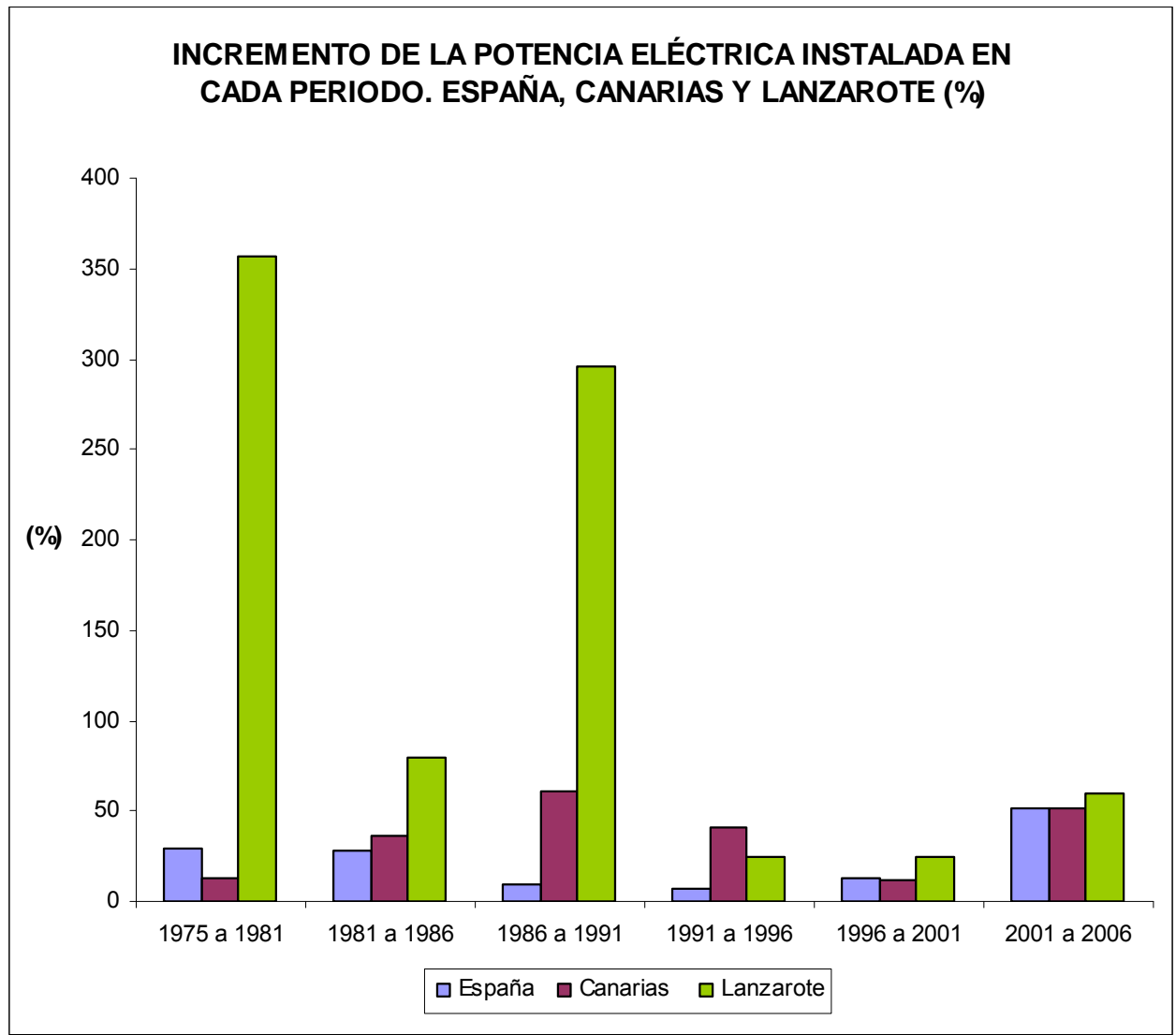

Fuente: Elaboración propia a partir de Ministerio de Industria, Turismo y Comercio, Dirección General de Industria y Energía del Gobierno de Canarias, CEDOC e ISTAC. Referencia Tabla 241.

Por otro lado, a los cinco años de puesta en marcha de la primera potabilizadora-desaladora ésta ya no puede cubrir el crecimiento de la demanda. Para poder alcanzar la cobertura de las necesidades básicas reales en relación al estándar (112 l/hab*día), la isla debe 
incrementar su producción en un 52\%. A partir del año 1975 comenzará la intervención pública en la desalación de agua, de la que va a depender todo el abastecimiento, con constantes ampliaciones de la infraestructura que permitan asistir las explosiones de demanda, que llegan hasta nuestros días. Paralelamente, por esta época se abre una política vinculada al proceso de urbanización, que permite la instalación de desaladoras de pequeña escala en complejos turísticos y a su servicio, como vía para no coartar del proceso de implantación, que crecerán en número hasta nuestros días de forma poco controlada por la Administración y con desconocimiento sobre el volumen que producen.

Ambas infraestructuras tendrán como prioridad dotar las zonas litorales en desarrollo turístico. El beneficio de la población local se producirá, pero su abastecimiento es secundario, principalmente en las zonas rurales, aunque la mejora del bienestar en este sentido se produce y es considerable (en 1970 el $28 \%$ de la viviendas disponía de agua corriente, frente al $86 \%$ en 1981), la disponibilidad para el consumo doméstico es aún muy reducida, no se garantiza el suministro, y está constantemente afectada por los crecimientos turísticos y demográficos señalados.

Aunque ningún núcleo de población carece de comunicación viaria, la capacidad de las comunicaciones internas, que afectan a la accesibilidad y la movilidad, es intervenida en dos sentidos: ampliación de kilómetros y del ancho de la red, pues tiene características propias de sociedades rurales, no preparadas para la dinámica socioeconómica descrita (en 1970 el $100 \%$ de las carreteras tiene menos de $6 \mathrm{~m}$ de ancho, mientras que en 1986 se han reducido al $32 \%$ ). Estas ampliaciones afectarán a la conexión entre los núcleos que concentran los nuevos desarrollos turísticos, el aeropuerto y el centro administrativo de la isla. La evolución será positiva en términos de accesibilidad y seguridad.

El crecimiento continuado del PIB y la renta per capita provocan mejoras en el poder adquisitivo local, que se materializa en el rápido crecimiento del volumen de vehículos que circulan en la isla, donde el $25 \%$ de los mismos corresponde a coches de alquiler para el consumo turístico. El índice de motorización insular, a partir de 1986 superará el registrado para España y la Comunidad Autónoma, como se puede ver en la figura siguiente.

Tabla 242. Evolución del índice de motorización. Lanzarote, Canarias y España (\%)

\begin{tabular}{||l|c|c|c|c|c|c|c|c||}
\cline { 2 - 10 } \multicolumn{1}{c|}{} & 1970 & 1975 & 1981 & 1986 & 1991 & 1996 & 2001 & 2006 \\
\hline España & 7 & 13 & 20 & 25 & 32 & 36 & 43 & 46 \\
\hline Canarias & 8 & 13 & 21 & 21 & 31 & 35 & 43 & 46 \\
\hline Lanzarote & 4 & --- & --- & 27 & 32 & 39 & 41 & 51 \\
\hline
\end{tabular}

Fuente: Elaboración propia a partir de datos del Ministerio de Fomento, ISTAC e INE. 
Gráfico 227. Evolución del índice de motorización. Lanzarote, Canarias y España (\%)

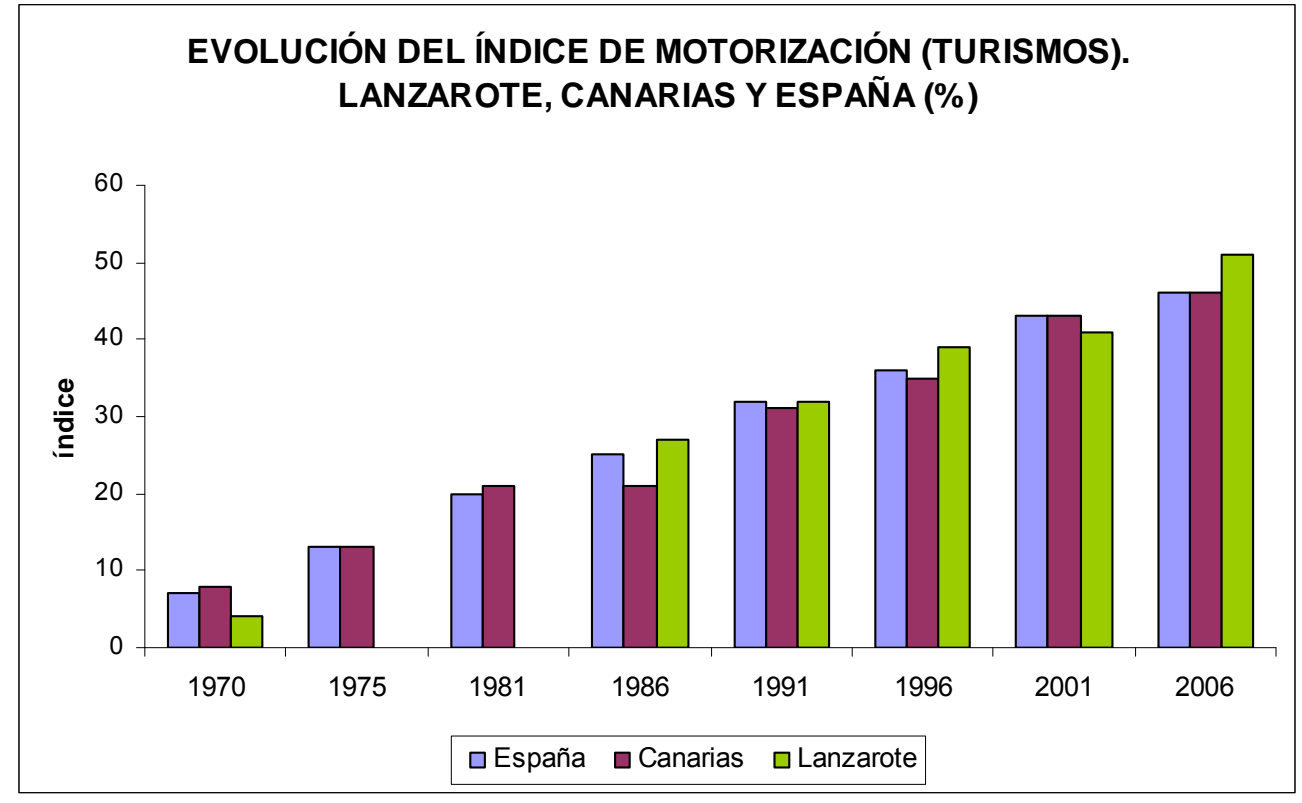

Fuente: Elaboración propia a partir de datos del Ministerio de Fomento, ISTAC e INE. Referencia Tabla 242.

Situación que se prolonga hasta nuestros días, propiciada por las escasas inversiones en la mejora y ampliación del transporte público regular de pasajeros. Aunque aún no se van a sentir los efectos negativos medioambientales y paisajísticos, las posibilidades en las comunicaciones viarias de los residentes han mejorado cualitativa y cuantitativamente.

El bienestar social derivado de la dinámica descrita se ha modificado radicalmente. El servicio al turista trae nuevas oportunidades y posibilidades para la sociedad anfitriona con efectos claramente positivos sobre el bienestar.

\section{2.- LA CONSOLIDACIÓN DEL DESARROLLO TURÍSTICO. 1986-1996}

En lo que se ha denominado en la tesis Segunda etapa (1986-1996) y Tercera etapa (19962006) se aprecia que el PIB per cápita relativo de Lanzarote mantiene una tendencia positiva que permanece hasta 2006, pero siempre con valores de PIB per cápita inferiores a los de la Provincia, Comunidad Autónoma y Estado.

En la Segunda etapa (1986-1996), como apreciábamos en las Figuras anteriores, el incremento de la mejora relativa del PIB per cápita de Lanzarote respecto a Canarias y España es sostenido, pasando de cifras del orden del $60 \%$ a cifras del orden del $80 \%$ al final del periodo, mientras que el incremento de oferta turística se mantiene muy moderado (semejante al de España en su conjunto y del orden de la mitad del de Canarias en el período 1986-91, aunque en el período 1991-96 mejora muy sensiblemente la pérdida de oferta que se produce en el conjunto del archipiélago). Sin embargo, en estos períodos va a 
ser el incremento relativo de la demanda respecto a estos dos ámbitos (mucho más fuerte que el de España, que en su conjunto se reduce sobre los datos de 1986; y del orden de un $50 \%$ mayor que el de Canarias) lo que va a explicar en gran parte la mejora del PIB per cápita relativo. En todo caso esta mejora relativa viene asociada, como se ha señalado en el epígrafe 5.2., a una fuerte crisis del sector turístico a finales de la década de los ochenta a consecuencia de un sobre-exceso de oferta, fundamentalmente extra-hotelera, que como se ha señalado llega a ser el $91 \%$ del total en 1986, y que genera un descenso del nivel de ocupación de hoteles y apartamentos y una caída de los precios, con una fuerte incidencia en el conjunto de la economía de la isla.

Para afrontar esta situación, en 1986 se empieza a elaborar el Plan Insular de Ordenación del Territorio (PIOT), que es definitivamente aprobado en 1991 y su Revisión aprobada provisionalmente en 1999. El PIOT de 1991 fija unos límites cuantitativos máximos de plazas "alojativas" turísticas para el conjunto de la isla (del orden de 95.400 plazas), por municipios y núcleos de población turística, a desarrollar hasta 2002, si bien se requería una adaptación del planeamiento urbanístico municipal que no en todos los casos se había producido en el año 2000 (sólo San Bartolomé modificó sus Normas subsidiarias para su adaptación en 1995). No obstante, se inicia una reducción del peso de la construcción (de cifras del orden del $24 \%$ en 1986 pasa al $14 \%$ en 1991 y al $9 \%$ en 1996) y del monocultivo turístico con base extra-hotelera (se pasa del señalado $91 \%$ para 1986 al $78 \%$ en 1991 y al $71 \%$ para 1996) con una mejora sustancial no sólo en el PIB per cápita asociado a la producción turística, sino también en los niveles de instrucción que acoge la isla, que se van a elevar, perdiendo presencia la población "sin estudios", que observaba una fuerte mayoría en el periodo anterior, a favor de la formación profesional.

En paralelo, el incremento de población en Lanzarote en el período 1986-1996 (39\%) es muy superior al registrado en España (3\%) y en Canarias (9\%), lo que hace que su incidencia en el incremento del PIB per cápita de Lanzarote se reduzca, al aumentar el denominador poblacional en mayor medida que en estos ámbitos. Adicionalmente, de nuevo el fuerte incremento poblacional se produce a partir de una intensa inmigración que lleva a que la población autóctona en la isla pase del $82 \%$, en 1986 , a sólo el $67 \%$ en 1996, más que cuadriplicándose los provenientes del extranjero (que ya son más del $6 \%$ de la población residente de la isla) triplicándose los provenientes de la península (que computan más del $16 \%$ de la población residente de la isla), y casi duplicándose los provenientes de otras islas canarias (que ya son más del $10 \%$ de la población total de la isla). Cifras que se entienden si se tiene en cuenta que Lanzarote mantiene unas cifras de paro que, aunque muy concentradas en el sector servicios y que van en crescendo, están muy por debajo de la media de Canarias y de España ( $13 \%$ en 1986, frente a $24 \%$ en Canarias y $22 \%$ en España, y del $17 \%$ en 1996, frente a $25 \%$ en Canarias y $22 \%$ en España), lo que refleja una situación socioeconómica diferencialmente positiva. La incidencia de la inmigración ha 
dejado de ser reducida e irá en aumento, como nos muestra la Tabla y Figura siguiente, desembocando finalmente en desequilibrios demográficos, pues en 1996 los alóctonos alcanzan el $33 \%$ de los residentes, que junto a los turistas equivalentes al día, la isla registra, aproximadamente, un $59 \%$ de foráneos en la población que acoge a diario.

Tabla 243. Evolución de la población alóctona, autóctona y foránea (alóctonos y turistas diarios) de Lanzarote. 1970-2006 (\%)

\begin{tabular}{|l|r|r|r|}
\cline { 2 - 4 } \multicolumn{1}{c|}{} & ALÓCTONOS & AUTÓCTONOS & FORÁNEOS \\
\hline $\mathbf{1 9 7 0}$ & 3,90 & 96,00 & 4,97 \\
\hline $\mathbf{1 9 7 5}$ & 5,90 & 94,00 & 5,90 \\
\hline $\mathbf{1 9 8 1}$ & 8,30 & 92,00 & 16,95 \\
\hline $\mathbf{1 9 8 6}$ & 18,10 & 82,00 & 37,12 \\
\hline $\mathbf{1 9 9 1}$ & 25,00 & 75,00 & 48,99 \\
\hline $\mathbf{1 9 9 6}$ & 32,80 & 67,00 & 58,77 \\
\hline $\mathbf{2 0 0 1}$ & 58,98 & 41,02 & 71,37 \\
\hline $\mathbf{2 0 0 6}$ & 51,44 & 48,56 & 62,48 \\
\hline
\end{tabular}

Fuente: Elaboración propia a partir de la población por lugar de nacimiento, recogida en Censos de Población y Padrones Municipales a través del ISTAC e INE y de la estimación propia de turistas equivalentes diarios. Referencia en Tablas 25, 27, 98, 99, 163 y 164.

Gráfico 228. Evolución de la población alóctona, autóctona y foránea de Lanzarote. 1970-2006 (\%)

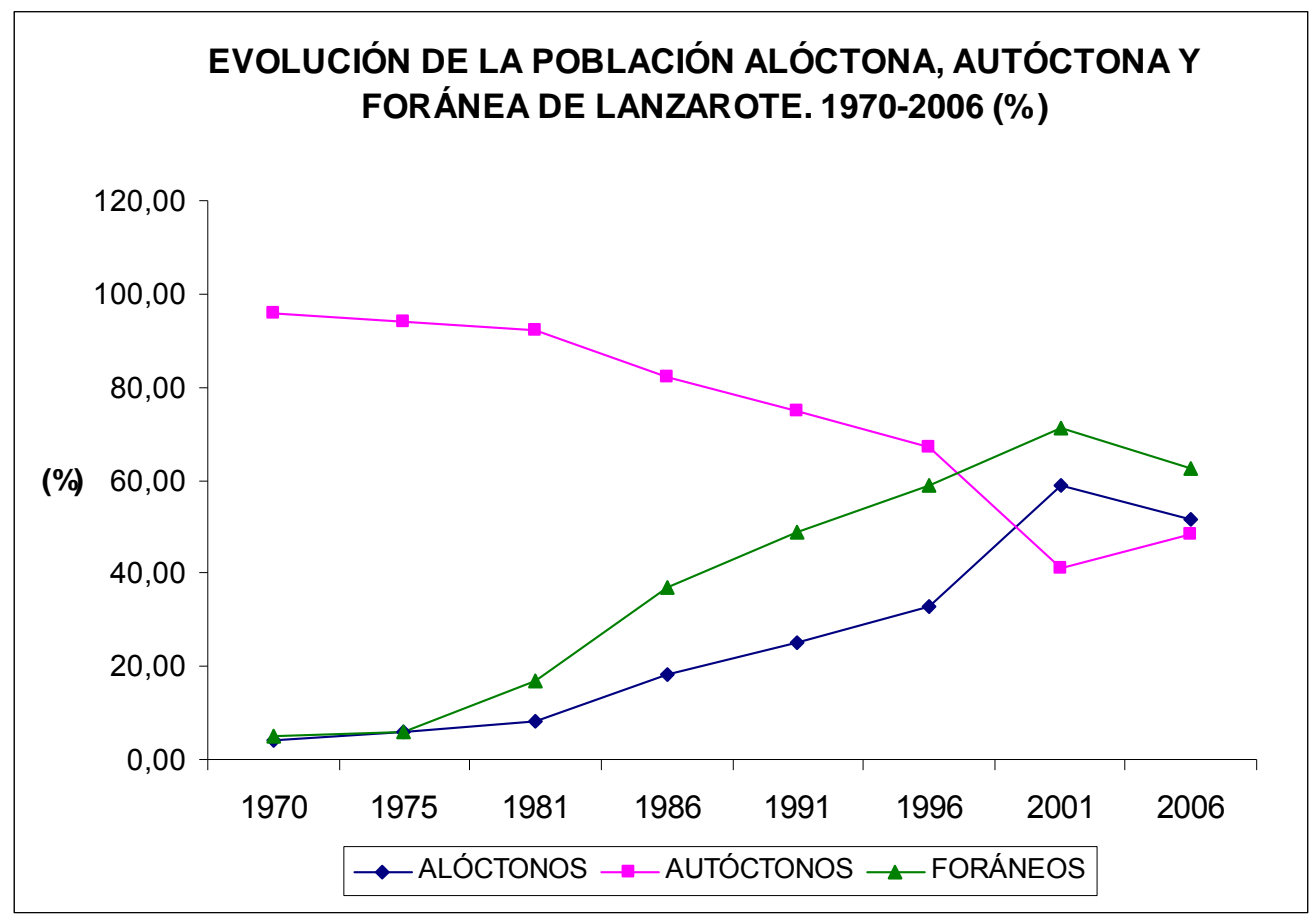

Fuente: Elaboración propia a partir de la población por lugar de nacimiento, recogida en Censos de Población y Padrones Municipales a través del ISTAC e INE y de la estimación propia de turistas equivalentes diarios. Referencia Tabla 243. 
El incremento demográfico y de la demanda turística señalada incidirá de nuevo en el nivel de equipamientos e infraestructuras de forma significativamente notable en la sanidad, pues el boom de la construcción a partir del año 1986 impide acabar el nuevo hospital planificado. El enorme impulso al crecimiento de la oferta turística arrastra los recursos materiales y humanos y se convierte en un obstáculo al bienestar social en materia de adaptación de las dotaciones hospitalarias a la demanda demográfica. No será hasta la década de los años noventa cuando esta situación pueda ser superada, iniciándose con ampliaciones dotacionales en este ámbito que permiten, por un lado, reducir los efectos de la insularidad en la sanidad pública, es decir, la dependencia de la capital de provincia, Las Palmas, que sigue centralizando las especialidades. $Y$ por otro lado se inicia un proceso de descentralización extrahospitalaria que poco a poco ampliará el mapa sanitario insular y que durará hasta entrado el nuevo siglo, mejorando la dotación en las cabeceras municipales, descongestionando la atención primaria y generando cierta difusión territorial del bienestar.

La infraestructura energética, destinada a la generación de electricidad, seguirá creciendo empujada por la fuerte demanda que reduce rápidamente su capacidad mermando las mejoras conseguidas, y la ampliación de la central térmica eléctrica a través de la incorporación de nuevos motores diesel es la solución más rápida, incrementando los gases de efecto invernadero y la contaminación derivada, que se empieza a hacer notar al final de la etapa. No obstante, comienza en 1991 la apuesta por las energías renovables con la apertura de un parque eólico, pero su aportación al sistema en 1996 es tan sólo del 4,4\% y otro tipo de renovables no tienen presencia.

Similar dinámica sufre la capacidad de potabilización de agua, ampliando las plantas y sus módulos, que incorporan en su totalidad el tratamiento por osmosis inversa, consiguiendo así mejoras en el abastecimiento de agua corriente, que empieza a llegar a todas las zonas rurales aunque de modo intermitente, sin garantías; no así para las urbanas-turísticas que tendrán siempre prioridad sobre el resto de los núcleos de población. La austeridad en el consumo de los residentes compensa el exhibicionismo del turista. En contrapartida produce efectos negativos en el consumo de energía y en la contaminación (emisiones de $\mathrm{CO}_{2}$, salmuera, etc.). Estas mejoras sólo conseguirán alivios muy temporales pues las presiones demográficas son elevadas y no paran de crecer en toda esta etapa y la siguiente. La aportación al sistema de las desaladoras privadas (que siguen creciendo en número contabilizándose por esta época unas 40) se desconoce, aunque las fuentes utilizadas en esta tesis revelan que en buena parte, las instalaciones hoteleras, se abastecen del agua corriente pública (ver epígrafe 5.2.8.1). Todo ello confirma dos cosas, no existe garantía en el suministro y la actividad turística es un fuerte competidor por el agua. A ello se añade los avisos que llegan desde diferentes informes señalando la necesidad de mejorar el estado de la red, que genera importantes pérdidas. Con todo, el sistema de tarifas según usos de la isla revela al sector turístico, y todo el proceso industrial derivado del mismo, como el 
verdadero financiador del sistema de abastecimiento de agua de Lanzarote, que permite precios razonables para los residentes, positivo en términos de bienestar.

La política con respecto al transporte por carretera seguirá siendo la misma que en el periodo anterior, el crecimiento de la economía medida en PIB per cápita relativo seguirá permitiendo el acceso al vehículo privado, por lo que los índices de motorización seguirán siendo superiores a los del país y el conjunto del archipiélago. Se empieza a sentir la presión de la circulación en el eje central (Arrecife, Aeropuerto, Puerto del Carmen).

La contención del volumen de población diario que acoge la isla a través de la limitación del crecimiento de la oferta y la demanda turística se marca en el discurso social, científico y político en esta década, y llega a nuestros días, como la vía para el cambio de signo de los efectos sociales e infraestructurales negativos que sobre el bienestar ya se detectan.

\subsection{1.- MADUREZ TURÍSTICA Y NEGATIVA DEPENDENCIA DEL MONOCULTIVO DE LA CONSTRUCCIÓN Y DEL TURISMO}

La Tercera etapa incluida en esta tesis abarca el período 1996-2006, considerando la evolución del PIB per cápita para el período 1996-2003, para el que se han podido homogeneizar los datos, y con ella se culmina el período global 1970-2006 tenido en cuenta en la tesis.

Su inicio coincide con la Revisión del PIOT 1991 y con la realización de la Estrategia de Lanzarote en la Biosfera, donde el planteamiento de objetivos de un desarrollo más sostenible implica la concepción de un nuevo modelo para el territorio. El nuevo Plan Insular va a fijar un techo de plazas turísticas en 67.695 para 2010 (lo que supone una reducción de casi el $29 \%$ con respecto al límite máximo establecido en el PIOT 1991) y va a sustituir plazas turísticas del PIOT de 1991 por plazas residenciales, pero con cautelas para evitar el crecimiento desproporcionado de la vivienda para residencia. Por último, en este período se adapta todo el planeamiento al nuevo PIOT salvo en el caso de Yaiza (a pesar de ser un municipio de elevada importancia turística), que, en 2006, continuaba con el planeamiento de 1973. El periodo de análisis de esta tesis termina, precisamente, con la anulación de este PIOT aprobado en 2000, por sentencia de 11 de febrero de 2005.

Con respecto a la evolución del PIB per cápita de Lanzarote, como se ha podido apreciar en las Figuras anteriores, hasta 2001 continúa mejorando tanto ante la provincia de Las Palmas, como ante Canarias y ante España, produciéndose en el período 2001-2003 un cierto estancamiento en la mejora. En todo caso, no se llega a alcanzar el valor del PIB per cápita de estos territorios, aunque en 2003 se supera el $90 \%$ del mismo en todos los casos y se llega al $98 \%$ del de Canarias; y ello aunque el crecimiento de la población (en la década) sigue siendo mucho mayor en Lanzarote (64\%) que en Canarias (24\%) o en España (13\%), 
lo que contribuye a una reducción relativa para Lanzarote del PIB per cápita. Y, nuevamente es la inmigración la causa principal de este crecimiento demográfico, lo que reduce la población autóctona hasta el 49\% para 2006, si bien en 2001 llega a ser el 41\%. En todo caso, la población nacida fuera de la isla es mayoría a lo largo del siglo XXI y en ella destacan los extranjeros (nacidos en otro país), que representan casi el $26 \%$ del total de los residentes registrados en el año 2006 ( $y$, dentro de ellos, los nacidos en Colombia (4\% de la población residente total), Reino Unido (4\%), Alemania (3\%) y Marruecos (3\%). America será el continente con mayor representación (40\%), seguido de Europa con un peso del $38 \%)$, los peninsulares $(17 \%)$ y los nacidos en otras islas $(8,6 \%)$. Otra característica importante es que el $86 \%$ de estos nacidos fuera de las islas es población potencialmente activa, con un máximo en el intervalo entre 25 y 45 años, que representan el $43 \%$ del total de alóctonos. La mayor proporción se alcanza en el año 2001, derivada de una nueva oleada de entrada de mano de obra que acontece a lo largo del quinquenio (entre 1996 y el año 2001 la población residente sufre un incremento cercano al 140\%), similar a lo ocurrido en la etapa desarrollista (entre 1981 y 1986 la población residente creció un 144\%). Estamos ante un patrón de crecimiento del pasado, que se produce en este lustro a consecuencia del anuncio de la puesta en marcha de la Moratoria Turística, que provoca una nueva fiebre de la construcción antes de su entrada en vigor. La modificación del planeamiento vigente supone un sobre impulso previo de la edificación, por lo que la oferta quedará constreñida en el quinquenio siguiente (2001-2006) y no antes, que es cuando se reduce muy significativamente y se mantiene por debajo de las cifras respectivas de España y Canarias (como veíamos en la figura recogida anteriormente), incrementándose en un $23 \%$ en el período, frente al $31 \%$ de Canarias o el $41 \%$ de España. Adicionalmente, continúa reduciéndose el peso de la oferta extra-hotelera en el total, pasando del $71 \%$ de 1996 al $61 \%$ de 2006 , cifra más semejante a lo tradicional en otros ámbitos, aunque todavía con valores más elevados de los característicos de Canarias (54\% en 2006) que prefiguran un turismo en la isla con un fuerte peso relativo de la oferta turística extra-hotelera.

Igualmente, la demanda sufre una reducción de su crecimiento en el período, con un crecimiento del $23 \%$ entre 1996 y 2001 , pero un descenso de casi un 4\% entre 2001 y 2006 que, aunque mejor que las cifras de Canarias ( $3 \%$ y $-6 \%$ respectivamente) se encuentran muy por debajo de los valores de España en el conjunto del período ( $39 \%$ y $27 \%$ respectivamente). Algunos lo tildarán de crisis y otros no, lo cierto es que sí se percibe una clara incidencia (registrada para todo el turismo en España) de la emergencia de destinos internacionales alternativos con mejores relaciones de calidad-precio, de la aparición de líneas de bajo coste que operan en aeropuertos secundarios, de la entrada del euro y de una tendencia a la reducción de las aportaciones del turismo a la economía local. Esta llamada crisis de afluencia frena el crecimiento de la población alóctona y foránea que diariamente acoge la isla, reduciendo los desequilibrios demográficos y aliviando la presión sobre las infraestructuras y servicios. 
Pese a la menor incidencia de la oferta turística y a la supuesta restricción edificatoria de la revisión del PIOT, en el período se aprecian dos fenómenos: en primer lugar la necesidad de moderar la presión humana sobre el territorio no se ha conseguido (como se deriva de los datos anteriores); y en segundo lugar se registra un incremento del empleo en la construcción, pasando del $9 \%$ del total, en 1996, al 17\% en 2006, e incrementándose la población ocupada en este sector en unas 9.300 personas. Fenómenos ambos que se explican por el efecto "llamada" generado por el anuncio de una moratoria descrito anteriormente. La agricultura y la industria se sitúan en cifras marginales en 2006 (0,5\% y $1,7 \%$, respectivamente) reduciendo el número de empleados entre 1996 y 2006 , y sólo el sector servicios incrementa también sus empleos en unas 18.000 personas, pasando a representar, en 2006, el 78\% del empleo. La dependencia económica de la construcción y de los servicios $(96 \%$ del empleo total) adquiere proporciones absolutamente desaconsejables por la fragilidad que representa para la economía de la Isla, que ha quedado sujeta a una demanda inestable por su directa vinculación con el turismo, por tanto inestable también será lo que caracteriza su oferta de empleo. En paralelo, Lanzarote sigue gozando de una situación de ventaja en la tasa de paro que se mantiene muy por debajo de la de Canarias y de la de España, aunque al final del período ya no podemos ser tan optimistas pues supera la tasa nacional $(8.5 \%)$, con un $9,7 \%$, paro, que se concentra fundamentalmente en el sector servicios (comercio y hostelería).

El incremento del empleo en la construcción no es independiente de la burbuja inmobiliaria especulativa que, desde la modificación de la ley estatal del suelo, de 1998, afecta a toda España y que va a ser una de las bases del crecimiento económico y del empleo del período. Efectivamente, como se aprecia en la Figura siguiente, el número de viviendas familiares totales (primera y segunda residencia, más vacías y resto) crece exponencial en la Isla multiplicándose por más de seis entre 1970 y 2001 pero con un último decenio (19912001) en que el número de viviendas más que se duplica. Pero, en este último periodo, de las casi 39.000 viviendas nuevas, 23.000 son segundas residencias, pasando a representar las viviendas principales del $77 \%$, en 1970 , al $47 \%$ del total en 2001 . A comienzos del siglo XXI ni la mitad de la población es autóctona ni la mitad de las viviendas son para residencia familiar. 
Gráfico 229. Censos de vivienda familiar. Lanzarote. 1970-2001

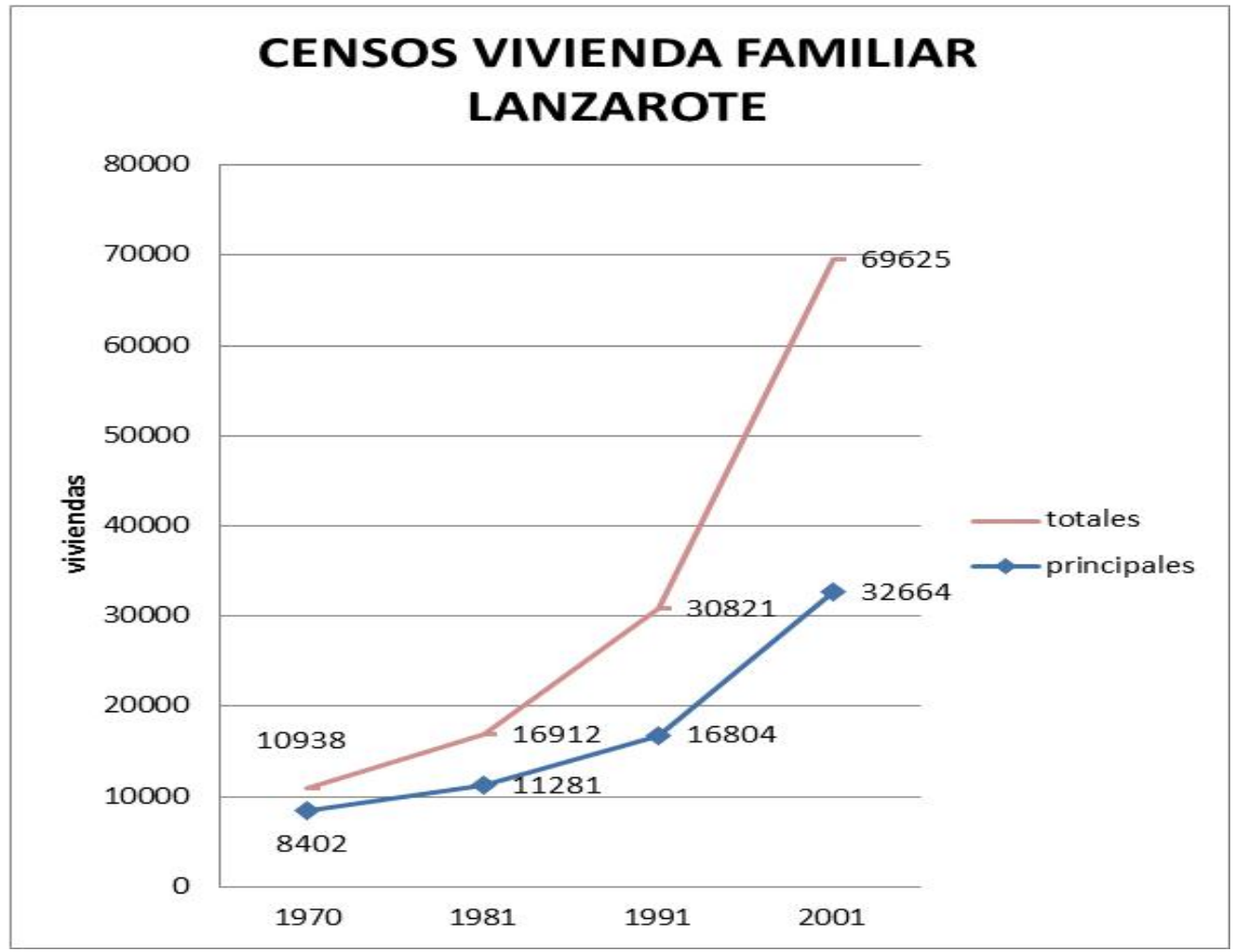

Fuente: Elaboración propia a partir de datos del INE. Censos de población y vivienda municipales.

Tras 2001 el ritmo cambia radicalmente pues entre 1996 y 2001 sólo se visan en la isla 4.441 viviendas nuevas, que pasan a ser 7.638 en el período 2001-2006, lo que sólo significa un incremento del $11 \%$, en cinco años, sobre la totalidad del parque de 69.625 viviendas familiares existentes en la Isla en 2001, mostrando la moderación sobre las casi 40.000 viviendas añadidas entre 1991 y 2001. En paralelo, los precios de la vivienda registran un fuerte incremento en el período como nos muestran los datos medios disponibles para Canarias y la provincia de Las Palmas (no existen datos para la Isla fiables y homologables):

Tabla 244. Evolución del precio de la vivienda libre. Las Palmas y Canarias. 1996-2006

\begin{tabular}{|c||c|c|c|c||}
\hline \multirow{2}{*}{$\begin{array}{c}\text { Media anual } \\
\text { precio en } \boldsymbol{\epsilon} / \mathbf{m}^{\mathbf{2}}\end{array}$} & \multicolumn{2}{|c||}{ Total viviendas libres } & \multicolumn{2}{c|}{ Índice base 100=1996 } \\
\cline { 2 - 5 } & CANARIAS & LAS PALMAS & CANARIAS & LAS PALMAS \\
\hline $\mathbf{2 0 0 6}$ & $1.695,20$ & $1.734,40$ & 273 & 275 \\
\hline $\mathbf{2 0 0 1}$ & $1.081,90$ & $1.141,80$ & 174 & 181 \\
\hline $\mathbf{1 9 9 6}$ & 620,20 & 629,60 & 100 & 100 \\
\hline
\end{tabular}

Fuente: Ministerio de Vivienda e ISTAC. [En línea. Ref. 20 de mayo de 2012]. Disponible en Web: (http://www.datosdelanzarote.com/itemDetalles.asp?idFamilia=10\&idltem=4871. 
El resultado de este proceso en relación al PIB per cápita es el incremento de la baja productividad del empleo, el soporte a una inmigración de población de baja cualificación (el colectivo de alóctonos "sin estudios" o "primaria incompleta" pasa del $7 \%$ en 1996, al 30\% en 2001, del total de inmigrantes) y una transformación territorial por la urbanización, aspectos todos ellos bastante desacordes con los planteamientos de la Estrategia de Lanzarote en la Biosfera.

A lo que se añade otras áreas que se van a ver afectadas de igual forma por el proceso de crecimiento demográfico y de la construcción a lo largo de este periodo como es la energía y el ciclo del agua, ambos sectores no dejarán de crecer en producción eléctrica y desalinización de agua de mar, pues deben responder a las nuevas puntas de demanda, con importantes crecimientos de los consumos unitarios, la contaminación derivada y la dependencia del exterior, ya que el sistema de generación eléctrica, descrito en el apartado anterior, no se ha modificado sino que se amplía la Central Térmica (el gasóleo, seguido del fuel-oil, sigue siendo la fuente para la generación de energía eléctrica en todo el archipiélago. Por lo que no se reducen las emisiones de efecto invernadero y no se cumple con el protocolo de KIOTO), aunque también lo hacen las energías renovables que seguirán teniendo escasa aportación al sistema. El incremento relativo de la potencia eléctrica instalada volverá a ser muy superior al de Canarias y del Estado para el mismo periodo, como se ha reflejado en una de las figuras anteriores, de cuya producción el $14 \%$ será destinado a desalinizar agua de mar (estimación de 2006).

La rapidez con que la isla ha respondido en estos años a las constantes explosiones de demanda, han convertido este sistema (que es una red conjunta Lanzarote-Fuerteventura en simple circuito) en un sistema frágil, en el sentido de que subsiste al límite pues se encuentra saturado en dirección sur-este (la parte del territorio insular que soporta los desarrollos turísticos-residenciales) y existen caídas de tensión en Fuerteventura. Esta saturación impide detener la generación de dicha energía para mantenimiento de los motores. No existe por tanto seguridad de suministro.

Estado similar vive la infraestructura de producción de agua en la isla, que, de igual forma, las plantas de tratamiento no han dejado de ampliarse con nuevos módulos, tendiendo a conseguir más producción con menor consumo energético y mayor rentabilidad, y multiplicando por dos la producción en este periodo, con mayor impulso en el primer lustro por el crecimiento de la actividad en la construcción y de la demanda turística descrita. La isla produce más agua por residente y día que Canarias y España, aún así no es suficiente. Las pérdidas en red seguirán siendo una de las debilidades de este sistema, que se estiman mayores del 30\% (derivadas de conducciones defectuosas y en mal estado, fugas en depósitos, consumos no autorizados (por parte de la agricultura y el sector hotelero) y deficiente gestión del servicio a los usuarios), seguido de una precaria garantía de abastecimiento pues los depósitos seguirán teniendo escasa capacidad de almacenamiento 
(dos-tres días) y se depende de la producción diaria, por lo que es un sistema enormemente vulnerable a averías y a paros por mantenimiento. A ello se añade el incumplimiento, en algunas zonas, de la obligación de que cada vivienda tenga sus propios depósitos. Este estado de precariedad afecta en mayor medida a áreas rurales, a las que sólo se les abastece de agua corriente dos veces en semana. Las tarifas aplicadas, en relación al uso, seguirán sin modificaciones hasta el año 2007, por lo que en ellas no se ha contemplado el encarecimiento energético ni la ampliación de la infraestructura, lo que apoya el crecimiento del déficits de este sistema público de desalinización. La información sobre producción de las plantas privadas sigue sin ser clara.

Con respecto a las etapas anteriores, el balance final de esta nos lleva a afirmar que, si la mayor presión sobre el sistema energético e hídrico insular la ha venido ejerciendo la actividad turística-industrial, el descenso de la actividad en la misma no ha permitido ahorros en el consumo por dos motivos interrelacionados: a) pérdida de la cultura tradicional en relación a la austeridad en el uso del agua y desvanecimiento de conciencia de escasez; b) constante incorporación de población externa a residir. Más de la mitad de la población que reside en la isla proviene de otras regiones españolas, europeas y de países externos a Europa, con diferentes hábitos que no favorecen el estado en el que se encuentra este recurso en la isla.

Esta multiculturalidad que acoge, parece diluir la cultura local tradicional en este sentido, pero también, cualitativamente y en términos de integración constituye todo un reto para el sistema educativo insular, pues debe atender la enorme heterogeneidad cultural e idiomática del alumnado procedente del exterior dentro de la enseñanza obligatoria, que se estima en un $19 \%$ del total de alumnos, más del doble que la media de Canarias (9\%) y de España $(8,6 \%)$.

A pesar de la ralentización del crecimiento de la oferta y la caída de la demanda turística, la producción y el consumo de agua y energía eléctrica no van a dejar de crecer, como se muestra en las figuras siguientes. Por lo que el reconducir a la isla hacia los principios recogidos en la Estrategia de la Biosfera pasa por la reducción del volumen de personas que diariamente soporta, a partir de una política turística pero también de una política demográfica. 
Tabla 245. Evolución de la producción y consumo de energía eléctrica, en relación a la oferta y demanda turística y la población residente. Lanzarote. 1970-2006 (1970=100).

\begin{tabular}{|l|r|r|r|r|r|}
\cline { 2 - 6 } \multicolumn{1}{l|}{} & \multicolumn{1}{c|}{ Producción } & Consumo & Oferta Turística & Demanda Turística & Población Residente \\
\hline $\mathbf{1 9 7 0}$ & 100,00 & 100,00 & 100,00 & 100,00 & 100,00 \\
\hline $\mathbf{1 9 7 5}$ & 227,48 & 185,12 & 460,81 & 317,59 & 107,76 \\
\hline $\mathbf{1 9 8 1}$ & 686,74 & 583,73 & 730,77 & 699,91 & 123,27 \\
\hline $\mathbf{1 9 8 6}$ & 1538,14 & 1307,42 & 2189,87 & 1746,72 & 135,53 \\
\hline $\mathbf{1 9 9 1}$ & 3031,06 & 2859,63 & 2712,74 & 3865,21 & 157,76 \\
\hline $\mathbf{1 9 9 6}$ & 4182,04 & 3928,26 & 3005,12 & 5572,32 & 188,06 \\
\hline $\mathbf{2 0 0 1}$ & 6065,94 & 5722,77 & 3397,90 & 6880,89 & 250,44 \\
\hline $\mathbf{2 0 0 6}$ & 7613,77 & 7874,03 & 3714,05 & 6639,42 & 309,77 \\
\hline
\end{tabular}

Fuente: Elaboración propia a partir de datos del Ministerio de Industria, Turismo y Comercio, de la Dirección General de Industria y Energía del Gobierno de Canarias, del PECAN y del PTEOIE-LZ, del Centro de datos del Cabildo Insular de Lanzarote y de Censos de Población y Padrones Municipales del INE

Gráfico 230. Evolución de la producción y consumo de energía eléctrica, en relación a la oferta y demanda turística y la población residente. Lanzarote. 1970-2006 (1970=100).

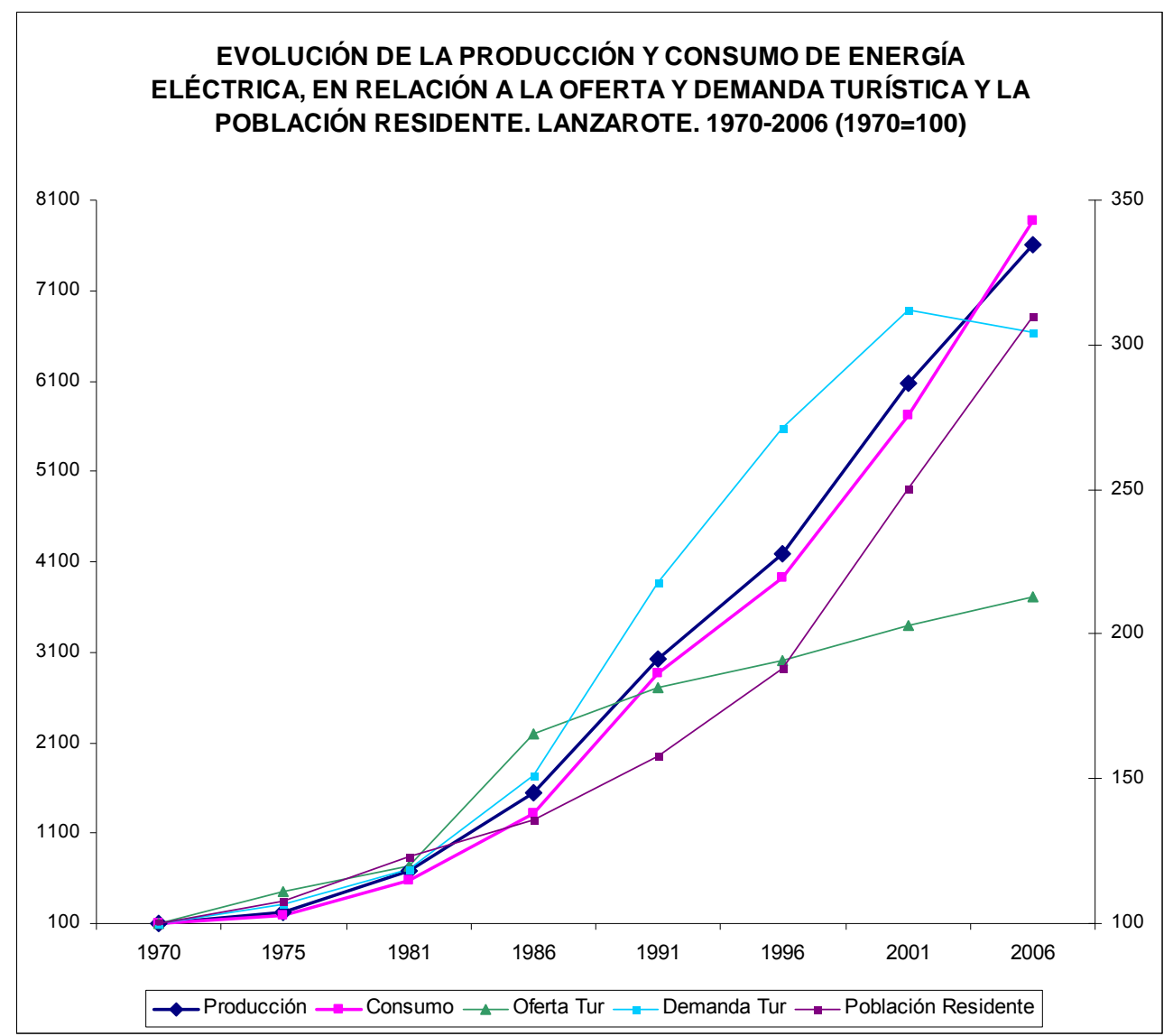

Fuente: Elaboración propia a partir de datos del Ministerio de Industria, Turismo y Comercio, de la Dirección General de Industria y Energía del Gobierno de Canarias, del PECAN y del PTEOIE-LZ, del Centro de datos del Cabildo Insular de Lanzarote y de Censos de Población y Padrones Municipales del INE. Referencia Tabla 245. 
Tabla 246. Evolución del consumo y la disponibilidad de agua después de pérdidas en red (I/hab*día), en relación a demanda y oferta turística y a la población residente. Lanzarote. 1970$2006(1970=100)$.

\begin{tabular}{|l|r|r|r|r|r||}
\cline { 2 - 6 } \multicolumn{1}{c|}{} & Disponibilidad & Consumo & Oferta Turística & Demanda Turística & Población Residente \\
\hline \hline $\mathbf{1 9 7 0}$ & 100,00 & 100,00 & 100,00 & 100,00 & 100,00 \\
\hline $\mathbf{1 9 7 5}$ & 140,54 & 134,63 & 460,81 & 317,59 & 107,76 \\
\hline $\mathbf{1 9 8 1}$ & 212,70 & 249,16 & 730,77 & 699,91 & 123,27 \\
\hline $\mathbf{1 9 8 6}$ & 309,72 & 251,75 & 2189,87 & 1746,72 & 135,53 \\
\hline $\mathbf{1 9 9 1}$ & 279,55 & 257,19 & 2712,74 & 3865,21 & 157,76 \\
\hline $\mathbf{1 9 9 6}$ & 310,78 & 327,26 & 3005,12 & 5572,32 & 188,06 \\
\hline $\mathbf{2 0 0 1}$ & 361,15 & 416,69 & 3397,90 & 6880,89 & 250,44 \\
\hline $\mathbf{2 0 0 6}$ & 412,83 & 447,00 & 3714,05 & 6639,42 & 309,77 \\
\hline \hline
\end{tabular}

Fuente: Elaboración propia a partir de datos del ISTAC e INE, del Plan Insular de Lanzarote, 1973; Avance PIOT, 1987; Avance PIOL, 2008 y Avance PIOL, 2010 y Centro de datos del Cabildo Insular de Lanzarote. (Disponible en Web: www.datosdelanzarote.com)

Gráfico 231. Evolución del consumo y la disponibilidad de agua después de pérdidas en red (I/hab*día), en relación a demanda y oferta turística y a la población residente. Lanzarote. 1970-2006 $(1970=100)$.

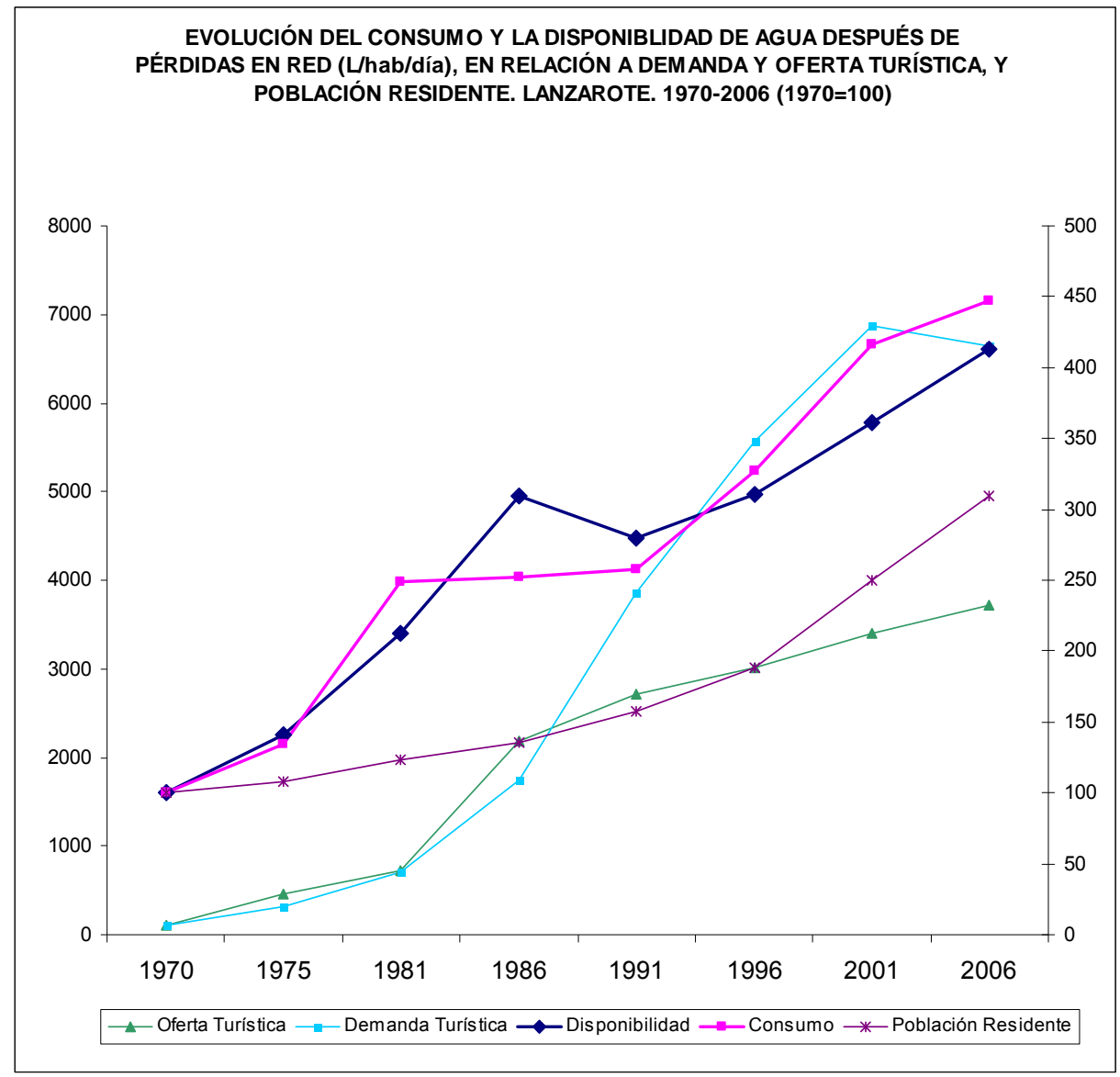

Fuente: Elaboración propia a partir de datos del ISTAC e INE, Plan Insular de Lanzarote, 1973; Avance PIOT, 1987; Avance PIOL, 2008 y 2010 y Centro de datos del Cabildo Insular de Lanzarote. Referencia Tabla 246. 
Los crecimientos descritos seguirán afectando negativamente sobre el equipamiento sanitario hospitalario, cuyo estrangulamiento dotacional ya es estructural, como se señaló anteriormente. Sin embargo la modificación y el pequeño éxito estará en una política aplicada que abre dos procesos de descentralización: 1) crecimiento de las especialidades médicas que reducen la dependencia con respecto a los servicios de la capital de provincia, Las Palmas, reduciéndose por tanto los efectos negativos de la insularidad; 2) ampliación de las instalaciones de asistencia primaria o extrahospitalaria, rompiendo con los desequilibrios territoriales existentes (adaptándose al crecimiento demográfico de los diferentes municipios y los núcleos donde ésta se concentra), es decir, se produce cierta difusión del bienestar. La disponibilidad de médicos que siempre ha sido escasa comparativamente al indicador canario y al nacional, ahora se aproximan, aunque la isla siempre se sitúa por debajo en capacidad de recursos humanos al conjunto del archipiélago y España, como podemos constatar en la siguiente figura.

Tabla 247. Evolución del número de habitantes por médico. España, Canarias y Lanzarote. 1970-2006

\begin{tabular}{|l|r|r|r||}
\cline { 2 - 4 } \multicolumn{1}{c|}{} & Lanzarote & Canarias & \multicolumn{1}{c|}{ España } \\
\hline $\mathbf{1 9 7 0}$ & 1.372 & 1.315 & 948 \\
\hline $\mathbf{1 9 7 5}$ & 1.478 & 952 & 660 \\
\hline $\mathbf{1 9 8 1}$ & 1.691 & 938 & 634 \\
\hline $\mathbf{1 9 8 6}$ & 1.549 & 357 & 294 \\
\hline $\mathbf{1 9 9 1}$ & 1.014 & 669 & 701 \\
\hline $\mathbf{1 9 9 6}$ & 561 & 574 & 555 \\
\hline $\mathbf{2 0 0 1}$ & 596 & 533 & 527 \\
\hline $\mathbf{2 0 0 6}$ & 518 & 530 & 482 \\
\hline
\end{tabular}

Fuente: elaboración propia a partir de datos del INE, ISTAC; Planes de Ordenación Insulares; Hospital Insular de Lanzarote y Centro de datos del Cabildo Insular de Lanzarote. (Disponible en Web: www.datosdelanzarote.com) 
Gráfico 232. Evolución del número de habitantes por médico. España, Canarias y Lanzarote. 1970-2006

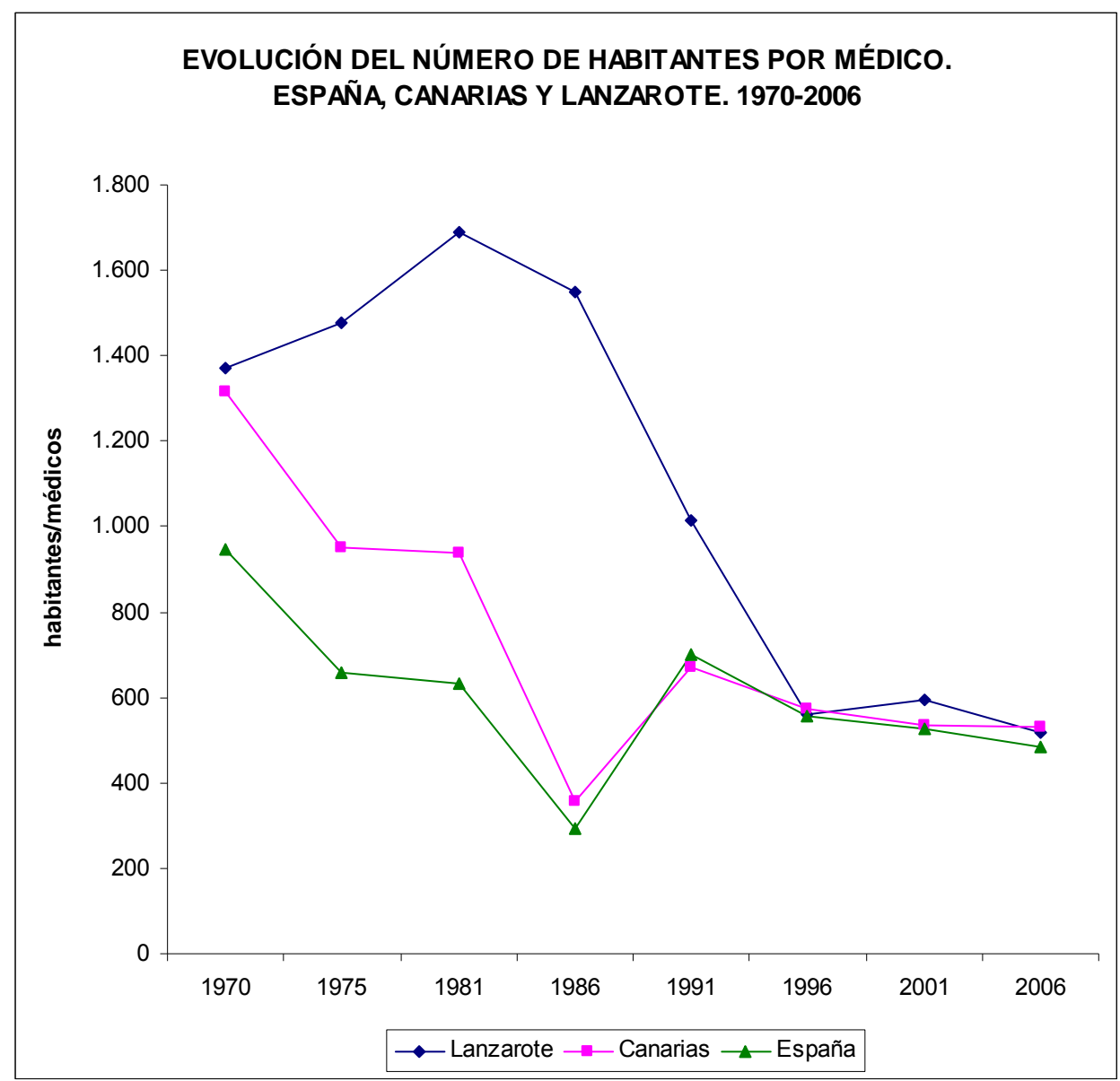

Fuente: elaboración propia a partir de datos del INE, ISTAC; Planes de Ordenación Insulares; Hospital Insular de Lanzarote y Centro de datos del Cabildo Insular de Lanzarote. (Disponible en Web: www.datosdelanzarote.com). Referencia Tabla 247.

La política con respecto a comunicaciones por carretera se modifica en esta etapa, pues ya no se considera necesario incrementar el ancho de vía y la conectividad, pues la velocidad de circulación a la que se puede llegar en la isla está alcanzada. El crecimiento de la economía medida en PIB per cápita relativo seguirá permitiendo el acceso al vehículo privado, por lo que las intensidades medias de tráfico no han dejado de crecer y los índices de motorización seguirán siendo superiores a los del país y el conjunto del archipiélago como ha quedado constancia en figuras anteriores, uniéndose a ello los vehículos de alquiler. La presión de la circulación en el eje norte-sur por el litoral (Costa de TeguiseArrecife-Aeropuerto-Puerto del Carmen-Playa Blanca) es notable, con dificultades de acceso a la capital entrado el nuevo siglo. Al crecimiento del factor renta que impulsa esta dinámica se une los efectos derivados de las políticas territoriales aplicadas que han propiciado la dispersión del hábitat y procesos de periurbanización en la década de los noventa elevando los indicadores mencionados. A ello se añade la histórica insuficiencia y falta de eficiencia de la oferta de servicio regular de transporte de pasajeros que continúa existiendo, convirtiéndose en un medio poco usado (representa el $7 \%$ de todos los desplazamientos 
mecanizados), además los trayectos por ocio no han incentivado su mejora ( $5 \%$ del total de trayectos). La mitificación del transporte privado y la posesión de vehículo propio como signo de posición social, siendo el uso del transporte público símbolo de carestía, ha quedado arraigado en el imaginario colectivo como demuestran investigaciones realizadas por los servicios del Cabildo de Lanzarote, lo que dificulta que tome un nuevo impulso con consecuencias negativas sobre el medio ambiente y el bienestar derivado.

La áreas tocantes al bienestar social aquí tratadas se han visto compensadas negativamente cuando Lanzarote se ha convertido en un destino maduro, el balance final no es positivo. En estos casos, la elaboración y gestión de la ordenación del territorio bajo principios de equidad y sostenibilidad se vuelve fundamental, pues como queda demostrado es la calidad y no la cantidad la que debe presidir las políticas de desarrollo turístico para que no revierta hacia los efectos descritos.

\section{4.- UN BALANCE MEJORABLE}

Desde uno de los primeros documentos de planificación turística de la Isla, el "Plan Insular de Ordenación de la Oferta Turística de la Isla de Lanzarote" elaborado por PROINTEC para la entonces Secretaría de Estado de Turismo, en 1982, hasta la actualidad, Lanzarote ha sido objeto de numerosos estudios, análisis y planes, $Y$ son muchas las fuentes que marcan 2006 como el punto de inflexión en una evolución cuyos resultados ya no pueden considerarse óptimos para la Isla. Se piensa que quedan muy atrás los beneficios de una etapa de turismo local transformador de una sociedad agraria en una sociedad abierta y ligada al sector servicios, con fuerte mejora de la situación de la población autóctona en la década de los setenta; pero que se continúa en una segunda fase de transición al turismo de masas, con peso decreciente de la población autóctona y con unos beneficios también decrecientes para la misma; y que culmina en una tercera y última fase de madurez, donde la demanda y la actividad turística empiezan a no representar beneficios tan claros para una población autóctona ya en minoría y absolutamente ligada al monocultivo turístico y constructor, con cada vez de menor valor añadido para la población y más depredador para el territorio. La Oficina de Turismo Interior del Cabildo de Lanzarote ha reflejado estas tres fases a través de la evolución de la afluencia turística, según se refleja en la Figura siguiente: 


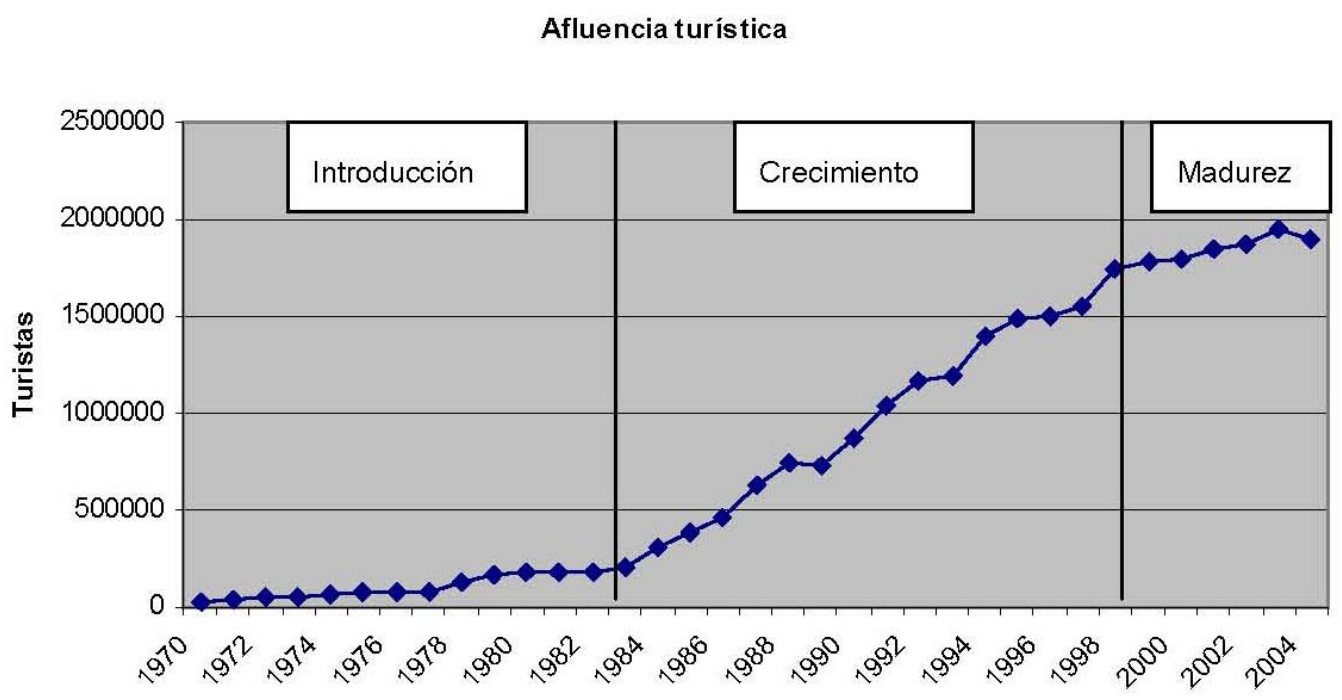

Fuente: Oficina de turismo interior del Cabildo de Lanzarote, recogida por Calero, P. (2005, pp. 13).

Pero son los grandes "tour operators" internacionales los que presiden la gran expansión de la etapa 1984 a 1999 generalizando un turismo de masas que les permitan apropiarse de los beneficios asociados a las economías de escala que este tipo de turismo les proporciona. Las condiciones financieras de la Isla y los incentivos para bajar los costes del capital, junto a la falta de alternativas de inversión atractiva favorecen la inversión internacional y peninsular, atraída tanto por la alta rentabilidad del sector turístico (en cinco años se podía amortizar la inversión en un hotel) como por los beneficios especulativos históricos asociados a la inversión inmobiliaria.

En paralelo se produce un abaratamiento relativo de la mano de obra por la llegada de inmigrantes que mejora la rentabilidad de las inversiones pero incide negativamente sobre la renta de la población autóctona. Complementariamente, en este empeoramiento de las condiciones de la población autóctona también va a incidir la progresiva expansión del "todo incluido" por parte de los "tour operators", que deslocaliza de la Isla el valor añadido de los servicios y actividades turísticas proporcionadas. Por último, una variable fundamental en el turismo de masas y muy negativa para la sostenibilidad del desarrollo de la Isla, es su dependencia de factores externos incontrolables desde ésta, como son la situación económica de los países de origen (Alemania y Gran Bretaña, fundamentalmente para la Isla) y la situación de los ámbitos competitivos (este y sur del Mediterráneo, fundamentalmente). La crisis en los primeros van a significar problemas para la Isla, mientras que las crisis en los segundos (guerras, terrorismo, inseguridad,...) van a significar incrementos de la demanda registrada. Así, la buena situación económica en Gran Bretaña hasta el año 2001 explica en gran parte el auge de la demanda desde este ámbito, al igual que la crisis alemana de principios de siglo va a explicar parte de la desaceleración que se produce en la etapa final del ciclo estudiado. 


\section{5.- LA DIMENSIÓN TERRITORIAL DEL PROCESO.}

Cada una de las fases consideradas tiene una secuencia y una trascendencia diferencial en cada zona del territorio, en su PIB per cápita y en sus indicadores de bienestar asociados a la distinta incidencia que ha tenido, a lo largo del tiempo, el desarrollo de la actividad constructora y turística, y el grado en que esta actividad iba suplantando a la agricultura, a la pesca y a la incipiente industria local localizada casi exclusivamente en Arrecife.

Para concretar esta evolución diferenciada territorialmente, se va a partir de los datos de la tabla siguiente donde se registra la evolución del PIB per cápita medio de cada municipio, homogeneizado respecto al conjunto de la isla de Lanzarote. $Y$ consideraremos, en paralelo, los datos de evolución de la oferta y demanda turística, el número de viviendas y la población y estructura productiva de los empleados residentes en cada municipio, como factores en alguna medida incidentes en la evolución del correspondiente PIB per cápita, si bien hay que tener en cuenta que la reducida dimensión de la Isla permite el desplazamiento cotidiano de la residencia al trabajo, por lo que la actividad productiva de la población residente en cada municipio no está totalmente correlacionada con el PIB per cápita de su lugar de residencia. Es decir, la producción y el empleo que la genera pueden estar radicados en municipios distintos con lo que, incluso, los valores medios estimados del PIB per cápita municipal pueden reflejar errores sustanciales respecto a la realidad. Realidad que, en todo caso, sólo está representada por un valor medio que no atiende a aspectos mucho más significativos como es la distribución de la renta entre los distintos estratos de población y, para los objetivos de esta tesis, cómo se sitúan en esa distribución los autóctonos de Lanzarote.

Con estas salvedades, los datos correspondientes se recogen en la tabla y la figura siguientes:

Tabla 248. PIB per cápita a precios corrientes de mercado de los municipios de la isla (Lanzarote=100)

\begin{tabular}{|l||c|c|c|c|c|c|c|c|}
\cline { 2 - 10 } \multicolumn{1}{l|}{} & 1970 & 1975 & 1981 & 1986 & 1991 & 1996 & $\mathbf{2 0 0 1}$ & $\mathbf{2 0 0 3}$ \\
\hline \hline Arrecife & 115 & 105 & 151 & 144 & 125 & 100 & 100 & 100 \\
\hline Haría & 76 & 84 & 84 & 100 & 70 & 100 & 100 & 100 \\
\hline San Bartolomé & 71 & 70 & 73 & 87 & 100 & 100 & 110 & 100 \\
\hline Teguise & 71 & 84 & 100 & 73 & 100 & 125 & 110 & 100 \\
\hline Tías & 75 & 163 & 151 & 117 & 100 & 141 & 120 & 109 \\
\hline Tinajo & 77 & 84 & 73 & 117 & 81 & 89 & 100 & 91 \\
\hline Yaiza & 94 & 84 & 84 & 73 & 125 & 112 & 110 & 109 \\
\hline
\end{tabular}

Fuente: Elaboración propia a partir de los datos del CIES, Anuario BANESTO, Anuario Económico de la Caixa, INE: Contabilidad Regional de España y Alcaide, J. (2003). 
Gráfico 233. PIB per cápita a precios corrientes de mercado de los municipios de la isla (Lanzarote=100)

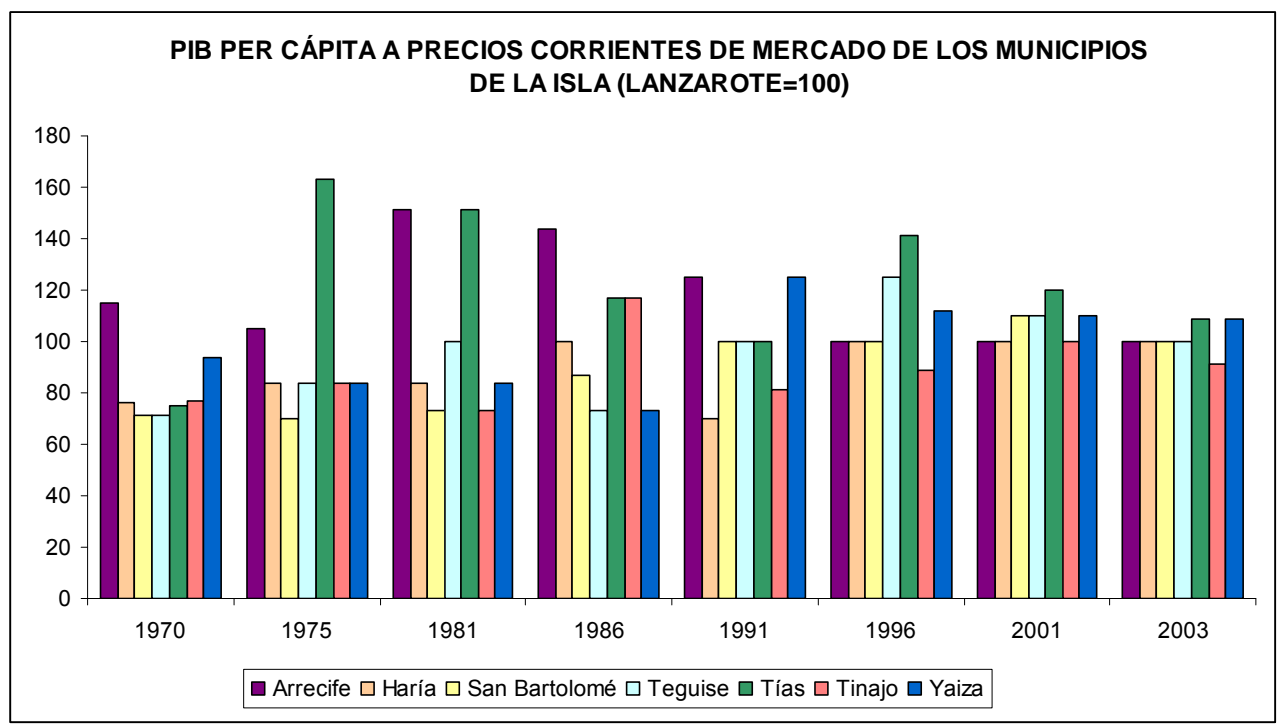

Fuente: Elaboración propia a partir de los datos del CIES, Anuario BANESTO, Anuario Económico La Caixa, INE: Contabilidad Regional de España y Alcaide, J. (2003). Referencia Tabla 248.

Con la Figura anterior se refuerzan algunos de los elementos señalados para la isla de Lanzarote en su conjunto. Así, se aprecia que la transformación del período 1970-75 se registra fundamentalmente en el municipio de Tías, que va a ser el que va a tener mayor incidencia en el crecimiento del PIB per cápita de Lanzarote (del $75 \%$, en 1970, a un 163\% del PIB per cápita de Lanzarote en 1975) seguido a mucha distancia de Teguise (del 71 al $84 \%$ ) y de Haría (del 76 al 84\%) con el resultado de que el resto de municipios reducen su PIB per cápita relativo con respecto al medio de Lanzarote. La dinámica demográfica (denominador del PIB per cápita) explica en parte esta evolución, tal y como se aprecia en las Tablas y Figuras siguientes, al registrar Arrecife, San Bartolomé y Yaiza un crecimiento demográfico mayor que la media de la Isla. Crecimiento que, por otra parte y desde los objetivos de esta tesis, hay que destacar que del incremento de unas 3.200 personas de la Isla entre 1970 y 1975, sólo unas 1.000 personas se corresponden con alóctonos, siendo el resto autóctonas. En este período, por lo tanto, los cambios registrados van a afectar, fundamentalmente a la población local. 
Tabla 249. Evolución de la población municipal. Lanzarote. 1970-2011

\begin{tabular}{|l||c|c|c|c|c|c|c|c|c||}
\cline { 2 - 11 } \multicolumn{1}{c|}{} & 1970 & 1975 & 1981 & 1986 & 1991 & 1996 & $\mathbf{2 0 0 1}$ & $\mathbf{2 0 0 6}$ & $\mathbf{2 0 1 1}$ \\
\hline \hline Arrecife & 21.135 & 23.294 & 28.864 & 30.694 & 33.906 & 38.091 & 45.549 & 55.203 & 57.357 \\
\hline Haría & 2.986 & 2.878 & 2.624 & 2.790 & 2.851 & 3.531 & 4.285 & 5.004 & 5.203 \\
\hline San Bartolomé & 3.550 & 3.866 & 4.650 & 5.229 & 6.217 & 9.852 & 14.835 & 17.610 & 18.468 \\
\hline Teguise & 5.977 & 6.211 & 6.096 & 6.475 & 8.189 & 8.691 & 12.905 & 16.616 & 20.788 \\
\hline Tías & 3.018 & 3.241 & 3.484 & 5.383 & 7.556 & 10.096 & 14.442 & 17.884 & 20.102 \\
\hline Tinajo & 2.822 & 2.975 & 3.071 & 3.229 & 3.517 & 3.755 & 4.670 & 5.476 & 5.728 \\
\hline Yaiza & 1.658 & 1.872 & 1.932 & 1.994 & 2.675 & 3.363 & 6.358 & 9.664 & 14.871 \\
\hline \hline
\end{tabular}

Fuente: Elaboración propia a partir del Padrón Municipal de Habitantes. INE.

Gráfico 234. Evolución de la población municipal. Lanzarote. 1970-2011

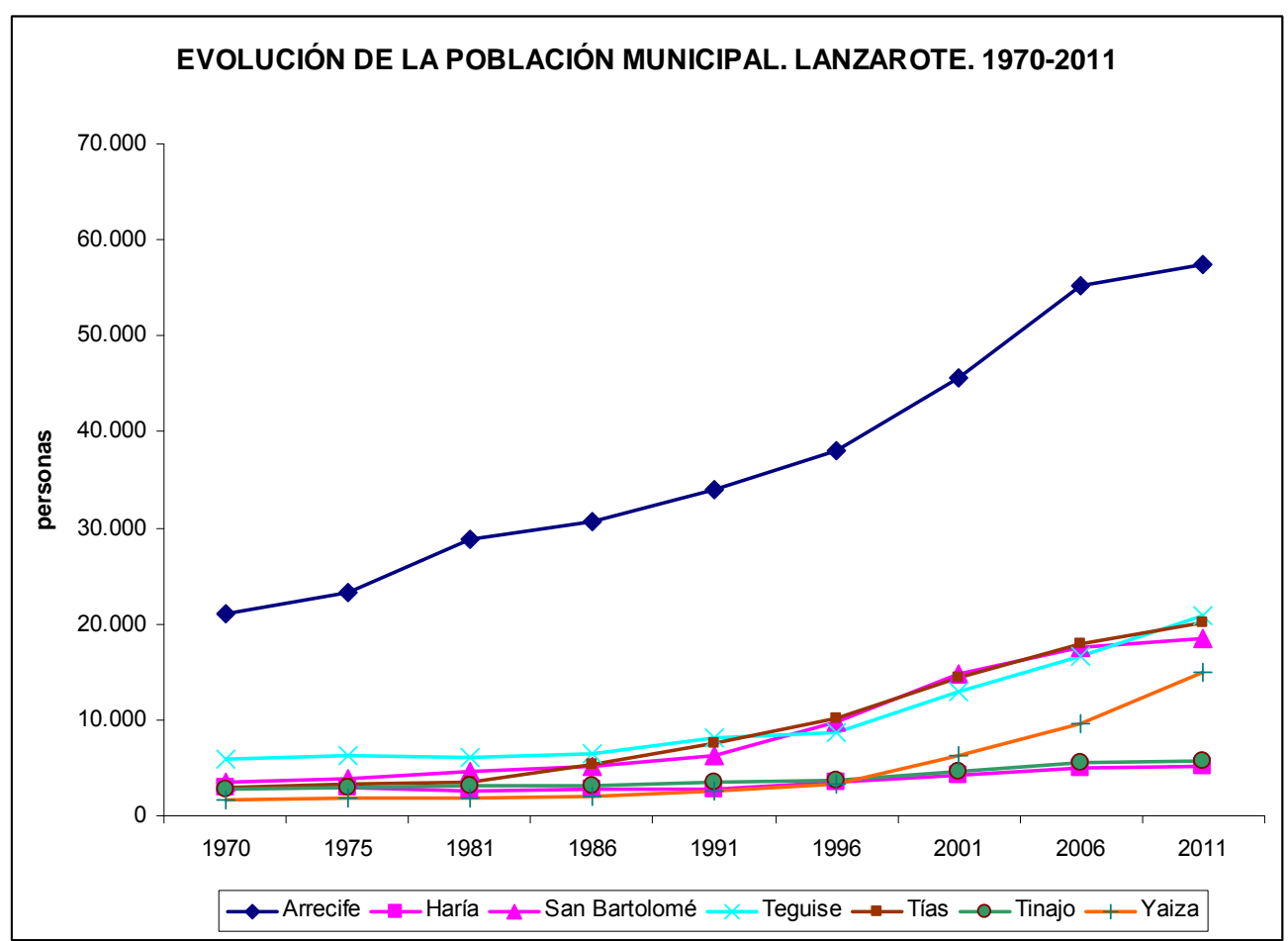

Fuente: Elaboración propia a partir del Padrón Municipal de Habitantes. INE. Referencia Tabla 249. 
Tabla 250. Índice de evolución de la población municipal e insular. Lanzarote.1970-2006 $(1970=100)$.

\begin{tabular}{|l|l|l|l|l|l|l|l|l|}
\cline { 2 - 9 } \multicolumn{1}{c|}{} & $\mathbf{1 9 7 0}$ & $\mathbf{1 9 7 5}$ & $\mathbf{1 9 8 1}$ & $\mathbf{1 9 8 6}$ & $\mathbf{1 9 9 1}$ & $\mathbf{1 9 9 6}$ & $\mathbf{2 0 0 1}$ & $\mathbf{2 0 0 6}$ \\
\hline \hline TOTAL & 100 & 108 & 123 & 136 & 158 & 188 & 250 & 310 \\
\hline Arrecife & 100 & 110 & 137 & 145 & 160 & 180 & 216 & 261 \\
\hline Haría & 100 & 96 & 88 & 93 & 95 & 118 & 144 & 168 \\
\hline San Bartolomé & 100 & 109 & 131 & 147 & 175 & 278 & 418 & 496 \\
\hline Teguise & 100 & 104 & 102 & 108 & 137 & 145 & 216 & 278 \\
\hline Tías & 100 & 107 & 115 & 178 & 250 & 335 & 479 & 593 \\
\hline Tinajo & 100 & 105 & 109 & 114 & 125 & 133 & 165 & 194 \\
\hline Yaiza & 100 & 113 & 117 & 120 & 161 & 203 & 383 & 583 \\
\hline
\end{tabular}

Fuente: Elaboración propia a partir del Padrón Municipal de Habitantes. INE.

Gráfico 235. Índice de evolución de la población municipal e insular. Lanzarote.1970-2006 (1970=100).

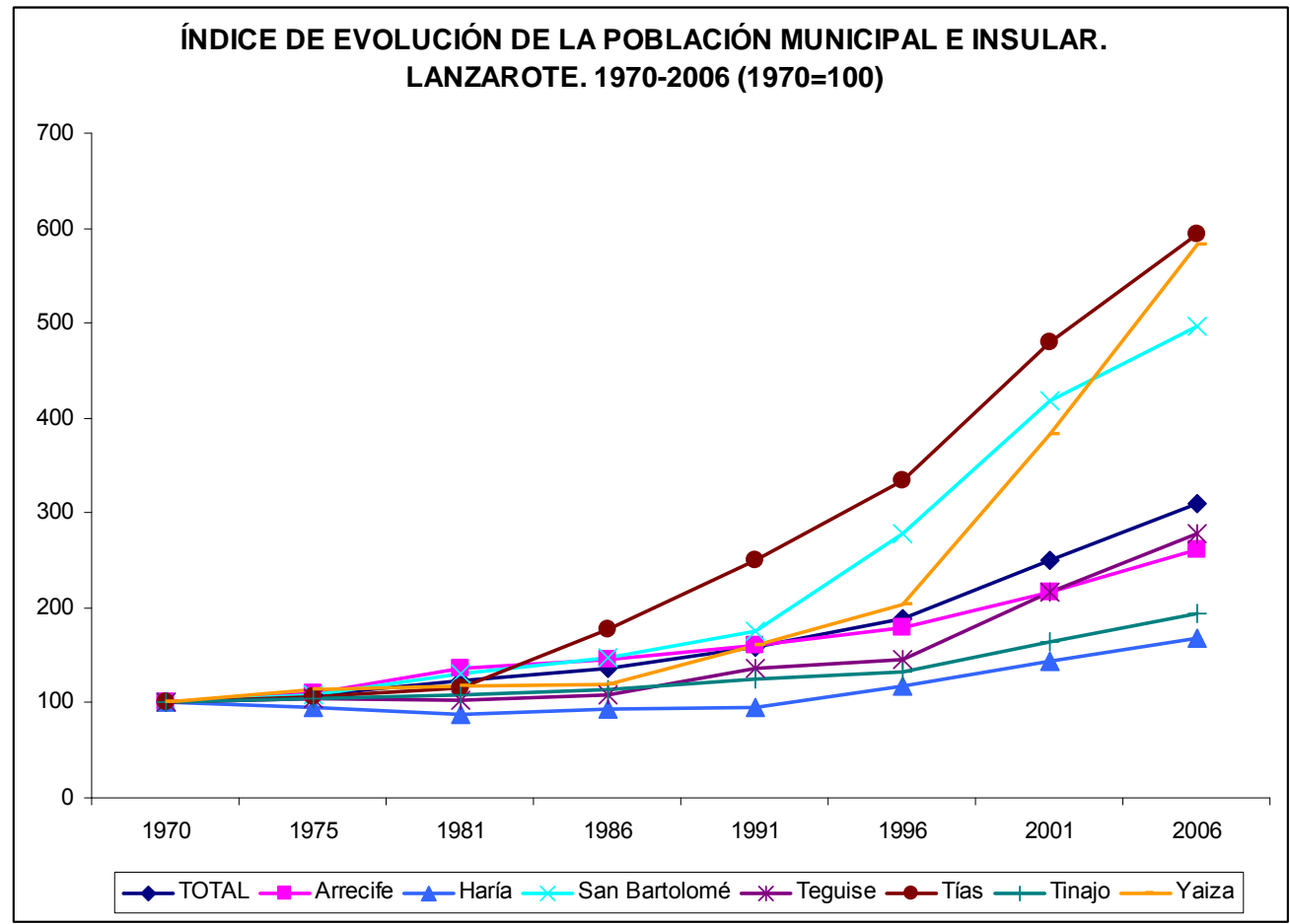

Fuente: Elaboración propia a partir del Padrón Municipal de Habitantes. INE. Referencia Tabla 250. 
Mapa 37. Evolución demográfica municipal. Lanzarote. 1970-2006 $(1970=100)$

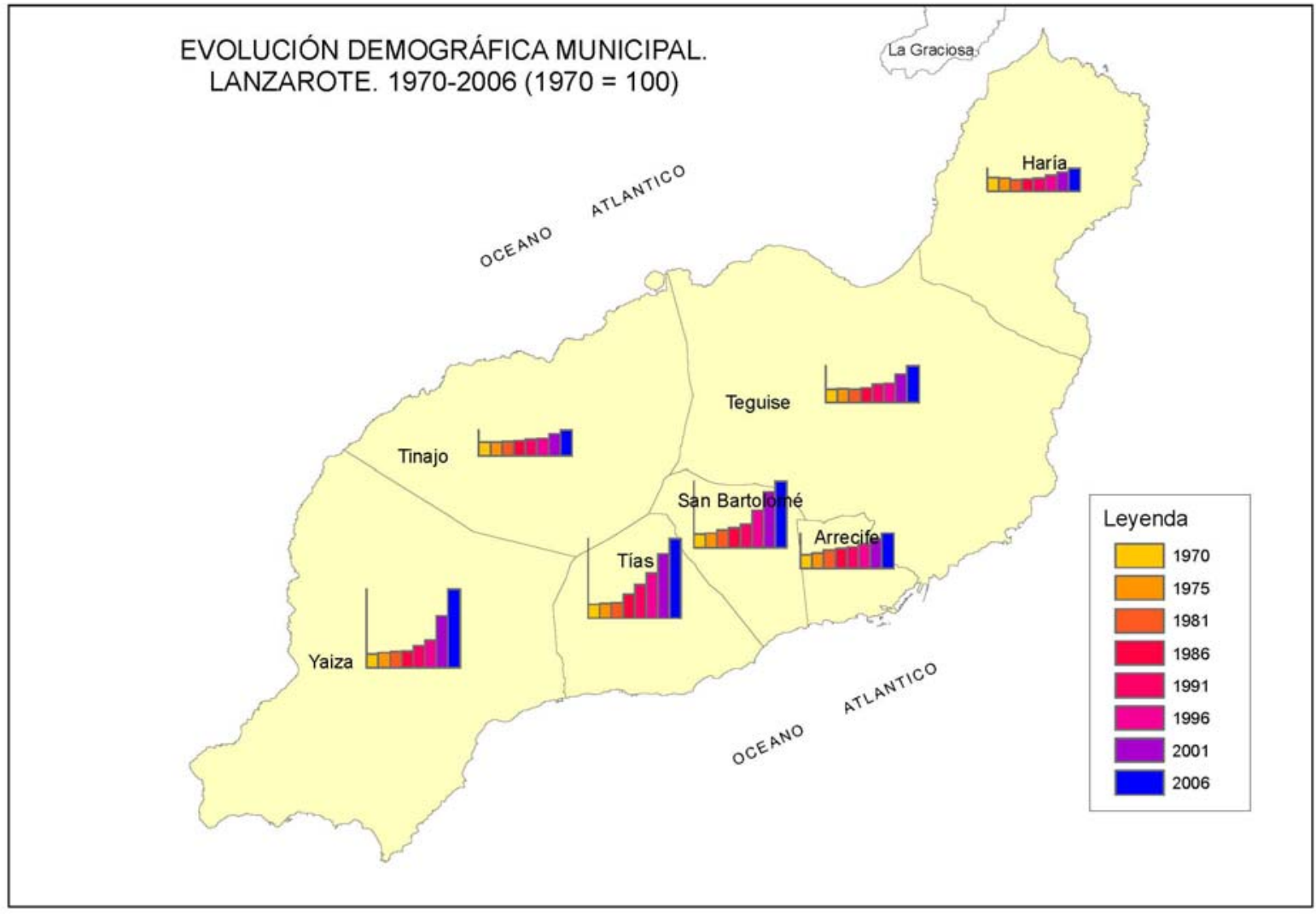

Fuente: Elaboración propia a partir de datos del Padrón Municipal de Habitantes. INE.

El resto de la explicación de la evolución señalada para el PIB per cápita hay que encontrarla en el hecho de que la oferta hotelera de la Isla se inicia en 1966 con la apertura del Hotel Fariones, en Tías, continuándose con otras instalaciones hoteleras y turísticas en Playa Blanca (1967) y en Costa Luz (1970), en el este de la isla (Pueblo de la Tiñosa, hoy Puerto del Carmen). Tías, favorecida por su cercanía y comunicación con el aeropuerto de la Isla, va a convertirse en el primer asentamiento turístico significativo de la misma, que se continuaría después en el municipio de Teguise (Costa de Teguise) y en Yaiza (en el señalado Pueblo de Playa Blanca). Aunque Arrecife, con la inauguración del Gran Hotel Arrecife, en 1968, sería una oferta complementaria de plazas hoteleras de calidad para el turismo, la consolidación de una segunda oferta turística significativa no se va a producir hasta que las urbanizaciones de Costa Teguise (promovidas por la empresa Río Tinto) comiencen su desarrollo, con la inauguración del Hotel Salinas, en 1978, ya dentro del período 1975-1981.

El resultado es que no es hasta 1986 cuando existe una oferta de plazas turísticas significativa respecto al predominio de Tías en plazas turísticas totales, o al de Arrecife en cuanto a plazas hoteleras y hosteleras. En 1970 Arrecife tenía 347 plazas entre hoteles y hostales, Tías 144, San Bartolomé 15 y Yaiza 12. En 1981 las plazas hoteleras y hosteleras 
de Tías ya ocupan el primer lugar (905), seguidas de las de Arrecife (790) y Teguise (593). Pero es a partir de 1986 cuando la evolución de la oferta de plazas turísticas totales empieza a correlacionarse en mayor medida con la evolución del PIB per cápita, tal y como apreciamos en los próximos párrafos, a partir de los datos que se recogen en la Tabla siguiente y su correspondiente Figura:

Tabla 251. Distribución municipal de la oferta turística. Lanzarote. 1986-2006 (\%)

\begin{tabular}{|l|r|r|r|r|r||}
\cline { 2 - 7 } \multicolumn{1}{c|}{} & 1986 & 1991 & 1996 & 2001 & 2006 \\
\hline Arrecife & 3 & 2 & 3 & 2 & 3 \\
\hline Haría & 1 & 0 & 1 & 1 & 1 \\
\hline San Bartolomé & 0 & 0 & 0 & 0 & 0 \\
\hline Teguise & 15 & 20 & 26 & 27 & 24 \\
\hline Tías & 71 & 63 & 55 & 49 & 44 \\
\hline Tinajo & 3 & 3 & 2 & 2 & 2 \\
\hline Yaiza & 8 & 12 & 14 & 20 & 27 \\
\hline \hline
\end{tabular}

Fuente: Elaboración propia a partir del Avance del PIOT de Lanzarote, 1987 (Tomo 5. Sociedad y Turismo. Capítulo IV. 3.1.) y del Anuario Estadístico de Lanzarote, 1992 y 1996, 2001 y 2006. Centro de datos. Cabildo de Lanzarote.

Gráfico 236. Distribución municipal de la oferta turística. Lanzarote. 1986-2006 (\%)

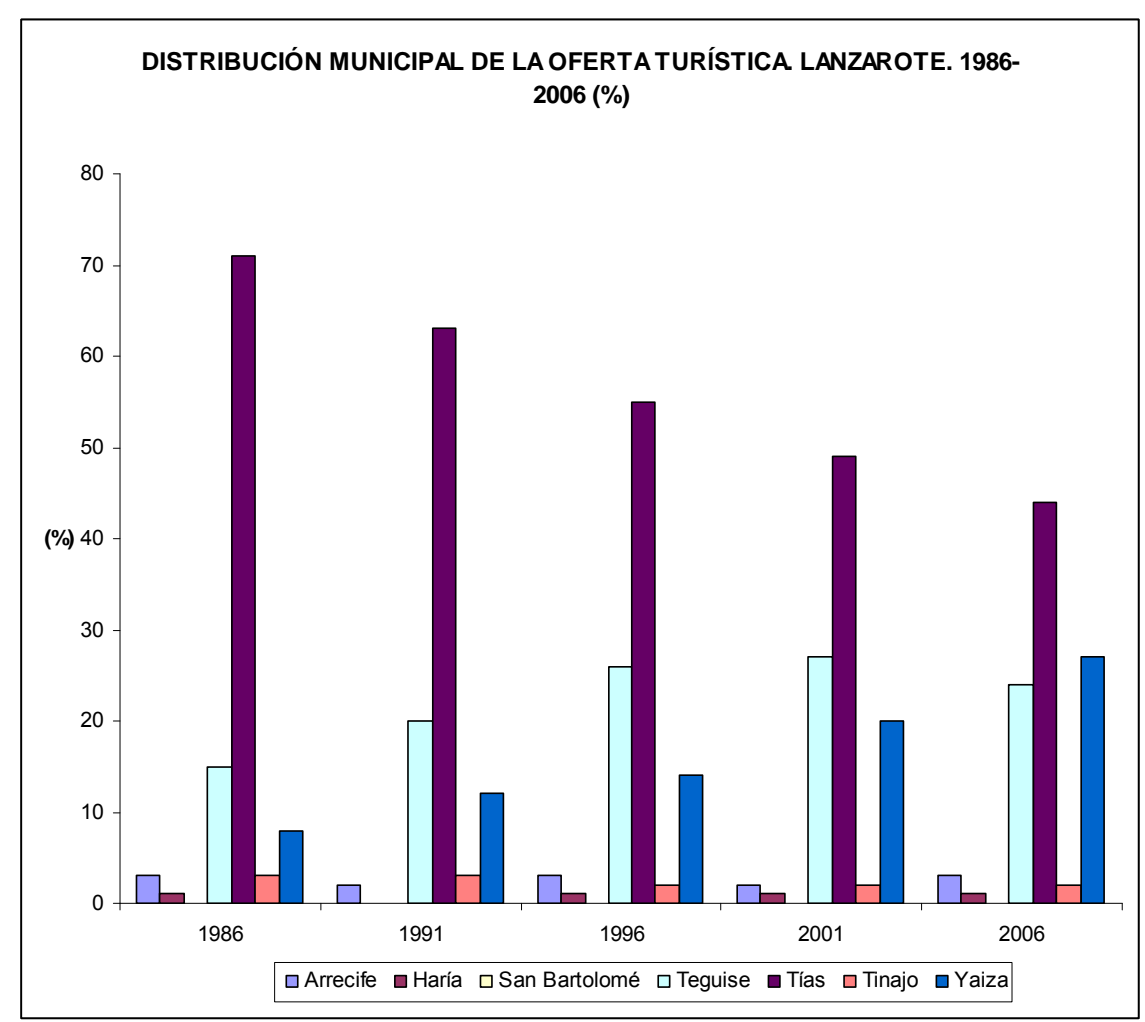

Fuente: Elaboración propia a partir del Avance del PIOT de Lanzarote, 1987, y del Anuario Estadístico de Lanzarote, 1992 y 1996,2001 y 2006. Centro de datos. Cabildo de Lanzarote. Referencia Tabla 251. 
En efecto, como se apreciaba en la Figura de páginas anteriores, Arrecife después de alcanzar el máximo nivel de PIB per cápita en 1981, empieza un declive relativo que se mantiene hasta 1996, donde alcanza el valor medio de la Isla que ya mantendrá hasta 2003. Como en casos anteriores, hasta 1991 el que su población crezca a mayor ritmo que la media de la Isla, explica parte de su reducción relativa de PIB per cápita, pero no sucede lo mismo en el período 1991-2006 en que el ritmo de crecimiento de su población es menor a la media de la Isla. Su reducido papel en la oferta turística y la fuerte reducción de la actividad pesquera e industrial localizada en este municipio, dan razón a su declive relativo respecto a la media de crecimiento del PIB per cápita en un Isla cada vez más especializada en el monocultivo turístico y en la construcción. Aspecto que también confirma, hasta 2001, último año sobre el que se tienen datos de número de viviendas homologables, del INE, la evolución del número total de éstas, con un peso decreciente en el total desde 1970 a 2001 y el escaso peso, junto a San Bartolomé, de las viviendas que no son principales con respecto al total.

Tabla 252. Número de viviendas familiares censadas, por municipio. Lanzarote. 1970-2001

\begin{tabular}{|l|r|r|r|r|}
\cline { 2 - 5 } \multicolumn{1}{c|}{} & $\mathbf{1 9 7 0}$ & $\mathbf{1 9 8 1}$ & $\mathbf{1 9 9 1}$ & $\mathbf{2 0 0 1}$ \\
\hline Arrecife & 4.789 & 7.827 & 11.556 & 19.685 \\
\hline Haría & 1.441 & 1.572 & 2.498 & 3.343 \\
\hline San Bartolomé & 833 & 1.647 & 2.923 & 6.945 \\
\hline Teguise & 1.974 & 2.809 & 4.654 & 9.410 \\
\hline Tías & 694 & 1.278 & 6.226 & 21.743 \\
\hline Tinajo & 660 & 913 & 1.399 & 2.744 \\
\hline Yaiza & 547 & 866 & 1.565 & 5.755 \\
\hline
\end{tabular}

Fuente: Elaboración propia a partir de los datos del INE sobre los Censos de Población y Vivienda. 
Gráfico 237. Viviendas familiares censadas, por municipio. Lanzarote. 1970-2001

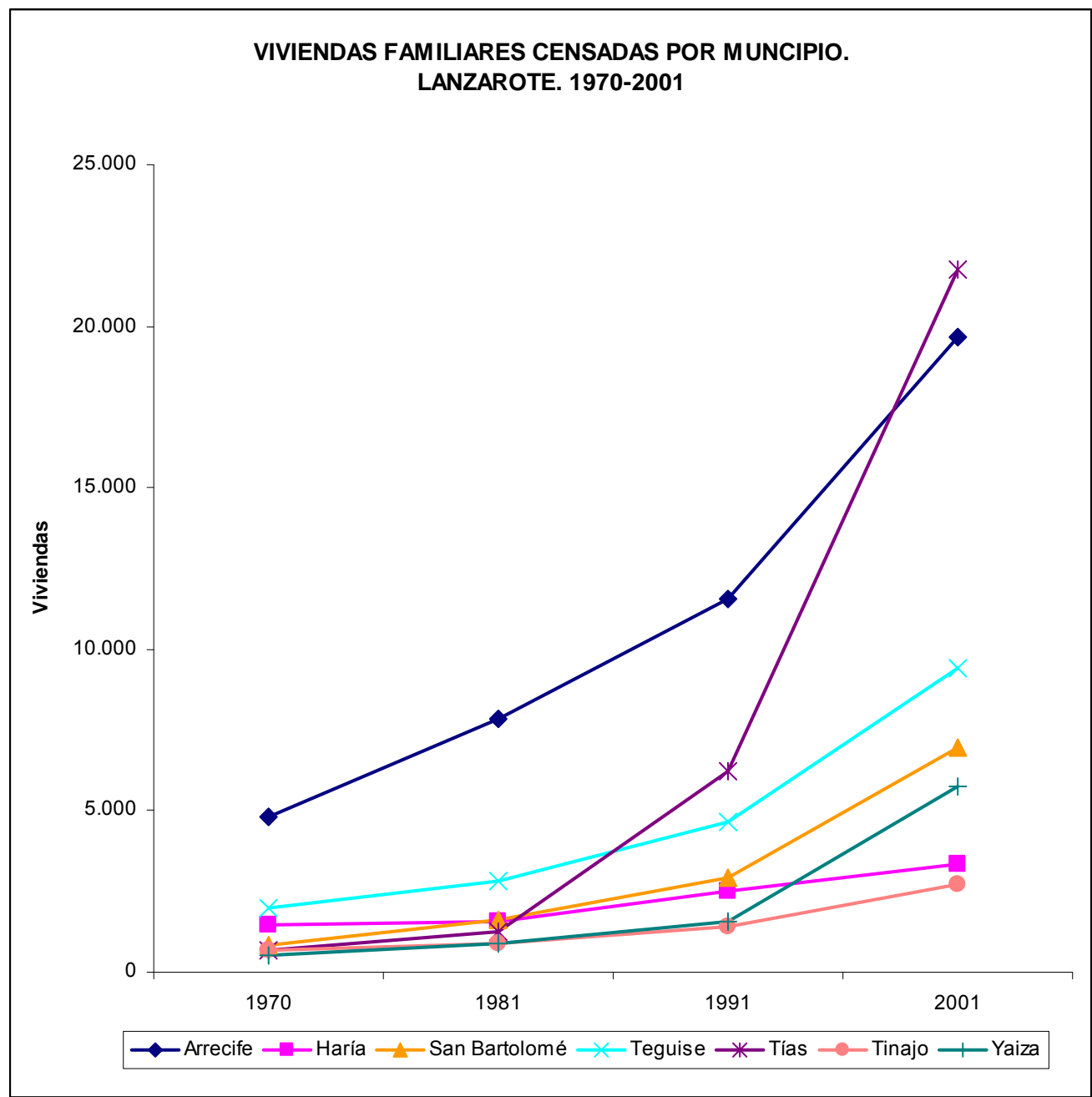

Fuente: Elaboración propia a partir de los datos del INE sobre los Censos de Población y Vivienda. Referencia Tabla 252.

Tabla 253. Viviendas principales censadas, por municipio e isla. Lanzarote. 1970-2001

\begin{tabular}{|l||c|c|c|c|c|c|c|c|}
\cline { 2 - 9 } \multicolumn{1}{l|}{} & Arrecife & Haría & S. Bartolomé & Teguise & Tías & Tinajo & Yaiza & LANZAROTE \\
\hline \hline $\mathbf{1 9 7 0}$ & 86 & 50 & 89 & 64 & 89 & 87 & 67 & 77 \\
\hline $\mathbf{1 9 8 1}$ & 80 & 45 & 64 & 51 & 60 & 72 & 52 & 67 \\
\hline $\mathbf{1 9 9 1}$ & 71 & 34 & 57 & 47 & 37 & 64 & 45 & 55 \\
\hline $\mathbf{2 0 0 1}$ & 69 & 49 & 73 & 42 & 21 & 54 & 41 & 47 \\
\hline
\end{tabular}

Fuente: Elaboración propia a partir de los datos del INE sobre los Censos de Población y Vivienda. 
Gráfico 238. Viviendas principales censadas, por municipio e isla. Lanzarote. 1970-2001

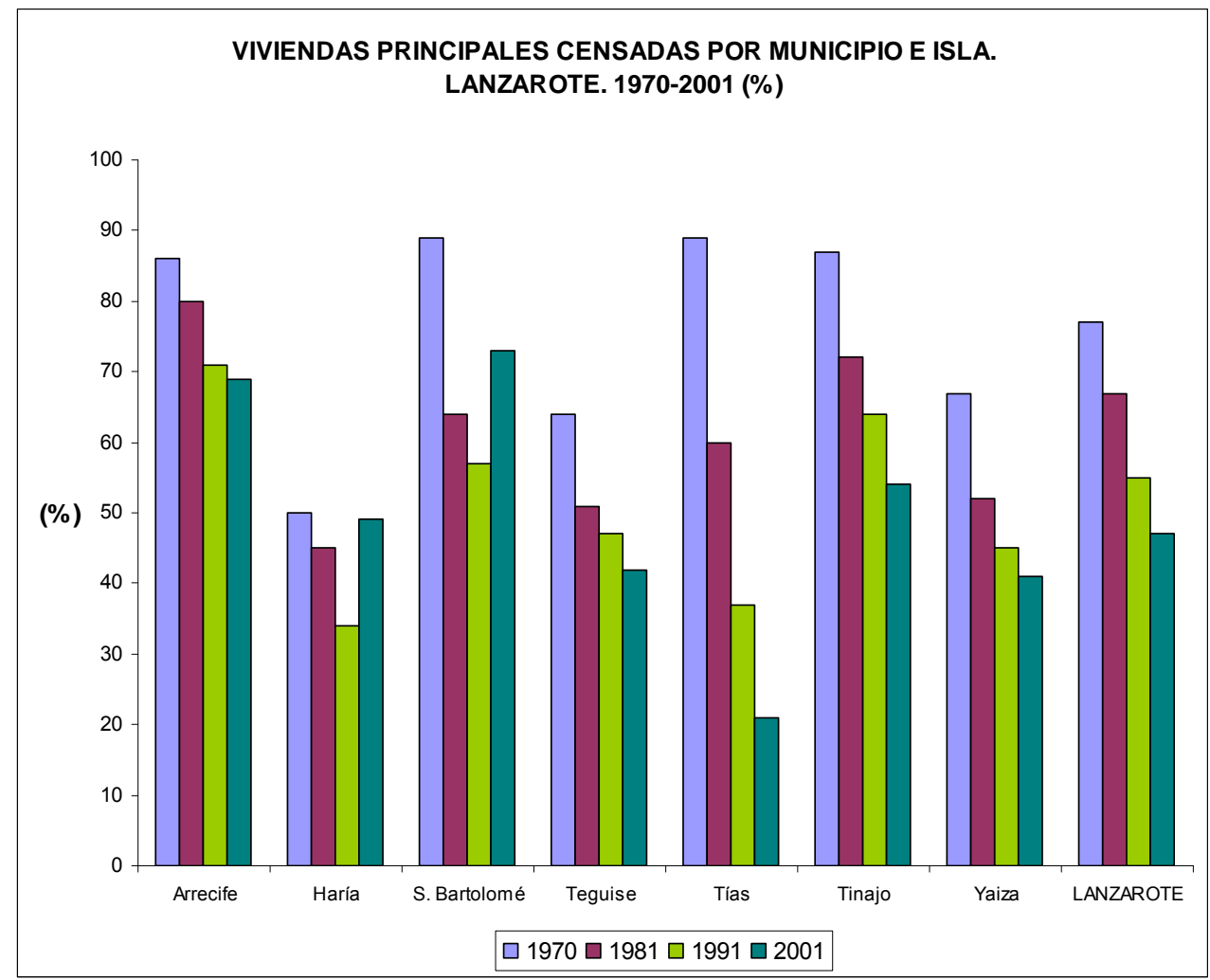

Fuente: Elaboración propia a partir de los datos del INE sobre los Censos de Población y Vivienda. Referencia 253.

Tras Arrecife, el segundo municipio con una evolución significativa en su PIB per cápita es el de Tías, con una dinámica con respecto a la media de la Isla, que tras sus elevadas cotas de 1975 y 1981 a las que le conduce su temprano despertar urbanístico-inmobiliario y turístico, registra una fuerte caída hasta 1991, un repunte entre 1991 y 1996, y una nueva caída hasta el nivel 109 en 2003. El hecho de que entre 1981 y 1991 multiplique por 2,2 su población, mientras que la Isla crece a menos de un 30\%, y que entre 1996 y 2003 la incremente casi en un $80 \%$, mientras que Lanzarote lo hace sólo en un $65 \%$, explican en parte estos altibajos en el PIB per cápita relativo con respecto a la Isla, al incrementar en mucho mayor medida que ésta el denominador (población) del PIB per cápita. En cuanto a la relación entre las variaciones en el PIB per cápita y la oferta de plazas turísticas, tras ser el municipio pionero en la oferta, en 1986 Tías representa el $71 \%$ de la oferta turística total, pero desde esta fecha su crecimiento de la oferta va a ser menor a la del resto de la Isla por lo que cada período va significando un porcentaje más reducido de ese total, hasta llegar, en 2006 , a representar exclusivamente el $44 \%$ del mismo. No obstante, su parque de viviendas se sigue incrementando de forma significativa desde 1970 a 1981, y de forma crecientemente acelerada del año 1981 a 1991 y de 1991 a 2001, convirtiéndose en el municipio con más viviendas familiares de la Isla, y superando en el censo de este año al número de viviendas de Arrecife en más de 2000 (más del 10\% de las viviendas de 
Arrecife). La incidencia de la construcción en el municipio es clara al igual que lo es el peso de la segunda residencia/vivienda vacacional, ya que del total de cerca de 22.000 viviendas familiares, sólo la quinta parte de sus viviendas son viviendas principales en 2001 (4.566 viviendas), cuando lo eran cerca del noventa por ciento en 1970 (618 viviendas). Teóricamente, el número de familias residentes en el municipio se ha incrementado en un $738 \%$ mientras que las viviendas no principales lo han hecho en un $22.601 \%$, lo que nos da una idea de la transformación turística de este municipio, que es sin duda el que ha registrado un mayor cambio en Lanzarote.

Teguise es el tercer municipio con cambios más sustanciales en el período asociados a la dinámica turística. Entre 1970 y 1981, Teguise mejora su PIB per cápita en relación con el medio de la Isla, llegando a alcanzar éste (valor 100) en 1981, mientras mantiene su población prácticamente constante en el período, por lo que la mejora se debe a mejora en la producción, ligada en parte al incremento de su oferta turística en el período. La variación en la oferta turística explicaría también la relativa caída que se produce entre 1981 y 1986 en el PIB per cápita. Hay que tener en cuenta que ya en 1970 Teguise mantiene un porcentaje de viviendas principales en su parque muy reducido (64\%) y que éste baja entre 1970 y 1981 (al 51\%) para caer hasta el año 2001 al 42\% del total, de manera que es el tercer municipio de la Isla por número de viviendas (9.410 en 2001) y menos de 4000 corresponden a residencia familiar. Desde 1986 su PIB per cápita relativo al de la Isla repunta hasta el valor de 125, en 1996, y vuelve a caer desde entonces hasta el nivel 100 en 2003, volviendo a tener la construcción de viviendas (se dispara de 1991 a 2001) y el incremento de la oferta turística (se incrementa de 1986 a 1996, se estabiliza de 1986 a 2001 y desciende de 2001 a 2006) una influencia significativa. Menor influencia relativa tiene la población, ya que aunque crece en mayor medida que la media de la Isla entre 1986 y 1991 y entre 1996 y 2006, y lo hace en menor medida entre 1991 y 1996, lo cierto es que las diferencias no son especialmente significativas, por lo que su corrección media en el denominador del PIB per cápita no es muy elevada. En síntesis, un municipio con fuertes transformaciones por el turismo en el que el resultado relativo, como en Tías, ha sido una mejora del PIB per cápita desde valores del orden del $70 \%$ de la media de Lanzarote a un valor equiparado a esa media para 2003.

Tras Arrecife, y junto a Teguise y Tías, el municipio con mayor población en 2006 es San Bartolomé, cuya evolución presenta peculiaridades específicas que se deducen de la propia dinámica de su crecimiento y localización. De hecho, su crecimiento, que se produce fundamentalmente entre 1991 y 2006, periodo en el que prácticamente triplica su población, se produce como expansión metropolitana de Arrecife, y aprovechando el corredor litoral entre Arrecife y Puerto del Carmen (en Tías) que se convierte en un verdadero continuo urbano, fundamentalmente para residencia principal y servicios, en el caso de San Bartolomé. En efecto, su oferta turística es irrelevante en el conjunto de la isla, y es el 
municipio con un mayor porcentaje de vivienda familiar que es principal. La mejora de su PIB per cápita relativo se produce entre 1986 y 1991 en que alcanza el nivel 100, que ya prácticamente mantendrá hasta 2003. Entre 1970 y 1991 mantiene un crecimiento suave y sostenido de su mejora de posiciones relativas, que va en paralelo a su evolución demográfica en términos porcentuales, siempre relativamente similar a la de la media de la Isla hasta 1996 en que incrementa muy sustancialmente su crecimiento.

A un nivel demográfico del orden de la mitad de los municipios anteriores en 2006, se encuentra Yaiza, que siendo el municipio de población más reducida en 1970 (1.658 habitantes) característica que mantiene hasta 1996, desde 1996 a 2006 prácticamente triplica su población. En paralelo, hasta 1996 este municipio pierde posiciones relativas en el PIB per cápita respecto a la media de la Isla, pasando de un $94 \%$, en 1970 , a un $73 \%$, en 1986, Entre 1986 y 1991 es Yaiza quién impulsa el crecimiento relativo de la Isla, seguido de San Bartolomé y Teguise, lo que se corresponde, fundamentalmente, con su fuerte aumento relativo en la oferta turística del municipio (pasa del $8 \%$ al $12 \%$ de la oferta total de la Isla). En efecto, en la última fase (1996-2006) la construcción de nuevas camas se realiza fundamentalmente en Playa Blanca, en el municipio de Yaiza, aunque también en el resto de zonas turísticas se continúan desarrollando promociones turísticas y residenciales, que llevan a que se intente responder a la sobrecapacidad de la oferta con una paralización de la construcción de camas hasta el año 2010, con lo que se vino a denominar "moratoria turística". Se comienza a orientar la nueva planificación a través de un Plan Territorial Especial dirigido a las zonas turísticas y posteriormente, se comenzará la revisión del Plan Insular de Ordenación. Los datos de base recogidos en "Lanzarote. Reserva de la Biosfera, 1998" y en el "Plan Territorial Especial de Ordenación Turística Insular, 2006", que encuadran la problemática aquí recogida, se aprecian en las dos imágenes siguientes, extraídas respectivamente, de los citados documentos. 


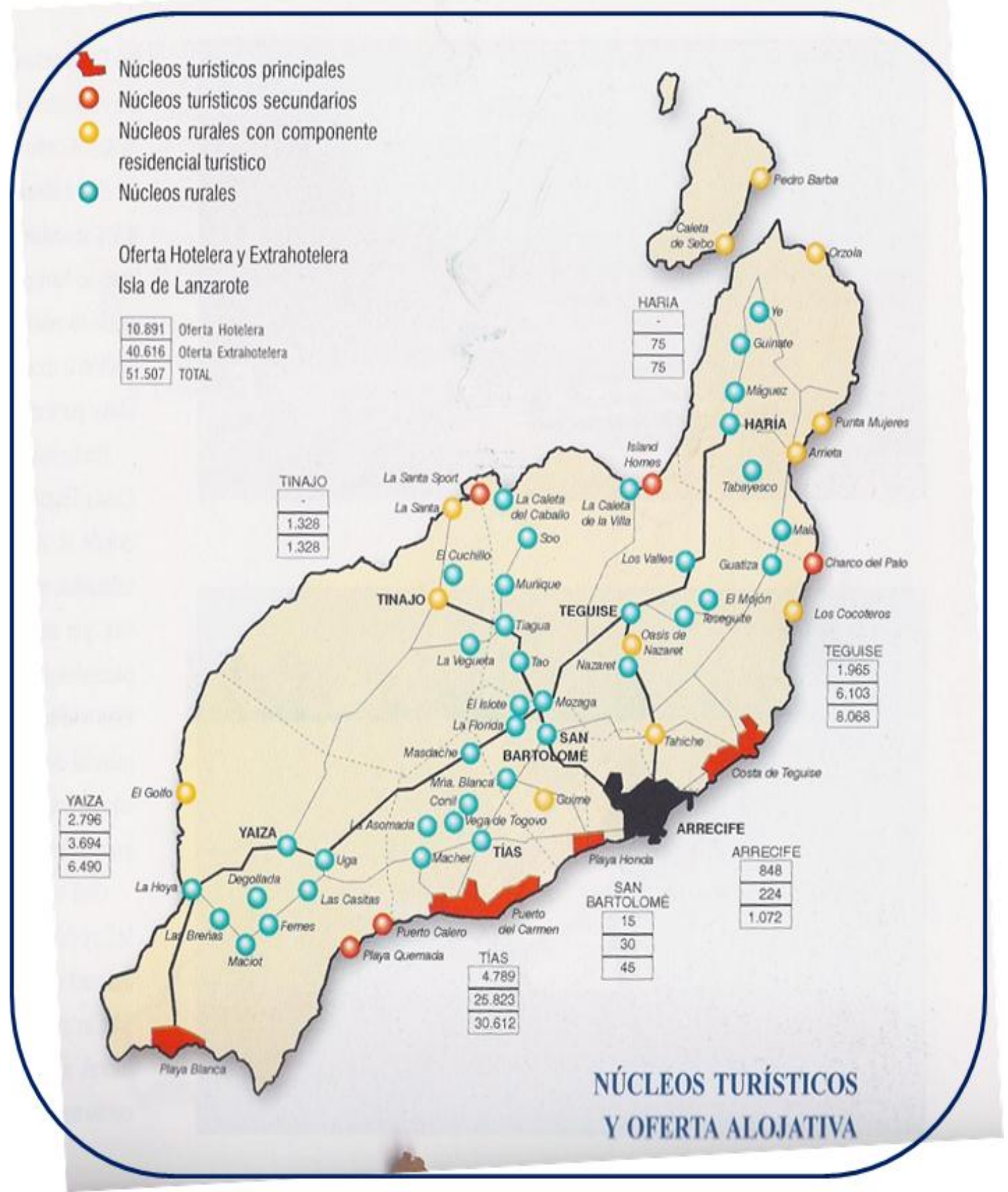

Fuente: Lanzarote. Reserva de la Biosfera. 2006, p. 141 
Mapa 39. Oferta de ocio y suelo disponible para nueva oferta. Lanzarote, 2006

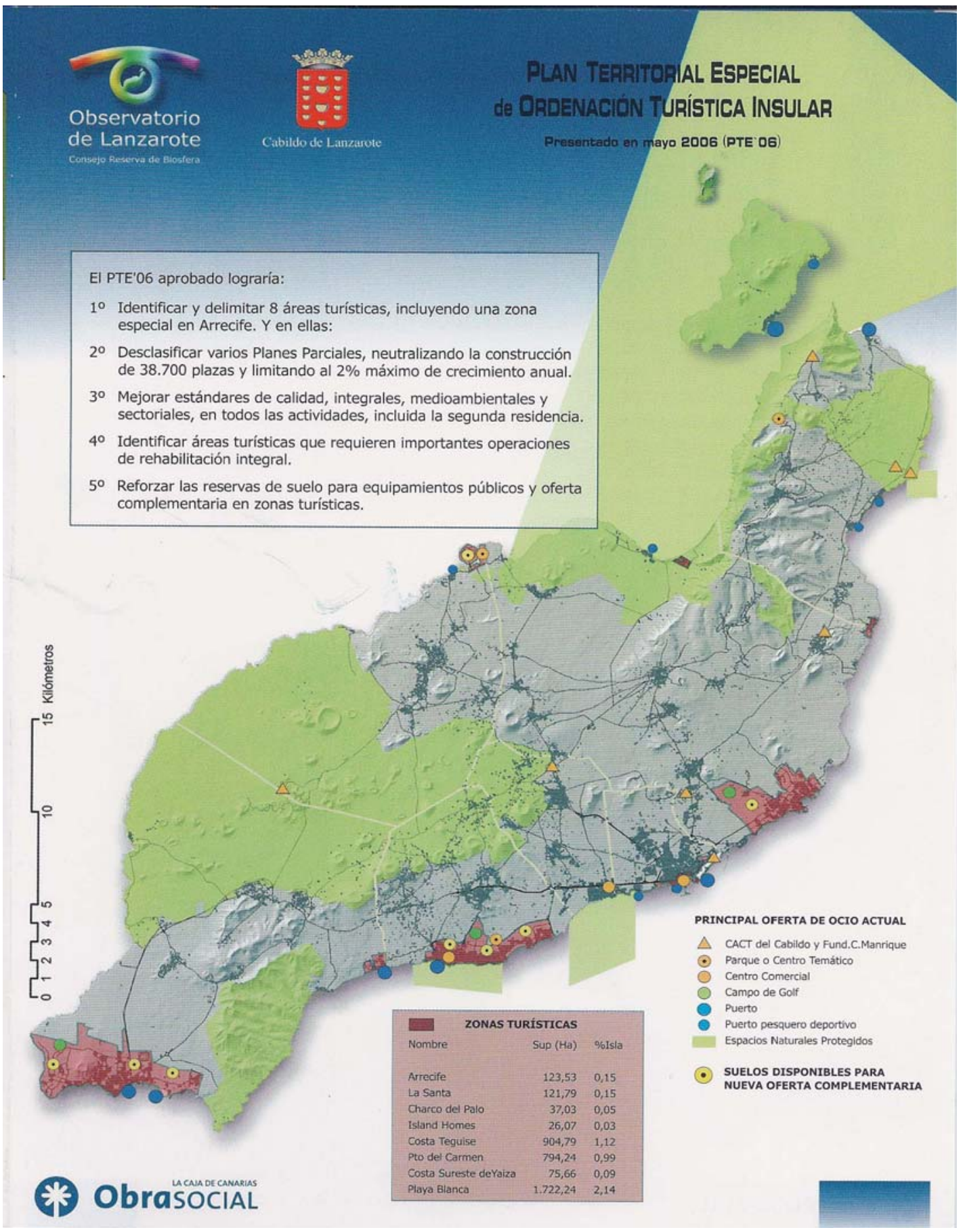

Por último, en este marco, hay que señalar que, entre 1981 y 1986 son Haría y Tinajo, dos municipios cuyo nivel del PIB per cápita en 1970 se situaba en el entorno del $75 \%$ de la media de la Isla, los dos municipios que aportan las mayores tasas de crecimiento a dicho PIB per cápita de la misma, hecho en parte explicado por su menor crecimiento relativo de la población, pero también por la crisis relativa del turismo en el período. No obstante, Tinajo aumenta su parque de viviendas familiares, entre 1970 y 1981, en más de un $50 \%$, más que triplicando las que no tenían carácter de primera residencia. En todo caso, estos dos 
municipios son los de menor incidencia en el parque total de viviendas, tanto de primera (del orden de 1.600 viviendas) como de segunda residencia/turísticas (del orden de 1.500 viviendas) y en la oferta turística (junto a San Bartolomé) global de la Isla. Y situados en el área norte y noroeste de Lanzarote, son los dos municipios con características menos transformadas relativamente por la urbanización y la actividad turística y, también los de menor mejora relativa en sus índices de PIB per cápita.

\section{6.- ELEMENTOS COMPLEMENTARIOS PARA LA COMPRENSIÓN DE LAS TRANSFORMACIONES PRODUCIDAS.}

De los apartados anteriores quedan pocas dudas respecto a la fortísima transformación registrada en Lanzarote desde que se inicia el proceso de crecimiento turístico, a mediados de la década de los sesenta del siglo XX, hasta el año 2006, en que la sentencia del Tribunal Superior de Justicia de Canarias anula el Decreto 95/2000 de aprobación definitiva de la Revisión parcial del PIOT, en noviembre de 2006 (Sentencia 105/2005 de 11 de febrero de TSJC), que había intentado poner freno y racionalizar una dinámica cuyos beneficios $\mathrm{y}$, sobre todo la parte de estos beneficios que recaen o han recaído sobre la población autóctona, presenta serias dudas, tal y como se pretende demostrar en esta tesis.

Los procesos de transformación registrados en el período han implicado cambios muy sustanciales en la población autóctona que, de ser una población impelida a la emigración por la falta de oportunidades en la Isla, se ve inmersa en un proceso de terciarización turística y de boom de la construcción que, indudablemente, presenta ventajas claras para la misma en sus primeras etapas (mejoras en las infraestructuras y servicios, acceso a equipamientos y dotaciones de servicio público, etc.) pero que a medida que el turismo entra en la fase de "turismo de masas" gobernada por operadores alóctonos ("tour operators") empieza a tener un balance no tan claro, no ya en el negativo proceso de transformación urbanística y degradación ambiental de la Isla, documentado en distintos trabajos a los que se ha ido haciendo referencia anteriormente, sino en el propio proceso social objeto de consideración en esta tesis.

Así, y como apreciamos en los dos cuadros siguientes, que recogen la estructura funcional del empleo en 1965 y 2008, la Isla parte, antes de su transformación turística, de una población dedicada a la agricultura y a la pesca con todos los municipios especializados funcionalmente en estas actividades, salvo Arrecife. Haría es el que presenta una especialización más elevada en agricultura, con más del $80 \%$ dedicada al sector primario (un $7 \%$ a la pesca), seguida de Tías (48\% agricultura y $26 \%$ pesca), Teguise ( $46 \%$ agricultura y $21 \%$ pesca), Yaiza (28\% agricultura y $39 \%$ pesca), Tinajo (54\% agricultura y $7 \%$ pesca) y San Bartolomé (34\% agricultura y $13 \%$ pesca). Sólo San Bartolomé $(28 \%)$, Tinajo (19\%) y Arrecife (15\%) presentan un porcentaje de población significativo trabajando 
en la construcción que, de todas maneras, absorbe el 14\% del empleo total de la Isla. La industria ( $6 \%$ del empleo total) se radica en Arrecife y el sector servicios sólo tiene un porcentaje de empleo significativo en este sector (39\%) correspondiéndose con su capitalidad administrativa.

Tabla 254. Estructura municipal del empleo. Lanzarote. 1965 (\%)

\begin{tabular}{|l|c|c|c|c|c|c|c|c||}
\hline \multicolumn{1}{|c|}{1965} & $\begin{array}{c}\text { Agricultura } \\
\text { Autónomos }\end{array}$ & $\begin{array}{c}\text { Braceros } \\
\text { Agrícolas }\end{array}$ & $\begin{array}{c}\text { Pesca } \\
\text { (capturas) }\end{array}$ & Construcción & Industria & Servicios & TOTAL & $\%$ ISLA \\
\hline \hline LANZAROTE & 20 & 8 & 23 & 14 & 6 & 28 & 100 & 100 \\
\hline Arrecife & 0 & 0 & 31 & 15 & 15 & 39 & 100 & 41 \\
\hline Haría & 40 & 33 & 7 & 3 & 0 & 18 & 100 & 11 \\
\hline S.Bartolomé & 29 & 5 & 13 & 28 & 0 & 24 & 100 & 10 \\
\hline Teguise & 38 & 8 & 21 & 12 & 0 & 21 & 100 & 19 \\
\hline Tías & 34 & 14 & 26 & 9 & 0 & 17 & 100 & 8 \\
\hline Tinajo & 39 & 15 & 7 & 19 & 0 & 20 & 100 & 7 \\
\hline Yaiza & 11 & 17 & 39 & 11 & 0 & 22 & 100 & 4 \\
\hline
\end{tabular}

Fuente: Elaboración propia a partir de los datos del "Plan Insular de Ordenación de la isla de Lanzarote". Boletín n 11. Apéndice estadístico y gráfico. Cuadro n 20. Elaboración: Centro de Investigación Económica y Social de la Caja Insular de Ahorros (CIES). Octubre de 1971.

Tabla 255. Estructura municipal del empleo. Lanzarote. 2008 (\%)

\begin{tabular}{|c|c|c|c|c|c|c|c|c|c|c|}
\hline \multirow[b]{2}{*}{2008} & \multirow[b]{2}{*}{ Agricultura } & \multirow[b]{2}{*}{ Industria } & \multirow[b]{2}{*}{ Construcción } & \multirow[b]{2}{*}{ Servicios } & \multicolumn{4}{|c|}{ Servicios significativos } & \multirow[b]{2}{*}{ Total } & \multirow[b]{2}{*}{$\%$ ISLA } \\
\hline & & & & & $\begin{array}{l}\text { Comercio, } \\
\text { Reparación de } \\
\text { vehículos y } \\
\text { artículos }\end{array}$ & Hosteleria & $\begin{array}{c}\text { Actividad } \\
\text { Inmobiliaria y } \\
\text { Servicios } \\
\text { Empresarial }\end{array}$ & $\begin{array}{l}\text { Admón Pública, } \\
\text { defensa y } \\
\text { seguridad social }\end{array}$ & & \\
\hline LANZAROTE & 1 & 3 & 11 & 84 & 26 & 30 & 11 & 13 & 100 & 100 \\
\hline Arrecife & 1 & 5 & 13 & 81 & 37 & 7 & 14 & 20 & 100 & 42 \\
\hline Haría & 4 & 2 & 11 & 83 & 20 & 27 & 7 & 22 & 100 & 1 \\
\hline S.Bartolomé & 1 & 2 & 17 & 80 & 31 & 12 & 16 & 10 & 100 & 12 \\
\hline Teguise & 3 & 3 & 9 & 85 & 15 & 47 & 9 & 9 & 100 & 13 \\
\hline Tías & 1 & 2 & 6 & 91 & 18 & 51 & 8 & 4 & 100 & 17 \\
\hline Tinajo & 2 & 7 & 22 & 69 & 21 & 40 & 5 & 15 & 100 & 3 \\
\hline Yaiza & 1 & 1 & 6 & 92 & 10 & 67 & 6 & 8 & 100 & 12 \\
\hline
\end{tabular}

Fuente: Elaboración propia a partir de los datos sobre "Empleo Registrado" (media anual) del Instituto Canario de Estadística (ISTAC).

Más de treinta y cinco años después, al final del período considerado, la estructura del empleo de la población es radicalmente distinta. El trinomio construcción, comercio y hostelería representa el $60 \%$ del empleo registrado. 
El sector primario (agricultura y capturas pesqueras) pesa menos del $1 \%$ del empleo, por lo que la población autóctona que por su edad en 1970 no se haya jubilado, ha tenido que registrar un fuerte proceso de adaptación a las nuevas actividades productivas, en paralelo a procesos similares registrados en el resto de España. Sólo Haría, Teguise y Tinajo son municipios que aún conservan un cierto atisbo de actividad productiva en el sector primario, en el que destacan por el cultivo de la vid, que se va recuperando derivado de la demanda de vino que genera la actividad turística (actualmente supone el $70 \%$ de la superficie agraria insular). El turismo abrió las puertas al mercado del vino local, que no ha dejado de crecer hasta la actualidad, impulsando una política de intervención directa para intentar paliar la desaparición del paisaje agrícola, derivado de la original forma en la que este cultivo se realiza y que constituye uno de los atractivos turísticos paisajísticos para el visitante. Es decir, el patrimonio cultural es mantenido por su poder de atracción de visitantes, desde la visión de la Teoría Crítica y la izquierda freudomarxista estaríamos ante el hecho de la folklorización y mercantilización de la cultura local. Así, la agricultura insular se encuentra completamente subvencionada, mantenida con finalidades de atracción turística.

La construcción, que ha crecido de forma muy significativa a lo largo del proceso, ahora, en la madurez, comienza a registrar un retroceso en la estructura del empleo y se sitúa en el $11 \%$ del total, destacando Tinajo (22\%) y San Bartolomé $(17 \%)$ en la población empleada en esta actividad, manteniendo una cierta tradición con su especialización en la misma respecto al inicio del período.

La escasa y preocupante incidencia de la industria en la Isla se ve acrecentada a lo largo del período analizado, en el que va perdiendo peso relativo hasta situarse en un reducidísimo $3 \%$ del empleo total, si bien con una distribución más homogénea en toda la Isla. Unido a la caída de la agricultura, este hecho nos muestra la tremenda dependencia de la Isla en la importación de productos agrícolas, pesqueros e industriales del exterior, ante su incapacidad para haber desarrollado una estructura productiva propia que satisfaga sus necesidades.

Complementariamente, como era de esperar, el sector servicios canaliza más del $84 \%$ de los empleos de la Isla, con los municipios de Tías y Yaiza superando el $90 \%$ y sólo Tinajo por debajo del $80 \%$. Arrecife y San Bartolomé concentran el comercio, la reparación, la actividad inmobiliaria y los servicios empresariales; Teguise, Tías y Yaiza la hostelería; y Tinajo, Haría y Arrecife el empleo en la administración pública, como actividades más destacadas del sector servicios.

No obstante, si la actividad económica dominante en el empleo de los residentes ha sufrido un cambio trascendental, no lo ha sido menos en lo relativo a la estructura territorial de la distribución de este empleo. En efecto, tras más de treinta y cinco años, Arrecife sigue concentrando del orden del $42 \%$ del empleo total de la Isla, sin cambios significativos en su 
posición respecto a la misma, pero si son sustancialmente muy elevados los cambios, en positivo, para San Bartolomé (del $10 \%$ al $12 \%$ ), Tías (del $8 \%$ al $17 \%$ ) y Yaiza (del $4 \%$ al $12 \%$ ). $Y$, en negativo, para Haría, que pierde importancia de una forma muy significativa (del $11 \%$ al $1 \%$ ), Teguise (que pasa del $19 \%$ al $13 \%$ ) y Tinajo (que pasa del $7 \%$ al $3 \%$ ). Es decir, hay una clara traslación de la actividad económica hacia el este y sur de la Isla, con una pérdida de importancia significativa del norte y noroeste de la misma.

Estos cambios en la estructura del empleo productivo vienen acompañados de fuertes cambios demográficos, sobre todo por el crecimiento registrado en Tías, San Bartolomé y Yaiza, con una importantísima influencia de dos tipos de inmigración diferenciadas: la turístico-residencial y la de mano de obra, que han llegado a hacer que la población nacida en la Isla se sitúe por debajo del $50 \%$ del total, con la desarticulación cultural implícita a este hecho. Cómo se distribuye esta población alóctona por países, a 1 de enero de 2006, se aprecia en el cuadro siguiente:

Tabla 256. Estructura de la población nacida fuera de la Isla. 2006 (\%)

\begin{tabular}{|l||c|c|c|c|c|c|c|c||}
\hline País de Nacimiento & LANZAROTE & Arrecife & Haría & San Bartolomé & Teguise & Tías & Tinajo & Yaiza \\
\hline \hline España & 74 & 77 & 83 & 80 & 78 & 58 & 85 & 67 \\
\hline Alemania & 3 & 0 & 6 & 2 & 4 & 6 & 2 & 6 \\
\hline Reino Unido & 4 & 0 & 4 & 3 & 7 & 11 & 3 & 7 \\
\hline Marruecos & 3 & 2 & 1 & 1 & 1 & 6 & 1 & 5 \\
\hline Colombia & 4 & 6 & 1 & 3 & 0 & 3 & 1 & 3 \\
\hline Otros países & 13 & 14 & 6 & 11 & 9 & 17 & 9 & 16 \\
\hline Total & 100 & 100 & 100 & 100 & 100 & 100 & 100 & 100 \\
\hline
\end{tabular}

Fuente: Elaboración propia a partir de datos del Padrón Municipal de Habitantes. Instituto Canario de Estadística (ISTAC).

La población con origen en Europa, no española, es ligeramente inferior a la población con origen en América en el conjunto de la Isla, situándose en unos 12.500 habitantes, aunque en términos relativos poseen prácticamente el mismo peso $(10 \%$ de la población total de la Isla cada una).

Adicionalmente, en las explotaciones del padrón municipal realizadas por el ISTAC (2006), la población nacida en otro país, registrada en los municipios de Lanzarote, presenta una estructura de edad más joven que la española y con una población potencialmente activa también más elevada (el $85 \%$ del total entre 15 y 64 años frente al $72 \%$ de la nacional) aunque diferenciada en cada municipio. Así el máximo envejecimiento de esta población se produce en Haría y Tías (10\% del total son mayores de 65 años) seguida de Yaiza y Teguise $(9 \%)$. Por el contrario, la población potencialmente activa encuentra su máximo en 
Arrecife y Tinajo ( $88 \%$ del total entre 15 y 64 años), que son los únicos que superan los porcentajes medios de la Isla.

Estas cifras nos muestran cómo los municipios en que los residentes de la Unión Europea tienen un peso significativo, y no lo tienen los de África o América, presentan un índice de envejecimiento de los inmigrantes no españoles más elevado (Haría, Teguise, Tías y Yaiza) y una población potencialmente activa menor (Haría, Teguise y Tías). Por el contrario, los que tienen mayor porcentaje de inmigrantes nacionales, africanos o americanos, son los que presentan una tasa de población potencialmente activa extranjera más elevada (Arrecife y Tinajo). Y esta situación se proyecta con alguna diferencia significativa al conjunto de la población de la Isla para la población total. Así, va a ser Yaiza - que presenta una mayor tasa de población potencialmente activa sobre el conjunto municipal ( $81 \%$ de la población total entre 15 y 65 años) y que además tiene representación significativa de inmigrantes de los tres continentes principales señalados - y Tías (con el $77 \%$ ), los que alcanzan estas cifras por el peso de la población potencialmente activa española radicada en el municipio. Con esta excepción, sólo Arrecife y San Bartolomé presentan tasas semejantes a la media de la Isla $(75 \%)$ estando las demás por debajo y, muy en particular, Haría $(70 \%)$, Teguise (74\%) y Tinajo $(74 \%)$.

Tabla 257. Estructura de la población por lugar de nacimiento y edad. Lanzarote. 2006. (\%)

\begin{tabular}{|c|c|c|c|c|c|c|c|c|c|}
\hline & & LANZAROTE & Arrecife & Haría & $\begin{array}{c}\text { San } \\
\text { Bartolomé }\end{array}$ & Teguise & Tías & Tinajo & Yaiza \\
\hline \multirow{4}{*}{ España } & $0-14$ & 19 & 19 & 16 & 21 & 19 & 21 & 18 & 14 \\
\hline & $15-64$ & 72 & 72 & 67 & 73 & 72 & 72 & 72 & 80 \\
\hline & 65 y más & 8 & 9 & 17 & 6 & 9 & 7 & 10 & 6 \\
\hline & TOTAL & 100 & 100 & 100 & 100 & 100 & 100 & 100 & 100 \\
\hline \multirow{4}{*}{ Resto de UE-27 } & $0-14$ & 8 & 9 & 8 & 10 & 10 & 8 & 6 & 7 \\
\hline & $15-64$ & 80 & 98 & 81 & 83 & 80 & 76 & 88 & 78 \\
\hline & 65 y más & 12 & 3 & 11 & 7 & 11 & 16 & 6 & 14 \\
\hline & TOTAL & 100 & 100 & 100 & 100 & 100 & 100 & 100 & 100 \\
\hline \multirow{4}{*}{ Resto de Europa } & $0-14$ & 8,2 & 11 & 4 & 12 & 8 & 7 & 0 & 8 \\
\hline & $15-64$ & 79 & 89 & 79 & 77 & 84 & 79 & 100 & 64 \\
\hline & 65 y más & 13 & 0 & 17 & 11 & 8 & 13 & 0 & 29 \\
\hline & TOTAL & 100 & 100 & 100 & 100 & 100 & 100 & 100 & 100 \\
\hline
\end{tabular}




\begin{tabular}{|c|c|c|c|c|c|c|c|c|c|}
\hline & & LANZAROTE & Arrecife & Haría & $\begin{array}{c}\text { San } \\
\text { Bartolomé }\end{array}$ & Teguise & Tías & Tinajo & Yaiza \\
\hline \multirow{4}{*}{ África } & $0-14$ & 5 & 5 & 6 & 6 & 2 & 5 & 8 & 5 \\
\hline & $15-64$ & 93 & 93 & 93 & 93 & 96 & 94 & 92 & 94 \\
\hline & 65 y más & 1 & 1 & 2 & 1 & 2 & 2 & 0 & 1 \\
\hline & TOTAL & 100 & 100 & 100 & 100 & 100 & 100 & 100 & 100 \\
\hline \multirow{4}{*}{ América } & $0-14$ & 13 & 13 & 9 & 14 & 12 & 11 & 13 & 11 \\
\hline & $15-64$ & 85 & 85 & 84 & 83 & 84 & 87 & 86 & 87 \\
\hline & 65 y más & 2 & 2 & 6 & 3 & 4 & 2 & 2 & 2 \\
\hline & TOTAL & 100 & 100 & 100 & 100 & 100 & 100 & 100 & 100 \\
\hline
\end{tabular}

Fuente: Elaboración propia a partir de la explotación del Padrón municipal de 2006. INE e ISTAC.

Las conclusiones son evidentes en un doble sentido. Por un lado, la inmigración de la Unión Europea no española, radicada en Tías, Teguise, Yaiza y Haría, es la población que más aportación realiza a la vejez, pues aproximadamente el $12 \%$ de la misma son mayores de 65 años de edad, destacando los de origen alemán o británico. Frente a la población que tiene origen en otros continentes cuya aportación al envejecimiento es prácticamente nula.

En Tías y Yaiza la población europea convive con otra de inmigrantes africanos y americanos (colombianos y marroquíes, fundamentalmente) con estructura de edad centrada entre los 25 y 44 años, cuya función principal es servir de mano de obra, y que matizan los niveles de dependencia demográfica municipales. Cosa que no sucede en igual medida en Teguise, Tinajo y Haría, lo que hace que estos municipios presenten mayores niveles de dependencia demográfica por envejecimiento (Haría, con el 16\% de población mayor de 65 años, y Tinajo y Teguise con el 9\%). Arrecife, Haría, Tinajo y San Bartolomé son los municipios que superan ampliamente el porcentaje medio de población nacida en España y se minimiza el porcentaje de nacidos en otros países de la Unión Europea, mostrando el carácter básicamente laboral de la inmigración. Además son los municipios que menos contratación de extranjeros registran, pues es Tías (48\%) seguido de Yaiza (50\%) quienes no sólo superan la media de la isla sino de toda Canarias (19,3\%), como se recoge en análisis anteriores.

A todo lo descrito se une un fenómeno observado en diferentes estudios, desde la década de los años noventa, y que se ha podido corroborar, como es la segmentación de la contratación a extranjeros en relación al origen, pues los europeos (no españoles) no trabajan en la construcción o en la escasa agricultura y sufren menos temporalidad. Los inmigrantes procedentes de los países menos desarrollados ocupan puestos más bajos o 
marginales, porque son las oportunidades de empleo de las que disponen y por su escaso poder social de negociación.

Estos procesos, desde la perspectiva de la evolución del PIB per cápita, ya hemos apreciado que han dado lugar a una homogeneización de los niveles municipales, pasando de una diferencia, en 1970, marcada por un máximo del $15 \%$ superior a la media, para Arrecife, y un mínimo de un $29 \%$ inferior a la media, para San Bartolomé y Teguise, a un máximo del $9 \%$ superior a la media, para Tías y Yaiza, y un mínimo, un $9 \%$ inferior a la media, para Tinajo. Las diferencias se han reducido de 44 puntos, en 1970, a 18 puntos en 2003. Y la supremacía relativa de Arrecife y Yaiza, en 1970, muy ligada a la importancia de las capturas pesqueras, ha sido sustituida por una supremacía ligada al sector servicios y, en particular, a la hostelería.

Similares resultados se encuentran en los datos disponibles para el año 2007 (Anuario Estadístico del Cabildo de Lanzarote) obtenidos de la Encuesta de Calidad de Vida, del INE, que proporciona datos para una variable diferente hasta la ahora considerada, que es el Ingreso disponible per cápita, junto a otras variables de importante significación para las estadísticas establecidas por la UE a través de EUROSTAT con respecto a las Condiciones de vida y niveles de pobreza de la población europea. Sin embargo, la información proporcionada sólo se da para el conjunto de la isla de Lanzarote y para los ámbitos que se denominan norte (Haría y Teguise), este (Arrecife, San Bartolomé y Tías) y suroeste (Tinajo y Yaiza):

Tabla 258. Ingreso disponible per cápita. Lanzarote. 2007

\begin{tabular}{|l|c|c|c|c|c|}
\cline { 2 - 6 } \multicolumn{1}{c|}{} & $\begin{array}{c}\text { Ingreso } \\
\text { disponible } \\
\text { en el hogar }\end{array}$ & $\begin{array}{c}\text { Ingreso } \\
\text { disponible } \\
\text { per cápita }\end{array}$ & $\begin{array}{c}\text { Ingreso } \\
\text { equivalente } \\
\text { (mediana) }\end{array}$ & $\begin{array}{c}\text { Ingreso } \\
\text { medio por } \\
\text { trabajo }\end{array}$ & $\begin{array}{c}\text { Valor relativo } \\
\text { Ingreso } \\
\text { disponible per } \\
\text { cápita }\end{array}$ \\
\hline Lanzarote & $1.989,23$ & 699,46 & 954,17 & $1.196,30$ & 100 \\
\hline Lanzarote - Este (Arrecife, San Bartolomé y Tías) & $2.044,43$ & 701,43 & 947,92 & $1.213,08$ & 100 \\
\hline Lanzarote - Norte (Haría y Teguise) & $2.091,06$ & 658,89 & $1.027,78$ & $1.146,20$ & 94 \\
\hline Lanzarote - Suroeste (Tinajo y Yaiza) & $1.666,52$ & 743,09 & 916,67 & $1.166,30$ & 106 \\
\hline
\end{tabular}

Fuente: Elaboración propia a partir de datos del Anuario Cabildo Lanzarote 2007 con base en el INE. Encuesta calidad de vida INE 2007.

Aunque no se refieren exactamente a la misma variable, los datos anteriores reflejan una estructura relativa con respecto al valor medio de Lanzarote, en el Ingreso disponible per cápita, relativamente distinta a la encontrada para 2003 en la estimación de PIB per cápita realizada en páginas anteriores. Las principales diferencias se encuentran en Tías, que al estar incluido con Arrecife y San Bartolomé, queda integrado en el grupo del $100 \%$ del valor de la Isla (valor de 109\% para 2003 en nuestra estimación); de Tinajo y Yaiza, con valor 
106, que al integrarse conjuntamente en el suroeste compensan los distintos valores (91 para Tinajo y 109 para Yaiza en nuestra estimación), y de los municipios de la zona norte (Haría y Teguise), con valor 100 en nuestra estimación y que en este caso se reduce al $94 \%$.

Las diferencias entre Ingreso disponible per cápita y PIB per cápita justifican en parte estas diferencias que, en todo caso, nos muestran una distribución media municipal bastante equilibrada en 2007 (resultado también encontrado para 2003), un sur y este más rico (Yaiza, San Bartolomé, Arrecife y Teguise) y un norte (Haría y Tinajo) menos favorecido.

Esta diferenciación territorial se aprecia mucho más claramente multiplicando las cifras anteriores por la población municipal respectiva, con lo que estimamos el ingreso total municipal de la Isla y su distribución. Los resultados son que del orden del $70 \%$ del ingreso disponible total se localiza en la zona sureste (Arrecife, San Bartolomé y Tías), del orden de un $16 \%$ adicional en el norte (Haría y Teguise) y el último $13 \%$ en el sur-suroeste (Tinajo y Yaiza). 



\section{Capítulo 5}

\section{SÍNTESIS Y CONCLUSIONES}





\section{CAPÍTULO 5.- SÍNTESIS Y CONCLUSIONES.}

El objeto principal de esta tesis doctoral es analizar los principales efectos sociales que tiene el turismo sobre algunos de los aspectos básicos del bienestar social y, concretamente, a consecuencia de la implantación de una actividad turística cuyo crecimiento culmina en un modelo turístico de masas.

Inicialmente parte del necesario establecimiento de los marcos conceptuales, epistemológicos y jurídico-administrativos, donde se inscriben las relaciones entre el bienestar social y el turismo, para, posteriormente, centrarse en analizar los cambios y efectos experimentados, como resultado de dicha implantación, sobre las áreas básicas del bienestar social en un territorial insular, la isla de Lanzarote.

\section{1.- SÍNTESIS DE APORTACIONES}

Los puntos de partida y principales aportaciones al análisis y verificación de objetivos e hipótesis se sintetizan en los siguientes 31 puntos:

1. Entendemos por Bienestar Social, a los efectos de esta tesis, un concepto complejo, multidisciplinar, multidimensional, objetivo y objetivable, mensurable a través de indicadores sociales objetivos, referido al acceso a servicios primordiales, recogidos como derechos, que tienen reflejo en el nivel de vida y en el estado de la "igualdad de oportunidades", con correspondencia hacia el nivel de satisfacción de las necesidades y el desarrollo.

2. El turismo, desde su acepción enunciada por la OMT, está referido aquí a las actividades de las personas que se desplazan a un lugar distinto al de su entorno habitual, por un periodo de tiempo inferior a un año y por un motivo principal distinto al de ejercer una actividad que se remunere en el lugar visitado. Conlleva por tanto, interacción directa e indirecta con la sociedad de acogida, y con sus recursos, teniendo efectos socioeconómicos, ambientales y territoriales sobre ambos.

3. Se considera el turismo como factor de cambio. La dirección que dicho cambio toma está alumbrada por el pensamiento sociológico, cuyos discursos se mueven en la disyuntiva de si éste es un factor de desarrollo para las sociedades receptoras, o por el contrario un generador de subdesarrollo y dependencia.

4. La Administración Pública es un elemento esencial en la evolución turística por su papel en la promoción, coordinación, planificación, control, regulación, gestión y garantía de orden en el sistema turístico. Se destaca en la tesis el rol de los Cabildos, en cuanto administración propia de las islas y órgano político supramunicipal, que es el que 
establece los objetivos de desarrollo marcados para la Isla, y elabora la ordenación del territorio, de la cual ostenta la responsabilidad, así como la potestad de observancia y control de su cumplimiento.

5. La Ordenación del Territorio (OT) ha sido la guía para la diferenciación de las etapas de desarrollo turístico y su posterior análisis, en tanto que ésta, al plantear el modelo territorial asociado a la política turística adoptada en cada momento, afecta de diferentes formas al bienestar social derivado. Cada Plan o proceso de OT se corresponde así con fases distintas de desarrollo turístico en Lanzarote.

6. El proceso registrado en la Isla, a lo largo de los treinta y cinco años objeto de análisis, impulsado por la actividad turística, ha significado una fortísima transformación socioeconómica, ambiental y territorial. Los principales aspectos de ésta que han afectado al bienestar, desde el objetivo aquí asumido y de las hipótesis de partida adoptadas, se centran en aspectos demográficos, con conversión de la población autóctona en minoritaria en la Isla; de acceso a dotaciones y servicios, y de fuertes modificaciones en las condiciones de empleo, paro y generación de renta, y tal y como se particulariza en las conclusiones siguientes.

7. La evolución turística hace que la Isla registre una fuerte transformación en su estructura de ocupación del territorio y en las actividades que desarrolla en el mismo, avanzando hacia una ocupación más equilibrada del territorio frente a la primacía inicial del municipio de Arrecife. Desde el punto de vista demográfico Tías, Yaiza y San Bartolomé (sur-sureste de la Isla) van a registrar los mayores cambios poblacionales, más que quintuplicando su población inicial y dando lugar, en 2006, a una estructura más equilibrada territorialmente, un conjunto de núcleos rurales en mejores condiciones relativas, y unas áreas turísticas litorales en el este y sur de la Isla que proporcionan un acceso más equilibrado de la población al conjunto de los núcleos del territorio. Sólo en el norte y oeste (Haría y Tinajo) se produce un menor peso relativo de la población y un cierto desequilibrio respecto a la dinámica demográfica del resto.

8. En paralelo a los cambios demográficos, ha habido también un cambio muy importante en la distribución territorial del empleo de los residentes. En efecto, tras más de treinta y cinco años, Arrecife sigue concentrando del orden del $41 \%$ del empleo total de la Isla, sin cambios significativos en su posición respecto a la misma, pero sí son sustancialmente muy elevados los cambios, en positivo, para el sector sur y sureste de la Isla (San Bartolomé, Tías y Yaiza), mientras que disminuyen en importancia relativa los sectores norte, noreste y noroeste (Haría, Teguise y Tinajo). Es decir, al igual que en la demografía, hay una clara traslación del empleo hacia el este y sur de la Isla, con una pérdida de importancia relativa notable del norte y noroeste de la misma, aunque en todos los municipios hay un incremento sustancial del empleo en el global del período. 
9. La Isla parte, antes de su transformación turística, de una población dedicada a la agricultura y a la pesca con todos los municipios especializados funcionalmente en estas actividades, salvo Arrecife, donde el sector servicios tiene un porcentaje de empleo significativo, que se corresponde con su función de capital administrativa. Más de treinta y cinco años después, al final del período considerado, la estructura del empleo de la población es radicalmente distinta. El sector primario (agricultura y capturas pesqueras) representa menos del $1 \%$ del empleo final del periodo, por lo que la población autóctona que por su edad en 1970 no se había jubilado, tuvo que registrar un fuerte proceso de adaptación a las nuevas actividades productivas, siendo sólo las zonas norte y noroeste de la Isla (Haría, Teguise y Tinajo) las que aún conservan un cierto atisbo de actividad productiva en el sector primario que era una de las fuentes básicas de empleo en la Isla al inicio del proceso de análisis.

10. La construcción es la actividad productiva asociada al crecimiento turístico que suele ser el destino inicial de la población agrícola; y así sucede también en las etapas de desarrollo turístico inicial de la Isla. Pero la culminación del modelo ligado al desarrollo de un "turismo de masas" en fase de madurez, y la propia reacción de Lanzarote a la sobre-urbanización, ha dado lugar a que la construcción también registre un claro retroceso en la estructura del empleo, en las últimas etapas analizadas, lo que puede considerarse positivo desde la perspectiva de la ocupación de un recurso escaso, como es el suelo en una isla, que se asocia a este sector, de su menor productividad relativa y de la baja cualificación de la mayoría de la población que tradicionalmente emplea. Tinajo y San Bartolomé son los municipios que destacan en la población empleada al final del período en esta actividad, manteniendo una cierta tradición con su especialización en la misma respecto al inicio del período.

11. La preocupante escasa incidencia de la industria en la Isla se ve acrecentada a lo largo del período analizado, en el que va perdiendo peso relativo hasta situarse en un $3 \%$ del empleo total, reduciendo a la mitad la ya de por sí muy reducida cifra de empleo en este sector al inicio del período. Si bien al final del período la industria presenta una distribución más homogénea en toda la Isla, la caída de su importancia junto a la caída de la agricultura, nos muestra la tremenda doble dependencia del exterior de la Isla: por la influencia turística y por la necesidad de importar productos agrícolas, pesqueros e industriales, ante su incapacidad para haber desarrollado una estructura productiva interna que satisfaga esas necesidades propias y derivadas de la demanda turística.

12. La transformación en el período de análisis hacia la especialización en el sector servicios de la Isla es abrumadora, canalizando éste más del $86 \%$ de los empleos, con los municipios del sur-suroeste de la Isla (Tías y Yaiza) destacando claramente sobre el total, fundamentalmente por su especialización hostelera. Aunque en principio la mayor productividad relativa del sector servicios respecto a la agricultura tradicional de la Isla 
es una ventaja en la evolución registrada de las condiciones y características del empleo y paro registrado, esta afirmación tiene sus claros oscuros y sus matices respecto a la repercusión sobre la población autóctona en las etapas siguientes del desarrollo del turismo de masas.

13. De la dependencia inicial del sector primario se pasa a la dependencia absoluta del sector turístico con el desarrollo del turismo de masas. Sectores como el agrario y la industria no tienen fuerza, por su escasa participación en la economía, para arrastrar el empleo, o para relocalizar los activos laborales en momentos de elevada reducción de la afluencia turística. Adicionalmente, se produce un manejo de la economía desde el exterior, antítesis del desarrollo autosuficiente, como ya se observaba desde el pensamiento de la Sociología (Gaviria, 1974; Nash, 1970 y 1987, etc.) y Antropología (Britton, 1978, Crick, 1979, etc.) de la década de los años setenta y ochenta. El turismo de masas ha borrado actividades, ecosistemas y estructuras sociales preexistentes, a la vez que ha anulado otras opciones incapaces de competir con el tipo de poder socioeconómico asociado al turismo de masas.

14. El crecimiento económico registrado en el período ha favorecido la atracción (inmigración) e incremento de la población activa femenina y masculina, y el incremento del empleo, fundamentalmente en el sector servicios y la hostelería, pero con una demanda de baja cualificación, que se multiplica cuando crece la actividad en la construcción, y que permite hablar de una estructura ocupacional no muy positiva para los autóctonos, ya que promueve una estructura social polarizada, a todas luces negativa. A este hecho contribuyen la supremacía de los contratos temporales, sobre todo en hostelería (alrededor de un tercio de la población ocupada) y los reducidos salarios medios mensuales, unido a la tardía adaptación de la formación profesional, que se imparte en la isla, a los mercados laborales impulsados (desajuste cualitativo).

15. Los cambios en la estructura del empleo productivo vienen acompañados de fuertes cambios demográficos, derivados tanto de la inmigración de mano de obra demandada por la actividad turística, sobre todo por el crecimiento registrado en Tías, San Bartolomé y Yaiza, como, a un nivel mucho menor, por la inmigración la turísticoresidencial. Conjuntamente ha llegado a hacer que la población nacida en la Isla, se sitúe por debajo del $50 \%$ del total de residentes, con la desarticulación cultural implícita a este hecho. En relación a la estimación final del número de habitantes diarios en la Isla, menos del $38 \%$ han nacido en ella. En la evolución hasta alcanzar esta cifra, los desequilibrios demográficos derivados de la dinámica histórico que se va produciendo viene caracterizada por el continuo descenso de la población autóctona (nacidos en la isla), que sólo mengua en la etapas de crisis de afluencia, que reducen tanto el volumen de turistas diarios como el incremento del volumen de incorporación de población externa (inmigrantes). Pero las crisis cíclicas de afluencia turística también dificultan la 
estabilidad en los empleos, base fundamental del bienestar social, e incrementa el paro, como queda demostrado tras la crisis de sobreproducción que vivió la isla a finales de la década de los años ochenta.

16. La inmigración registrada presenta características diferenciadas tanto en su estructura de edad como para su función económica, tanto en lo que se refiere a la turísticoresidencial, como a la laboral. La primera presenta unos niveles de envejecimiento más elevados y mayores niveles de renta, pero una dependencia de ingresos y tributación que distintos informes sitúan fuera de la Isla y de nuestras fronteras; y dan lugar a procesos de envejecimiento en la población municipal (Haría, con el 11\% de población mayor de 65 años, o Teguise con el 9\%). Mientras que la segunda eleva significativamente el porcentaje de población potencialmente activa municipal, cotiza y paga sus impuestos reglamentarios, aunque exporta capital a sus países de origen a través de las remesas de emigrantes, lo que incide en unos niveles de consumo más ajustados en la Isla.

17. También en las cifras de paro los cambios estructurales producidos por el turismo de masas en la Isla han tenido sus consecuencias. Así, se ha constatado que históricamente Lanzarote ha tenido tasas de paro muy inferiores a las de Canarias y España, si bien éstas se van reduciendo con la creciente influencia del turismo de masas y, en 2006, las fuertes diferencias históricas con España desaparecen, presentando ambos ámbitos una tasa del 8,5\%. El paro se concentra más en las mujeres que en los hombres y fundamentalmente en el sector servicios (78\%) basado más en servicios a personas (restauración, comercio, etc.), que a empresas; y, por supuesto, en la construcción (13\%). Espacialmente el paro se localiza en Arrecife, San Bartolomé, Teguise y Tías, que son también los municipios más poblados; pero las mayores tasas de paro se dan en Haría, Tinajo y Arrecife, manifestando nuevamente la debilidad relativa del norte y oeste de la Isla.

18. La dinámica creciente en la evolución del turismo de masas de funcionar en base a ofertas turísticas y contratos de última hora por parte de los "Tour operators", ha incrementado la temporalidad, la intensificación de los ritmos de trabajo, el alargamiento de las jornadas y la accidentalidad del trabajador; y reducido la duración de los contratos, con niveles salariales no adaptados al coste de la vida de la Isla, lo que ha afectado negativamente tanto al servicio prestado como a las condiciones de trabajo de la población residente. La inestabilidad y el abaratamiento del mercado laboral serán la tónica en la madurez del destino. Por tanto, el turismo de masas convertido en monocultivo productivo confirma la hipótesis de la Teoría Crítica, produciendo una explotación insostenible de los recursos (fundamentalmente suelo y mano de obra) en espacios limitados, como es una Isla, y dificultando la consecución del bienestar social para la población residente. Consecuentemente y en relación al empleo, el turismo de 
masas genera efectos socioeconómicos y sobre el bienestar cuyo balance no se considera positivo.

19. Territorialmente, estos procesos, sin embargo, han generado, desde la perspectiva de la evolución del PIB per cápita, una homogeneización relativa de los niveles municipales, pasando de una diferencia, en 1970 , de un máximo de un $15 \%$ superior a la media, para Arrecife, y un mínimo, un $29 \%$ inferior a la media, para San Bartolomé y Teguise, a un máximo de un $9 \%$ superior a la media, para Tías y Yaiza, y un mínimo, un $9 \%$ inferior a la media, para Tinajo. Por tanto, las diferencias se han reducido de 44 puntos, en 1970, a 18 puntos al final del periodo analizado. Y la supremacía relativa de Arrecife y Yaiza, en 1970, muy ligada a la importancia de las capturas pesqueras, ha sido sustituida por una supremacía ligada al sector servicios y, en particular, a la hostelería en el sursureste. Las distintas fases de la ordenación territorial y urbanística de la Isla y su adecuación a las necesidades del turismo de masas, sobre todo en el sur y suroeste, son elementos claves para la explicación de este proceso.

20. La evolución turística inicial incrementó muy sustancialmente el bienestar económico de la Isla y de sus residentes (en su mayoría autóctonos), con una clara mejora en el empleo, en la renta, en la riqueza, en los equipamientos, servicios y dotaciones públicas. Pero el que el crecimiento turístico y constructor se produjera en base a actuaciones alóctonas, con promotores externos que han controlado las grandes operaciones en suelo a partir de adquisiciones a los locales a precio muy reducido en las primeras etapas del crecimiento turístico, y el que la demanda esté controlada por "Tour operators" europeos hace que el control del sector esté muy alejado de los interés locales, y que se haya propiciado una sobreoferta turística y un desarrollo considerado crecientemente desequilibrado por los sucesivos análisis y planes realizados sobre la Isla, que no ha sido beneficioso para los residentes. Además este proceso ha generado un progresivo deterioro de la competitividad turística de la Isla por la emergencia de nuevas ofertas internacionales de mejor relación calidad/precio. Imperialismo y colonización reflejada en el manejo de la economía local por extranjeros (como denuncian Young, Nash, Gaviria, etc., ya en la década de los años setenta) han llevado a sobrepasar los puntos de equilibrio en los que los beneficios para la población autóctona superaban a los perjuicios finalmente producidos.

21. La mejora de los equipamientos de bienestar a lo largo del periodo tiene matices en cuando a su repercusión sobre la población residencial. Pues no en todos los casos ni etapas se van a producir saldos positivos. Así, dentro del área de la salud, las dotaciones hospitalarias (siempre centralizadas en Arrecife) tienen una adaptación tardía a las nuevas presiones demográficas; y con obstáculos derivados, por un lado, de los rápidos procesos de crecimiento demográfico descritos; $y$, por otro lado, derivados de la desproporción entre el fuerte crecimiento de la oferta turística insular, que absorbe 
materiales y profesionales de la rama de la construcción hacia la inversión privada, y las posibilidades de inversiones públicas en el área de la salud. Los indicadores del sector se mantendrán siempre muy por debajo de los estándares de calidad recomendados por fuentes internacionales. No obstante, en el ámbito extrahospitalario, a partir del año 1996, se observa un proceso de descentralización de la zona básica de salud, favoreciendo las áreas de crecimiento demográfico de los diferentes municipios, y los núcleos donde la actividad turística se concentra.

22. La fuerza que ejerce en la Isla la incorporación de un sistema capitalista, urbano y de consumo, basado en actividades del terciario turístico, impulsa una larga etapa de mejoras del recurso humano insular basadas en la erradicación del analfabetismo y en la corrección de las altas tasas de desescolarización existentes previamente, perfil que se consigue a mediados de los ochenta. Pero el tipo de mercado laboral que se define, basado en servicios a personas y no a empresas, concentrado en el trinomio construcción, hostelería y comercio, no permitirá que la cualificación se eleve más allá de los niveles educativos obligatorios seguidos por las primeras etapas de la formación profesional, como se detecta en la evolución desde 1986.

23. La evolución del equipamiento educativo viene a caracterizarse por la eliminación de los estrangulamientos dotacionales en la enseñanza obligatoria, existentes al iniciar el despegue hacia la actividad turística de masas, lo que a partir de la mitad de la década de los años ochenta llevará a superávits (relación alumnos potenciales respecto a plazas ofertadas). A partir de que se alcanza la escolarización plena de la población, la isla va creciendo en centros específicos para formación profesional. El nivel de equipamiento en este ámbito seguirá cubriendo la demanda. A ello se añade una progresiva ruptura con el modelo de centralización de estas dotaciones en la capital insular, Arrecife, que caracterizó los años setenta y los ochenta. La descentralización se va a notar a partir de la siguiente década, principalmente por la construcción de nuevos centros de secundaria, ubicados fuera de Arrecife.

24. Consecuencia de los procesos inmigratorios generados por el turismo de masas es que, en términos cualitativos, el sistema educativo insular, en el nuevo siglo, tendrá que enfrentarse a la heterogeneidad cultural e idiomática de sus alumnos, que poseen orígenes muy diversos, pues aproximadamente el $18 \%$ de los matriculados venían de fuera de España, lo que supone un reto a la integración social y cultural e incidía en los malos resultados finales alcanzados.

25. También el constante incremento de la oferta y la demanda turística provocan el abandono prematuro de los estudios (en este sentido Canarias posee, al final del periodo de análisis, una de las tasas más elevadas de abandono de España), fenómeno que se observa en todos los ámbitos socioeconómicos donde se ha producido un rápido 
crecimiento vinculado al sector de los servicios asociados al turismo de masas, ya que éste atrae a los jóvenes hacia los empleos generados, aunque estos sean de baja cualificación. Los impulsos de la actividad en la construcción a finales de siglo provocan un nuevo engrosamiento de la base de los niveles de instrucción, potenciando pérdidas en el enriquecimiento cultural. La dinámica descrita en todo el período para los niveles de instrucción, inicialmente potencia la incorporación de actividades del terciario turístico, que impulsa mejoras en el nivel de instrucción de la población residente, pero, al generalizase el turismo de masas se potencia un mercado de trabajo que no demanda elevada capacitación, manteniendo bajos niveles de instrucción finales en su madurez.

26. Las inversiones en infraestructuras de energía eléctrica y en desalinización de agua, han sido fundamentales para posibilitar el crecimiento de la oferta y demanda turística, de la que progresivamente se beneficia la población residente en dos sentidos: la disponibilidad de recursos y el menor precio de estos recursos para el consumo doméstico pues el turismo aparece como el verdadero financiador del sistema de desalinización del agua que posee la Isla, y de muchos de los generadores energéticos de la misma.

27. Pero el modelo turístico de masas, en su fase de madurez, y la sobre-urbanización revelan limitaciones a la satisfacción de la demanda en épocas punta, siendo las zonas rurales (norte y noroeste) las que soportan agudas restricciones, principalmente en el acceso al agua, frente a las áreas urbanas, ya que la oferta existente está dirigida a garantizar el consumo del turista, con estándares de consumo muy alejados de los tradicionales consumos austeros característicos de un territorio con difícil acceso a estos recursos. Adicionalmente, los rápidos crecimientos de la población equivalente diaria producidos (o población total), dan lugar a una creciente incapacidad de los sistemas generales anteriores (electricidad y agua) para asistir a las puntas de demanda, situación que se solventa con la constante ampliación de la oferta. En el caso de la energía eléctrica a través del uso del petróleo y sus derivados como solución rápida, pues también hay que producir más agua, siendo así que aproximadamente el $23 \%$ de la producción eléctrica se destina al ciclo del agua. La presión a la que están sujetos estos sistemas y las soluciones adoptadas, los han convertido en sistemas altamente vulnerables a fallos: ambos, subsisten al límite, y son muy contaminantes, poniendo en duda la seguridad en el suministro, fundamentalmente para la población residente.

28. La histórica austeridad en el consumo de agua y energía que ha caracterizado a la cultura local da síntomas de desaparición en la madurez del destino, como consecuencia del enorme cambio en la estructura social acontecido en estos treinta y cinco años. Son efectos de la aculturación producida y de la multiculturalidad que ahora acoge la Isla, que rompen comportamientos históricos sostenibles. 
29. La carencia de fuentes de energía primaria convencional en el la isla, y el incomprensible olvido de los potenciales de las energías renovables en la misma como fuentes autóctonas de abastecimiento, genera un modelo energético absolutamente dependiente del exterior, basado en centrales térmicas equipadas con grupos electrógenos alimentados con fuel-oil y gasoil, enormemente contaminantes, en un sistema de red conjunta Lanzarote-Fuerteventura en simple circuito. Las energías renovables no se van a incorporar, y con relativa baja intensidad, hasta la década de los años noventa. Principalmente basadas en el viento, su potencia y capacidad de oferta final será meramente testimonial, mostrando uno de los ejemplos más palmarios de desaprovechamiento de los recursos autóctonos para potenciar un modelo de desarrollo menos dependiente del exterior.

30. Modelo de desarrollo sobre cuya insostenibilidad y dependencia también influye de manera significativa los cambios producidos por la evolución turística sobre el sistema de transporte. Los altos índices de motorización alcanzados, alimentados por los crecimientos iniciales del PIB per cápita y por un sistema de transporte público que ha venido siendo considerado en todo el periodo, tanto insuficiente como ineficiente para la fuerte dispersión del hábitat que se produce por los nuevos desarrollos urbanísticos asociados al turismo, y por la localización de las dotaciones de ocio. Motorización y uso del vehículo privado también asociada al desarrollo de una cultura de consumo que ha derivado hacia la concepción del uso del transporte público como indicador de clase.

31. Desde la perspectiva de las infraestructuras y servicios de transporte, la irrupción de la líneas aéreas de bajo coste y las tendencias liberalizadoras en el transporte aéreo y en los servicios, así como la problemática asociada a los nuevos problemas ambientales globales y los nuevos destinos emergentes competitivos, eran un reto creciente a lo largo de los años considerados del siglo XX que, en 2006, no predecían una evolución favorable para el futuro de la población autóctona de la Isla, ante la evidente madurez de su oferta turística y la total especialización turística establecida para la misma.

\section{2.- CONCLUSIONES}

Como conclusión final se puede señalar que los procesos considerados en la tesis nos permiten afirmar que: "el conocimiento de otras realidades", supuestamente favorecido por el turismo de masas, no es un elemento que incida necesariamente sobre el bienestar de la población local afectada, contrariamente a lo que organizaciones de la talla de la OCDE y la OMT alegaron para promover su implantación en países pobres, basándose en corrientes humanistas. Esta contradicción se convierte en un hecho al considerar los efectos de ejemplos como el de los consumos de agua del turista, que se estiman en más de un $65 \%$ por encima del de los residentes, en un territorio sin agua. Consecuentemente, no sólo el 
turismo de masas no es un factor que establezca empatía entre los pueblos, ya que es exhibicionista y depredador, y vive al margen de la realidad de la sociedad anfitriona, sino que las bondades de esta actividad, cuando alcanza un determinado tamaño, quedan en entredicho.

Se contrasta así la verificación de las hipótesis iniciales de la tesis, en cuanto que se evidencia que la implantación de la actividad turística en territorios insulares inicia un primer periodo de incremento del bienestar en la sociedad de acogida, en términos socioeconómicos, infraestructurales y dotacionales, de los que se beneficia la población autóctona y residente; pero tras la consolidación en el territorio del turismo como monocultivo, y la implantación de un modelo en forma de turismo masificado (o de masas), esta sociedad de acogida se ve negativamente afectada por dinámicas de transformación territorial, económica y social poco compatibles con estos beneficios inicialmente generados, y sin reflejo positivo final sobre el bienestar de los ciudadanos.

En efecto, se producen desequilibrios demográficos que afectan negativamente a la situación relativa de la población autóctona, que en última instancia dificultan la conservación de los rasgos culturales locales, que son también un recurso turístico, y la reducción de los niveles de instrucción a estándares básicos, pues la línea de ascenso está condicionada por el mercado de trabajo que no demanda elevada capacitación. Todo lo cual supone una fuerte limitación del capital humano y social, recurso importantísimo en todo desarrollo.

El crecimiento de la oferta turística, y sus efectos territoriales y ambientales, no tienen un reflejo proporcional en el volumen de empleos, y genera fuertes niveles de precariedad en el mismo (claro indicador de malestar social); colapso en las dotaciones sanitarias y dificultades infraestructurales para la producción y el acceso a la energía y al agua; con el derivado endurecimiento de las condiciones de vida locales por dificultades en la accesibilidad y la disponibilidad de este recurso, escaso y caro en la Isla, unido a la invasión de la escena por el vehículo privado.

A ello se unen cambios significativos en la histórica austeridad y adaptación a los recursos autóctonos de la población de la Isla, afectando a la sostenibilidad de la misma, y cuyo origen está en los desequilibrios demográficos citados (población inmigrante con otras pautas culturales y turismo con sobredotación de recursos que no siente la necesidad de un comportamiento ahorrador). El modelo de desarrollo asociado al turismo de masas convierte al turista, en un espacio limitado y de recursos acotados, como es una isla, en competidor por un abastecimiento limitado, depredador en sus comportamientos y que somete el bienestar de la sociedad anfitriona a sus fluctuaciones y crisis, quedando aquella absolutamente dependiente de los intereses del sector turístico, fuertemente dependientes del exterior de la propia Isla. 
Finalmente, a través del análisis efectuado, se confirma una conclusión tradicional de este tipo de estudios cual es que la calidad, y no la cantidad, debería presidir las políticas de desarrollo turístico. La contención de la oferta y la demanda turística mucho antes de que adquieran un nivel de masificación que les convierta en monocultivo territorial, y la diversificación de la actividad productiva en base a los potenciales y recursos autóctonos, se convierten en las vías deseables para posibilitar el conseguir una mejora real del bienestar social. De ahí la importancia y función de una ordenación territorial y turística, como garantía de alcanzar un turismo sostenible dirigido a la consecución y mantenimiento del bienestar local como fin último. Sin embargo, pese a los objetivos reiteradamente definidos, los efectos finalmente producidos y escritos en la tesis, muestran que el éxito de la política territorial y turística insular ha de ser puesto en entredicho. 



\section{Fuentes de información}

- Bibliográficas

- Legislativas 


\section{3.- FUENTES BIBLIOGRÁFICAS}

ACOSTA, E. Y CURBELO A. "La evolución demográfica reciente de la isla de Lanzarote: EL papel de la dinámica natural". En $V$ Jornadas de Lanzarote y Fuerteventura. Puerto del Rosario: Cabildo de Lanzarote y Fuerteventura, 1994 (pp. 219-244). Disponible en Web:

http://www.memoriadelanzarote.com/detalle.php?Tema $=\&$ Temac $=\&$ Tpadre $=\&$ Tpadrec $=\&$ $\underline{\mathrm{f}=\mathrm{BIBL} I \& \mathrm{ir}=3844}$

ACOSTA, E. El turismo en Lanzarote: producción de espacio de ocio y desarticulación de la economía tradicional. Informe Insular. Lanzarote: Cabildo Insular de Lanzarote, 1990. Disponible en Web:

http://www.datosdelanzarote.com/itemDetalles.asp?idFamilia=26\&idltem=220

ACOSTA HERNÁNDEZ, A. D. Informe sobre las Facultades de Intervención administrativa del Cabildo Insular en el control de la oferta alojativa turística [en línea] Arrecife: Cabildo Insular de Lanzarote, 2003. [Referencia de 10-09-2009]. Disponible en Web:

http://www.datosdelanzarote.com/itemDetalles.asp?idFamilia=26\&idltem=1625

ÁLVAREZ, MARCELO. Estructura social de Canarias II. La reproducción social del subdesarrollo. En Cuadernos Canarios de Ciencias Sociales. № 6. Las Palmas de Gran Canaria: Centro de Investigación Económica y Social de la Caja Insular de Ahorros de Canarias (C.I.E.S). 1980.

ÁLVAREZ RICO, M. La crisis del Estado de Bienestar en el marco de la Globalización: Incidencia en el sector público". En Revista Sociedad y Utopía. 1998, № 12, pp.123-135.

ARRILLAGA, J. I. Ensayos sobre turismo. Barcelona: Editur, 1962.

- (1974). El Turismo como ciencia. Revista de Estudios Turísticos, № 41. Madrid: Instituto de Estudios Turísticos, 1974.

- (1989) ARRILLAGA, J. I. Valores espirituales y sociales del turismo. Madrid: Edice, 1989.

ARTIGUES, Albert A. Turismos de espacios litorales e insulares. En Geografía mundial del turismo. Madrid: Síntesis, 2001 (pp. 91-122).

ADUAR, Grupo. Diccionario de Geografía Urbana, Urbanismo y Ordenación del Territorio. Madrid: Ariel, S.A. 2000.

BANESTO. Anuario del Mercado Español, 1983. Madrid. Banco Español de Crédito, 1983. 
- (1988). Anuario del Mercado Español, 1983. Madrid. Banco Español de Crédito, 1988.

- (1993). Anuario del Mercado Español, 1983. Madrid. Banco Español de Crédito, 1933.

BLANCO, A. Y DÍAZ, D. El bienestar social: su concepto y medición. Revista Psicothema, 2005, Volumen 17, Número 004. Oviedo: Universidad de Oviedo 2005, (Pág. 582-589).

BARRETO, M. As ciencias sociais aplicadas ao turismo. En Serrano, C., Bruhns, H. e Luchiari, M.T.D.P., Olhares Contemporàneos sobre o turismo. Campinas, Papirus, 2000 (pp. 17-36).

BAYÓN MARINÉ, F. 50 años de turismo español. Un análisis histórico y estructural Madrid: Centro de Estudios Ramón Areces, 1999. 1.106 p.

BENABENT FERNÁNDEZ DE CÓRDOBA, M. La Ordenación del Territorio en España. Sevilla: Universidad de Sevilla, Junta de Andalucía, Consejería de Obras Públicas y Transportes, 2006.

BERIÁIN, J. (1990). Estado de Bienestar, Planificación e Ideología. Madrid: Popular, S. A., 1990. $107 \mathrm{p}$.

BLANQUER CRIADO, D. [et al] Ordenación y gestión del territorio Turístico. Colección Ocio y turismo, 2; Valencia: Tirant lo Blanch, 2002. 950 p.

BOORSTIN, D. The Image. A Guide to Pseudoevents in America. New York: Atheneum, $1^{\text {a }}$ edición, 1972. [8ª impression], 1980. 315 p.

BRITTON, R. A. (1978). International torism and indigenous development objectives; a study with special reference to the West Indies. PhD Tesis, Univ. Minnesota. 1978. 264 p.

BUENO CAMPOS, E. Introducción a la edición española de Klir, G. J.: Teoría General de Sistemas: un enfoque metodológico. Madrid: ICE, 1981, 383 p.

BURCKLEY, W. La sociología y la teoría moderna de los sistemas. Buenos Aires: Amorrortu, 1970. 320 p.

CABALLERO, C. El transporte colectivo regular de viajeros por carretera en la isla de Lanzarote (1947-1996). En VIII Jornadas de Estudios sobre Lanzarote y Fuerteventura. Tomo I. Arrecife: Cabildo Insular de Fuerteventura y de Lanzarote, 1999 (pp. 547-563). Disponible en Web:

http://www.memoriadelanzarote.com/detalle.php?Tema=\&Temac $=\&$ Tpadre $=\&$ Tpadrec $=\&$ $\underline{\mathrm{f}=\mathrm{BIBLI} \& \mathrm{ir}=1014}$ 
- (2001). La movilidad espacial por carretera de la población de la isla de Lanzarote (1990-1995). En IX Jornadas de Lanzarote y Fuerteventura. Puerto del Rosario: Cabildo Insular de Fuerteventura y de Lanzarote, 2001 (p. 322-339). ISBN: 8487461-81-6. Disponible en Web:

http://www.memoriadelanzarote.com/detalle.php?Tema=\&Temac=\&Tpadre=\&Tpadre $\mathrm{c}=\& \mathrm{f}=\mathrm{BIBLI} \& \mathrm{ir}=1013$

CABILDO INSULAR DE LANZAROTE. Plan Insular de Ordenación de la isla de Lanzarote. Lanzarote, 1973. [Redacción: Cáceres, E., et al.]. Cabildo Insular de Lanzarote, 1973. [Disponible en CD-Rom en el Centro de Datos del Cabildo Insular de Lanzarote]. Varios documentos:

- Documento I. Información urbanística del suelo.

- Documento IV. Ordenación Económica y Social.

- Anexo mapas. 1973.

- (1987) Avance del Plan Insular de Ordenación del Territorio de la Isla de Lanzarote (PIOT). [Elaborado por "Arquitectos Urbanistas, Ingenieros Asociados" (AUIA)] Arrecife: Cabildo Insular de Lanzarote, 1987. [Disponible en CD-Rom en el Centro de Datos del Cabildo Insular de Lanzarote]. Varios documentos:

- Tomo 4. Área Económica.

- Tomo 5. Área de Sociedad y Turismo.

- Tomo 6. Área Jurídica. Dictamen sobre el Planeamiento Urbanístico existente y Futuro de Lanzarote.

- Tomo 7. Escenario Tendencial. Hipótesis sobre la evolución Insular según las tendencias actuales.

- (1991). Plan Insular de Ordenación del Territorio de la Isla de Lanzarote. [Dirección: AUIA] Arrecife: Cabildo Insular de Lanzarote, 1991. [Disponible en CD-Rom en el Centro de Datos del Cabildo Insular de Lanzarote]. Varios documentos:

- Resumen. Capítulo III. Breve diagnóstico de la situación actual de Lanzarote.

- Tomo 10.1. Información, Diagnóstico y Marco de Referencia.

- Tomo 10.2. Memoria.

- Tomo 10.6. Programa de Actuación y Estudio Económico - Financiero.

- (1992 a). Consideraciones generales y breve síntesis sobre los contenidos básicos del Plan Insular. Arrecife: Oficina del Plan Insular. Cabildo Insular de Lanzarote, 1992.

- (1992 b). Dossier de prensa. Arrecife: Oficina del Plan Insular Cabildo Insular de Lanzarote, 1992. 
- (1992 c). Anuario Estadístico de Lanzarote, 1992. Centro de datos. Lanzarote: Cabildo Insular de Lanzarote, 1992.

- (1996). Anuario Estadístico de Lanzarote, 1996. Centro de datos. Lanzarote: Cabildo Insular de Lanzarote 1996. Disponible en Web: http://www.datosdelanzarote.com

- (1998 a). Lanzarote en la Biosfera. Una estrategia hacia el desarrollo sostenible de la isla. Aplicación de la Agenda Local 21 a Lanzarote, reserva de la biosfera. Programa Life de la Unión Europea. Documentos de trabajos: 1, 2, 4, 5, 6 y 7 [Coordinación AUIA]. Arrecife: Cabildo Insular de Lanzarote, 1998.

- (1998 b). Lanzarote. Reserva de la Biosfera. Resumen de la Memoria Informativa [Elaborado por Gracia Márquez, Mª.E.]. Lanzarote: Cabildo Insular de Lanzarote, 1998.

- (1999). Revisión del Plan Insular de Ordenación Territorial de Lanzarote. Documento de Aprobación Provisional. Arrecife: Cabildo Insular de Lanzarote, Octubre 1999.

- (2001). Anuario Estadístico de Lanzarote, 2001. Centro de datos. Lanzarote: Cabildo Insular de Lanzarote, 2001. Disponible en Web: http://www.datosdelanzarote.com

- (2002). Proyecto maretas. Lanzarote: Área de Educación y Cultura. Cabildo Insular de Lanzarote, 2002.

- (2004). Encuesta a usuarios de transporte interurbano. Centro de datos. Lanzarote: Cabildo Insular de Lanzarote, 2004. Disponible en Web:

http://www.datosdelanzarote.com

- (2006). Anuario Estadístico de Lanzarote, 2006. Centro de datos. Lanzarote: Cabildo Insular de Lanzarote, 2006. Disponible en Web: http://www.datosdelanzarote.com

- (2006). Plan Territorial Especial de Ordenación Turística de Lanzarote (PTE). Resumen. [Elaborado por AUIA]. [En línea]. Arrecife: Cabildo Insular de Lanzarote, 2006 [Ref. 17-06-2011]. Disponible en Web:

http://www.datosdelanzarote.com/Uploads/doc/20060509094942153RESUMENPTE.pdf

- (2007). Encuesta de Infraestructuras y equipamientos. Lanzarote, 2007. Centro de datos. Lanzarote: Cabildo Insular de Lanzarote, 2007. Disponible en Web: http://www.datosdelanzarote.com

- (2008) Plan Territorial Especial de Ordenación de las Infraestructuras Energéticas de Lanzarote (PTEOIE-LZ). Memoria Informativa, 2008 [en línea]. Arrecife: Cabildo 
Insular de Lanzarote, 2008 [Ref. de 15 de Noviembre de 2011]. Disponible en Web: http://www.datosdelanzarote.com/Uploads/doc/20080429155901908Completo.pdf

- (2009). Informe: Morir en Lanzarote. Datos de mortalidad y sus causas. Hábitos y equipamientos funerarios [en línea]. Centro de datos. Lanzarote: Cabildo Insular de Lanzarote, 2009. [Referencia 12 de enero de 2012]. Disponible en Web:

http://www.datosdelanzarote.com/itemDetalles.asp?idFamilia=6\&idltem=4394

CAIXA. Anuario Comercial de España, 1998. Barcelona: Caja de Ahorros y Pensiones de Barcelona, 1998.

- (2003). Anuario Económico de España, 2003. Barcelona: Caja de Ahorros y pensiones de Barcelona, 2003.

CÁCERES MORALES, E. Génesis y desarrollo del espacio turístico en Canarias. Una hipótesis de trabajo. Las Palmas: Gobierno de Canarias y ULPGC. 2002.

CALLIZO SONEIRO, J. Aproximación a la geografía del turismo. Madrid: Síntesis, 1991.

CALS, Joan (1986). Turismo y Territorio: los términos de una dialéctica. En Cursos Internacionales Benidorm. Ecología, economía y turismo en el Mediterráneo. Alicante: Universidad de Alicante y Ayuntamiento de Benidorm. (pp. 153-162).

CEDOC. Estadísticas básicas de Canarias. 1980-1985. Centro de Estadística y documentación de Canarias. Consejería de Economía y Comercio, 1986.

- (1986) Anuario estadístico de Canarias, 1986. Canarias: Centro de Estadística y Documentación de Canarias. Gobierno de Canarias, 1986.

C.E.S. Informe anual 2002 del CES sobre la situación, económica, social y laboral de Canarias durante el año 2001. [En línea]. Consejo Económico y Social de Canarias (CES), 2002. [Ref. 04 de marzo de 2011]. Disponible en Web:

http://www.cescanarias.org/?q=informes anuales

C.I.E.S. Plan de Ordenación Territorial de la Isla de Lanzarote. Boletín № 11. Las Palmas de Gran Canaria: Centro de Investigación Económico y Social de la Caja Insular de Ahorros de Canarias. Octubre, 1971.

- (1971). Economía Canaria, 1969 y 1970. Boletín n 10. Las Palmas de Gran Canaria. Centro de Investigación Económico y Social de la Caja Insular de Ahorros de Canarias. Agosto, 1971.

CHIB, S. N. Tourism and the Third World. Third World, Q. 11. 1980 (p. 283-294). 
CLEVERDON, R. The economic and Social Impact of International Tourism on Developing Countries. London: Economist Intelligence Unit. Ltd. 1979

COHEN, E. Towards sociology of international tourism. In Social Research $n^{\circ}$ 39, 1972 (p. 164-182).

COMITÉ de expertos sobre Población e Inmigración en Canarias. Población e inmigración en Canarias. Conclusiones y propuestas. [En líneas]. Las Palmas: Gobierno de Canarias, 2003. 42 p. [ref. de 25 de enero de 2012]. Disponible en Web:

http://www.datosdelanzarote.com/itemDetalles.asp?idFamilia=6\&idltem=510

CONSEJERÍA DE EDUCACIÓN, CULTURA Y DEPORTES. Plan Sur: Acción Lanzarote. [En línea]. Arrecife: Consejería de Educación, Cultura y Deportes. Gobierno de Canarias, 2001. [Referencia 07 de febrero de 2008] Disponible en Web:

http://www.datosdelanzarote.com/Uploads/doc/20060414122824251LanzaroteFINAL.pdf

CONSEJERÍA DE TURISMO Y TRANSPORTE. ELITUR: plan de excelencia y liderazgo del sector turístico de Canarias. Consejería de Turismo y Transporte Gobierno de Canarias, 2003. Disponible en Web:

http://www.datosdelanzarote.com/itemDetalles.asp?idFamilia=30\&idltem=3390

CONSEJERÍA DE INFRAESTRUCTURA, TRANSPORTE Y VIVIENDA. Plan Estratégico de Transporte de Canarias. Lanzarote (PETCAN), 2006. [En línea]. Las Palmas: Consejería de Infraestructura, Transporte y Vivienda. Gobierno de Canarias, 2006 (p. 104-134). [Referencia 20 de noviembre de 2011]. Disponible en Web:

http://www.datosdelanzarote.com/Uploads/doc/Plan-de-Transportes-de-Canarias.Lanzarote-20111007133801176PETLanzarote.pdf

CONSEJERÍA DE ECONOMÍA Y HACIENDA Y EMPLEO Y ASUNTOS SOCIALES. Medidas de acción social para paliar los efectos de la inmigración en la isla de Lanzarote. 2005-2007. Consejería de Economía y Hacienda y Empleo y Asuntos sociales. Cabildo Insular de Lanzarote y Gobierno de Canarias, 2006.

$\underline{\text { http://www.datosdelanzarote.com/itemDetalles.asp?idFamilia=6\&idltem=3020 }}$

CONSEJO INSULAR DE AGUAS DE LANZAROTE. Plan hidrológico Insular de Lanzarote, 2000. Memoria. Cabildo Insular de Lanzarote. B.O.C. № 138. Lunes 22 de Octubre de 2001 (pp. 15917-16007). 
CRICK, M. Representations of international tourism in the social sciences: sun, sex, sights, savings and servility. En Review Annual Anthropology, Vol. 18, 1989 (p. 307-344). Disponible en web.

http://www.annualreviews.org/doi/abs/10.1146/annurev.an.18.100189.001515

CROMPTON, J. L. "Motivations for pleasure vacations". En Tourism Research. № 6. 1979 (p. 408-424).

DE LA TORRE, Oscar. El Turismo: fenómeno social. $1^{\text {a }}$ ed., $2^{\text {a }}$ reimpresión. México: Fondo de Cultura Económica, 1980. ISBN: 9681606469.

DELEGACIÓN INSULAR DE TURISMO de Lanzarote. Datos estadísticos de 1986. Consejería de Turismo y transporte. Gobierno de Canarias, 1986. Disponible en Web: http://www.datosdelanzarote.com/itemDetalles.asp?idFamilia=72\&idltem=728

DÍAZ ÁLVAREZ, J.R. Geografía del Turismo. Madrid: Síntesis. 1993.

DÍAZ FERIA, L.; MARTÍN ROSA, M.A.; LAIZ HERRERAS, N. Lanzarote 2001. Análisis de la evolución reciente de la edificación y el turismo. Arrecife: Cabildo Insular de Lanzarote, 2001.

DÍAZ MARTíNEZ, J.A. Tema 1. Sociología del Turismo. En: Sociología del Turismo. Cap. 1. $2^{\circ}$ Edición. Madrid: UNED, 2003, p.23-54.

DOMÍNGUEZ MOLINER. Derecho Administrativo General y Turístico. Madrid: Síntesis, 1991.

DOYAL, L y Gough, I. Una Teoría de las necesidades humanas. Colección Economía Crítica, No 7. Barcelona: ICARIA, FUHEM, D.L, 1994.

DUMAZEDIER, J. Sociologie empirique du loisir: critique el contrecritique de la civilisation du loisir. Paris: Du Seuil, 1974.

ESPANYA. (1992). Competencias en materia de Turismo. [Recopilador. Bayón Mariné, F.] Madrid: Ed. Síntesis, 1992. 300 p.

ESTEBAN, A. Análisis de la estructura de costes de INALSA. Síntesis. [En línea]. Abril de 2006. [Referencia 05 noviembre de 2011]. GEA21. En Centro de Datos del Cabildo Insular de Lanzarote. Disponible en Web:

http://www.datosdelanzarote.com/itemDetalles.asp?idFamilia=18\&idltem=2973

ESTEBAN NOGUERA, J. La ordenación urbanística: conceptos, herramientas y prácticas. $2^{\circ}$ ed. Barcelona: Electa. 2003. 
ESTEVAN, A. Informe sobre las carreteras de Lanzarote. Fundación Cesar Manrique. Lanzarote, 1998. Disponible en Web:

http://www.datosdelanzarote.com/itemDetalles.asp?idFamilia=34\&idltem=763

EXELTUR. IMPACTUR Canarias, 2006. Estudio del impacto económico del turismo sobre la economía y el empleo de las Islas Canarias. [En línea]. EXELTUR (Alianza para el excelencia turística) y Gobierno de Canarias, 2006. [Referencia de 6 de diciembre de 2009].

http://www.exceltur.org/excel01/contenido/portal/listawrap.aspx?nid=190

http://www.gobcan.es/opencms8/opencms/presidencia/turismo/downloads/Impactur/infor me Canarias 06.pdf

- (2009) IMPACTUR Canarias, 2009. Estudio del impacto económico del turismo sobre la economía y el empleo de las Islas Canarias. [En línea]. EXELTUR (Alianza para el excelencia turística) y Gobierno de Canarias, 2009. [Referencia 2 de diciembre de 2010].

http://www.exceltur.org/excel01/contenido/portal/listawrap.aspx?nid=190

http://www.datosdelanzarote.com/itemDetalles.asp?idFamilia=26\&idltem=3888

EXTRAMEDIA CONSULTORES La moratoria turística de Lanzarote. Aspectos sociales. [En línea]. Lanzarote: ExtraMedia Consultores, 1999. [Referencia 22 de enero de 2010]. Disponible en Web:

http://www.datosdelanzarote.com/itemDetalles.asp?idFamilia=26\&idltem=232

EZQUIAGA ARQUITECTURA, SOCIEDAD Y TERRITORIO, S.L. Plan Insular de Ordenación de Lanzarote (PIOL). Memoria Inicial, 2008. [En línea]. Arrecife: Cabildo Insular de Lanzarote, 2008. [Referencia 10 mayo de 2011]. Disponible en Web: http://www.datosdelanzarote.com/itemDetalles.asp?idFamilia=3\&idltem=3922

- (2010) Plan Insular de Ordenación de Lanzarote. Avance. [En línea] Arrecife: Cabildo de Lanzarote, 2010. [Referencia 02-07-2011] Disponible en Web: www.cabildodelanzarote.com.

FAJARDO SPÍNOLA, L. Informe jurídico sobre la posibilidad de limitar el acceso a la segunda residencia en Lanzarote. En Life Lanzarote, 2001-2004. [Dirección Prats, F. AUIA] Arrecife: Cabildo de Lanzarote y Caja Insular de Ahorros de Canarias, 2003.

FERNÁNDEZ FUSTER, L. Introducción a la teoría y técnica del turismo. Serie Textos 97. Madrid: Alianza Editorial, 1988. 
- (1991). Historia general del turismo de masas. Serie Textos 136. Madrid: Alianza Editorial, 1991.

FIGUEROLA PALOMO, M. Economía turística. Elementos de una Teoría económica del turismo y métodos para su análisis cuantitativo. Madrid: Impreso por IMNASA, 1979.

- (1985). Factores de influencia en la evolución turística: el crecimiento económico, la inflación y la relación de cambio. En: IV Jornadas de Estudios Económicos Canarios. El Turismo en Canarias. Las Palmas: Gobierno de Canarias. 1985, (p. 31-41).

FIKA, Ma.L.; RODRÍGUEZ, Ma . D.; GONZÁLEZ, R. [et al]. De la Residencia Sanitaria Nuestra Señora de los Volcanes al Hospital General de Lanzarote. En: XI Jornadas de Estudios sobre Fuerteventura y Lanzarote. Tomo II. [En línea]. Puerto del Rosario: Cabildo Insular de Lanzarote y Fuerteventura, 2004, p. 260-278. [Referencia 15 abril de 2010]. Disponible en Web:

http://www.memoriadelanzarote.com/detalle.php?Tema=39\&Temac=Sanidad\&Tpadre=\& Tpadrec=\&f=BIBLI\&ir=3959FORSTER, J. The sociological consequences of tourism. En: International Journal of Comparative Sociology. V. 5. [s.I.] [s.n.]. 1964, p. 217-227.

GARCÍA COTARELO, R. Crítica de la Teoría de sistemas. Madrid: Centro de Investigaciones Sociológicas, 1979

GARDE ROCA, J.A. Economía Global y Estado de Bienestar, de nuevo a examen. En: Políticas sociales y Estado de Bienestar en España. Informe 2003. Madrid: Fundación Hogar del Empleo, 2003, (pp. 13-43).

GAVIRIA, Mario. España a Go-Go. Turismo charter y neocolonialismo del espacio. Madrid: Turner, 1974.

- (1976). Ecologismo y Ordenación del Territorio en España. Madrid: Cuadernos para el diálogo, 1976.

GONZÁLEZ MORALES, A. "Fuerza de Trabajo y Turismo en Lanzarote y Fuerteventura”. En IV Jornadas de Lanzarote y Fuerteventura. Cabildo Insular de Lanzarote y Cabildo Insular de Fuerteventura. Arrecife, 1995 (p. 321-359). ISBN: 84-87021-21-2.

- (1999). La evolución reciente de la Población de Lanzarote y Fuerteventura (18571996). En VIII Jornadas de Lanzarote y Fuerteventura. Arrecife: Cabildo Insular de Lanzarote y Cabildo Insular de Fuerteventura, 1999 (p. 461-484). ISBN: 84-8702146-8. Disponible en Web:

http://www.memoriadelanzarote.com/detalle.php?Tema=\&Temac=\&Tpadre=\&Tpadre $\mathrm{c}=\& \mathrm{f}=\mathrm{BIBLI} \& \mathrm{ir}=932$ 
- (2001). La inmigración reciente en Fuerteventura y Lanzarote. Algo más que pateras. En IX Jornadas de Lanzarote y Fuerteventura. Puerto del Rosario: Cabildo Insular de Lanzarote y Cabildo Insular de Fuerteventura, 2001 (p. 535-541). ISBN: 84-8746181-6. Disponible en Web:

http://www.memoriadelanzarote.com/detalle.php?Tema=\&Temac=\&Tpadre=\&Tpadre $\underline{\mathrm{c}=\& \mathrm{f}=\mathrm{BIBLI} \& \mathrm{ir}=1003}$

- (2006). Urbanismo y crecimiento turístico en Lanzarote durante la segunda mitad del siglo XX. [En línea]. En Rev. Papeles de Geografía, núm. 44, 2006, p. 39-57. [Referencia 6 de diciembre de 2009]. Disponible en Web:

$\underline{\text { http://redalyc.uaemex.mx/src/inicio/ArtPdfRed.jsp?iCve }=40704403}$

GONZÁLEZ MORALES, A., COUCEIRO, A., [et al.]. Evolución del Transporte y la infraestructura viaria en la isla de Lanzarote. En IV Jornadas de Lanzarote y Fuerteventura. Tomo II. Arrecife: Cabildo Insular de Lanzarote y Cabildo Insular de Fuerteventura., 1995 (p. 13-50). Disponible en Web:

http://www.memoriadelanzarote.com/detalle.php?Tema=31\&Temac=Transportes\&Tpadr $\underline{\mathrm{e}=\& \text { Tpadrec }=\& \mathrm{f}=\mathrm{BIBLI} \& \mathrm{ir}=3635}$

GONZÁLEZ MORALES, A. y HERNÁNDEZ LUIS, J.A. El desarrollo del turismo en Lanzarote. Tomo I y II. Las Palmas de Gran Canaria: Ediciones Idea, 2005. 620p.

GONZÁLEZ MORALES, A. y RODRÍGUEZ GONZÁLEZ, C. La industrialización en la isla de Lanzarote: Aproximación al modelo de transición económica. En VI Jornadas de Lanzarote y Fuerteventura. Arrecife, 1995 (p. 271-288). Disponible en Web:

http://www.memoriadelanzarote.com/detalle.php?Tema $=\&$ Temac $=\&$ Tpadre $=\&$ Tpadrec $=\&$ $\underline{\mathrm{f}=\mathrm{BIBLI} \& \mathrm{ir}=759}$

GONZÁLEZ, A., y RODRÍGUEZ, C. La industrialización en la isla de Lanzarote: aproximación al modelo de transición económica. En VI Jornadas de Lanzarote y Fuerteventura. Cabildo Insular de Lanzarote y Cabildo Insular de Fuerteventura. Arrecife, 1995 (p. 271-286). Disponible en Web:

http://www.memoriadelanzarote.com/detalle.php?Tema $=\&$ Temac $=\&$ Tpadre $=\&$ Tpadrec $=\&$ $\underline{\mathrm{f}=\mathrm{BIBLI} \& \mathrm{ir}=759}$

GONZÁLEZ, M. J. y MENDOZA, I. ¿A dónde va el sector público? Del Estado de Bienestar al bienestar con menos Estado. Madrid: Informes del Instituto de Estudios y Análisis Económicos. Secretaría de Estado de Economía. 1994. 
GONZÁLEZ VIEITEZ, A. La inmigración reciente en Fuerteventura y Lanzarote. En IX Jornadas de Lanzarote y Fuerteventura. Puerto del Rosario: Cabildo Insular de Lanzarote y Cabildo Insular de Fuerteventura., 2001 (p. 543-554). Disponible en Web:

http://www.memoriadelanzarote.com/detalle.php?Tema=\&Temac=\&Tpadre $=\&$ Tpadrec $=\&$ $\underline{\mathrm{f}=\mathrm{BIBLI} \& \mathrm{ir}=997}$

GREENWOOD, D. J. Tourism as an agent of change: a Spanish Basque case. Ethnology, 1972, n.11 (p. 80-81).

- (1992) La cultura al peso: perspectiva antropológica del turismo en tanto proceso de mercantilización cultural. En Anfitriones e invitados: antropología del turismo. (Cap. 8). Serie: Turismo y Sociedad. Madrid: Endymion, 1992 (p. 257-279). 481 p.

HARRIS, D. La justificación del Estado de Bienestar. Madrid: Instituto de Estudios Fiscales. Ministerio de Economía y Hacienda, 1990.

HEIBERG, T. y HOEIVIK, T. Centre-periphery tourism and self-reliance. International Social Science Journal 32 (1), 1980 (p. 69-98).

HERNÁNDEZ DÍAZ, E. A. Planificación turística: un enfoque metodológico. México: Trillas, 1991

HERNÁNDEZ LUIS, J. A. Tendencias de la movilidad terrestre en la isla de Lanzarote (19912001). En XII Jornadas de Estudios sobre Lanzarote y Fuerteventura. Tomo III, Vol. 2. (p. 156-178). [En línea] Arrecife: Cabildo Insular de Lanzarote y de Fuerteventura, 2008. [Referencia 05 de Septiembre de 2009]. Disponible en Web:

http://www.memoriadelanzarote.com/detalle.php?Tema=31\&Temac=Transportes\&Tpadr $\underline{e=\& \text { Tpadrec }=\& f=B \mid B L I \& i r=3005}$

HERNÁNDEZ, S.; GINÉS, C.; y SÁNCHEZ, C. Territorio, recursos turísticos y capacidad de carga. Interpretación teórica del caso de la isla de Lanzarote. En Revista Vegueta 9. Las Palmas: ULPGC, 2006 (p. 193-218).

HERRERA Y ESTEBAN, L. Capítulo 3. La expansión. 1962-1972. En "50 años del Turismo Español. Un análisis histórico y estructural”. Madrid: Centro de Estudios Ramón Areces, S.A, 1999 (p. 71-104).

HIRSCH, F. Los límites sociales al crecimiento. Colección Popular 238. México: Fondo de Cultura Económica, 1985.

ICEC. Bases para la realización de un proyecto sobre inmigración, escolarización y educación multicultural en Canarias. [En línea]. Las Palmas: Instituto Canario de 
Evaluación y Calidad Educativa. Consejería de Educación, Cultura y Deportes. Gobierno de Canarias, 2003. [Referencia 30 de Enero de 2011]. Disponible en Web:

http://www.datosdelanzarote.com/itemDetalles.asp?idFamilia=71\&idltem=2566

- (2009). Indicadores Prioritarios de la Educación en Canarias. Edición de 2009. [En línea]. Las Palmas: Instituto Canario de Evaluación y Calidad Educativa, Consejería de Educación, Universidades, Cultura y Deporte. Gobierno de Canarias, 2009. Colección: Evaluación e Investigación educativa. [Referencia 30 de Enero de 2011]. Disponible en Web:

http://www.gobiernodecanarias.org/educacion/Portal/WeblCEC/scripts/default.asp?W $=1 \& \mathrm{P}=1 \& \mathrm{~S}=22$

IET. Estadísticas de Turismo. 1969-1991. Madrid: Instituto de Estudios Turístico. Ministerio de Transporte, Turismo y Comunicaciones. Gobierno de España., 1991.

- (1993). Anuario Estadísticos, 1993. Madrid: Ministerio de Industria, Comercio y Turismo.: Gobierno de España., 1993.

- (1997). Turismo en Cifras, 1996. Madrid: Ministerio de Ministerio de Comercio y Turismo. Gobierno de España, 1997.

- (2001). Turismo en Cifras, 2000. Madrid: Ministerio de Economía y Hacienda. Gobierno de España, 2001.

- (2004). 25 años de turismo español en cifras. 1978-2003. [en línea]. Madrid: Ministerio de Economía. Gobierno de España, 2004. [Referencia 6 de mayo de 2007] Disponible en Web:

http://www.iet.tourspain.es/es-

es/documentacionturistica/otraspublicaciones/otras/paginas/elturismoespanolencifras aspx

- (2007). El turismo español en cifras, 2007. [En línea]. Madrid: Ministerio de Industria, Turismo y Comercio. Gobierno de España, 2009. [Referencia 20 de febrero de 2010]. Disponible en Web:

http://www.iet.tourspain.es/eses/documentacionturistica/otraspublicaciones/otras/paginas/elturismoespanolencifras aspx

- (2009). Balance de resultados de demanda turística internacional 2004-2007 desde la óptica de los mercados emisores. [En línea]. Madrid: Ministerio de Industria, Turismo 
y Comercio. Gobierno de España, 2009. [Referencia 3 de febrero de 2010]. Disponible en Web:

http://www.iet.tourspain.es/es-ES/Documents/Balance2004-2007.pdf

INALSA. Memoria Anual, 1994. Arrecife: Insular de Aguas de Lanzarote, S.A. (INALSA), 1995.

- (1996). Producción de agua en plantas potabilizadoras de Lanzarote, 1996. Arrecife: Insular de Aguas de Lanzarote, S.A. (INALSA), 1996. Disponible en Web:

http://www.datosdelanzarote.com/itemDetalles.asp?idFamilia=22\&idltem=2874

- (1996). Consumo de agua de Lanzarote según tipo, 1996. Arrecife: Insular de Aguas de Lanzarote, S.A. (INALSA), 1996. Disponible en Web:

http://www.datosdelanzarote.com/itemDetalles.asp?idFamilia=22\&idltem=2876

- (2001). Producción de agua en plantas potabilizadoras de Lanzarote, 2001. Arrecife: Insular de Aguas de Lanzarote, S.A. (INALSA), 2001. Disponible en Web:

http://www.datosdelanzarote.com/itemDetalles.asp?idFamilia=22\&idltem=2108

- (2001). Consumo de agua de Lanzarote según municipio, 2001. Arrecife: Insular de Aguas de Lanzarote, S.A. (INALSA), 2001. Disponible en Web:

http://www.datosdelanzarote.com/itemDetalles.asp?idFamilia=22\&idltem=2100

- (2006). Producción de agua en plantas potabilizadoras de Lanzarote, 2006. Arrecife: Insular de Aguas de Lanzarote, S.A. (INALSA), 2006. Disponible en Web:

http://www.datosdelanzarote.com/itemDetalles.asp?idFamilia=22\&idltem=3365

- (2006). Consumo de agua de Lanzarote según tipo, 2006. Arrecife: Insular de Aguas de Lanzarote, S.A. (INALSA), 2006. Disponible en Web:

http://www.datosdelanzarote.com/itemDetalles.asp?idFamilia=22\&idltem=3369

- (2008). Plan de Viabilidad y Modernización de INALSA. 2008-2012 [en línea]. Arrecife: Insular de Aguas de Lanzarote, S.A. (INALSA), 2008 [Ref. de 3 de marzo de 2012]. Disponible en Web:

http://www.datosdelanzarote.com/Uploads/doc/20080424170059194Plan Inalsa 200 $\underline{\text { 8.pdf }}$ 
- (2008). Ordenanza municipal marco para la gestión y uso eficiente del agua. Arrecife: Insular de Aguas de Lanzarote, S.A. (INALSA). Consorcio Insular de Aguas de Lanzarote, 2008. 28p. Disponible en Web:

http://www.datosdelanzarote.com/itemDetalles.asp?idFamilia=22\&idltem=4617

INSTITUTO ESPAÑOL DE TURISMO. IV Jornadas de Estudios Económicos Canarios. El turismo en Canarias. Instituto de Desarrollo Regional. Universidad de La Laguna. Madrid: Instituto Español de Turismo. 1985.

INE. Censo de Población y Viviendas de Canarias, 1970. Madrid: Instituto Nacional de Estadística. Gobierno de España, 1991. Disponible en Web: http://www.ine.es

- (1971). Anuario estadístico de España, 1971. Madrid: Instituto Nacional de Estadística. Gobierno de España, 1971. Disponible en Web:

http://www.ine.es/prodyser/pubweb/anuarios mnu.htm

- (1976). Anuario estadístico de España, 1976. Madrid: Instituto Nacional de Estadística. Gobierno de España, 1976. [En línea]. Disponible en Web:

http://www.ine.es/prodyser/pubweb/anuarios mnu.htm

- (1978). Anuario estadístico de España, 1978. Madrid: Instituto Nacional de Estadística. Gobierno de España, 1978 [en línea]. Disponible en Web:

http://www.ine.es/prodyser/pubweb/anuarios mnu.htm

- (1981). Medida del bienestar social. Programa de la OCDE de elaboración de los indicadores sociales. Anexo I. Madrid: Instituto Nacional de Estadística. Gobierno de España, 1981 (pp. 251-258). http://www.ine.es

- (1981). Censo de Población y Viviendas de Canarias, 1981. Madrid: Instituto Nacional de Estadística. Gobierno de España, 1981. Disponible en Web: http://www.ine.es

- (1982). Anuario estadístico de España, 1982. Madrid: Instituto Nacional de Estadística. Gobierno de España, 1982. Disponible en Web:

http://www.ine.es/prodyser/pubweb/anuarios mnu.htm

- (1985). Anuario estadístico de España, 1985. Madrid: Instituto Nacional de Estadística. Gobierno de España, 1985. Disponible en Web:

http://www.ine.es/prodyser/pubweb/anuarios mnu.htm 
- (1987). Anuario estadístico de España, 1987. Madrid: Instituto Nacional de Estadística. Gobierno de España, 1987. Disponible en Web:

http://www.ine.es/prodyser/pubweb/anuarios mnu.htm

- (1991). Censo de Población y Viviendas de Canarias, 1991. Madrid: Instituto Nacional de Estadística. Gobierno de España, 1991. Disponible en Web: http://www.ine.es

- (1992). Anuario estadístico de España, 1992. Madrid: Instituto Nacional de Estadística. Gobierno de España, 1992. Disponible en Web:

http://www.ine.es/prodyser/pubweb/anuarios mnu.htm

- (1996). Encuesta sobre suministro y tratamiento del agua, 1996. [En línea]. Madrid: Instituto Nacional de Estadística. Gobierno de España, 1996. [Referencia 30 de junio de 2010] Disponible en Web:

http://www.ine.es/jaxi/menu.do?type=pcaxis\&file=pcaxis\&path=\%2Ft26\%2Fp067\%2F p01\%2F\%2Fa1996-1999

- (1997). Anuario estadístico de España, 1997. Madrid: Instituto Nacional de Estadística. Gobierno de España, 1997. Disponible en Web:

http://www.ine.es/prodyser/pubweb/anuarios mnu.htm

- (1997). Contabilidad Regional de España. Base 1986. Serie 1986-1996. Madrid: Instituto Nacional de Estadística. Gobierno de España, 2001. Disponible en Web:

http://www.ine.es/jaxi/menu.do?type=pcaxis\&path=/t35/p010/a1996\&file=pcaxis

- (2001) Censo de Población y Viviendas de Canarias, 2001. Madrid: Gobierno de España, 2001. Disponible en Web: http://www.ine.es

- (2001). Encuesta sobre suministro y tratamiento del agua, 2001. [En línea]. Madrid: Instituto Nacional de Estadística. Gobierno de España, 2001. [Referencia 30 de junio de 2010] Disponible en Web:

http://www.ine.es/jaxi/menu.do?type=pcaxis\&file=pcaxis \&path=\%2Ft26\%2Fp067\%2F p01\%2F\%2Fa2001

- (2004) Cuenta Satélite del Turismo. Metodología. Instituto Nacional de Estadística [en línea] Madrid: Gobierno de España, 2004. Disponible en Web:

http://www.ine.es/jaxi/menu.do?type=pcaxis\&path=\%2Ft35\%2Fp011\&file=inebase \&L $=0$ 
- (2006). Encuesta sobre suministro y tratamiento del agua, 2006. [En línea]. Madrid: Instituto Nacional de Estadística. Gobierno de España, 2006. [Referencia 30 de junio de 2010]. Disponible en Web:

http://www.ine.es/jaxi/menu.do?type=pcaxis\&file=pcaxis\&path=\%2Ft26\%2Fp067\%2F p01\%2F\%2Fa2006

- (2010). Contabilidad Regional de España. Serie homogénea 1995-2009. Madrid: Instituto Nacional de Estadística. Gobierno de España, 2001. Disponible en Web:

http://www.ine.es/jaxi/menu.do?type=pcaxis\&path=/t35/p010/homoge\&file=pcaxis

- (2010). Contabilidad Nacional de España. Serie homogénea 1995-2009. Madrid: Instituto Nacional de Estadística. Gobierno de España, 2001. Disponible en Web: http://www.ine.es/daco/daco42/cne00/pib9508.xls\#Tabla 1!A1

ISTAC. Canarias en cifras, 1987. Las Palmas: Instituto Canario de Estadística, Gobierno de Canarias, 1987.

- (1991). Estadísticas insulares y municipales, 1991. Las Palmas: Instituto Canario de Estadística, Gobierno de Canarias, 1991.

- (1993). Estadísticas Básicas de Canarias, 1987-1992. Las Palmas: Instituto Canario de Estadística. Gobierno de Canarias, 1993.

- (1996 a). Encuesta de Población de Canarias, 1996. Las Palmas: Instituto Canario de Estadística, Gobierno de Canarias, 1996. Disponible en Web:

http://www2.gobiernodecanarias.org/istac/index.jsp

- (1996 b). Encuesta de Población de Canarias, 1996. Población Extranjera. Comunidad Autónoma, Islas y Municipios. Instituto Canario de Estadística (ISTAC) [en línea]. Las Palmas: Gobierno de Canarias, 1999. [Referencia 2 de febrero de 2009]. Disponible en Web:

http://www.datosdelanzarote.com/Uploads/doc/2005122521131434EncPob96Extranj eros.pdf

- (2000) Anuario Estadístico de Canarias, 1999. Las Palmas: Instituto Canario de Estadística, Gobierno de Canarias, 2000. Disponible en Web:

http://www.gobiernodecanarias.org/opencms8/export/sites/istac/galerias/documentos/ C00052A/Anuario 1999.pdf 
- (2001). Anuario Estadístico de Canarias, 2001. Las Palmas: Instituto Canario de Estadística, 2002. Disponible en Web:

http://www.gobiernodecanarias.org/opencms8/export/sites/istac/galerias/documentos/ C00052A/Anuario 2000.pdf

- (2002). Anuario Estadístico de Canarias, 2002. Las Palmas: Instituto Canario de Estadística Gobierno de Canarias. Disponible en Web:

http://www2.gobiernodecanarias.org/istac/index.jsp

- (2006). Estadística de empleo registrado. Resultados trimestrales. 2001 y 2006. Las palmas: Instituto Canario de Estadística Gobierno de Canarias. Disponible en Web:

http://www2.gobiernodecanarias.org/istac/jaxiweb/menu.do?path=/05011/C00040A/P0001\&file=pcaxis\&type $=$ pcaxis \&L=0

- (2008). Anuario Estadístico de Canarias, 2008. Las Palmas: Instituto Canario de Estadística Gobierno de Canarias. Disponible en Web:

http://www2.gobiernodecanarias.org/istac/index.jsp

ISTAC e IET. FRONTUR Canarias, 1996, 2001 y 2006. Las Palmas: Instituto Canario de Estadística e Instituto de Estudios Turísticos. Gobierno de Canarias y Gobierno de España. Disponible en Web:

http://www2.gobiernodecanarias.org/istac/jaxiweb/menu.do?path=/08021/E16028B/P0001\&file=pcaxis\&type=pcaxis\&L=0

JOHNSON, NORMAN. El Estado de Bienestar en Transición: la teoría y práctica del pluralismo de bienestar. Informes. Madrid: Ministerio de Trabajo y Seguridad Social, 1990. ISBN: 84-7434-637-1.

JURDAO ARRONES, F. España en venta. Madrid: Endymion, 1990. Serie Turismo y Sociedad. 500 p. ISBN: 84-7731-064-5

- (1992). Los mitos del Turismo. Madrid: Endymion, 1992. Serie Turismo y Sociedad 403 p. ISBN: 84-7731-132-3

KADT, Emanuel de. Turismo, pasaporte al desarrollo: perspectivas sobre los efectos sociales y culturales del turismo en los países en vías de desarrollo. [Traducción de Lisón Arcal, José C.]. Madrid: Endymion, 1991. Colección Turismo y Sociedad. 495 p. ISBN: 84-7731-107-2 
KNEBEL, Hans-Joachin (1973). Sociología del Turismo: cambios estructurales en el turismo moderno (Traducción de Núñez Espallargas, J. Mª). Barcelona: Hispano Europea, 1973. Colección Biblioteca de Ciencias Sociales. 201 p. ISBN: 84-2550-346-9

LE CORBUSIER. Principios de Urbanismo: la carta de Atenas. $5^{\mathrm{a}}$ Ed. Barcelona: Ariel, S.A. 1989. 151 p. ISBN 84-344-0705-1.

LIEW, J. Tourism and development. A re-examination. En Tourism in the South Pacific. The contribution of Research to Development and Planning: proceedings of UNESCO. Editado por Pearce, D.G.; Christchurch: Dept. Geography, Univ. de Canterbury, for New Zealand National Commission for UNESCO, 1980 (p. 13-17). Serie New Zealand man and the biosphere report, $\mathrm{n}^{\circ}$. 6. $181 \mathrm{p}$.

LILIENFELD, R. Teoría de Sistemas. Orígenes y Aplicaciones en Ciencias Sociales. (Traducción de Cosacov, E.). México: Trillas. 1984. Colección Biblioteca sistemática educativa. $342 \mathrm{p}$.

LÓPEZ DE SEBASTIÁN, J. Economía de los espacios del ocio. Madrid: Instituto de Estudios de Administración local, 1975. Colección Nuevo Urbanismo, № 14. 303 p.

LUHMANN, Niklas. (1981). Teoría política en el Estado de Bienestar. [Traducción Vallespín, F.]. Madrid: Alianza Editorial, 1993. Edición en castellano. 170 p.

MACCANNELL, D. El turista: una nueva teoría de la clase ociosa. [Traducción de Casals, E.] Barcelona: Melusina, 2003. 291 p.; Original: The Tourist. A new theory of the Leisure Class. New York: Schocken Books, 1976.

MARÍN, Cipriano y MENDARO, Ceferino. Turismo y Desarrollo Sostenible. El desafío ante el s. XXI. Los casos de Lanzarote, Menorca y Sierra de las Nieves. Santa Cruz de Tenerife. Comité Español del Programa MAB.1996.

MARRERO, J.R.; Hernández, R.; León, J.S.; Santana, M.A. La situación del empleo en el sector turístico de Lanzarote. [En línea]. Lanzarote: Cabildo Insular de Lanzarote y Universidad de la Laguna, 2007. [Referencia 10 de mayo de 2011]. Disponible en Web:

http://www.datosdelanzarote.com/itemDetalles.asp?idFamilia=16\&idltem=3709

MARTÍN MUÑOZ, G. (1999). "La inmigración reciente en Fuerteventura y Lanzarote”. IX Jornadas de Lanzarote y Fuerteventura. Puerto del Rosario, 2001 (pp. 555-571).

MARTíN RUIZ, J.F. (1982). Dinámica y estructura de la población de las Canarias Orientales (s. XIX y XX). Tomo I. Excma. Mancomunidad de Cabildos de Las Palmas y Excmo. Cabildo Insular de Gran Canaria. Madrid, 1985. 
MARTÍNEZ QUINTANA, V. (2002). Historia del Turismo. En Sociología del Turismo (Tema 2). UNED, $2^{\circ}$ edición, Madrid, 2003 (pp. 57-111).

MATHIESON, A. y Wall, G. Tourism: Economic, Physical and Social Impacts. Longman Group Limited, 1986. Versión en español: "Turismo: repercusiones sociales, económicas y físicas”. México: Editorial Trillas, 1990. 278 p. ISBN: 9682436133.

MAZÓN, T. Sociología del Turismo. Madrid: Centro de Estudios Ramón Areces, D.L., 2001. Colección Estudios Turísticos. 300 p. ISBN: 84-80044713

MACINTOSH, R. Turismo, Planeación, Administración y Perspectivas. México: Limusa, 1993. 406 p. ISBN: 96-8181620-X

MILLER, D. Social Justice and principle of need. En The Frontiers of Political Theory. Brighton: eds. M. Freeman y D. Robertson, Harvester press, 1980.

MINISTERIO DE FOMENTO. Anuario Estadístico del Ministerio de Fomento, 1970. Madrid: Gobierno de España, 1971

- (1976) Anuario Estadístico del Ministerio de Fomento, 1975. Madrid: Gobierno de España, 1982

- (1982) Anuario Estadístico del Ministerio de Fomento, 1981. Madrid: Gobierno de España, 1982

- (1987) Anuario Estadístico del Ministerio de Fomento, 1986. Madrid: Gobierno de España.

- (2009) Anuario Estadístico del Ministerio de Fomento, 2008. [En línea] Madrid: Gobierno de España. Disponible en Web:

http://www.fomento.gob.es/NR/rdonlyres/39931BC3-5EB5-48BC-8F98A04F442037C3/110318/anuar2008.pdf

MINISTERIO DE INFORMACIÓN Y TURISMO. Guía oficial de Hoteles. 1970. Madrid: Gobierno de España, 1970.

MINISTERIO DE INDUSTRIA, TURISMO Y COMERCIO. Plan Insular de Ordenación de la Oferta Urbanística de la isla de Lanzarote. Madrid: Secretaría de Estado de Turismo. Gobierno de España, Junio 1982. [Disponible en CD-Rom en el Centro de Datos del Cabildo Insular de Lanzarote]. Documentos:

- Tomo I. Objetivos y definición del producto turístico.

- Tomo II. Información y análisis.

- Tomo III. Información y análisis. 
- Anexo Mapas.

- (1996) Estadística de la industria de energía eléctrica, 1996. [En línea] Ministerio de Industria, Turismo y Comercio. Gobierno de España, 1996. [Referencia 14 de Noviembre de 2010]. Disponible en Web:

http://www.minetur.gob.es/energia/balances/Publicaciones/ElectricasAnuales/Pagina s/ElectricasAnuales.aspx

- (2001) Estadística de la industria de energía eléctrica, 2001. [En línea] Ministerio de Industria, Turismo y Comercio. Gobierno de España, 2001. [Referencia 14 de noviembre de 2010]. Disponible en Web:

http://www.minetur.gob.es/energia/balances/Publicaciones/ElectricasAnuales/Pagina s/ElectricasAnuales.aspx

- (2006) Estadística de la industria de energía eléctrica, 2006. [En línea] Ministerio de Industria, Turismo y Comercio. Gobierno de España, 2006. [Referencia 14 de noviembre de 2010]. Disponible en Web:

http://www.minetur.gob.es/energia/balances/Publicaciones/ElectricasAnuales/Pagina s/ElectricasAnuales.aspx

- (2011) Plan FuturE 2011. [En línea]. Madrid: Ministerio de Industria, Turismo y Comercio. Gobierno de España, 2011. [Referencia 20 de mayo de 2011]. Disponible en Web:

http://www.mityc.es/turismo/es-ES/Paginas/FuturE2011.aspx.

MINISTERIO DE TRABAJO Y SEGURIDAD SOCIAL. Estadísticas laborales. Movimiento laboral registrado. 1996, 2001 y 2006. [En INE] Ministerio de Trabajo y Seguridad Social. Gobierno de España. 1996, 2001 y 2006. Disponible en Web:

http://www.ine.es/jaxi/menu.do?type=pcaxis \&path=/t22/a061\&file=inebase \&N=\&L= http://www.empleo.gob.es/es/estadisticas/mercado trabajo/MLR/welcome.htm

MATOSO MELIÁN, E. Apuntes de un nuevo fenómeno: la agricultura a tiempo parcial en la isla de Lanzarote. En VI Jornadas de Estudios sobre Lanzarote y Fuerteventura. Arrecife: Cabildo Insular de Lanzarote y Cabildo Insular de Fuerteventura, 1995 (p. 255270). Disponible en Web:

http://www.memoriadelanzarote.com/detalle.php?Tema $=\&$ Temac $=\&$ Tpadre $=\&$ Tpadrec $=\&$ $\underline{\mathrm{f}=\mathrm{BIBLI} \& \mathrm{ir}=751}$ 
MIRA GONZÁLEZ, E. Turismo, arquitectura, espacio y sociedad. Entre la modernización y la crisis. Tomo I, II, XI Tesis Doctoral, Universidad de Alicante. Alicante, 1992.

MOIX MARTíNEZ, M. (1986). Bienestar Social. $2^{\circ}$ Edición. Madrid: Trivium, S.A., 1986.

MOLINA E., Sergio. Turismo y ecología. México: Trillas, 1986. 93 p.

MONTANER MONTEJANO, J. Estructura del mercado turístico. $2^{\circ}$ Edición. Madrid: Síntesis, 1996. Colección Gestión Turística. 397 p.

MONTIEL TORRES, Ana Ma $\mathrm{M}^{\mathrm{a}}$ et al]. Estadística para turismo. Madrid: McGraw-Hill, D.L., 2007. 290 p.

MORALES FIGUEROA, J.M. La Arquitectura del Ocio en la Costa del Sol. Málaga: Universidad de Málaga y Ayuntamiento de Marbella, 1982. 230 p.

MORALES MEJÍA, D., [et al]. Financiamiento turístico: fuentes internas y externas. México: Trillas, 1987. Colección Trillas Turismo. 153 p.

MOYA GONZÁLEZ, L. y CANDELA, Celestino. La práctica del Planeamiento Urbanístico. Madrid: Síntesis. 1994. Colección Espacios y Sociedades. Serie General, 1. 278 p.

MUÑOZ DE BUSTILLO, R. Crisis y futuro del Estado de Bienestar. Madrid: Alianza Editorial, 1989. Colección Alianza Universidad; 593. Economía. 272 p.

MUÑOZ DE ESCALONA, F. Un sector productivo: el sector turístico. En Revista Papeles de Turismo, N 3, 1990 (pp. 5-17).

MUSGRAVE, R. A. The theory of public finance. A study in public economy. New York: McGraw-Hill, 1959. 628 p.

NASH, D. (1992). "El Turismo considerado como una forma de Imperialismo"; En Smith, V. Anfitriones e Invitados: antropología del turismo. (Edición española). Capítulo 2. Serie Turismo y Sociedad. Madrid: Endymion, 1992. (pp. 69-91). 481 p.

NORONHA, R. (1979). "Social and Cultural Dimensions of tourism: a review of the Literature in English". World Bank Working Paper.

NúÑ̃ZZ, T. A. Los estudios del turismo dentro de una perspectiva antropológica. En Anfitriones e invitados: antropología del turismo. (Edición española).Capítulo 14. Serie: Turismo y Sociedad. Madrid: Endymion, (pp. 397-413). 481 p.

OBECAN Informe sobre migración laboral en Canarias. Análisis de la contratación, 2006. [En línea]. Las Palmas: Observatorio Canario del empleo y de la formación profesional 
Consejería de Industria, Empleo y Comercio. Gobierno de Canarias. [Referencia 02 de octubre de 2011]. Disponible en Web:

http://www2.gobiernodecanarias.org/empleo/funcatra/observatorio/

- (2006) Estadística de contratos registrados. 2001 y 2006. SPEE. [En línea]. Las Palmas: Consejería de Empleo, Industria y Comercio. Gobierno de Canarias [Ref. de 02 de octubre de 2011]. Disponible en Web:

http://www2.gobiernodecanarias.org/empleo/funcatra/observatorio/

- (2006) Estadística de paro registrado (demandantes). 2001 y 2006. SPEE. [En línea]. Las Palmas: Observatorio Canario del empleo y de la formación profesional e INEM. Consejería de Empleo, Industria y Comercio. Gobierno de Canarias [Ref. de 02 de octubre de 2011]. Disponible en Web:

\section{http://www2.gobiernodecanarias.org/empleo/funcatra/observatorio/}

OCDE Liste des préoccupations sociales communes à la plupart des pays de l'OCDE. París. OCDE, 1973.

OFFE, Clauss. Contradicciones en el Estado de Bienestar. (Versión española de Escohotado, A.). Madrid: Alianza Editorial, 1994 [Re-imp]. Colección Ciencias Sociales, 647. $309 \mathrm{p}$.

OLIVER SUÑER, G.; MOREY, J.; ROCA, J. Calviá. Estudio de unos fenómenos sociales y urbanísticos cuando el crecimiento económico se basa exclusivamente en el turismo. Barcelona: Publicaciones del Colegio Oficial de Arquitectos de Cataluña y Baleares. Editado por La Gaya Ciencia. 1973.

SANCHO, A. Introducción al Turismo. Madrid: O.M.T., 1998. Serie de la OMT en Educación Turística. $390 \mathrm{p}$.

OMT. Declaración de Manila sobre Turismo Mundial. Filipinas, 1980.

OPASCHOWSKI, H. W. "¿Turismo de masa o turismo a medida? Límites Económicos, Ecológicos y Psicológicos". En Papers de Turisme, $\mathrm{N}^{\circ}$ 4. Valencia: Unidad de Investigación y Desarrollo. Instituto Turístico de Valencia, 1990, (p. 68-80).

PERDOMO, M. A. "El modelo de desarrollo turístico en la Isla de Lanzarote: ¿Hacia una estética del turismo?". En I Jornadas de Lanzarote y Fuerteventura. Puerto del Rosario: Cabildo Insular de Lanzarote y Fuerteventura, 1987 (p. 432-443). Disponible en Web:

http://www.memoriadelanzarote.com/detalle.php?Tema=\&Temac $=\&$ Tpadre $=\&$ Tpadrec $=\&$ $\underline{\mathrm{f}=\mathrm{BIBLI} \& \mathrm{ir}=546}$ 
PEREA SORO, J. Mª. (1986). "Administración Pública y Planificación Turística”. En Cursos Internacionales Benidorm. "Ecología, economía y turismo en el Mediterráneo". Alicante: Universidad de Alicante y Ayuntamiento de Benidorm. (p.201-217). 218 p.

PERERA, D., PÉREZ, P. y SUÁREZ, P. "La distribución de la Población en la Isla de Lanzarote (1920-1996)". En IX Jornadas de Lanzarote y Fuerteventura. Puerto del Rosario: Cabildo Insular de Lanzarote y Fuerteventura, 2001 (pp. 341-371). Disponible en Web:

http://www.memoriadelanzarote.com/detalle.php?Tema $=\&$ Temac $=\&$ Tpadre $=\&$ Tpadrec $=\&$ $\underline{\mathrm{f}=\mathrm{BIBLI} \& \mathrm{ir}=1016}$

PIGOU, A.C. (1928). The economics of welfare; Versión en castellano (Traducida por Sánchez Ramón, F). La economía del bienestar. Madrid: Aguilar, S.A., 1946. Colección Biblioteca de Ciencias Económicas, políticas y sociales.

PECAN (Plan Energético de Canarias), 2002 [En línea]. Consejería de la Presidencia e Innovación Tecnológica. Gobierno de Canarias, Mayo 2003. [Referencia 04 de diciembre de 2010]. Disponible en Web:

http://www.datosdelanzarote.com/Uploads/doc/20060115100753398pecan 2002.pdf

PECAN (Plan Energético de Canarias), 2006 [en línea] Consejería de Industria, Comercio y Nuevas Tecnologías. Gobierno de Canarias, 2006. [Referencia 04 de diciembre de 2010]. Disponible en Web:

http://www.datosdelanzarote.com/Uploads/doc/Plan-energ\%C3\%A9tico-de-Canarias(PECAN)-2006--20120203134728558pecan.pdf

PLANT R.; LESSER, H.; TAYLOR, P. Political Philosophy and Social Welfare: essays on the normative basis of welfare provision. London: Routledge, 1980.

PRATS, F. Y MANCHÓN, F. Reflexiones sobre Turismo, Territorio y Sociedad desde el Plan Insular de Lanzarote. En Ciudad y Territorio, $N^{\circ} 77-3 / 1988$. Madrid: Instituto Nacional de Administración Pública. Julio-Septiembre 1988.

PRATS PALAZUELO, F. Territorio, Turismo y Desarrollo Sostenible: El caso de Lanzarote. Lanzarote: Excmo. Cabildo Insular de Lanzarote, 1995.

- (2003). Lanzarote: una isla con la capacidad de carga agotada, ante las directrices regionales de Canarias. En Actas Congreso: Urbanismo, para un desarrollo más sostenible. Equilibrio territorial. Hacia una utilización más responsable del territorio. Palma de Mallorca: noviembre 2003. 
PROD'HOMME, Jean-Pierre (1985). ¿Turismo Tentador, Turismo destructor? En IV Jornadas de Estudios Económicos Canarios. El Turismo en Canarias. Gobierno de Canarias y Ministerio de Transporte, Turismo y Comunicaciones. 1985 (pp. 21-29). Colección Viera y Clavijo V.

PUJADAS, R y FONT, J. Ordenación y Planificación Territorial. En Serie de Espacios y Sociedades, № 8. Madrid: Síntesis, 1998.

HARRIS, Ralph, (1989). Más allá del Estado de Bienestar. Madrid: Instituto de Estudios Económicos, 1989. Colección Punto de vista. 33 p.

RAMÍREZ TORRECABOTA, P. Análisis de los principales indicadores sobre la inmigración por municipios. Lanzarote. En Tebeo: Anuario del Archivo Histórico Insular de Fuerteventura, № 12 (pp. 315-354). Puerto del Rosario: Cabildo Insular de Fuerteventura, 1999.

RAMÓN FERNÁNDEZ, T. (2002). Política Territorial, Desarrollo Sostenible y Seguridad Jurídica. En Blanquer, D. Ordenación y gestión del territorio turístico. Capítulo I. Aproximación Interdisciplinar. Valencia. Tirant lo Blanch, 2002 Colección Ocio y Turismo, $N^{\circ} 2.950$ p.

RAZQUIN LIZARRAGA, M.M. Planificación turística y planificación territorial: la necesidad de una convergencia. En Blanquer Criado, D. Ordenación y gestión del territorio Turístico. Valencia: Tirant lo Blanch, 2002. (p. 111-151). Colección Ocio y Turismo, № 2. 950 p.

RODRIGO, J. Bases jurídicas para la regulación de la oferta de vehículos de alquiler sin conductor en Lanzarote [en línea]. En Life-Lanzarote 2001-2004. [Coordinación AUIA]. Arrecife: Cabildo de Lanzarote y Caja Insular de ahorros de Canarias, 2003. [Ref. 04 de abril de 2010]. Disponible en Web:

http://www.datosdelanzarote.com/Uploads/doc/20051219190022572des7.pdf

- (2004). Informe jurídico sobre la gestión sostenible de los flujos turísticos en puertos y aeropuertos: el caso del aeropuerto de Lanzarote. [En línea]. En Life Lanzarote 20012004. [Coordinación AUIA]. Arrecife: Cabildo de Lanzarote y Caja Insular de ahorros de Canarias, 2004. [Ref. 04 de abril de 2010]. Disponible en Web:

http://www.datosdelanzarote.com/Uploads/doc/20051219195031431des8.pdf

RODRÍGUEZ CABRERO, G. (2002). Tendencias del cambio en política social. En Rodríguez Cabrero, G.; Sotelsek Salem, D. Apuntes sobre Bienestar Social. Capítulo 1. Alcalá de Henares: Universidad de Alcalá de Henares, 2002 (p. 17-37). 380 p. 
RODRÍGUEZ MARTÍN, J.A. "El turismo en la economía canaria: delimitación e impacto económico". En IV Jornadas de Estudios Económicos Canarios. El Turismo en Canarias. Gobierno de Canarias y Ministerio de Transporte, Turismo y Comunicaciones. 1985 ( $p$. 241-268). Colección Viera y Clavijo V.

ROGER, G. "El urbanismo y la ordenación y gestión del territorio turístico". En Blanquer Criado, D. Ordenación y gestión del territorio Turístico. Valencia: Tirant lo Blanch, 2002, (p. 51-80). 950 p.

RUBIO GIL, A. [et al]. Sociología del Turismo. Barcelona: Ariel, 2003.

SÁNCHEZ DE MADARIAGA, I. Introducción al Urbanismo. Conceptos y métodos de planificación Urbana. Madrid: Alianza Editorial, 1999. 173 p.

SANTANA, A. (1997). Antropología y turismo, ¿Nuevas hordas, viejas culturas? Barcelona: Ariel, 1997. Colección Ariel Antropología, 1997. 220 p.

SECRETARÍA DE ESTADO DE TERRITORIO. Plan de Ordenación de la Oferta Turística de la Provincia de Las Palmas. Madrid: Estudio Siete [colaborador Marketur. Gobierno de España, 1978.

SERRANO RODRÍGUEZ, A. "Ordenación del territorio y medio ambiente. Conceptos básicos y bases epistemológicas. Tema 1". Apuntes académicos de Ordenación del Territorio. Valencia: UPV, 1986. [Nimeo].

- (2003) Introducción a la Ordenación del Territorio y el Medio Ambiente como condicionadotes del Urbanismo actual. Ponencia en el Curso de Introducción al Urbanismo del Colegio de Ing. de Caminos, Canales y Puertos. Madrid. Febrero de 2002. [Nimeo].

- (2011). ¿Es posible un turismo con empleo estable y realmente sostenible, territorial y medioambientalmente? [En línea]. En Revista Sistema digital, 12 de mayo de 2011. [Referencia 1 junio de 2011].

— (2012). Políticas de la Tierra. Balance y expectativas ante una sociedad en cambio.

SETIÉN, Ma . L. Indicadores sociales de calidad de vida. Un sistema de medición aplicado al País Vasco. Monografía №. 133. Madrid: Centro de Investigaciones Sociológicas (CIS), 1993.

SIMMEL, G.; WOLFF, Kurt H. The Sociology of George Simmel. Glencoe, III, The Free Press, 1950. 
SMITH, E.A. Teoría del Bienestar Social. [Ed. $1^{a}$ de 1965]. Buenos Aires: Humanitas, 1971 [edición en castellano].

SMITH, M. A., Turner, L. (1973). Some aspects of the sociology of tourism. En Sociología del ocio, n.5 (p. 55-71).

SMITH, V. Anfitriones e invitados: antropología del turismo. Serie: Turismo y Sociedad. Madrid: Endymion, 1992. 481 p.

SOSA ESPINOSA, A. Agricultura, paisaje rural y turismo. El caso de Lanzarote. En Cuadernos de Ordenación del Territorio, № 6. Tercera Época, 1999. Especial Monográfico Islas Canarias. Madrid: Asociación Interprofesional de Ordenación del Territorio (FUNDICOT), 1999 (p. 18-22).

- (2002). Los planes de ordenación del territorio como principio ordenador del desarrollo turístico. En Cuadernos de Ordenación del Territorio, № 3. Cuarta Época. Madrid: Asociación Interprofesional de Ordenación del Territorio (FUNDICOT), 2002 (. 2333).

- (2004). La adaptación social al turismo de masas y sus efectos. Una mirada desde la sociedad anfitriona. En $X$ Jornadas de estudios sobre Lanzarote y Fuerteventura. Tomo I. Arrecife: Cabildo Insular de Lanzarote y Fuerteventura, 2004 (p. 437-450)

TAYLOR-GOOBY, P. Social Change, Social Welfare and Social Science. Londres: Harvester, 1991.

TOMÁS CARPI, J. A. (1984). La teoría de sistemas y la realidad social: limitaciones y posibilidades de una perspectiva. Cuadernos de Trabajo, № 30 . Valencia: Universidad de Valencia. Facultad de CC. Económicas y Empresariales, 1984.

TORTOSA, J. M. Sociología del Sistema Mundial. Madrid: Tecnos, 1992.

TRAPERO, J.J. La práctica del planeamiento urbanístico en España. En La práctica del planeamiento urbanístico. Capítulo 1. Espacios y Sociedades, № 1. Madrid, 1994.

TRIBE, J. Economics of Leisure and Tourism". Reed Educational \& Professional Publishing Ltd. 1999. Edición en castellano: Economía del ocio y del turismo. [Ed. 2ª]. Madrid: Síntesis, 2000.

TROITIÑO VINUESA, M.A. Turismo y desarrollo sostenible en ciudades históricas. En Revista Ería, № 47. Universidad de Oviedo. 1998 (p. 221-227).

TURNER, L. y Ash, J. La horda dorada. El turismo internacional y la periferia del placer. [1 ${ }^{a}$ ed. 1975] Edición en Castellano. Madrid: Endymion. 1991 
UNIVERSIDAD DE ALICANTE. Ecología, economía y turismo en el Mediterráneo. Serie "Cursos Internacionales Benidorm". Edita Ayuntamiento de Benidorm. Alicante. 1986.

VASALLO TOMÉ, I. "Crisis y Consolidación. 1972-1982". Capítulo 4 de "50 años del Turismo Español. Un análisis histórico y estructural". Madrid: Centro de Estudios Ramón Areces, S.A., 1999 (p. 105-124).

VELASCO GONZÁLEZ, Ma ${ }^{a}$ La Política Turística. Gobierno y Administración en España (1952-2004). Valencia: Tirant lo Blanch., 2004.

VERA REBOLLO, J.F. y MARCHENA GÓMEZ, M, "Turismo y desarrollo: un planteamiento actual". Papers de Turisme, $\mathrm{N}^{0} 3$. Valencia: Unidad de Investigación y Desarrollo. Instituto Turístico de Valencia, 1990 (p. 59-83).

VERA REBOLLO, J.F. Análisis territorial del Turismo. Barcelona: Ariel Geografía, 1997. $408 \mathrm{p}$.

VERA GALVÁN, J.R., LLARENA QUINTANA, A. [et al.]. Turismo y transformación del Territorio. En IV Jornadas de Lanzarote y Fuerteventura. Tomo II. Arrecife: Cabildo de Lanzarote y Fuerteventura, 1995 (p. 251-262). Disponible en Web:

http://www.memoriadelanzarote.com/contenidos/20090218113255galv\%C3\%A1n-1.pdf

- (1995) El dispositivo Territorial Turístico. En IV Jornadas de Lanzarote y Fuerteventura. Tomo II. Arrecife. Cabildo de Lanzarote y Fuerteventura, 1995 (p. 271-277). Disponible en Web:

http://www.memoriadelanzarote.com/contenidos/20090218113724galv\%C3\%A1n-3.pdf

VERA GALVÁN, J.R. (1989). La Comunicación Turística y sus problemas. En IV Jornadas de Lanzarote y Fuerteventura. Tomo II. Arrecife: Cabildo de Lanzarote y Fuerteventura 1995 (p. 305-320).

V.V.A.A. Estrategia integral para la Comunidad Autónoma de Canarias (Plan Canarias). Gobierno de Canarias y España, 2009.

WLADIMIRO Rodríguez Brito. Canarias: Agricultura y Ecología. Tenerife: Centro de Cultura Popular de Canarias, Cabildo Insular de Tenerife. 1992.

WOOD, R. E. International tourism and culture change in S. E. Asia. Econ. En Dev. Cult. Change, No 49; 1980 (p. 561-581).

WTTC. Travel \& tourism's. Economic Perspective. Bruselas: World Travel \& Tourism Council, 1995. 23 p. 
YOUNG, R. C. The structural context of the Caribbean tourist industry. A comparative study. En Economic Development, Cultural Change, Nº 25; 1977 (p. 657-671).

YOUNG, Sir G. Tourism. Blessing or Blight? Harmondseorth. Penguin. 1973

ZARAGOZA ORTS, P. "Actuaciones Administrativas. 1972-1982". Capítulo 5. En 50 años del Turismo Español. Un análisis histórico y estructural. Madrid: Centro de Estudios Ramón Areces, S.A., 1999. (pp. 125-153). 1.106 p.

\section{4.- BIBLIOGRAFÍA LEGISLATIVA}

Decreto 187/1995, de 20 de julio, de reestructuración de la Administración Pública de la Comunidad Autónoma de Canarias. Boletín Oficial de Canarias, 21 de julio de 1995, núm. 093, p. 7335. Disponible en Web:

http://www.gobiernodecanarias.org/boc/1995/093/001.html

Decreto 281/1995, 11 septiembre, del Reglamento Orgánico de la Consejería de Turismo y Transportes. Boletín oficial de Canarias, 04 de octubre de 1995, núm. 128, p. 10256. Disponible en Web: http://www.gobiernodecanarias.org/boc/1995/128/001.html

Decreto 135/1997, de 11 de julio, por el que se aprueba el Estatuto Orgánico del Consejo Insular de Aguas de Lanzarote. Boletín Oficial de Canarias, 18 de agosto de 1997, núm. 107, p. 10121. Disponible en Web:

http://www.gobiernodecanarias.org/boc/1997/107/003.html

Decreto 108/1999, de 25 de mayo, por el que se suspende el otorgamiento de licencias de obras que supongan la creación de nueva oferta turística alojativa en Lanzarote. Boletín Oficial de Canarias, 28 de mayo de 1999, núm. 65, p. 7460. Disponible en Web:

http://www.gobiernodecanarias.org/boc/1999/068/005.html

Decreto 95/2000, de 22 de mayo, de aprobación definitiva de la Revisión Parcial del Plan Insular de Ordenación de Lanzarote. Boletín Oficial de Canarias, 29 de mayo de 2000, núm. 66, p. 6996. Disponible en Web: http://www.gobcan.es/boc/2000/066/001.html

Decreto legislativo 1/2000, de 8 de mayo, por el que se aprueba el Texto refundido de las leyes de Ordenación del Territorio de Canarias y de Espacios naturales de Canarias. Boletín oficial de Canarias, 15 de mayo de 2000, núm. 060, p. 5989. Disponible en Web: http://www.gobcan.es/boc/2000/060/boc-2000-060-001.pdf 
Decreto 4/2001, de 12 de enero, por el que se acuerda la formulación de las Directrices de Ordenación General y del Turismo de Canarias. Boletín oficial de Canarias, 15 de enero de 2001, núm. 007, p. 482. Disponible en Web:

http://www.gobiernodecanarias.org/boc/2001/007/boc-2001-007-014.pdf

Decreto 167/2001 de 30 de julio, por el que se aprueba el Plan Hidrológico Insular de Lanzarote. B.O.C, No 138 de 22 de octubre de 2001 (p. 15926). Disponible en Web:

\section{http://www.gobiernodecanarias.org/boc/2001/138/002.html}

Decreto 241/2003, de 11 de julio del Presidente, por el que se determinan el número, denominación y competencias de las Consejerías. Boletín Oficial de Canarias, 14 de julio de 2003, núm. 134, p.12027. Disponible en Web:

http://www.gobiernodecanarias.org/boc/2003/134/boc-2003-134-001.pdf

Decreto 84/2004, de 29 de junio, por el que se aprueba el Reglamento Orgánico de la Consejería de Turismo. Boletín Oficial de Canarias, 19 de julio de 2004, núm. 138, p. 11251. Disponible en Web:

http://www.gobiernodecanarias.org/boc/2004/138/boc-2004-138-001.pdf

Decreto 75/2005, de 17 de mayo, por el que se regula el Registro General de Empresas, Actividades y Establecimientos Turísticos, así como el sistema de información turística y se aprueba el sistema informático que les da soporte. Boletín Oficial de Canarias, 26 de mayo de 2005, núm. 103, p. 9070 . Disponible en Web:

\section{http://www.gobiernodecanarias.org/boc/2005/103/boc-2005-103-002.pdf}

Decreto 206/2007, de 13 de julio, del Presidente, por el que se determinan el número, denominación y competencias de las Consejerías. Boletín Oficial de Canarias, 14 de julio de 2007, núm. 141, p. 18207. Disponible en Web:

http://www.gobiernodecanarias.org/boc/2007/141/001.html

Ley 14/1970, de 4 de agosto, General de Educación y Financiamiento de la Reforma Educativa. Boletín Oficial del Estado, 06 de agosto de 1970, núm. 1987, p. 12525. Disponible en Web:

http://www.boe.es/boe/dias/1970/08/06/pdfs/A12525-12546.pdf

Ley Orgánica 10/1982 de 10 de agosto, de Estatuto de Autonomía de Canarias. Boletín Oficial del Estado, 16 de agosto de 1982, núm. 195, p. 22047. Disponible en Web:

http://www.boe.es/boe/dias/1982/08/16/pdfs/A22047-22053.pdf 
Ley Orgánica 8/1985, de 3 de julio, reguladora del Derecho a la Educación. Boletín Oficial del Estado, 4 de junio de 1985. núm. 159, p. 21015. Disponible en Web:

http://www.boe.es/boe/dias/1985/07/04/pdfs/A21015-21022.pdf

Ley $7 / 1985$, de 2 de abril, Reguladora de las Bases del Régimen Local. Boletín Oficial del Estado, núm. 80, p. 8945. Disponible en Web:

http://www.boe.es/boe/dias/1985/04/03/pdfs/A08945-08964.pdf

Ley 14/1986, de 25 de abril, General de Sanidad. Boletín Oficial del Estado, de 29 de abril de 1986, núm. 101, p. 15207.

http://www.boe.es/buscar/doc.php?id=BOE-A-1986-10499.

Ley $1 / 1987$ de 13 de marzo Reguladora de los Planes Insulares de Ordenación. Boletín Oficial del Estado, 6 de abril de 1987, núm. 82, p. 10161.

http://www.boe.es/boe/dias/1987/04/06/pdfs/A10161-10163.pdf

Ley 12/1987, de 19 de junio, de Declaración de Espacios Naturales de Canarias. Boletín Oficial del Estado, 11 de noviembre de 1987, núm. 270, p. 33529. Disponible en Web:

http://www.boe.es/boe/dias/1987/11/11/pdfs/A33529-33599.pdf

Ley Orgánica 1/1990, de 3 octubre de Ordenación general del Sistema educativo. Boletín Oficial del Estado, 4 de octubre de 1990, núm. 238, p. 28927. Disponible en Web:

http://www.boe.es/boe/dias/1990/10/04/pdfs/A28927-28942.pdf

Ley $7 / 1990$, de 14 de mayo, de Disciplina Urbanística y Territorial. Boletín Oficial del Estado, 16 de junio de 1990, núm. 144, p. 16748. Disponible en Web:

http://www.boe.es/boe/dias/1990/06/16/pdfs/A16748-16756.pdf

Ley 14/1990, de 26 de julio, de reforma de la Ley 8/1986, de 18 de noviembre, de Régimen Jurídico de las Administraciones Públicas de Canarias. Boletín Oficial del Estado, 19 de septiembre de 1990, núm. 225, p. 27369. Disponible en Web:

http://www.boe.es/boe/dias/1990/09/19/pdfs/A27369-27382.pdf

Ley 28/1991, de 5 de diciembre, por la que se deroga la Ley 197/1963, de 28 de diciembre, sobre Centros y Zonas de Interés Turístico Nacional. Boletín Oficial del Estado, 6 de diciembre de 1991, núm. 292, p. 39632. Disponible en Web:

http://www.boe.es/boe/dias/1991/12/06/pdfs/A39632-39633.pdf 
Ley 30/1992, de 26 de noviembre, de Régimen Jurídico de las Administraciones Públicas y del Procedimiento Administrativo Común. Boletín Oficial del Estado, 27 de noviembre de 1992, núm. 285, p. 40300. Disponible en Web:

http://www.boe.es/boe/dias/1992/11/27/pdfs/A40300-40319.pdf

Ley 12/1994, de 19 de diciembre, de Espacios Naturales de Canarias. Boletín Oficial del Estado, 3 de febrero de 1995, núm. 29, p. 3510. Disponible en Web:

http://www.boe.es/boe/dias/1995/02/03/pdfs/A03510-03519.pdf

Ley 11/1994, de 26 de julio, de Ordenación Sanitaria de Canarias. Boletín Oficial de Canarias, 5 de agosto de 1994, núm. 96, p. 5501. Disponible en Web:

http://www.gobiernodecanarias.org/boc/1994/096/boc-1994-096-001.pdf

Ley $7 / 1995$, de 6 de abril de Ordenación del Turismo de Canarias. Boletín Oficial del Estado, 23 de mayo de 1995, núm. 122, p. 15038. Disponible en Web:

http://www.boe.es/boe/dias/1995/05/23/pdfs/A15038-15055.pdf

Ley 5/1999 de 15 de marzo, de Modificación de la Ley 7/1995, de 6 de abril, de Ordenación del Turismo de Canarias. Boletín Oficial del Estado, 9 de abril de 1999, núm. 85, p. 13299. Disponible en Web:

http://www.boe.es/boe/dias/1999/04/09/pdfs/A13299-13300.pdf

Ley 9/1999, de 13 de mayo, Ordenación del Territorio de Canarias. Boletín Oficial del Estado, 12 de junio de 1999, núm. 140, p. 22603. Disponible en Web:

http://www.boe.es/boe/dias/1999/06/12/pdfs/A22603-22670.pdf

Ley 8/2001, 3 diciembre, de modificación parcial de la Ley 14/1990, 26 julio, de Régimen Jurídico de las Administraciones Publicas Canarias. Boletín Oficial del Estado, 24 de enero de 2002, núm. 21, p. 3063. Disponible en Web:

http://www.boe.es/boe/dias/2002/01/24/pdfs/A03063-03066.pdf

Ley 19/2003, de 14 de abril, por la que se aprueban las Directrices de Ordenación General y la Directrices de Ordenación del Turismo de Canarias. B.O.E., 8 de julio de 2003, núm. 162, p. 26429. Disponible en Web:

http://www.boe.es/boe/dias/2003/07/08/pdfs/A26429-26519.pdf 
Ley 57/2003, de 16 de diciembre, de medidas para la modernización del gobierno local. Boletín Oficial del Estado, 17 de diciembre de 2003, núm. 301, p. 44771. Disponible en Web: http://www.boe.es/boe/dias/2003/12/17/pdfs/A44771-44791.pdf

Ley $6 / 2009$, de 6 de mayo, de medidas urgentes en materia de ordenación territorial para la dinamización sectorial y la ordenación del turismo. Boletín Oficial del Estado, 1 de junio de 2009, núm. 132, p. 46079. Disponible en Web:

http://www.boe.es/boe/dias/2009/06/01/pdfs/BOE-A-2009-9047.pdf

Orden de 16 de junio de 1995 de desarrollo del Real Decreto 328/1995, de 3 de marzo, por la que se crea el Consejo Promotor del Turismo. Boletín Oficial del Estado, 21 de junio de 1995, núm. 147, p. 18637. Disponible en Web:

http://www.boe.es/boe/dias/1995/06/21/pdfs/A18637-18637.pdf

Orden de 30 de enero de 1986 sobre planificación de la educación especial y ampliación de la experimentación de la integración en el curso 1986/1987. Boletín Oficial de Estado, de 4 de febrero de 1986, núm. 30, p. 4586. Disponible en Web:

http://www.boe.es/boe/dias/1986/02/04/pdfs/A04686-04687.pdf

Real Decreto 6/1994, de 14 de enero, por el que se crea la Comisión Interministerial de Turismo. Boletín Oficial del Estado, 8 de febrero de 1994, núm. 33, p. 4044. Disponible en Web:

http://www.boe.es/boe/dias/1994/02/08/pdfs/A04044-04045.pdf

Real Decreto 1116/1998, de 8 de junio, por el que se crea el Observatorio del Turismo. Boletín Oficial del Estado, 17 junio de 1998, núm. 144, p. 19941. Disponible en Web:

http://www.boe.es/boe/dias/1998/06/17/pdfs/A19941-19943.pdf

Reglamento Orgánico del Cabildo Lanzarote. B. O. Provincia de Las Palmas de 2007, núm. 138, p. 19082. Disponible en Web:

http://www.cabildodelanzarote.com/Uploads/doc/20080118143846601.pdf

Real Decreto 137/1984, de 11 de enero, sobre estructuras básicas de salud. Boletín Oficial del Estado, núm. 27, p. 2627. Disponible en Web:

http://www.boe.es/boe/dias/1984/02/01/pdfs/A02627-02629.pdf

Real Decreto 1004/1991, de 14 de junio, por el que se establecen los requisitos mínimos de los Centros que impartan enseñanzas de régimen general no universitarias. Boletín Oficial del Estado, 26 de junio de 1991, núm. 152, p. 21181. Disponible en Web: 


\section{http://www.boe.es/boe/dias/1991/06/26/pdfs/A21181-21187.pdf}

Real Decreto 2346/1996, de 8 de noviembre, por el que se establece el régimen de ayudas y se regula su sistema de gestión en aplicación del II Plan Marco de Competitividad del Turismo Español (1996-1999). Boletín Oficial del Estado, 23 de noviembre de 1996, núm. 283, p. 35412. Disponible en Web:

\section{http://www.boe.es/boe/dias/1996/11/23/pdfs/A35412-35414.pdf}

Real Decreto 1537/2003, de 5 de diciembre, por el que se establecen los requisitos mínimos de los centros que impartan enseñanzas escolares de régimen general. Boletín Oficial del Estado, 10 de siembre de 2003, núm. 295, p. 43808. Disponible en Web:

\section{http://www.boe.es/boe/dias/2003/12/10/pdfs/A43808-43813.pdf}

Resolución 6L/CG-009 Sobre las condiciones y evolución del mercado turístico en el trienio 2003-2006, en cumplimiento de la disposición transitoria segunda, apartado quinto, de la Ley 19/2003, de 14 de abril, por la que se aprueban las Directrices de Ordenación General y las Directrices de Ordenación del Turismo de Canarias. B. O. Parlamento de Canarias, VI Legislatura, № 130. A 2 de Mayo de 2006. [En línea].

http://www.parcan.es/pub/bop/61/2007/062/bo062.pdf 